ENGINEERING CHANGE NOTICE
$H$

1. ECN $66008 \%$

Page 1 of 2

\begin{tabular}{|c|c|}
\hline 2. ECN Category (mark one) & 3. Originator's Name, Or \\
\hline Supplemental & J. A. Diediker, \\
\hline Direct Revision & $373-7752$ \\
\hline Change ECN & 6. Project Title/No.Nor \\
\hline Temporary & Programmatic B \\
\hline Standby & ase \\
\hline Supersedure & sheet no. and rev.) \\
\hline Cancel/Noid & HNF-1946, 1 \\
\hline $\begin{array}{l}\text { 12a. Modification Work } \\
\square \text { Yes (fill out Blk. 12b) } \\
\square \text { No } \underset{\text { (NA Blks. 12b) }}{\text { (2c, 12d) }}\end{array}$ & $\begin{array}{l}\text { 12b. Work Package No. } \\
\text { N/A }\end{array}$ \\
\hline
\end{tabular}

13a. Description of Change

\begin{tabular}{|l|l} 
4. USQ Required? & 5. Date \\
$\square$ Yes $\bigotimes$ No & $4 / 21 / 00$
\end{tabular}

8. Approval Designator

$\mathrm{N} / \mathrm{A}$

$\mathrm{N} / \mathrm{A}$

10. Related ECN No(s).

11. Related PO No.

$\mathrm{N} / \mathrm{A}$

$\mathrm{N} / \mathrm{A}$

12c. Modification Work Completed

$\mathrm{N} / \mathrm{A}$ Design Authority/Cog. Engineer Signature \& Date

13b. Design Baseline Document? $\square$ Yes $\bigotimes$ No

General changes due to name changes, program changes, and corporation changes. 12d. Restored to Original Condition (Temp. or Standby ECNs only)

$\mathrm{N} / \mathrm{A}$

Design Authority/Cog. Engineer Signature \& Date

\begin{tabular}{ll}
\hline 14a. Justification (mark one) \\
Criteria Change \\
Design Improvement \\
Environmental & $\square$ \\
Facility Deactivation & $\square$ \\
As-Found & $\square$ \\
Facilitate Const. & $\square$ \\
Const. Error/Omission & $\square$ \\
Design Error/Omission & $\square$
\end{tabular}

15. Distribution (include name, MSIN, and no. of copies)

See Distribution sheet 14b. Justification Details

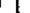

$\square$

] 
ENGINEERING CHANGE NOTICE

16. Design Verification

Required

$\square$ Yes

$\bigotimes$ No
17. Cost Impact

ENGINEERING

Additional $\square$

Savings
$\$ \underline{N} / \mathrm{A}$

$\$ \mathrm{~N} / \mathrm{A}$

Change Impact Review: Indicate the related documents (other than the engineering the change described in Block 13. Enter the affected document number in Block 20.

CONSTRUCTION

$\$ \underline{N} / \mathrm{A}$

$\$ N / A$
1. ECN (use no. from pg. 1) 660087

18. Schedule Impact (days)

Improvement

$\mathrm{N} / \mathrm{A}$

Delay

$\square \mathrm{N} / \mathrm{A}$

\section{Approvals}

SDD/DD

Functional Design Criteria

Operating Specification

Criticality Specification

Conceptual Design Report

Equipment Spec.

Const. Spec.

Procurement Spec.

Vendor Information

FSAR/SAR

Safety Equipment List

Radiation Work Permit

Environmental Impact Statement

Environmental Report

Environmental Permit
OM Manual

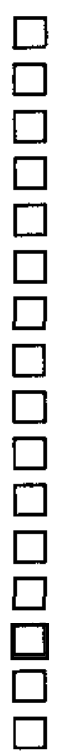

Seismic/Stress Analysis

Stress/Design Report

Interface Control Drawing

Calibration Procedure

Installation Procedure

Maintenance Procedure

Engineering Procedure

Operating Instruction

Operating Procedure

Operational Safety Requirement

IEFD Drawing

Cell Arrangement Drawing

Essential Material Specification

Fac. Proc. Samp. Schedule

Inspection Plan

Inventory Adjustment Request
20. Other Affected Documents: (NOTE: Documents listed below will not be revised by this ECN.) Signatures below indicate that the signing organization has been notified of other affected documents listed below.

Document Number/Revision

Document Number/Revision

Document Number/Revision
$\mathrm{N} / \mathrm{A}$
$\mathrm{N} / \mathrm{A}$

$\mathrm{N} / \mathrm{A}$
Tank Calibration Manual Health Physics Procedure Spares Multiple Unit Listing Test Procedures/Specification Component Index

ASME Coded Item Human Factor Consideration Computer Software Electric Circuit Schedule ICRS Procedure Process Control Manual/Plan Process Flow Chart Purchase Requisition

Tickler File

$\square$ NONE 区
Signature

Date

Design Authority

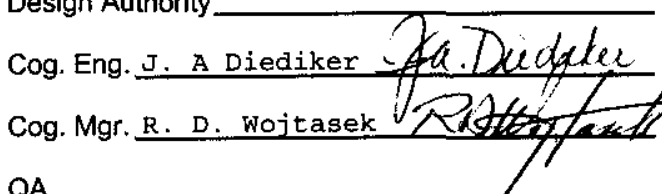

QA

Safety

Environ.

Other
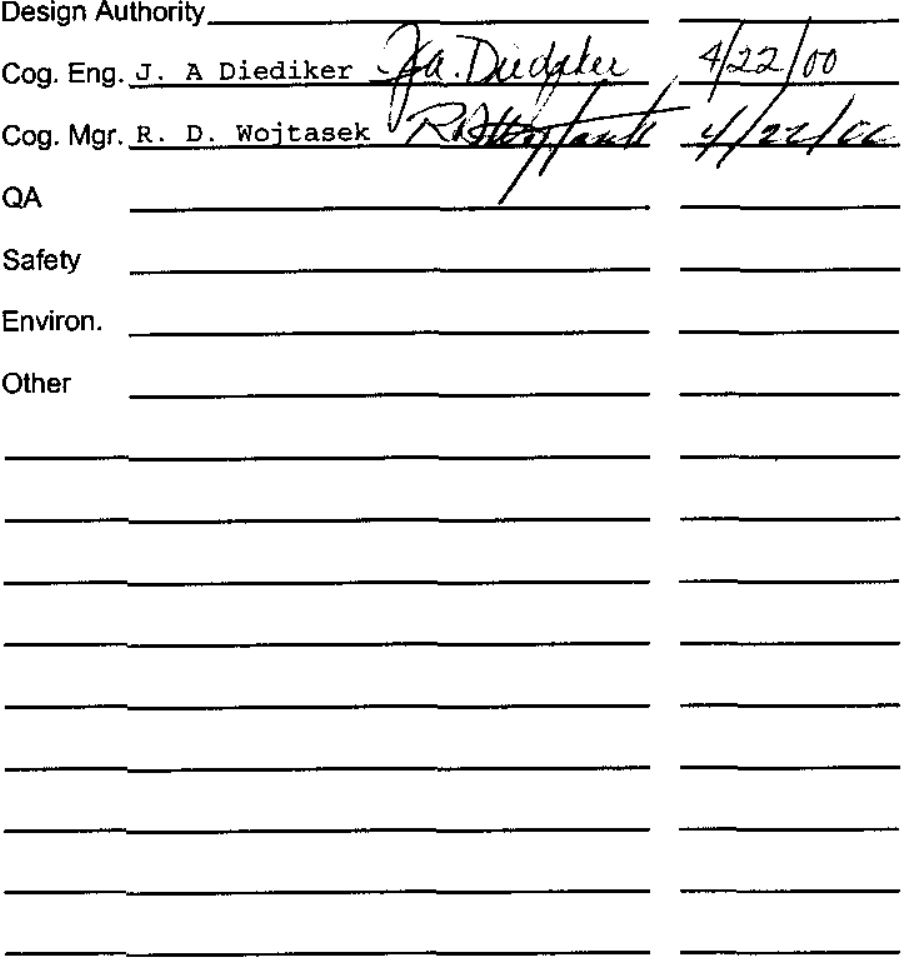

\section{DEPARTMENT OF ENERGY}

Signature or a Control Number that tracks the Approval Signature

$N / A$

ADDITIONAL.
Design Agent

PE

QA

Safety

Design

Environ.

Other

$\square$
$\square$
$\square$
$\square$
$\square$
$\square$
$\square$
$\square$
$\square$
$\square$
$\square$
$\square$
$\square$
$\square$
$\square$
$\square$




\title{
Programmatic Baseline Summary for Phase 1 Privatization for the Tank Farm Contractor
}

\author{
J. A. Diediker \\ CH2M HILL Hanford Group, Inc. \\ Richland, WA 99352 \\ U.S. Department of Energy Contract DE-AC06-99RL14047

$\begin{array}{lll}\text { EDT/ECN: } & 660087 & \text { UC: } 2030 \\ \text { Cost Center: } 71300 & \text { Charge Code: } 108521 / \text { AA30 } \\ \text { B\&R Code: } & \text { EW3 } 130010 & \text { Total Pages: } 20152\end{array}$

Key Words: River Protection Project, Retrieval and Disposal Mission baseline summary

\section{Abstract:}

The document describes the systematic integrated baseline planning process and provides a summary of the Tank Farm Contractor scope, schedule and cost analysis developed in support of the phase 1 Privatization mission.

TRADEMARK DISCLAIMER. Reference herein to any specific commercial product, process, or service by trade name, trademark, manufacturer, or otherwise, does not necessarily constitute or imply its endorsement, recommendation, or favoring by the United States Government or any agency thereof or its contractors or subcontractors.

Printed in the United States of America. To obtain copies of this document, contact: Document Control Services, P.O. Box 950, Mailstop H6-08, Richland WA 99352, Phone (509) 372-2420; Fax (509) 376-4989.
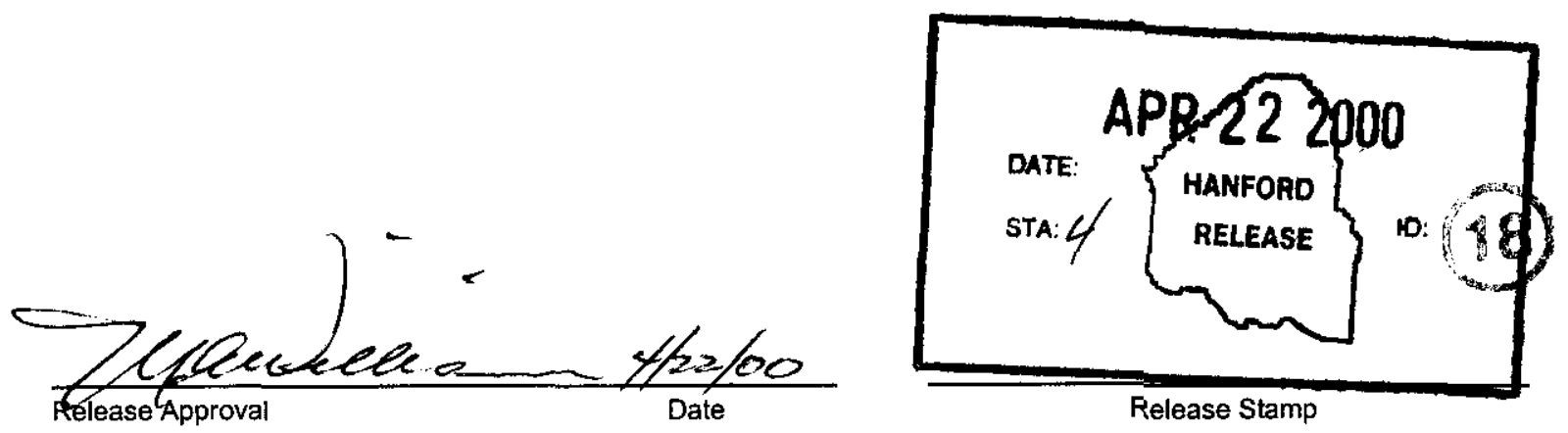

\section{Approved For Public Release}


RECORD OF REVISION

\begin{tabular}{l|l} 
(1) Document Number & \\
HNF-1946, Rev 2 & Page 1 \\
\hline
\end{tabular}

(2) Title

Programmatic Baseline Summary for Phase 1 Privatization for the Tank Farm Contractor

Change Control Record

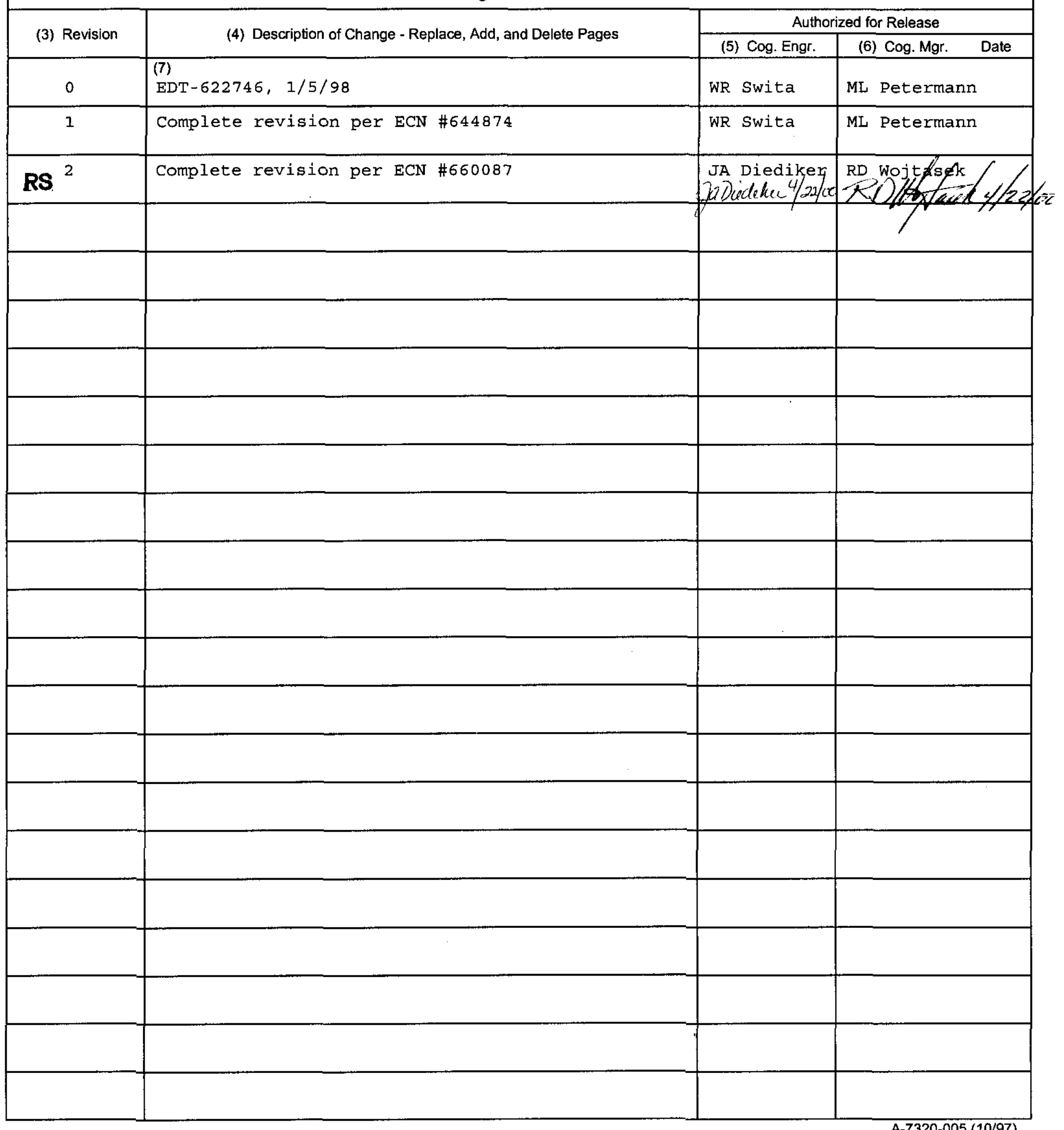


HNF-1946

Volume 1

Revision 2

\section{Programmatic Baseline} Summary for Phase 1 Privatization for the Tank Farm Contractor

Prepared for the U.S. Department of Energy

Assistant Secretary for Environmental Management

\section{CH2NHILL Hanford Group, Inc.}

Richland, Washington

Contractor for the U.S. Department of Energy

Office of River Protection under Contract DE-AC06-99RL14047

Approved for Public Release; Further Dissemination Unlimited 
HNF-1946

Volume I

Revision 2

\title{
Programmatic Baseline Summary for Phase 1 Privatization for the Tank Farm Contractor
}

\author{
J. A. Diediker
}

Date Published

April 2000

Prepared for the U.S. Department of Energy

Assistant Secretary for Environmental Management

\section{CH2MHILL}

Hanford Group, Inc.

P. O. Box 1500

Richland, Washington

Contractor for the U.S. Department of Energy

Office of River Protection under Contract DE-AC06-99RL14047

Approved for Public Release; Further Dissemination Unlimited 
LEGAL DISCLAIMER

This report was prepared as an account of work sponsored by an agency of the United States Government. Neither the United States Government nor any agency thereof, nor any of their employees, nor any of their contractors, subcontractors or their employees, makes any warranty, express or implied, or assumes any legal liability or responsibility for the accuracy, completeness, or any third party's use or the results of such use of any information, apparatus, product, or process disclosed, or represents that its use would not infringe privately owned rights. Reference herein to any specific commercial product, process, or service by trade name, trademark, manufacturer, or otherwise, does not necessarily constitute or imply its endorsement, recommendation, or favoring by the United States Government or any agency thereof or its contractors or subcontractors. The views and opinions of authors expressed herein do not necessarily state or reflect those of the United States Government or any agency thereof.

This report has been reproduced from the best available copy.

Available in paper copy and microfiche.

Available electronically at

http://www.doe.gov/bridge. Available for a processing fee to the U.S. Department of Energy and its contractors, in paper, from:

U.S. Department of Energy

Office of Scientific and Technical Information

P.O. Box 62

Oak Ridge, TN 37831-0062

phone: $865-576-8401$

fax: 865-576-5728

email: reports@adonis.osti.gov(423) 576-8401

Available for sale to the public, in paper, from:

U.S. Department of Commerce

National Technical Information Service

5285 Port Royal Road

Springfield, VA 22161

Phone: 800-553-6847

fax: 703-605-6900

email: orders@ntis.fedworld.gov

online ordering:

hutp://www.ntis.gov/ordering.htm 
HNF-1946 REV 2

Document Title: Programmatic Baseline Summary for Phase 1 Privatization for the Tank Farm Contractor

Approved by:
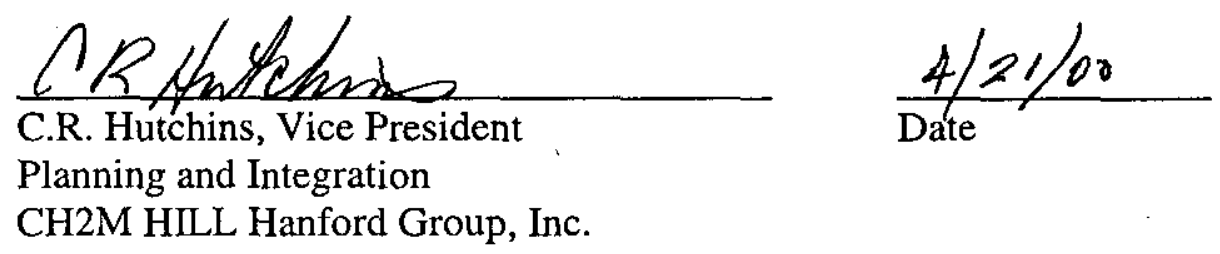
CH2M HILL Hanford Group, Inc. 


\section{EXECUTIVE SUMMARY}

The Programmatic Baseline Summary for Phase 1 Privatization for the Tank Farm Contractor is one of several documents prepared to provide evidence of the readiness to proceed with Phase 1 of the U.S. Department of Energy, Office of River Protection, mission. CH2M HILL Hanford Group, Inc. (CHG), is the Tank Farm Contractor responsible for performing the planning and operations necessary for tank waste storage, retrieval, feed delivery, and disposal or shipment of the immobilized products in support of the River Protection Project.

The baseline summary provides a review of the scope, schedule, and associated costs developed to demonstrate the TFC's ability to execute the project mission.

Key areas of the document are as follows:

- Introduction and description of the Integrated Baseline planning process used to produce the scope, schedule, and cost exhibits

- Summary scope descriptions for the Tank Farm Contractor components of the River Protection Project

- Summary cost exhibits, including the Tank.Farm Contractor Phase 1 cost summary profile, the Tank Farm Contractor Phase 1 detailed cost-loading report derived from the logic-driven, resource-loaded schedule, and a summary of life-cycle costs

- Schedule descriptions and exhibits, including the River Protection Project Master Schedule, Tank Farm Contractor Project Master Baseline Schedule for Phase 1, Tank Farm Contractor Critical Path Schedule by Tank, and the Tank Farm Contractor Integrated Resource-Loaded Detailed Schedule for Phase 1

- Summary program-level description of changes for Phase 1 from the River Protection Project FY 2000 Multi-Year Work Plan Summary (CHG 2000a) to the Programmatic Baseline Summary for Phase 1 Privatization for the Tank Farm Contractor (Diediker 2000). 


\section{HNF-1946 REV 2}

The overall conclusion of this document is that the scope, schedule, and estimated costs support installing and operating selected tank farm system upgrades, infrastructure improvements, and immobilized waste management facilities to successfully execute the Privatization Phase 1 mission as contracted with the Tank Farm Contractor. 


\section{CONTENTS}

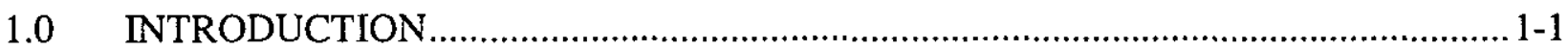

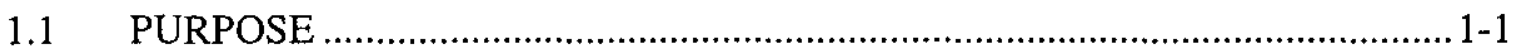

2.0 INTEGRATED BASELINE SUMMARY ............................................................. 2-1

2.1 INTEGRATED BASELINE PLANNING PROCESS DETAILS ........................2-1

2.2 INTEGRATED BASELINE PLANNING PROCESS RESULTS ...................... 2-4

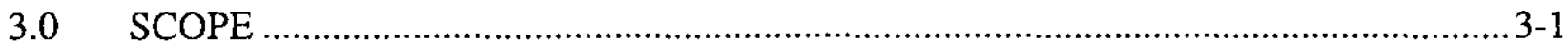

3.1 RIVER PROTECTION PROJECT LOGIC ................................................... 3-1

3.2 RIVER PROTECTION PROJECT WORK BREAKDOWN

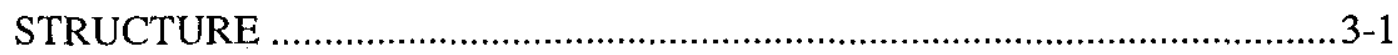

3.3 TANK FARM CONTRACTOR PHASE 1 FEED DELIVERY, STORAGE AND DISPOSAL MISSION SUMMARY FOR 2006 HOT

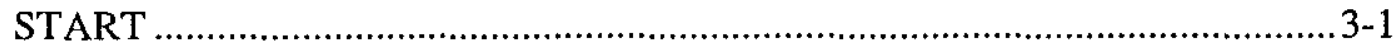

3.4 LEVEL 1 LOGIC .................................................................................. 3-11

3.5 CROSSWALK FROM THE LEVEL 1 LOGIC TO THE WORK BREAKDOWN STRUCTURE.................................................................. 3-11

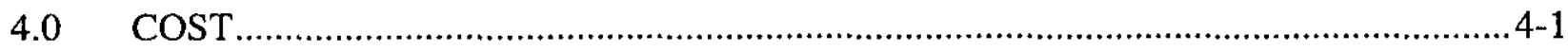

4.1 PRICING BASIS .................................................................................

4.2 ESCALATION ASSUMPTIONS …………...............................................

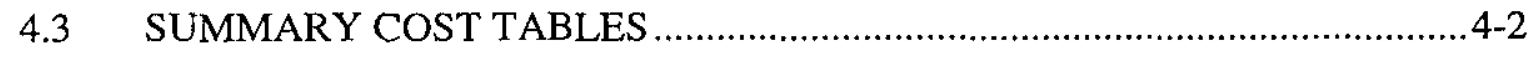

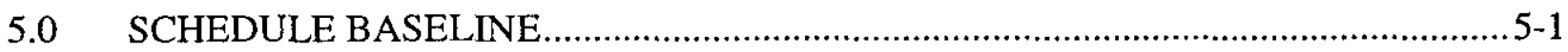

5.1 PROJECT MASTER BASELINE SCHEDULE............................................. $5-1$

5.2 CRITICAL PATH SCHEDULE ……………..................................................5-1

5.3 LIFE-CYCLE INTEGRATED RESOURCE-LOADED SCHEDULE ................5-1

5.4 MILESTONE LIST ..................................................................................... 5-1

6.0 SUMMARY OF PROGRAM-LEVEL-CHANGES FOR PHASE 1 .............................. 6-1

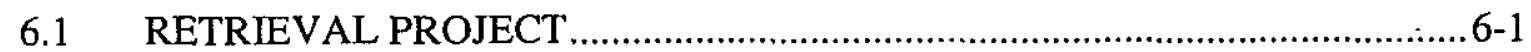

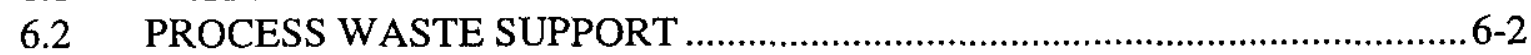

6.3 INFRASTRUCTURE PROJECT .............................................................. 6-2

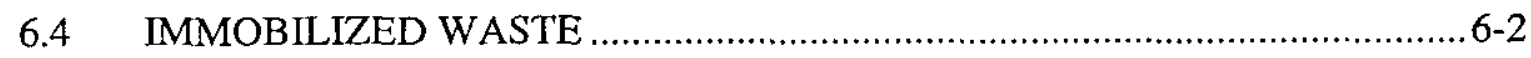

6.5 CHARACTERIZATION PROJECT ………................................................6-3

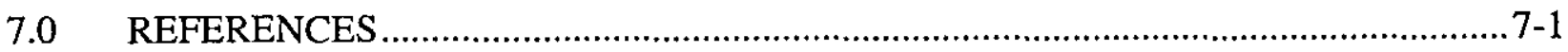


HNF-1946 REV 2

\section{APPENDICES}

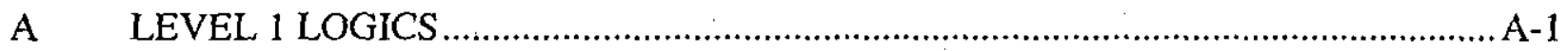

B CROSSWALK FROM THE LEVEL 1 LOGIC TO THE WORK BREAKDOWN STRUCTURE LEVEL 6 ............................................................................... $\mathrm{B}-1$

' $\mathrm{C}$ TANK FARM CONTRACTOR INTEGRATED RESOURCE-LOADED SCHEDULE. C-1

\section{FIGURES}

Figure 1-1. Tank Farm Contractor Document Structure..................................................... 1-2

Figure 2-1, River Protection Project Top-Level Document Relationships. ..................................2-2

Figure 3-1. River Protection Project Logic............................................................................3-3

Figure 3-2 River Protection Project Work Breakdown Structure. ............................................... 3-5

Figure 3-3. Tank Farm Contractor Phase 1 Feed Delivery, Storage, and Disposal Mission Summary for 2006 Hot Start.

Figure 4-1. Total Cost by Project Baseline Summary for Fiscal Years 2000 through 2018-Unescalated. (\$ in 000's) 


\section{HNF-1946 REV 2}

\section{TABLES}

Table 4-1. Escalation Assumptions Operating and Maintenance

Projects/All Construction..

Table 4-2. Retrieval and Disposal Phase 1 Costs by Project Baseline Summary for Fiscal

Years 2000 through 2018-Unescalated.

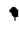

Table 4-3. Retrieval and Disposal Phase 1 Costs by Work Breakdown Structure Level 6

- Unescalated.....................................................................................................4-4

Table 4-4. Life-Cycle Cost Summary for the Tank Farm Contractor........................................4-6

Table 4-5. Retrieval and Disposal Cost Loading Report by WBS Level 6 - Unescalated ( $\$$ in 000's) (FY 2000 through FY 2008).............................................................4-7

Table 5-1. Tank Farm Contractor Key Milestones. .................................................................5-2 


\section{HNF-1946 REV 2}

\section{TERMS}

BNFL

CHG

CEIS

DOE

DST

- FY

HLW

IHLW

ILAW

LAW

LCC

MYWP

ORP

RPP

RTP

SST

TBR

TFC

WBS

WFD
BNFL Inc.

$\mathrm{CH} 2 \mathrm{M}$ Hill Hanford Group Inc.

cost estimating input sheet

U.S. Department of Energy

double-shell tank

fiscal year

high-level waste

immobilized high level waste

immobilized low activity waste

low-activity waste

life-cycle cost

multi-year work plan

Office of River Protection

River Protection Project

readiness to proceed

single shell tank

technical basis review

tank farm contractor

work breakdown structure

Waste Feed Delivery 


\section{HNF-1946 REV 2}

\subsection{INTRODUCTION}

As part of the U.S. Department of Energy, Office of River Protection (ORP), assessment of contractor readiness to proceed (RTP), the Tank Farm Contractor (TFC), CH2M HILL Hanford Group, Inc. (CHG), has prepared the Programmatic Baseline Summary for Phase 1 Privatization. This document, with additional supporting data, substantiates that the necessary systems, personnel, and equipment are ready to proceed with the Phase 1 mission.

- The programmatic baseline consists of three interconnected elements: scope, schedule, and cost. All three elements are necessary to execute the following activities:

- Safely retrieve and deliver tank waste as feed for the waste treatment facilities

- Receive immobilized tank waste products for storage and disposal

- Receive secondary waste and specified byproducts for treatment or disposal

- Provide infrastructure support for the waste treatment facilities.

As shown in Figure 1-1, Tank Farm Contractor Document Summary, the programmatic baseline is integrated with the mission definition and management plans, and is based on the technical baseline documented in the Technical Baseline Summary Description for the Tank Farm Contractor (HNF-1901, Rev. 2).

\subsection{PURPOSE}

The Programmatic Baseline Summary describes the systematic, integrated baseline planning process and provides the results of the TFC's scope, schedule, and cost analysis for Phase 1 Privatization. 


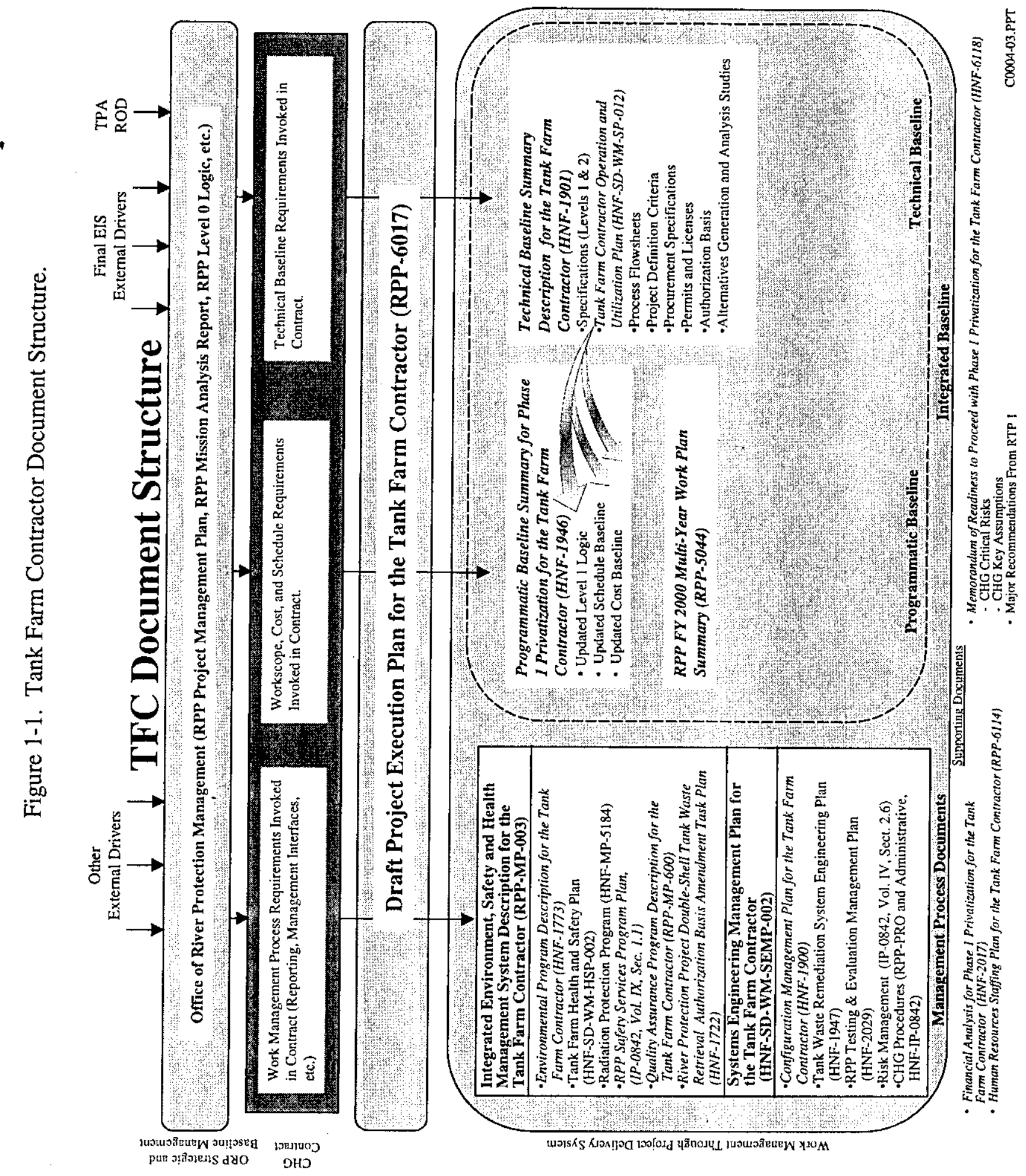


HNF-1946 REV 2

\subsection{INTEGRATED BASELINE SUMMARY}

The TFC's Integrated Baseline Planning Process is a defined system and process that guides all aspects of the project to provide a consistent, efficient, and effective means for successful project development, performance, and delivery (CHG 1999a). The integrated baseline planning process includes a comprehensive set of management and control processes to identify and control risk, maintain configuration control, balance competing requirements, and integrate project work scope, providing a powerful management tool. Figure 2-1 shows the elements of the integrated baseline, their relationship to upper level guidance documents, and the River Protection Project (RPP) plans and procedures that control the integrated baseline development. The integrated baseline process is used to perform the following:

- Manage the TFC scope as a project

- Provide the foundation for integrated scope definition, estimating, and logic-driven, critical-path scheduling for all work scope

- Establish risk-based priorities

- Document the approved project scope, schedule, and cost for approval and work authorization

- Measure project progress and performance during project execution

- Incorporate changes to the baseline using strict change control procedures.

\subsection{INTEGRATED BASELINE PLANNING PROCESS DETAILS}

To conduct the RTP planning process, the contractor established multi-disciplined teams with technically knowledgeable-and experienced representatives from Operations; Characterization; Retrieval and Disposal; Projects; Nuclear Safety \& Licensing; Environmental, Safety, Health and Quality Assurance; Engineering; Planning \& Integration; and Maintenance. The use of these subject matter experts ensures that performing organization interfaces are identified for each activity and series of activities and the work is integrated between the programs, projects, and operations.

The integrated baseline planning process can be subdivided into the three project management areas: (1) scope definition, (2) schedule integration, and (3) cost estimating.

The integrated baseline begins with the River Protection Project Mission Analysis Report (MAR) (ORP 2000), which captures the Hanford Site-level requirements assigned to the RPP, defines the initial and final end states, identifies major interfaces, and provides an initial assessment of activities that the RPP must execute to achieve the defined mission. The MAR is used to develop the RPP Mission Logic. 


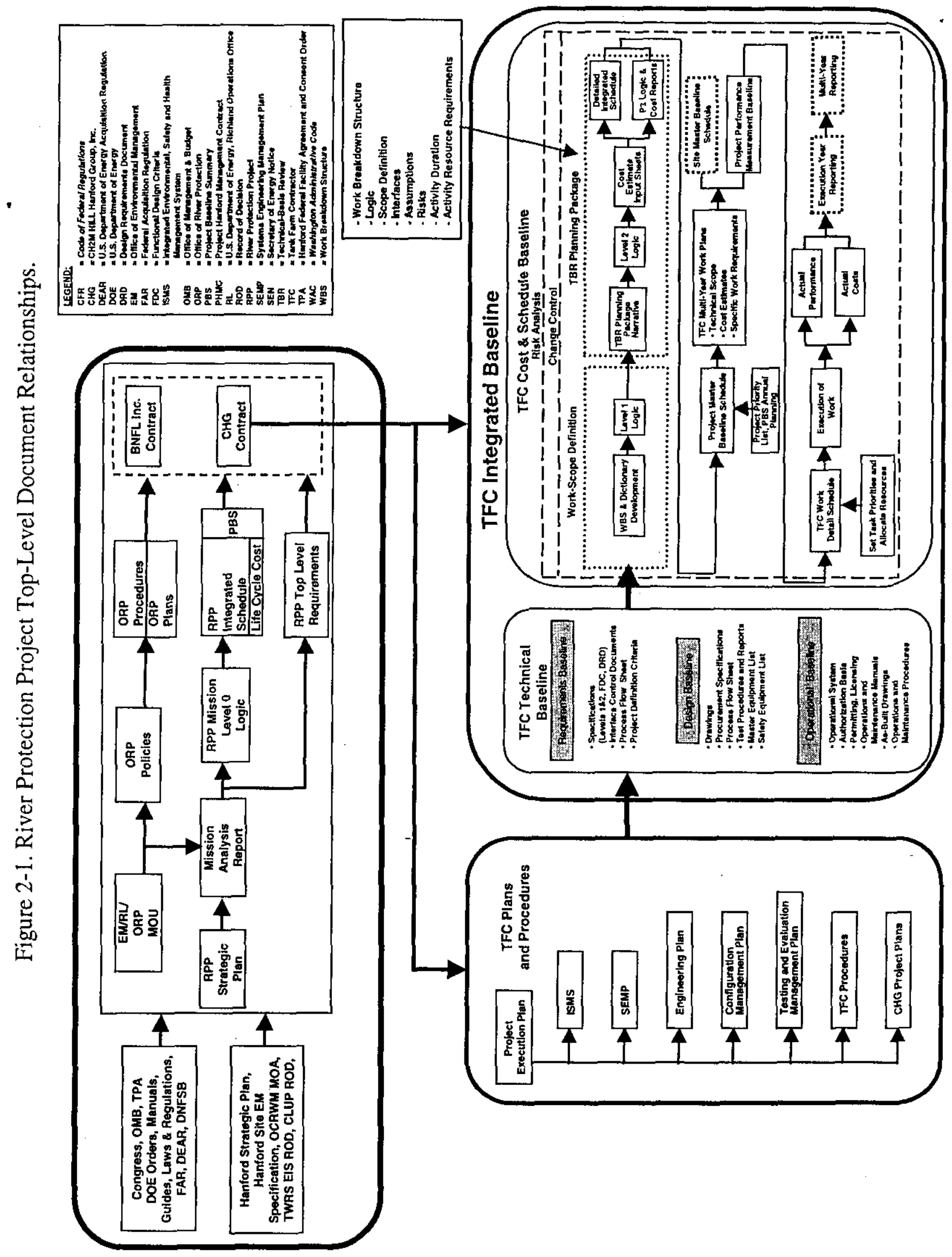




\section{HNF-1946 REV 2}

The RPP Mission Logic depicts the RPP mission as a sequence of activities necessary to meet the technical requirements. Section 3 addresses the major work that the RPP must perform, including safe storage, waste immobilization (Phase 1), waste immobilization and disposal completion (Phase 2), and closure. The RPP Mission Logic was used to define the technical scope for the TFC and is the top-level basis used for planning and traceable to lower level planning documentation.

CHG developed lower level scope activities and prepared the Tank Farm Contractor Phase 1

- Feed Delivery, Storage and Disposal Mission Summary for 2006 Hot Start (RPP-5742, Rev. 1) diagram using River Protection Project Key Planning Assumptions, RPP-5993 (CHG 2000b), which defined the operating scenario, feed delivery sequence, and rates to the Privatization Contractor, with one exception. The programmatic baseline planning document is based on earlier draft assumptions, which indicated that the Privatization Contractor would deploy a sulfate-removal process and accommodate a vitrification ramp-up rate of 100 percent. The sulfate-removal assumption and vitrification ramp-up were modified just before issuance of the key enabling assumptions, which introduced the inconsistency between RPP-5993 and the integrated baseline. Preliminary analysis indicates that the net effect of these changes is within CHG's capabilities to resolve. The post-RTP gap analysis will address these issues.

The Tank Farm Contractor Phase 1 Feed Delivery, Storage and Disposal Mission Summary diagram summarizes the Retrieval, Projects, and Operations mission activities. To update the Mission Summary, the RTP planning team evaluated projects and operation baselines to determine how well they supported the preferred waste retrieval and disposal scenarios. The RTP team assessed candidate waste feed delivery, storage, and disposal scenarios for their capability to support the requirements and assumptions. Using the Hanford Tank Waste Operation Simulator (HTWOS), the RTP team evaluated these key data to determine the overall success of executing the mission. Detailed planning assumptions and information on tank waste composition and existing or planned equipment and operational capabilities are defined in HNF-SD-WM-SP-012, Operation and Utilization Plan for the Tank Farm Contractor (Kirkbride 2000).

CHG used activity-based planning to define work scope and develop Level 1 logics that depict unique activities, logical interdependencies, and the sequence of the technical scope necessary to achieve the Retrieval and Disposal mission. Scope driven by logic development ensures that work scope is consistent with the technical requirements and each activity on the Level 1 logic correlates to the RPP work breakdown structure (WBS).

Preparation of the technical basis review (TBR) packages was initiated on completion of the Level 1 logics. The TBR process provides for development of the lower levels of the WBS, generally at Level 7, and the lower levels of the schedule logic. TBR packages define the work to be performed; document the technical basis; list the reference documents, enabling assumptions, inputs, deliverables, trade studies, decisions, risk, labor and non-labor resources required to perform the work; and document organizational responsibilities for work performance. They also define how and when the work will be executed. 
Each Level 1 activity and its logic was decomposed to the next level of detail necessary to prepare the required components of the TBR package. Components of each TBR package are as follows:

- TBR control/approval log

- Technical basis review narratives

- Primavera Project Planner ${ }^{1}$ (P3)-generated subactivity (task) logic networks

- Sub-activity (task) cost-estimating input sheets (CEIS)

- P3-generated resource and cost-loading reports.

Activity-based cost estimating methodology is used to generate cost estimates, which are prepared to a level at which costs are tracked and performance is evaluated. Because of variations in the current phases of the TFC's projects, several estimating techniques are used to construct the cost estimate. Approved commercial and government estimating methods used include analogy, definitive, parametric, factored, cost review and update. In addition, formal construction project estimates are developed and maintained for the life of each line-item construction project in accordance with the U.S. Department of Energy (DOE) policy. Cost estimates are prepared in accordance with the G430.1-1, DOE Cost Estimating Guide (DOE 1997); DOE/RL-97-90, Hanford Cost Estimating and Schedule Guide (RL 1997); and RPP-PRO-585, Cost Estimating (CHG 1999). Each CEIS documents costs, including labor, equipment, materials, and subcontracts, and includes the estimate basis, assumptions, and exclusions for each TBR activity.

The TFC developed an integrated, resource-loaded schedule to support Phase 1 Privatization. The schedule, prepared in P3, was developed from, and is traceable to, the Level 1 logics, formal TBR package data, and the WBS. Resources from the CEISs were loaded and priced in P3 to produce the cost for each activity. The integrated resource-loaded schedule provides a timephased plan with a logical sequence of interdependent activities, milestones, and constraints.

\subsection{INTEGRATED BASELINE PLANNING PROCESS RESULTS}

The implementation of the integrated planning process resulted in the development of the documentation described in the following paragraphs.

Electronic access can be used to view the Feed Delivery Storage and Disposal Mission Summary diagram, Level 1 logics, and TBR packages on the Hanford Intranet, RPP Technical Resources web site.

A Feed Delivery Storage and Disposal Mission Summary diagram was prepared that identifies 24 low-activity waste (LAW) feed batches and 50 high-level waste (HLW) feed batches in support of the Phase 1 mission.

\footnotetext{
${ }^{1}$ Primavera Project Planner is a trademark of Primavera Systems, Inc.
} 


\section{HNF-1946 REV 2}

Fifty-seven sheets of Level 1 logics were prepared for Low-Activity Waste feed, High-Level Waste Feed, Immobilized LAW, Immobilized HLW, and Infrastructure Phase 1 projects; the Single-Shell Tank Program; the Management Assessment, Waste Feed Project Definition, and Waste Feed Delivery Programs; and the RPP Tank Waste Retrieval/Disposal Division.

The integrated resource-loaded P3 schedule contains more than 12,000 activities that identify the TF C's (TFC) ability to execute the mission as required to support the Privatization Contractor.

The RTP Team developed more than 900 TBR packages that document the TFC's Phase 1 scope. The final TBR packages consist of the TBR narrative descriptions, subactivity logics, P3 costloading reports, and detailed cost estimates. The final packages were reconciled to the approved schedule. Each TBR package has been approved by the program and performing organization managers and placed under configuration control. 


\section{HNF-1946 REV 2}

This page intentionally left blank. 


\subsection{SCOPE}

\subsection{RIVER PROTECTION PROJECT LOGIC}

The River Protection Project Logic, TWR-2086 (see Figure 3-1), is a tool for translating the RPP mission requirements identified in the MAR (ORP 2000) into a sequence of activities necessary

- to achieve the mission objectives. Figure 3-1 illustrates the major work that the RPP must perform to accomplish its mission including safe storage, waste immobilization (Phase 1), waste immobilization and disposal completion (Phase 2), and closure. A diagonal line through a task boxes indicates tasks that have been completed.

\subsection{RIVER PROTECTION PROJECT WORK BREAKDOWN STRUCTURE}

The RPP WBS (see Figure 3-2) has been organized to provide a common framework for work planning, scope definition, and integration of the baseline for all levels and components of the project. The RPP WBS consists of 10 major elements and provides these elements to $\mathrm{CHG}$ and the Privatization Contractor for further decomposition. The Programmatic Baseline Summary focuses on the subset of activities in the WBS for the TFC in support of Phase 1 scope. The subset of the WBS includes the following:

- TW01 Tank Waste Characterization

- TW03 Project W-314, Tank Farm Operations

- TW04 Retrieval

- TW05 Process Waste Support

- TW08 Privatization Infrastructure

- TW09 Immobilized Tank Waste Storage \& Disposal.

\subsection{TANK FARM CONTRACTOR PHASE 1 FEED DELIVERY, STORAGE AND DISPOSAL MISSION SUMMARY FOR 2006 HOT START}

The Tank Farm Contractor Phase 1 Feed Delivery, Storage and Disposal Mission Summary for 2006 Hot Start (see Figure 3-3) shows the Retrieval, Projects, and Operations mission activities. The Mission Summary uses planning assumptions and information on tank waste composition, existing or planned equipment, and operational capabilities as defined in HNF-SD-WM-SP-012, Tank Farm ContractorOperation and Utilization Plan (Kirkbride 2000).

The Mission Summary operational need dates are indicated in Figure 3-3 by a black dot "•", and are used as "reference points/Operational Need Dates" (OND) for a set of key programmatic dates supporting the TFC's retrieval of tank waste for the Privatization Contractor under ORP's direction. The black dot represents the programmatic date when all construction upgrades to individual tanks, tank farms, and the Privatization Contractor interfaces and the startup and 
HNF-1946 REV 2

This page intentionally left blank 


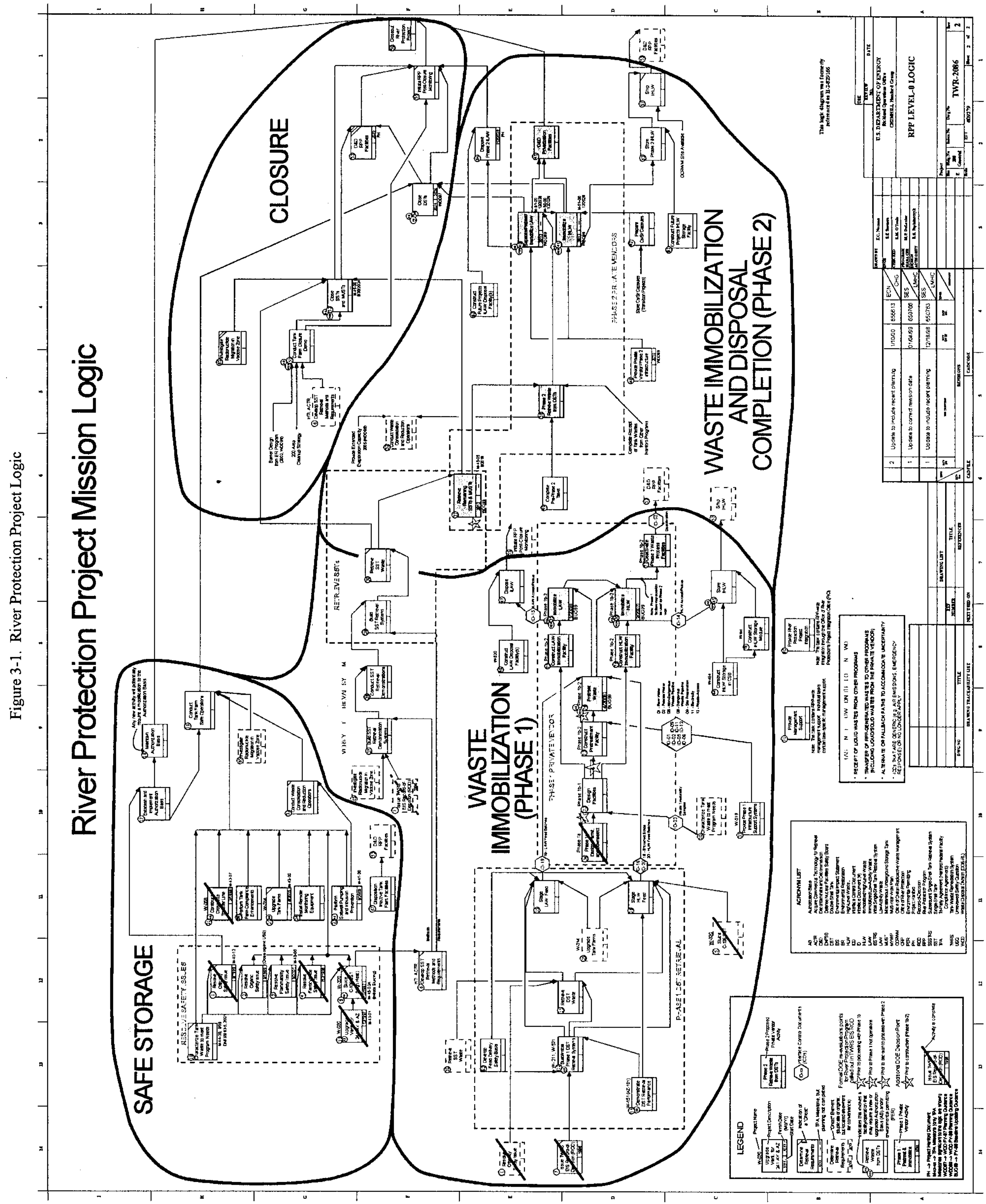


络

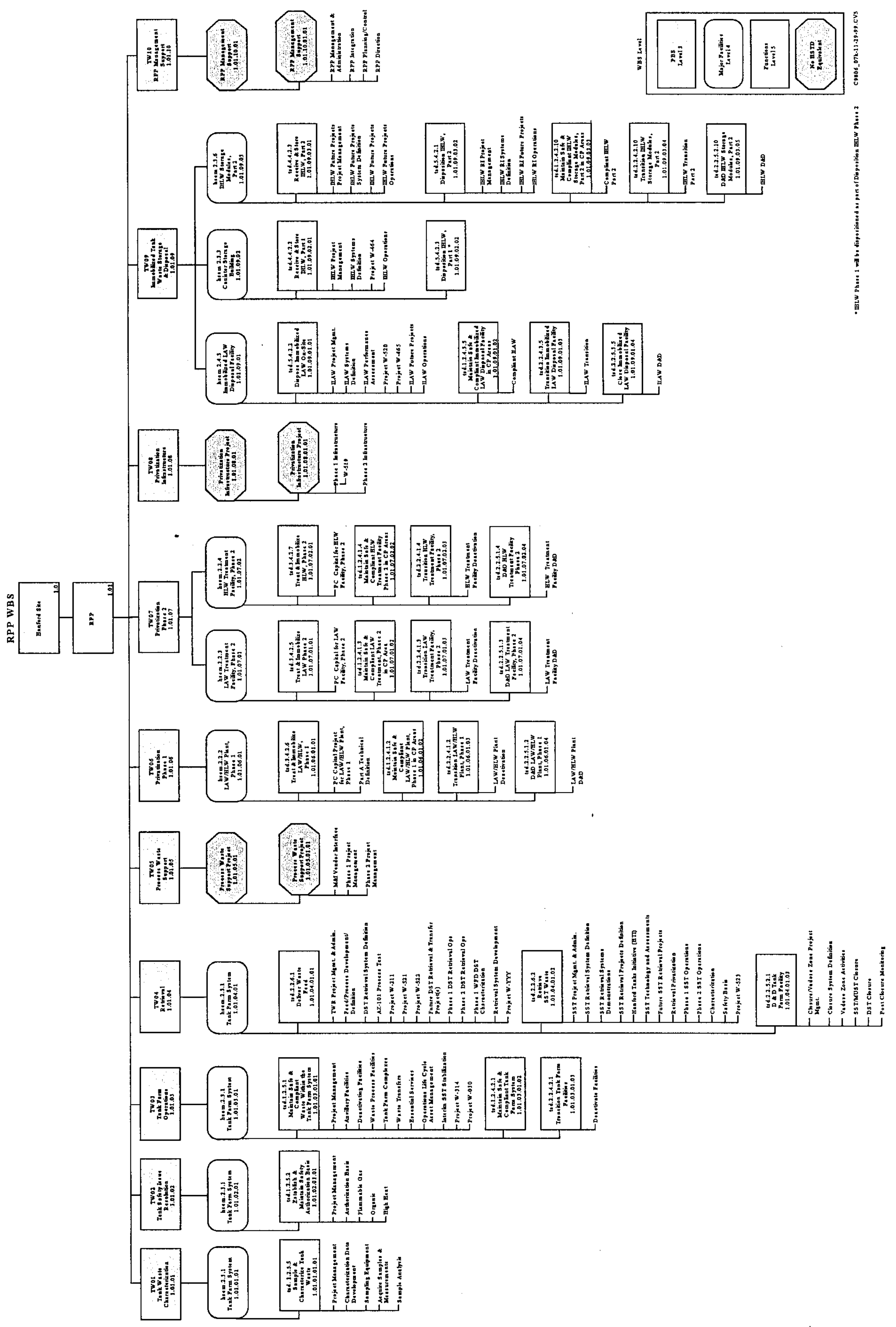




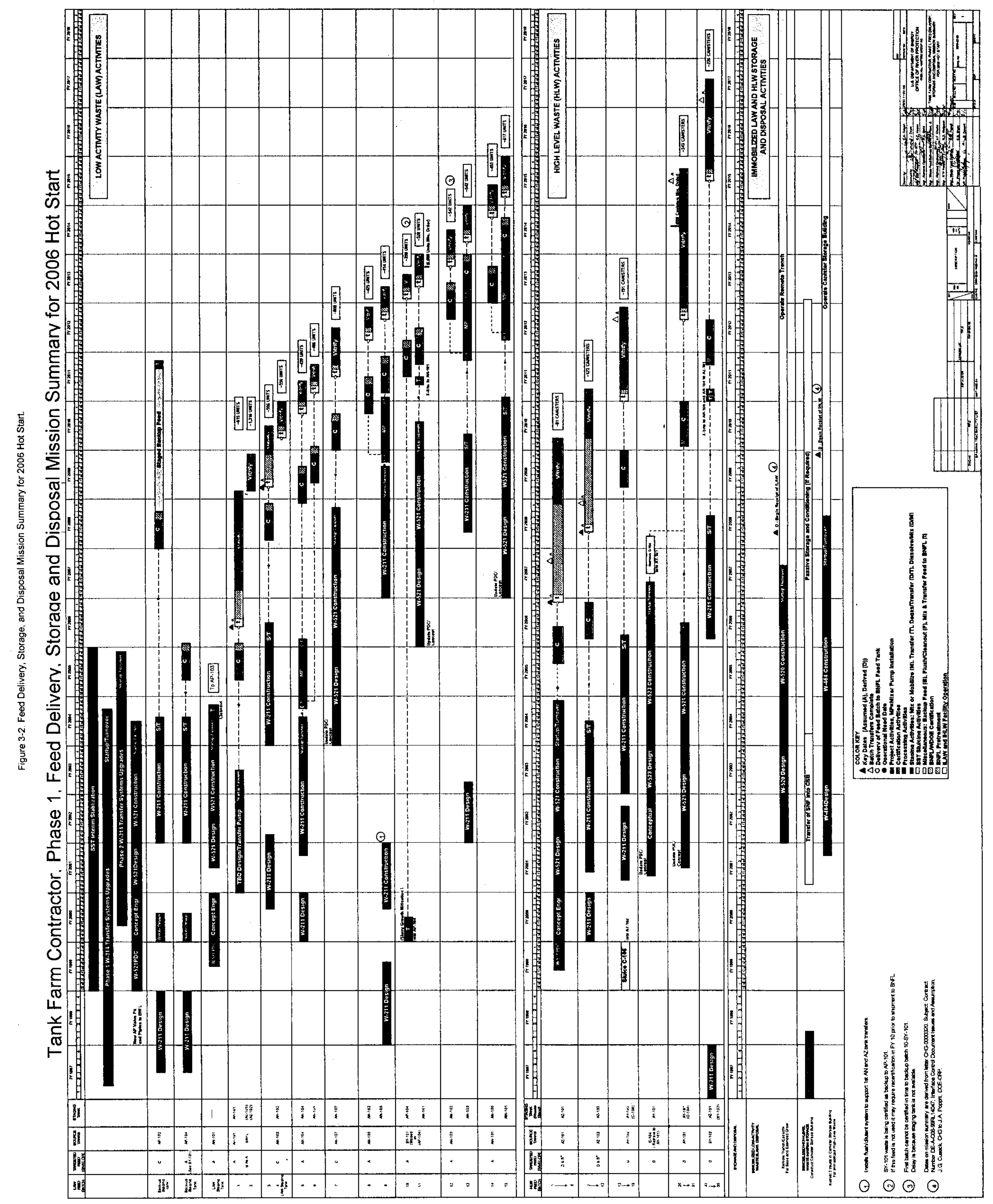




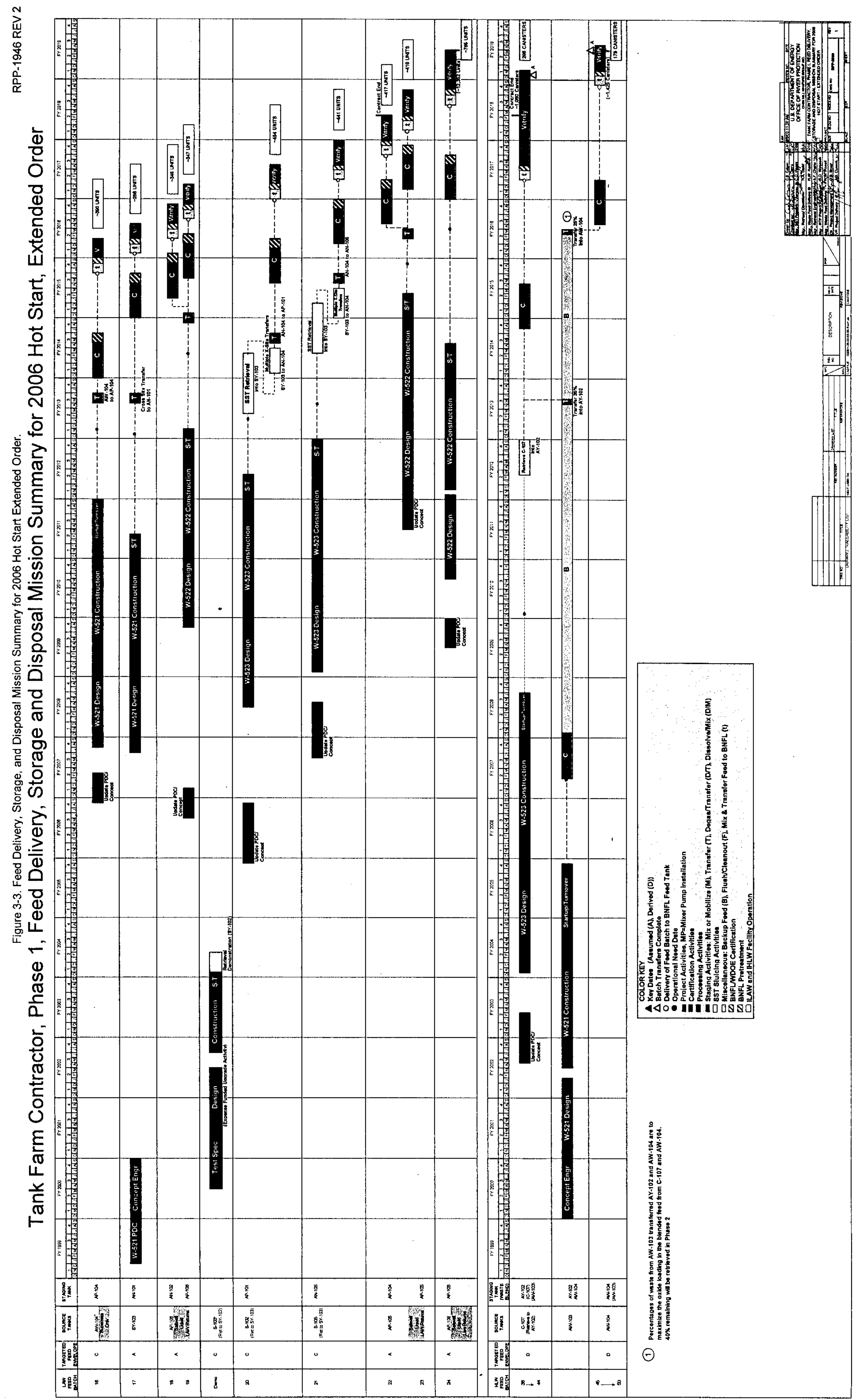


turnover activities completed. At this point, Tank Waste Operations has accepted the upgrades and is maintaining the WFD systems in support of the Retrieval and Disposal mission.

The OND represents the point in time beyond which activities preceding them in the integrated schedule cannot slip without incurring programmatic risk in delivering waste to the Privatization Contractor. In addition, the OND is part of the tank backup strategy that permits the TFC to have tanks being delivered in Phase 1 backed up by succeeding tanks. The placement of the black dots represents bringing forward the next tank in sequence, certifying the waste, and delivering the waste to the Privatization Contractor in time to meet delivery requirements for the earlier waste if the waste from the primary tank is not certifiable.

\subsection{LEVEL 1 LOGIC}

The Level 1 Logic defines and details the Phase 1 scope and sequence of activities required to complete the Retrieval and Disposal mission as reflected in the WBS. Level 1 Logics were prepared for Low-Activity Waste Feed, High-Level Waste Feed, Immobilized LAW, and Immobilized HLW projects; Infrastructure Phase 1 activities; the Single-Shell Tank, Management Assessment, and Waste Feed Project Definition projects; the Waste Feed Delivery Program; and the RPP Tank Waste Retrieval/Disposal Division.

These logics were used to further define the scope, schedule, and cost estimates as documented in the TBR packages. Each activity on the Level 1 Logic represents a TBR package. Primary activity owners, including Operations, Projects, Environmental, Nuclear Safety \& Licensing, Retrieval., Characterization, Maintenance, Management, and selected activities for ORP and the Privatization Contractor are identified on the Level 1 Logic diagram. A critical path for each feed batch is identified on the tank-specific logic diagrams.

\subsection{CROSSWALK FROM THE LEVEL 1 LOGIC TO THE WORK BREAKDOWN STRUCTURE}

Appendix B is a crosswalk for the Tank Waste Retrieval and Disposal Phase 1 Privatization scope as identified on the Level 1 Logic to Level 6 of the WBS. 
HNF-1946 REV 2

This page intentionally left blank. 


\section{0 $\operatorname{CosT}$}

The TFC budget requirements have been developed in accordance with ORP guidance and the PIO planning assumptions. This section provides the cost summaries, which resulted from a thorough analysis of the labor and non-labor resources needed to execute Phase 1 Privatization. Fiscal year 2001 funding has been constrained to $\$ 382.1 \mathrm{M}$. Budget/fund levels are unconstrained from FY 2002 through the life cycle and are tied to full compliance requirements.

The RTP integrated planning effort has reduced the funding requirements for Phase 1 from the FY 2000 Multi-Year Work Plan (MYWP) (CHG 2000a). Section 6.0 of this document identifies the major areas of scope changes and the Financial Analysis for Phase 1 Privatization for the Tank Farm Contractor, HNF-2017, Rev. 2, further explains the financial changes and adjustments for the TFC.

\subsection{PRICING BASIS}

The resources specified in the TBR package cost estimates were priced in the schedule using a P3 resource rate library based on rates provided to the ORP as referenced in Contract No. DE-AC06-99RL14047; Revised Submittal of Fiscal Year 2000 Indirect Annual Work Plans dated November 30, 1999 (Barrett 2000), and Contract No. DE-AC06-99RL14047; Fiscal Year 2001 and Out-Year Pricing Rates, dated December 16, 1999 (Short 2000a).

The labor and non-labor rates in the library are fully burdened with the applicable adders except for escalation.

\subsection{ESCALATION ASSUMPTIONS}

Escalation has been applied to the project costs as directed by Contract No. DE-A06-99RL14047, U.S. Department of Energy, Office of River Protection (ORP) Mission Planning Guidance for Fiscal Year (FY) 2002, Revision 1, dated February 03, 2000 (Short $2000 \mathrm{~b}$ ). Outyears beyond FY 2008 are escalated at $2.0 \%$ annually.

Table 4-1. Escalation Assumptions Operating and Maintenance Projects/All Construction.

\begin{tabular}{|c|c|c|}
\hline Fiscal Year & Annual Rate (\%) & Cumulative Rate (\%) \\
\hline 2001 & 2.0 & 2.0 \\
\hline 2002 & 2.0 & 4.0 \\
\hline 2003 & 2.0 & 6.1 \\
\hline 2004 & 2.0 & 8.2 \\
\hline 2005 & 2.0 & 10.4 \\
\hline 2006 & 2.0 & 12.6 \\
\hline 2007 & 2.0 & 14.9 \\
\hline
\end{tabular}




\subsection{SUMMARY COST TABLES}

The cost tables (Tables 4-2 and Figure 4-1 and Tables 4-3 through 4-5) summarize the budget requirements by fiscal year through FY 2018. The cost tables cover the following items:

- Retrieval and Disposal Phase 1 Costs by Project Baseline Summary. Table 4-2 represents the time-phased budget requirements (unescalated) by Project Baseline Summary for the Retrieval and Disposal Phase 1 mission from FY 2000 through FY 2018. Figure 4-1 shows the relative size of each Project Baseline Summary for Phase 1.

- Retrieval and Disposal Phase 1 Costs by Work Breakdown Structure - Level 6. Table 4-3 represents the time-phased budget requirements (unescalated) by the WBS-Level 6 element for the Retrieval and Disposal Phase 1 mission.

- Life-Cycle Cost Summary for the Tank Farm Contractor. Table 4-4 provides the life-cycle cost profile for the TFC from FY 1997 through FY 2018.

- Retrieval and Disposal Cost Loading Report. Table 4-5 summarizes the Retrieval and Disposal costs by fiscal year (FY 2000 through FY 2018) necessary to perform work defined in the TBR packages in support of the Phase 1 mission.

Interfaces with other essential Hanford Site facilities have been coordinated and integrated. The cost for these facilities are not included in this document, but are funded and supported through Phase 1 by Fluor Hanford, Inc. (FHI). The excluded facility base operations are as follows:

- The 222-S Laboratory base operation costs to support tank characterization

- The 242-A Evaporator operations

- The Effluent Treatment Facility, which is necessary to support treatment of the 242-A Evaporator condensate and supports the Privatization Contractor

- The Liquid Effluent Retention Facility, which is necessary for treatment of radioactive or dangerous liquid effluents generated by the Privatization Contractor

- The Treated Effluent Disposal Facility, which is necessary to provide treatment of nonradioactive, non-dangerous liquid effluents generated by the Privatization Contractor. 
Table 4-2. Retrieval and Disposal Phase 1 Costs by Project Baseline Summary for Fiscal Years 2000 through 2018-Unescalated. (\$ in 000's)

\begin{tabular}{|c|c|c|c|c|c|c|c|c|c|c|c|c|}
\hline 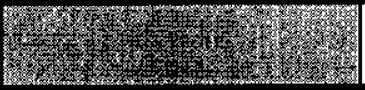 & FYOO & FY01 & Y02 & FY03 & FY04 & =Y05 & FY06 & FYo7 & FY08 & $\begin{array}{l}\text { Sub } \\
\text { Total }\end{array}$ & $\begin{array}{l}\text { FY09 - } \\
\text { FY18 }\end{array}$ & Total \\
\hline $\begin{array}{l}\text { Tw01 Characterization } \\
\text { Support to Retrieval }\end{array}$ & $\$ 17$ & $\$ 10$ & & 6 & $\$$ & $\$$ & 6 & $\$$ & $\$$ & 70 & 36 & 106 \\
\hline W03 Project W-314 & $\$ 26$ & $\$ 51$ & $\$ 68$ & $\$ 31$ & $\$ 31$ & $\$ 11$ & $\$$ & $\$$ & $\$$ & $\$ 218$ & $\$$ & $\$ 218$ \\
\hline TW04 Retrieval Project & $\$ 51$ & $\$ 70$ & $\$ 171$ & $\$ 195$ & $\$ 132$ & $\$ 132$ & $\$ 138$ & $\$ 107$ & $\$ 93$ & $\$ 1,089$ & $\$ 637$ & $\$ 1,726$ \\
\hline $\begin{array}{r}\text { Waste Feed Delivery } \\
\text { Subtotal }\end{array}$ & $\$ 94$ & $\$ 131$ & $\$ 247$ & $\$ 232$ & $\$ 172$ & $\$ 149$ & $\$ 144$ & $\$ 110$ & $\$ 98$ & $\$ 1,377$ & $\$ 673$ & $\$ 2,050$ \\
\hline $\begin{array}{l}\text { W05 Process Waste } \\
\text { Support }\end{array}$ & 1 & & $\$$ & & $\$$ & 2 & 2 & 2 & - & 13 & $\$$ & 13 \\
\hline $\begin{array}{l}\text { TW08 Privatization } \\
\text { nfrastructure }\end{array}$ & $\$ 19$ & $\$ 17$ & $\$$ & & $\$ 11$ & $\$ 34$ & $\$ 14$ & $\$ 15$ & $\$ 15$ & $\$ 139$ & $\$ 148$ & $\$ 287$ \\
\hline $\begin{array}{l}\text { W09 Immobilized Waste } \\
\text { Storage and Disposal }\end{array}$ & $\$$ & $\$ 10$ & $\$ 11$ & $\$ 19$ & $\$ 39$ & 65 & 44 & $\$ 13$ & 24 & $\$ 234$ & $\$ 590$ & $\$ 824$ \\
\hline $\begin{array}{l}\text { Total Retrioval and } \\
\text { Reflect Digosal Rhase } 1\end{array}$ & $\$ 123$ & $\$ 159$ & 267 & 259 & $\$ 224$ & 250 & $\$ 204$ & $\$ 140$ & 137 & $\$ 1,763$ & $\$ 1,411$ & $\$ 3,174$ \\
\hline
\end{tabular}

Figure 4-1. Total Cost by Project Baseline Summary for Fiscal Years 2000 through 2018 - Unescalated. (\$ in 000's)

Based Upon Proposed Retrieval and Disposal Phase 1 Budget (\$3174M)

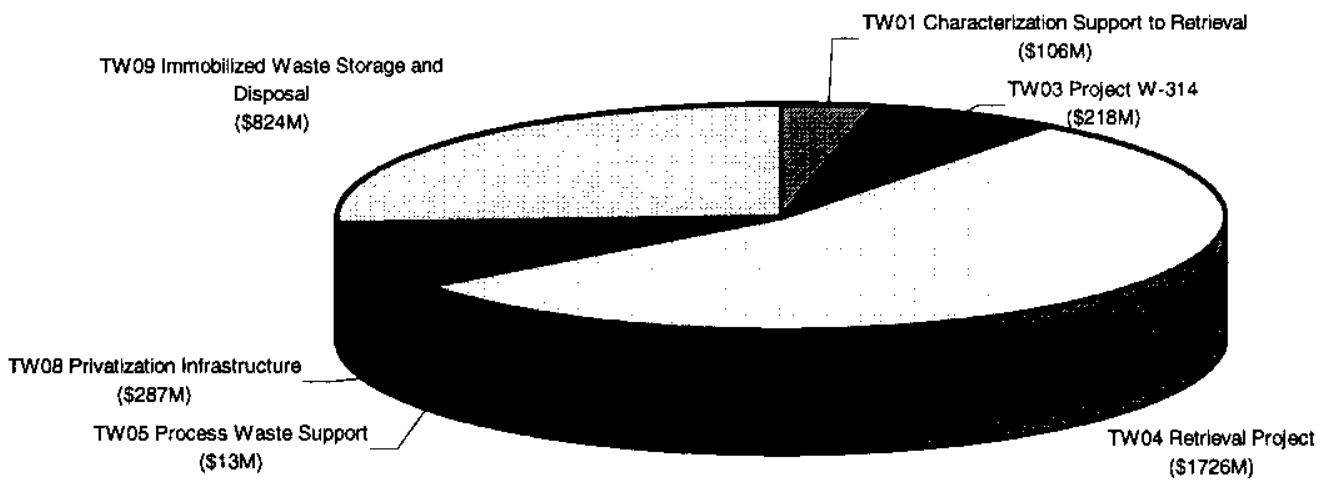




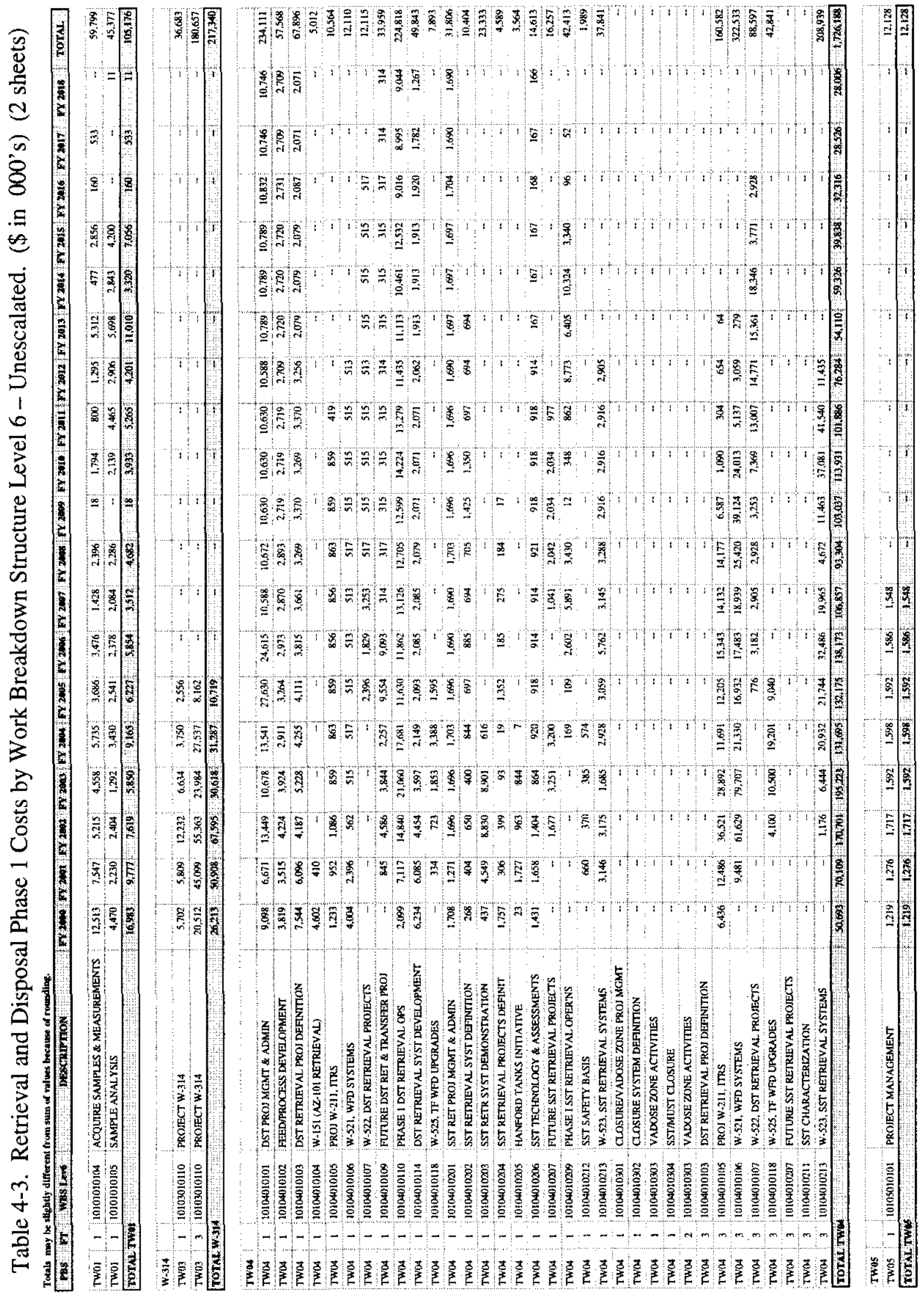




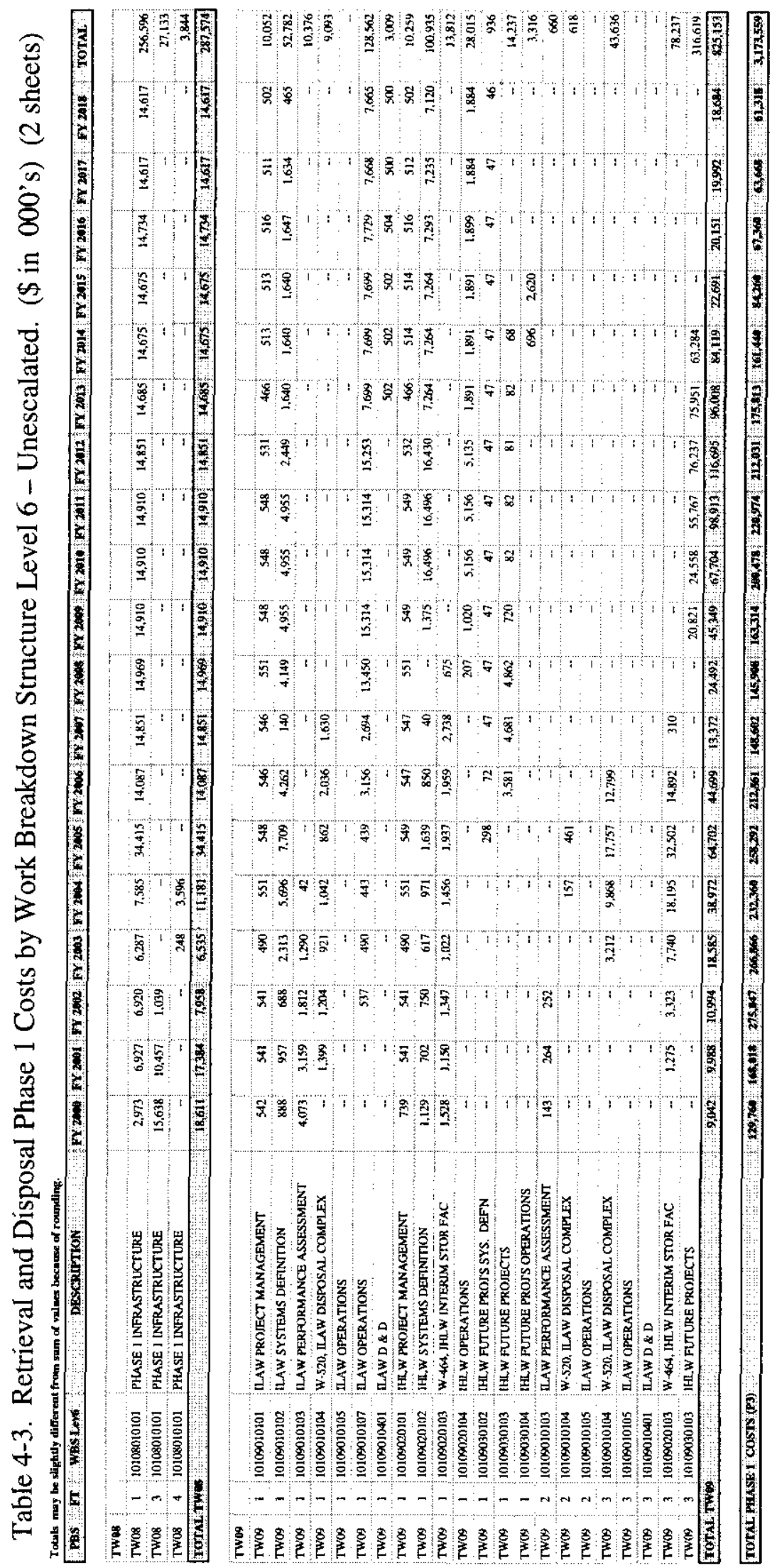


HNF-1946 REV 2

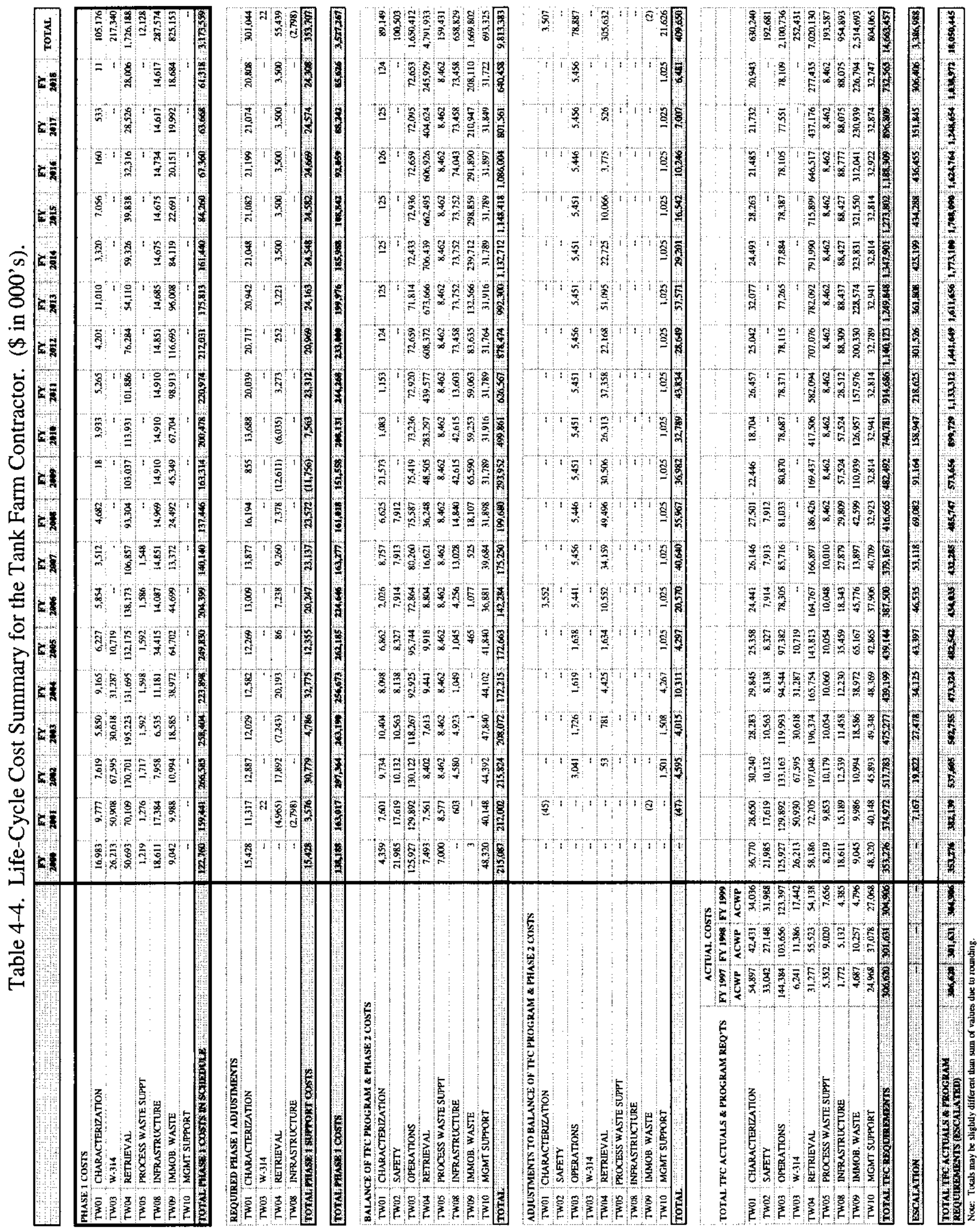


HNF-1946 REV 2

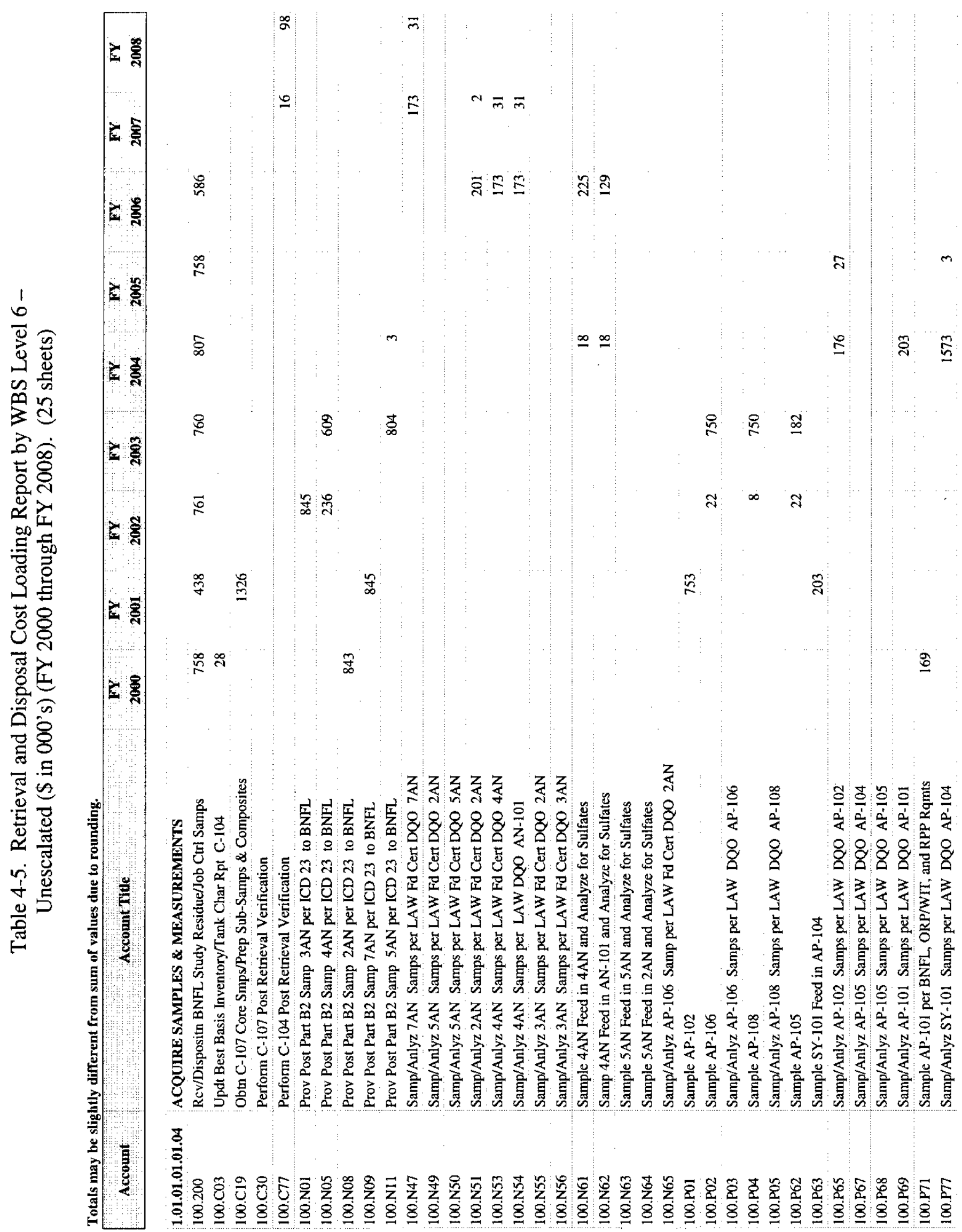




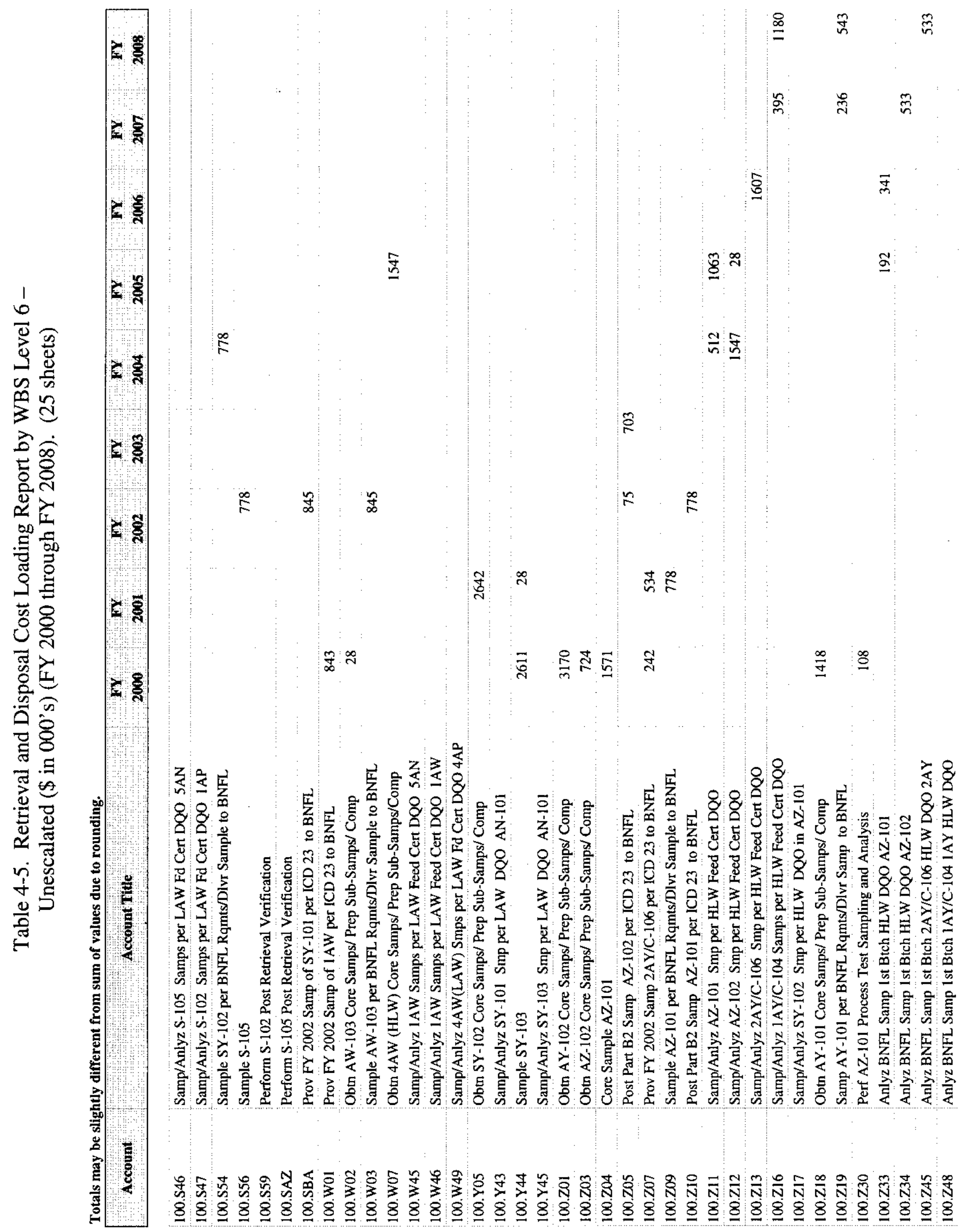


HNF-1946 REV 2

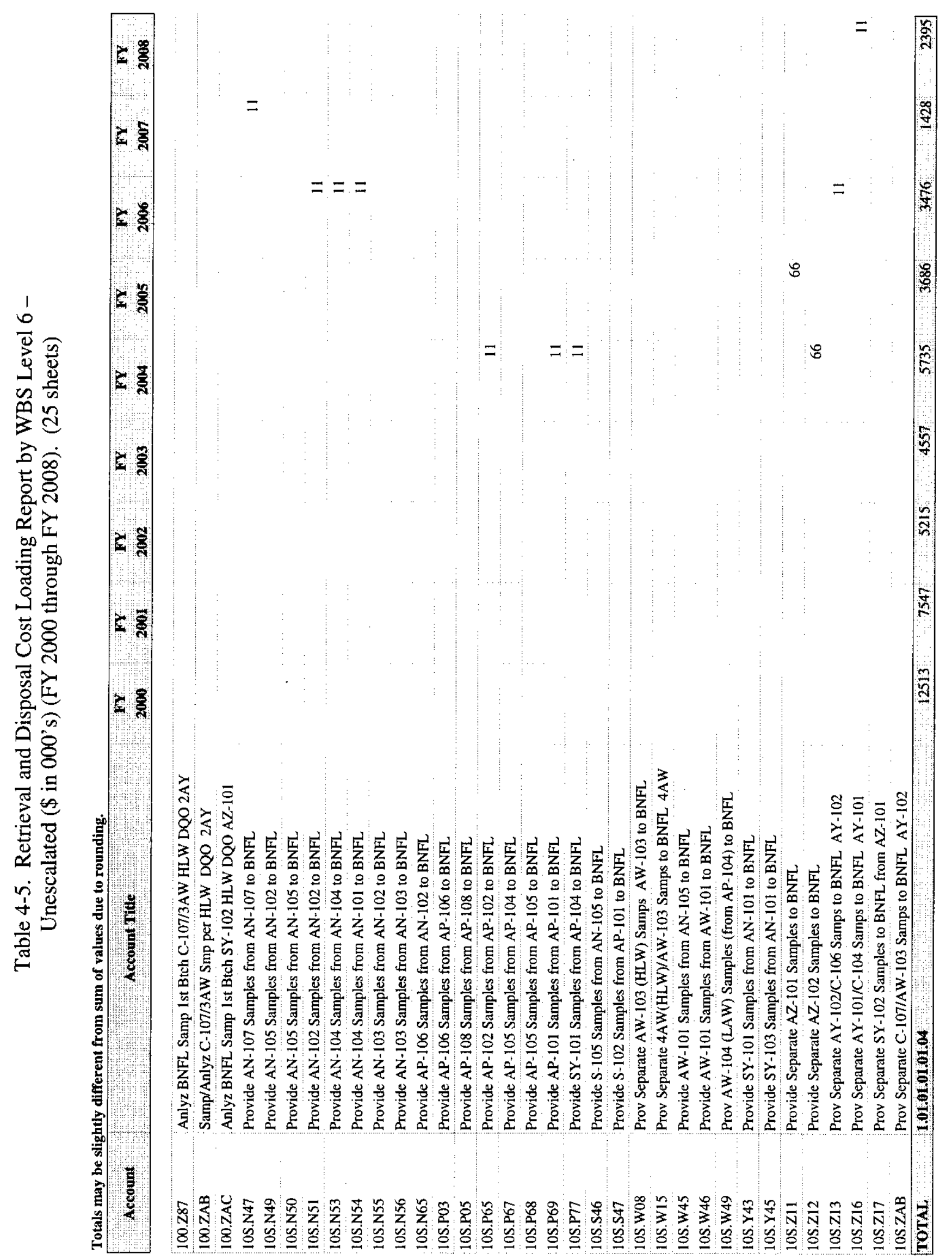


HNF-1946 REV 2

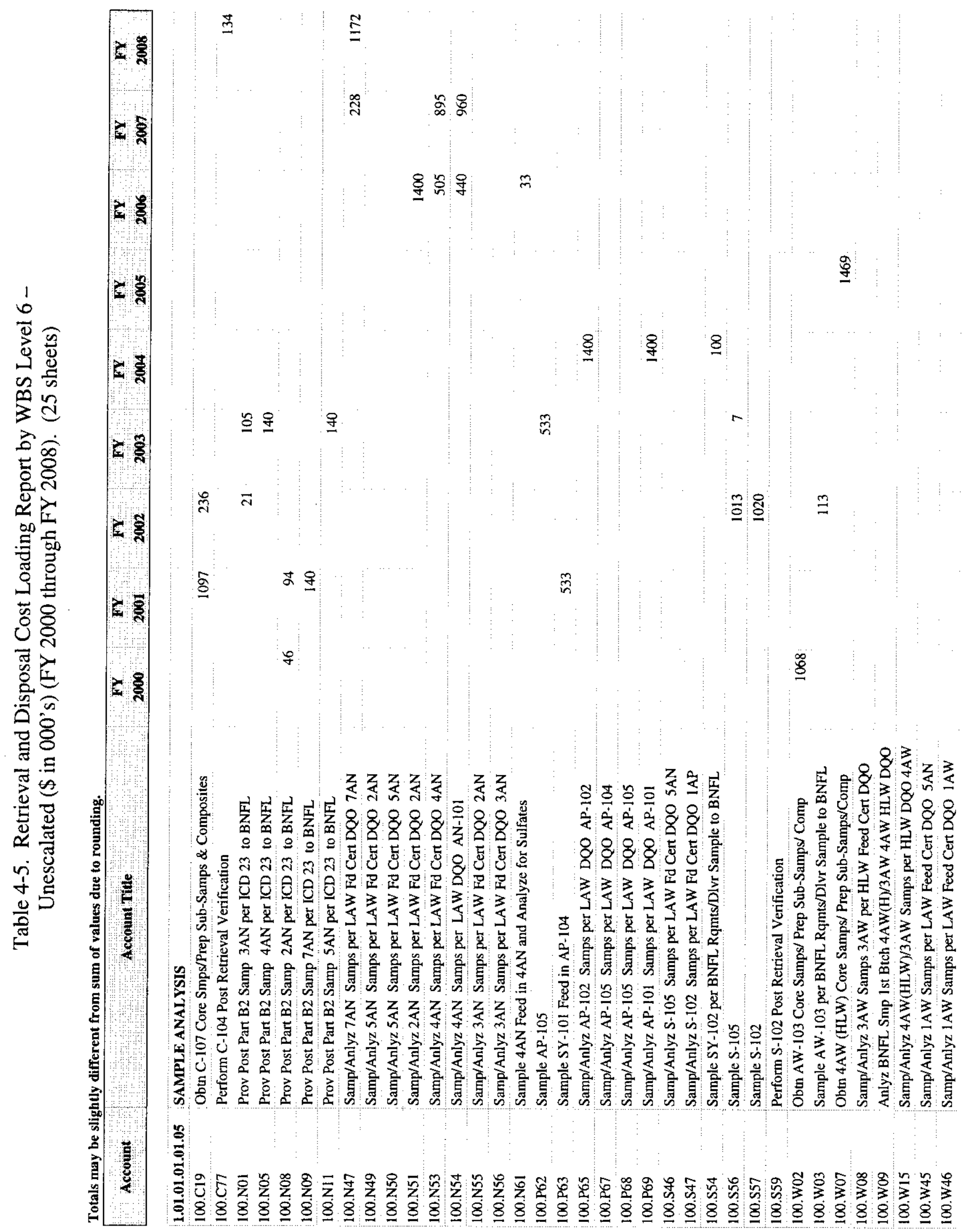


HNF-1946 REV 2
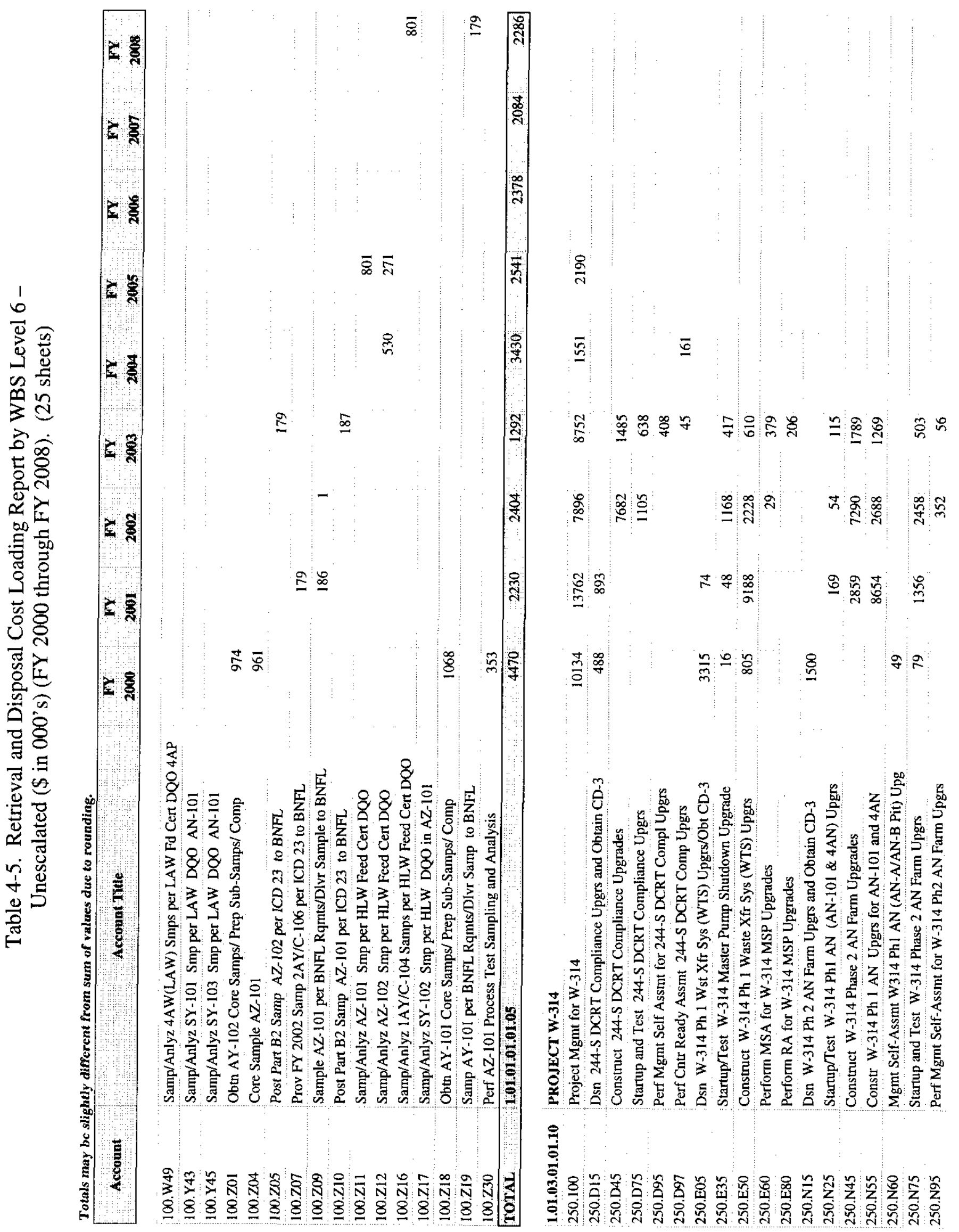

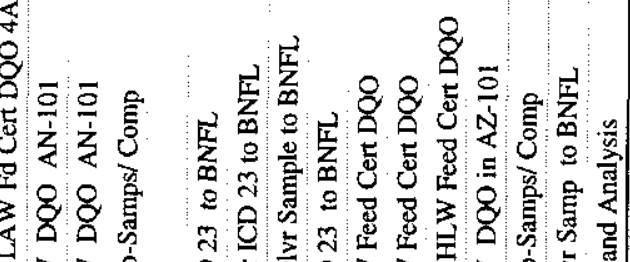

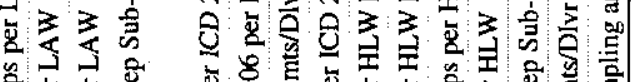

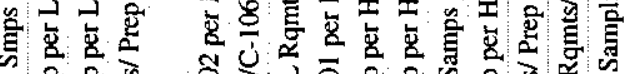

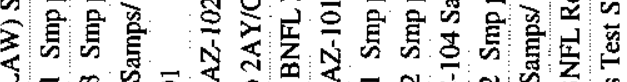

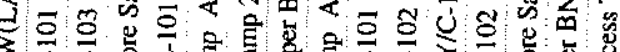

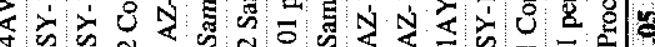

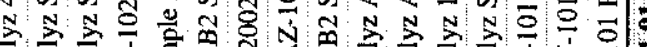

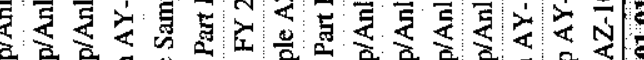

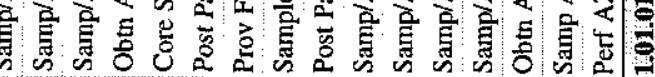

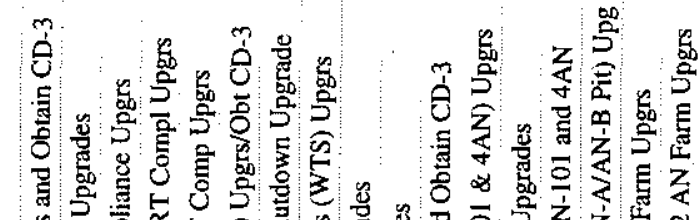

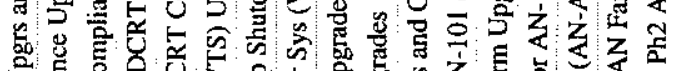

5ै.

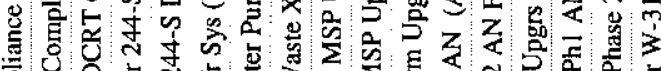

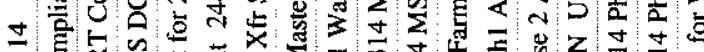
t3

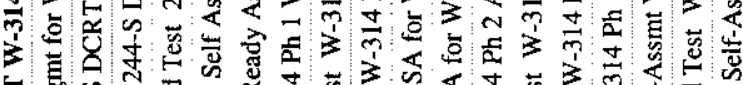

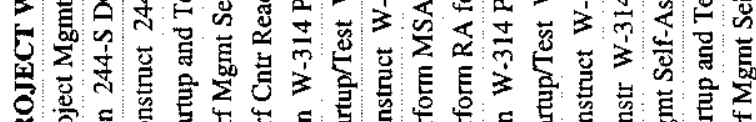

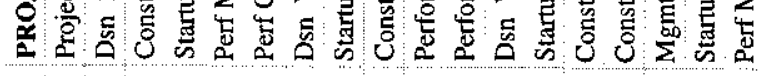

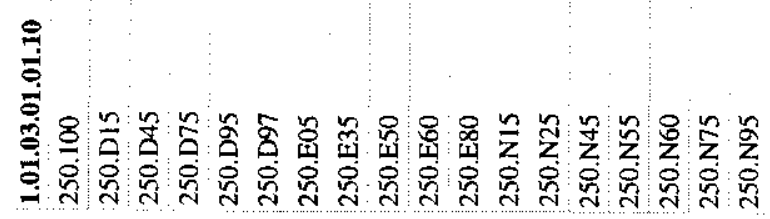




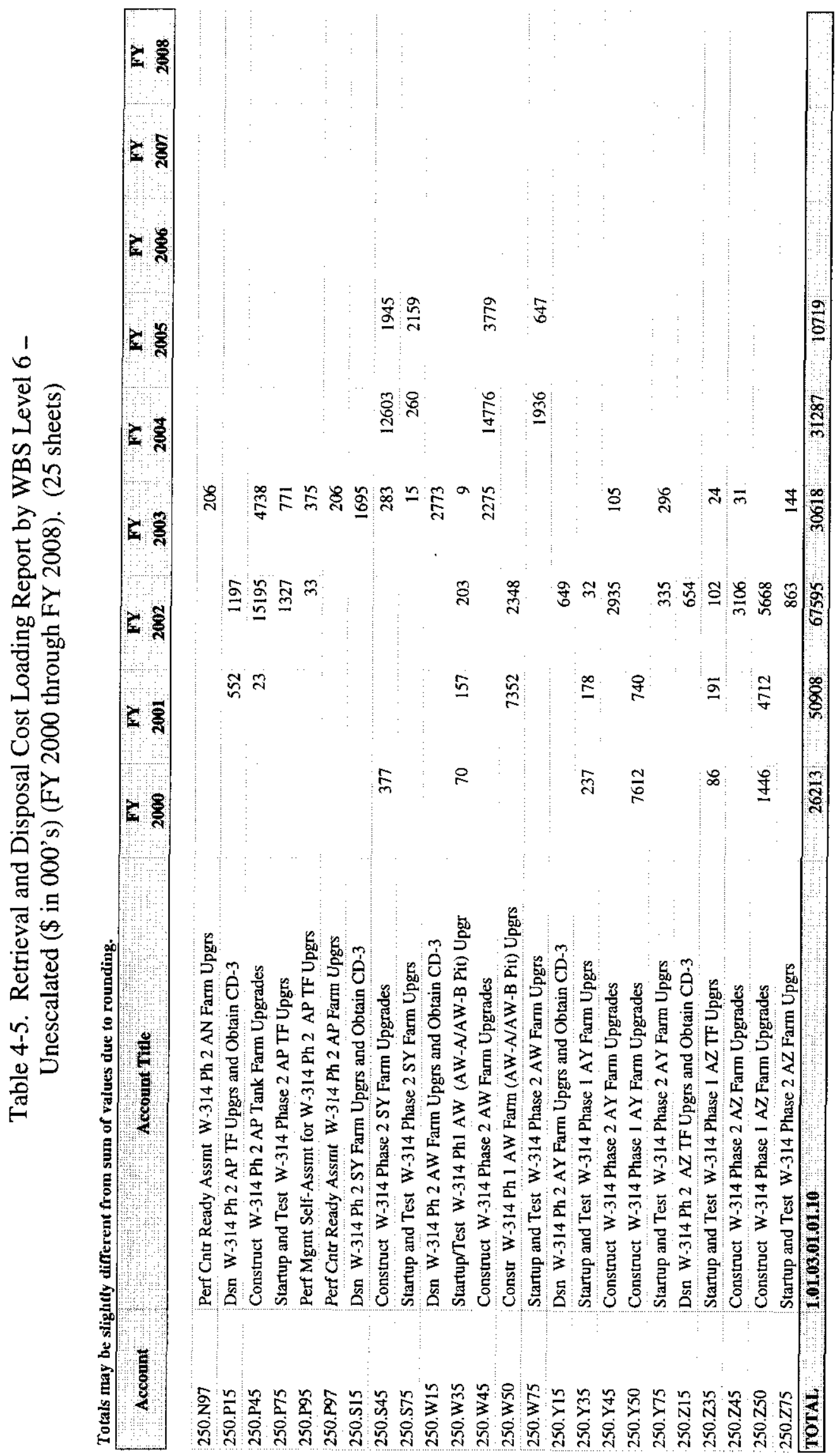

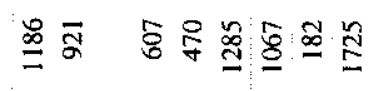

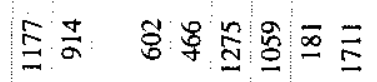

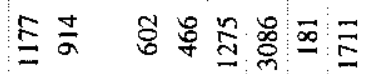

है Ш অ

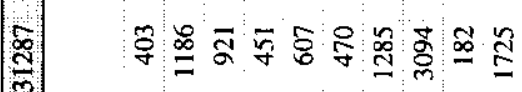

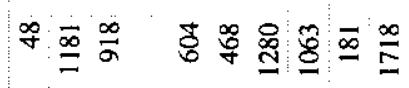

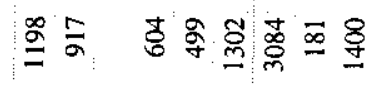

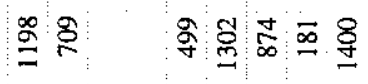

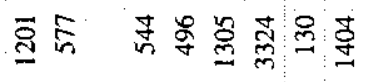
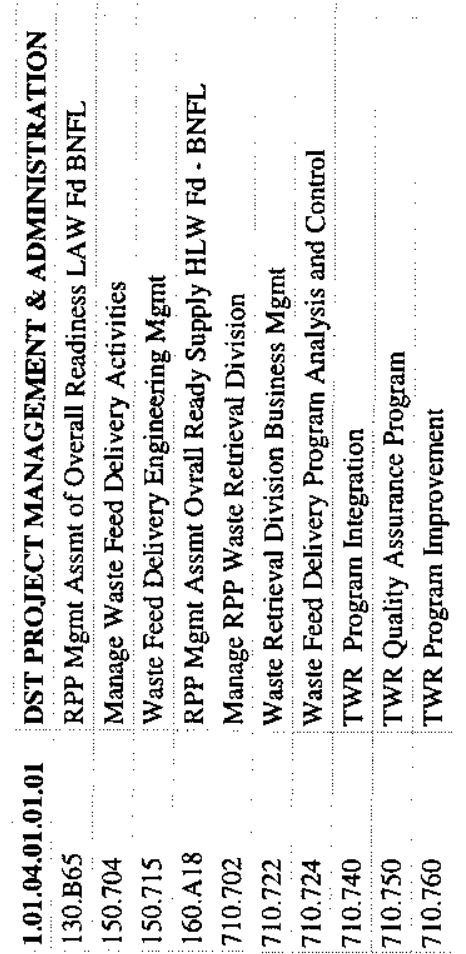
HNF-1946 REV 2

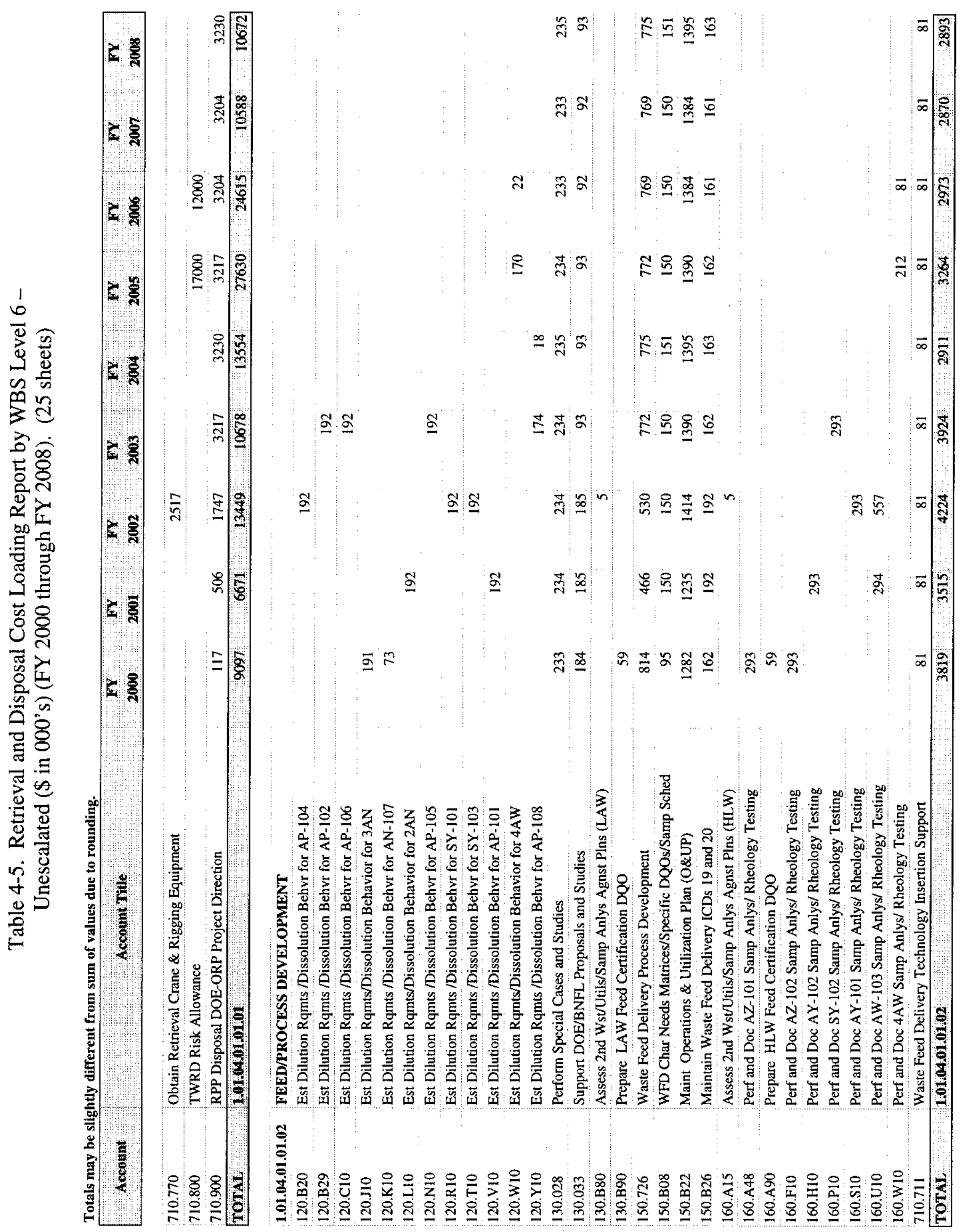




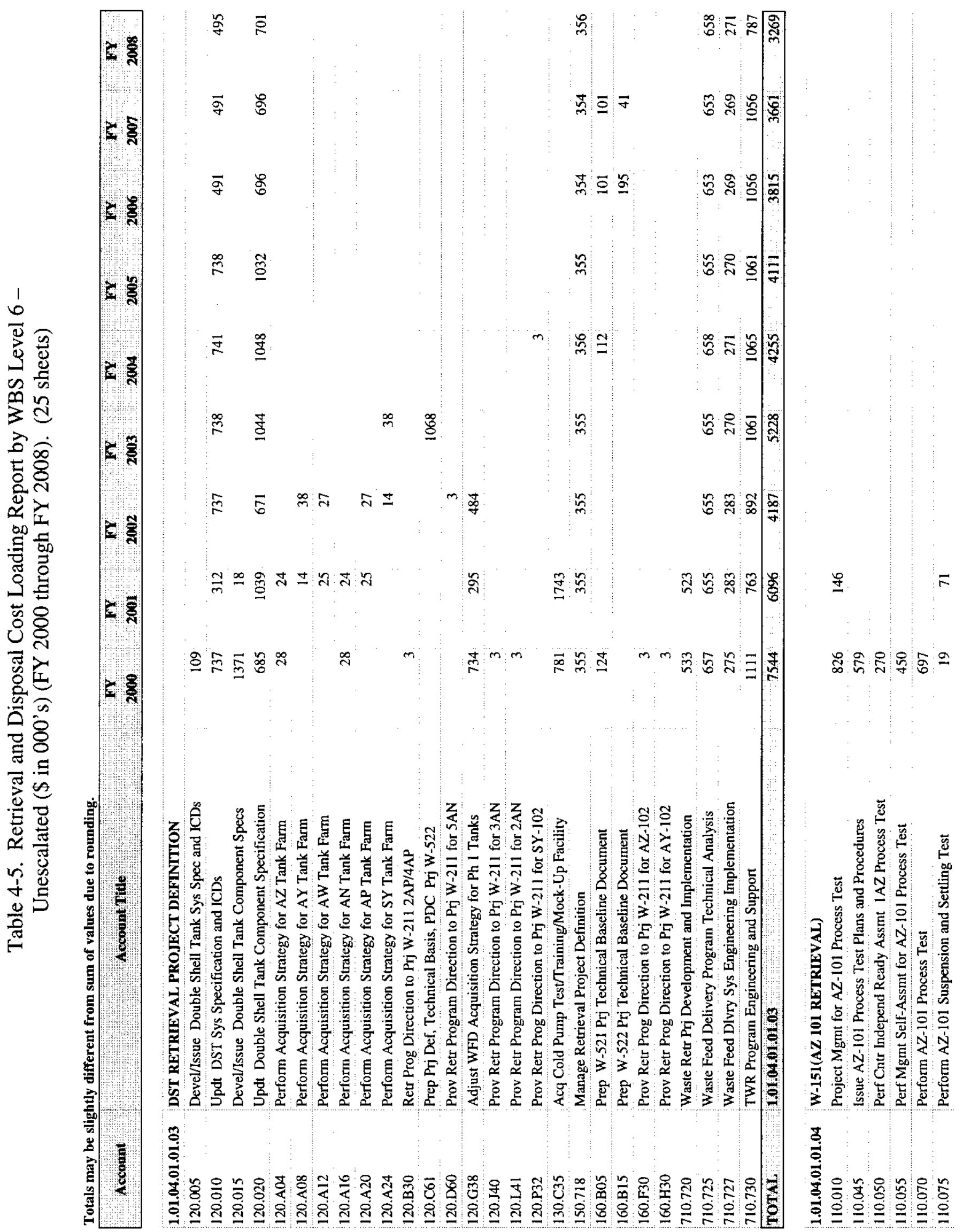


HNF-1946 REV 2

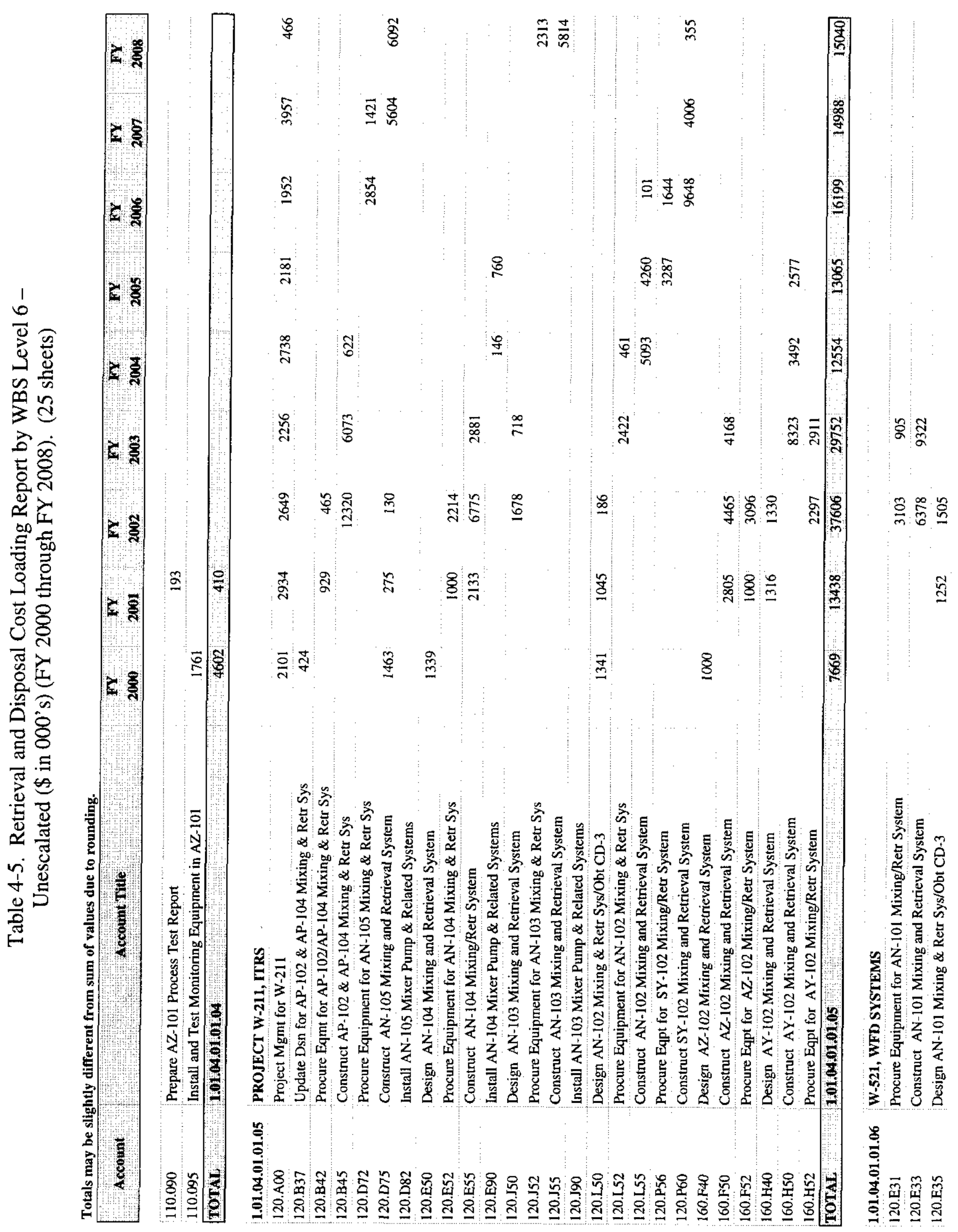


HNF-1946 REV 2

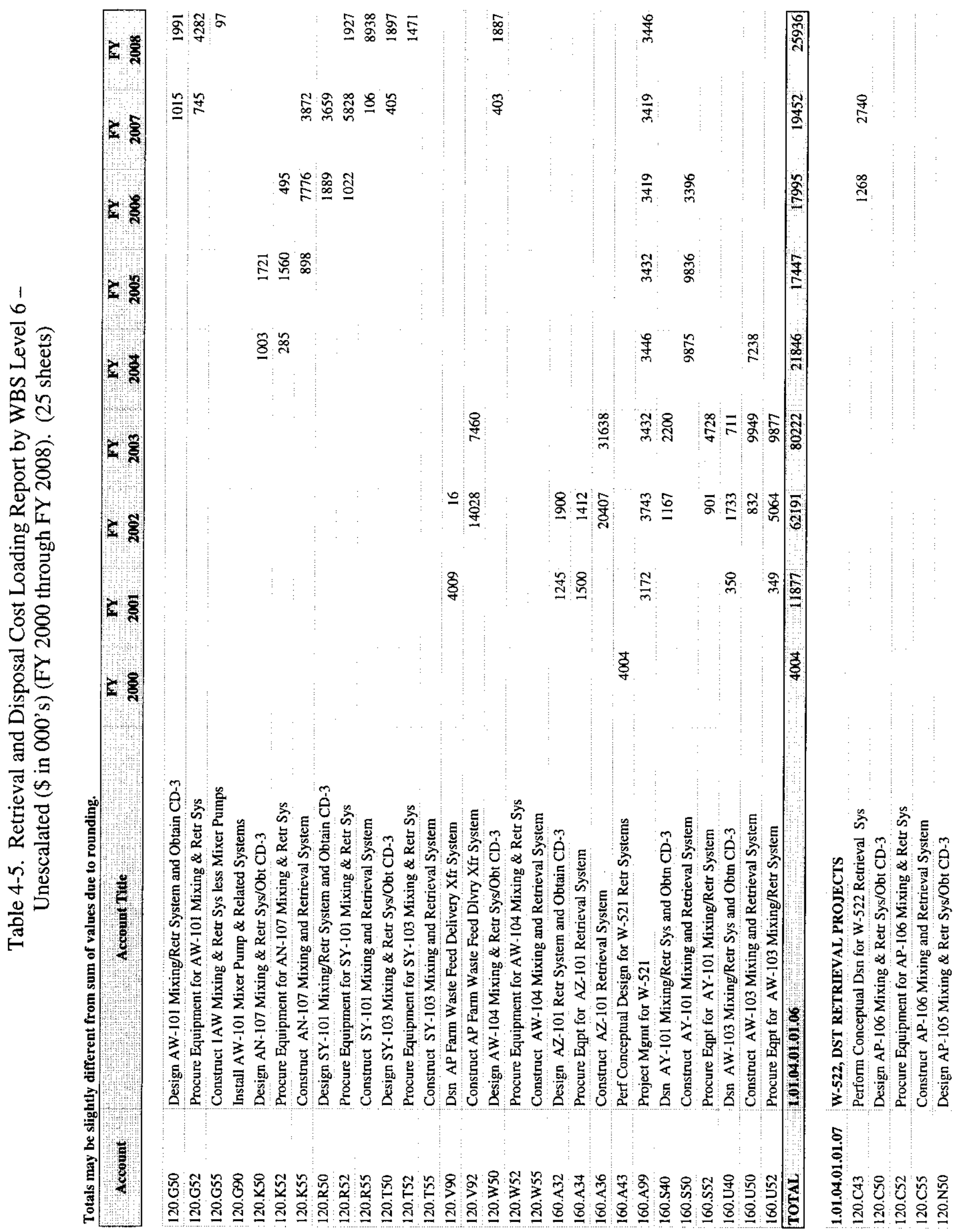


HNF-1946 REV 2

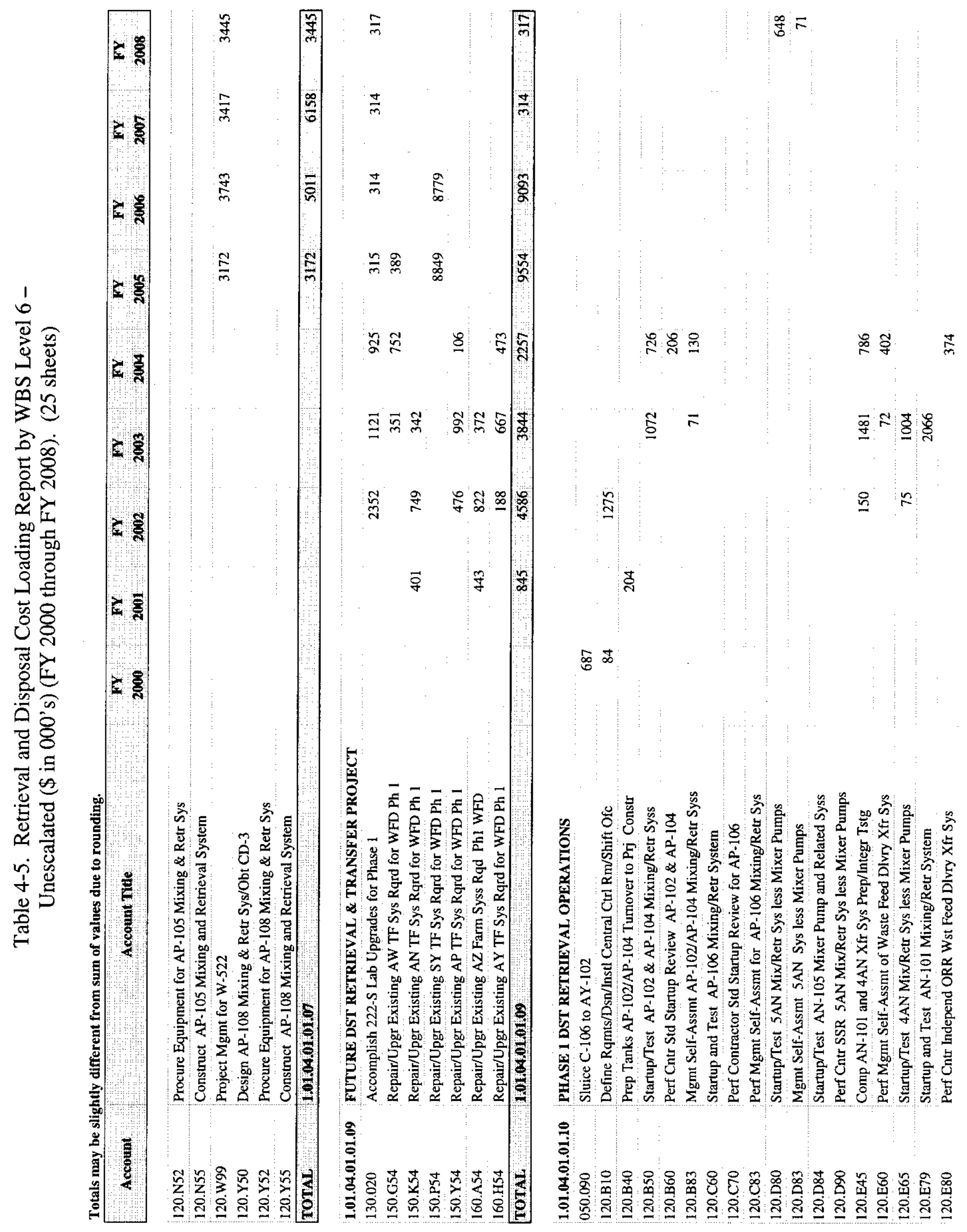


HNF-1946 REV 2

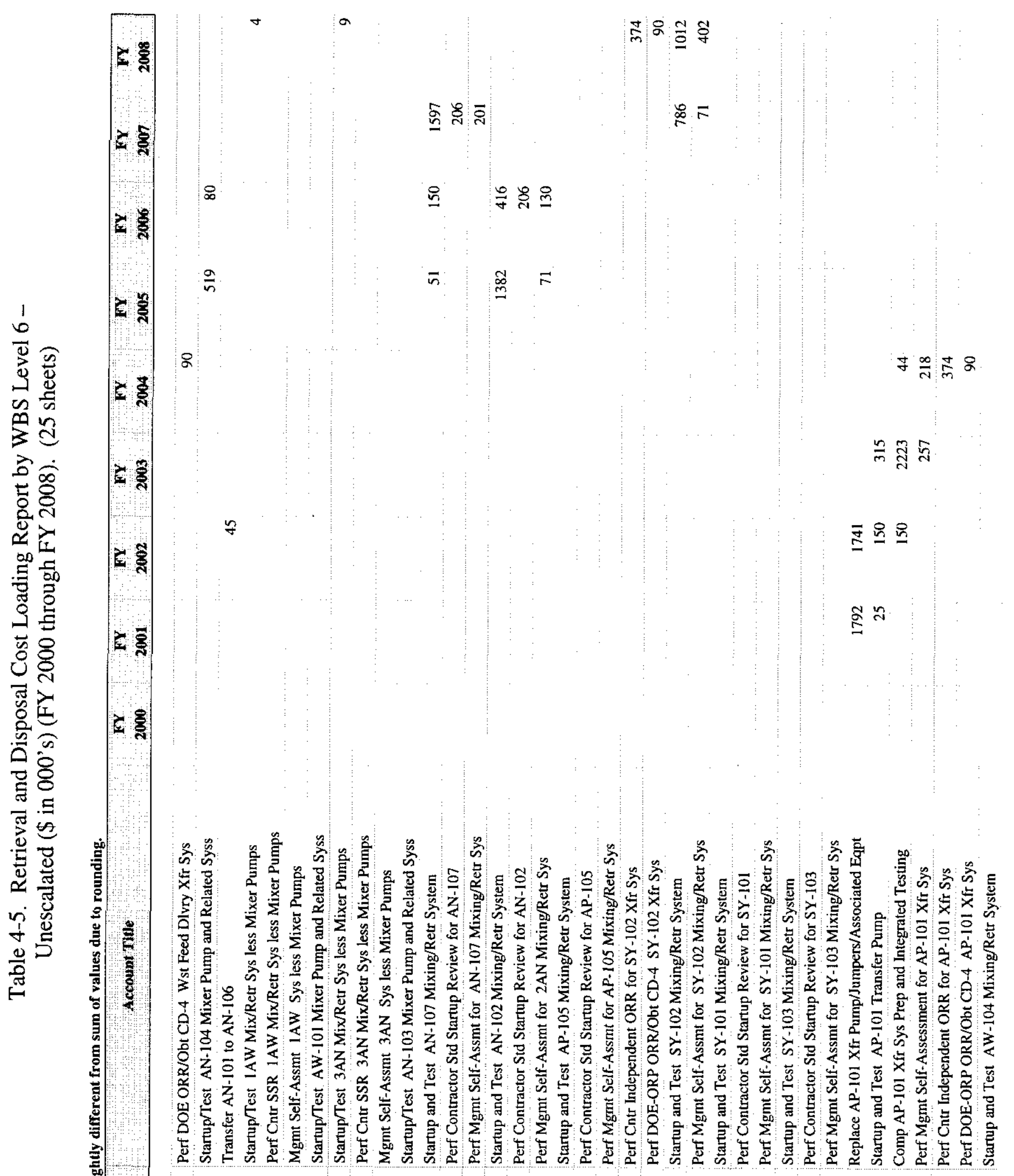

है

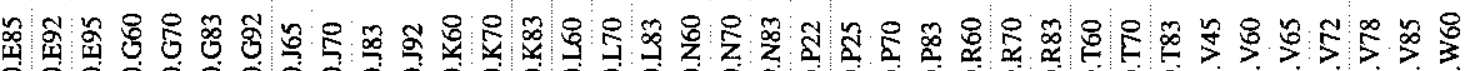

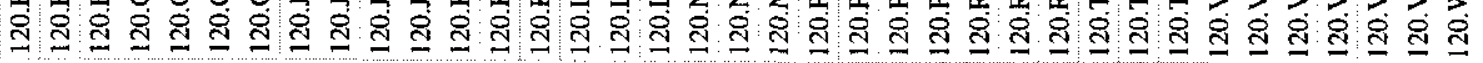


HNF-1946 REV 2

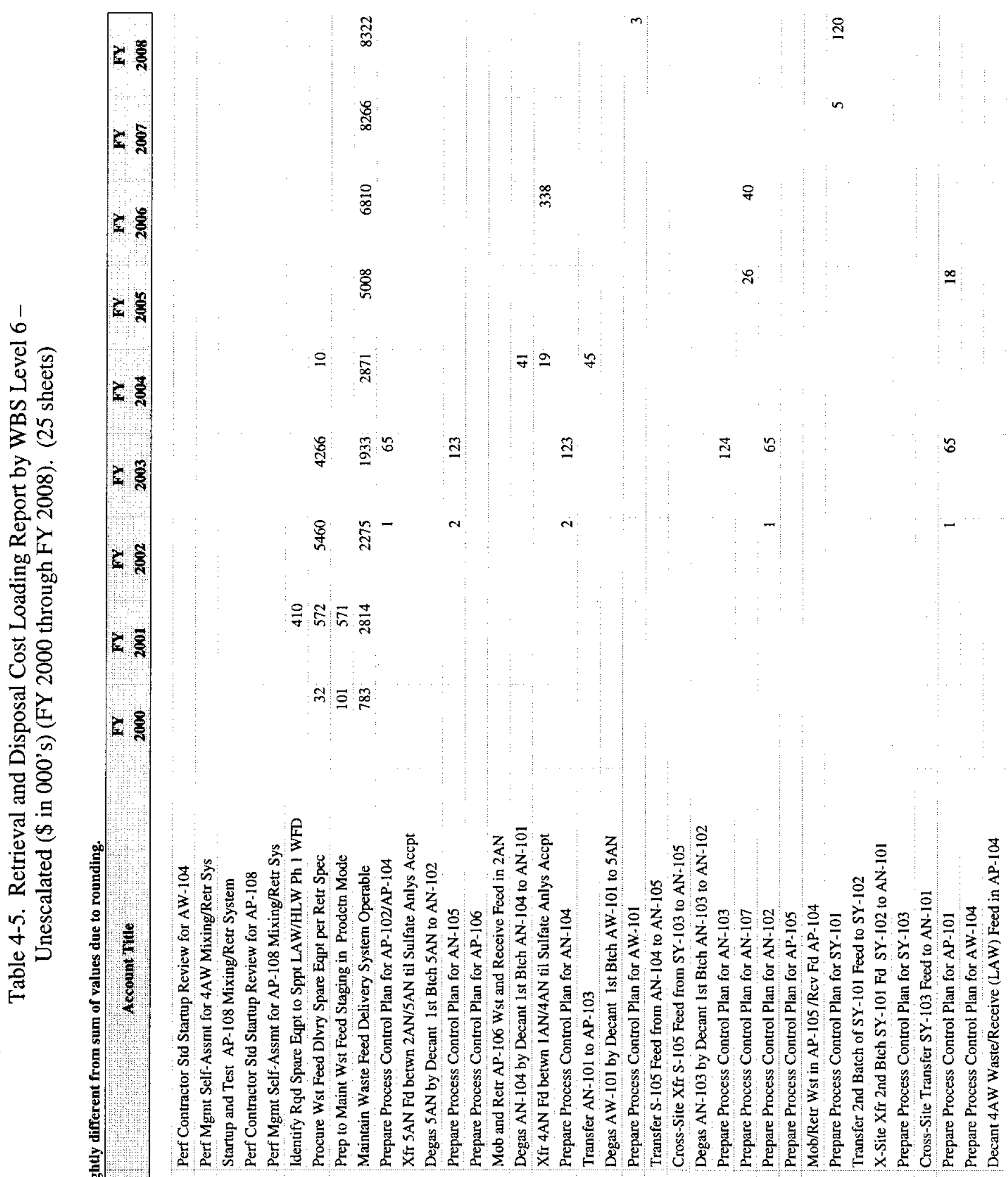

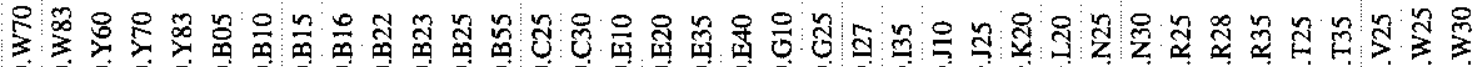

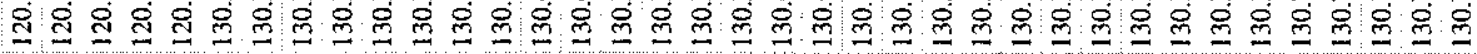




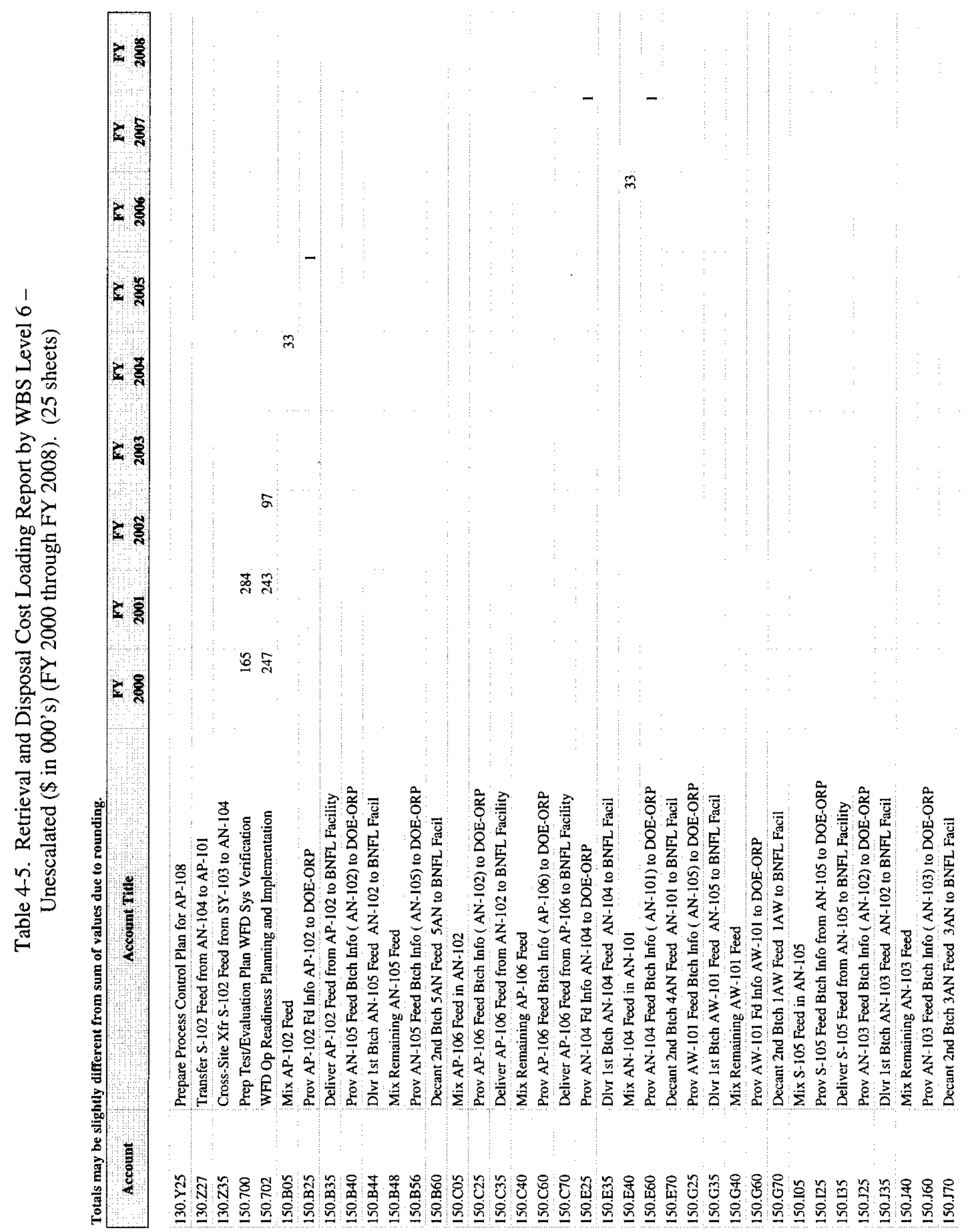



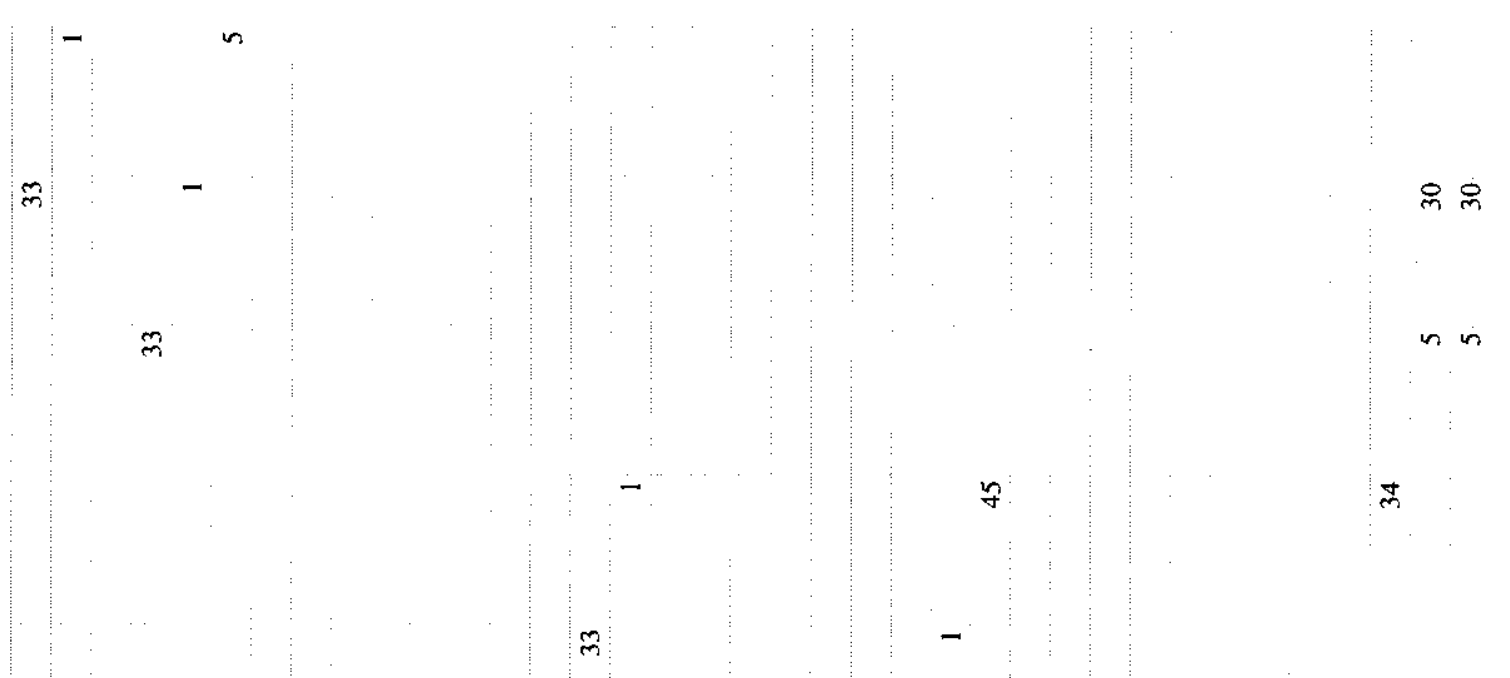


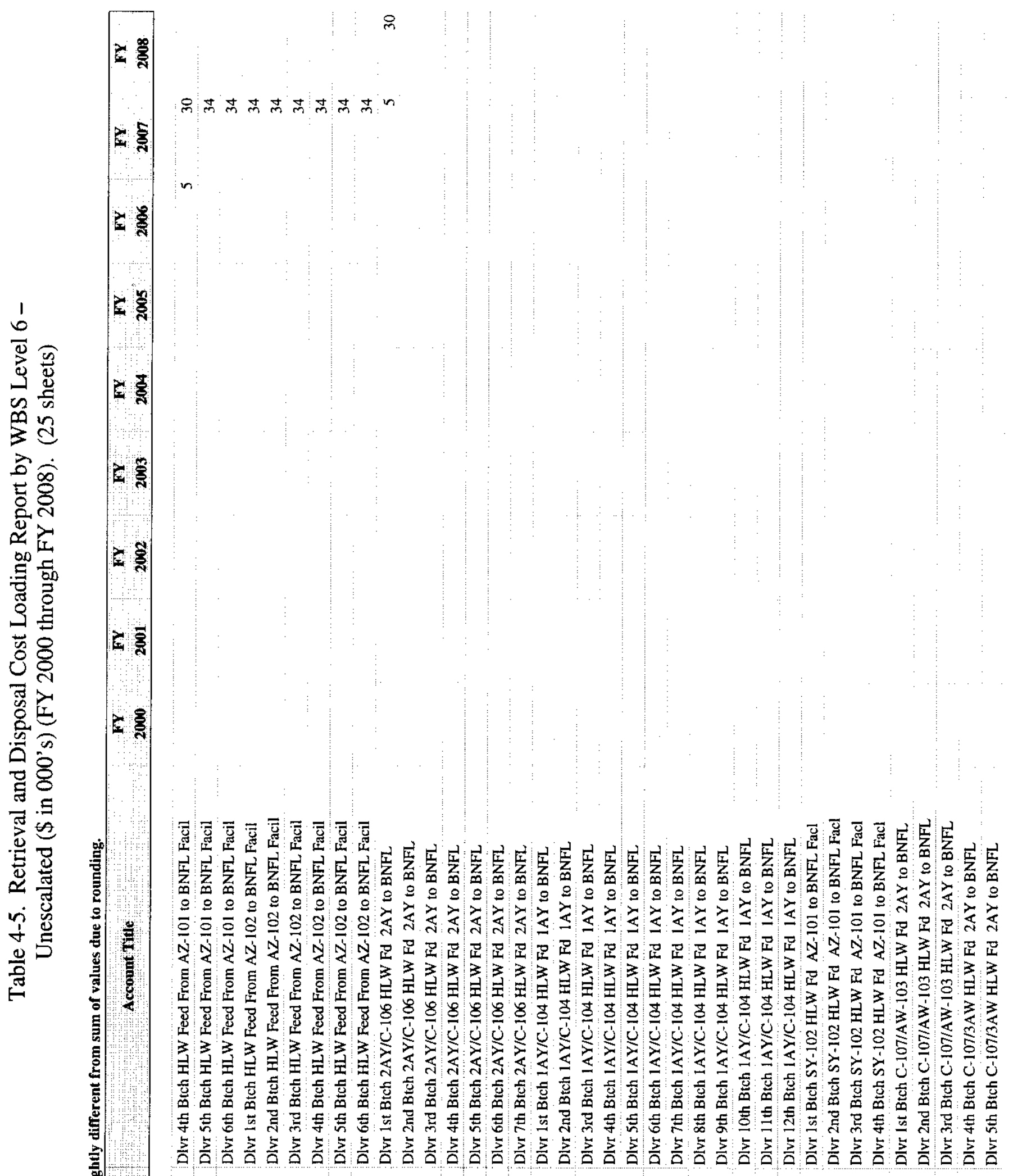

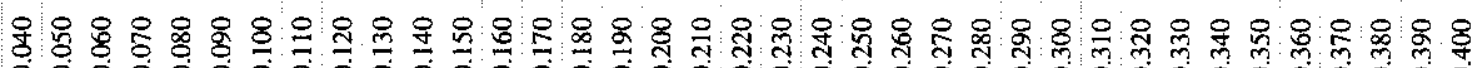
0. 


\section{HNF-1946 REV 2}
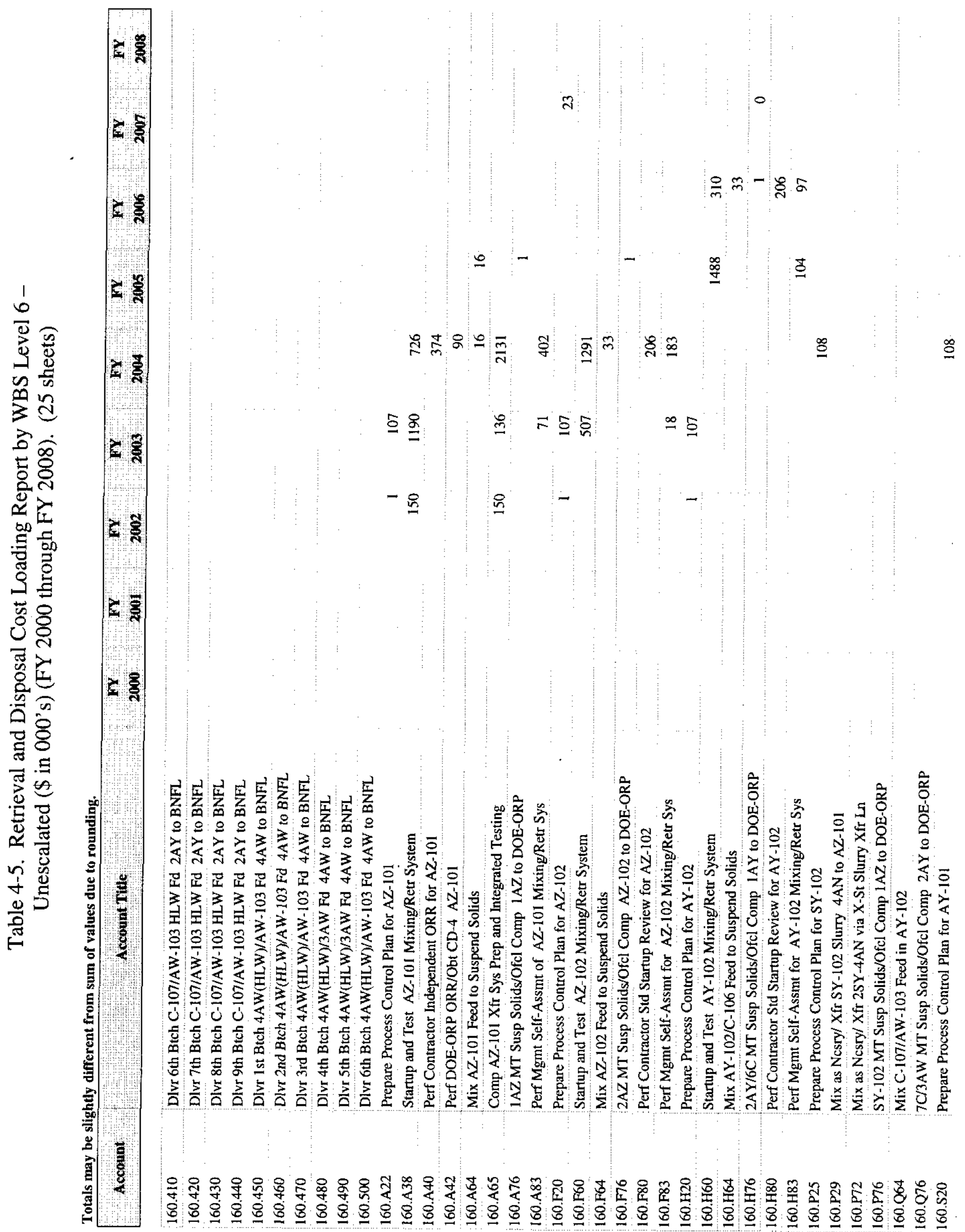
HNF-1946 REV 2
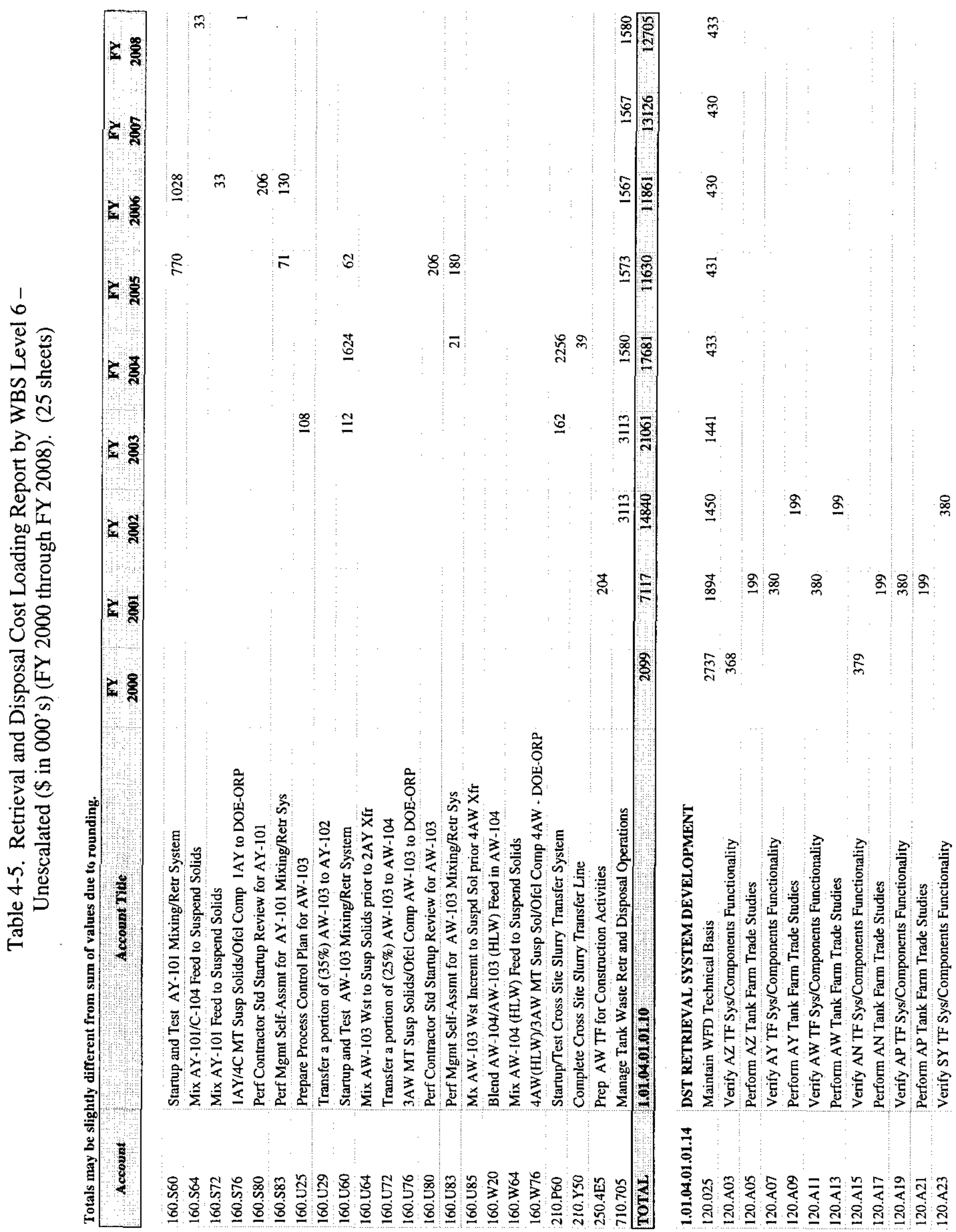


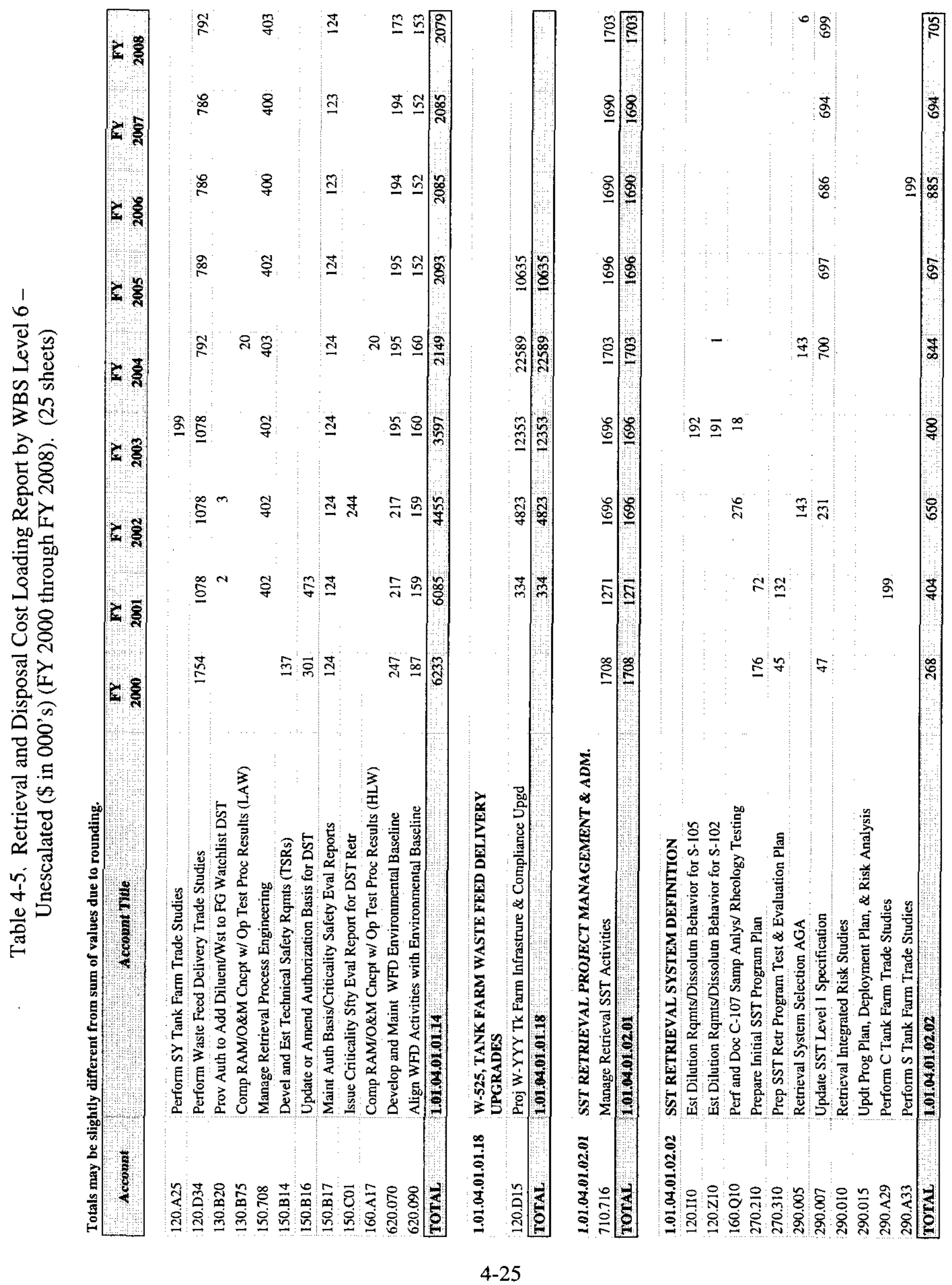




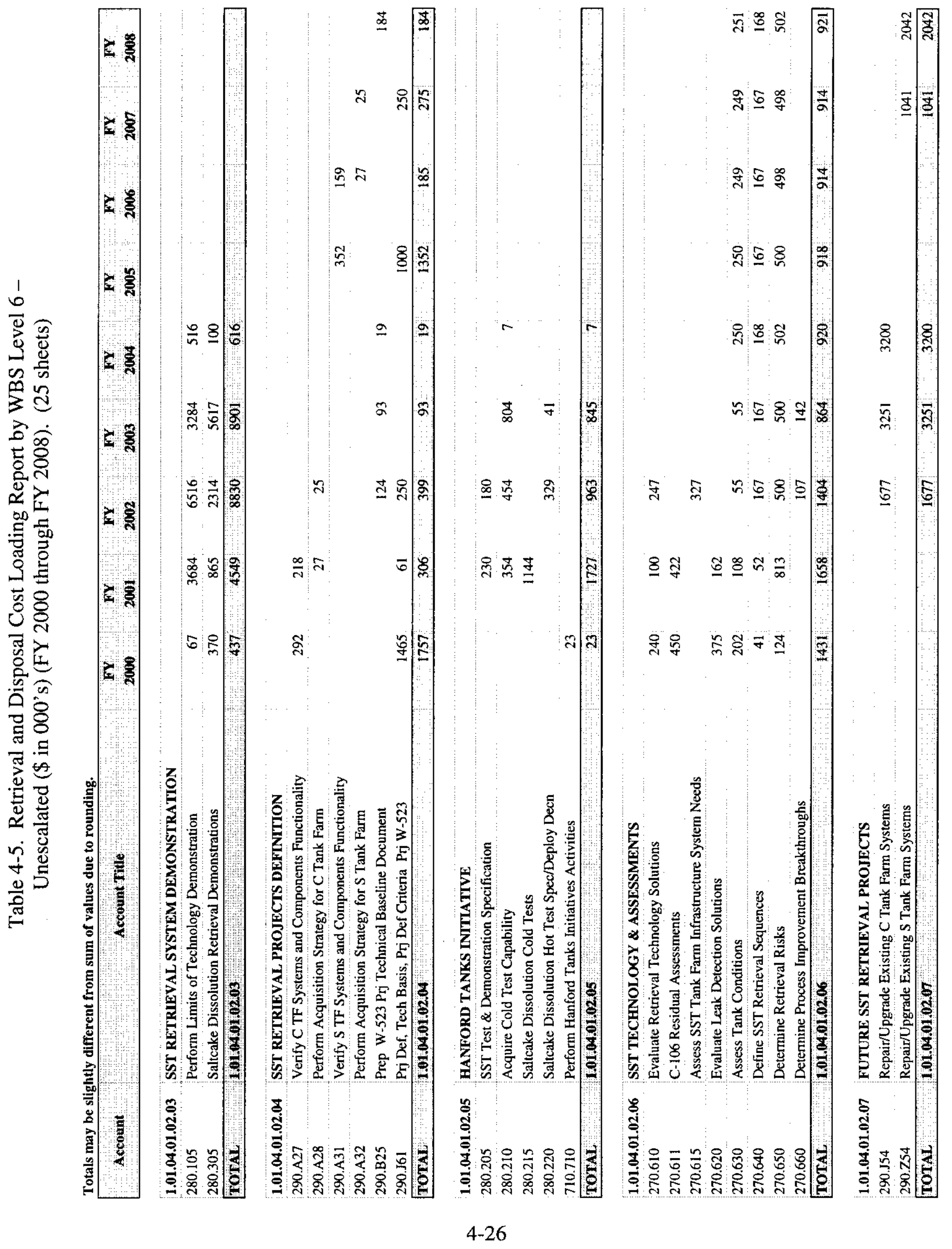


HNF-1946 REV 2

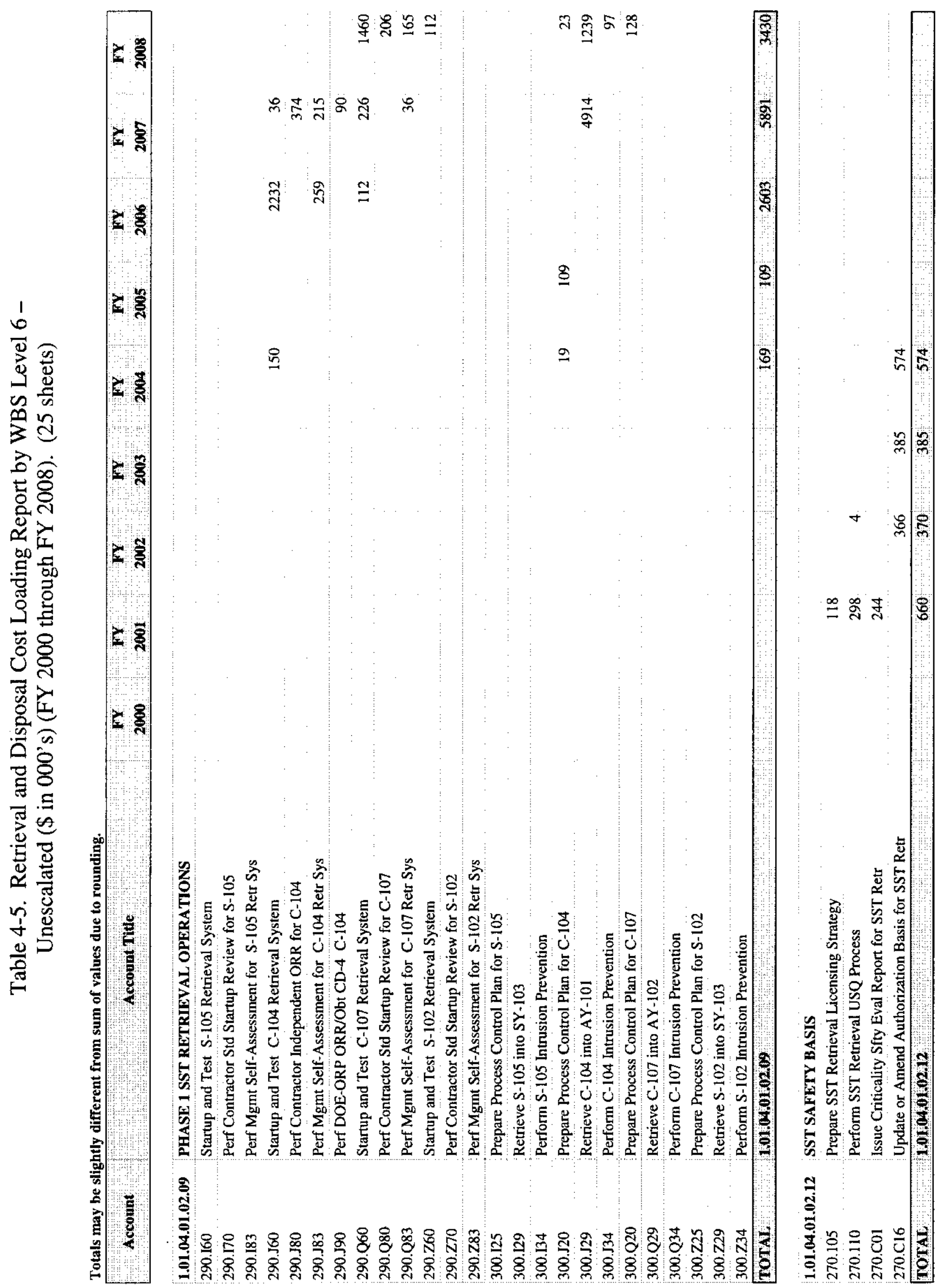


HNF-1946 REV 2

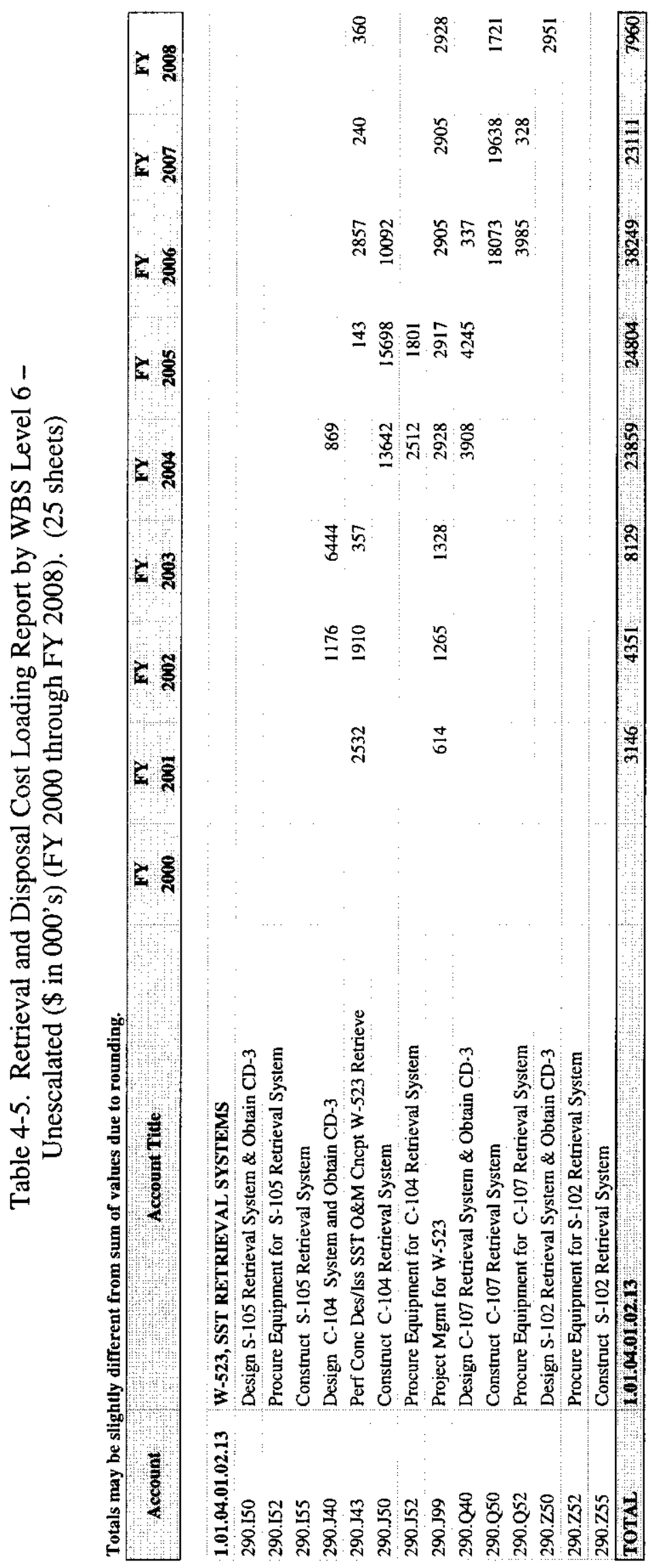

\begin{tabular}{|c|c|c|c|c|}
\hline & 5 & 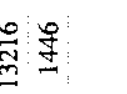 & & \\
\hline 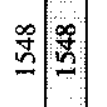 & : & E赾 & & \\
\hline 象: & 鸪 & g: & & \\
\hline 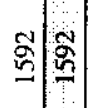 & 总等 & 淃 & & \pm \\
\hline 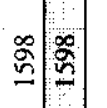 & 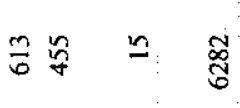 & 3 & 8 & 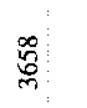 \\
\hline 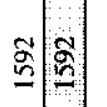 & 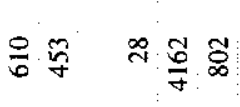 & $5:$ & $=\%$ & \\
\hline & 吉李品是尊 & $\Omega$ & 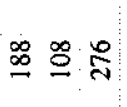 & \\
\hline 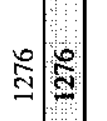 & 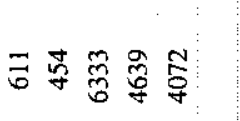 & & 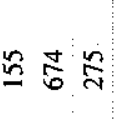 & \\
\hline & 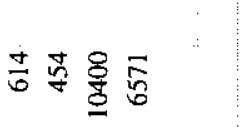 & 9 & 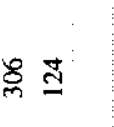 & \\
\hline
\end{tabular}


HNF-1946 REV 2

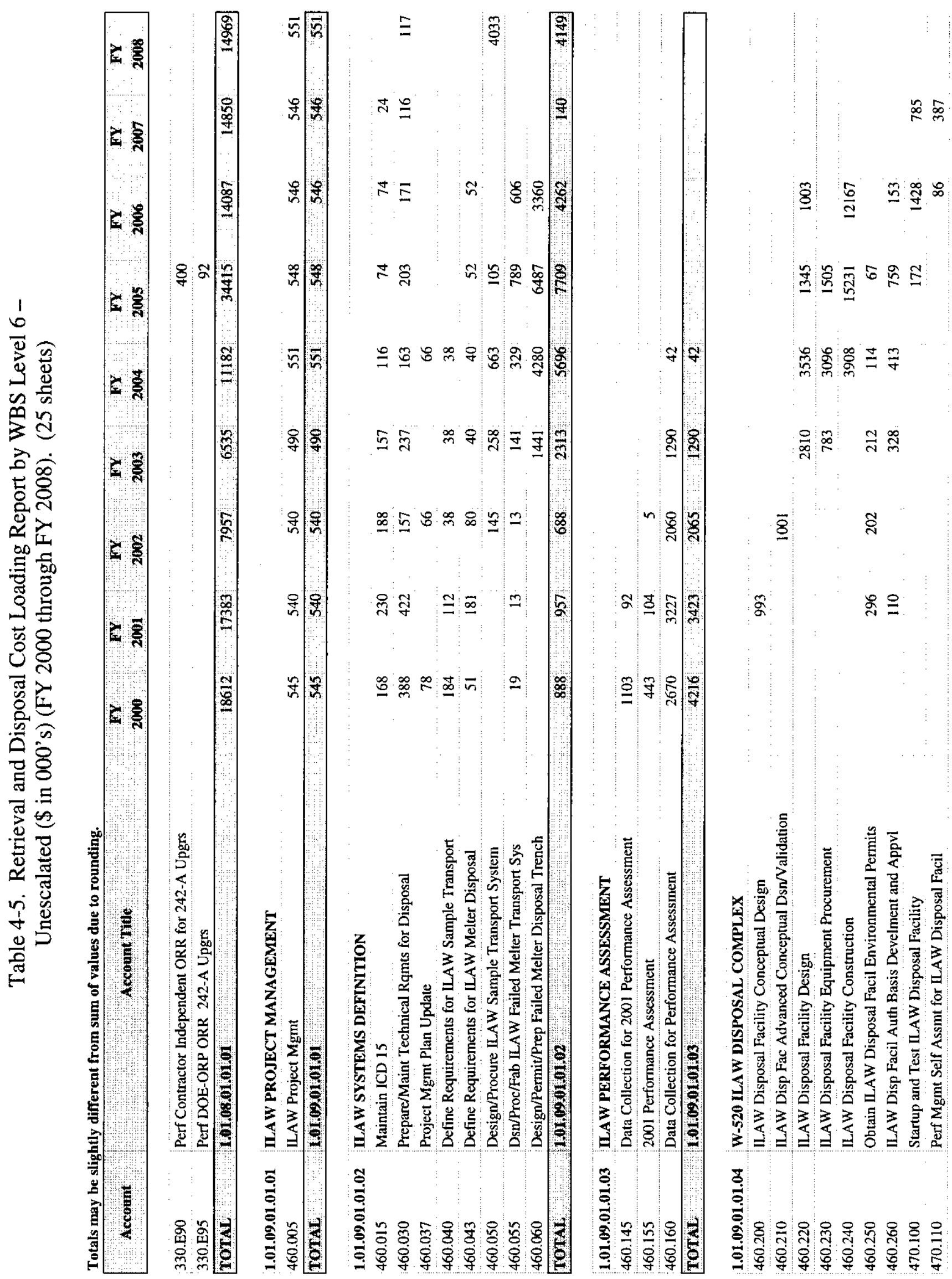


HNF-1946 REV 2
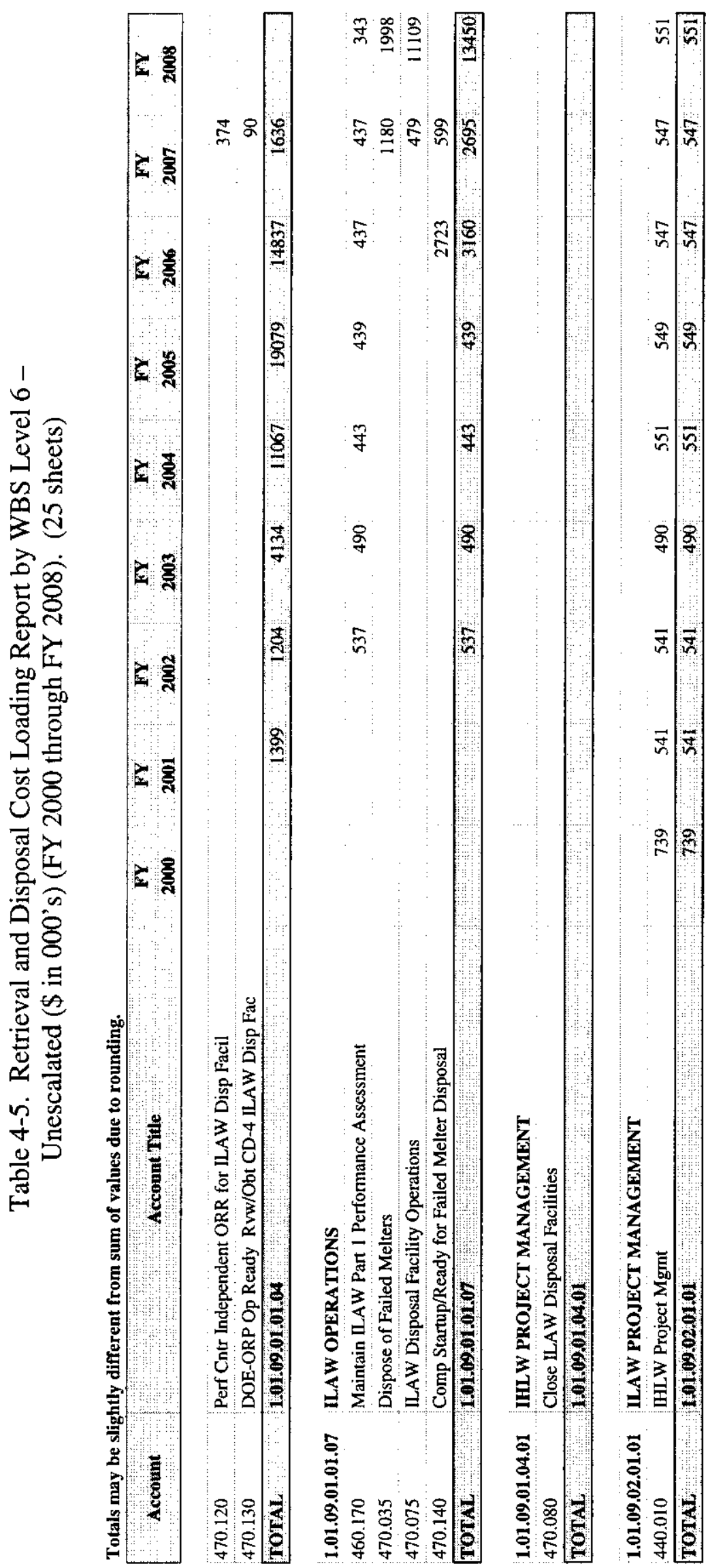

im

$\frac{m}{2}$

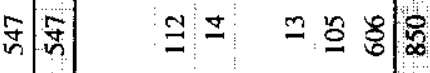

픙

जิ

넉 융

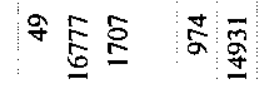

$\bar{n}$

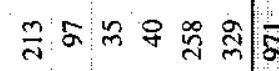

ga

\&) लूलm

讨等 8

जि:

$\stackrel{m}{\frac{m}{2} \infty} \bar{m}$

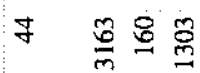

$\overrightarrow{5}$

을 옹

$\sim 8$

2. $2 \equiv \overline{7}$

लेलि

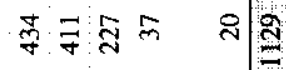

$\stackrel{\mathscr{8}}{9} \stackrel{\circ}{9}$

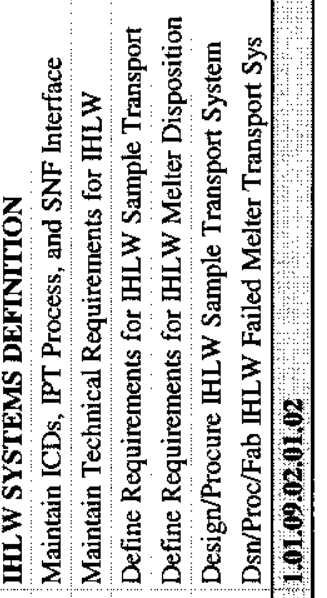

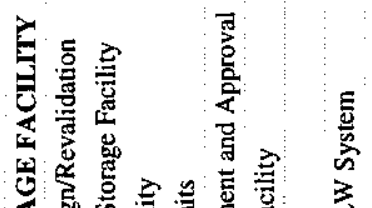

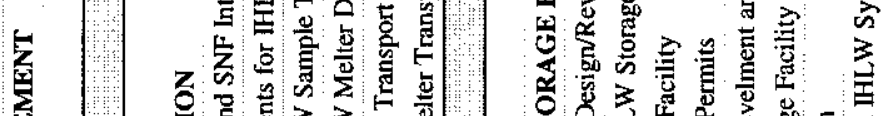
की

z)

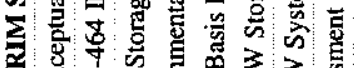

会

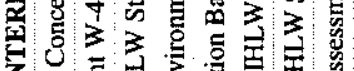

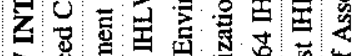

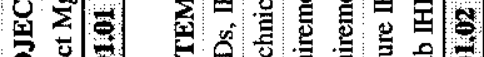

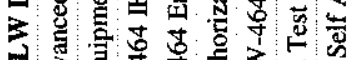

변?

की

3

3 造造

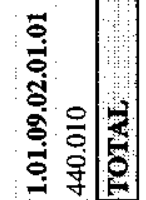

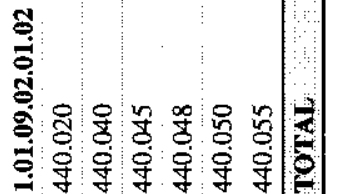

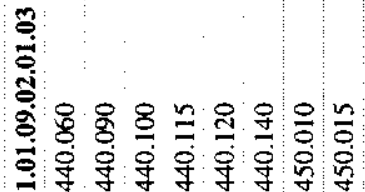


HNF-1946 REV 2

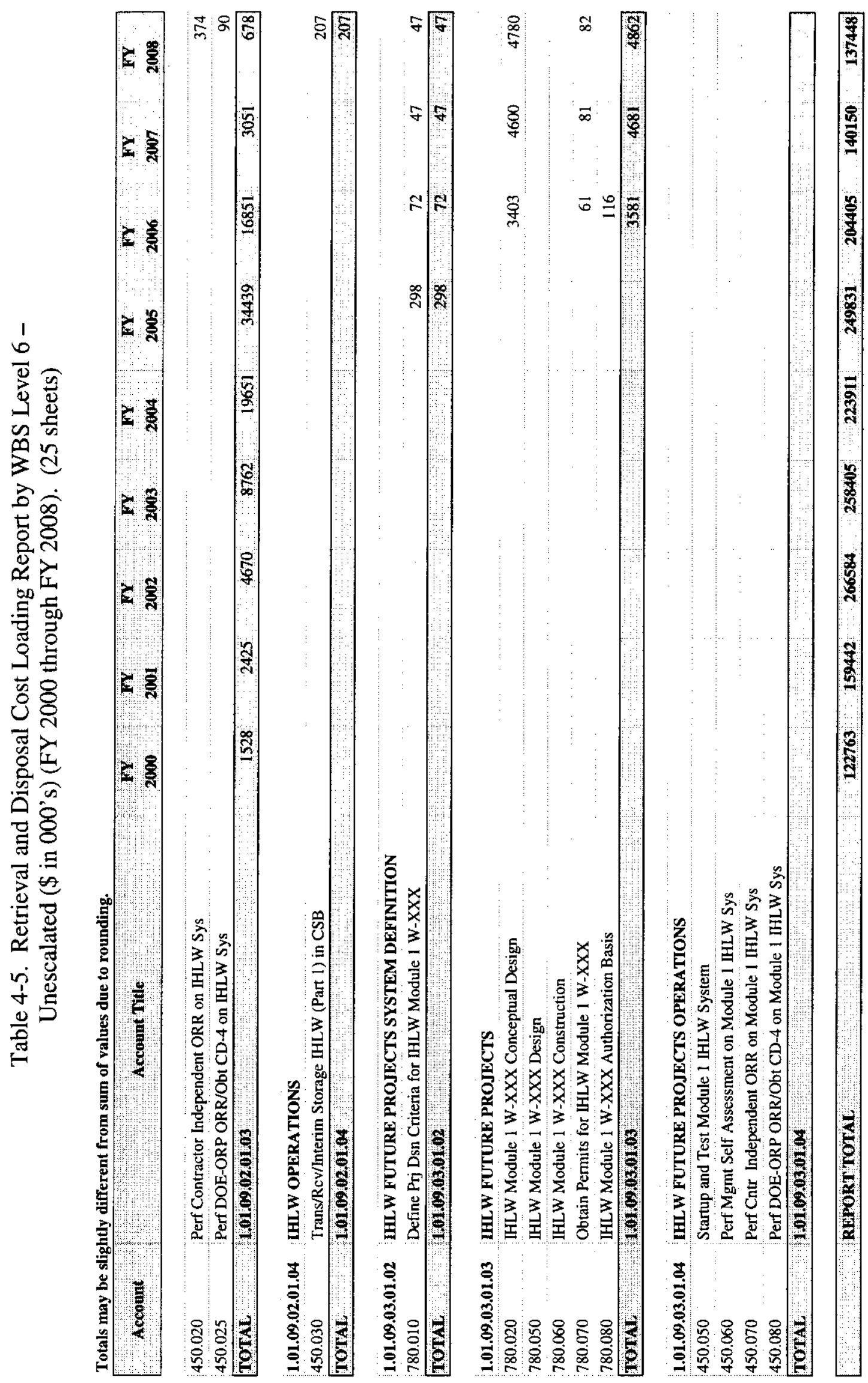


This page cannot be converted.

Please view the native document

for the original page. 


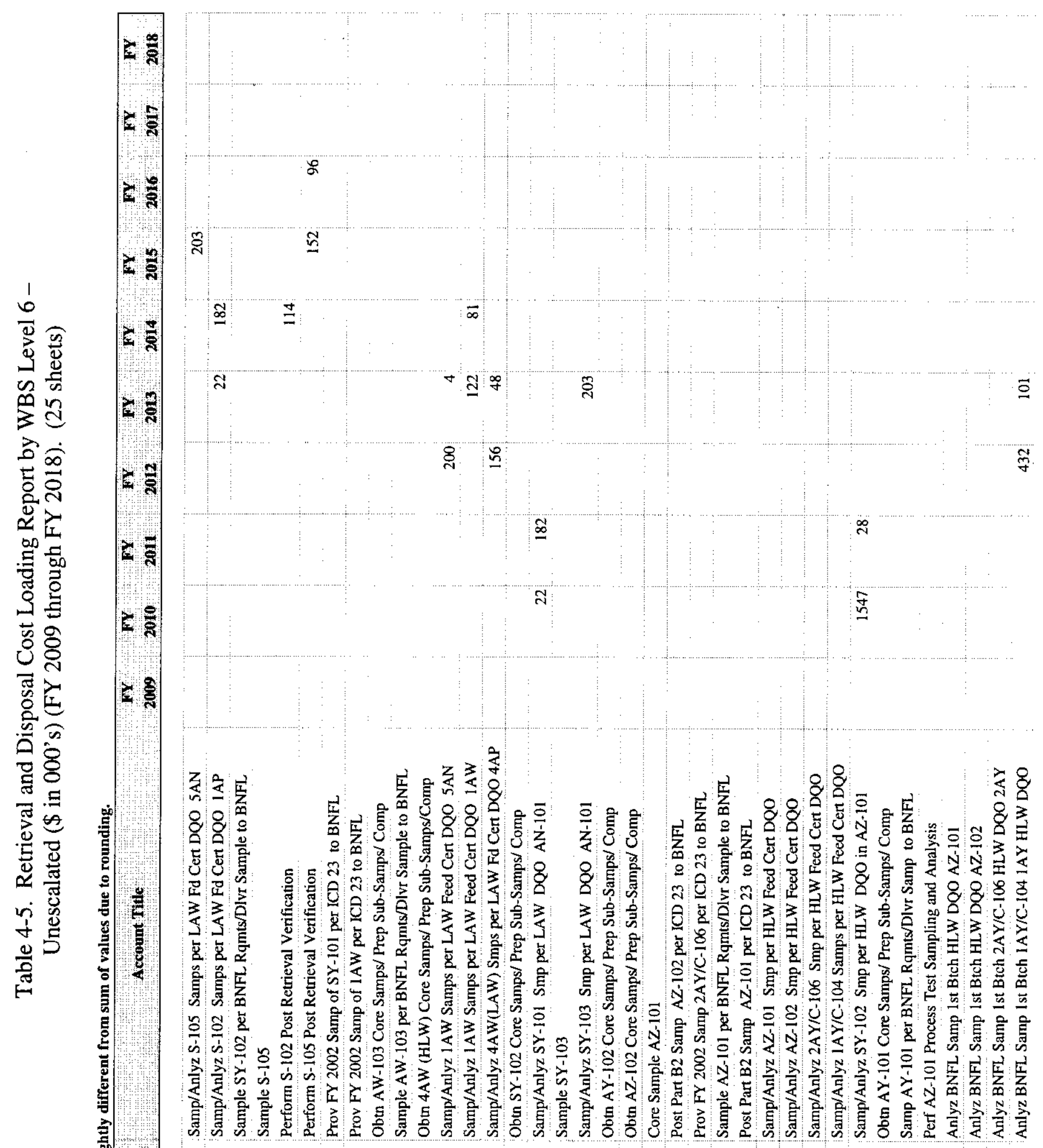

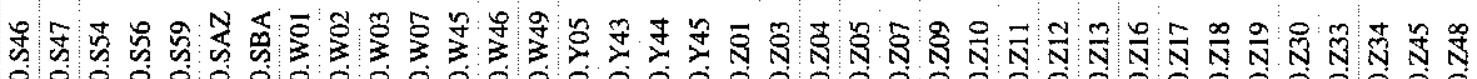

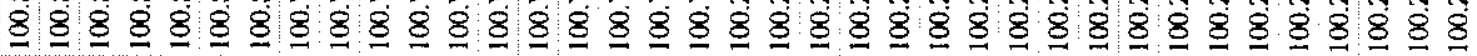




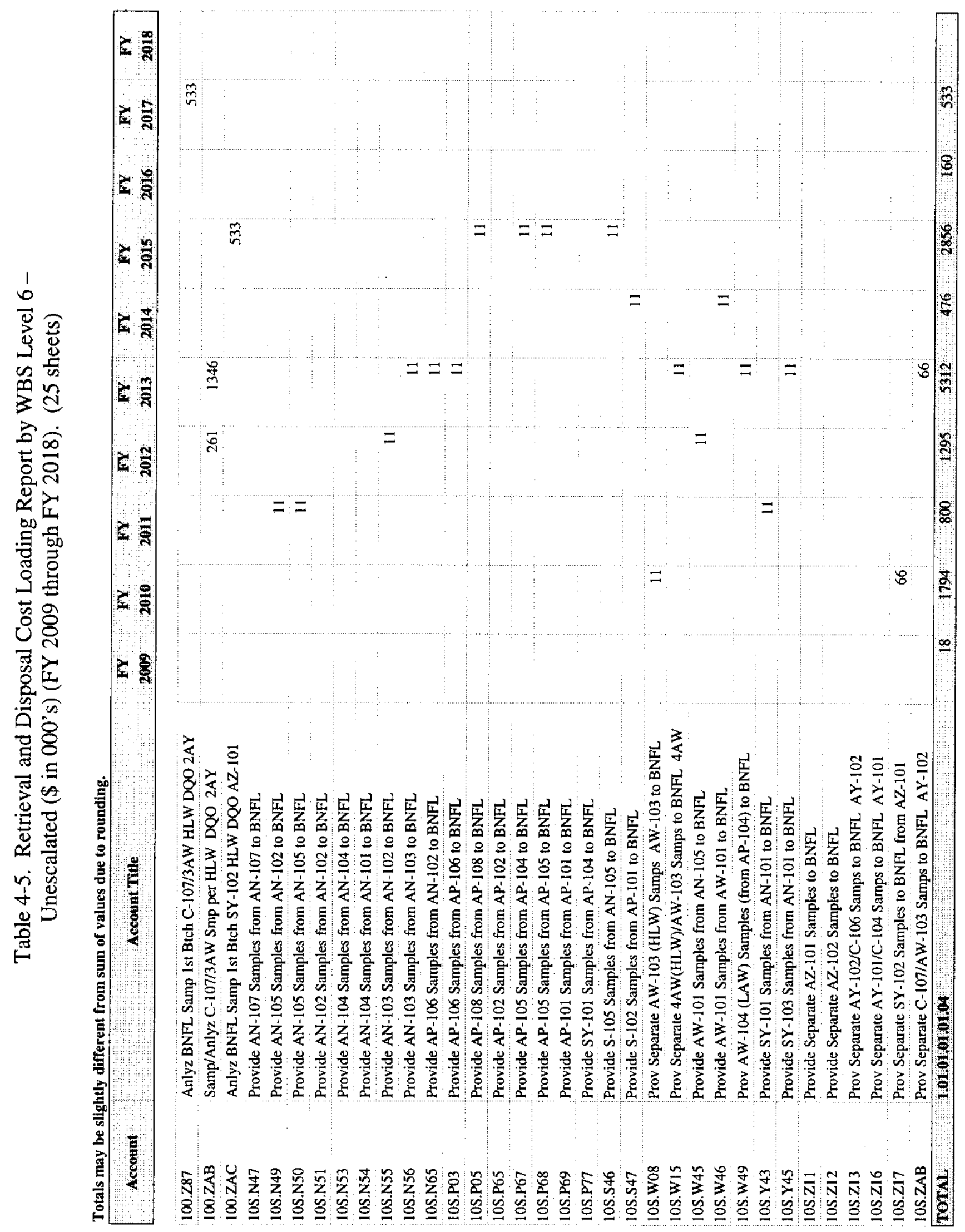




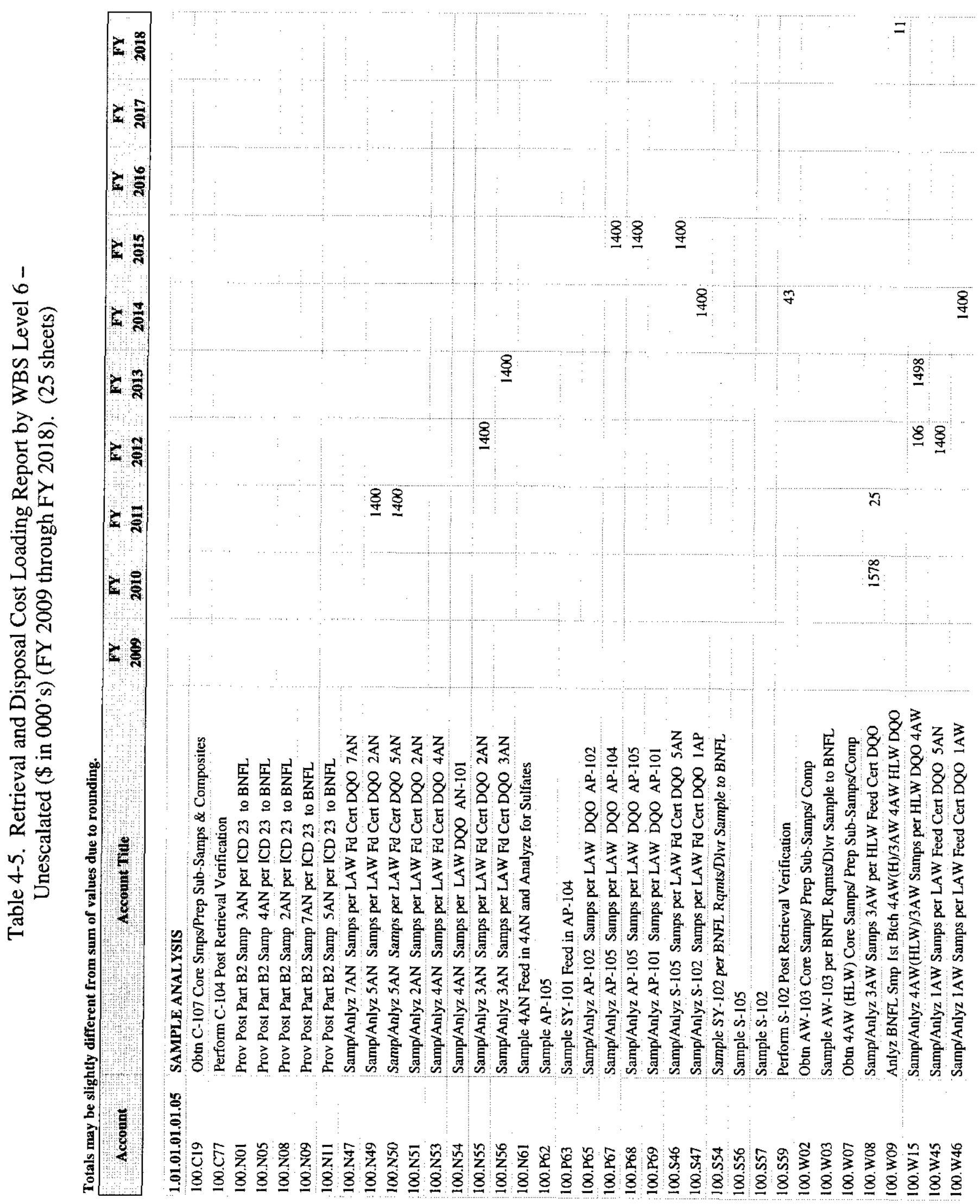



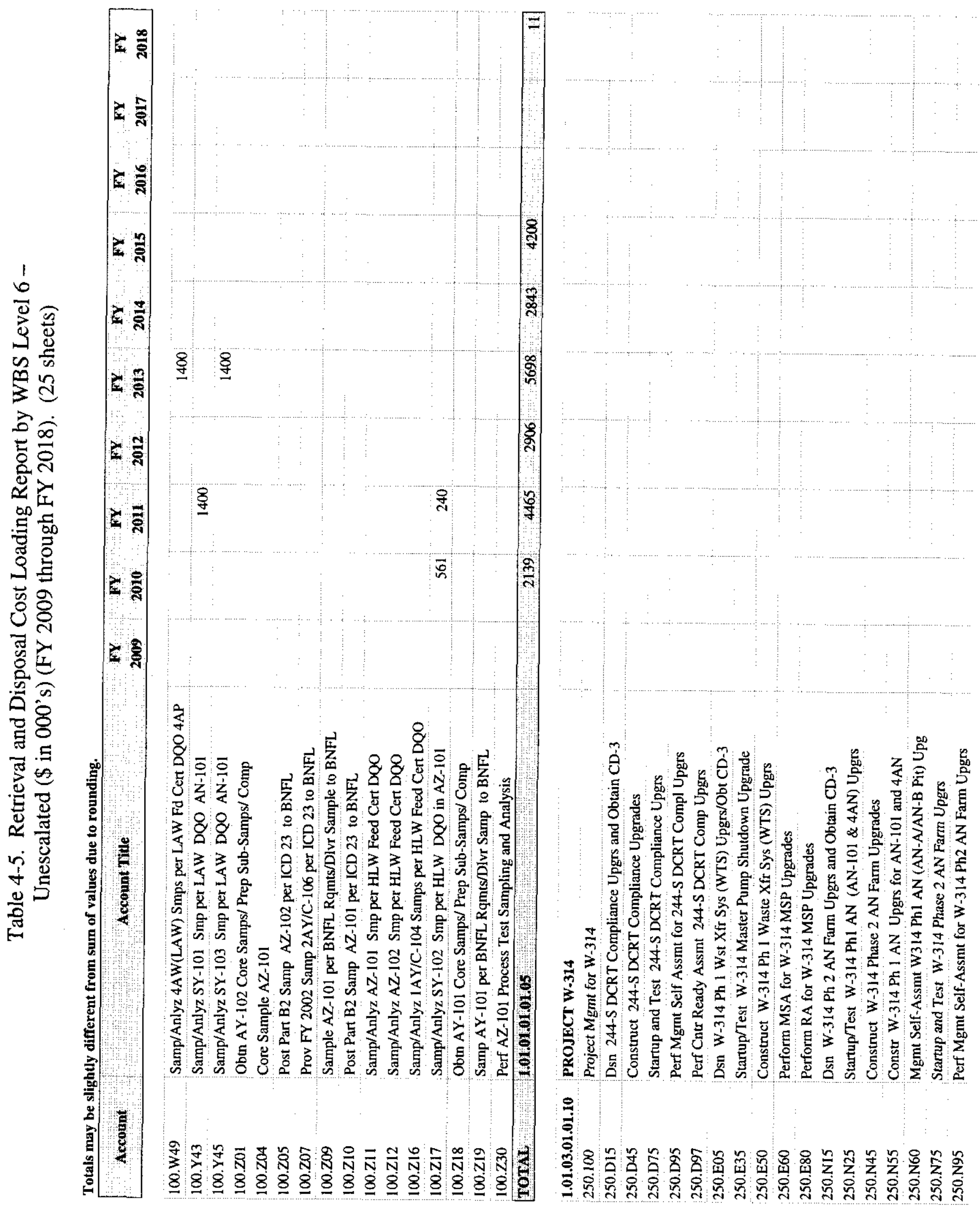


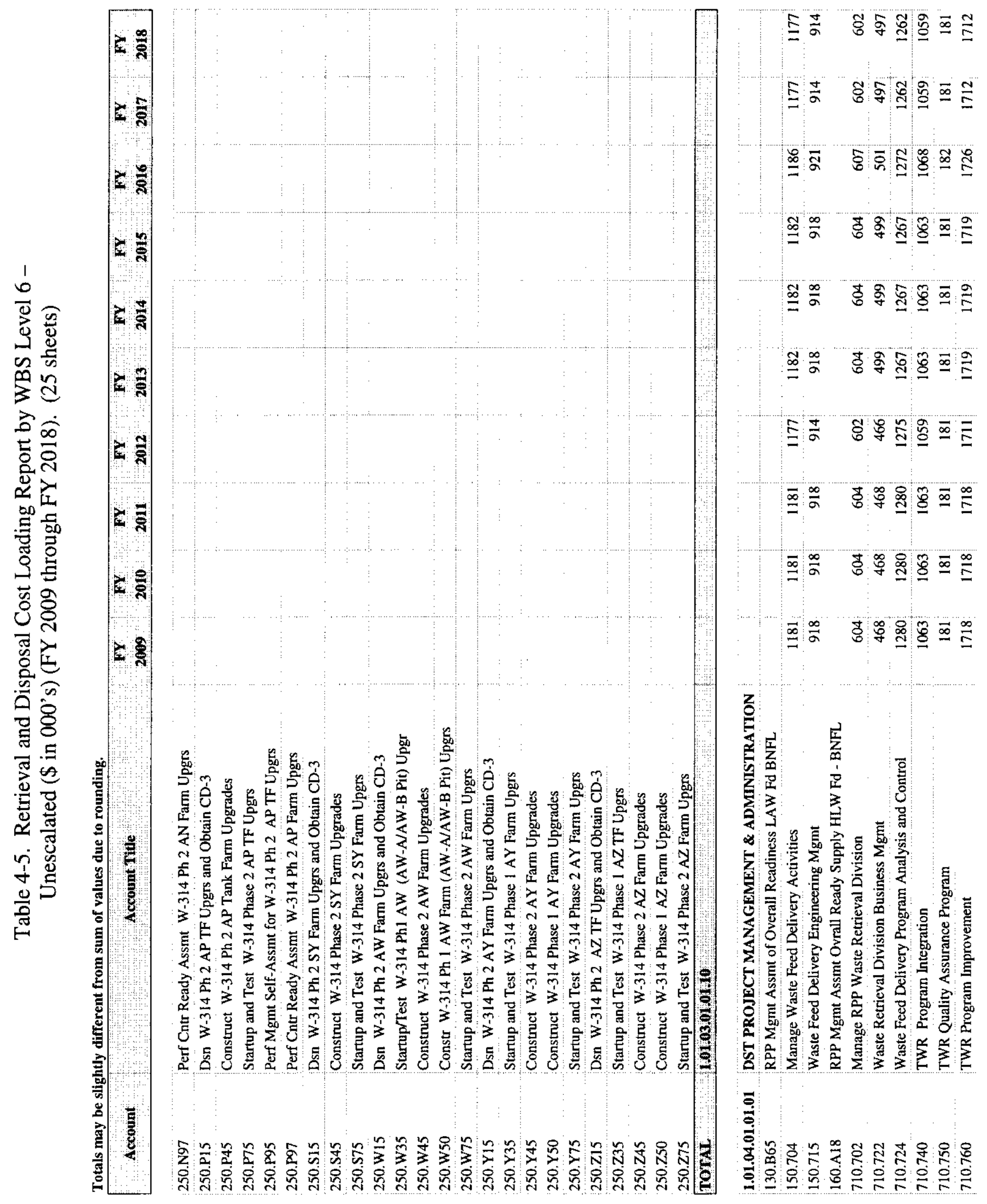




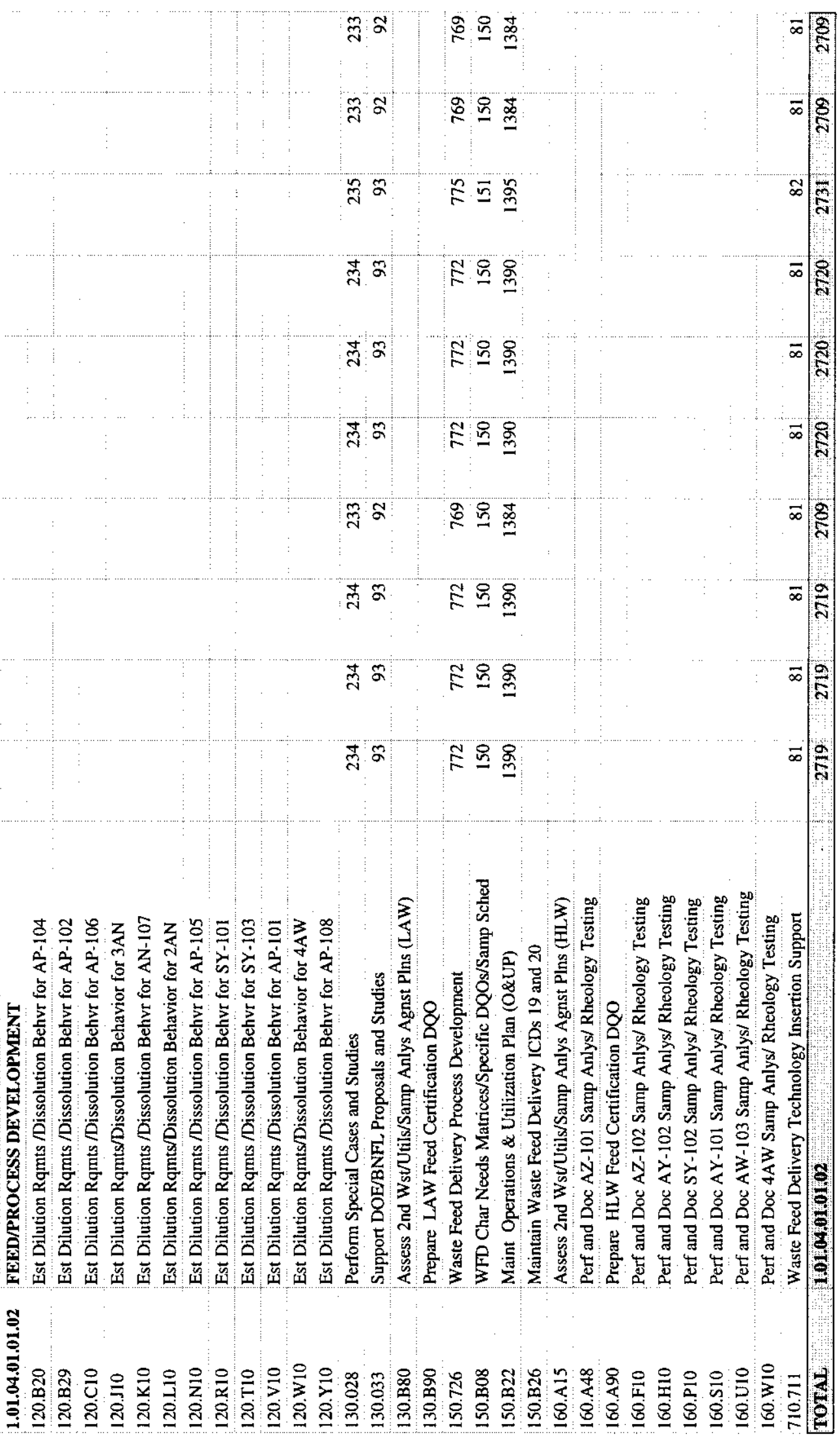




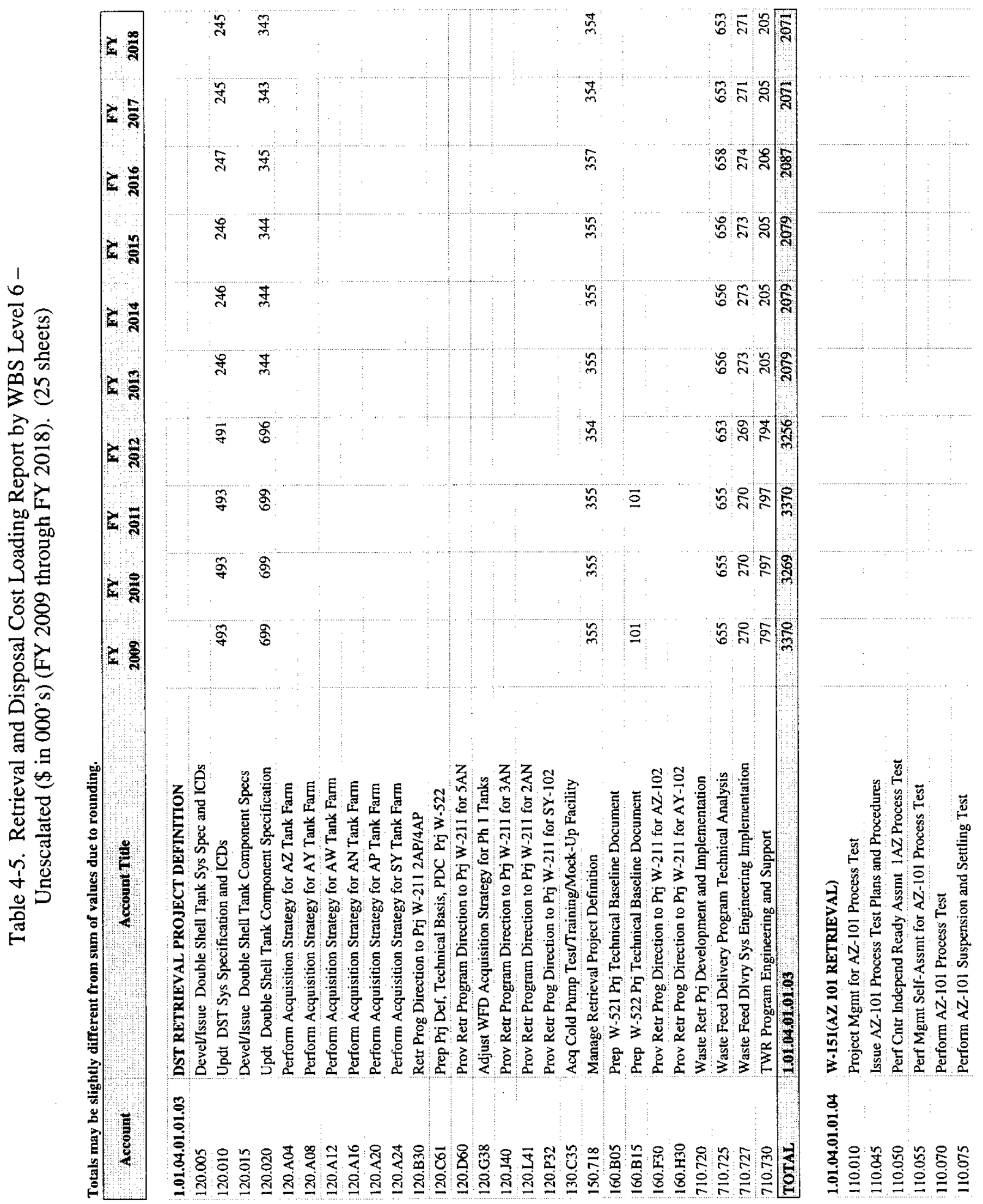



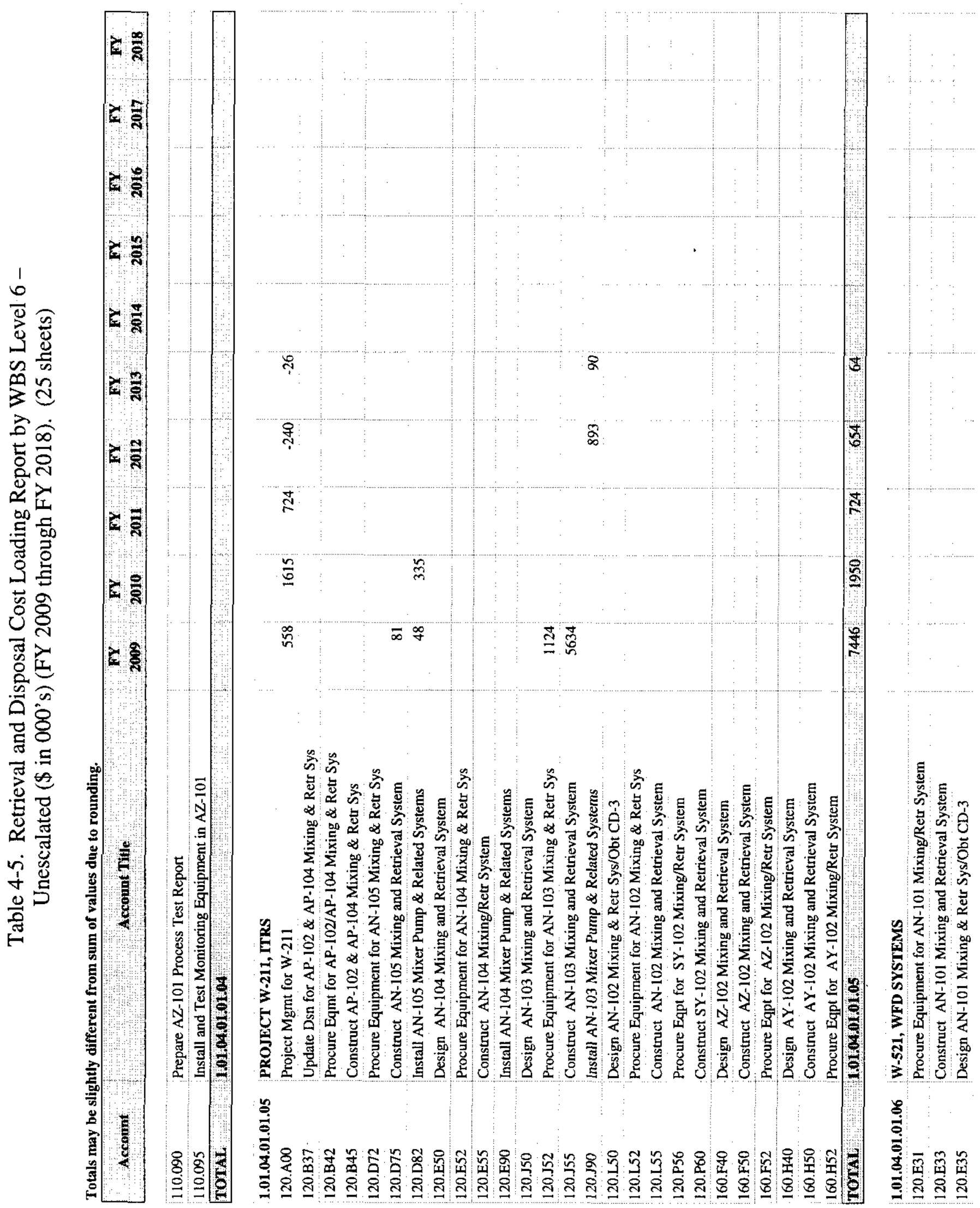


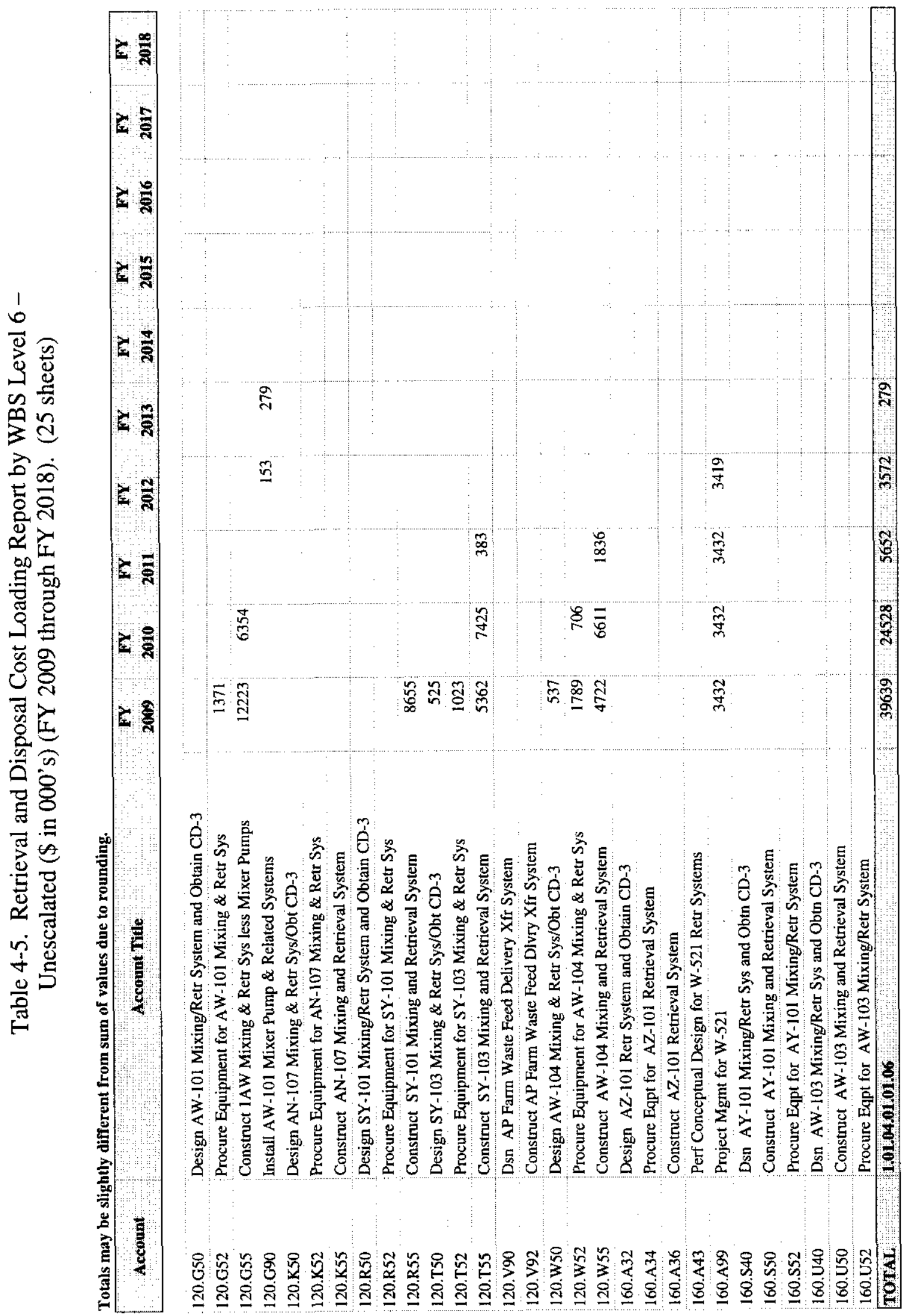

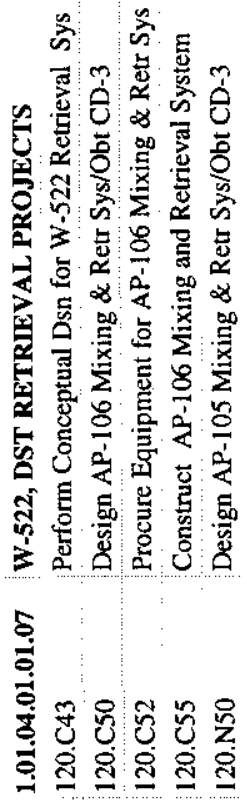




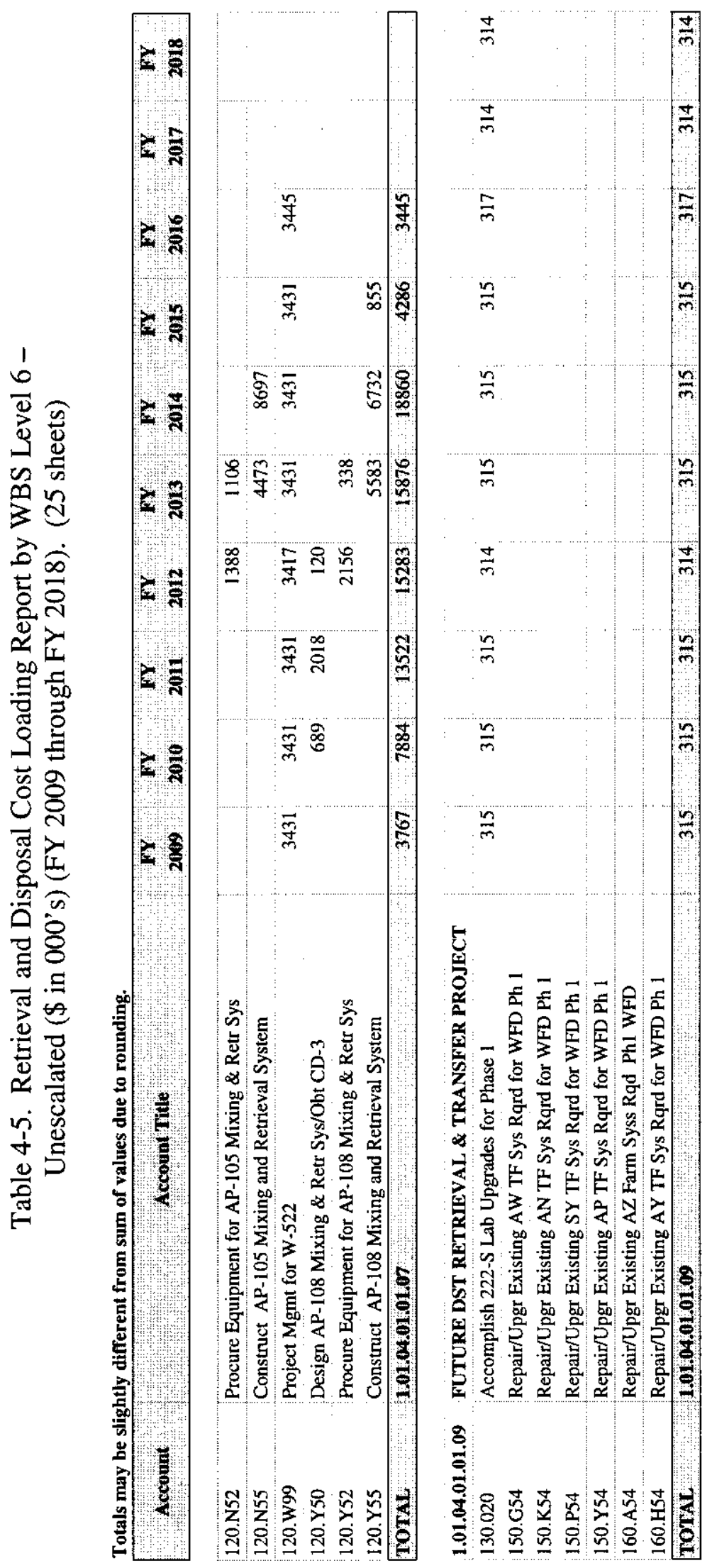

๑
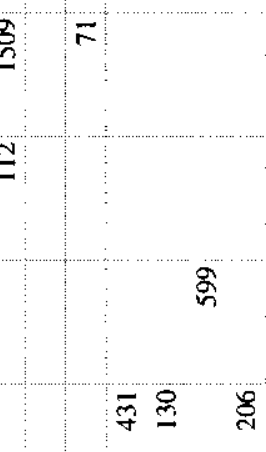

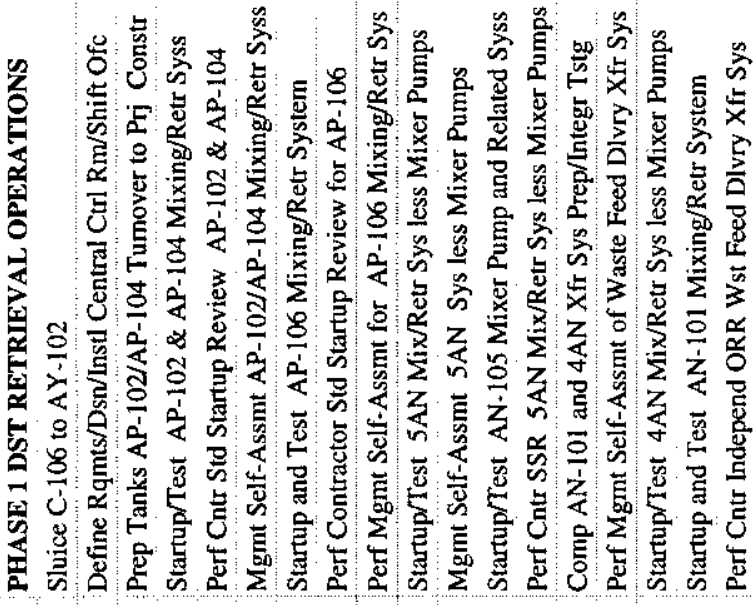

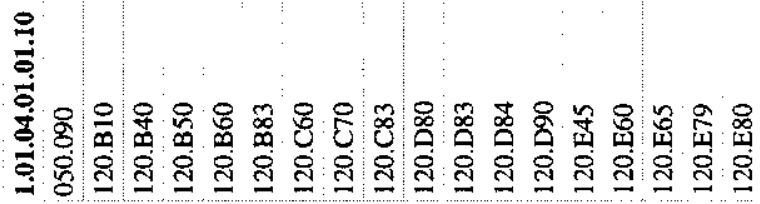




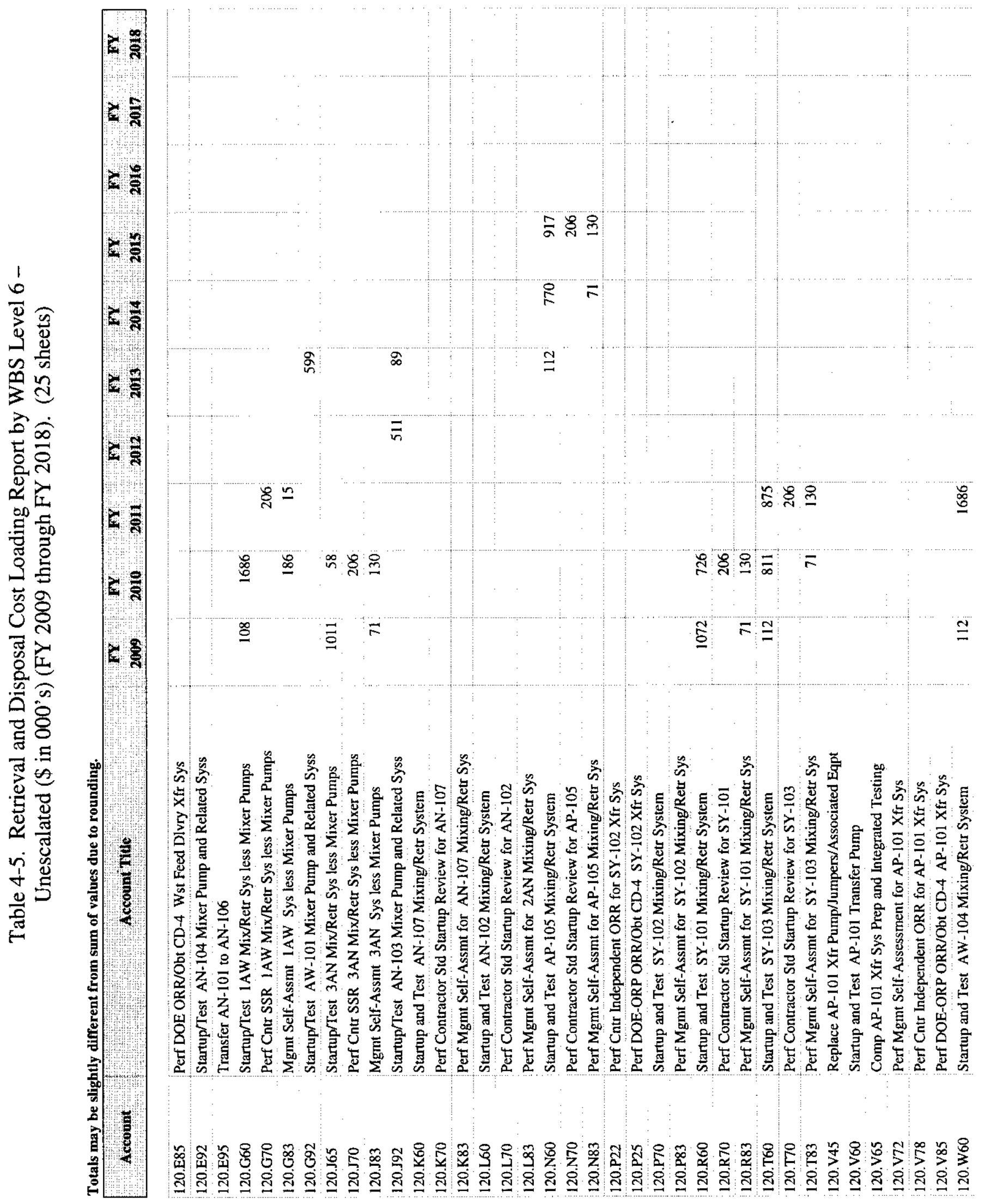




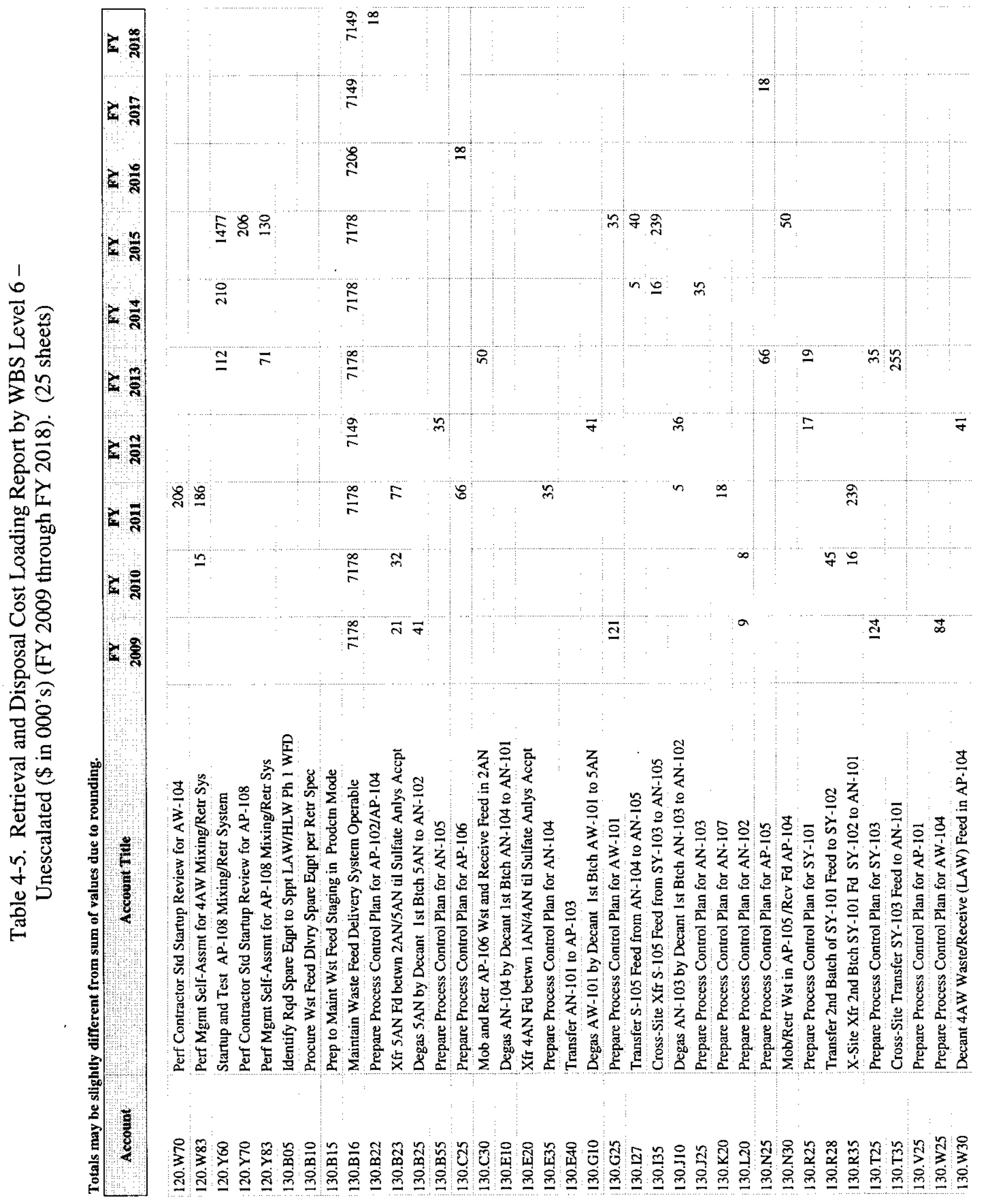




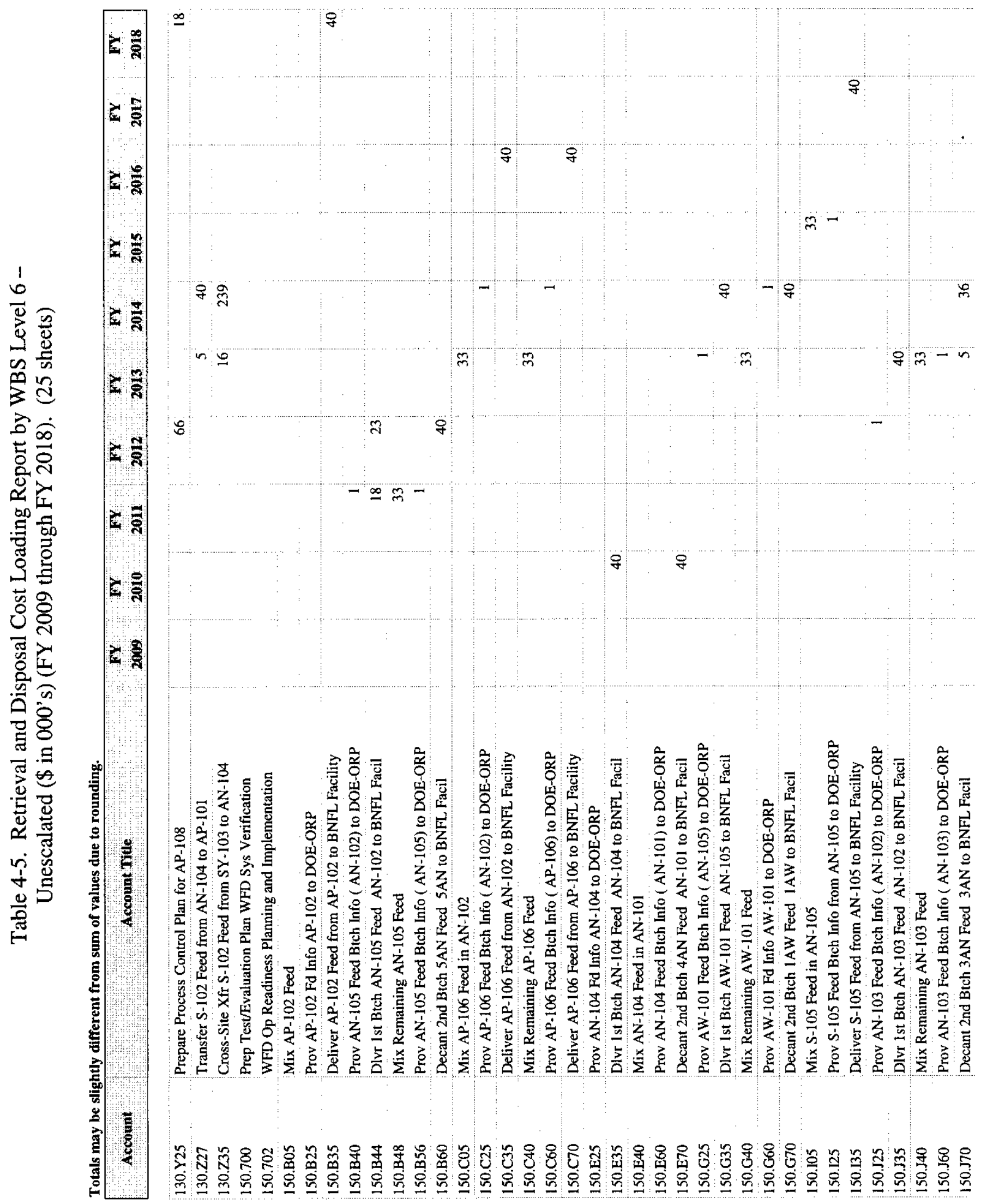


HNF-1946 REV 2

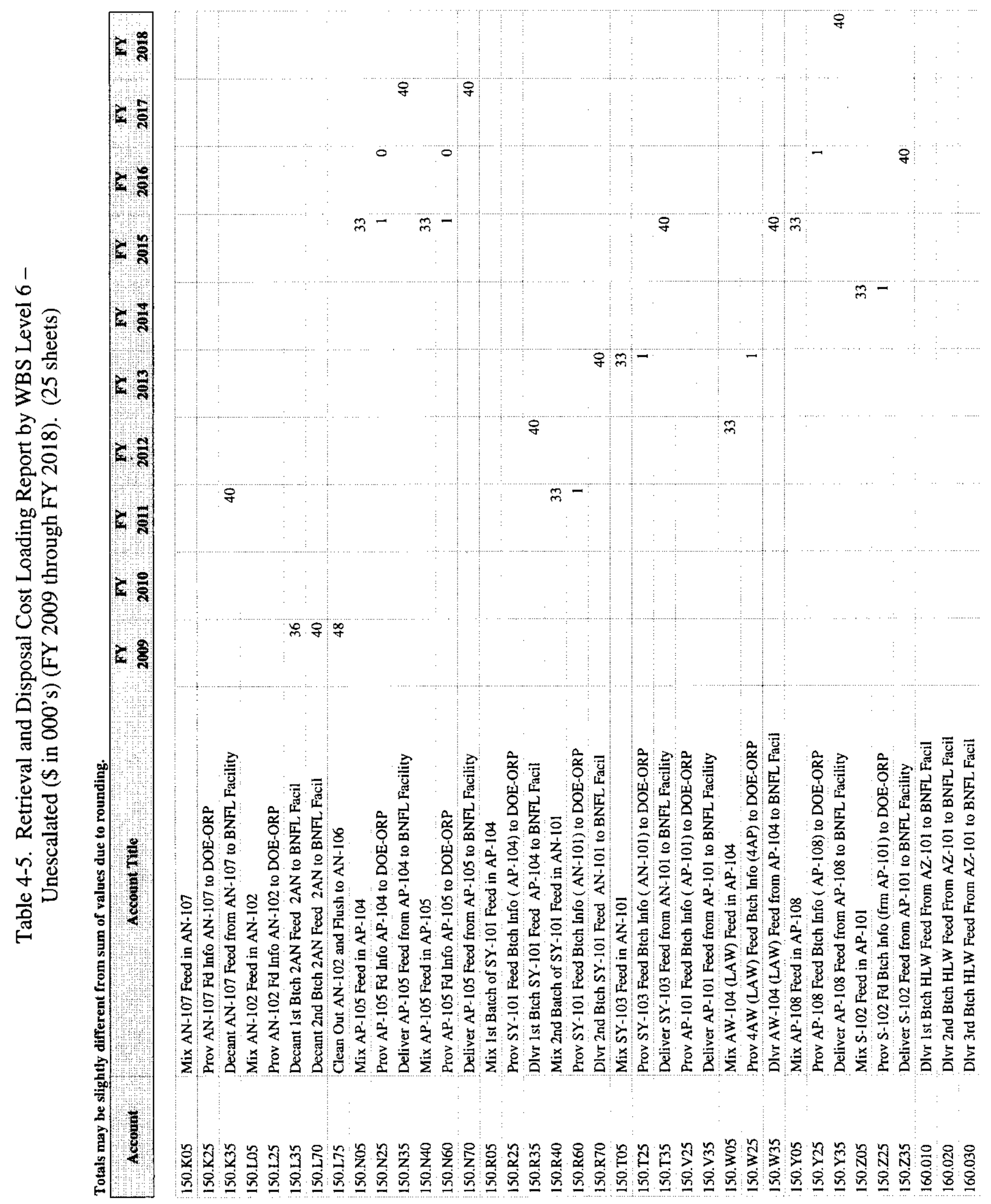




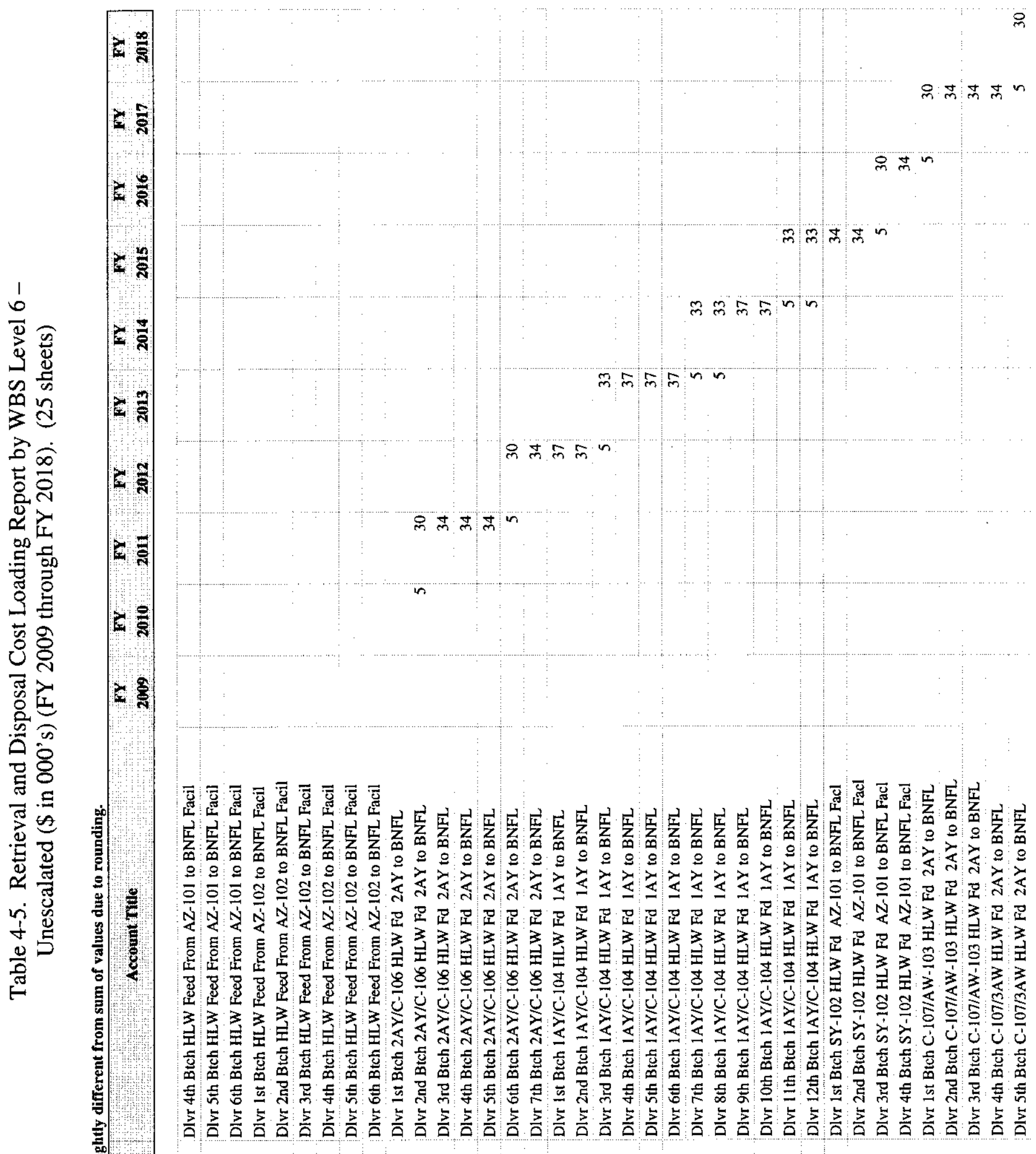

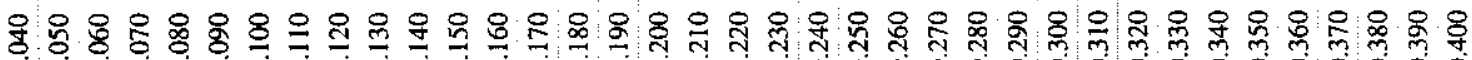

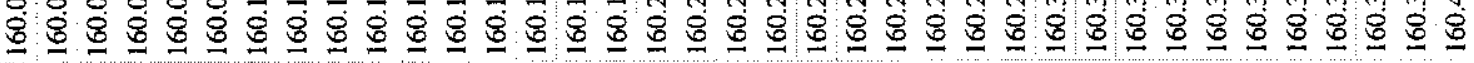




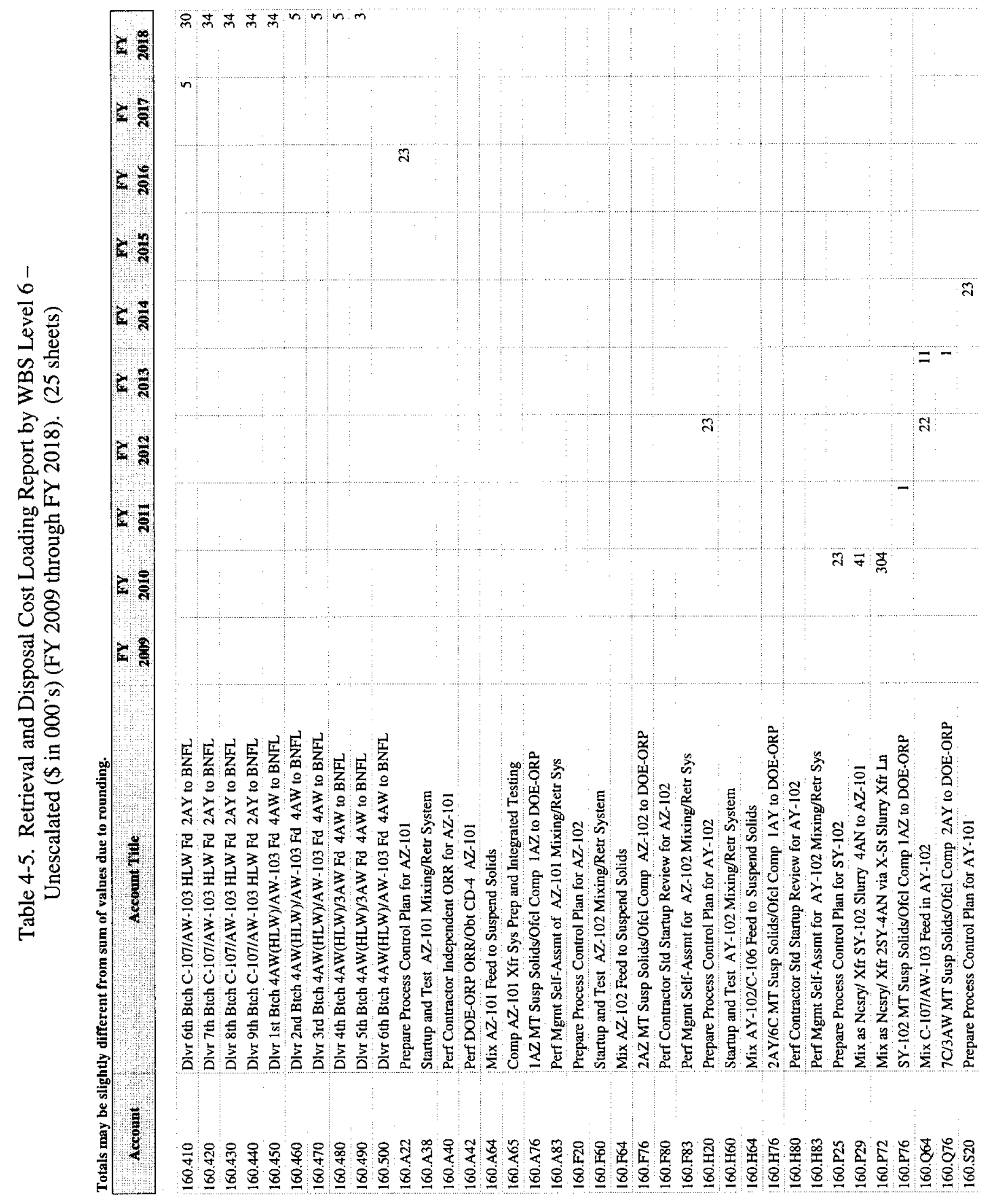




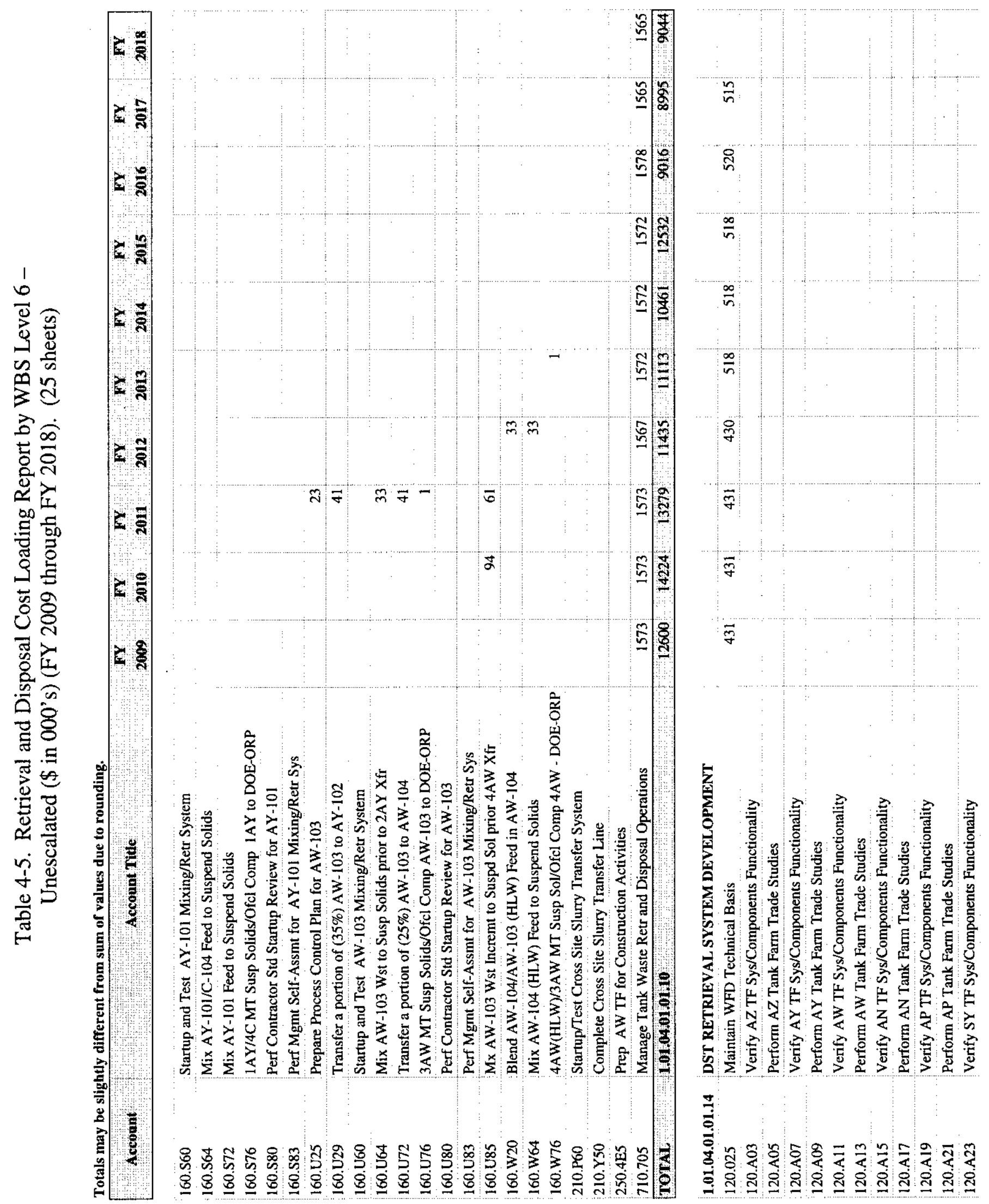




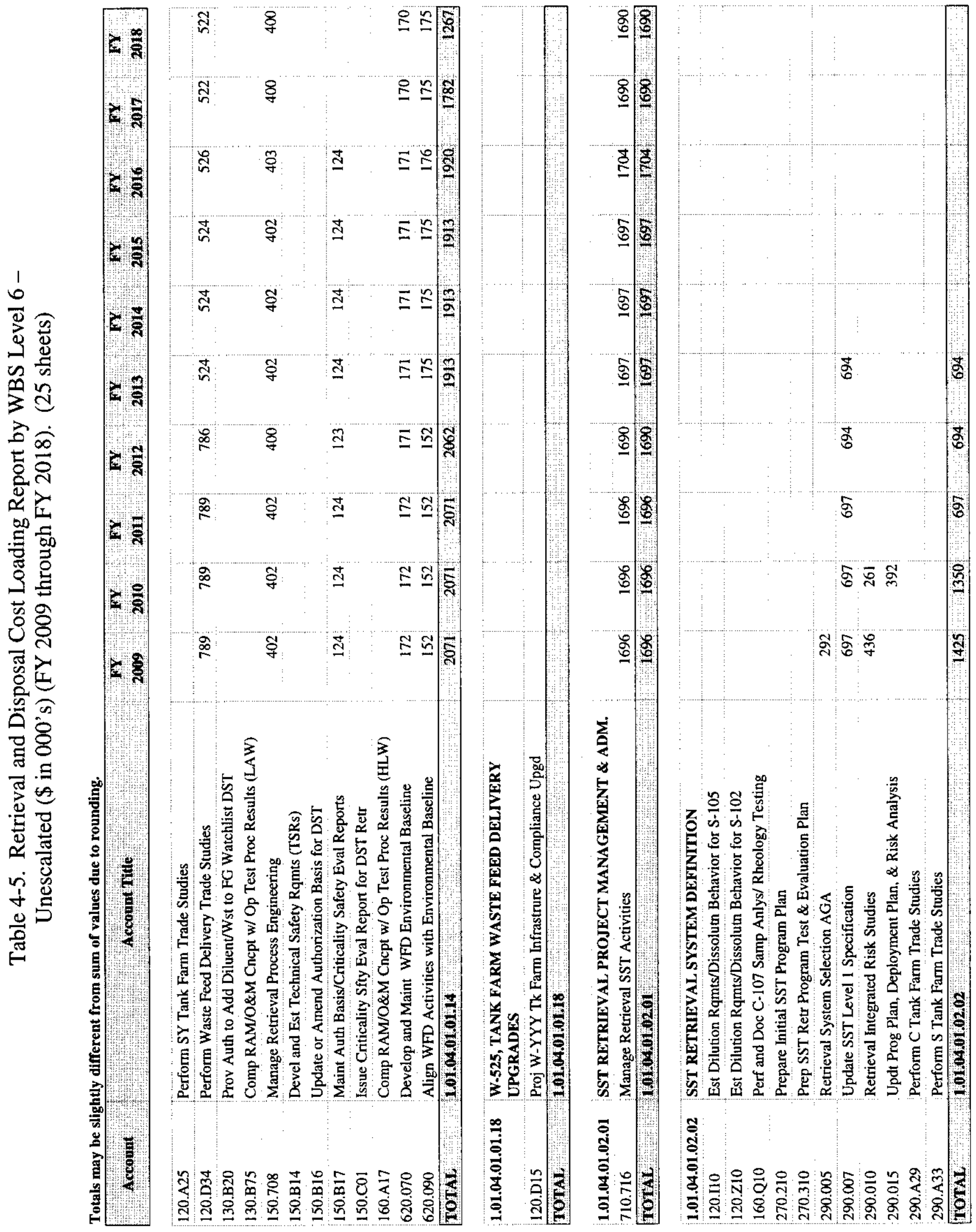




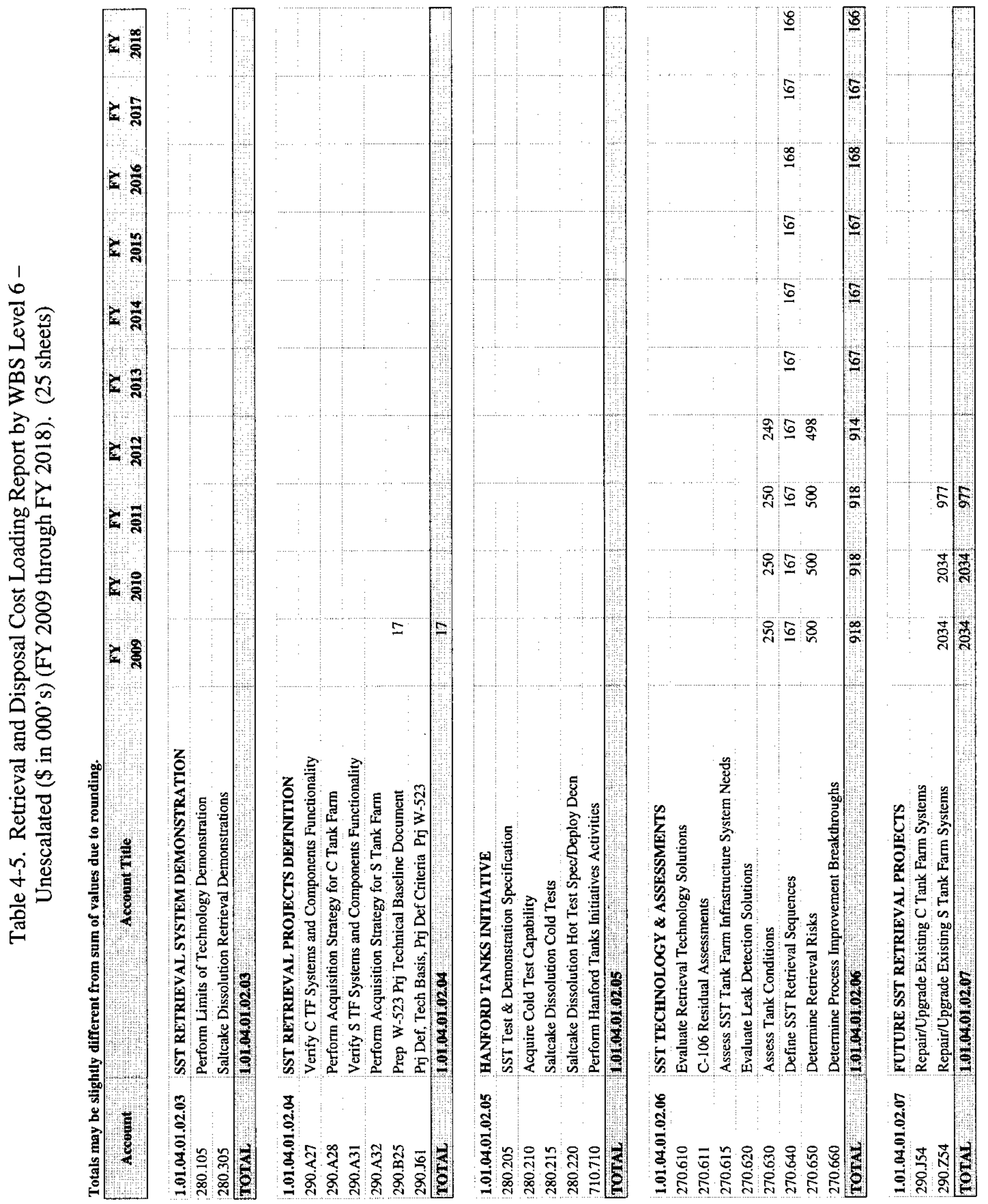




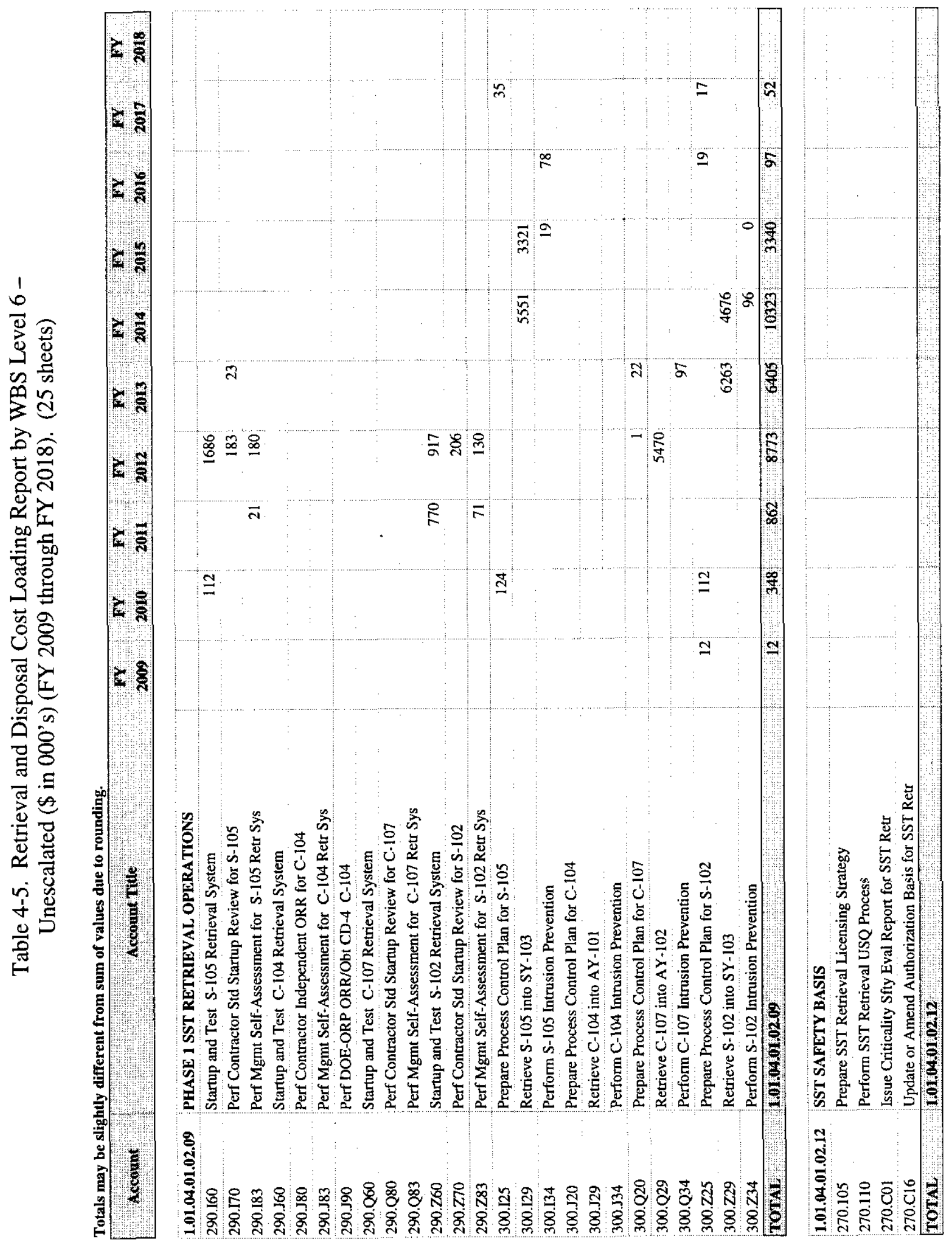



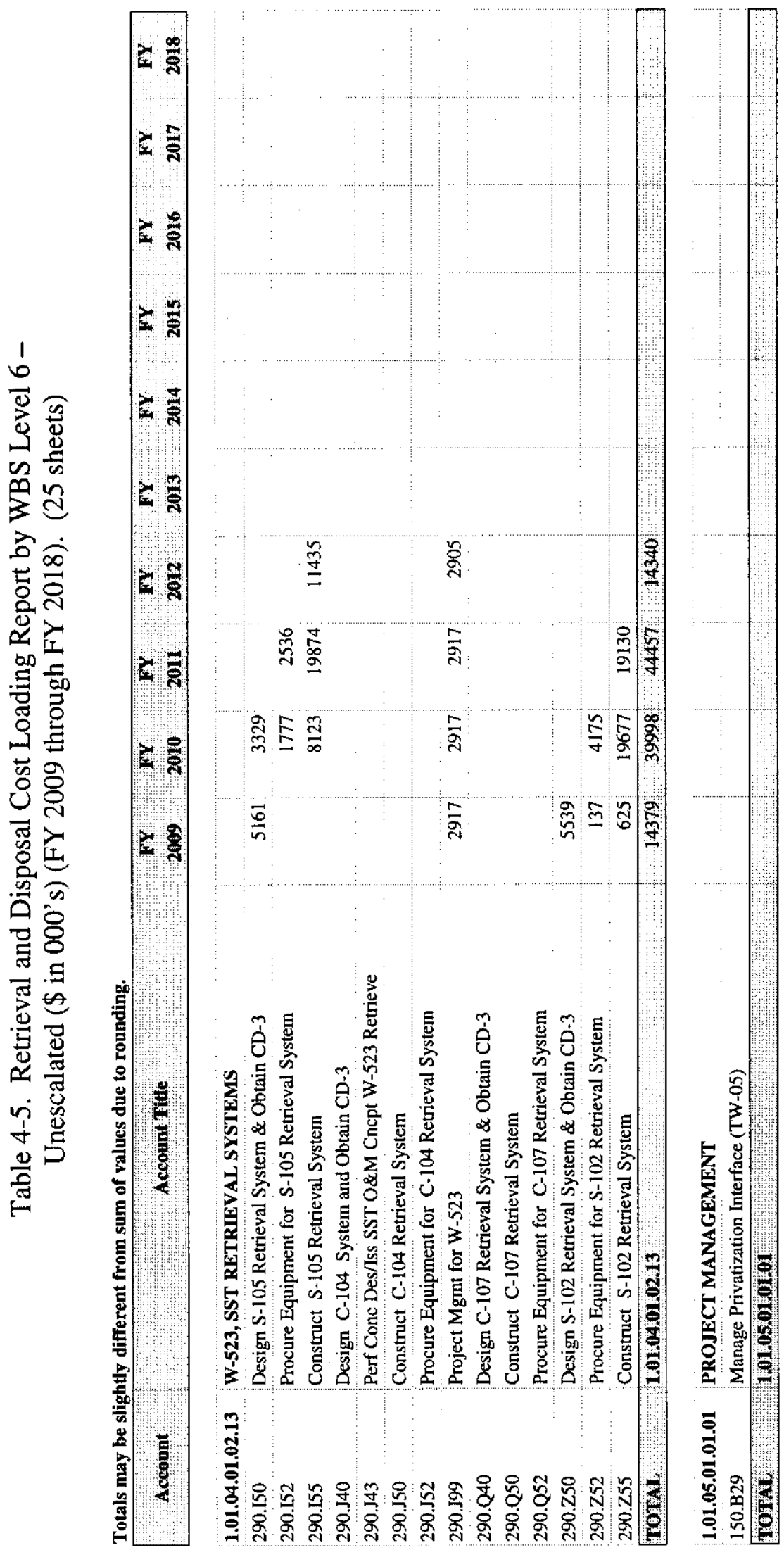

\begin{tabular}{|c|c|}
\hline 啹 & $\stackrel{\mathscr{c}}{m} \stackrel{\infty}{=}$ \\
\hline 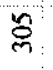 & 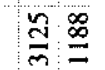 \\
\hline$\delta$ & స్లివ \\
\hline 8 & $E g$ \\
\hline 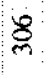 & $E \cong$ \\
\hline 8 & 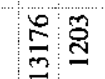 \\
\hline ठ & 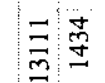 \\
\hline$\stackrel{8}{~}$ & $\frac{d}{m}$ \\
\hline$\stackrel{8}{~}$ & 总昌 \\
\hline 8 & 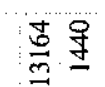 \\
\hline
\end{tabular}

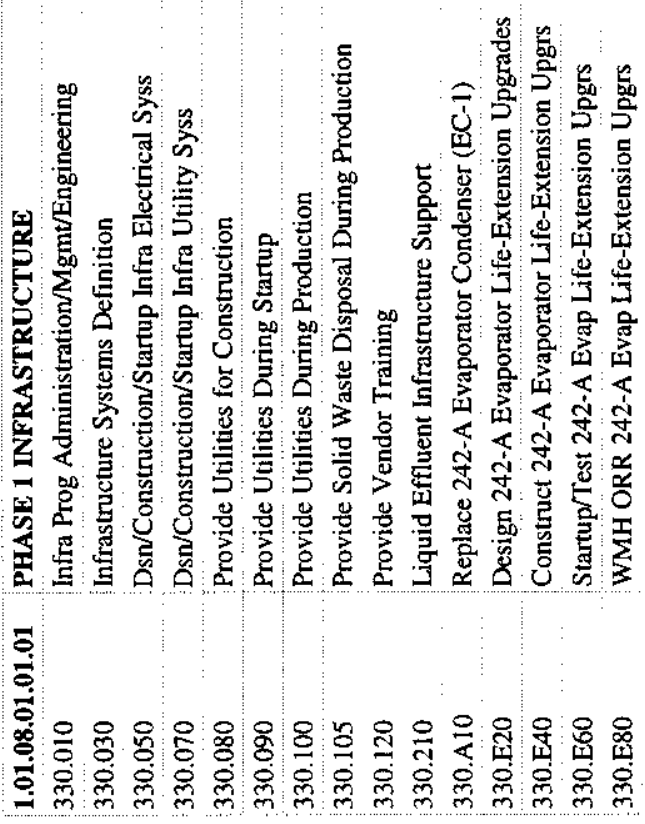




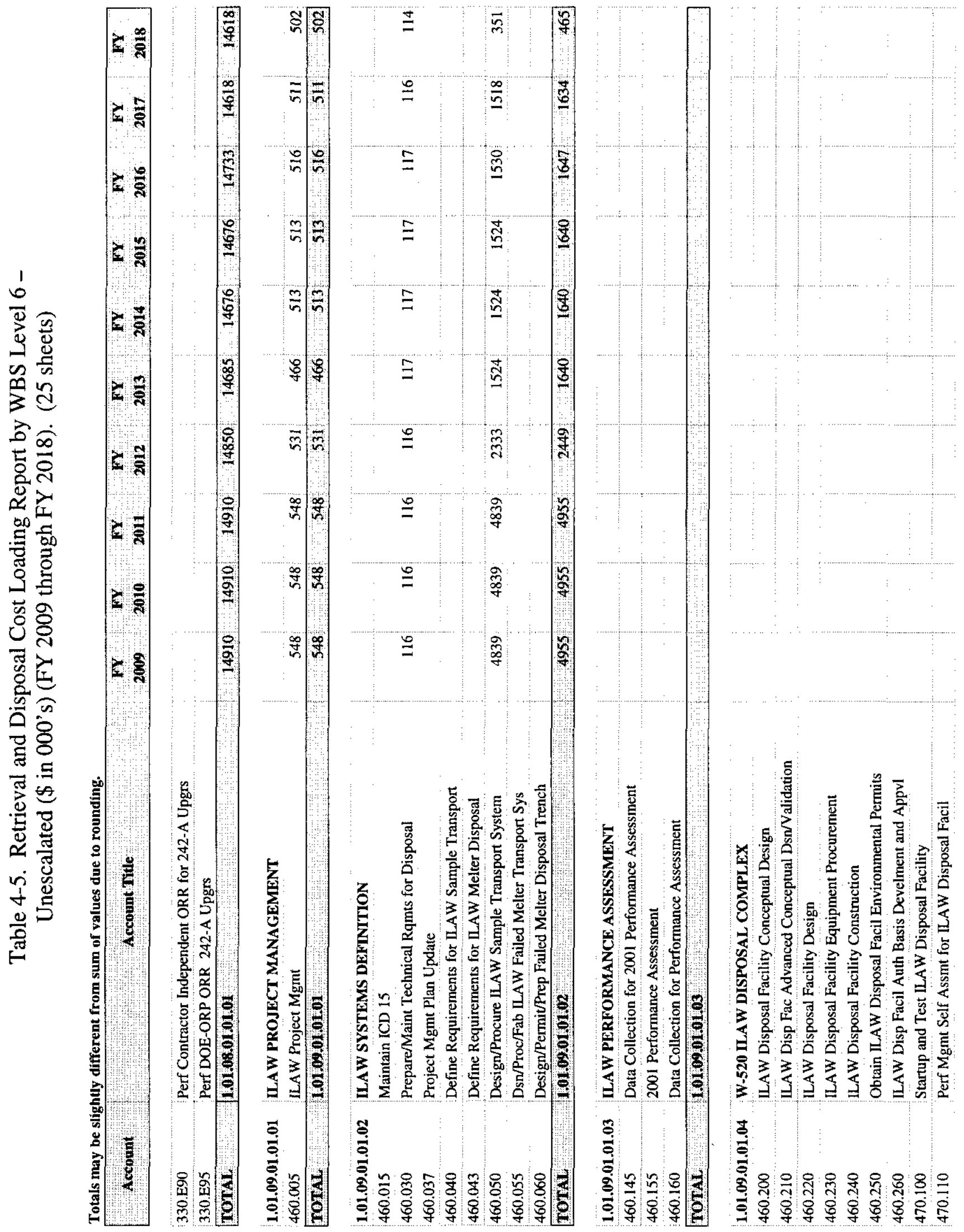


HNF-1946 REV 2

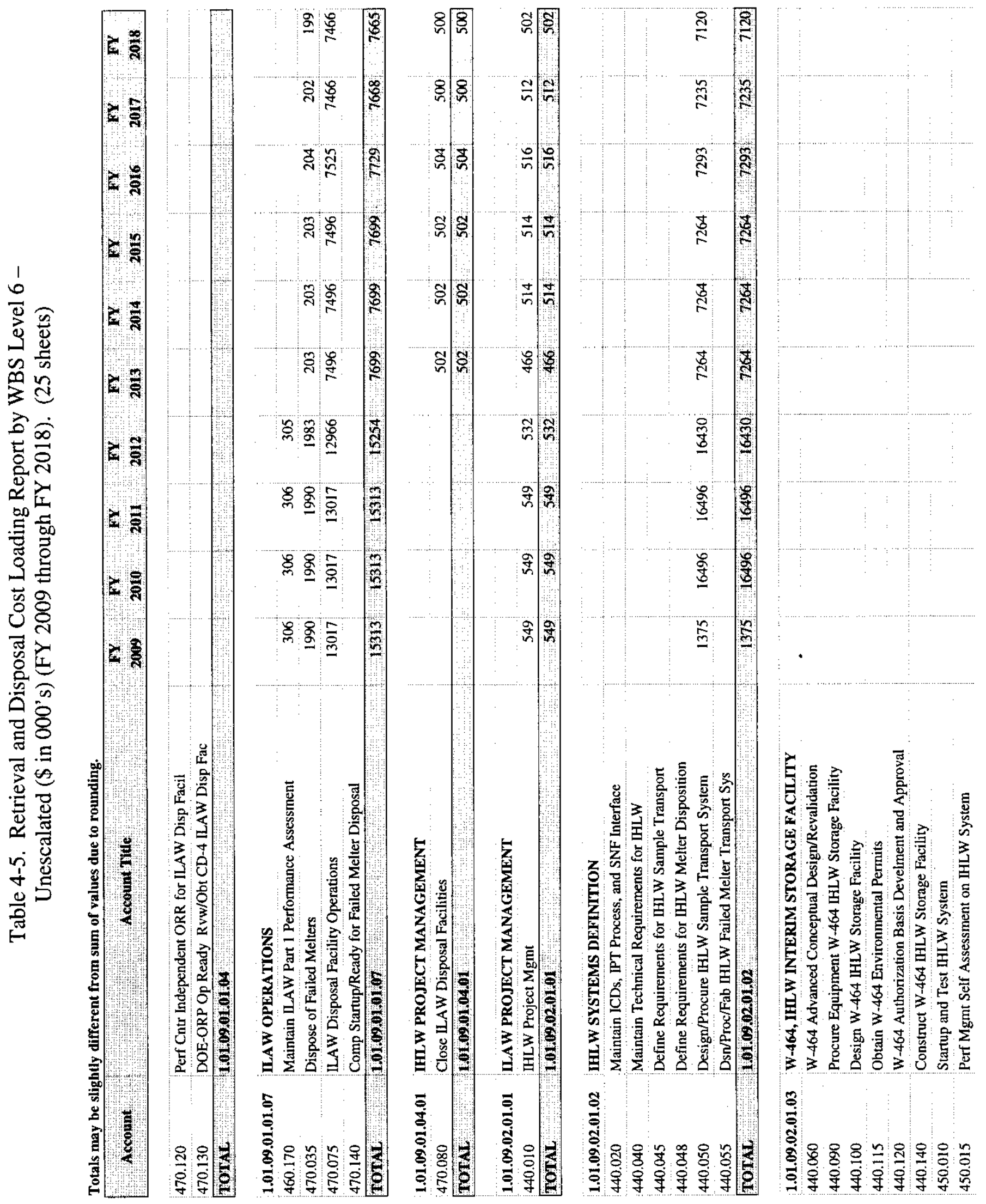




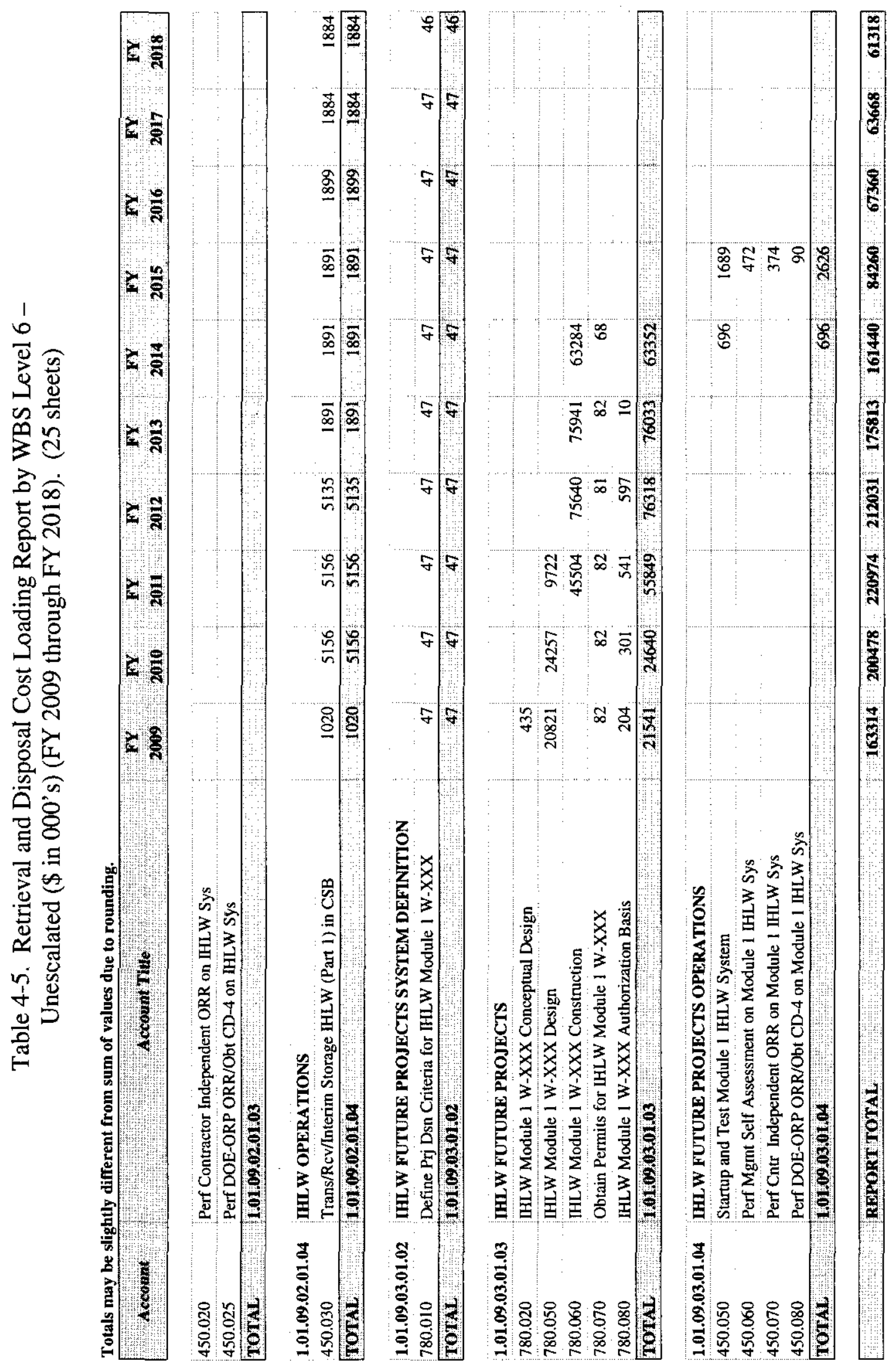




\subsection{SCHEDULE BASELINE}

The RPP Retrieval and Disposal P3 schedule has been prepared to reflect the technical and programmatic requirements necessary to execute the mission. The TFC schedules are developed in a hierarchical structure allowing for flow of performance measurement and reporting data from lower level schedules to higher level schedules.

The schedule products selected are presented in Appendix $\mathrm{C}$ and are discussed in Sections 5.1 through 5.4.

\subsection{PROJECT MASTER BASELINE SCHEDULE}

The Project Master Baseline Schedule (Appendix C) summarizes all activities and logic relationships for Phase 1. This schedule has been summarized from the lower level detail for each Level 1 Logic.

\subsection{CRITICAL PATH SCHEDULE}

The TFC Retrieval and Disposal P3 schedule with a critical path defined for each tank feed batch (Level 1 Logic) is provided in Appendix C. Constraining the "Provide Approval to Transfer" activity end-point for each feed batch as the "zero-float" activity generated this schedule. To create this critical path schedule, schedule contingency was removed. The P3 schedule was calculated and those activities that drive the end-point (within 60 days or less float) were selected and printed. This calculation was performed for each source tank logic sheet. (See Appendix C.)

\subsection{LIFE-CYCLE INTEGRATED RESOURCE- LOADED SCHEDULE}

.The detailed resource-loaded schedule was developed from and can be traced to the Level 1 Logic diagrams, TBR package data, and the WBS developed to define the scope, schedule, and cost for Phase 1 activities. The schedule, prepared in P3, is task oriented, logic driven, and resource loaded. TBR cost estimates were loaded and priced in $\mathrm{P} 3$ to produce the labor and nonlabor resources presented in this document. (See Appendix C.)

\subsection{MILESTONE LIST}

Table 5-1 provides a list of the major and key milestones in support of the TFC Phase 1 scope. 
Table 5-1. Tank Farm Contractor Key Milestones.

\begin{tabular}{|c|c|c|}
\hline Milestone Description 1 & $\begin{array}{l}\text { RTP P3 Target } \\
\text { Dates }\end{array}$ & $\begin{array}{r}\text { Tri-Party Agreement } \\
\text { Milestone \# }\end{array}$ \\
\hline \multicolumn{3}{|l|}{ Regulatory } \\
\hline Complete Sluicing Retrieval of Tank 241-C-106 & 31-Dec-99 & $\mathrm{M}-45-03 \mathrm{~B}$ \\
\hline Complete Tank Farm Upgrades & 16-Oct-03 & $\mathrm{M}-4300$ \\
\hline Start Construction in 2nd Farm & $01-$ Oct-99 & $\mathrm{M} 43-13$ \\
\hline Start Construction in 3rd Farm & 03-Jul-00 & $M-434$ \\
\hline Start Construction in 4 th Farm & 12-Apr-01 & $\mathrm{M}-43-15$ \\
\hline Start Construction in 5th Farm & 24-Apr-02 & $\mathrm{M}-43-16$ \\
\hline Update SST Retrieval Sequence & 29-Sep-17 & M-45-02 \\
\hline Annual Update SST Retrieval Sequence & 30-Sep-00 & $\mathrm{M}-45-02 \mathrm{E}$ \\
\hline Annual Update SST Retrieval Sequence & $30-$ Sep-01 & $\mathrm{M}-45-02 \mathrm{~F}$ \\
\hline Annual Update SST Retrieval Sequence & 30-Sep-02 & $\mathrm{M}-45-02 \mathrm{G}$ \\
\hline Annual Update SST Retrieval Sequence & $30-$ Sep-03 & $\mathrm{M}-45-02 \mathrm{H}$ \\
\hline Annual Update SST Retrieval Sequence & $30-$ Sep-04 & $\mathrm{M}=45-02 \mathrm{I}$ \\
\hline Annual Update SST Retrieval Sequence & 30-Sep-05 & $\mathrm{M}-45-02 \mathrm{~J}$ \\
\hline Annual Update SST Retrieval Sequence & 30-Sep-06 & $\mathrm{M}-45,02 \mathrm{~K}$ \\
\hline Annual Update SST Retrieval Sequence & 30-Sep-07 & $\mathrm{M}-45,02 \mathrm{~L}$ \\
\hline Annual Update SST Retrieval Sequence & $30-$ Sep-08 & $\mathrm{M}-45-02 \mathrm{M}$ \\
\hline Annual Update SST Retrieval Sequence & 30-Sep-09 & $\mathrm{M}-45 \cdot 02 \mathrm{~N}$ \\
\hline Annual Update SST Retrieval Sequence & $30-\operatorname{Sep}-10$ & $\mathrm{M}-45-020$ \\
\hline Annual Update SST Retrieval Sequence & 30-Sep-11 & $\mathrm{M}-45-02 \mathrm{P}$ \\
\hline Annual Update SST Retrieval Sequence & $30-$ Sep-12 & $\mathrm{M}-4502 \mathrm{Q}$ \\
\hline Annual Update SST Retrieval Sequence & $30-$ Sep-13 & $\mathrm{M}-4502 \mathrm{R}$ \\
\hline Annual Update SST Retrieval Sequence & $30-$ Sep-14 & $\mathrm{M}-4502 \mathrm{~S}$ \\
\hline Annual Update SST Retrieval Sequence & $30-$ Sep-15 & $\mathrm{M}-45.02 \mathrm{~T}$ \\
\hline Annual Update SST Retrieval Sequence & $29-\operatorname{Sep}-16$ & $\mathrm{M}-45-02 \mathrm{U}$ \\
\hline Annual Update SST Retrieval Sequence & 29-Sep-17 & $\mathrm{M}-45-02 \mathrm{~V}$ \\
\hline Complete Sluicing Retrieval of Tank 241-C-106 & 31-Dec-99 & $\mathrm{M}-45-03 B$ \\
\hline Initial Retrieval from 2 SSTs & $11-F e b-13$ & $\mathrm{M}-45-05-\mathrm{TO} 2$ \\
\hline Submit Annual LDMM Progress Reports & $30-$ Sep-00 & $\mathrm{M}-45-09 \mathrm{E}$ \\
\hline Submit Annual LDMM Progress Reports & $30-S e p-01$ & $\mathrm{M}-4509 \mathrm{~F}$ \\
\hline Submit Annual LDMM Progress Reports & $30-$ Sep-02 & $\mathrm{M}-45-09 \mathrm{G}$ \\
\hline Submit Annual LDMM Progress Reports & $30-$ Sep-03 & $\mathrm{M}-45,09 \mathrm{H}$ \\
\hline Submit CSB part B Application to Ecology & 31-May-02 & $M-20-56$ \\
\hline Submit ILAW Disposal Part B Permit Application to Ecology & 30-Aug-02 & $\mathrm{M}-20-57$ \\
\hline
\end{tabular}


Table 5-1. Tank Farm Contractor Key Milestones.

\begin{tabular}{|c|c|c|}
\hline Milestone Description, & RTP P3 Target & $\begin{array}{l}\text { Tri-Party Agreement } \\
\text { Milestone \# }\end{array}$ \\
\hline Complete W-520 Detailed Design & 30-Jun-04 & M-9 \\
\hline CD 3-Initiate W-520 Construction & 01-Jul-04 & $\mathrm{M}$ \\
\hline CD-4 Initiate Hot Operations W-520 & 08-Jun-07 & $\mathrm{M}-9$ \\
\hline Complete W-464 Construction (including startup) & 05-Jun-08 & $\mathrm{M}$ \\
\hline \multicolumn{3}{|l|}{ Internal Milestones } \\
\hline \multicolumn{3}{|l|}{ Phase 1 Pretreatment Facility } \\
\hline ICD \# 19 - PHMC Transfer LAW Feed Batch to BNFL & 09-Jan-05 & \\
\hline ICD \# 20 - PHMC Transfer HLW Feed Batch to BNFL & 11-Aug-05 & \\
\hline \multicolumn{3}{|l|}{ Phase-1 Waste Retrieval: Waste Transfer System Upgrades } \\
\hline Complete New AZ Pit & 18-Jun-01 & \\
\hline Complete Pipline - AN Farm to New AZ Valve & 19-Dec-01 & \\
\hline Complete 200 East Area Construction & 21-May-02 & \\
\hline Complete Site System Upgrades & 25-Jun-04 & \\
\hline \multicolumn{3}{|l|}{ Phase-1 Waste Retrieval: AN Farm Upgrades } \\
\hline Complete AN-Farm Upgrades & 10-Nov-04 & \\
\hline \multicolumn{3}{|l|}{$\begin{array}{l}\text { Phase } 1 \text { Waste Retrieval: Eng/Design/Construction/Startup \& } \\
\text { Turnover AN-101 }\end{array}$} \\
\hline Complete AN-101 & $17-\mathrm{Jul}-03$ & \\
\hline \multicolumn{3}{|l|}{$\begin{array}{l}\text { Phase } 1 \text { Waste Retrieval: Eng/Design/Construction/Startup \& } \\
\text { Turnover AN-102 }\end{array}$} \\
\hline Complete AN-102 & 06-Apr-06 & \\
\hline \multicolumn{3}{|l|}{$\begin{array}{l}\text { Phase } 1 \text { Waste Retrieval: Sample/Analysis, BNFL Approval } \\
\text { AN--102 }\end{array}$} \\
\hline Complete AN-102 & 12-Oct-06 & \\
\hline \multicolumn{3}{|l|}{ Phase 1 Waste Retrieval: Vitrify AN-102 } \\
\hline Complete AN-102 & $30-$ Sep-10 & \\
\hline \multicolumn{3}{|l|}{$\begin{array}{l}\text { Phase } 1 \text { Waste Retrieval: Eng/Design/Construction/Startup \& } \\
\text { Turnover AN-103 }\end{array}$} \\
\hline Complete AN-103 & 12-Dec-12 & \\
\hline \multicolumn{3}{|l|}{$\begin{array}{l}\text { Phase } 1 \text { Waste Retrieval: Sample/Analysis, BNFL Approval } \\
\text { AN--103 }\end{array}$} \\
\hline Complete AN-103 & 21-Jun-13 & \\
\hline \multicolumn{3}{|l|}{ Phase 1 Waste Retrieval: Vitrify AN-103 } \\
\hline Complete AN-103 & $30-\mathrm{Sep}-14$ & \\
\hline
\end{tabular}


Table 5-1. Tank Farm Contractor Key Milestones.

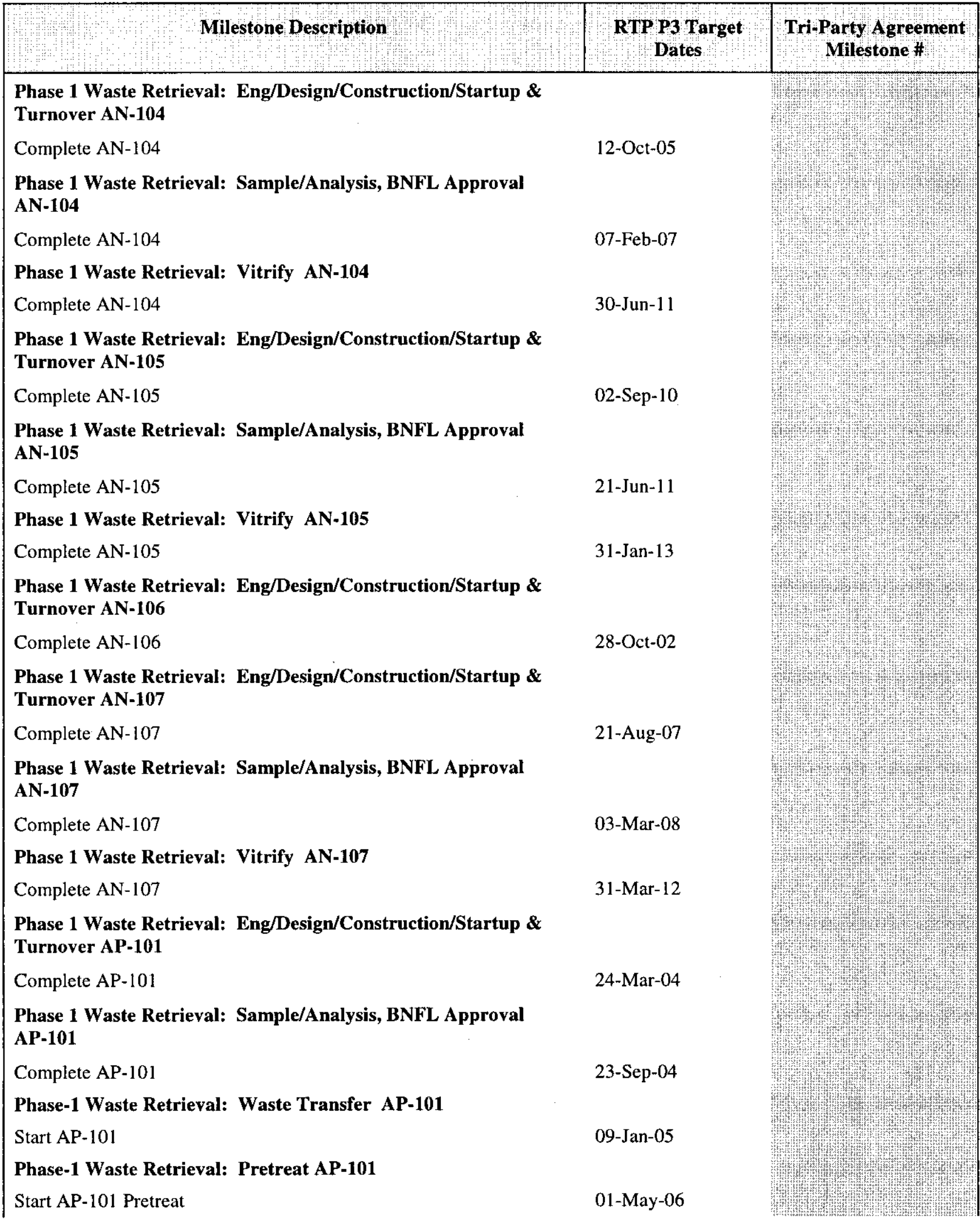


Table 5-1. Tank Farm Contractor Key Milestones.

\begin{tabular}{|c|c|c|}
\hline Milestone Description & $\begin{array}{l}\text { RTP P3 Target } \\
\text { Dates }\end{array}$ & $\begin{array}{l}\text { Tri-Party Agreement } \\
\text { Milestone } \#\end{array}$ \\
\hline \multicolumn{3}{|l|}{ Phase-1 Waste Retrieval: Vitrify AP-101 } \\
\hline Start AP-101 Vitrification & 01-Dec-06 & \\
\hline \multicolumn{3}{|l|}{ Phase 1 Waste Retrieval: Vitrify AP-101 } \\
\hline Complete AP-101 & 31-Aug-09 & \\
\hline \multicolumn{3}{|l|}{$\begin{array}{l}\text { Phase } 1 \text { Waste Retrieval: Eng/Design/Construction/Startup \& } \\
\text { Turnover AP-102 }\end{array}$} \\
\hline Complete AP-102 & 06-May-04 & \\
\hline \multicolumn{3}{|l|}{$\begin{array}{l}\text { Phase } 1 \text { Waste Retrieval: Sample/Analysis, BNFL Approval } \\
\text { AP-102 }\end{array}$} \\
\hline Complete AP-102 & 11-Nov-04 & \\
\hline \multicolumn{3}{|l|}{$\begin{array}{l}\text { Phase } 1 \text { Waste Retrieval: Eng/Design/Construction/Startup \& } \\
\text { Turnover AP-103 }\end{array}$} \\
\hline Complete AP-103 & 05-May-03 & \\
\hline \multicolumn{3}{|l|}{$\begin{array}{l}\text { Phase } 1 \text { Waste Retrieval: Eng/Design/Construction/Startup \& } \\
\text { Turnover AP-104 }\end{array}$} \\
\hline Complete AP-104 & 13-Aug-03 & \\
\hline \multicolumn{3}{|l|}{$\begin{array}{l}\text { Phase } 1 \text { Waste Retrieval: Eng/Design/Construction/Startup \& } \\
\text { Turnover AP-105 }\end{array}$} \\
\hline Complete AP-105 & 19-Mar-15 & \\
\hline \multicolumn{3}{|l|}{$\begin{array}{l}\text { Phase } 1 \text { Waste Retrieval: Sample/Analysis, BNFL Approval } \\
\text { AP-105 }\end{array}$} \\
\hline Complete AP-105 & $05-O c t-15$ & \\
\hline \multicolumn{3}{|l|}{ Phase 1 Waste Retrieval: Vitrify AP-105 } \\
\hline Complete AP-105 & $31-J u l-18$ & \\
\hline \multicolumn{3}{|l|}{$\begin{array}{l}\text { Phase } 1 \text { Waste Retrieval: Eng/Design/Construction/Startup \& } \\
\text { Turnover AP-106 }\end{array}$} \\
\hline Complete AP-106 & 11-Mar-13 & \\
\hline \multicolumn{3}{|l|}{$\begin{array}{l}\text { Phase } 1 \text { Waste Retrieval: Sample/Analysis, BNFL Approval } \\
\text { AP-106 }\end{array}$} \\
\hline Complete AP-106 & 14-Nov-13 & \\
\hline \multicolumn{3}{|l|}{ Phase 1 Waste Retrieval: Vitrify AP-106 } \\
\hline Complete AP-106 & 31-Dec-16 & \\
\hline \multicolumn{3}{|l|}{$\begin{array}{l}\text { Phase } 1 \text { Waste Retrieval: Eng/Design/Construction/Startup \& } \\
\text { Turnover AP-107 }\end{array}$} \\
\hline Complete AP-107 & 05-May-03 & \\
\hline $\begin{array}{l}\text { Phase } 1 \text { Waste Retrieval: Eng/Design/Construction/Startup \& } \\
\text { Turnover AP-108 }\end{array}$ & & \\
\hline
\end{tabular}


Table 5-1. Tank Farm Contractor Key Milestones.

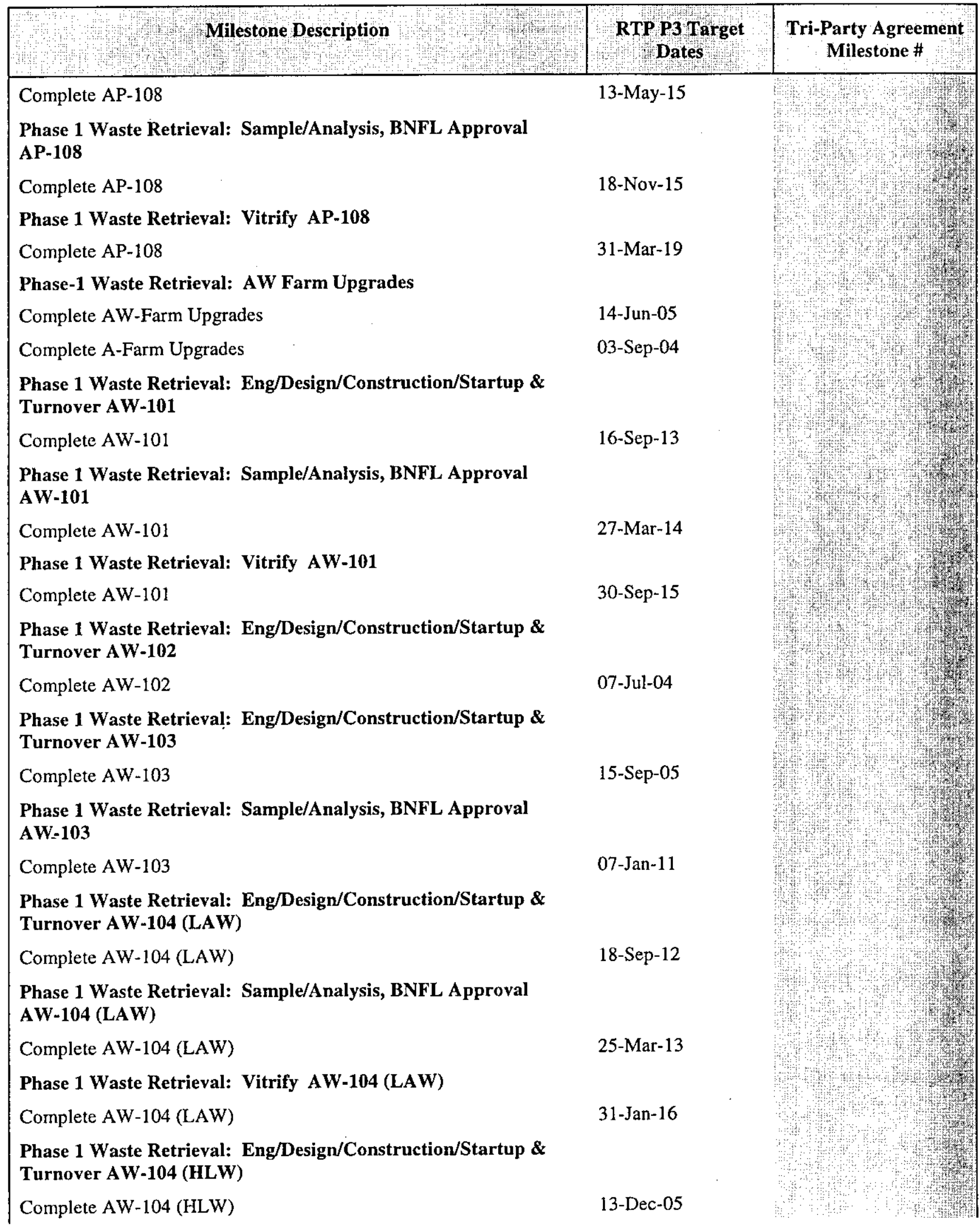


Table 5-1. Tank Farm Contractor Key Milestones.

\begin{tabular}{|c|c|c|}
\hline (1) Milestone Description & $\begin{array}{l}\text { RTP P3 Target } \\
\text { Dates }\end{array}$ & $\begin{array}{l}\text { Tri-Party Agreement } \\
\text { Milestone \# }\end{array}$ \\
\hline \multicolumn{3}{|l|}{$\begin{array}{l}\text { Phase } 1 \text { Waste Retrieval: Sample/Analysis, BNFL Approval } \\
\text { AW-104 (HLW) }\end{array}$} \\
\hline Complete AW-104 (HLW) & 15-Jul-13 & \\
\hline \multicolumn{3}{|l|}{$\begin{array}{l}\text { Phase } 1 \text { Waste Retrieval: Eng/Design/Construction/Startup \& } \\
\text { Turnover AW-105 }\end{array}$} \\
\hline Complete AW-105 & 12-Mar-04 & \\
\hline \multicolumn{3}{|l|}{$\begin{array}{l}\text { Phase } 1 \text { Waste Retrieval: Eng/Design/Construction/Startup \& } \\
\text { Turnover AW-106 }\end{array}$} \\
\hline Complete AW-106 & 28-May 04 & \\
\hline \multicolumn{3}{|l|}{ Phase-1 Waste Retrieval: AY Farm Upgrades } \\
\hline Complete AY-Farm Upgrades & $31-J a n-03$ & \\
\hline \multicolumn{3}{|l|}{$\begin{array}{l}\text { Phase } 1 \text { Waste Retrieval: Eng/Design/Construction/Startup \& } \\
\text { Turnover AY-101 }\end{array}$} \\
\hline Complete AY-101 & 10-Apr-06 & \\
\hline \multicolumn{3}{|l|}{$\begin{array}{l}\text { Phase } 1 \text { Waste Retrieval: Sample/Analysis, BNFL Approval AY- } \\
101\end{array}$} \\
\hline Complete AY-101 & 22-Jul-08 & \\
\hline \multicolumn{3}{|l|}{$\begin{array}{l}\text { Phase } 1 \text { Waste Retrieval: Eng/Design/Construction/Startup \& } \\
\text { Turnover AY-102 }\end{array}$} \\
\hline Complete AY-102 & 20-Jan-06 & \\
\hline \multicolumn{3}{|l|}{$\begin{array}{l}\text { Phase } 1 \text { Waste Retrieval: Sample/Analysis, BNFL Approval } \\
\text { AY-102 }\end{array}$} \\
\hline Complete AY-102 & $06-$-ct-06 & \\
\hline \multicolumn{3}{|l|}{ Phase-1 Waste Retrieval: AZ Farm Upgrades } \\
\hline Complete AZ-Farm Upgrades & 18-Mar-03 & \\
\hline \multicolumn{3}{|l|}{$\begin{array}{l}\text { Phase } 1 \text { Waste Retrieval: Eng/Design/Construction/Startup \& } \\
\text { Turnover AZ-101 }\end{array}$} \\
\hline Complete AZ-101 & 27-Sep-04 & \\
\hline \multicolumn{3}{|l|}{$\begin{array}{l}\text { Phase } 1 \text { Waste Retrieval: Sample/Analysis, BNFL Approval } \\
\text { AZ-101 }\end{array}$} \\
\hline Complete AZ-101 & 16-Jun-05 & \\
\hline \multicolumn{3}{|l|}{ Phase-1 Waste Retrieval: Waste Transfer AZ-101 } \\
\hline Start AZ-101 & 03-Aug-05 & \\
\hline \multicolumn{3}{|l|}{ Phase-1 Waste Retrieval: Pretreat AZ-101 } \\
\hline Start AZ-101 Pretreat & 01-Nov-06 & \\
\hline \multicolumn{3}{|l|}{ Phase-1 Waste Retrieval: Vitrify AZ-101 } \\
\hline Start AZ-101 Vitrification & $01-\operatorname{Sep}-08$ & \\
\hline
\end{tabular}


Table 5-1. Tank Farm Contractor Key Milestones.

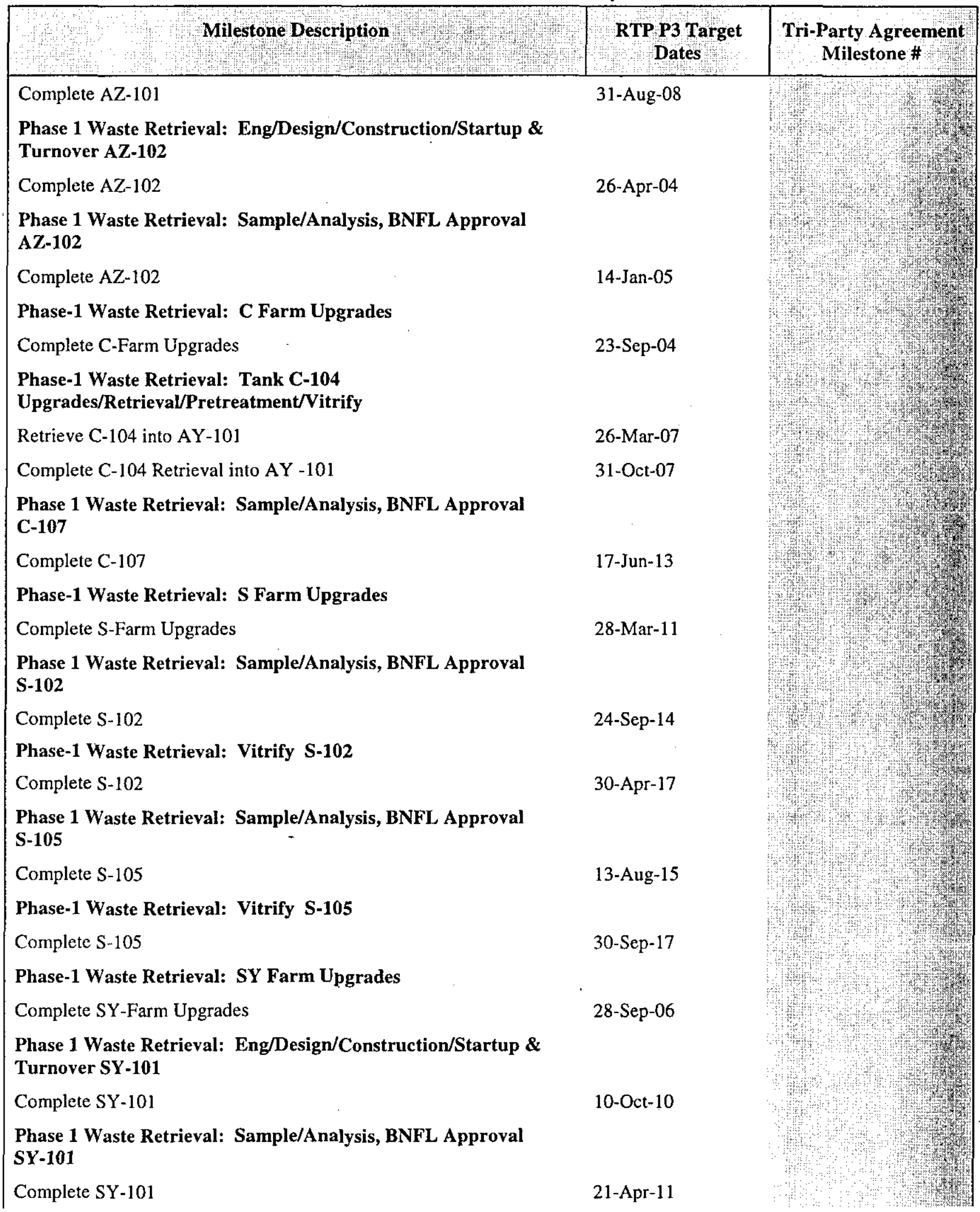


Table 5-1. Tank Farm Contractor Key Milestones.

\begin{tabular}{|c|c|c|}
\hline Milestone Description & $\begin{array}{l}\text { RTPP3 Target } \\
\text { Dates }\end{array}$ & $\begin{array}{c}\text { Tri-Party Agreement } \\
\text { Milestone } \#\end{array}$ \\
\hline \multicolumn{3}{|l|}{ Phase-1 Waste Retrieval: Vitrify SY-101 } \\
\hline Complete SY-101 & $30-$ Sep- 13 & \\
\hline \multicolumn{3}{|c|}{$\begin{array}{l}\text { Phase } 1 \text { Waste Retrieval: Eng/Design/Construction/Startup \& } \\
\text { Turnover SY-102 }\end{array}$} \\
\hline Complete SY-102 & 16-Apr-10 & \\
\hline \multicolumn{3}{|l|}{$\begin{array}{l}\text { Phase } 1 \text { Waste Retrieval: Sample/Analysis, BNFL Approval } \\
\text { SY-102 }\end{array}$} \\
\hline Complete SY-102 & 07-Jan-11 & \\
\hline \multicolumn{3}{|c|}{$\begin{array}{l}\text { Phase } 1 \text { Waste Retrieval: Eng/Design/Construction/Startup \& } \\
\text { Turnover SY-103 }\end{array}$} \\
\hline Complete SY-103 & 14-Mar-11 & \\
\hline \multicolumn{3}{|c|}{$\begin{array}{l}\text { Phase } 1 \text { Waste Retrieval: Sample/Analysis, BNFL Approval } \\
\text { SY-103 }\end{array}$} \\
\hline Complete SY-103 & 19-Aug-13 & \\
\hline \multicolumn{3}{|l|}{ Phase-1 Waste Retrieval: Vitrify SY-103 } \\
\hline Complete SY-103 & 30-Apr-16 & \\
\hline \multicolumn{3}{|l|}{ Phase-1 Waste Retrieval: U Farm Upgrades } \\
\hline Complete U-Farm Upgrades & 30-Mar-01 & \\
\hline \multicolumn{3}{|l|}{ Infrastructure } \\
\hline Complete Construction Power 7MW Complete for BNFL & $30-$ Nov-00 & \\
\hline Complete Electrical Power for BNFL, Operations & $01-$ Aug-03 & \\
\hline \multicolumn{3}{|l|}{$\begin{array}{l}\text { Immobilized Waste: Phase-1 ILAW Disposal Facility } \\
\text { Procurement/Title III }\end{array}$} \\
\hline W-520 Procurement/Title IIII & 30-Jun-06 & \\
\hline \multicolumn{3}{|l|}{ M-90-10: CD 4-Initiate W-520 Hot Ops } \\
\hline CD 4-Initiate Hot Operations W-520 & 08-Jun-07 & \\
\hline \multicolumn{3}{|l|}{ Immobilized Waste: ILAW Facility Initial Hot Operations } \\
\hline Receive Last Phase 1 ILAW for Disposal & $30-$ Sep-15 & \\
\hline ILAW Disposal Complete & 28 -Sep-18 & \\
\hline \multicolumn{3}{|l|}{ Immobilized Waste: Complete W-464 Detailed Design } \\
\hline Complete W-464 Detailed Design & 30-Jul-04 & \\
\hline \multicolumn{3}{|l|}{ Immobilized Waste: W-464 Operation } \\
\hline Operation of HLW Canister Storage & 06-Jun-08 & \\
\hline Receive Last Phase IHLW for Disposal & 30-Apr-17 & \\
\hline
\end{tabular}


HNF-1946 REV 2

This page intentionally left blank. 


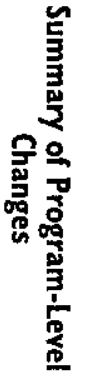




\subsection{SUMMARY OF PROGRAM-LEVEL CHANGES FOR PHASE 1}

This section provides a summary-level discussion of the scope, schedule, and cost changes between the Programmatic Baseline Summary for Phase 1 for the TFC and the RPP FY 2000 Multi-Year Work Plan Summary (RPP-5044, Rev. 1). This section specifically addresses the scope directly associated with executing the Retrieval and Disposal Phase 1 in support of the Privatization mission.

The TFC has reduced Phase 1 costs by approximately $\$ 676 \mathrm{M}$. This reduction is associated with the assumptions of unconstrained funding starting in FY 2001. However, because of scope shift and time phasing, as well as other programmatic adjustments, the majority of this reduction to Phase 1 is a reallocation to other program areas. The Retrieval and Disposal Mission Phase 1 Financial Analysis, HNF-2017, Rev. 2, further documents the life-cycle financial changes.

\subsection{RETRIEVAL PROJECT}

Based on preparation of Level 1 Logics and associated baseline review and updates, the following changes are noted.

\section{DST Retrieval Project $(\$ 230 \mathrm{M})$}

A new DST retrieval sequence was implemented in this schedule based on guidance from ORP. AP-101 retrieval was accelerated by 11 years to become the first waste delivered to the Privatization Contractor, supporting ORP direction to start processing LAW before HLW. Schedule acceleration was accompanied by a simplification in the retrieval equipment installed in this tank to support a supernatant-only transfer. Consistent with the directed retrieval sequence, two DSTs were eliminated from W-522 Phase 1 feed delivery scope and estimates were refined for the retrieval equipment needed for three of the tanks. In addition, W-525 scope was further defined, resulting in a reduction for Phase 1 activities.

\section{Single-Shell Tank Retrieval Project (\$318M)}

The SST Retrieval Project made several significant changes to the FY 2000 MYWP planning basis during the RTP evaluation. The principal change driver was the directive from ORP (September 30, 1999, Work Authorization, Rev. 0) to incorporate the retrieval of tank 241-C-104 into the Phase 1, Waste Feed Delivery minimum order. This directive required the SST Retrieval Project to accelerate the retrieval of waste from Tank 241-C-104 from the MYWP date of FY 2010 to mid-FY 2007, and re-plan the balance of the Phase 1 SST retrieval projects to meet Waste Feed Delivery Phase 1 Extended Order delivery requirements.

The performance of the sluicing campaign in 241-C-106 resulted in a re-evaluation of the objectives of the "Limits of Technology" test and demonstration project. This project was planned as an alternative technology deployment to remove the anticipated hard heel from Tank 241-C-106. However, preliminary evaluation has indicated that a second retrieval campaign in Tank 241-C-106 may not be warranted. Activities have been included in RTP to 
obtain a determination of operational closure for Tank 241-C-106 and the "Limits of Technology" test and demonstration project has been replanned.

In summary the major changes from the FY 2000 MYWP to the RTP-2 planning base for the SST Retrieval Project include:

1. Acceleration of Tank 241-C-104 retrieval from FY 2010 to FY 2007

2. Rescheduling of Tanks $241-\mathrm{C}-107,241-\mathrm{S}-102$, and $241-\mathrm{S}-105$ to meet revised feed delivery requirements

3. Replanning of the "Limits of Technology" project and elimination of the hard heel retrieval deployment in Tank 241-C-106

4. Acceleration of the Saltcake Dissolution test and demonstration project activities to support cost reduction initiatives and Phase 1 saltcake retrieval

5. Incorporation of new activities to plan and attain operational closure for Tank 241-C-106

6. Reallocation of test and deployment demonstration projects, not required to support the selected W-523 Phase 1 retrievals, to Phase 2 costs

7. Revised planning and estimating for FY $2000 \mathrm{~W}-523$ and programmatic activities to support the accelerated Tank 241-C-104 schedule.

\subsection{PROCESS WASTE SUPPORT}

After preparation of the Level 1 Logics and associated baseline review and updates, no scope, schedule, or cost changes were made.

\subsection{INFRASTRUCTURE PROJECT (\$9M)}

Based on preparation of the Level 1 Logics and associated baseline review and updates, no scope or schedule changes occurred. The following cost changes were made.

Costs for Privatization Infrastructure Phase 1 activities are \$9.0 Million lower than those shown in the FY 2000 MYWP. The reduction is primarily attributable to a change in the labor rate table and a reduction in the approved escalation rate table. No scope or schedule changes occurred.

\subsection{IMMOBILIZED WASTE $(\$ 59 \mathrm{M})$}

Based on preparation of Level 1 Logics and associated baseline review and updates the following changes are noted.

6.4.1.1 Immobilized Low-Activity Waste Disposal Storage. CHG recommended and ORP approved cancellation of Project W-465, Interim Storage Facility, and the shift to a Remote 
Handled Trench concept for disposal of ILAW. Project W-520, ILAW Disposal Facility, scope was revised to delete concrete vaults and incorporate the Remote Handled Trench architecture. Project W-520 design activities were accelerated from September 2005 to October 2002, and construction completion was accelerated from September 2010 to July 2006, with startup/turnover activities accelerated from May 2011 to June 2007. In addition, Disposal of Failed Melters was moved from the IHLW Program to ILAW Program.

6.4.1.2 Immobilized High-Level Waste Interim Storage. As a result of revised project delivery dates of IHLW to CHG, preparation and submittal of the Part B Permit for Project W-464 is deferred from FY 2000 to FY 2002 to match the revised Tri-Party Agreement milestone date. Completion of construction for Project W-464 was deferred from March 2005 to March 2007 consistent with the revised need date and startup of W-464 was deferred from March 2006 to June 2008.

\subsection{CHARACTERIZATION PROJECT (\$65M)}

Waste feed characterization sampling and analysis scope was reduced for Phase 1 . Changes to requirements contained in ICDs 19,20, and 23 reduced the number of HLW and LAW samples and associated laboratory analysis required to certify feed delivered to the privatization contractor. Significant changes were reducing the number of core samples from 2 to 1 for HLW tanks and analyzing only the first batch instead of all batches for high-level waste transfers. 


\section{HNF-1946 REV 2}

This page intentionally left blank. 


\section{HNF-1946 REV 2}

\subsection{REFERENCES}

Barrett, M. K., 2000, "Contract No. DE-AC06-99RL14047 - The U.S. Department of Energy, Office of River Protection (ORP) Mission Planning Guidance for Fiscal Year (FY) 2002 - Revision 2," (letter 00-BMA-027 to M. P. DeLozier, CH2M HILL Hanford Group, Inc., April 4), U.S. Department of Energy, Office of River Protection, Richland, Washington.

Short, J. J., II, 2000a, "Contract No. DE-AC06-99RL14047 - Office of River Protection (ORP) Mission Planning Guidance for Fiscal Year (FY) 2002," (letter 00-MSO-007 to M. P. DeLozier, CH2M HILL Hanford Group, Inc., January 31), U.S. Department of Energy, Office of River Protection, Richland, Washington.

Short, J. J., II, 2000b, "Contract No. DE-AC06-99RL14047 - The U.S. Department of Energy, Office of River Protection (ORP) Mission Planning Guidance for Fiscal Year (FY) 2002 - Revision 1," (letter 00-MSO-009 to M. P. DeLozier, CH2M HILL Hanford Group, Inc., February 3), U.S. Department of Energy, Office of River Protection, Richland, Washington.

CHG, 1999a, Integrated Planning Process, HNF-IP-0842, Rev. 0A, CH2M HILL Hanford Group, Inc., Richland, Washington.

CHG, 1999, Cost Estimating, HNF-PRO-585, Rev. 0, CH2M HILL Hanford Group, Inc., Richland, Washington.

CHG, 2000a, River Protection Project FY 2000 Multi-Year Work Plan Summary, RPP-5044, Rev. 1, CH2 M HILL Hanford Group, Inc., Richland, Washington.

CHG, 2000b, River Protection Project Key Planning Assumptions, RPP-5993, Rev. 0, CH2M HILL Hanford Group, Inc., Richland, Washington.

Diediker, J. A., 2000, Programmatic Baseline Summary for Phase I Privatization for the Tank Farm Contractor, HNF-1946, Rev. 2, CH2M HILL Hanford Group, Inc., Richland, Washington.

DOE, 1997, Cost Estimating Guide, DOE G 430.1-1, U.S. Department of Energy, Washington, D.C.

Kirkbride, R. A., 2000, Tank Farm Contractor Operation and Utilization Plan, HNF-SD-WM-SP-012, Rev. 2, CH2M HILL Hanford Group, Inc., Richland, Washington.

LMHC, 1999, River Protection Project FY 2000 Multi-Year Work Plan Summary, RPP-5044, Rev. 0, Lockheed Martin Hanford Corporation, Richland, Washington.

ORP, 2000, River Protection Project Mission Analysis Report, DOE/ORP-2000-10, Rev. 0, U.S. Department of Energy, Office of River Protection, Richland, Washington. 
RL, 1997, Hanford Site Cost Estimating and Scheduling Guide, DOE/RL 97-90, Rev. 0, U.S. Department of Energy, Richland Operations Office, Richland, Washington.

Seeman, S. E., 2000, River Protection Project Level-O Logic, TWR-2086, Rev. 2, CH2M HILL Hanford Group, Inc., Richland, Washington.

Sieracki, S. A., 2000, "Contract No. DE-AC06-96RL13200 - Fiscal Year (FY) 2001 and Outyear Pricing Rates," (letter 00-FIN-135 to R. D. Hanson, Fluor Daniel Hanford, Inc., April 17), U.S. Department of Energy, Richland Operations Office, Richland, Washington.

Wood, R. F., 1999, "Contract Number DE-AC06-99RL14047; Revised Submittal of Fiscal Year 2000 Indirect Annual Work Plans," (letter LMHC-9957721 R1 to J. J. Short, U.S. Department of Energy, Office of River Protection, November 30), Lockheed Martin Hanford Corporation, Richland, Washington. 
HNF-1946 REV 2

APPENDIX A

\section{LEVEL 1 LOGICS}


HNF-1946 REV 2

This page intentionally left blank.

A-ii 


\section{APPENDIX A}

\section{LEVEL 1 LOGICS}

Level 1 Logics have been prepared for the Phase 1 Privatization mission in three media formats: 10 sets of drawings, "C" size; 10 titled CD ROMs titled "RTP II" (4/00); and electronic access via the Hanford intranet, RPP Technical Resources web site.

\section{A.1 LOW-ACTIVITY WASTE FEED BATCHES, LEVEL 1 LOGICS}

\begin{tabular}{|l|c|c|}
\hline Title & Drawing & Revision \\
\hline Tank 241-AN-102 & TWR-2097 & 2.0 \\
\hline Tank 241-AN-103 & TWR-2093 & 2.0 \\
\hline Tank 241-AN-104 & TWR-2091 & 2.0 \\
\hline Tank 241-AN-105 & TWR-2090 & 2.0 \\
\hline Tank 241-AN-107 & TWR-2096 & 2.0 \\
\hline Tank 241-AP-101 & TWR-2094 & 2.0 \\
\hline Tank 241-AP-102/4 & RPP-5009 & 1.0 \\
\hline Tank 241-AP-105 & RPP-5021 & 1.0 \\
\hline Tank 241-AP-106 & RPP-5928 & 0.0 \\
\hline Tank 241-AP-108 & RPP-5929 & 0.0 \\
\hline Tank 241-AW-101 & TWR-2092 & 2.0 \\
\hline Tank 241-AW-104 & RPP-5010 & 1.0 \\
\hline Tank 241-S-102 & RPP-5024 & 1.0 \\
\hline Tank 241-S-105 & RPP-5013 & 1.0 \\
\hline Tank 241-SY-101 & TWR-2099 & 2.0 \\
\hline Tank 241-SY-103 & TWR-2100 & 2.0 \\
\hline
\end{tabular}




\section{A.2 HIGH-LEVEL WASTE FEED BATCHES, LEVEL 1 LOGICS}

\begin{tabular}{|c|c|c|}
\hline Title & Drawing & Revision \\
\hline Tank 241-AW-103 & RPP-5011 & 1.0 \\
\hline Tank 241-AW-104 & RPP-5022 & 1.0 \\
\hline Tank 241-AY-101 & TWR-2095 & 2.0 \\
\hline Tank 241-AY-102 & TWR-2103 & 2.0 \\
\hline Tank 241-AZ-101 & TWR-2101 & 2.0 \\
\hline Tank 241-AZ-102 & TWR-2102 & 2.0 \\
\hline Tank 241-C-104 & TWR-2104 & 2.0 \\
\hline Tank 241-C-107 & RPP-5012 & 1.0 \\
\hline Tank 241-SY-102 & RPP-5025 & 1.0 \\
\hline
\end{tabular}

\section{A.3 IMMOBILIZED LOW-ACTIVITY, HIGH LEVEL WASTE LOGICS AND INFRASTRUCTURE LOGICS}

\begin{tabular}{|c|c|c|}
\hline Title & Drawing & Revision \\
\hline IILAW & TWR-2087 & 2.0 \\
\hline IHLAW & TWR-2088 & 2.0 \\
\hline Infrastructure & TWR-2089 & 2.0 \\
\hline
\end{tabular}

\section{A.4 WASTE FEED DELIVERY DEFINITION, PROGRAM MANAGEMENT AND SST PROGRAM LOGICS}

\begin{tabular}{|c|c|c|}
\hline Title & Drawing & Revision \\
\hline RPP Retrieval & RPP-5027 & 1.0 \\
\hline Waste Feed Delivery (WFD) & RPP-5016 & 1.0 \\
\hline WFD Project Definition & RPP-5028 & 0 \\
\hline Management. Assessment & RPP-5026 & 1.0 \\
\hline SST Program & RPP-5015 & 0 \\
\hline
\end{tabular}


HNF-1946 REV 2

\section{APPENDIX B}

TANK FARM CONTRACTOR INTEGRATED RESOURCE LOADED SCHEDULE 


\section{HNF-1946 REV 2}

This page intentionally left blank

B-ii 


\section{APPENDIX B \\ TANK FARM CONTRACTOR INTEGRATED RESOURCE LOADED SCHEDULE}

Table B-1. Crosswalk from the Level 1 Logic to the Work Breakdown Structure.

\begin{tabular}{|c|c|c|}
\hline \multicolumn{3}{|c|}{ BNFL Inc. Phase 1 Privatization activities identified at WBS Level 3 (1.01.06). } \\
\hline $\begin{array}{l}\text { Thel Logic } \\
\text { TBR Number }\end{array}$ & 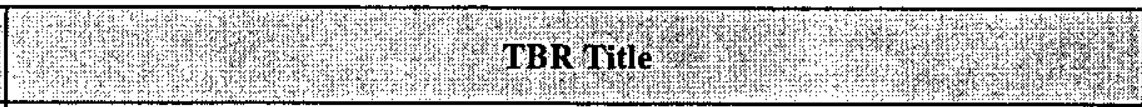 & WBS Level 6 \\
\hline 050.090 & Sluice $\mathrm{C}-106$ to $\mathrm{AY}-102$ & 1.01 .04 .01 .01 .10 \\
\hline 100.200 & Receive and Disposition BNFL Study Residue and Job Control Samples & 1.01 .01 .01 .01 .04 \\
\hline $100 . \mathrm{C} 03$ & Update Best Basis Inventory and Tank Characterization Report for C-104 & 1.01 .01 .01 .01 .04 \\
\hline $100 . \mathrm{C} 19$ & Obtain C-107 Core Samples and Prepare Sub-Samples and Composites & 1.01 .01 .01 .01 .04 \\
\hline $100 . C 30$ & Perform C-107 Post Retrieval Verification & 1.01 .01 .01 .01 .04 \\
\hline $100 . C 77$ & Perform C-104 Post Retrieval Verification & 1.01 .01 .01 .01 .04 \\
\hline $100 . \mathrm{N} 01$ & Provide Post Part B2 Sample of AN-103 per ICD 23 Schedule to BNFL & 1.01 .01 .01 .01 .04 \\
\hline 100.N05 & Provide Post Part B2 Sample of AN-104 per ICD 23 Schedule to BNFL & 1.01 .01 .01 .01 .04 \\
\hline 100.N08 & Provide Post Part B2 Sample of AN-102 per ICD 23 Schedule to BNFL & 1.01 .01 .01 .01 .04 \\
\hline 100.N09 & Provide Post Part B2 Sample of AN-107 per ICD 23 Schedule to BNFL & 1.01.01.01.01.04 \\
\hline 100.N11 & Provide Post Part B2 Sample of AN-105 per ICD 23 Schedule to BNFL & 1.01 .01 .01 .01 .04 \\
\hline 100.N47 & $\begin{array}{l}\text { Sample and Analyze AN-107 Feed Certification Samples per LAW Feed Cert } \\
\text { DQO from AN-107 }\end{array}$ & 1.01 .01 .01 .01 .04 \\
\hline 100.N49 & $\begin{array}{l}\text { Sample and Analyze AN-105 Feed Certification Samples per LAW Feed Cert } \\
\text { DQO from AN-102 }\end{array}$ & 1.01 .01 .01 .01 .04 \\
\hline 100.N50 & $\begin{array}{l}\text { Sample and Analyze AN-105 Feed Certification Samples per LAW Feed Cert } \\
\text { DQO from AN-105 }\end{array}$ & 1.01.01.01.01.04 \\
\hline 100.N51 & $\begin{array}{l}\text { Sample and Analyze AN-102 Feed Certification Samples per LAW Feed Cert } \\
\text { DQO from AN-102 }\end{array}$ & 1.01 .01 .01 .01 .04 \\
\hline 100.N53 & $\begin{array}{l}\text { Sample and Analyze AN-104 Feed Certification Samples per LAW Feed Cert } \\
\text { DQO from AN-104 }\end{array}$ & 1.01 .01 .01 .01 .04 \\
\hline 100.N54 & $\begin{array}{l}\text { Sample and Analyze AN-104 Feed Certification Samples per the LAW Feed } \\
\text { Cert DQO from AN-101 }\end{array}$ & 1.01.01.01.01.04 \\
\hline 100.N55 & $\begin{array}{l}\text { Sample and Analyze AN-103 Feed Certification Samples per LAW Feed Cert } \\
\text { DQO from AN-102 }\end{array}$ & 1.01 .01 .01 .01 .04 \\
\hline 100.N56 & $\begin{array}{l}\text { Sample and Analyze AN-103 Feed Certification Samples per LAW Feed Cert } \\
\text { DQO from AN-103 }\end{array}$ & 1.01 .01 .01 .01 .04 \\
\hline 100.N61 & Sample AN-104 Feed in AN-104 and Analyze for Sulfates & 1.01 .01 .01 .01 .04 \\
\hline
\end{tabular}




\section{HNF-1946 REV 2}

Table B-1. Crosswalk from the Level 1 Logic to the Work Breakdown Structure.

\begin{tabular}{|c|c|c|}
\hline \multicolumn{3}{|c|}{ BNFL Inc. Phase 1 Privatization activities identified at WBS Level 3 (1.01.06). } \\
\hline $\begin{array}{l}\text { Level } 1 \text { Logic } \\
\text { TBR Number }\end{array}$ & 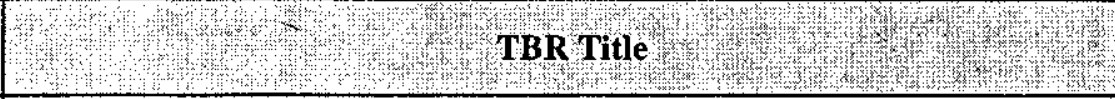 & WBS Level 6 \\
\hline 100.N62 & Sample AN-104 Feed in AN-101 and Analyze for Sulfates & 1.01 .01 .01 .01 .04 \\
\hline 100.N63 & Sample AN-105 Feed in AN-105 and Analyze for Sulfates & 1.01 .01 .01 .01 .04 \\
\hline 100.N64 & Sample AN-105 Feed in AN-102 and Analyze for Sulfates & 1.01 .01 .01 .01 .04 \\
\hline 100.N65 & $\begin{array}{l}\text { Sample and Analyze AP-106 Feed Certification Samples per LAW Feed Cert } \\
\text { DQO from AN-102 }\end{array}$ & 1.01.01.01.01.04 \\
\hline 100.P01 & Sample AP-102 & 1.01 .01 .01 .01 .04 \\
\hline 100.P02 & Sample AP-106 & 1.01 .01 .01 .01 .04 \\
\hline 100.P03 & $\begin{array}{l}\text { Sample and Analyze AP-106 Feed Certification Samples per LAW Feed Cert } \\
\text { DQO from AP-106 }\end{array}$ & 1.01 .01 .01 .01 .04 \\
\hline 100.P04 & Sample AP-108 & 1.01.01.01.01.04 \\
\hline 100.P05 & $\begin{array}{l}\text { Sample and Analyze AP-108 Feed Certification Samples per LAW Feed Cert } \\
\text { DQO from AP-108 }\end{array}$ & 1.01.01.01.01.04 \\
\hline $100 . P 62$ & Sample AP-105 & 1.01 .01 .01 .01 .04 \\
\hline $100 . \mathrm{P} 63$ & Sample SY-101 Feed in AP-104 & 1.01 .01 .01 .01 .04 \\
\hline 100.P65 & $\begin{array}{l}\text { Sample and Analyze AP-102 Feed Certification Samples per LAW Feed Cert } \\
\text { DQO from AP-102 }\end{array}$ & 1.01 .01 .01 .01 .04 \\
\hline $100 . P 67$ & $\begin{array}{l}\text { Sample and Analyze AP-105 Feed Certification Samples per LAW Feed Cert } \\
\text { DQO from AP-104 }\end{array}$ & 1.01 .01 .01 .01 .04 \\
\hline 100.P68 & $\begin{array}{l}\text { Sample and Analyze AP-105 Feed Certification Samples per LAW Feed Cert } \\
\text { DQO from AP-105 }\end{array}$ & 1.01 .01 .01 .01 .04 \\
\hline 100.P69 & $\begin{array}{l}\text { Sample and Analyze AP-101 Feed Certification Samples per LAW Feed Cert } \\
\text { DQO from AP-101 }\end{array}$ & 1.01 .01 .01 .01 .04 \\
\hline $100 . P 71$ & Sample AP-10I per BNFL, ORP/WIT, and RPP Requirements & 1.01 .01 .01 .01 .04 \\
\hline $100 . P 77$ & $\begin{array}{l}\text { Sample and Analyze SY-101 Feed Certification Samples per LAW Feed Cert } \\
\text { DQO from AP-104 }\end{array}$ & 1.01 .01 .01 .01 .04 \\
\hline $100 . \$ 46$ & $\begin{array}{l}\text { Sample and Analyze S-105 Feed Certification Samples per LAW Feed Cert } \\
\text { DQO from AN-105 }\end{array}$ & 1.01 .01 .01 .01 .04 \\
\hline $100 . S 47$ & $\begin{array}{l}\text { Sample and Analyze S-102 Feed Certification Samples per LAW Feed Cert } \\
\text { DQO from AP-101 }\end{array}$ & 1.01 .01 .01 .01 .04 \\
\hline 100.554 & Sample SY-102 per BNFL Requirements and Deliver Sample to BNFL & 1.01 .01 .01 .01 .04 \\
\hline $100 . S 56$ & Sample S-105 & 1.01 .01 .01 .01 .04 \\
\hline 100.557 & Sample S-102 & 1.01 .01 .01 .01 .05 \\
\hline 100.559 & Perform S-102 Post Retrieval Verification & 1.01.01.01.01.04 \\
\hline
\end{tabular}




\section{APPENDIX B}

\section{TANK FARM CONTRACTOR INTEGRATED RESOURCE LOADED SCHEDULE}

Table B-1. Crosswalk from the Level 1 Logic to the Work Breakdown Structure.

\begin{tabular}{|c|c|c|}
\hline \multicolumn{3}{|c|}{ BNFL Inc. Phase 1 Privatization activities identified at WBS Level 3 (1.01.06). } \\
\hline Level 1 Logic & 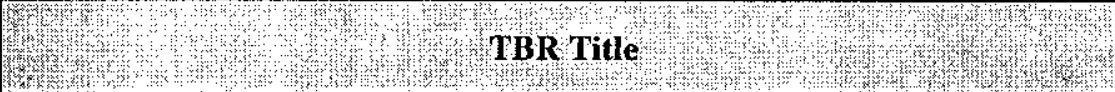 & WBS Level 6 \\
\hline 050.090 & Sluice C-106 to AY-102 & 1.01.04.01.01.10 \\
\hline 100.200 & Receive and Disposition BNFL Study Residue and Job Control Samples & 1.01 .01 .01 .01 .04 \\
\hline $100 . \mathrm{C} 03$ & Update Best Basis Inventory and Tank Characterization Report for C-104 & 1.01 .01 .01 .01 .04 \\
\hline 100.C19 & Obtain C-107 Core Samples and Prepare Sub-Samples and Composites & 1.01 .01 .01 .01 .04 \\
\hline $100 . \mathrm{C} 30$ & Perform C-107 Post Retrieval Verification & 1.01 .01 .01 .01 .04 \\
\hline $100 . \mathrm{C} 77$ & Perform C-104 Post Retrieval Verification & 1.01.01.01.01.04 \\
\hline $100 . \mathrm{N} 01$ & Provide Post Part B2 Sample of AN-103 per ICD 23 Schedule to BNFL & 1.01 .01 .01 .01 .04 \\
\hline 100.N05 & Provide Post Part B2 Sample of AN-104 per ICD 23 Schedule to BNFL & 1.01 .01 .01 .01 .04 \\
\hline 100.N08 & Provide Post Part B2 Sample of AN-102 per ICD 23 Schedule to BNFL & 1.01 .01 .01 .01 .04 \\
\hline 100.N09 & Provide Post Part B2 Sample of AN-107 per ICD 23 Schedule to BNFL & 1.01 .01 .01 .01 .04 \\
\hline 100.N11 & Provide Post Part B2 Sample of AN-105 per ICD 23 Schedule to BNFL & 1.01 .01 .01 .01 .04 \\
\hline 100.N47 & $\begin{array}{l}\text { Sample and Analyze AN-107 Feed Certification Samples per LAW Feed Cert } \\
\text { DQO from AN-107 }\end{array}$ & 1.01 .01 .01 .01 .04 \\
\hline 100.N49 & $\begin{array}{l}\text { Sample and Analyze AN-105 Feed Certification Samples per LAW Feed Cert } \\
\text { DQO from AN-102 }\end{array}$ & 1.01 .01 .01 .01 .04 \\
\hline 100.N50 & $\begin{array}{l}\text { Sample and Analyze AN-105 Feed Certification Samples per LAW Feed Cert } \\
\text { DQO from AN-105 }\end{array}$ & 1.01.01.01.01.04 \\
\hline 100.N51 & $\begin{array}{l}\text { Sample and Analyze AN-102 Feed Certification Samples per LAW Feed Cert } \\
\text { DQO from AN-102 }\end{array}$ & 1.01.01.01.01.04 \\
\hline $100 . N 53$ & $\begin{array}{l}\text { Sample and Analyze AN-104 Feed Certification Samples per LAW Feed Cert } \\
\text { DQO from AN-104 }\end{array}$ & 1.01 .01 .01 .01 .04 \\
\hline 100.N54 & $\begin{array}{l}\text { Sample and Analyze AN-104 Feed Certification Samples per the LAW Feed } \\
\text { Cert DQO from AN-101 }\end{array}$ & 1.01 .01 .01 .01 .04 \\
\hline $100 . \mathrm{N} 55$ & $\begin{array}{l}\text { Sample and Analyze AN-103 Feed Certification Samples per LAW Feed Cert } \\
\text { DQO from AN-102 }\end{array}$ & 1.01 .01 .01 .01 .04 \\
\hline 100.N56 & $\begin{array}{l}\text { Sample and Analyze AN-103 Feed Certification Samples per LAW Feed Cert } \\
\text { DQO from AN-103 }\end{array}$ & 1.01 .01 .01 .01 .04 \\
\hline 100.N61 & Sample AN-104 Feed in AN-104 and Analyze for Sulfates & 1.01 .01 .01 .01 .04 \\
\hline
\end{tabular}


Table B-1. Crosswalk from the Level 1 Logic to the Work Breakdown Structure.

\begin{tabular}{|c|c|c|}
\hline \multicolumn{3}{|c|}{ BNFL Inc. Phase 1 Privatization activities identified at WBS Level 3 (1.01.06). } \\
\hline $\begin{array}{l}\text { Level } 1 \text { Logic } \\
\text { TBR Number }\end{array}$ & TBR Title & WBS Level 6 \\
\hline 100.N62 & Sample AN-104 Feed in AN-101 and Analyze for Sulfates & 1.01 .01 .01 .01 .04 \\
\hline 100.N63 & Sample AN-105 Feed in AN-105 and Analyze for Sulfates & 1.01 .01 .01 .01 .04 \\
\hline 100. N64 & Sample AN-105 Feed in AN-102 and Analyze for Sulfates & 1.01 .01 .01 .01 .04 \\
\hline 100.N65 & $\begin{array}{l}\text { Sample and Analyze AP-106 Fecd Certification Samples per LAW Feed Cert } \\
\text { DQO from AN-102 }\end{array}$ & 1.01.01.01.01.04 \\
\hline 100.P01 & Sample AP-102 & 1.01 .01 .01 .01 .04 \\
\hline $100 . P 02$ & Sample AP-106 & 1.01 .01 .01 .01 .04 \\
\hline 100.P03 & $\begin{array}{l}\text { Sample and Analyze AP-106 Feed Certification Samples per LAW Feed Cert } \\
\text { DQO from AP-106 }\end{array}$ & 1.01 .01 .01 .01 .04 \\
\hline 100.P04 & Sample AP-108 & 1.01.01.01.01.04 \\
\hline 100.P05 & $\begin{array}{l}\text { Sample and Analyze AP-108 Feed Certification Samples per LAW Feed Cert } \\
\text { DQO from AP-108 }\end{array}$ & 1.01 .01 .01 .01 .04 \\
\hline 100.P62 & Sample AP-105 & 1.01 .01 .01 .01 .04 \\
\hline 100.P63 & Sample SY-101 Feed in AP-104 & 1.01 .01 .01 .01 .04 \\
\hline 100.P65 & $\begin{array}{l}\text { Sample and Analyze AP-102 Feed Certification Samples per LAW Feed Cert } \\
\text { DQO from AP-102 }\end{array}$ & 1.01 .01 .01 .01 .04 \\
\hline $100 . P 67$ & $\begin{array}{l}\text { Sample and Analyze AP-105 Feed Certification Samples per LAW Feed Cert } \\
\text { DQO from AP-104 }\end{array}$ & 1.01.01.01.01.04 \\
\hline $100 . P 68$ & $\begin{array}{l}\text { Sample and Analyze AP-105 Feed Certification Samples per LAW Feed Cert } \\
\text { DQO from AP-105 }\end{array}$ & 1.01.01.01.01.04 \\
\hline $100 . P 69$ & $\begin{array}{l}\text { Sample and Analyze AP-101 Feed Certification Samples per LAW Feed Cert } \\
\text { DQO from AP-101 }\end{array}$ & 1.01 .01 .01 .01 .04 \\
\hline $100 . P 71$ & Sample AP-101 per BNFL, ORP/WIT, and RPP Requirements & 1.01 .01 .01 .01 .04 \\
\hline 100.P77 & $\begin{array}{l}\text { Sample and Analyze SY-101 Feed Certification Samples per LAW Feed Cert } \\
\text { DQO from AP-104 }\end{array}$ & 1.01 .01 .01 .01 .04 \\
\hline $100 . \$ 46$ & $\begin{array}{l}\text { Sample and Analyze S-105 Feed Certification Samples per LAW Feed Cert } \\
\text { DQO from AN-105 }\end{array}$ & 1.01.01.01.01.04 \\
\hline 100.S47 & $\begin{array}{l}\text { Sample and Analyze S-102 Feed Certification Samples per LAW Feed Cert } \\
\text { DQO from AP-101 }\end{array}$ & 1.01.01.01.01.04 \\
\hline 100.554 & Sample SY-102 per BNFL Requirements and Deliver Sample to BNFL & 1.01 .01 .01 .01 .04 \\
\hline 100.S56 & Sample S-105 & 1.01 .01 .01 .01 .04 \\
\hline $100 . S 57$ & Sample S-102 & 1.01.01.01.01.05 \\
\hline 100.559 & Perform S-102 Post Retrieval Verification & 1.01 .01 .01 .01 .04 \\
\hline
\end{tabular}




\section{HNF-1946 REV 2}

Table B-1. Crosswalk from the Level 1 Logic to the Work Breakdown Structure.

\begin{tabular}{|c|c|c|}
\hline \multicolumn{3}{|c|}{ BNFL Inc. Phase 1 Privatization activities identified at WBS Level 3 (1.01.06). } \\
\hline $\begin{array}{l}\text { Level } 1 \text { Logic } \\
\text { TBR Number }\end{array}$ & \begin{tabular}{|l|l} 
TBR Title \\
\end{tabular} & WBS Cevel 6 \\
\hline 100.SAZ & Perform S-105 Post Retrieval Verification & 1.01 .01 .01 .01 .04 \\
\hline 100.SBA & Provide FY 2002 Sample of SY-101 per ICD 23 Schedule to BNFL & 1.01.01.01.01.04 \\
\hline 100.W01 & Provide FY 2002 Sample of AW-101 per ICD 23 Schedule to BNFL & 1.01.01.01.01.04 \\
\hline 100.W02 & Obtain AW-103 Core Samples and Prepare Sub-Samples and Composites & 1.01 .01 .01 .01 .05 \\
\hline 100.W03 & Sample AW-103 per BNFL Requirements and Deliver Sample to BNFL & 1.01 .01 .01 .01 .04 \\
\hline 100.W07 & $\begin{array}{l}\text { Obtain AW-104 (HLW) Core Samples and Prepare Sub-Samples and } \\
\text { Composites }\end{array}$ & 1.01.01.01.01.04 \\
\hline 100.W08 & $\begin{array}{l}\text { Sample and Analyze AW-103 Feed Certification Samples from AW-103 per } \\
\text { HLW Feed Cert. DQO }\end{array}$ & 1.01 .01 .01 .01 .05 \\
\hline 100.W09 & $\begin{array}{l}\text { Analyze BNFL Provided Sample of 1st Batch of AW-104(HLW)/AW-103 } \\
\text { Feed From AW-104 to HLW Feed Cert. DQO }\end{array}$ & 1.01 .01 .01 .01 .05 \\
\hline 100.W15 & $\begin{array}{l}\text { Sample and Analyze AW-104(HLW)/AW-103 Feed Certification Samples per } \\
\text { HLW Feed Cert. DQO from AW-104 }\end{array}$ & 1.01 .01 .01 .01 .05 \\
\hline 100.W45 & $\begin{array}{l}\text { Sample and Analyze AW-101 Feed Certification Samples per LAW Feed Cert } \\
\text { DQO from AN-105 }\end{array}$ & 1.01.01.01.01.04 \\
\hline 100.W46 & $\begin{array}{l}\text { Sample and Analyze AW-101 Feed Certification Samples per LAW Feed Cert } \\
\text { DQO from AW-101 }\end{array}$ & 1.01 .01 .01 .01 .04 \\
\hline 100.W49 & $\begin{array}{l}\text { Sample and Analyze AW-104 (LAW) Feed Certification Samples per LAW } \\
\text { Feed Cert DQO from AP-104 }\end{array}$ & 1.01 .01 .01 .01 .04 \\
\hline 100.Y05 & Obtain SY-102 Core Samples and Prepare Sub-Samples and Composites & 1.01 .01 .01 .01 .04 \\
\hline $100 . Y 43$ & $\begin{array}{l}\text { Sample and Analyze SY-101 Feed Certification Samples per LAW Feed Cert } \\
\text { DQO from AN-101 }\end{array}$ & 1.01 .01 .01 .01 .04 \\
\hline 100.Y44 & Sample SY-103 & 1.01 .01 .01 .01 .04 \\
\hline 100.Y45 & $\begin{array}{l}\text { Sample and Analyze SY-103 Feed Certification Samples per LAW Feed Cert } \\
\text { DQO from AN-101 }\end{array}$ & 1.01 .01 .01 .01 .04 \\
\hline 100.Z01 & Obtain AY-102 Core Samples and Prepare Sub-Samples and Composites & 1.01 .01 .01 .01 .04 \\
\hline $100 . \mathrm{Z} 03$ & Obtain AZ-102 Core Samples and Prepare Sub-Samples and Composites & 1.01 .01 .01 .01 .04 \\
\hline $100 . \mathrm{Z} 04$ & Core Sample AZ-101 & 1.01 .01 .01 .01 .04 \\
\hline $100 . \mathrm{Z} 05$ & Provide Post Part B2 Sample of AZ-102 per ICD 23 Schedule to BNFL & 1.01.01.01.01.04 \\
\hline $100 . \mathrm{Z} 07$ & Provide FY 2002 Sample of AY-102/C-106 per ICD 23 Schedule to BNFL & 1.01 .01 .01 .01 .04 \\
\hline 100.Z09 & Sample AZ-101 per BNFL Requirements and Deliver Sample to BNFL & 1.01 .01 .01 .01 .04 \\
\hline $100 . \mathrm{Z} 10$ & Provide Post Part B2 Sample of AZ-101 per ICD 23 Schedule to BNFL & 1.01 .01 .01 .01 .04 \\
\hline $100 . Z 11$ & Sample and Analyze AZ-101 Feed Certification Samples per HLW Feed Cert. & 1.01 .01 .01 .01 .04 \\
\hline
\end{tabular}




\section{HNF-1946 REV 2}

Table B-1. Crosswalk from the Level 1 Logic to the Work Breakdown Structure.

\begin{tabular}{|c|c|c|}
\hline \multicolumn{3}{|c|}{ BNFL Inc. Phase 1 Privatization activities identified at WBS Level 3 (1.01.06). } \\
\hline Level 1 Logic & TBR Title & WBS Level 6 \\
\hline & DQO & \\
\hline $100 . \mathrm{Z} 12$ & $\begin{array}{l}\text { Sample and Analyze AZ-102 Feed Certification Samples per HLW Feed Cert. } \\
\text { DQO }\end{array}$ & 1.01 .01 .01 .01 .04 \\
\hline $100 . \mathrm{Zl3}$ & $\begin{array}{l}\text { Sample and Analyze AY-102/C-106 Feed Certification Samples per HLW Feed } \\
\text { Cert. DQO }\end{array}$ & 1.01.01.01.01.04 \\
\hline $100 . \mathrm{Z16}$ & $\begin{array}{l}\text { Sample and Analyze AY-101/C-104 Feed Certification Samples per HLW Feed } \\
\text { Cert. DQO }\end{array}$ & 1.01.01.01.01.04 \\
\hline $100 . \mathrm{Z17}$ & $\begin{array}{l}\text { Sample and Analyze SY-102 Feed Certification Samples per HLW Feed Cert. } \\
\text { DQO in AZ-101 }\end{array}$ & 1.01 .01 .01 .01 .04 \\
\hline $100 . \mathrm{Z18}$ & Obtain AY-101 Core Samples and Prepare Sub-Samples and Composites & 1.01.01.01.01.04 \\
\hline 100.Z19 & Sample AY-101 per BNFL Requirements and Deliver Sample to BNFL & 1.01.01.01.01.04 \\
\hline $100 . \mathrm{Z} 30$ & Perform AZ-101 Process Test Sampling and Analysis & 1.01 .01 .01 .01 .04 \\
\hline $100 . \mathrm{Z33}$ & $\begin{array}{l}\text { Analyze BNFL Provided Sample of Ist Batch of HLW Feed From AZ-101 to } \\
\text { HLW Feed Cert. DQO }\end{array}$ & 1.01.01.01.01.04 \\
\hline $100 . \mathrm{Z34}$ & $\begin{array}{l}\text { Analyze BNFL Provided Sample of 1st Batch of HLW Feed From AZ-102 to } \\
\text { HLW Feed Cert. DQO }\end{array}$ & 1.01 .01 .01 .01 .04 \\
\hline $100 . \mathrm{ZA5}$ & $\begin{array}{l}\text { Analyze BNFL Provided Sample of 1st Batch of AY-102/C-106 HLW Feed } \\
\text { From AY-102 to HLW Feed Cert. DQO }\end{array}$ & 1.01.01.01.01.04 \\
\hline $100 . \mathrm{ZA8}$ & $\begin{array}{l}\text { Analyze BNFL Provided Sample of 1st Batch of AY-101/C-104 HLW Feed } \\
\text { From AY-101 to HLW Feed Cert. DQO }\end{array}$ & 1.01.01.01.01.04 \\
\hline $100 . Z 87$ & $\begin{array}{l}\text { Analyze BNFL Provided Sample of 1st Batch of C-107/AW-103 HLW Feed } \\
\text { From AY-102 to HLW Feed Cert. DQO }\end{array}$ & 1.01 .01 .01 .01 .04 \\
\hline 100.ZAB & $\begin{array}{l}\text { Sample and Analyze C-107/AW-103 Feed Certification Samples per HLW } \\
\text { Feed Cert. DQO from AY-102 }\end{array}$ & 1.01 .01 .01 .01 .04 \\
\hline 100.ZAC & $\begin{array}{l}\text { Analyze BNFL Provided Sample of 1st Batch of SY-102 HLW Feed From AZ- } \\
101 \text { to HLW Feed Cert. DQO }\end{array}$ & 1.01 .01 .01 .01 .04 \\
\hline 10S.N47 & Provide AN-107 Samples from AN-107 to BNFL & 1.01 .01 .01 .01 .04 \\
\hline 10S.N49 & Provide AN-105 Samples from AN-102 to BNFL & 1.01.01.01.01.04 \\
\hline 10S.N50 & Provide AN-105 Samples from AN-105 to BNFL & $1.01 .01 .01 .01 .04^{\circ}$ \\
\hline 10S.N51 & Provide AN-102 Samples from AN-102 to BNFL & 1.01 .01 .01 .01 .04 \\
\hline 10S.N53 & Provide AN-104 Samples from AN-104 to BNFL & 1.01 .01 .01 .01 .04 \\
\hline 10S.N54 & Provide AN-104 Samples from AN-101 to BNFL & 1.01 .01 .01 .01 .04 \\
\hline 10S.N55 & Provide AN-103 Samples from AN-102 to BNFL & 1.01 .01 .01 .01 .04 \\
\hline 10S.N56 & Provide AN-103 Samples from AN-103 to BNFL & 1.01 .01 .01 .01 .04 \\
\hline
\end{tabular}




\section{HNF-1946 REV 2}

Table B-1. Crosswalk from the Level 1 Logic to the Work Breakdown Structure.

\begin{tabular}{|c|c|c|}
\hline \multicolumn{3}{|c|}{ BNFL Inc. Phase 1 Privatization activities identified at WBS Level 3 (1.01.06). } \\
\hline $\begin{array}{l}\text { Level } 1 \text { Logic } \\
\text { TBR Number }\end{array}$ & 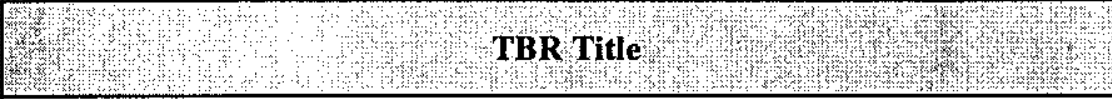 & WBS Level 6 \\
\hline 10S.N65 & Provide AP-106 Samples from AN-102 to BNFL & 1.01 .01 .01 .01 .04 \\
\hline 10S.P03 & Provide AP-106 Samples from AP-106 to BNFL & 1.01 .01 .01 .01 .04 \\
\hline $10 \mathrm{~S} . \mathrm{P} 05$ & Provide AP-108 Samples from AP-108 to BNFL & 1.01 .01 .01 .01 .04 \\
\hline $10 \mathrm{~S} . \mathrm{P} 65$ & Provide AP-102 Samples from AP-102 to BNFL & 1.01 .01 .01 .01 .04 \\
\hline 10S.P67 & Provide AP-105 Samples from AP-104 to BNFL & 1.01 .01 .01 .01 .04 \\
\hline 10S.P68 & Provide AP-105 Samples from AP-105 to BNFL & 1.01.01.01.01.04 \\
\hline 10S.P69 & Provide AP-101 Samples from AP-101 to BNFL & 1.01.01.01.01.04 \\
\hline 10S.P77 & Provide SY-101 Samples from AP-104 to BNFL & 1.01 .01 .01 .01 .04 \\
\hline 10S.S46 & Provide S-105 Samples from AN-105 to BNFL & 1.01.01.01.01.04 \\
\hline 10S.S47 & Provide S-102 Samples from AP-101 to BNFL & 1.01 .01 .01 .01 .04 \\
\hline 10S.W08 & Provide Separate AW-103 (HLW) Samples from AW-103 to BNFL & 1.01 .01 .01 .01 .04 \\
\hline 10S.W15 & Provide Separate AW-104(HLW)/AW-103 Samples to BNFL from AW-104 & 1.01 .01 .01 .01 .04 \\
\hline $10 \mathrm{~S} . \mathrm{W} 45$ & Provide AW-101 Samples from AN-105 to BNFL & 1.01 .01 .01 .01 .04 \\
\hline 10S.W46 & Provide AW-101 Samples from AW-101 to BNFL & 1.01.01.01.01.04 \\
\hline 10S.W49 & Provide AW-104 (LAW) Samples (from AP-104) to BNFL & 1.01 .01 .01 .01 .04 \\
\hline $10 S . Y 43$ & Provide SY-101 Samples from AN-101 to BNFL & 1.01 .01 .01 .01 .04 \\
\hline $10 \mathrm{~S} . \mathrm{Y} 45$ & Provide SY-103 Samples from AN-101 to BNFL & 1.01 .01 .01 .01 .04 \\
\hline 10S.Z11 & Provide Separate AZ-101 Samples to BNFL & 1.01 .01 .01 .01 .04 \\
\hline $10 \mathrm{~S} . \mathrm{Z} 12$ & Provide Separate AZ-102 Samples to BNFL & 1.01 .01 .01 .01 .04 \\
\hline 10S.Z13 & Provide Separate AY-102/C-106 Samples to BNFL from AY-102 & 1.01 .01 .01 .01 .04 \\
\hline 10S.Z16 & Provide Separate AY-101/C-104 Samples to BNFL from AY-101 & 1.01 .01 .01 .01 .04 \\
\hline $10 \mathrm{~S} . \mathrm{Z} 17$ & Provide Separate SY-102 Samples to BNFL from AZ-101 & 1.01 .01 .01 .01 .04 \\
\hline 10S.ZAB & Provide Separate C-107/AW-103 Samples to BNFL from AY-102 & 1.01 .01 .01 .01 .04 \\
\hline 110.010 & Project Management for AZ-101 Process Test & 1.01.04.01.01.04 \\
\hline 110.045 & Issue AZ-101 Process Test Plans and Procedures & 1.01 .04 .01 .01 .04 \\
\hline 110.050 & Perform Contractor Independent Readiness Assessment for AZ-101 Process & 1.01 .04 .01 .01 .04 \\
\hline
\end{tabular}




\section{HNF-1946 REV 2}

Table B-1. Crosswalk from the Level 1 Logic to the Work Breakdown Structure.

\begin{tabular}{|c|c|c|}
\hline \\
\hline \multirow{2}{*}{\multicolumn{3}{|c|}{ 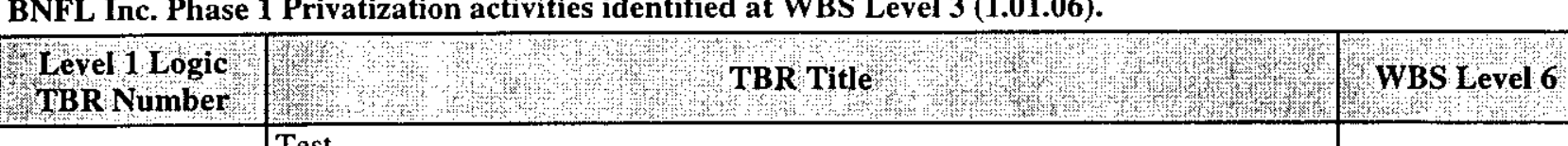 }} \\
\hline THE Tumber & & \\
\hline \multirow{2}{*}{\begin{tabular}{|l}
110.055 \\
110.070
\end{tabular}} & Perform Management Self-Assessment for AZ-101 Process Test & 1.01 .04 .01 .01 .04 \\
\hline & Perform AZ-101 Process Test & 1.01 .04 .01 .01 .04 \\
\hline 110.075 & Perform AZ-101 Suspension and Settling Test & 1.01 .04 .01 .01 .04 \\
\hline 110.090 & Prepare AZ-101 Process Test Report & 1.01 .04 .01 .01 .04 \\
\hline 110.095 & Install and Test Monitoring Equipment in AZ-101 . & 1.01 .04 .01 .01 .04 \\
\hline 120.005 & Develop and Issue the Double Shell Tank System Specification and ICDs & 1.01 .04 .01 .01 .03 \\
\hline 120.010 & Update the Double Shell Tank System Specification and ICDs & 1.01 .04 .01 .01 .03 \\
\hline 120.015 & Develop and Issue the Double Shell Tank Component Specifications & 1.01 .04 .01 .01 .03 \\
\hline 120.020 & Update the Double Shell Tank Component Specification & 1.01.04.01.01.03 \\
\hline 120.025 & Maintain WFD Technical Basis & 1.01.04.01.01.14 \\
\hline 120.A00 & Project Management for W-211 & 1.01 .04 .01 .01 .05 \\
\hline $120 . \mathrm{A03}$ & Verify AZ Tank Farm Systems and Components Functionality & 1.01.04.01.01.14 \\
\hline 120.A04 & Perform Acquisition Strategy for AZ Tank Farm & 1.01 .04 .01 .01 .03 \\
\hline 120.A05 & Perform AZ Tank Farm Trade Studies & 1.01 .04 .01 .01 .14 \\
\hline 120.A07 & Verify AY Tank Farm Systems and Components Functionality & 1.01 .04 .01 .01 .14 \\
\hline 120.A08 & Perform Acquisition Strategy for AY Tank Farm & 1.01.04.01.01.03 \\
\hline 120.A09 & Perform AY Tank Farm Trade Studies & 1.01.04.01.01.14 \\
\hline 120.A11 & Verify AW Tank Farm Systems and Components Functionality & 1.01 .04 .01 .01 .14 \\
\hline 120.A12 & Perform Acquisition Strategy for AW Tank Farm & 1.01 .04 .01 .01 .03 \\
\hline $120 . \mathrm{A} 13$ & Perform AW Tank Farm Trade Studies & 1.01 .04 .01 .01 .14 \\
\hline 120.A15 & Verify AN Tank Farm Systems and Components Functionality & 1.01 .04 .01 .01 .14 \\
\hline $120 . \mathrm{A} 16$ & Perform Acquisition Strategy for AN Tank Farm & 1.01.04.01.01.03 \\
\hline 120.A17 & Perform AN Tank Farm Trade Studies & 1.01 .04 .01 .01 .14 \\
\hline 120.A19 & Verify AP Tank Farm Systems and Components Functionality & 1.01 .04 .01 .01 .14 \\
\hline 120.A20 & Perform Acquisition Strategy for AP Tank Farm & 1.01 .04 .01 .01 .03 \\
\hline
\end{tabular}




\section{HNF-1946 REV 2}

Table B-1. Crosswalk from the Level 1 Logic to the Work Breakdown Structure.

\begin{tabular}{|c|c|c|}
\hline \multicolumn{3}{|c|}{ BNFL Inc. Phase 1 Privatization activities identified at WBS Level 3 (1.01.06). } \\
\hline $\begin{array}{l}\text { Level 1 Logic } \\
\text { TBR Number }\end{array}$ & 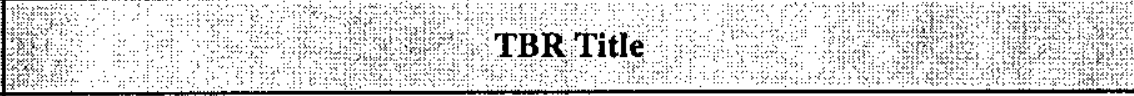 & WBS Level 6 \\
\hline 120.A21 & Perform AP Tank Farm Trade Studies & 1.01 .04 .01 .01 .14 \\
\hline 120.A23 & Verify SY Tank Farm Systems and Components Functionality & 1.01 .04 .01 .01 .14 \\
\hline $120 . \mathrm{A} 24$ & Perform Acquisition Strategy for SY Tank Farm & 1.01 .04 .01 .01 .03 \\
\hline $120 . \mathrm{A} 25$ & Perform SY Tank Farm Trade Studies & 1.01 .04 .01 .01 .14 \\
\hline $120 . \mathrm{B} 10$ & Define Requirements, Design, Install Central Control Room, and Shift Office & 1.01 .04 .01 .01 .10 \\
\hline $120 . \mathrm{B} 20$ & Establish Dilution Requirements and Dissolution Behavior for AP-104 & 1.01 .04 .01 .01 .02 \\
\hline 120.B29 & Establish Dilution Requirements and Dissolution Behavior for AP-102 & 1.01 .04 .01 .01 .02 \\
\hline $120 . \mathrm{B} 30$ & Provide Retrieval Program Direction to Project W-211 for AP-102 \& AP-104 & 1.01 .04 .01 .01 .03 \\
\hline 120.837 & $\begin{array}{l}\text { Update the Design for the AP-102 \& AP-104 Mixing and Retrieval Systems \& } \\
\text { Obtain CD-3 }\end{array}$ & 1.01 .04 .01 .01 .05 \\
\hline $120 . \mathrm{B} 40$ & Prepare Tanks AP-102 \& AP-104 for Turnover to Project for Construction & 1.01 .04 .01 .01 .10 \\
\hline 120.B42 & Procure Equipment for the AP-102 \& AP-104 Mixing and Retrieval Systems & 1.01 .04 .01 .01 .05 \\
\hline 120.B45 & Construct the AP-102 \& AP-104 Mixing and Retrieval Systems & 1.01 .04 .01 .01 .05 \\
\hline 120.B50 & Startup and Test the AP-102 \& AP-104 Mixing and Retrieval Systems & 1.01 .04 .01 .01 .10 \\
\hline 120.B60 & Perform Contractor Standard Startup Review for AP-102 \& AP-104 & 1.01 .04 .01 .01 .10 \\
\hline $120 . \mathrm{B} 65$ & Provide CD-4 Approval for AP-102 \& AP-104 & 1.01 .04 .01 .01 .10 \\
\hline $120 . \mathrm{B} 83$ & $\begin{array}{l}\text { Perform Management Self-Assessment for the AP-102 and AP-104 Mixing and } \\
\text { Retrieval Systems }\end{array}$ & 1.01 .04 .01 .01 .10 \\
\hline $120 . \mathrm{C} 10$ & Establish Dilution Requirements and Dissolution Behavior for AP-106 & 1.01 .04 .01 .01 .02 \\
\hline $120 . C 43$ & Perform Conceptual Design for W-522 Retrieval Systems & 1.01 .04 .01 .01 .07 \\
\hline $120 . \mathrm{C} 50$ & Design the AP-106 Mixing and Retrieval System and Obtain CD-3. & 1.01.04.01.01.07 \\
\hline $120 . \mathrm{C} 52$ & Procure Equipment for the AP-106 Mixing and Retrieval System & 1.01.04.01.01.07 \\
\hline $120 . \mathrm{C} 55$ & Construct the AP-106 Mixing and Retrieval System & 1.01 .04 .01 .01 .07 \\
\hline $120 . \mathrm{C} 56$ & Provide Critical Decision 1 Approval for Project W-522 & 1.01 .04 .01 .01 .10 \\
\hline $120 . C 60$ & Startup and Test the AP-106 Mixing and Retrieval System & 1.01.04.01.01.10 \\
\hline $120 . \mathrm{C} 61$ & Prepare Project Definition, Technical Basis, and PDC for Project W-522 & 1.01.04.01.01.03 \\
\hline $120 . \mathrm{C} 67$ & Provide Critical Decision 2 Approval for Project W-522 & 1.01 .04 .01 .01 .10 \\
\hline
\end{tabular}




\section{HNF-1946 REV 2}

Table B-1. Crosswalk from the Level 1 Logic to the Work Breakdown Structure.

\begin{tabular}{|c|c|c|}
\hline \multicolumn{3}{|c|}{ BNFL Inc. Phase 1 Privatization activities identified at WBS Level 3 (1.01.06). } \\
\hline Level 1 Logic & \begin{tabular}{|c|c|} 
\\
W
\end{tabular} & WBS Level 6 \\
\hline $120 . C 70$ & Perform Contractor Standard Startup Review for AP-106 & 1.01.04.01.01.10 \\
\hline $120 . C 75$ & Provide CD-4 Approval for AP-106 & 1.01.04.01.01.10 \\
\hline $120 . \mathrm{C} 83$ & $\begin{array}{l}\text { Perform Management Self-Assessment for the AP-106 Mixing and Retrieval } \\
\text { System }\end{array}$ & 1.01 .04 .01 .01 .10 \\
\hline 120.D15 & Complete Tank Farm Infrastructure and Compliance Upgrades & 1.01 .04 .01 .01 .18 \\
\hline 120.D34 & Perform Waste Feed Delivery Trade Studies & 1.01 .04 .01 .01 .14 \\
\hline 120.D60 & Provide Retrieval Program Direction to Project W-211 for AN-105 & 1.01.04.01.01.03 \\
\hline 120.D72 & Procure Equipment for the AN-105 Mixing and Retrieval System & 1.01 .04 .01 .01 .05 \\
\hline $120 . \mathrm{D} 75$ & Construct the AN-105 Mixing and Retrieval System & 1.01.04.01.01.05 \\
\hline 120.D80 & Startup and Test the AN-105 Mixing and Retrieval System less Mixer Pumps & 1.01 .04 .01 .01 .10 \\
\hline 120.D82 & Install the AN-105 Mixer Pump and Related Systems & 1.01 .04 .01 .01 .05 \\
\hline 120.D83 & $\begin{array}{l}\text { Perform Management Self-Assessment for AN-105 Mixing and Retrieval } \\
\text { System less Mixer Pumps }\end{array}$ & 1.01 .04 .01 .01 .10 \\
\hline 120.D84 & Startup and Test the AN-105 Mixer Pump and Related Systems & 1.01 .04 .01 .01 .10 \\
\hline 120.D90 & $\begin{array}{l}\text { Perform Contractor Standard Startup Review for AN-105 Mixing and Retrieval } \\
\text { System less Mixer Pumps }\end{array}$ & 1.01.04.01.01.10 \\
\hline 120.D95 & $\begin{array}{l}\text { Provide CD-4 Approval for AN-105 Mixing and Retrieval System less Mixer } \\
\text { Pumps }\end{array}$ & 1.01.04.01.01.10 \\
\hline 120.E31 & Procure Equipment for AN-101 Mixing and Retrieval System & 1.01.04.01.01.06 \\
\hline 120.E33 & Construct the AN-101 Mixing and Retrieval System & 1.01.04.01.01.06 \\
\hline 120.E35 & Design the AN-101 Mixing and Retrieval System and Obtain CD-3 & 1.01.04.01.01.06 \\
\hline 120.E45 & $\begin{array}{l}\text { Complete AN-101 and AN-104 Transfer System Preparations and Integrated } \\
\text { Testing }\end{array}$ & 1.01 .04 .01 .01 .10 \\
\hline 120.E50 & Design the AN-104 Mixing and Retrieval System and Obtain CD-3 & 1.01.04.01.01.05 \\
\hline 120.E52 & Procure Equipment for the AN-104 Mixing and Retrieval System & 1.01 .04 .01 .01 .05 \\
\hline $120 . \mathrm{E} 55$ & Construct the AN-104 Mixing and Retrieval System & 1.01.04.01.01.05 \\
\hline 120.E60 & $\begin{array}{l}\text { Perform Management Self-Assessment of Waste Feed Delivery Transfer } \\
\text { System }\end{array}$ & 1.01.04.01.01.10 \\
\hline $120 . \mathrm{E} 65$ & Startup and Test the AN-104 Mixing and Retrieval System less Mixer Pumps & 1.01.04.01.01.10 \\
\hline 120.E79 & Startup and Test the AN-101 Mixing and Retrieval System & 1.01.04.01.01.10 \\
\hline
\end{tabular}




\section{HNF-1946 REV 2}

Table B-1. Crosswalk from the Level 1 Logic to the Work Breakdown Structure.

\begin{tabular}{|c|c|c|}
\hline \multicolumn{3}{|c|}{ BNFL Inc. Phase 1 Privatization activities identified at WBS Level 3 (1.01.06). } \\
\hline $\begin{array}{l}\text { Level 1 Logic } \\
\text { TBR Number }\end{array}$ & TBR Title & WBS Level 6 \\
\hline 120.E80 & $\begin{array}{l}\text { Perform Contractor Independent Operational Readiness Review for Waste Feed } \\
\text { Delivery Transfer System }\end{array}$ & 1.01.04.01.01.10 \\
\hline $120 . \mathrm{E} 85$ & $\begin{array}{l}\text { Perform DOE Operational Readiness Review and Obtain CD.4 for Waste Feed } \\
\text { Delivery Transfer System }\end{array}$ & 1.01.04.01.01.10 \\
\hline 120.E90 & Install the AN-104 Mixer Pump and Related Systems & 1.01 .04 .01 .01 .05 \\
\hline 120.E92 & Startup and Test the AN-104 Mixer Pump and Related Systems & 1.01 .04 .01 .01 .10 \\
\hline 120.E95 & Transfer AN-101 to AN-106 & 1.01 .04 .01 .01 .10 \\
\hline $120 . \mathrm{G} 38$ & Adjust WFD Acquisition Strategy for Phase 1 Tanks & 1.01 .04 .01 .01 .03 \\
\hline $120 . G 50$ & Design AW-101 Mixing and Retrieval System and Obtain CD-3 & 1.01.04.01.01.06 \\
\hline $120 . \mathrm{G} 52$ & Procure Equipment for the AW-101 Mixing and Retrieval System & 1.01 .04 .01 .01 .06 \\
\hline 120.G55 & Construct the AW-101 Mixing and Retrieval System less Mixer Pumps & 1.01 .04 .01 .01 .06 \\
\hline $120 . \mathrm{G} 60$ & Startup and Test the AW-101 Mixing and Retrieval System less Mixer Pumps & 1.01 .04 .01 .01 .10 \\
\hline $120 . \mathrm{G} 70$ & $\begin{array}{l}\text { Perform Contractor Standard Startup Review for AW-101 Mixing and } \\
\text { Retrieval System less Mixer Pumps }\end{array}$ & 1.01.04.01.01.10 \\
\hline $120 . G 75$ & $\begin{array}{l}\text { Provide CD-4 Approval for AW-101 Mixing and Retrieval System less Mixer } \\
\text { Pumps }\end{array}$ & 1.01 .04 .01 .01 .10 \\
\hline $120 . G 83$ & $\begin{array}{l}\text { Perform Management Self-Assessment for AW-101 Mixing and Retrieval } \\
\text { System less Mixer Pumps }\end{array}$ & 1.01 .04 .01 .01 .10 \\
\hline $120 . \mathrm{G} 90$ & Install the AW-101 Mixer Pump and Related Systems & 1.01 .04 .01 .01 .06 \\
\hline $120 . \mathrm{G} 92$ & Startup and Test the AW-101 Mixer Pump and Related Systems & 1.01 .04 .01 .01 .10 \\
\hline 120.110 & Establish Dilution Requirements and Dissolution Behavior for S-105 & 1.01 .04 .01 .02 .02 \\
\hline 120.J 10 & Establish Dilution Requirements and Dissolution Behavior for AN-103 & 1.01 .04 .01 .02 .02 \\
\hline $120 . J 40$ & Provide Retrieval Program Direction to Project W-211 for AN-103 & 1.01 .04 .01 .01 .03 \\
\hline 120.J50 & Design the AN-103 Mixing and Retrieval System and Obtain CD-3 & 1.01 .04 .01 .01 .05 \\
\hline $120 . J 52$ & Procure Equipment for the AN-103 Mixing and Retrieval System & 1.01.04.01.01.05 \\
\hline 120.J55 & Construct the AN-103 Mixing and Retrieval System & 1.01 .04 .01 .01 .05 \\
\hline 120.J65 & Startup and Test the AN-103 Mixing and Retrieval System less Mixer Pumps & 1.01.04.01.01.10 \\
\hline $120 . J 70$ & $\begin{array}{l}\text { Perform Contractor Standard Startup Review for AN-103 Mixing and Retrieval } \\
\text { System less Mixer Pumps }\end{array}$ & 1.01.04.01.01.10 \\
\hline 120.J75 & $\begin{array}{l}\text { Provide CD-4 Approval for AN-103 Mixing and Retrieval System less Mixer } \\
\text { Pumps }\end{array}$ & 1.01 .04 .01 .01 .10 \\
\hline
\end{tabular}




\section{HNF-1946 REV 2}

Table B-1. Crosswalk from the Level 1 Logic to the Work Breakdown Structure.

\begin{tabular}{|c|c|c|}
\hline \multicolumn{3}{|c|}{ BNFL Inc. Phase 1 Privatization activities identified at WBS Level 3 (1.01.06). } \\
\hline $\begin{array}{l}\text { Level } 1 \text { Logic } \\
\text { TBR Number }\end{array}$ & 26. & WBS Level 6 \\
\hline 120.J83 & $\begin{array}{l}\text { Perform Management Self-Assessment for AN-103 Mixing and Retrieval } \\
\text { System less Mixer Pumps }\end{array}$ & 1.01.04.01.01.10 \\
\hline 120.J90 & Install the AN-103 Mixer Pump and Related Systems & 1.01.04.01.01.05 \\
\hline 120.392 & Startup and Test the AN-103 Mixer Pump and Related Systems & 1.01.04.01.01.10 \\
\hline $120 . \mathrm{K} 10$ & Establish Dilution Requirements and Dissolution Behavior for AN-107 & 1.01 .04 .01 .01 .02 \\
\hline $120 . \mathrm{K} 50$ & Design the AN-107 Mixing and Retrieval System and Obtain CD-3 & 1.01.04.01.01.06 \\
\hline $120 . \mathrm{K} 52$ & Procure Equipment for the AN-107 Mixing and Retrieval System & 1.01.04.01.01.06 \\
\hline $120 . \mathrm{K} 55$ & Construct the AN-107 Mixing and Retrieval System & 1.01 .04 .01 .01 .06 \\
\hline $120 . \mathrm{K} 60$ & Startup and Test the AN-107 Mixing and Retrieval System & 1.01 .04 .01 .01 .10 \\
\hline $120 . \mathrm{K} 70$ & Perform Contractor Standard Startup Review for AN-107 & 1.01.04.01.01.10 \\
\hline $120 . \mathrm{K} 75$ & Provide CD-4 Approval for AN-107 & 1.01 .04 .01 .01 .10 \\
\hline $120 . \mathrm{K} 83$ & $\begin{array}{l}\text { Perform Management Self-Assessment for the AN-107 Mixing and Retrieval } \\
\text { System }\end{array}$ & 1.01 .04 .01 .01 .10 \\
\hline 120.L10 & Establish Dilution Requirements and Dissolution Behavior for AN-102 & 1.01 .04 .01 .01 .02 \\
\hline 120.L41 & Provide Retrieval Program Direction to Project W-211 for AN-102 & 1.01 .04 .01 .01 .03 \\
\hline 120.L50 & Design the AN-102 Mixing and Retrieval System and Obtain CD-3 & 1.01 .04 .01 .01 .05 \\
\hline 120.L52 & Procure Equipment for the AN-102 Mixing and Retrieval System & 1.01.04.01.01.05 \\
\hline 120.L55 & Construct the AN-102 Mixing and Retrieval System & 1.01 .04 .01 .01 .05 \\
\hline 120.L60 & Startup and Test the AN-102 Mixing and Retrieval System & 1.01 .04 .01 .01 .10 \\
\hline 120.L70 & Perform Contractor Standard Startup Review for AN-102 & 1.01 .04 .01 .01 .10 \\
\hline 120.L75 & Provide CD-4 Approval for AN-102 & 1.01 .04 .01 .01 .10 \\
\hline 120.L83 & $\begin{array}{l}\text { Perform Management Self-Assessment for the AN-102 Mixing and Retrieval } \\
\text { System }\end{array}$ & 1.01.04.01.01.10。 \\
\hline $120 . N 10$ & Establish Dilution Requirements and Dissolution Behavior for AP-105 & 1.01 .04 .01 .01 .02 \\
\hline $120 . N 50$ & Design the AP-105 Mixing and Retrieval System and Obtain CD-3 & 1.01 .04 .01 .01 .07 \\
\hline $120 . \mathrm{N} 52$ & Procure Equipment for the AP-105 Mixing and Retrieval System & 1.01 .04 .01 .01 .07 \\
\hline $120 . N 55$ & Construct the AP-105 Mixing and Retrieval System & 1.01.04.01.01.07 \\
\hline $120 . \mathrm{N} 60$ & Startup and Test the AP-105 Mixing and Retrieval System & 1.01 .04 .01 .01 .10 \\
\hline
\end{tabular}




\section{HNF-1946 REV 2}

Table B-1. Crosswalk from the Level 1 Logic to the Work Breakdown Structure.

\begin{tabular}{|c|c|c|}
\hline \multicolumn{3}{|c|}{ BNFL Inc. Phase 1 Privatization activities identified at WBS Level 3 (1.01.06). } \\
\hline $\begin{array}{l}\text { Level } 1 \text { Logic } \\
\text { TBR Number }\end{array}$ & W & WBS Level 6 \\
\hline $120 . N 70$ & Perform Contractor Standard Startup Review for AP-105 & 1.01.04.01.01.10 \\
\hline $120 . N 75$ & Provide CD-4 Approval for AP-105 & 1.01.04.01.01.10 \\
\hline $120 . N 83$ & $\begin{array}{l}\text { Perform Management Self-Assessment for AP-105 Mixing and Retrieval } \\
\text { System }\end{array}$ & 1.01.04.01.01.10 \\
\hline $120 . P 22$ & $\begin{array}{l}\text { Perform Contractor Independent Operational Readiness Review for SY-102 } \\
\text { Transfer System }\end{array}$ & 1.01 .04 .01 .01 .10 \\
\hline 120.P25 & $\begin{array}{l}\text { Perform DOE-ORP Operational Readiness Review and Obtain CD-4 for SY- } \\
102 \text { Transfer System }\end{array}$ & 1.01 .04 .01 .01 .10 \\
\hline $120 . P 32$ & Provide Retrieval Program Direction to Project W-211 for SY-102 & 1.01.04.01.01.03 \\
\hline 120.P56 & Procure Equipment for the SY-102 Mixing and Retrieval System & 1.01 .04 .01 .01 .05 \\
\hline $120 . P 60$ & Construct the SY-102 Mixing and Retrieval System & 1.01.04.01.01.05 \\
\hline $120 . P 70$ & Startup and Test the SY-102 Mixing and Retrieval System & 1.01 .04 .01 .01 .10 \\
\hline $120 . P 83$ & $\begin{array}{l}\text { Perform Management Self-Assessment for the SY-102 Mixing and Retrieval } \\
\text { System }\end{array}$ & 1.01.04.01.01.10 \\
\hline 120.R10 & Establish Dilution Requirements and Dissolution Behavior for SY-101 & 1.01 .04 .01 .01 .02 \\
\hline 120.R50 & Design SY-101 Mixing and Retrieval System and Obtain CD-3 & 1.01.04.01.01.06 \\
\hline 120.R52 & Procure Equipment for the SY-101 Mixing and Retrieval System & 1.01 .04 .01 .01 .06 \\
\hline 120.R55 & Construct the SY-101 Mixing and Retrieval System & 1.01 .04 .01 .01 .06 \\
\hline 120.R60 & Startup and Test the SY-101 Mixing and Retrieval System & 1.01 .04 .01 .01 .10 \\
\hline $120 . R 70$ & Perform Contractor Standard Startup Review for SY-101 & 1.01 .04 .01 .01 .10 \\
\hline 120.R75 & Provide CD-4 Approval for SY-101 & 1.01 .04 .01 .01 .10 \\
\hline $120 . \mathrm{R} 83$ & $\begin{array}{l}\text { Perform Management Self-Assessment for the SY-101 Mixing and Retrieval } \\
\text { System }\end{array}$ & 1.01 .04 .01 .01 .10 \\
\hline $120 . \mathrm{T} 10$ & Establish Dilution Requirements and Dissolution Behavior for SY-103 & 1.01.04.01.01.02 \\
\hline $120 . \mathrm{T} 50$ & Design the SY-103 Mixing and Retrieval System and Obtain CD-3 & 1.01 .04 .01 .01 .06 \\
\hline $120 . \mathrm{T} 52$ & Procure Equipment for the SY-103 Mixing and Retrieval System & 1.01.04.01.01.06 \\
\hline 120.T55 & Construct the SY-103 Mixing and Retrieval System & 1.01 .04 .01 .01 .06 \\
\hline $120 . \mathrm{T} 60$ & Startup and Test the SY-103 Mixing and Retrieval System & 1.01.04.01.01.10 \\
\hline $120 . T 70$ & Perform Contractor Standard Startup Review for SY-103 & 1.01 .04 .01 .01 .10 \\
\hline
\end{tabular}




\section{HNF-1946 REV 2}

Table B-1. Crosswalk from the Level 1 Logic to the Work Breakdown Structure.

\begin{tabular}{|c|c|c|}
\hline \multicolumn{3}{|c|}{ BNFL Inc. Phase 1 Privatization activities identified at WBS Level 3 (1.01.06). } \\
\hline Level 1 Logic & 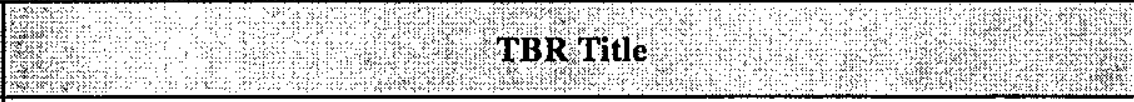 & WBS Level 6 \\
\hline $120 . \mathrm{T} 75$ & Provide CD-4 Approval for SY -103 & 1.01.04.01.01.10 \\
\hline $120 . \mathrm{T} 83$ & $\begin{array}{l}\text { Perform Management Self-Assessment for the SY-103 Mixing and Retrieval } \\
\text { System }\end{array}$ & 1.01 .04 .01 .01 .10 \\
\hline $120 . \mathrm{V} 10$ & Establish Dilution Requirements and Dissolution Behavior for AP-101 & 1.01 .04 .01 .01 .02 \\
\hline $120 . \mathrm{V} 12$ & Analyze AP-101 per BNFL, ORP/WIT, and RPP Requirements & 1.01 .04 .01 .01 .02 \\
\hline 120.V45 & Replace AP-101 Transfer Pump, Jumpers, and Associated Equipment & 1.01.04.01.01.10 \\
\hline $120 . \mathrm{V} 60$ & Startup and Test the AP-101 Transfer Pump & 1.01 .04 .01 .01 .10 \\
\hline 120.V65 & Complete AP-101 Transfer System Preparations and Integrated Testing & 1.01 .04 .01 .01 .10 \\
\hline $120 . V 72$ & Perform Management Self-Assessment for AP-101 Transfer System & 1.01.04.01.01.10 \\
\hline $120 . V 78$ & $\begin{array}{l}\text { Perform Contractor Independent Operational Readiness Review for AP-101 } \\
\text { Transfer System }\end{array}$ & 1.01 .04 .01 .01 .10 \\
\hline $120 . \mathrm{V} 85$ & $\begin{array}{l}\text { Perform DOE-ORP Operational Readiness Review and Obtain CD-4 for AP- } \\
101 \text { Transfer System }\end{array}$ & 1.01.04.01.01.10 \\
\hline $120 . V 90$ & Design the AP Farm Waste Feed Delivery Transfer System & 1.01 .04 .01 .01 .06 \\
\hline $120 . \mathrm{V} 92$ & Construct the AP Farm. Waste Feed Delivery Transfer System & 1.01 .04 .01 .01 .06 \\
\hline 120.W10 & Establish Dilution Requirements and Dissolution Behavior for AW-104 & 1.01 .04 .01 .01 .02 \\
\hline 120.W50 & Design the AW-104 Mixing and Retrieval System and Obtain CD-3 & 1.01 .04 .01 .01 .06 \\
\hline 120.W52 & Procure Equipment for the AW-104 Mixing and Retrieval System & 1.01.04.01.01.06 \\
\hline 120.W55 & Construct the AW-104 Mixing and Retrieval System & 1.01.04.01.01.06 \\
\hline 120.W60 & Startup and Test the AW-104 Mixing and Retrieval System & 1.01 .04 .01 .01 .10 \\
\hline 120.W70 & Perform Contractor Standard Startup Review for AW-104 & 1.01 .04 .01 .01 .10 \\
\hline 120.W75 & Provide CD-4 Approval for AW-104 & 1.01.04.01.01.10 \\
\hline 120.W83 & $\begin{array}{l}\text { Perform Management Self-Assessment for AW-104 Mixing and Retrieval } \\
\text { System }\end{array}$ & 1.01.04.01.01.10 \\
\hline 120.W99 & Project Management for W-522 & 1.01.04.01.01.07 \\
\hline $120 . Y 10$ & Establish Dilution Requirements and Dissolution Behavior for AP-108 & 1.01 .04 .01 .01 .02 \\
\hline $120 . Y 50$ & Design the AP-108 Mixing and Retrieval System and Obtain CD-3 & 1.01.04.01.01.07 \\
\hline $120 . Y 52$ & Procure Equipment for the AP-108 Mixing and Retrieval System & 1.01 .04 .01 .01 .07 \\
\hline $120 . Y 55$ & Construct the AP-108 Mixing and Retrieval System & 1.01 .04 .01 .01 .07 \\
\hline
\end{tabular}


Table B-1. Crosswalk from the Level 1 Logic to the Work Breakdown Structure.

\begin{tabular}{|c|c|c|}
\hline \multicolumn{3}{|c|}{ BNFL Inc. Phase 1 Privatization activities identified at WBS Level 3 (1.01.06). } \\
\hline Level 1 Logic & W. & WBS Level 6 \\
\hline 120.Y60 & Startup and Test the AP-108 Mixing and Retrieval System & 1.01.04.01.01.10 \\
\hline $120 . Y 70$ & Perform Contractor Standard Startup Review for AP-108 & 1.01 .04 .01 .01 .10 \\
\hline $120 . Y 75$ & Provide CD-4 Approval for AP-108 & 1.01 .04 .01 .01 .10 \\
\hline $120 . Y 83$ & $\begin{array}{l}\text { Perform Management Self-Assessment for AP-108 Mixing and Retrieval } \\
\text { System }\end{array}$ & 1.01 .04 .01 .01 .10 \\
\hline $120 . \mathrm{Z} 10$ & Establish Dilution Requirements and Dissolution Behavior for S-102 & 1.01 .04 .01 .02 .02 \\
\hline 130.020 & Accomplish 222-S Laboratory Upgrades for Phase 1 & 1.01 .04 .01 .01 .09 \\
\hline 130.028 & Perform Special Cases and Studies & 1.01 .04 .01 .01 .02 \\
\hline 130.033 & Support DOE/BNFL Proposals and Studies & 1.01 .04 .01 .01 .02 \\
\hline 130.B05 & Identify Required Spare Equipment to Support LAW/HLW Phase 1 WFD & 1.01 .04 .01 .01 .10 \\
\hline $130 . \mathrm{B} 10$ & Procure Waste Feed Delivery Spare Equipment per Retrieval Specification & 1.01.04.01.01.10 \\
\hline $130 . \mathrm{B} 15$ & Prepare to Maintain Waste Feed Staging in the Production Mode & 1.01 .04 .01 .01 .10 \\
\hline 130.B16 & Maintain Waste Feed Delivery System Operable & 1.01 .04 .01 .01 .10 \\
\hline 130.B20 & Provide Authorization to Add Diluent and Waste to FG Watchlist DSTs & 1.01 .04 .01 .01 .14 \\
\hline 130.B22 & Prepare Process Control Plan for AP-102/AP-104 & 1.01 .04 .01 .01 .10 \\
\hline 130.B23 & $\begin{array}{l}\text { Transfer AN-105 Feed between AN-102 and AN-105 until Sulfate Analysis is } \\
\text { Acceptable }\end{array}$ & 1.01 .04 .01 .01 .10 \\
\hline 130.B25 & Degas AN- 105 by Decanting the 1 st Batch of $\mathrm{AN}-105$ to $\mathrm{AN}-102$ & 1.01 .04 .01 .01 .10 \\
\hline 130.B55 & Prepare Process Control Plan for AN-105 & 1.01 .04 .01 .01 .10 \\
\hline $130 . \mathrm{B} 65$ & $\begin{array}{l}\text { Perform RPP Management Assessment of Overall Readiness to Supply LAW } \\
\text { Feed to BNFL. }\end{array}$ & 1.01 .04 .01 .01 .01 \\
\hline 130.B75 & $\begin{array}{l}\text { Compare RAM and O\&M Concept with Operational Test Procedure Results } \\
\text { (LAW) }\end{array}$ & 1.01 .04 .01 .01 .14 \\
\hline 130.B80 & Assess Secondary Waste, Utilities and Sample Analysis Against Plans (LAW) & 1.01 .04 .01 .01 .02 \\
\hline $130 . \mathrm{B} 90$ & Prepare the LAW Feed Certification DQO & 1.01 .04 .01 .01 .02 \\
\hline $130 . \mathrm{C} 25$ & Prepare Process Control Plan for AP-106 & 1.01 .04 .01 .01 .10 \\
\hline $130 . C 30$ & Mobilize and Retrieve AP-106 Waste and Receive Feed in AN -102 & 1.01 .04 .01 .01 .10 \\
\hline $130 . \mathrm{C} 35$ & Acquire Cold Pump Test, Training, and Mock-Up Facility & 1.01 .04 .01 .01 .03 \\
\hline 130.E10 & Degas AN-104 by Decanting 1st Batch of AN-104 to AN-101 & 1.01 .04 .01 .01 .10 \\
\hline
\end{tabular}




\section{HNF-1946 REV 2}

Table B-1. Crosswalk from the Level 1 Logic to the Work Breakdown Structure.

\begin{tabular}{|c|c|c|}
\hline $\begin{array}{l}\text { Level } 1 \text { Logic } \\
\text { TBR Number }\end{array}$ & 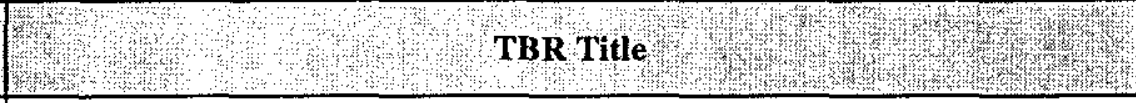 & $\begin{array}{l}\text { WBS Level } 6 \\
\end{array}$ \\
\hline 130.E20 & $\begin{array}{l}\text { Transfer AN-104 Feed between AN-101 and AN-104 until Sulfate Analysis is } \\
\text { Acceptable }\end{array}$ & 1.01 .04 .01 .01 .10 \\
\hline 130.E35 & Prepare Process Control Plan for AN-104 & 1.01 .04 .01 .01 .10 \\
\hline $130 . \mathrm{E} 40$ & Transfer AN-101 to AP-103 & 1.01 .04 .01 .01 .10 \\
\hline $130 . G 10$ & Degas AW-101 by Decanting the 1st Batch of AW-101 to AN-105 & 1.01 .04 .01 .01 .10 \\
\hline $130 . \mathrm{G} 25$ & Prepare Process Control Plan for AW-101 & 1.01 .04 .01 .01 .10 \\
\hline 130.127 & Transfer S-105 Feed from AN-104 to AN-105 & 1.01 .04 .01 .01 .10 \\
\hline 130.135 & Cross-Site Transfer S-105 Feed from SY-103 to AN-105 & 1.01 .04 .01 .01 .10 \\
\hline $130 . \mathrm{J} 10$ & Degas AN-103 by Decanting 1st Batch of AN-103 to AN-102 & 1.01 .04 .01 .01 .10 \\
\hline $130 . \mathrm{J} 25$ & Prepare Process Control Plan for AN-103 & 1.01 .04 .01 .01 .10 \\
\hline $130 . \mathrm{K} 20$ & Prepare Process Control Plan for AN-107 & 1.01 .04 .01 .01 .10 \\
\hline 130.L20 & Prepare Process Control Plan for AN-102 & 1.01 .04 .01 .01 .10 \\
\hline $130 . \mathrm{N} 25$ & Prepare Process Control Plan for AP-105 & 1.01 .04 .01 .01 .10 \\
\hline $130 . \mathrm{N} 30$ & Mobilize and Retrieve Waste in AP-105 and Receive Feed in AP-104 & 1.01 .04 .01 .01 .10 \\
\hline 130.R25 & Prepare Process Control Plan for SY-101 & 1.01 .04 .01 .01 .10 \\
\hline 130.R28 & Transfer 2nd Batch of SY-101 Feed to SY-102 & 1.01 .04 .01 .01 .10 \\
\hline $130 . \mathrm{R} 35$ & Cross-Site Transfer 2 nd Batch of SY-101 Feed from SY-102 to AN-101 & 1.01 .04 .01 .01 .10 \\
\hline $130 . \mathrm{T} 25$ & Prepare Process Control Plan for SY-103 & 1.01 .04 .01 .01 .10 \\
\hline $130 . \mathrm{T} 35$ & Cross-Site Transfer SY-103 Feed to AN-101 & 1.01 .04 .01 .01 .10 \\
\hline $130 . \mathrm{V} 25$ & Prepare Process Control Plan for AP-101 & 1.01 .04 .01 .01 .10 \\
\hline 130.W25 & Prepare Process Control Plan for AW-104 & 1.01 .04 .01 .01 .10 \\
\hline 130.W30 & Decant AW-104 Waste and Receive (LAW) Feed in AP-104 & 1.01 .04 .01 .01 .10 \\
\hline $130 . \mathrm{Y} 25$ & Prepare Process Control Plan for AP-108 & 1.01 .04 .01 .01 .10 \\
\hline 130.227 & Transfer S-102 Feed from AN-104 to AP-101 & 1.01 .04 .01 .01 .10 \\
\hline 130.235 & Cross-Site Transfer S-102 Feed from SY-103 to AN-104 & 1.01.04.01.01.10 \\
\hline 150.700 & Prepare Test and Evaluation Plan for WFD Systems Verification & 1.01 .04 .01 .01 .10 \\
\hline
\end{tabular}


Table B-1. Crosswalk from the Level 1 Logic to the Work Breakdown Structure.

\begin{tabular}{|c|c|c|}
\hline \multicolumn{3}{|c|}{ BNFL Inc. Phase 1 Privatization activities identified at WBS Level 3 (1.01.06). } \\
\hline $\begin{array}{l}\text { Level } 1 \text { Logic } \\
\text { TBR Number }\end{array}$ & \begin{tabular}{|l|l|} 
& TBR Title \\
\end{tabular} & WBS Level 6 \\
\hline 150.702 & Perform WFD Operational Readiness Planning and Implementation & 1.01.04.01.01.10 \\
\hline 150.704 & Manage Waste Feed Delivery Activities & 1.01 .04 .01 .01 .01 \\
\hline 150.708 & Manage Retrieval Process Engineering & 1.01 .04 .01 .01 .14 \\
\hline 150.715 & Waste Feed Delivery Engineering Management & 1.01 .04 .01 .01 .01 \\
\hline 150.718 & Manage Retrieval Project Definition & 1.01 .04 .01 .01 .03 \\
\hline 150.726 & Waste Feed Delivery Process Development & 1.01 .04 .01 .01 .02 \\
\hline $150 . \mathrm{B} 05$ & Mix AP-102 Feed in AP-102 & 1.01 .04 .01 .01 .10 \\
\hline $150 . \mathrm{B} 08$ & $\begin{array}{l}\text { Maintain WFD Characterization Needs Matrices, Problem Specific DQOs, and } \\
\text { Sample Schedule }\end{array}$ & 1.01.04.01.01.02 \\
\hline $150 . \mathrm{B} 14$ & Develop and Establish Technical Safety Requirements (TSRs) & 1.01 .04 .01 .01 .14 \\
\hline $150 . \mathrm{B} 16$ & Update or Amend Authorization Basis for DST Retrieval & 1.01 .04 .01 .01 .14 \\
\hline $150 . \mathrm{B} 17$ & Maintain Authorization Basis and Criticality Safety Evaluation Reports & 1.01 .04 .01 .01 .14 \\
\hline $150 . \mathrm{B} 22$ & Maintain the Operations \& Utilization Plan (O\&UP) & 1.01.04.01.01.02 \\
\hline $150 . \mathrm{B} 25$ & Provide AP-102 Feed Batch Info from AP-102 to DOE-ORP & 1.01 .04 .01 .01 .10 \\
\hline $150 . \mathrm{B} 26$ & Maintain Waste Feed Delivery ICDs 19 and 20 & 1.01 .04 .01 .01 .02 \\
\hline 150.B29 & Manage Privatization Interface (TW-05) & 1.01 .05 .01 .01 .01 \\
\hline $150 . \mathrm{B} 30$ & Provide Approval to Deliver LAW Feed Batch \#8 & 1.01 .06 \\
\hline $150 . \mathrm{B} 31$ & Provide Approval to Deliver Spare LAW Feed Batch & 1.01 .06 \\
\hline $150 . \mathrm{B} 35$ & Deliver AP-102 Feed from AP-102 to BNFL Facility & 1.01 .04 .01 .01 .10 \\
\hline 150.840 & Provide AN-105 Feed Batch Info (from AN-102) to DOE-ORP & 1.01.04.01.01.10 \\
\hline 150.B44 & Deliver 1st Batch of AN-105 Feed from AN-102 to BNFL Facility & 1.01 .04 .01 .01 .10 \\
\hline $150 . \mathrm{B} 48$ & Mix Remaining AN-105 Feed & 1.01 .04 .01 .01 .10 \\
\hline 150.856 & Provide AN-105 Feed Batch Info (from AN-105) to DOE-ORP & 1.01 .04 .01 .01 .10 \\
\hline $150 . \mathrm{B} 60$ & Decant 2nd Batch of AN-105 Feed from AN-105 to BNFL Facility & 1.01 .04 .01 .01 .10 \\
\hline $150 . B 65$ & Provide Approval to Deliver LAW Feed Batch \#9 & 1.01 .06 \\
\hline 150.C01 & Issue Criticality Safety Evaluation Report for DST Retrieval & 1.01 .04 .01 .01 .14 \\
\hline
\end{tabular}




\section{HNF-1946 REV 2}

Table B-1. Crosswalk from the Level 1 Logic to the Work Breakdown Structure.

\begin{tabular}{|c|c|c|}
\hline \multicolumn{3}{|c|}{ BNFL Inc. Phase 1 Privatization activities identified at WBS Level 3 (1.01.06). } \\
\hline $\begin{array}{l}\text { Level } 1 \text { Logic } \\
\text { TBR Number }\end{array}$ & Wh TBitle & WBS Level 6 \\
\hline $150 . \mathrm{C} 05$ & Mix AP-106 Feed in AN-102 & 1.01.04.01.01.10 \\
\hline $150 . C 25$ & Provide AP-106 Feed Batch Info (from AN-102) to DOE-ORP & 1.01.04.01.01.10 \\
\hline $150 . \mathrm{C} 30$ & Provide Approval to Deliver LAW Feed Batch \#18 & 1.01 .06 \\
\hline $150 . \mathrm{C} 35$ & Deliver AP-106 Feed from AN-102 to BNFL Facility & 1.01 .04 .01 .01 .10 \\
\hline $150 . \mathrm{C} 40$ & Mix Remaining AP-106 Feed & 1.01 .04 .01 .01 .10 \\
\hline $150 . \mathrm{C} 60$ & Provide AP-106 Feed Batch Info (from AP-106) to DOE-ORP & 1.01 .04 .01 .01 .10 \\
\hline $150 . \mathrm{C} 65$ & Provide Approval to Deliver LAW Feed Batch \#19 & 1.01 .06 \\
\hline $150 . \mathrm{C} 70$ & Deliver AP-106 Feed from AP-106 to BNFL Facility & 1.01.04.01.01.10 \\
\hline 150.E25 & Provide AN-104 Feed Batch Info from AN-104 to DOE-ORP & 1.01 .04 .01 .01 .10 \\
\hline 150.E30 & Provide Approval to Deliver LAW Feed Batch \#5 & 1.01 .06 \\
\hline 150.E35 & Deliver 1st Batch of AN-104 Feed from AN-104 to BNFL Facility & 1.01 .04 .01 .01 .10 \\
\hline 150.E40 & Mix AN-104 Feed in AN-101 & 1.01 .04 .01 .01 .10 \\
\hline 150.E60 & Provide AN-104 Feed Batch Info (from AN-101) to DOE-ORP & 1.01 .04 .01 .01 .10 \\
\hline 150.E65 & Provide Approval to Deliver LAW Feed Batch \#6 & 1.01 .06 \\
\hline 150.E70 & Decant 2nd Batch of AN-104 Feed from AN-101 to BNFL Facility & 1.01.04.01.01.10 \\
\hline $150 . \mathrm{G} 25$ & Provide AW-101 Feed Batch Info (from AN-105) to DOE-ORP & 1.01 .04 .01 .01 .10 \\
\hline $150 . \mathrm{G} 30$ & Provide Approval to Deliver LAW Feed Batch \#14 & 1.01 .06 \\
\hline $150 . \mathrm{G} 35$ & Deliver 1st Batch of AW-101 Feed from AN-105 to BNFL Facility & 1.01 .04 .01 .01 .10 \\
\hline $150 . G 40$ & Mix Remaining AW-101 Feed & 1.01 .04 .01 .01 .10 \\
\hline 150.G54 & Repair/Upgrade Existing AW Tank Farm Systems Required for WFD Phase 1 & 1.01 .04 .01 .01 .09 \\
\hline $150 . \mathrm{G} 60$ & Provide AW-101 Feed Batch Info from AW-101 to DOE-ORP & 1.01 .04 .01 .01 .10 \\
\hline $150 . G 65$ & Provide Approval to Deliver LAW Feed Batch \#15 & 1.01 .06 \\
\hline $150 . G 70$ & Decant 2nd Batch of AW-101 Feed from AW-101 to BNFL Facility & 1.01 .04 .01 .01 .10 \\
\hline 150.I05 & Mix S-105 Feed in AN-105 & 1.01 .04 .01 .01 .10 \\
\hline 150.125 & Provide S-105 Feed Batch Info from AN-105 to DOE-ORP & 1.01 .04 .01 .01 .10 \\
\hline 150.130 & Provide Approval to Deliver LAW Feed Batch \#21 & 1.01 .06 \\
\hline
\end{tabular}


Table B-1. Crosswalk from the Level 1 Logic to the Work Breakdown Structure.

\begin{tabular}{|c|c|c|}
\hline \multicolumn{3}{|c|}{ BNFL Inc. Phase 1 Privatization activities identified at WBS Level 3 (1.01.06). } \\
\hline $\begin{array}{l}\text { Level } 1 \text { Logic } \\
\text { TBR Number }\end{array}$ & W & WBS Level 6 \\
\hline 150.135 & Deliver S-105 Feed from AN-105 to BNFL Facility & 1.01.04.01.01.10 \\
\hline $150 . \mathrm{J} 25$ & Provide AN-103 Feed Batch Info (from AN-102) to DOE-ORP & 1.01 .04 .01 .01 .10 \\
\hline 150.J30 & Provide Approval to Deliver LAW Feed Batch \#12 & 1.01 .06 \\
\hline 150.J35 & Deliver 1st Batch of AN-103 Feed from AN-102 to BNFL Facility & 1.01 .04 .01 .01 .10 \\
\hline $150 . J 40$ & Mix Remaining AN-103 Feed & 1.01 .04 .01 .01 .10 \\
\hline $150 . \mathrm{J} 60$ & Provide AN-103 Feed Batch Info (from AN-103) to DOE-ORP & 1.01 .04 .01 .01 .10 \\
\hline $150 . \mathrm{J} 65$ & Provide Approval to Deliver LAW Feed Batch \#13 & 1.01 .06 \\
\hline 150.570 & Decant 2nd Batch of AN-103 Feed from AN-103 to BNFL Facility & 1.01 .04 .01 .01 .10 \\
\hline 150.K05 & Mix AN-107 Feed in AN-107 & 1.01 .04 .01 .01 .10 \\
\hline $150 . \mathrm{K} 25$ & Provide AN-107 Feed Batch Info from AN-107 to DOE-ORP & 1.01 .04 .01 .01 .10 \\
\hline $150 . \mathrm{K} 30$ & Provide Approval to Deliver LAW Feed Batch \#7 & 1.01 .06 \\
\hline $150 . \mathrm{K} 35$ & Decant AN-107 Feed from AN-107 to BNFL Facility & 1.01 .04 .01 .01 .10 \\
\hline $150 . \mathrm{K} 54$ & Repair/Upgrade Existing AN Tank Farm Systems Required for WFD Phase 1 & 1.01.04.01.01.09 \\
\hline 150.LO5 & Mix AN-102 Feed in AN-102 & 1.01 .04 .01 .01 .10 \\
\hline $150 . \mathrm{L} 25$ & Provide AN-102 Feed Batch Info from AN-102 to DOE-ORP & 1.01 .04 .01 .01 .10 \\
\hline $150 . \mathrm{L} 30$ & Provide Approval to Deliver LAW Feed Batch \#3 and \#4 & 1.01 .06 \\
\hline 150.L35 & Decant 1st Batch of AN-102 Feed from AN-102 to BNFL Facility & 1.01 .04 .01 .01 .10 \\
\hline 150.L70 & Decant 2nd Batch of AN-102 Feed from AN-102 to BNFL Facility & 1.01.04.01.01.10 \\
\hline 150.L75 & Clean Out AN-102 and Flush to AN-106 & 1.01 .04 .01 .01 .10 \\
\hline 150.N05 & Mix AP-105 Feed in AP-104 & 1.01 .04 .01 .01 .10 \\
\hline $150 . \mathrm{N} 25$ & Provide AP-105 Feed Batch Info from AP-104 to DOE-ORP & 1.01 .04 .01 .01 .10 \\
\hline $150 . \mathrm{N} 30$ & Provide Approval to Deliver LAW Feed Batch \#22 & 1.01 .06 \\
\hline $150 . \mathrm{N} 35$ & Deliver AP-105 Feed from AP-104 to BNFL Facility & 1.01 .04 .01 .01 .10 \\
\hline $150 . \mathrm{N} 40$ & Mix AP-105 Feed in AP-105 & 1.01 .04 .01 .01 .10 \\
\hline $150 . \mathrm{N} 60$ & Provide AP-105 Feed Batch Info from AP-105 to DOE-ORP & 1.01.04.01.01.10 \\
\hline $150 . N 65$ & Provide Approval to Deliver LAW Feed Batch \#23 & 1.01 .06 \\
\hline
\end{tabular}




\section{HNF-1946 REV 2}

Table B-1. Crosswalk from the Level 1 Logic to the Work Breakdown Structure.

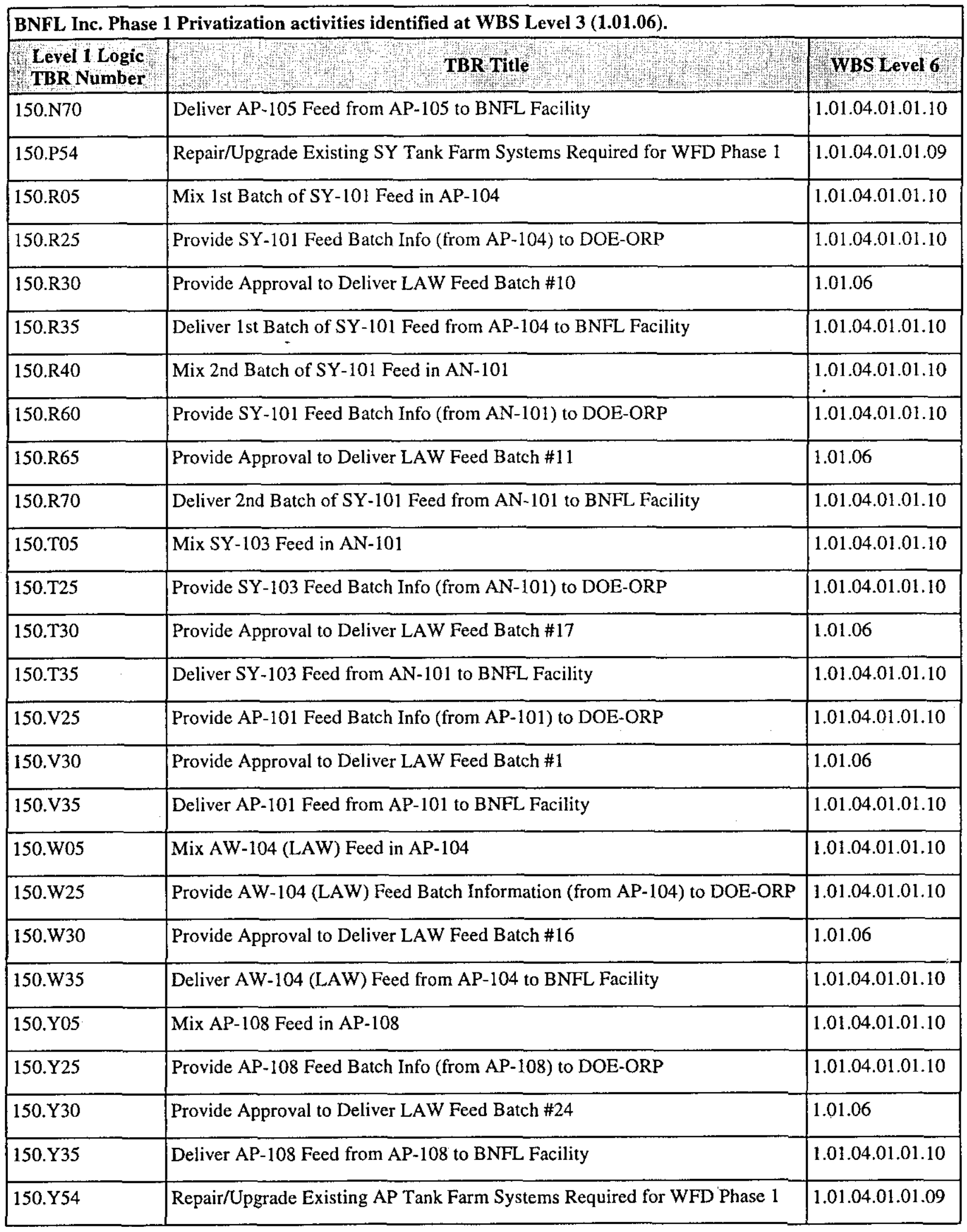


Table B-1. Crosswalk from the Level 1 Logic to the Work Breakdown Structure.

\begin{tabular}{|c|c|c|}
\hline \multicolumn{3}{|c|}{ BNFL Inc. Phase 1 Privatization activities identified at WBS Level 3 (1.01.06). } \\
\hline $\begin{array}{l}\text { Level } 1 \text { Logic } \\
\text { TBR Number }\end{array}$ & 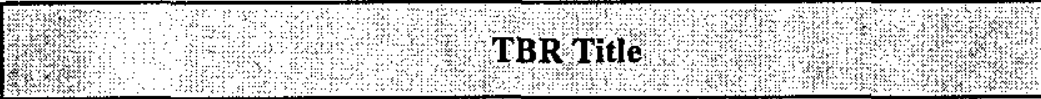 & WBS Level 6 \\
\hline $150 . \mathrm{Z} 05$ & Mix S-102 Feed in AP-101 & 1.01.04.01.01.10 \\
\hline 150.225 & Provide S-102 Feed Batch Info (from AP-101) to DOE-ORP & 1.01 .04 .01 .01 .10 \\
\hline $150 . \mathrm{Z} 30$ & Provide Approval to Deliver LAW Feed Batch \#20 & 1.01 .06 \\
\hline $150 . \mathrm{Z35}$ & Deliver S-102 Feed from AP-101 to BNFL Facility & 1.01 .04 .01 .01 .10 \\
\hline 160.010 & Deliver 1st Batch of HLW Feed From AZ-101 to BNFL Facility & 1.01 .04 .01 .01 .10 \\
\hline 160.020 & Deliver 2nd Batch of HLW Feed From AZ-101 to BNFL Facility & 1.01.04.01.01.10 \\
\hline 160.030 & Deliver 3rd Batch of HLW Feed From AZ-101 to BNFL Facility & 1.01 .04 .01 .01 .10 \\
\hline 160.040 & Deliver 4th Batch of HLW Feed From AZ-101 to BNFL Facility & 1.01.04.01.01.10 \\
\hline 160.050 & Deliver 5th Batch of HLW Feed From AZ-101 to BNFL Facility & 1.01 .04 .01 .01 .10 \\
\hline 160.060 & Deliver 6th Batch of HLW Feed From AZ-101 to BNFL Facility & 1.01 .04 .01 .01 .10 \\
\hline 160.070 & Deliver 1st Batch of HLW Feed From AZ-102 to BNFL Facility & 1.01 .04 .01 .01 .10 \\
\hline 160.080 & Deliver 2nd Batch of HLW Feed From AZ-102 to BNFL Facility & 1.01 .04 .01 .01 .10 \\
\hline 160.090 & Deliver 3rd Batch of HLW Feed From AZ-102 to BNFL Facility & 1.01 .04 .01 .01 .10 \\
\hline 160.100 & Deliver 4th Batch of HLW Feed From AZ-102 to BNFL Facility & 1.01 .04 .01 .01 .10 \\
\hline 160.110 & Deliver 5th Batch of HLW Feed From AZ-102 to BNFL Facility & 1.01 .04 .01 .01 .10 \\
\hline 160.120 & Deliver 6th Batch of HLW Feed From AZ-102 to BNFL Facility & 1.01.04.01.01.10 \\
\hline 160.130 & $\begin{array}{l}\text { Deliver 1st Batch of AY-102/C-106 HLW Feed From AY-102 to BNFL } \\
\text { Facility }\end{array}$ & 1.01 .04 .01 .01 .10 \\
\hline 160.140 & $\begin{array}{l}\text { Deliver 2nd Batch of AY-102/C-106 HLW Feed From AY-102 to BNFL } \\
\text { Facility }\end{array}$ & 1.01.04.01.01.10 \\
\hline 160.150 & $\begin{array}{l}\text { Deliver 3rd Batch of AY-102/C-106 HLW Feed From AY-102 to BNFL } \\
\text { Facility }\end{array}$ & 1.01.04.01.01.10 \\
\hline 160.160 & $\begin{array}{l}\text { Deliver 4th Batch of AY-102/C-106 HLW Feed From AY-102 to BNFL } \\
\text { Facility }\end{array}$ & $1.01 .04 .01 .01 .10^{8}$ \\
\hline 160.170 & $\begin{array}{l}\text { Deliver 5th Batch of AY-102/C-106 HLW Feed From AY-102 to BNFL } \\
\text { Facility }\end{array}$ & 1.01.04.01.01.10 \\
\hline 160.180 & $\begin{array}{l}\text { Deliver 6th Batch of AY-102/C-106 HLW Feed From AY-102 to BNFL } \\
\text { Facility }\end{array}$ & 1.01.04.01.01.10 \\
\hline 160.190 & $\begin{array}{l}\text { Deliver 7th Batch of AY-102/C-106 HLW Feed From AY-102 to BNFL } \\
\text { Facility }\end{array}$ & 1.01 .04 .01 .01 .10 \\
\hline 160.200 & $\begin{array}{l}\text { Deliver 1st Batch of AY-101/C-104 HLW Feed From AY-101 to BNFL } \\
\text { Facility }\end{array}$ & 1.01 .04 .01 .01 .10 \\
\hline
\end{tabular}


Table B-1. Crosswalk from the Level 1 Logic to the Work Breakdown Structure.

\begin{tabular}{|c|c|c|}
\hline \multicolumn{3}{|c|}{ BNFL Inc. Phase 1 Privatization activities identified at WBS Level 3 (1.01.06). } \\
\hline $\begin{array}{l}\text { Level } 1 \text { Logic } \\
\text { TBR Number }\end{array}$ & \begin{tabular}{|l|l|} 
& TBR Title
\end{tabular} & WBS Level 6 \\
\hline 160.210 & $\begin{array}{l}\text { Deliver 2nd Batch of AY-101/C-104 HLW Feed From AY-101 to BNFL } \\
\text { Facility }\end{array}$ & 1.01 .04 .01 .01 .10 \\
\hline 160.220 & $\begin{array}{l}\text { Deliver 3rd Batch of AY-101/C-104 HLW Feed From AY-101 to BNFL } \\
\text { Facility }\end{array}$ & 1.01.04.01.01.10 \\
\hline 160.230 & $\begin{array}{l}\text { Deliver 4th Batch of AY-101/C-104 HLW Feed From AY-101 to BNFL } \\
\text { Facility }\end{array}$ & 1.01 .04 .01 .01 .10 \\
\hline 160.240 & $\begin{array}{l}\text { Deliver 5th Batch of AY-101/C-104 HLW Feed From AY-101 to BNFL } \\
\text { Facility }\end{array}$ & 1.01 .04 .01 .01 .10 \\
\hline $\begin{array}{c}160.250 \\
-\end{array}$ & $\begin{array}{l}\text { Deliver 6th Batch of AY-101/C-104 HLW Feed From AY-101 to BNFL } \\
\text { Facility }\end{array}$ & 1.01 .04 .01 .01 .10 \\
\hline 160.260 & $\begin{array}{l}\text { Deliver 7th Batch of AY-101/C-104 HLW Feed From AY-101 to BNFL } \\
\text { Facility }\end{array}$ & 1.01 .04 .01 .01 .10 \\
\hline 160.270 & $\begin{array}{l}\text { Deliver 8th Batch of AY-101/C-104 HLW Feed From AY-101 to BNFL } \\
\text { Facility }\end{array}$ & 1.01 .04 .01 .01 .10 \\
\hline 160.280 & $\begin{array}{l}\text { Deliver 9th Batch of AY-101/C-104 HLW Feed From AY-101 to BNFL } \\
\text { Facility }\end{array}$ & 1.01 .04 .01 .01 .10 \\
\hline 160.290 & $\begin{array}{l}\text { Deliver 10th Batch of AY-101/C-104 HLW Feed From AY-101 to BNFL } \\
\text { Facility }\end{array}$ & 1.01 .04 .01 .01 .10 \\
\hline 160.300 & $\begin{array}{l}\text { Deliver 11th Batch of AY-101/C-104 HLW Feed From AY-101 to BNFL } \\
\text { Facility }\end{array}$ & 1.01 .04 .01 .01 .10 \\
\hline 160.310 & $\begin{array}{l}\text { Deliver 12th Batch of AY-101/C-104 HLW Feed From AY-101 to BNFL } \\
\text { Facility }\end{array}$ & 1.01 .04 .01 .01 .10 \\
\hline 160.320 & Deliver 1st Batch of SY-102 HLW Feed From AZ-101 to BNFL Facility & 1.01.04.01.01.10 \\
\hline 160.330 & Deliver 2nd Batch of SY-102 HLW Feed From AZ-101 to BNFL Facility & 1.01 .04 .01 .01 .10 \\
\hline 160.340 & Deliver 3rd Batch of SY-102 HLW Feed From AZ-101 to BNFL Facility & 1.01 .04 .01 .01 .10 \\
\hline 160.350 & Deliver 4th Batch of SY-102 HLW Feed From AZ-101 to BNFL Facility & 1.01 .04 .01 .01 .10 \\
\hline 160.360 & $\begin{array}{l}\text { Deliver 1st Batch of C-107/AW-103 HLW Feed From AY-102 to BNFL } \\
\text { Facility }\end{array}$ & 1.01.04.01.01.10 \\
\hline 160.370 & $\begin{array}{l}\text { Deliver 2nd Batch of C-107/AW-103 HLW Feed From AY-102 to BNFL } \\
\text { Facility }\end{array}$ & 1.01 .04 .01 .01 .10 \\
\hline 160.380 & $\begin{array}{l}\text { Deliver 3rd Batch of C-107/AW-103 HLW Feed From AY-102 to BNFL } \\
\text { Facility }\end{array}$ & 1.01 .04 .01 .01 .10 \\
\hline 160.390 & $\begin{array}{l}\text { Deliver 4th Batch of C-107/AW-103 HLW Feed From AY-102 to BNFL } \\
\text { Facility }\end{array}$ & 1.01 .04 .01 .01 .10 \\
\hline 160.400 & $\begin{array}{l}\text { Deliver 5th Batch of C-107/AW-103 HLW Feed From AY-102 to BNFL } \\
\text { Facility }\end{array}$ & 1.01.04.01.01.10 \\
\hline 160.410 & $\begin{array}{l}\text { Deliver 6th Batch of C-107/AW-103 HLW Feed From AY-102 to BNFL } \\
\text { Facility }\end{array}$ & 1.01 .04 .01 .01 .10 \\
\hline 160.420 & Deliver 7th Batch of C-107/AW-103 HLW Feed From AY-102 to BNFL & 1.01 .04 .01 .01 .10 \\
\hline
\end{tabular}




\section{HNF-1946 REV 2}

Table B-1. Crosswalk from the Level 1 Logic to the Work Breakdown Structure.

\begin{tabular}{|c|c|c|}
\hline \multicolumn{3}{|c|}{ BNFL Inc. Phase 1 Privatization activities identified at WBS Level 3 (1.01.06). } \\
\hline $\begin{array}{l}\text { Level } 1 \text { Logic } \\
\text { TBR Number }\end{array}$ & (Y) & WBSLevel 6 \\
\hline & Facility & \\
\hline 160.430 & $\begin{array}{l}\text { Deliver 8th Batch of C-107/AW-103 HLW Feed From AY-102 to BNFL } \\
\text { Facility }\end{array}$ & 1.01.04.01.01.10 \\
\hline 160.440 & $\begin{array}{l}\text { Deliver 9th Batch of C-107/AW-103 HLW Feed From AY-102 to BNFL } \\
\text { Facility }\end{array}$ & 1.01 .04 .01 .01 .10 \\
\hline 160.450 & $\begin{array}{l}\text { Deliver 1st Batch of AW-104(HLW)/AW-103 Feed From AW-104 to BNFL } \\
\text { Facility }\end{array}$ & 1.01.04.01.01.10 \\
\hline 160.460 & $\begin{array}{l}\text { Deliver 2nd Batch of AW-104(HLW)/AW-103 Feed From AW-104 to BNFL } \\
\text { Facility }\end{array}$ & 1.01.04.01.01.10 \\
\hline 160.470 & $\begin{array}{l}\text { Deliver 3rd Batch of AW-104(HLW)/AW-103 Feed From AW-104 to BNFL } \\
\text { Facility }\end{array}$ & 1.01.04.01.01.10 \\
\hline 160.480 & $\begin{array}{l}\text { Deliver 4th Batch of AW-104(HLW)/AW-103 Feed From AW-104 to BNFL } \\
\text { Facility }\end{array}$ & 1.01 .04 .01 .01 .10 \\
\hline 160.490 & $\begin{array}{l}\text { Deliver 5th Batch of AW-104(HLW)/AW-103 Feed From AW-104 to BNFL } \\
\text { Facility }\end{array}$ & 1.01 .04 .01 .01 .10 \\
\hline 160.500 & $\begin{array}{l}\text { Deliver 6th Batch of AW-104(HLW)/AW-103 Feed From AW-104 to BNFL } \\
\text { Facility }\end{array}$ & 1.01 .04 .01 .01 .10 \\
\hline 160.A15 & Assess Secondary Waste, Utilities \& Sample Analysis Against Plans (HLW) & 1.01 .04 .01 .01 .02 \\
\hline $160 . \mathrm{A} 17$ & $\begin{array}{l}\text { Compare RAM and O\&M Concept with Operational Test Procedure Results } \\
\text { (HLW) }\end{array}$ & 1.01.04.01.01.14 \\
\hline $160 . A 18$ & $\begin{array}{l}\text { Perform RPP Management Assessment of Overall Readiness to Supply HLW } \\
\text { Feed to BNFL }\end{array}$ & 1.01.04.01.01.01 \\
\hline 160.A22 & Prepare Process Control Plan for AZ-101 & 1.01.04.01.01.10 \\
\hline 160.A32 & Design the AZ-101 Retrieval System and Obtain CD-3 & 1.01.04.01.01.06 \\
\hline $160 . \mathrm{A} 34$ & Procure Equipment for the AZ-101 Retrieval System & 1.01 .04 .01 .01 .06 \\
\hline $160 . \mathrm{A} 36$ & Construct the AZ-101 Retrieval System & 1.01 .04 .01 .01 .06 \\
\hline 160.A38 & Startup and Test the AZ-101 Mixing and Retrieval System & 1.01 .04 .01 .01 .10 \\
\hline $160 . \mathrm{A} 40$ & Perform Contractor Independent Operational Readiness Review for AZ-101 & 1.01.04.01.01.10 \\
\hline 160.A42 & $\begin{array}{l}\text { Perform DOE-ORP Operational Readiness Review and Obtain CD-4 for AZ- } \\
101\end{array}$ & 1.01.04.01.01.10 \\
\hline 160.A43 & Perform Conceptual Design for W-521 Retrieval Systems & 1.01 .04 .01 .01 .06 \\
\hline 160.A48 & Perform and Document AZ-101 Sample Analyses and Rheology Testing & 1.01 .04 .01 .01 .02 \\
\hline 160.A54 & Repair/Upgrade Existing AZ Farm Systems Required for Phase 1 WFD & 1.01 .04 .01 .01 .09 \\
\hline $160 . \mathrm{A} 64$ & Mix AZ-101 Feed to Suspend Solids & 1.01.04.01.01.10 \\
\hline
\end{tabular}




\section{HNF-1946 REV 2}

Table B-1. Crosswalk from the Level 1 Logic to the Work Breakdown Structure.

\begin{tabular}{|c|c|c|}
\hline \multicolumn{3}{|c|}{ BNFL Inc. Phase 1 Privatization activities identified at WBS Level 3 (1.01.06). } \\
\hline $\begin{array}{l}\text { Level } 1 \text { Logic } \\
\text { TBR Number }\end{array}$ & 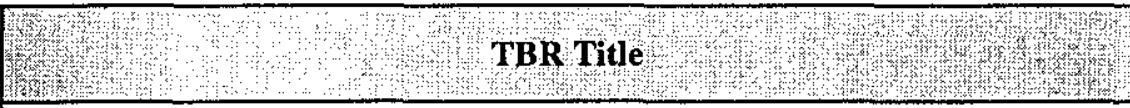 & WBS Level 6 \\
\hline 160.A65 & Complete AZ-101 Transfer System Preparations and Integrated Testing & 1.01 .04 .01 .01 .10 \\
\hline 160.A67 & Provide Critical Decision 2 Approval for Project W-521 & 1.01 .04 .01 .01 .10 \\
\hline 160.A70 & Provide Approval to Deliver AZ-101 Feed & 1.01 .04 .01 .01 .06 \\
\hline 160.A76 & $\begin{array}{l}\text { Provide AZ-101 MT of Suspended Solids and Official Composition from AZ- } \\
101 \text { to DOE-ORP }\end{array}$ & 1.01 .04 .01 .01 .10 \\
\hline 160.A83 & $\begin{array}{l}\text { Perform Management Self-Assessment of the AZ-101 Mixing and Retrieval } \\
\text { System }\end{array}$ & 1.01 .04 .01 .01 .10 \\
\hline 160.A90 & Prepare the HLW Feed Certification DQO & $1.01: 04.01 .01 .02$ \\
\hline 160.A99 & Project management for W-521 & 1.01 .04 .01 .01 .06 \\
\hline $160 . \mathrm{B} 05$ & Prepare the W-521 Project Technical Baseline Document & 1.01 .04 .01 .01 .03 \\
\hline 160.B 15 & Prepare the W-522 Project Technical Baseline Document & 1.01 .04 .01 .01 .03 \\
\hline 160.F10 & Perform and Document AZ-102 Sample Analyses and Rheology Testing & 1.01 .04 .01 .01 .02 \\
\hline 160.F20 & Prepare Process Control PIan for AZ-102 & 1.01 .04 .01 .01 .10 \\
\hline 160.F30 & Provide Retrieval Program Direction to Project W-211 for AZ-102 & 1.01 .04 .01 .01 .03 \\
\hline 160.F40 & Design the AZ-102 Mixing and Retrieval System and Obtain CD-3 & 1.01 .04 .01 .01 .05 \\
\hline $160 . F 50$ & Construct the AZ-102 Mixing and Retrieval System & 1.01.04.01.01.05 \\
\hline 160.F52 & Procure Equipment for the AZ-102 Mixing and Retrieval System & 1.01 .04 .01 .01 .05 \\
\hline $160 . F 60$ & Startup and Test the AZ-102 Mixing and Retrieval System & 1.01 .04 .01 .01 .10 \\
\hline 160.F64 & Mix AZ-102 Feed to Suspend Solids & 1.01 .04 .01 .01 .10 \\
\hline 160.F70 & Provide Approval to Deliver AZ-102 Feed & 1.01 .06 \\
\hline $160 . F 76$ & $\begin{array}{l}\text { Provide AZ-102 MT of Suspended Solids and Official Composition from AZ- } \\
102 \text { to DOE-ORP }\end{array}$ & 1.01 .04 .01 .01 .10 \\
\hline $160 . \mathrm{F} 80$ & Perform Contractor Standard Startup Review for AZ-102 & 1.01 .04 .01 .01 .10 \\
\hline 160.F83 & $\begin{array}{l}\text { Perform Management Self-Assessment for the AZ-102 Mixing and Retrieval } \\
\text { System }\end{array}$ & 1.01 .04 .01 .01 .10 \\
\hline 160.F90 & Provide CD-4 Approval for AZ-102 & 1.01 .04 .01 .01 .10 \\
\hline $160 . \mathrm{H} 10$ & Perform and Document AY-102 Sample Analyses and Rheology Testing & 1.01 .04 .01 .01 .02 \\
\hline $160 . \mathrm{H} 20$ & Prepare Process Control Plan for AY-102 & 1.01 .04 .01 .01 .10 \\
\hline $160 . \mathrm{H} 30$ & Provide Retrieval Program Direction to Project W-211 for AY-102 & 1.01 .04 .01 .01 .03 \\
\hline
\end{tabular}




\section{HNF-1946 REV 2}

Table B-1. Crosswalk from the Level 1 Logic to the Work Breakdown Structure.

\begin{tabular}{|c|c|c|}
\hline \multicolumn{3}{|c|}{ BNFL Inc. Phase 1 Privatization activities identified at WBS Level 3 (1.01.06). } \\
\hline $\begin{array}{l}\text { Level } 1 \text { Logic } \\
\text { TBR Number }\end{array}$ & (1) TBR Title & WBS Level 6 \\
\hline $160 . \mathrm{H} 40$ & Design the AY-102 Mixing and Retrieval System and Obtain CD-3 & 1.01 .04 .01 .01 .05 \\
\hline $160 . \mathrm{H} 50$ & Construct the AY-102 Mixing and Retrieval System & 1.01 .04 .01 .01 .05 \\
\hline $160 . \mathrm{H} 52$ & Procure Equipment for the AY-102 Mixing and Retrieval System & 1.01 .04 .01 .01 .05 \\
\hline 160.H54 & Repair/Upgrade Existing AY Tank Farm Systems Required for WFD Phase 1 & 1.01 .04 .01 .01 .09 \\
\hline 160.H60 & Startup and Test the AY-102 Mixing and Retrieval System & 1.01 .04 .01 .01 .10 \\
\hline $160 . \mathrm{H} 64$ & Mix AY-102/C-106 Feed to Suspend Solids & 1.01 .04 .01 .01 .10 \\
\hline $160 . \mathrm{H} 70$ & Provide Approval to Deliver AY-102/C-106 Feed from AY-102 & 1.01 .06 \\
\hline $160 . \mathrm{H} 76$ & $\begin{array}{l}\text { Provide AY-102/C-106 MT of Suspended Solids and Official Composition } \\
\text { from AY-101 to DOE-ORP }\end{array}$ & 1.01 .04 .01 .01 .10 \\
\hline $160 . \mathrm{H} 80$ & Perform Contractor Standard Startup Review for AY-102 & 1.01 .04 .01 .01 .10 \\
\hline $160 . \mathrm{H} 83$ & $\begin{array}{l}\text { Perform Management Self-Assessment for the AY-102 Mixing and Retrieval } \\
\text { System }\end{array}$ & 1.01 .04 .01 .01 .10 \\
\hline 160.H90 & Provide CD-4 Approval for AY-102 & 1.01.04.01.01.10 \\
\hline $160 . J 56$ & Provide Critical Decision 1 Approval for Project W-523 & 1.01 .04 .01 .02 .13 \\
\hline 160.J58 & Provide Critical Decision 2 Approval for Project W-523 & 1.01 .04 .01 .02 .13 \\
\hline $160 . P 10$ & Perform and Document SY-102 Sample Analyses and Rheology Testing & 1.01 .04 .01 .01 .02 \\
\hline $160 . \mathrm{P} 25$ & Prepare Process Control Plan for SY-102 & 1.01 .04 .01 .01 .10 \\
\hline $160 . P 29$ & Mix as Necessary and Transfer SY-102 Slurry from AN-104 to AZ-101 & 1.01 .04 .01 .01 .10 \\
\hline 160.P70 & Provide Approval to Deliver SY-102 Feed from AZ-101 & 1.01 .06 \\
\hline $160 . P 72$ & $\begin{array}{l}\text { Mix as Necessary and Transfer SY-102 to AN-104 via Cross-Site Slurry } \\
\text { Transfer Line }\end{array}$ & 1.01 .04 .01 .01 .10 \\
\hline $160 . P 76$ & $\begin{array}{l}\text { Provide SY-102 MT of Suspended Solids and Official Composition from AZ- } \\
101 \text { to DOE-ORP }\end{array}$ & 1.01.04.01.01.10 \\
\hline $160 . Q 10$ & Perform and Document C-107 Sample Analyses and Rheology Testing & 1.01 .04 .01 .02 .02 \\
\hline $160 . Q 64$ & Mix C-107/AW-103 Feed in AY-102 & 1.01 .04 .01 .01 .10 \\
\hline $160 . Q 70$ & Provide Approval to Deliver C-107/AW-103 Feed from AY-102 & 1.01 .06 \\
\hline $160 . Q 76$ & $\begin{array}{l}\text { Provide C-107/AW-103 MT of Suspended Solids and Official Composition } \\
\text { from AY-102 to DOE-ORP }\end{array}$ & 1.01 .04 .01 .01 .10 \\
\hline $160 . S 10$ & Perform and Document AY-101 Sample Analyses and Rheology Testing & 1.01 .04 .01 .01 .02 \\
\hline
\end{tabular}




\section{HNF-1946 REV 2}

Table B-1. Crosswalk from the Level 1 Logic to the Work Breakdown Structure.

\begin{tabular}{|c|c|c|}
\hline \multicolumn{3}{|c|}{ BNFL Inc. Phase 1 Privatization activities identified at WBS Level 3 (1.01.06). } \\
\hline Level 1 Logic & W & WBS Level 6 \\
\hline $160 . S 20$ & Prepare Process Control Plan for AY-101 & 1.01.04.01.01.10 \\
\hline $160 . S 40$ & Design the AY-101 Mixing and Retrieval System and Obtain CD-3 & 1.01.04.01.01.06 \\
\hline 160.550 & Construct the AY-101 Mixing and Retrieval System & 1.01.04.01.01.06 \\
\hline $160 . \mathrm{S} 52$ & Procure Equipment for the AY-101 Mixing and Retrieval System & 1.01.04.01.01.06 \\
\hline $160 . S 60$ & Startup and Test the AY-101 Mixing and Retrieval System & 1.01.04.01.01.10 \\
\hline 160.564 & Mix AY-101/C-104 Feed to Suspend Solids & 1.01 .04 .01 .01 .10 \\
\hline 160.570 & Provide Approval to Deliver AY-101/C-104 Feed from AY-101 & 1.01 .06 \\
\hline $160 . S 72$ & Mix AY-101 Feed to Suspend Solids & 1.01.04.01.01.10 \\
\hline $160 . S 76$ & $\begin{array}{l}\text { Provide AY-101/C-104 MT of Suspended Solids and Official Composition } \\
\text { from AY-101 to DOE-ORP }\end{array}$ & 1.01.04.01.01.10 \\
\hline $160 . S 80$ & Perform Contractor Standard Startup Review for AY-101 & 1.01 .04 .01 .01 .10 \\
\hline $160 . S 83$ & $\begin{array}{l}\text { Perform Management Self-Assessment for the AY-101 Mixing and Retrieval } \\
\text { System }\end{array}$ & 1.01 .04 .01 .01 .10 \\
\hline $160 . S 90$ & Provide CD-4 Approval for AY-101 & 1.01 .04 .01 .01 .10 \\
\hline $160 . \mathrm{U} 10$ & Perform and Document AW-103 Sample Analyses and Rheology Testing & 1.01 .04 .01 .01 .02 \\
\hline $160 . \mathrm{U} 25$ & Prepare Process Control Plan for AW-103 & 1.01 .04 .01 .01 .10 \\
\hline 160.U29 & Transfer a portion of (35\%) AW-103 to AY-102 & 1.01 .04 .01 .01 .10 \\
\hline $160 . U 40$ & Design the AW-103 Mixing and Retrieval System and Obtain CD-3 & 1.01.04.01.01.06 \\
\hline 160.U50 & Construct the AW-103 Mixing and Retrieval System & 1.01 .04 .01 .01 .06 \\
\hline $160 . \mathrm{U} 52$ & Procure Equipment for the AW-103 Mixing and Retrieval System & 1.01 .04 .01 .01 .06 \\
\hline $160 . U 60$ & Startup and Test the AW-103 Mixing and Retrieval System & 1.01 .04 .01 .01 .10 \\
\hline $160 . U 64$ & Mix AW-103 Waste to Suspend Solids prior to AY-102 Transfer & $1.01 .04 .01 .01 .10_{3}$ \\
\hline 160.U72 & Transfer a portion of (25\%) AW-103 to AW-104 & 1.01 .04 .01 .01 .10 \\
\hline 160.U76 & $\begin{array}{l}\text { Provide AW-103 MT of Suspended Solids and Official Composition from AW- } \\
103 \text { to DOE-ORP }\end{array}$ & 1.01 .04 .01 .01 .10 \\
\hline 160.U80 & Perform Contractor Standard Startup Review for AW-103 & 1.01 .04 .01 .01 .10 \\
\hline 160.U83 & $\begin{array}{l}\text { Perform Management Self-Assessment for the AW-103 Mixing and Retrieval } \\
\text { System }\end{array}$ & 1.01 .04 .01 .01 .10 \\
\hline 160.U85 & Mix AW-103 Waste by Incrementally Lowering Mixer Pump to Suspend & 1.01 .04 .01 .01 .10 \\
\hline
\end{tabular}




\section{HNF-1946 REV 2}

Table B-1. Crosswalk from the Level 1 Logic to the Work Breakdown Structure.

\begin{tabular}{|c|c|c|}
\hline \multicolumn{3}{|c|}{ BNFL Inc. Phase 1 Privatization activities identified at WBS Level 3 (1.01.06). } \\
\hline Tevel 1 Logic & 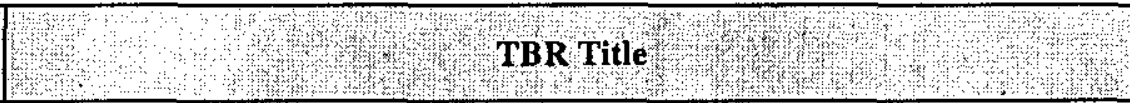 & WBS Level 6 \\
\hline & Solids prior to AW-104 Transfer & \\
\hline $160 . \mathrm{U} 90$ & Provide CD-4 Approval for AW-103 & 1.01 .04 .01 .01 .10 \\
\hline 160.W10 & Perform and Document AW-104 Sample Analyses and Rheology Testing & 1.01 .04 .01 .01 .02 \\
\hline 160.W20 & Blend AW-104(HLW)/AW-103 Feed in AW-104 & 1.01 .04 .01 .01 .10 \\
\hline 160.W64 & Mix AW-104 (HLW) Feed to Suspend Solids & 1.01 .04 .01 .01 .10 \\
\hline 160.W70 & Provide Approval to Deliver AW-104(HLW)/AW-103 Feed from AW-104 & 1.01 .06 \\
\hline 160.W76 & $\begin{array}{l}\text { Provide AW-104(HLW)/AW-103 MT of Suspended Solids and Official } \\
\text { Composition from AW-104 to DOE-ORP }\end{array}$ & 1.01 .04 .01 .01 .10 \\
\hline 210.P60 & Startup and Test Cross Site Slurry Transfer System & 1.01 .04 .01 .01 .10 \\
\hline $210 . \mathrm{Y} 50$ & Complete Cross Site Slurry Transfer Line & 1.01 .04 .01 .01 .10 \\
\hline 250.100 & Project Management for W-314 & 1.01 .03 .01 .01 .10 \\
\hline $250.4 \mathrm{E} 5$ & Prepare the AW Tank Farm for Construction Activities & 1.01 .04 .01 .01 .10 \\
\hline 250.D15 & Design the 244-S DCRT Compliance Upgrades and Obtain CD-3 & 1.01 .03 .01 .01 .10 \\
\hline 250.D45 & Construct the 244-S DCRT Compliance Upgrades & 1.01 .03 .01 .01 .10 \\
\hline $250 . \mathrm{D} 75$ & Startup and Test the 244-S DCRT Compliance Upgrades & 1.01 .03 .01 .01 .10 \\
\hline 250.D95 & Perform Management Self Assessment for 244-S DCRT Compliance Upgrades & 1.01 .03 .01 .01 .10 \\
\hline 250.D97 & $\begin{array}{l}\text { Perform Contractor Readiness Assessment for 244-S DCRT Compliance } \\
\text { Upgrades }\end{array}$ & 1.01 .03 .01 .01 .10 \\
\hline $250 . \mathrm{E} 05$ & $\begin{array}{l}\text { Design the W-314 Phase } 1 \text { Waste Transfer System (WTS) Upgrades and } \\
\text { Obtain CD-3 }\end{array}$ & 1.01 .03 .01 .01 .10 \\
\hline $250 . \mathrm{E} 35$ & Startup and Test the W-314 Master Pump Shutdown System (MPS) Upgrades & 1.01 .03 .01 .01 .10 \\
\hline 250.E50 & Construct the W-314 Phase 1 Waste Transfer System (WTS) Upgrades & 1.01.03.01.01.10 \\
\hline $250 . \mathrm{E} 60$ & Perform Management Self Assessment for W-314 MPS Upgrades & 1.01.03.01.01.10 \\
\hline 250.E80 & $\begin{array}{l}\text { Perform Contractor Readiness Assessment for W-314 Master Pump Shutdown } \\
\text { System }\end{array}$ & 1.01 .03 .01 .01 .10 \\
\hline $250 . \mathrm{N} 15$ & Design the W-314 Phase 2 AN Farm Upgrades and Obtain CD-3 & 1.01 .03 .01 .01 .10 \\
\hline $250 . \mathrm{N} 25$ & Startup and Test the W-314 Phase 1 AN Farm (AN-101 \& AN-104) Upgrades & 1.01 .03 .01 .01 .10 \\
\hline $250 . N 45$ & Construct the W-314 Phase 2 AN Farm Upgrades & 1.01 .03 .01 .01 .10 \\
\hline 250.N55 & Construct the W-314 Phase $1 \mathrm{AN}$ Farm Upgrades for AN-101 and AN-104 & 1.01 .03 .01 .01 .10 \\
\hline
\end{tabular}




\section{HNF-1946 REV 2}

Table B-1. Crosswalk from the Level 1 Logic to the Work Breakdown Structure.

\begin{tabular}{|c|c|c|}
\hline \multicolumn{3}{|c|}{ BNFL Inc. Phase 1 Privatization activities identified at WBS Level 3 (1.01.06). } \\
\hline $\begin{array}{l}\text { Level } 1 \text { Logic } \\
\text { TBR Number }\end{array}$ & 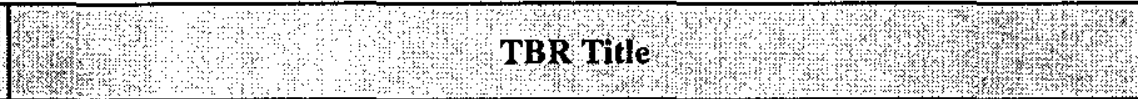 & WBSLevel 6 \\
\hline 250.N60 & $\begin{array}{l}\text { Perform Management Self-Assessment for the W-314 Phase } 1 \text { AN Tank Farm } \\
\text { (AN-A \& AN-B Pit) Upgrades }\end{array}$ & 1.01 .03 .01 .01 .10 \\
\hline $250 . \mathrm{N} 75$ & Startup and Test the W-314 Phase 2 AN Farm Upgrades & 1.01 .03 .01 .01 .10 \\
\hline 250.N95 & Perform Management Self-Assessment for W-314 Phase 2 AN Farm Upgrades & 1.01 .03 .01 .01 .10 \\
\hline 250.N97 & $\begin{array}{l}\text { Perform Contractor Readiness Assessment for W-314 Phase } 2 \text { AN Farm } \\
\text { Upgrades }\end{array}$ & 1.01 .03 .01 .01 .10 \\
\hline 250.P15 & Design the W-314 Phase 2 AP Tank Farm Upgrades and Obtain CD-3 & 1.01.03.01.01.10 \\
\hline $250 . \mathrm{P} 45$ & Construct the W-314 Phase 2 AP Tank Farm Upgrades & 1.01.03.01.01.10 \\
\hline $250 . P 75$ & Startup and Test the W-314 Phase 2 AP Tank Farm Upgrades & 1.01 .03 .01 .01 .10 \\
\hline 250.P95 & $\begin{array}{l}\text { Perform Management Self-Assessment for W-314 Phase } 2 \text { AP Tank Farm } \\
\text { Upgrades }\end{array}$ & 1.01.03.01.01.10 \\
\hline 250.P97 & $\begin{array}{l}\text { Perform Contractor Readiness Assessment for W-314 Phase } 2 \text { AP Farm } \\
\text { Upgrades }\end{array}$ & 1.01 .03 .01 .01 .10 \\
\hline $250 . \mathrm{S} 15$ & Design the W-314 Phase 2 SY Farm Upgrades and Obtain CD-3 & 1.01.03.01.01.10 \\
\hline 250.545 & Construct the W-314 Phase 2 SY Farm Upgrades & 1.01.03.01.01.10 \\
\hline 250.575 & Startup and Test the W-314 Phase 2 SY Farm Upgrades & 1.01 .03 .01 .01 .10 \\
\hline $250 . \mathrm{W} 15$ & Design the W-314 Phase 2 AW Farm Upgrades and Obtain CD-3 & 1.01 .03 .01 .01 .10 \\
\hline 250.W35 & Startup and Test the W-314 Phase 1 AW Farm (AW-A \& AW-B Pit) Upgrades & 1.01 .03 .01 .01 .10 \\
\hline 250.W45 & Construct the W-314 Phase 2 AW Farm Upgrades & 1.01.03.01.01.10 \\
\hline 250.W50 & Construct the W-314 Phase 1 AW Farm (AW-A \& AW-B Pit) Upgrades & 1.01 .03 .01 .01 .10 \\
\hline 250.W75 & Startup and Test the W-314 Phase 2 AW Farm Upgrades & 1.01.03.01.01.10 \\
\hline $250 . Y 15$ & Design the W-314 Phase 2 AY Farm Upgrades and Obtain CD-3 & 1.01.03.01.01.10 \\
\hline $250 . Y 35$ & Startup and Test the W-314 Phase 1 AY Farm Upgrades & 1.01.03.01.01.10 \\
\hline $250 . \mathrm{Y} 45$ & Construct the W-314 Phase 2 AY Farm Upgrades & 1.01 .03 .01 .01 .10 \\
\hline 250.Y50 & Construct the W-314 Phase 1 AY Farm Upgrades & 1.01 .03 .01 .01 .10 \\
\hline 250.Y75 & Startup and Test the W-314 Phase 2 AY Farm Upgrades & 1.01.03.01.01.10 \\
\hline $250 . \mathrm{Z} 15$ & Design the W-314 Phase 2 AZ Tank Farm Upgrades and Obtain CD-3 & 1.01 .03 .01 .01 .10 \\
\hline $250 . Z 35$ & Startup and Test the W-314 Phase 1 AZ Tank Farm Upgrades & 1.01 .03 .01 .01 .10 \\
\hline $250 . \mathrm{Z45}$ & Construct the W-314 Phase $2 \mathrm{AZ}$ Farm Upgrades & 1.01 .03 .01 .01 .10 \\
\hline
\end{tabular}




\section{HNF-1946 REV 2}

Table B-1. Crosswalk from the Level 1 Logic to the Work Breakdown Structure.

\begin{tabular}{|c|c|c|}
\hline \multicolumn{3}{|c|}{ BNFL Inc. Phase 1 Privatization activities identified at WBS Level 3 (1.01.06). } \\
\hline $\begin{array}{l}\text { Level } 1 \text { Logic } \\
\text { TBR Number }\end{array}$ & 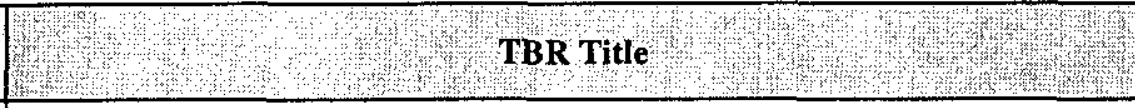 & WBS Level 6 \\
\hline 250.250 & Construct the W-314 Phase 1 AZ Farm Upgrades & 1.01 .03 .01 .01 .10 \\
\hline 250.275 & Startup and Test the W-314 Phase 2 AZ Farm Upgrades & 1.01 .03 .01 .01 .10 \\
\hline 270.105 & Prepare SST Retrieval Licensing Strategy & 1.01 .04 .01 .02 .12 \\
\hline 270.110 & Perform SST Retrieval USQ Process & 1.01 .04 .01 .02 .12 \\
\hline 270.210 & Prepare Initial SST Program Plan & 1.01 .04 .01 .02 .02 \\
\hline 270.310 & Prepare SST Retrieval Program Test \& Evaluation Plan & 1.01 .04 .01 .02 .02 \\
\hline 270.610 & Evaluate Retrieval Technology Solutions & 1.01 .04 .01 .02 .06 \\
\hline 270.611 & C-106 Residual Assessments & 1.01.04.01.02.06 \\
\hline 270.615 & Assess SST Tank Farm Infrastructure System Needs & 1.01 .04 .01 .02 .06 \\
\hline 270.620 & Evaluate Leak Detection Solutions & 1.01.04.01.02.06 \\
\hline 270.630 & Assess Tank Conditions & 1.01 .04 .01 .02 .06 \\
\hline 270.640 & Define SST Retrieval Sequences & 1.01 .04 .01 .02 .06 \\
\hline 270.650 & Determine Retrieval Risks & 1.01 .04 .01 .02 .06 \\
\hline 270.660 & Determine Process Improvement Breakthroughs & 1.01 .04 .01 .02 .06 \\
\hline $270 . \mathrm{C} 01$ & Issue Criticality Safety Evaluation Report for SST Retrieval & 1.01 .04 .01 .02 .12 \\
\hline $270 . \mathrm{C} 16$ & Update or Amend Authorization Basis for SST Retrieval & 1.01 .04 .01 .02 .12 \\
\hline 280.105 & Perform Limits of Technology Demonstration & 1.01 .04 .01 .02 .03 \\
\hline 280.205 & SST Test \& Demonstration Specification & 1.01 .04 .01 .02 .05 \\
\hline 280.210 & Acquire Cold Test Capability & 1.01 .04 .01 .02 .05 \\
\hline 280.215 & Saltcake Dissolution Cold Tests & 1.01 .04 .01 .02 .05 \\
\hline 280.220 & Saltcake Dissolution Hot Test Specification \& Deployment Decision & 1.01 .04 .01 .02 .05 \\
\hline 280.305 & Saltcake Dissolution Retrieval Demonstrations & 1.01 .04 .01 .02 .03 \\
\hline 290.005 & Retrieval System Selection AGA & 1.01 .04 .01 .02 .02 \\
\hline 290.007 & Update SST Level 1 Specification & 1.01 .04 .01 .02 .02 \\
\hline 290.010 & Retrieval Integrated Risk Studies & 1.01.04.01.02.02 \\
\hline 290.015 & Update Program Plan, Deployment Plan, \& Risk Analysis & 1.01 .04 .01 .02 .02 \\
\hline
\end{tabular}




\section{HNF-1946 REV 2}

Table B-1. Crosswalk from the Level 1 Logic to the Work Breakdown Structure.

\begin{tabular}{|c|c|c|}
\hline $\begin{array}{l}\text { Level } 1 \text { Logic } \\
\text { TBR Number }\end{array}$ & \begin{tabular}{|l}
$\mid$ \\
$W$
\end{tabular} & WBS Level 6 \\
\hline 290.A27 & Verify C Tank Farm Systems and Components Functionality & 1.01.04.01.02.04 \\
\hline 290.A28 & Perform Acquisition Strategy for C Tank Farm & 1.01 .04 .01 .02 .04 \\
\hline 290.A29 & Perform C Tank Farm Trade Studies & 1.01 .04 .01 .02 .02 \\
\hline 290.A31 & Verify S Tank Farm Systems and Components Functionality & 1.01 .04 .01 .02 .04 \\
\hline $290 . \mathrm{A} 32$ & Perform Acquisition Strategy for S Tank Farm & 1.01 .04 .01 .02 .04 \\
\hline $290 . \mathrm{A} 33$ & Perform S Tank Farm Trade Studies & 1.01 .04 .01 .02 .02 \\
\hline 290.B25 & Prepare the W-523 Project Technical Baseline Document & 1.01 .04 .01 .02 .04 \\
\hline 290.150 & Design the S-105 Retrieval System and Obtain CD-3 & 1.01 .04 .01 .02 .13 \\
\hline 290.152 & Procure Equipment for the S-105 Retrieval System & 1.01 .04 .01 .02 .13 \\
\hline 290.155 & Construct the S-105 Retrieval System & 1.01 .04 .01 .02 .13 \\
\hline 290.160 & Startup and Test the S-105 Retrieval System & 1.01 .04 .01 .02 .09 \\
\hline 290.170 & Perform Contractor Standard Startup Review for S-105 & 1.01 .04 .01 .02 .09 \\
\hline 290.175 & Provide CD-4 Approval for S-105 & 1.01 .04 .01 .02 .09 \\
\hline 290.183 & Perform Management Self-Assessment for the S-105 Retrieval System & 1.01 .04 .01 .02 .09 \\
\hline 290.J40 & Design the C-104 Retrieval System and Obtain CD-3 & 1.01 .04 .01 .02 .13 \\
\hline 290.J43 & $\begin{array}{l}\text { Perform Conceptual Design and Issue the SST O\&M Concept for the W-523 } \\
\text { Retrieval System }\end{array}$ & 1.01 .04 .01 .02 .13 \\
\hline $290 . J 50$ & Construct the C-104 Retrieval System & 1.01 .04 .01 .02 .13 \\
\hline 290.J52 & Procure Equipment for the C-104 Retrieval System & 1.01 .04 .01 .02 .13 \\
\hline 290.J54 & Repair/Upgrade Existing C Tank Farm Systems & 1.01 .04 .01 .02 .07 \\
\hline 290.J60 & Startup and Test the C-104 Retrieval System & 1.01 .04 .01 .02 .09 \\
\hline 290.J61 & $\begin{array}{l}\text { Prepare Project Definition, Technical Basis, and Project Definition Criteria for } \\
\text { Project W-523 }\end{array}$ & 1.01.04.01.02.04 \\
\hline 290.580 & Perform Contractor Independent Operational Readiness Review for C-104 & 1.01.04.01.02.09 \\
\hline 290.J83 & Perform Management Self-Assessment for the C-104 Retrieval System & 1.01 .04 .01 .02 .09 \\
\hline 290.J90 & Perform DOE-ORP Operational Readiness Review and Obtain CD-4 for C-104 & 1.01 .04 .01 .02 .09 \\
\hline 290.J99 & Project Management for W-523 & 1.01 .04 .01 .02 .13 \\
\hline
\end{tabular}




\section{HNF-1946 REV 2}

Table B-1. Crosswalk from the Level 1 Logic to the Work Breakdown Structure.

\begin{tabular}{|c|c|c|}
\hline \multicolumn{3}{|c|}{ BNFL Inc. Phase 1 Privatization activities identified at WBS Level 3 (1.01.06). } \\
\hline $\begin{array}{l}\text { Level } 1 \text { Logic } \\
\text { TBR Number }\end{array}$ & $\left.\right|_{\text {F }}$ & WBS Level 6 \\
\hline $290 . \mathrm{Q} 40$ & Design the C-107 Retrieval System and Obtain CD-3 & 1.01 .04 .01 .02 .13 \\
\hline $290 . Q 50$ & Construct the C-107 Retrieval System & 1.01 .04 .01 .02 .13 \\
\hline $290 . Q 52$ & Procure Equipment for the C-107 Retrieval System & 1.01.04.01.02.13 \\
\hline 290.Q60 & Startup and Test the C-107 Retrieval System & 1.01 .04 .01 .02 .09 \\
\hline $290 . \mathrm{Q} 80$ & Perform Contractor Standard Startup Review for C-107 & 1.01.04.01.02.09 \\
\hline $290 . Q 83$ & Perform Management Self-Assessment for the C-107 Retrieval System & 1.01.04.01.02.09 \\
\hline $290 . Q 90$ & Provide CD-4 Approval for C-107 & 1.01 .04 .01 .02 .09 \\
\hline $290 . \mathrm{Z50}$ & Design the S-102 Retrieval System and Obtain CD-3 & 1.01.04.01.02.13 \\
\hline $290 . \mathrm{Zs} 2$ & Procure Equipment for S-102 Retrieval System & 1.01 .04 .01 .02 .13 \\
\hline 290.754 & Repair/Upgrade Existing S Tank Farm Systems & 1.01.04.01.02.07 \\
\hline 290.755 & Construct the S-102 Retrieval System & 1.01 .04 .01 .02 .13 \\
\hline $290 . Z 60$ & Startup and Test the S-102 Retrieval System & 1.01.04.01.02.09 \\
\hline 290.270 & Perform Contractor Standard Startup Review for S-102 & 1.01.04.01.02.09 \\
\hline $290 . \mathrm{Z75}$ & Provide CD-4 Approval for S-102 & 1.01 .04 .01 .02 .09 \\
\hline 290.283 & Perform Management Self-Assessment for the S-102 Retrieval System & 1.01.04.01.02.09 \\
\hline 300.125 & Prepare Process Control Plan for S- 105 & 1.01.04.01.02.09 \\
\hline 300.129 & Retrieve S-105 into SY-103 & 1.01.04.01.02.09 \\
\hline 300.134 & Perform S-105 Intrusion Prevention & 1.01.04.01.02.09 \\
\hline $300 . J 20$ & Prepare Process Control Plan for C-104 & 1.01 .04 .01 .02 .09 \\
\hline $300 . J 29$ & Retrieve C-104 into AY-101 & 1.01 .04 .01 .02 .09 \\
\hline $300 . J 34$ & Perform C-104 Intrusion Prevention & 1.01 .04 .01 .02 .09 \\
\hline $300 . Q 20$ & Prepare Process Control Plan for C-107 & 1.01 .04 .01 .02 .09 \\
\hline $300 . Q 29$ & Retrieve C-107 into AY-102 & 1.01 .04 .01 .02 .09 \\
\hline $300 . Q 34$ & Perform C-107 Intrusion Prevention & 1.01 .04 .01 .02 .09 \\
\hline $300 . \mathrm{Z} 25$ & Prepare Process Control Plan for S-102 & 1.01 .04 .01 .02 .09 \\
\hline 300.229 & Retrjeve S-102 into SY-103 & 1.01.04.01.02.09 \\
\hline
\end{tabular}




\section{HNF-1946 REV 2}

Table B-1. Crosswalk from the Level 1 Logic to the Work Breakdown Structure.

\begin{tabular}{|c|c|c|}
\hline \multicolumn{3}{|c|}{ BNFL Inc. Phase 1 Privatization activities identified at WBS Level 3 (1.01.06). } \\
\hline $\begin{array}{l}\text { Level } 1 \text { Logic } \\
\text { TBR Number }\end{array}$ & 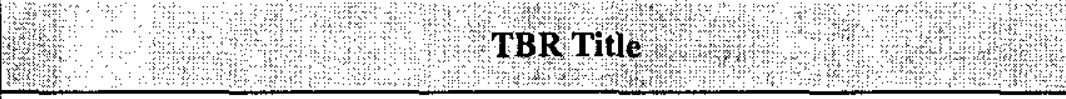 & WBS Level 6 \\
\hline $300 . \mathrm{Z} 34$ & Perform S-102 Intrusion Prevention & 1.01 .04 .01 .02 .09 \\
\hline 330.010 & Infrastructure Program Administration/Management/Engineering & 1.01 .08 .01 .01 .01 \\
\hline 330.030 & Infrastructure Systems Definition & 1.01 .08 .01 .01 .01 \\
\hline 330.050 & Design/Construction/Startup Infrastructure Electrical Systems & 1.01 .08 .01 .01 .01 \\
\hline 330.070 & Design/Construction/Startup Infrastructure Utility Systems & 1.01 .08 .01 .01 .01 \\
\hline 330.080 & Provide Utilities for Construction & 1.01 .08 .01 .01 .01 \\
\hline 330.090 & Provide Utilities During Startup & 1.01 .08 .01 .01 .01 \\
\hline 330.100 & Provide Utilities During Production & $1.01,08.01 .01 .01$ \\
\hline 330.105 & Provide Solid Waste Disposal During Production & 1.01 .08 .01 .01 .01 \\
\hline 330.110 & Provide Utilities During Deactivation & 1.01 .08 .01 .01 .01 \\
\hline 330.120 & Provide Vendor Training & 1.01 .08 .01 .01 .01 \\
\hline 330.210 & Liquid Effluent Infrastructure Support & 1.01 .08 .01 .01 .01 \\
\hline 330.A10 & Replace 242-A Evaporator Condenser (EC-1) & 1.01 .08 .01 .01 .01 \\
\hline 330.E20 & Design 242-A Evaporator Life-Extension Upgrades & 1.01 .08 .01 .01 .01 \\
\hline 330.E40 & Construct 242-A Evaporator Life-Extension Upgrades & 1.01 .08 .01 .01 .01 \\
\hline 330.E60 & Startup and Test 242-A Evaporator Life-Extension Upgrades & 1.01 .08 .01 .01 .01 \\
\hline 330.E80 & $\begin{array}{l}\text { Perform WMH Operational Readiness Review for 242-A Evaporator Life- } \\
\text { Extension Upgrades }\end{array}$ & 1.01 .08 .01 .01 .01 \\
\hline 330.E90 & $\begin{array}{l}\text { Perform Contractor Independent Operational Readiness Review for 242-A } \\
\text { Upgrades }\end{array}$ & 1.01.08.01.01.01 \\
\hline 330.E95 & Perform DOE-ORP Operational Readiness Review for 242-A Upgrades & 1.01 .08 .01 .01 .01 \\
\hline 350.010 & Pretreat 1st LAW Feed Batch & 1.01 .06 \\
\hline 350.015 & Vitrify 1st LAW Feed Batch & 1.01 .06 \\
\hline 350.020 & Pretreat 2nd LAW Feed Batch & 1.01 .06 \\
\hline 350.025 & Vitrify 2nd LAW Feed Batch & 1.01 .06 \\
\hline 350.030 & Pretreat 3rd LAW Feed Batch & 1.01 .06 \\
\hline 350.035 & Vitrify 3rd LAW Feed Batch & 1.01 .06 \\
\hline
\end{tabular}




\section{HNF-1946 REV 2}

Table B-1. Crosswalk from the Level 1 Logic to the Work Breakdown Structure.

\begin{tabular}{|c|c|c|}
\hline \multicolumn{3}{|c|}{ BNFL Inc. Phase 1 Privatization activities identified at WBS Level 3 (1.01.06). } \\
\hline $\begin{array}{l}\text { Level 1 Logic } \\
\text { TBR Number }\end{array}$ & TBR Title & WBS Level 6 \\
\hline 350.040 & Pretreat 4th LAW Feed Batch & 1.01 .06 \\
\hline 350.045 & Vitrify 4th LAW Feed Batch & 1.01 .06 \\
\hline 350.050 & Pretreat 5th LAW Feed Batch & 1.01 .06 \\
\hline 350.055 & Vitrify 5th LAW Feed Batch & 1.01 .06 \\
\hline 350.060 & Pretreat 6th LAW Feed Batch & 1.01 .06 \\
\hline 350.065 & Vitrify 6th LAW Feed Batch & 1.01 .06 \\
\hline 350.070 & Pretreat 7 th LAW Feed Batch & 1.01 .06 \\
\hline 350.075 & Vitrify 7 th LAW Feed Batch & 1.01 .06 \\
\hline 350.080 & Pretreat 8 th LAW Feed Batch & 1.01 .06 \\
\hline 350.085 & Vitrify 8th LAW Feed Batch & 1.01 .06 \\
\hline 350.090 & Pretreat 9th LAW Feed Batch & 1.01 .06 \\
\hline 350.095 & Vitrify 9th LAW Feed Batch & 1.01 .06 \\
\hline 350.100 & Pretreat 10th LAW Feed Batch & 1.01 .06 \\
\hline 350.105 & Vitrify 10th LAW Feed Batch & 1.01 .06 \\
\hline 350.110 & Pretreat 11th LAW Feed Batch & 1.01 .06 \\
\hline 350.115 & Vitrify 11th LAW Feed Batch & 1.01 .06 \\
\hline 350.120 & Pretreat 12th LAW Feed Batch & 1.01 .06 \\
\hline 350.125 & Vitrify 12th LAW Feed Batch & 1.01 .06 \\
\hline 350.130 & Pretreat 13th LAW Feed Batch & 1.01 .06 \\
\hline 350.135 & Vitrify 13th LAW Feed Batch & 1.01 .06 \\
\hline 350.140 & Pretreat 14th LAW Feed Batch & 1.01 .06 \\
\hline 350.145 & Vitrify 14th LAW Feed Batch & 1.01 .06 \\
\hline 350.150 & Pretreat 15th LAW Feed Batch & 1.01 .06 \\
\hline 350.155 & Vitrify 15 th LAW Feed Batch & 1.01 .06 \\
\hline 350.160 & Pretreat 16th LAW Feed Batch & 1.01 .06 \\
\hline 350.165 & Vitrify 16th LAW Feed Batch & 1.01 .06 \\
\hline
\end{tabular}




\section{HNF-1946 REV 2}

Table B-1. Crosswalk from the Level 1 Logic to the Work Breakdown Structure.

\begin{tabular}{|c|c|c|}
\hline \multicolumn{3}{|c|}{ BNFL Inc. Phase 1 Privatization activities identified at WBS Level 3 (1.01.06). } \\
\hline $\begin{array}{l}\text { Level } 1 \text { Logic } \\
\text { TBR Number }\end{array}$ & SW & WBS Level 6 \\
\hline 350.170 & Pretreat 17th LAW Feed Batch & 1.01 .06 \\
\hline 350.175 & Vitrify 17 th LAW Feed Batch & 1.01 .06 \\
\hline 350.180 & Pretreat 18 th LAW Feed Batch & 1.01 .06 \\
\hline 350.185 & Vitrify 18th LAW Feed Batch & 1.01 .06 \\
\hline 350.190 & Pretreat 19th LAW Feed Batch & 1.01 .06 \\
\hline 350.195 & Vitrify 19th LAW Feed Batch & 1.01 .06 \\
\hline 350.200 & Pretreat 20th LAW Feed Batch & 1.01 .06 \\
\hline 350.205 & Vitrify 20th LAW Feed Batch & 1.01 .06 \\
\hline 350.210 & Pretreat 21 st LAW Feed Batch & 1.01 .06 \\
\hline 350.215 & Vitrify 21st LAW Feed Batch & 1.01 .06 \\
\hline 350.220 & Pretreat 22nd LAW Feed Batch & 1.01 .06 \\
\hline 350.225 & Vitrify 22nd LAW Feed Batch & 1.01 .06 \\
\hline 350.230 & Pretreat 23rd LAW Feed Batch & 1.01 .06 \\
\hline 350.235 & Vitrify 23rd LAW Feed Batch & 1.01 .06 \\
\hline 350.240 & Pretreat 24th LAW Feed Batch & 1.01 .06 \\
\hline 350.245 & Vitrify 24th LAW Feed Batch & 1.01 .06 \\
\hline 350.250 & Pretreat Spare LAW Feed Batch & 1.01 .06 \\
\hline 350.255 & Vitrify Spare LAW Feed Batch & 1.01 .06 \\
\hline 360.010 & Pretreat 1st Batch of HLW Feed from AZ-101 & 1.01 .06 \\
\hline 360.015 & Vitrify HLW Feed Batches from AZ-101 & 1.01 .06 \\
\hline 360.020 & Pretreat 2nd Batch of HLW Feed from AZ-101 & 1.01 .06 \\
\hline 360.030 & Pretreat 3rd Batch of HLW Feed from AZ-101 & 1.01 .06 \\
\hline 360.040 & Pretreat 4th Batch of HLW Feed from AZ-101 & 1.01 .06 \\
\hline 360.050 & Pretreat 5th Batch of HLW Feed from AZ-101 & 1.01 .06 \\
\hline 360.060 & Pretreat 6th Batch of HLW Feed from AZ-101 & 1.01 .06 \\
\hline 360.070 & Pretreat 1st Batch of HLW Feed from AZ-102 & 1.01 .06 \\
\hline
\end{tabular}


Table B-1. Crosswalk from the Level 1 Logic to the Work Breakdown Structure.

\begin{tabular}{|c|c|c|}
\hline \multicolumn{3}{|c|}{ BNFL Inc. Phase 1 Privatization activities identified at WBS Level 3 (1.01.06). } \\
\hline $\begin{array}{l}\text { Level } 1 \text { Logic } \\
\text { TBR Number }\end{array}$ & TBR Title & WBS Level 6 \\
\hline 360.075 & Vitrify HLW Feed Batches from AZ-102 & 1.01 .06 \\
\hline 360.080 & Pretreat 2nd Batch of HLW Feed from AZ-102 & 1.01 .06 \\
\hline 360.090 & Pretreat 3rd Batch of HLW Feed from AZ-102 & 1.01 .06 \\
\hline 360.100 & Pretreat 4th Batch of HLW Feed from AZ-102 & 1.01 .06 \\
\hline 360.110 & Pretreat 5th Batch of HLW Feed from AZ-102 & 1.01 .06 \\
\hline 360.120 & Pretreat 6th Batch of HLW Feed from AZ-102 & 1.01 .06 \\
\hline 360.130 & Pretreat 1st Batch of AY-102/C-106 HLW Feed from AY-102 & 1.01 .06 \\
\hline 360.135 & Vitrify 1st Batch of AY-102/C-106 HLW Feed from AY-102 & 1.01 .06 \\
\hline 360.140 & Pretreat 2nd Batch of AY-102/C-106 HLW Feed from AY-102 & 1.01 .06 \\
\hline 360.145 & Vitrify 2nd Batch of AY-102/C-106 HLW Feed from AY-102 & 1.01 .06 \\
\hline 360.150 & Pretreat 3rd Batch of AY-102/C-106 HLW Feed from AY-102 & 1.01 .06 \\
\hline 360.155 & Vitrify 3rd Batch of AY-102/C-106 HLW Feed from AY-102 & 1.01 .06 \\
\hline 360.160 & Pretreat 4th Batch of AY-102/C-106 HLW Feed from AY-102 & 1.01 .06 \\
\hline 360.165 & Vitrify 4th Batch of AY-102/C-106 HLW Feed from AY-102 & 1.01 .06 \\
\hline 360.170 & Pretreat 5th Batch of AY-102/C-106 HLW Feed from AY-102 & 1.01 .06 \\
\hline 360.175 & Vitrify 5th Batch of AY-102/C-106 HLW Feed from AY-102 & 1.01 .06 \\
\hline 360.180 & Pretreat 6th Batch of AY-102/C-106 HLW Feed from AY-102 & 1.01 .06 \\
\hline 360.185 & Vitrify 6th Batch of AY-102/C-106 HLW Feed from AY-102 & 1.01 .06 \\
\hline 360.190 & Pretreat 7th Batch of AY-102/C-106 HLW Feed from AY-102 & 1.01 .06 \\
\hline 360.195 & Vitrify 7th Batch of AY-102/C-106 HLW Feed from AY-102 & 1.01 .06 \\
\hline 360.200 & Pretreat 1st Batch of AY-101/C-104 HLW Feed from AY-101 & 1.01 .06 \\
\hline 360.205 & Vitrify 1st Batch of AY-101/C-104 HLW Feed from AY-101 & 1.01 .06 \\
\hline 360.210 & Pretreat 2nd Batch of AY-101/C-104 HLW Feed from AY-101 & 1.01 .06 \\
\hline 360.215 & Vitrify 2nd Batch of AY-101/C-104 HLW Feed from AY-101 & 1.01 .06 \\
\hline 360.220 & Pretreat 3rd Batch of AY-101/C-104 HLW Feed from AY-101 & 1.01 .06 \\
\hline 360.225 & Vitrify 3rd Batch of AY-101/C-104 HLW Feed from AY-101 & 1.01 .06 \\
\hline
\end{tabular}




\section{HNF-1946 REV 2}

Table B-1. Crosswalk from the Level 1 Logic to the Work Breakdown Structure.

\begin{tabular}{|c|c|c|}
\hline \multicolumn{3}{|c|}{ BNFL Inc. Phase 1 Privatization activities identified at WBS Level 3 (1.01.06). } \\
\hline $\begin{array}{l}\text { Level } 1 \text { Logic } \\
\text { TBR Number }\end{array}$ & M. TBR Title & WBS Level 6 \\
\hline 360.230 & Pretreat 4th Batch of AY-101/C-104 HLW Feed from AY-101 & 1.01 .06 \\
\hline 360.235 & Vitrify 4th Batch of AY-101/C-104 HLW Feed from AY-101 & 1.01 .06 \\
\hline 360.240 & Pretreat 5th Batch of AY-101/C-104 HLW Feed from AY-101 & 1.01 .06 \\
\hline 360.245 & Vitrify 5th Batch of AY-101/C-104 HLW Feed from AY-101 & 1.01 .06 \\
\hline 360.250 & Pretreat 6th Batch of AY-101/C-104 HLW Feed from AY-101 & 1.01 .06 \\
\hline 360.255 & Vitrify 6th Batch of AY-101/C-104 HLW Feed from AY-101 & 1.01 .06 \\
\hline 360.260 & Pretreat 7th Batch of AY-101/C-104 HLW Feed from AY-101 & 1.01 .06 \\
\hline 360.265 & Vitrify 7th Batch of AY-101/C-104 HLW Feed from AY-101 & 1.01 .06 \\
\hline 360.270 & Pretreat 8th Batch of AY-101/C-104 HLW Feed from AY-101 & 1.01 .06 \\
\hline 360.275 & Vitrify 8 th Batch of AY-101/C-104 HLW Feed from AY-101 & 1.01 .06 \\
\hline 360.280 & Pretreat 9th Batch of AY-101/C-104 HLW Feed from AY-101 & 1.01 .06 \\
\hline 360.285 & Vitrify 9th Batch of AY-101/C-104 HLW Feed from AY-101 & 1.01 .06 \\
\hline 360.290 & Pretreat 10th Batch of AY-101/C-104 HLW Feed from AY-101 & 1.01 .06 \\
\hline 360.295 & Vitrify 10th Batch of AY-101/C-104 HLW Feed from AY-101 & 1.01 .06 \\
\hline 360.300 & Pretreat 11th Batch of AY-101/C-104 HLW Feed from AY-101 & 1.01 .06 \\
\hline 360.305 & Vitrify 11th Batch of AY-101/C-104 HLW Feed from AY-101 & 1.01 .06 \\
\hline 360.310 & Pretreat 12th Batch of AY-101/C-104 HLW Feed from AY-101 & 1.01 .06 \\
\hline 360.315 & Vitrify 12th Batch of AY-101/C-104 HLW Feed from AY-101 & 1.01 .06 \\
\hline 360.320 & Pretreat 1st Batch of SY-102 HLW Feed from AZ-101 & 1.01 .06 \\
\hline 360.325 & Vitrify 1st Batch of SY-102 HLW Feed from AZ-101 & 1.01 .06 \\
\hline 360.330 & Pretreat 2nd Batch of SY-102 HLW Feed from AZ-101 & 1.01 .06 \\
\hline 360.335 & Vitrify 2nd Batch of SY-102 HLW Feed from AZ-101 & 1.01 .06 \\
\hline 360.340 & Pretreat 3rd Batch of SY-102 HLW Feed from AZ-101 & 1.01 .06 \\
\hline 360.345 & Vitrify 3rd Batch of SY-102 HLW Feed from AZ-101 & 1.01 .06 \\
\hline 360.350 & Pretreat 4th Batch of SY-102 HLW Feed from AZ-101 & 1.01 .06 \\
\hline 360.355 & Vitrify 4th Batch of SY-102 HLW Feed from AZ-101 & 1.01 .06 \\
\hline
\end{tabular}


Table B-1. Crosswalk from the Level 1 Logic to the Work Breakdown Structure.

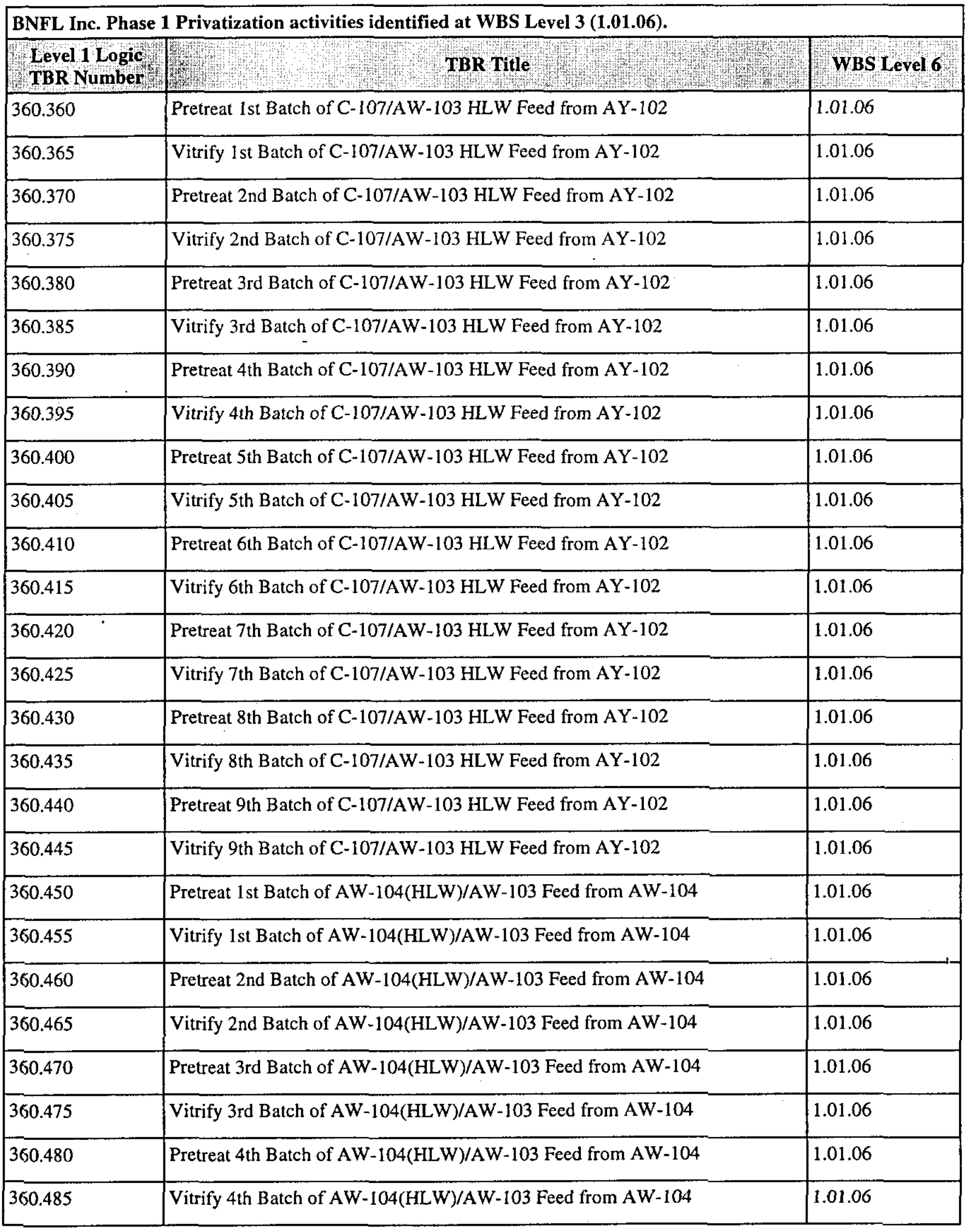


Table B-1. Crosswalk from the Level 1 Logic to the Work Breakdown Structure.

\begin{tabular}{|c|c|c|}
\hline \multicolumn{3}{|c|}{ BNFL Inc. Phase 1 Privatization activities identified at WBS Level 3 (1.01.06). } \\
\hline $\begin{array}{l}\text { Level } 1 \text { Logic } \\
\text { TBR Number }\end{array}$ & \begin{tabular}{|l|l} 
& TBR Title \\
\end{tabular} & WBS Level 6 \\
\hline 360.490 & Pretreat 5th Batch of AW-104(HLW)/AW-103 Feed from AW-104 & 1.01 .06 \\
\hline 360.495 & Vitrify 5th Batch of AW-104(HLW)/AW-103 Feed from AW-104 & 1.01 .06 \\
\hline 360.500 & Pretreat 6th Batch of AW-104(HLW)/AW-103 Feed from AW-104 & 1.01 .06 \\
\hline 360.505 & Vitrify 6th Batch of AW-104(HLW)/AW-103 Feed from AW-104 & 1.01 .06 \\
\hline 440.010 & IHLW Project Management & 1.01.09.02.01.01 \\
\hline 440.020 & Maintain ICDs, IPT Process, and SNF Interface & 1.01.09.02.01.02 \\
\hline 440.040 & Maintain Technical Requirements for IHLW & 1.01 .09 .02 .01 .02 \\
\hline 440.045 & Define Requirements for IHLW Sample Transport & 1.01 .09 .02 .01 .02 \\
\hline 440.048 & Define Requirements for IHLW Melter Disposition & 1.01.09.02.01.02 \\
\hline 440.050 & Design/Procure IHLW Sample Transport System & 1.01 .09 .02 .01 .02 \\
\hline 440.055 & Design/Procure/Fabricate IHLW Failed Melter Transport System & 1.01 .09 .02 .01 .02 \\
\hline 440.060 & W-464 Advanced Conceptual Design/Revalidation & 1.01.09.02.01.03 \\
\hline 440.090 & Procure Equipment W-464 IHLW Storage Facility & 1.01.09.02.01.03 \\
\hline 440.100 & Design W-464 IHLW Storage Facility & 1.01 .09 .02 .01 .03 \\
\hline 440.115 & Obtain W-464 Environmental Permits & 1.01 .09 .02 .01 .03 \\
\hline 440.120 & W-464 Authorization Basis Development and Approval & 1.01 .09 .02 .01 .03 \\
\hline 440.140 & Construct W-464 IHLW Storage Facility & 1.01.09.02.01.03 \\
\hline 450.010 & Startup and Test IHLW System & 1.01 .09 .02 .01 .03 \\
\hline 450.015 & Perform Management Self Assessment on IHLW System & 1.01 .09 .02 .01 .03 \\
\hline 450.020 & $\begin{array}{l}\text { Perform Contractor Independent Operational Readiness Review on IHLW } \\
\text { System }\end{array}$ & 1.01 .09 .02 .01 .03 \\
\hline 450.025 & $\begin{array}{l}\text { Perform DOE-ORP Operational Readiness Review and Obtain CD-4 on IHLW } \\
\text { System }\end{array}$ & 1.01.09.02.01.03 \\
\hline 450.030 & Transport/Receive/Interim Storage IHLW (Part 1) in CSB & 1.01 .09 .02 .01 .04 \\
\hline 450.050 & Startup and Test Module 1 IHLW System & 1.01 .09 .03 .01 .04 \\
\hline 450.060 & Perform Management Self Assessment on Module 1 IHLW System & 1.01 .09 .03 .01 .04 \\
\hline 450.070 & $\begin{array}{l}\text { Perform Contractor Independent Operational Readiness Review on Module } 1 \\
\text { IHLW System }\end{array}$ & 1.01 .09 .03 .01 .04 \\
\hline
\end{tabular}




\section{HNF-1946 REV 2}

Table B-1. Crosswalk from the Level 1 Logic to the Work Breakdown Structure.

\begin{tabular}{|c|c|c|}
\hline \multicolumn{3}{|c|}{ BNFL Inc. Phase 1 Privatization activities identified at WBS Level 3 (1.01.06). } \\
\hline Level 1 Logic & 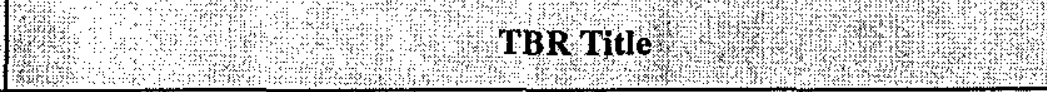 & WBS Level 6 \\
\hline 450.080 & $\begin{array}{l}\text { Perform DOE-ORP Operational Readiness Review and Obtain CD-4 on } \\
\text { Module } 1 \text { IHLW System }\end{array}$ & 1.01.09.03.01.04 \\
\hline 460.005 & ILAW Project Management & 1.01 .09 .01 .01 .01 \\
\hline 460.015 & Maintain ICD 15 & 1.01 .09 .01 .01 .02 \\
\hline 460.030 & Prepare/Maintain Technical Requirements for Disposal & 1.01.09.01.01.02 \\
\hline 460.037 & Project Management Plan Update & 1.01 .09 .01 .01 .02 \\
\hline 460.040 & Define Requirements for ILAW Sample Transport & 1.01 .09 .01 .01 .02 \\
\hline 460.043 & Define Requirements for ILAW Melter Disposal & 1.01 .09 .01 .01 .02 \\
\hline 460.050 & Design/Procure ILAW Sample Transport System & 1.01 .09 .01 .01 .02 \\
\hline 460.055 & Design/Procure/Fabricate ILAW Failed Melter Transport System & 1.01.09.01.01.02 \\
\hline 460.060 & Design/Permit/Prepare Failed Melter Disposal Trench & 1.01.09.01.01.02 \\
\hline 460.145 & Data Collection for 2001 Performance Assessment & 1.01 .09 .01 .01 .03 \\
\hline 460.155 & 2001 Performance Assessment & 1.01 .09 .01 .01 .03 \\
\hline 460.160 & Data Collection for Performance Assessment & 1.01 .09 .01 .01 .03 \\
\hline 460.170 & Maintain ILAW Part 1 Performance Assessment & 1.01 .09 .01 .01 .07 \\
\hline 460.200 & ILAW Disposal Facility Conceptual Design & 1.01 .09 .01 .01 .04 \\
\hline 460.210 & ILAW Disposal Facility Advanced Conceptual Design/Validation & 1.01 .09 .01 .01 .04 \\
\hline 460.220 & ILAW Disposal Facility Design & 1.01.09.01.01.04 \\
\hline 460.230 & ILAW Disposal Facility Equipment Procurement & 1.01 .09 .01 .01 .04 \\
\hline 460.240 & ILAW Disposal Facility Construction & 1.01.09.01.01.04 \\
\hline 460.250 & Obtain ILAW Disposal Facility Environmental Permits & 1.01 .09 .01 .01 .04 \\
\hline 460.260 & ILAW Disposal Facility Authorization Basis Development and Approval & 1.01 .09 .01 .01 .04 \\
\hline 470.035 & Dispose of Failed Melters & 1.01.09.01.01.07 \\
\hline 470.075 & ILAW Disposal Facility Operations & 1.01 .09 .01 .01 .07 \\
\hline 470.080 & Close ILAW Disposal Facilities & 1.01 .09 .01 .04 .01 \\
\hline 470.100 & Startup and Test ILAW Disposal Facility & 1.01 .09 .01 .01 .04 \\
\hline
\end{tabular}




\section{HNF-1946 REV 2}

Table B-1. Crosswalk from the Level 1 Logic to the Work Breakdown Structure.

\begin{tabular}{|c|c|c|}
\hline \multicolumn{3}{|c|}{ BNFL Inc. Phase 1 Privatization activities identified at WBS Level 3 (1.01.06). } \\
\hline $\begin{array}{l}\text { Level } 1 \text { Logic } \\
\text { TBR Number }\end{array}$ & 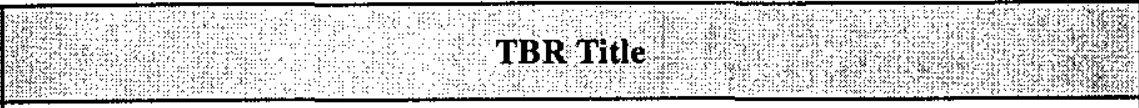 & WBS Level 6 \\
\hline 470.110 & Perform Management Self Assessment for ILAW Disposal Facility & 1.01 .09 .01 .01 .04 \\
\hline 470.120 & $\begin{array}{l}\text { Perform Contractor Independent Operational Readiness Review for ILAW } \\
\text { Disposal Facility }\end{array}$ & 1.01 .09 .01 .01 .04 \\
\hline 470.130 & $\begin{array}{l}\text { Conduct DOE-ORP Operational Readiness Review and Obtain CD-4 for ILAW } \\
\text { Disposal Facility }\end{array}$ & 1.01 .09 .01 .01 .04 \\
\hline 470.140 & Complete Startup and Readiness for Failed Melter Disposal & 1.01 .09 .01 .01 .07 \\
\hline 620.070 & Develop and Maintain the WFD Environmental Baseline & 1.01 .04 .01 .01 .14 \\
\hline 620.090 & Align Waste Feed Delivery Activities with the Environmental Baseline & 1.01 .04 .01 .01 .14 \\
\hline 710.702 & Manage RPP Waste Retrieval Division & 1.01 .04 .01 .01 .01 \\
\hline 710.705 & Manage Tank Waste Retrieval and Disposal Operations & 1.01 .04 .01 .01 .10 \\
\hline 710.710 & Perform Hanford Tanks Initiatives Activities & 1.01 .04 .01 .02 .05 \\
\hline 710.711 & Waste Feed Delivery Technology Insertion Support & 1.01 .04 .01 .01 .02 \\
\hline 710.716 & Manage Retrieval SST Activities & 1.01 .04 .01 .02 .01 \\
\hline 710.720 & Waste Retrieval Project Development and Implementation & 1.01 .04 .01 .01 .03 \\
\hline 710.722 & Waste Retrieval Division Business Management & 1.01 .04 .01 .01 .01 \\
\hline 710.724 & Waste Feed Delivery Program Analysis and Control & 1.01 .04 .01 .01 .01 \\
\hline 710.725 & Waste Feed Delivery Program Technical Analysis & 1.01 .04 .01 .01 .03 \\
\hline 710.727 & Waste Feed Delivery System Engineering Implementation & 1.01 .04 .01 .01 .03 \\
\hline 710.730 & TWR Program Engineering and Support & 1.01 .04 .01 .01 .03 \\
\hline 710.740 & TWR Program Integration & 1.01 .04 .01 .01 .01 \\
\hline 710.750 & TWR Quality Assurance Program & 1.01 .04 .01 .01 .01 \\
\hline 710.760 & TWR Program Improvement & $1.01 .04 .01 .01 .01^{\prime}$ \\
\hline 710.770 & Obtain Retrieval Crane and Rigging Equipment & 1.01 .04 .01 .01 .01 \\
\hline 710.800 & TWRD Risk Allowance & 1.01 .04 .01 .01 .01 \\
\hline 710.900 & RPP Disposal DOE-ORP Project Direction & 1.01 .04 .01 .01 .01 \\
\hline 730.100 & Construct HLW \& LAW Pretreatment/Immobilization Facility & 1.01 .08 .01 .01 .01 \\
\hline 730.200 & Startup and Test HLW \& LAW Pretreatment/Immobilization Facility & 1.01.08.01.01.01 \\
\hline
\end{tabular}




\section{HNF-1946 REV 2}

Table B-1. Crosswalk from the Level 1 Logic to the Work Breakdown Structure.

\begin{tabular}{|c|c|c|}
\hline \multicolumn{3}{|c|}{ BNFL Inc. Phase 1 Privatization activities identified at WBS Level 3 (1.01.06). } \\
\hline $\begin{array}{l}\text { Level } 1 \text { Logic } \\
\text { TBR Number }\end{array}$ & | & WBS Level 6 \\
\hline 730.300 & Operate HLW \& LAW Pretreatment/Immobilization Facility & 1.01 .08 .01 .01 .01 \\
\hline 780.010 & Define Project Design Criteria for IHLW Module $1 \mathrm{~W}-\mathrm{XXX}$ & 1.01 .09 .03 .01 .02 \\
\hline 780.020 & IHLW Module $1 \mathrm{~W}$-XXX Conceptual Design & 1.01 .09 .03 .01 .03 \\
\hline 780.050 & IHLW Module $1 \mathrm{~W}-\mathrm{XXX}$ Design & 1.01 .09 .03 .01 .03 \\
\hline 780.060 & IHLW Module $1 \mathrm{~W}-\mathrm{XXX}$ Construction & 1.01 .09 .03 .01 .03 \\
\hline 780.070 & Obtain Permits for IHLW Module $1 \mathrm{~W}-\mathrm{XXX}$ & 1.01 .09 .03 .01 .03 \\
\hline 780.080 & IHLW Module $1 \mathrm{~W}-\mathrm{XXX}$ Authorization Basis & 1.01 .09 .03 .01 .03 \\
\hline
\end{tabular}


HNF-1946 REV 2

This page intentionally left blank.

\section{Distr.-1}




\section{This document was too large to scan as a single document. It has been divided into smaller sections.}

\section{Section 1 of 2}

\section{Document Information}

\begin{tabular}{|l|l|l|l|}
\hline Document \# & HNF-1946 & Revision 2 & \\
\hline Title & $\begin{array}{l}\text { PROGRAMMATIC BASELINE SUMMARY FOR PHASE 1 } \\
\text { PRIVATIZATION FOR THE TANK FARM CONTRACTOR } \\
\text { APPENDIX C. INTEGRATED RESOURCE LOAD } \\
\text { SCHEDULE [VOL 2] }\end{array}$ \\
\hline Date & $\mathbf{0 4 / 2 2 / 2 0 0 0}$ & Originator Co. & CHG \\
\hline Originator & DIEDIKER JA & Recipient Co. & \\
\hline Recipient & \multicolumn{2}{|l|}{} \\
\hline References & ECN-660087 & \\
\hline Keywords & CRITICAL PATHS \\
\hline Projects & RPP,TFARM \\
\hline $\begin{array}{l}\text { Other } \\
\text { Information }\end{array}$ & SECTION 1 OF 2 CONTAINS CRITICAL PATHS \\
\hline & \multicolumn{2}{|l}{} \\
\hline
\end{tabular}


HNF-1946

Volume 11

Revision 2

\section{Programmatic Baseline Summary for Phase 1 Privatization for the Tank Farm Contractor}

\section{Appendix C. Integrated Resource Loaded Schedule}

Prepared for the U.S. Department of Energy

Assistant Secretary for Environmental Management

\section{CH2MHILL \\ Hanford Group, Inc.}

Richland, Washington

Contractor for the U.S. Department of Energy

Office of River Protection under Contract DE-AC06-99RL14047 


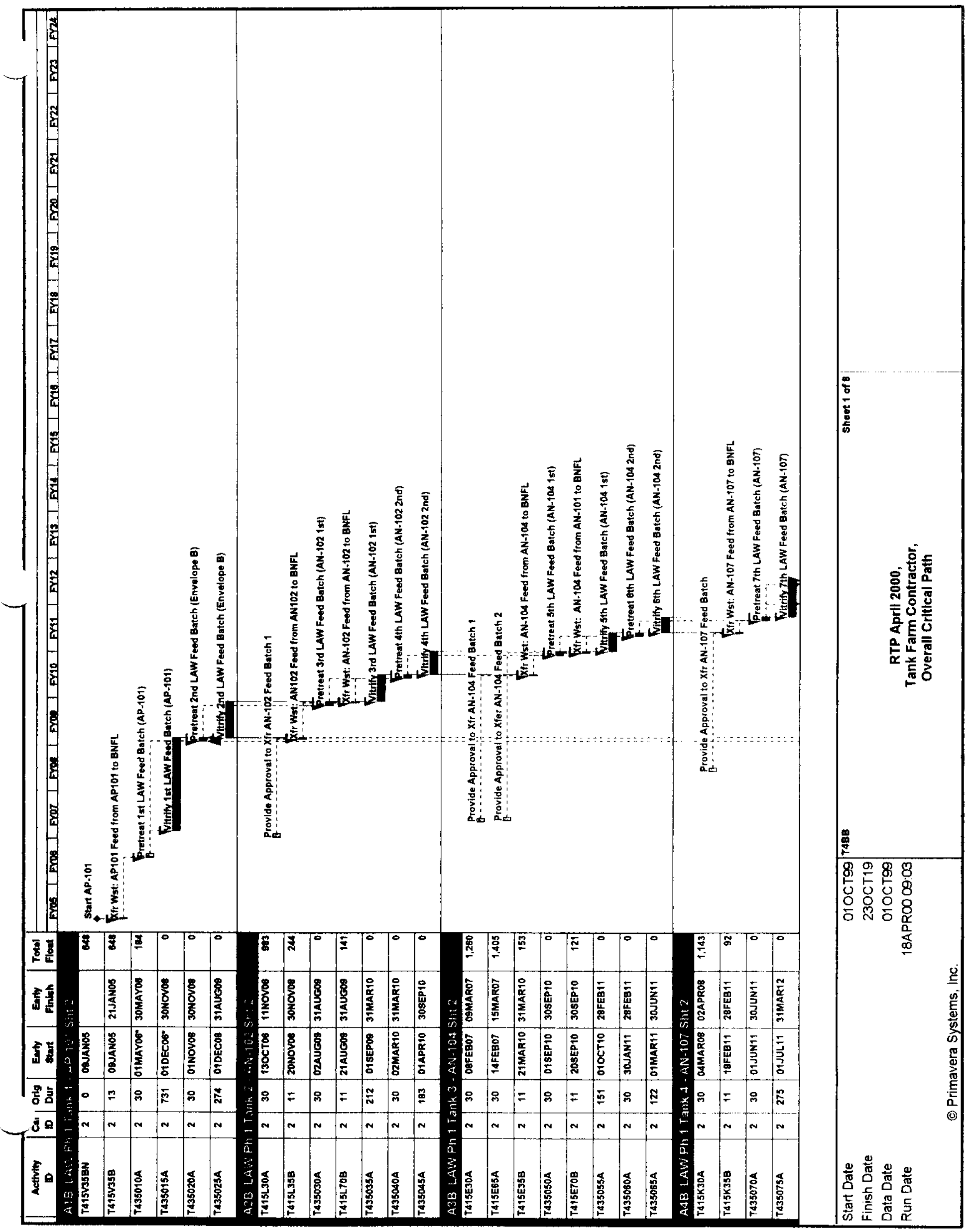




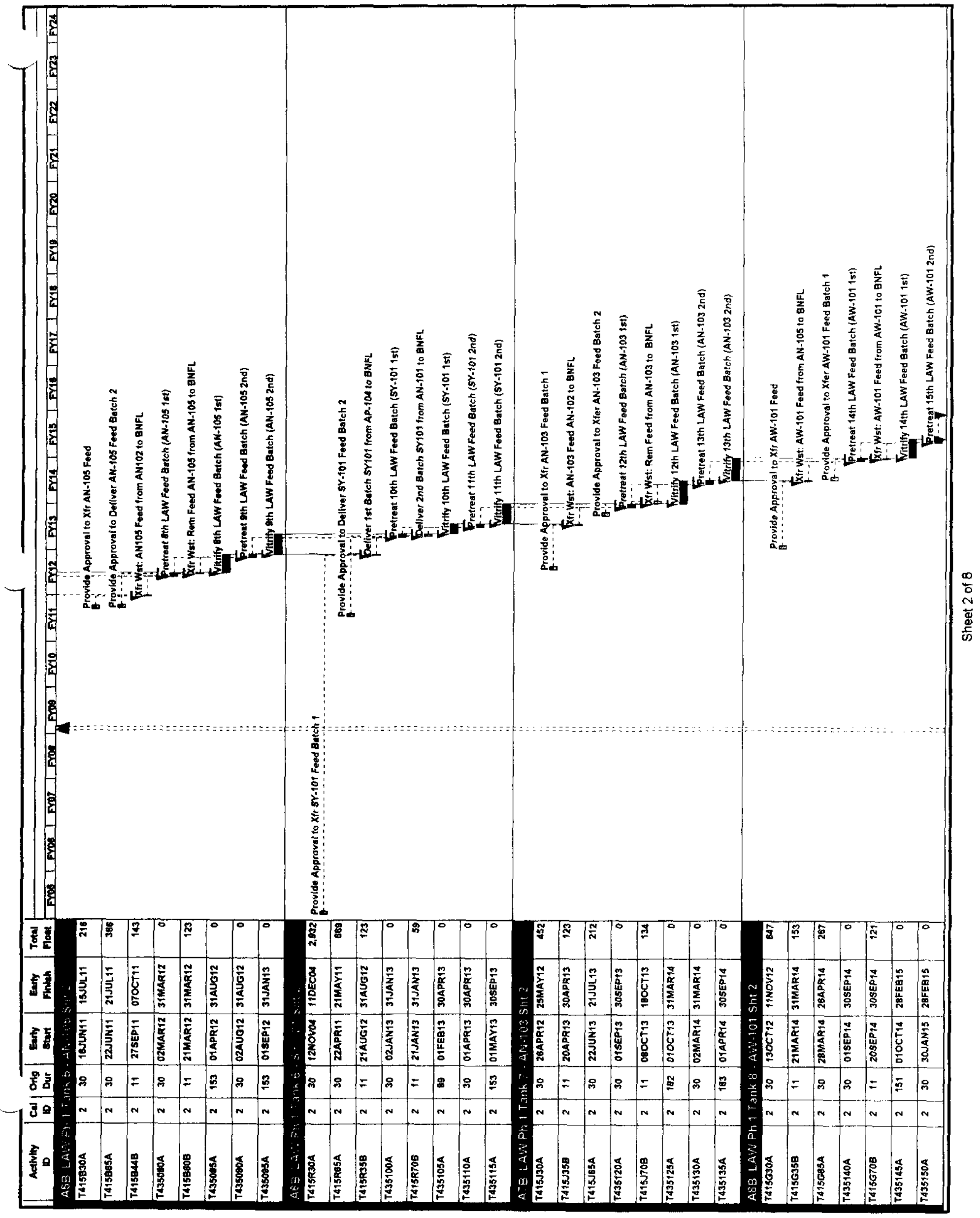




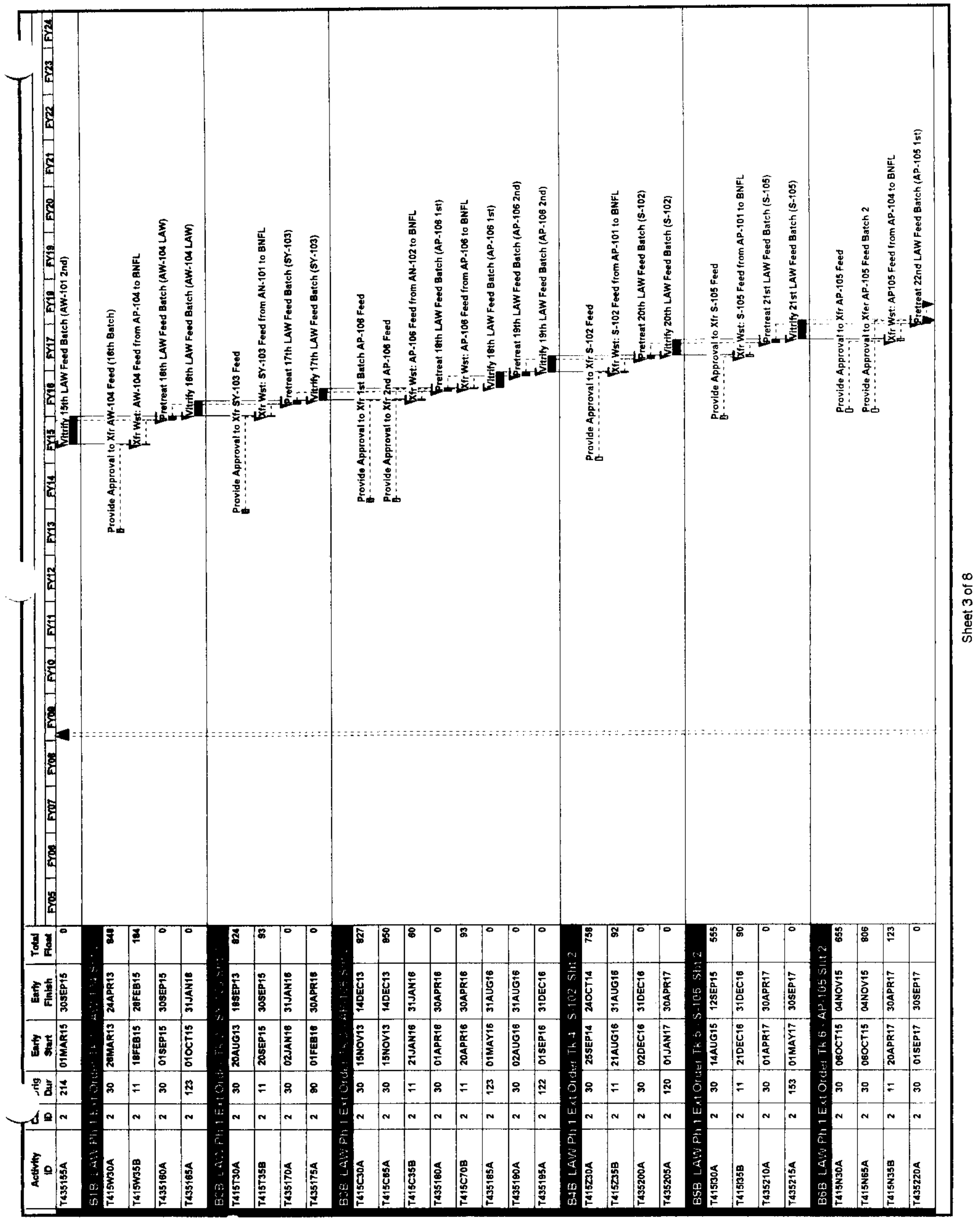




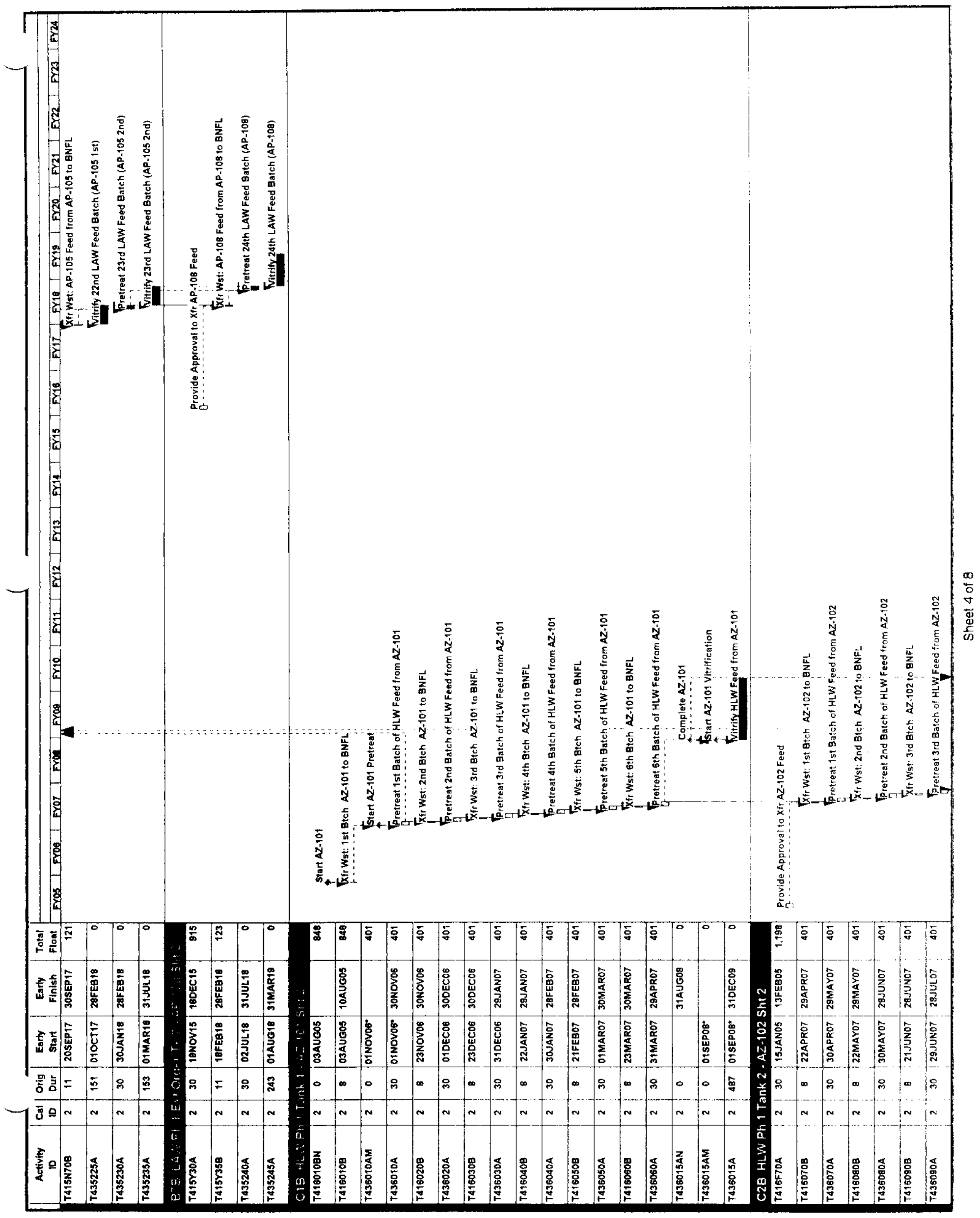




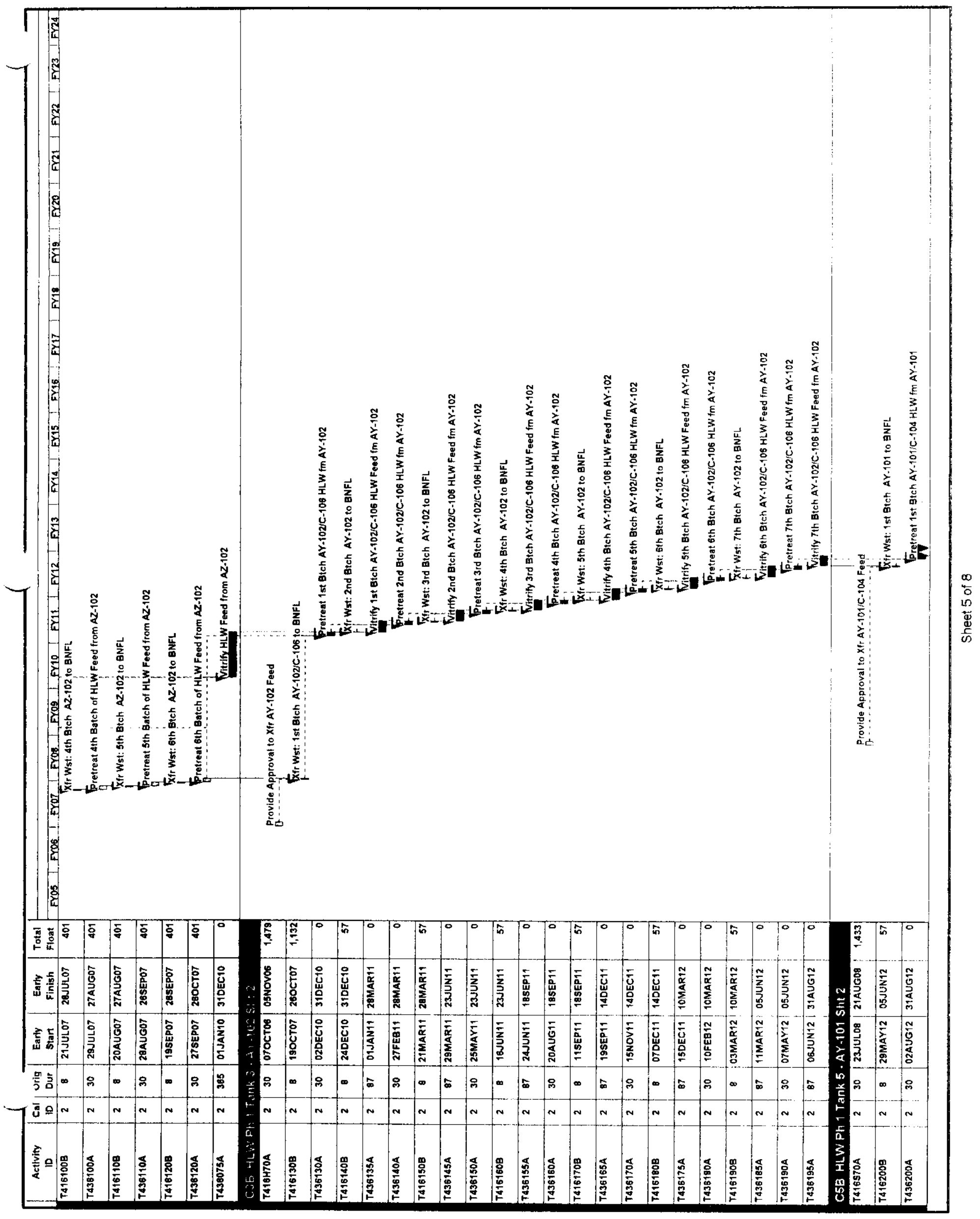




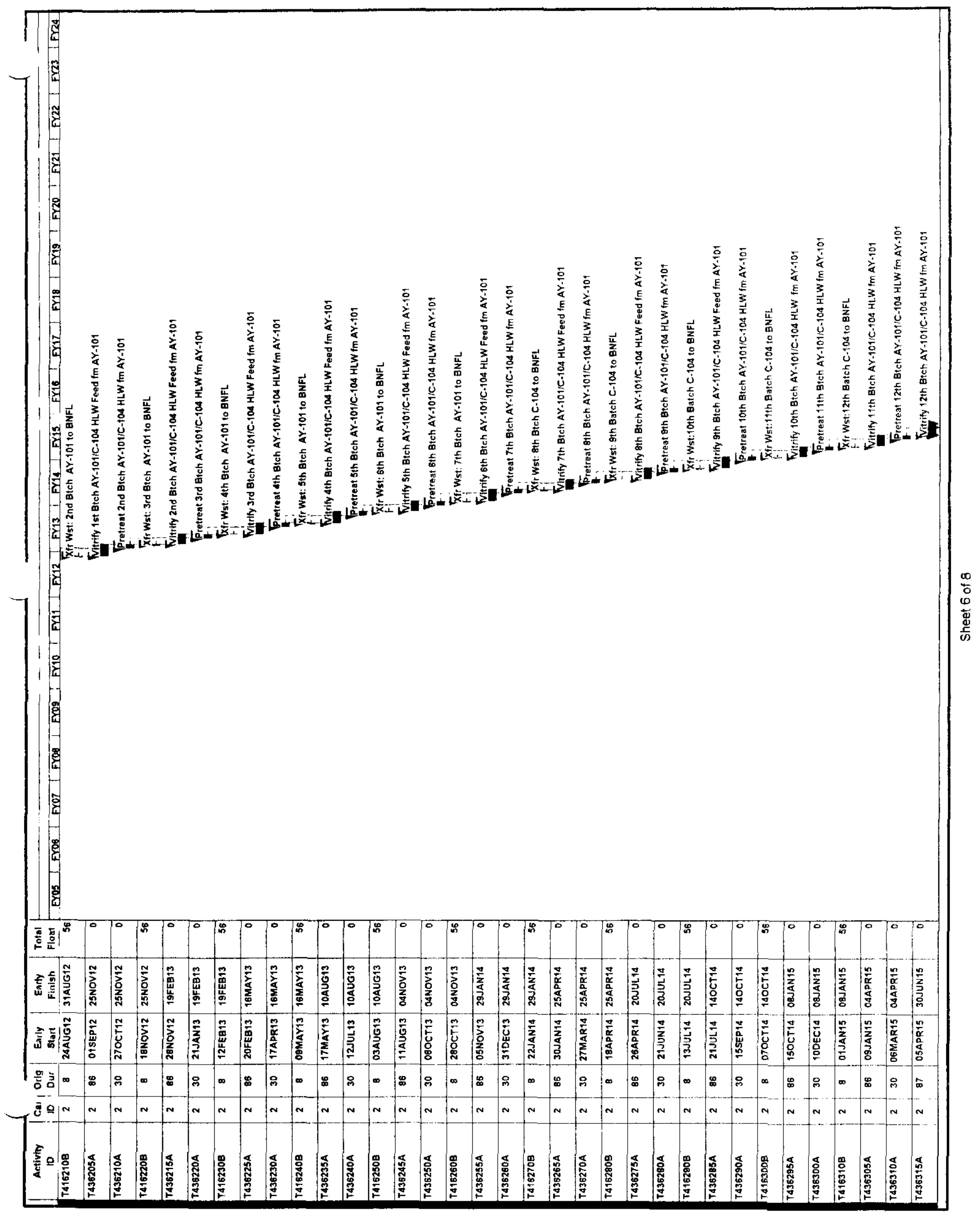




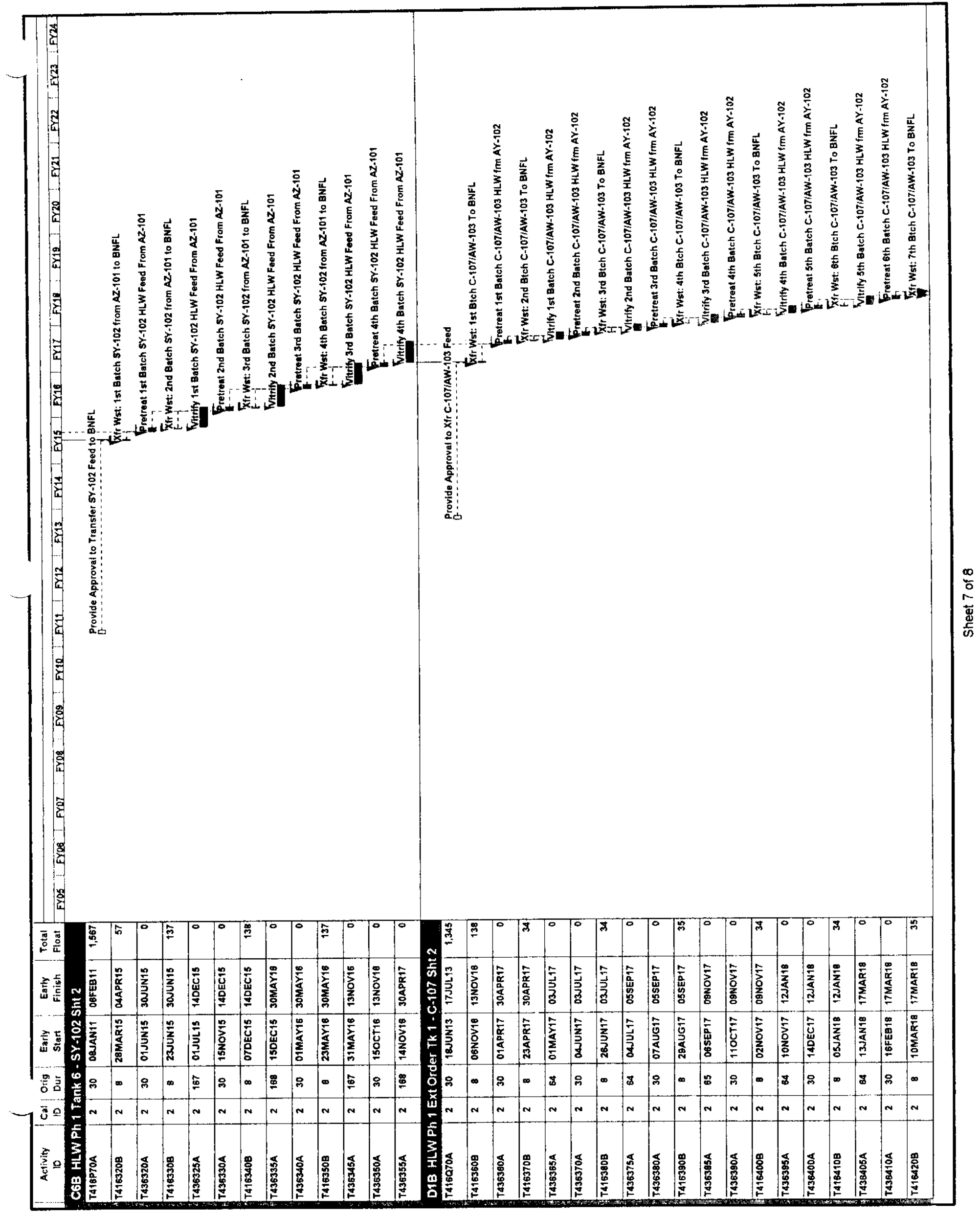




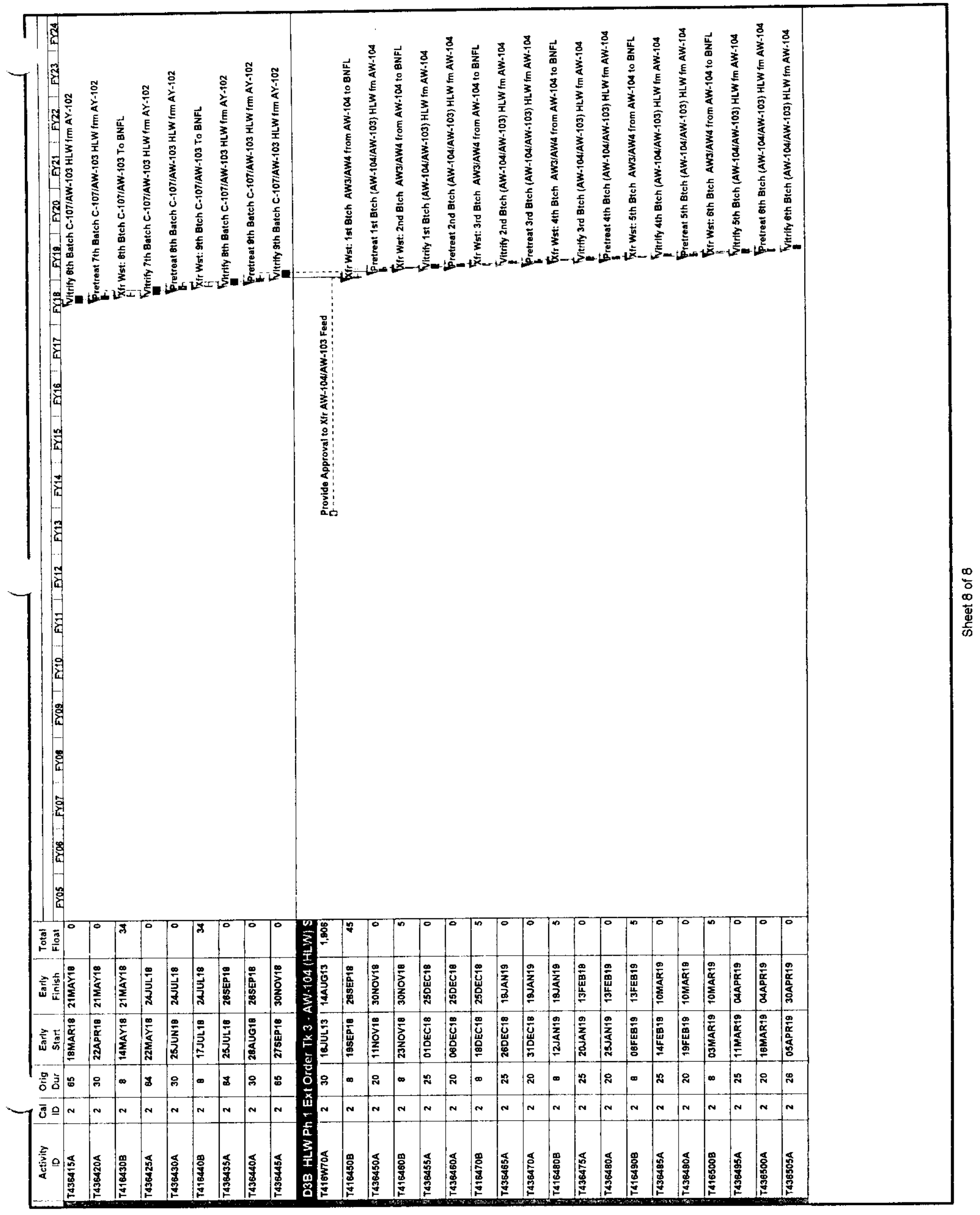




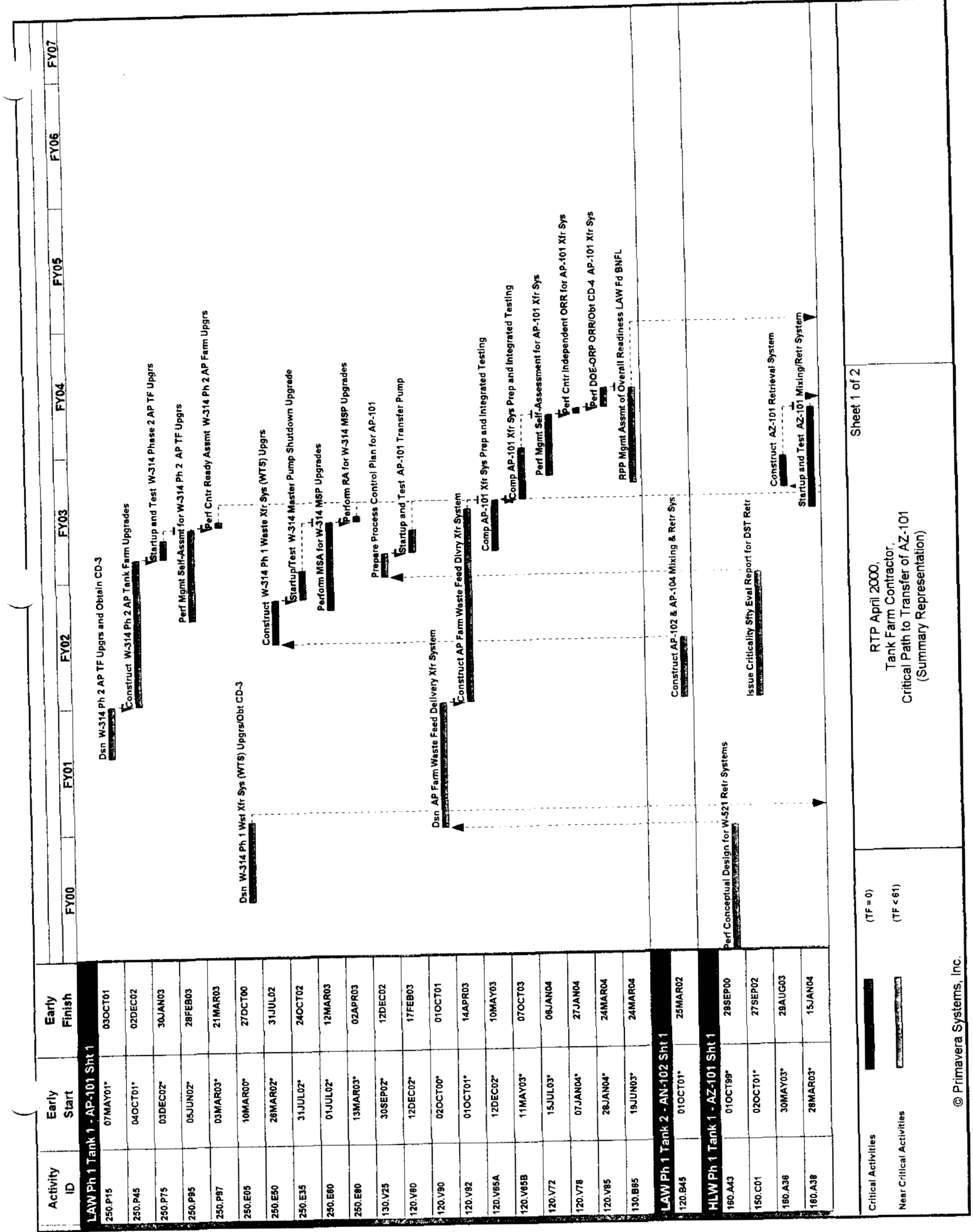




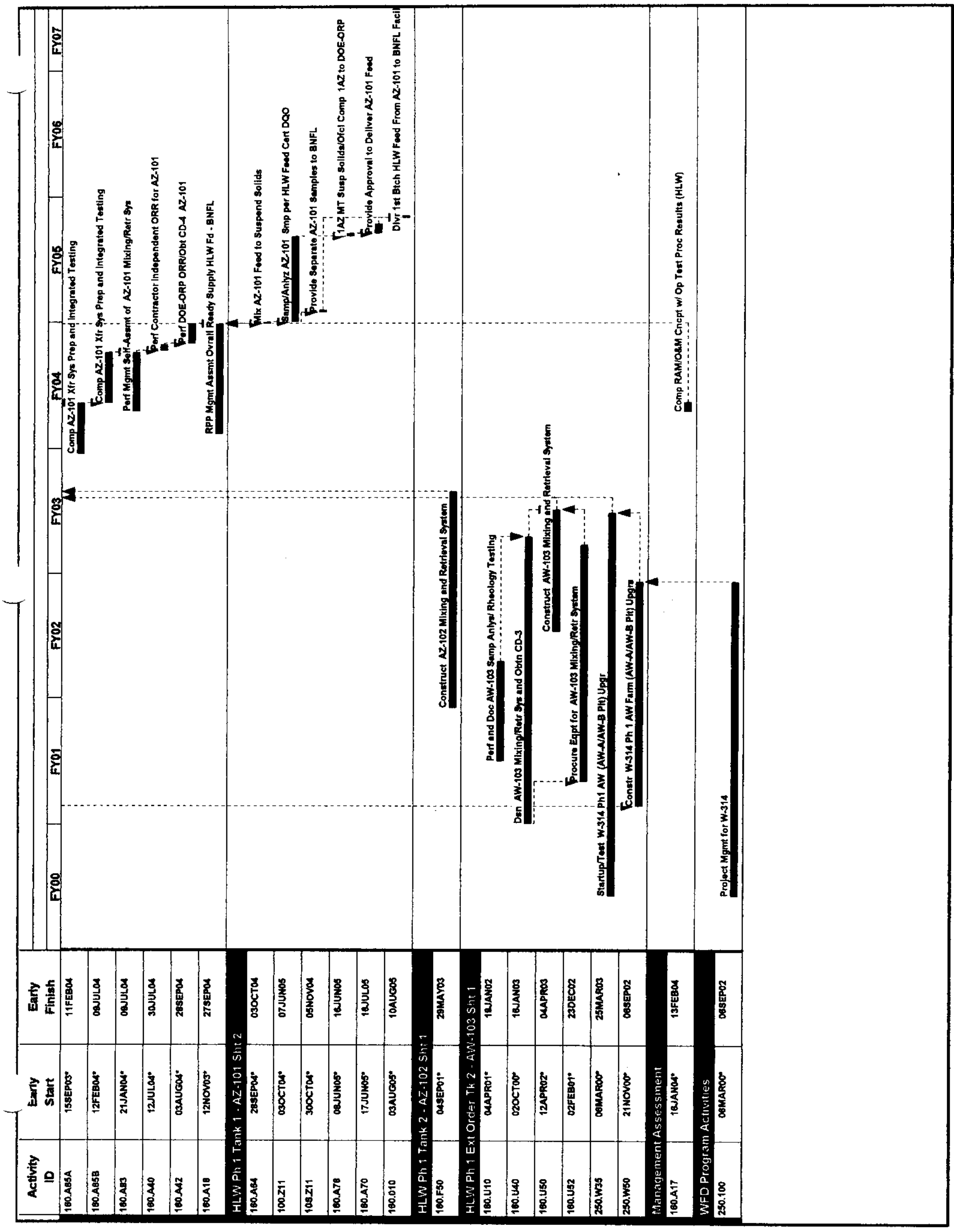




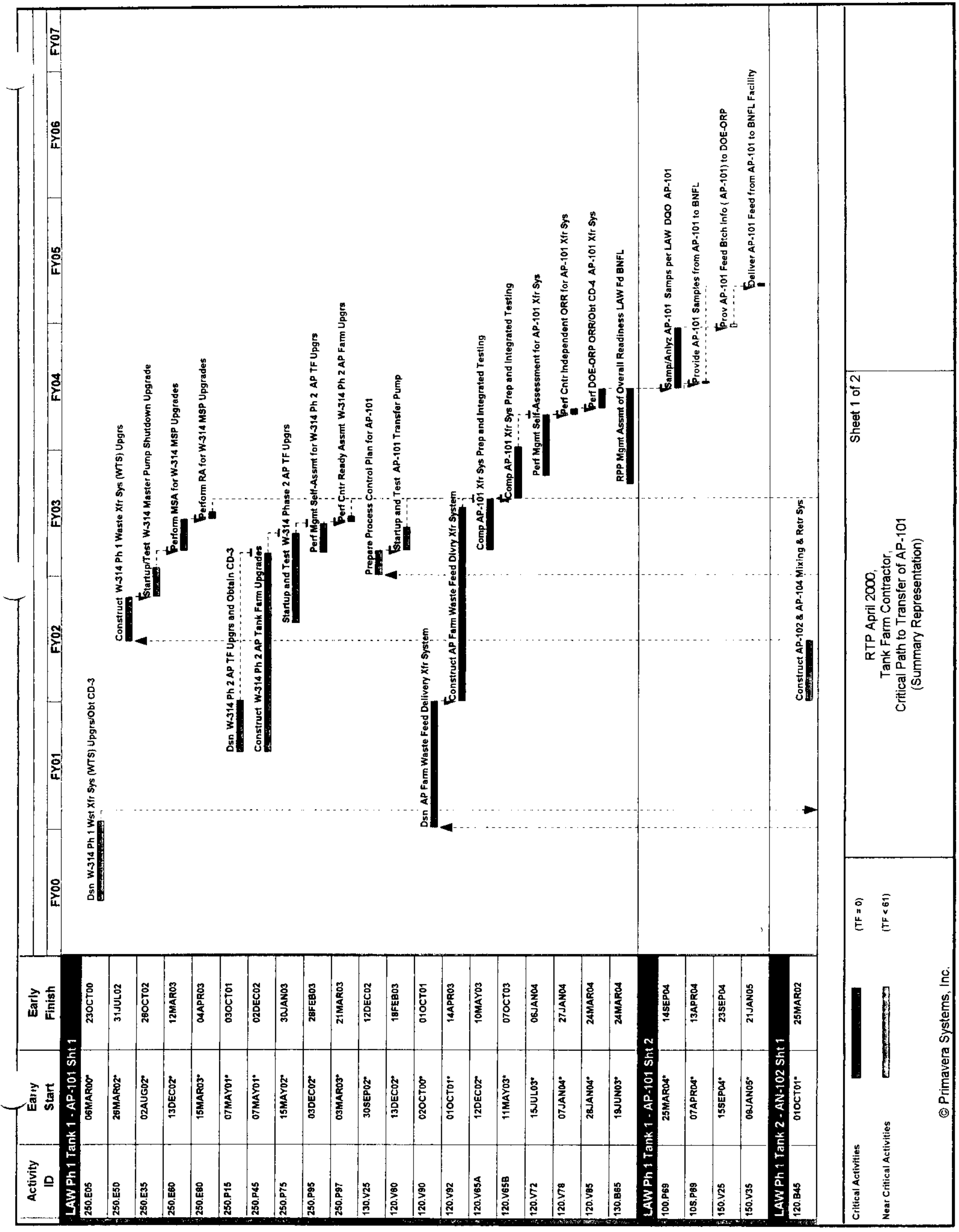




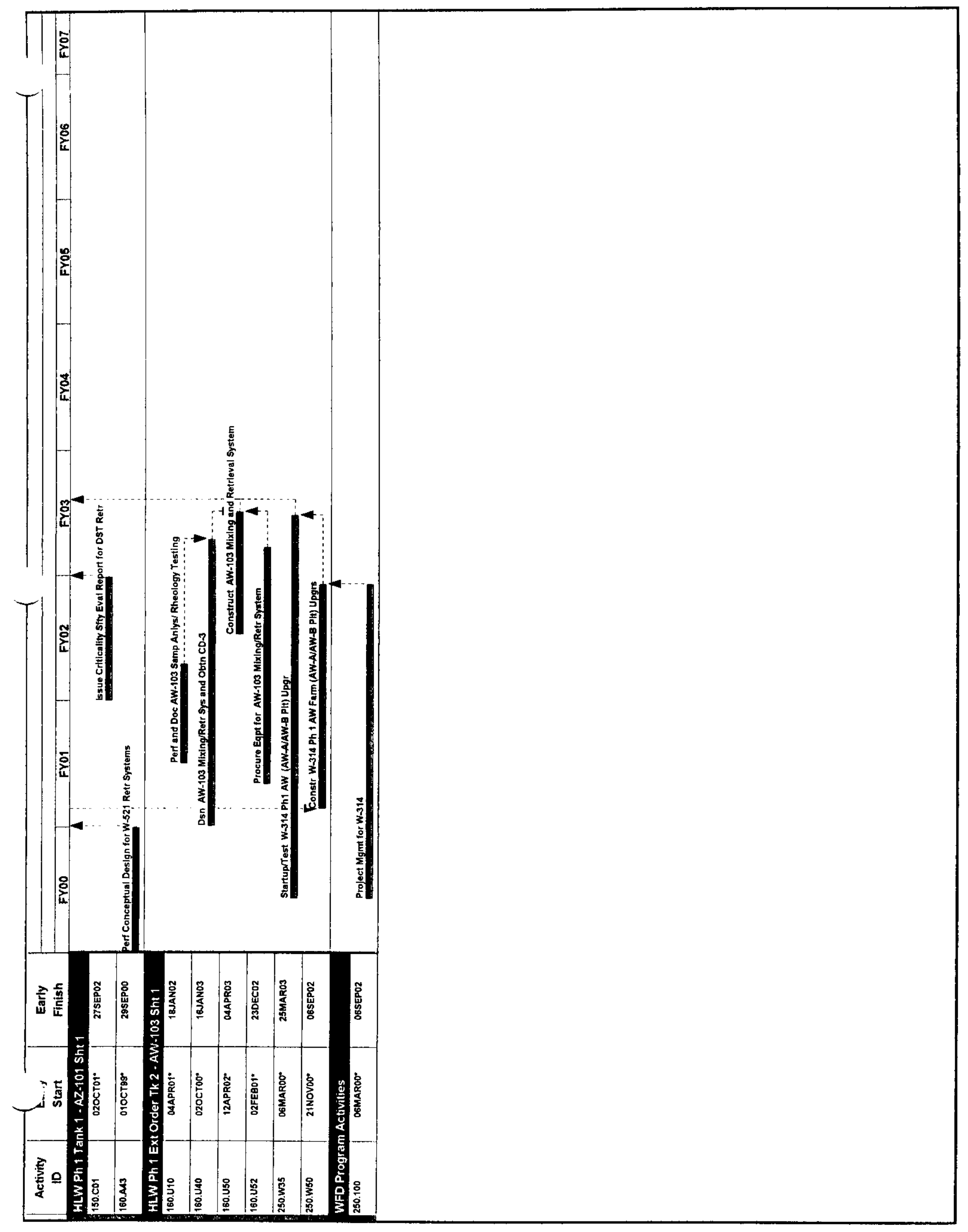




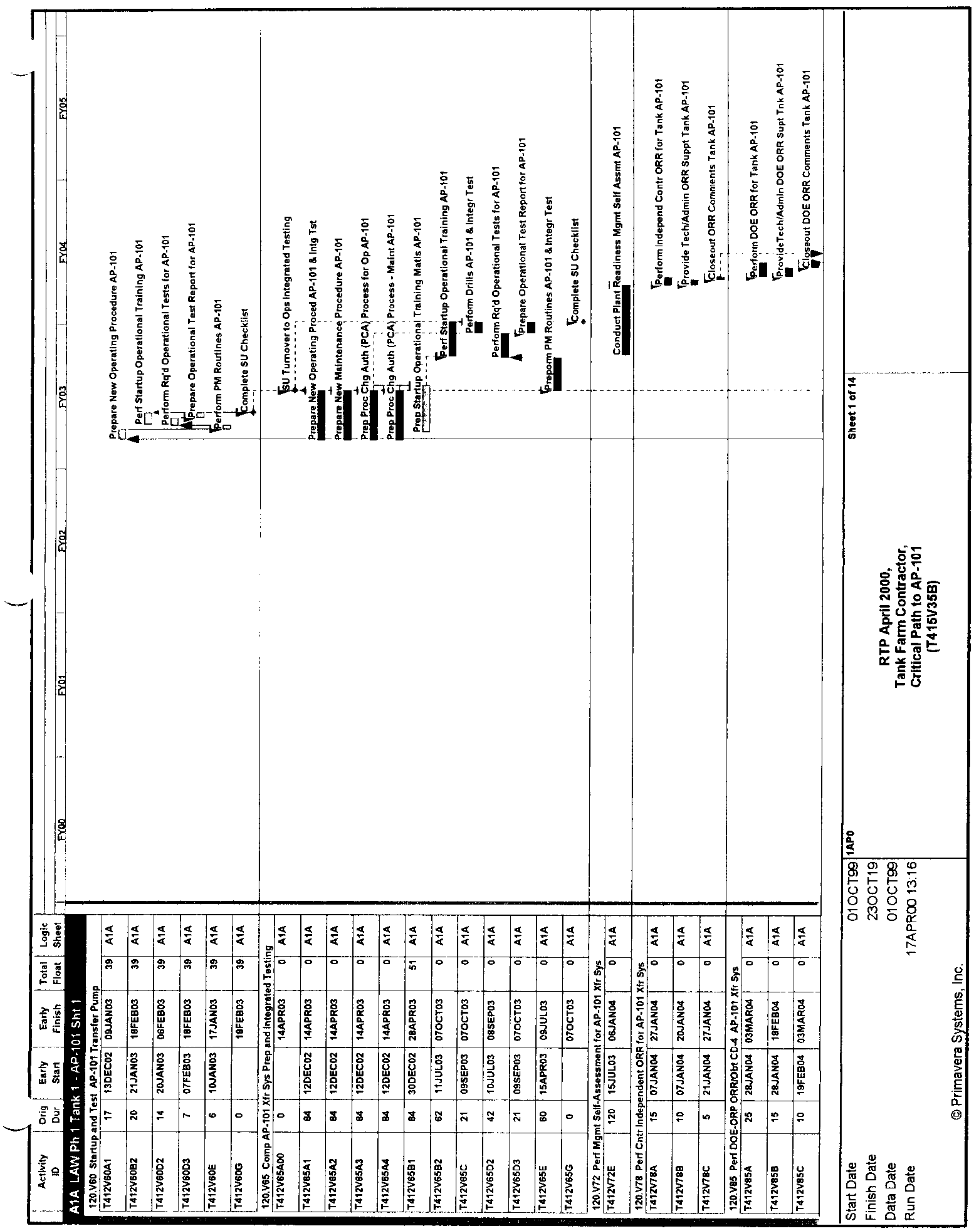




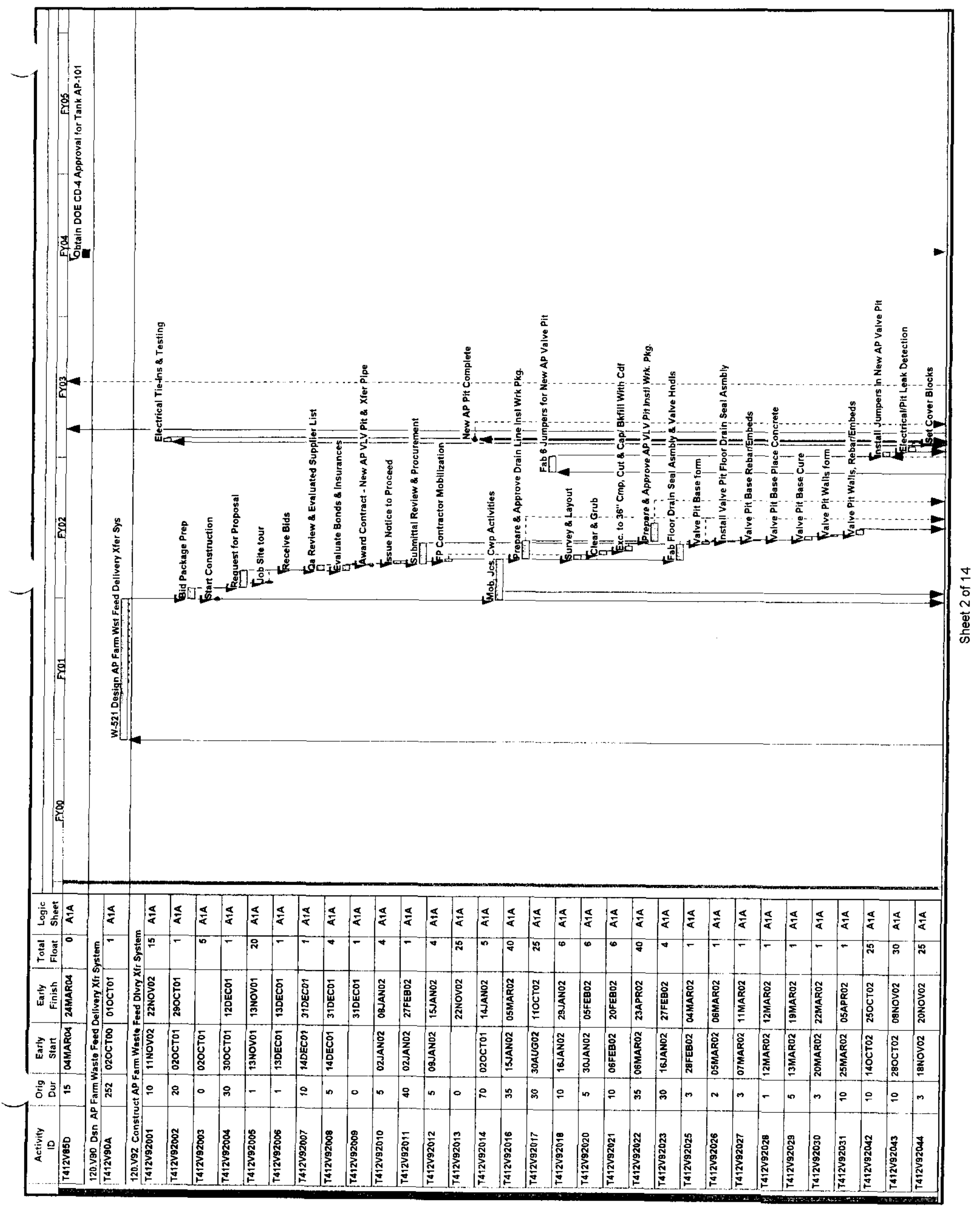




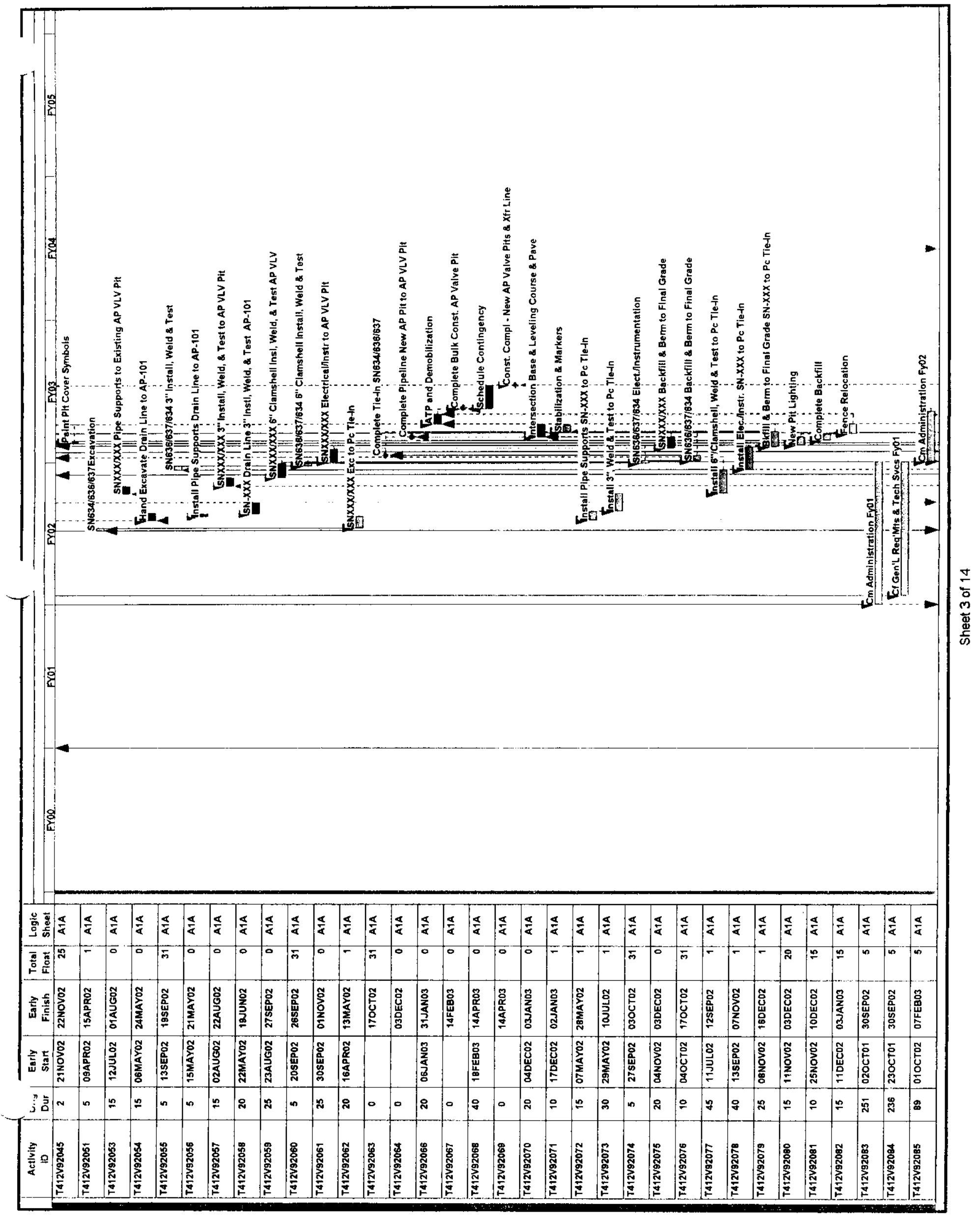




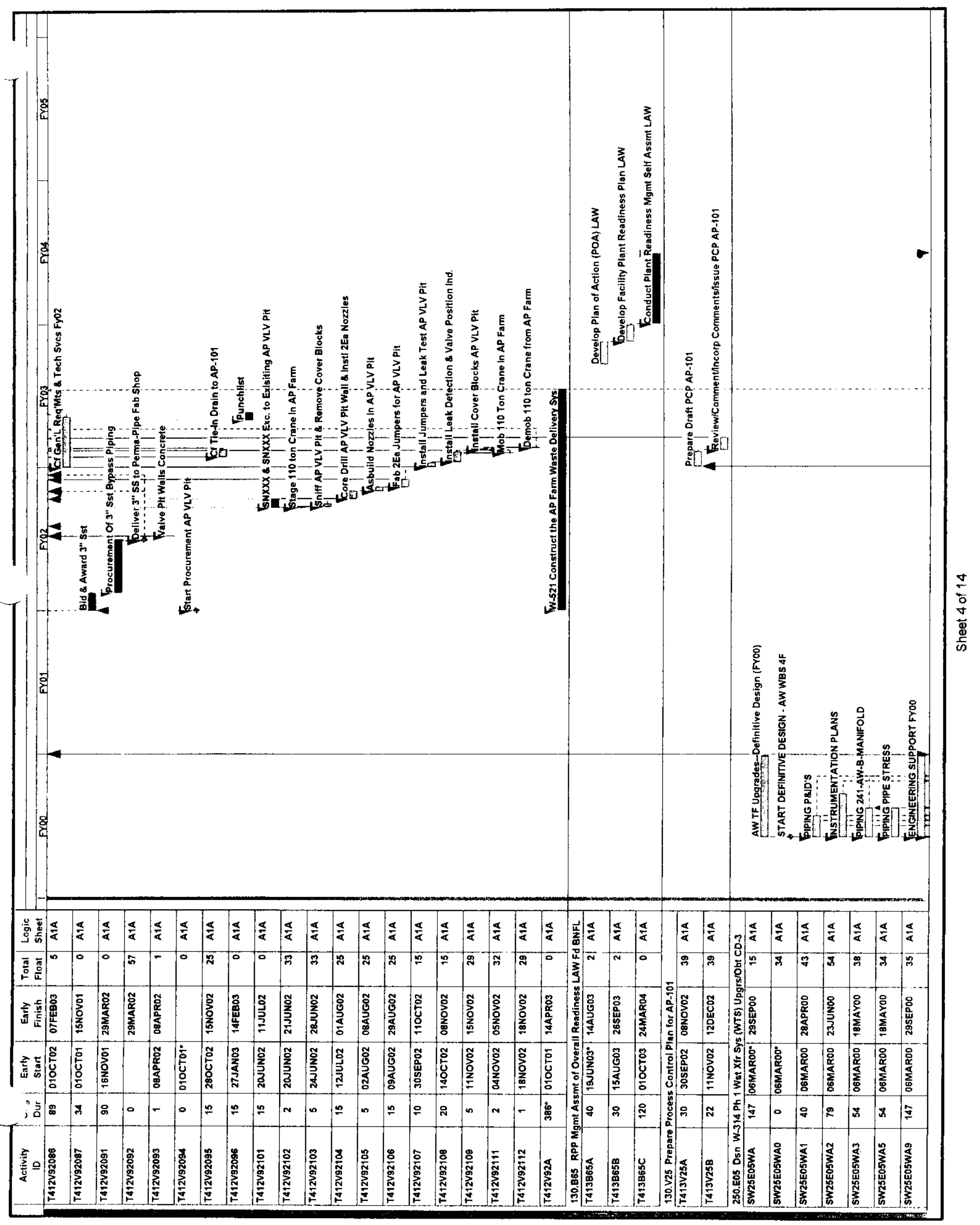




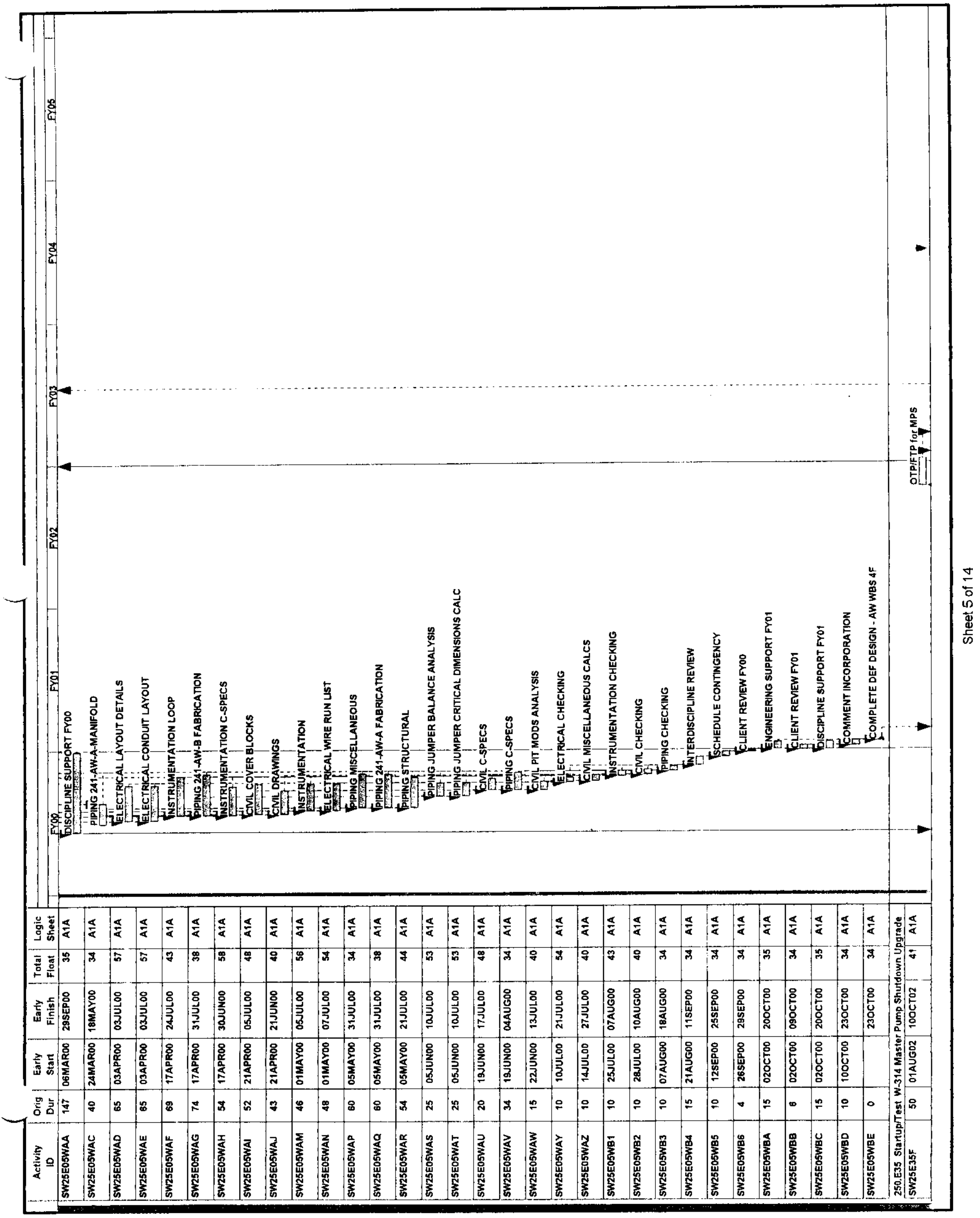




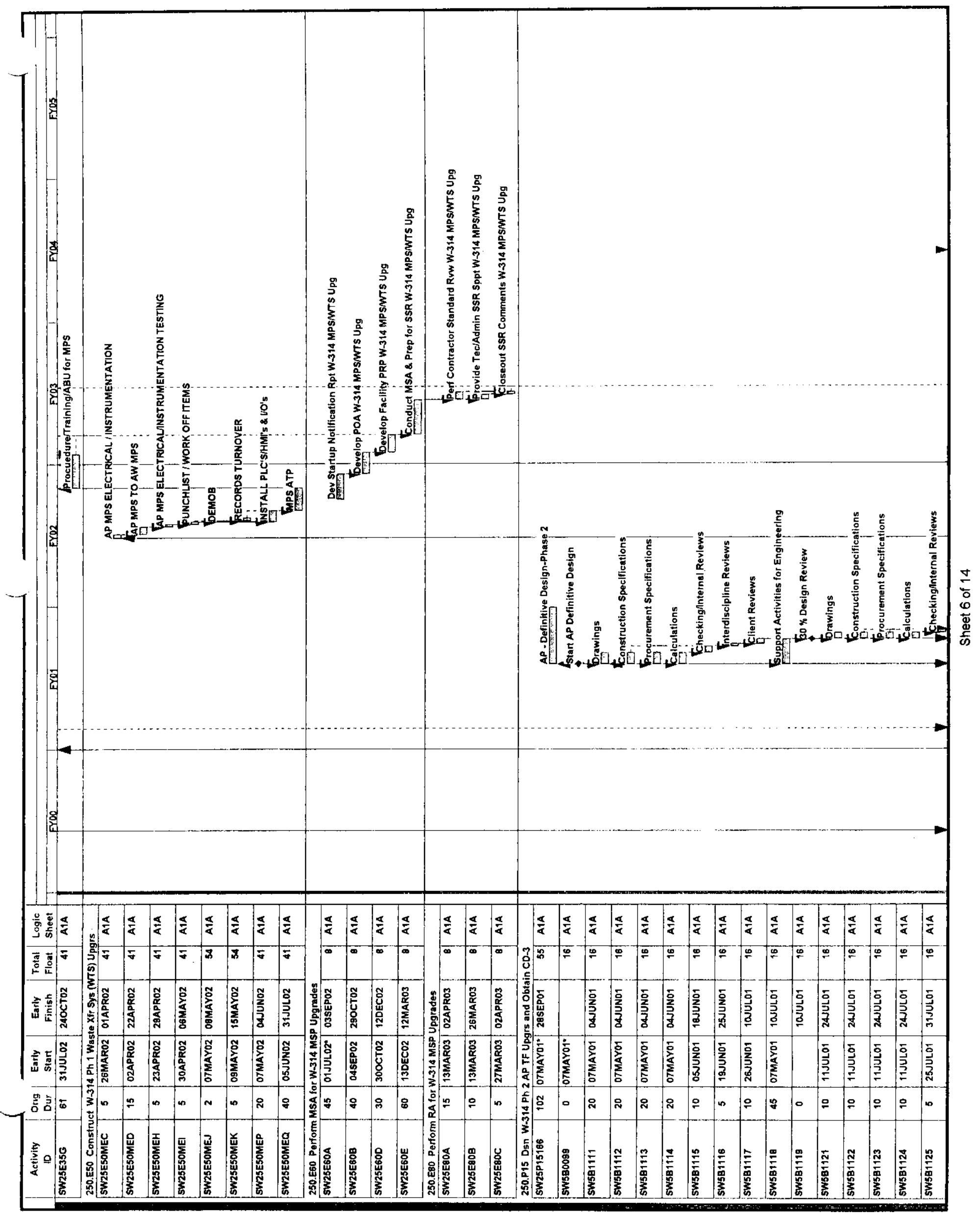




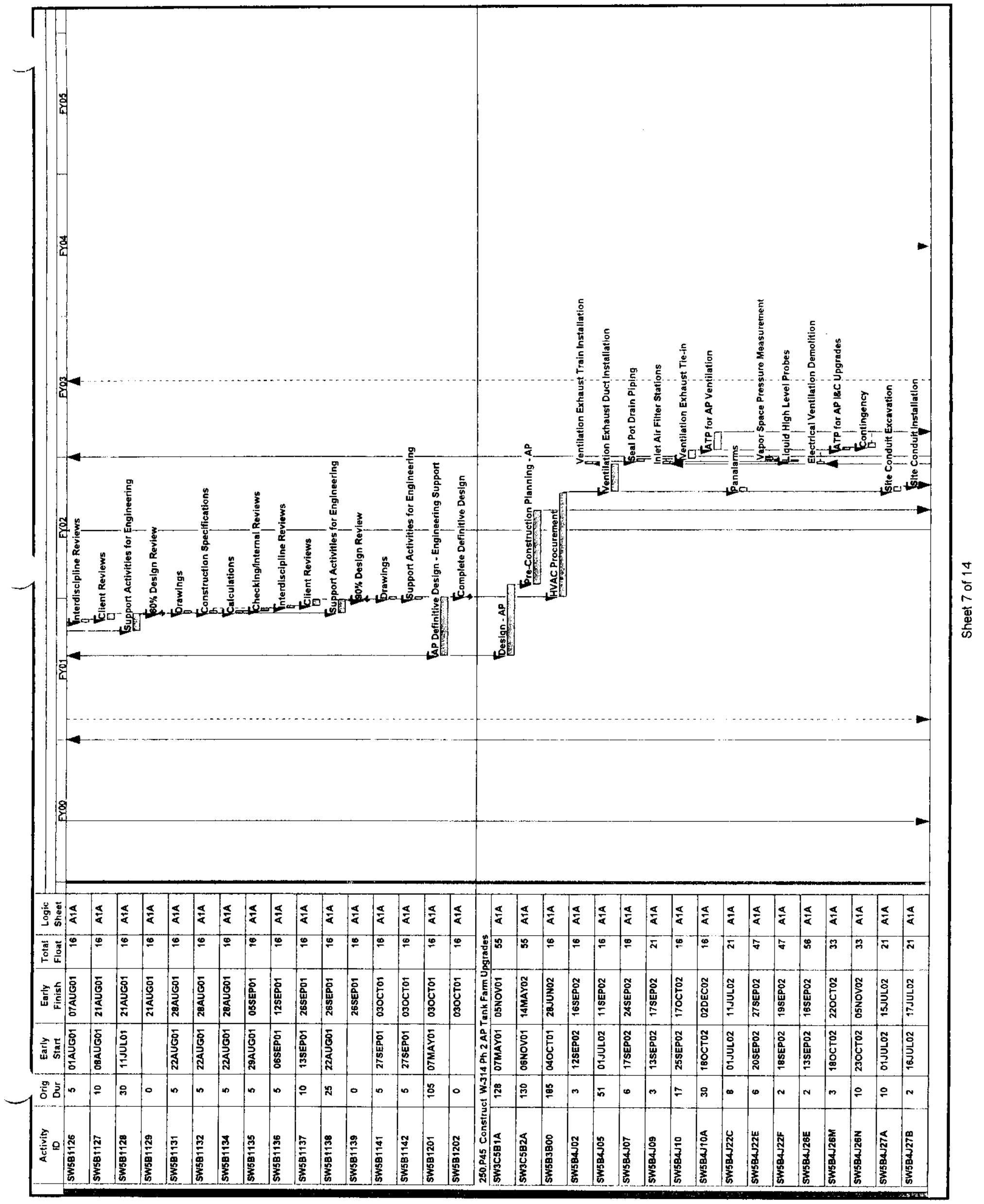




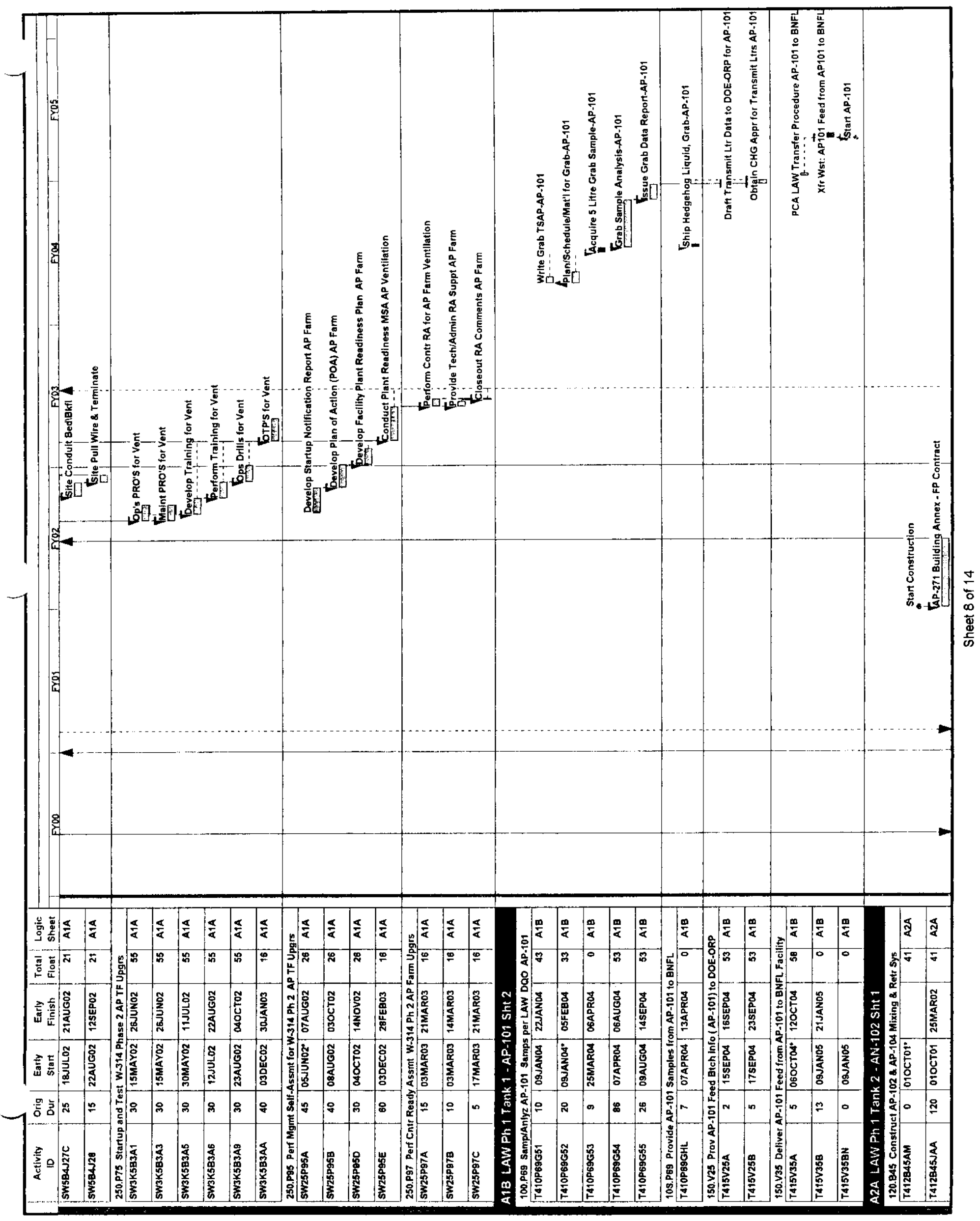




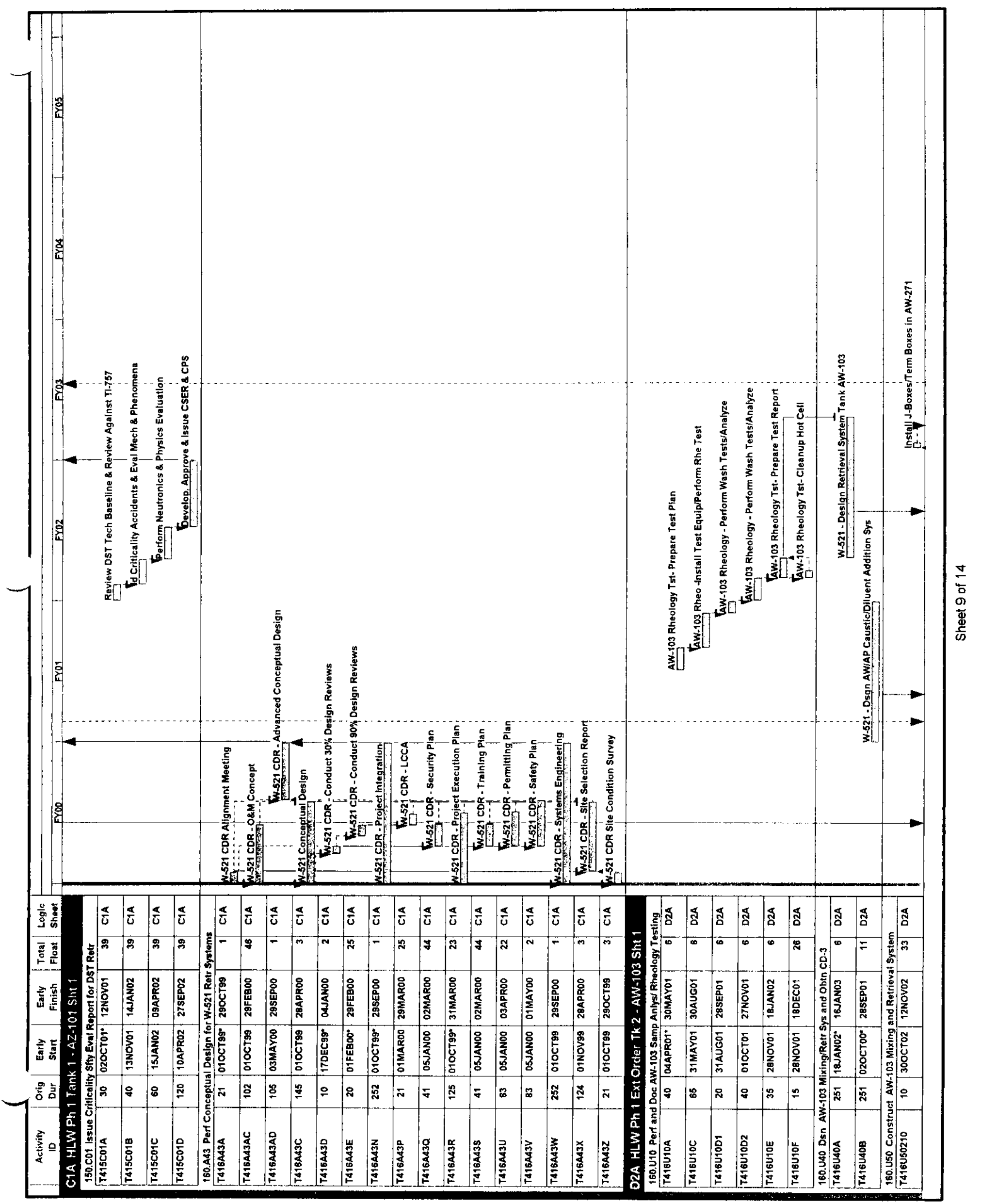




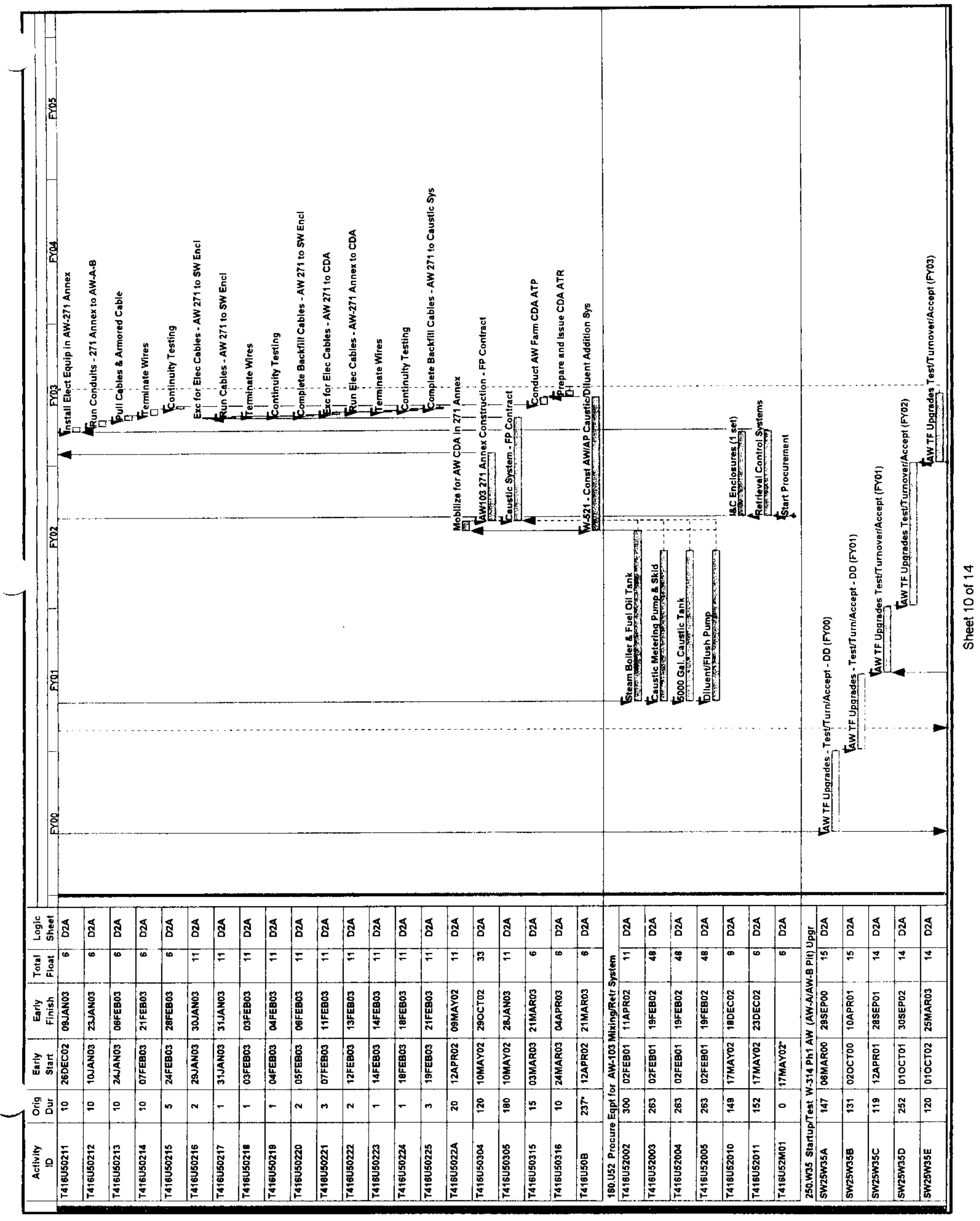




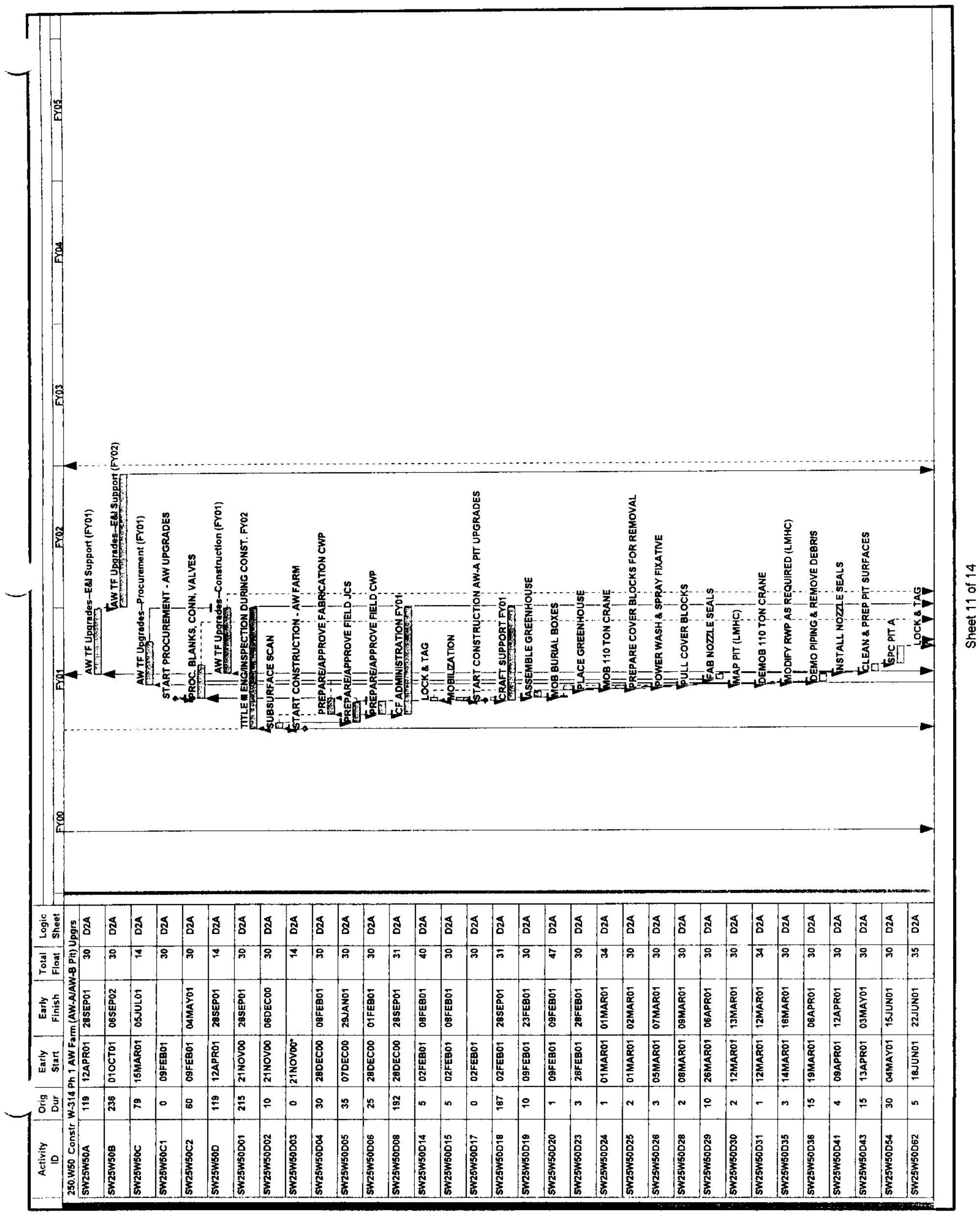




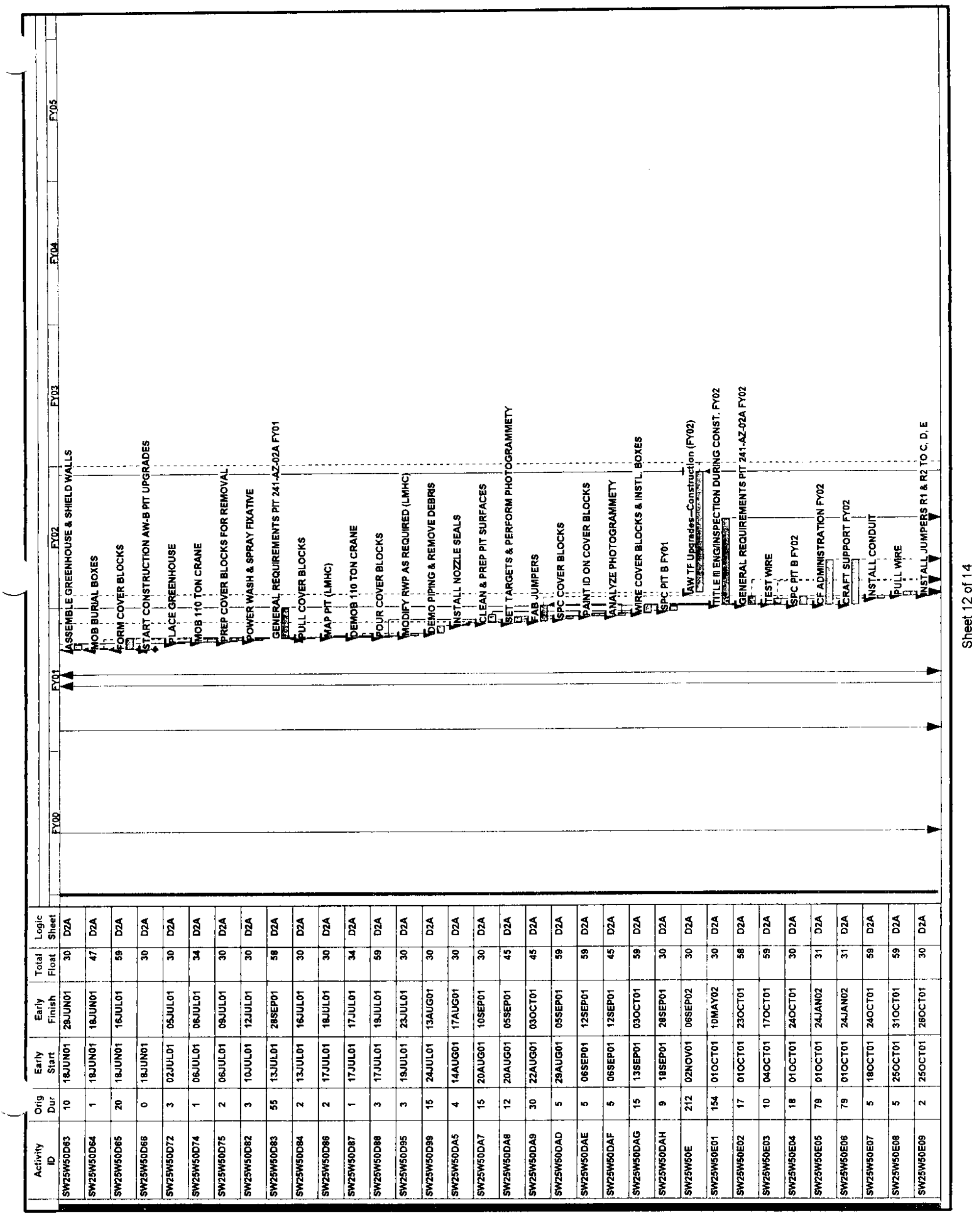




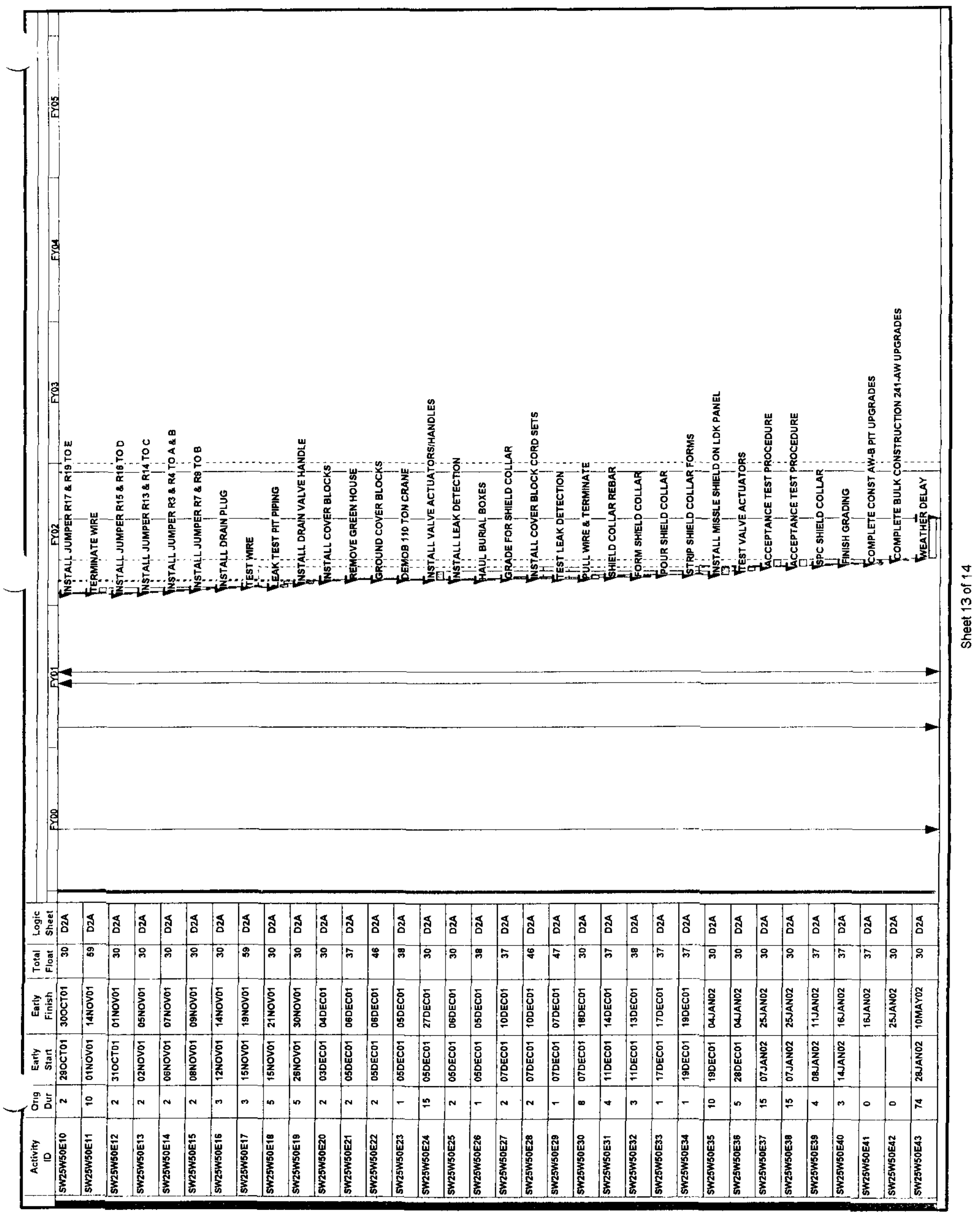




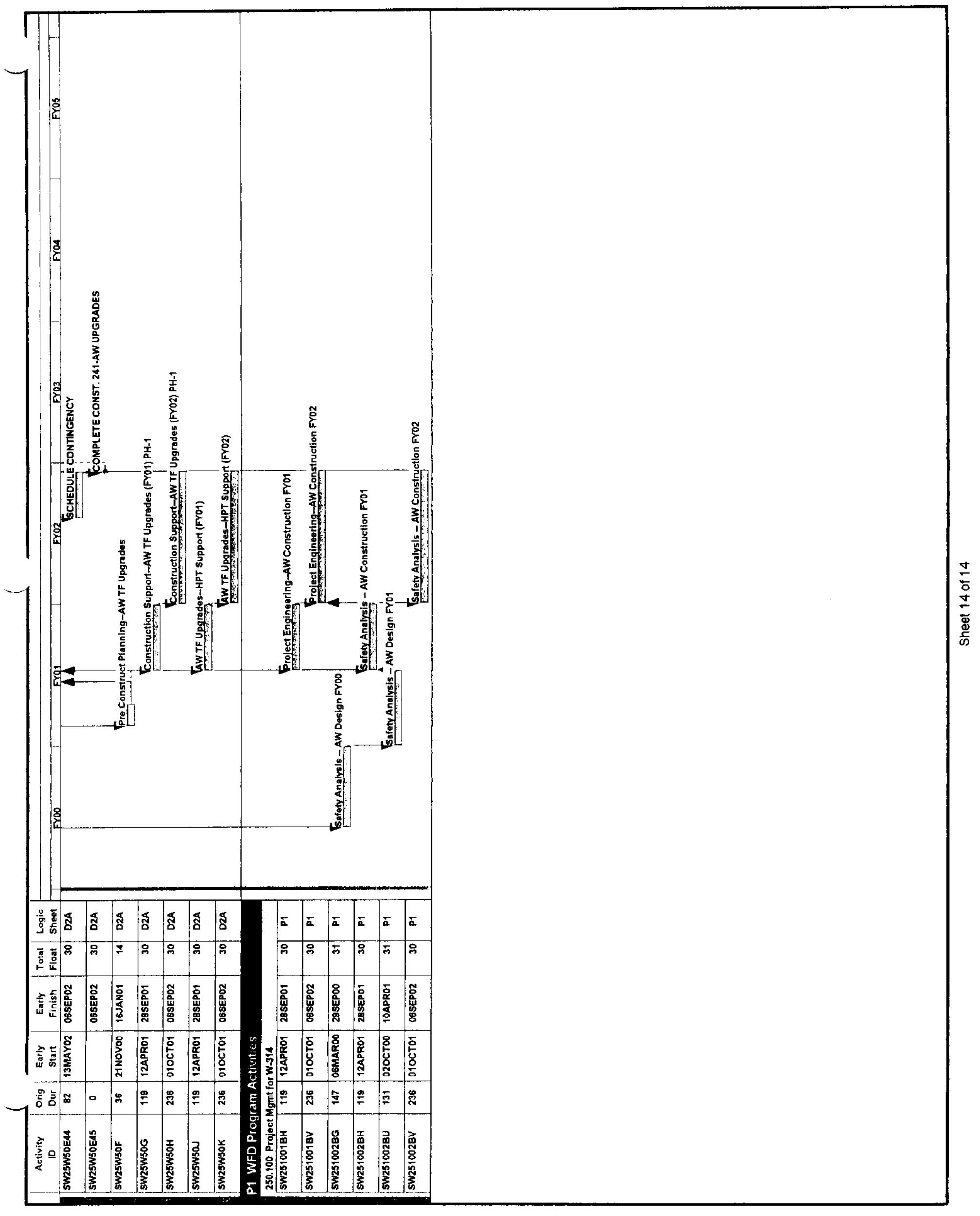




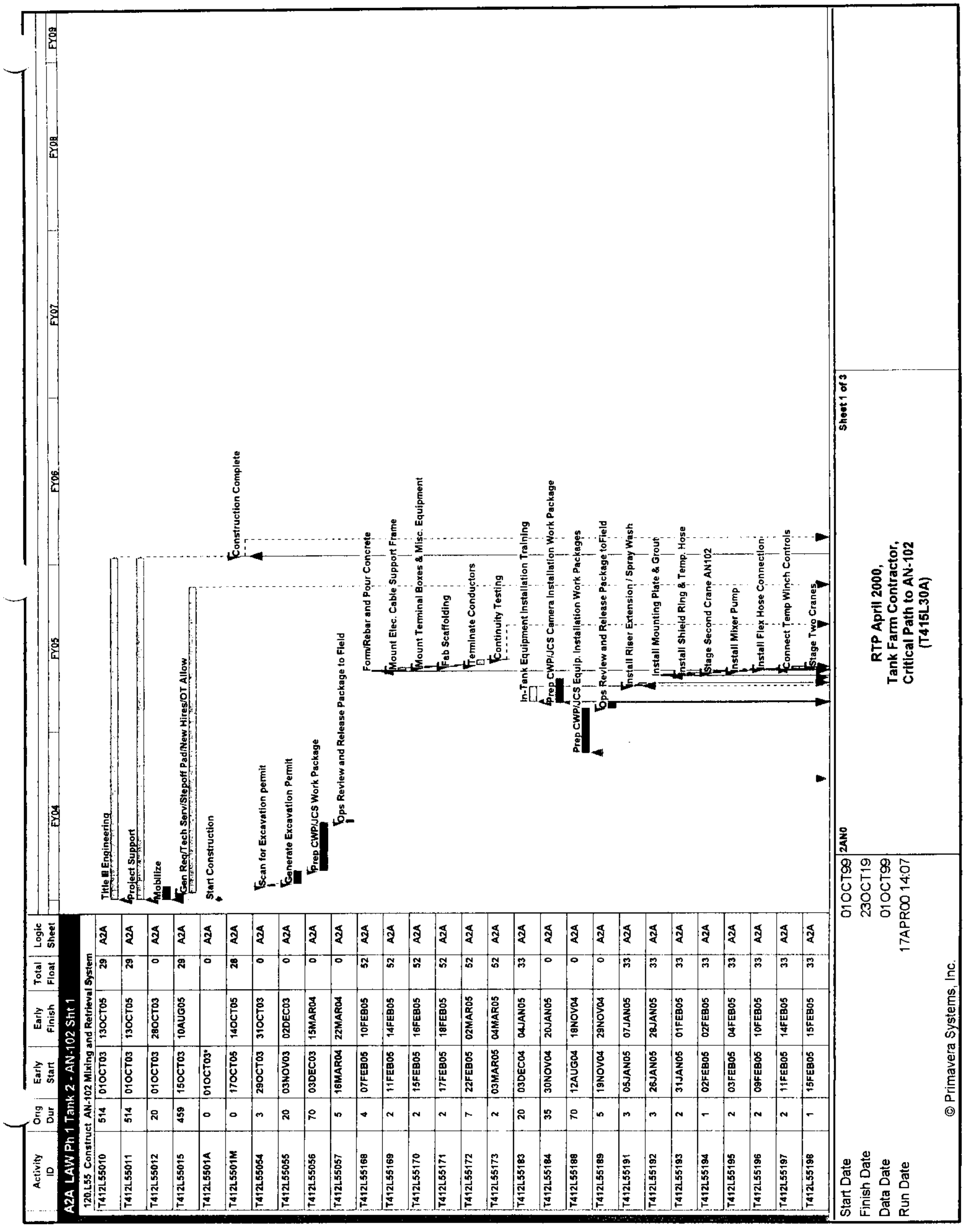




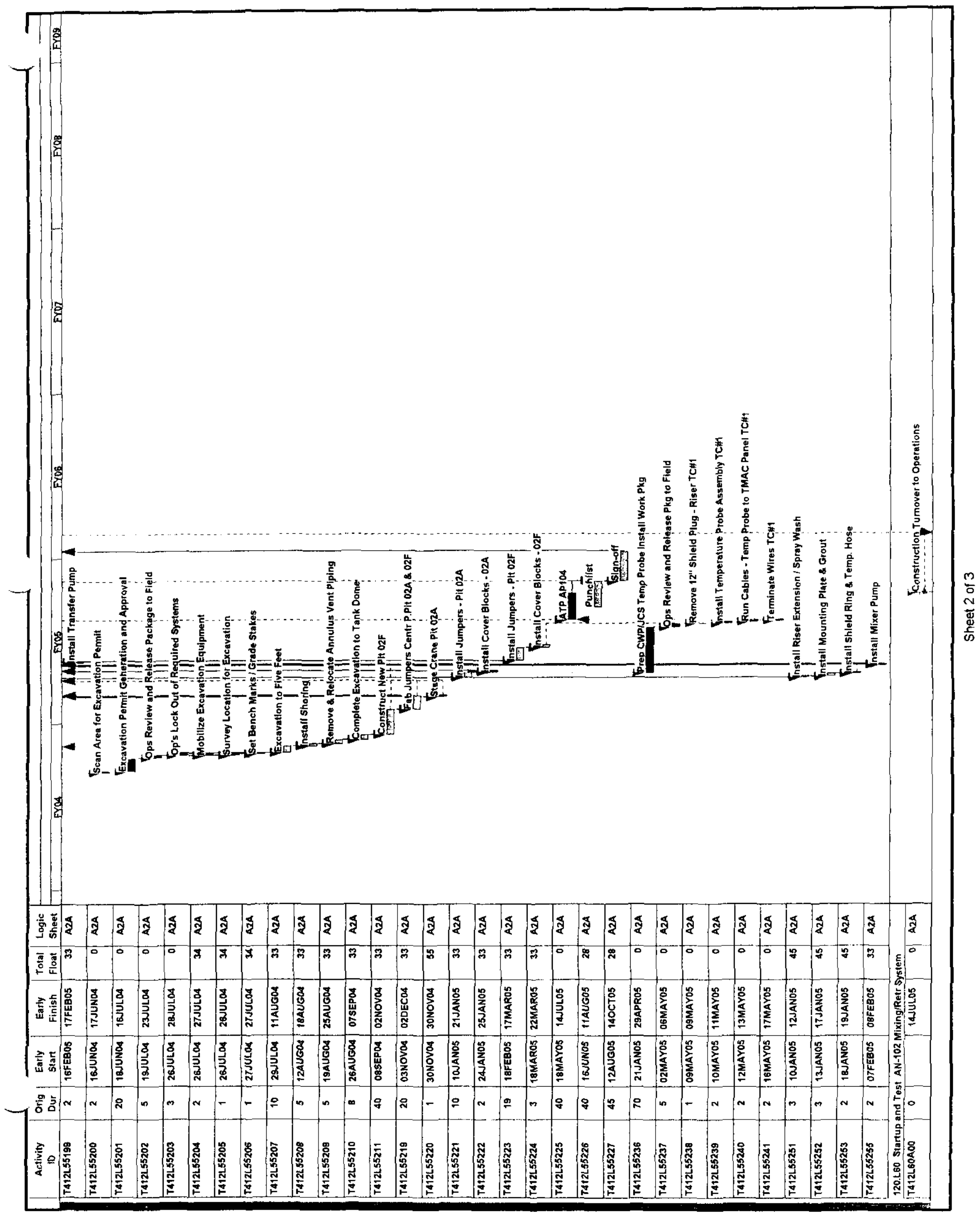




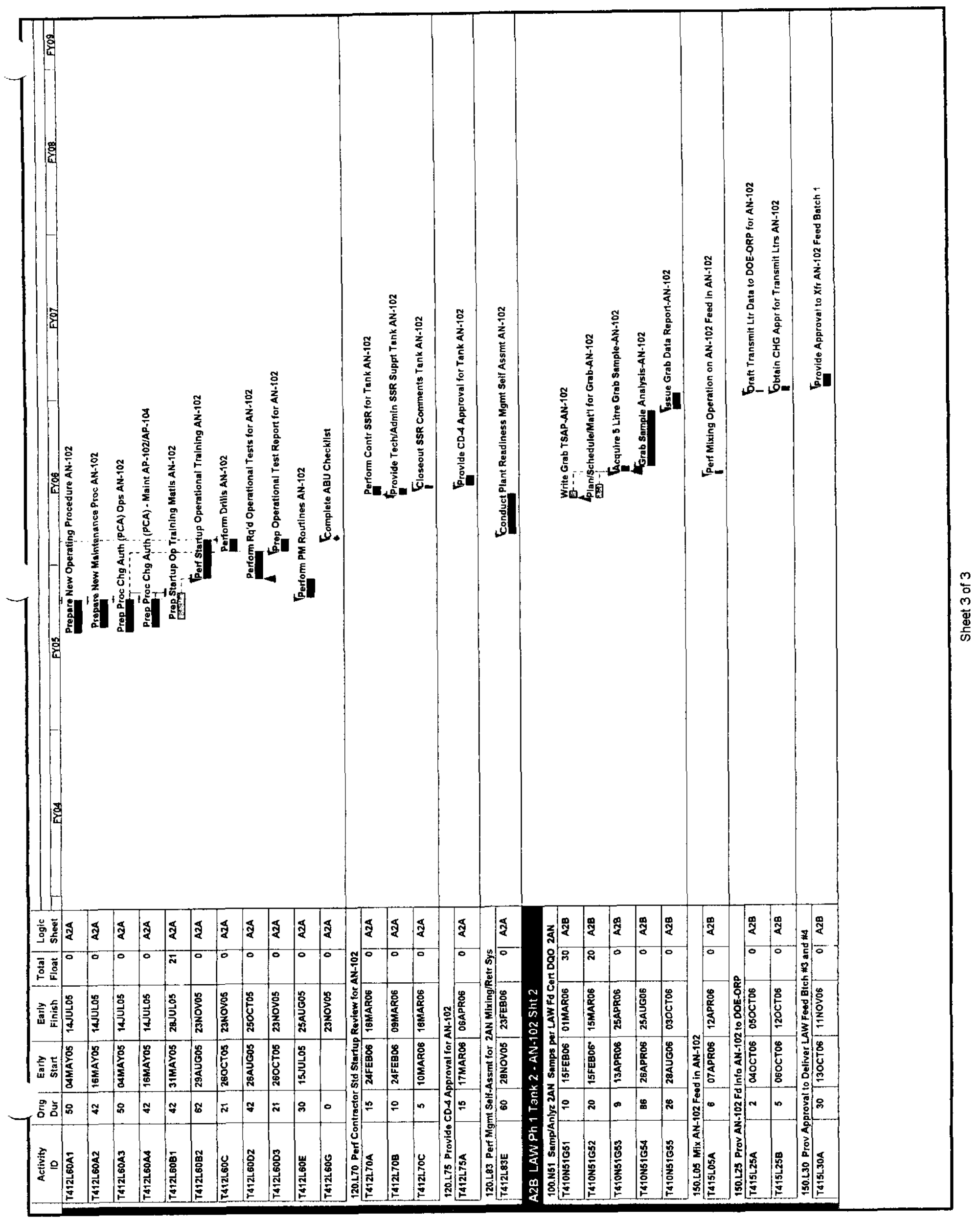




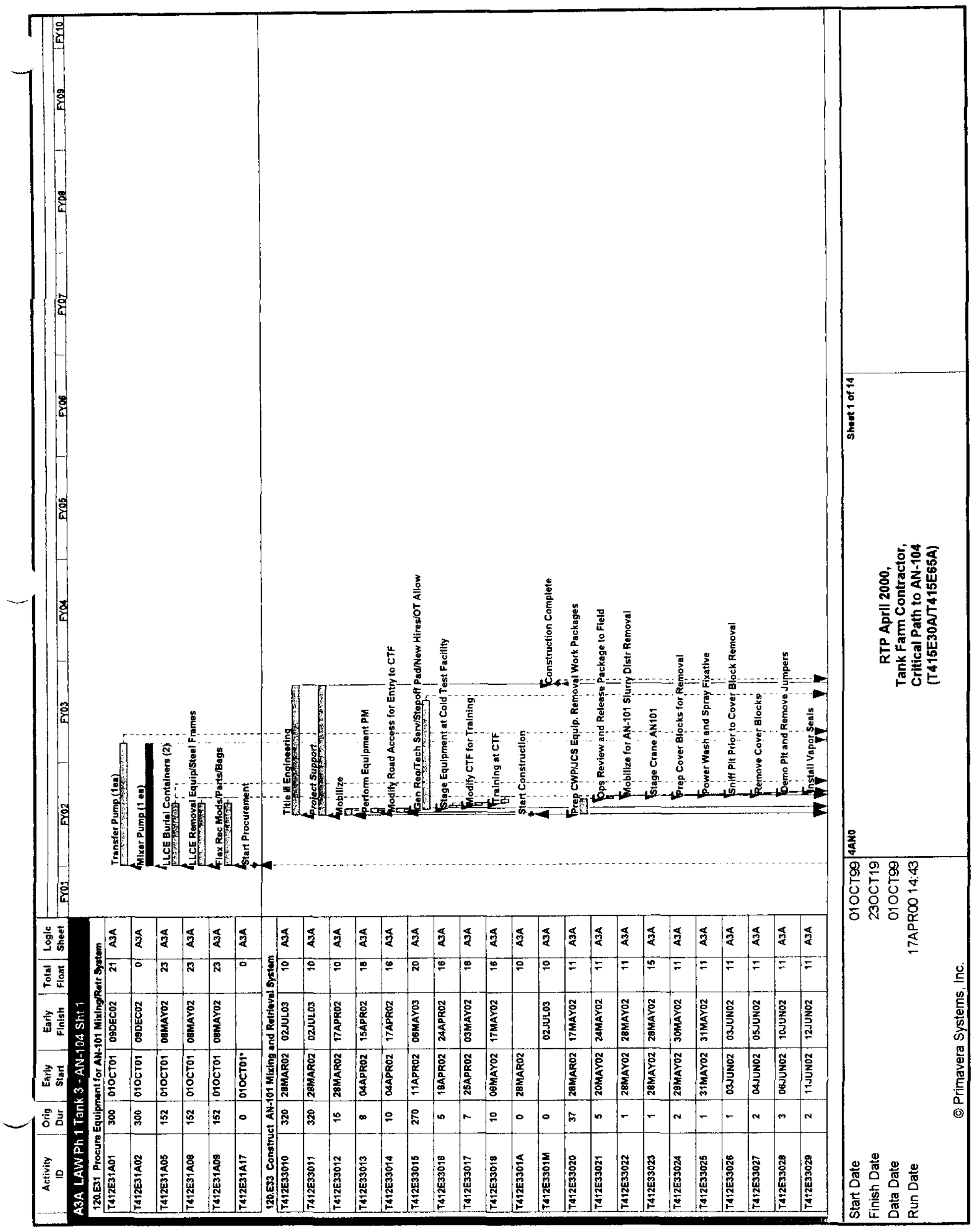




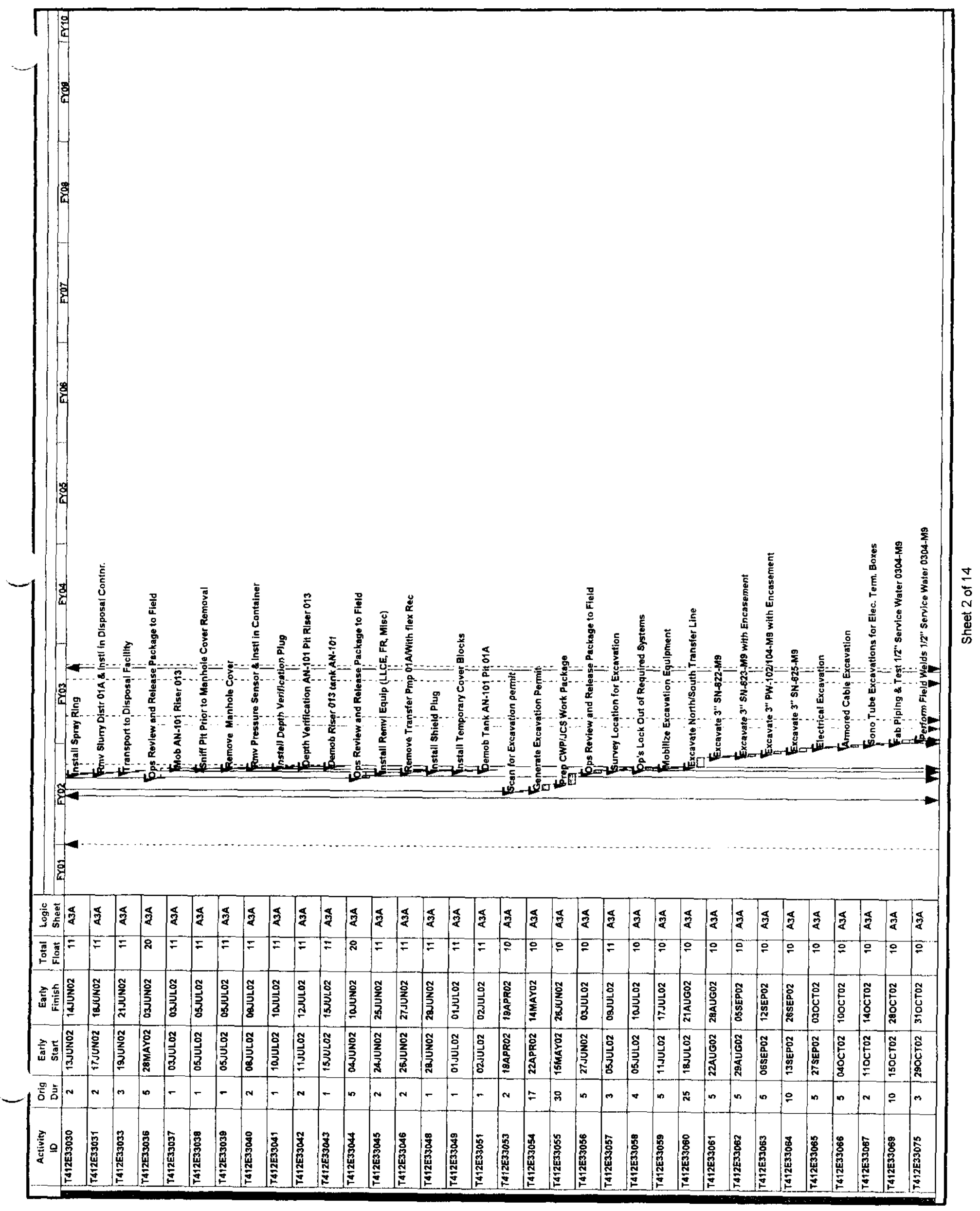




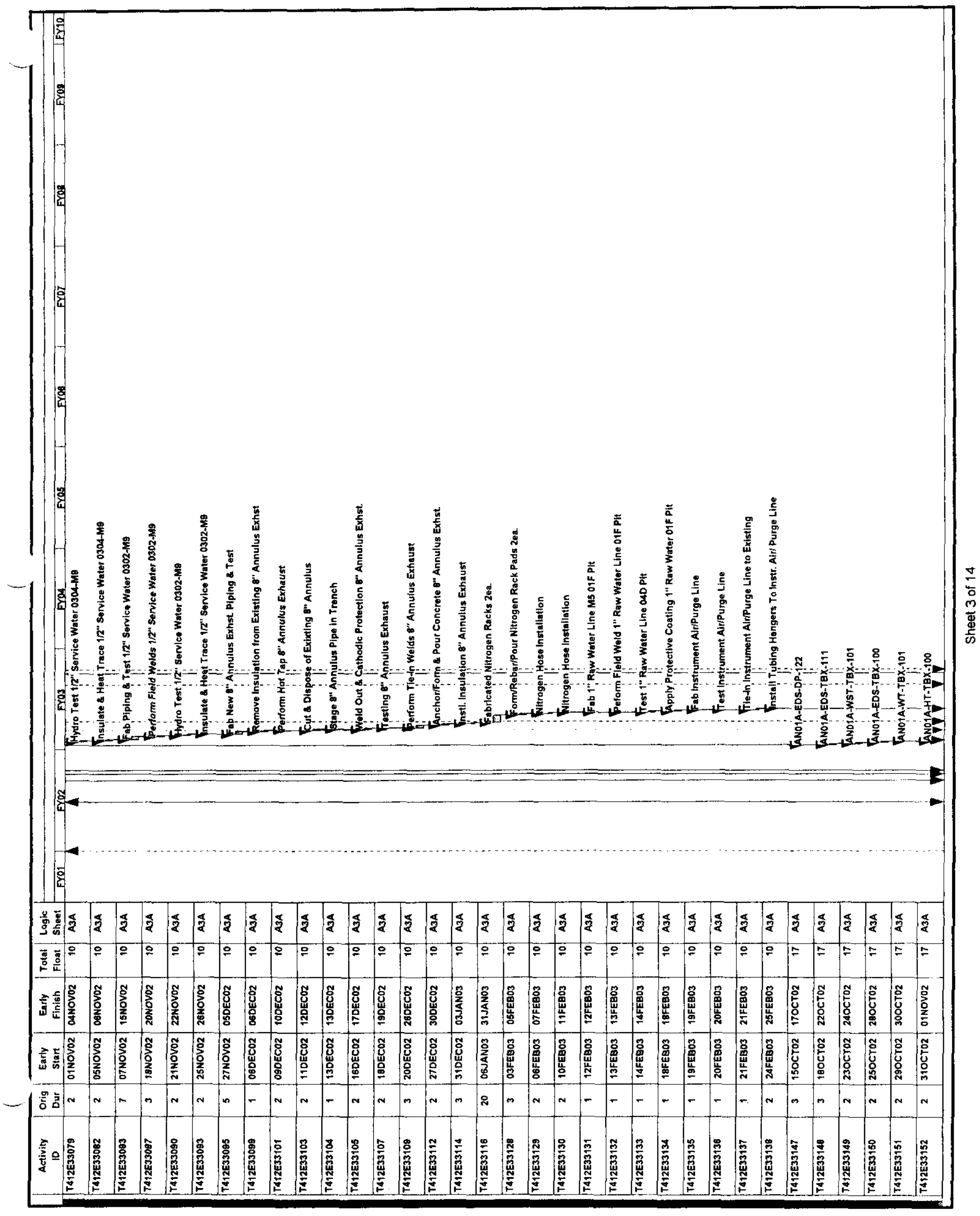




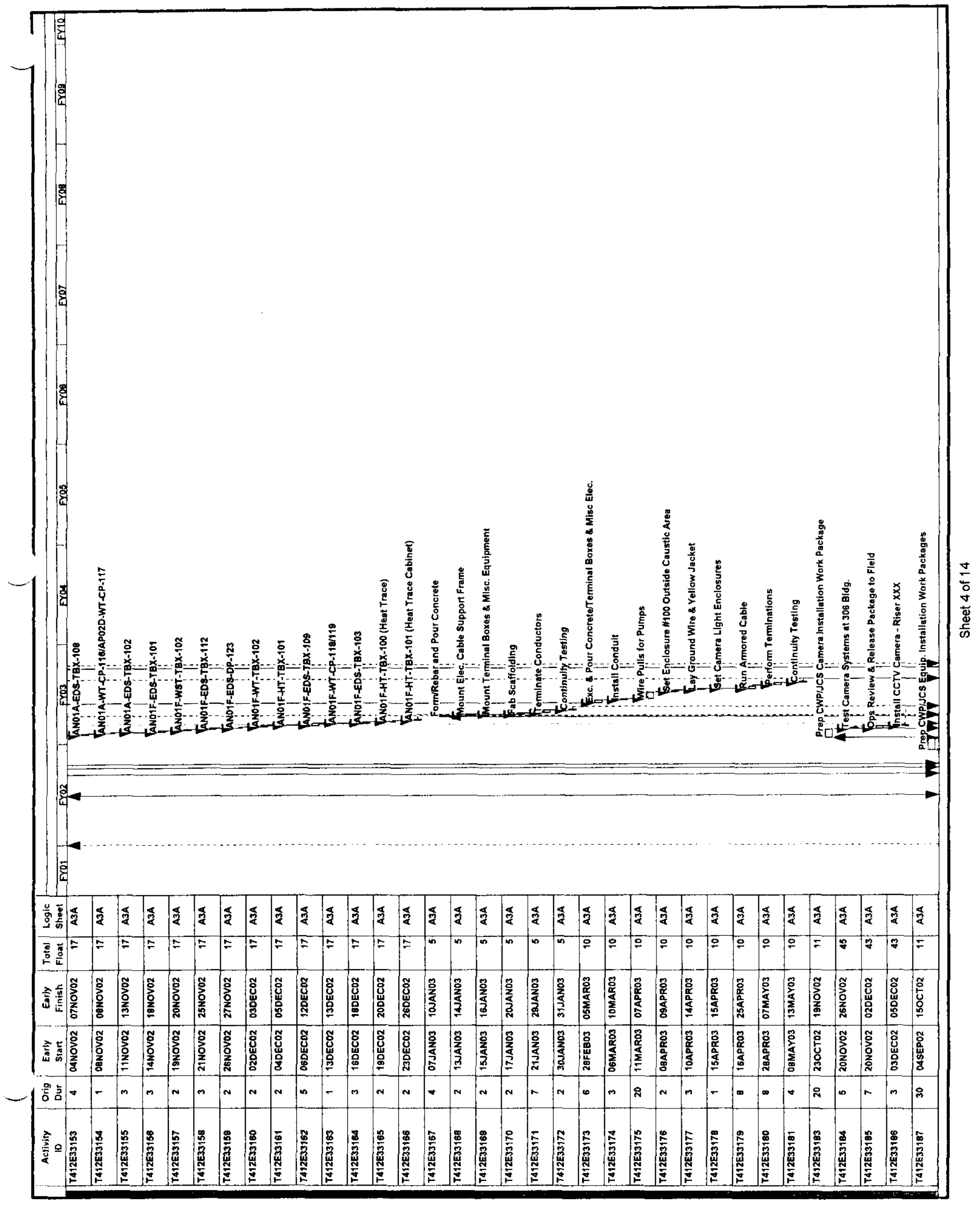




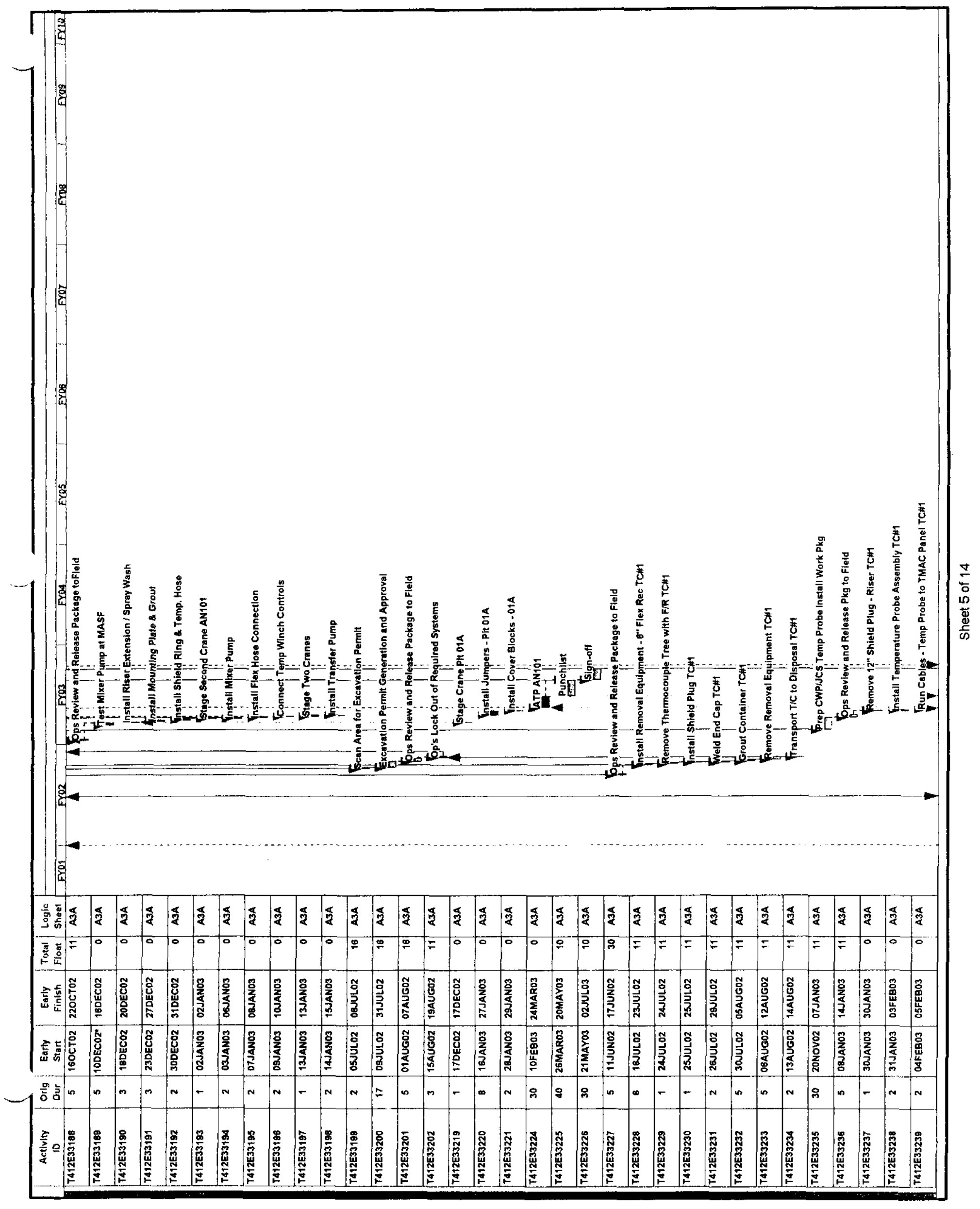




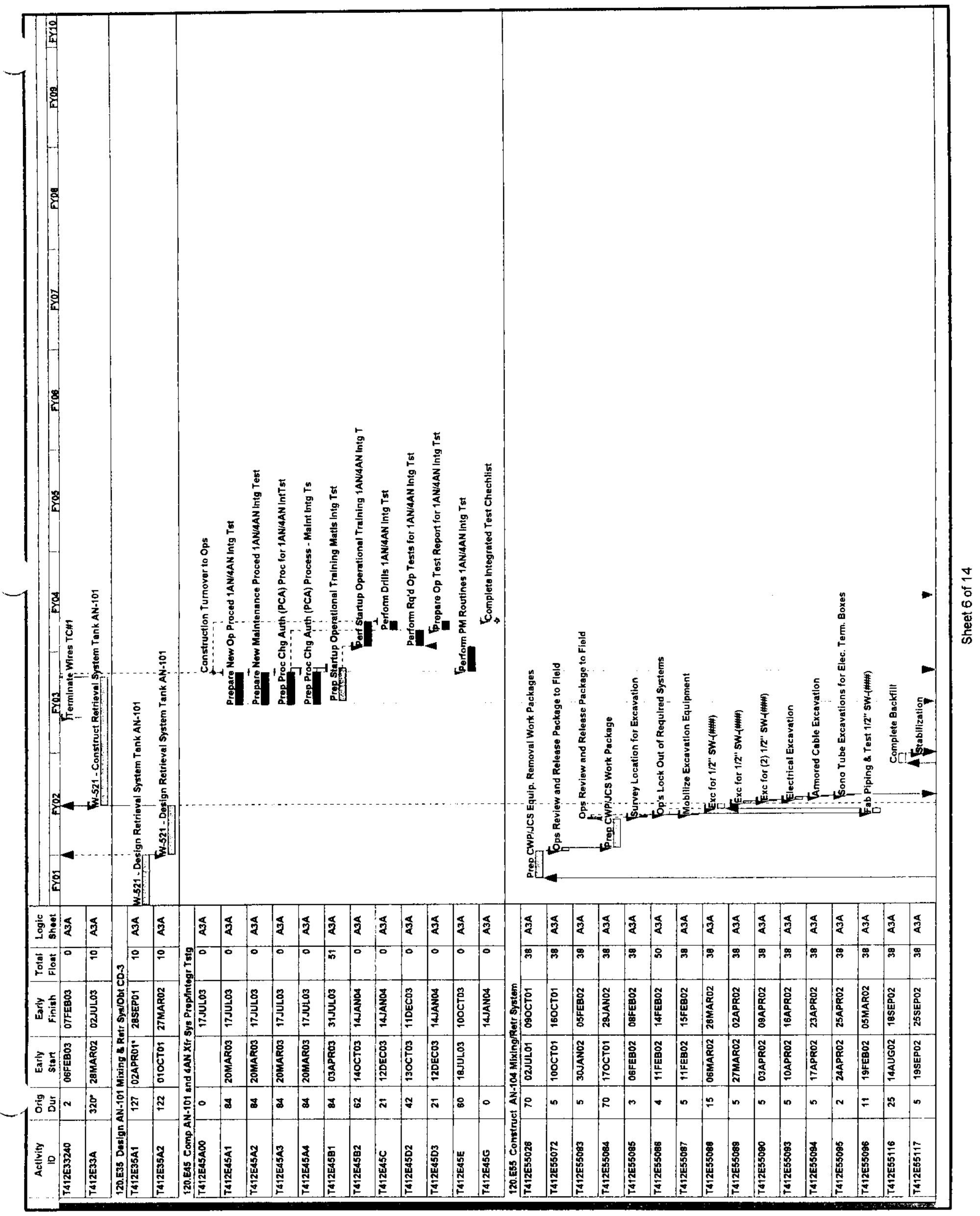




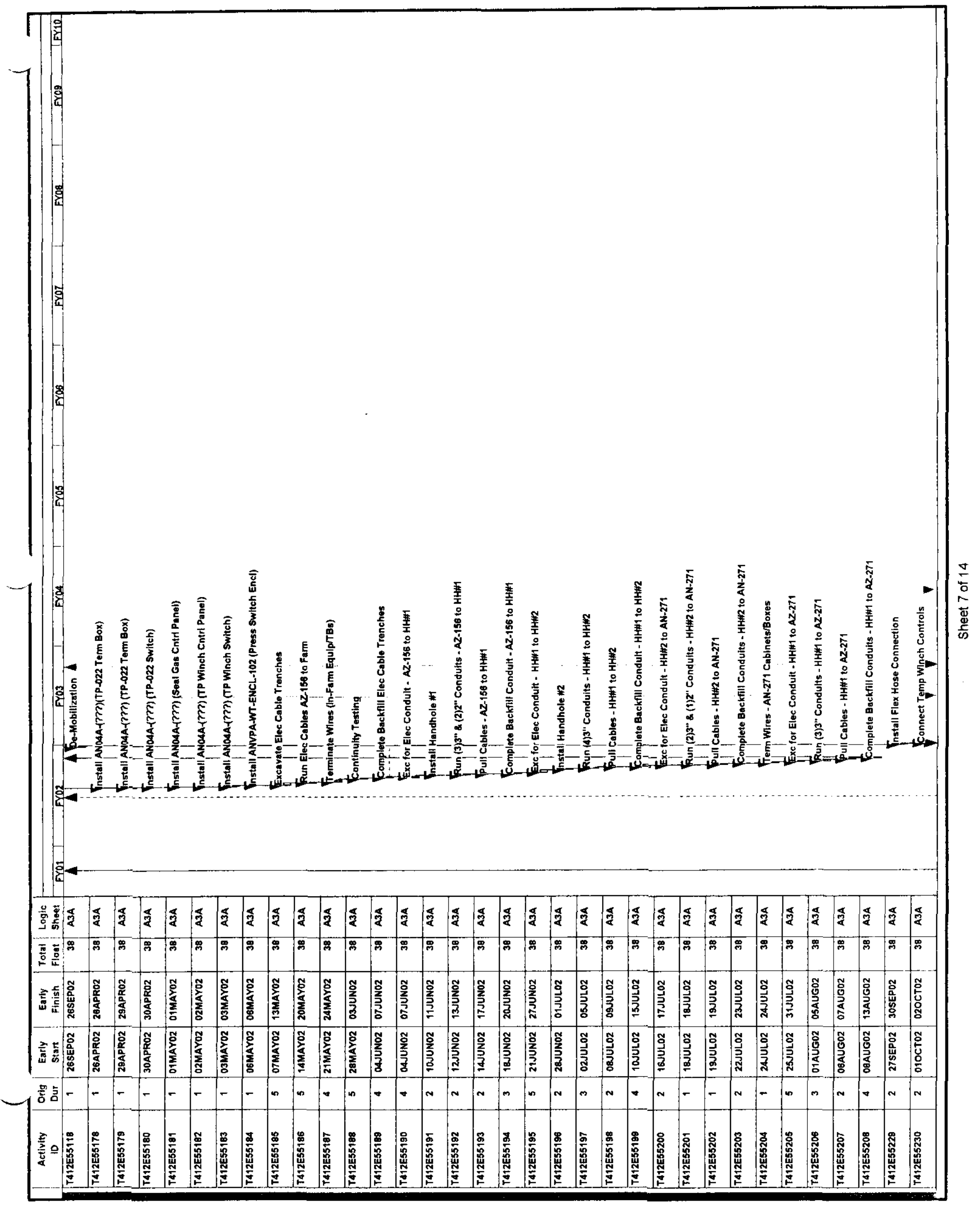




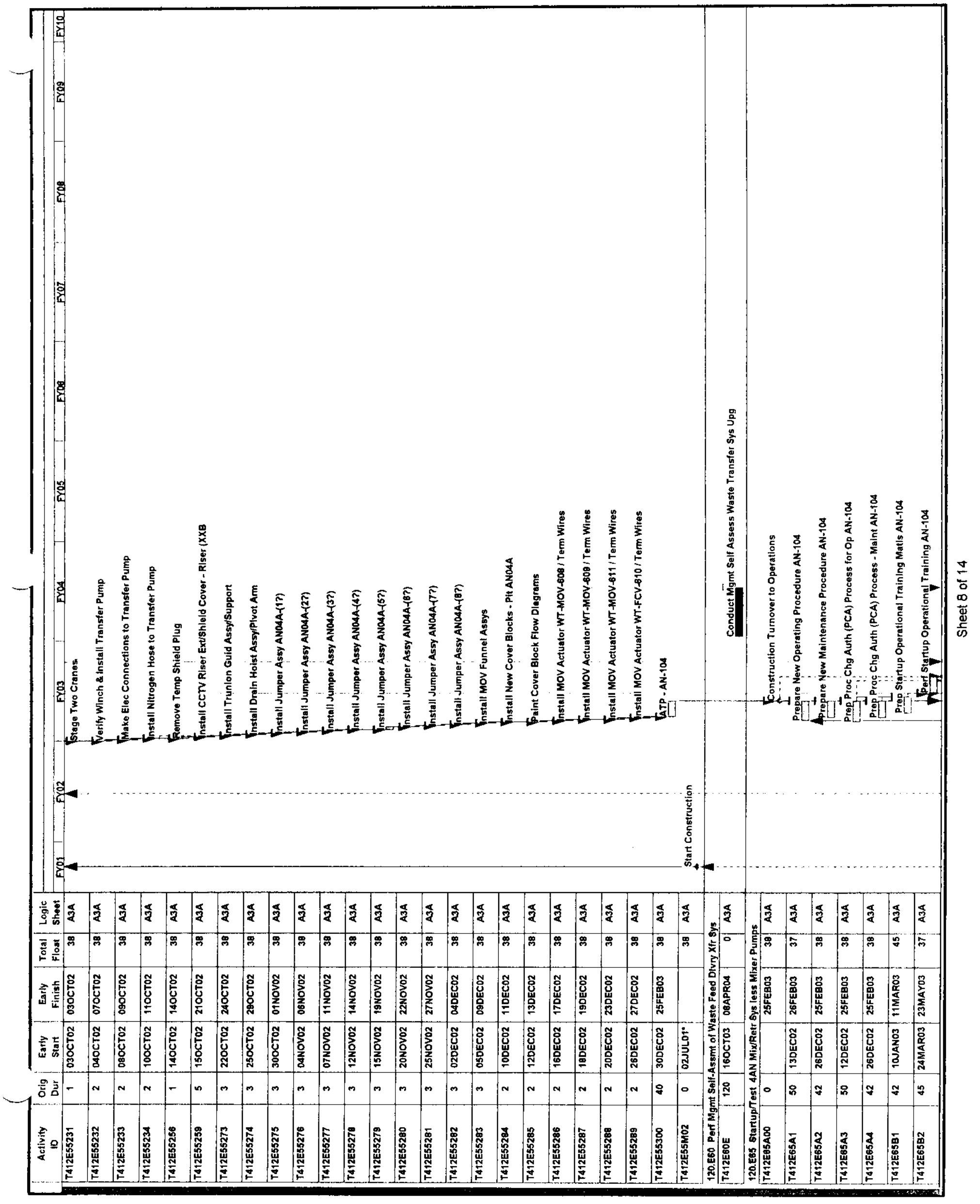




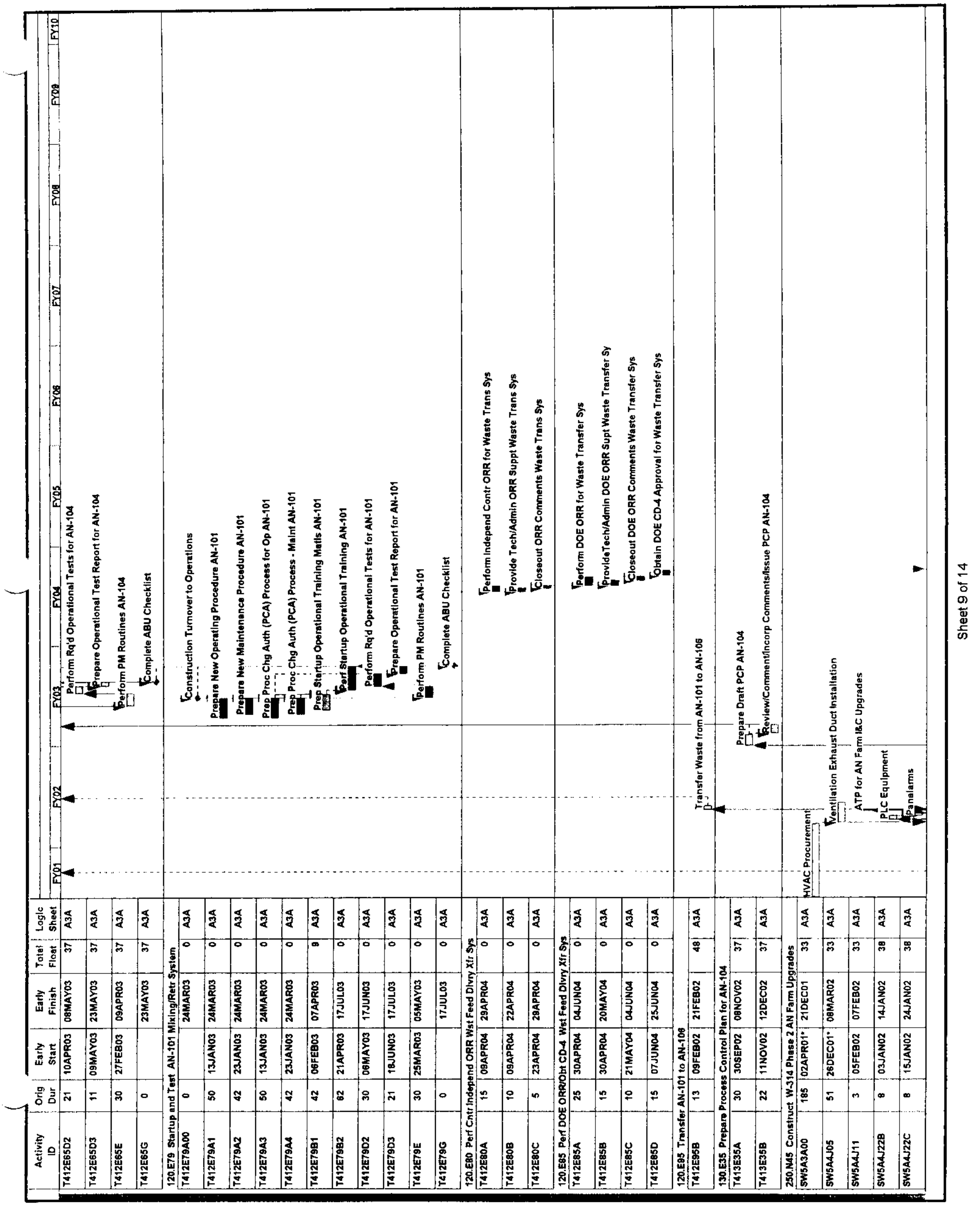




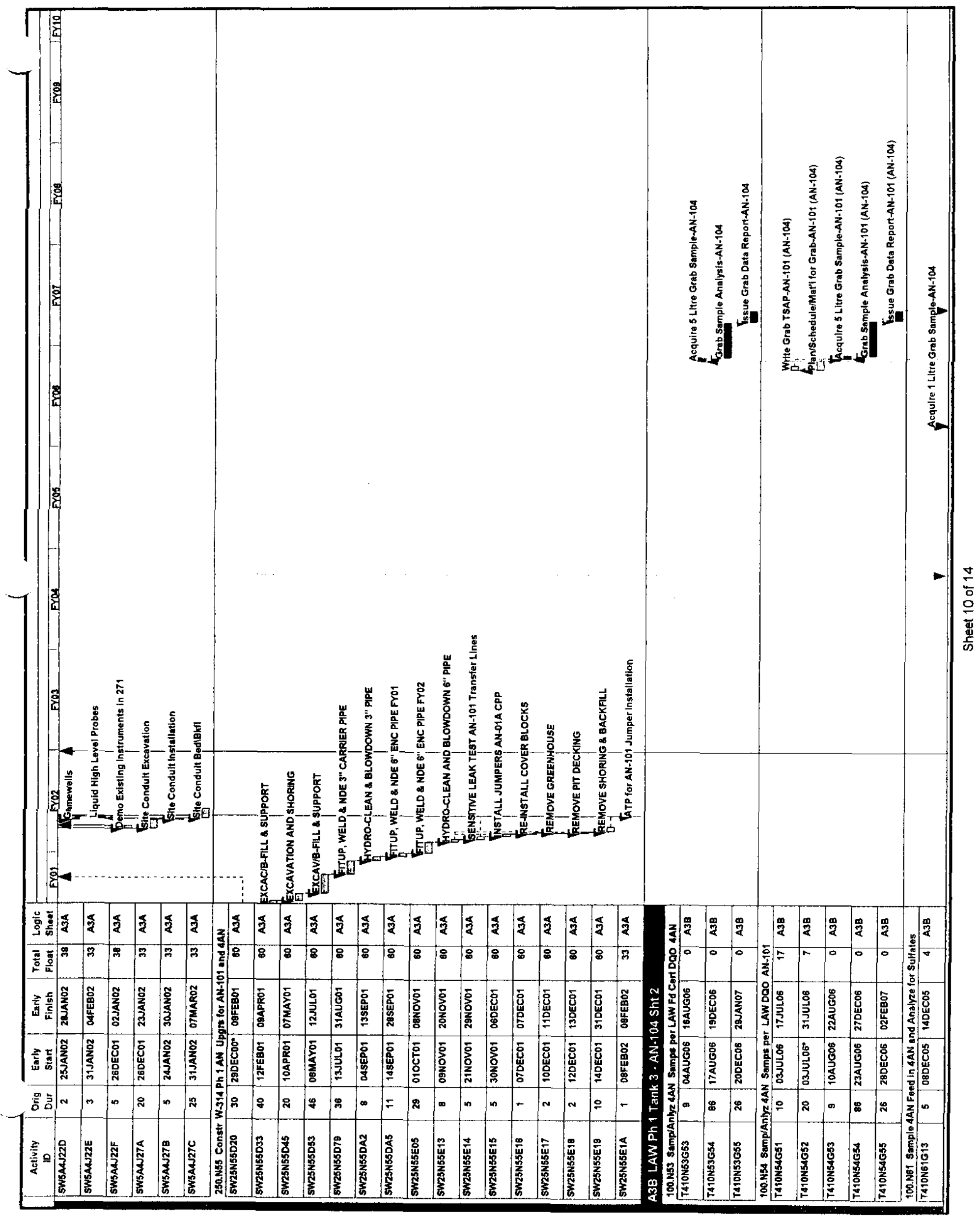




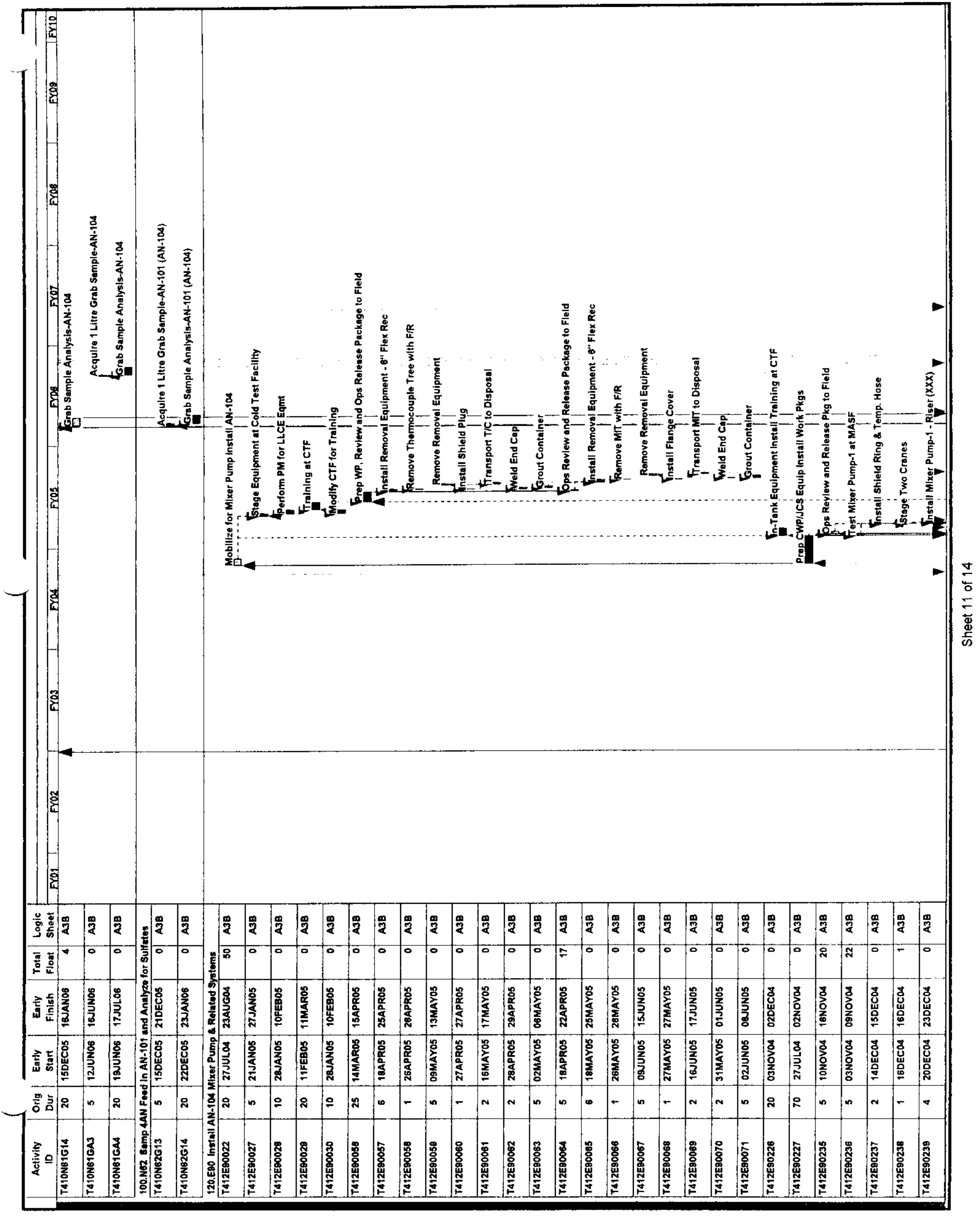




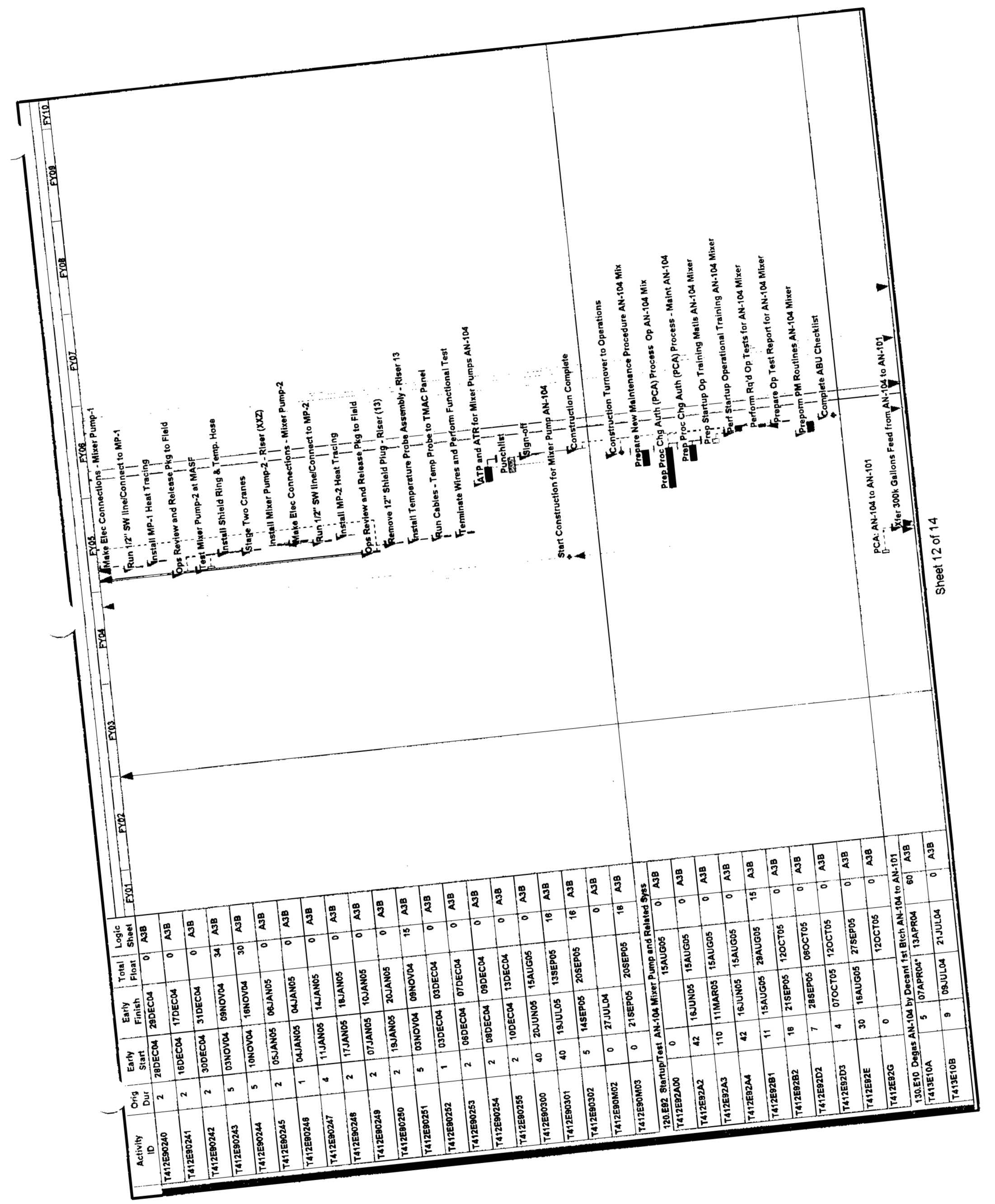




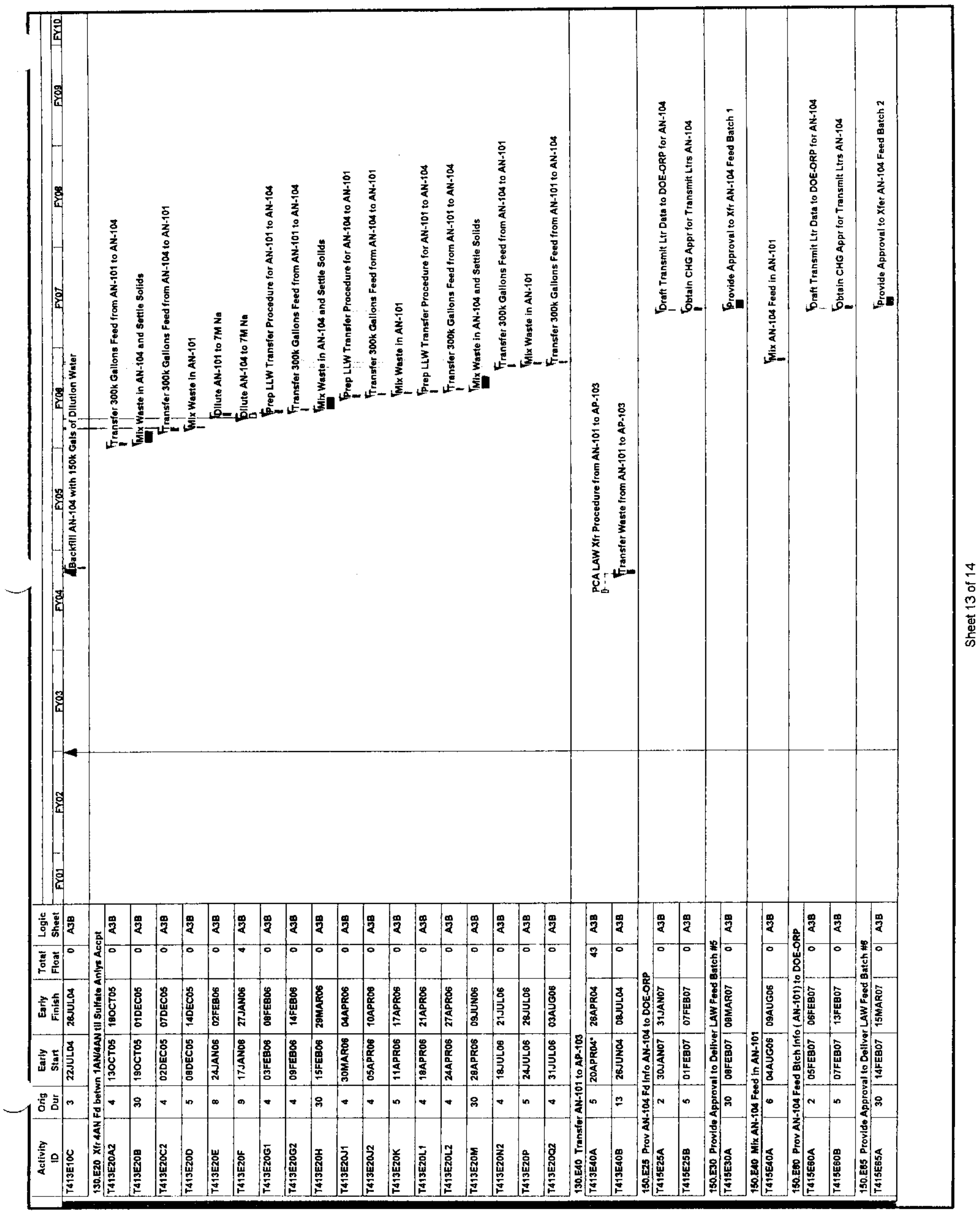




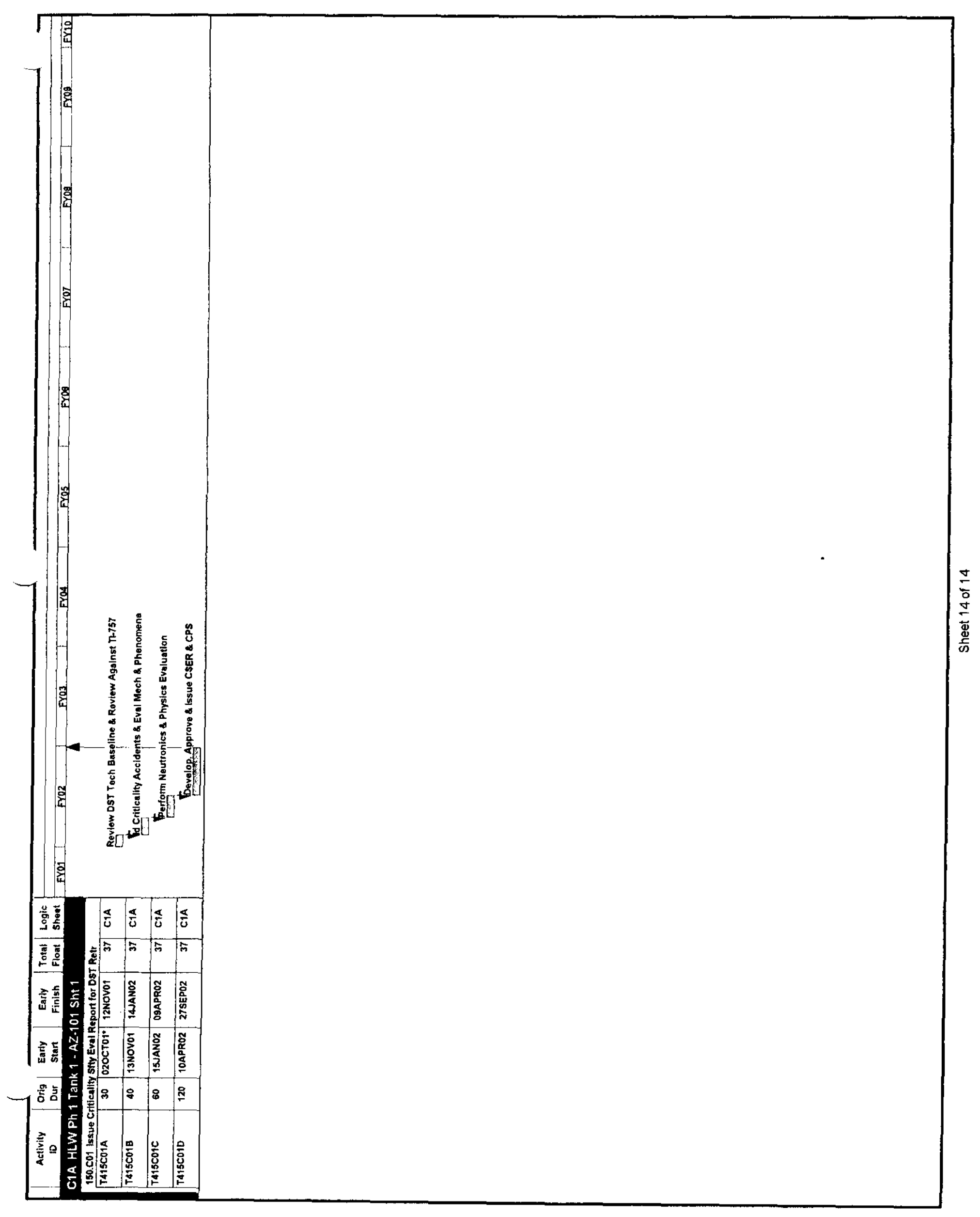




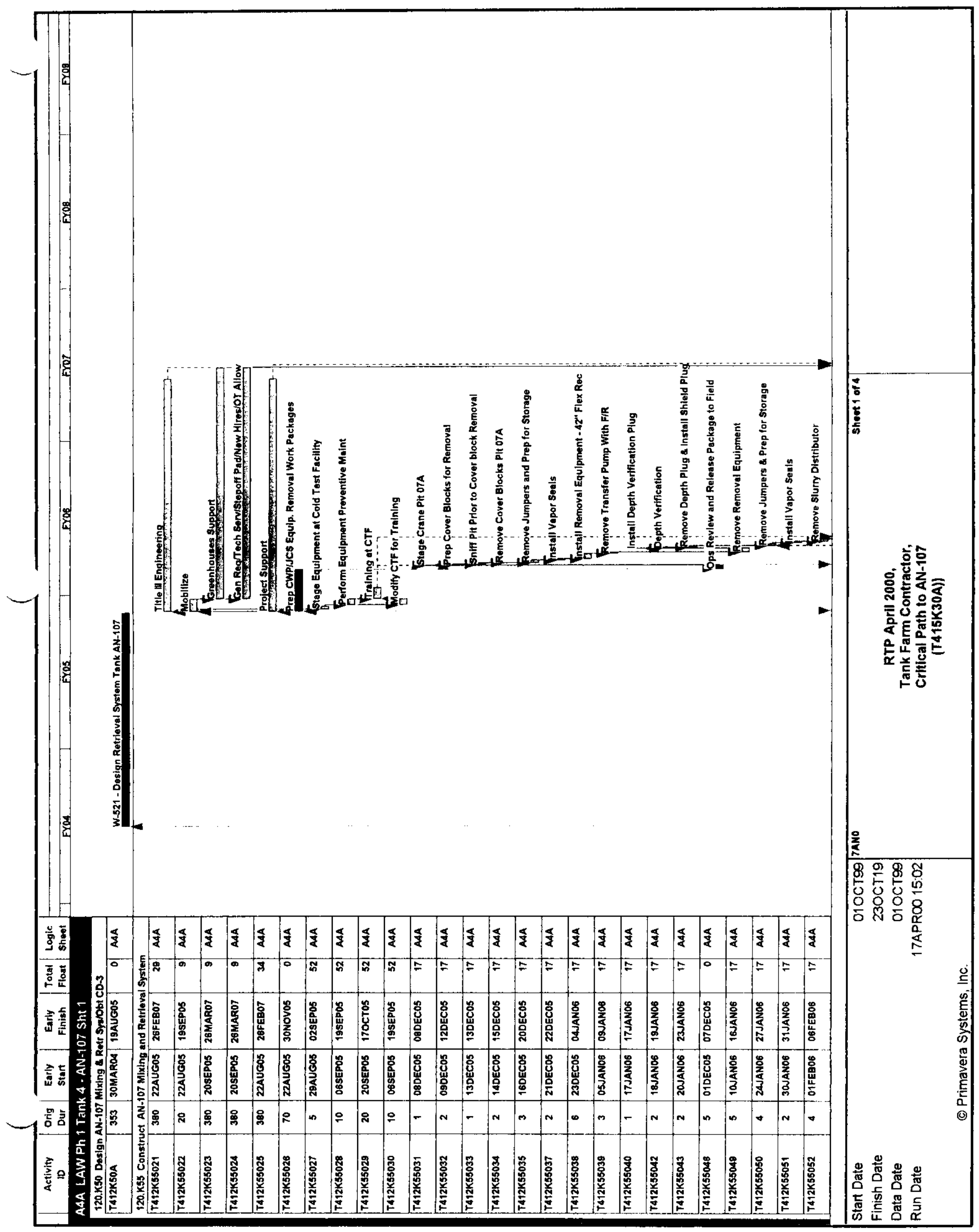




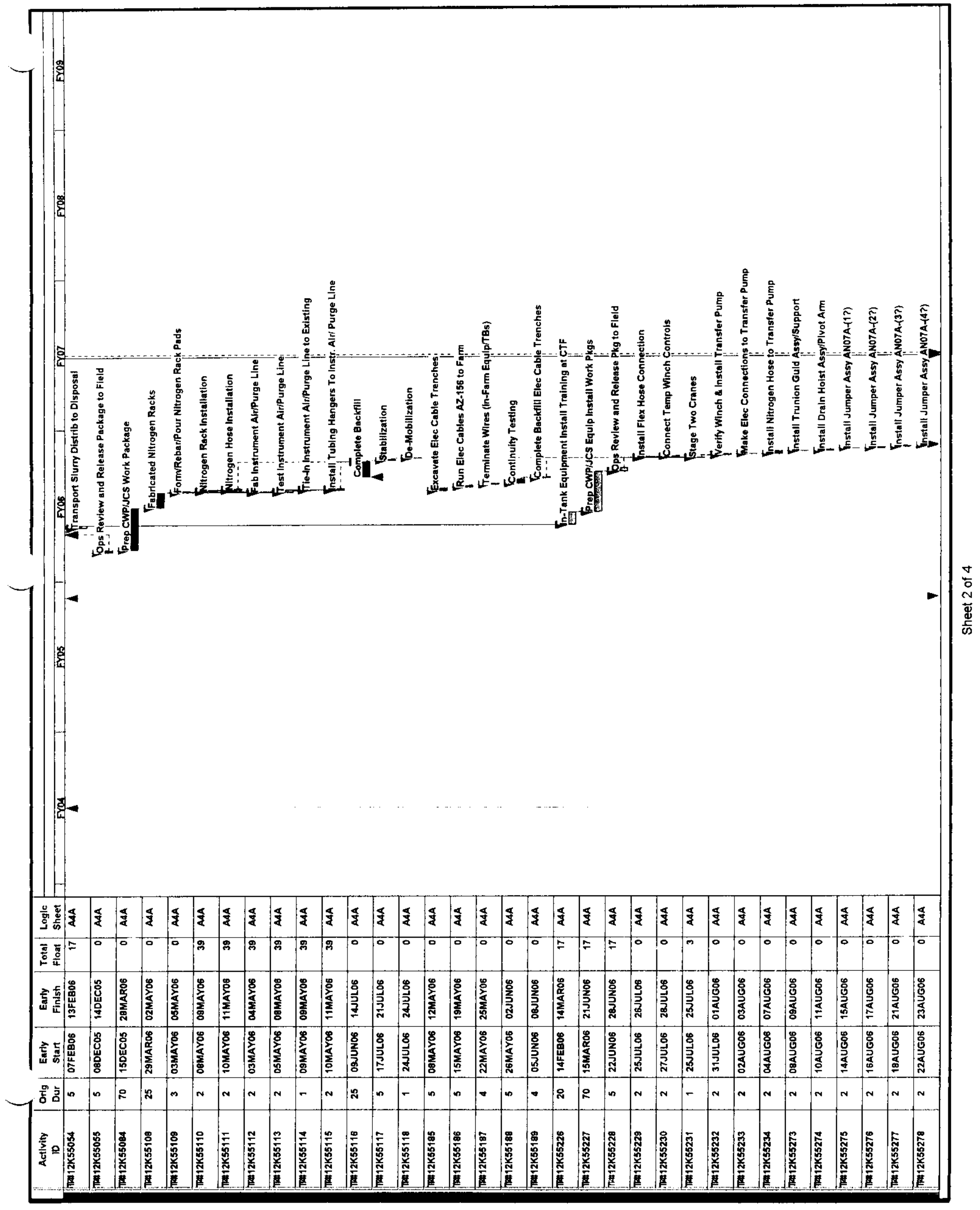




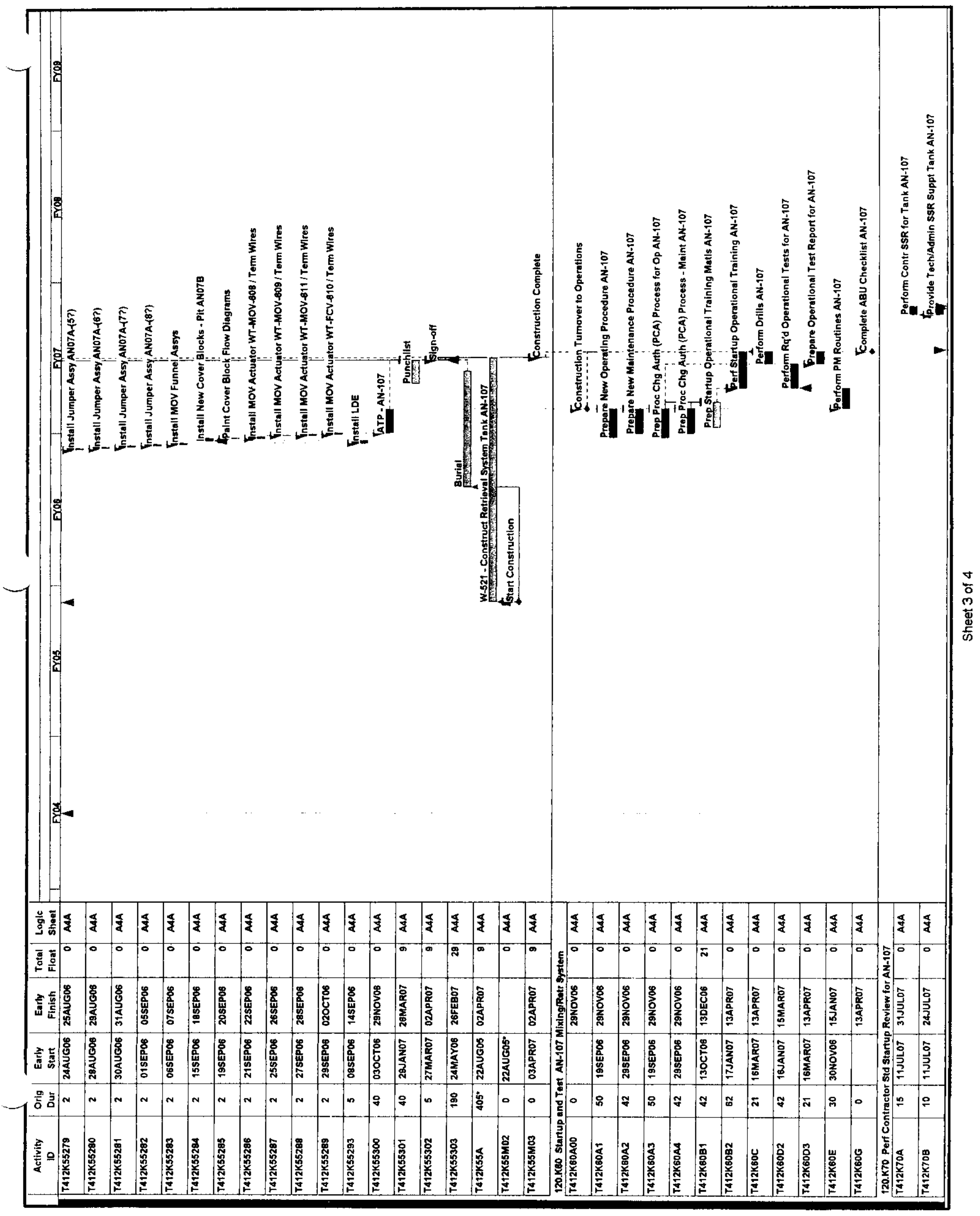




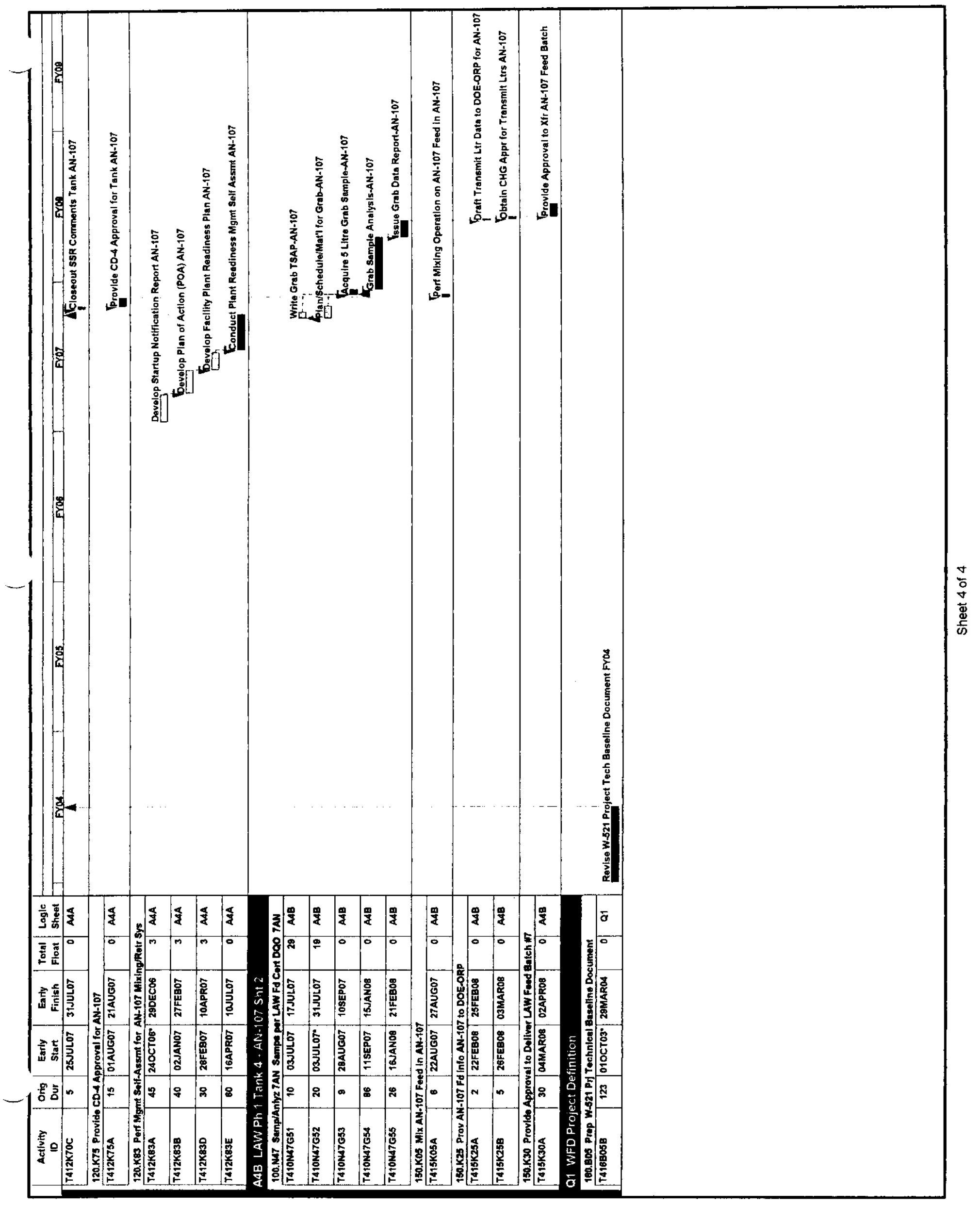




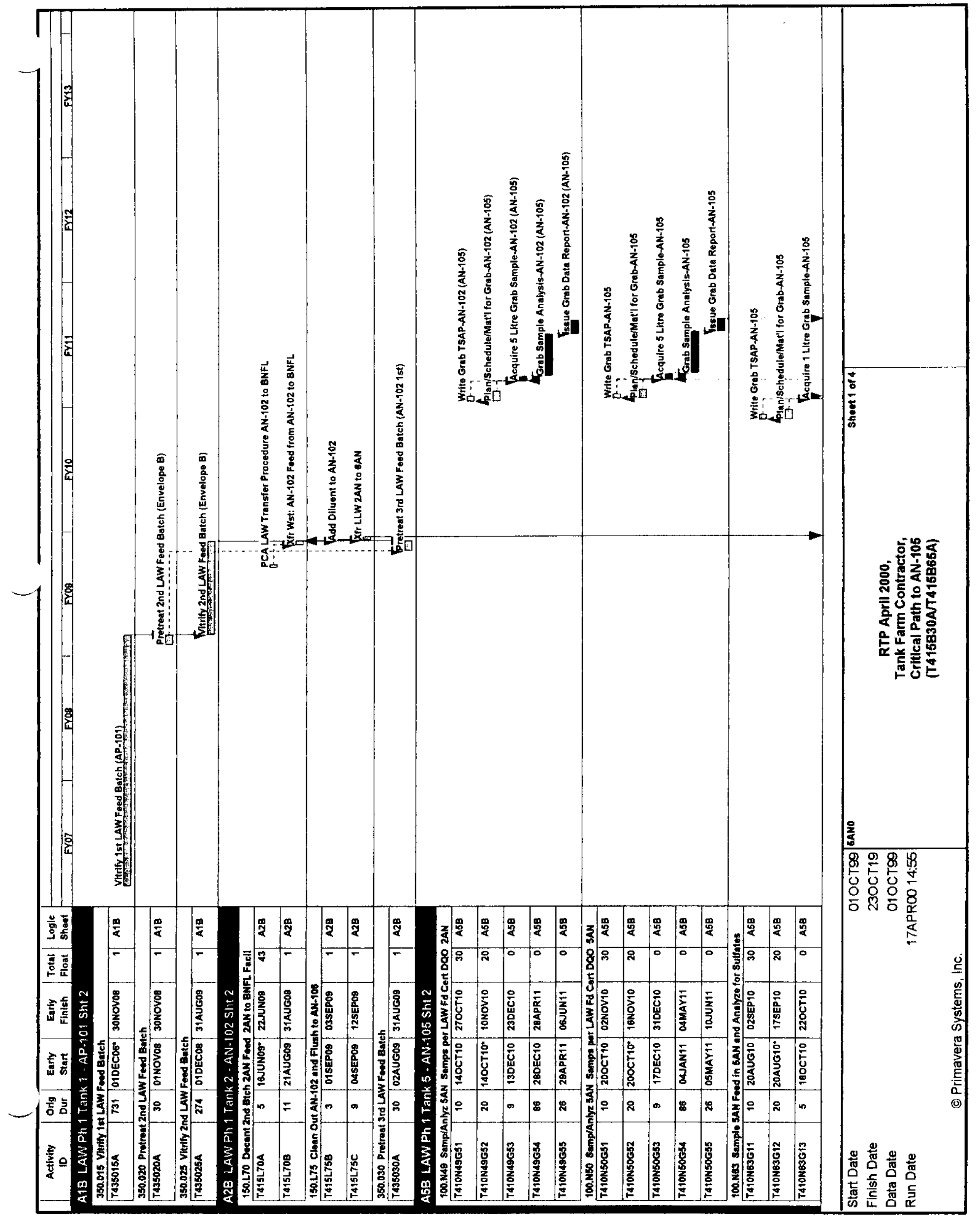




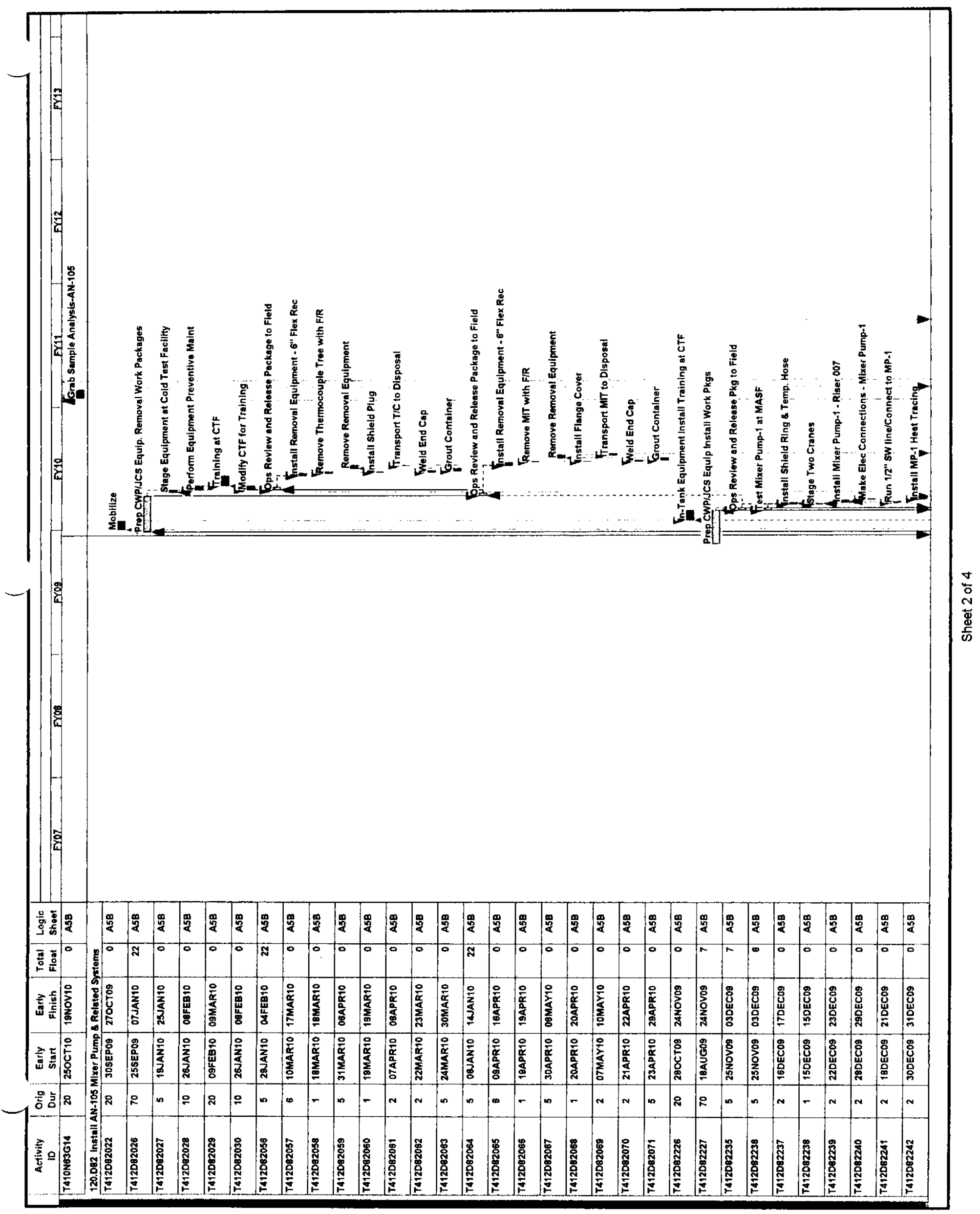




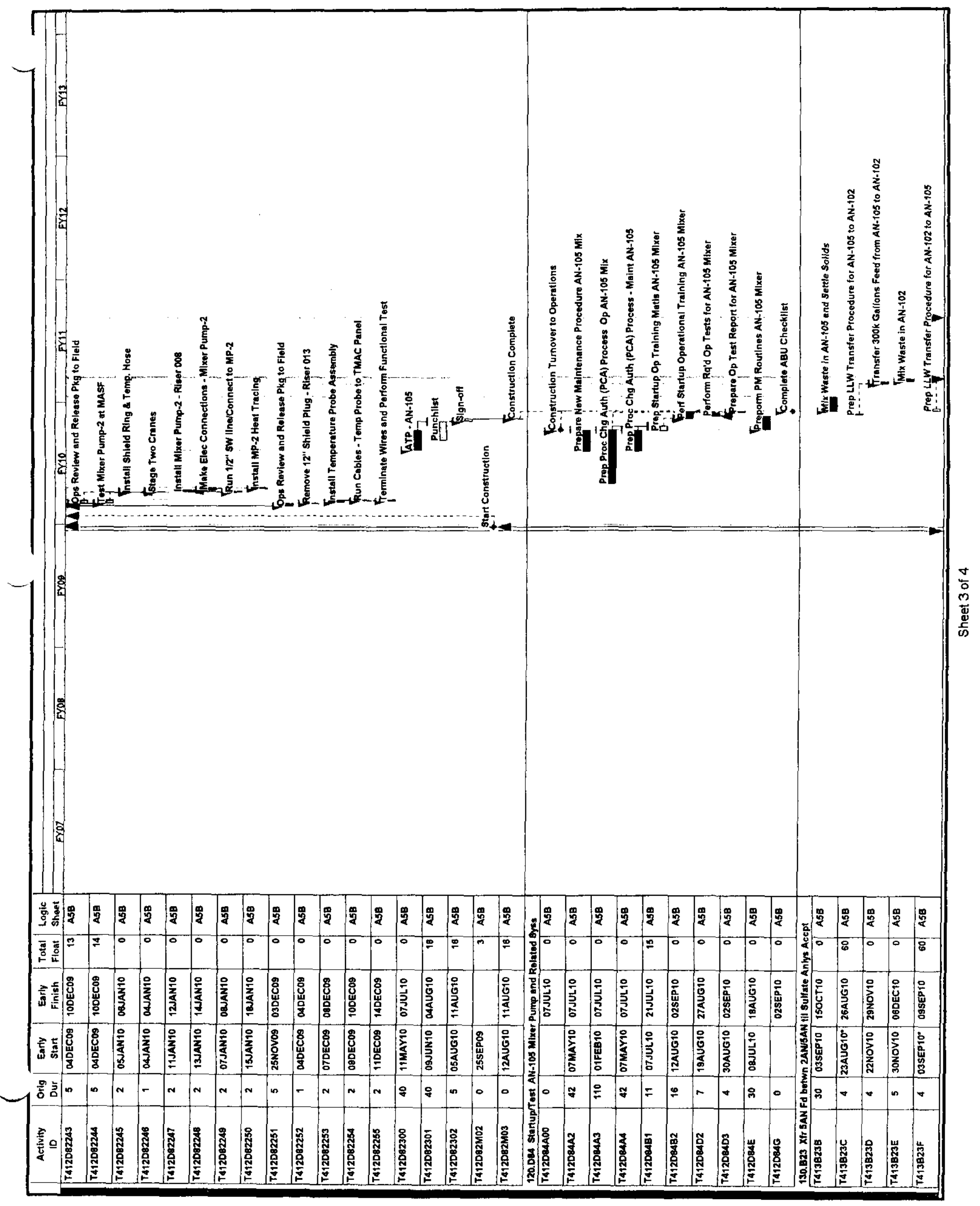




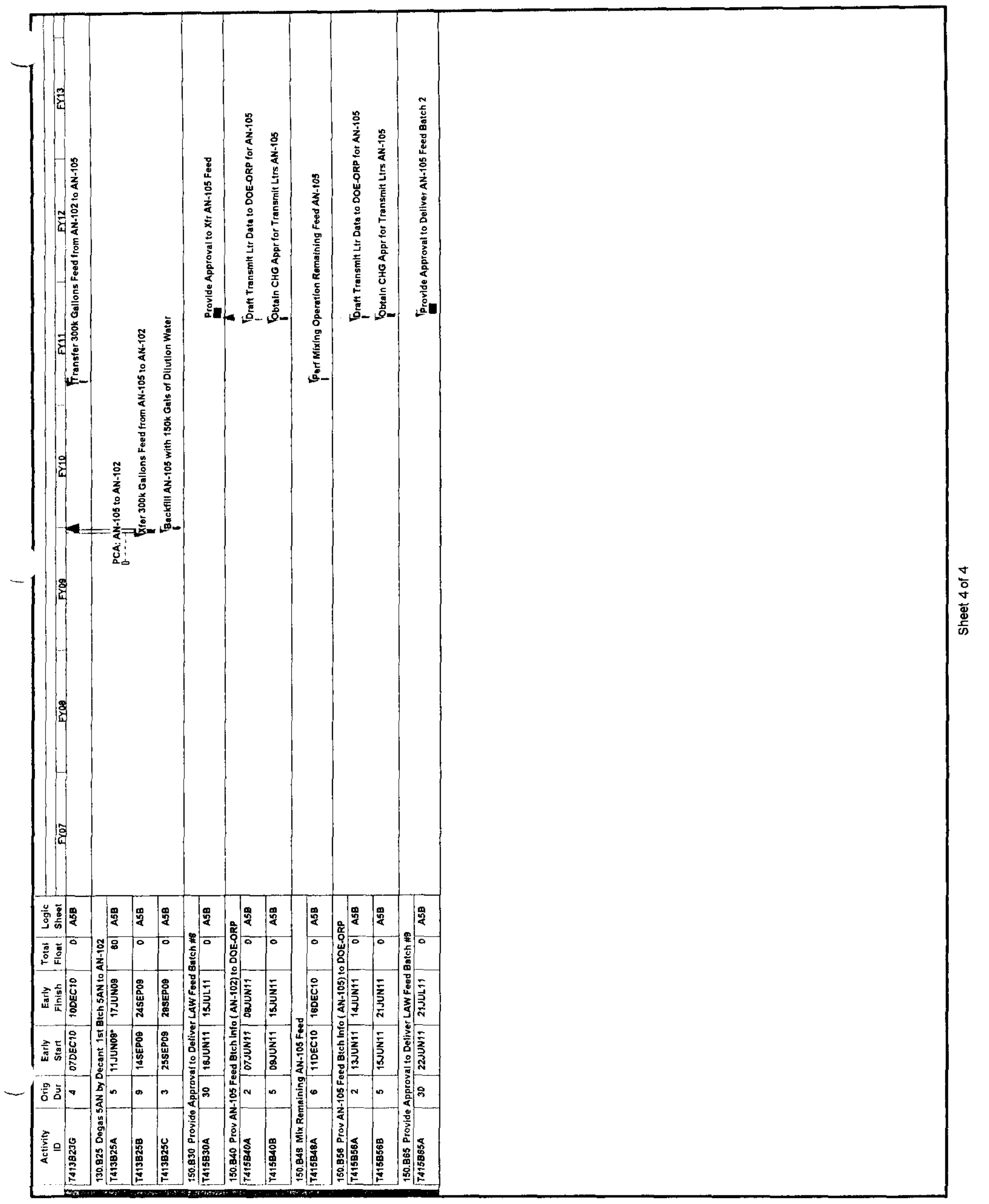




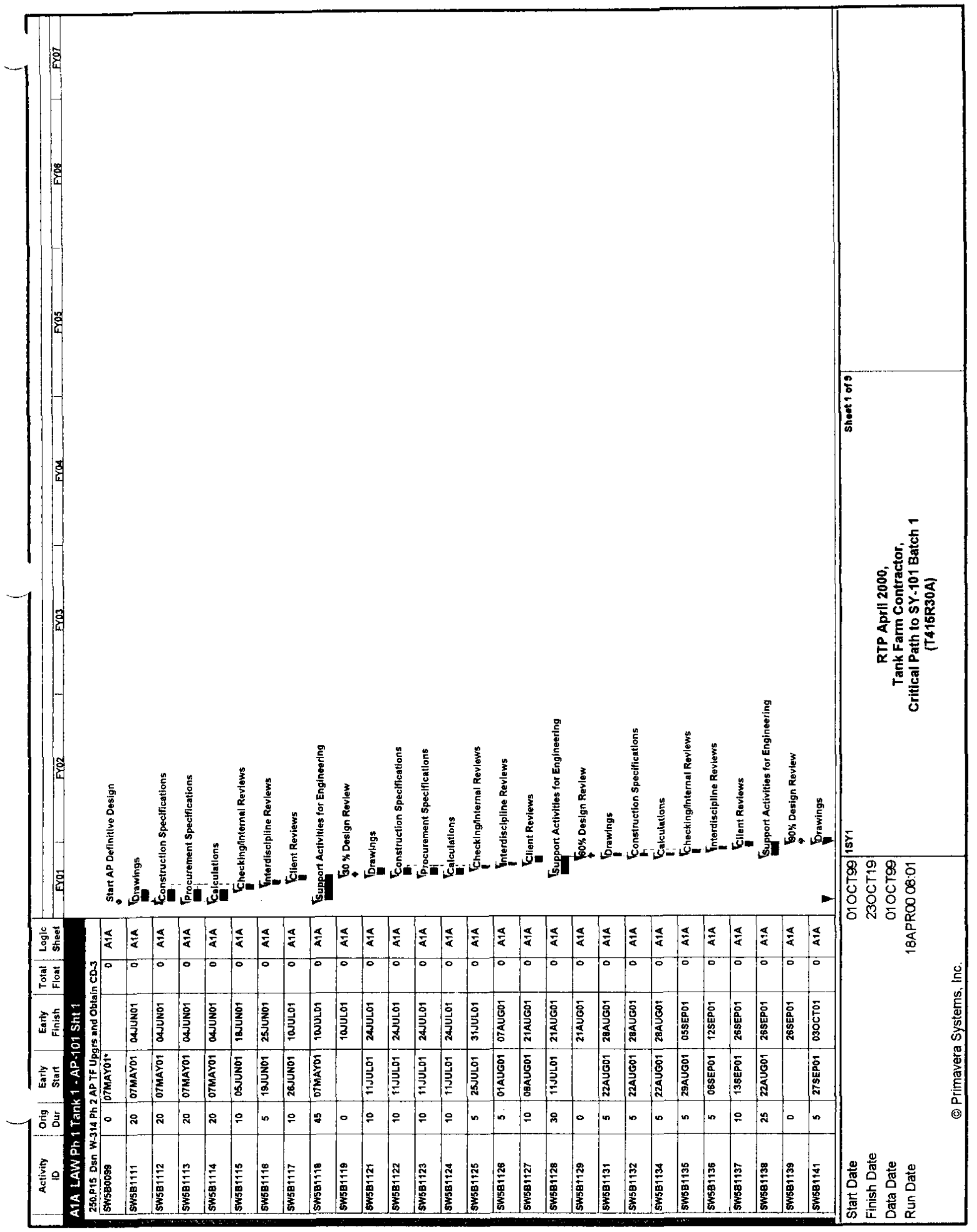




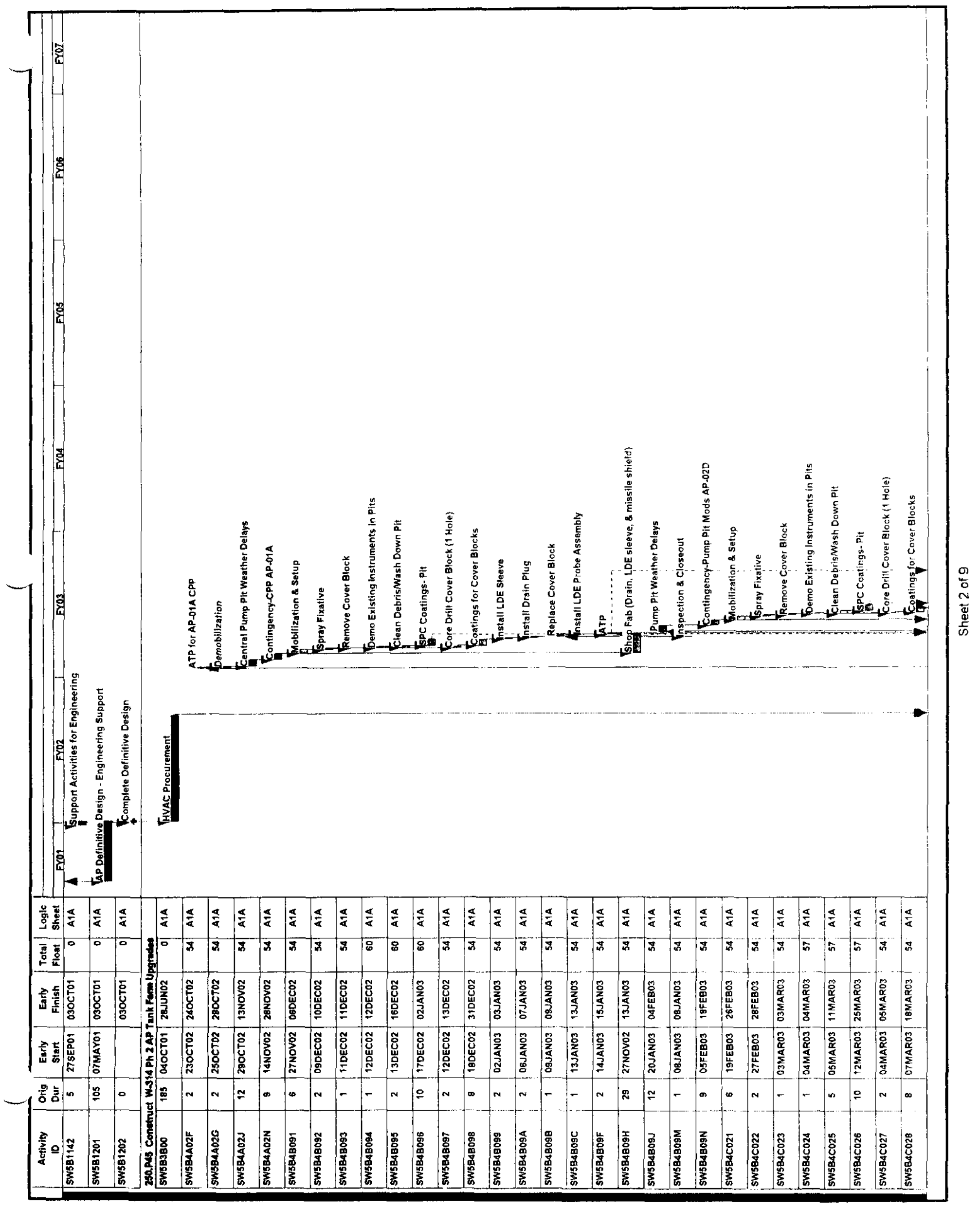




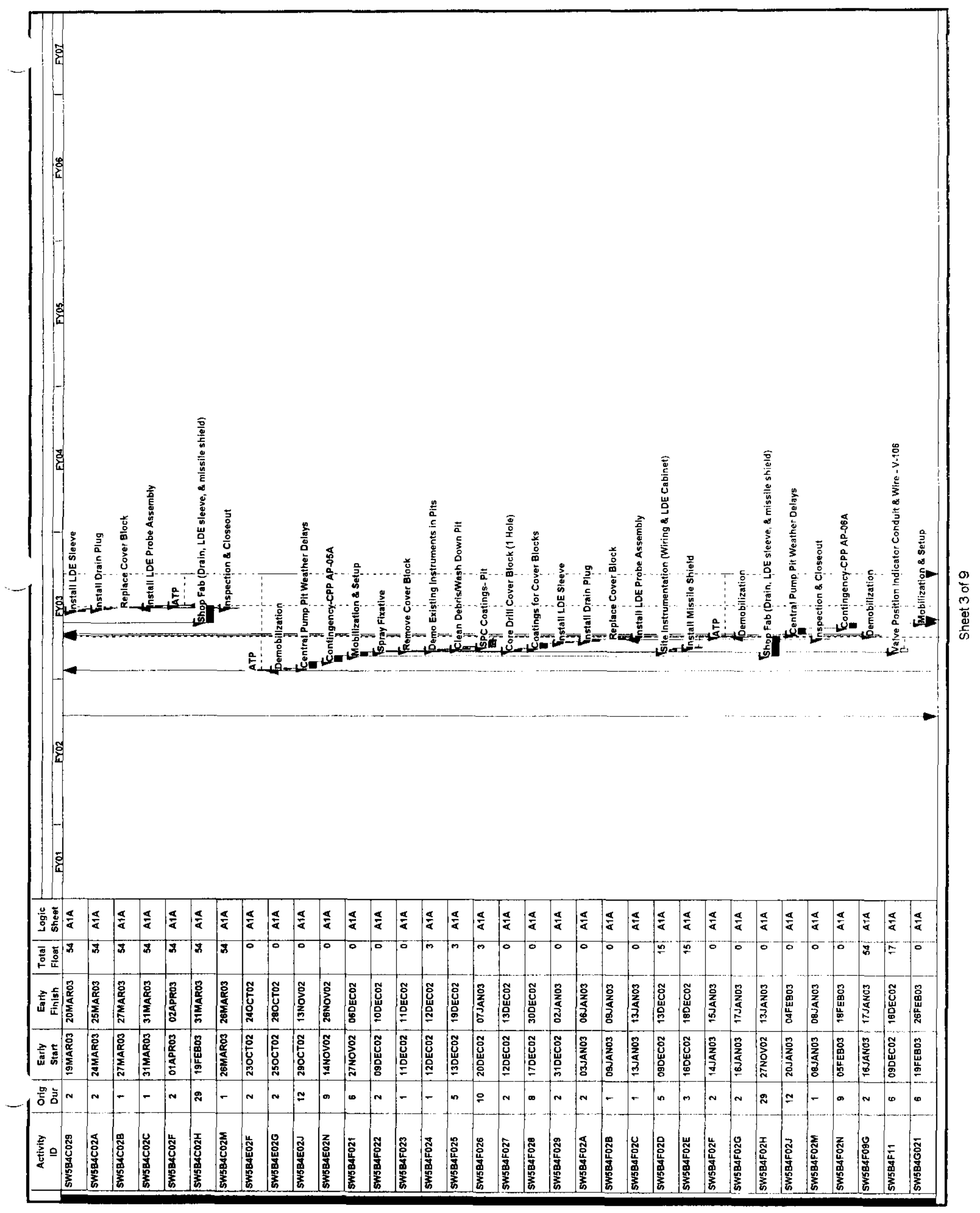


This page cannot be converted.

Please view the native document

for the original page. 


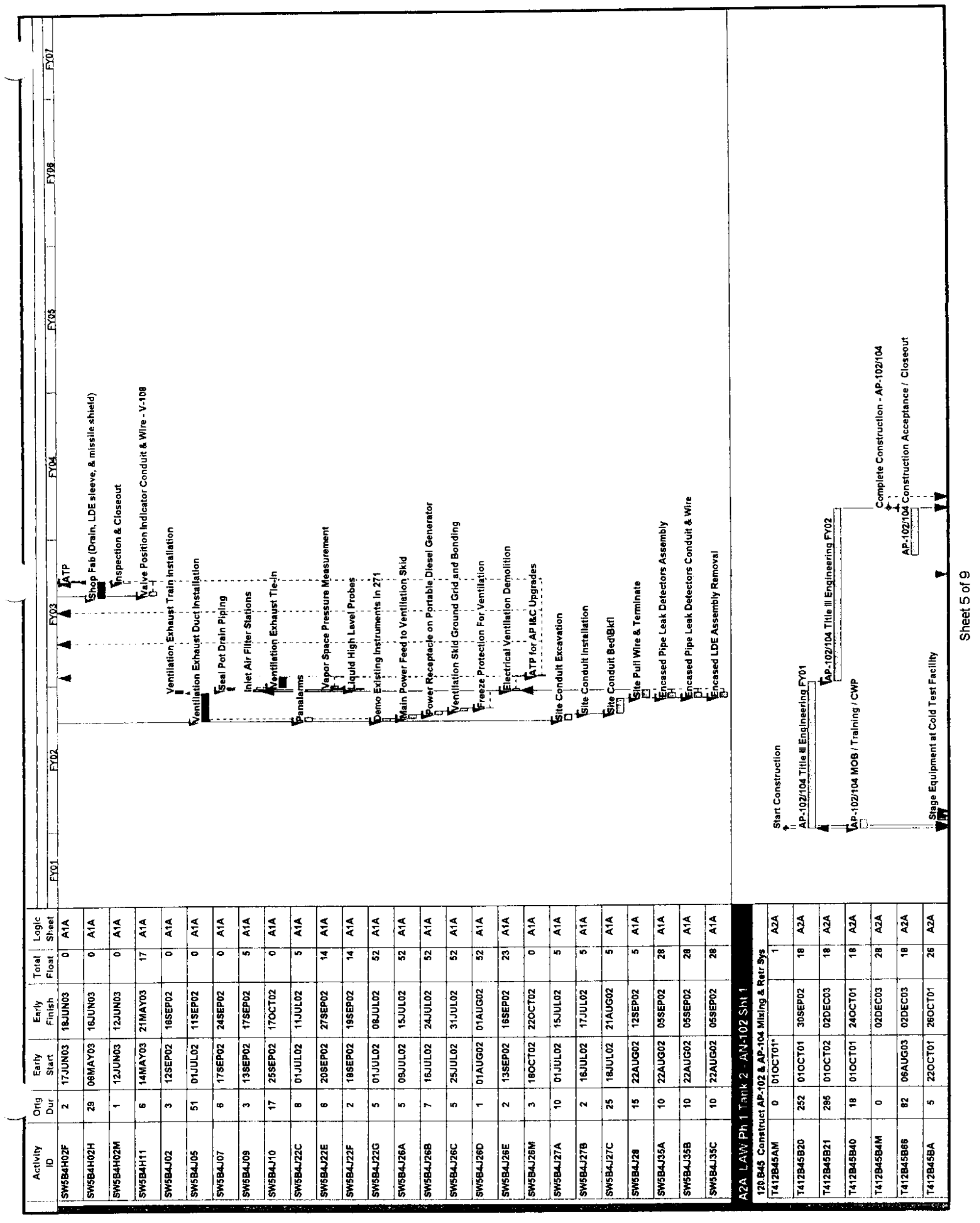




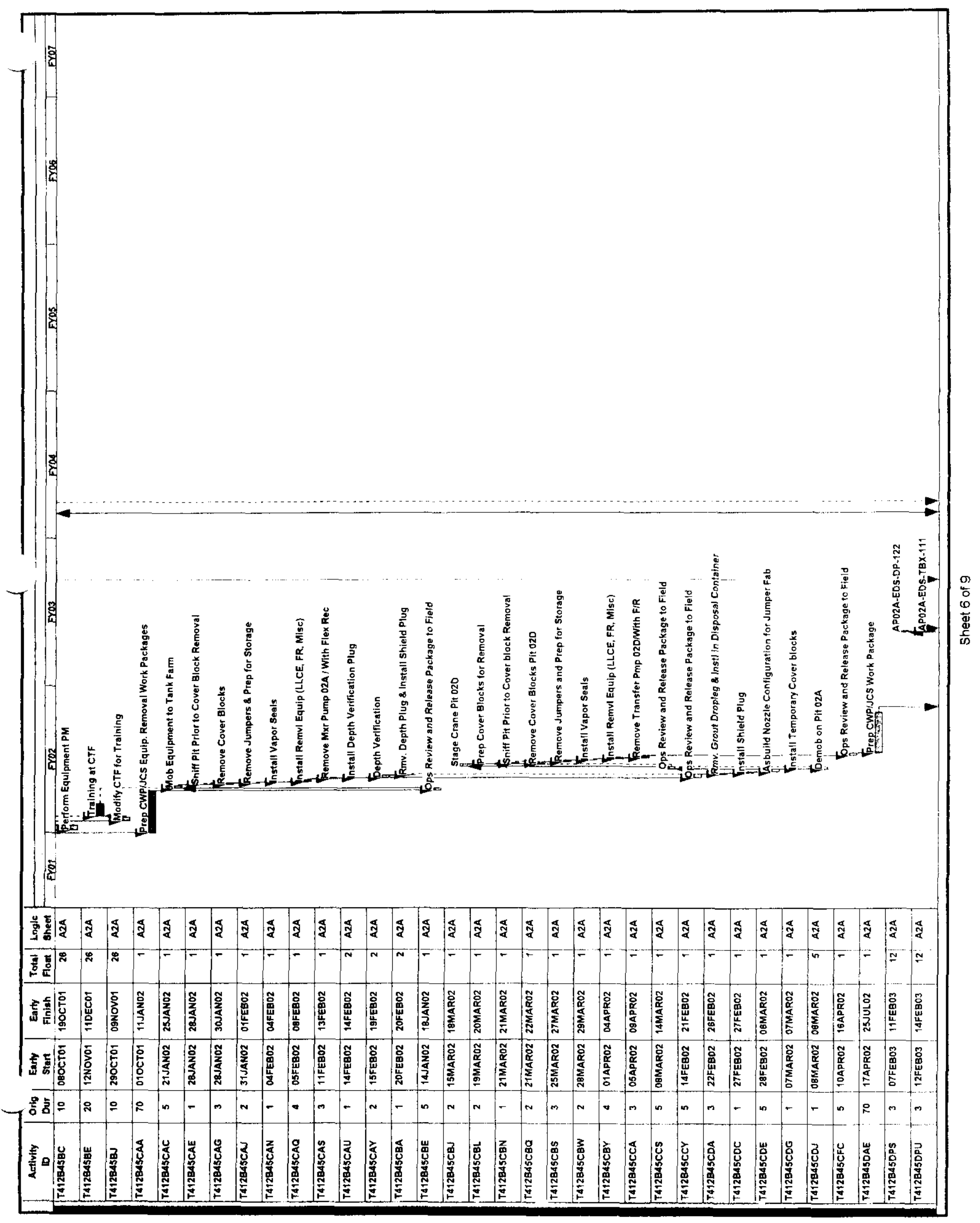




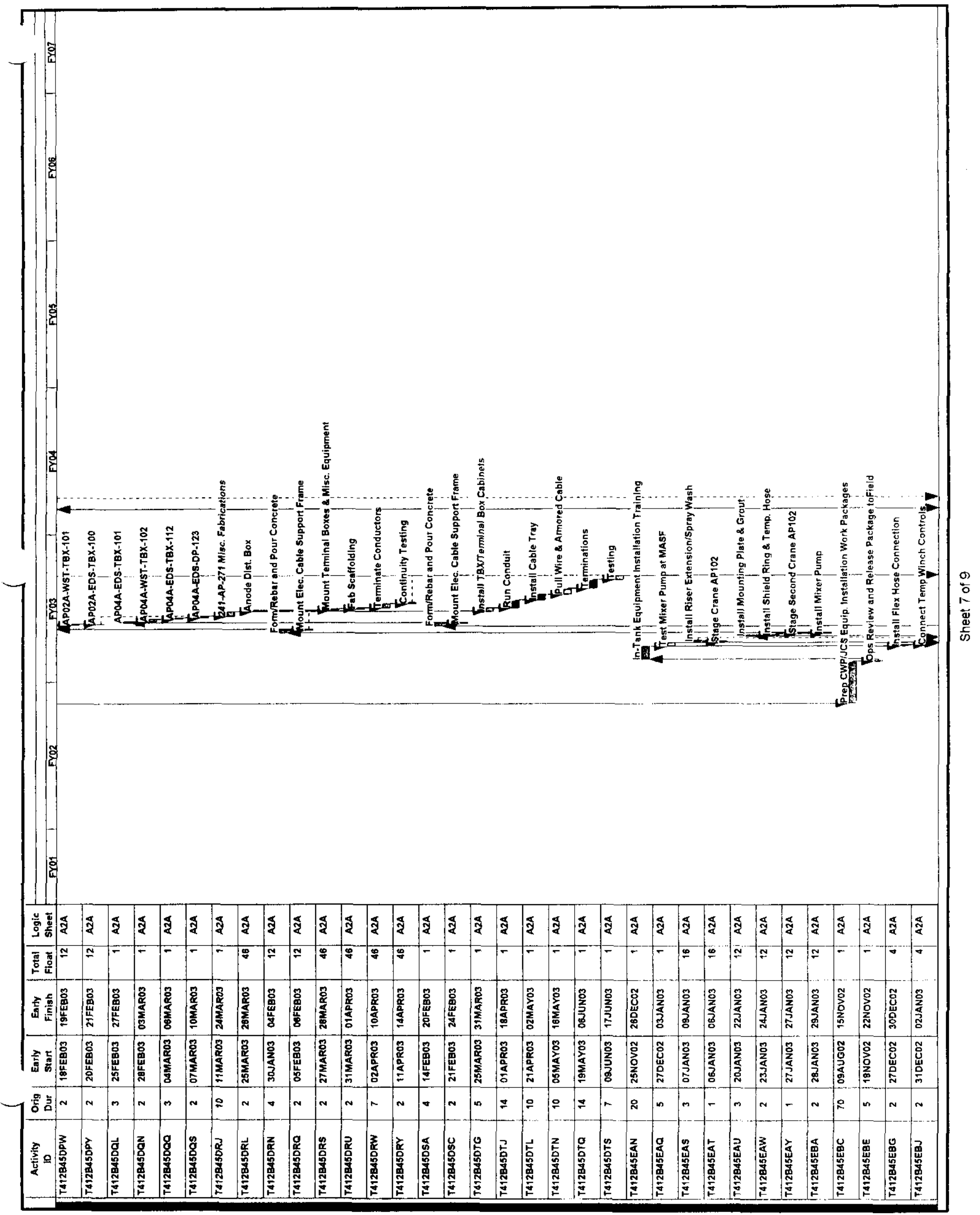




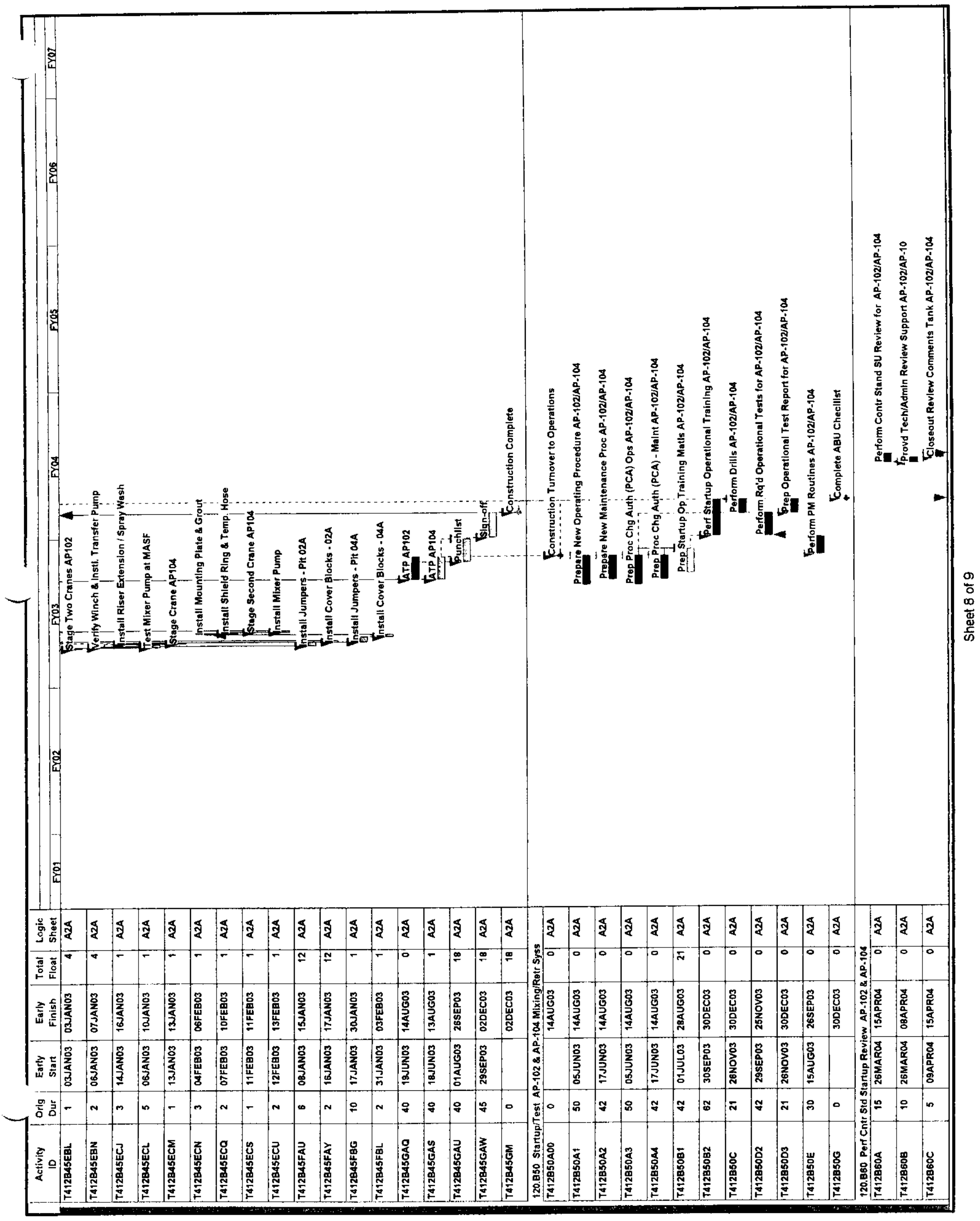




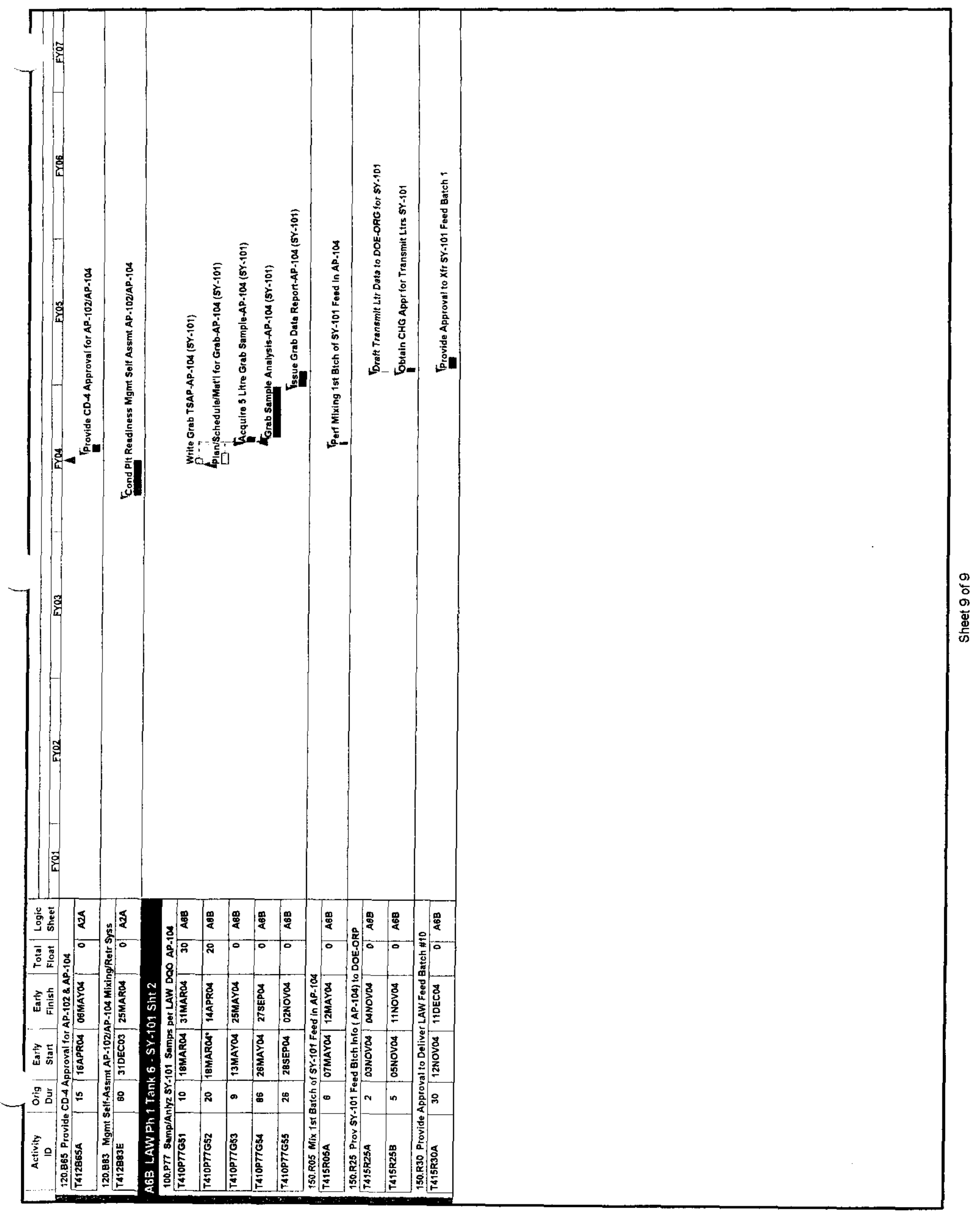




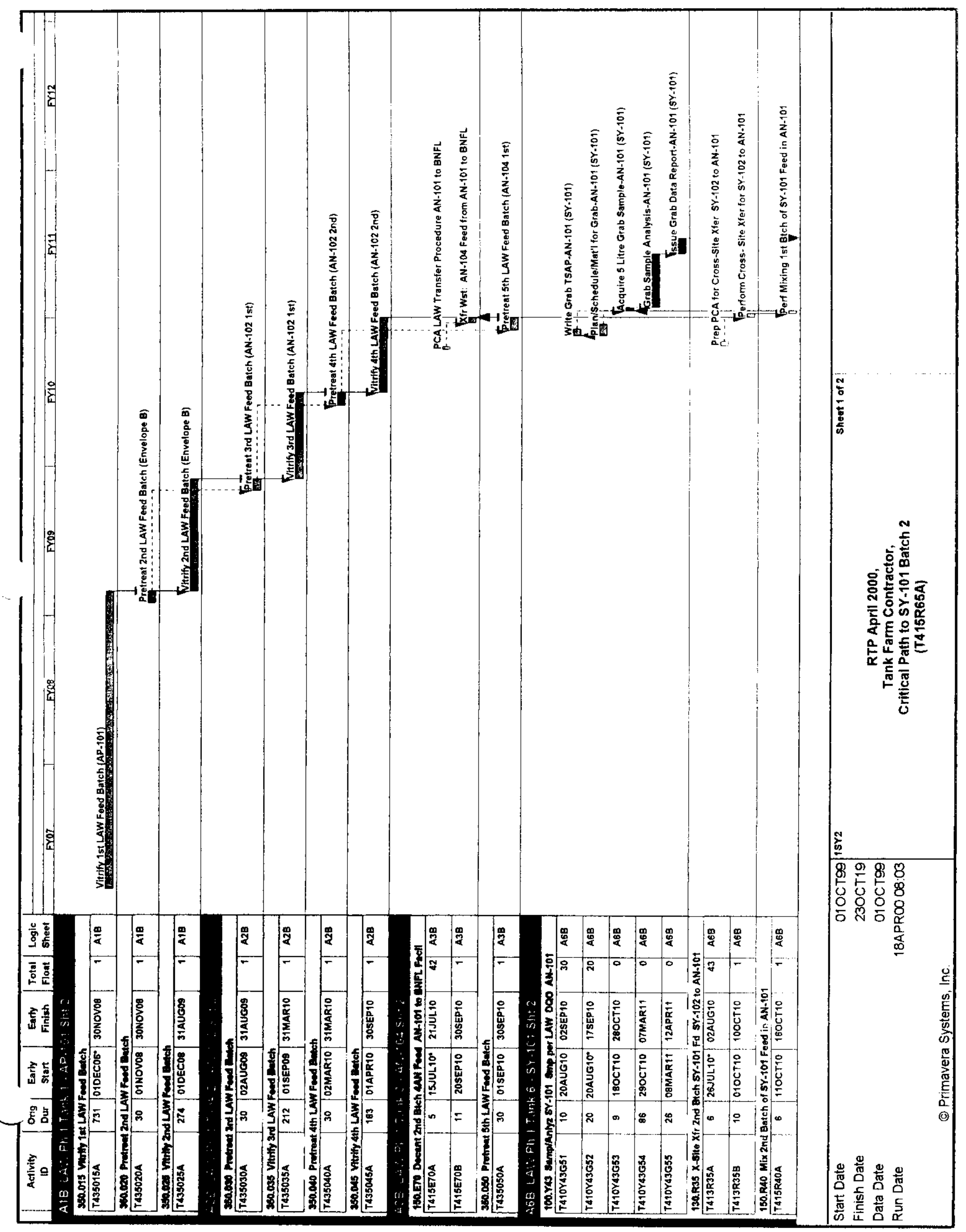




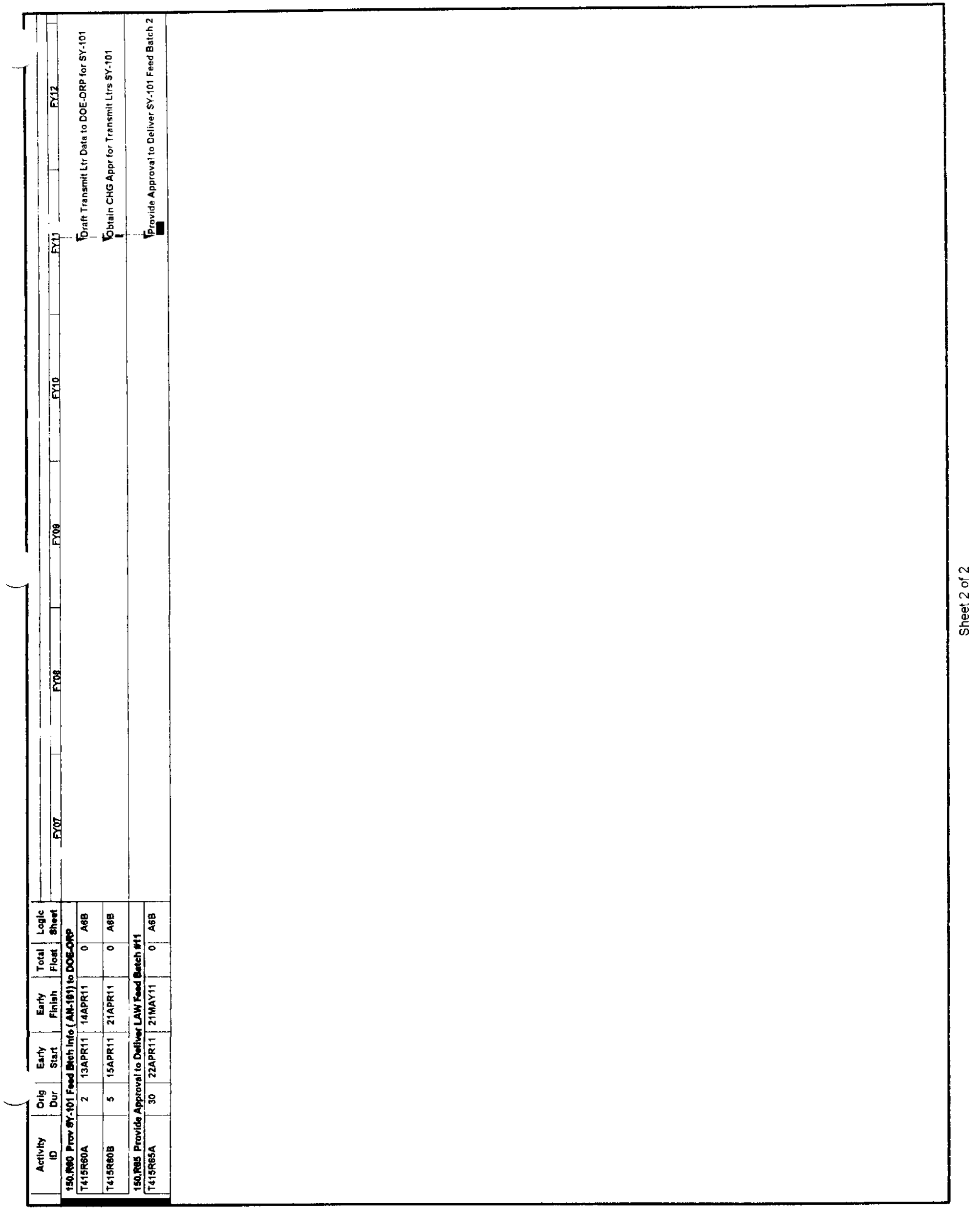




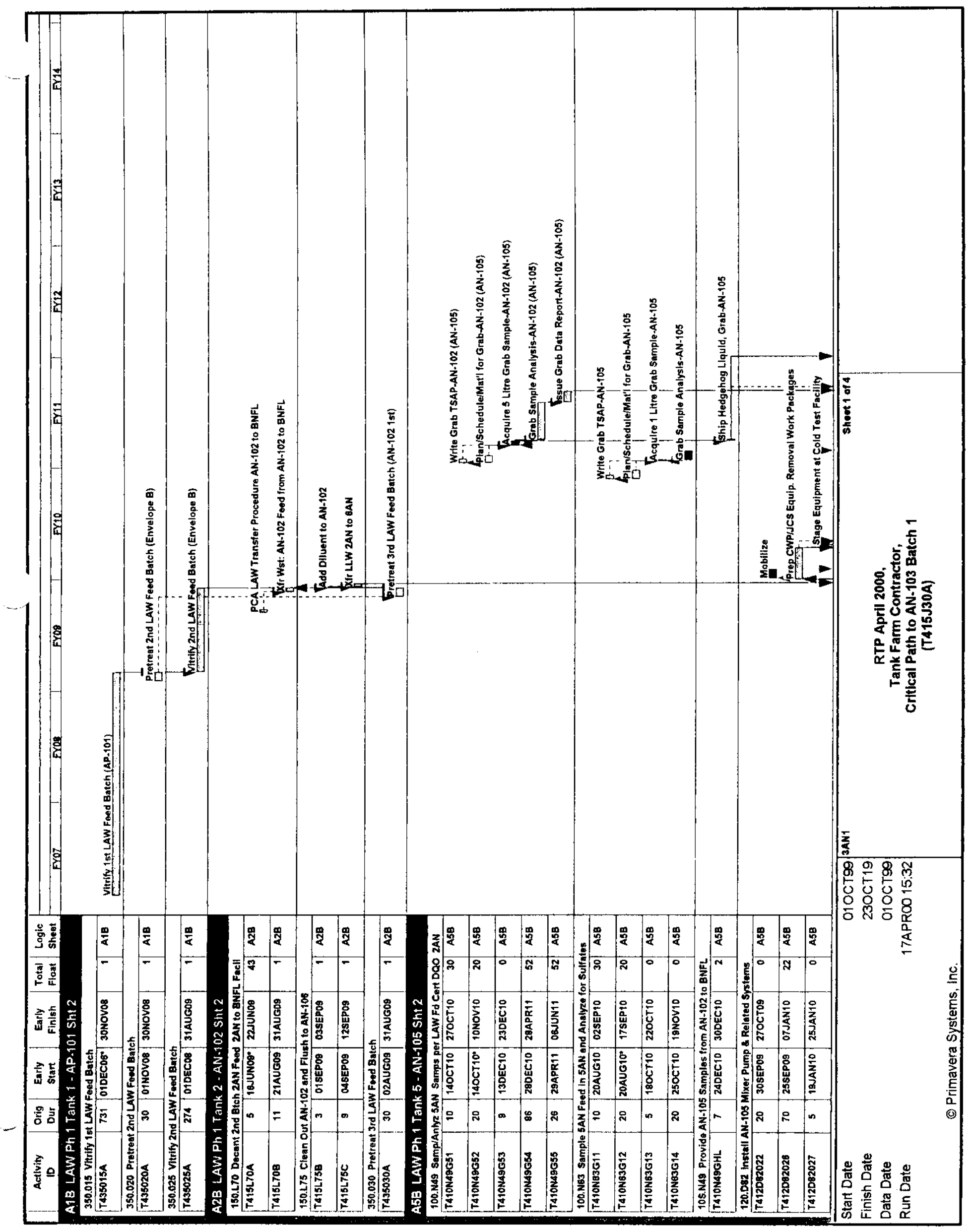




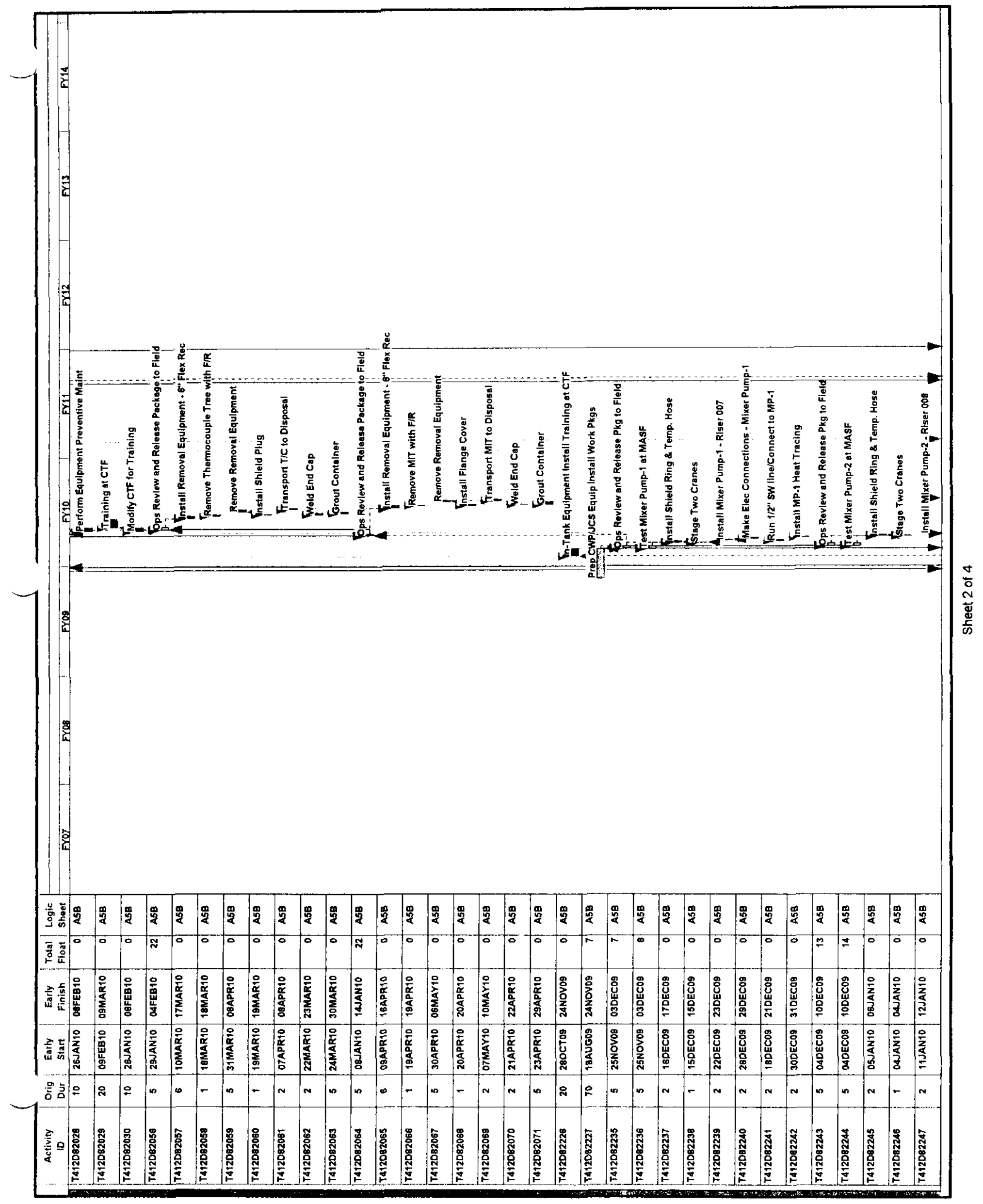




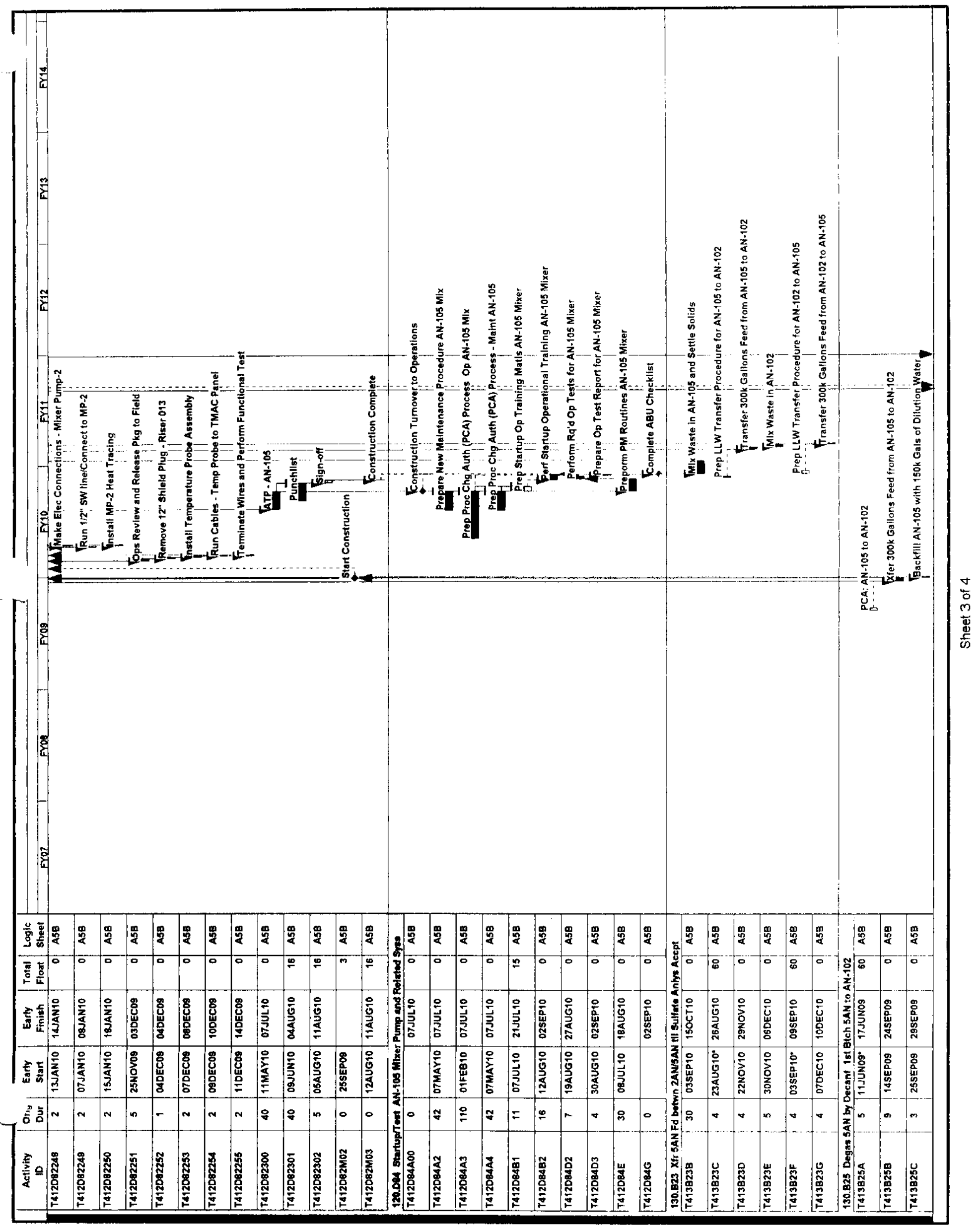




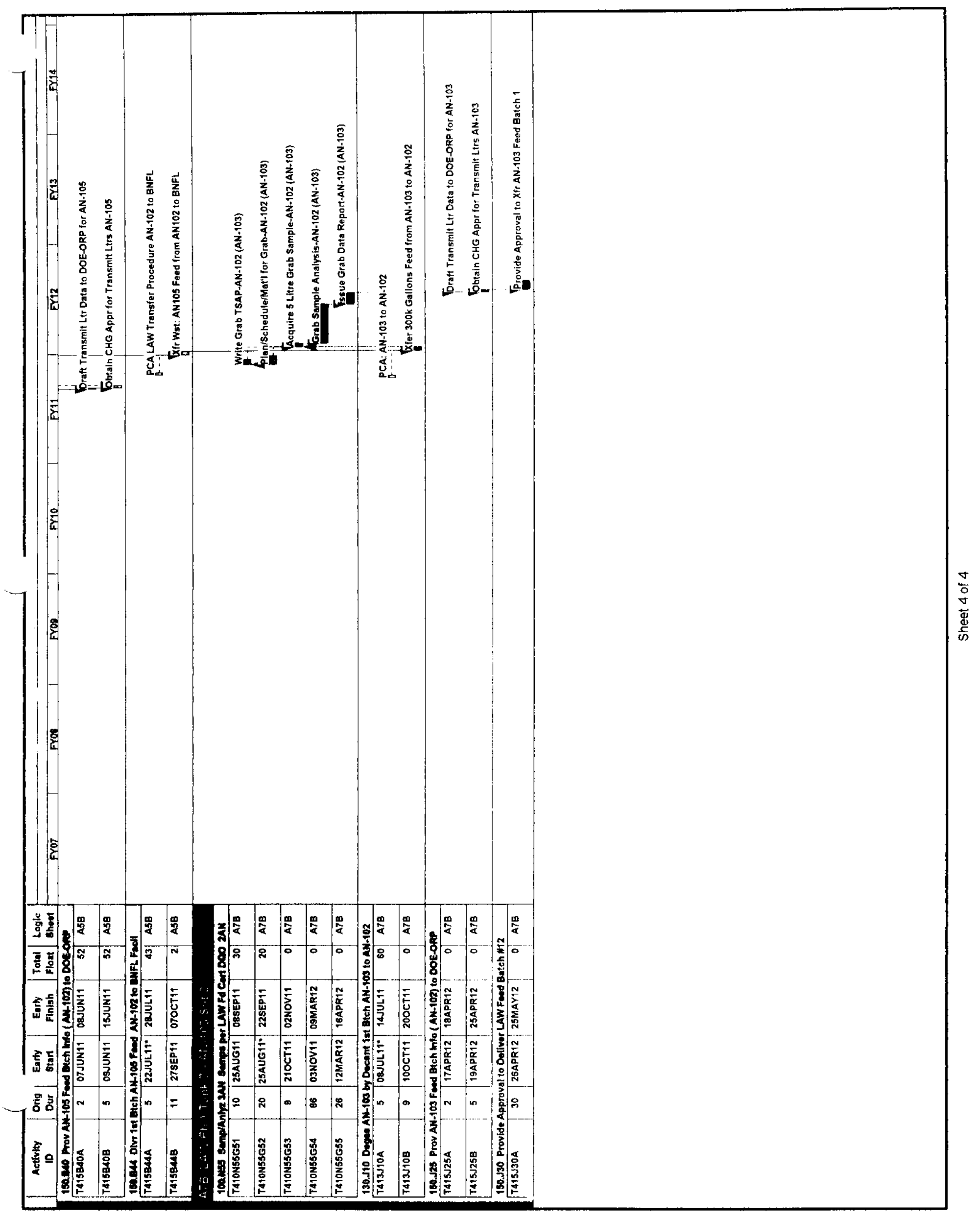




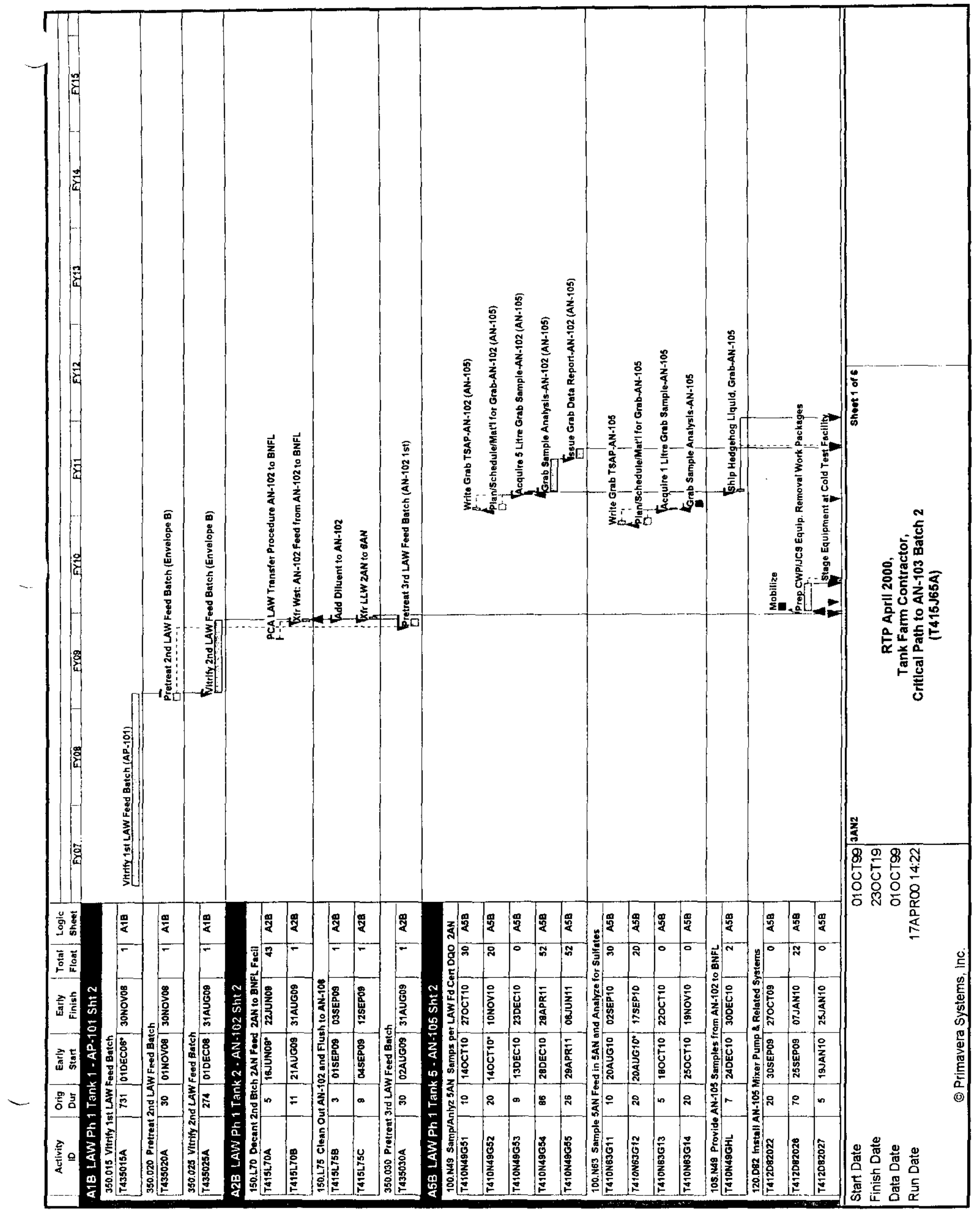




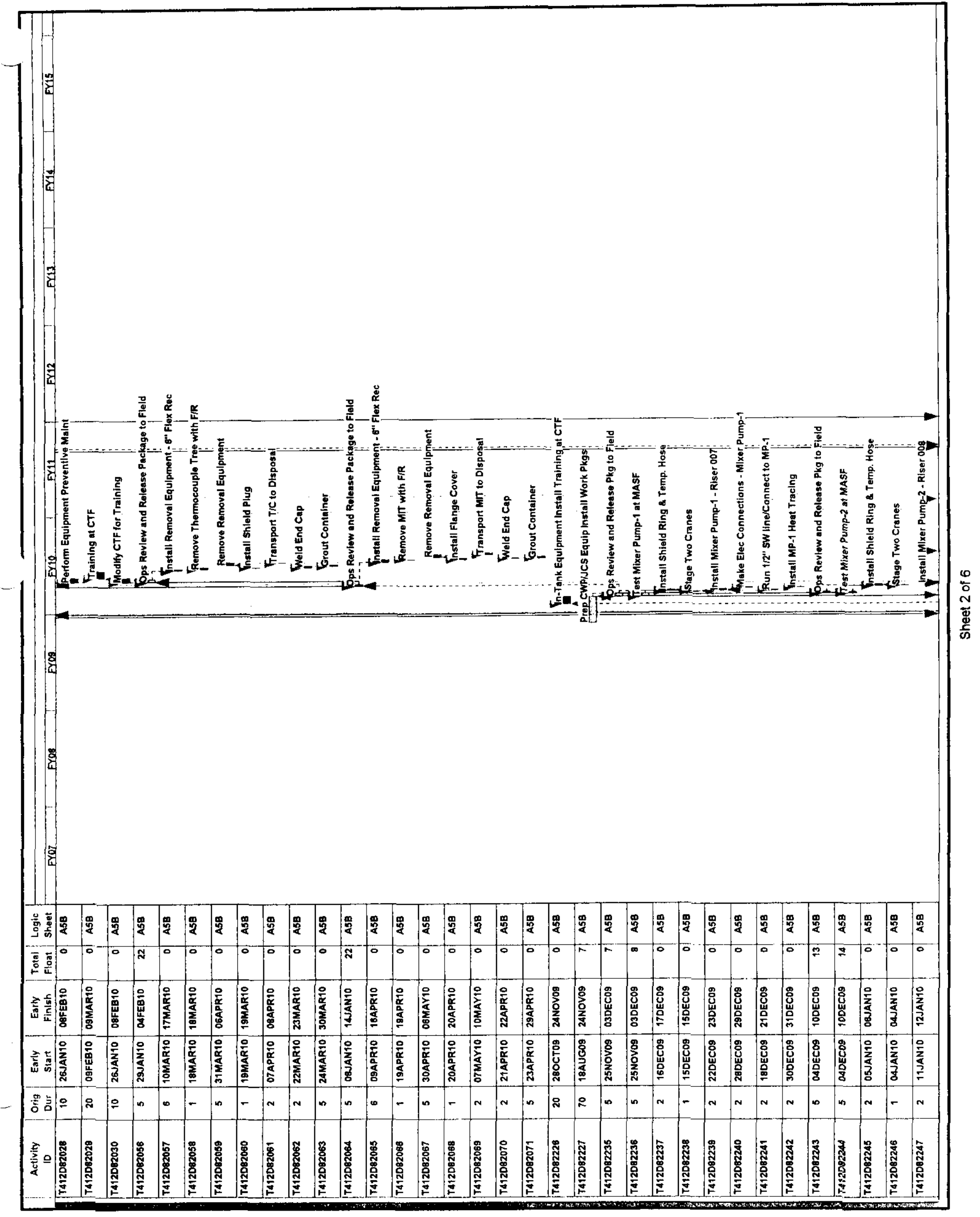




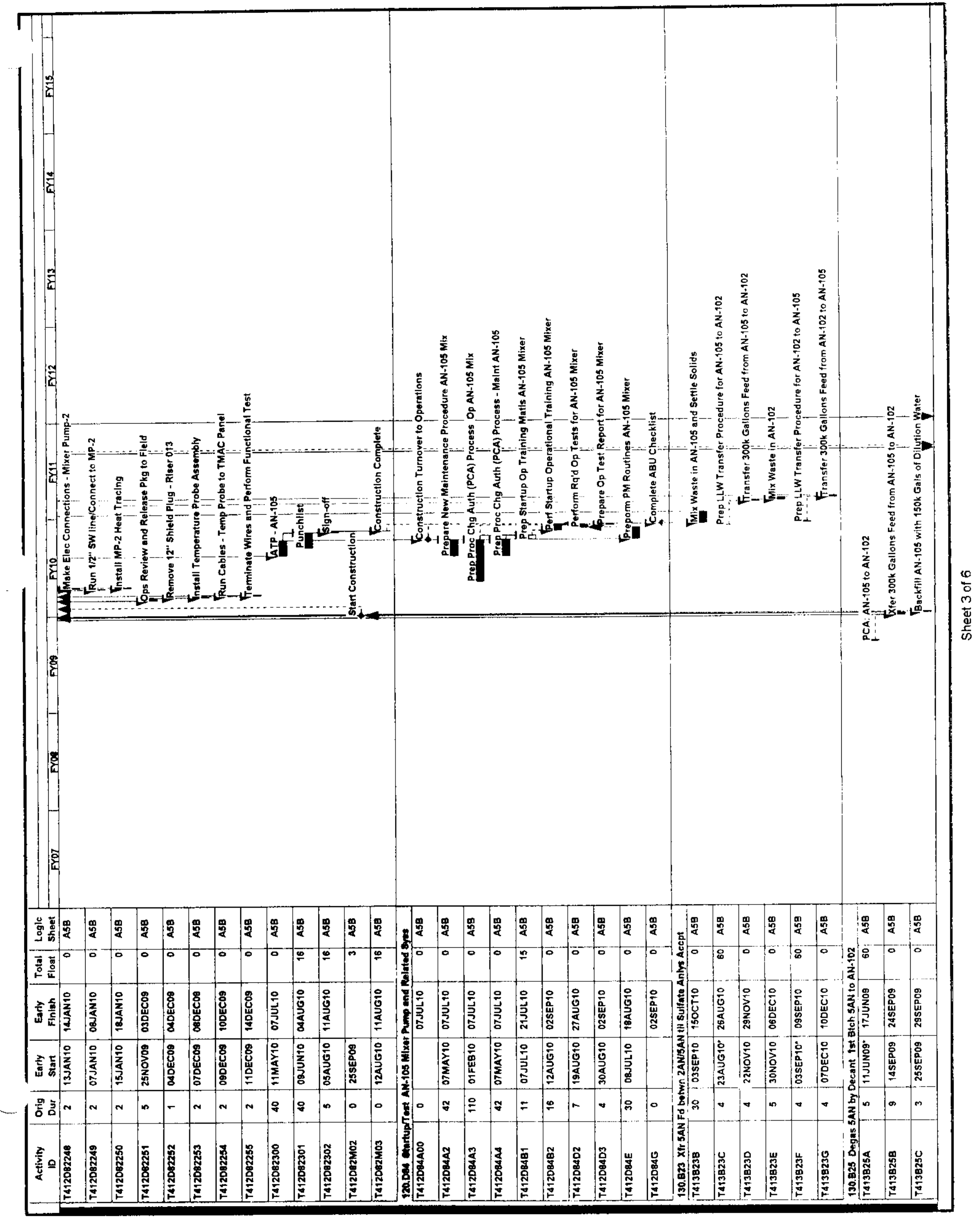




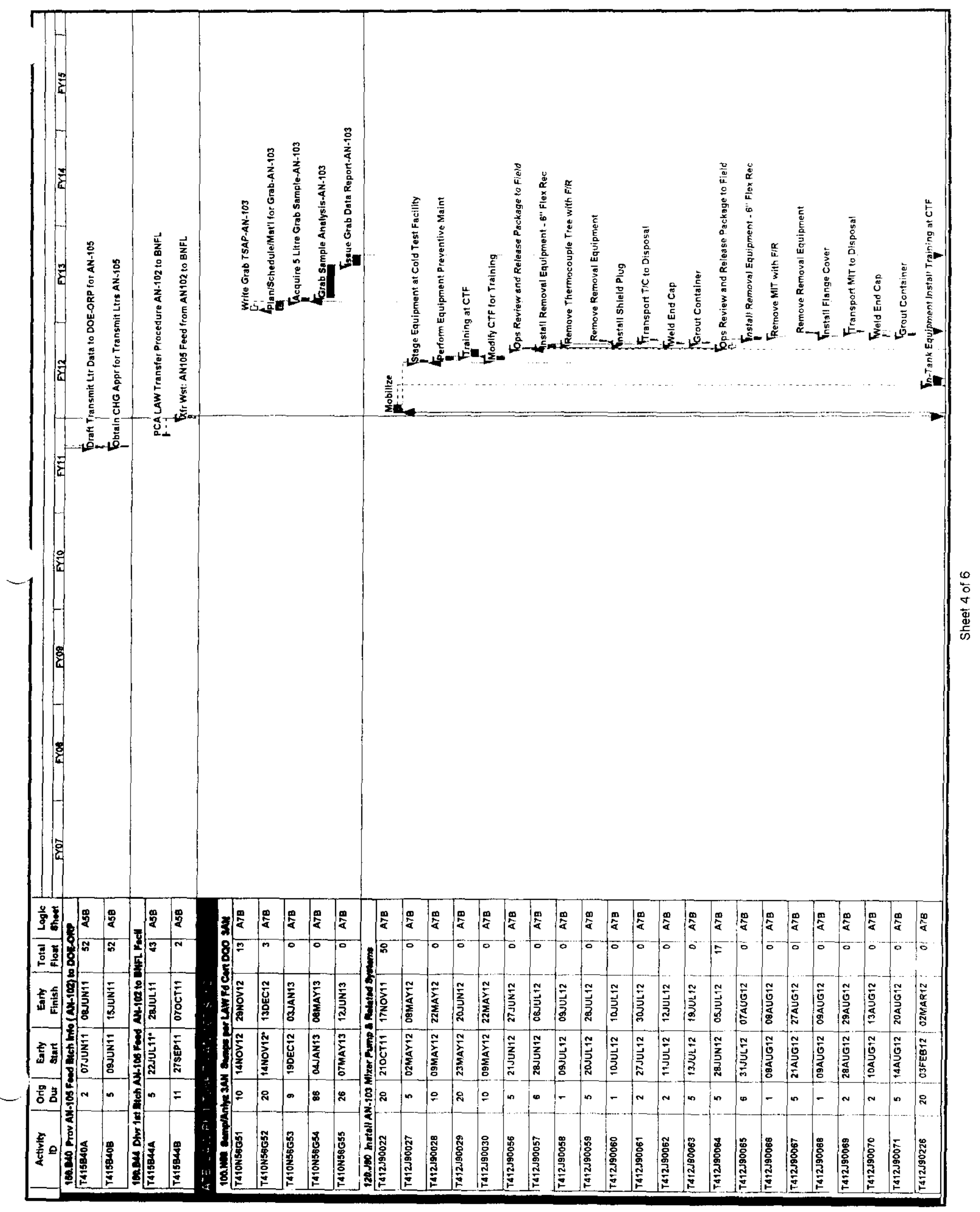




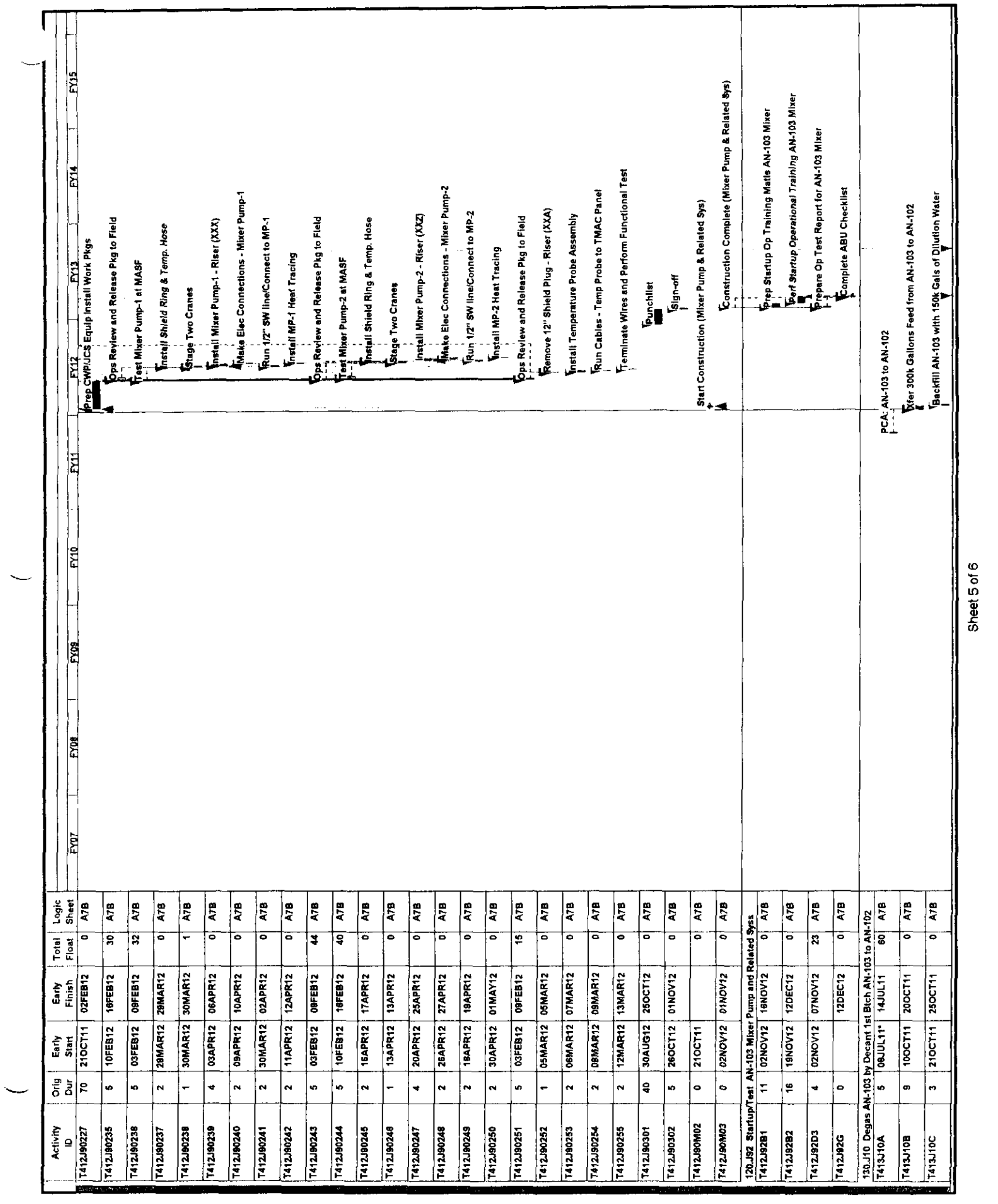




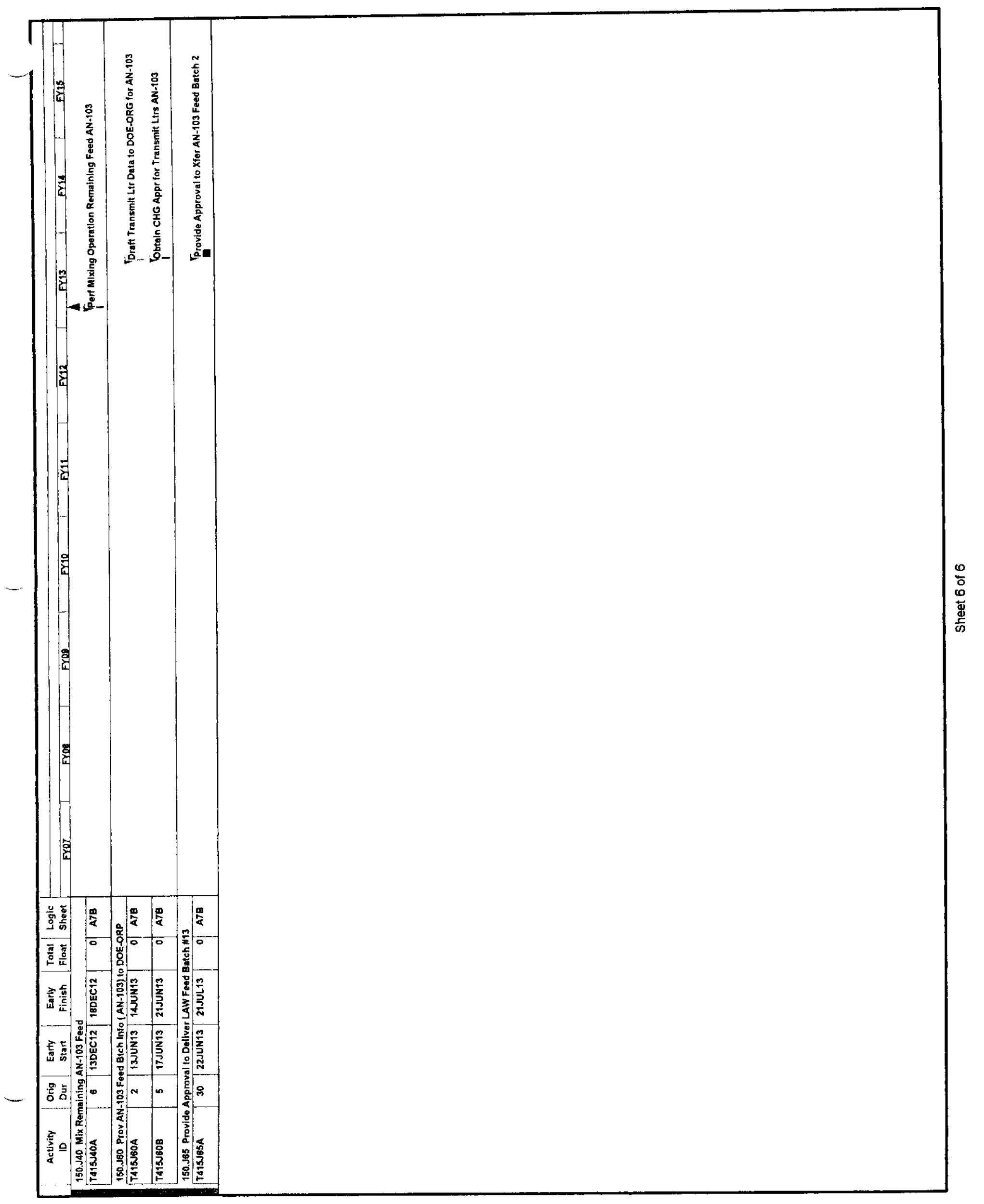




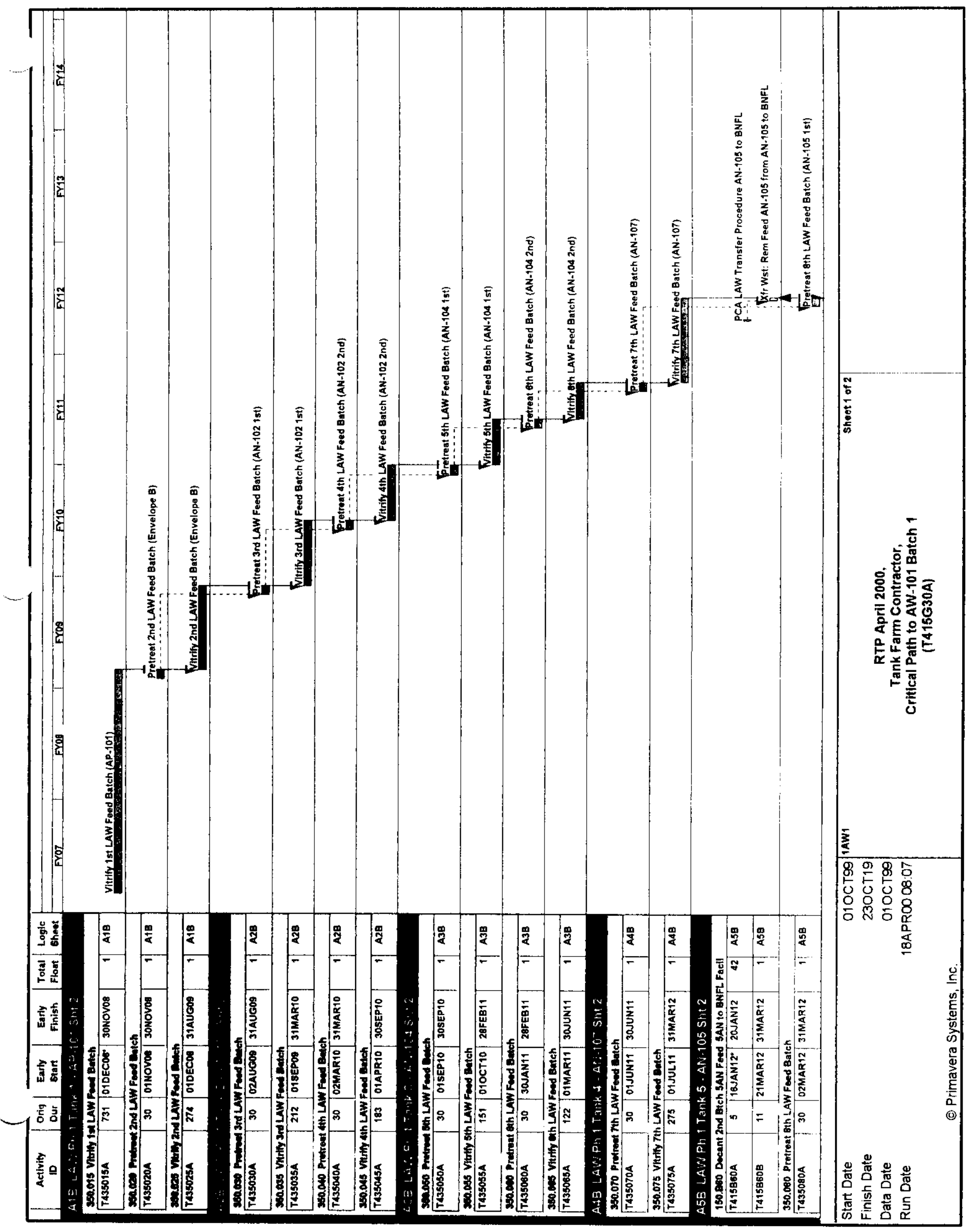




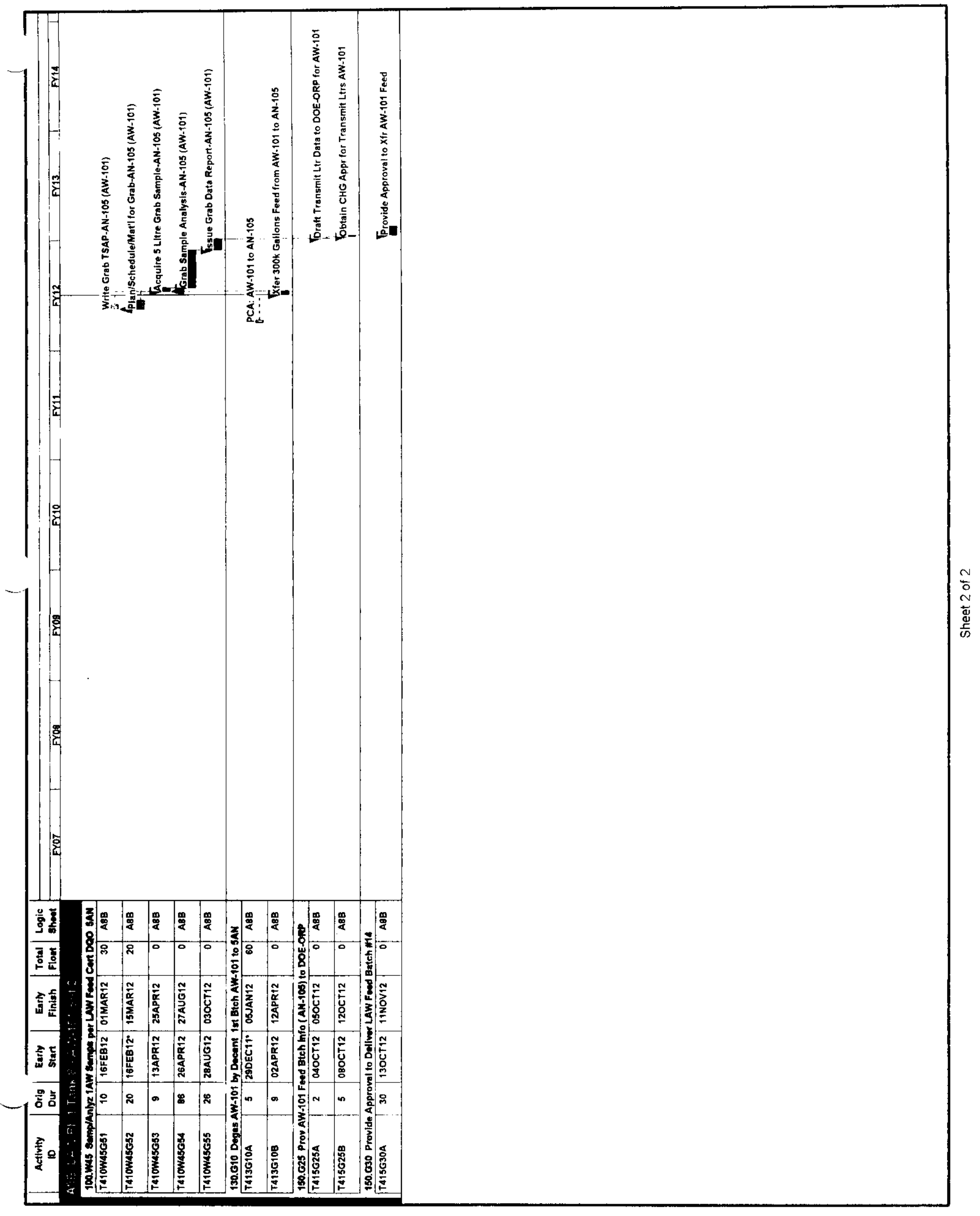




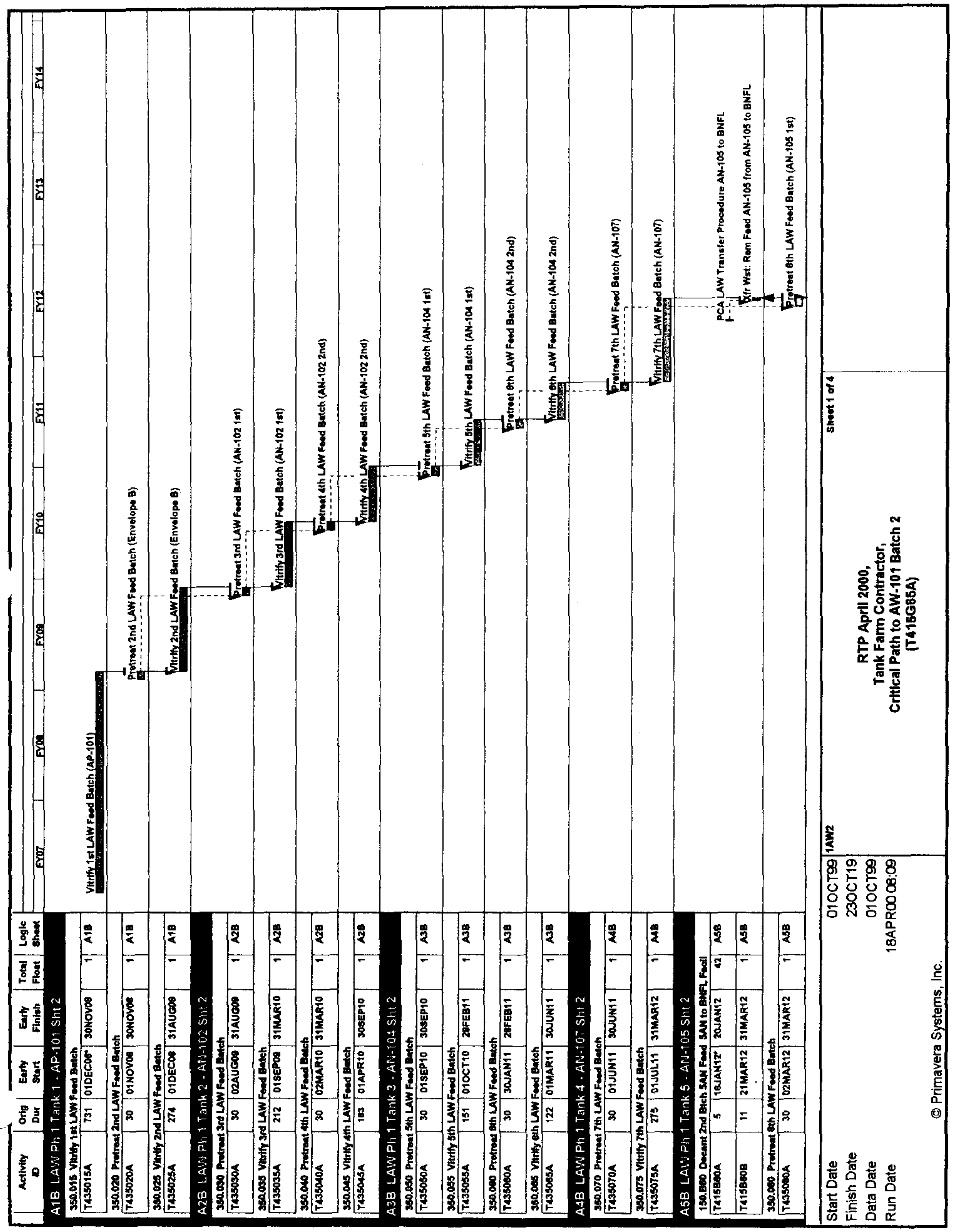




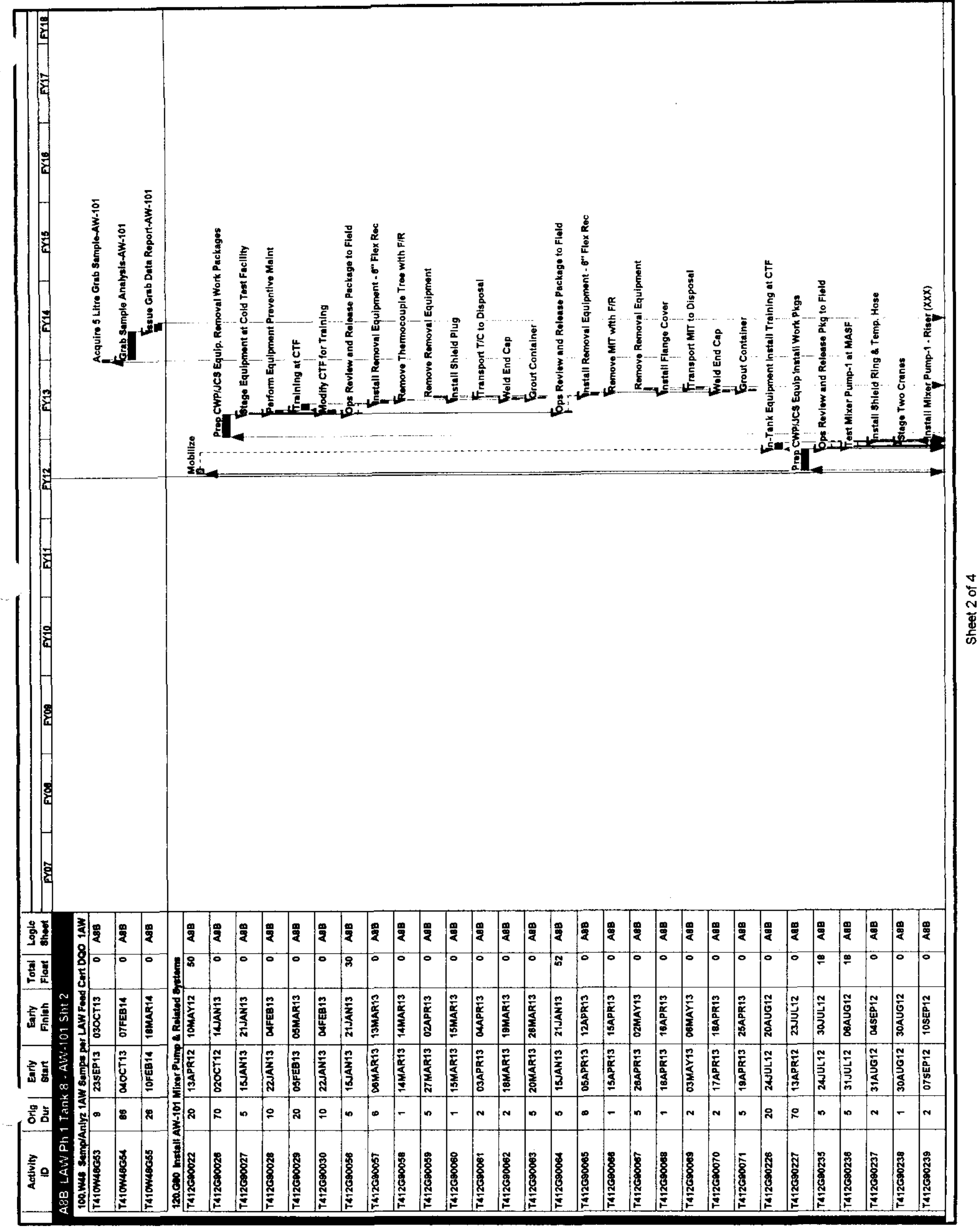




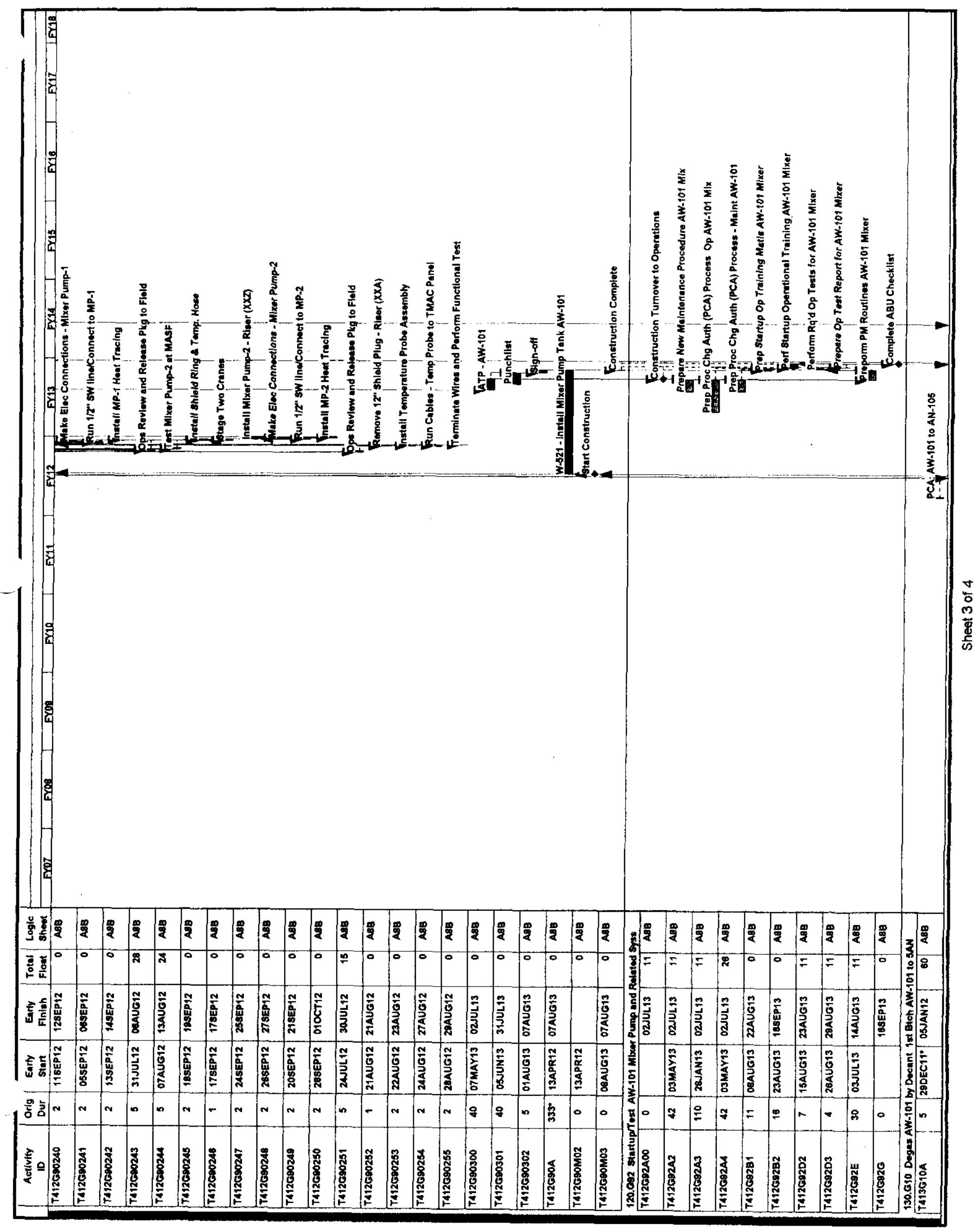




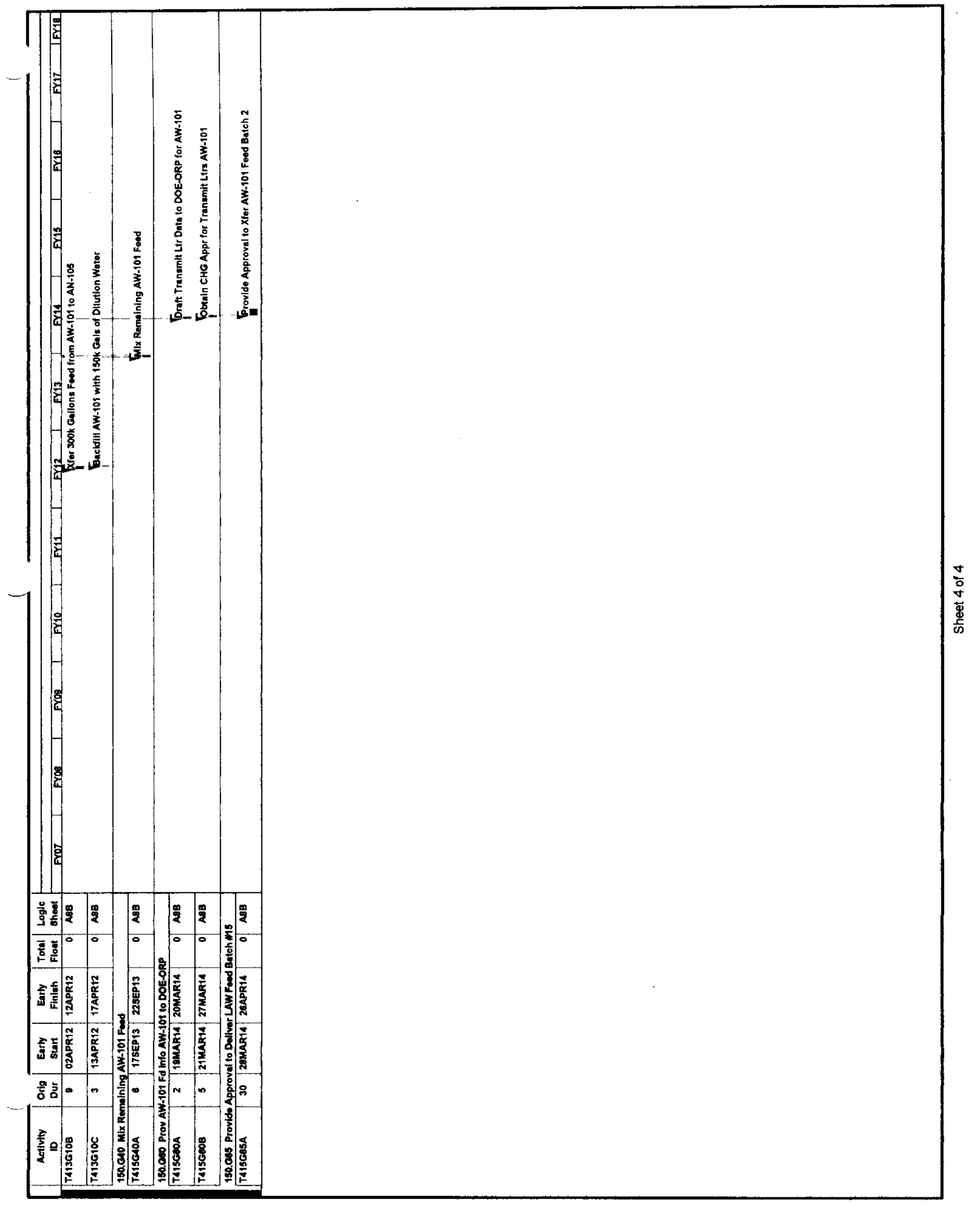




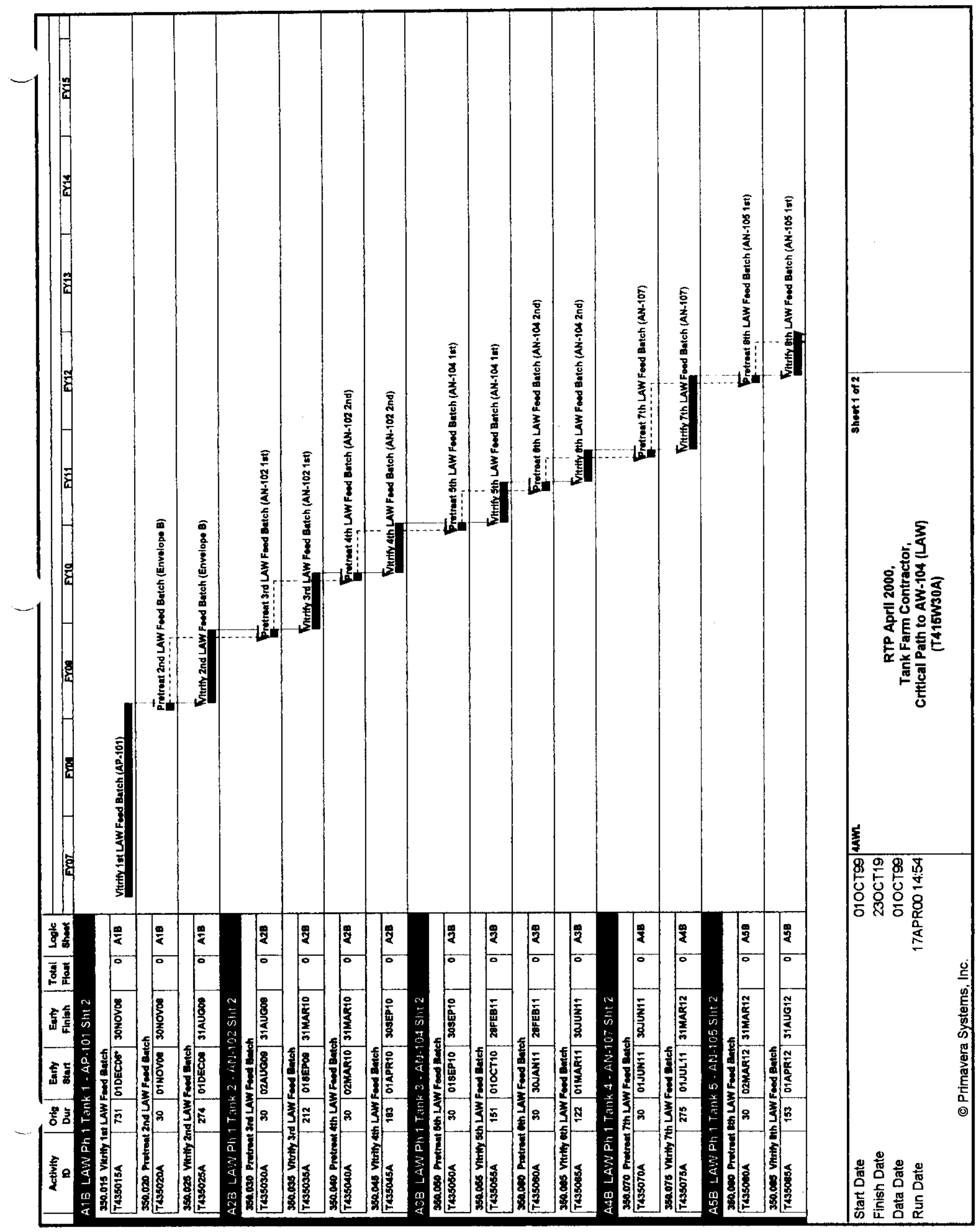




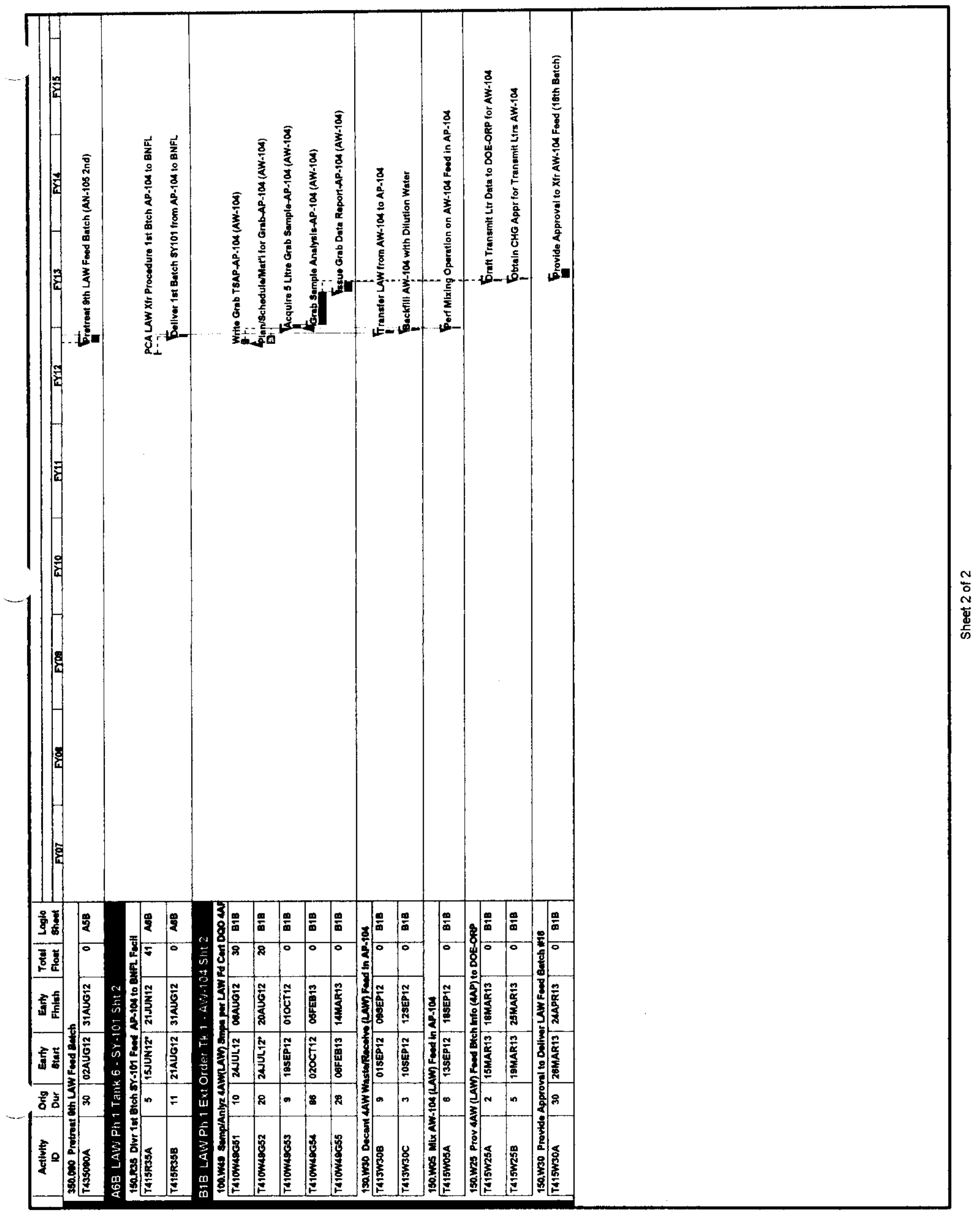




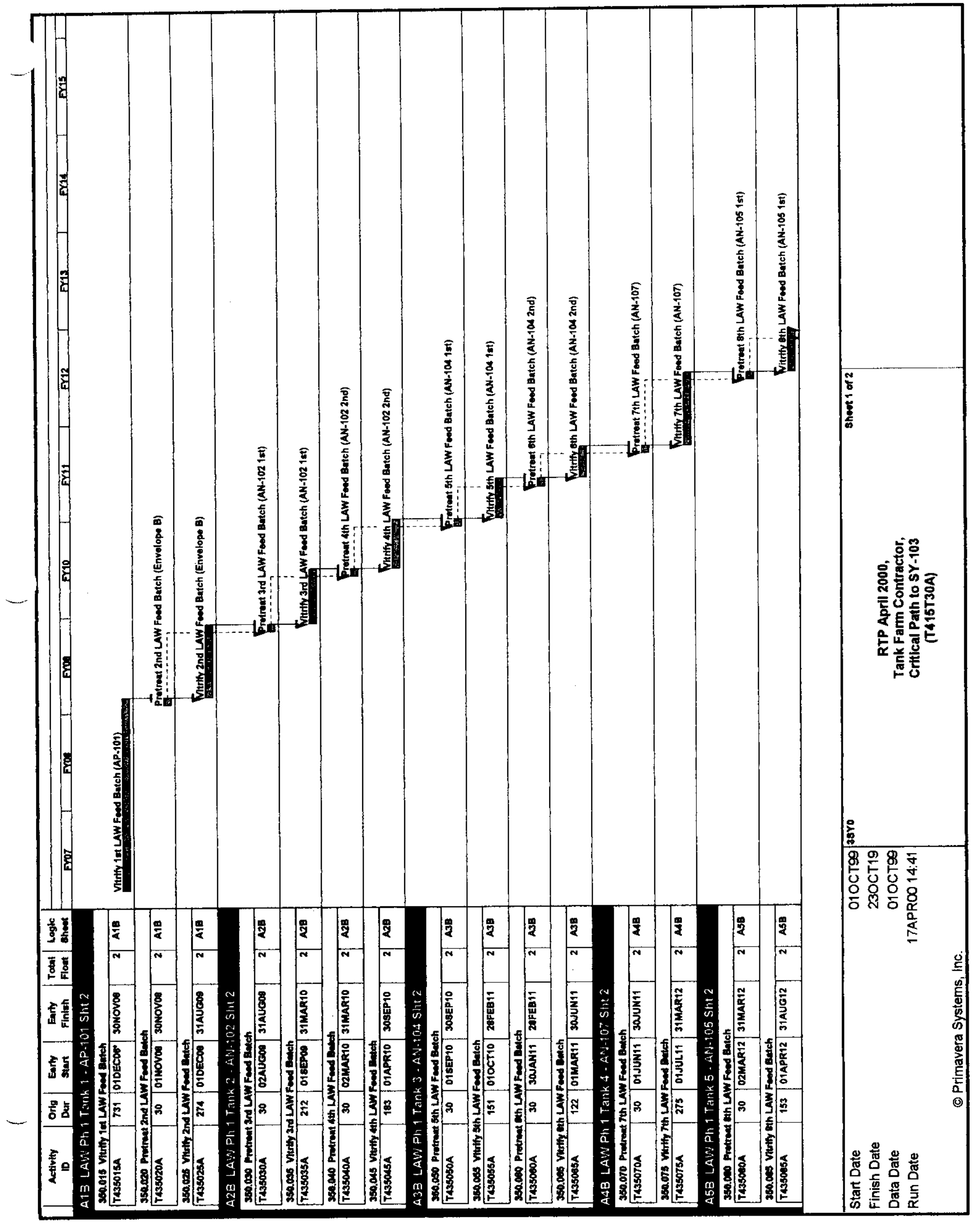




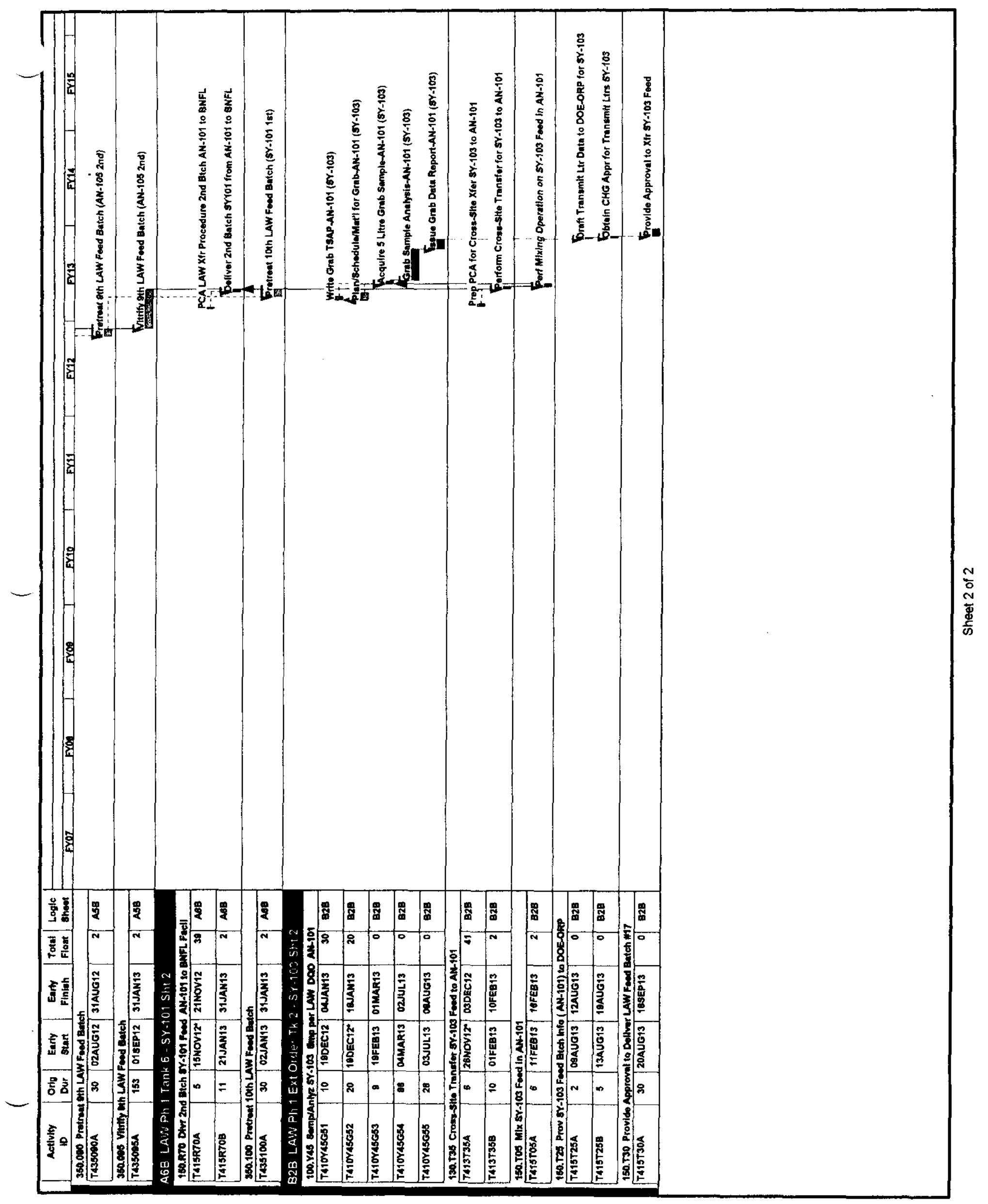




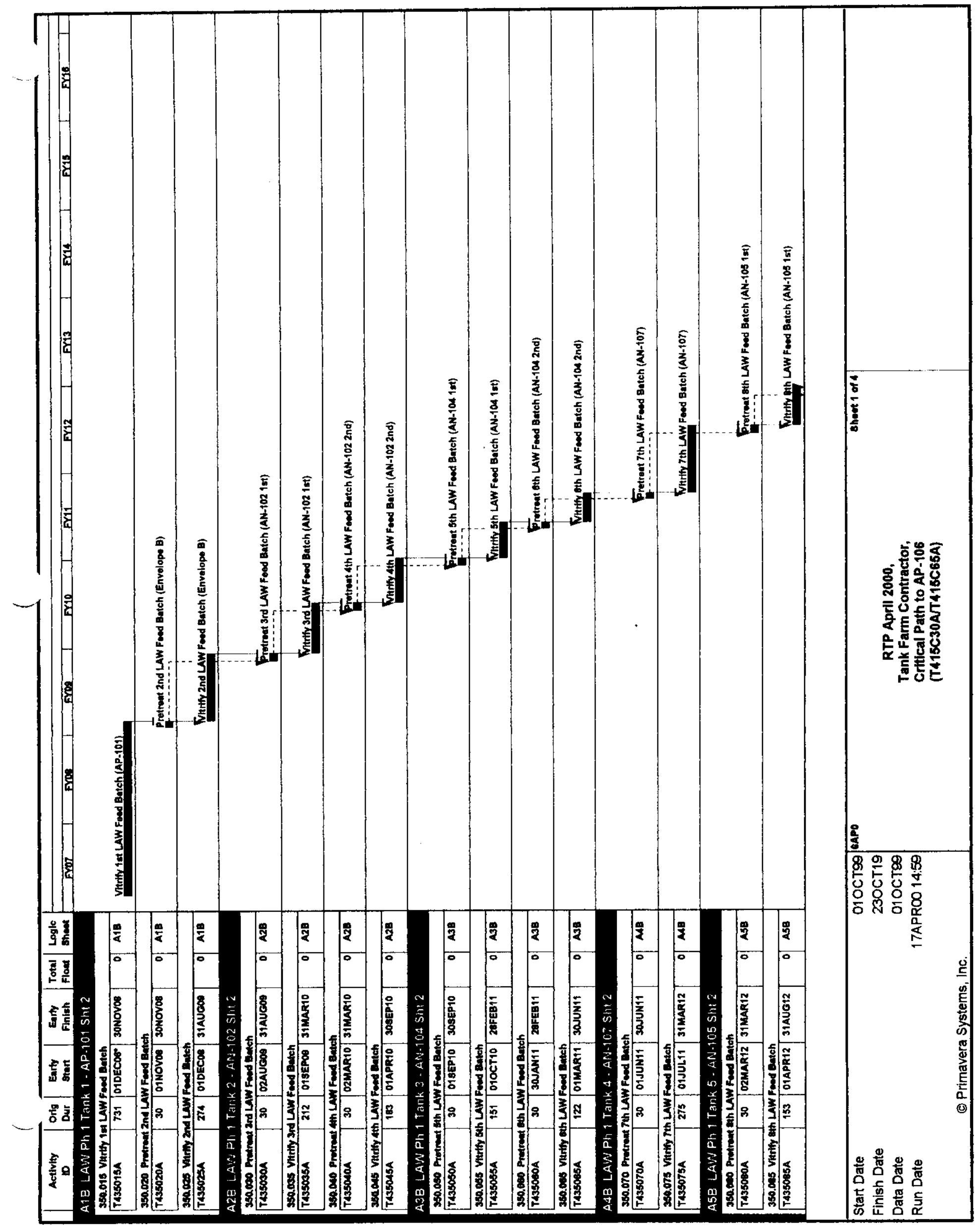




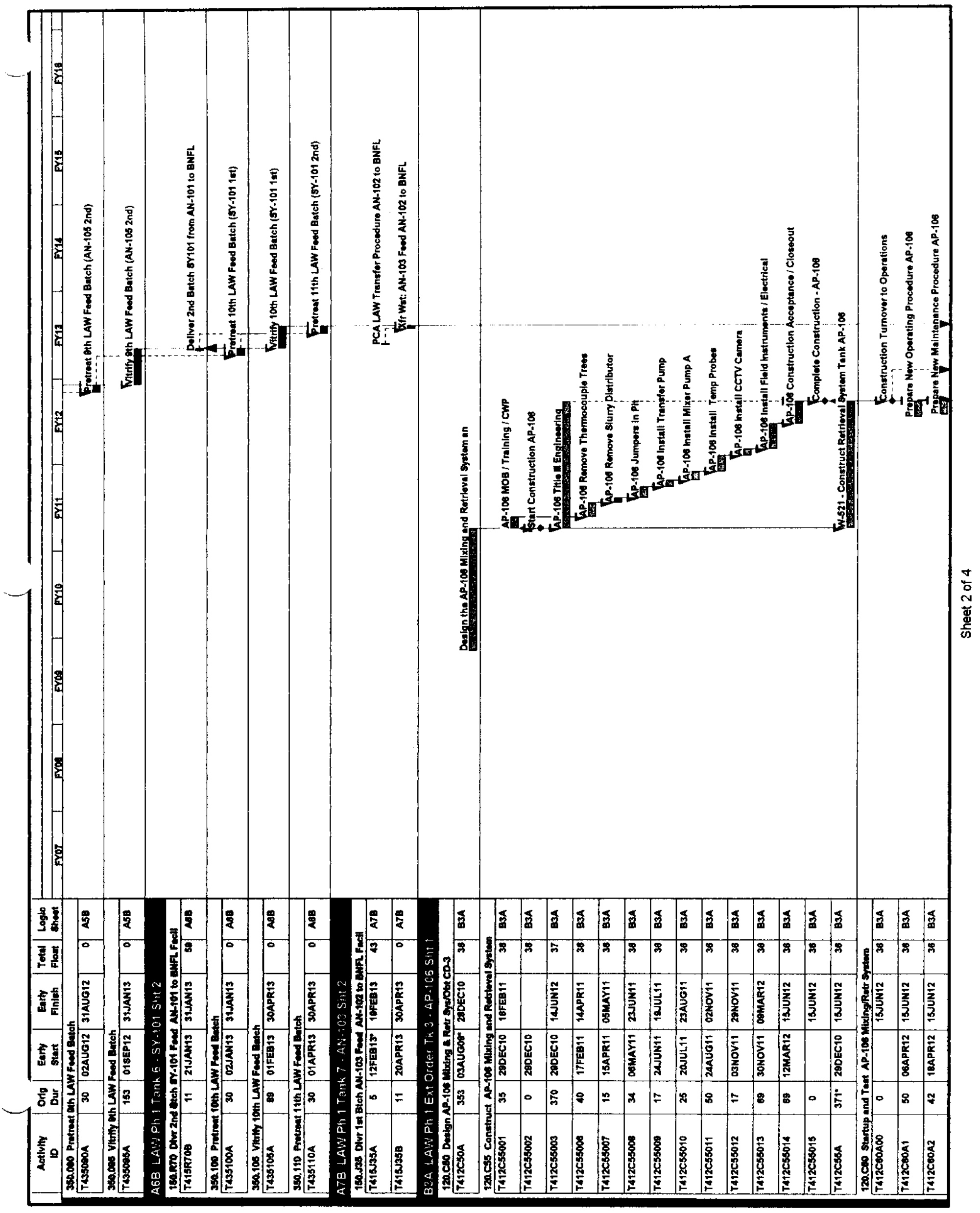




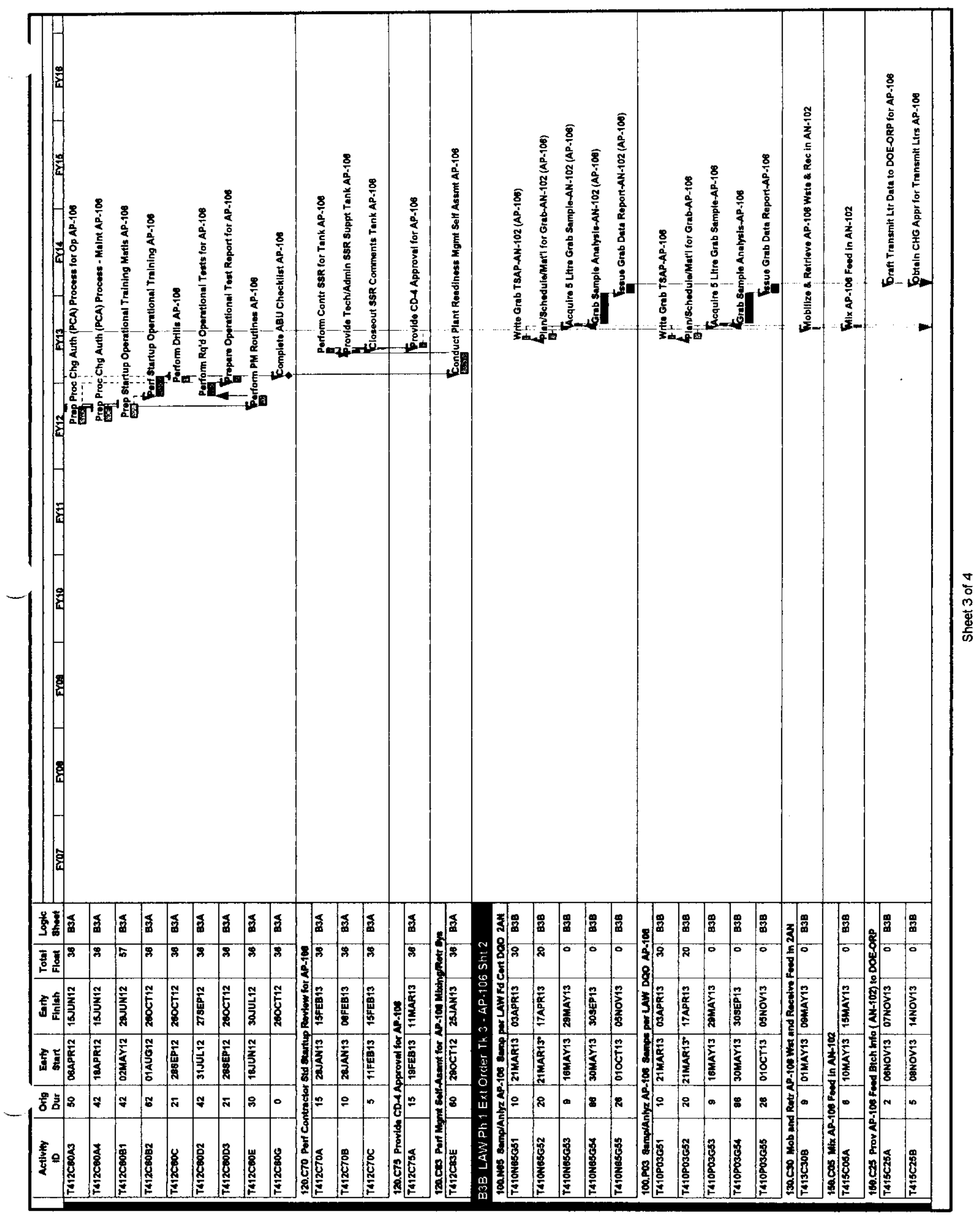




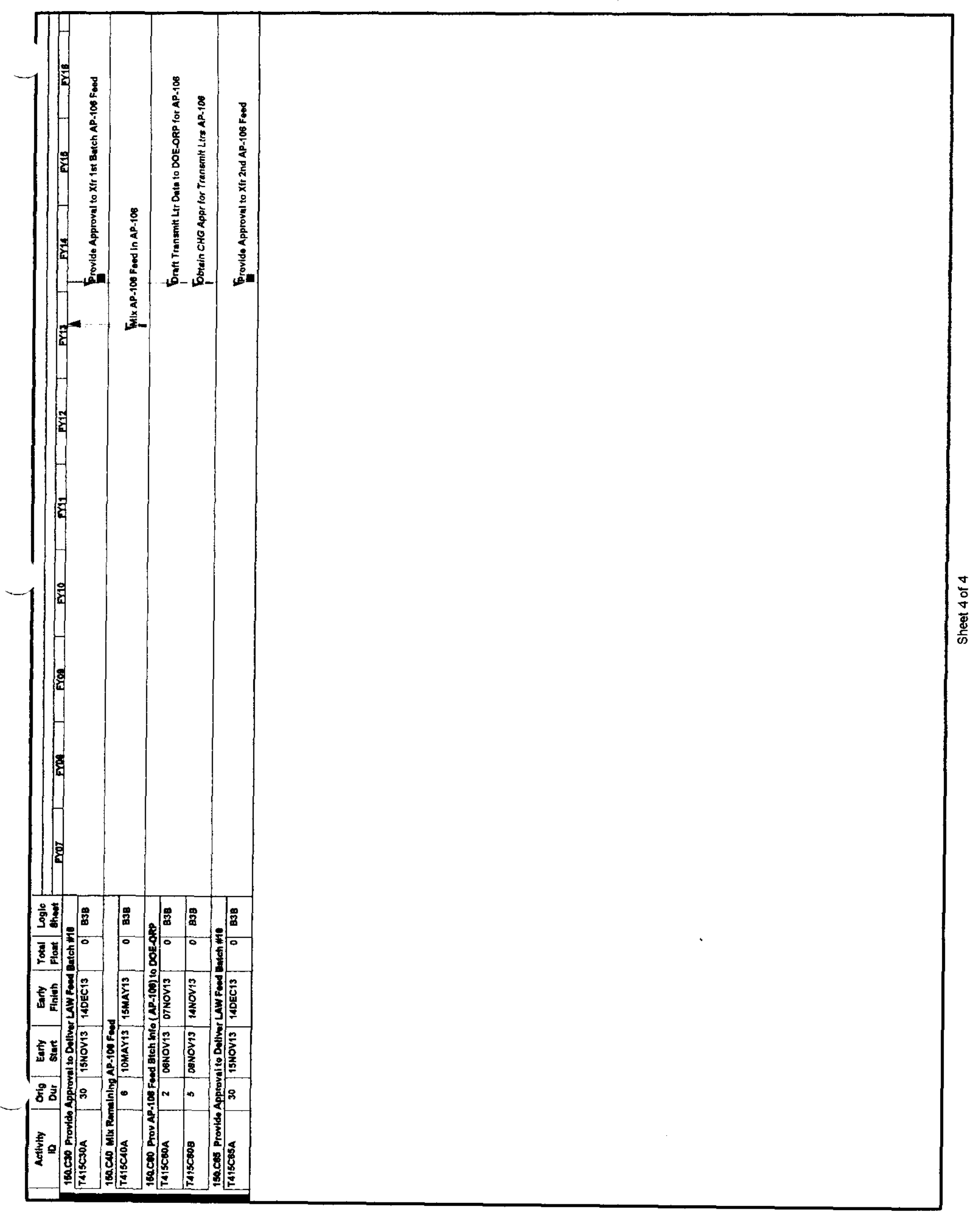




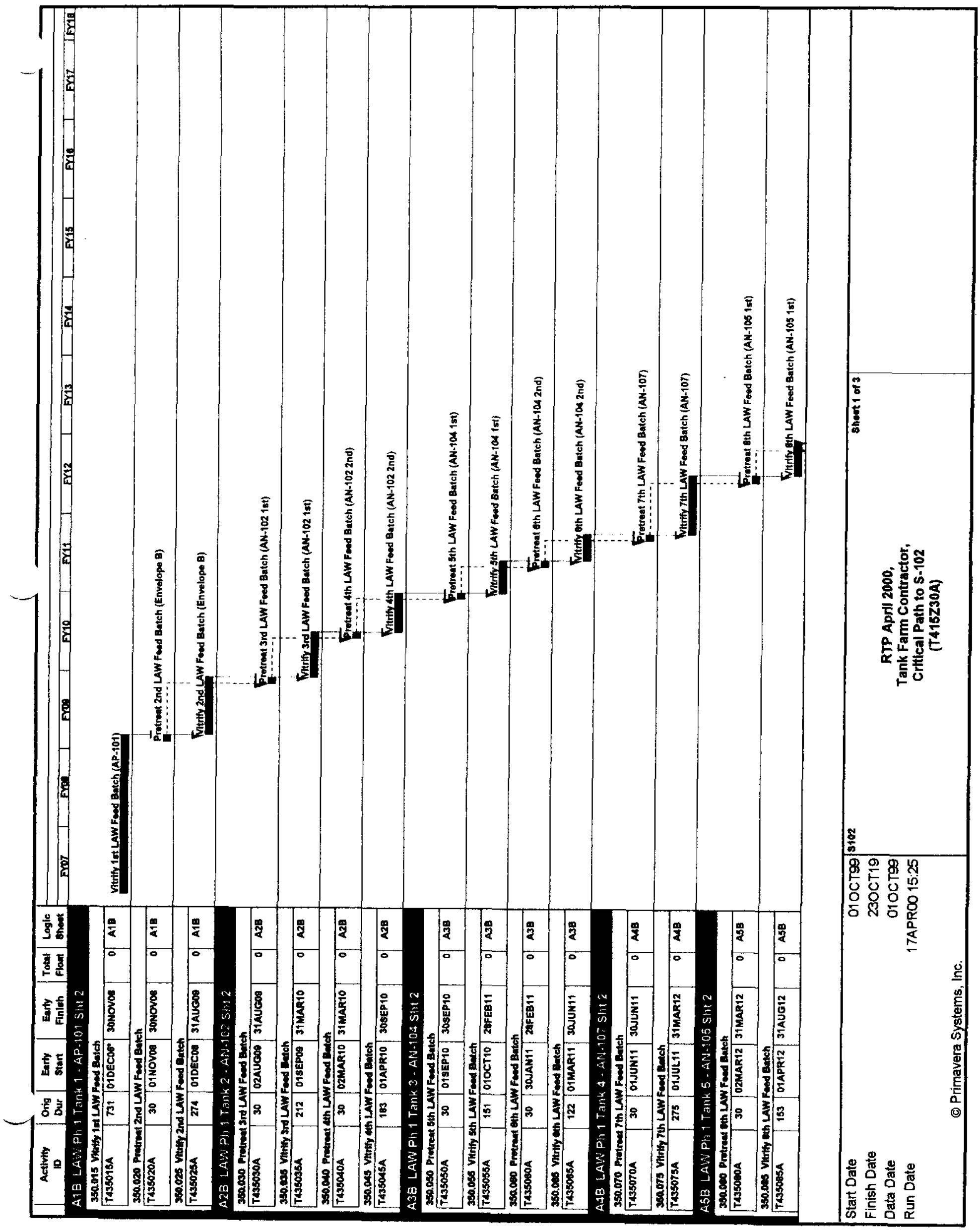




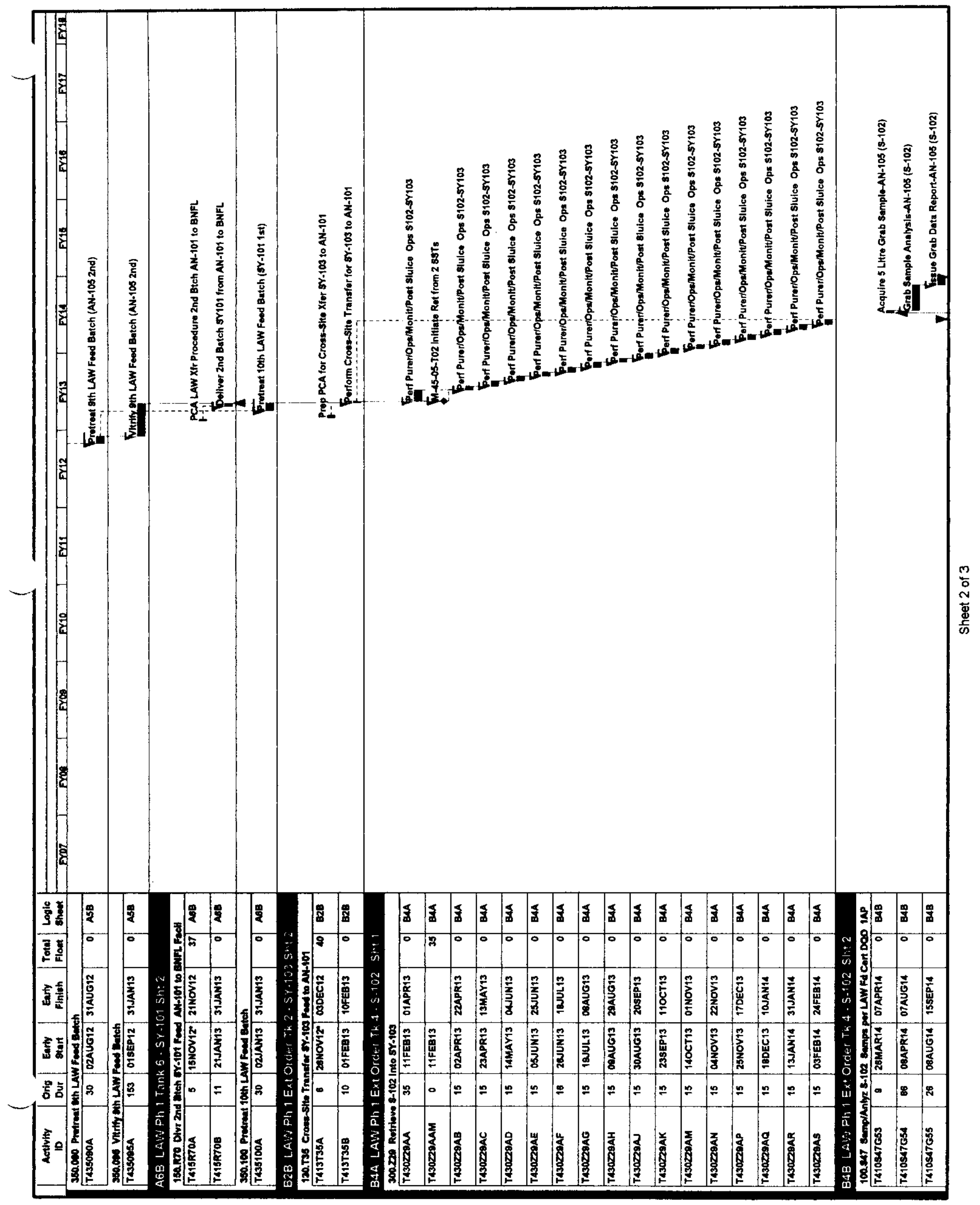




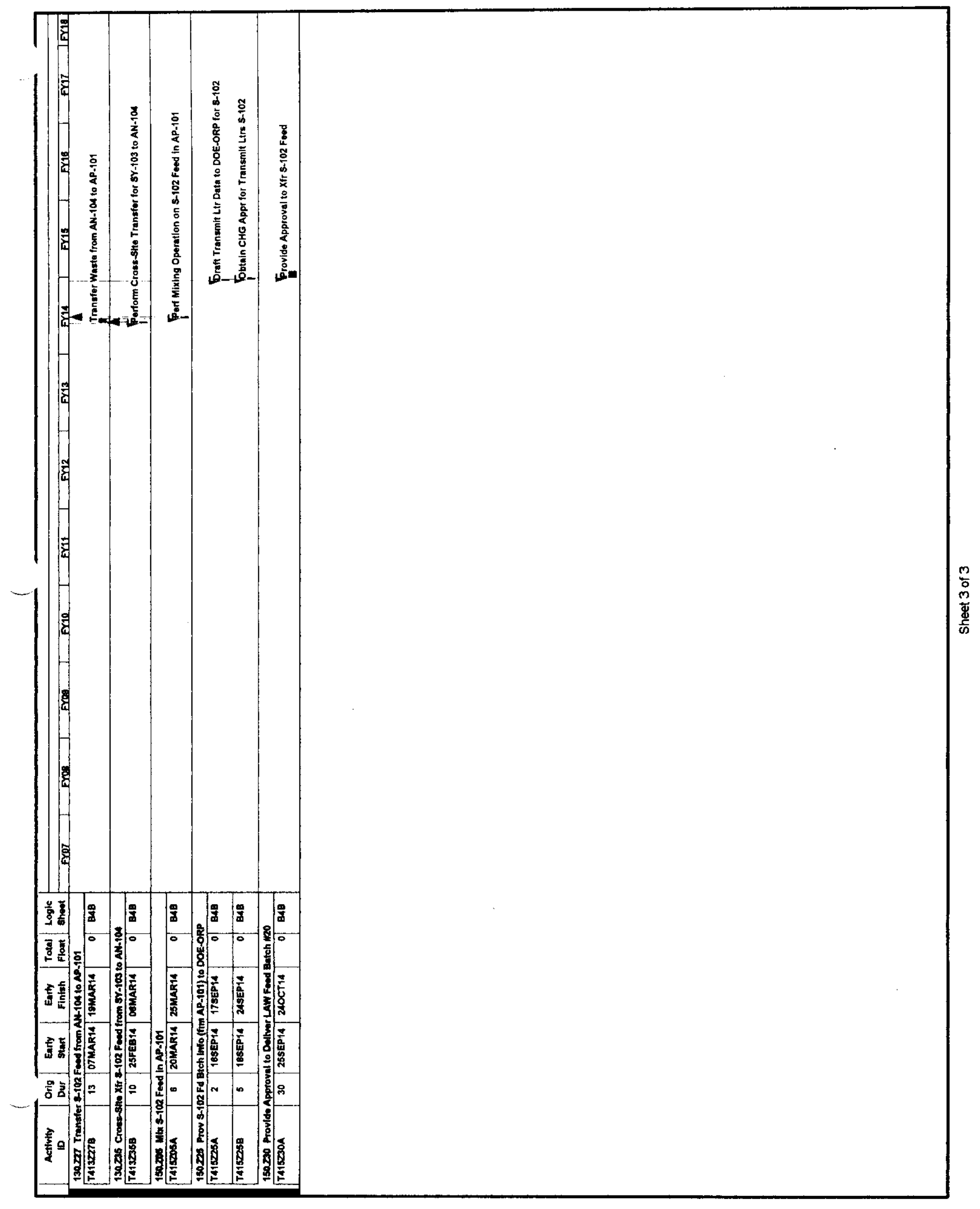




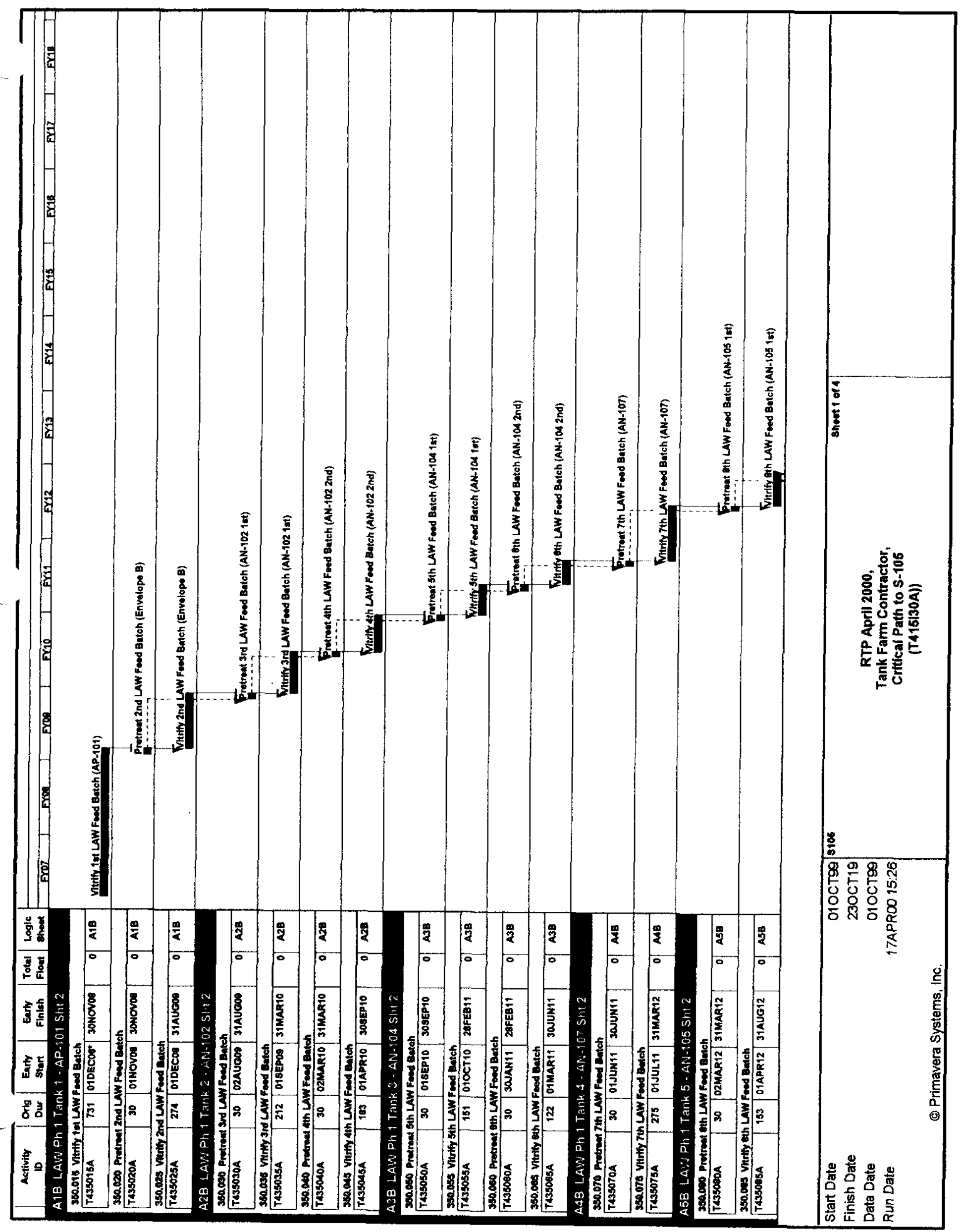




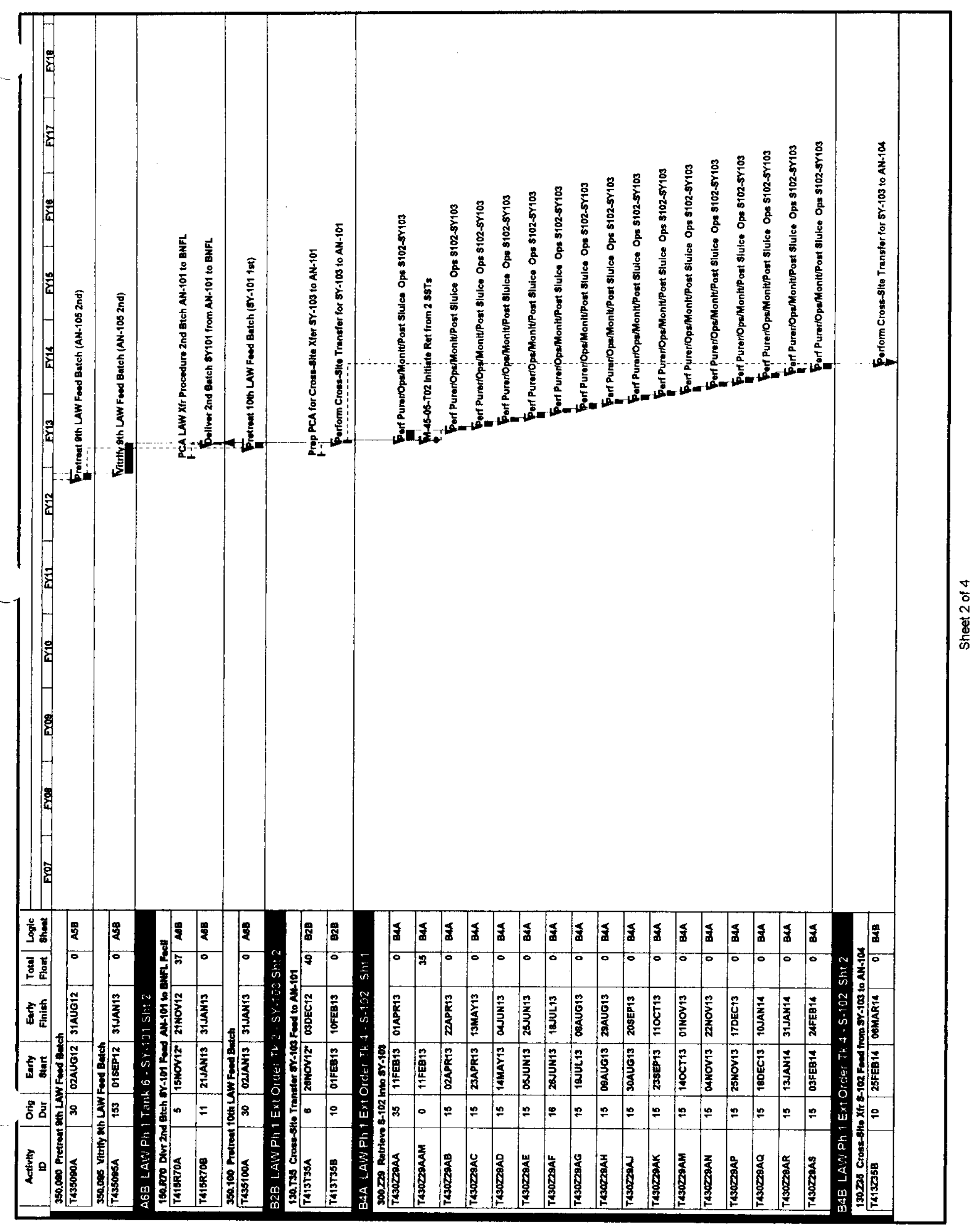




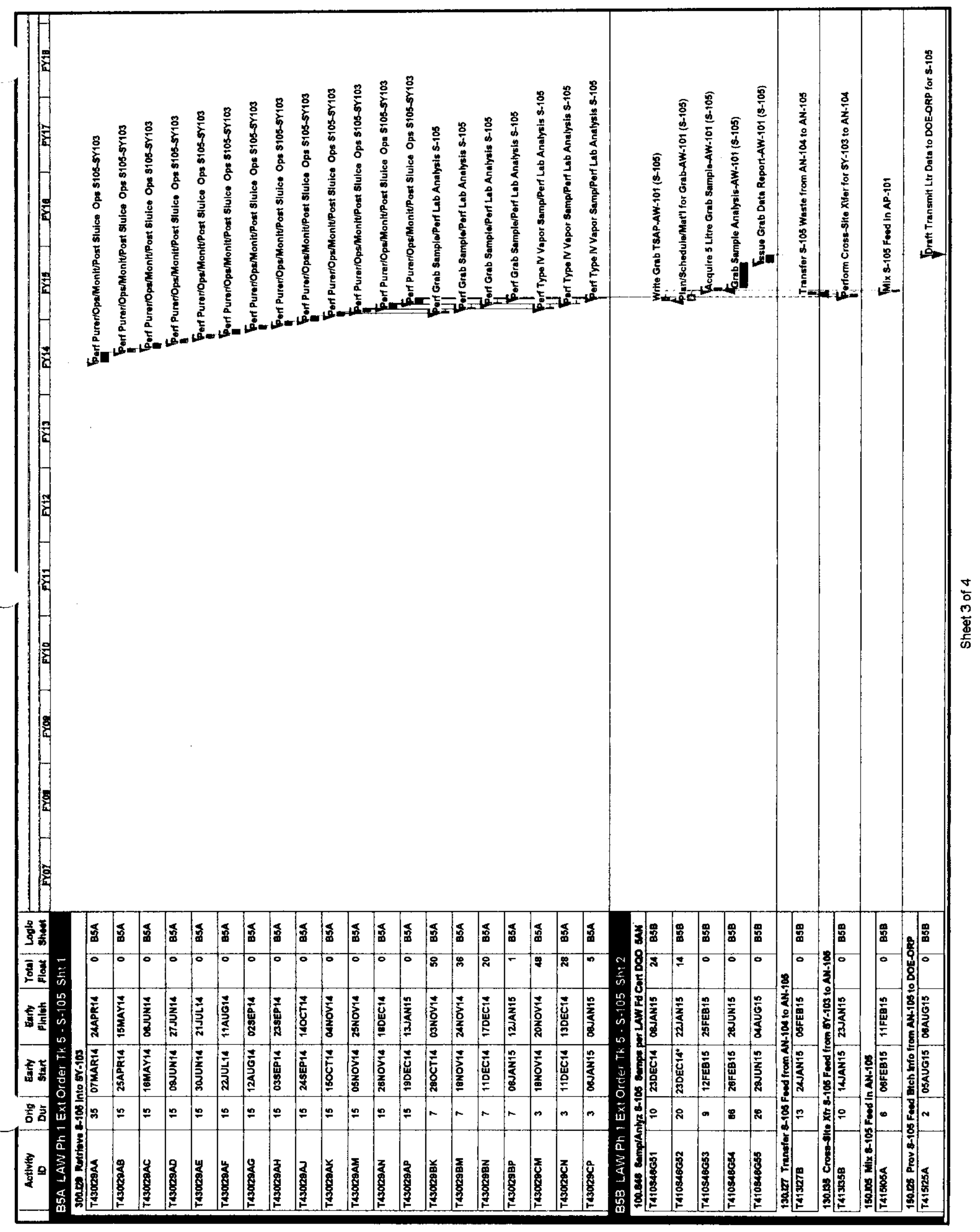




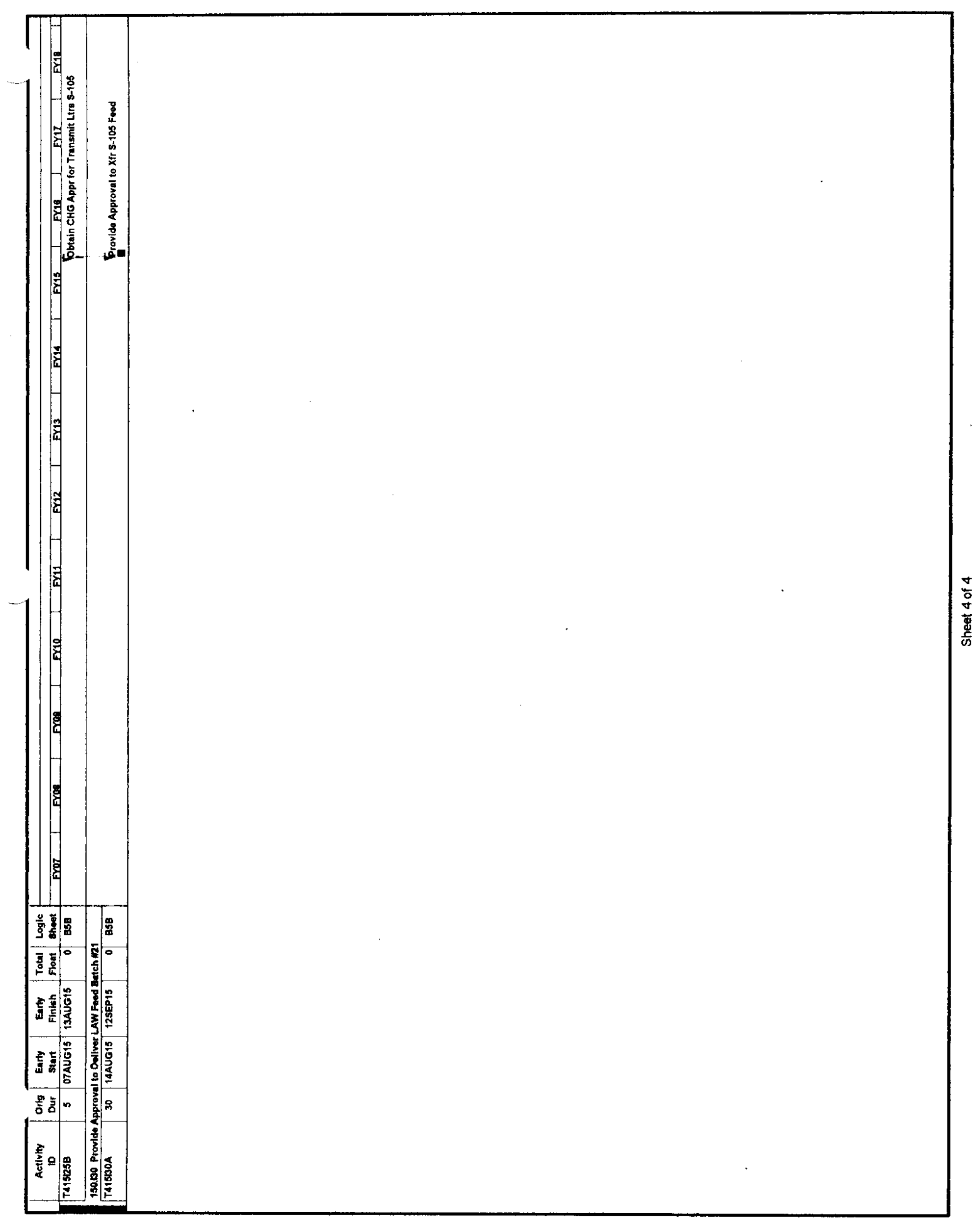




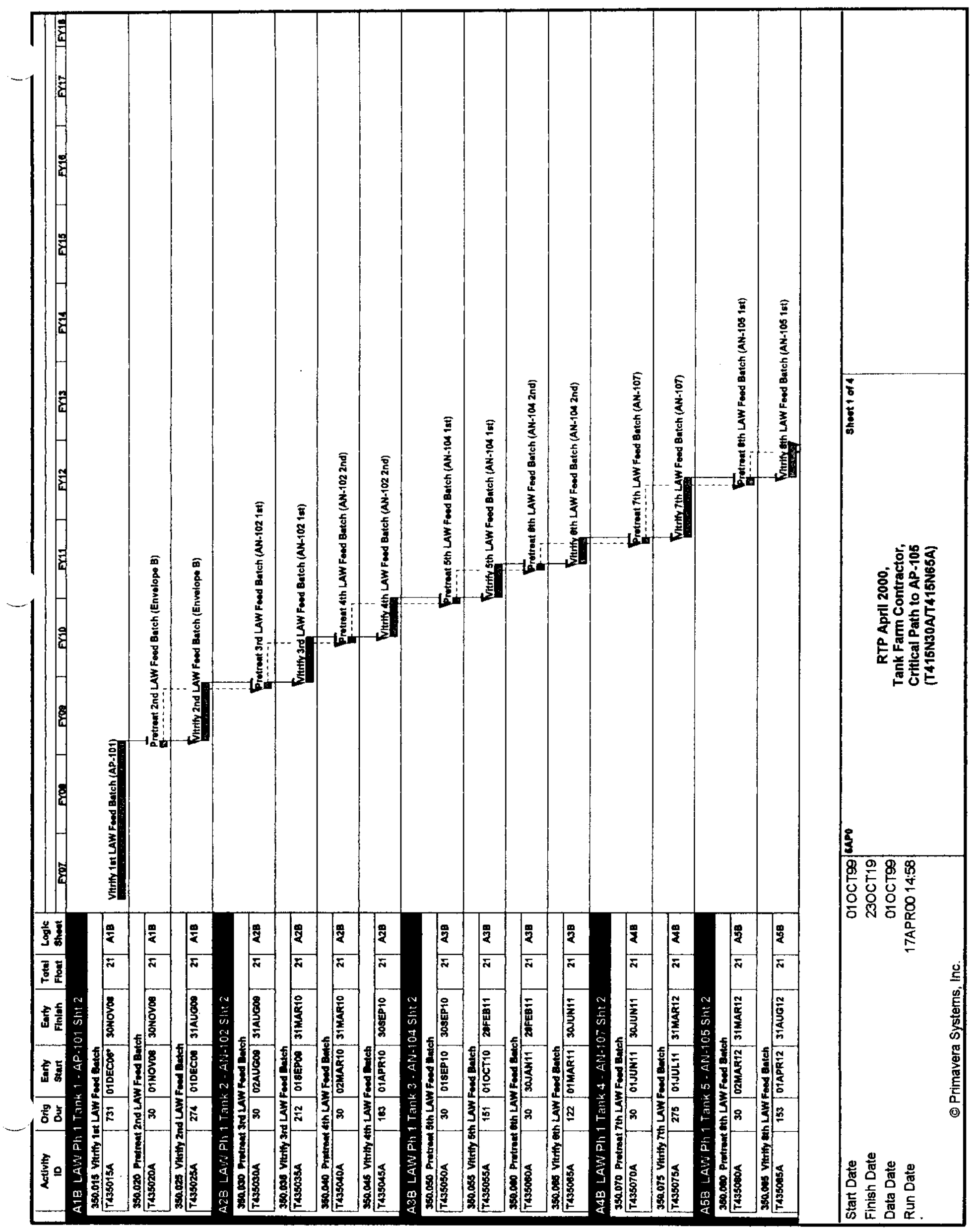




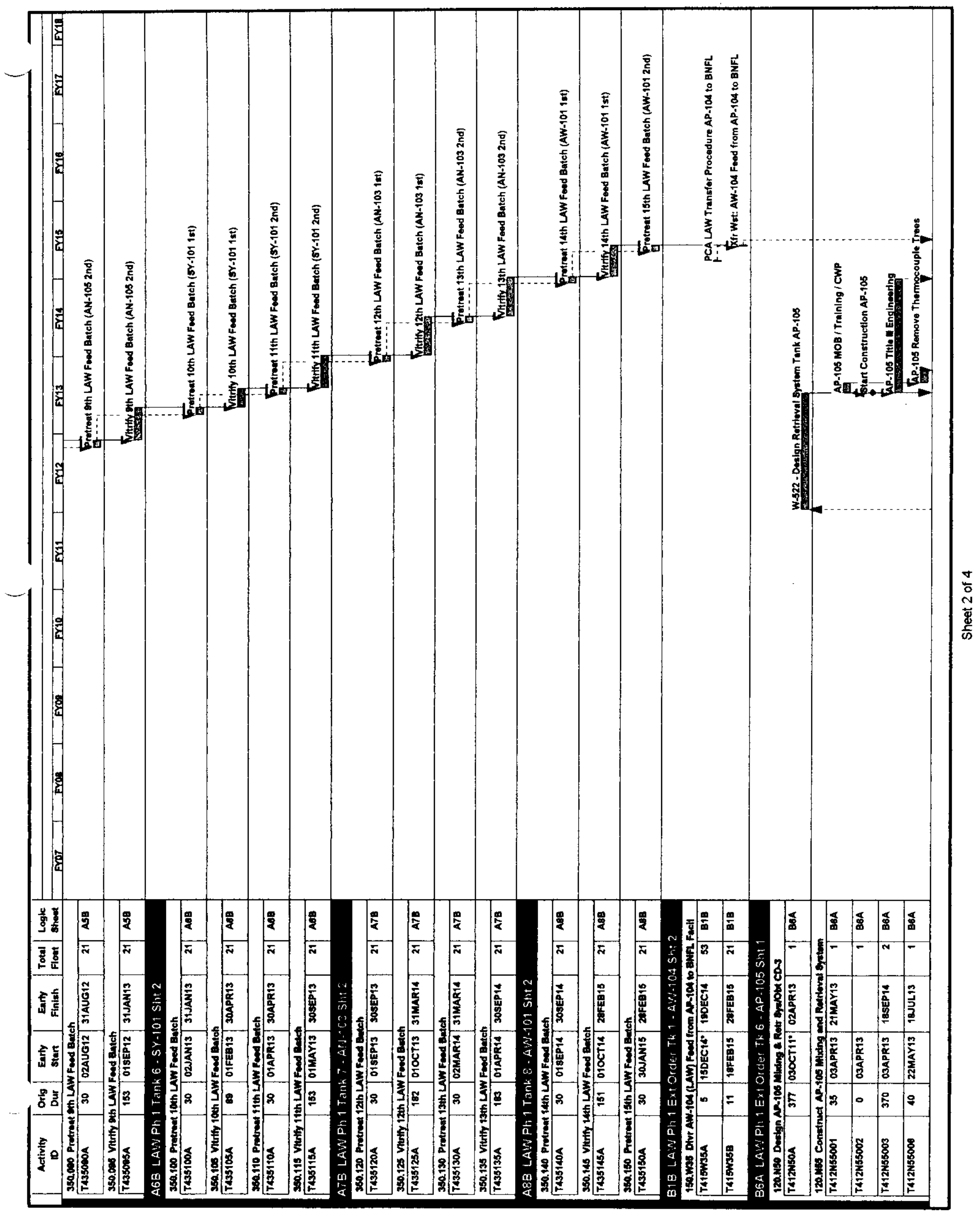




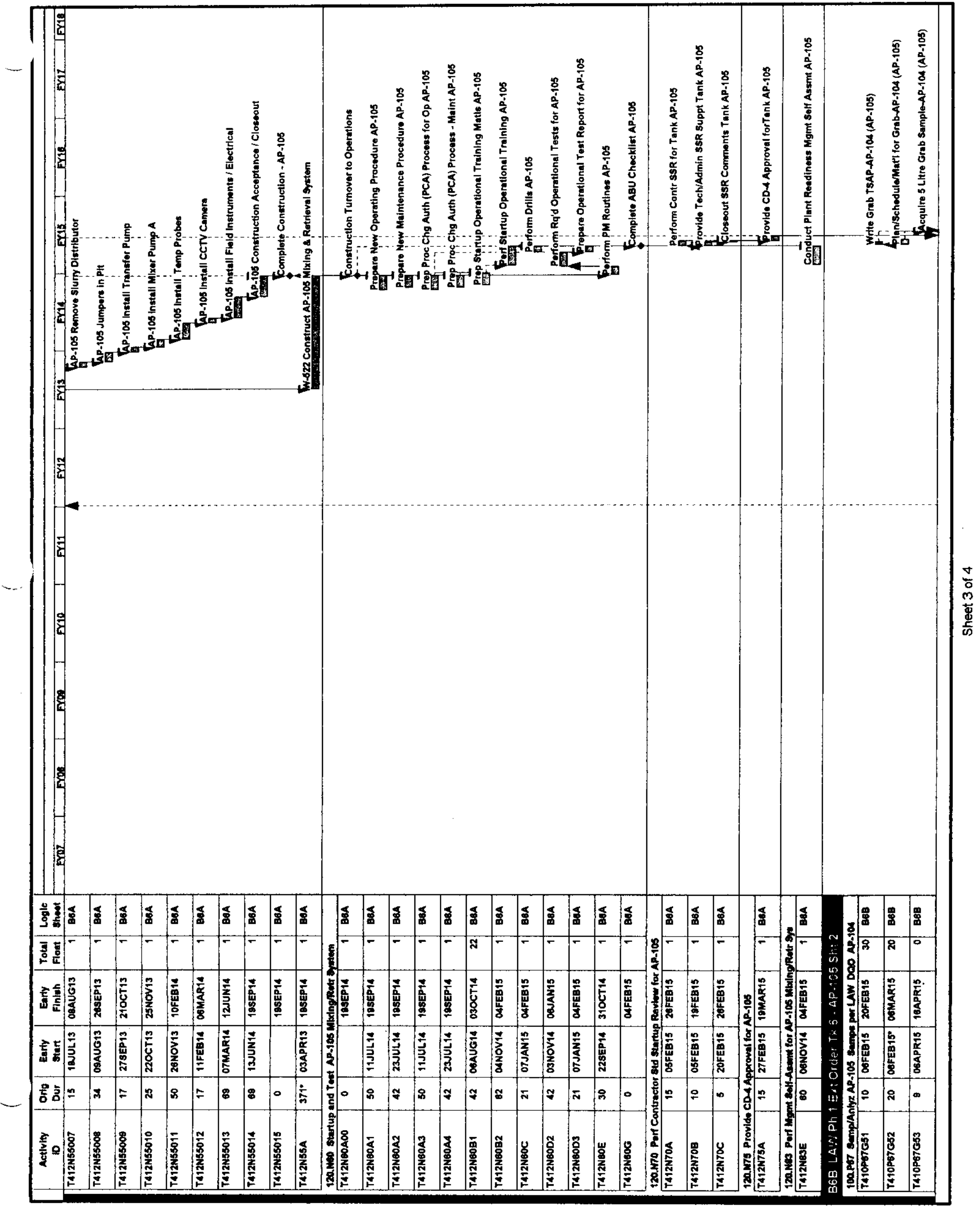




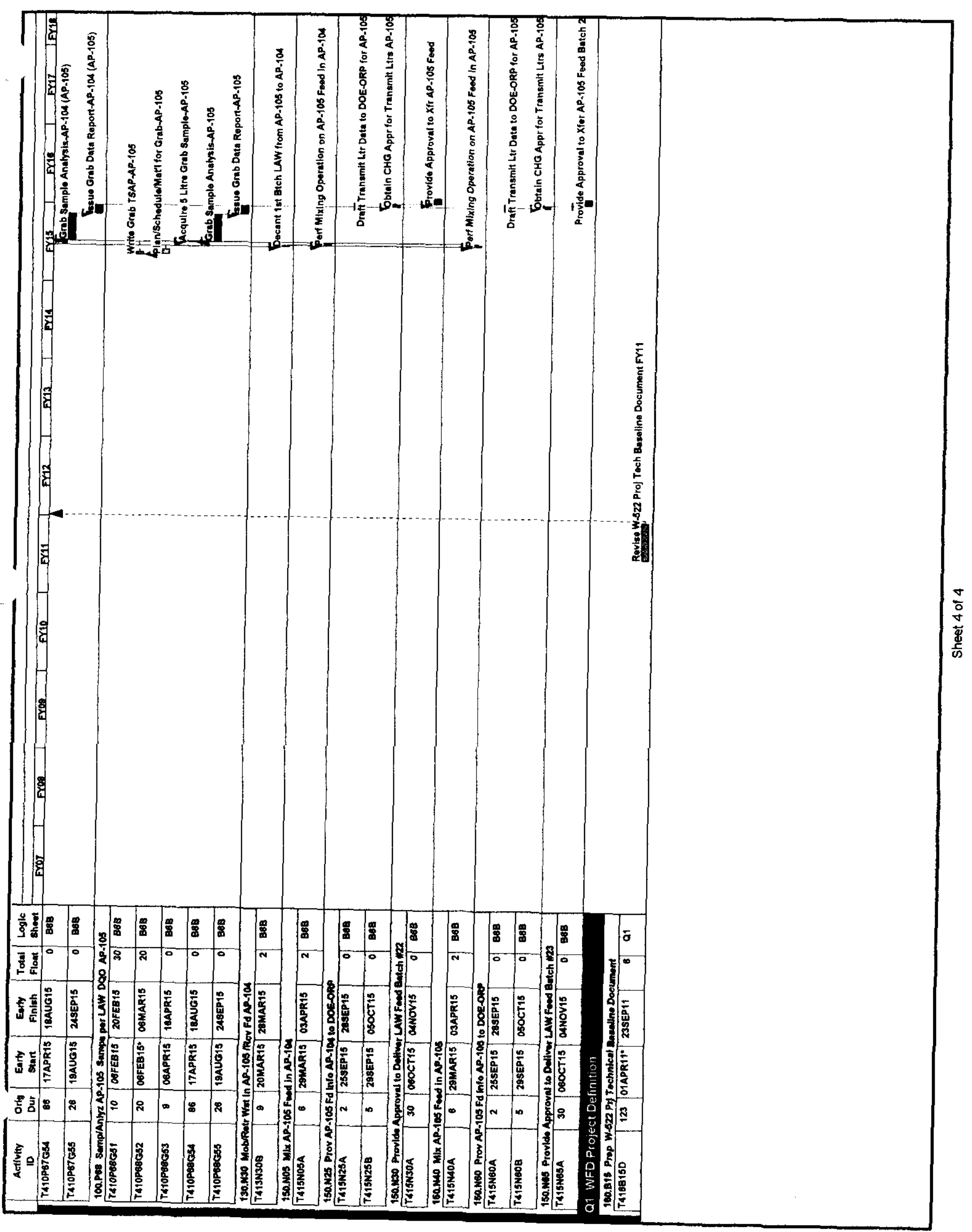




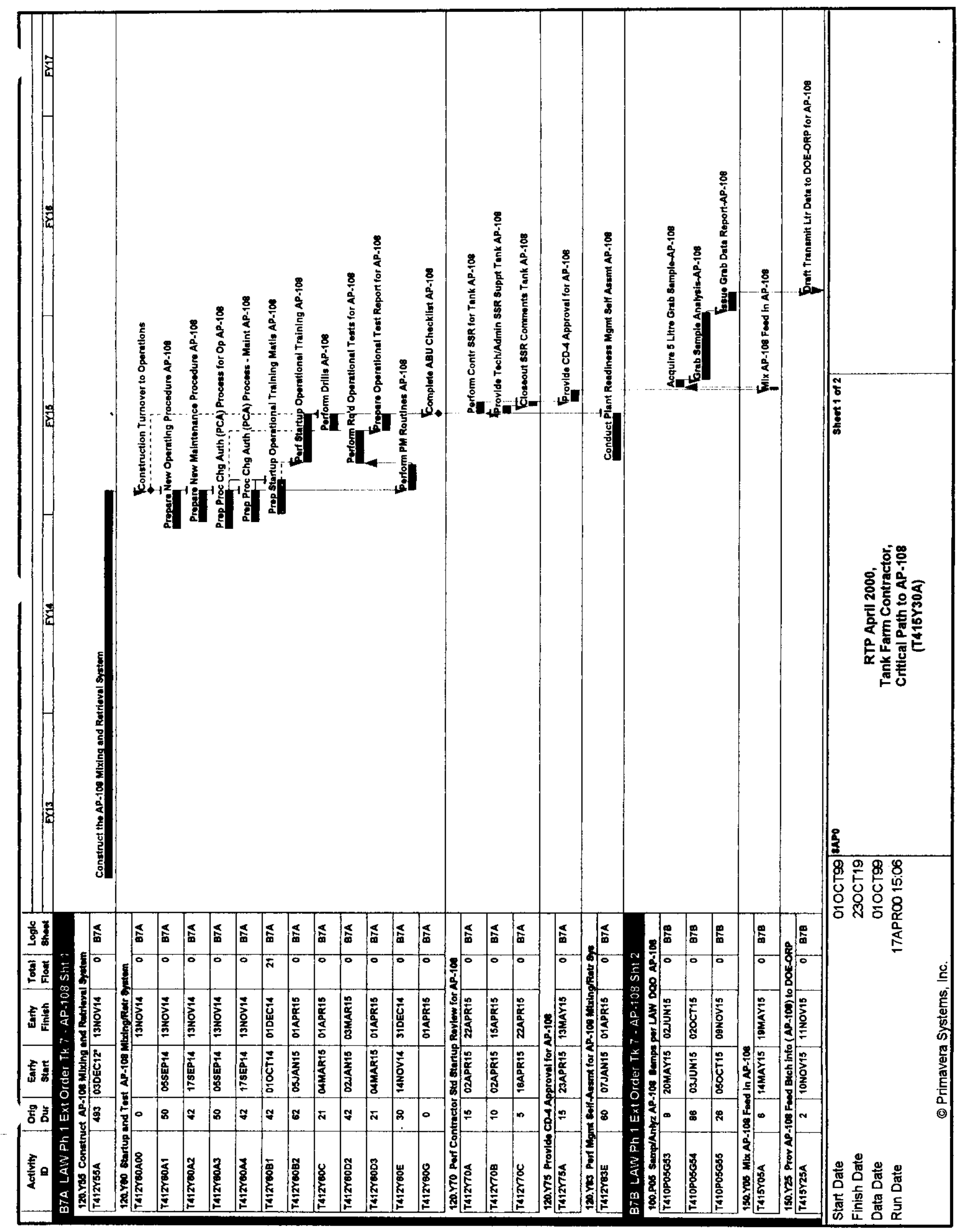




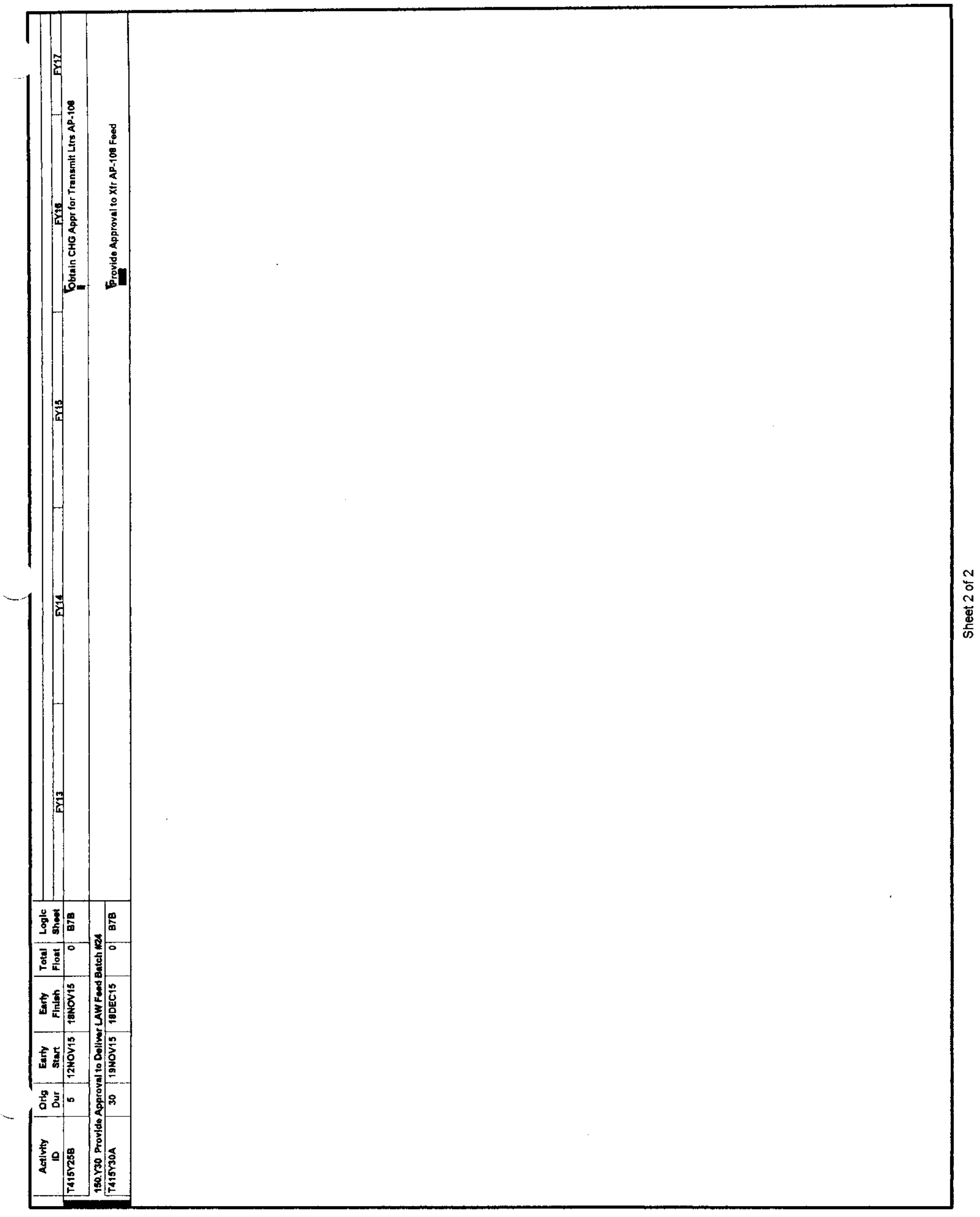




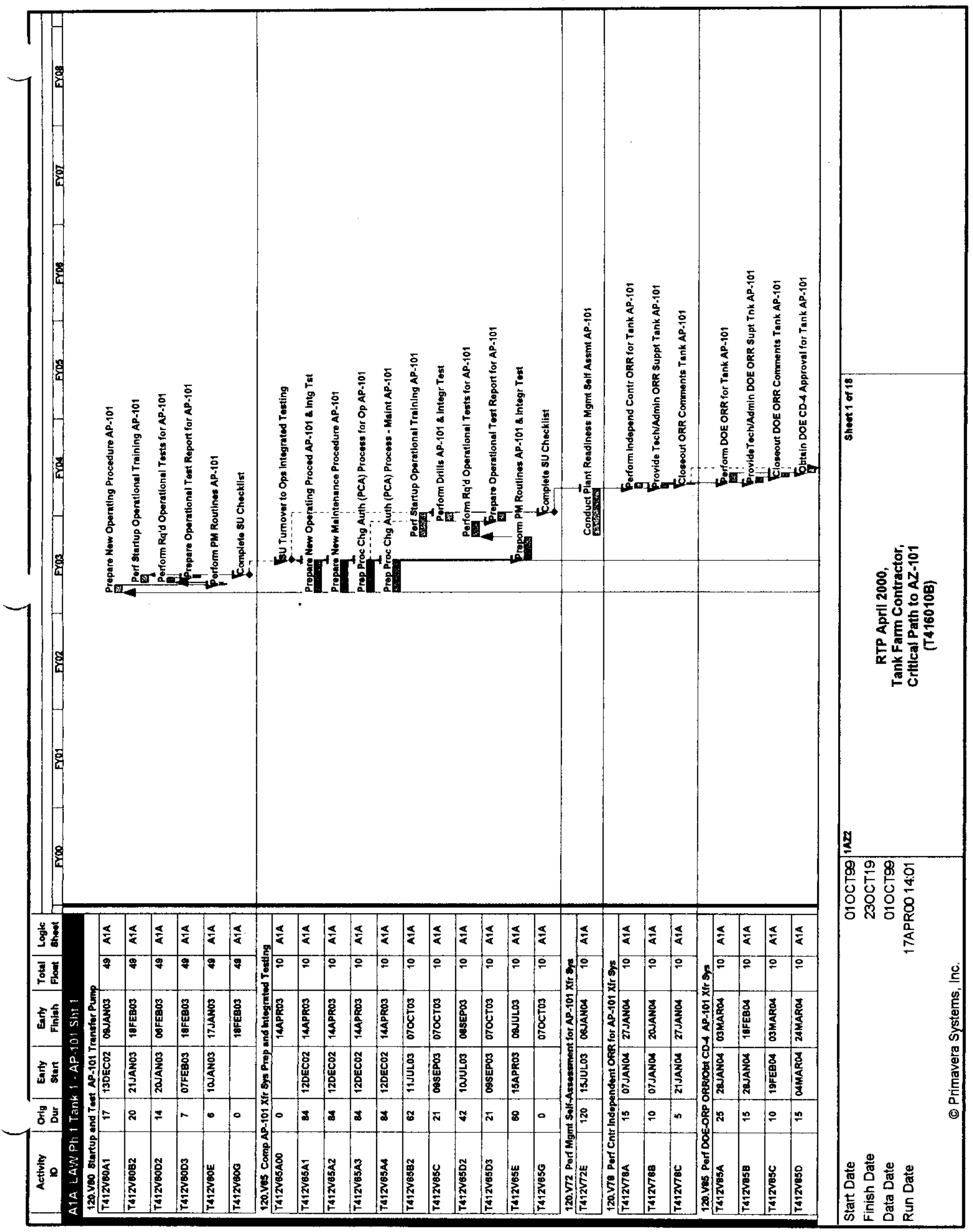




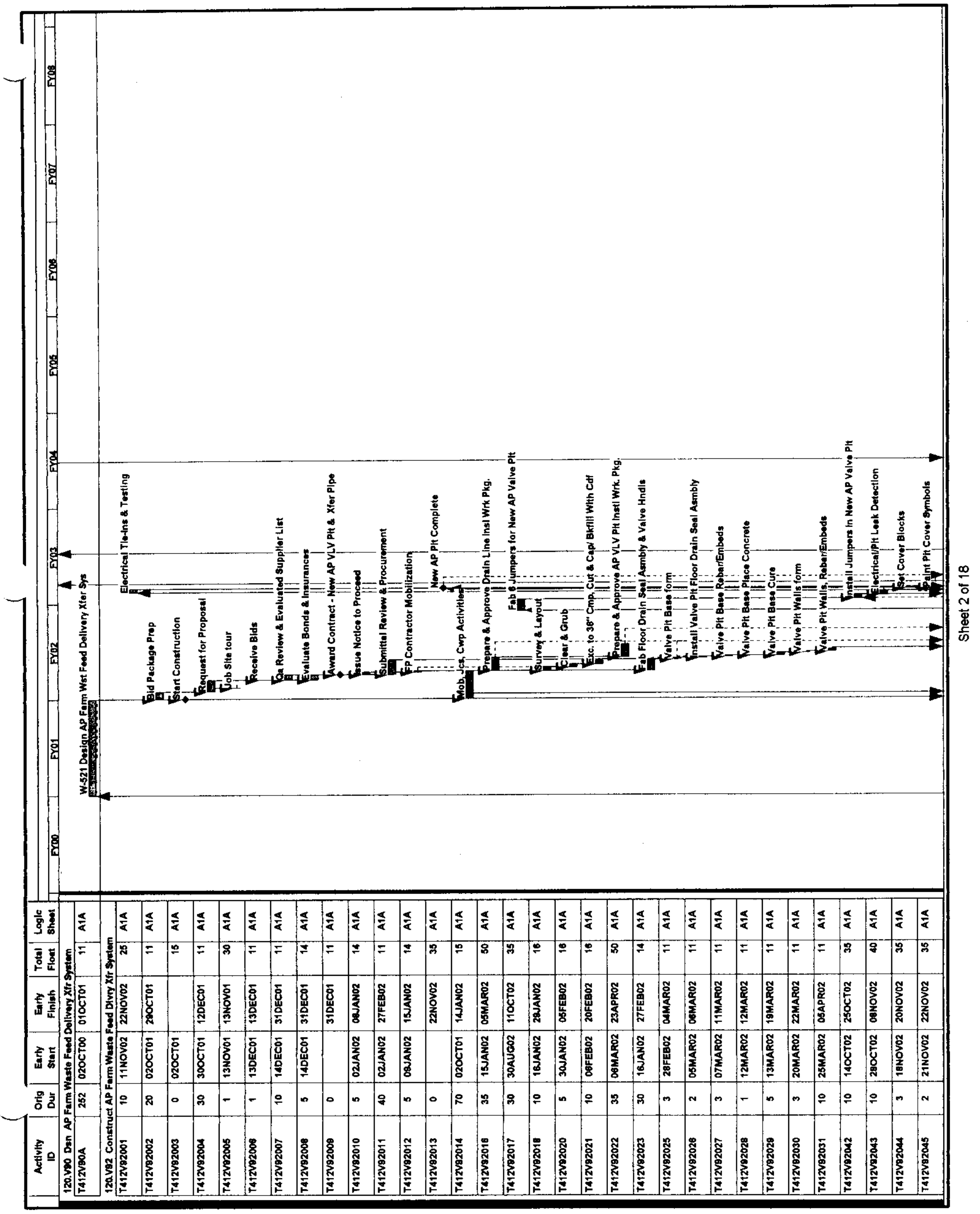




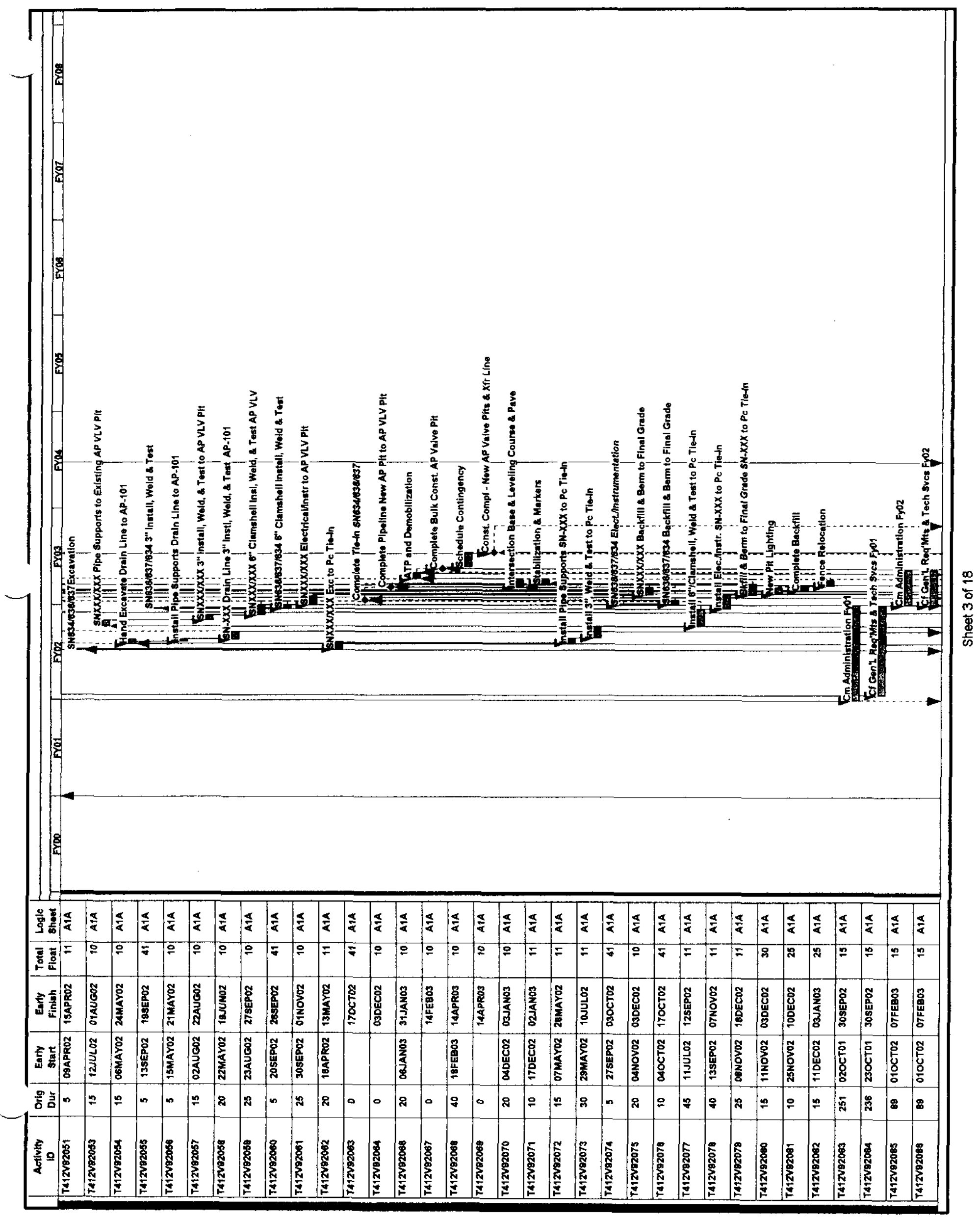




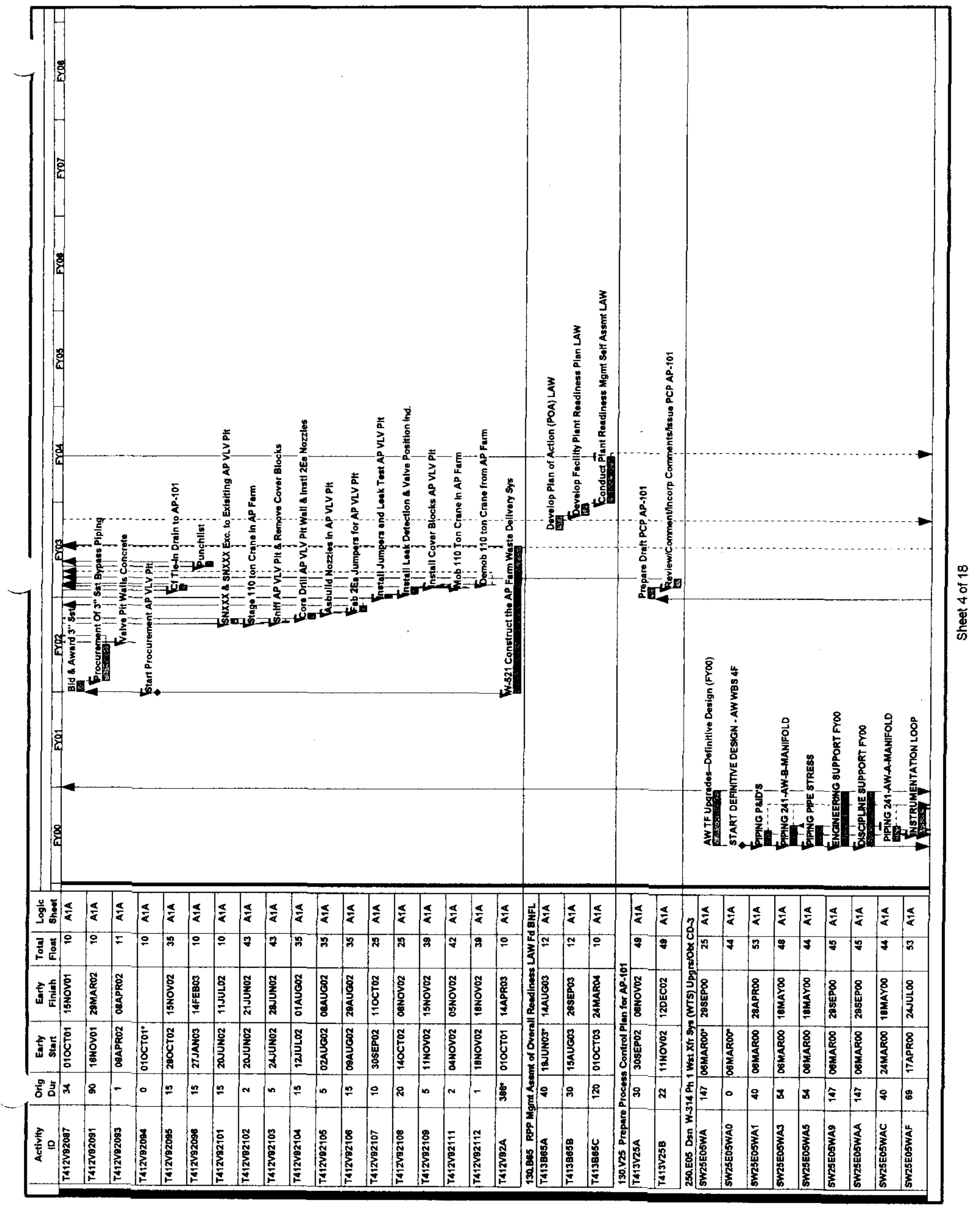




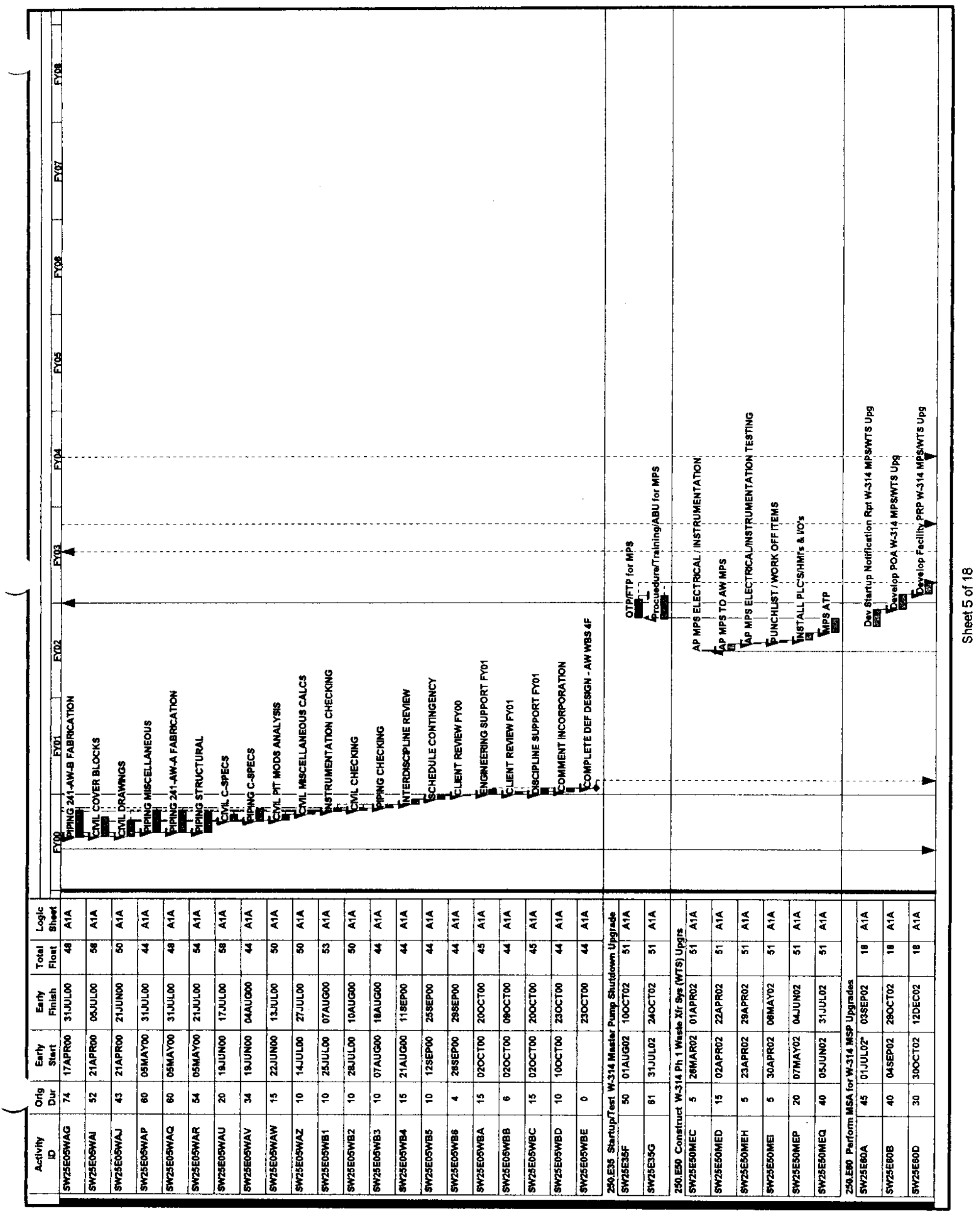




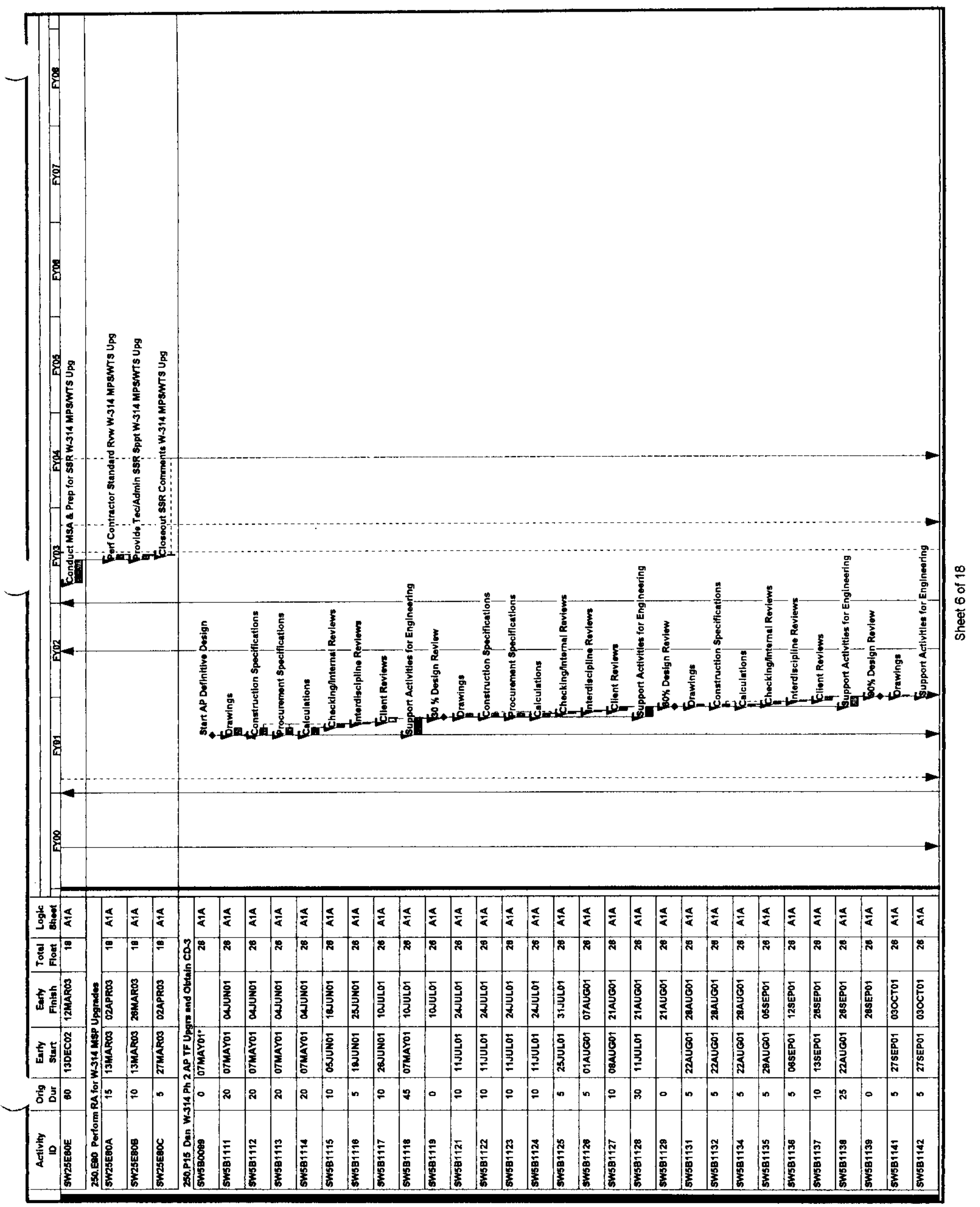




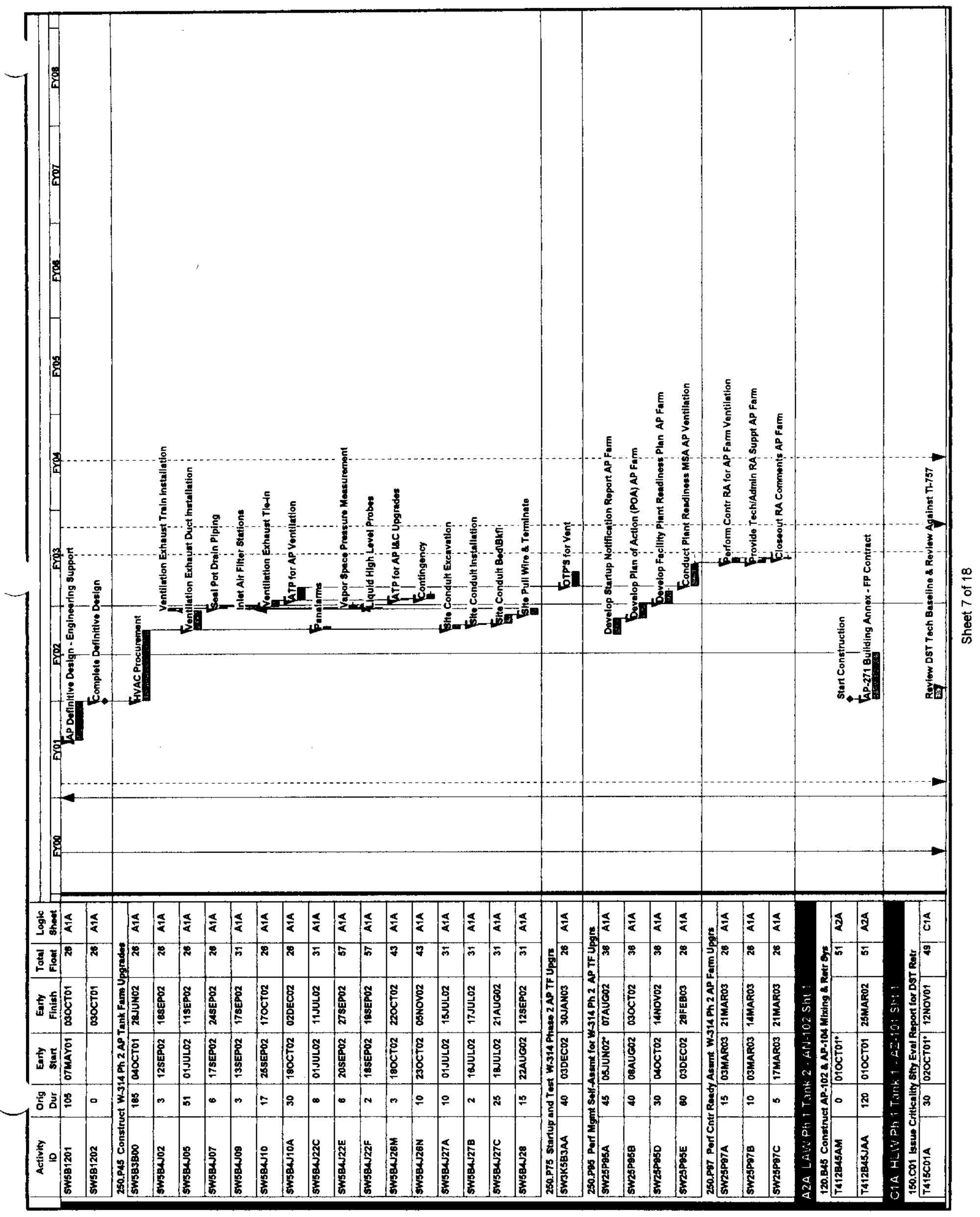




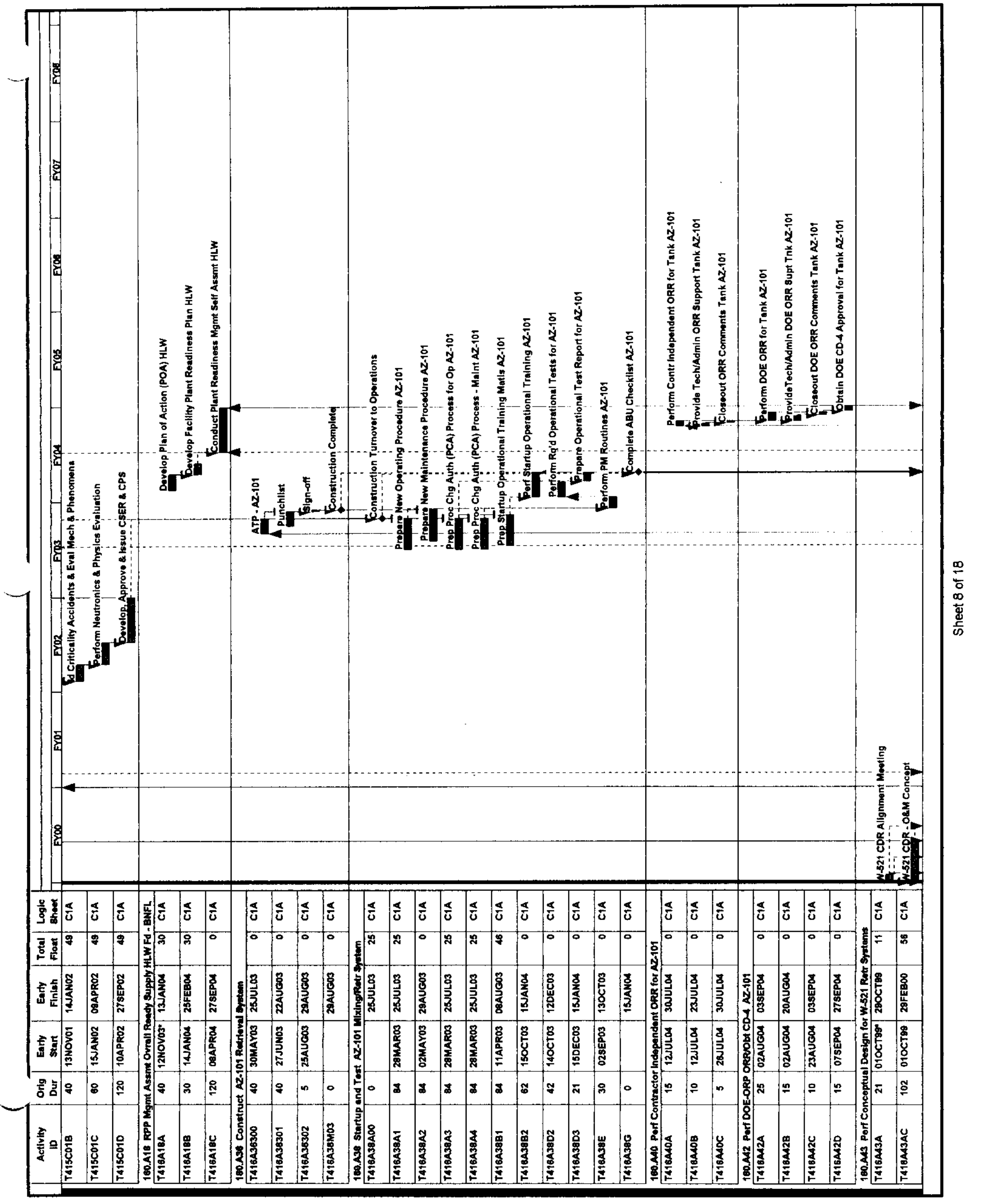




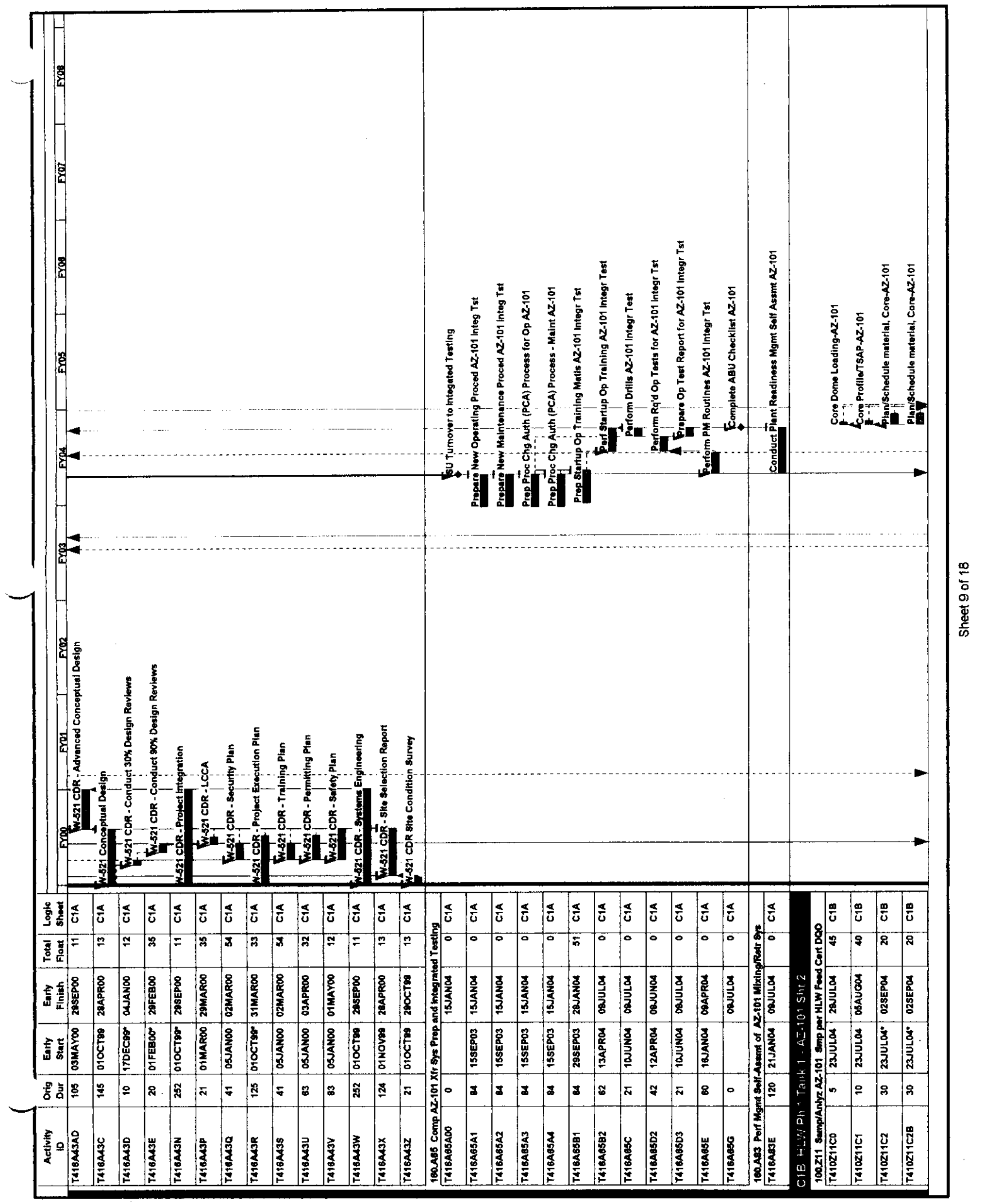




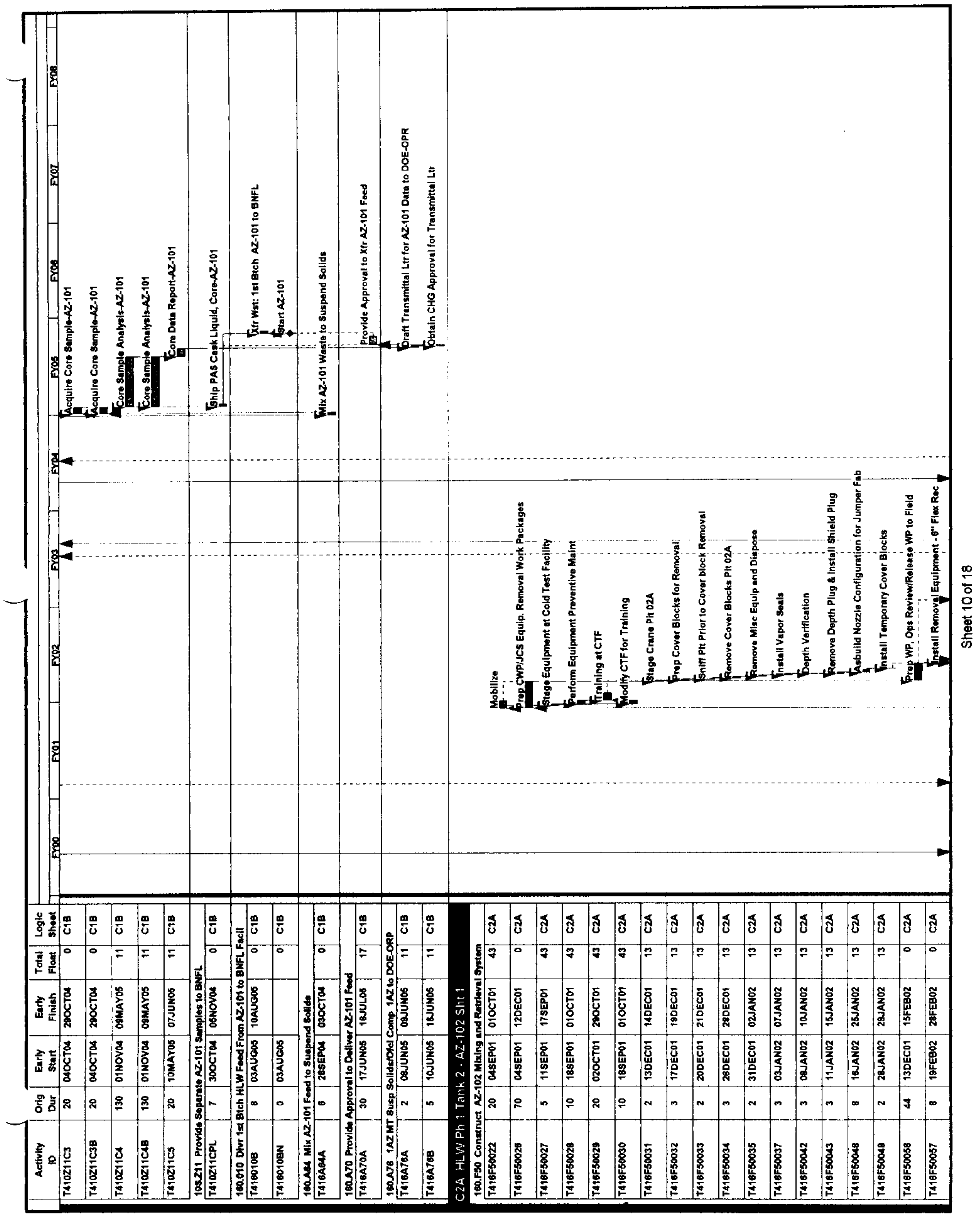




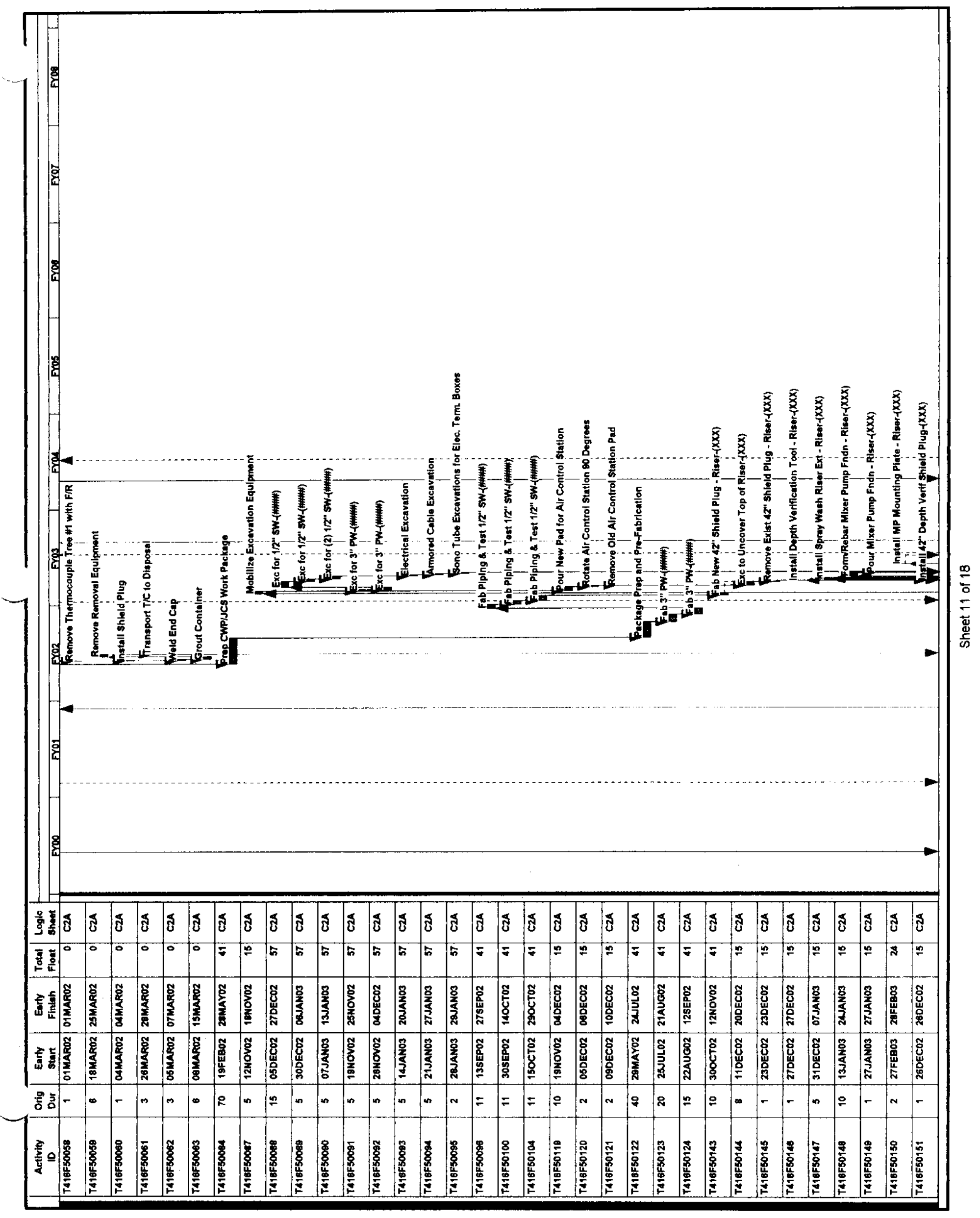




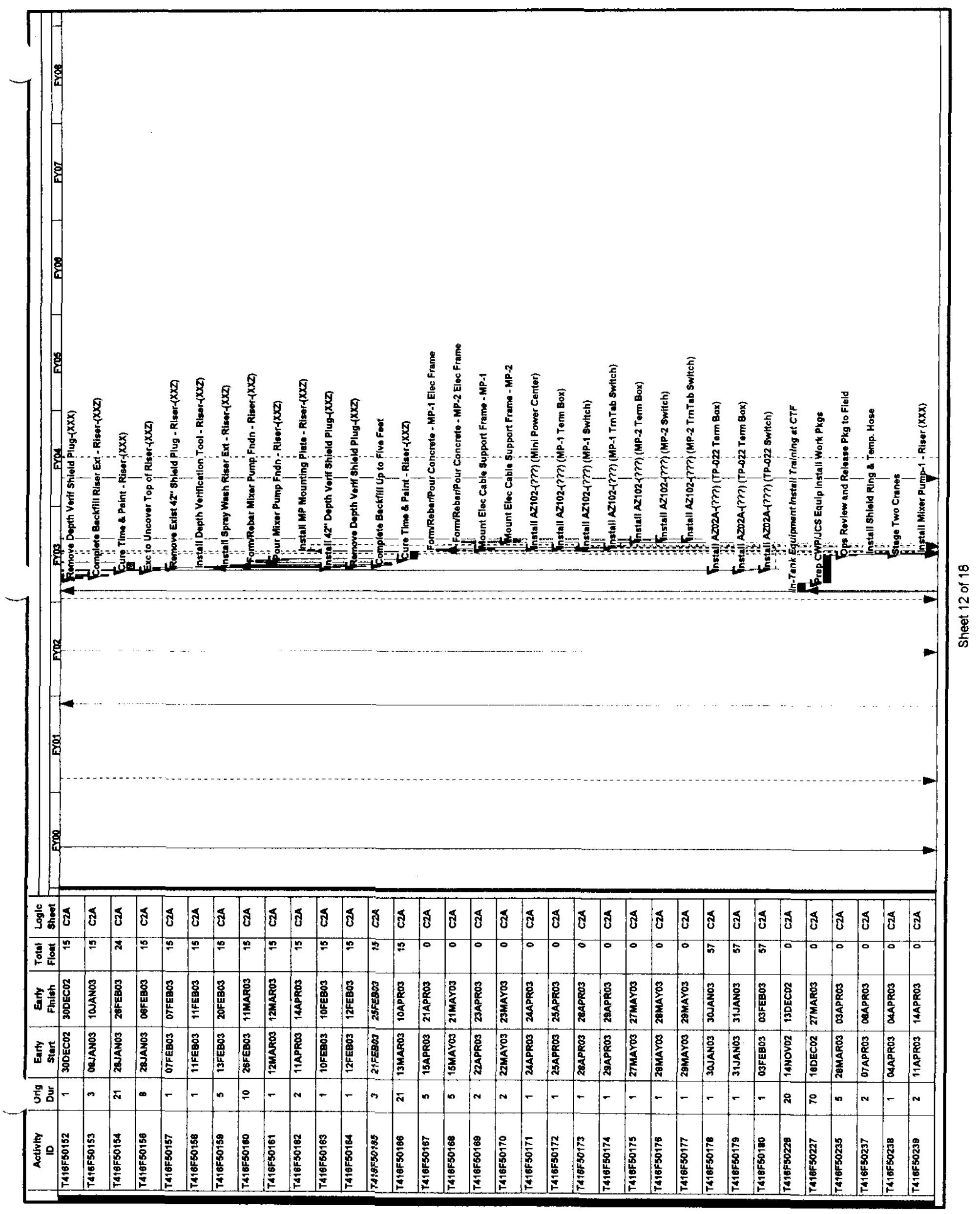




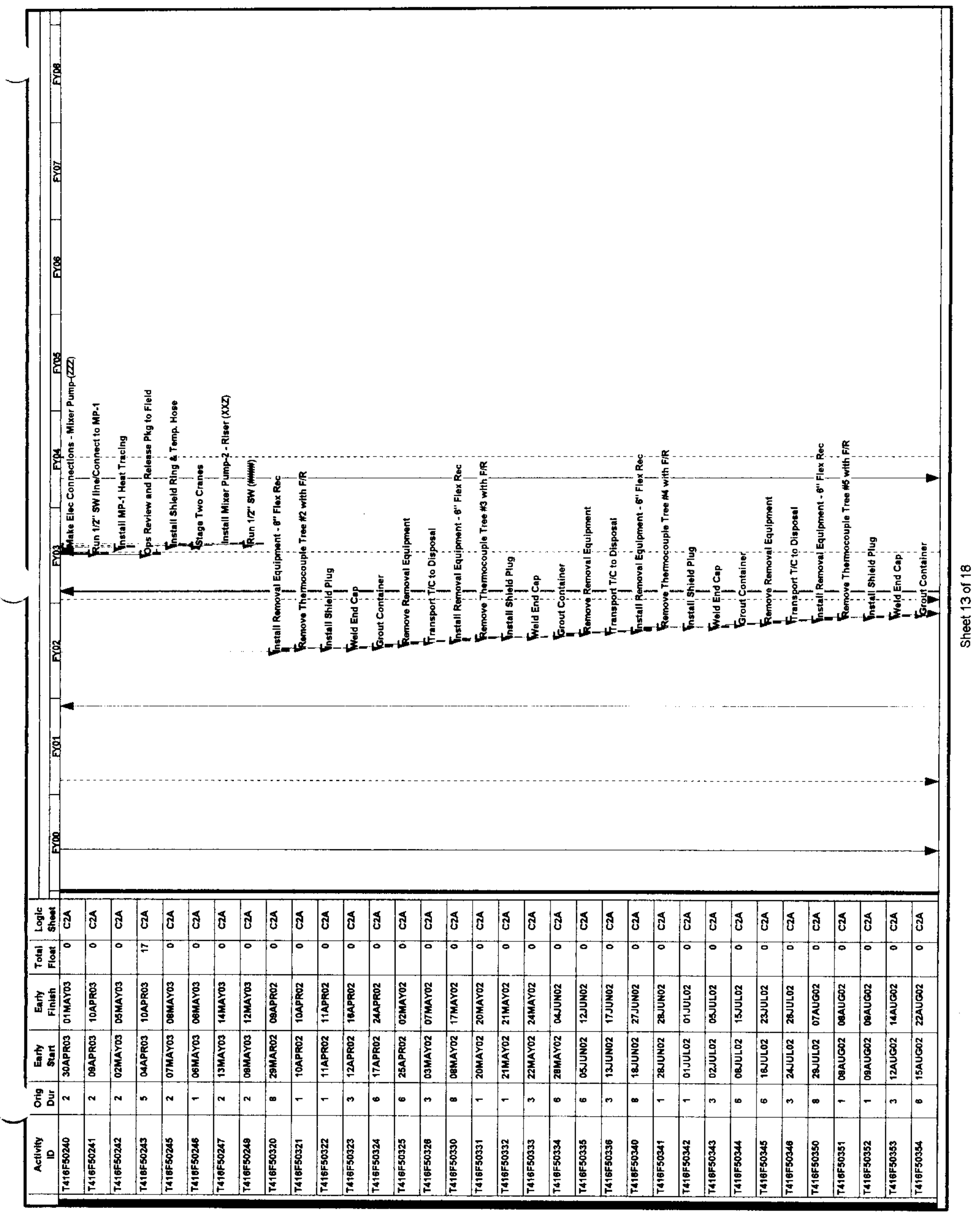




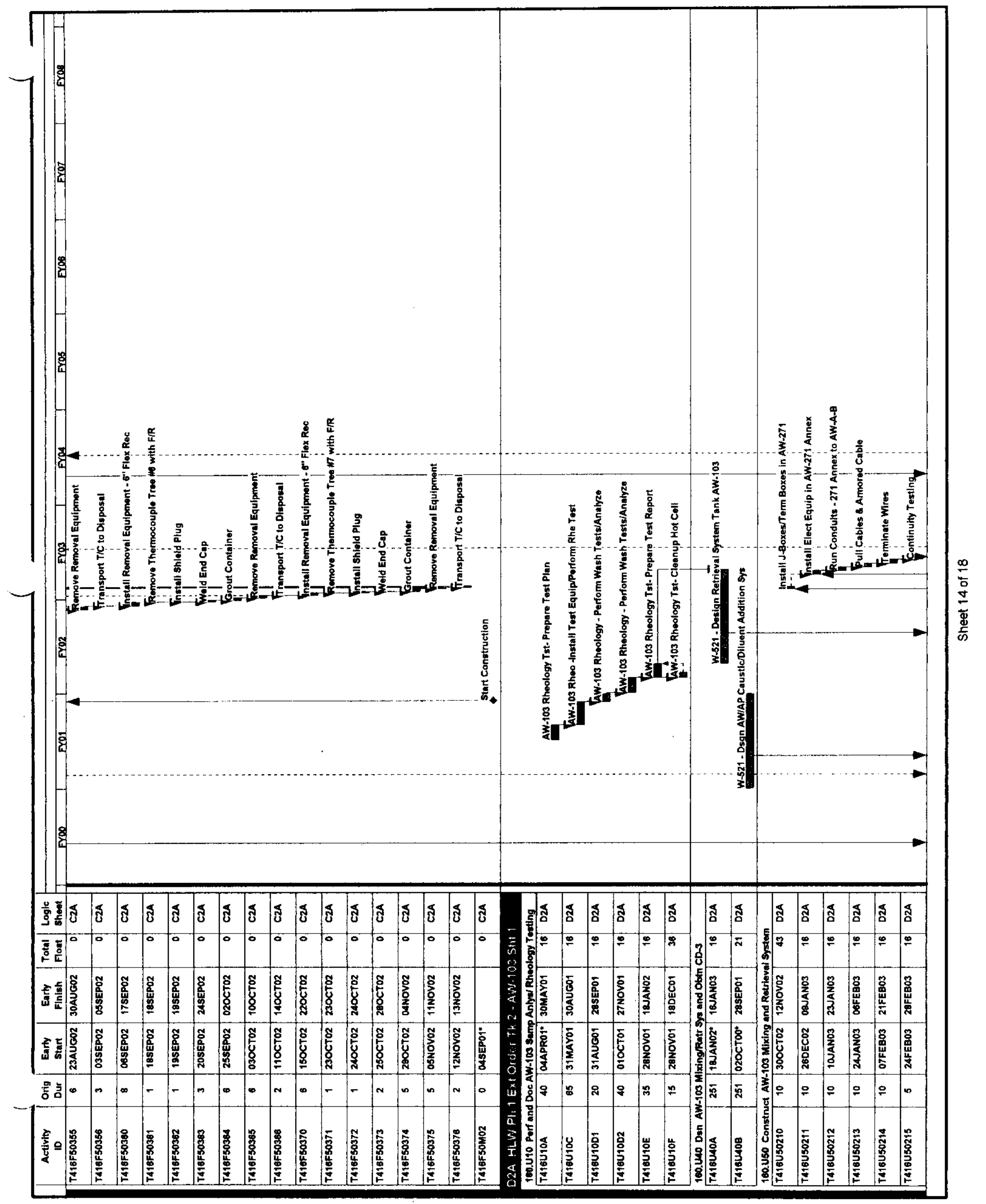




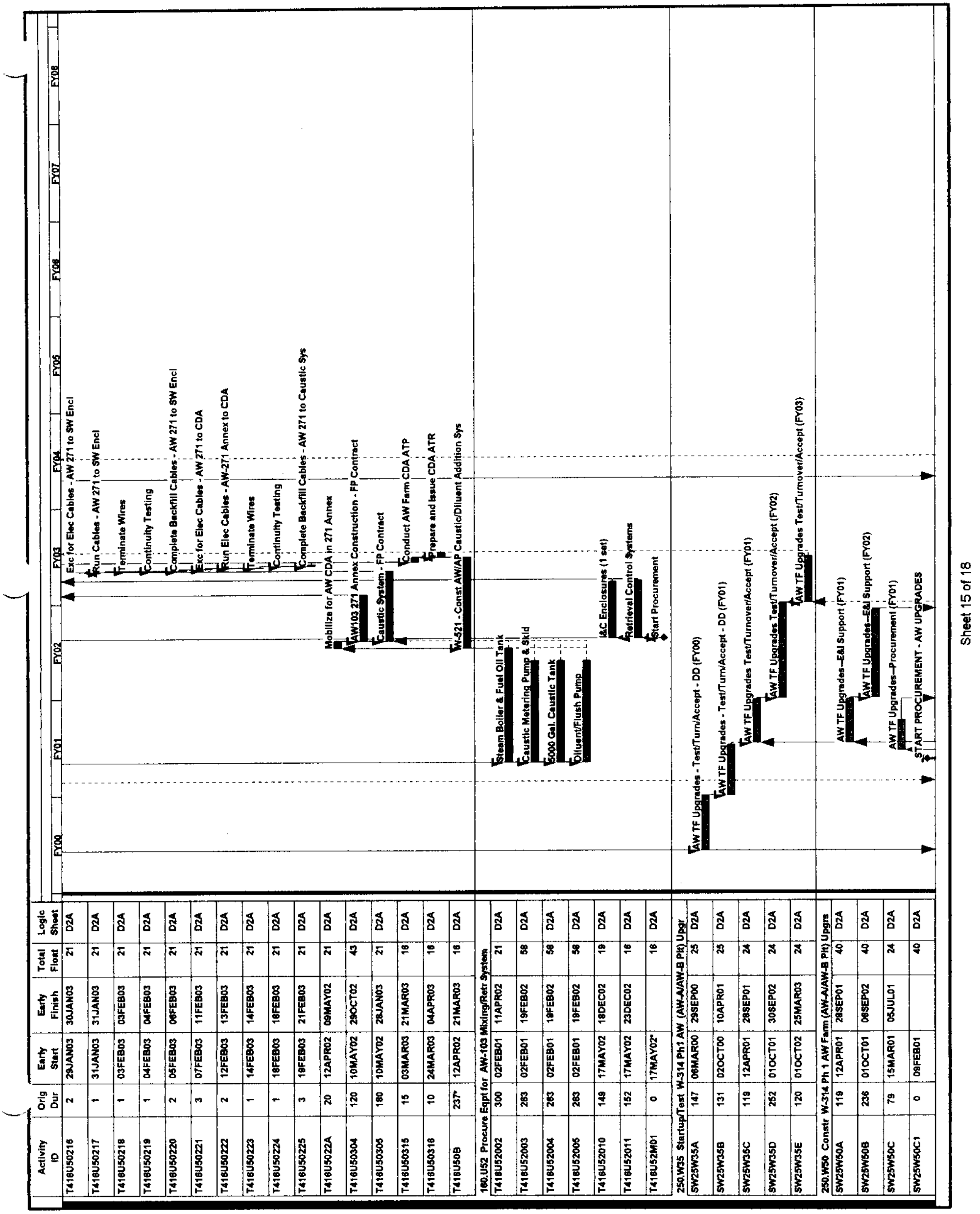




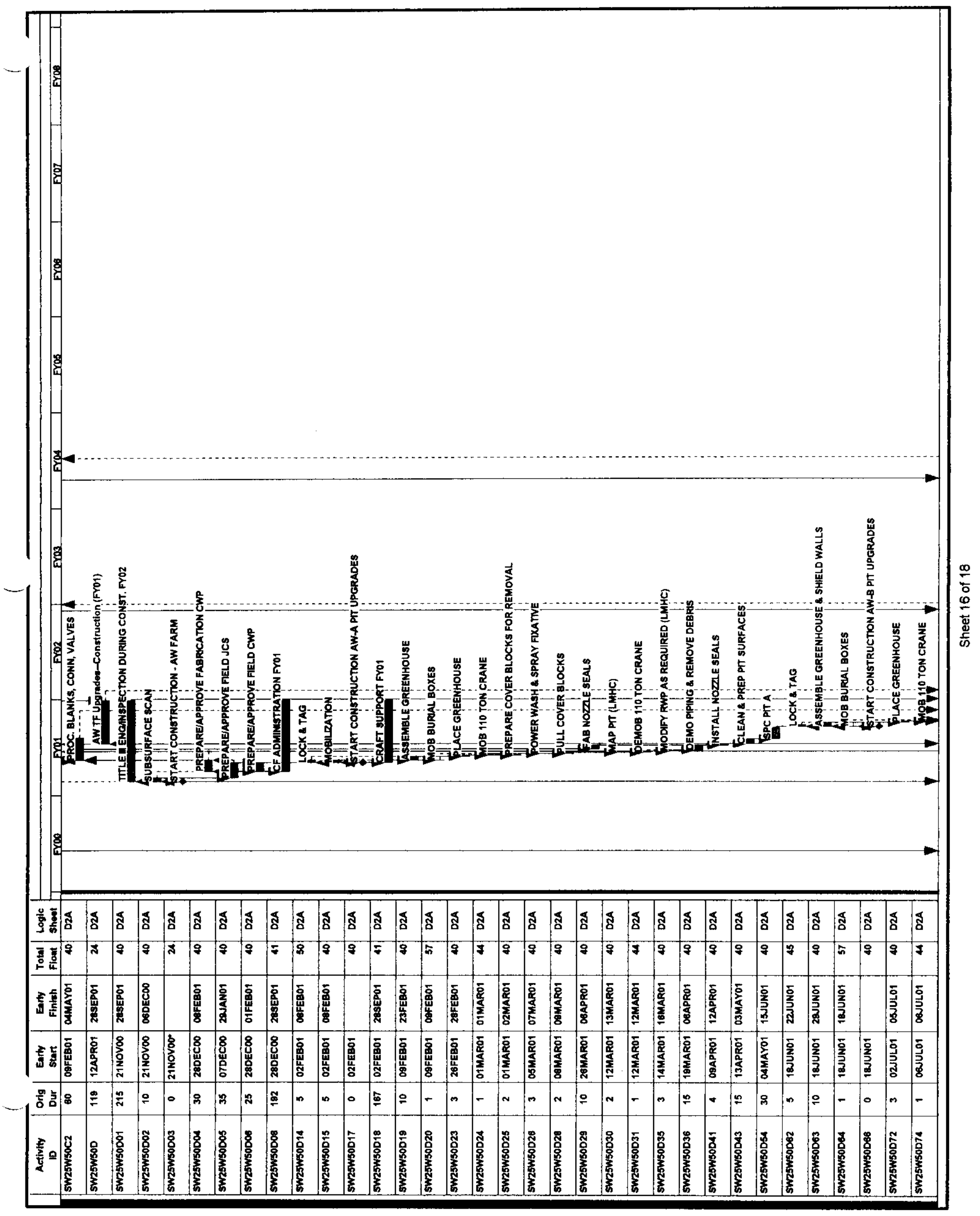




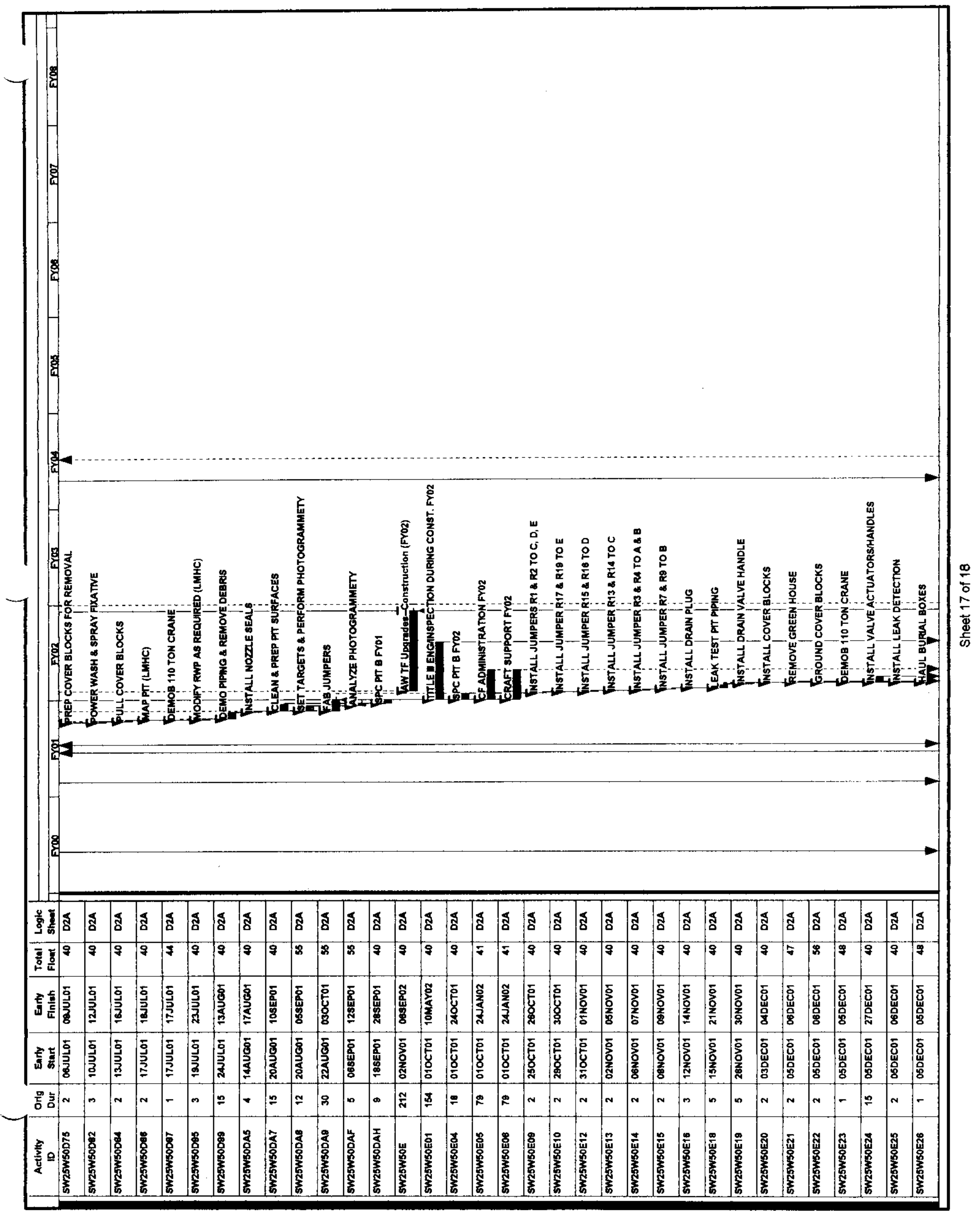




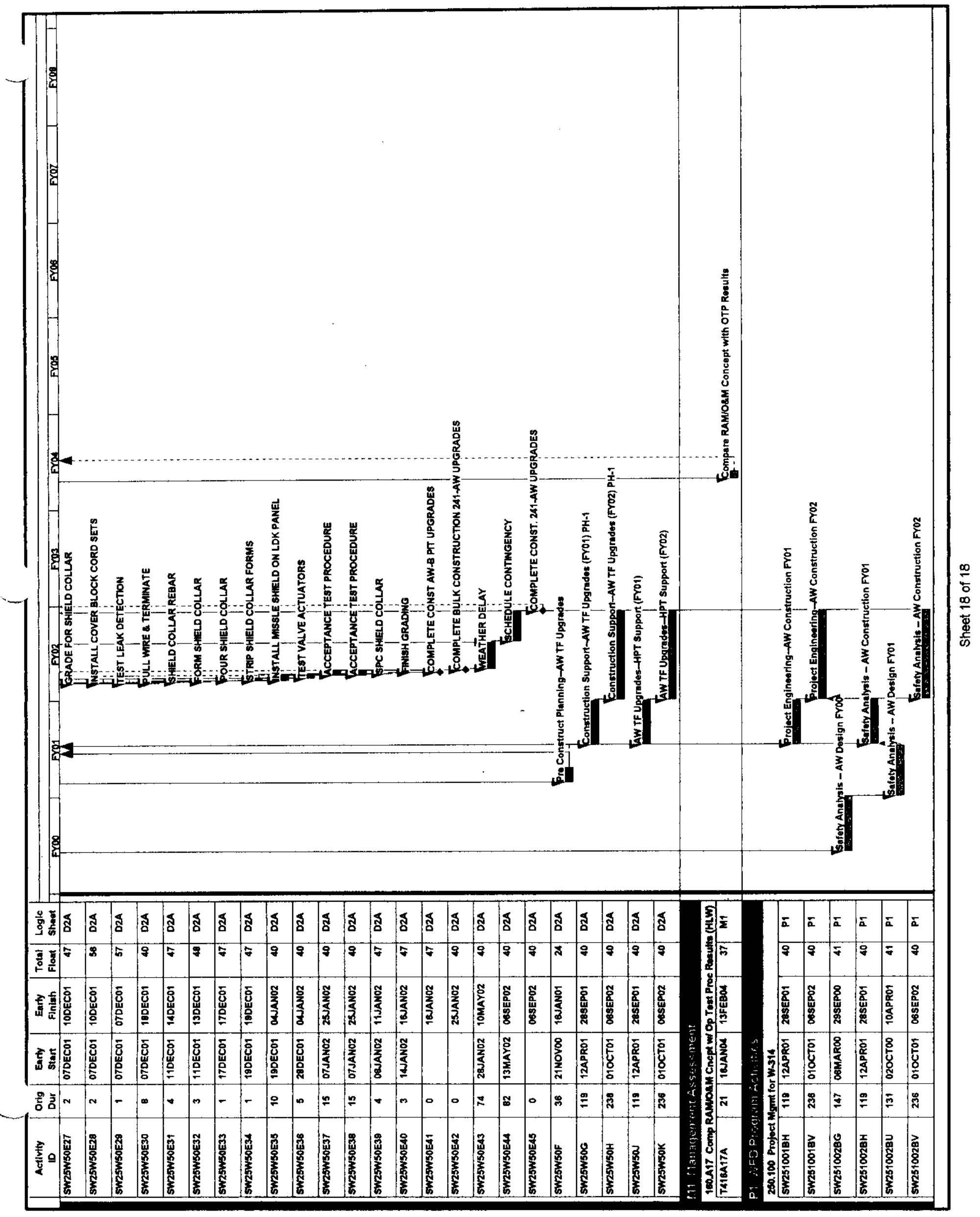




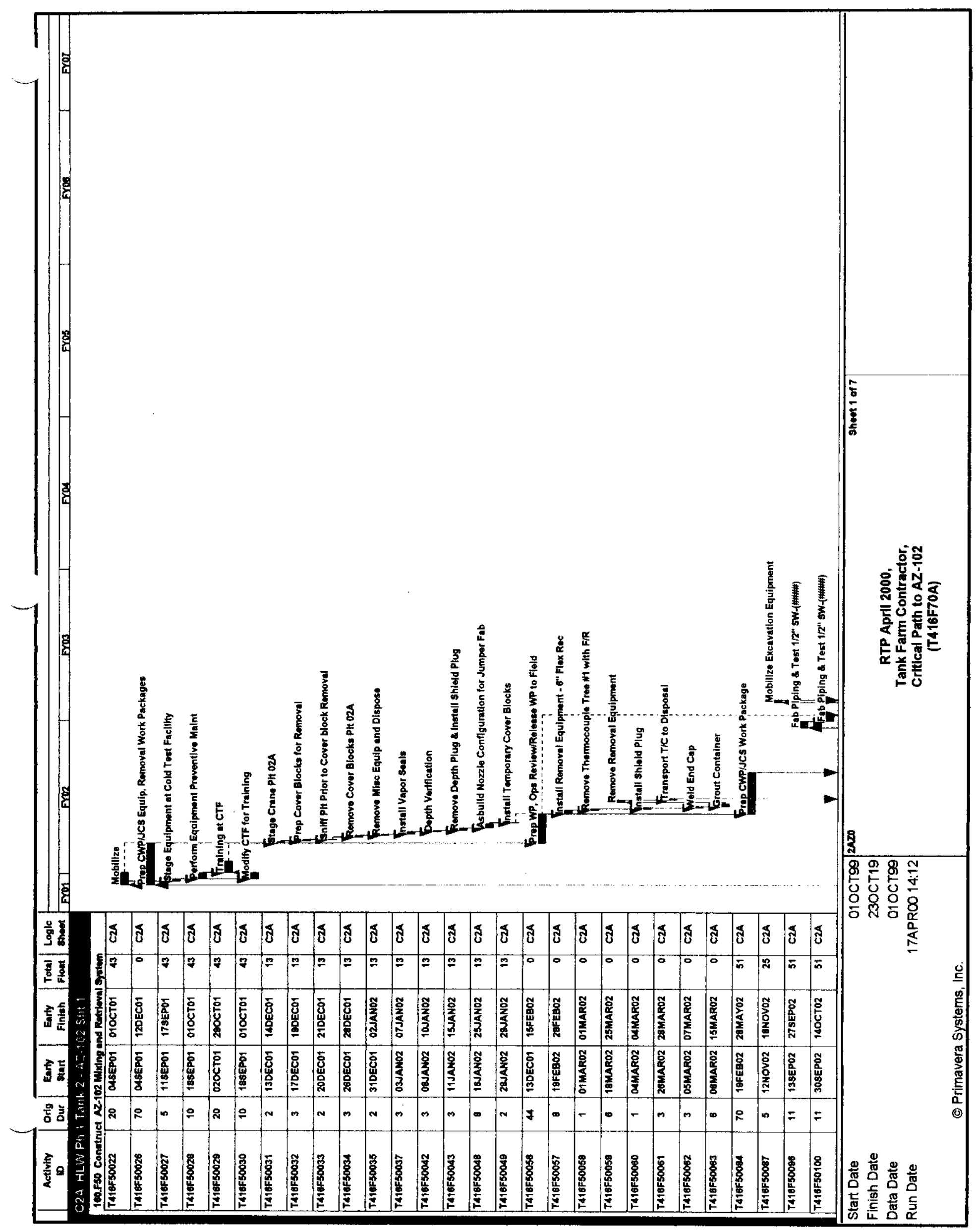




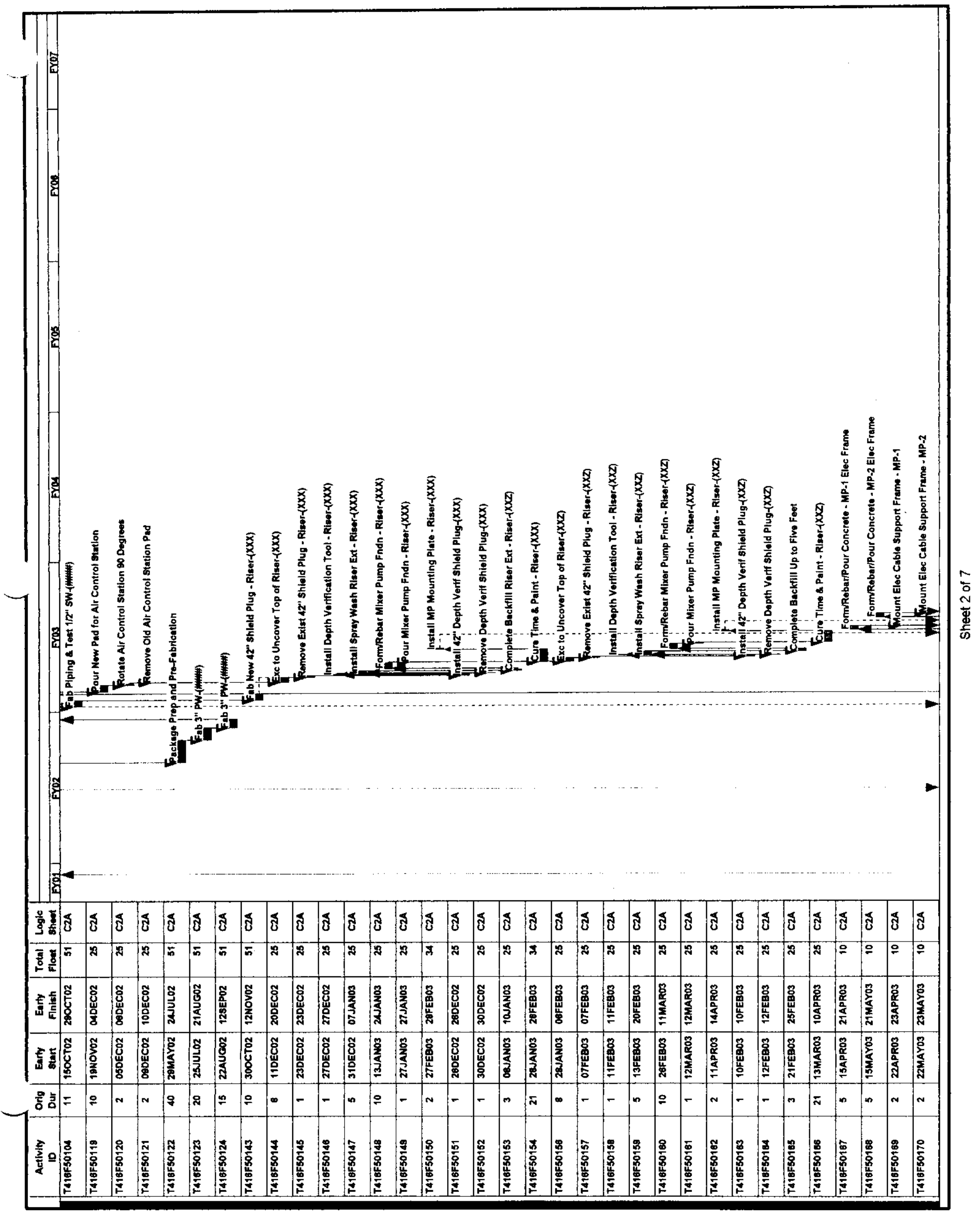




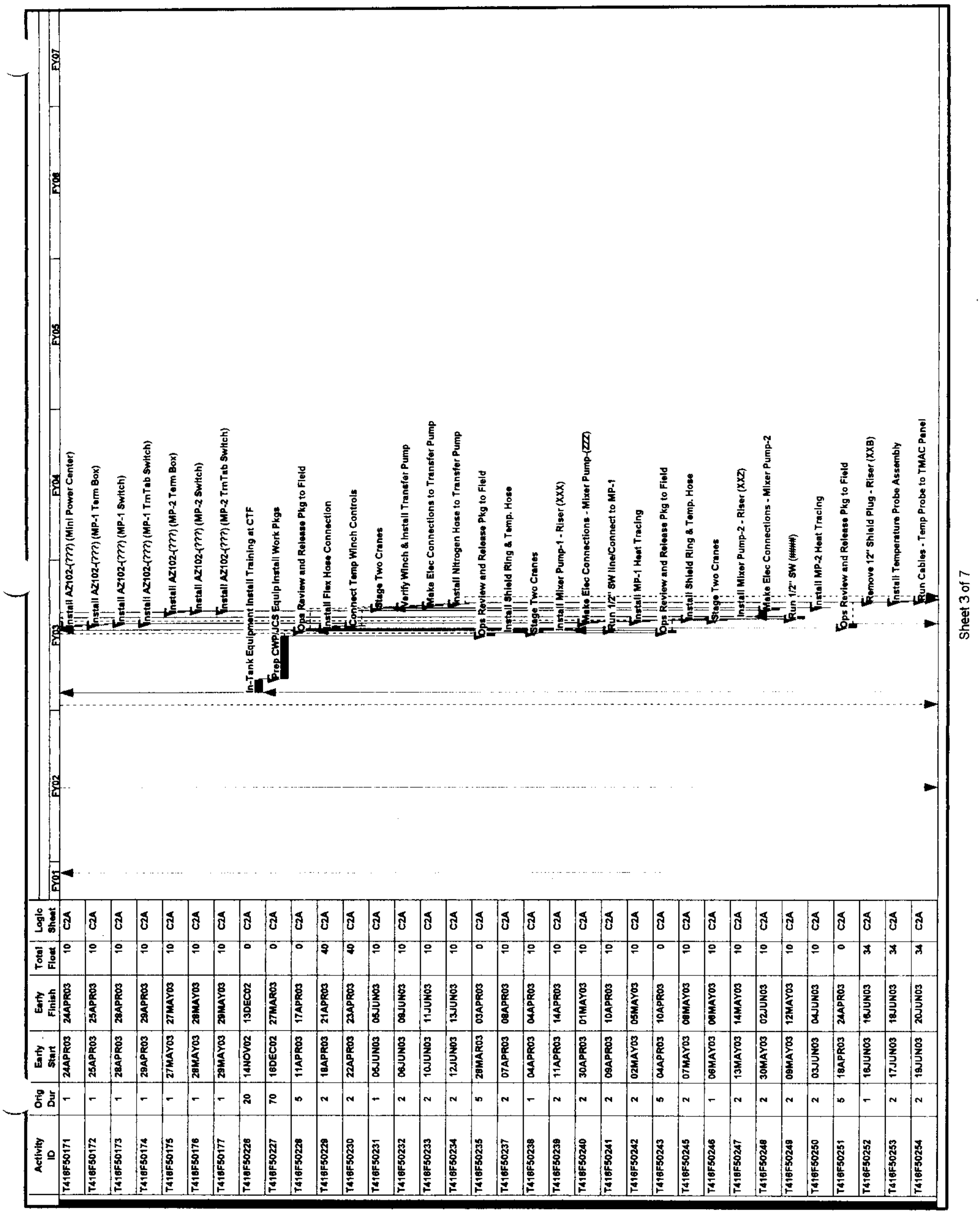




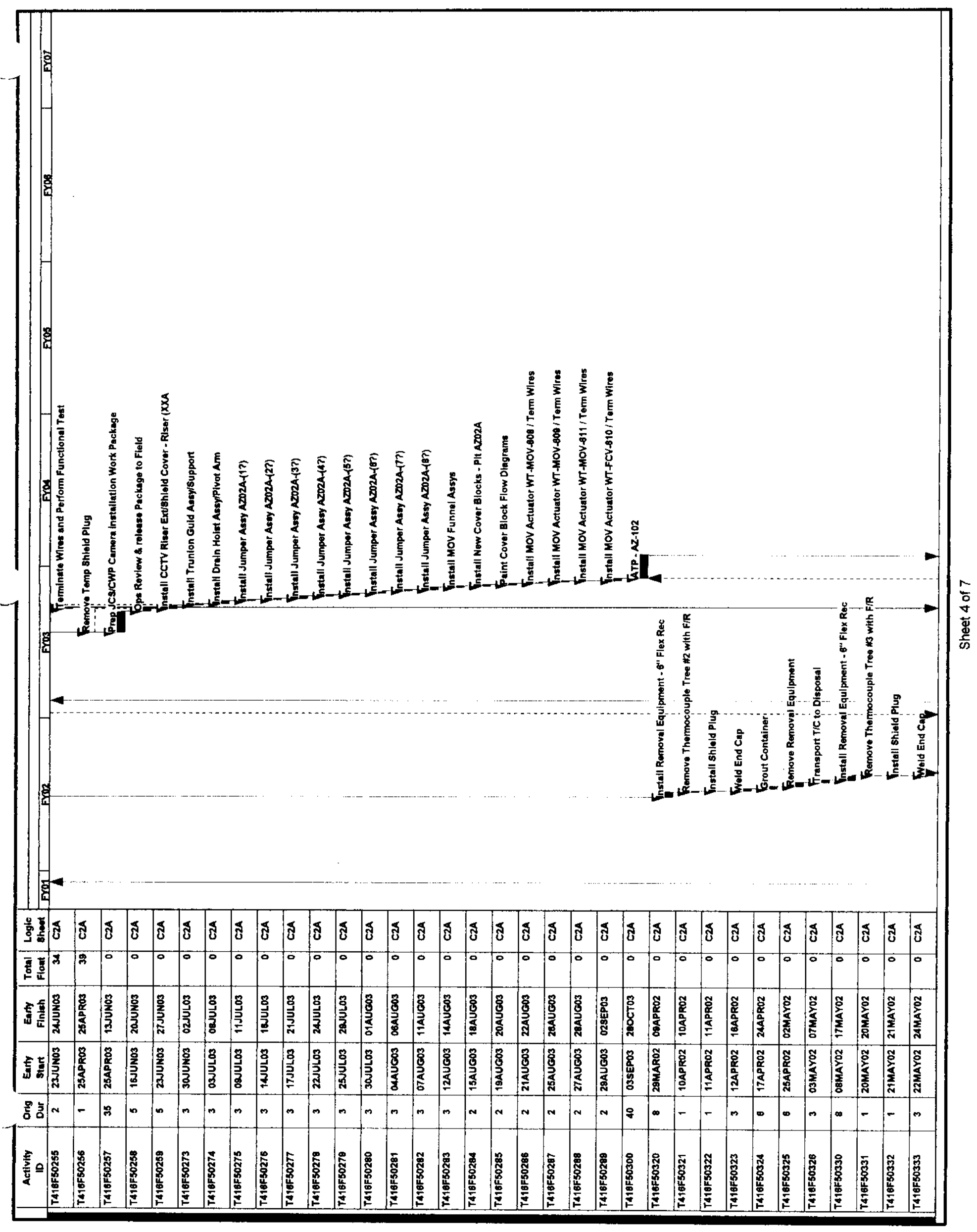




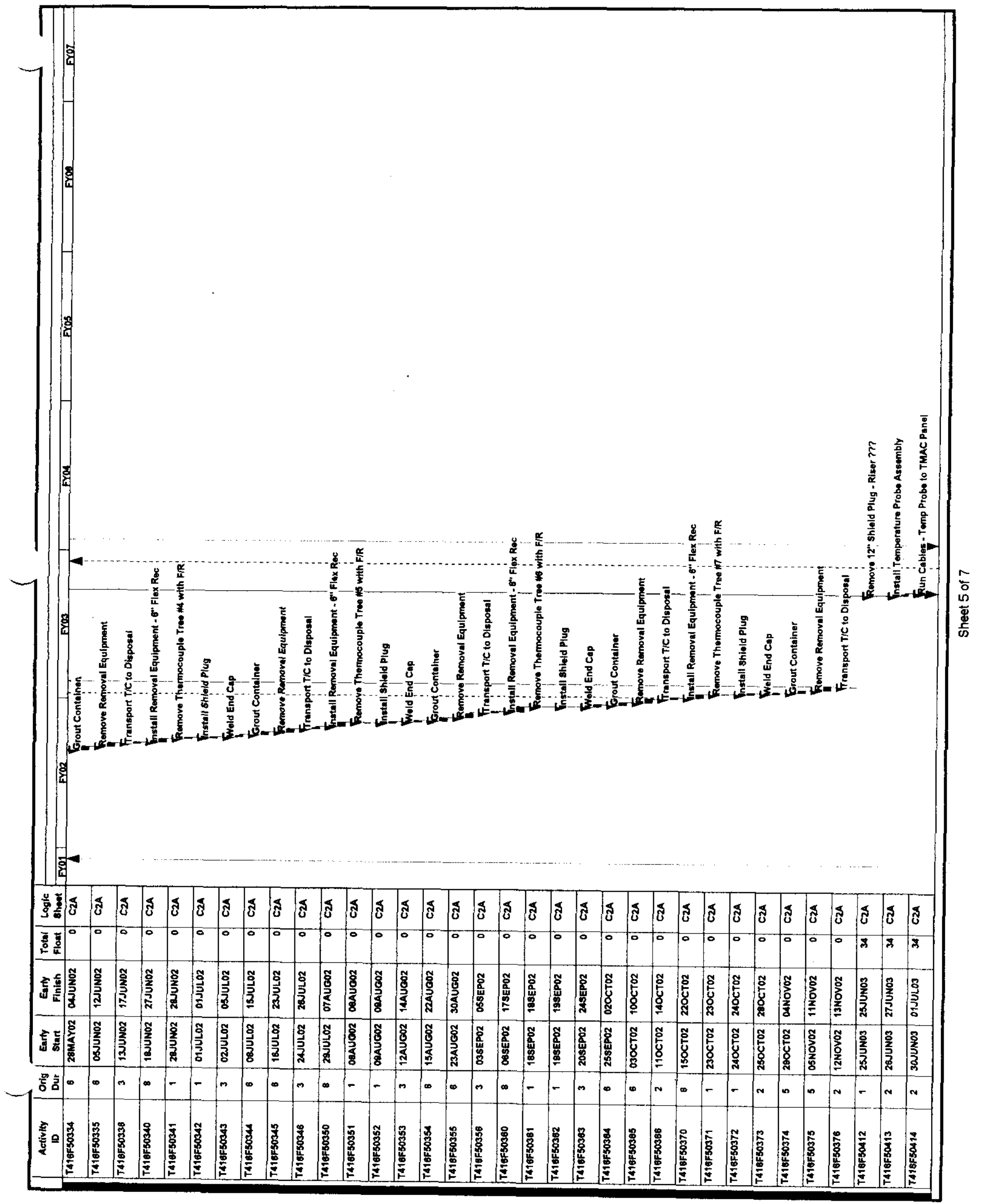




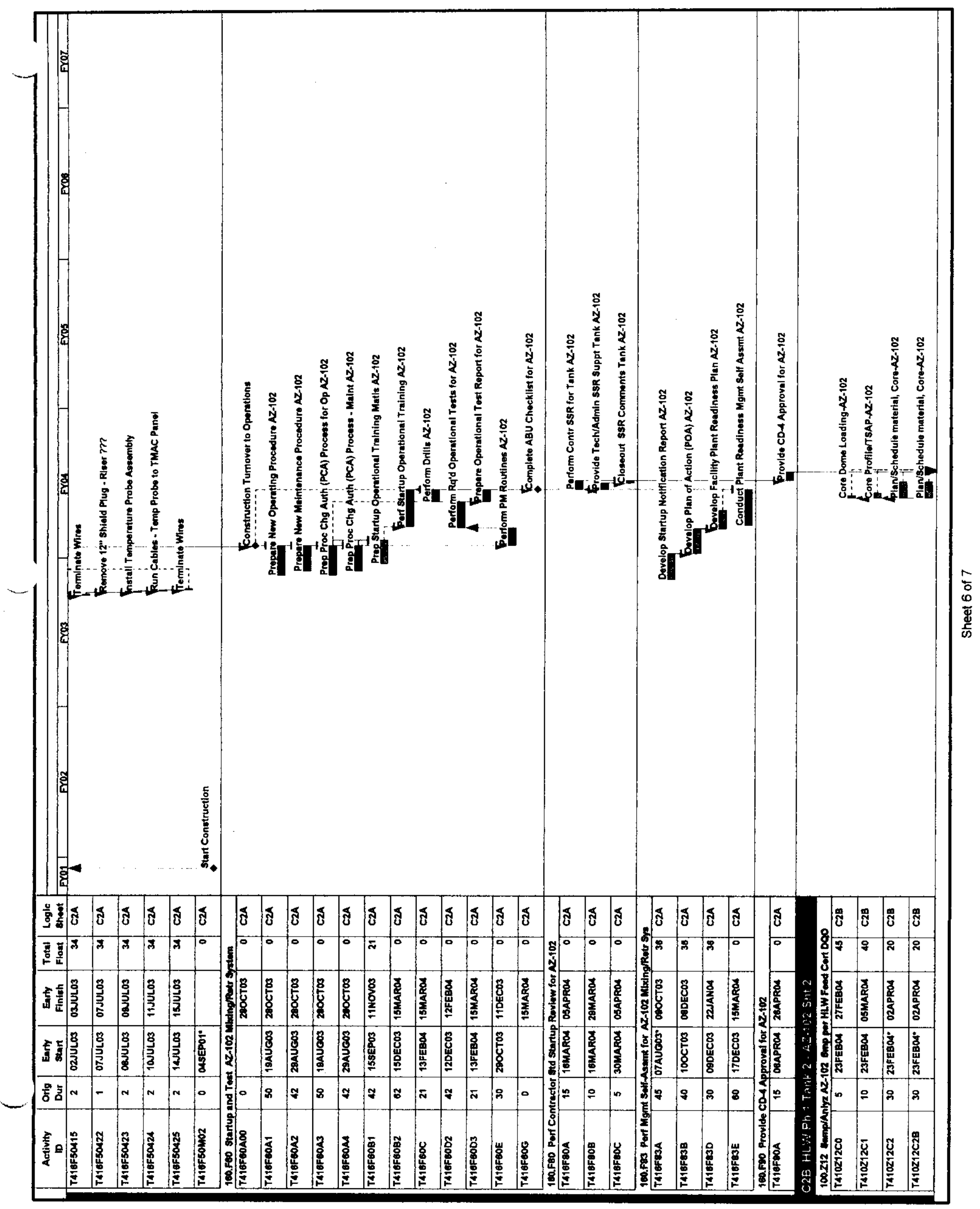




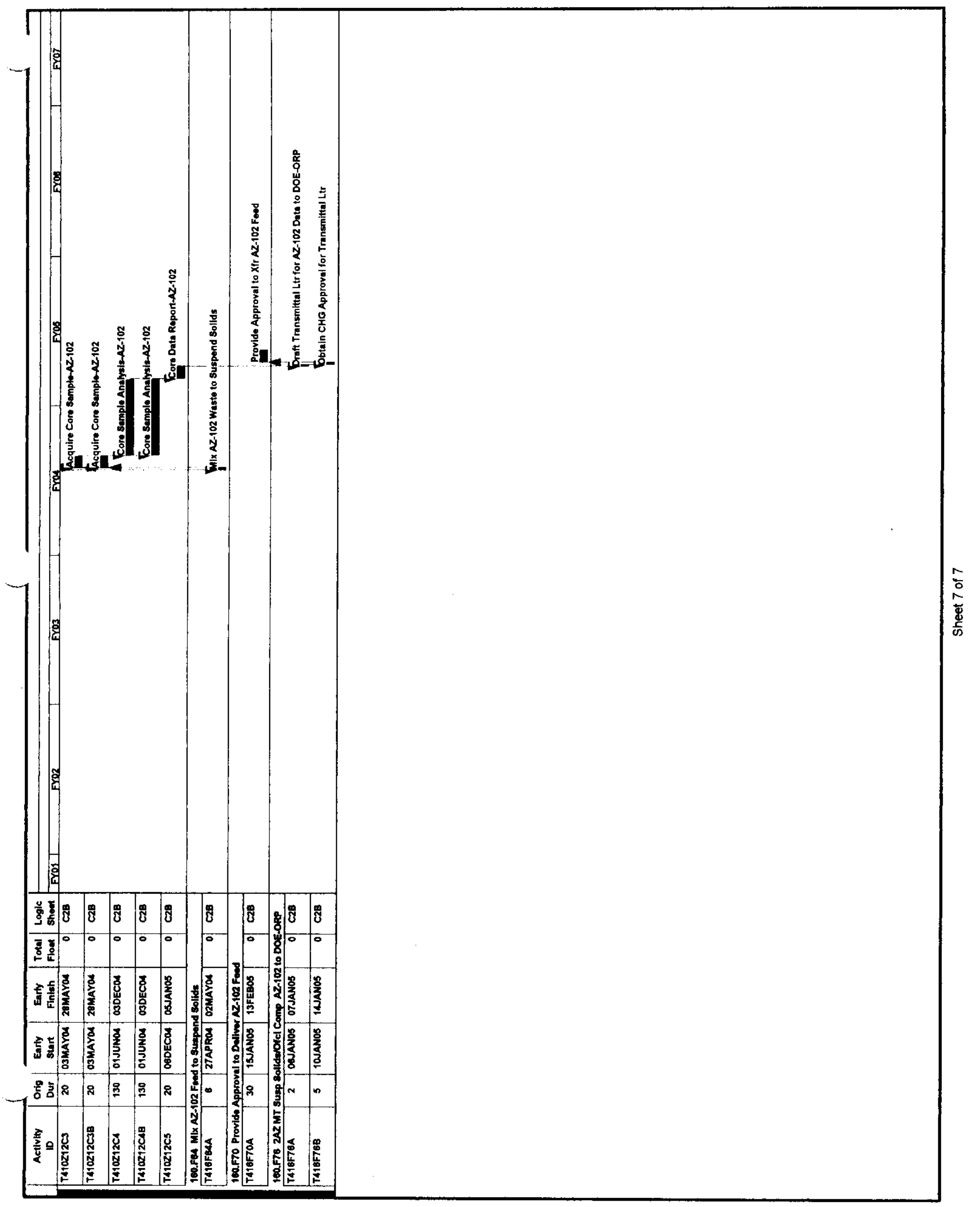




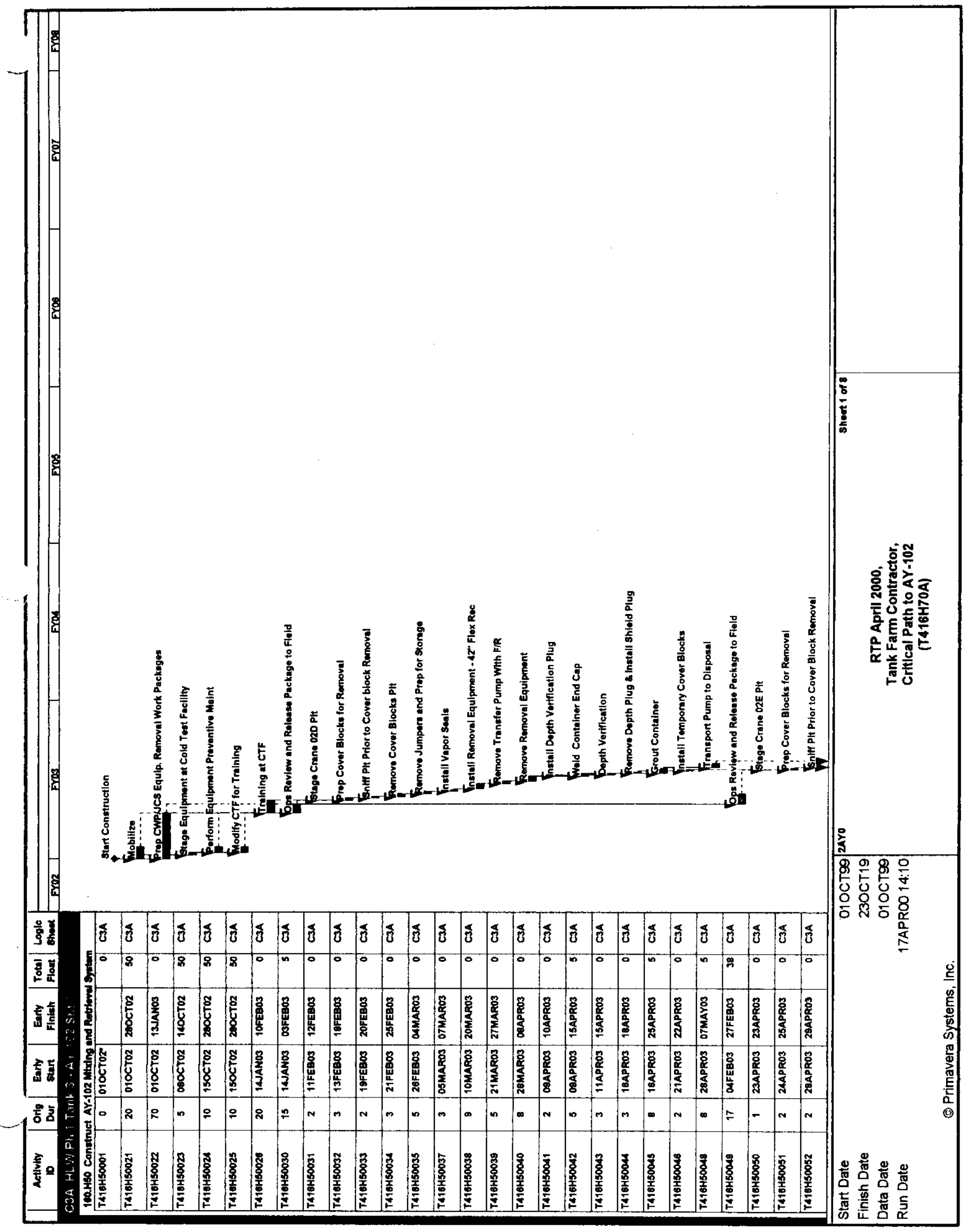




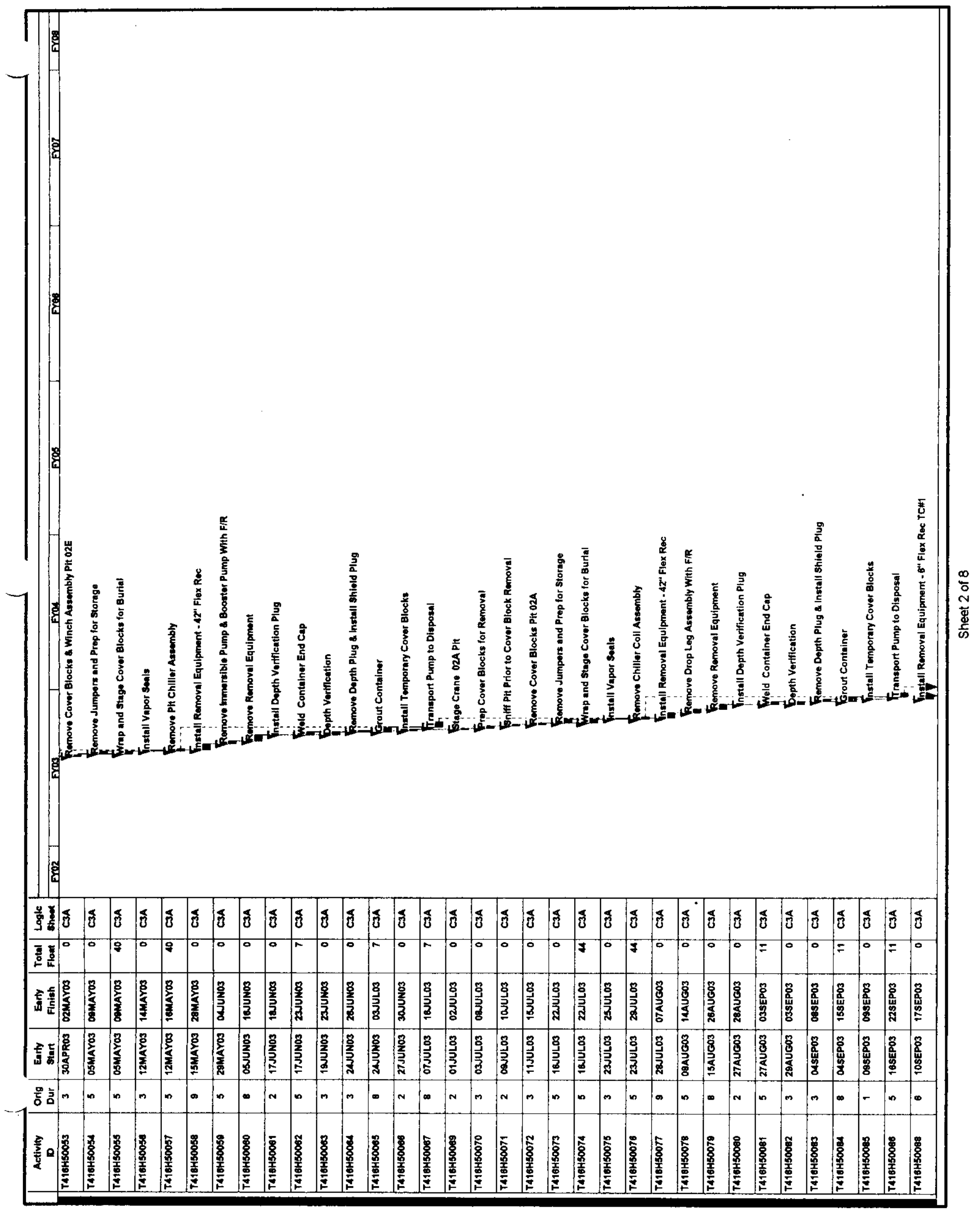




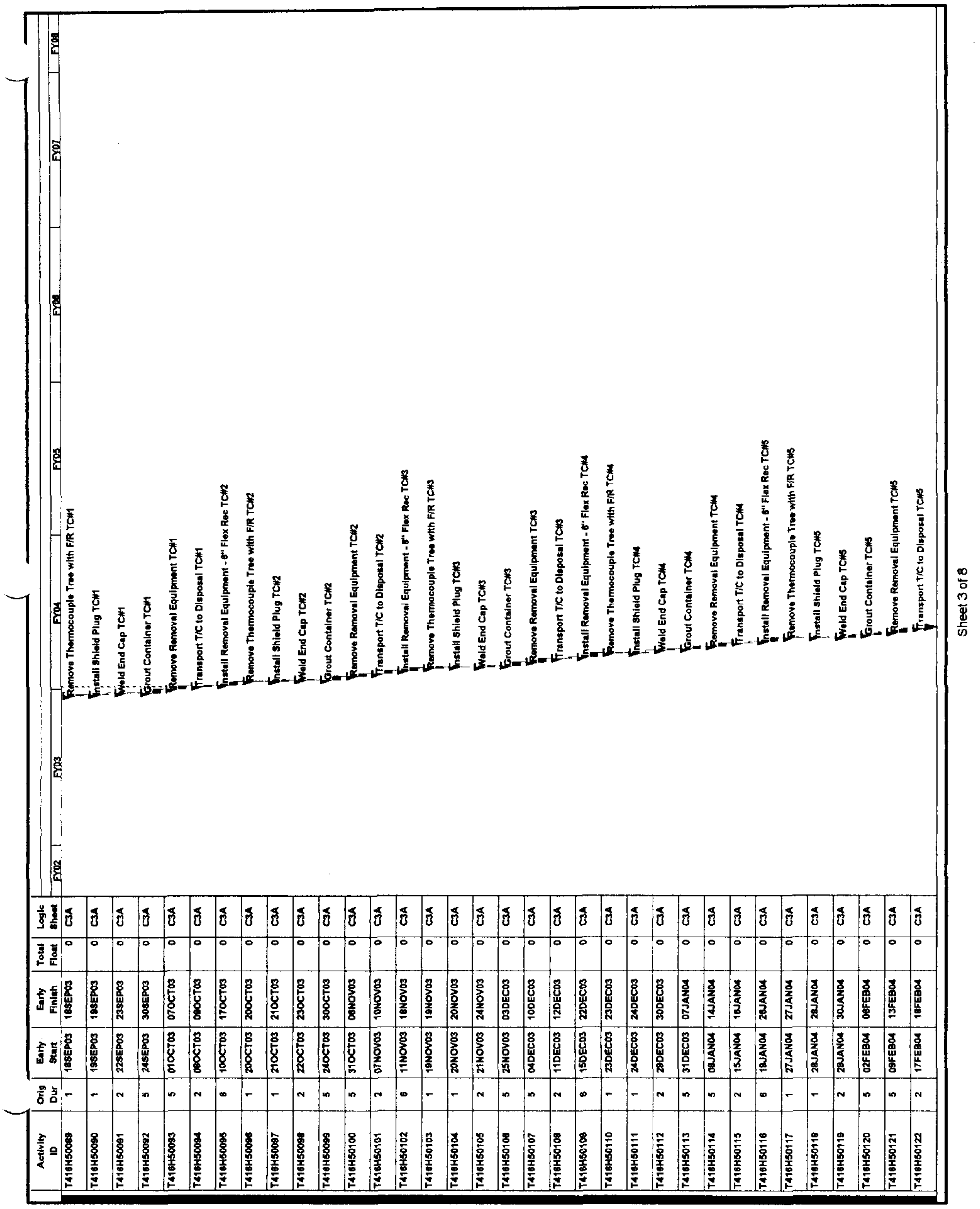




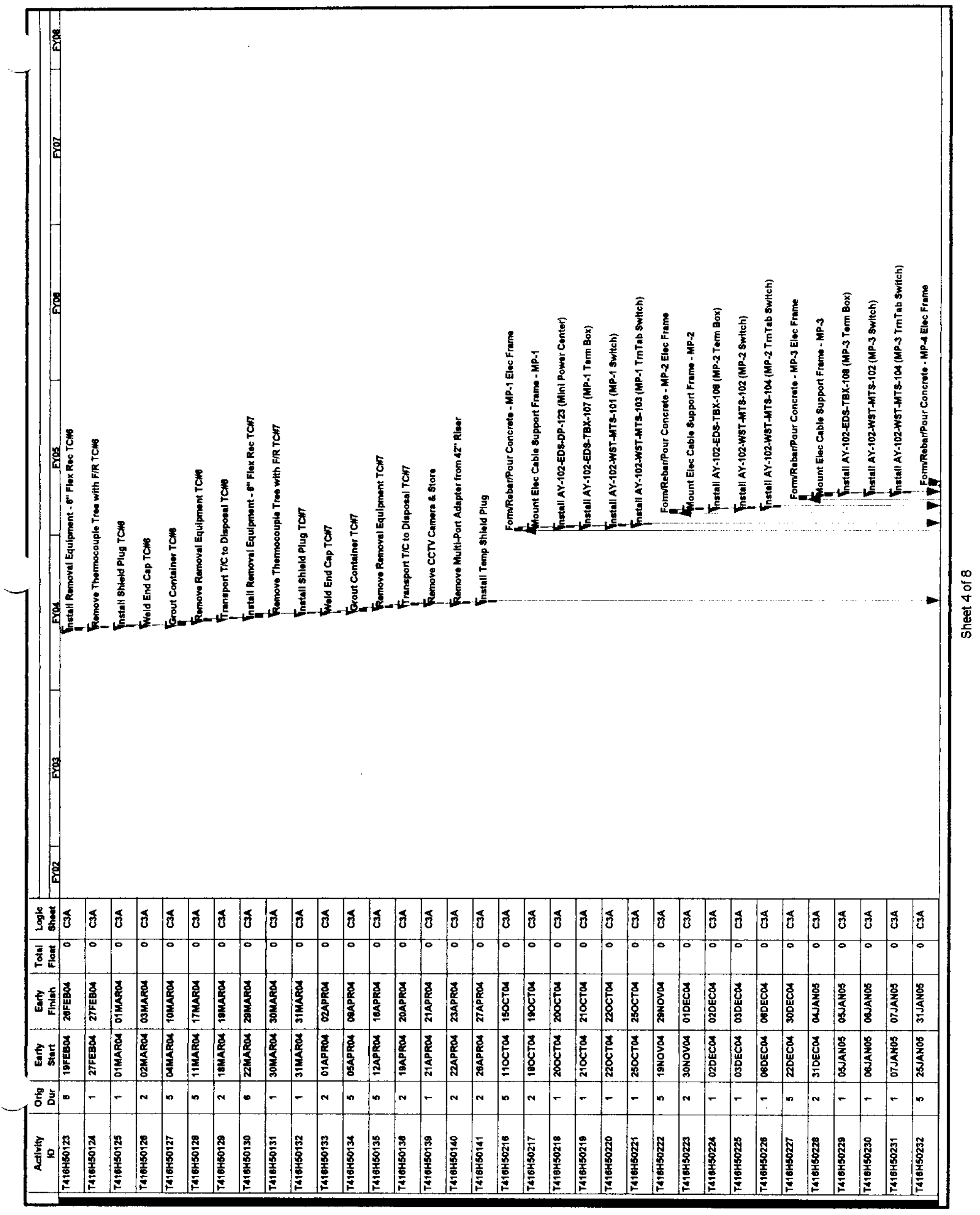




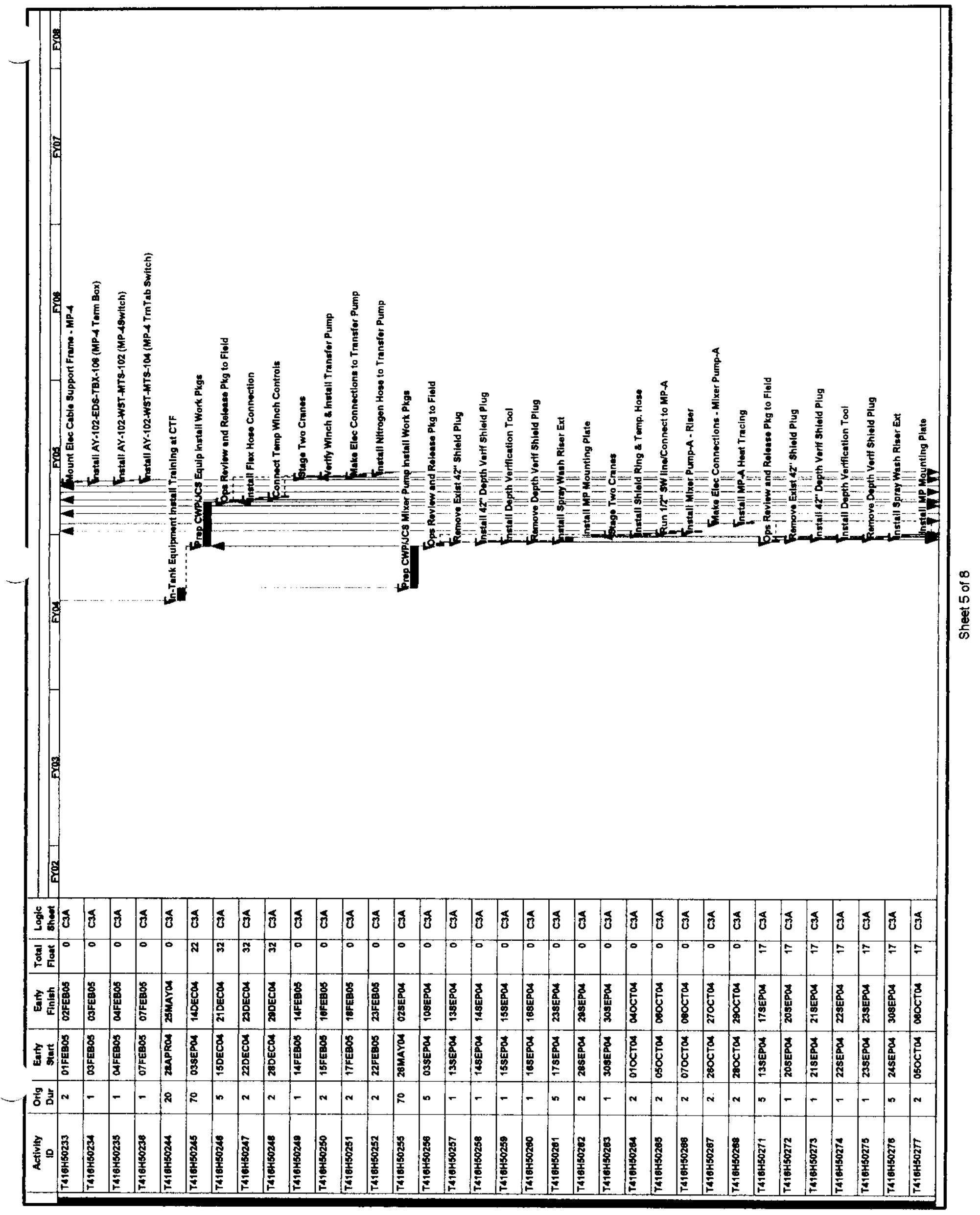




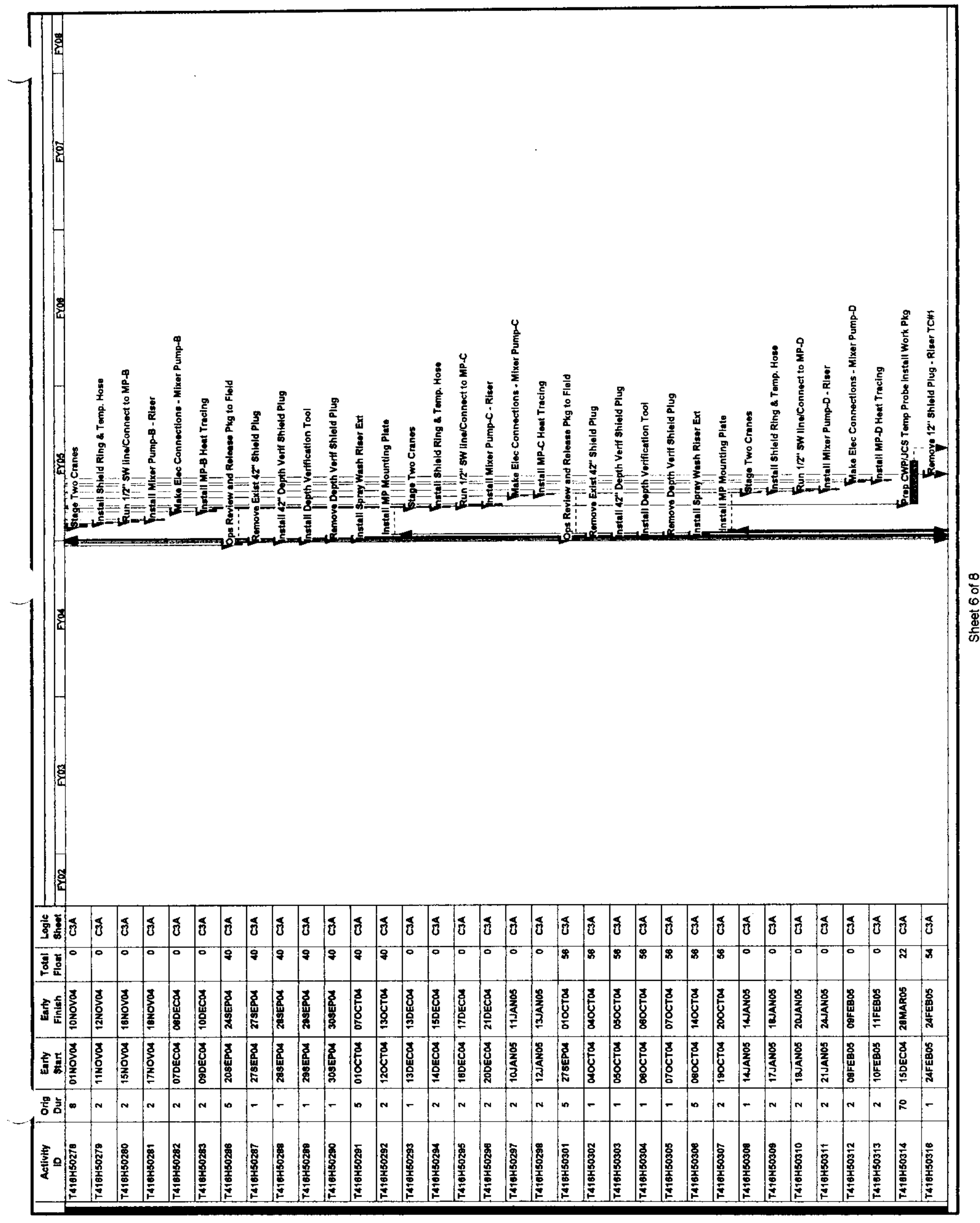




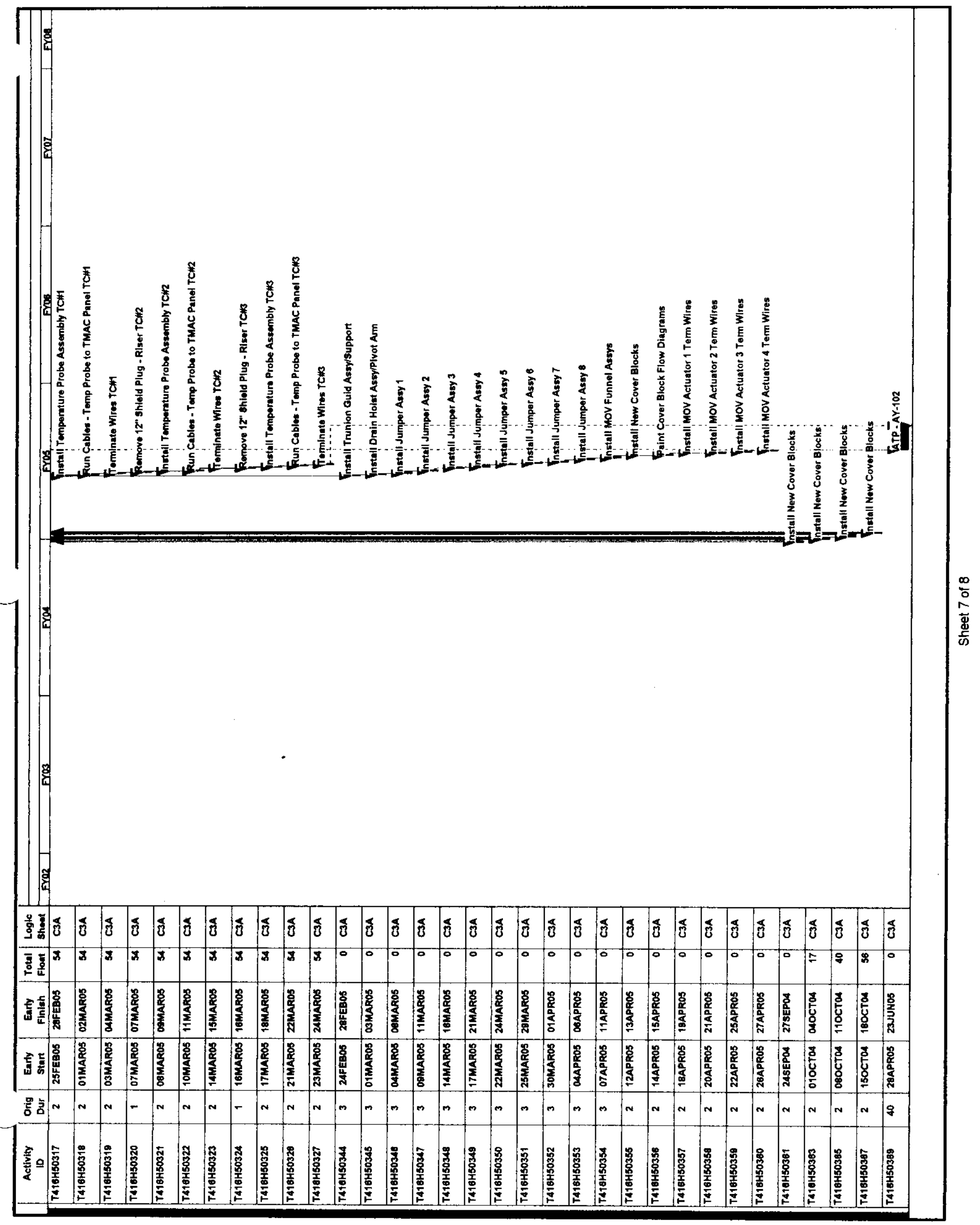




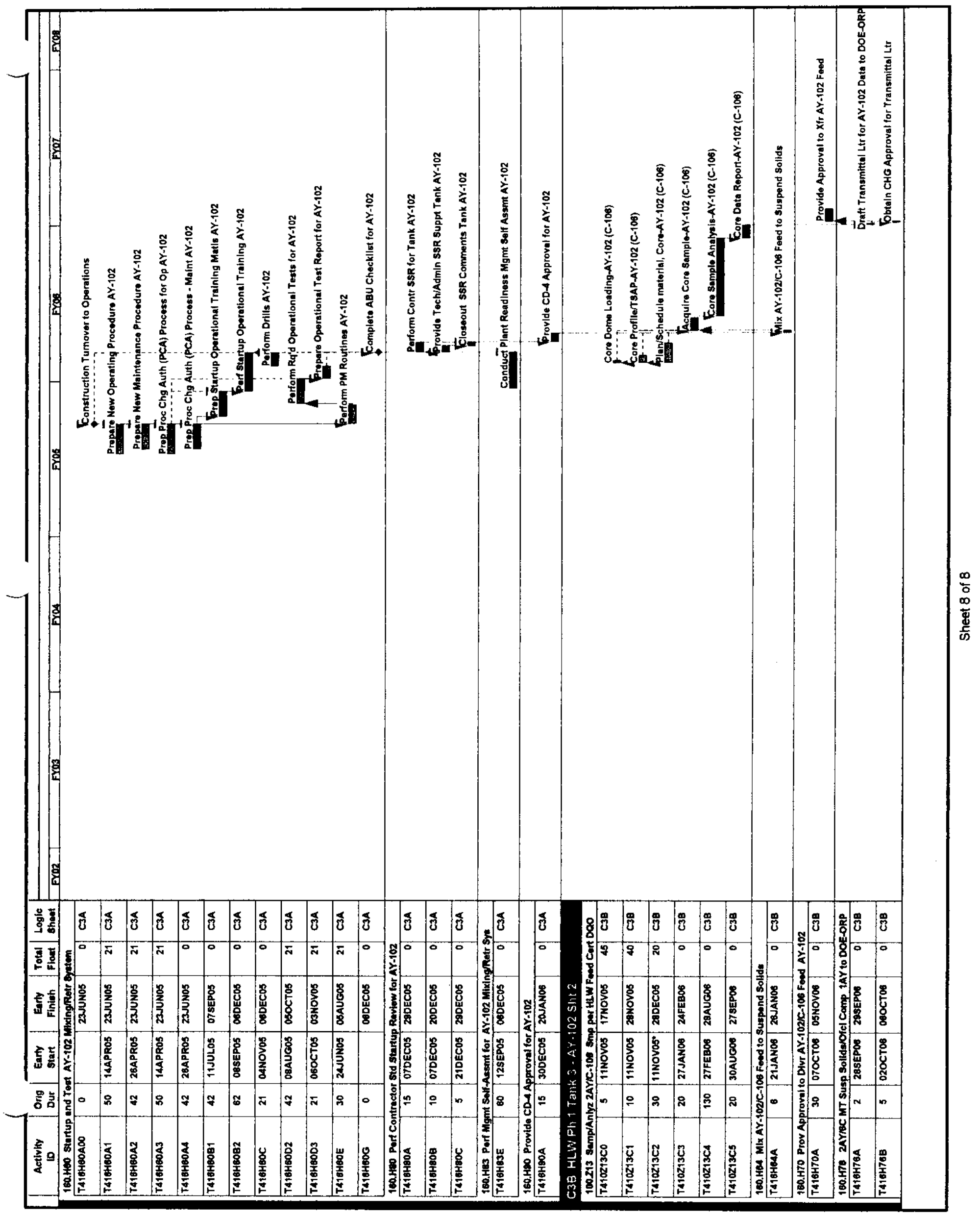




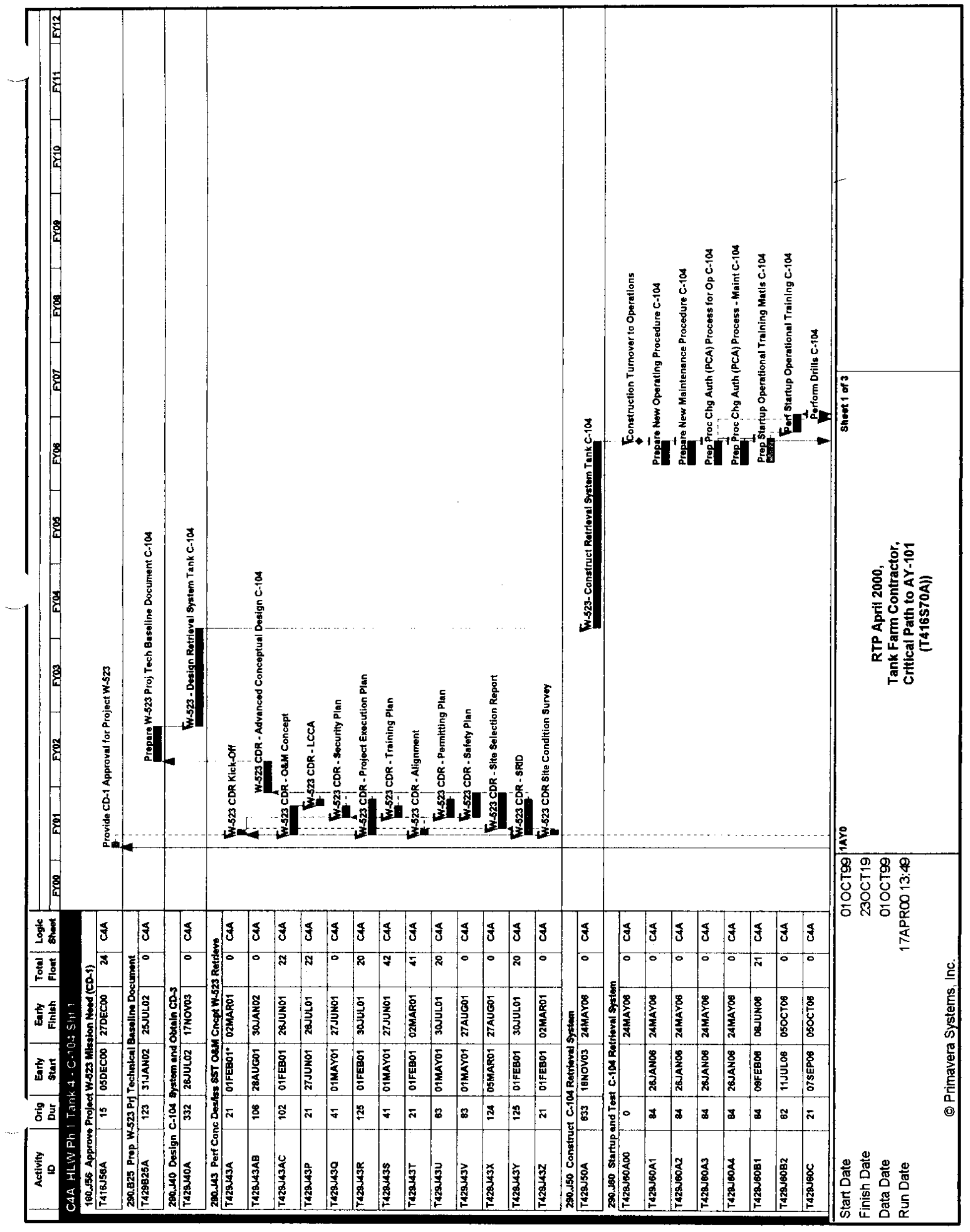




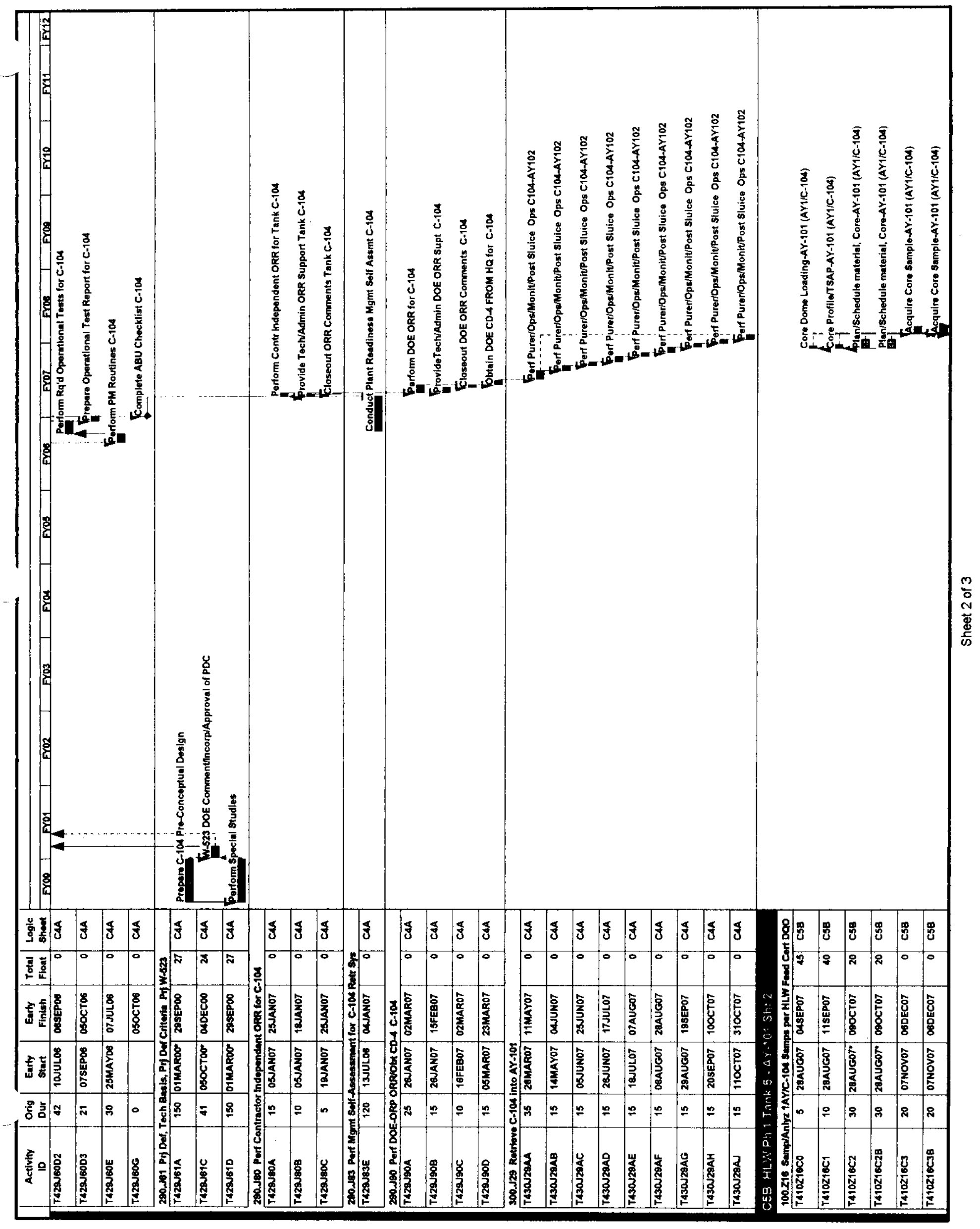




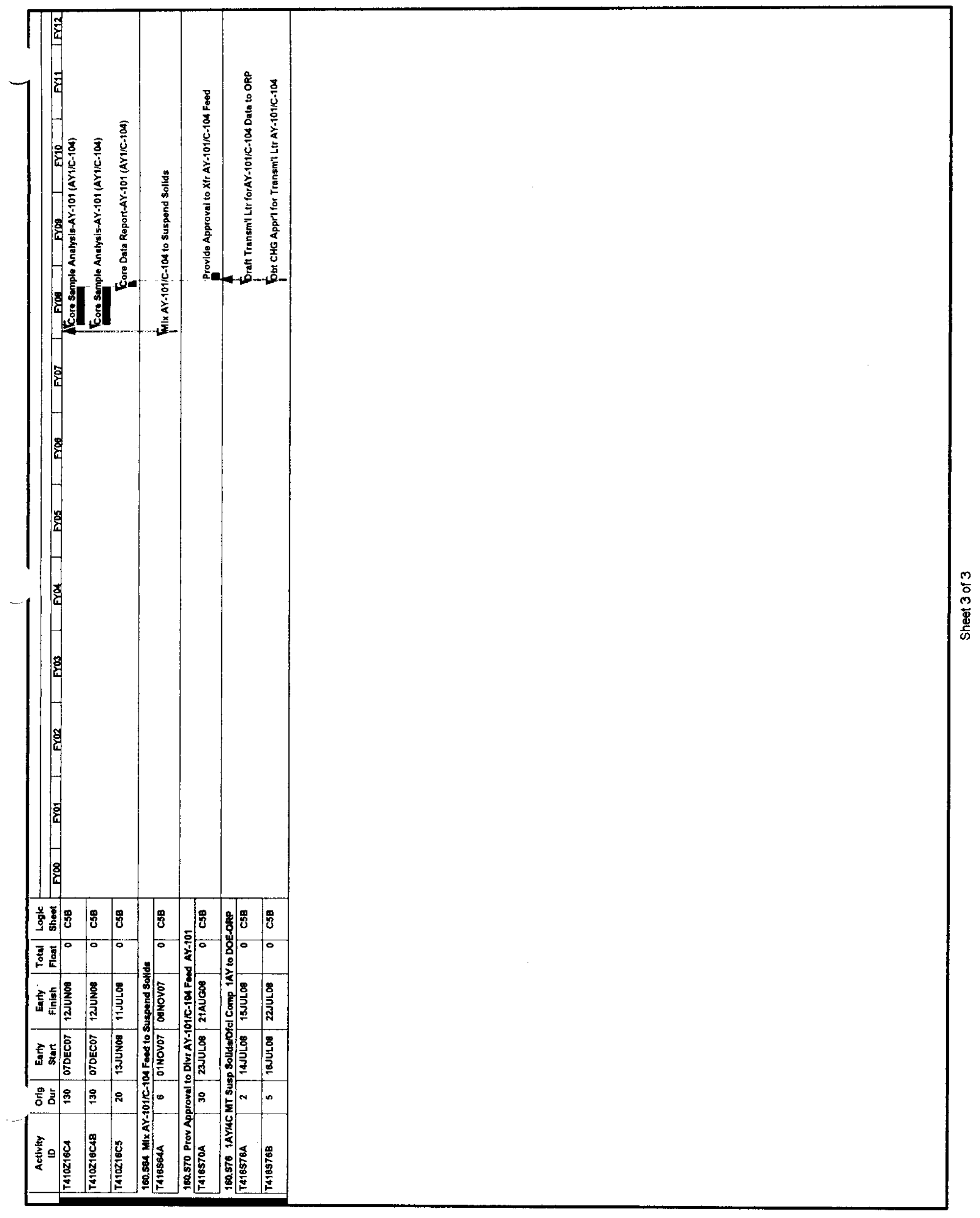




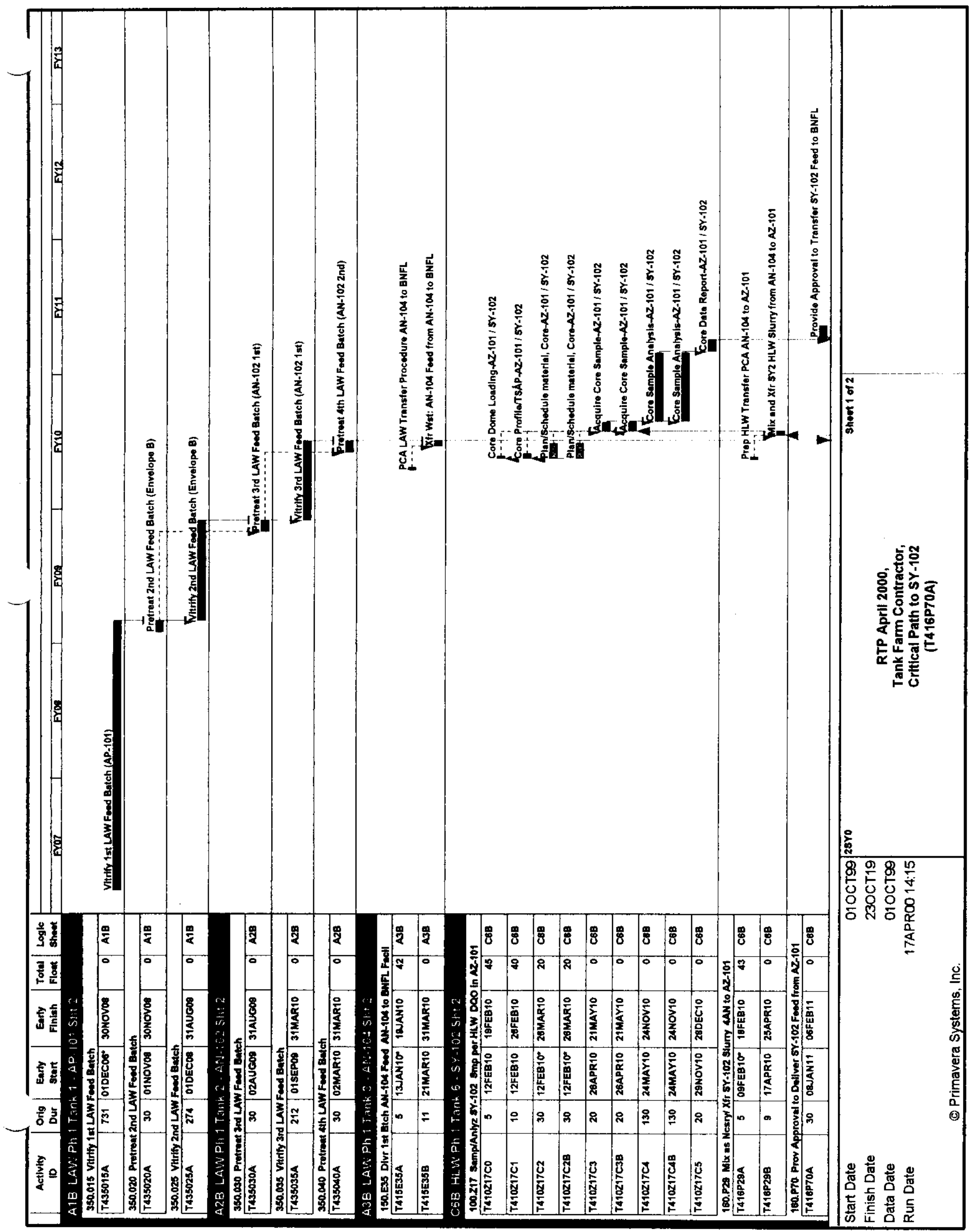




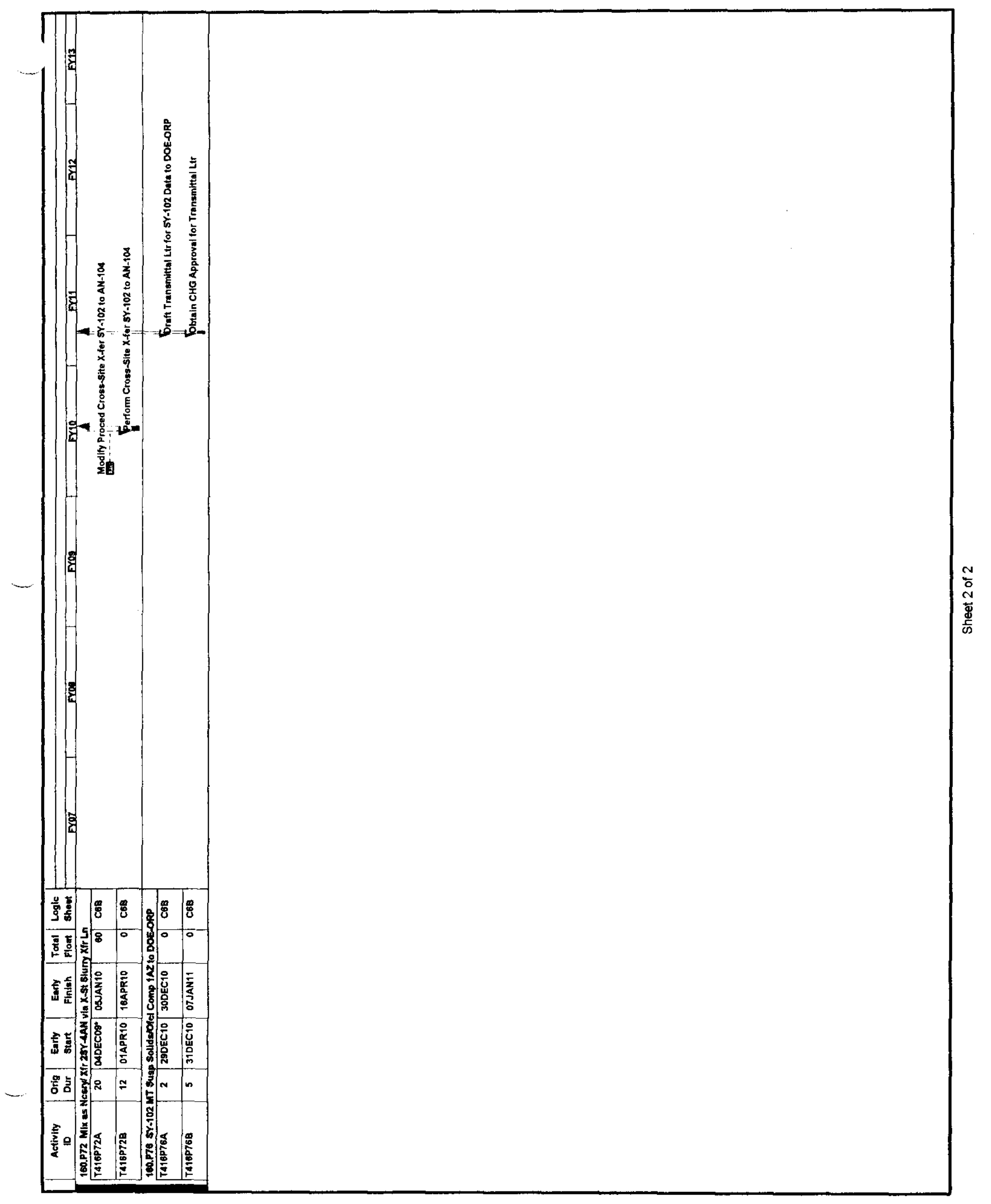




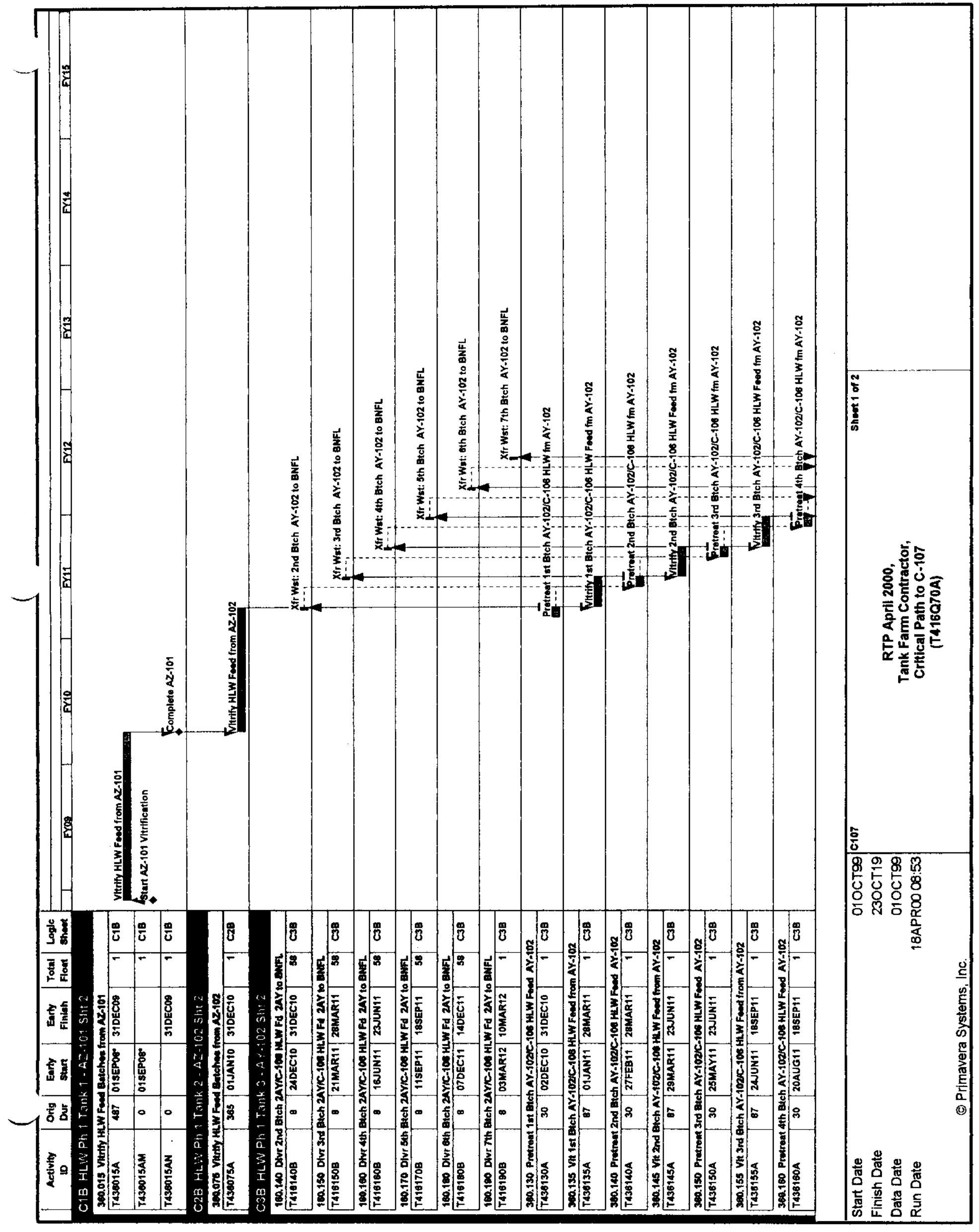




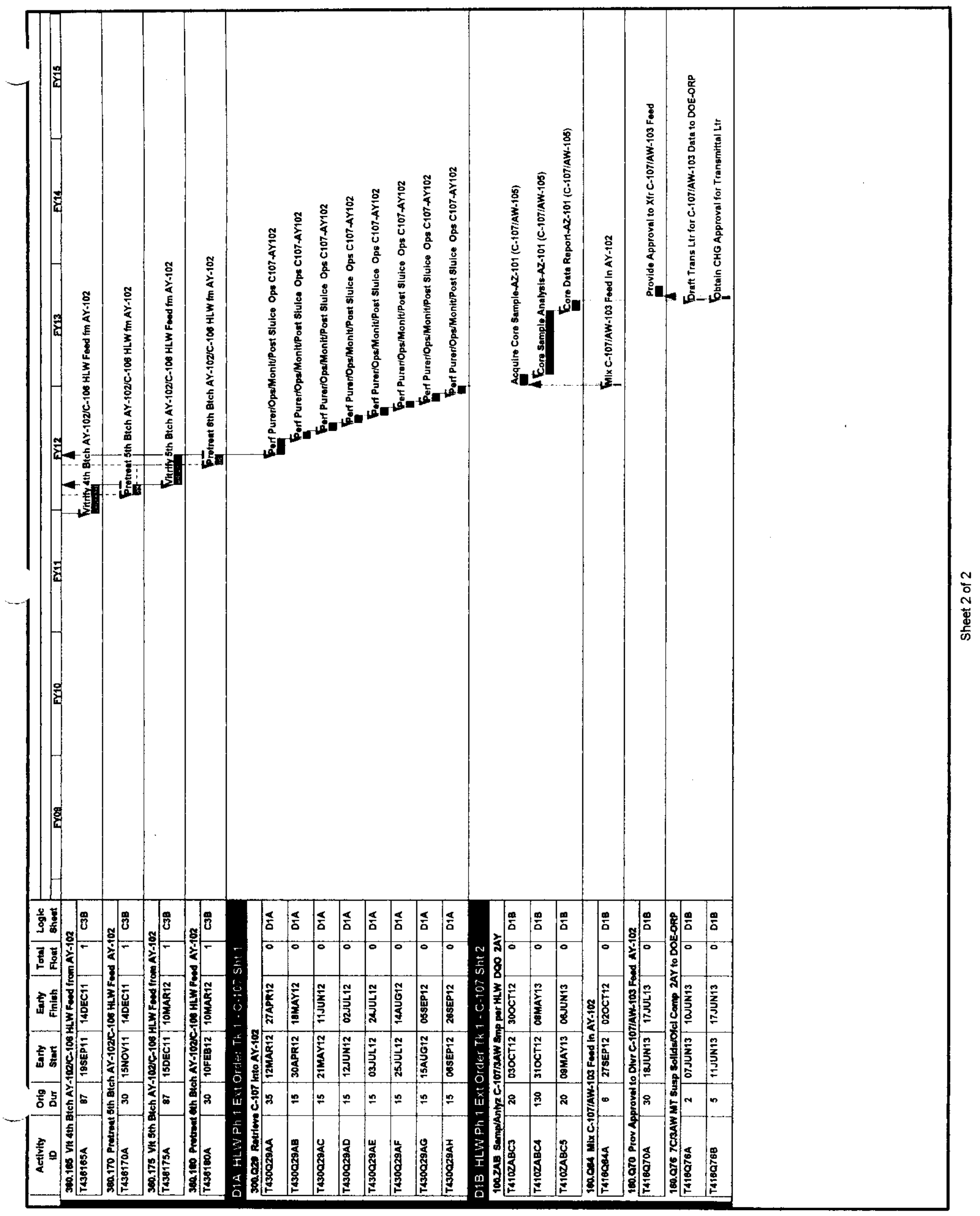




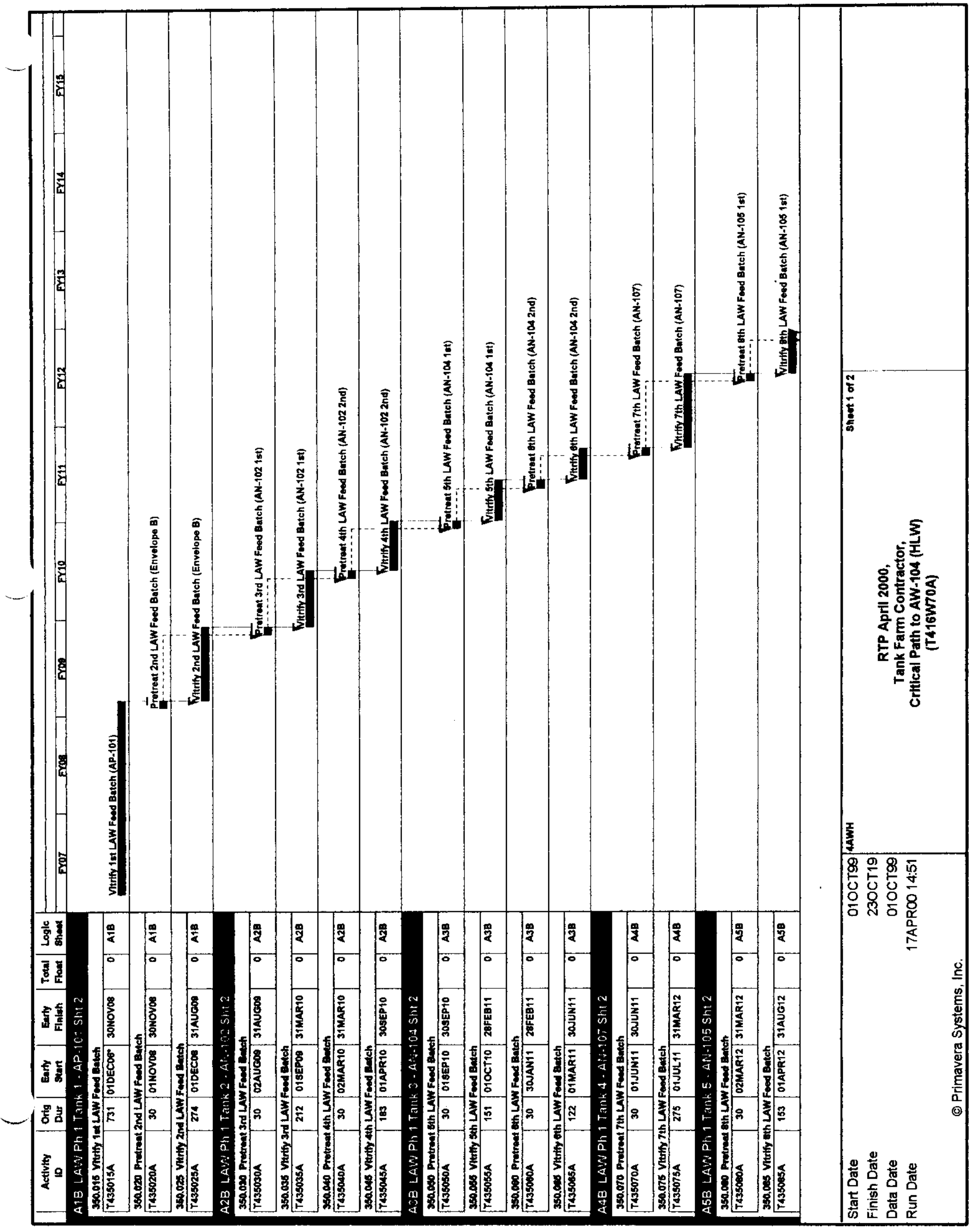




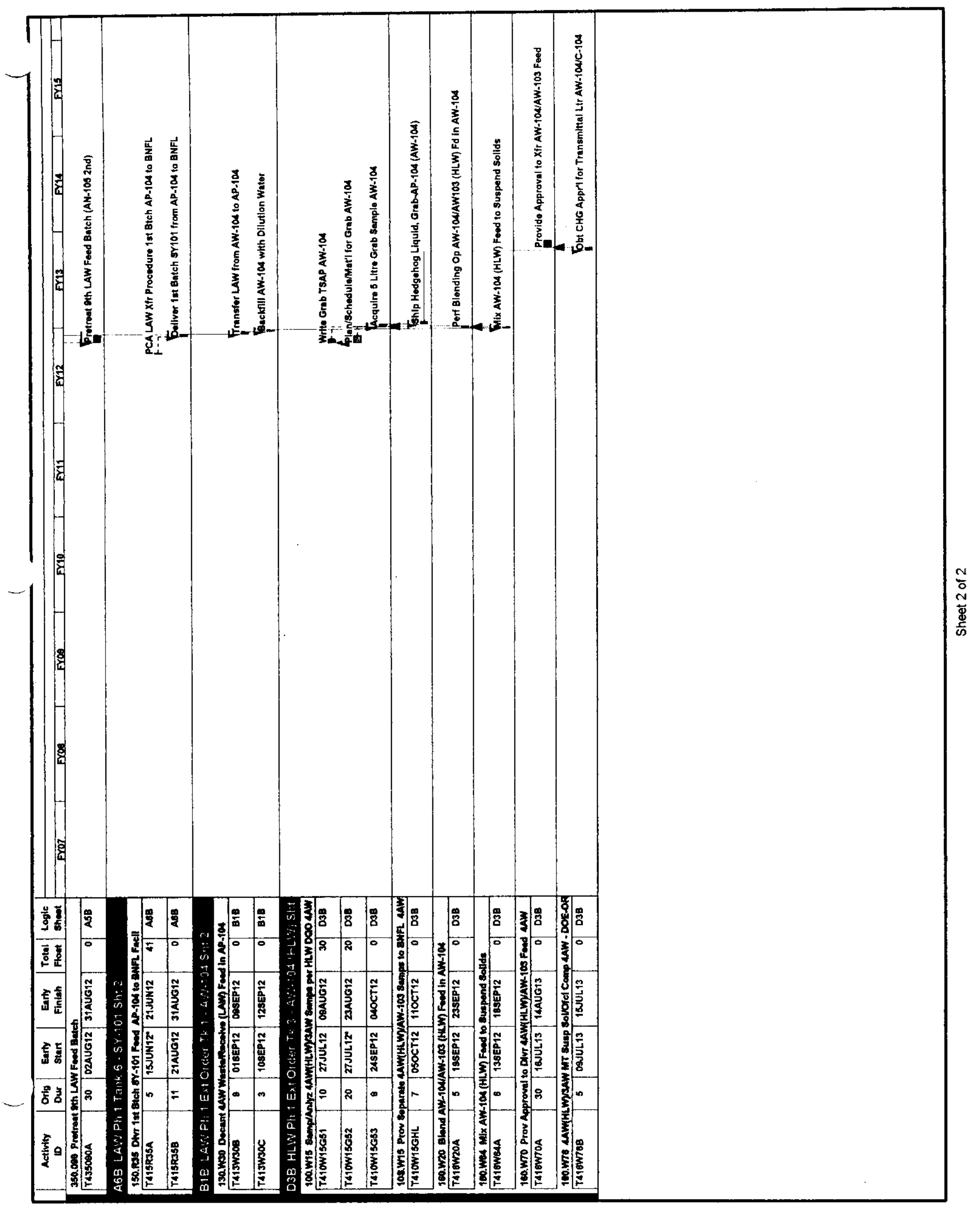




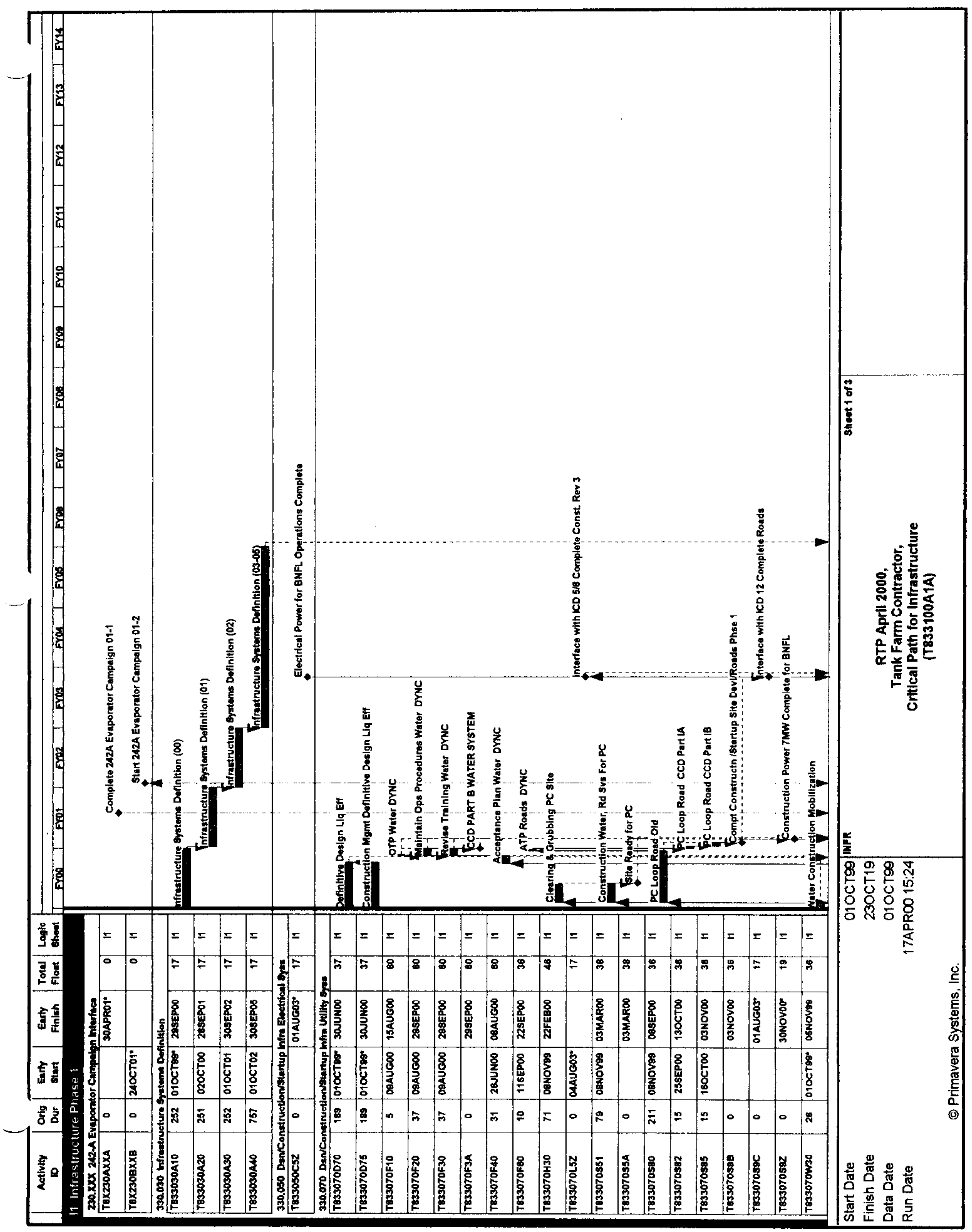




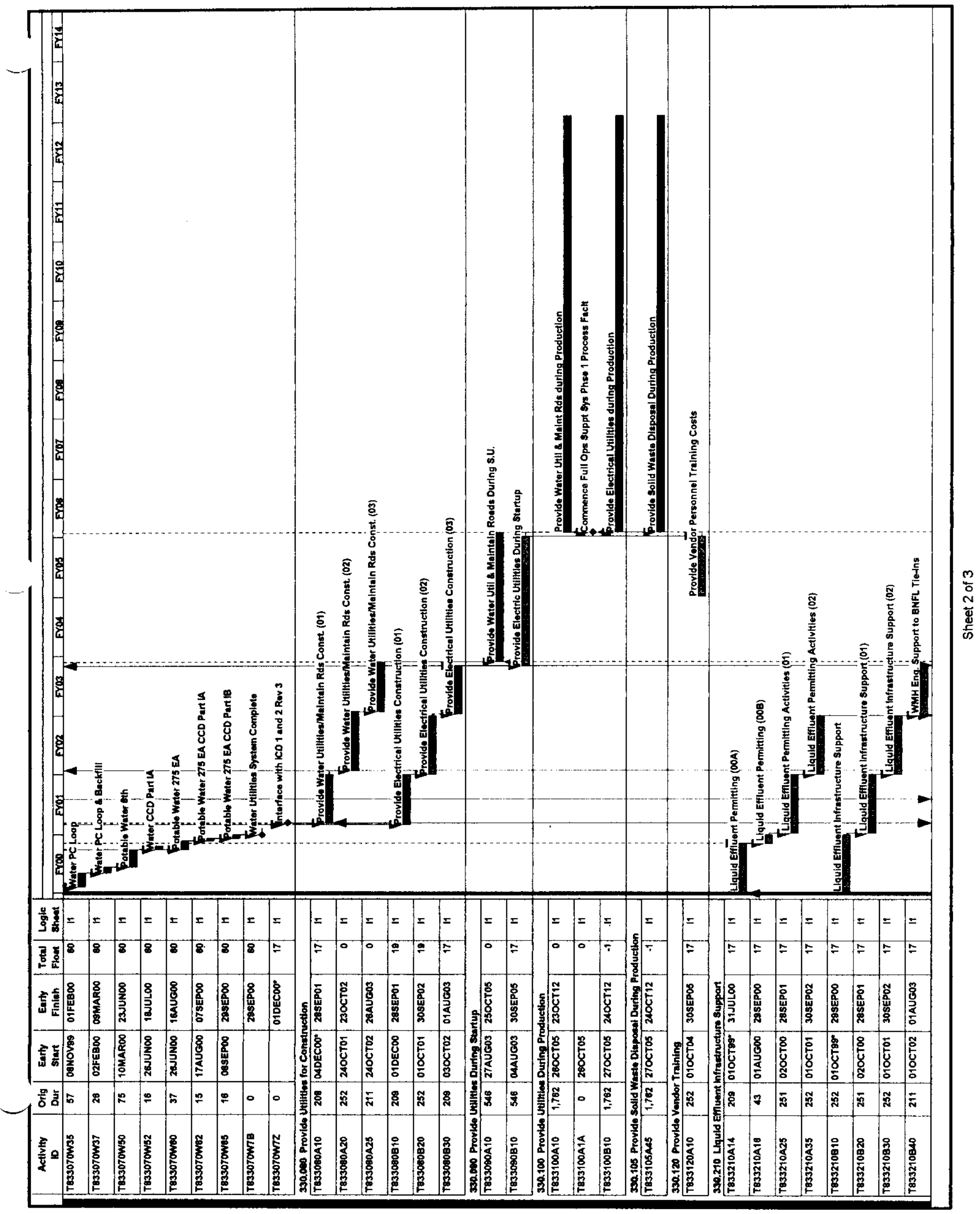




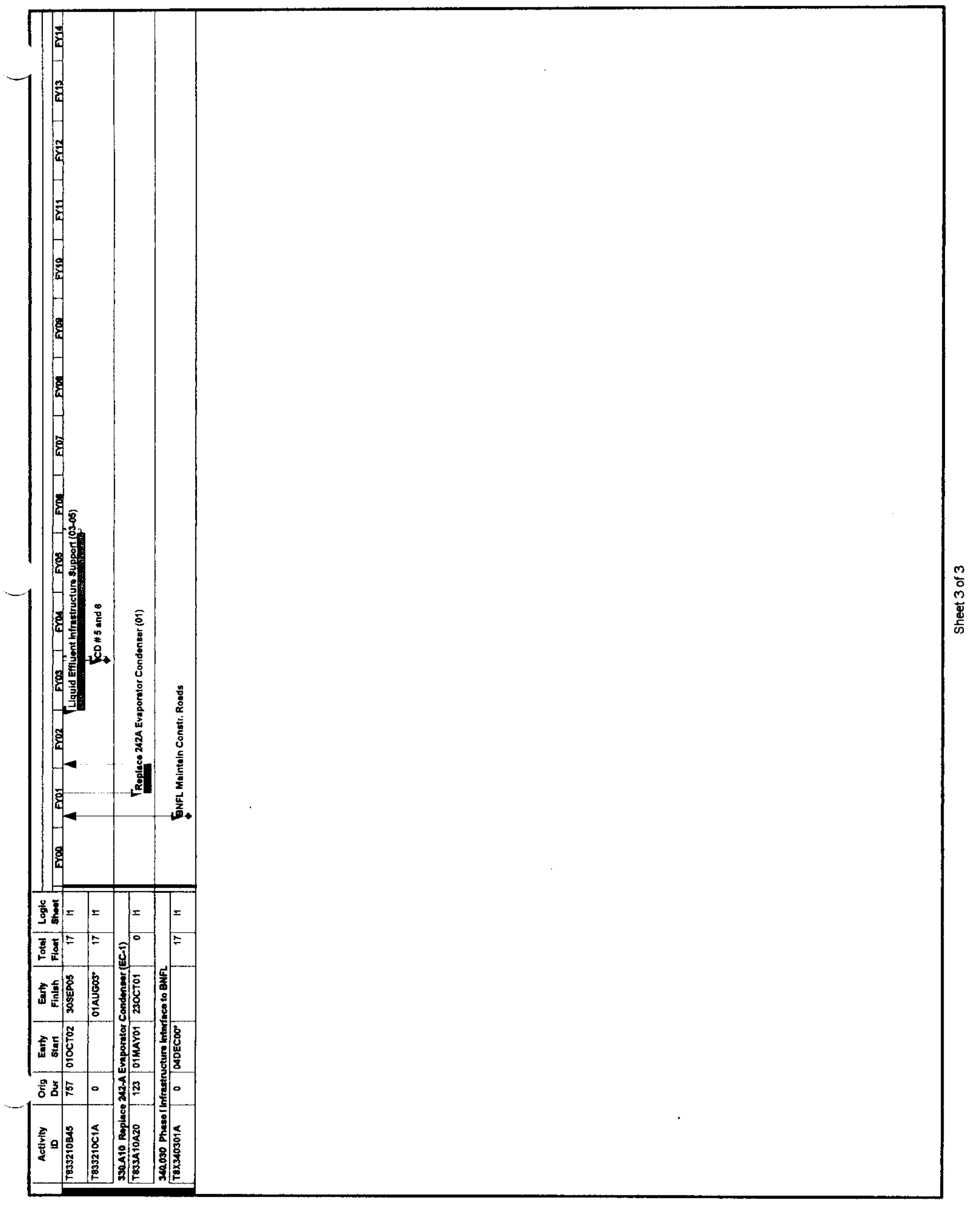




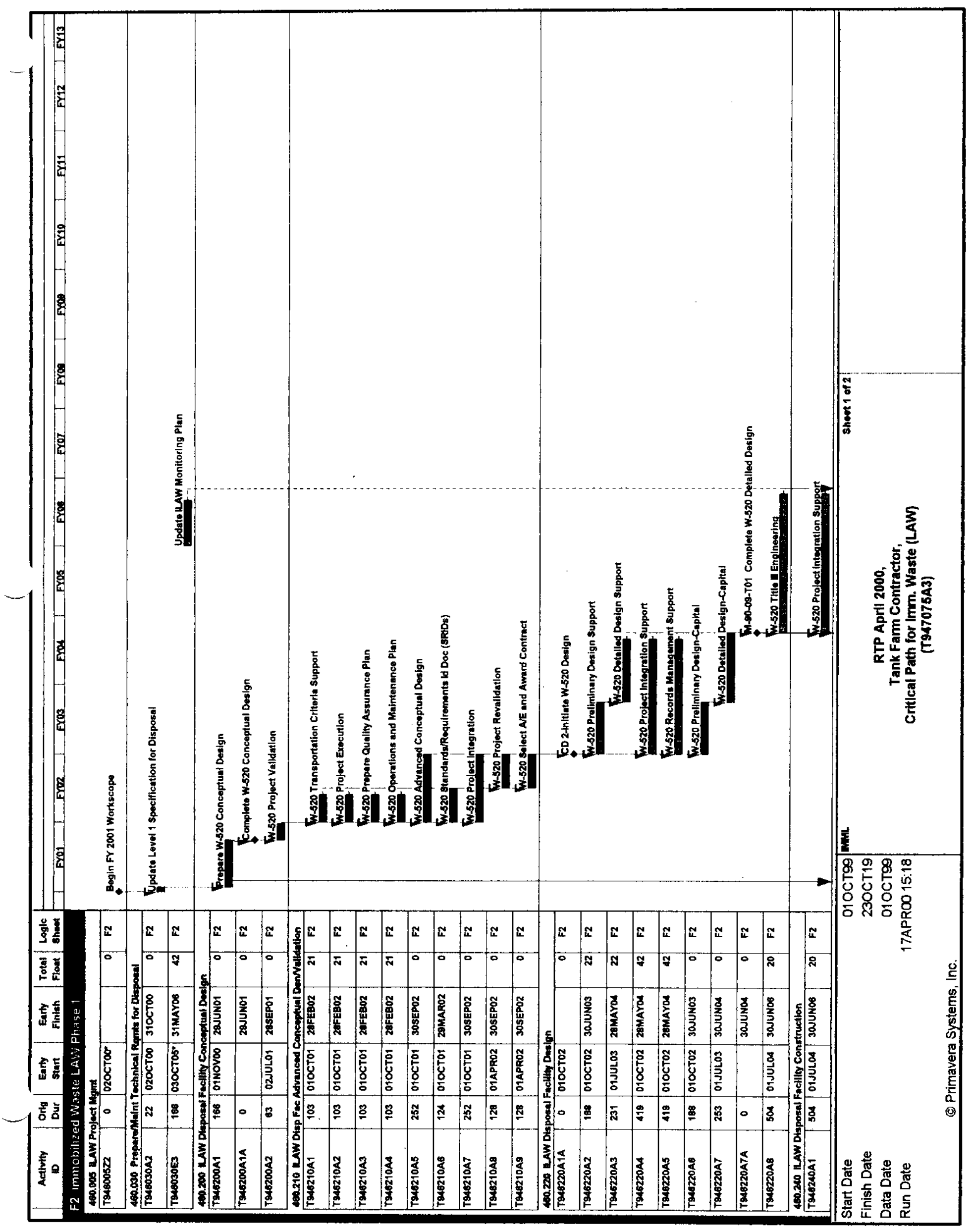




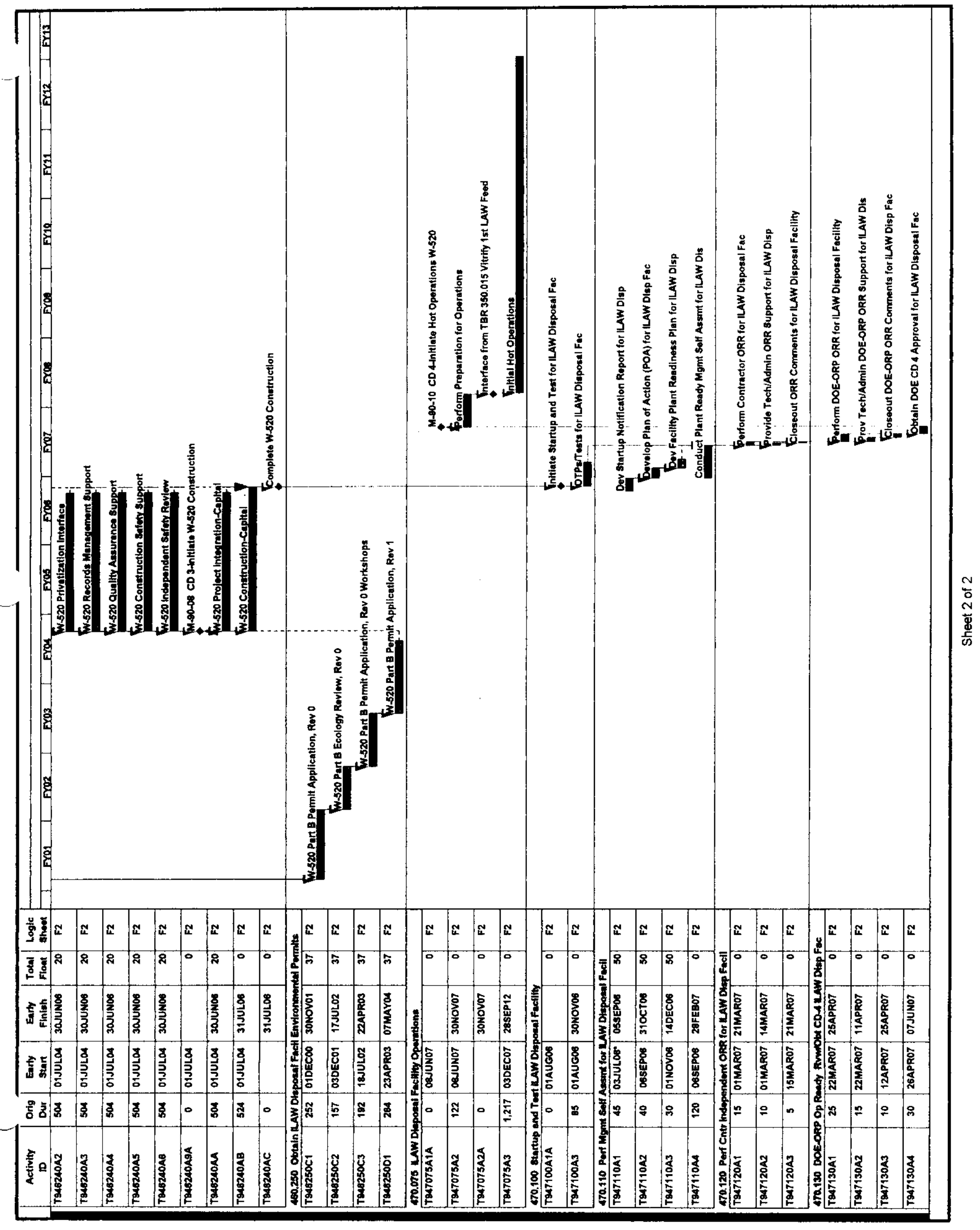




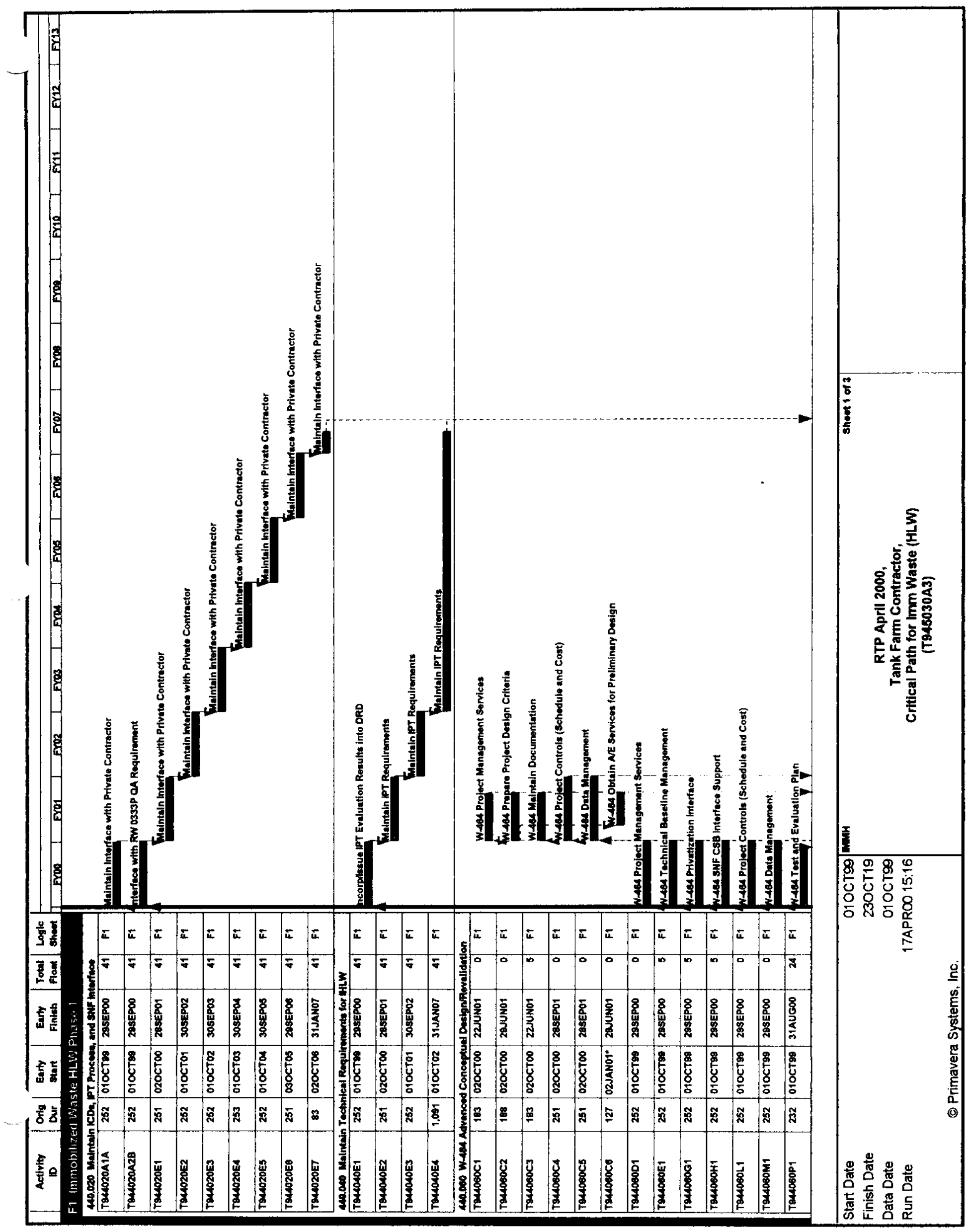




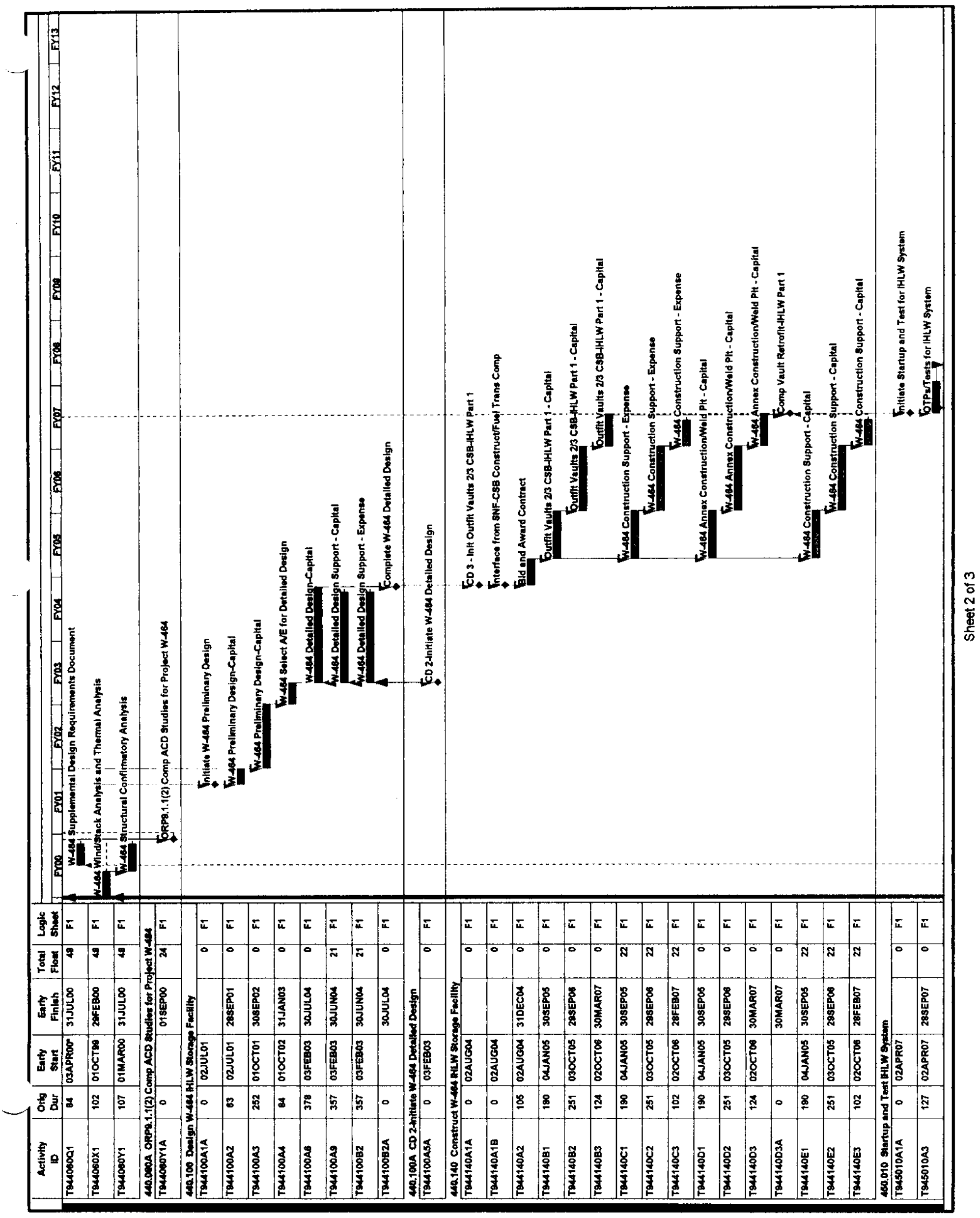




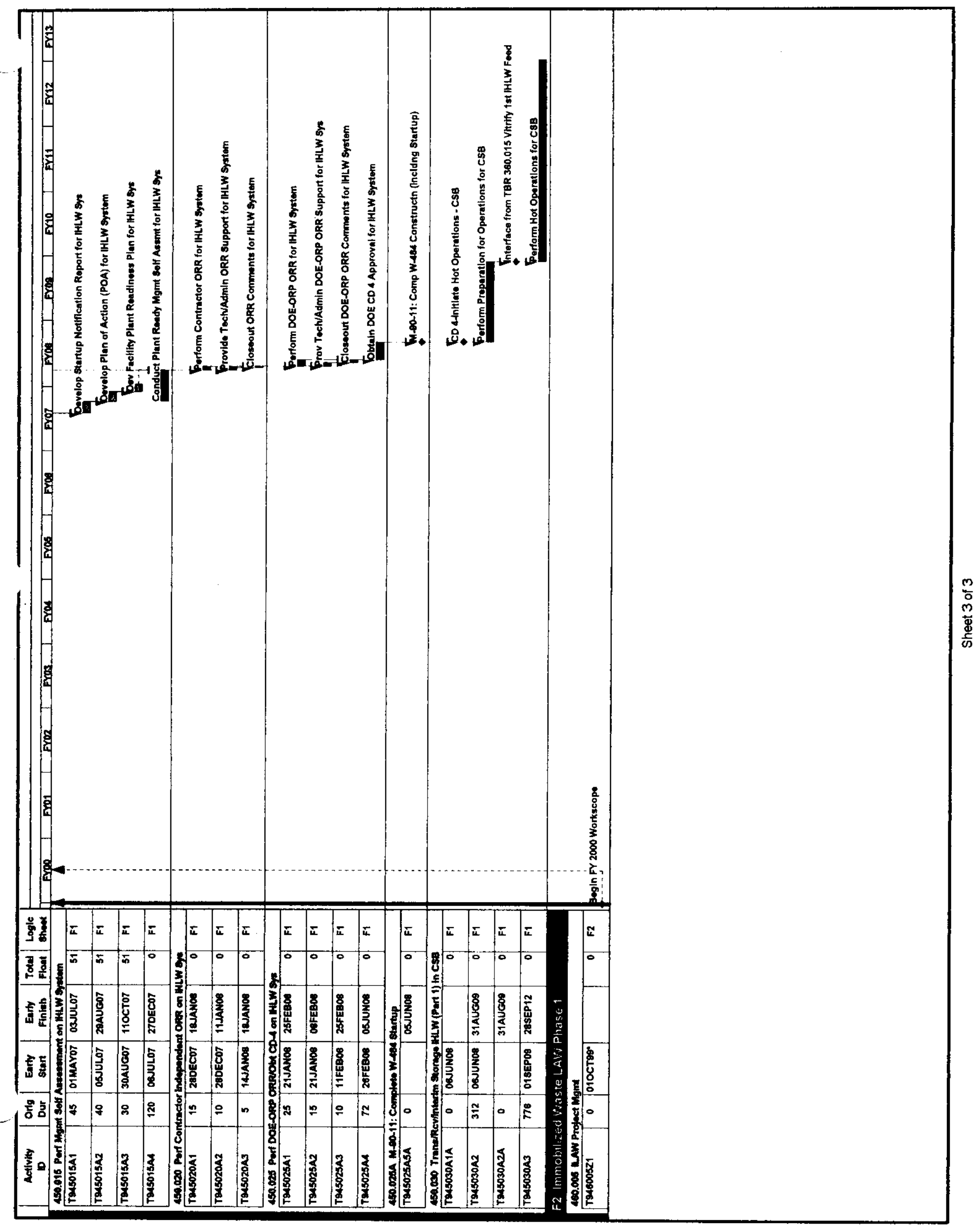




\section{Project Master Baseline Schedule - Index}

$\underline{\text { Logic Sheet Code }}$

A1A

AlB

A2A

A2B

A3A

A3B

$\mathrm{A} 4 \mathrm{~A}$

A4B

A5A

A5B

A6A

A6B

A7A

A7B

A8A

A8B

B1A

$\mathrm{B} 1 \mathrm{~B}$

B2A

B2B

B3A

B3B

B4A

B4B

B5A

B5B

B6A

B6B

B7A

B7B

ClA

C1B

$\mathrm{C} 2 \mathrm{~A}$

C2B

C3A

C3B

$\mathrm{C} 4 \mathrm{~A}$

C5A

C5B

C6A

C6B

D1A

D1B

D2A

D2B

D3A

D3B

E1A

EIB

F1 $\underline{\text { Logic Sheet Title }}$

$\underline{\text { Page \# }}$

WFD LAW Phase 1 Source Tank \#1 AP-101 - Sheet 1

- Sheet 2

WFD LAW Phase 1 Source Tank \#2 AN-102 - Sheet 1

- Sheet 2

WFD LAW Phase 1 Source Tank \#3 AN-104 - Sheet 1

- Sheet 2

WFD LAW Phase 1 Source Tank \#4 AN-107 - Sheet 1

- Sheet 2

WFD LAW Phase 1 Source Tank \#5 AN-105 - Sheet 1

- Sheet 2

WFD LAW Phase 1 Source Tank \#6 SY-101 - Sheet 1

- Sheet 2

WFD LAW Phase 1 Source Tank \#7 AN-103 - Sheet 1

- Sheet 2

WFD LAW Phase 1 Source Tank \#8 AW-101 - Sheet 1

- Sheet 2

WFD LAW Phase 1 Extended Order Source Tank \#1 AW-104 - Sheet 1

- Sheet 2

WFD LAW Phase 1 Extended Order Source Tank \#2 SY-103 - Sheet 1

- Sheet 2

WFD LAW Phase 1 Extended Order Source Tank \#3 AP-106 - Sheet 1

- Sheet 2

WFD LAW Phase 1 Extended Order Source Tank \#4 S-102 - Sheet 1

- Sheet 2

WFD LAW Phase 1 Extended Order Source Tank \#5 S-105 - Sheet 1

- Sheet 2

WFD LAW Phase 1 Extended Order Source Tank \#6 AP-105 - Sheet 1

- Sheet 2

WFD LAW Phase 1 Extended Order Source Tank \#7 AP-108 - Sheet 1

- Sheet 2

WFD HLW Phase 1 Source Tank \#1 AZ-101 - Sheet 1

- Sheet 2

WFD HLW Phase 1 Source Tank \#2 AZ-102 - Sheet 1

- Sheet 2

WFD HLW Phase 1 Source Tank \#3 AY-102 - Sheet 1

$$
\text { - Sheet } 2
$$

WFD HLW Phase 1 Source Tank \#4 C-104 - Sheet 1

WFD HLW Phase 1 Source Tank \#5 AY-101 - Sheet 1

- Sheet 2

WFD HLW Phase 1 Source Tank \#6 SY-102 - Sheet 1

- Sheet 2

WFD HLW Phase 1 Extended Order Source Tank \#1 C-107 - Sheet 1

- Sheet $2 \quad 55$

WFD HLW Phase 1 Extended Order Source Tank \#2 AW-103 - Sheet $1 \quad 57$

- Sheet $2 \quad 59$

WFD HLW Phase 1 Extended Order Source Tank \#3 AW-104 - Sheet $1 \quad 60$

- Sheet $2 \quad 61$

WFD Backup/Staging Tanks AP-102/AP-104 - Sheet 1

- Sheet 2

Immobilized HLW Phase 1 


\section{Project Master Baseline Schedule - Index}

$\begin{array}{llr}\text { F2 } & \text { Immobilized LAW Phase 1 } & 67 \\ \text { I1 } & \text { Infrastructure Phase 1 } & 69 \\ \text { M1 } & \text { Management Assessment } & 71 \\ \text { P1 } & \text { WFD Program Activities } & 72 \\ \text { Q1 } & \text { WFD Project Definition } & 74 \\ \text { R1 } & \text { WFD Retrieval Management } & 75 \\ \text { S1 } & \text { SST Program } & 76\end{array}$




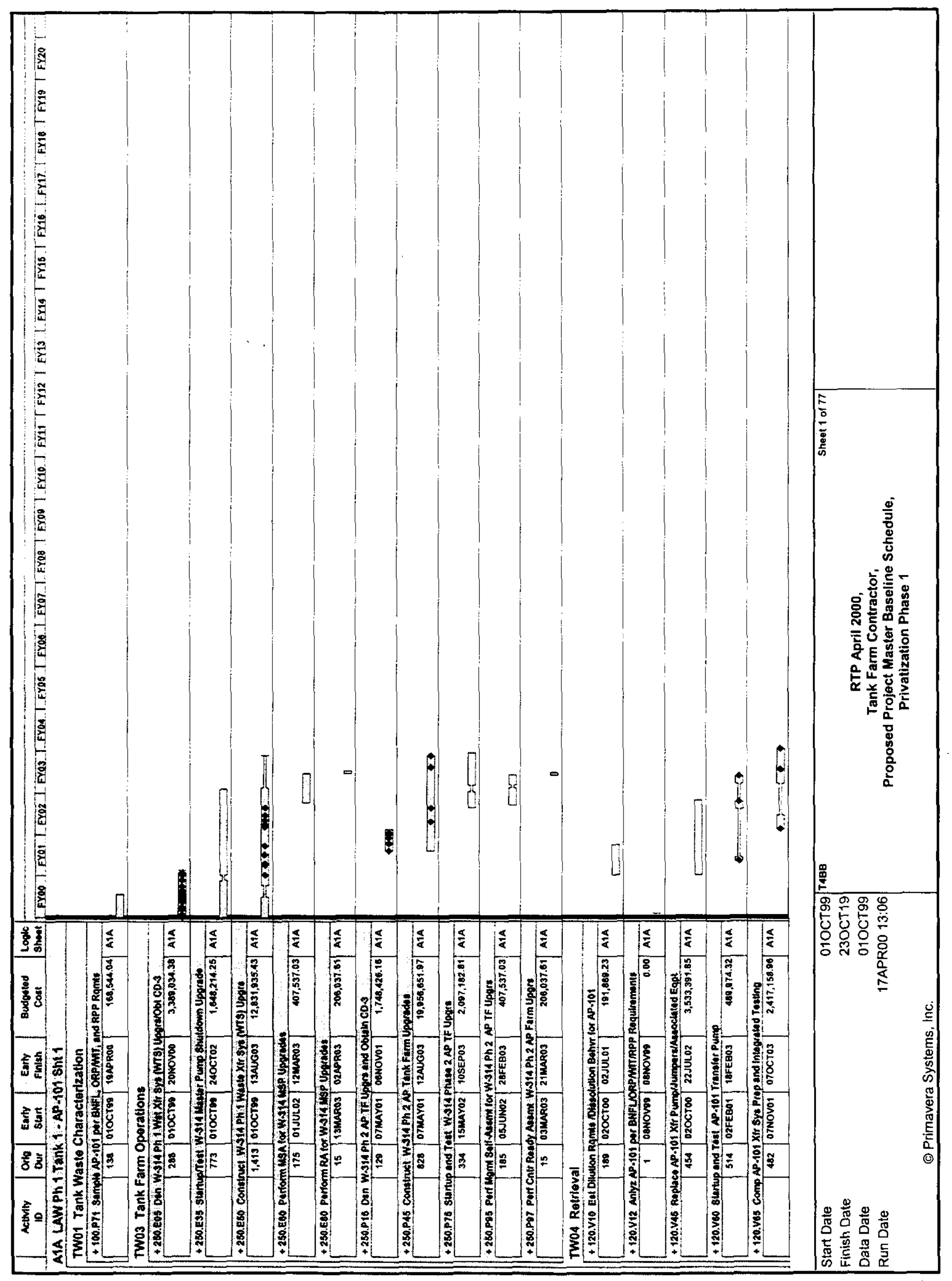




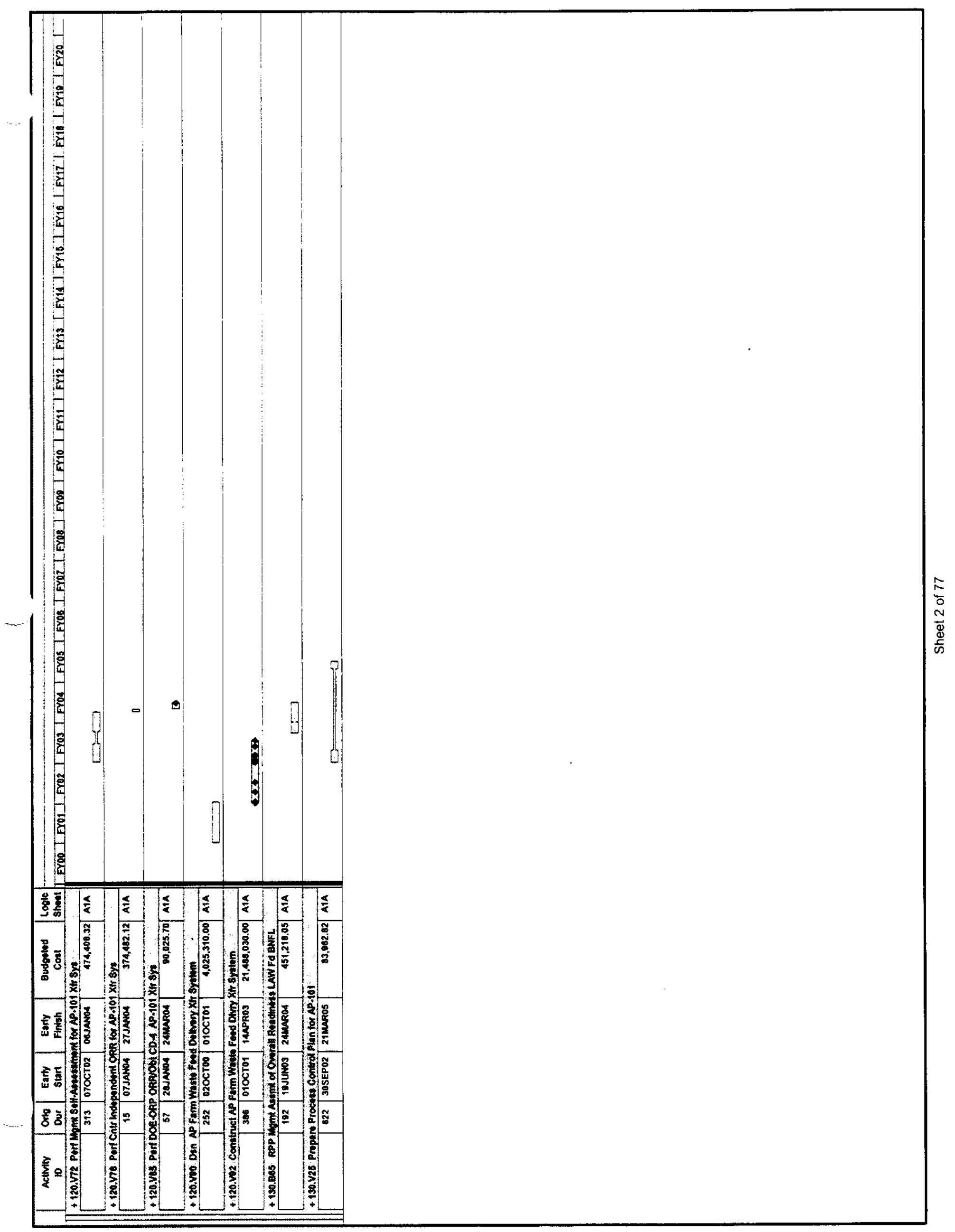




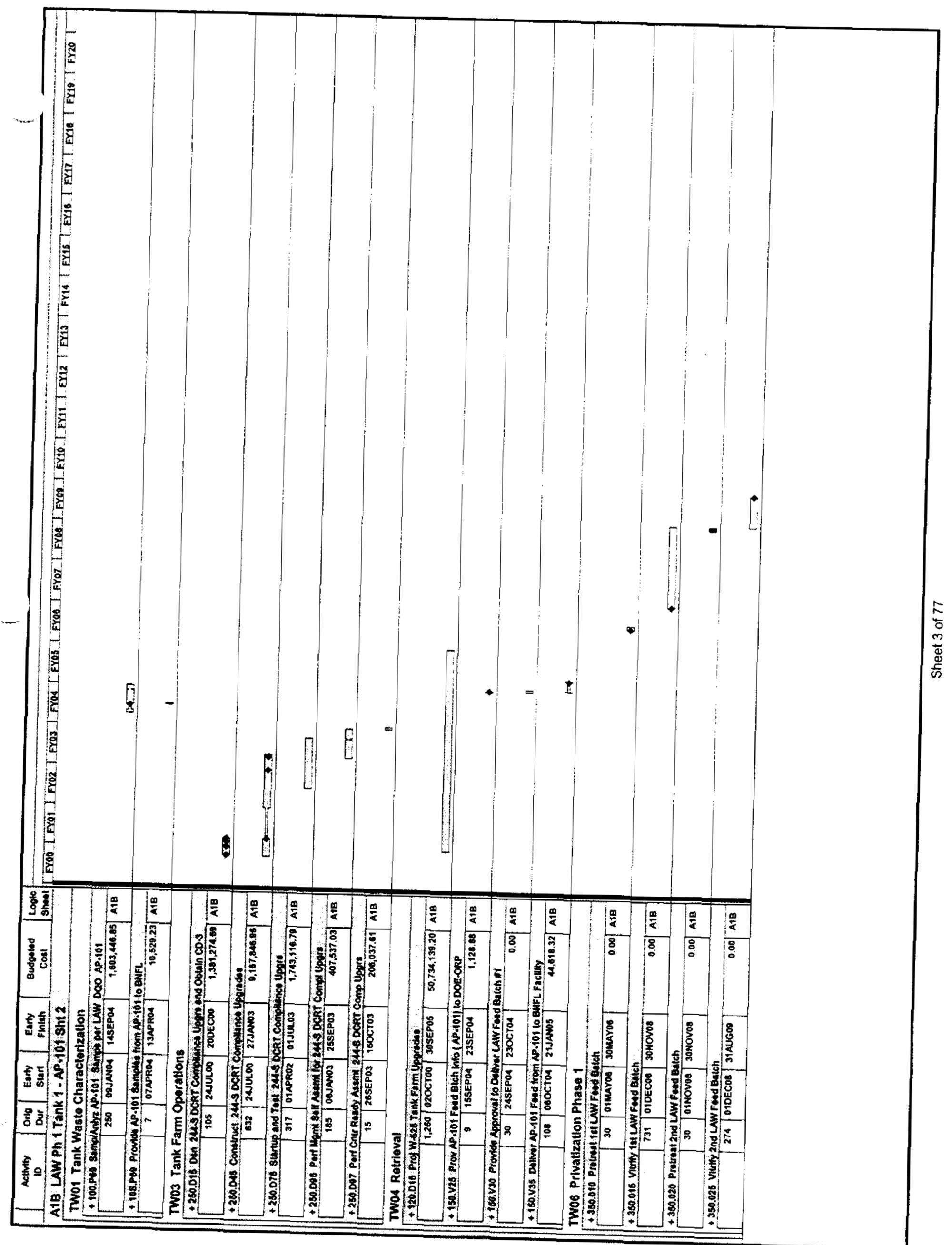




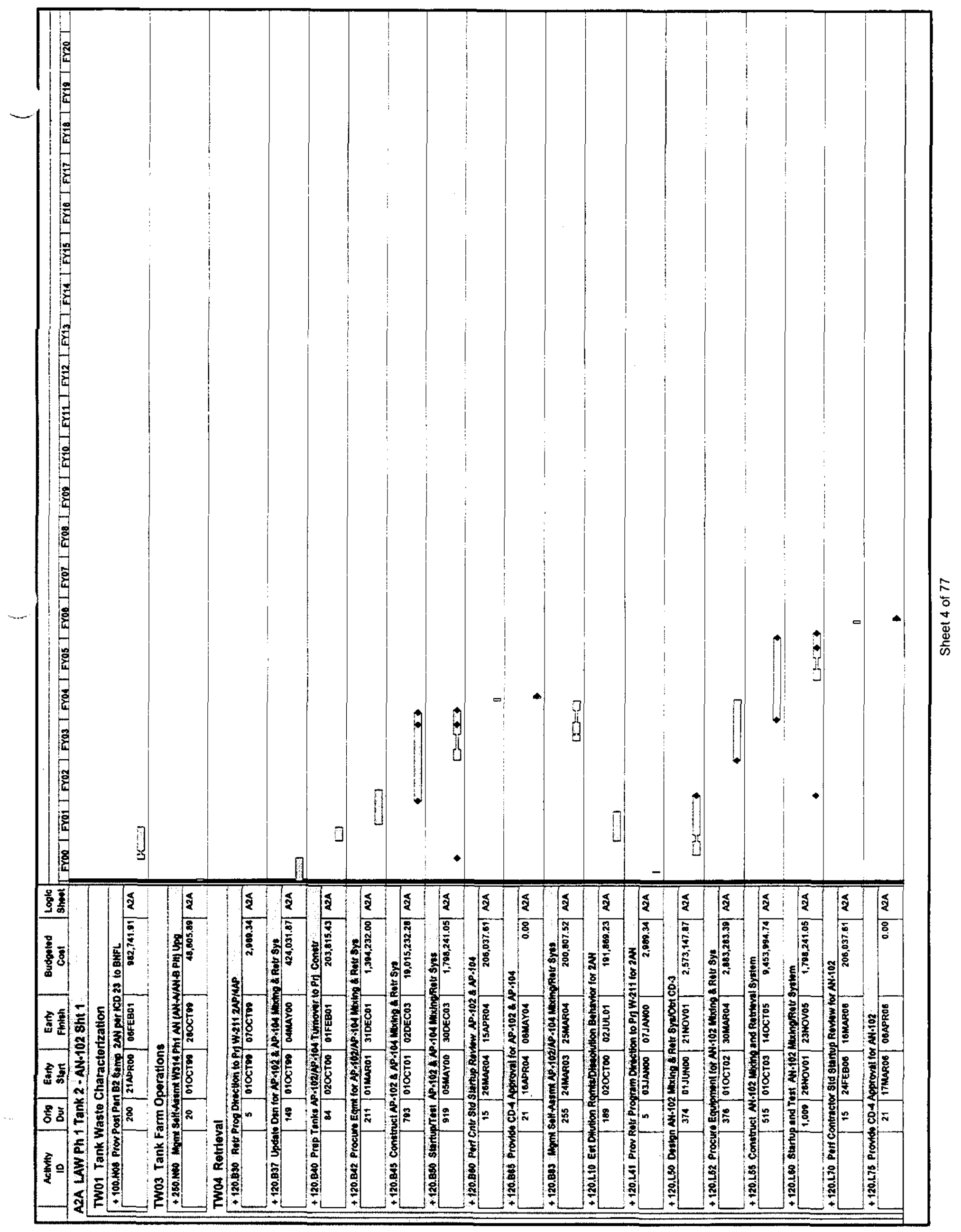




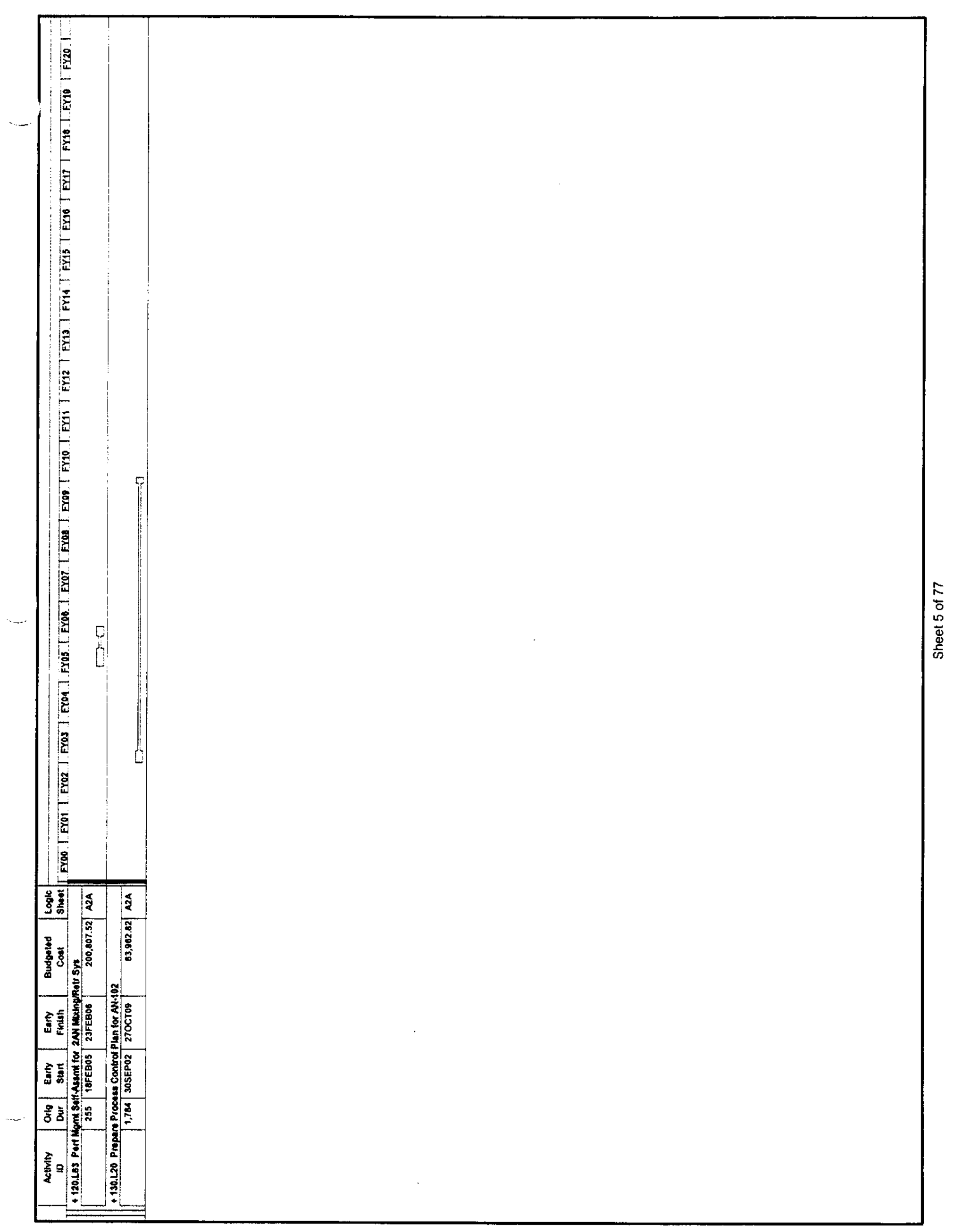




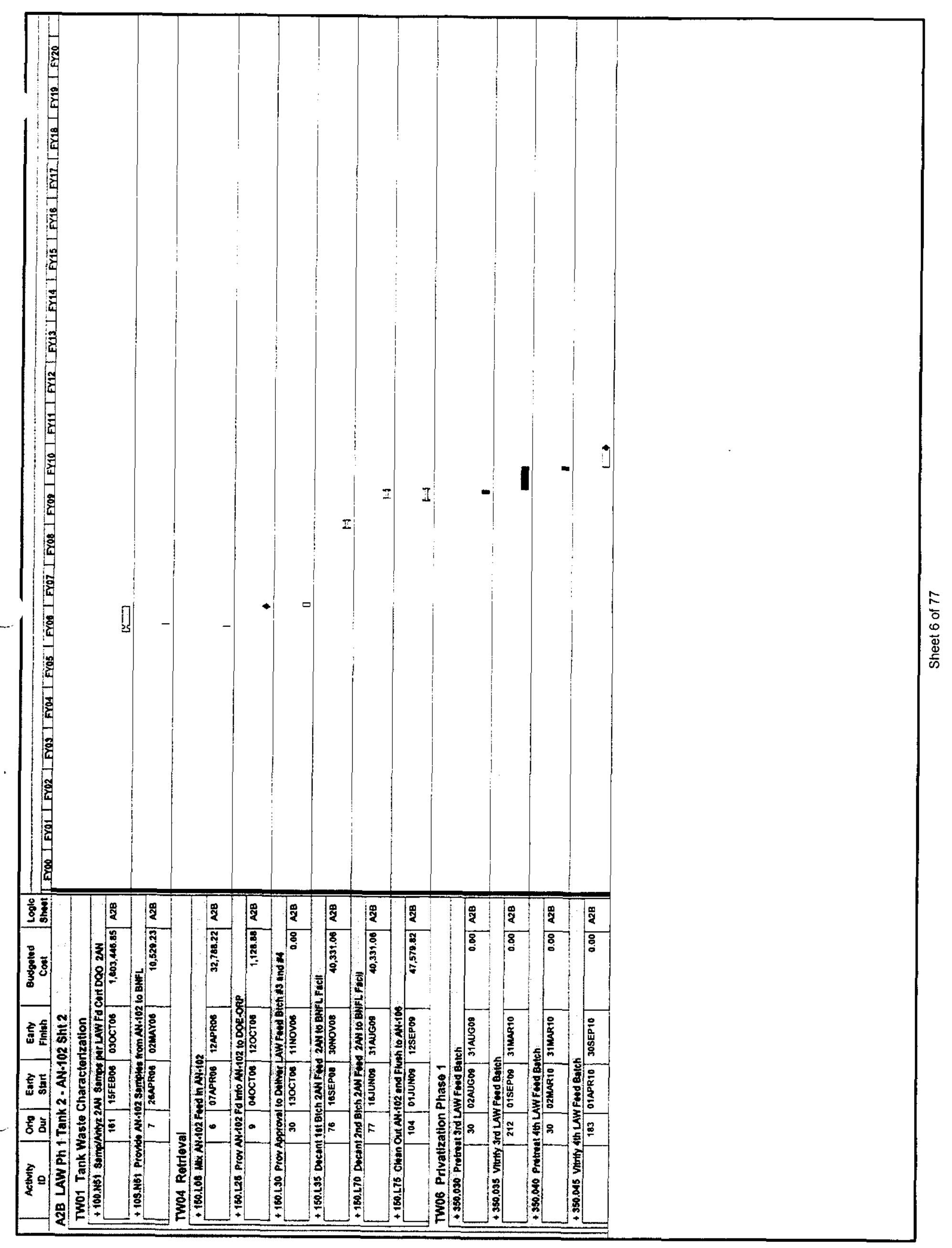




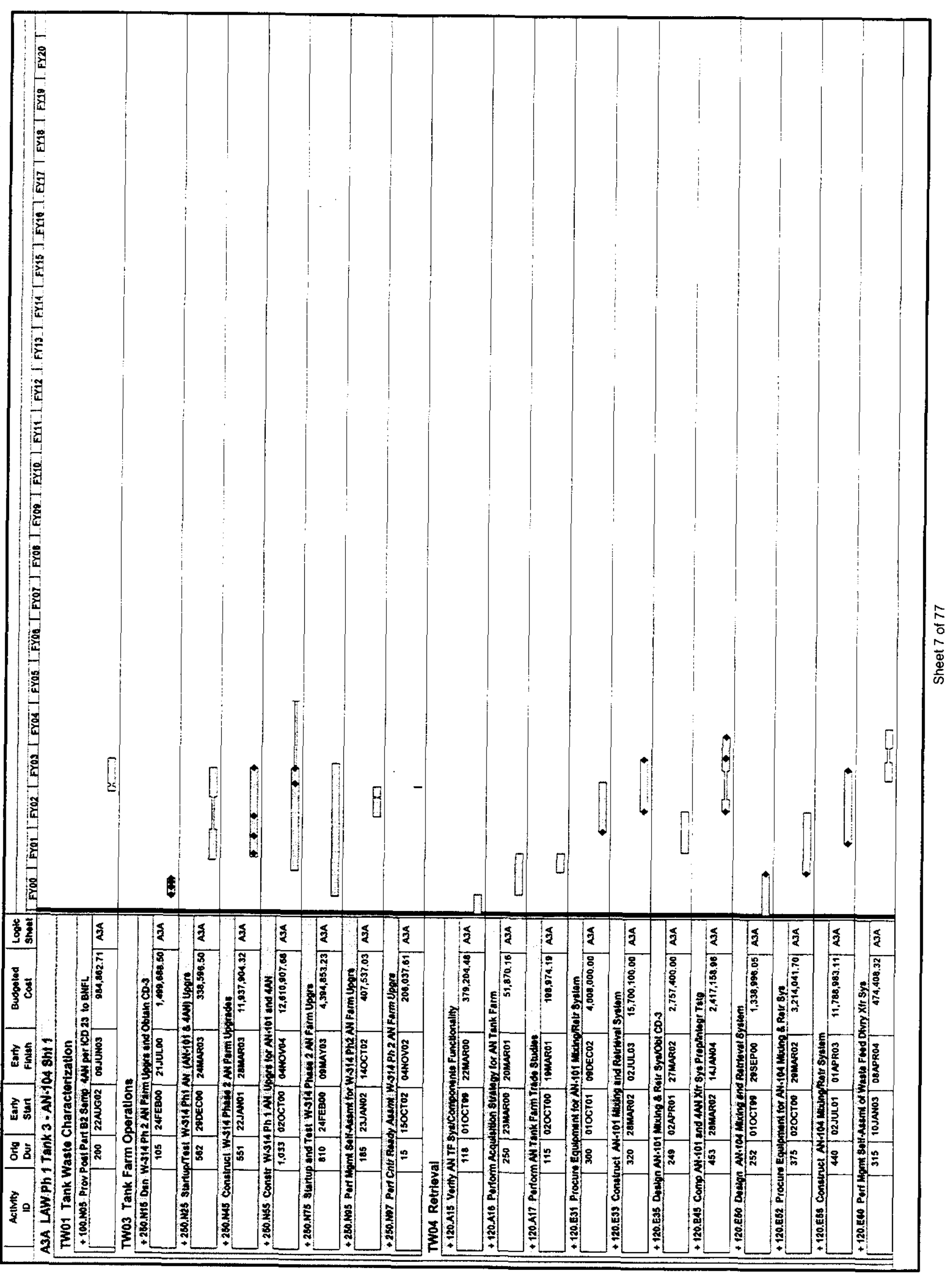




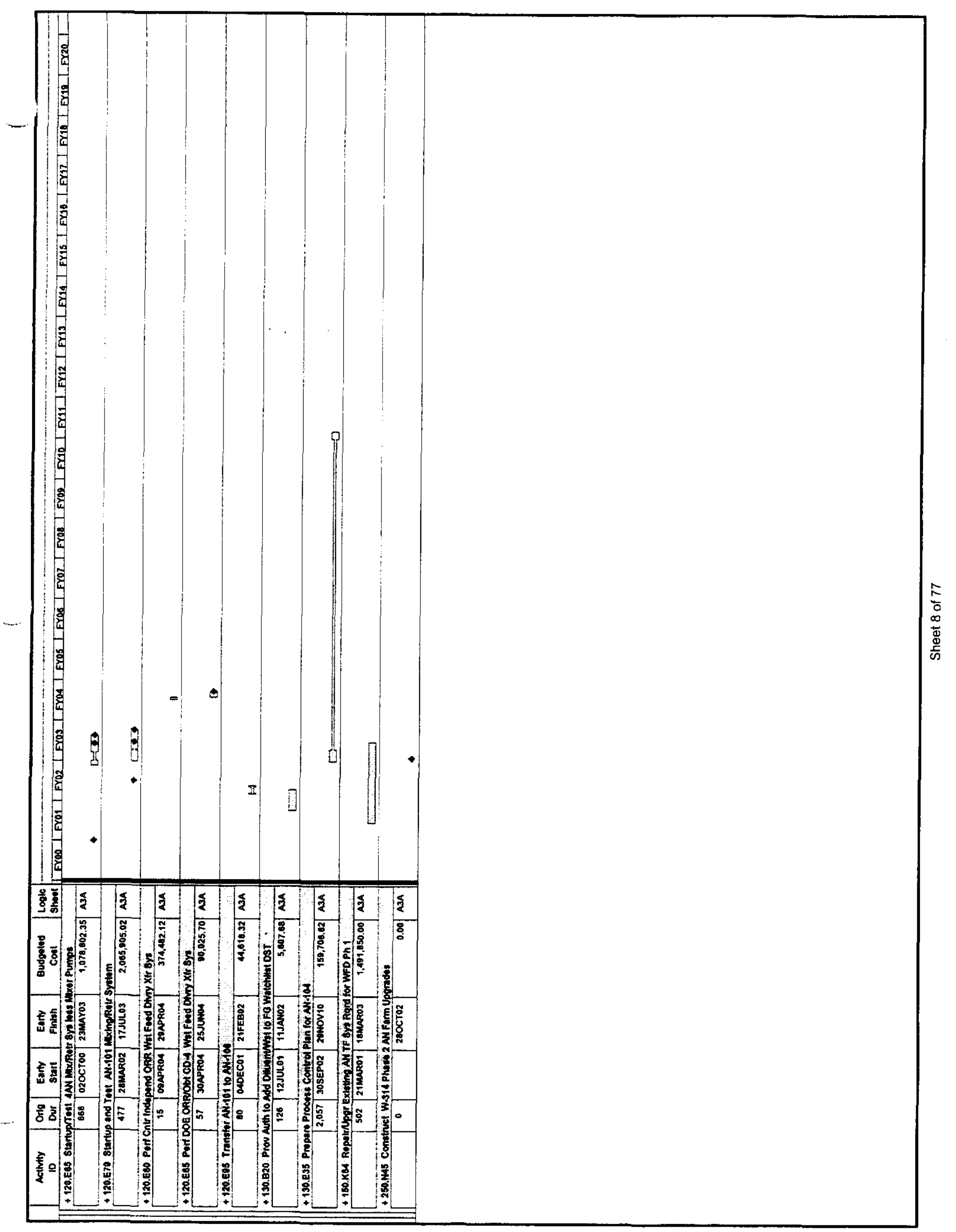




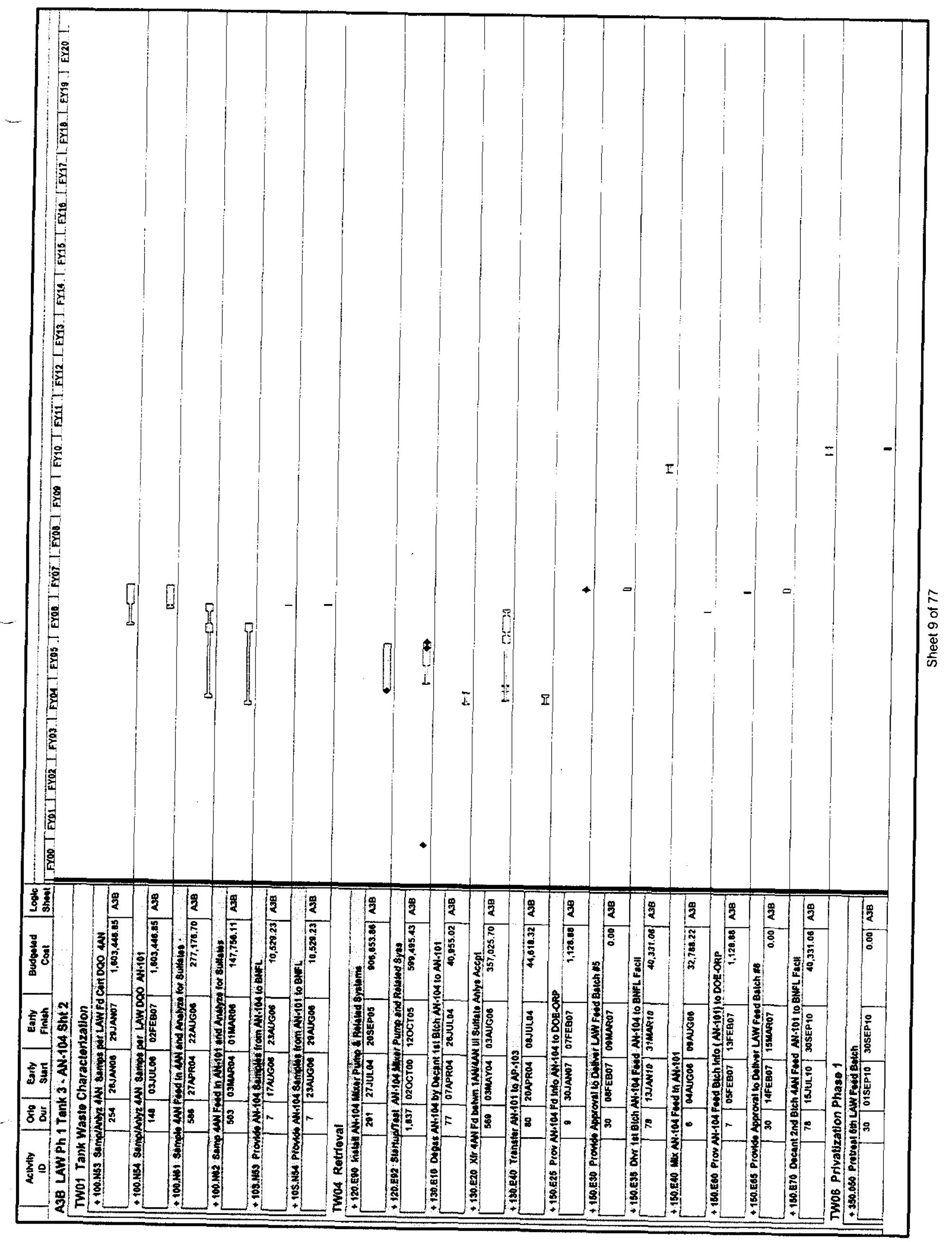




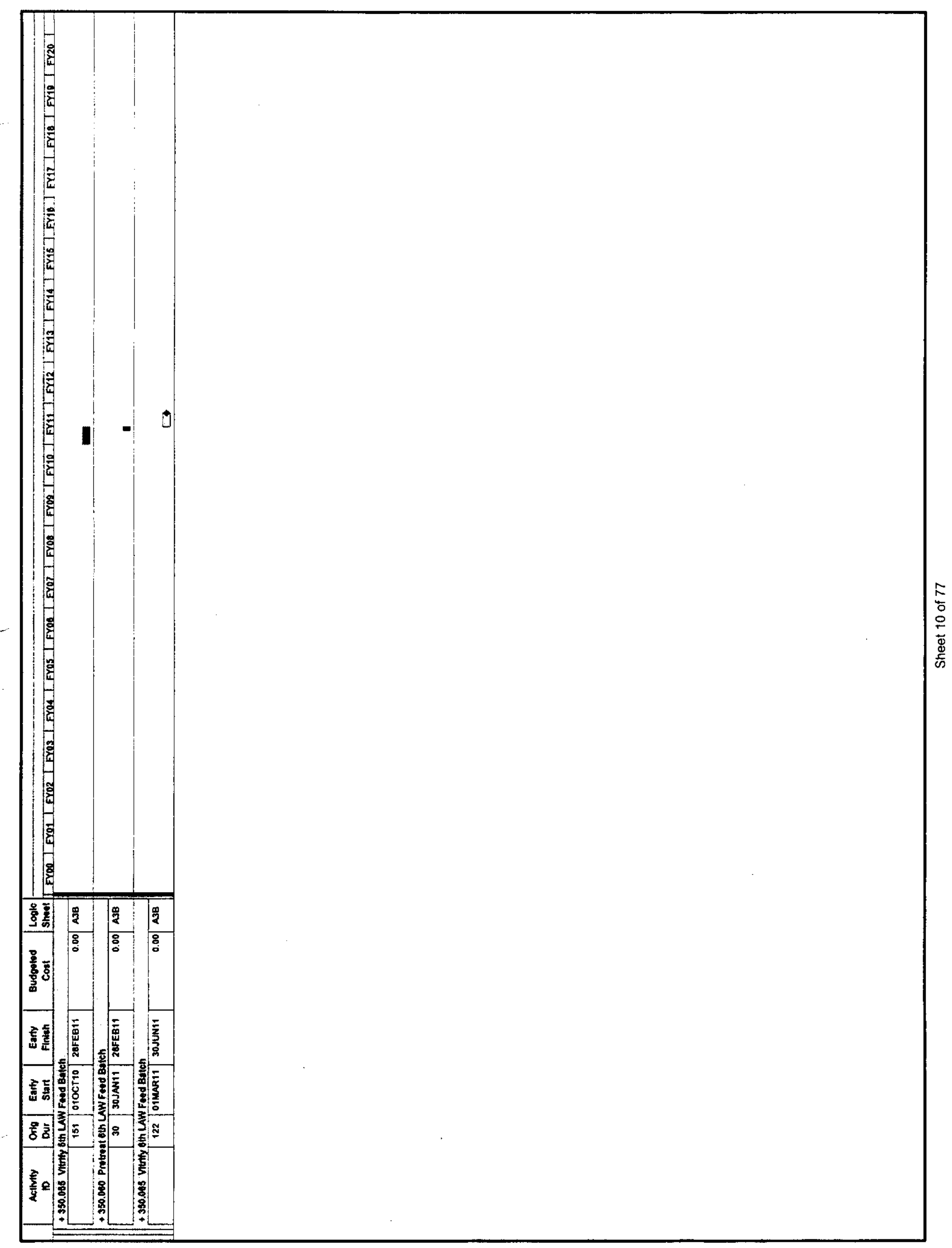




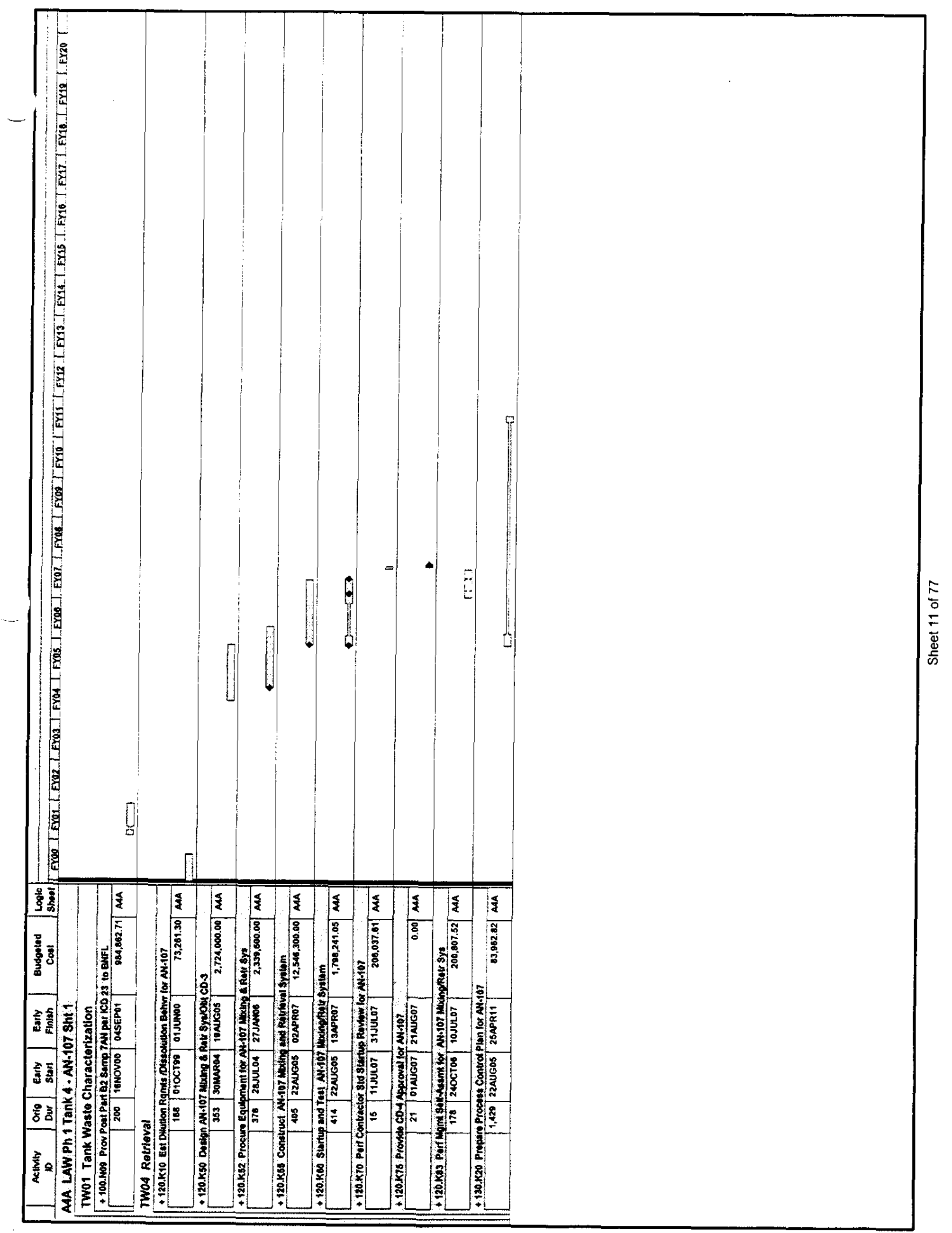




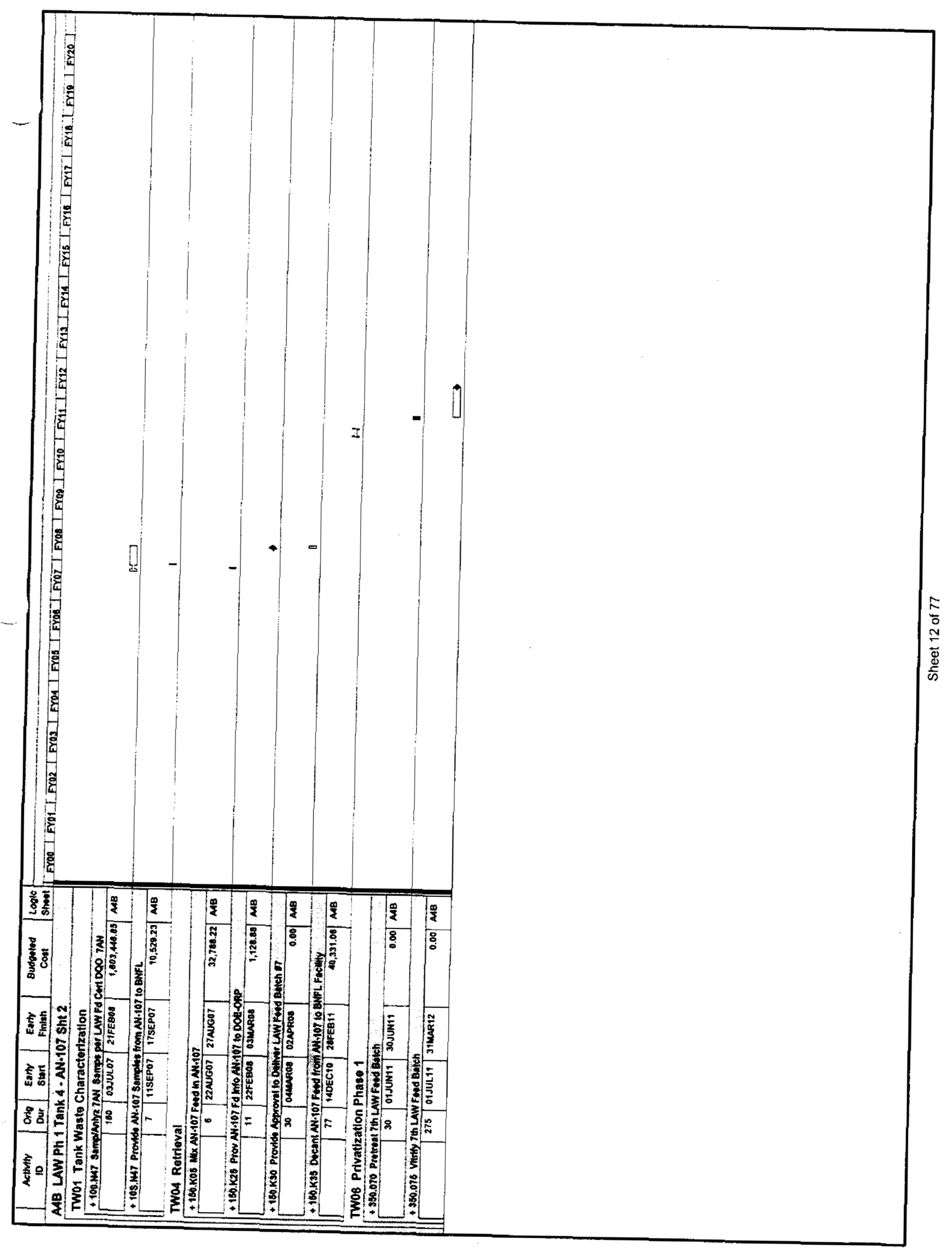




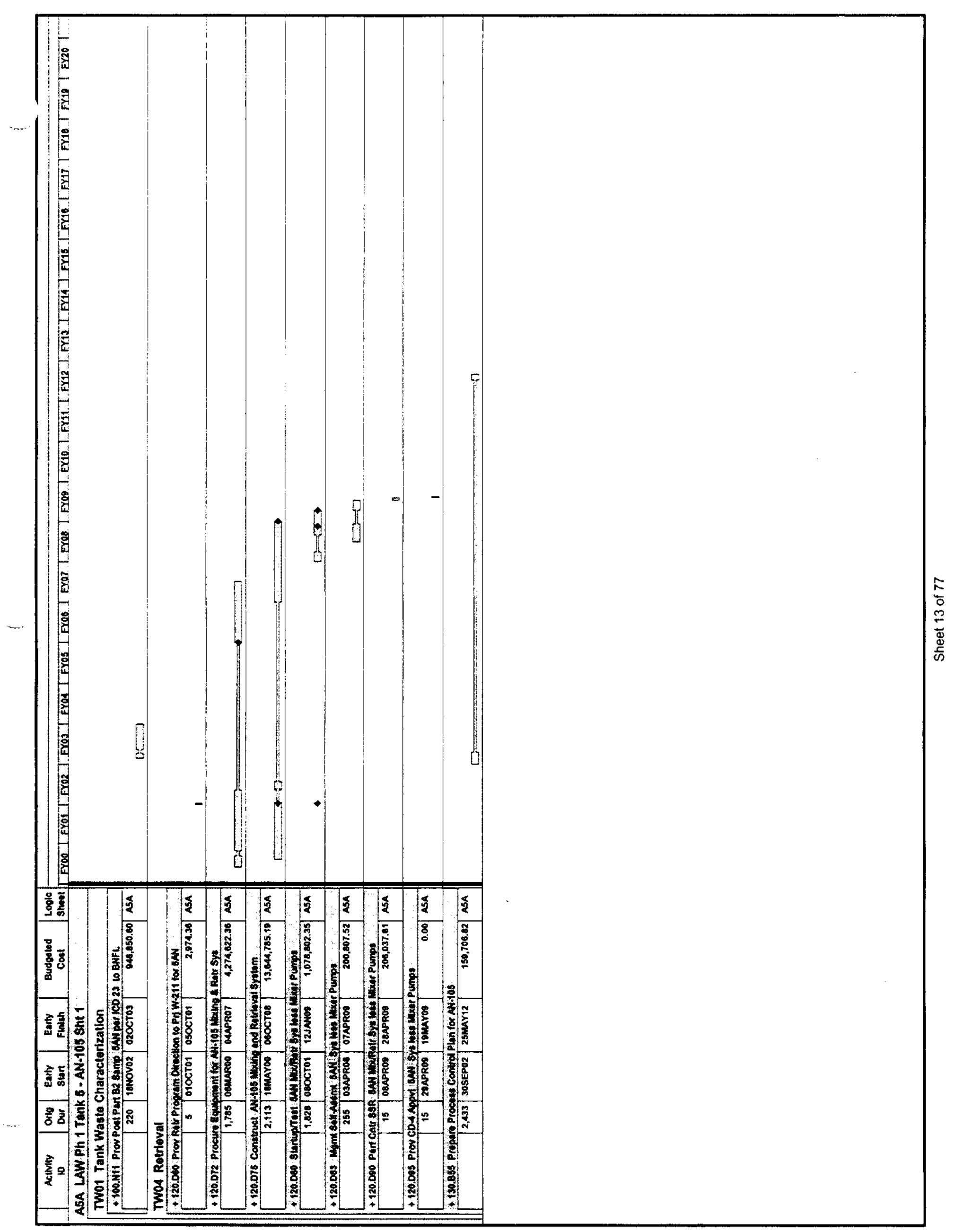




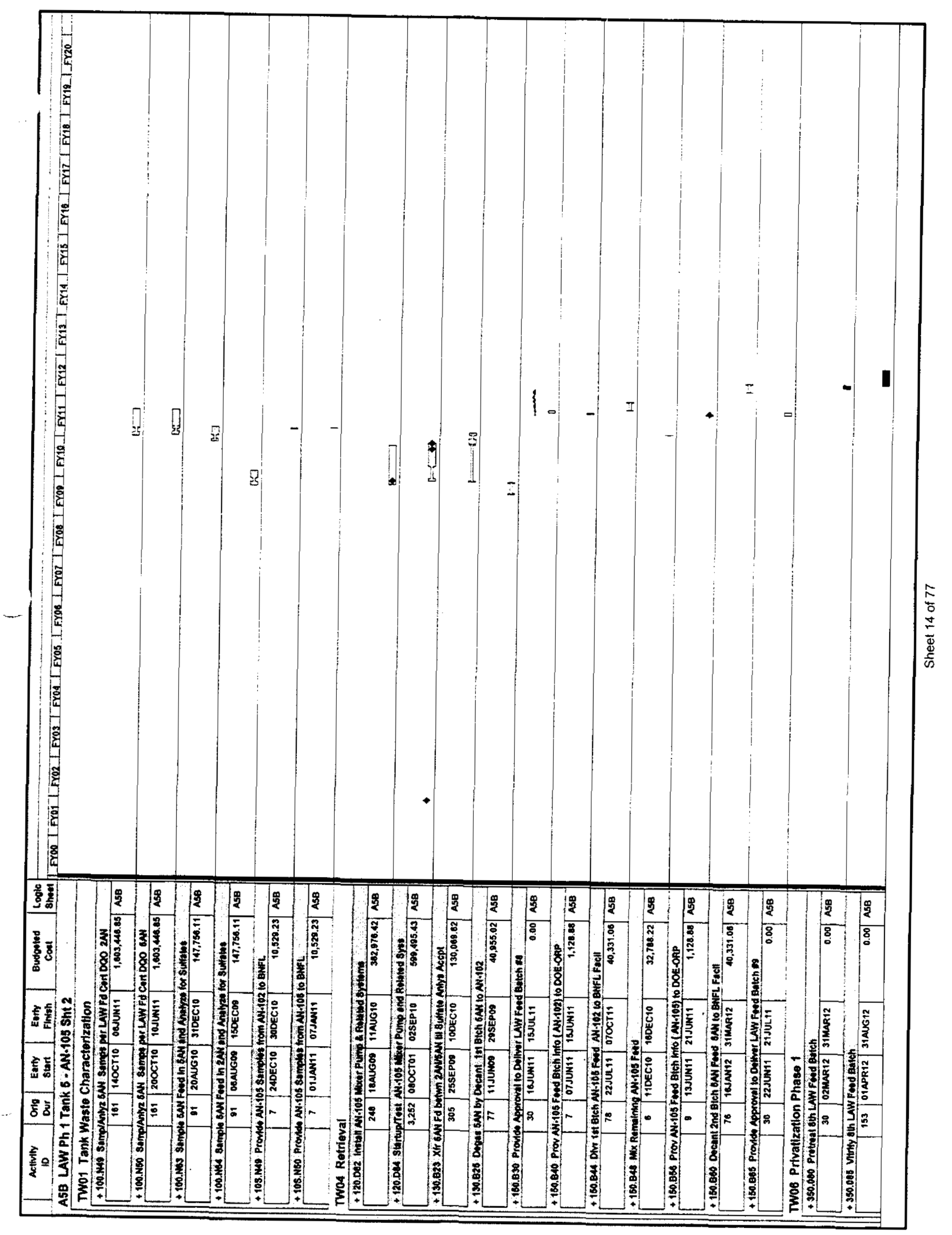




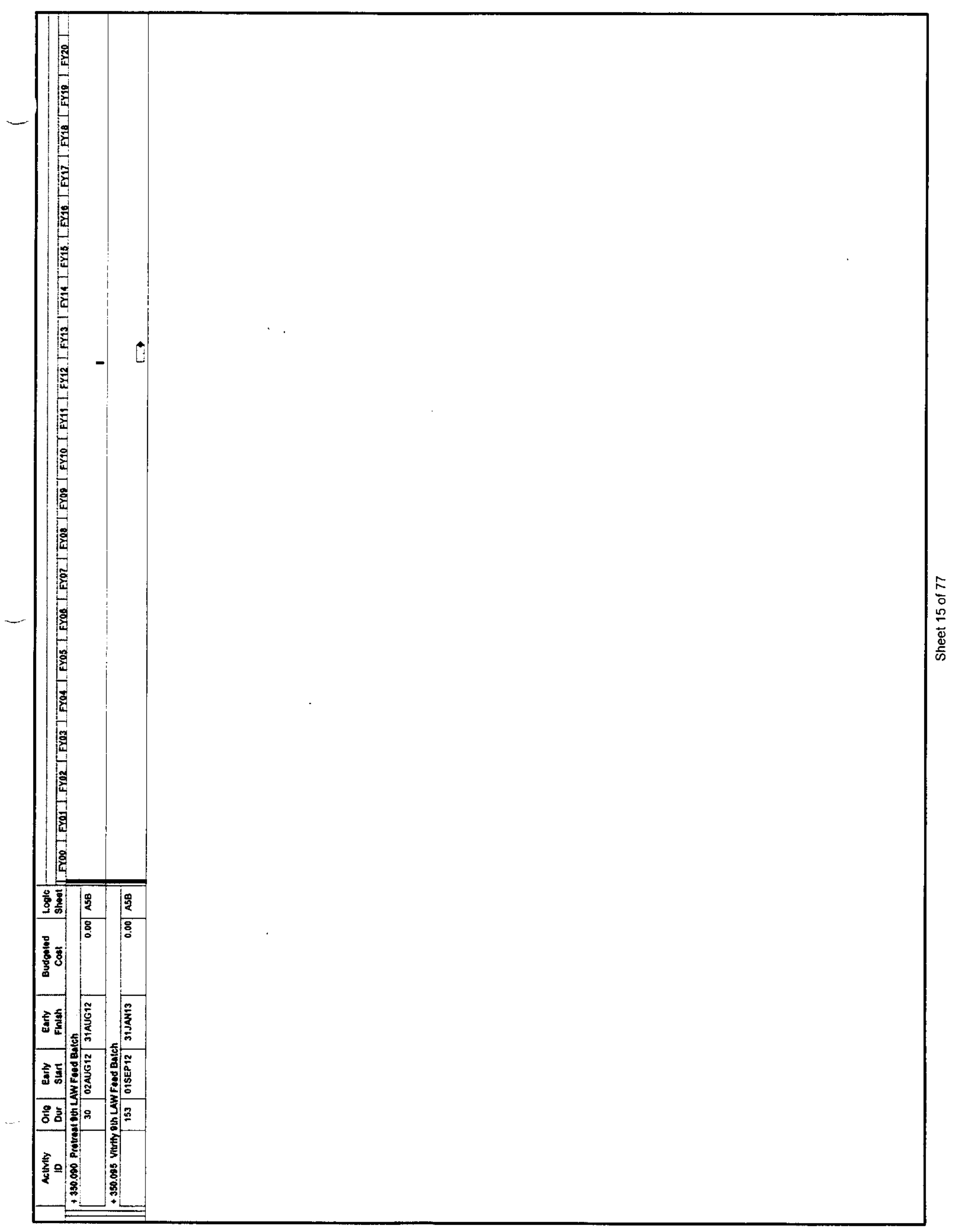




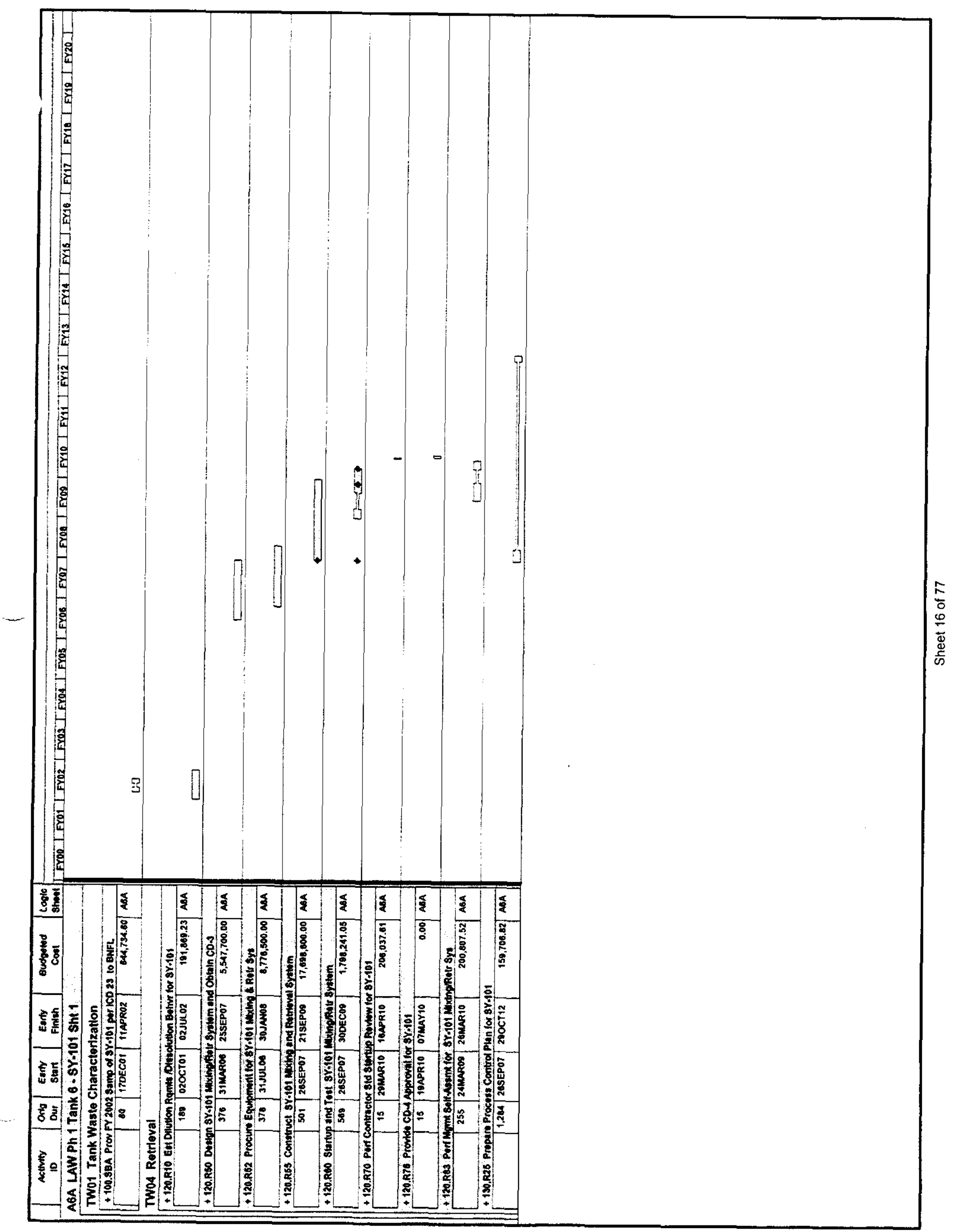




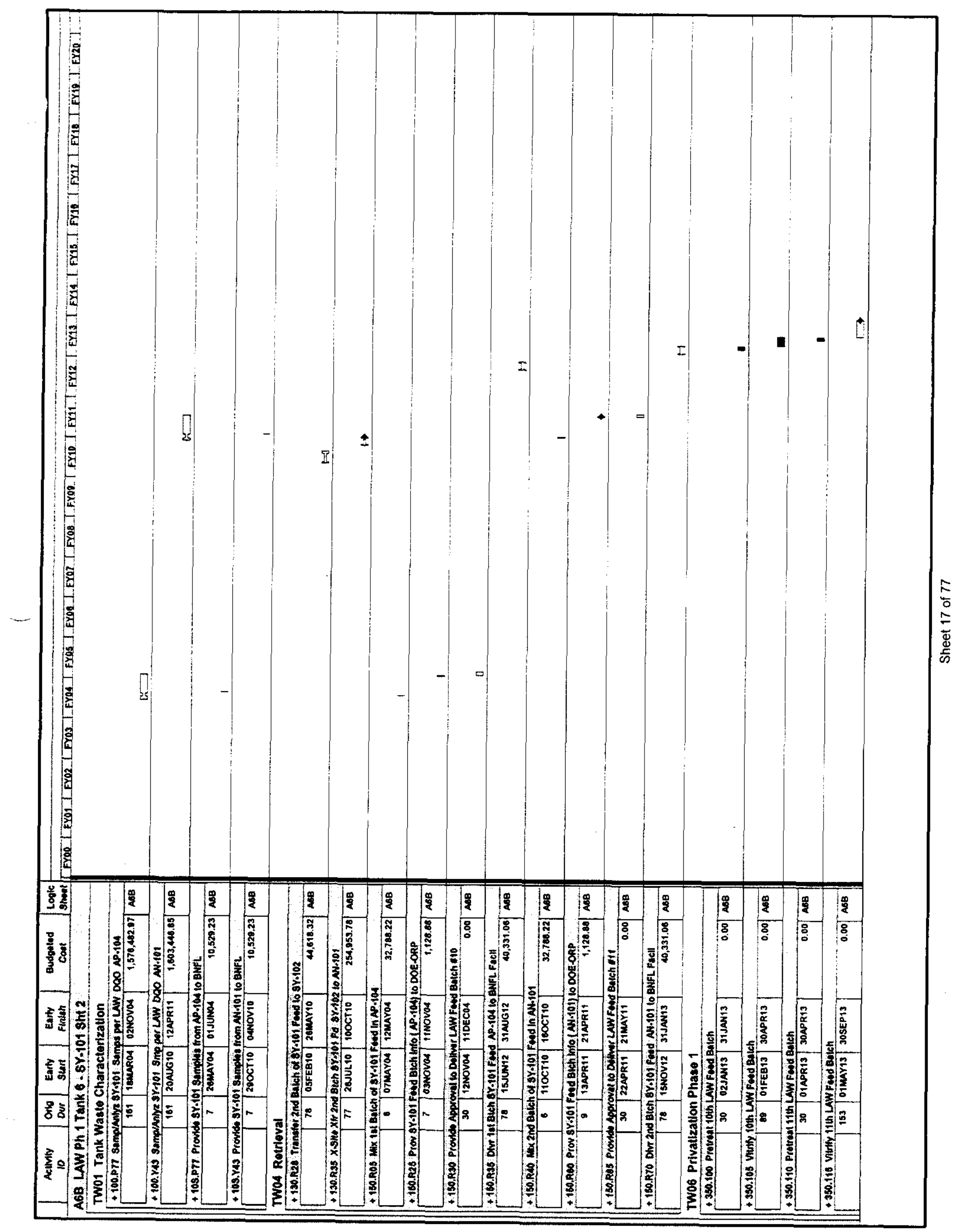




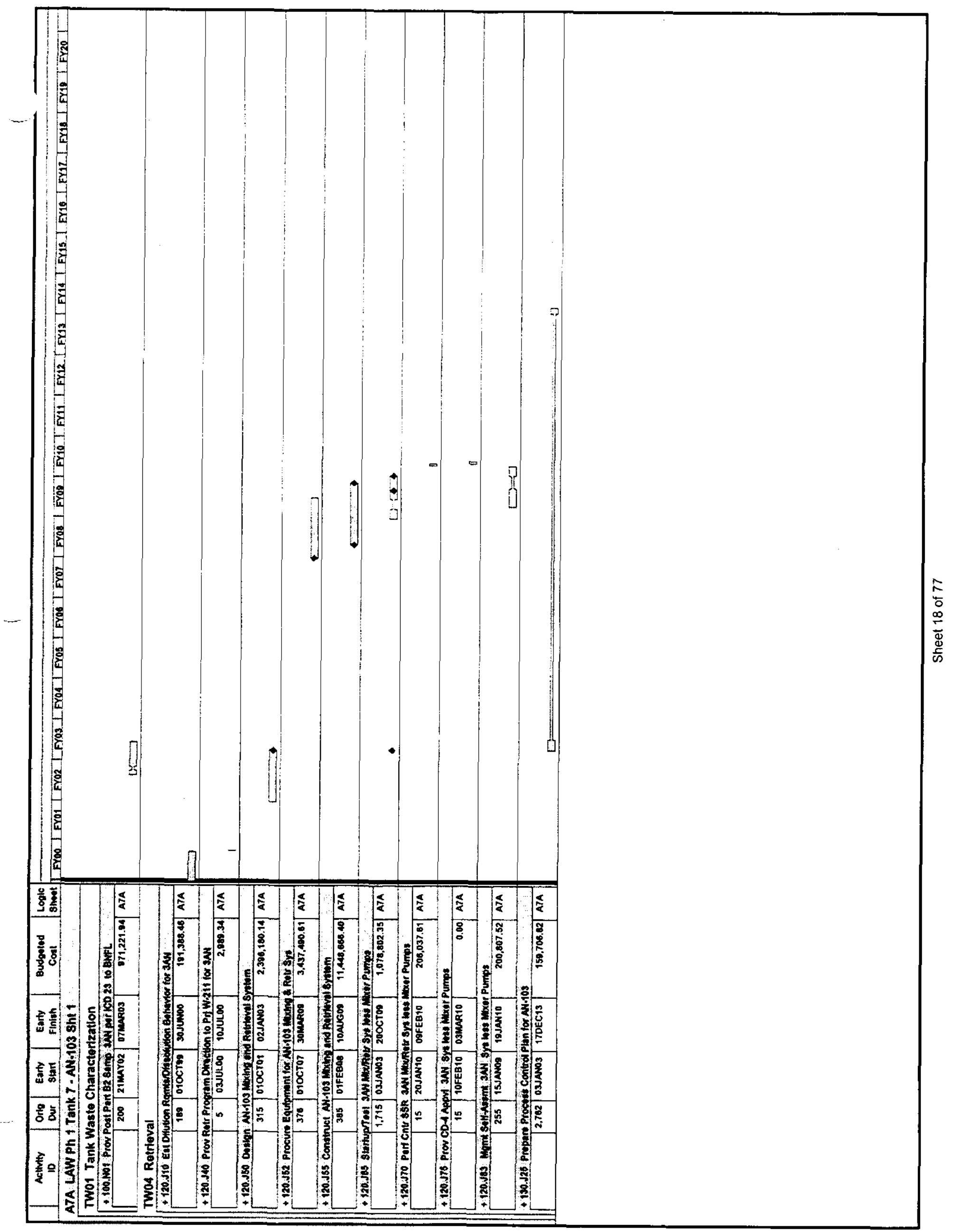




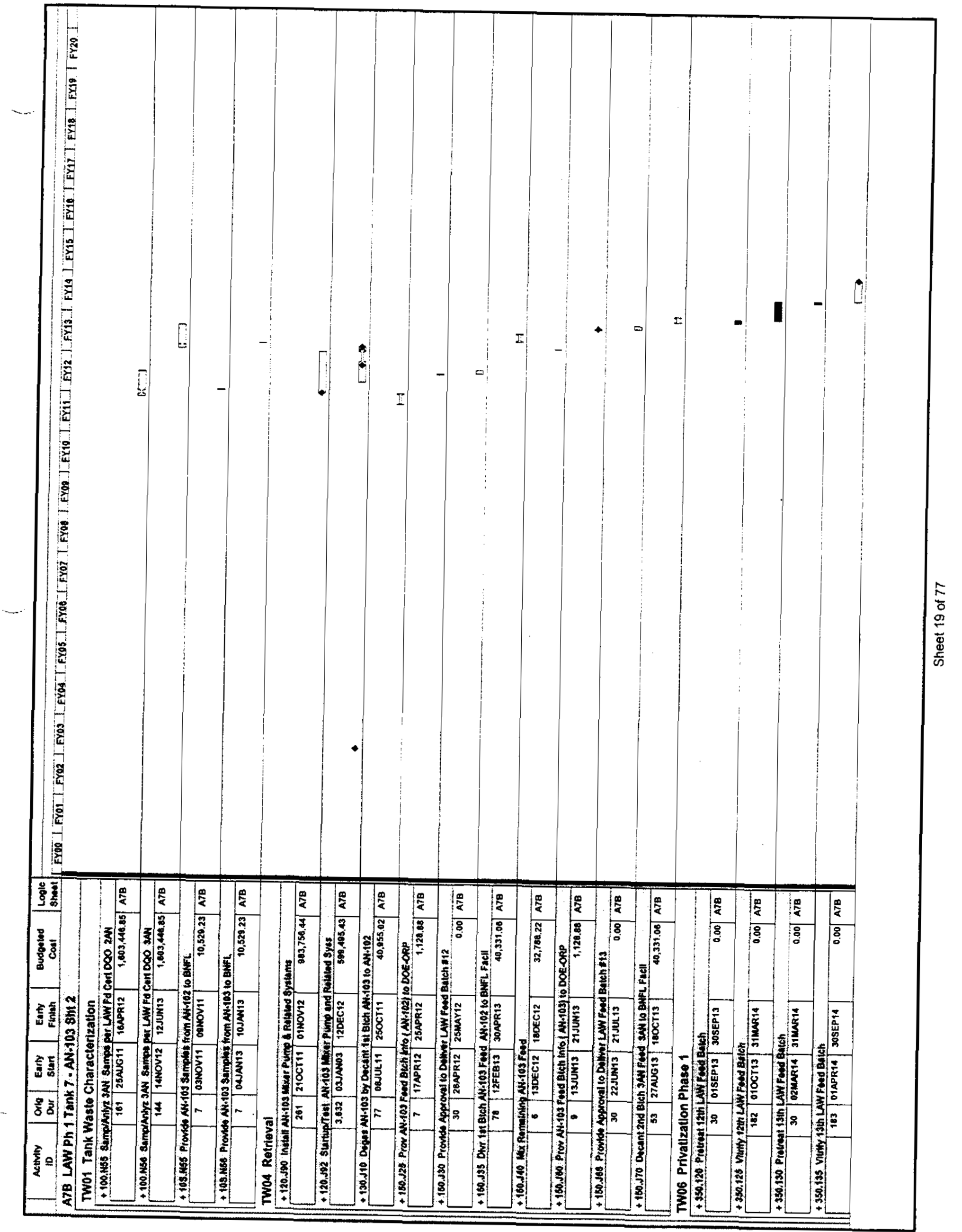




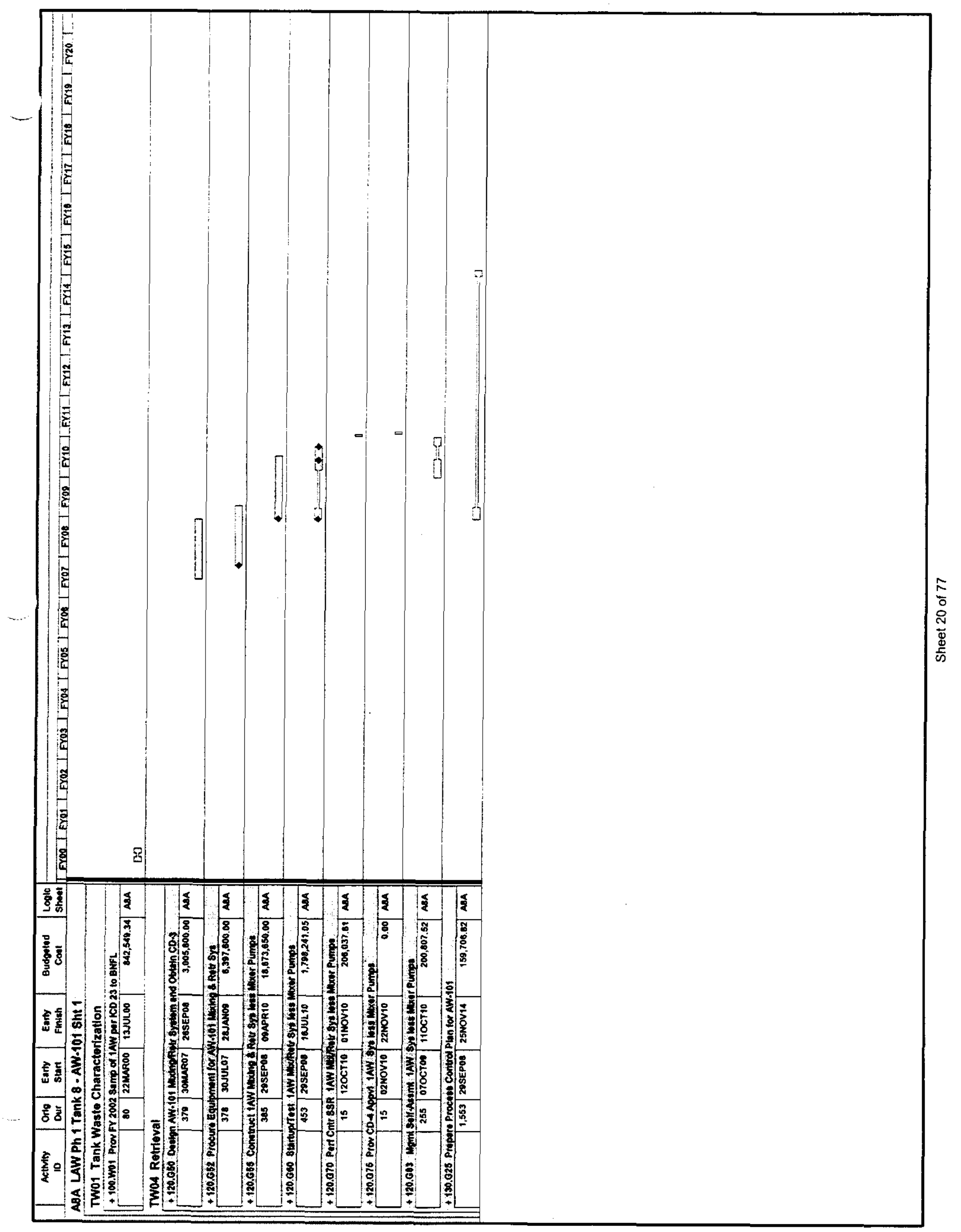




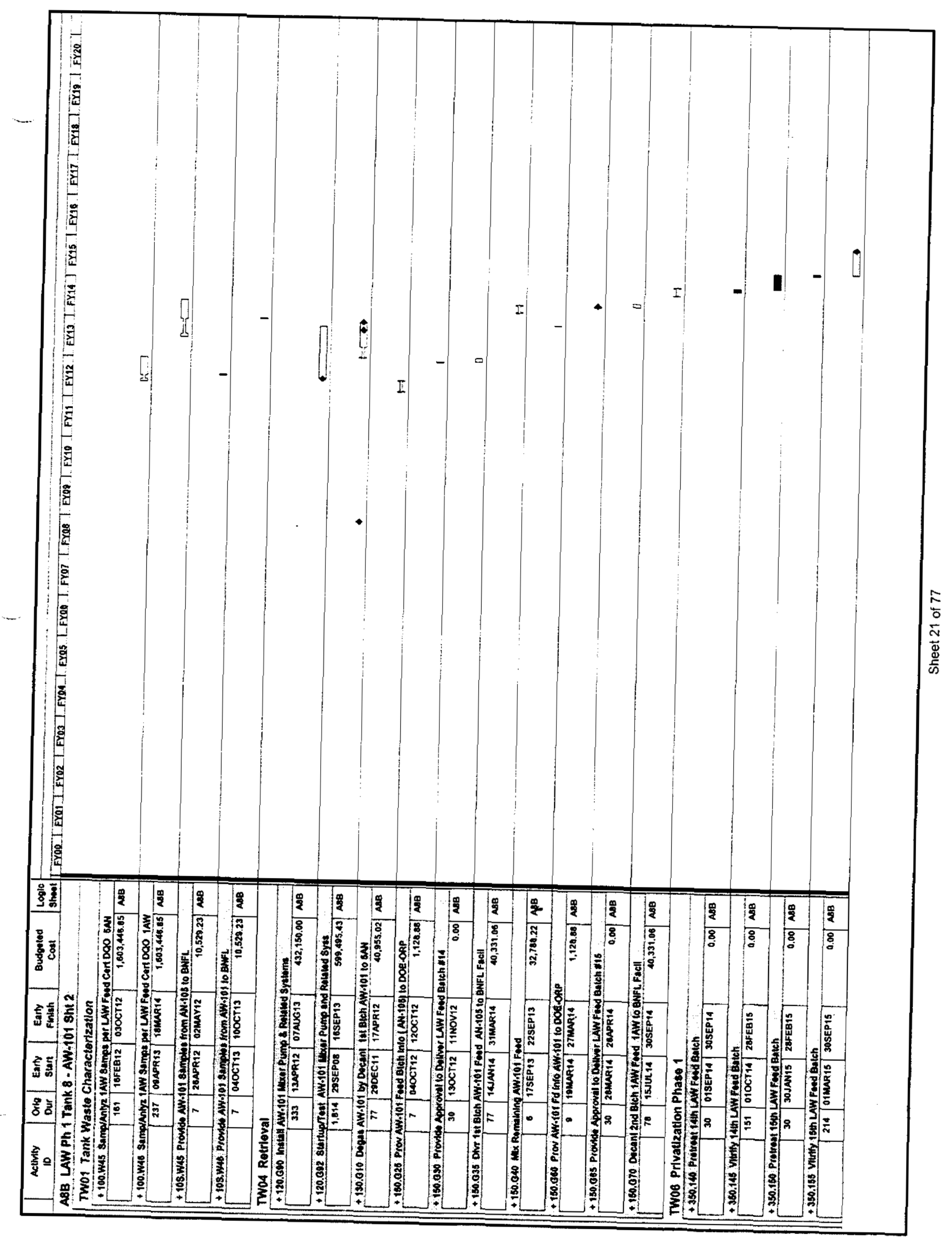




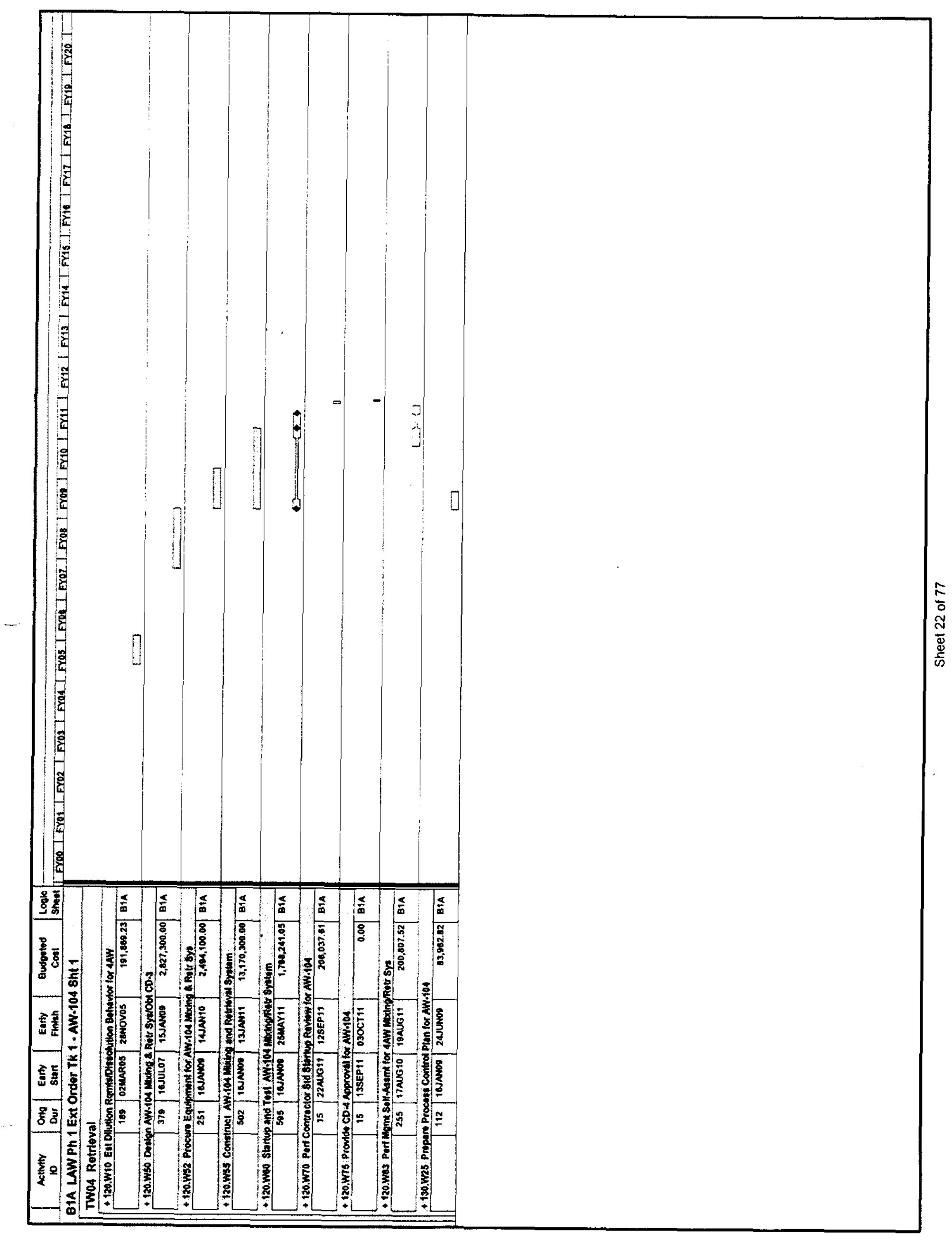




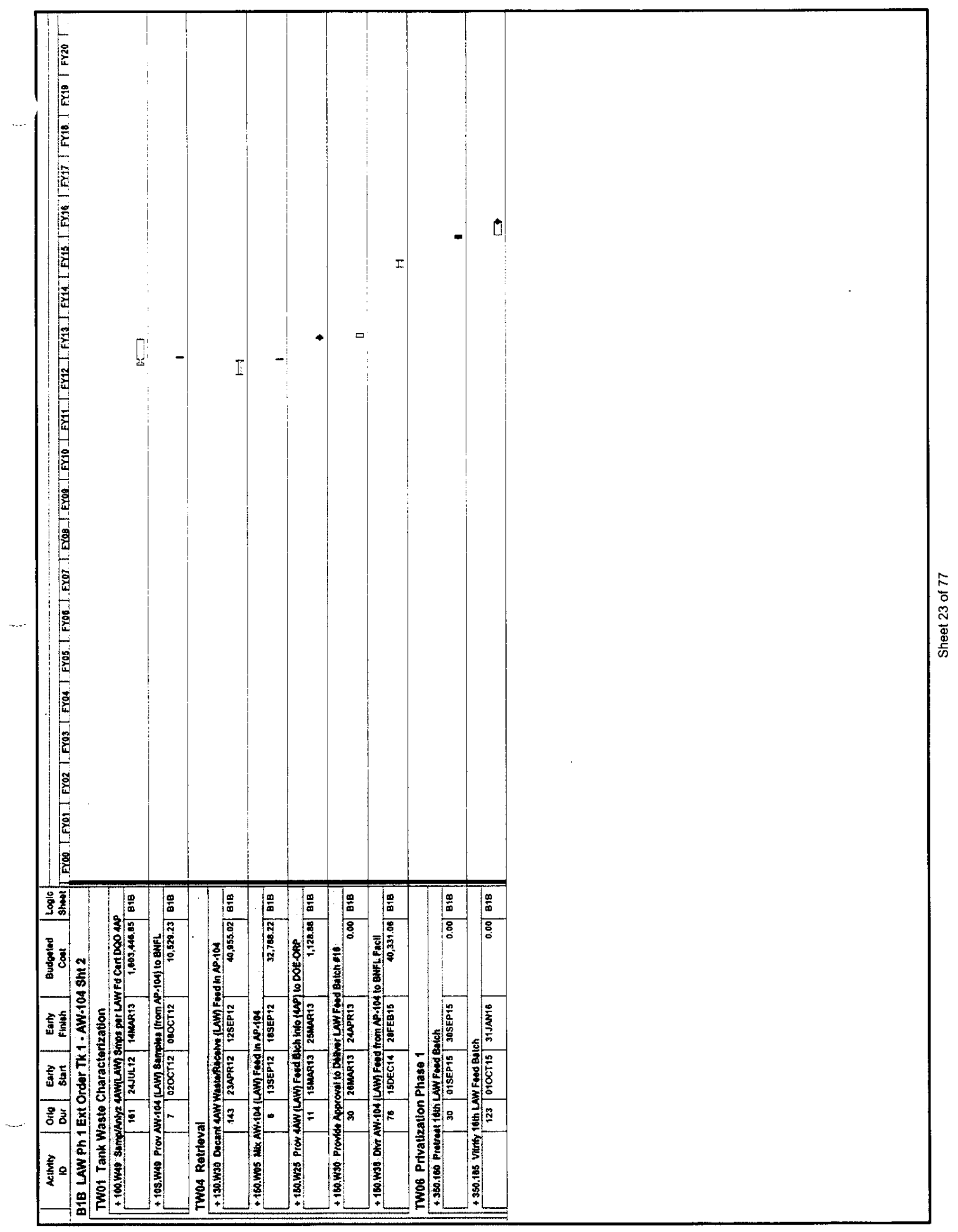




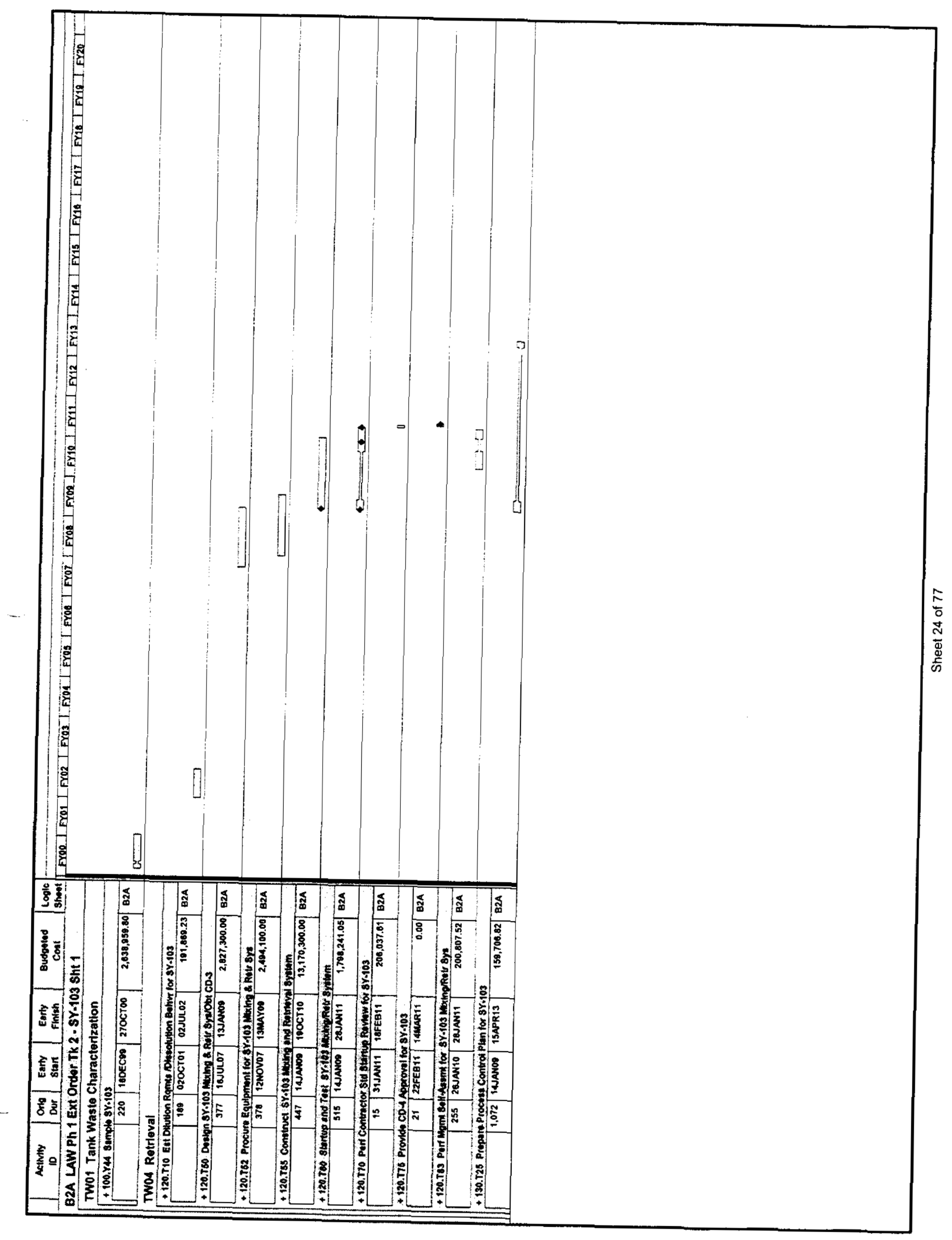




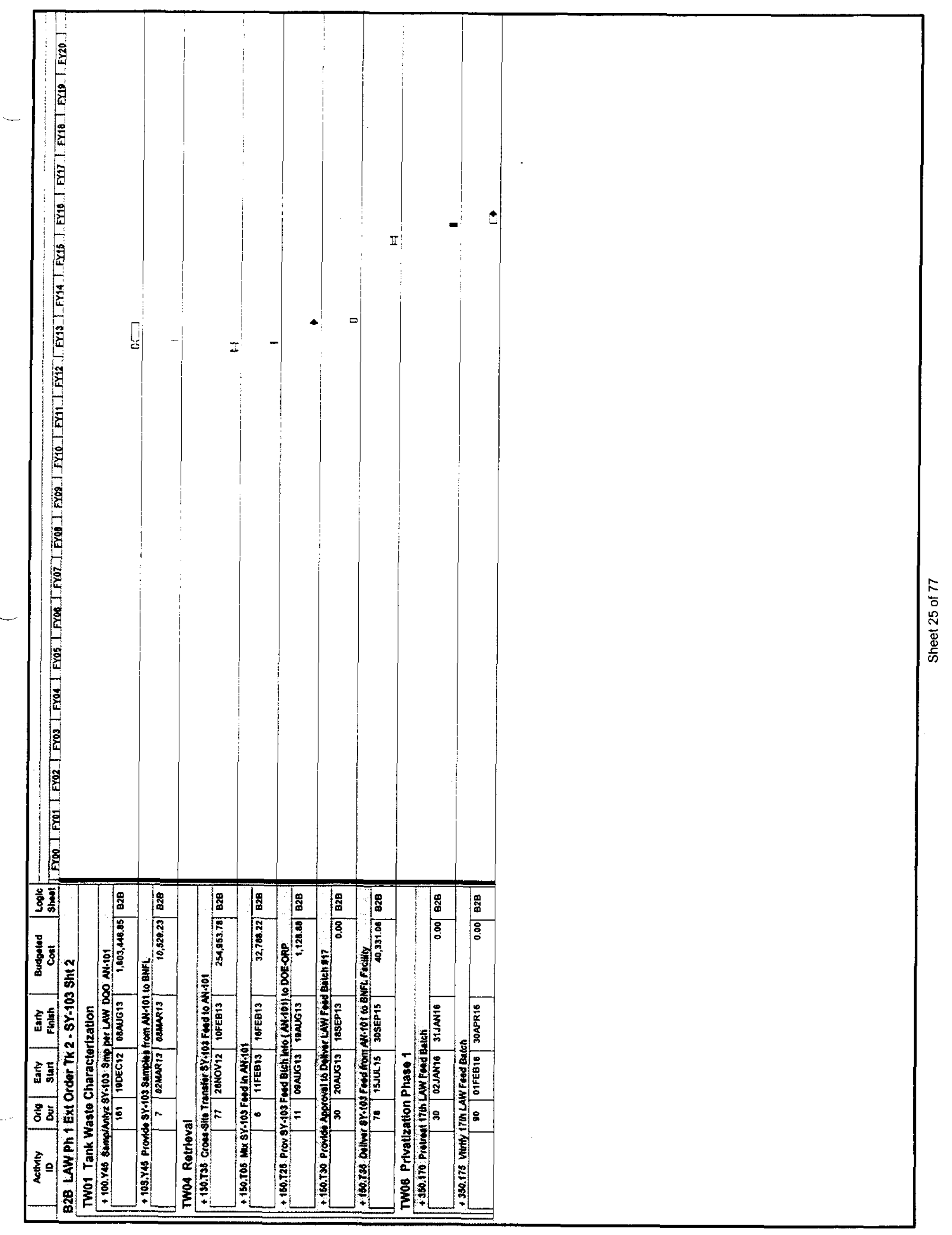




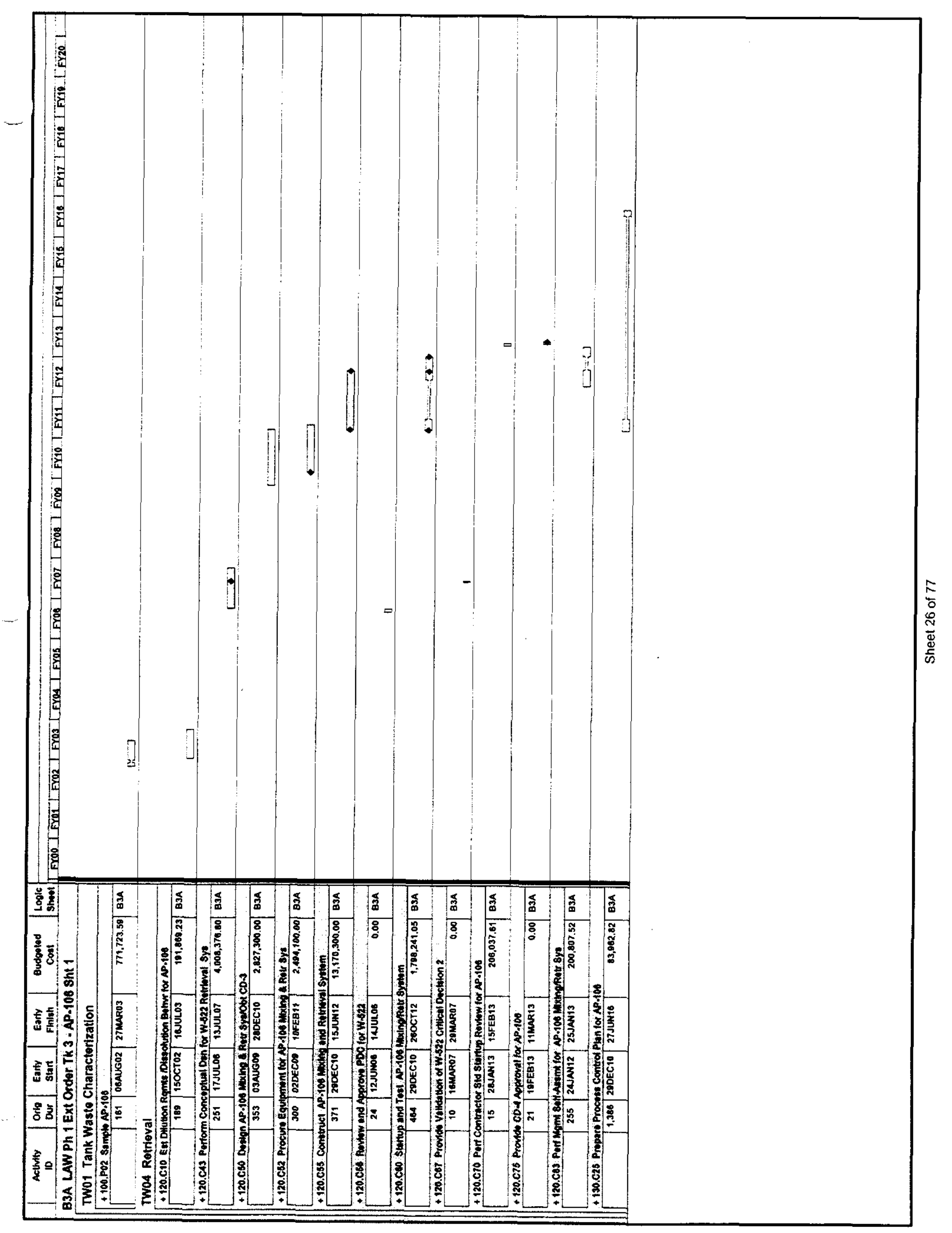




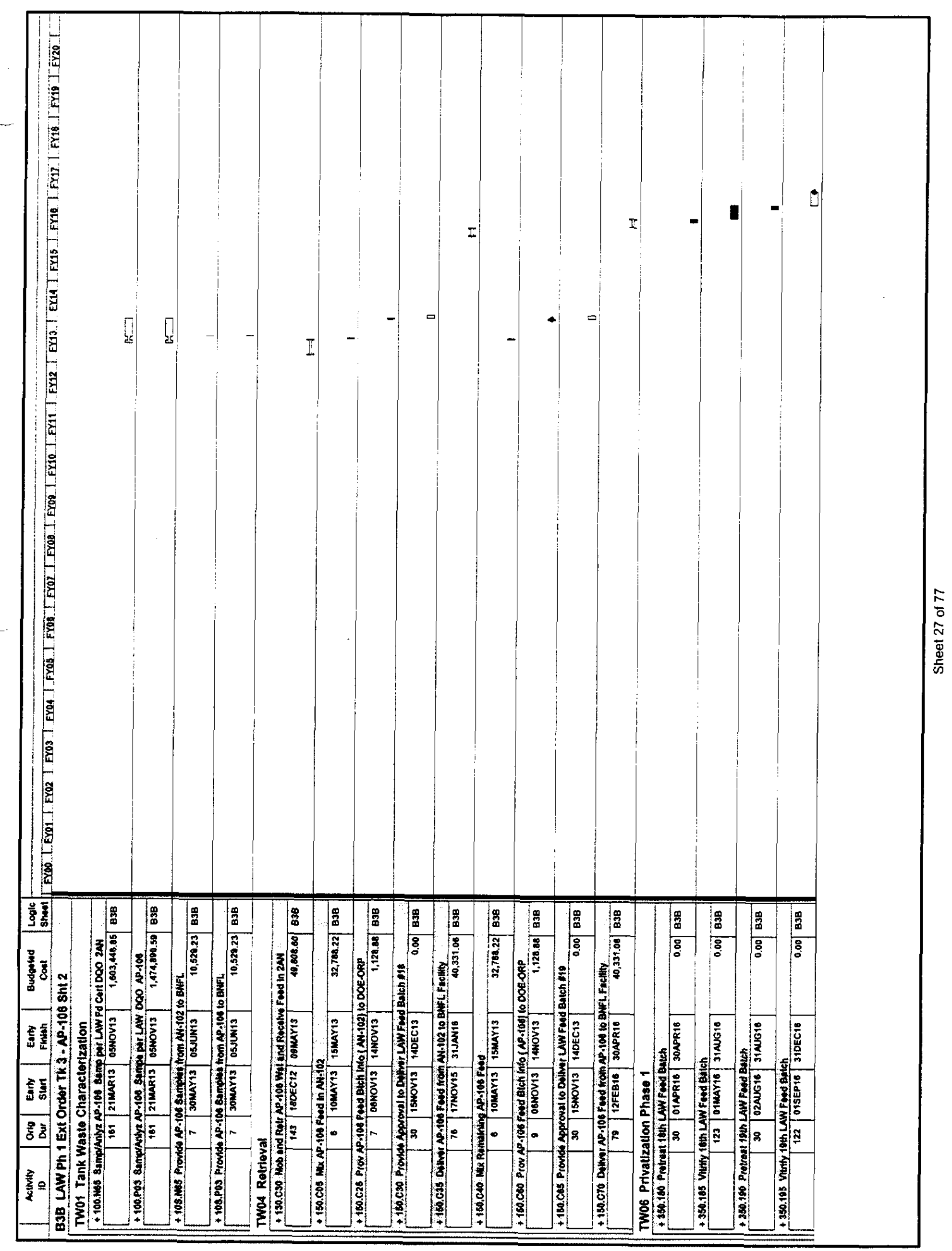




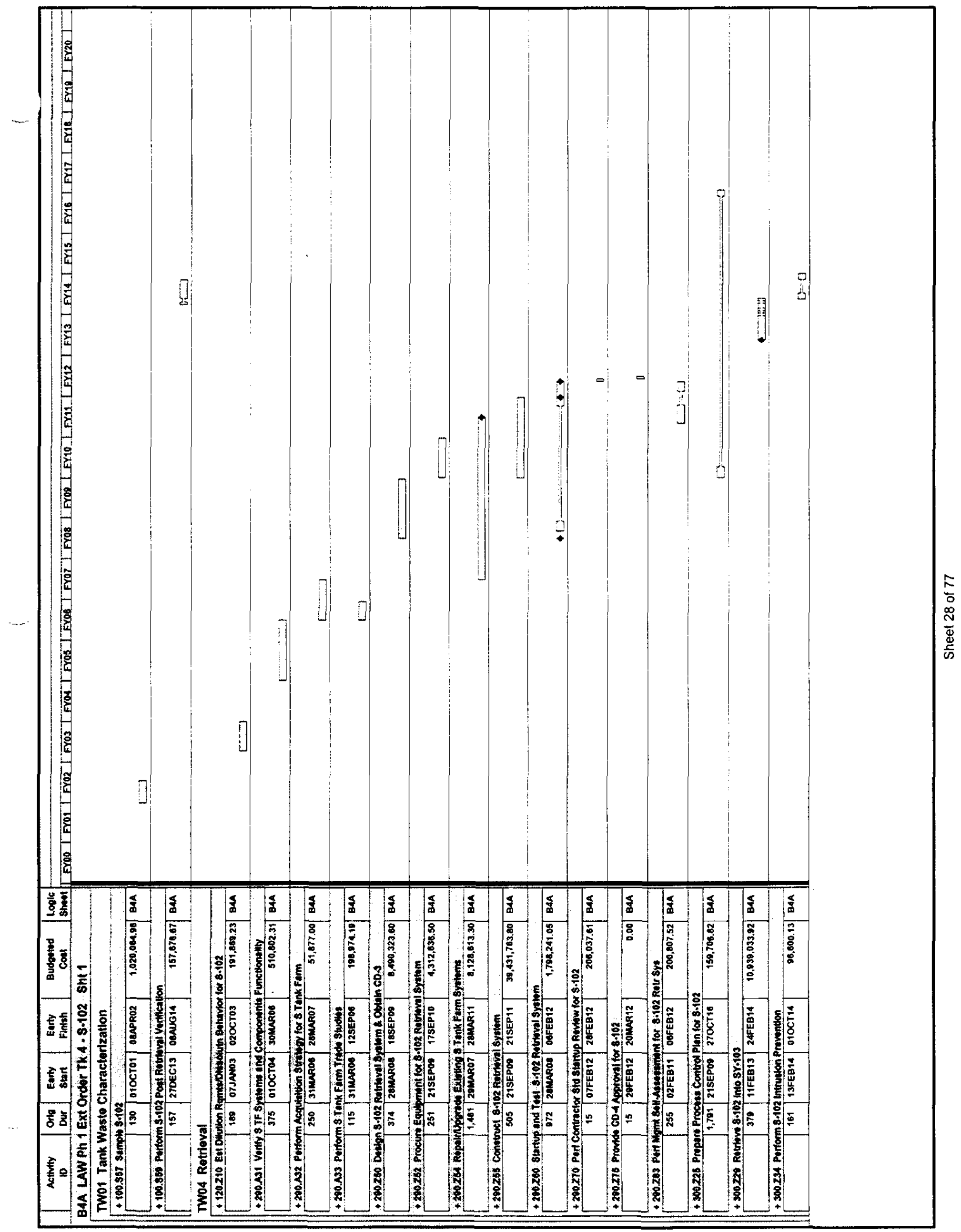




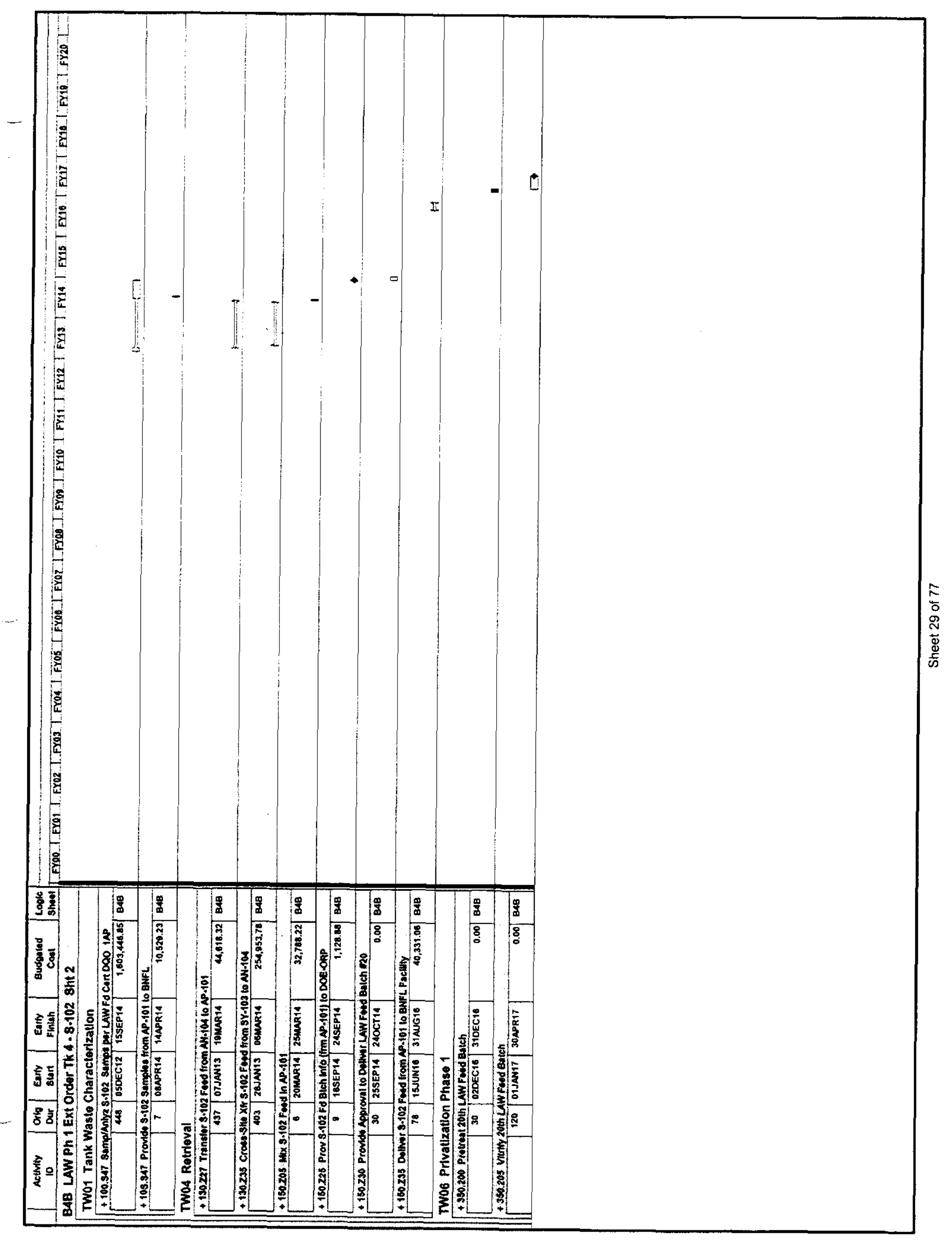




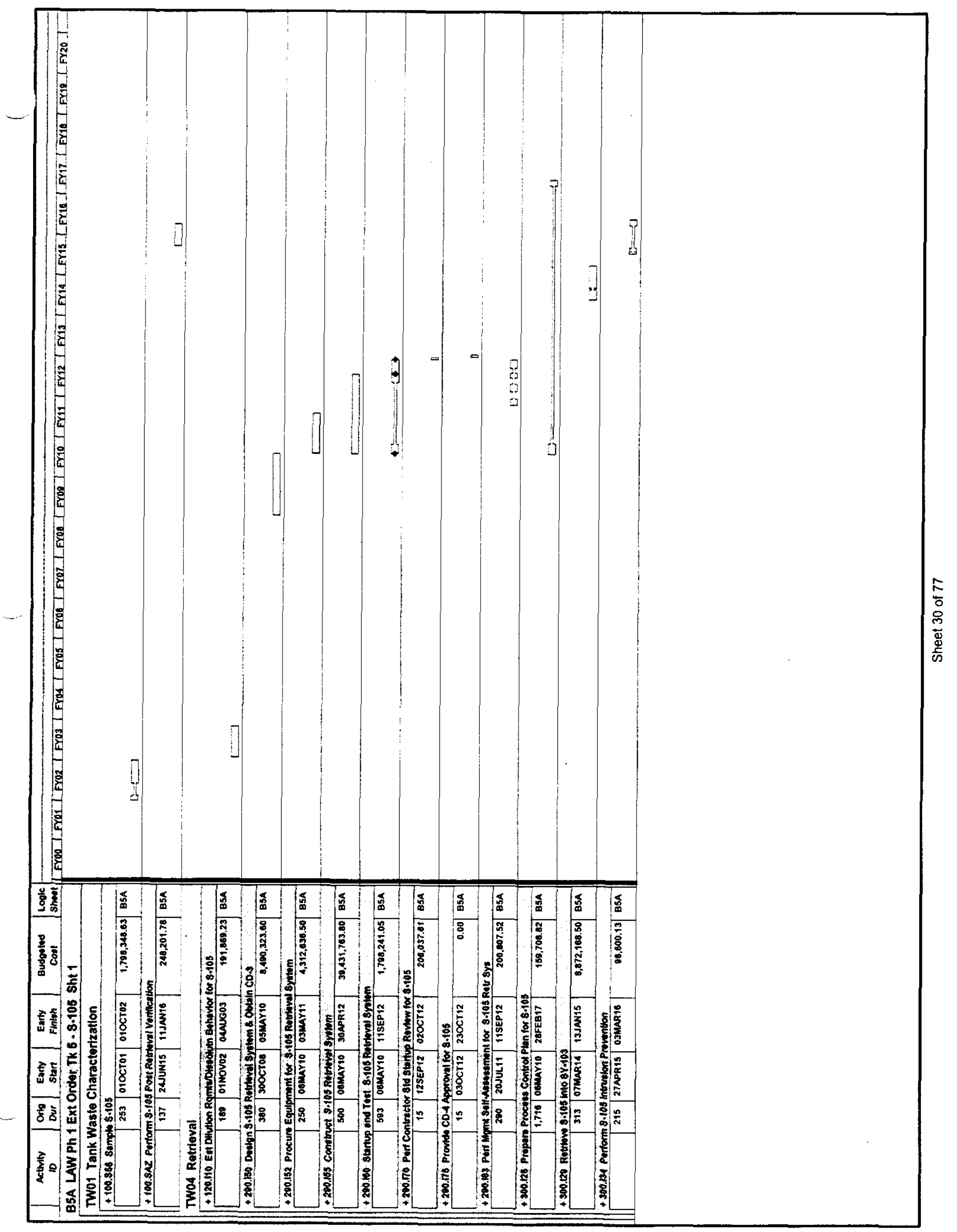




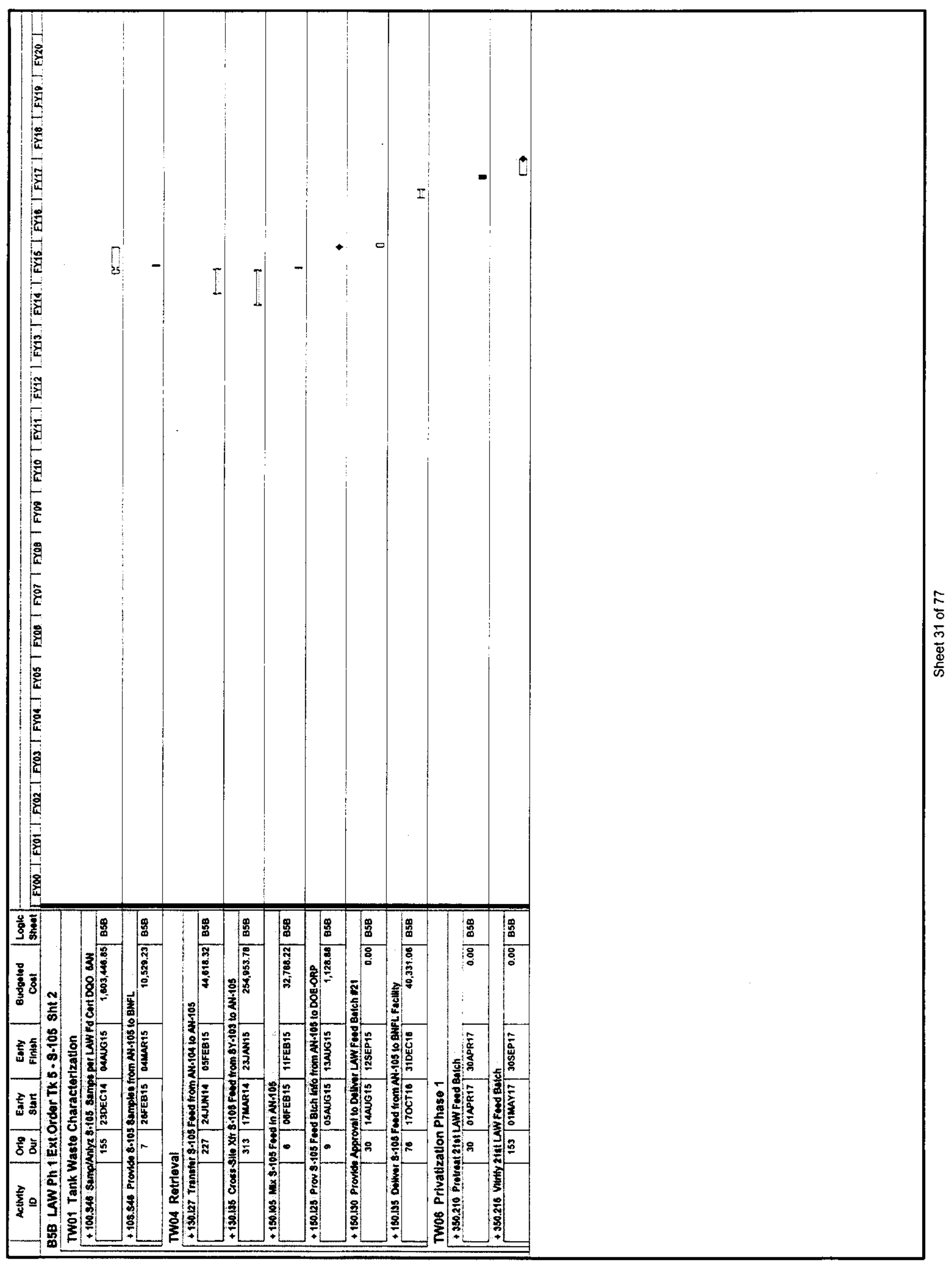




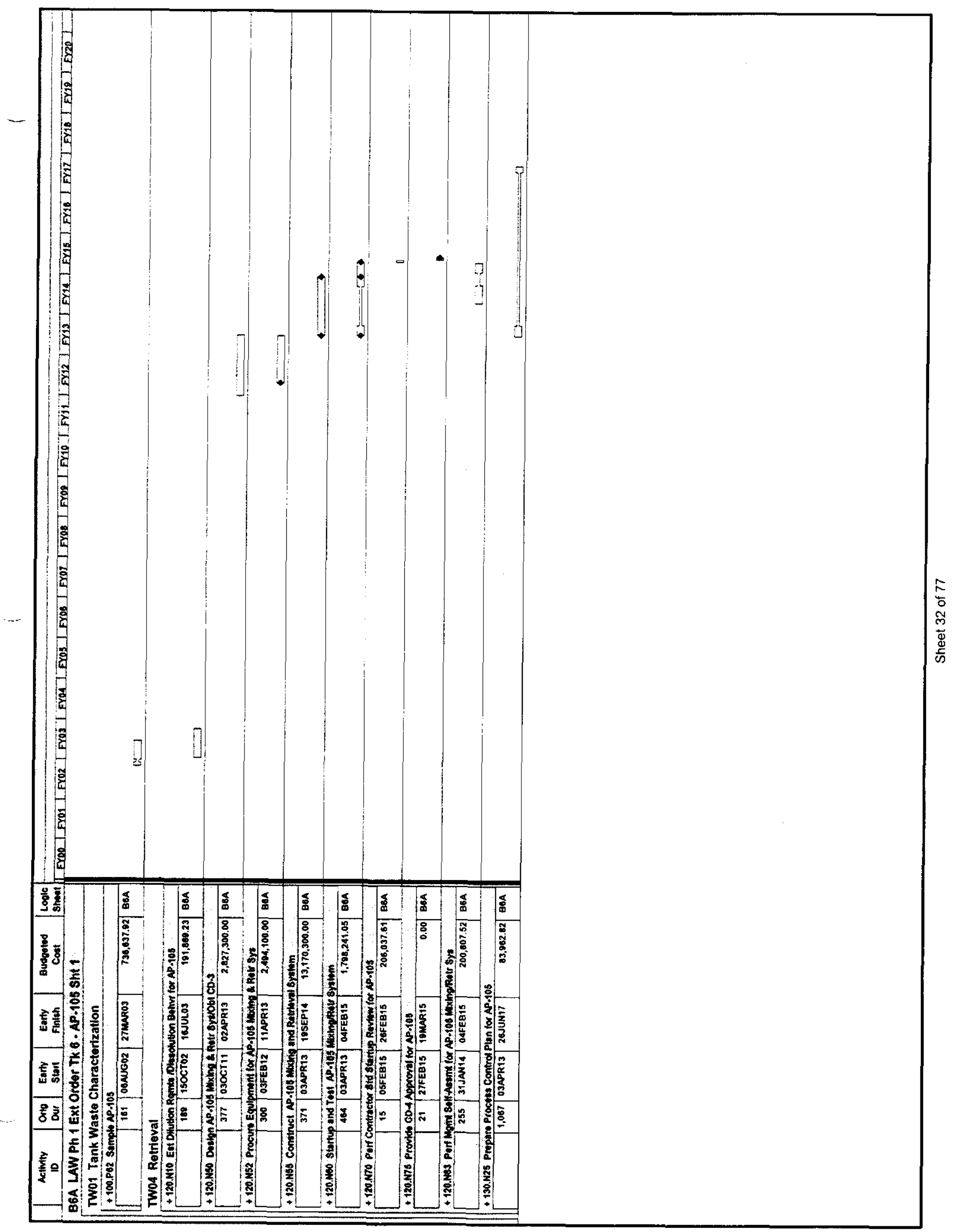




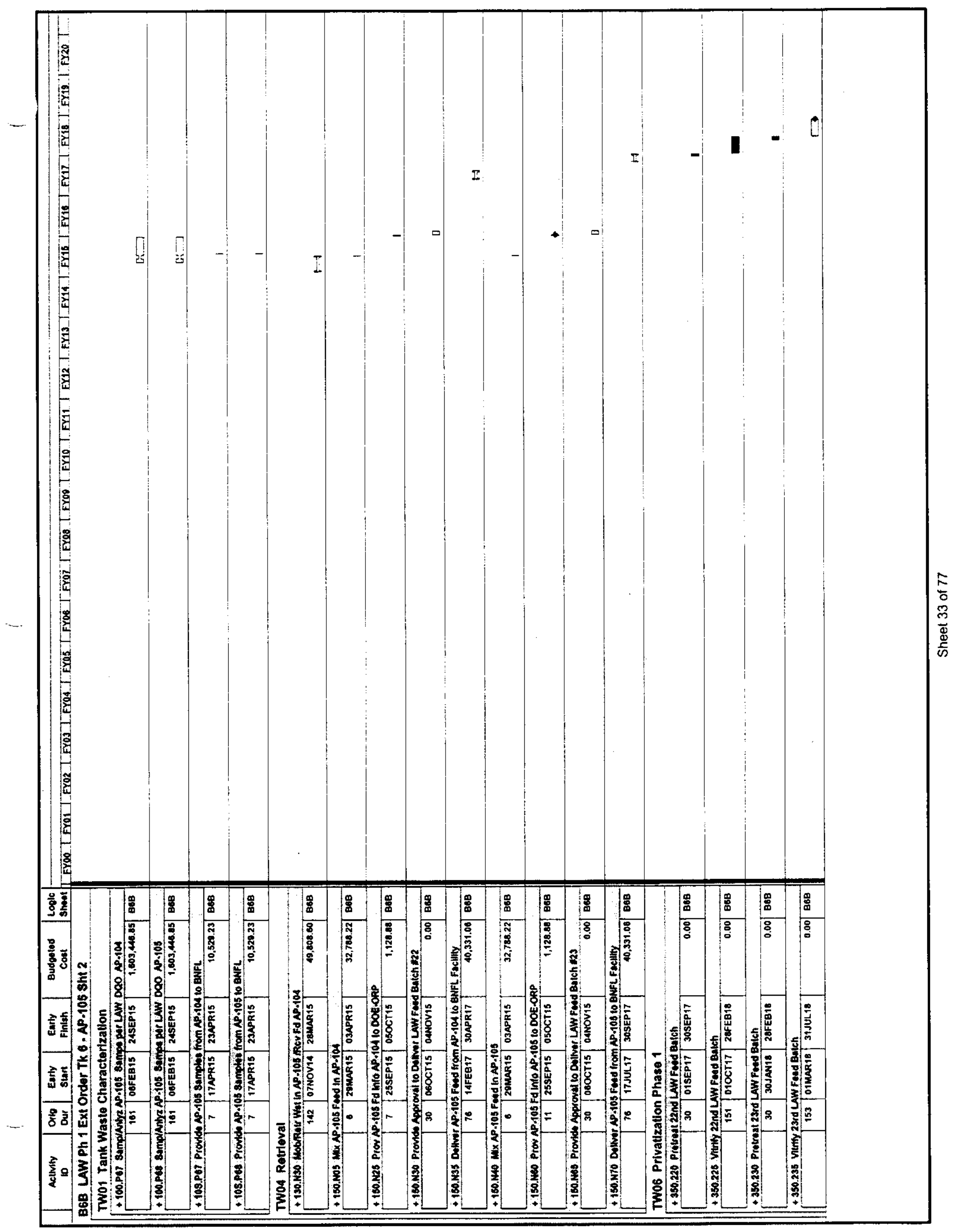




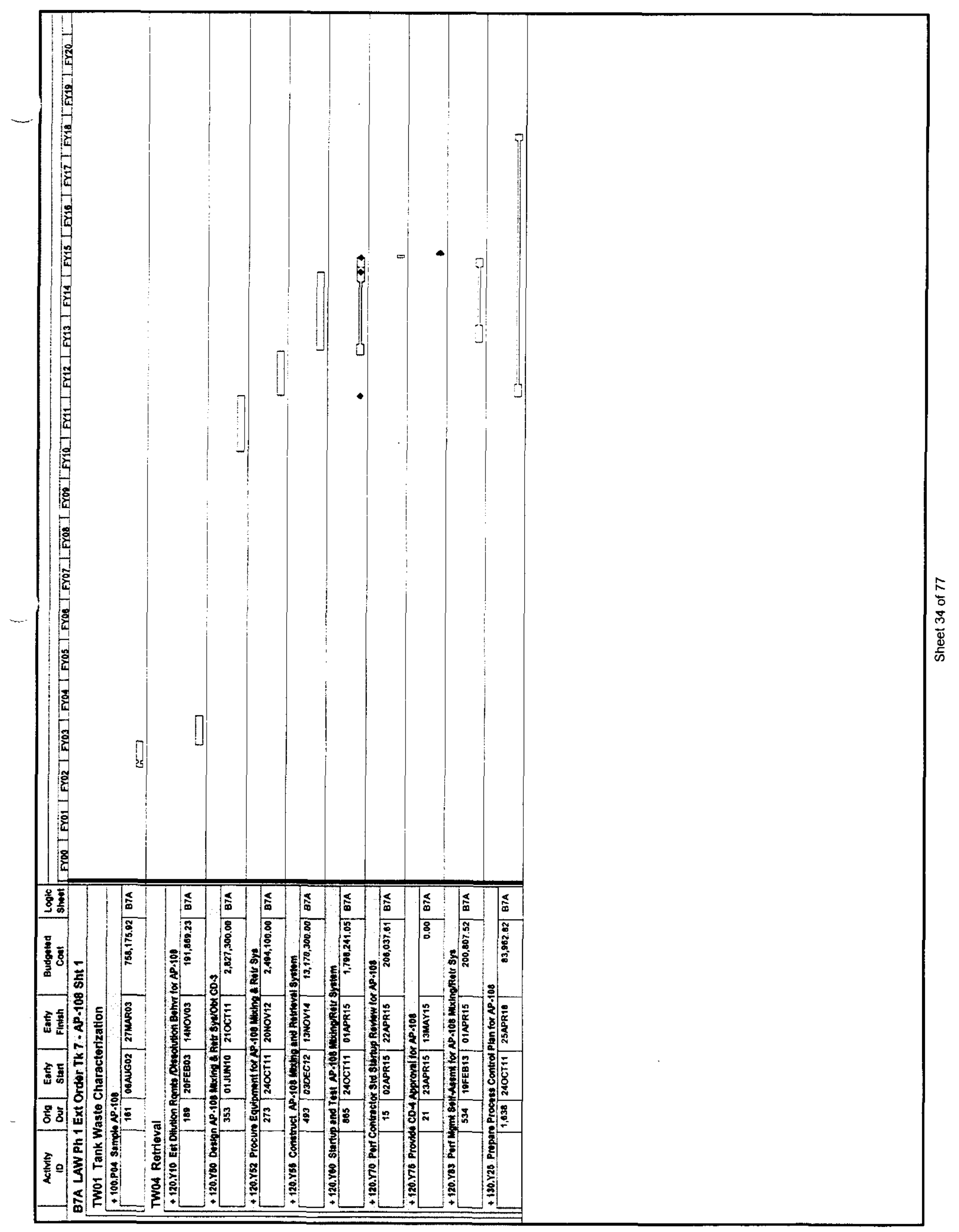




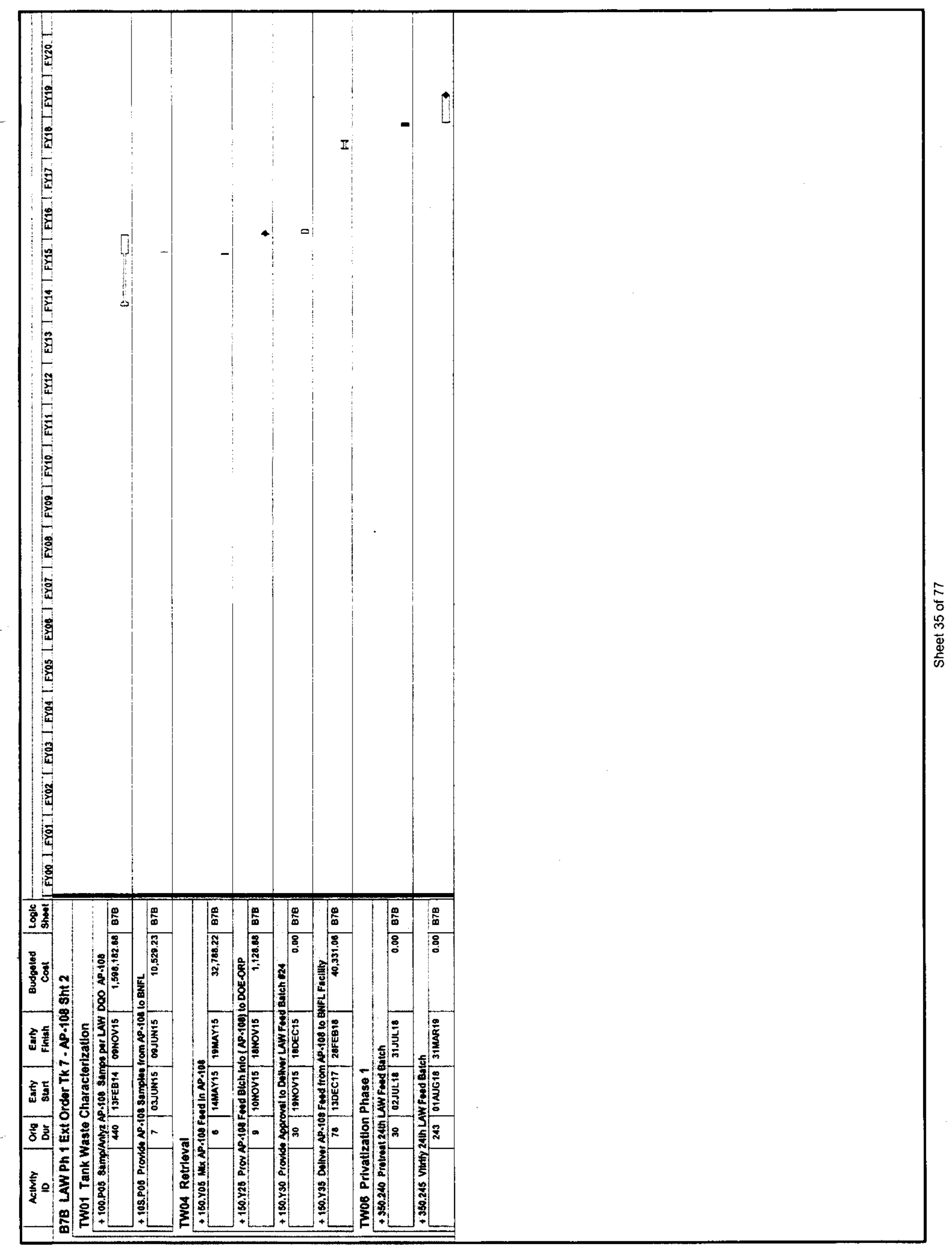




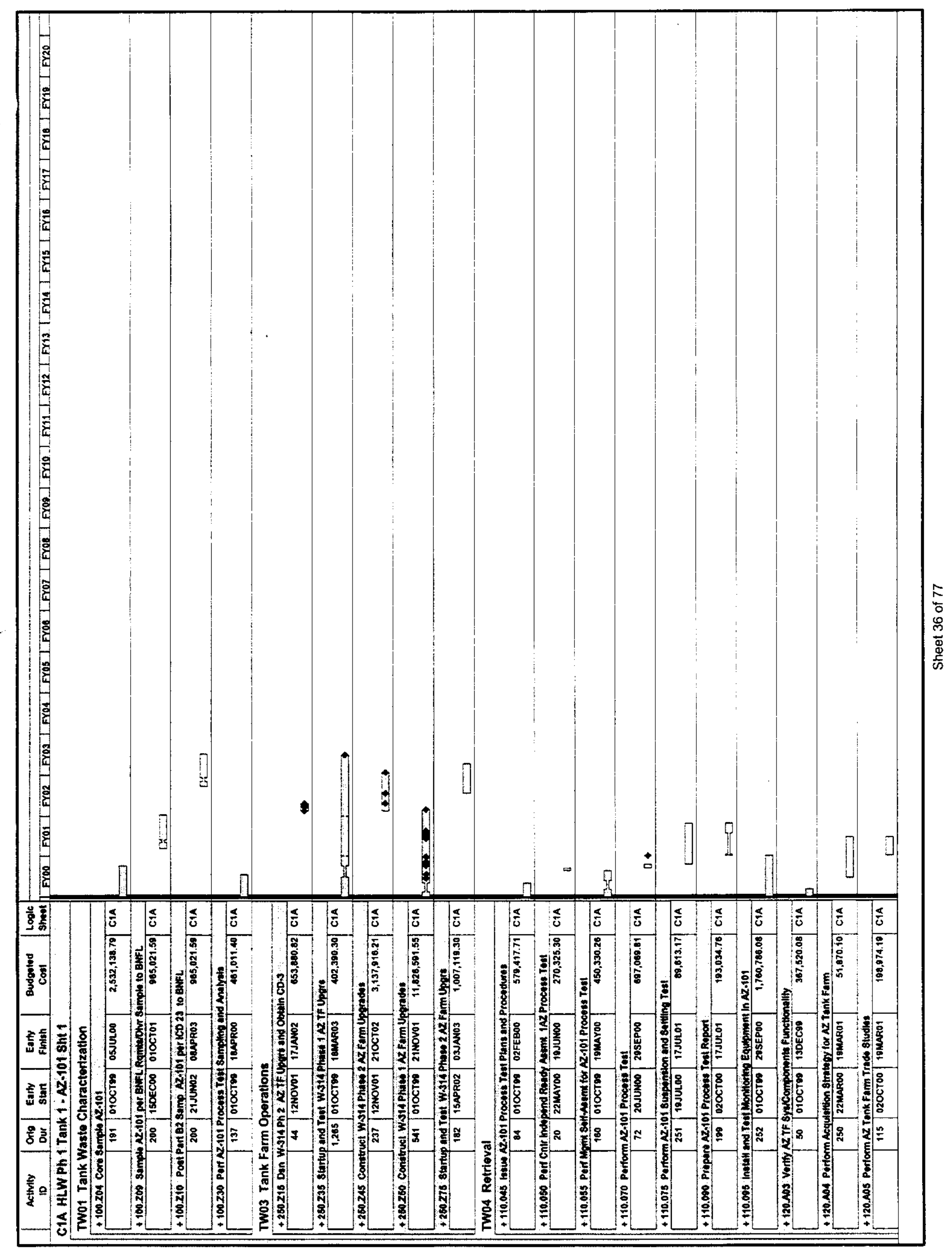




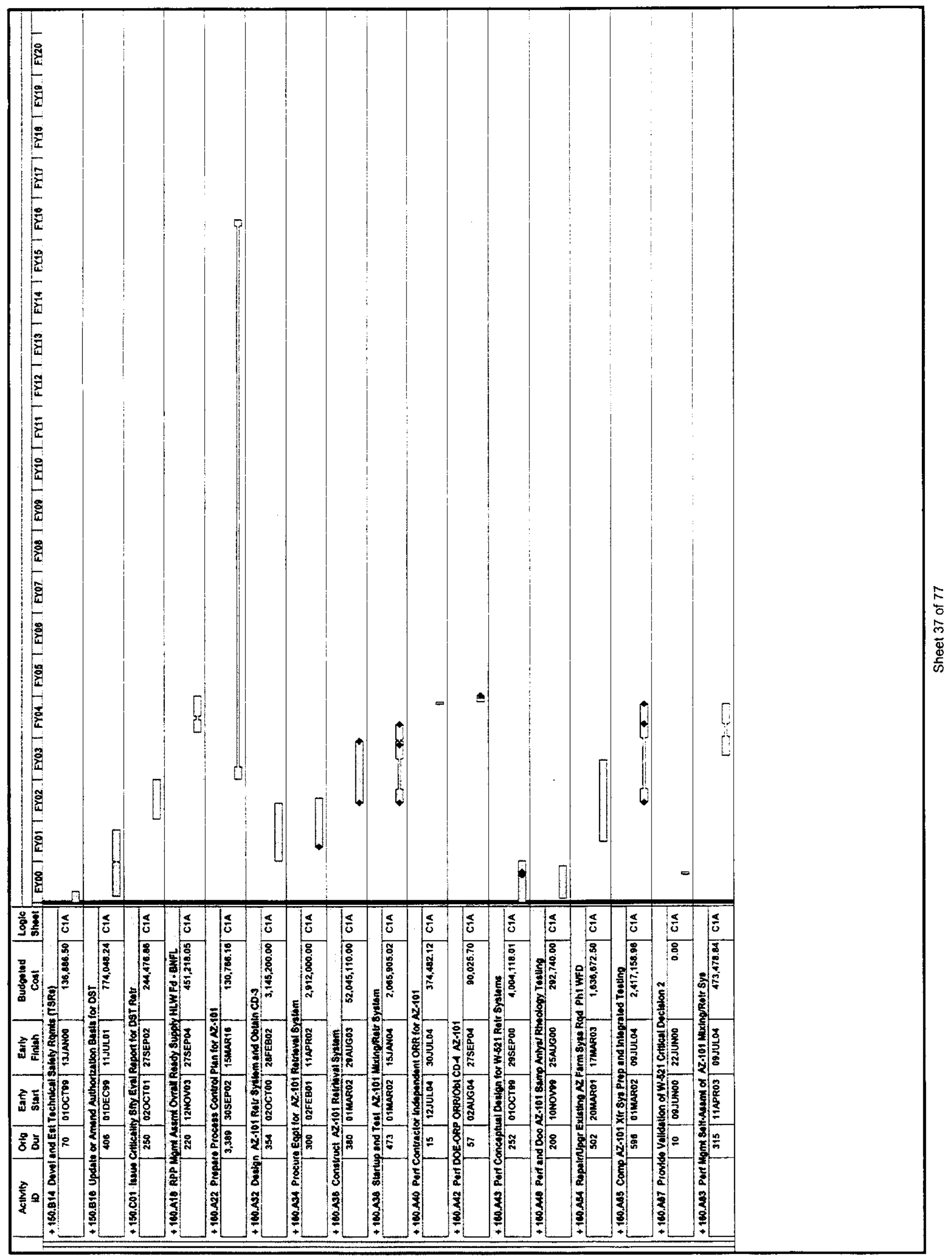




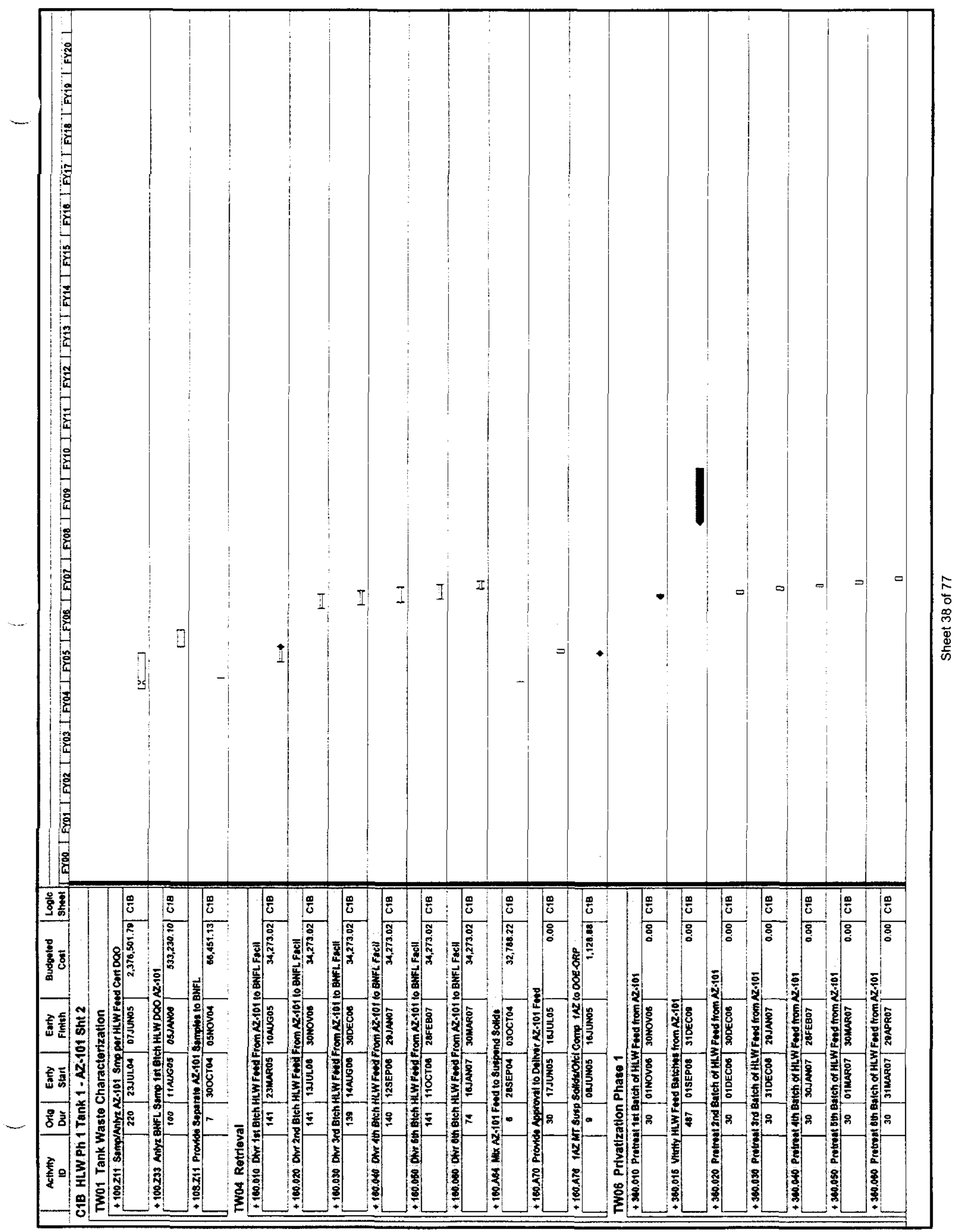




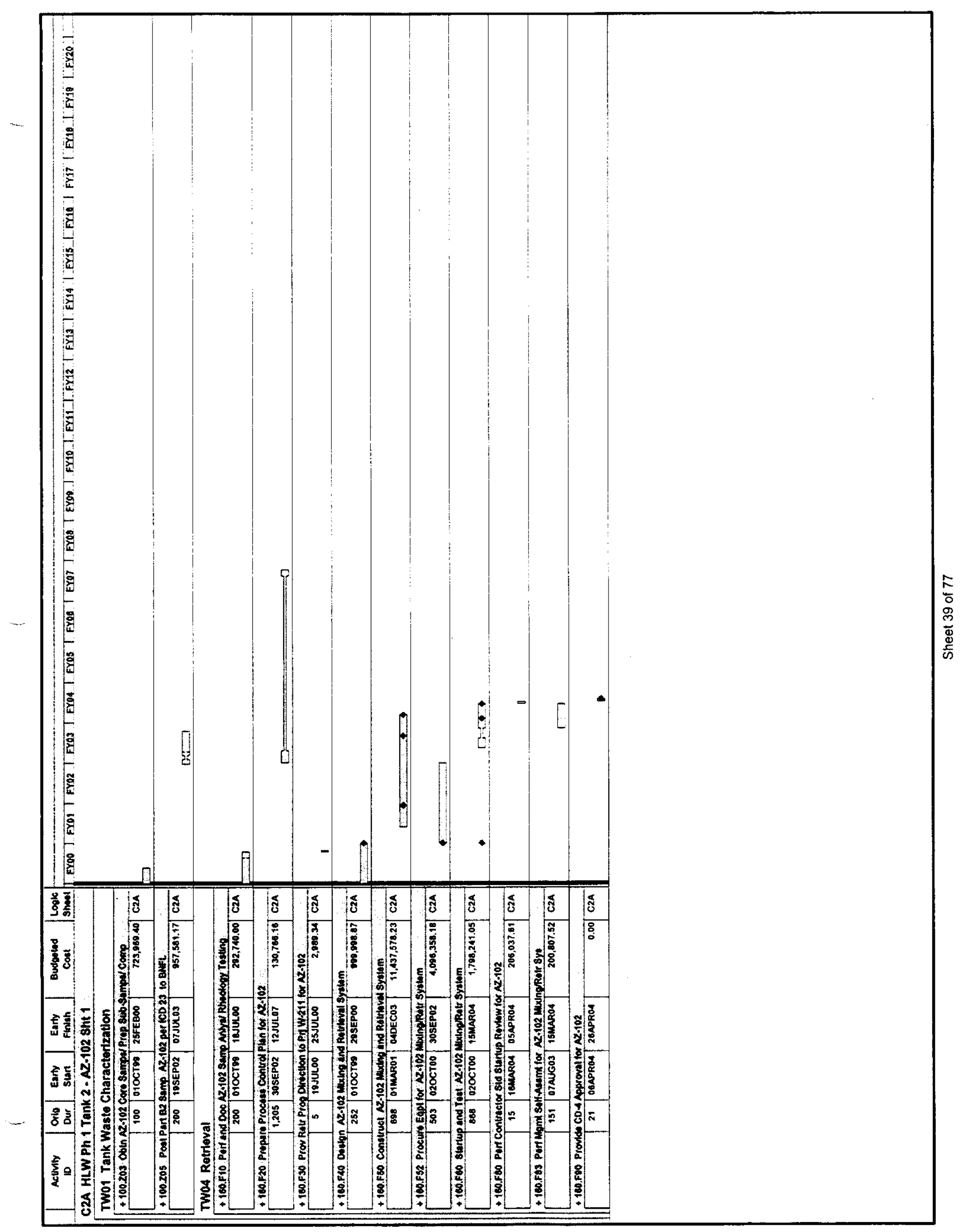




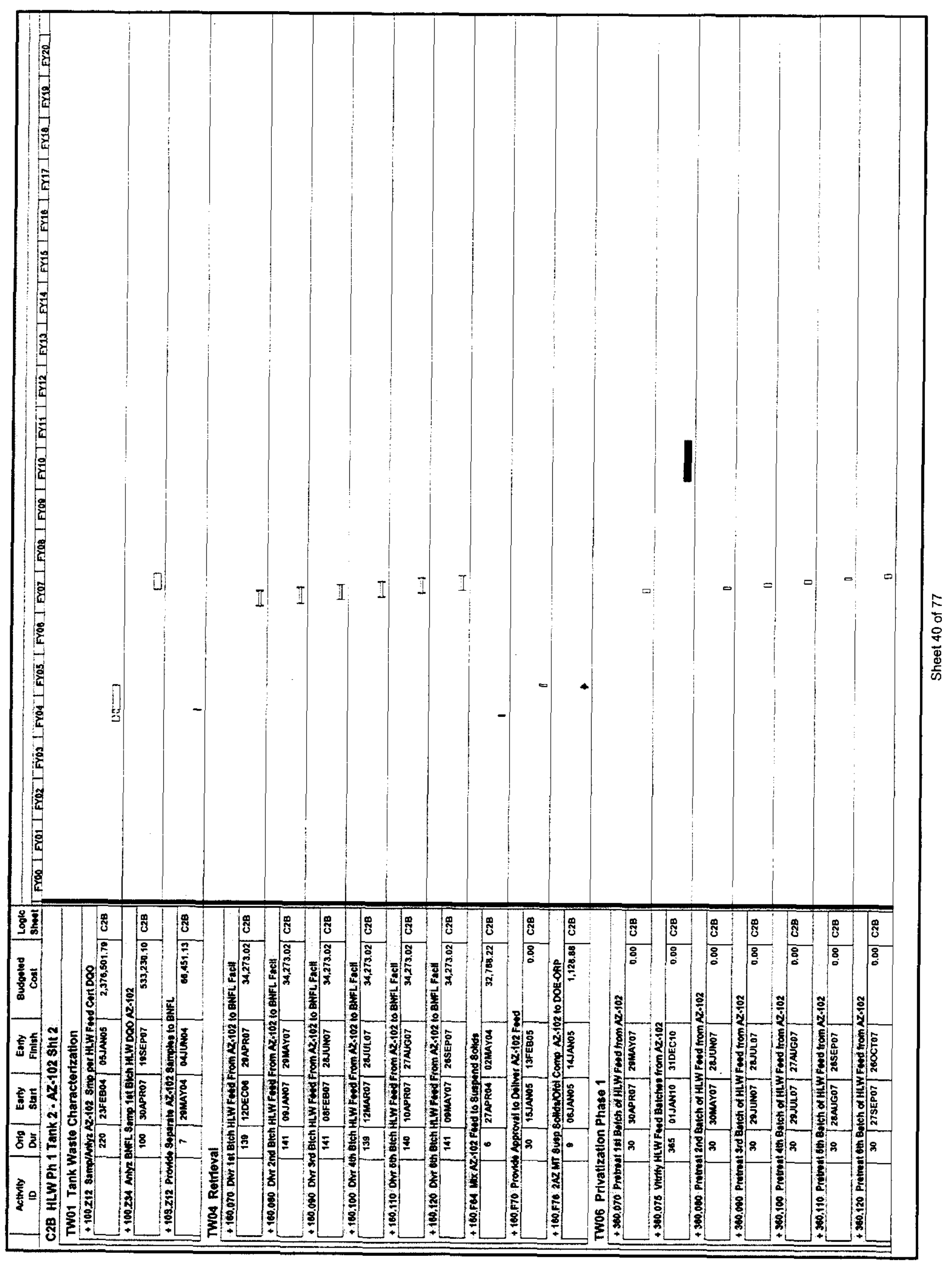




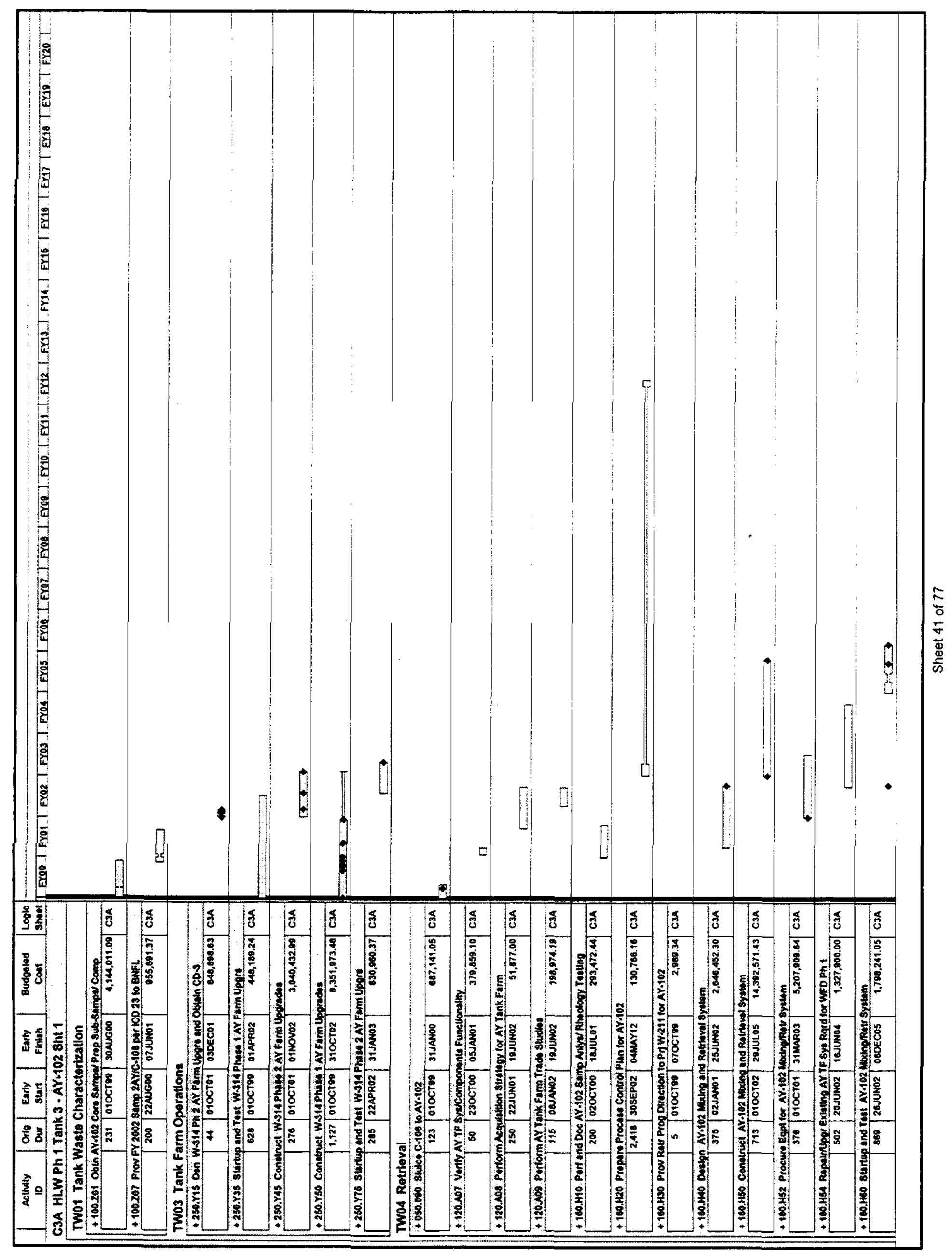




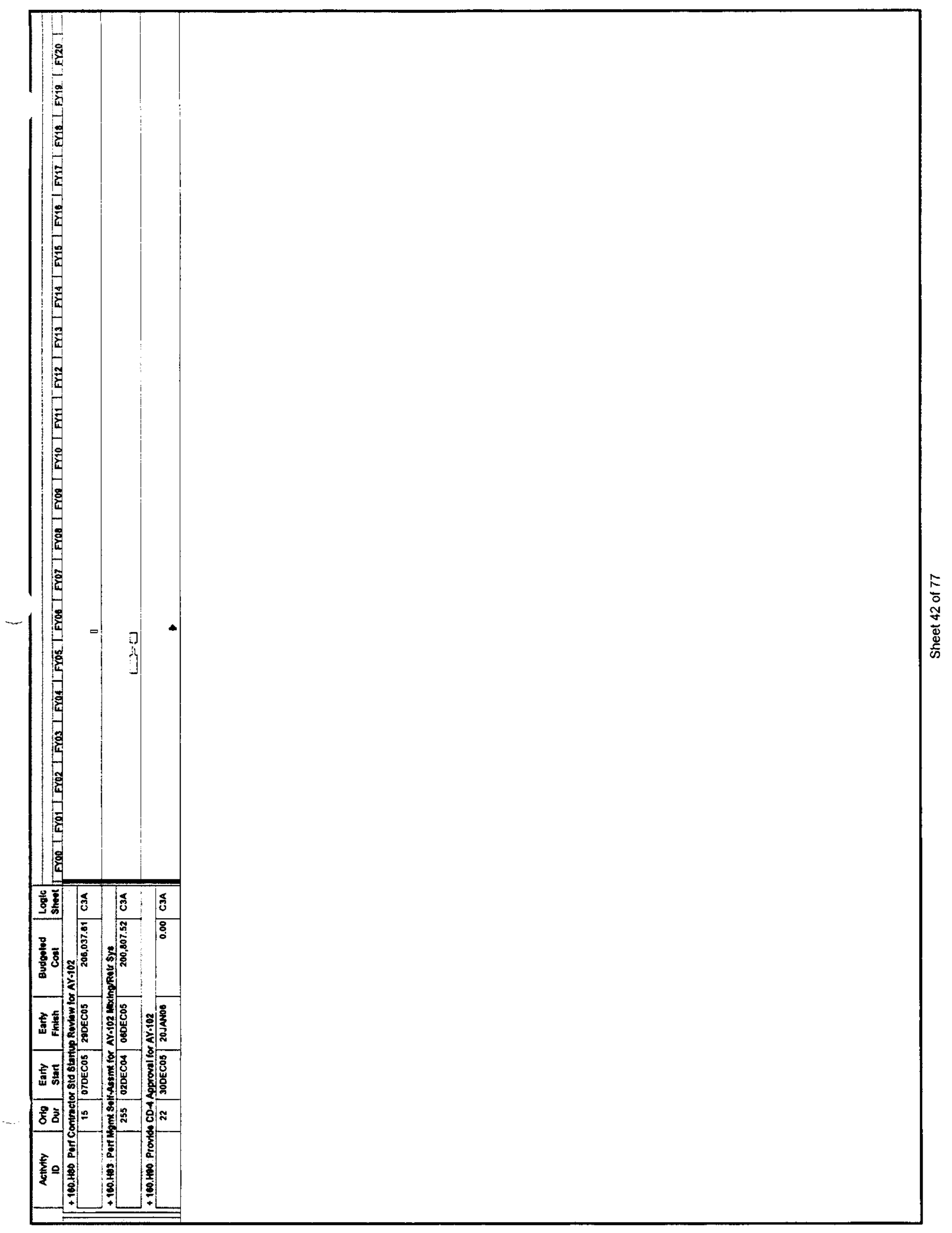




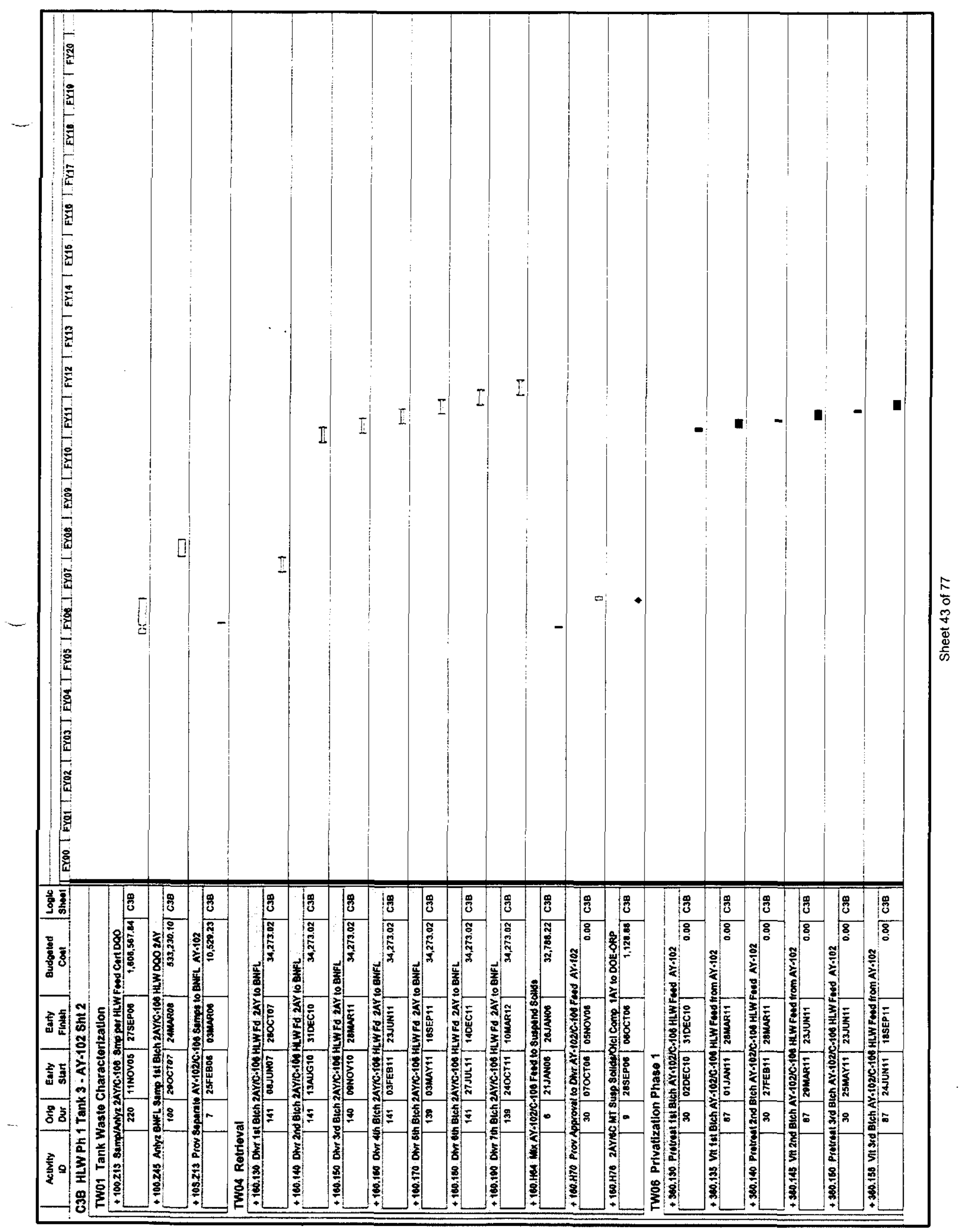




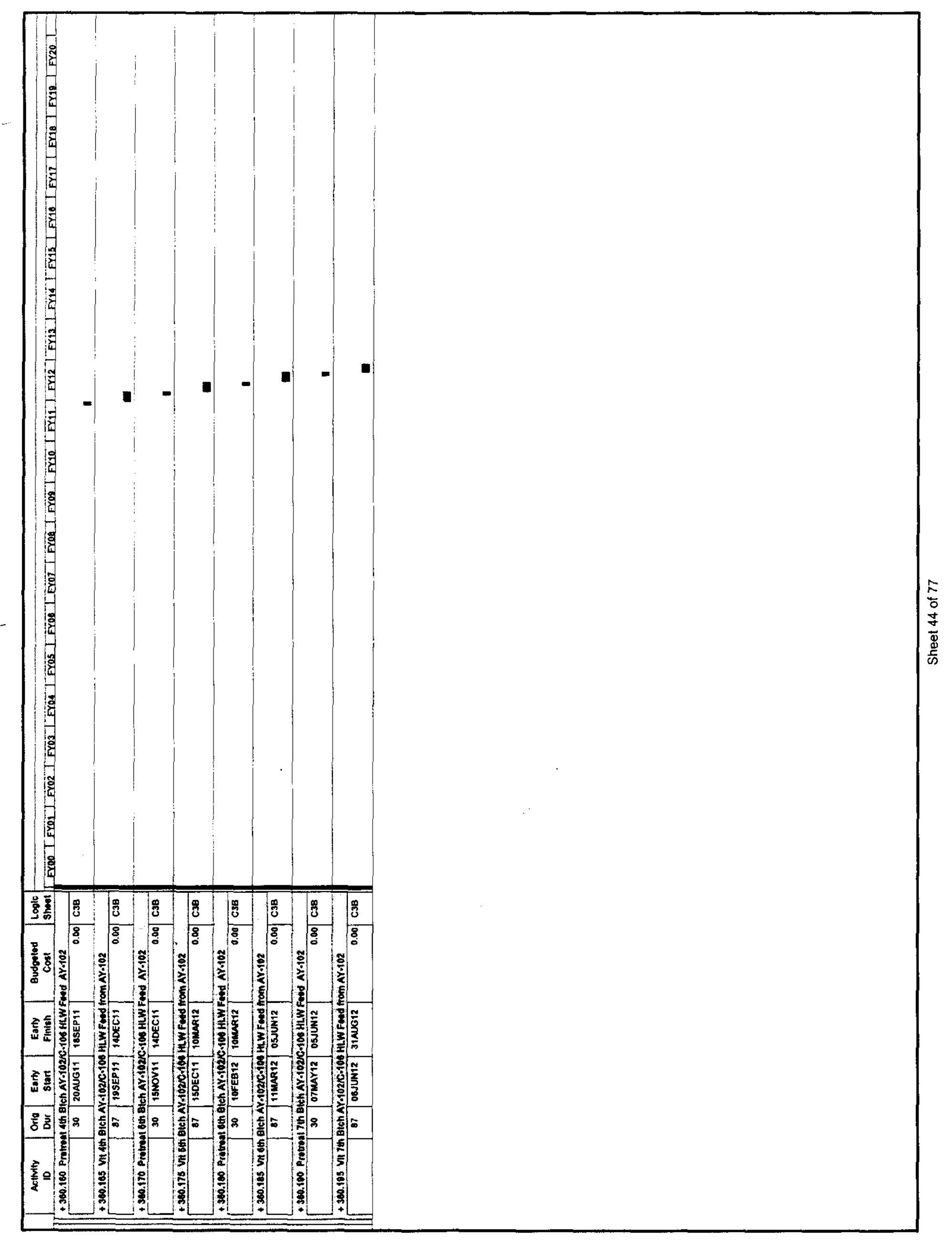




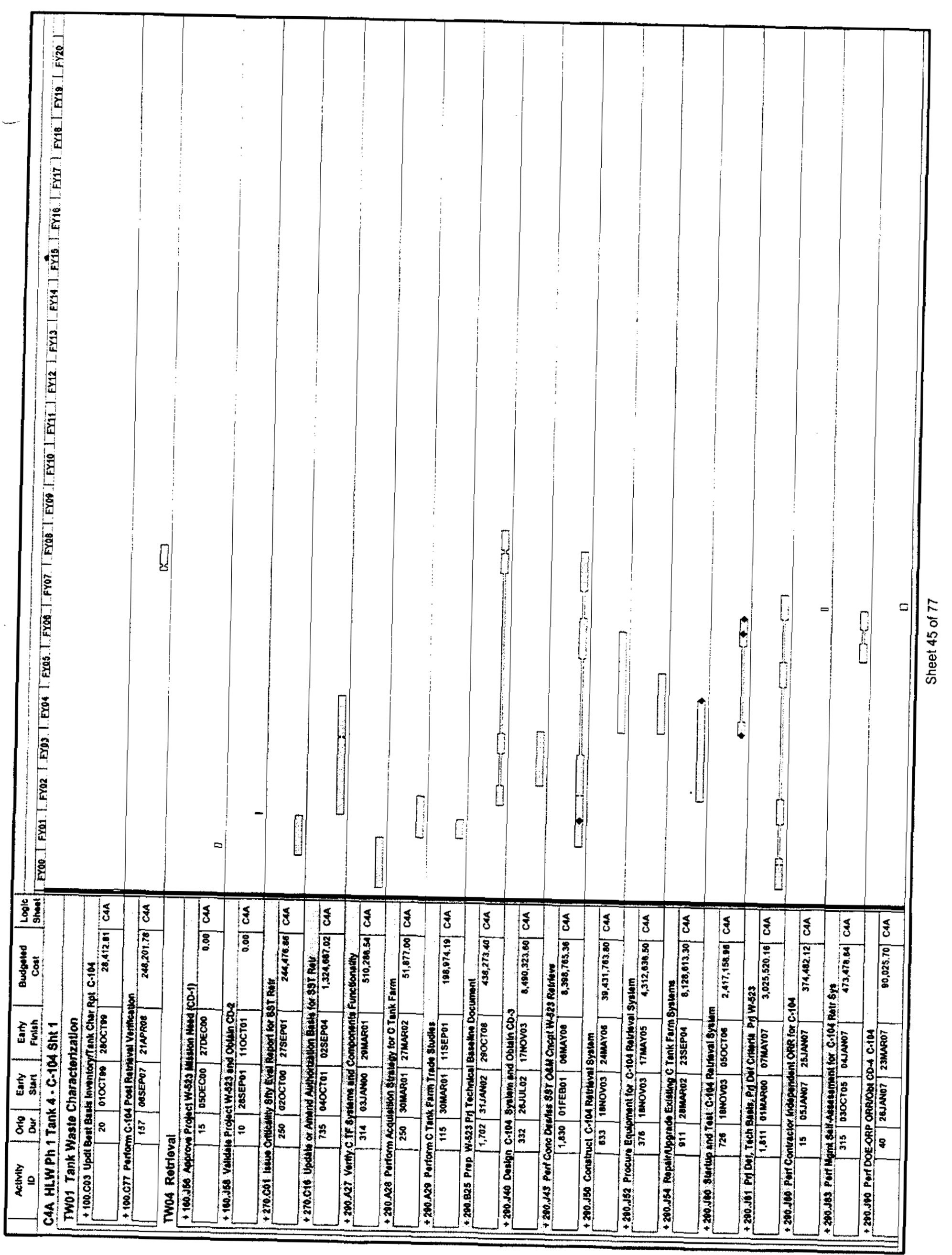




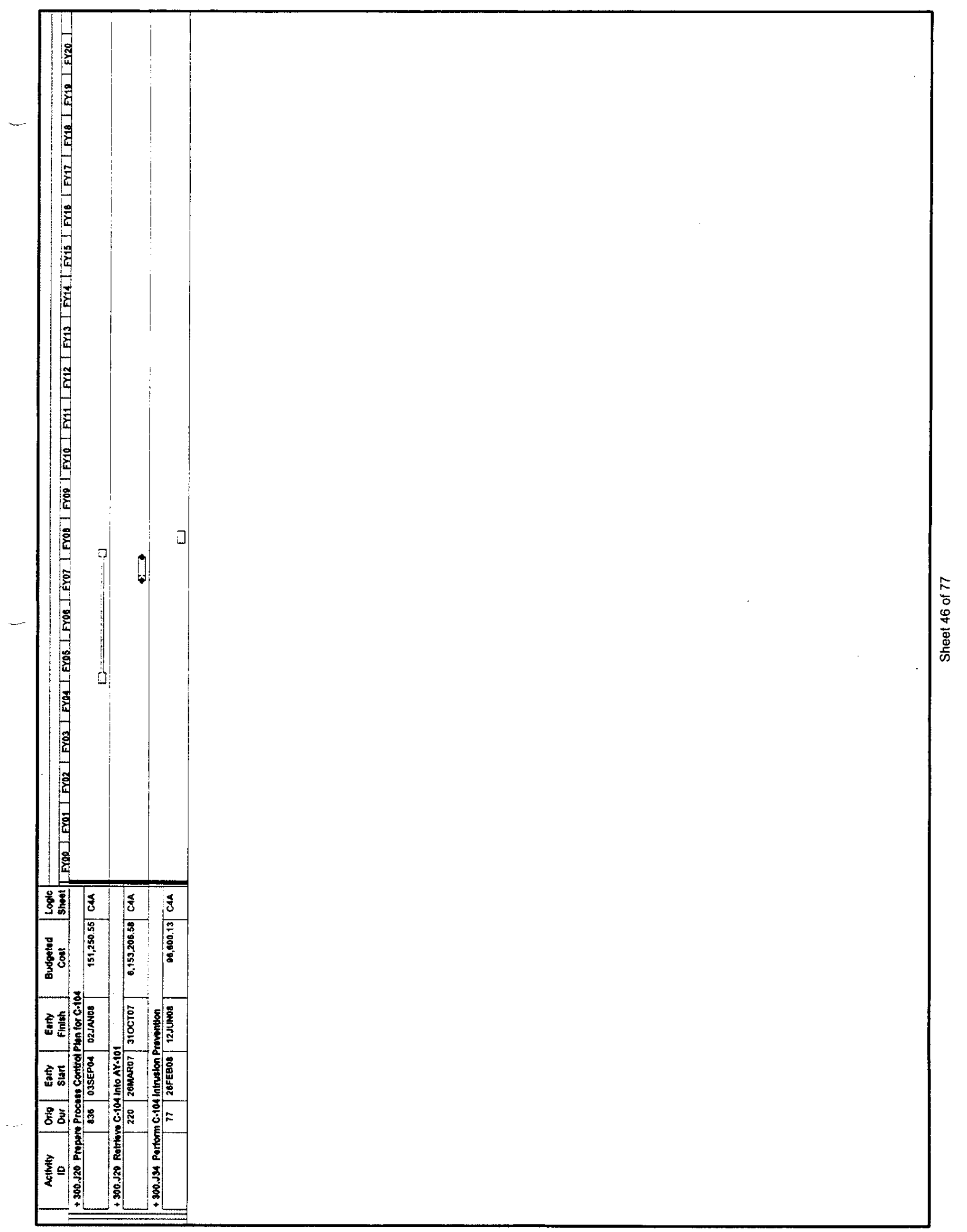




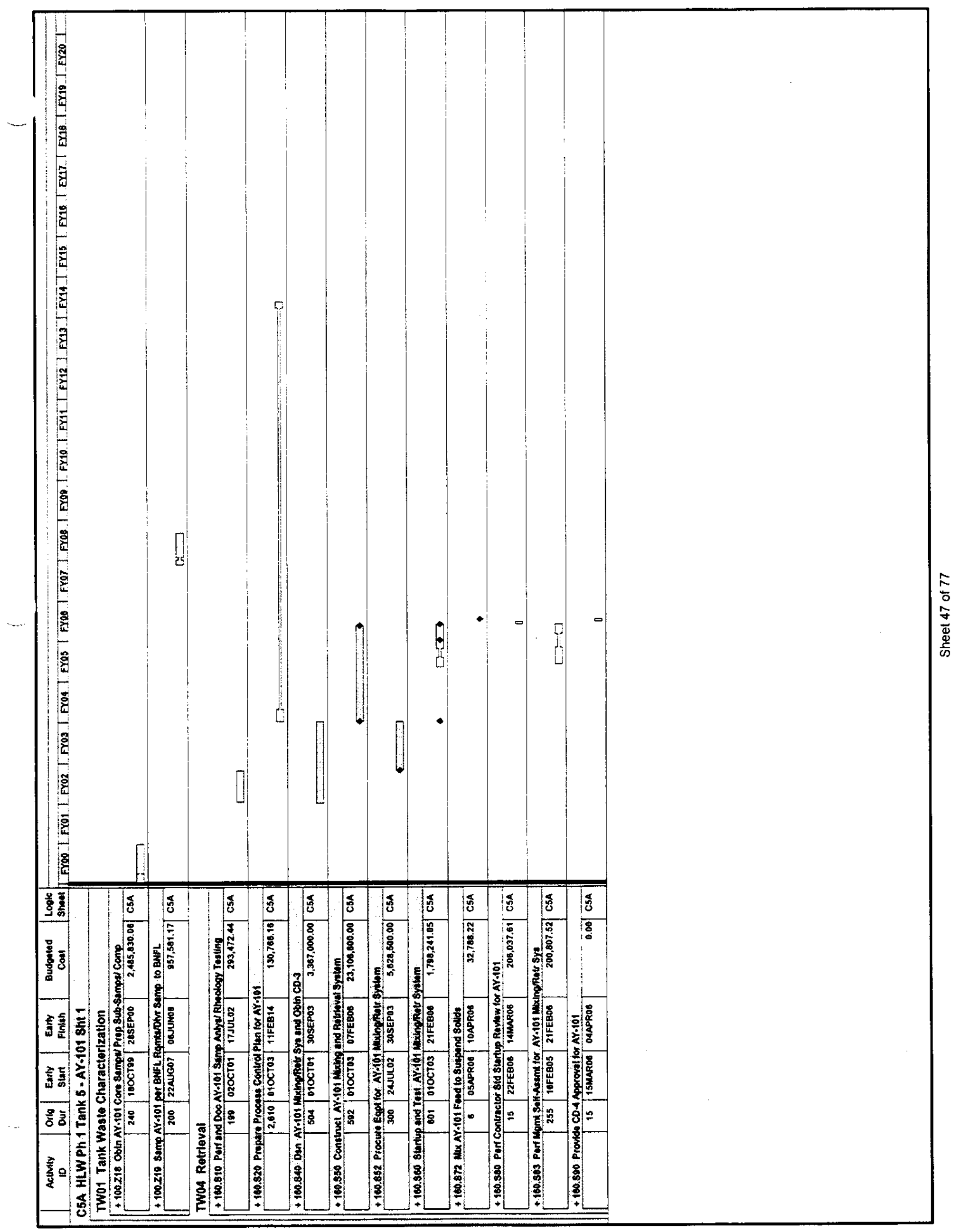




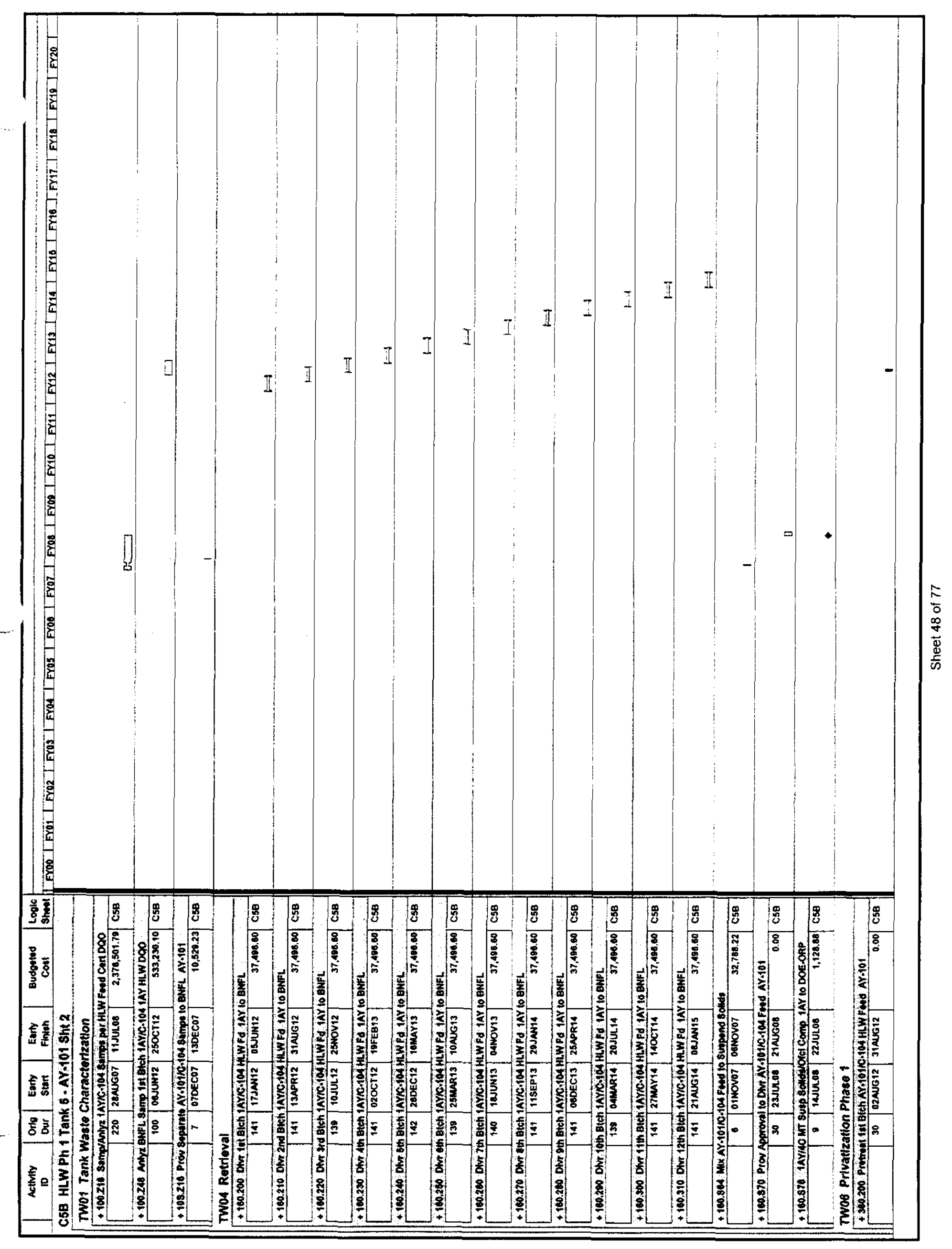




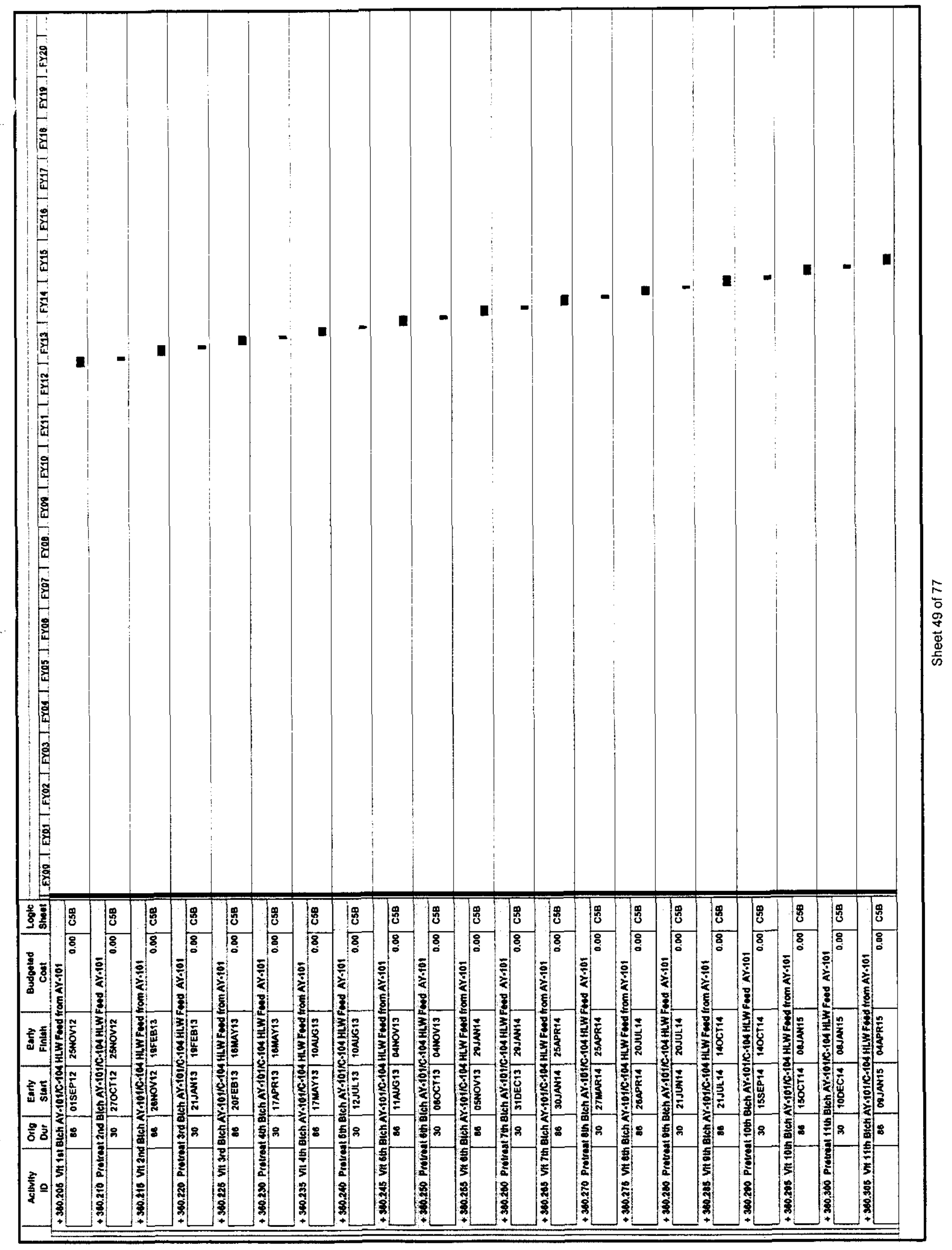




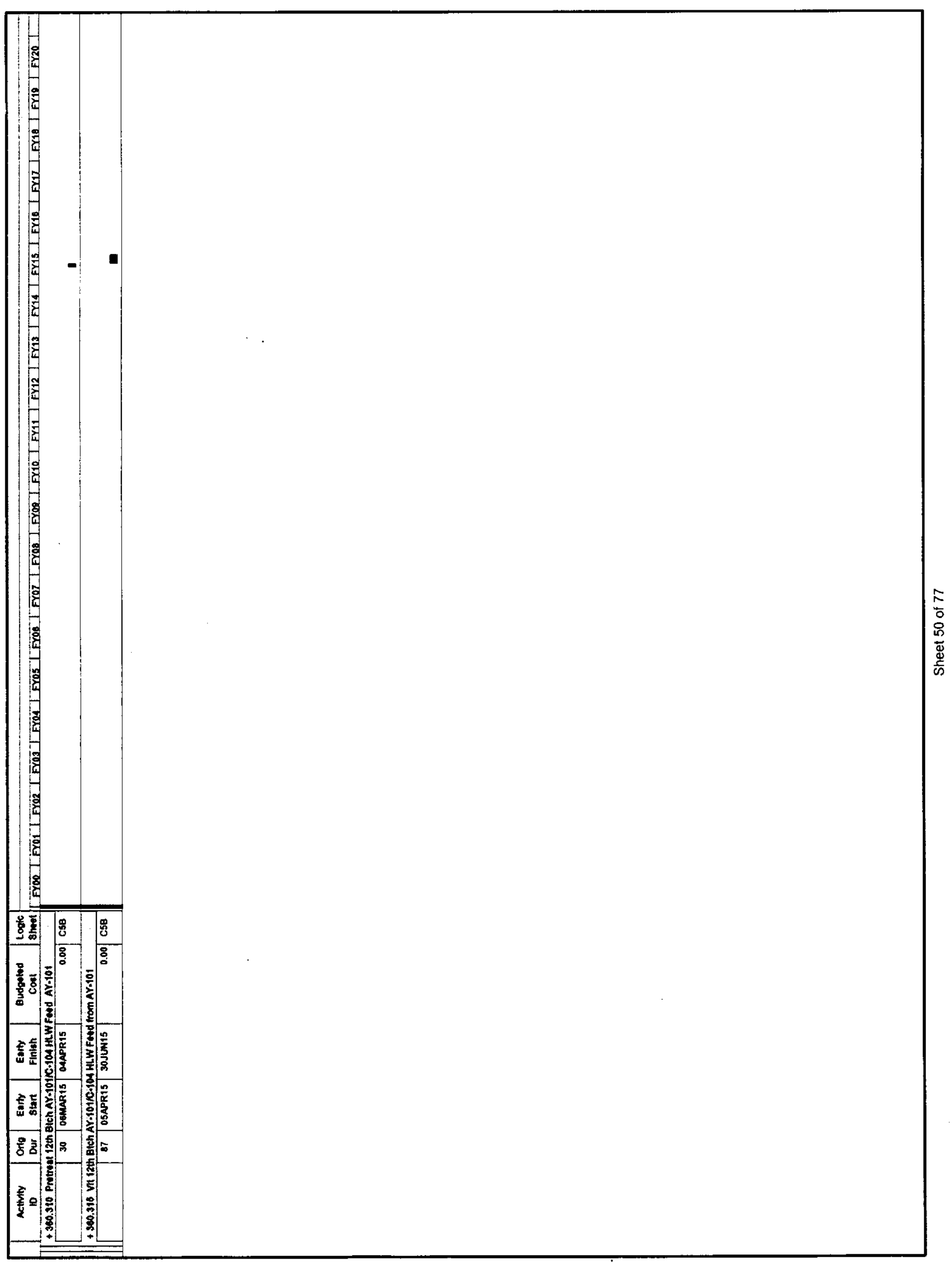




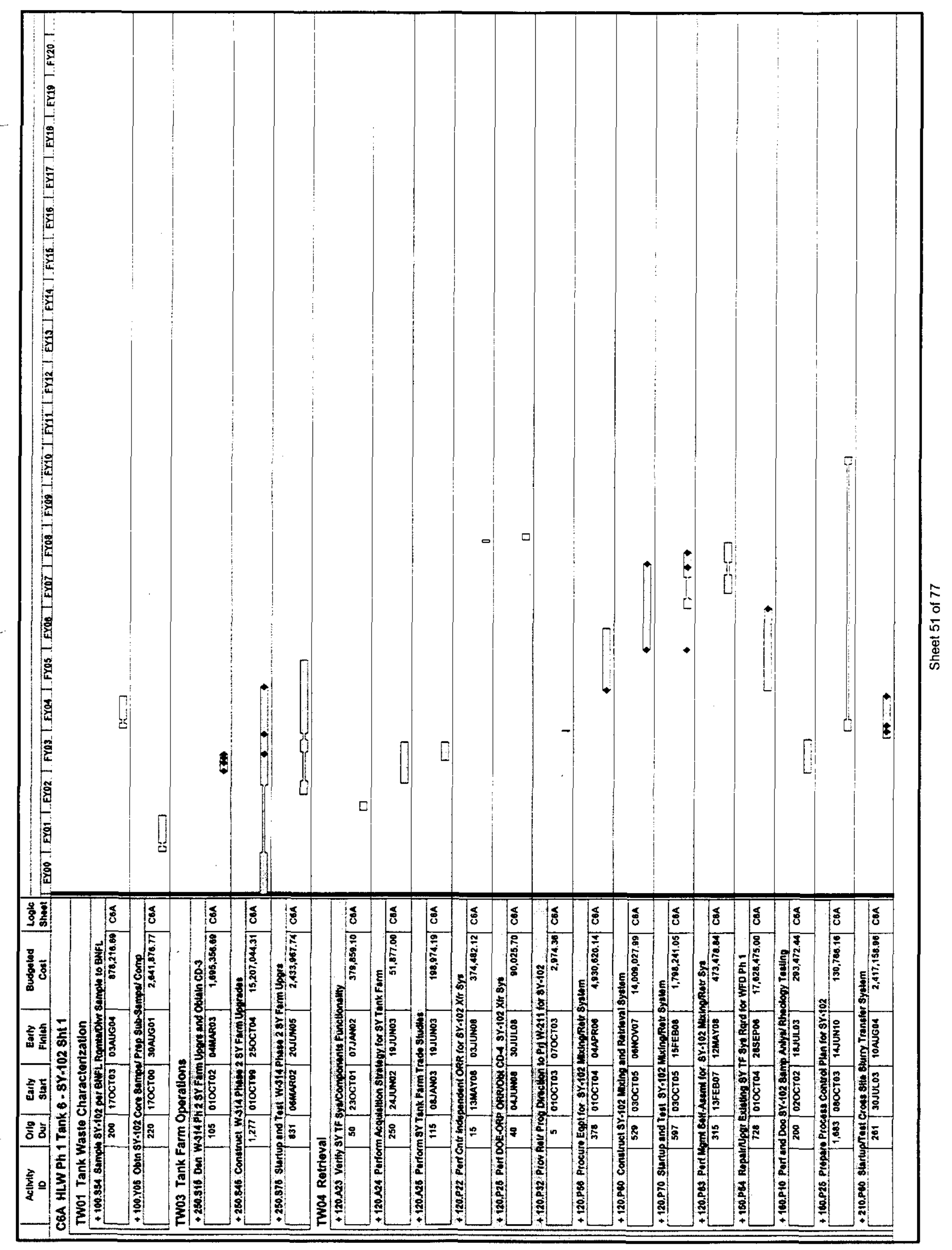




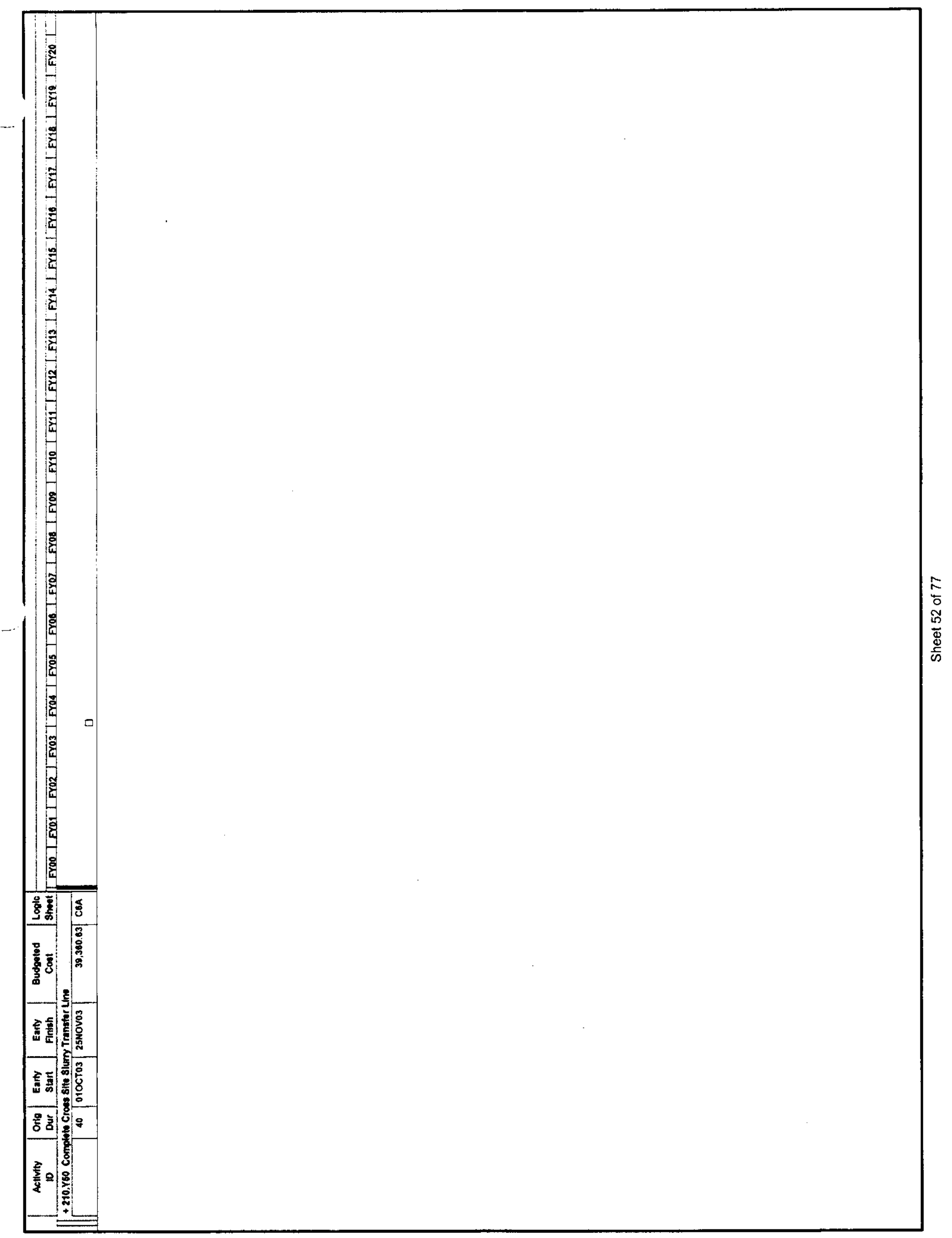




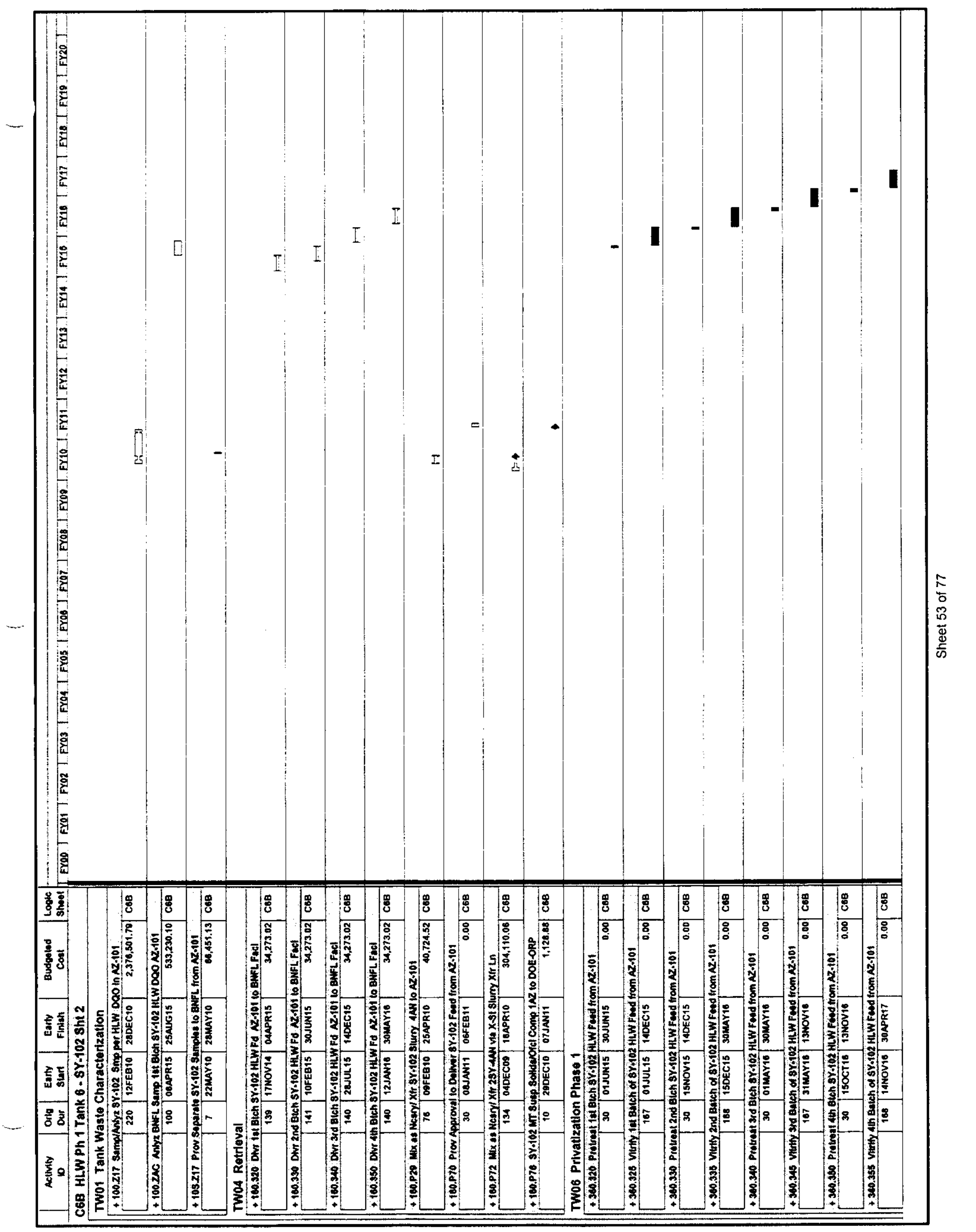




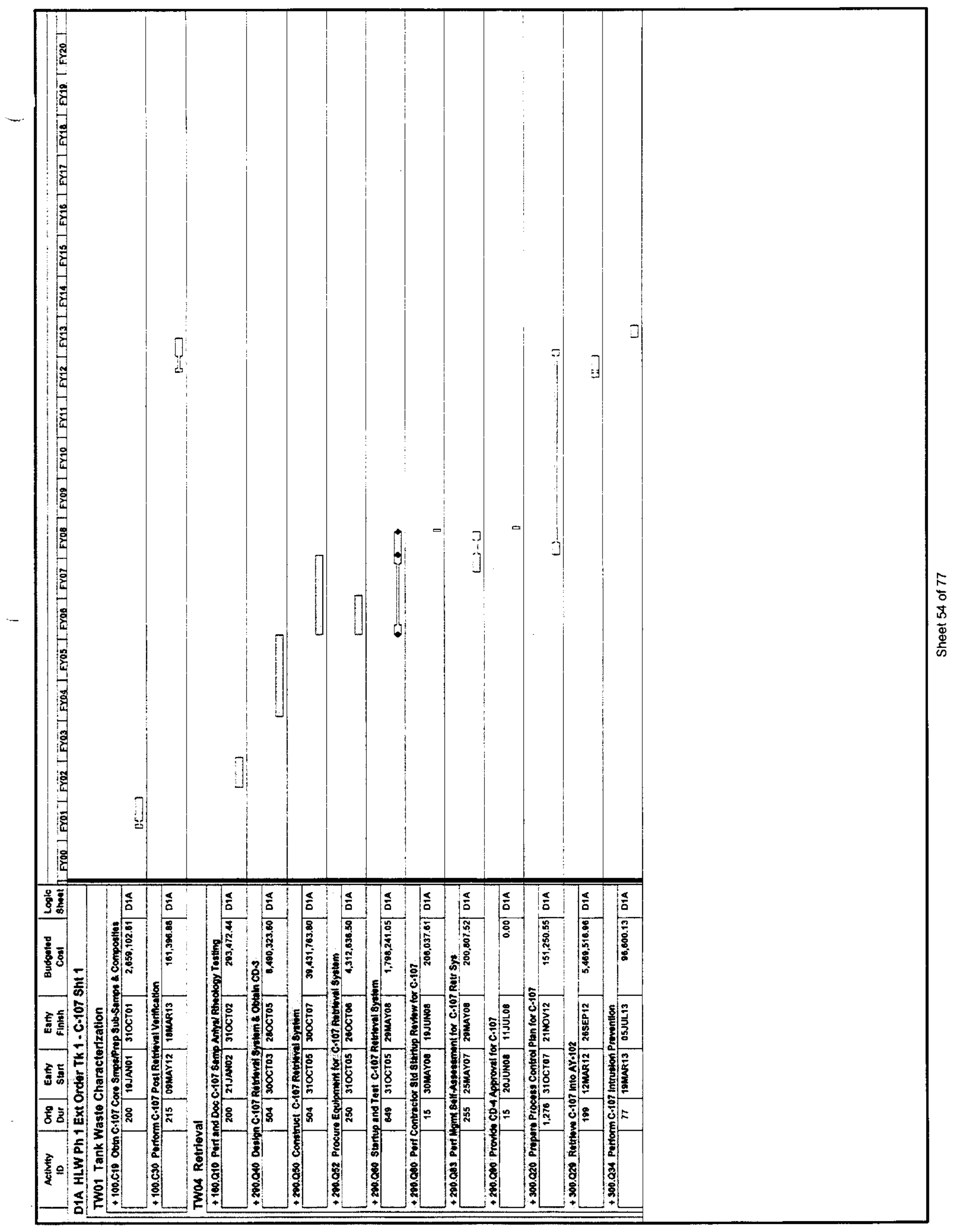




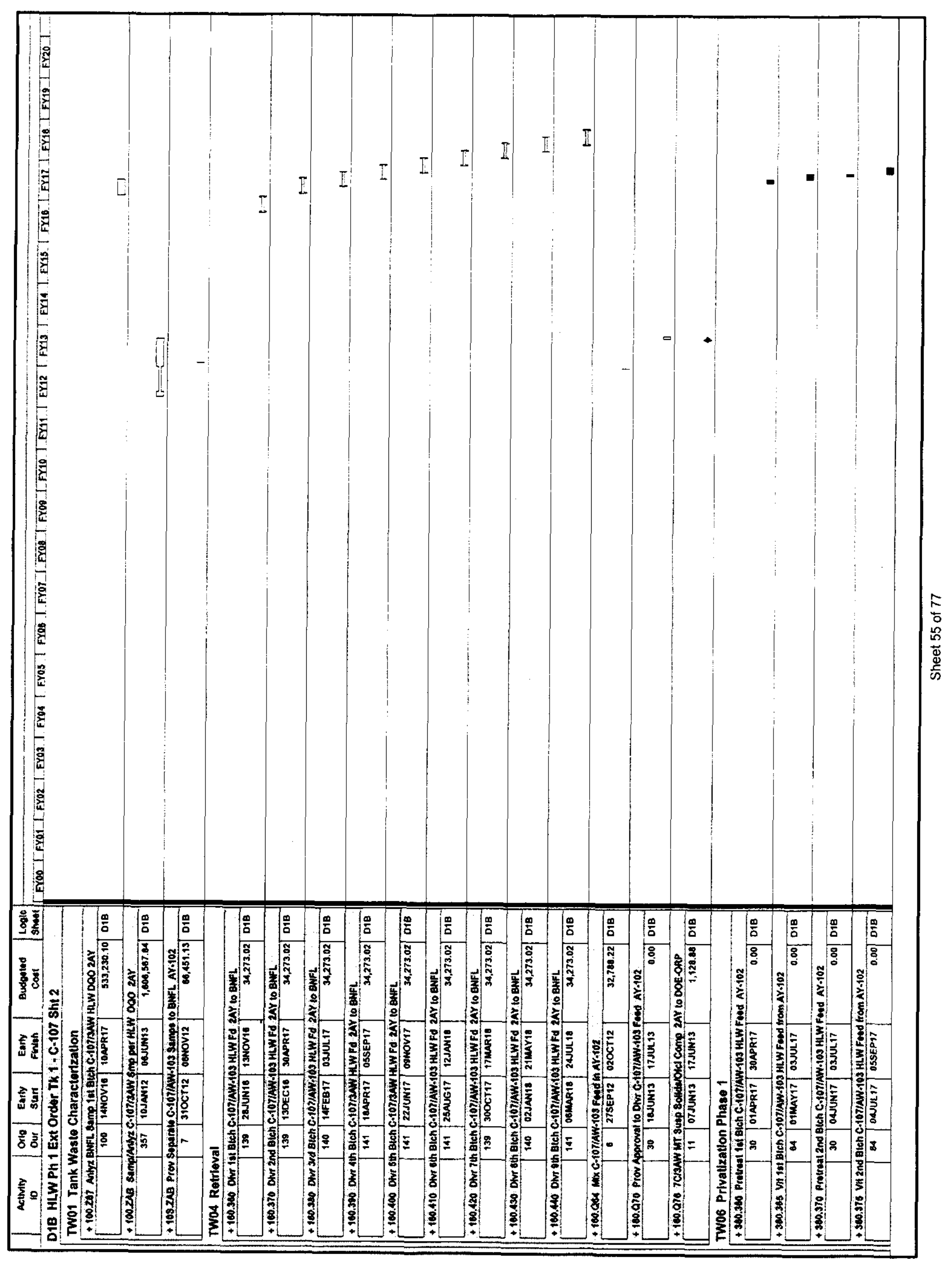




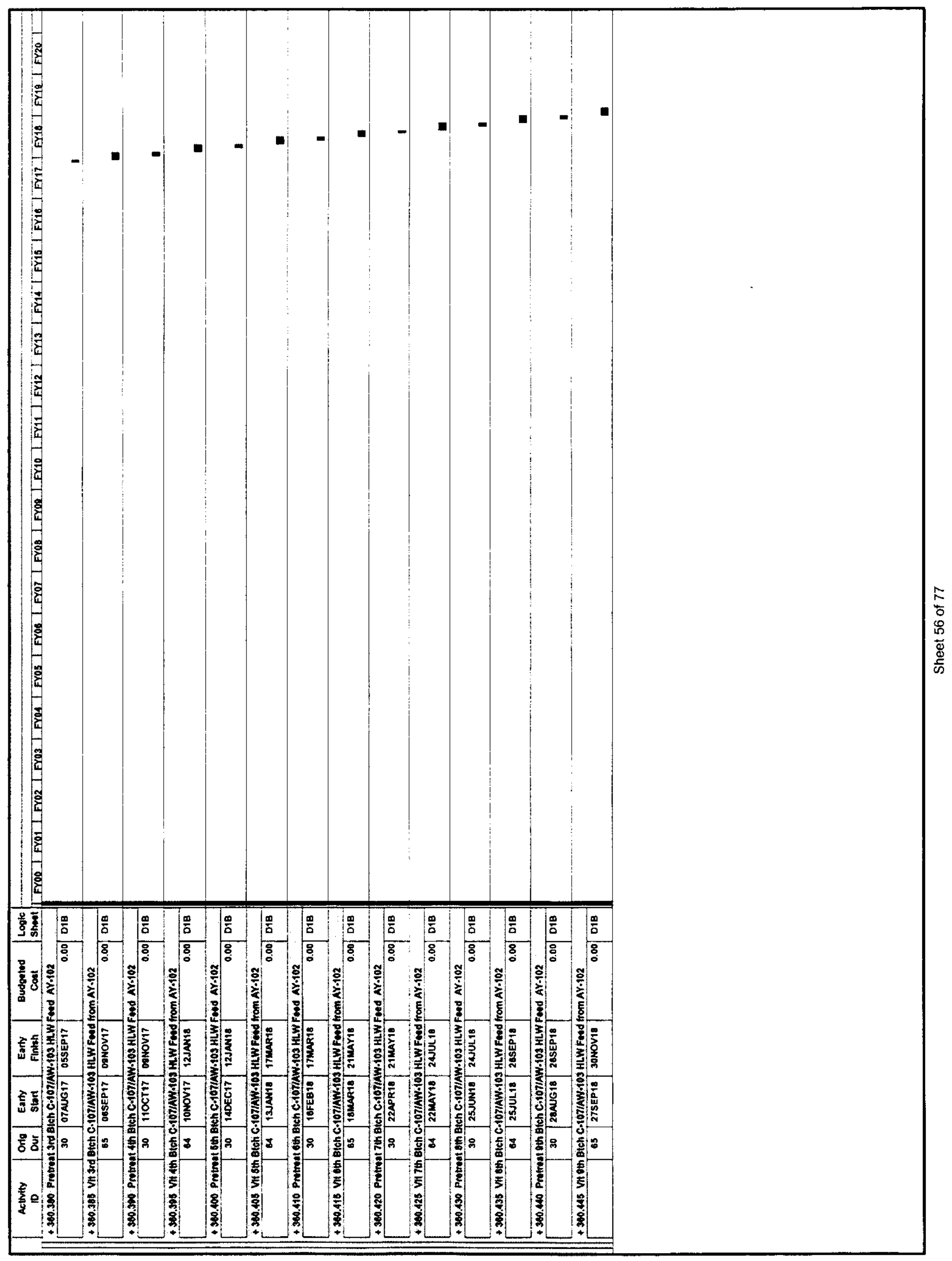




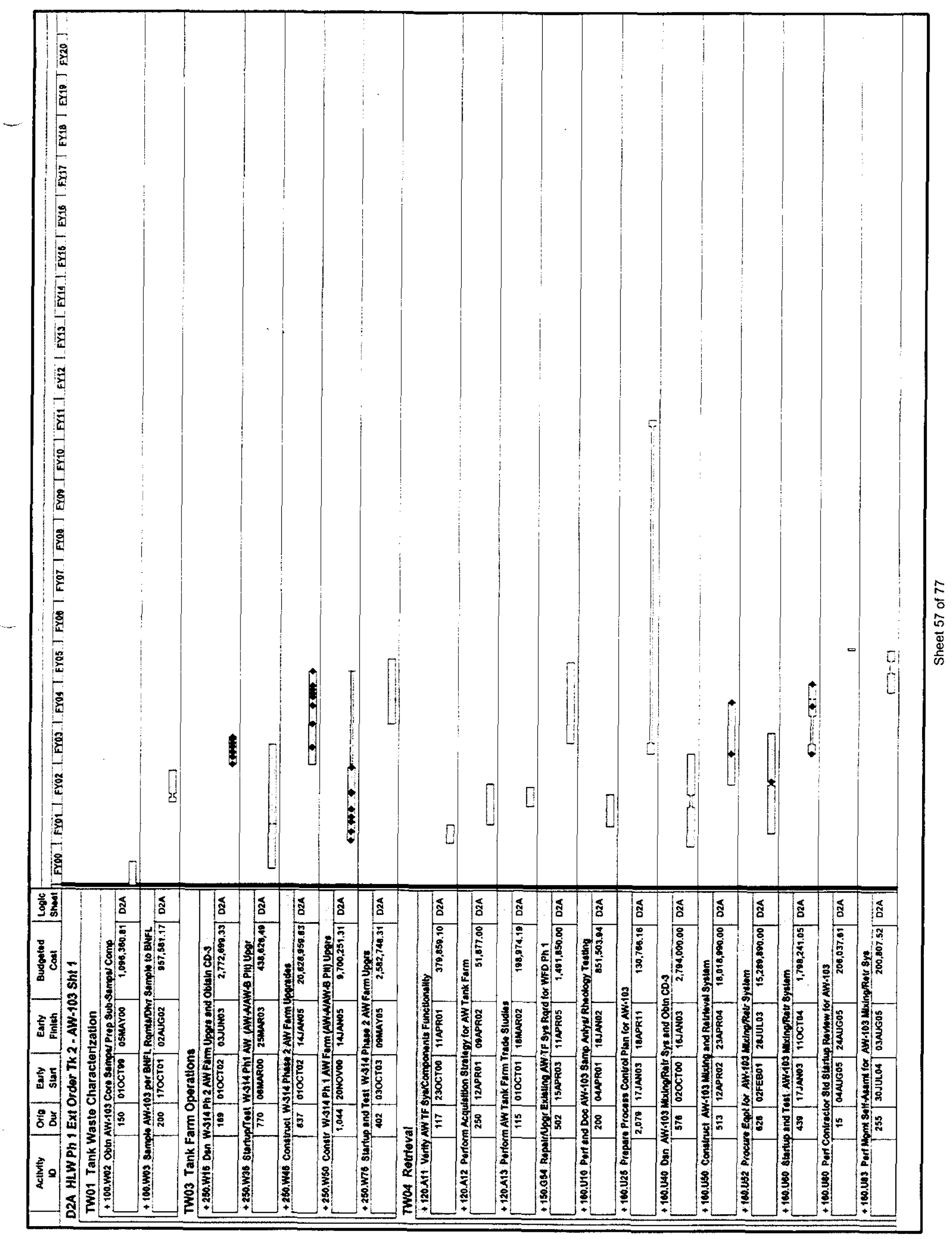




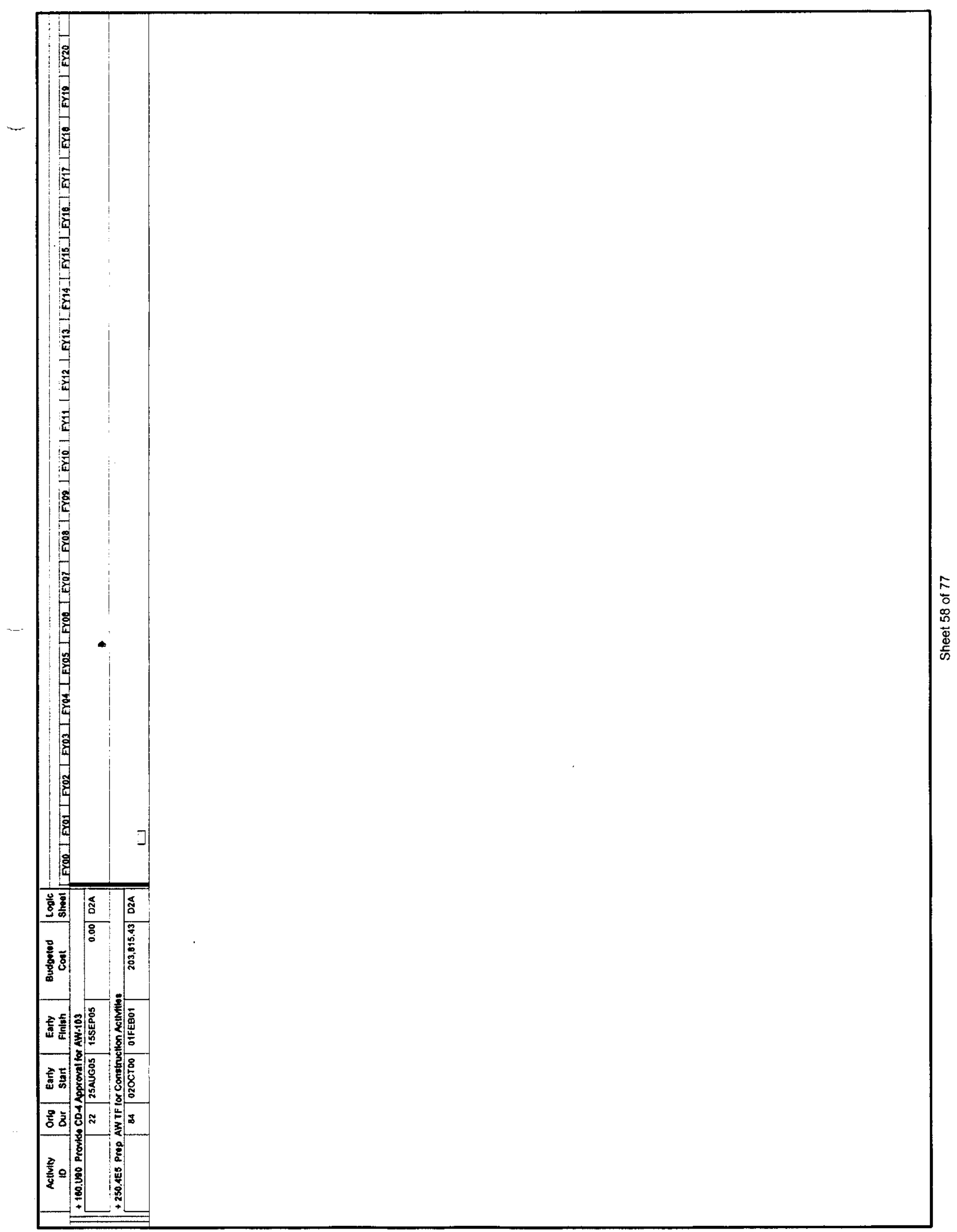




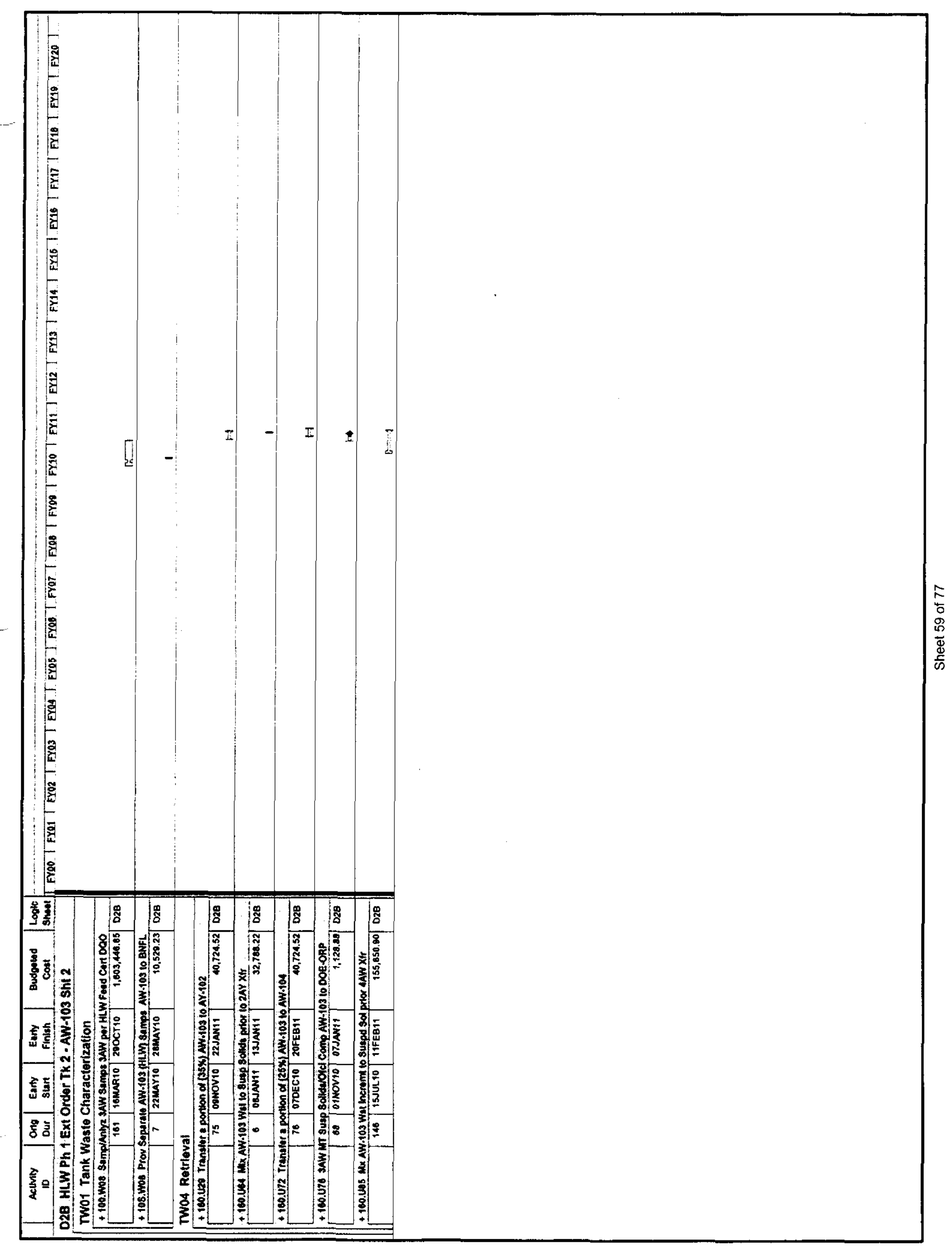




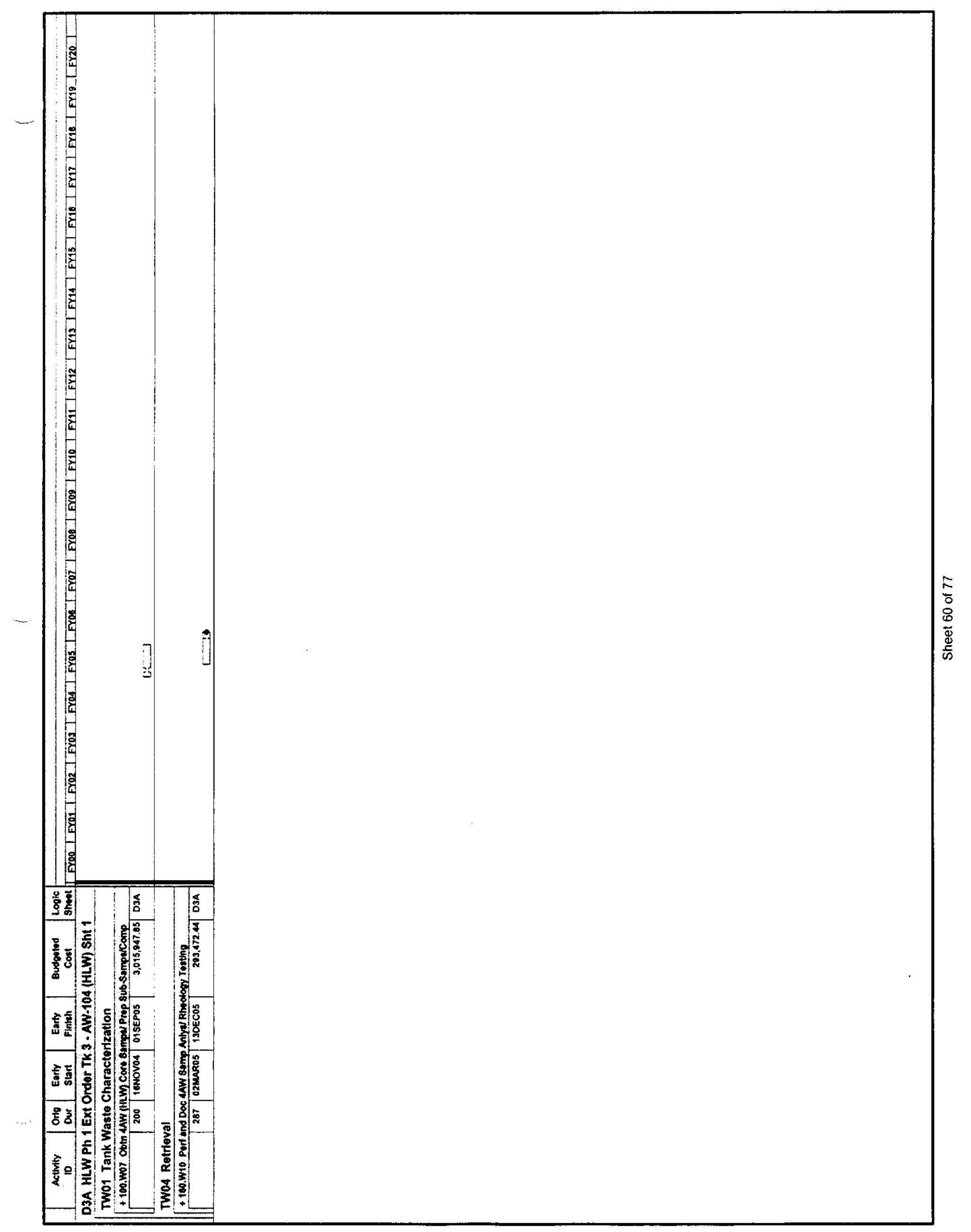




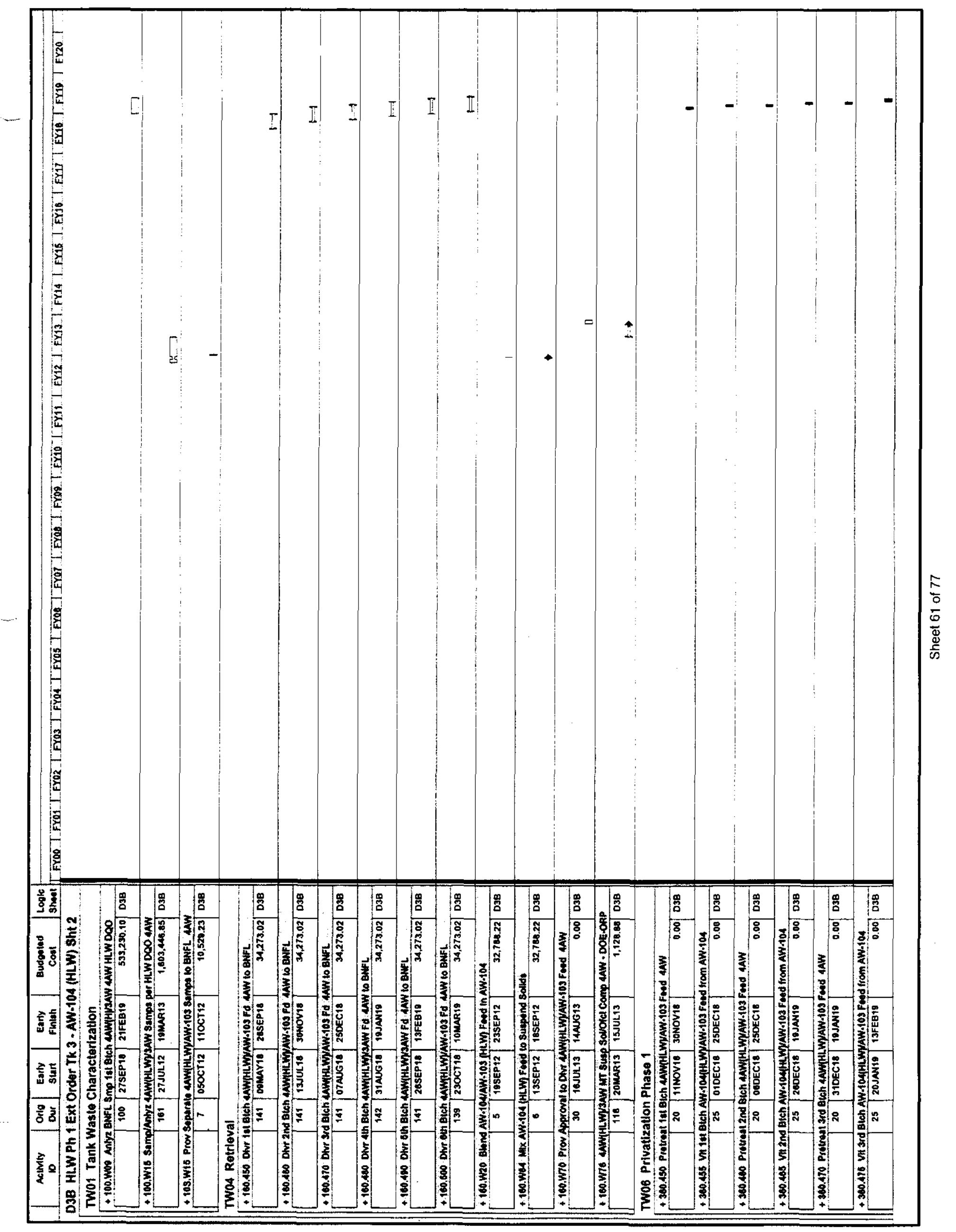




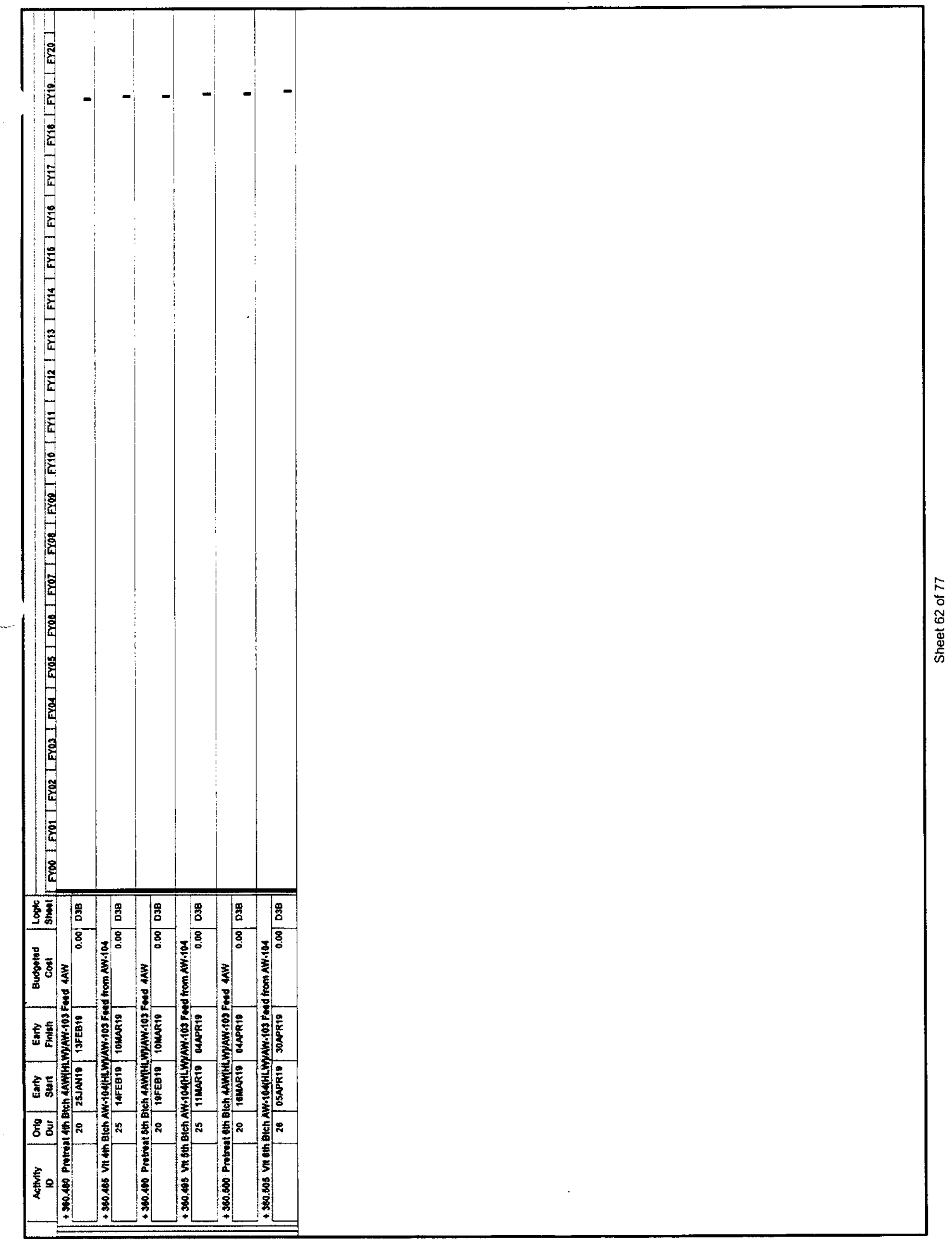




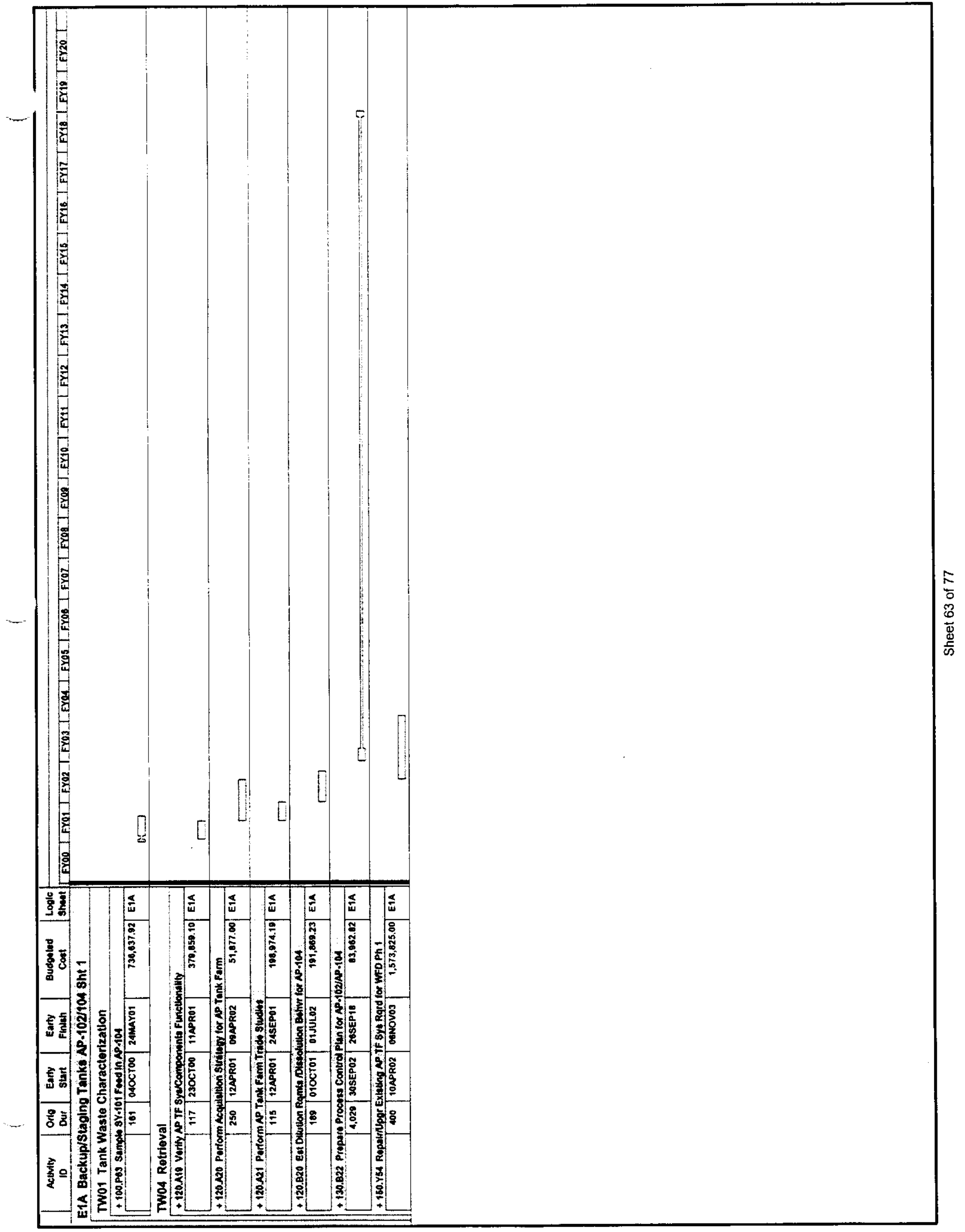




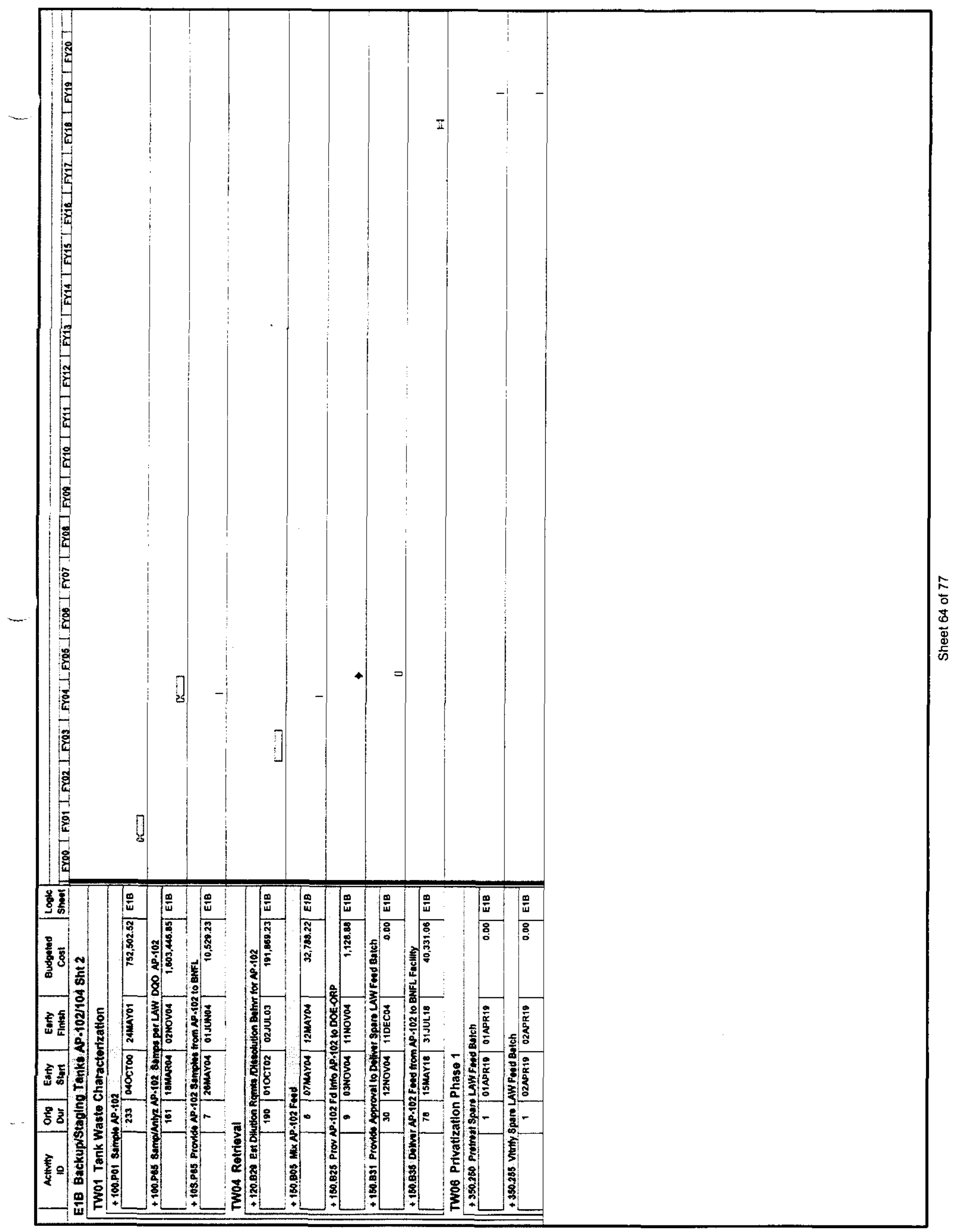


This page cannot be converted.

Please view the native document

for the original page. 


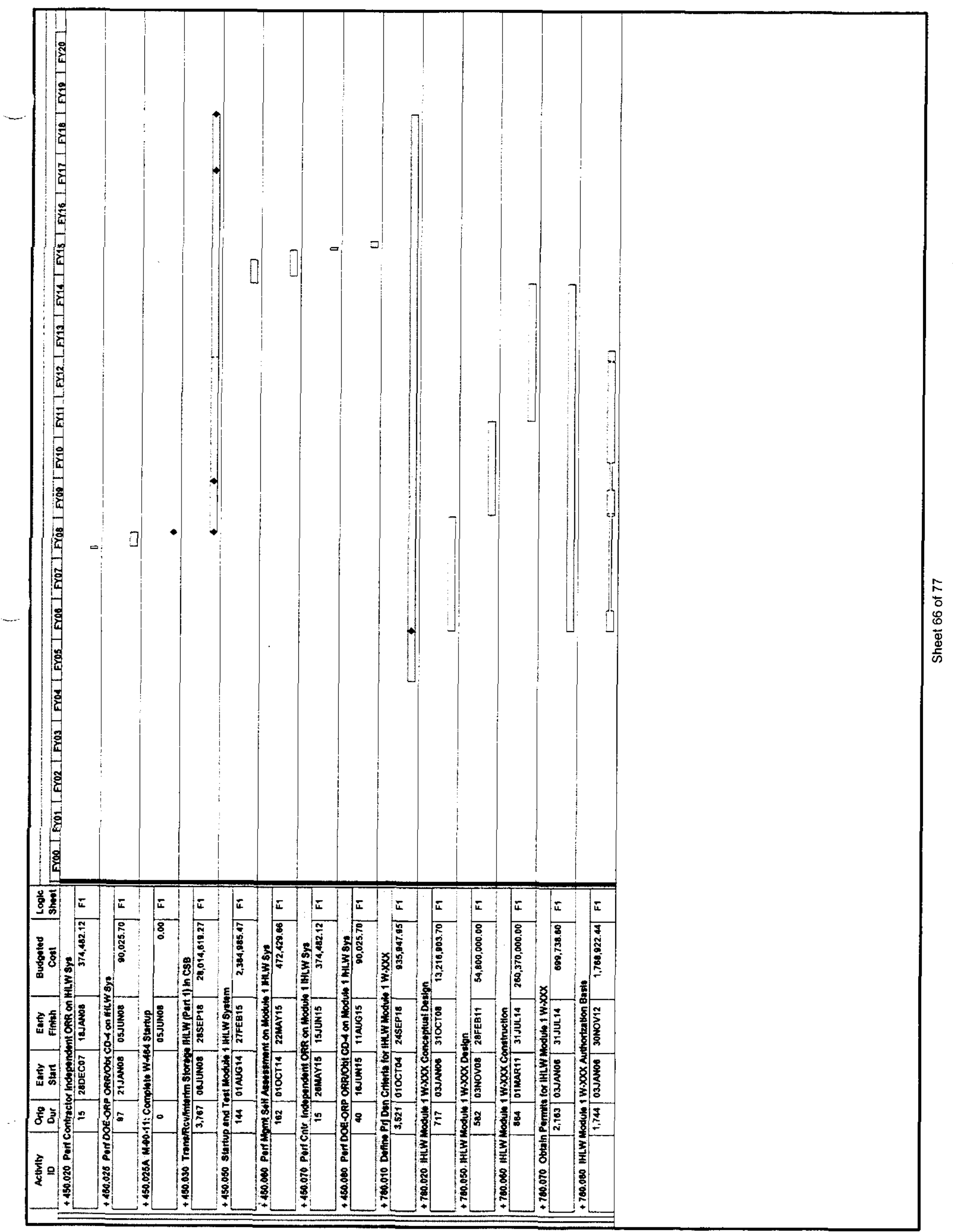




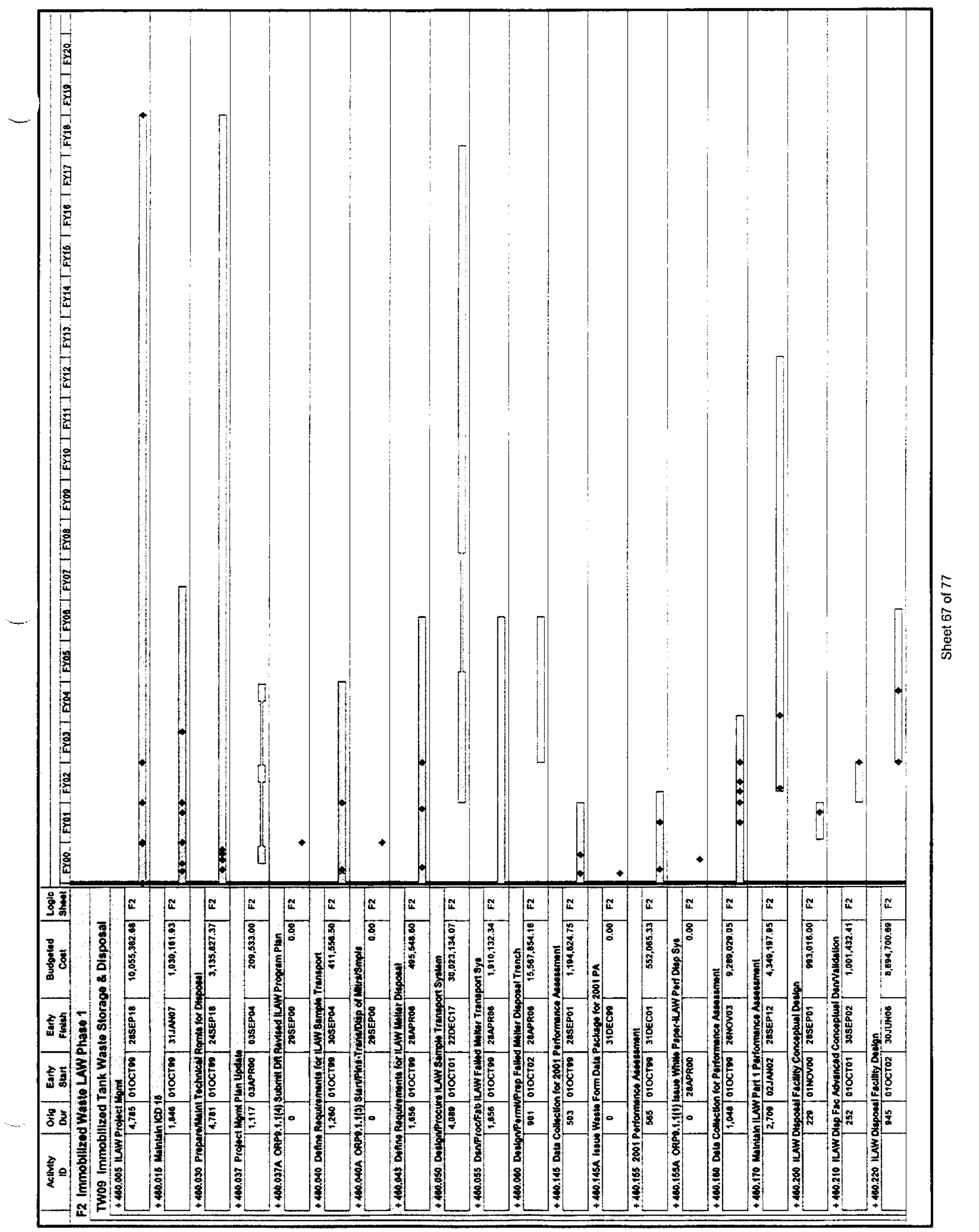




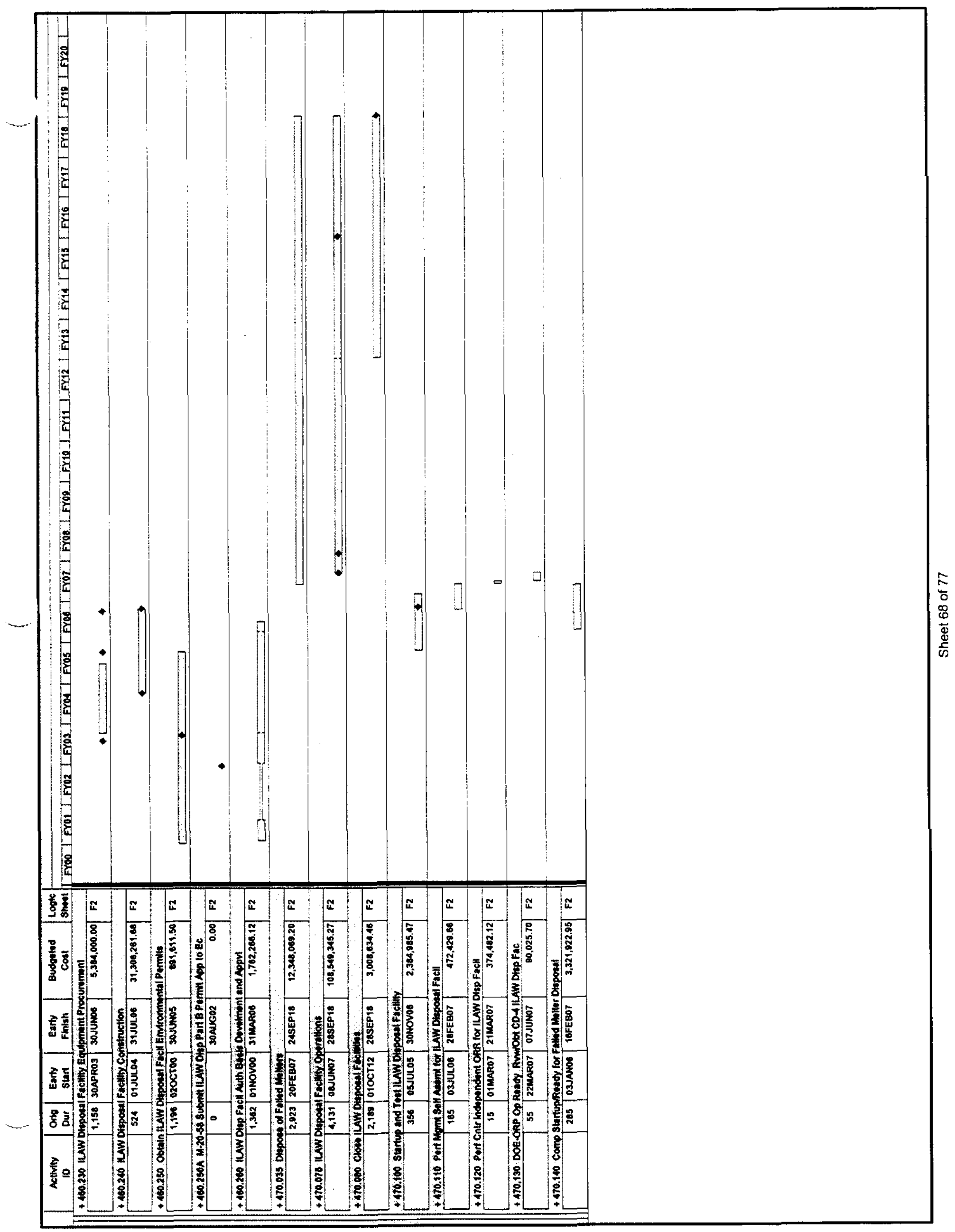




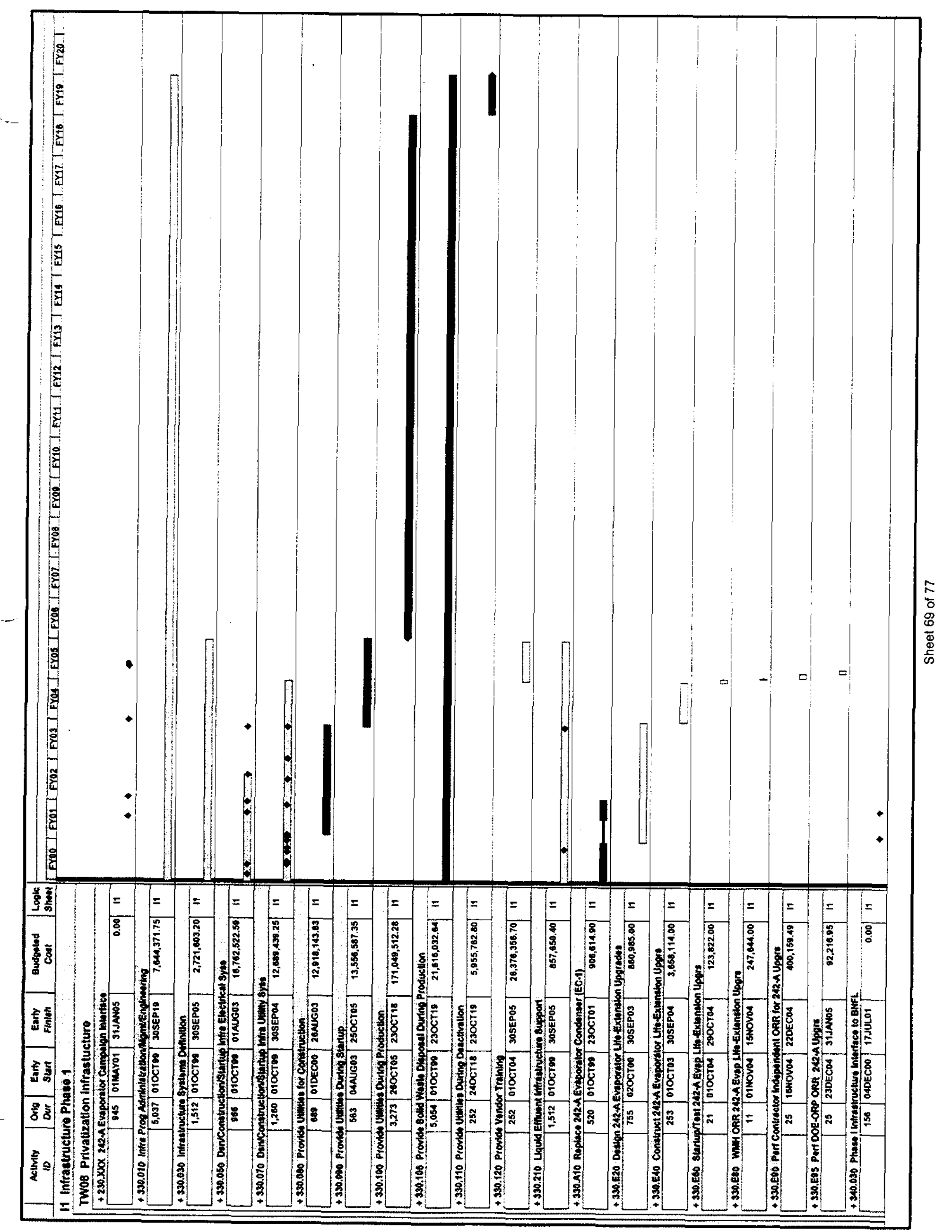




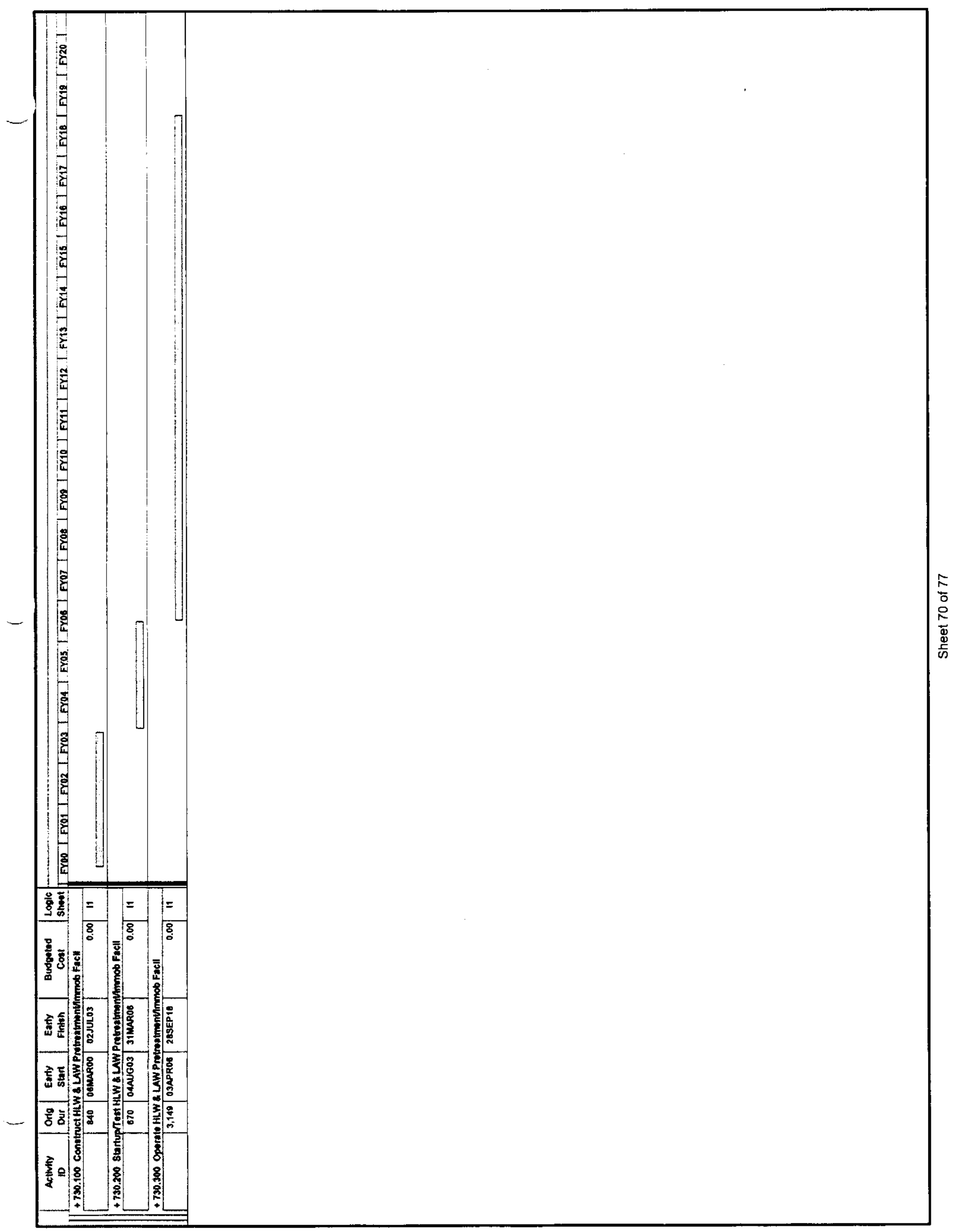




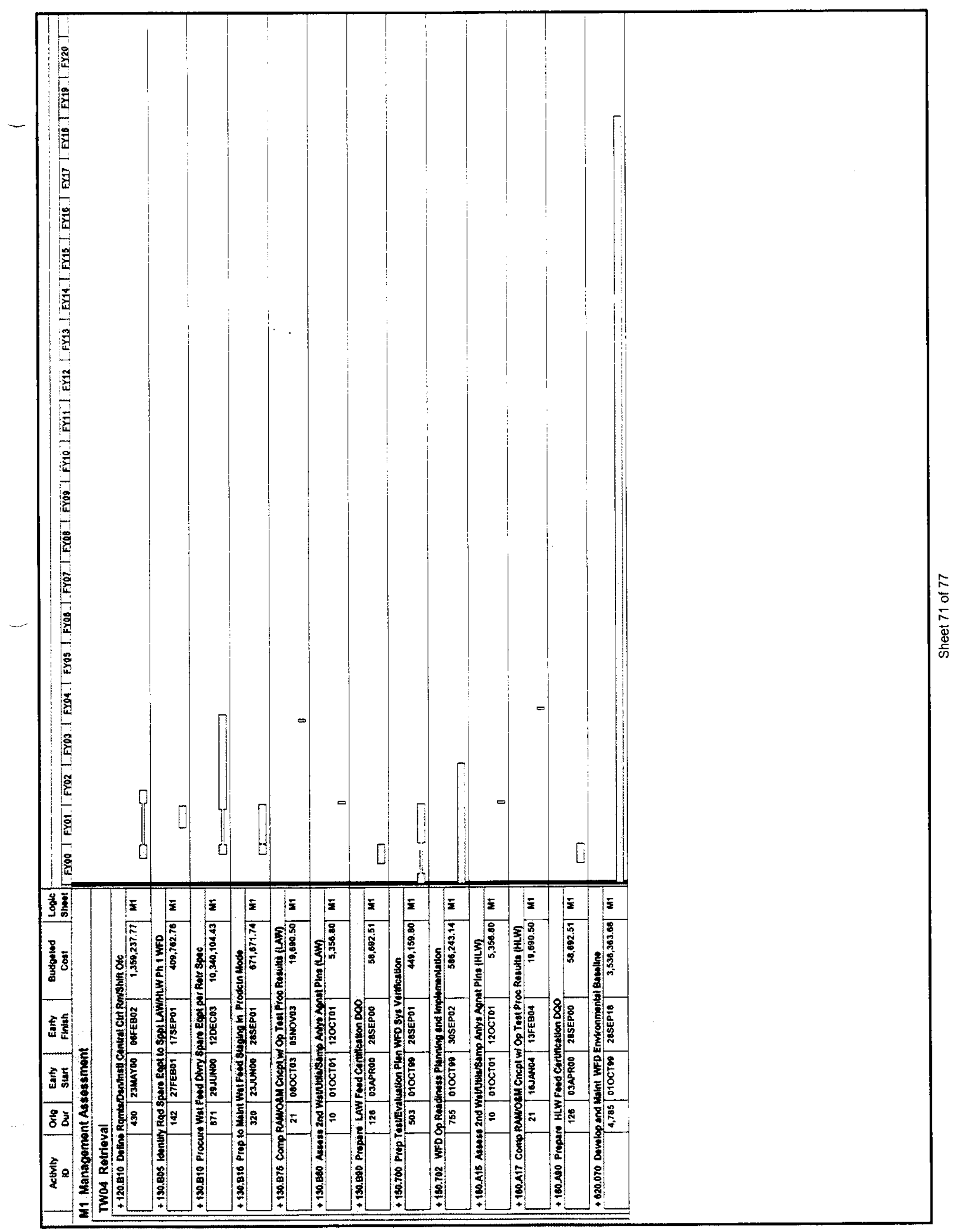




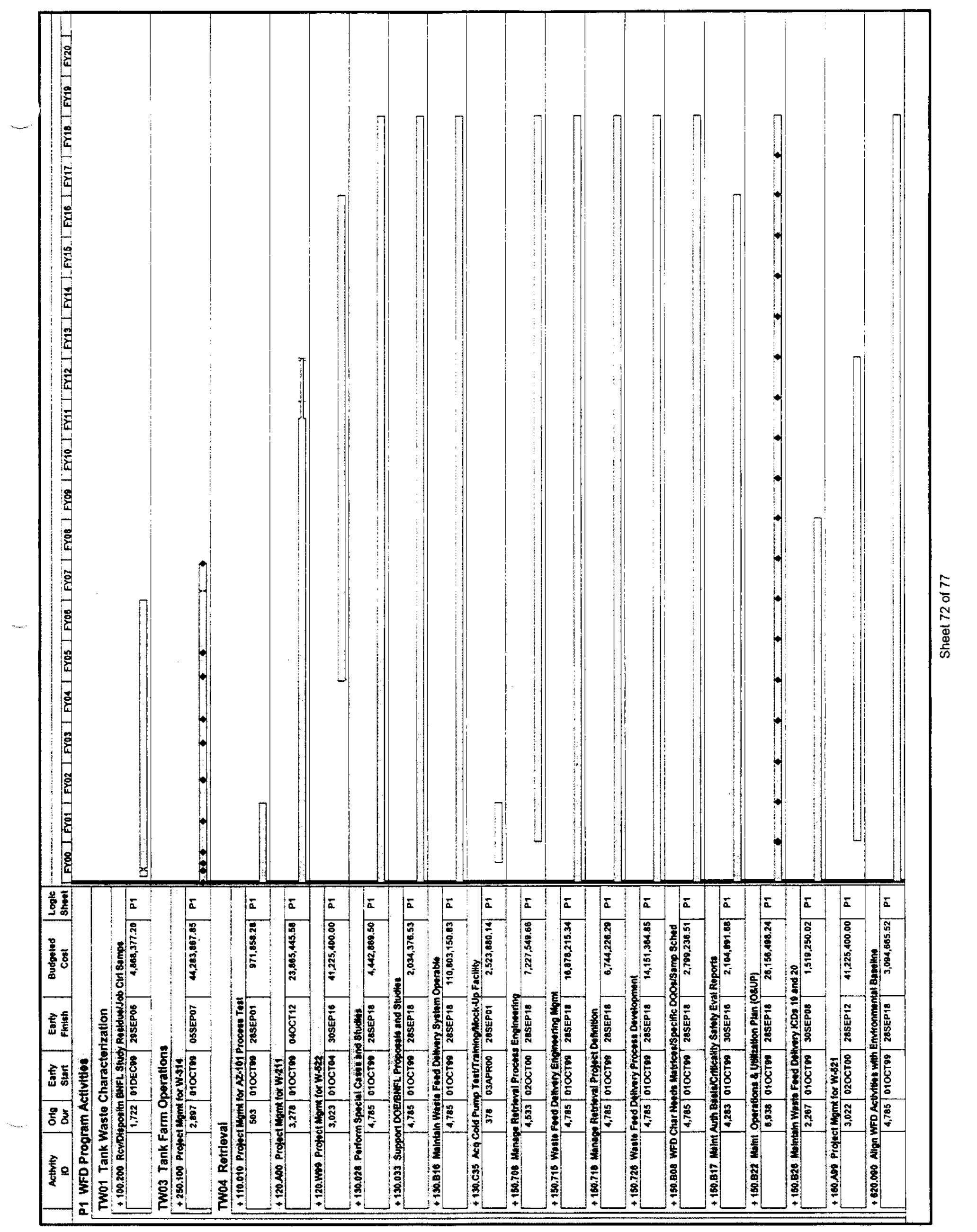




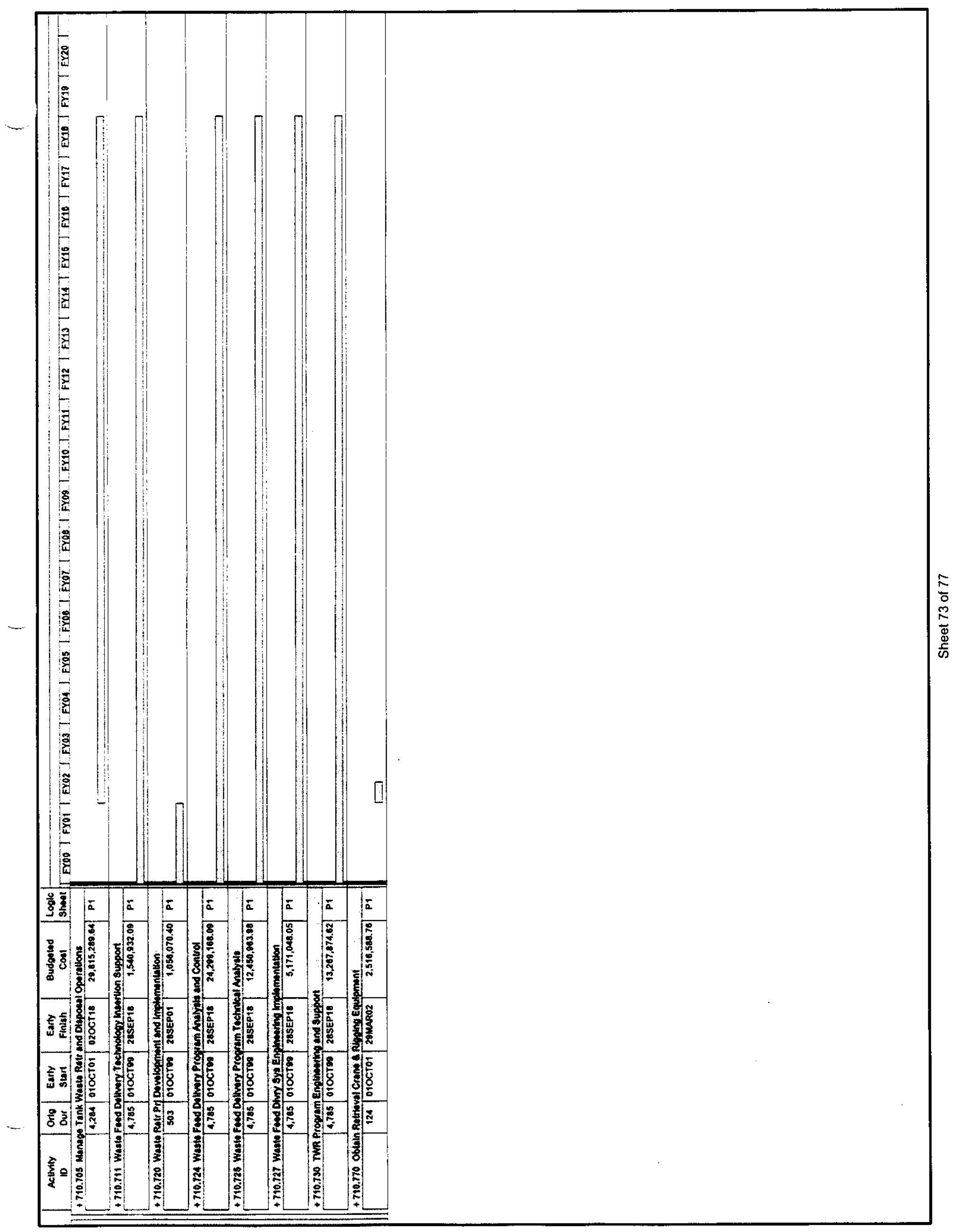




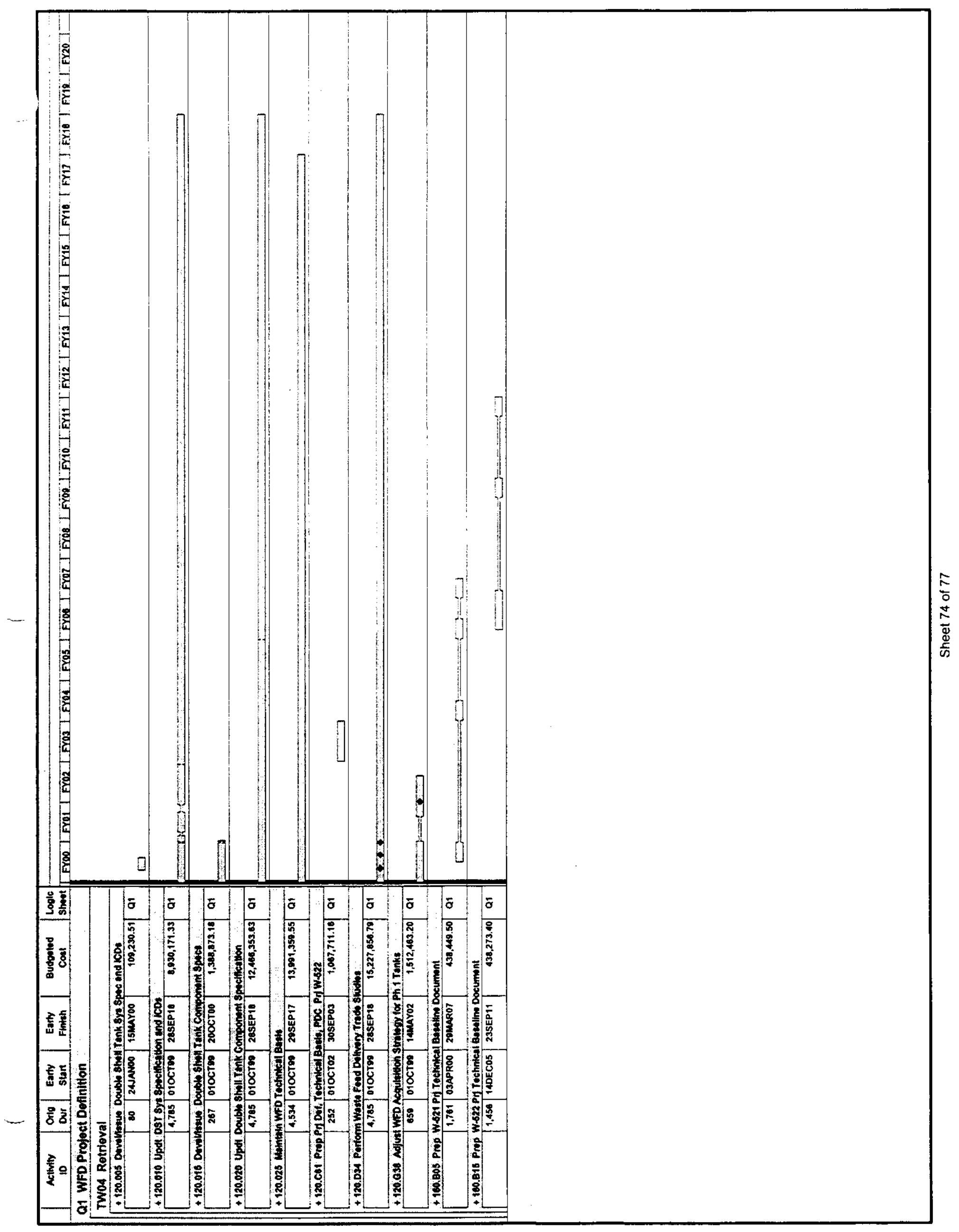




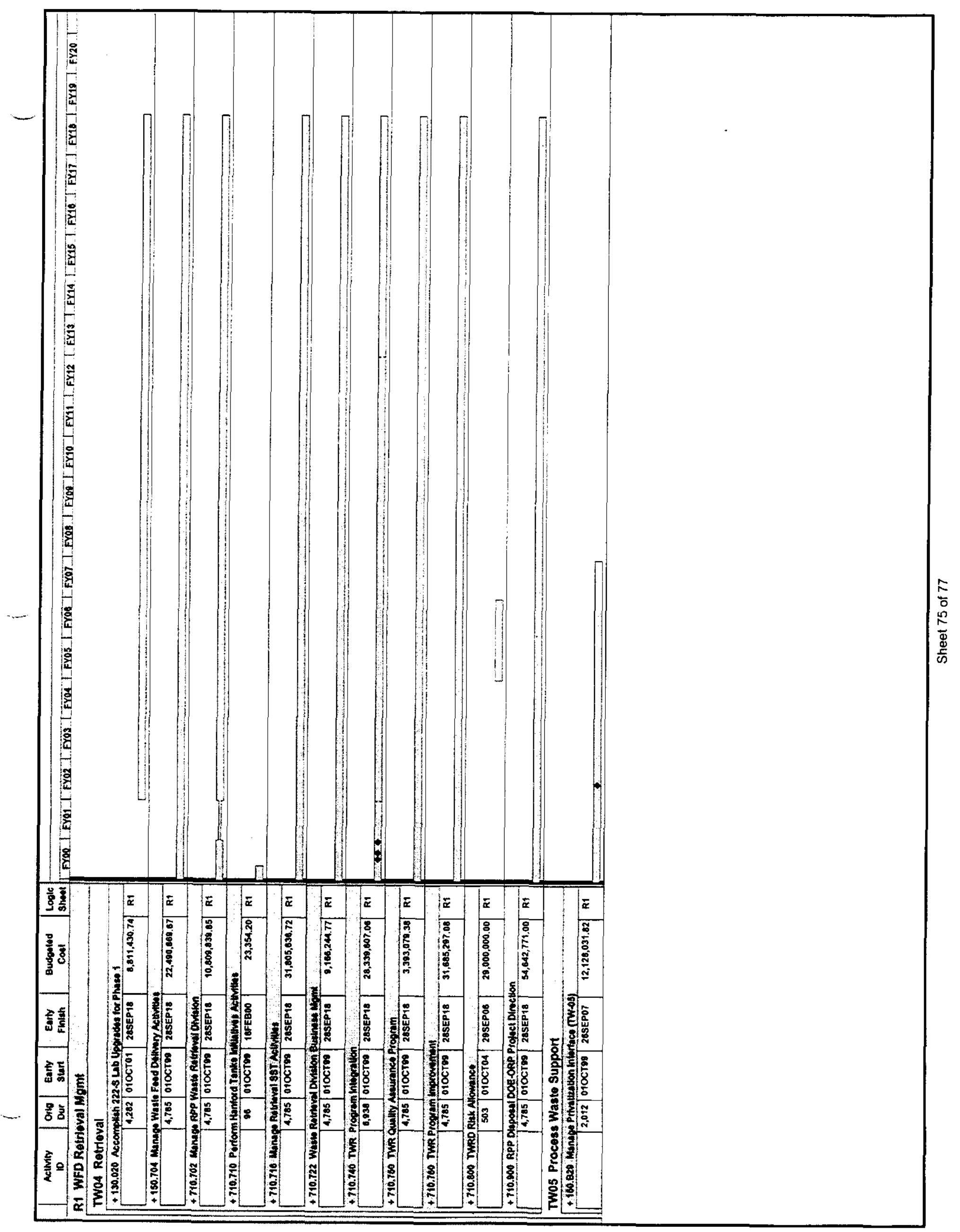




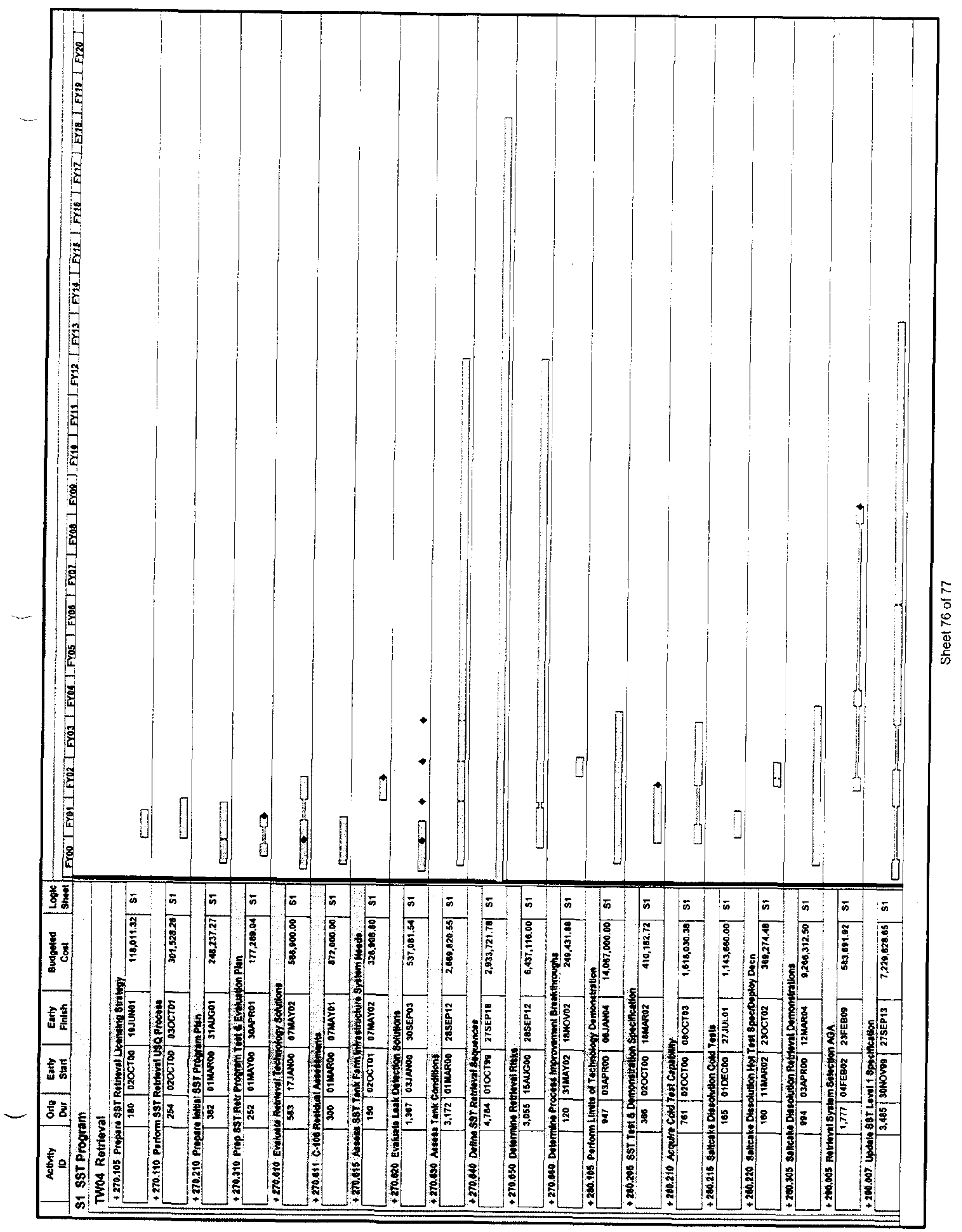




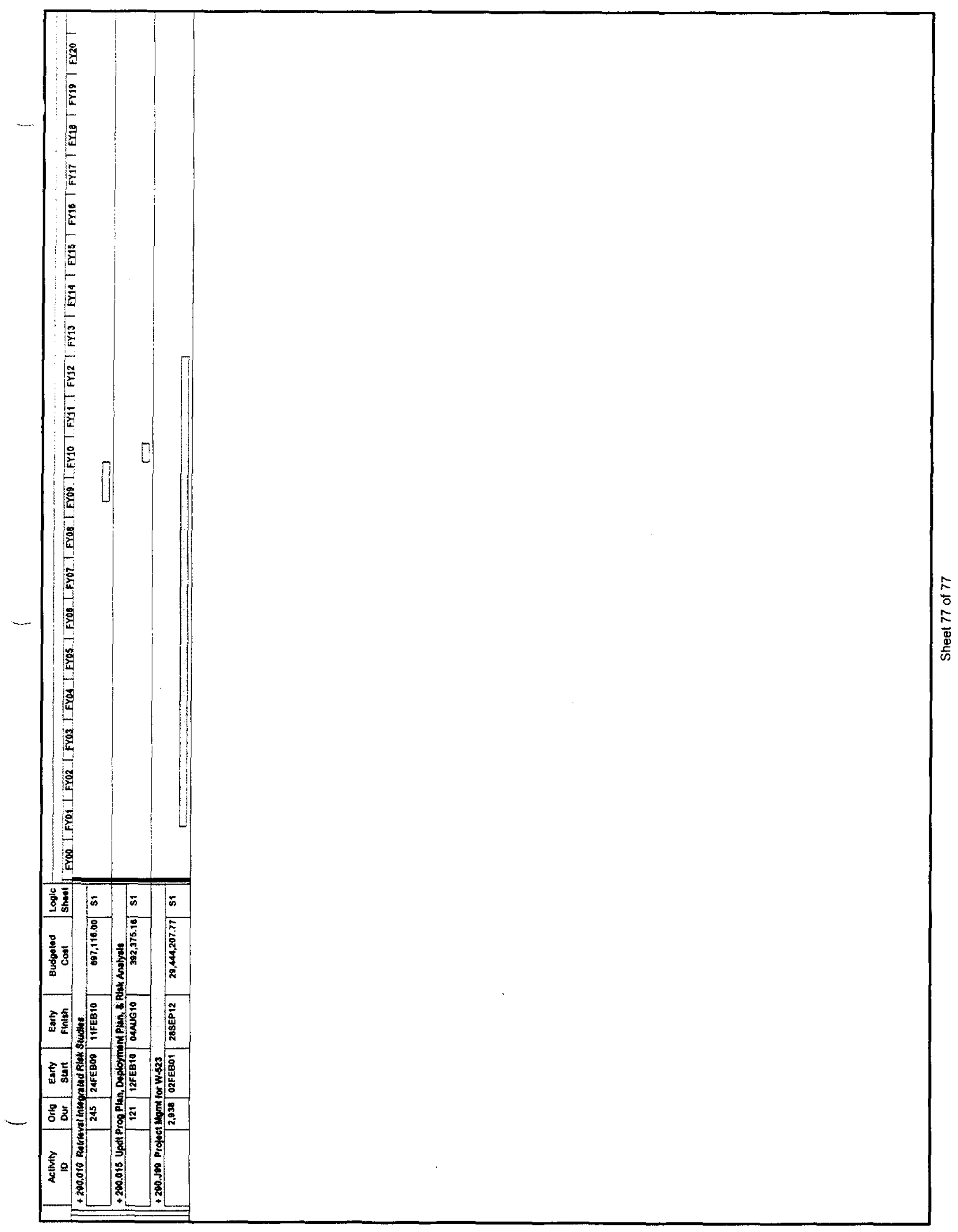




\section{This document was too large to scan as a single document. It has been divided into smaller sections.}

Section 2 of 2

\begin{tabular}{|l|l|l|l|}
\hline \multicolumn{4}{|c|}{ Document Information } \\
\hline Document \# & HNF-1946 & Revision 2 & \\
\hline Title & $\begin{array}{l}\text { PROGRAMMATIC BASELINE SUMMARY FOR PHASE 1 } \\
\text { PRIVATIZATION FOR THE TANK FARM CONTRACTOR } \\
\text { APPENDIX C. INTEGRATED RESOURCE LOAD } \\
\text { SCHEDULE [VOL 2] }\end{array}$ \\
\hline Date & 04/22/2000 & Originator Co. & CHG \\
\hline Originator & DIEDIKER JA & Recipient Co. & \\
\hline Recipient & \multicolumn{3}{|l|}{} \\
\hline References & ECN-660087 & \multicolumn{2}{|l|}{} \\
\hline Keywords & BASELINE SCHEDULES \\
\hline Projects & RPP,TFARM \\
\hline $\begin{array}{l}\text { Other } \\
\text { Information }\end{array}$ & $\begin{array}{l}\text { SECTION 2 OF 2 CONTAINS DETAILED BASELINE } \\
\text { SCHEDULES }\end{array}$ &
\end{tabular}




\section{Detailed Baseline Schedule - Index}

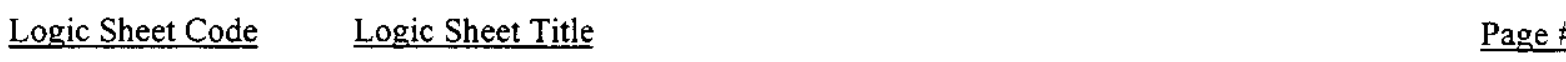

AlA

A1B

A2A

A2B

$\mathrm{A} 3 \mathrm{~A}$

$\mathrm{A} 3 \mathrm{~B}$

A4A

A4B

A5A

A5B

A6A

A6B

A7A

A7B

A8A

A8B

B1A

B1B

B2A

B2B

B3A

B3B

B4A

B4B

B5A

B5B

B6A

B6B

B7A

B7B

ClA

C1B

$\mathrm{C} 2 \mathrm{~A}$

C2B

$\mathrm{C} 3 \mathrm{~A}$

C3B

C4A

C5A

$\mathrm{C} 5 \mathrm{~B}$

C6A

C6B

D1A

DIB

D2A

D2B

D3A

D3B

ElA

E1B

F1

WFD LAW Phase 1 Source Tank \#1 AP-101 - Sheet 1

- Sheet 2

WFD LAW Phase 1 Source Tank \#2 AN-102 - Sheet 1

WFD LAW Phase 1 Source Tank \#3 AN-104 - Sheet $1 \quad 60$

- Sheet 2

WFD LAW Phase 1 Source Tank \#4 AN-107 - Sheet I 93

- Sheet 2

WFD LAW Phase 1 Source Tank \#5 AN-105 - Sheet $1 \quad 100$

- Sheet 2

WFD LAW Phase 1 Source Tank \#6 SY-101 - Sheet $1 \quad 114$

- Sheet 2

WFD LAW Phase 1 Source Tank \#7 AN-103 - Sheet $1 \quad 127$

- Sheet $2 \quad 136$

WFD LAW Phase 1 Source Tank \#8 AW-101 - Sheet $1 \quad 140$

- Sheet 2

WFD LAW Phase 1 Extended Order Source Tank \#1 AW-104 - Sheet 1

- Sheet $2 \quad 154$

WFD LAW Phase 1 Extended Order Source Tank \#2 SY-103 - Sheet 1

- Sheet $2 \quad 165$

WFD LAW Phase 1 Extended Order Source Tank \#3 AP-106 - Sheet $1 \quad 166$

- Sheet $2 \quad 169$

WFD LAW Phase 1 Extended Order Source Tank \#4 S-102 - Sheet $1 \quad 171$

- Sheet $2 \quad 175$

WFD LAW Phase 1 Extended Order Source Tank \#5 S-105 - Sheet $1 \quad 176$

- Sheet $2 \quad 179$

WFD LAW Phase 1 Extended Order Source Tank \#6 AP-105 - Sheet $1 \quad 180$

- Sheet $2 \quad 182$

WFD LAW Phase 1 Extended Order Source Tank \#7 AP-108 - Sheet $1 \quad 184$

186

187

208

210

221

223

249

251

256

268

271

290

292

295

298

324

325

326

328

329

WFD Backup/Staging Tanks AP-102/AP-104 - Sheet 1

- Sheet 2

Immobilized HLW Phase 1

330 


\section{Detailed Baseline Schedule - Index}

F2

Il

M1

Pl

Q1

$\mathrm{R} 1$

S1
Immobilized LAW Phase 1

Infrastructure Phase 1

Management Assessment

WFD Program Activities

WFD Project Definition

WFD Retrieval Management

SST Program
355

362

365

394

399

404 


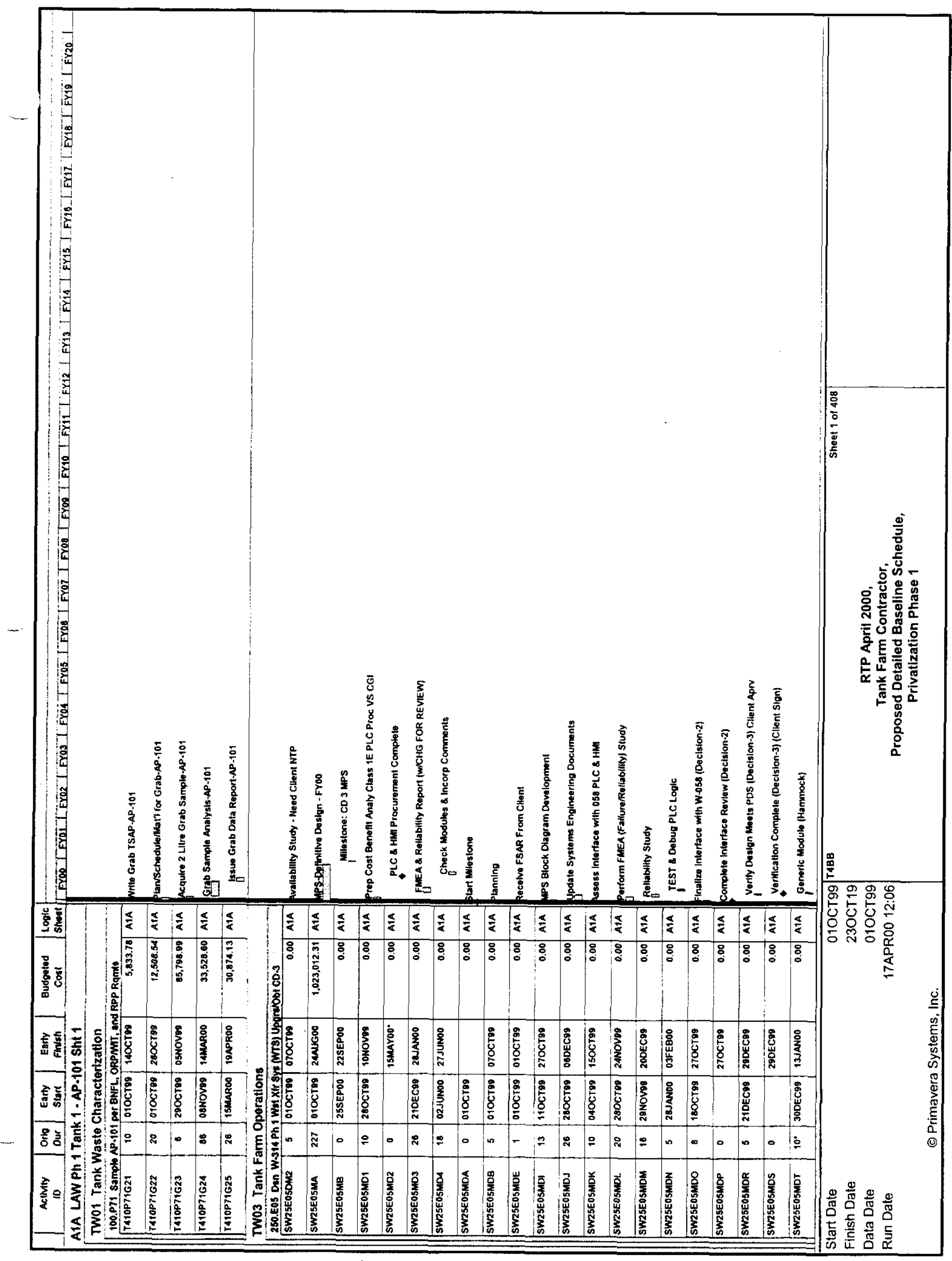




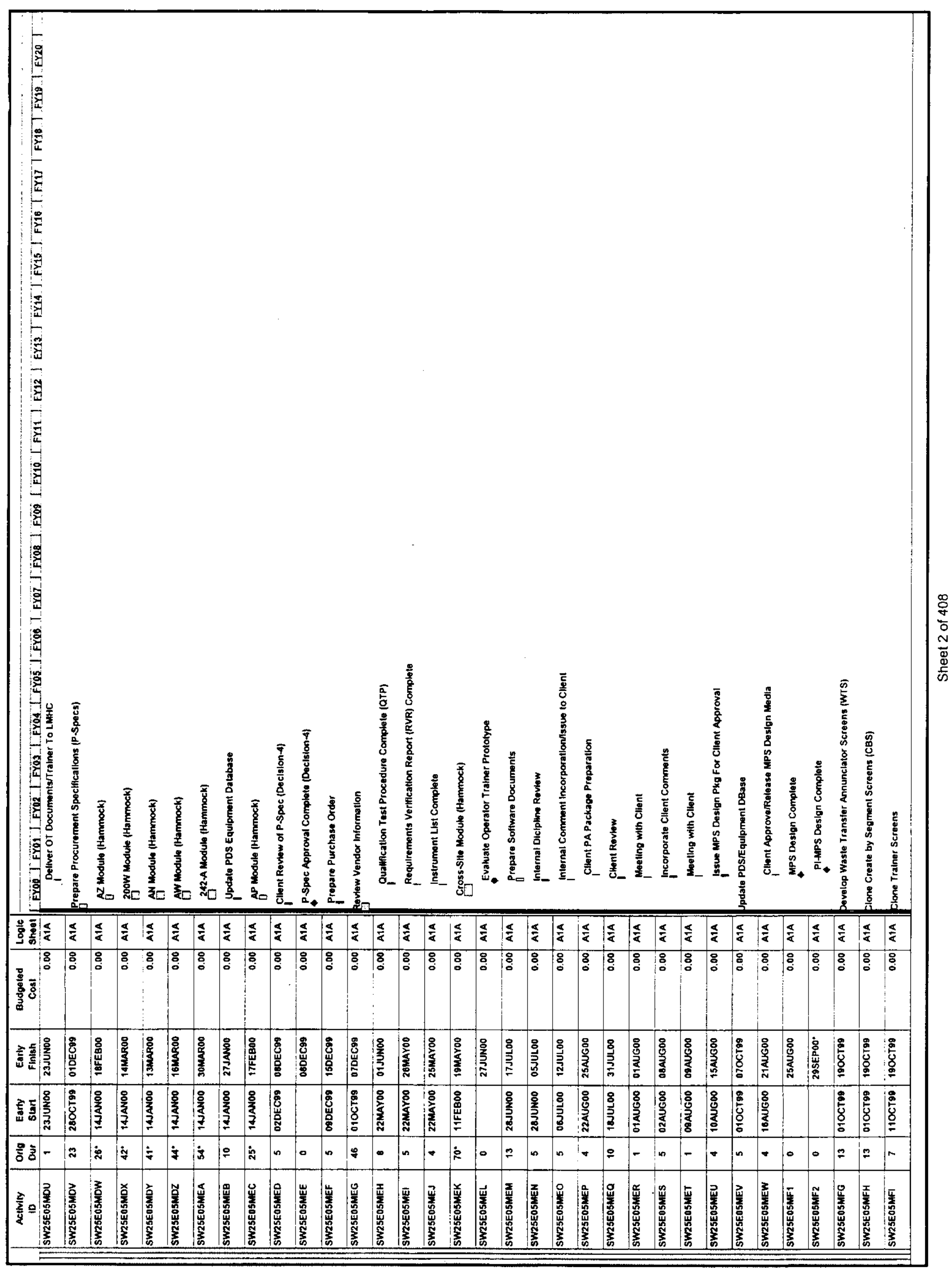




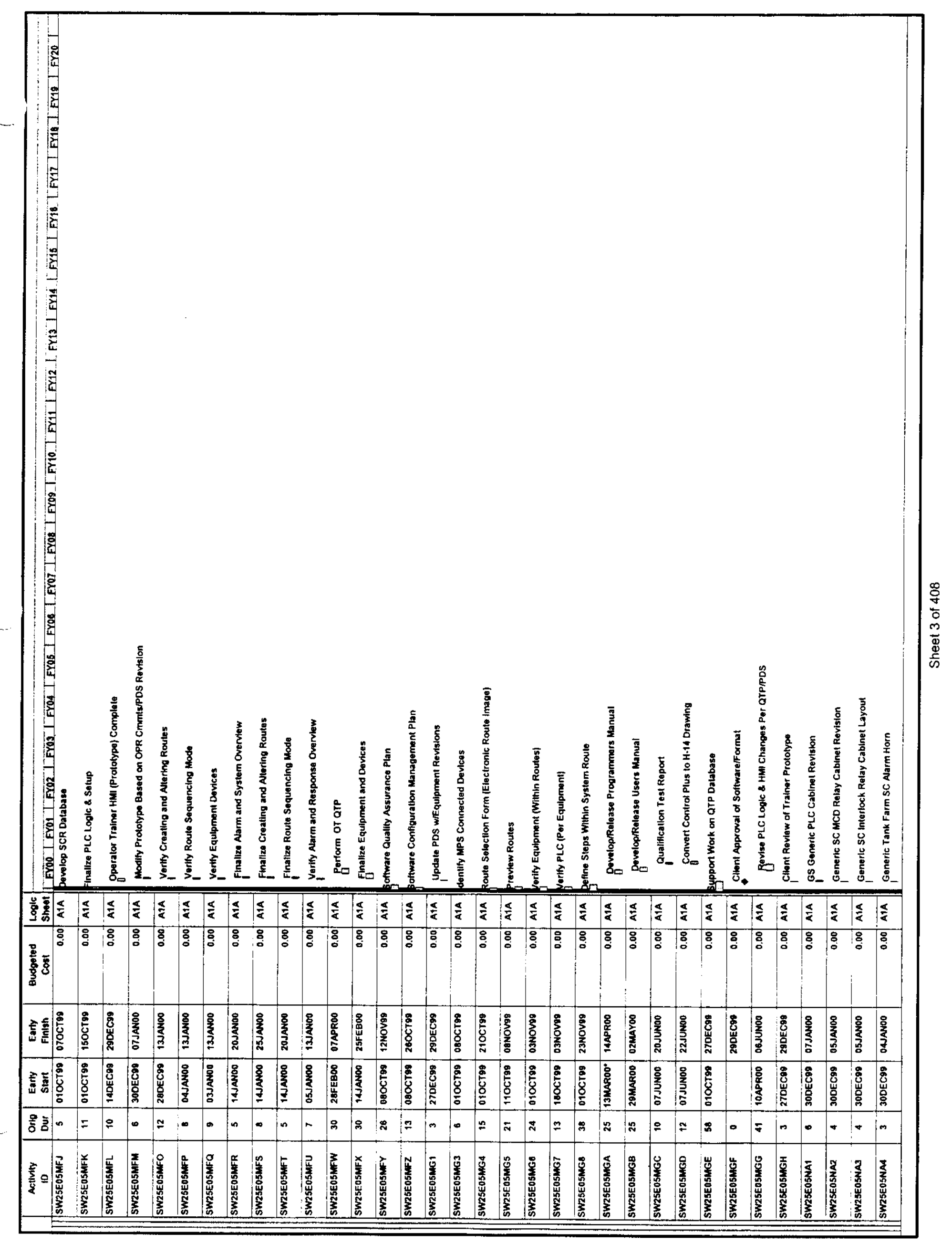




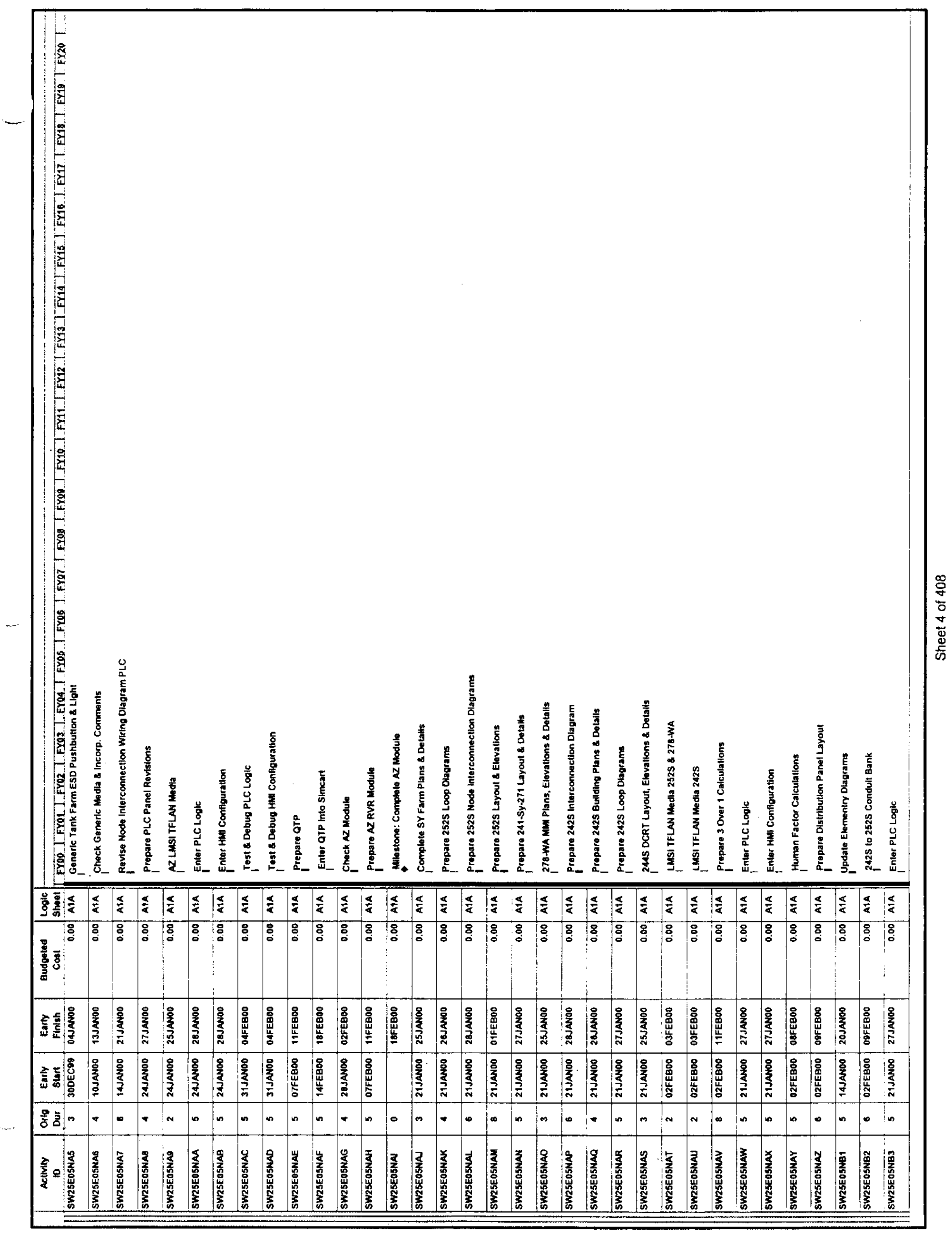




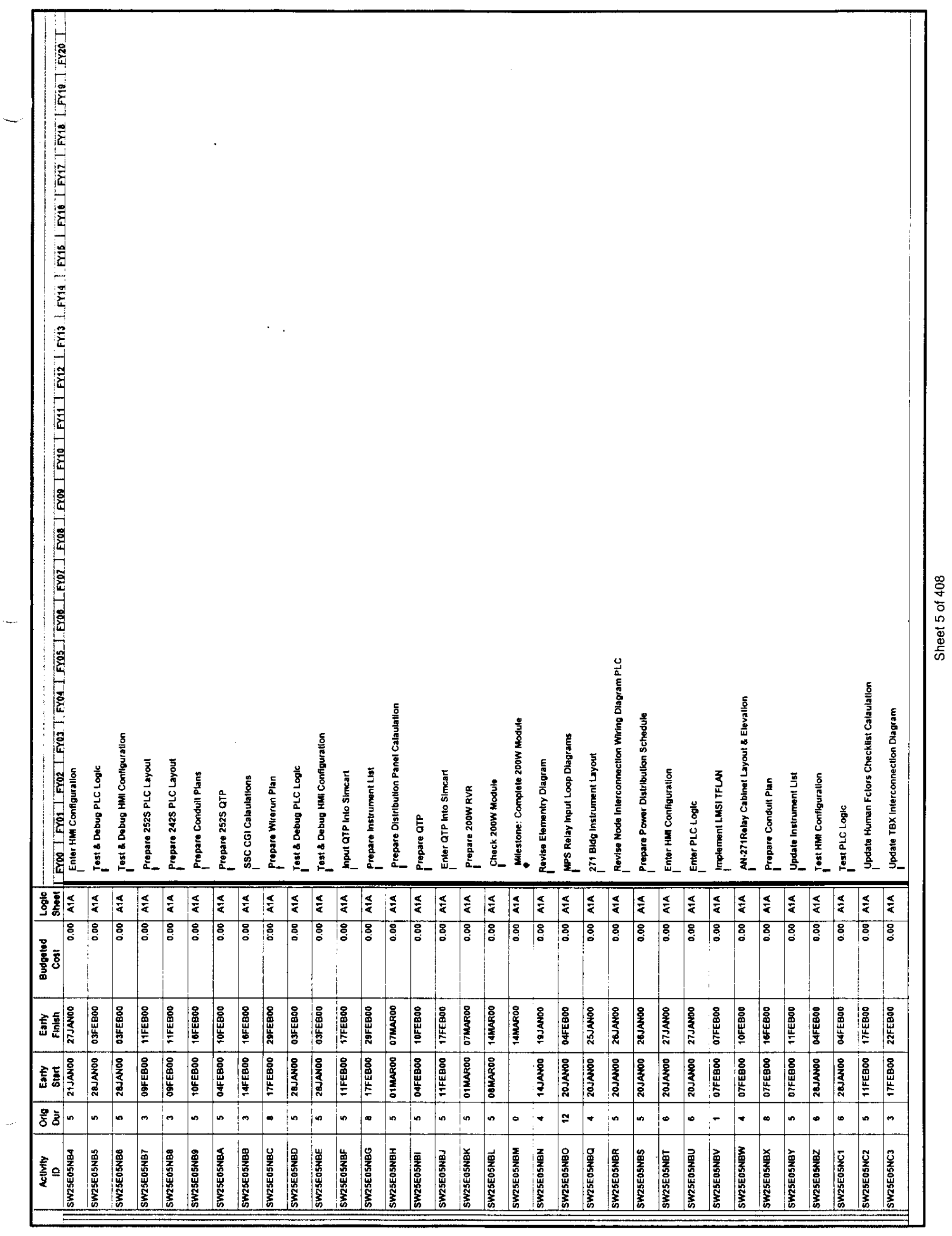




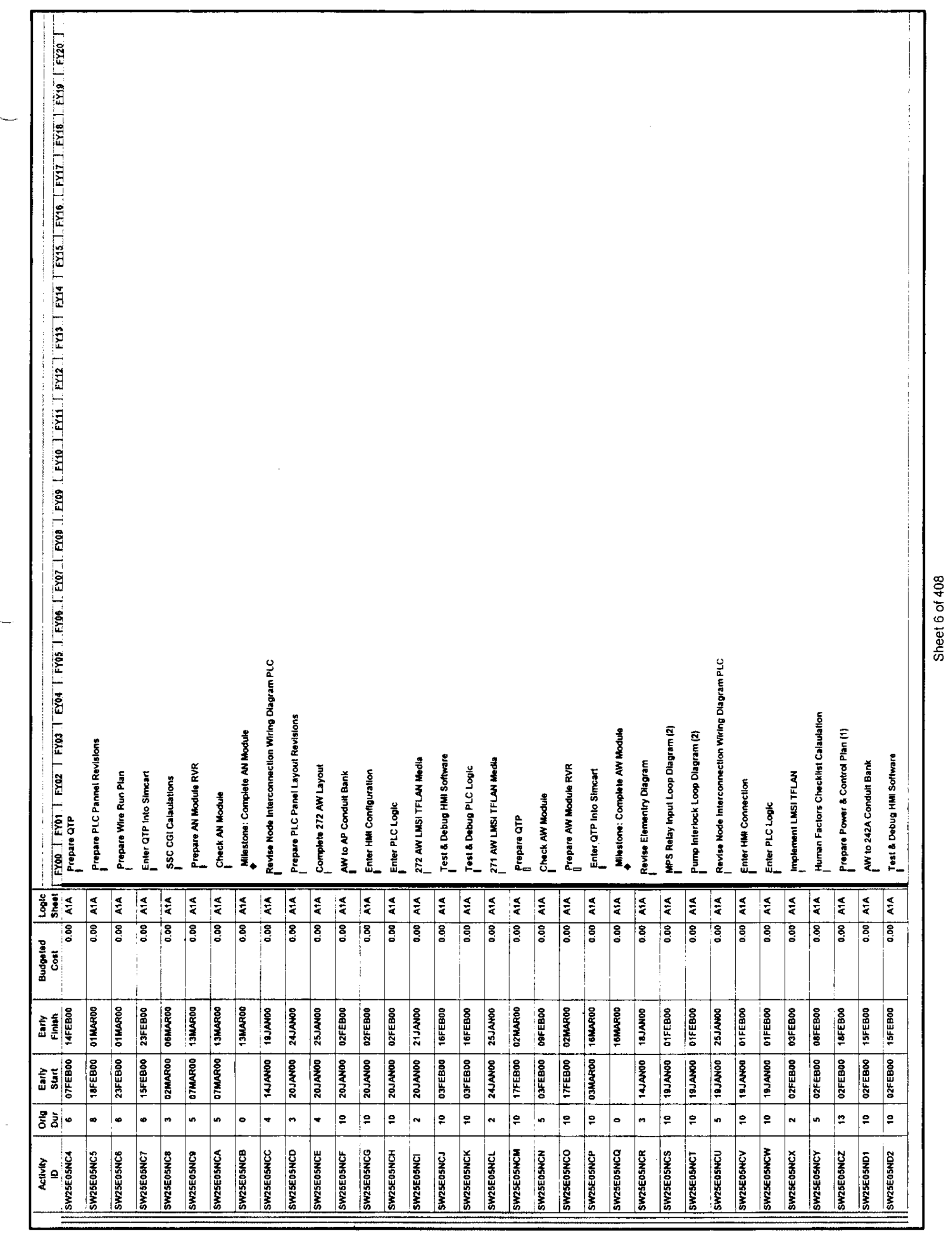




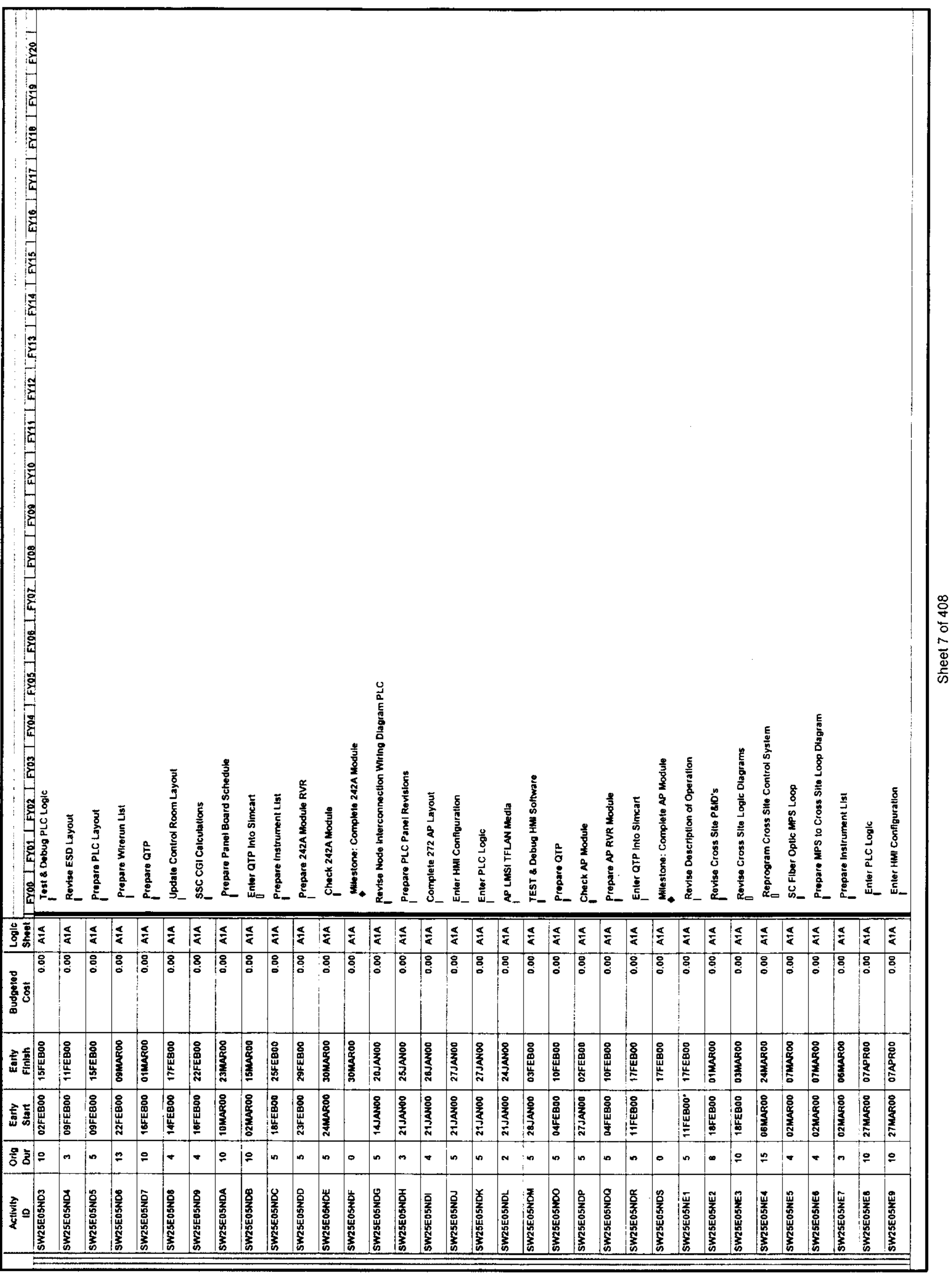




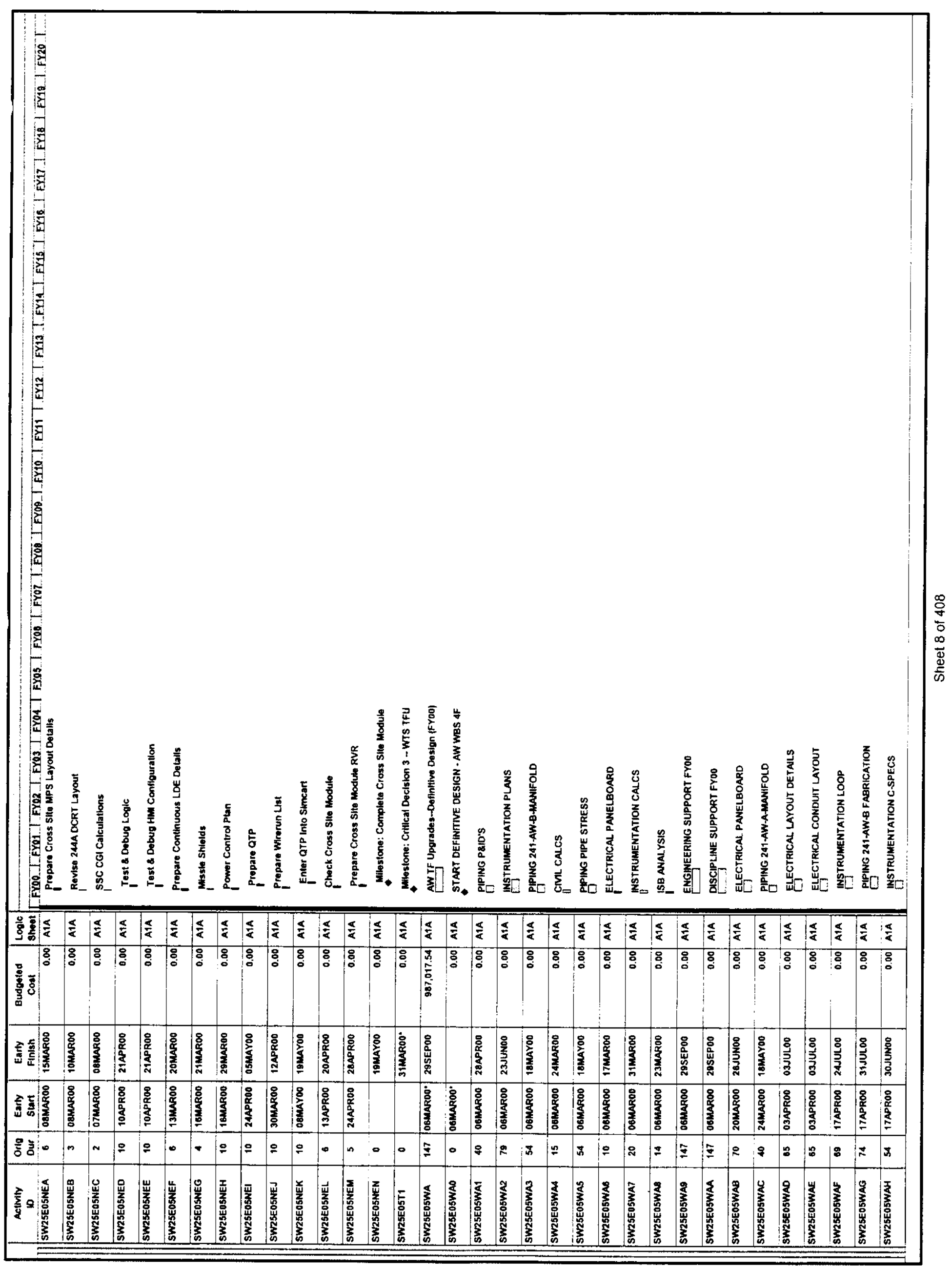




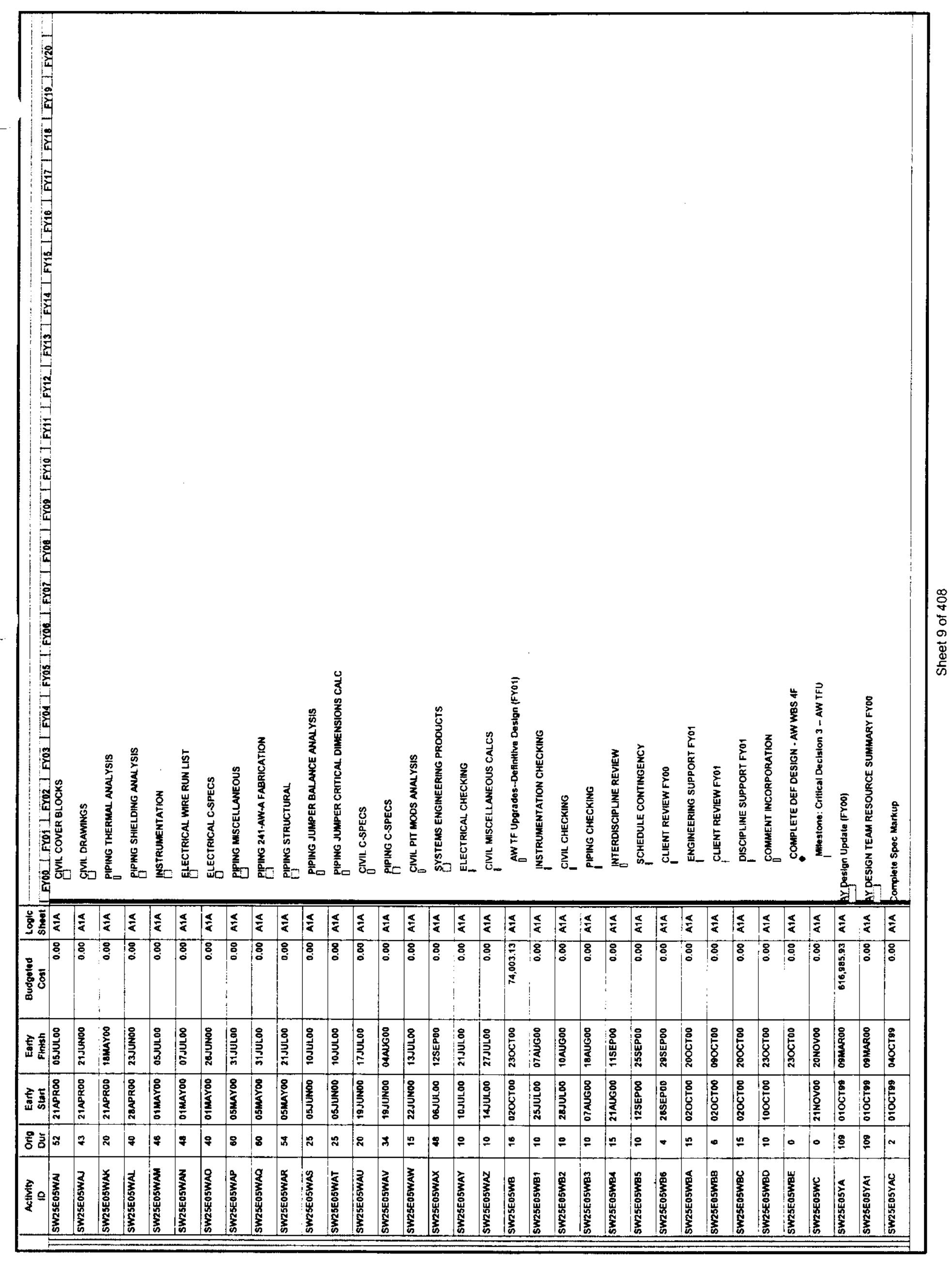




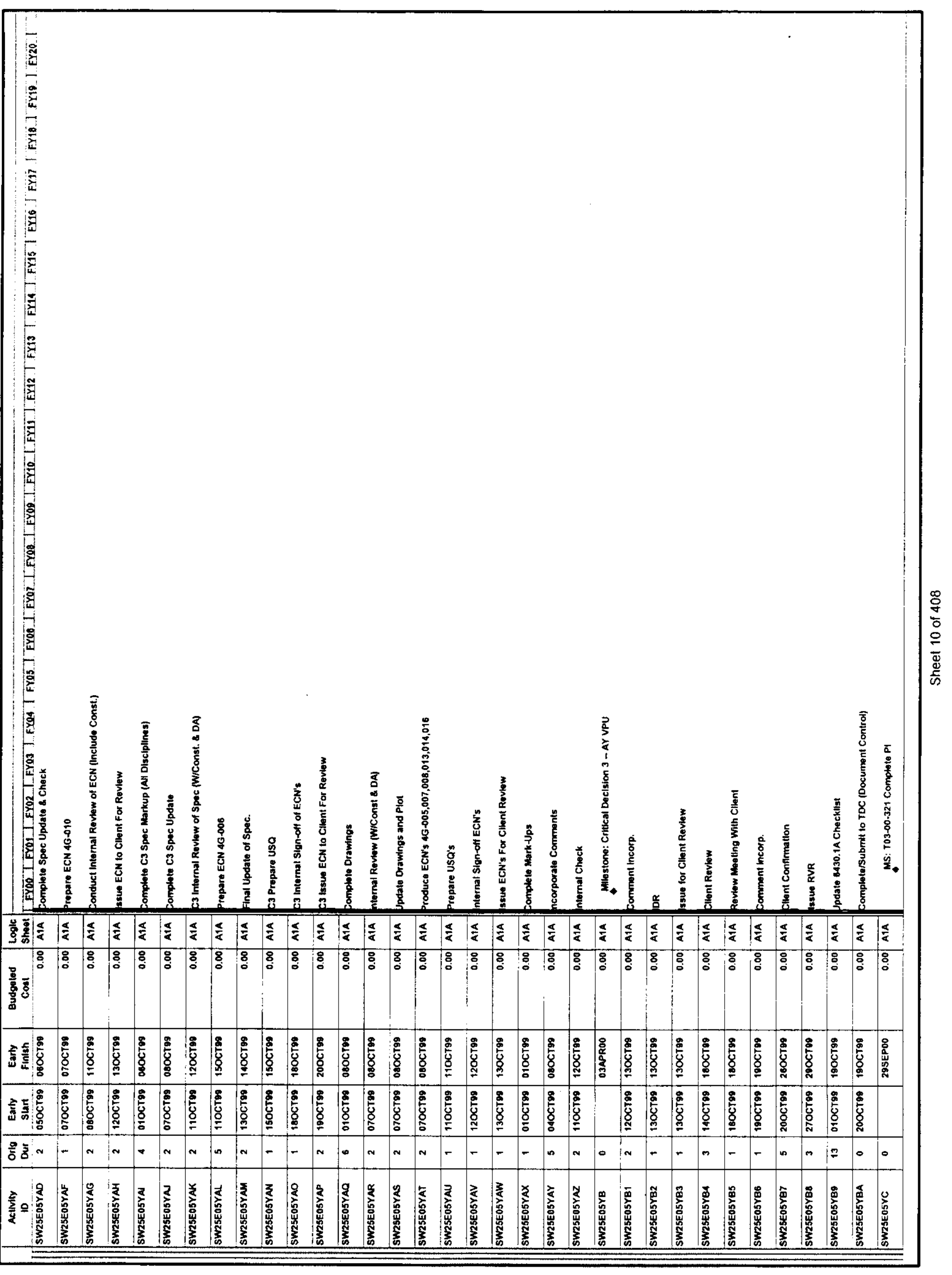




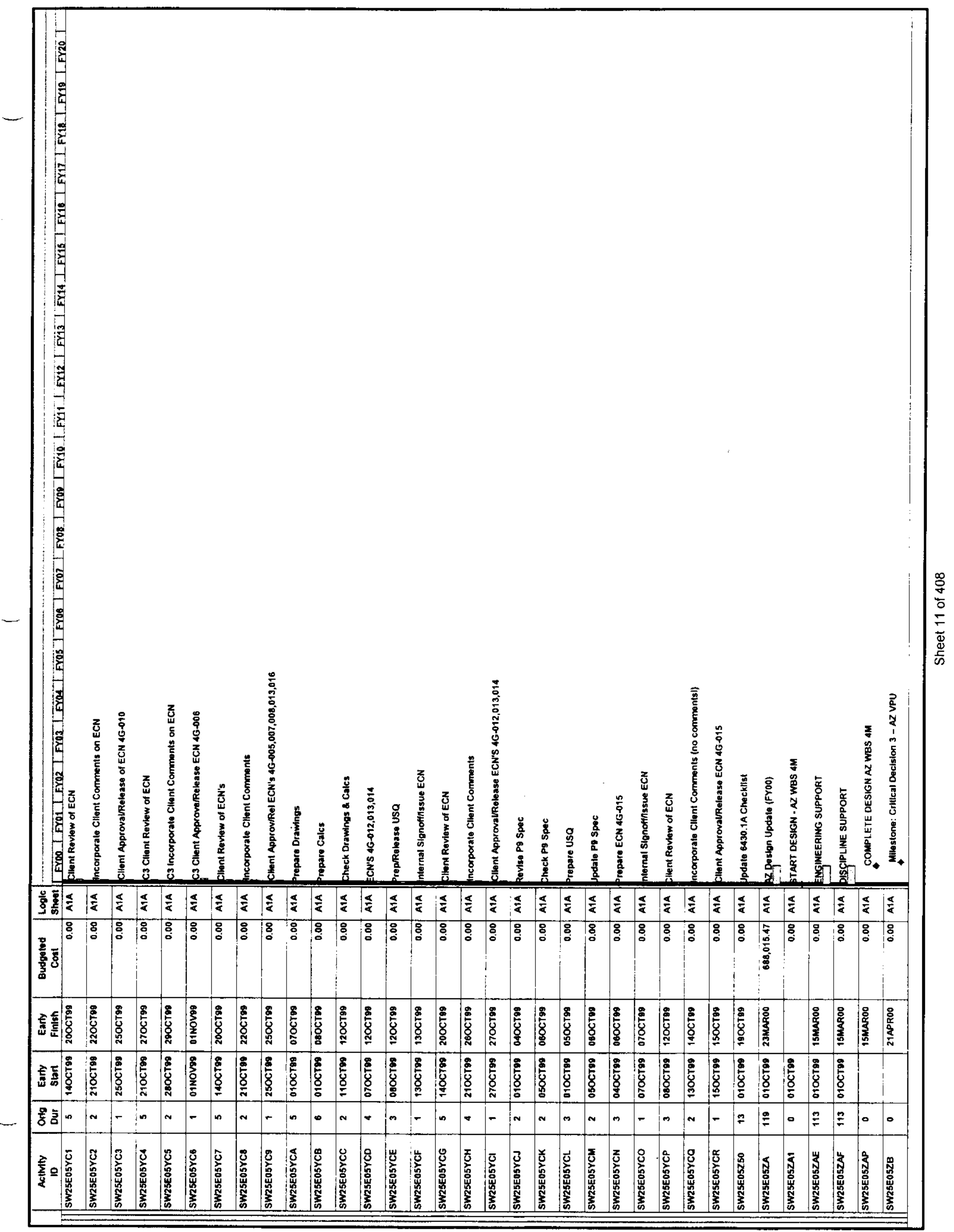




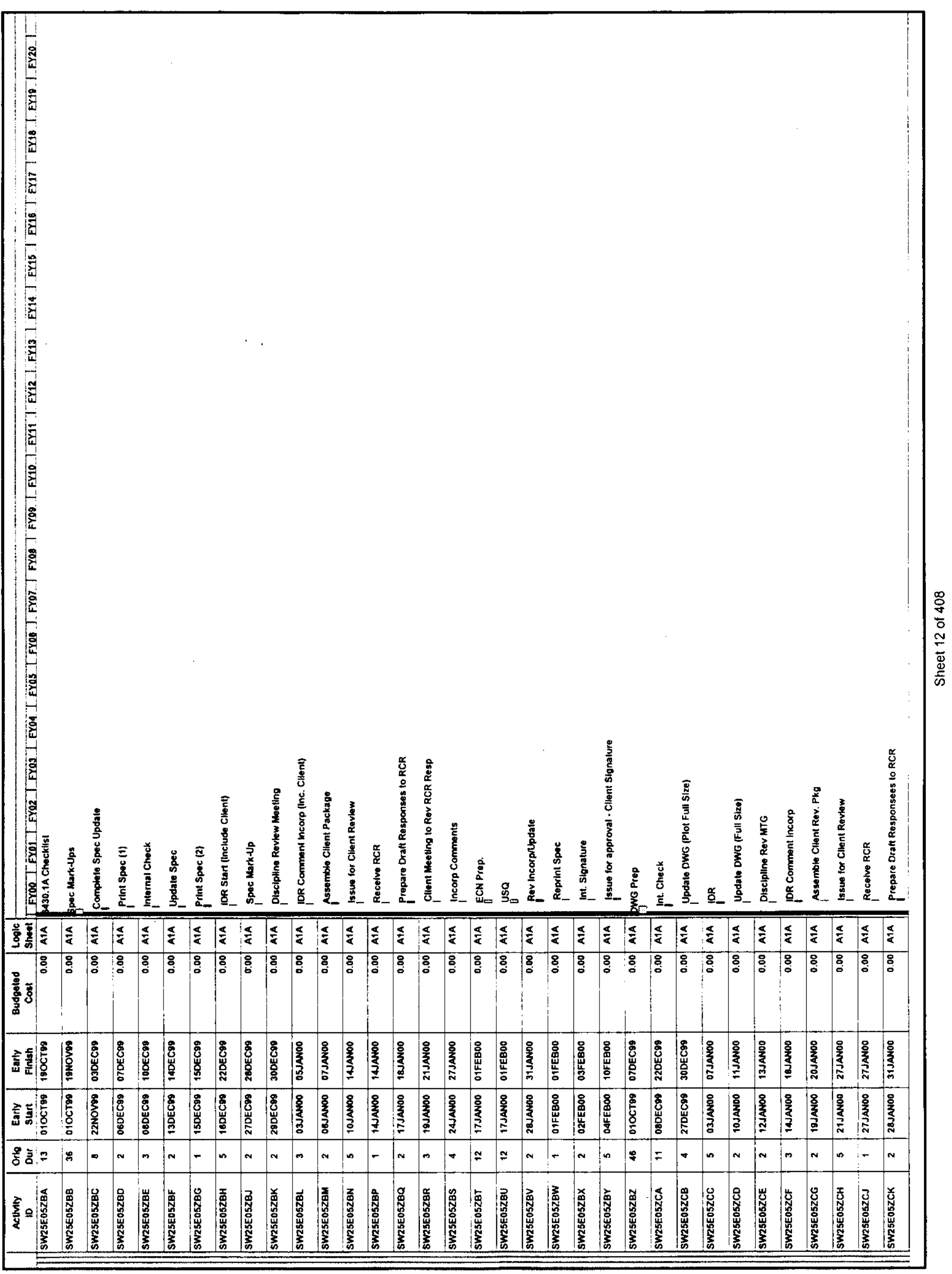




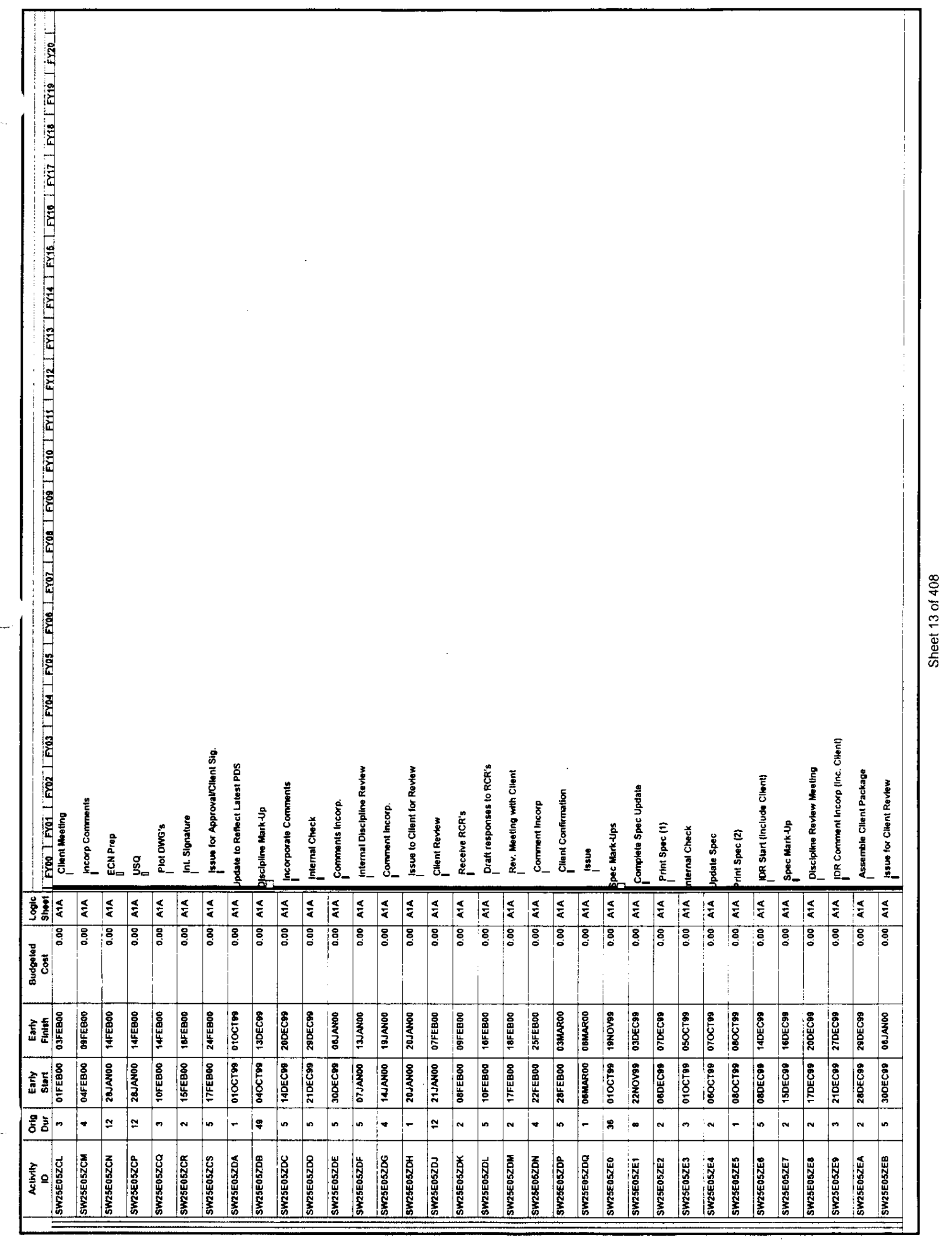




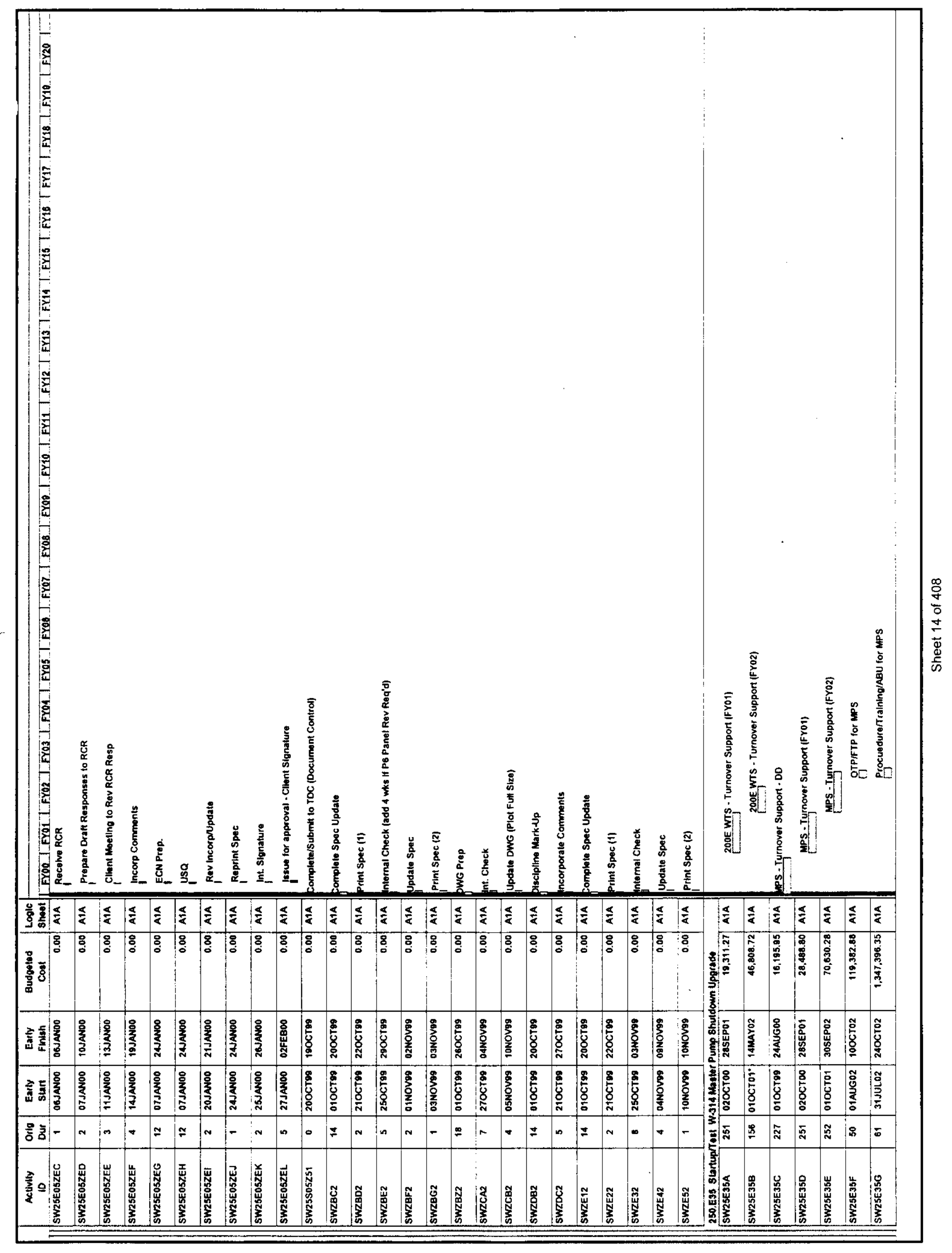




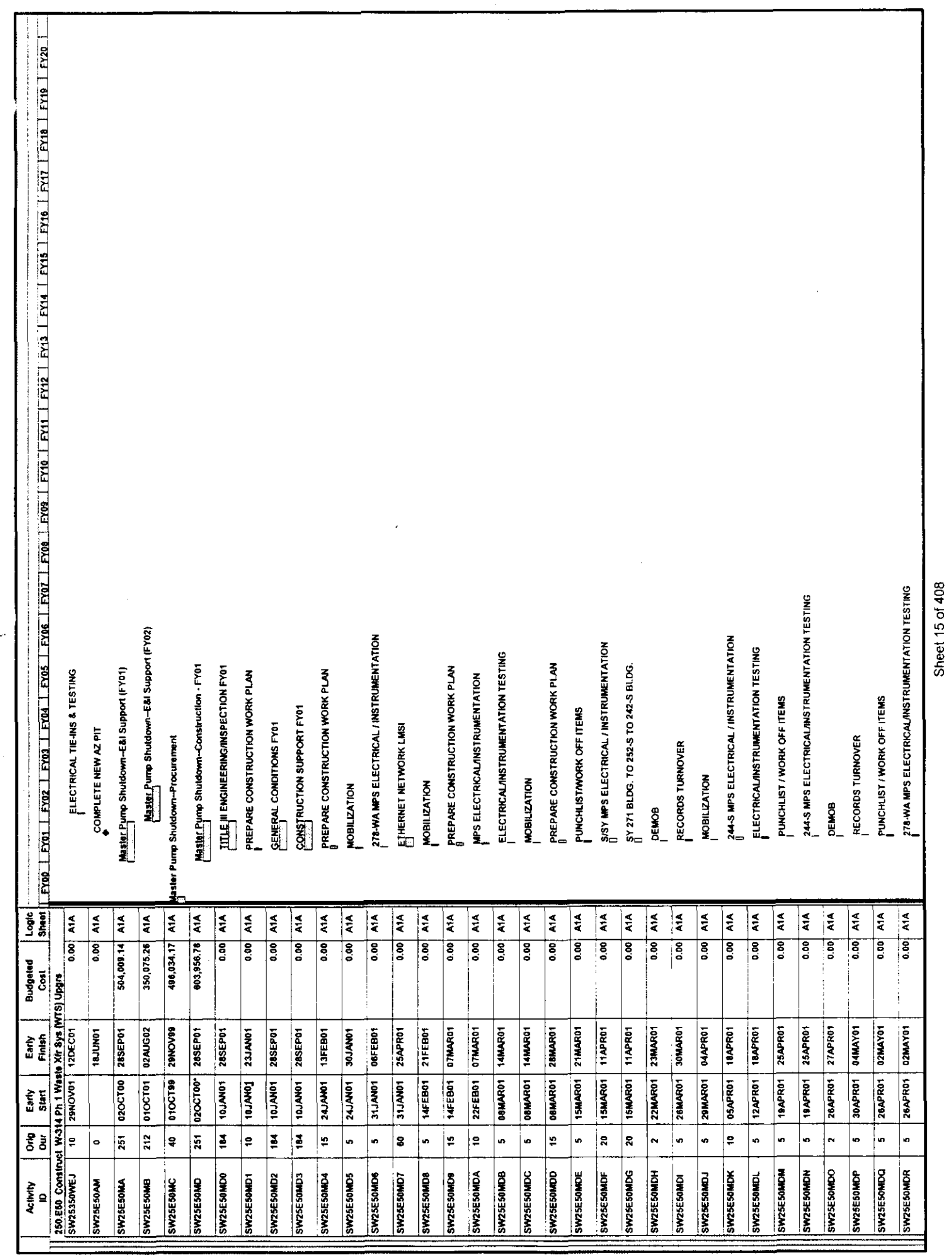




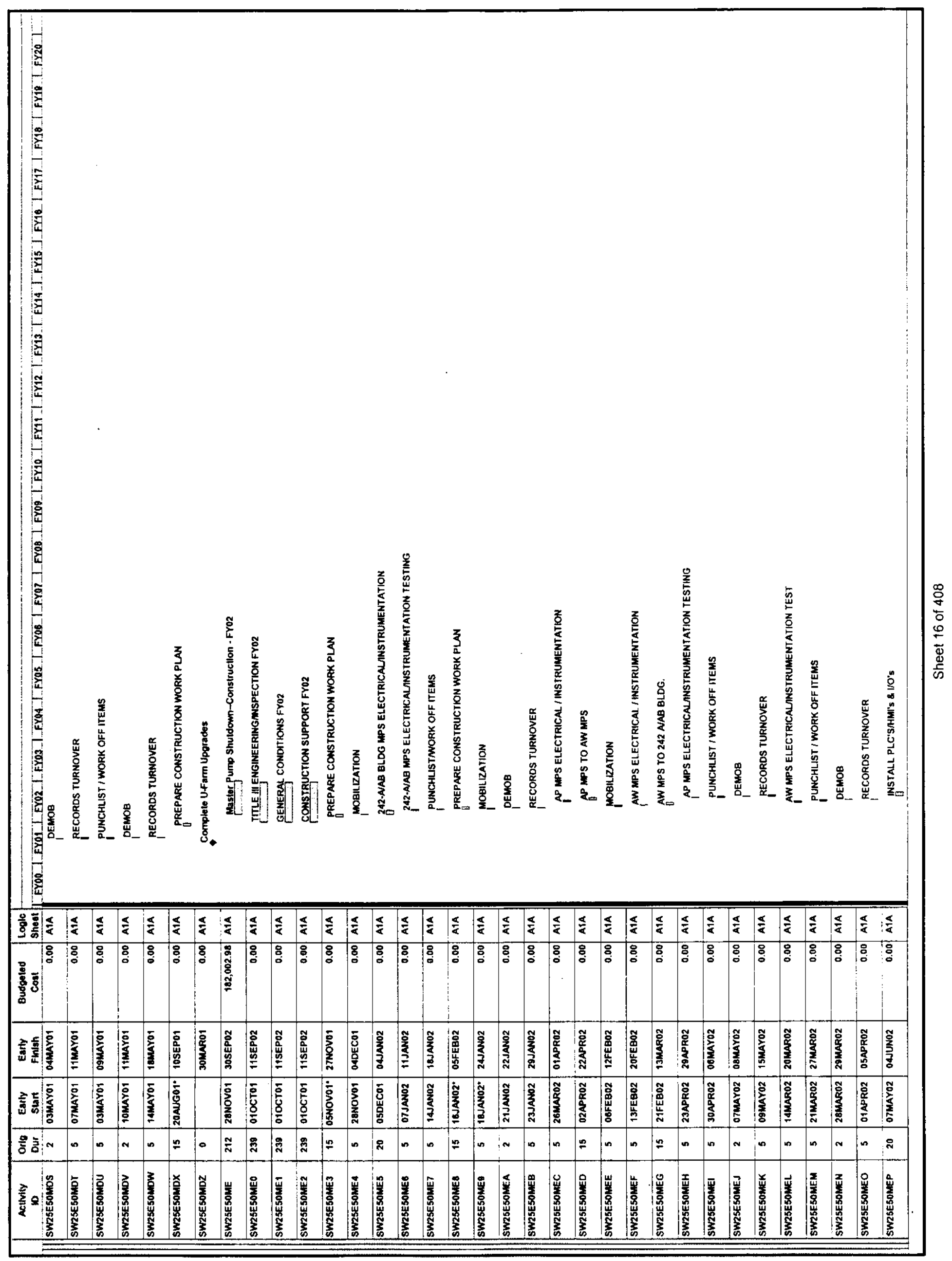




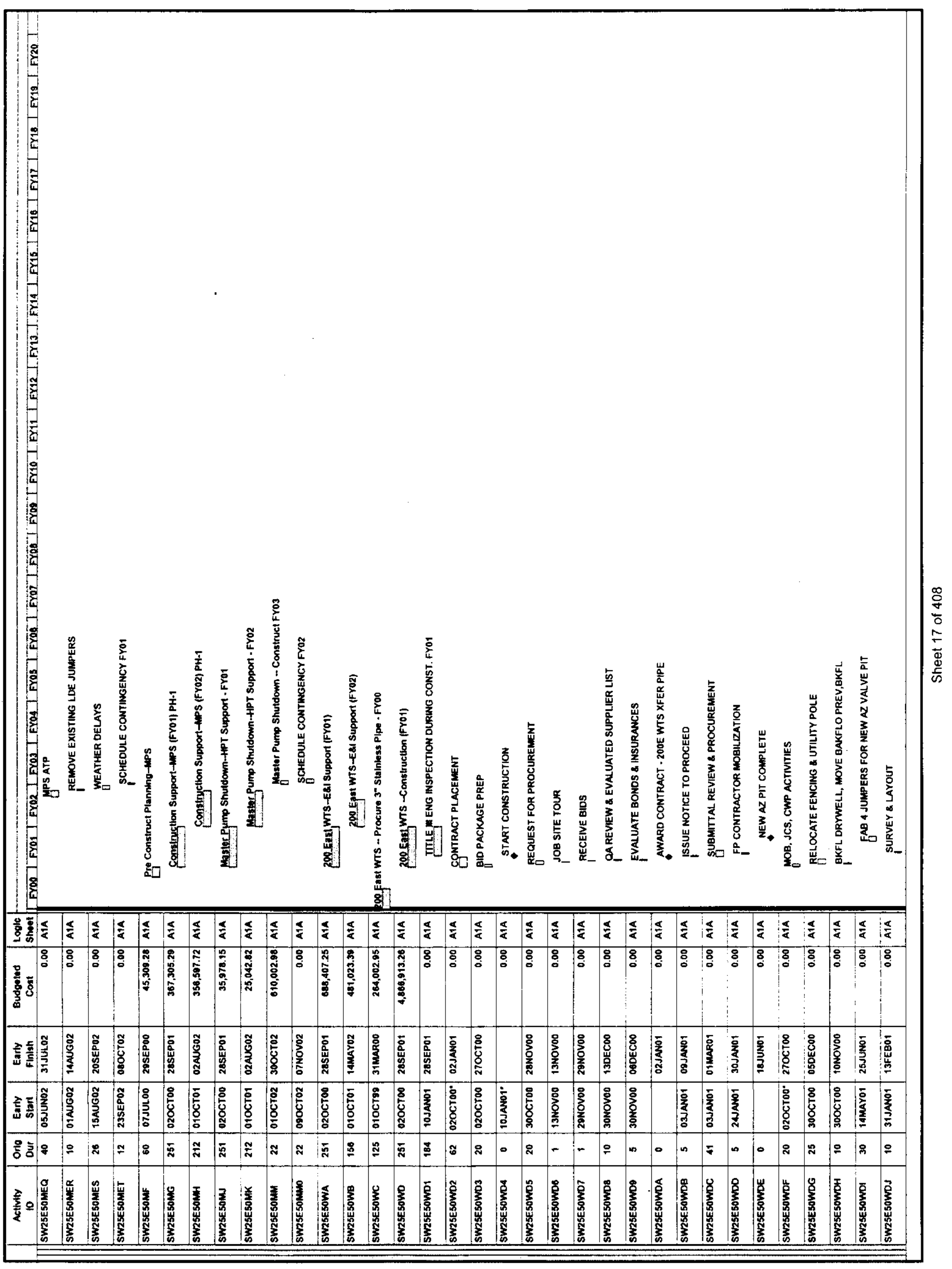




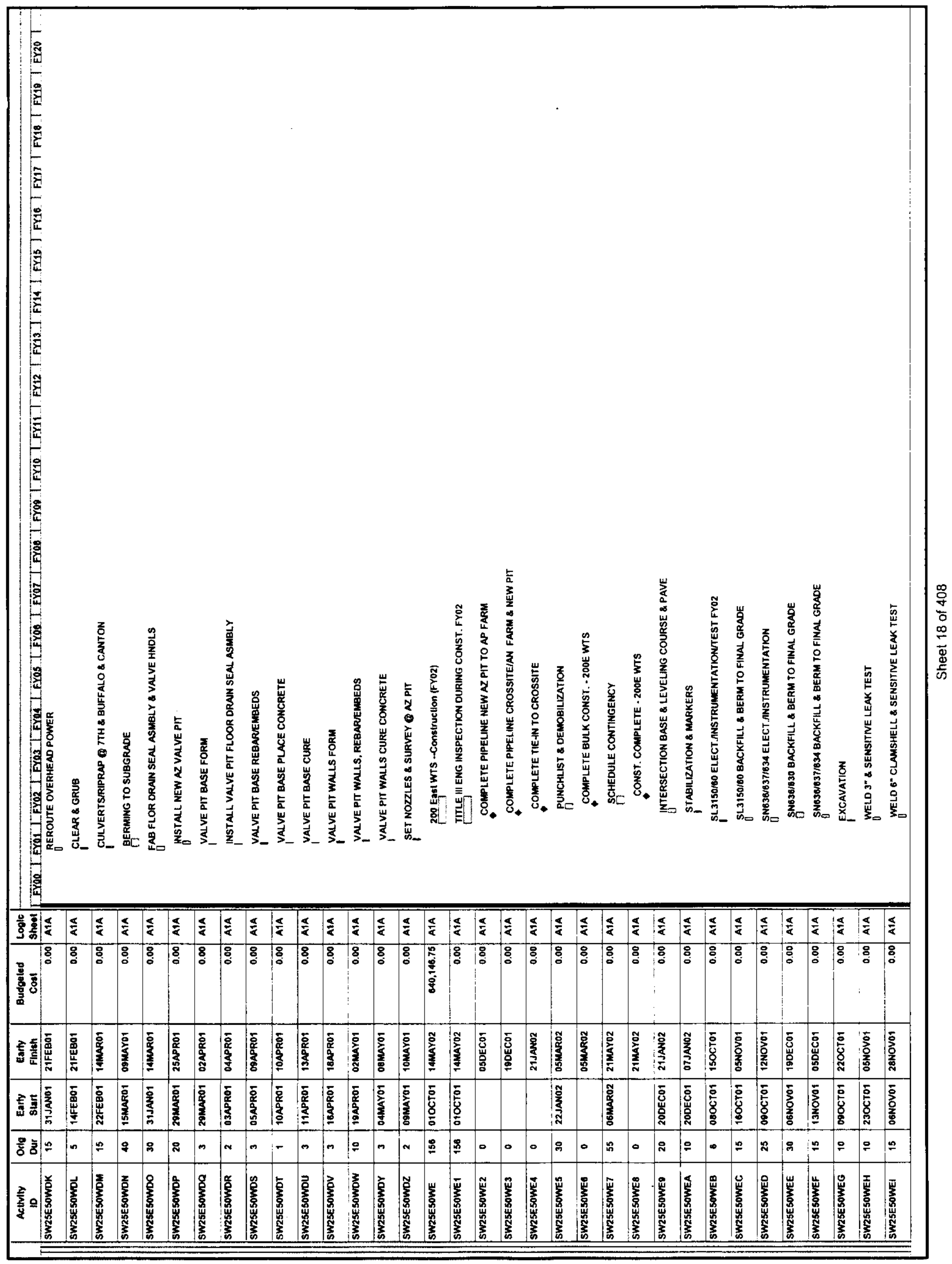




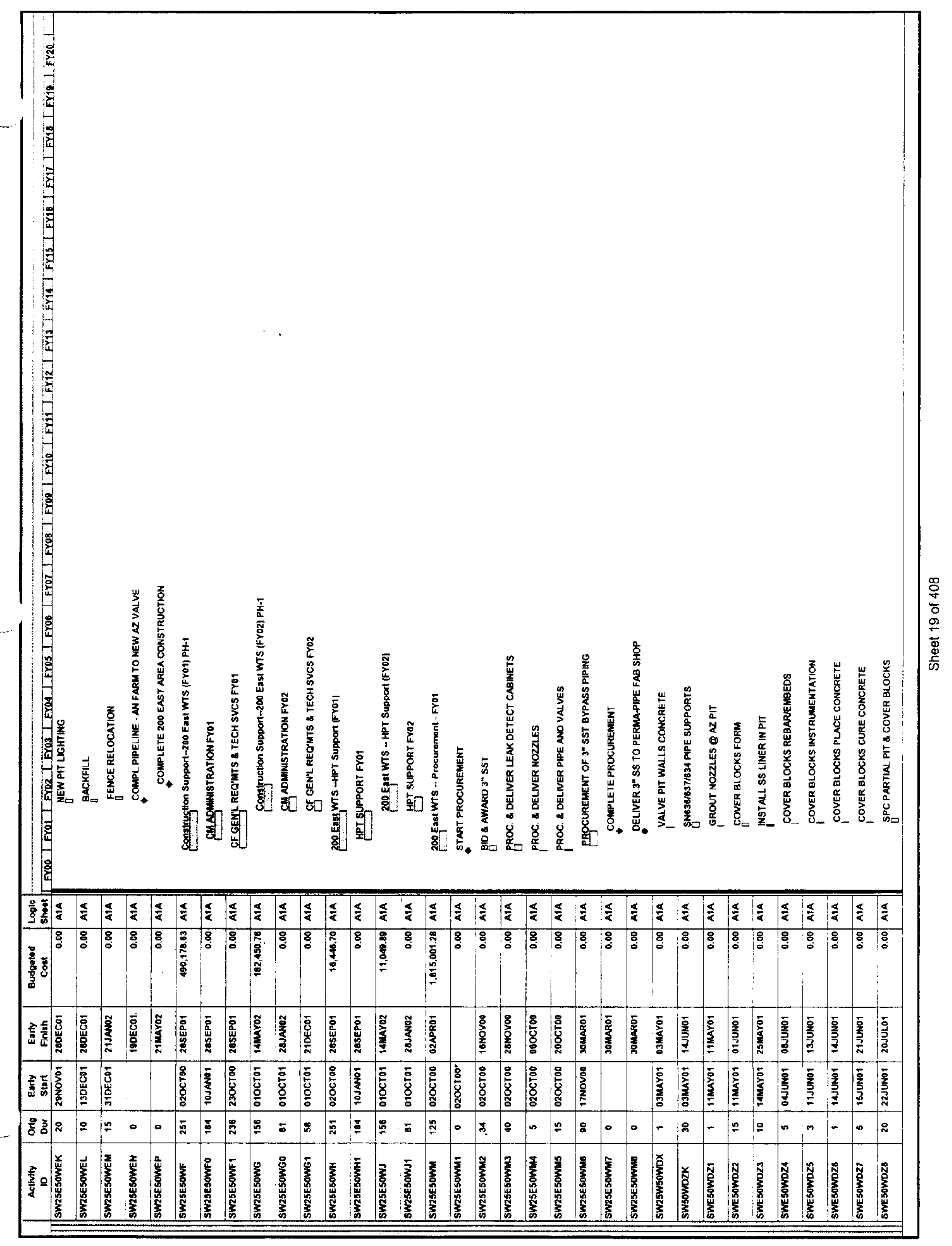




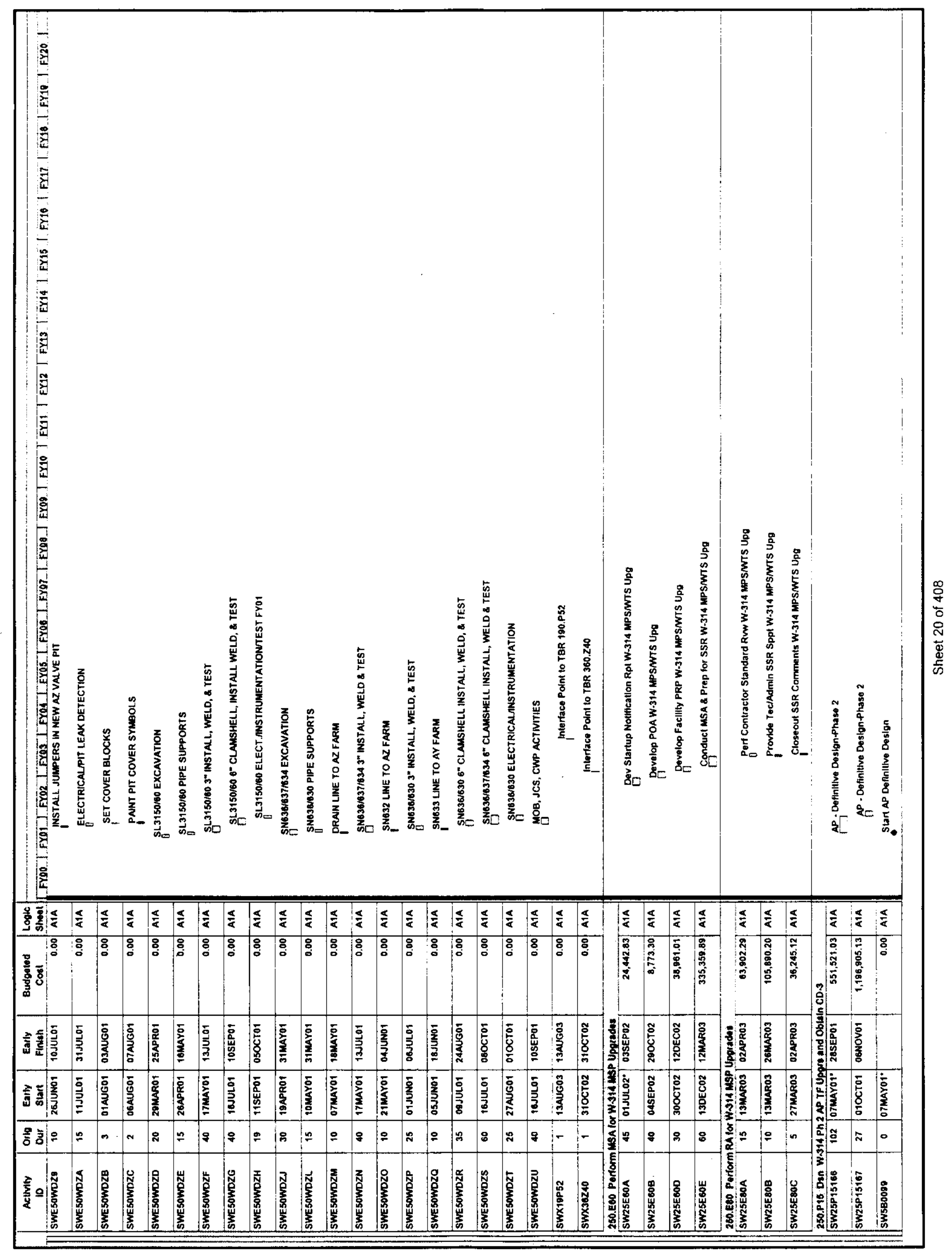




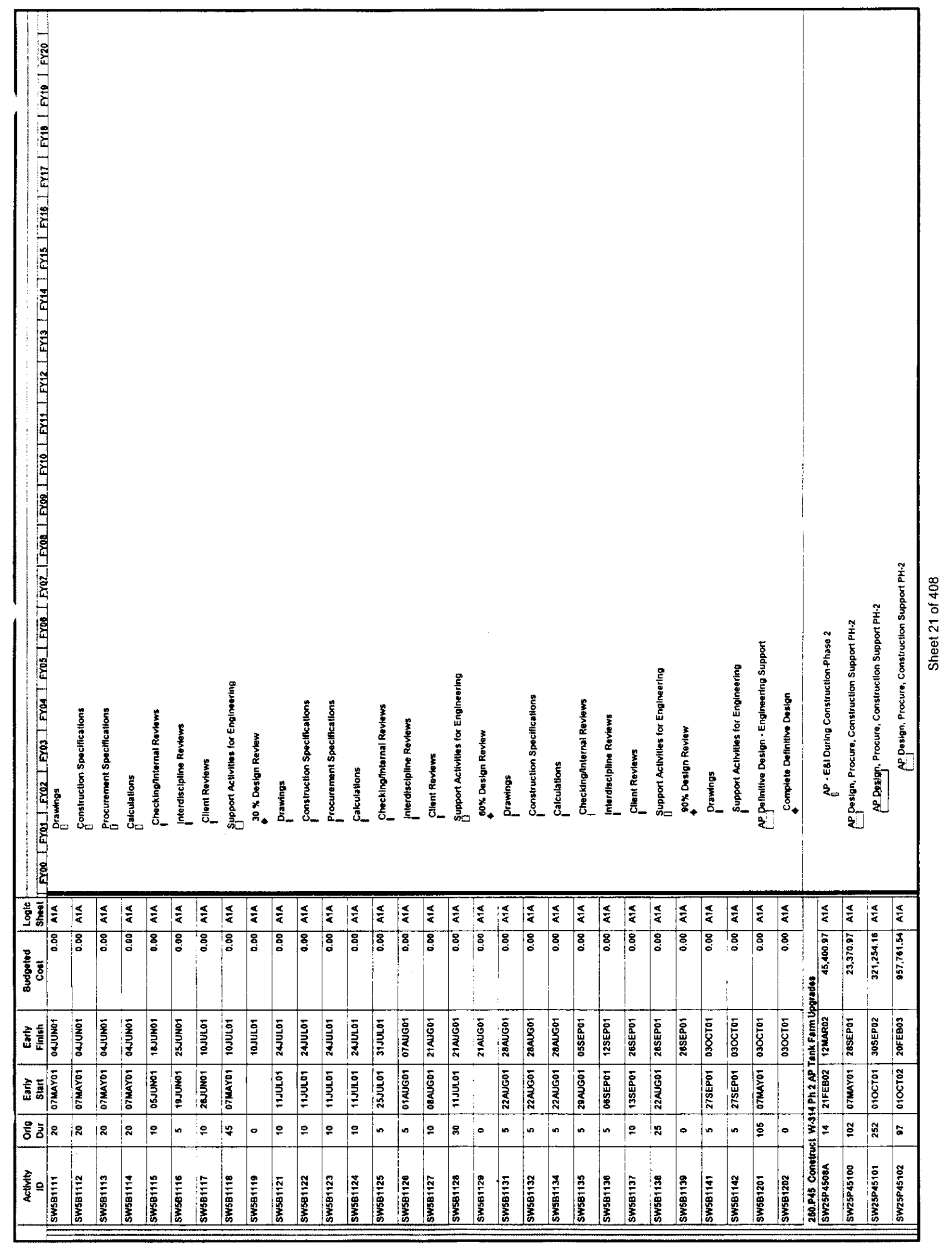




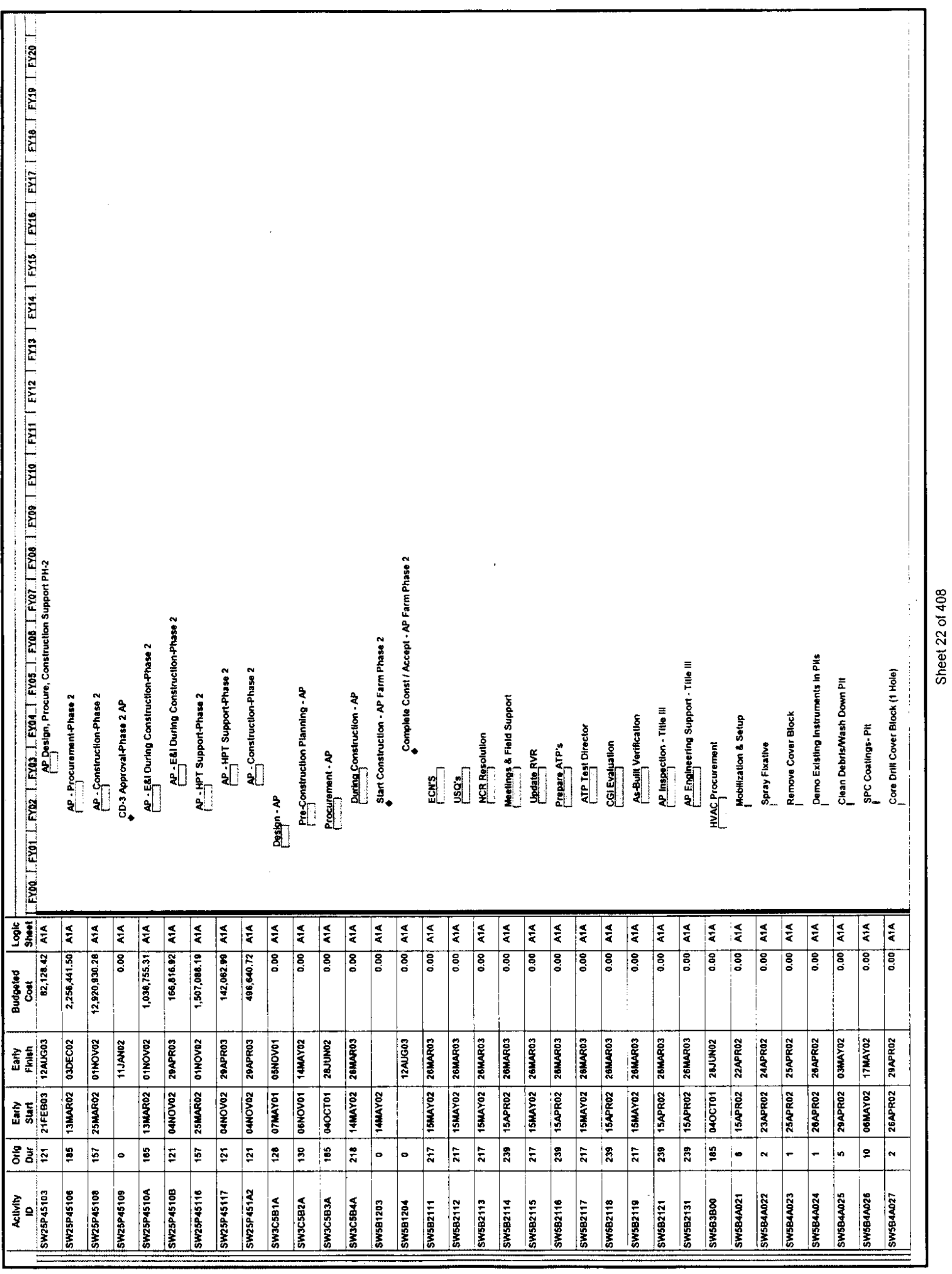




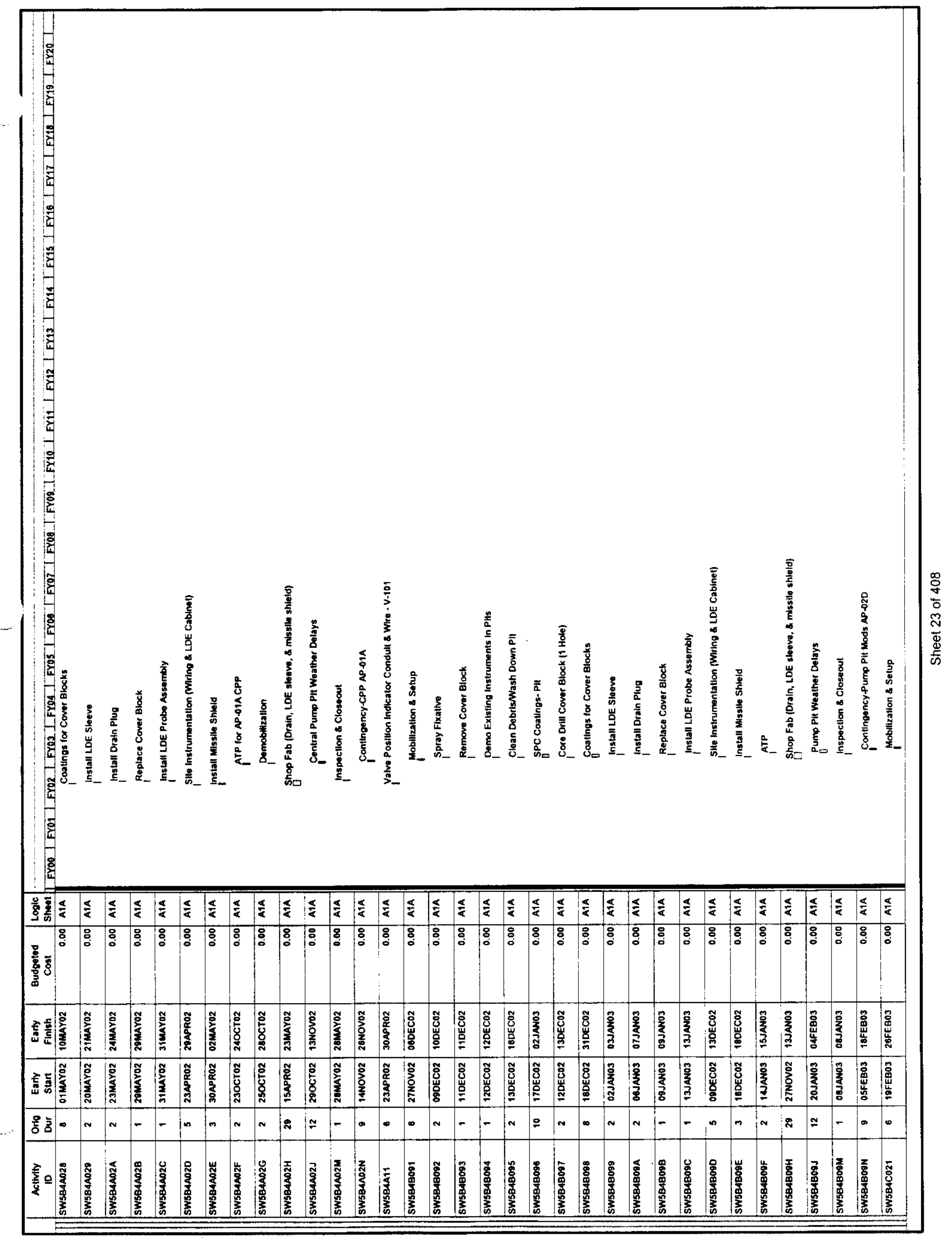




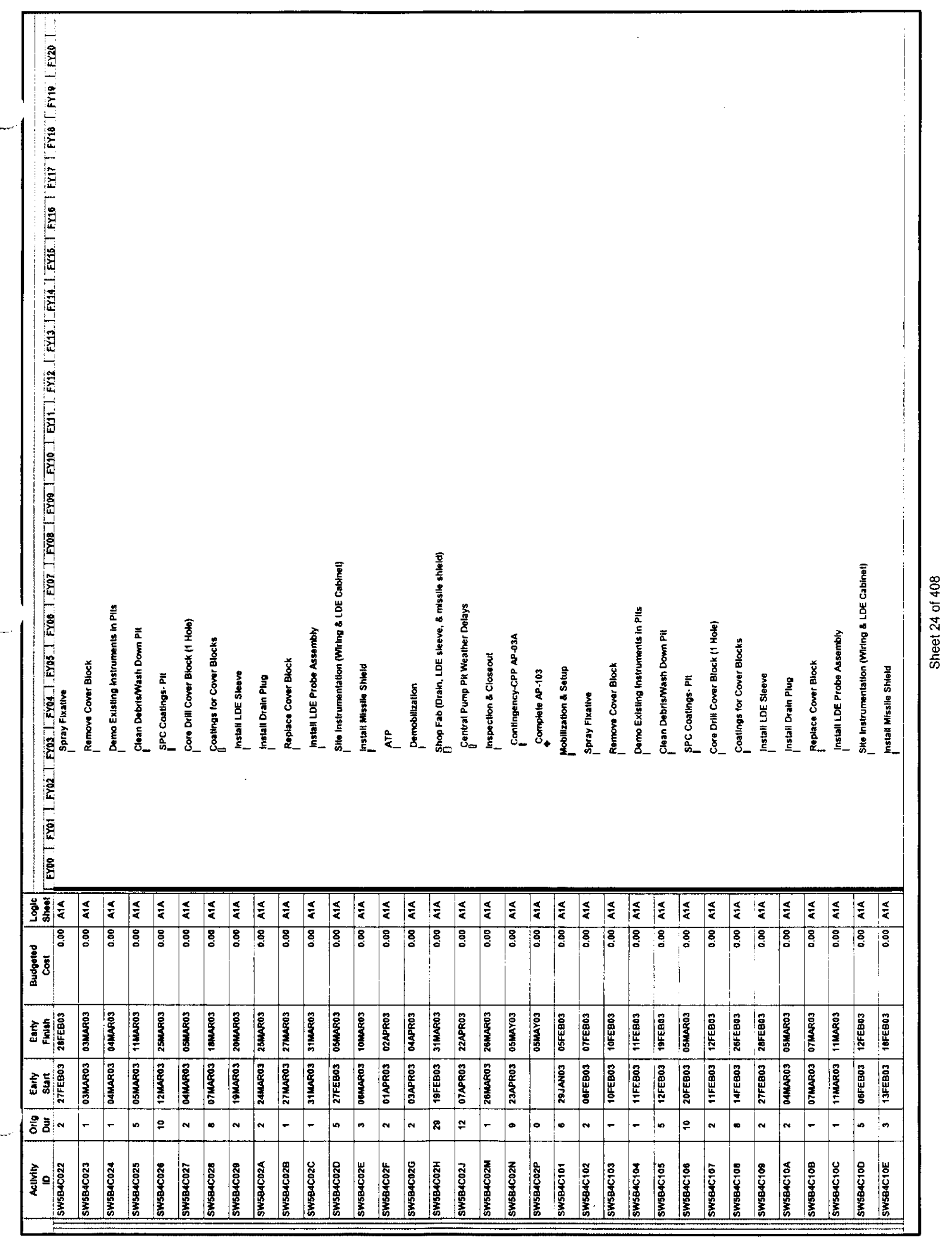




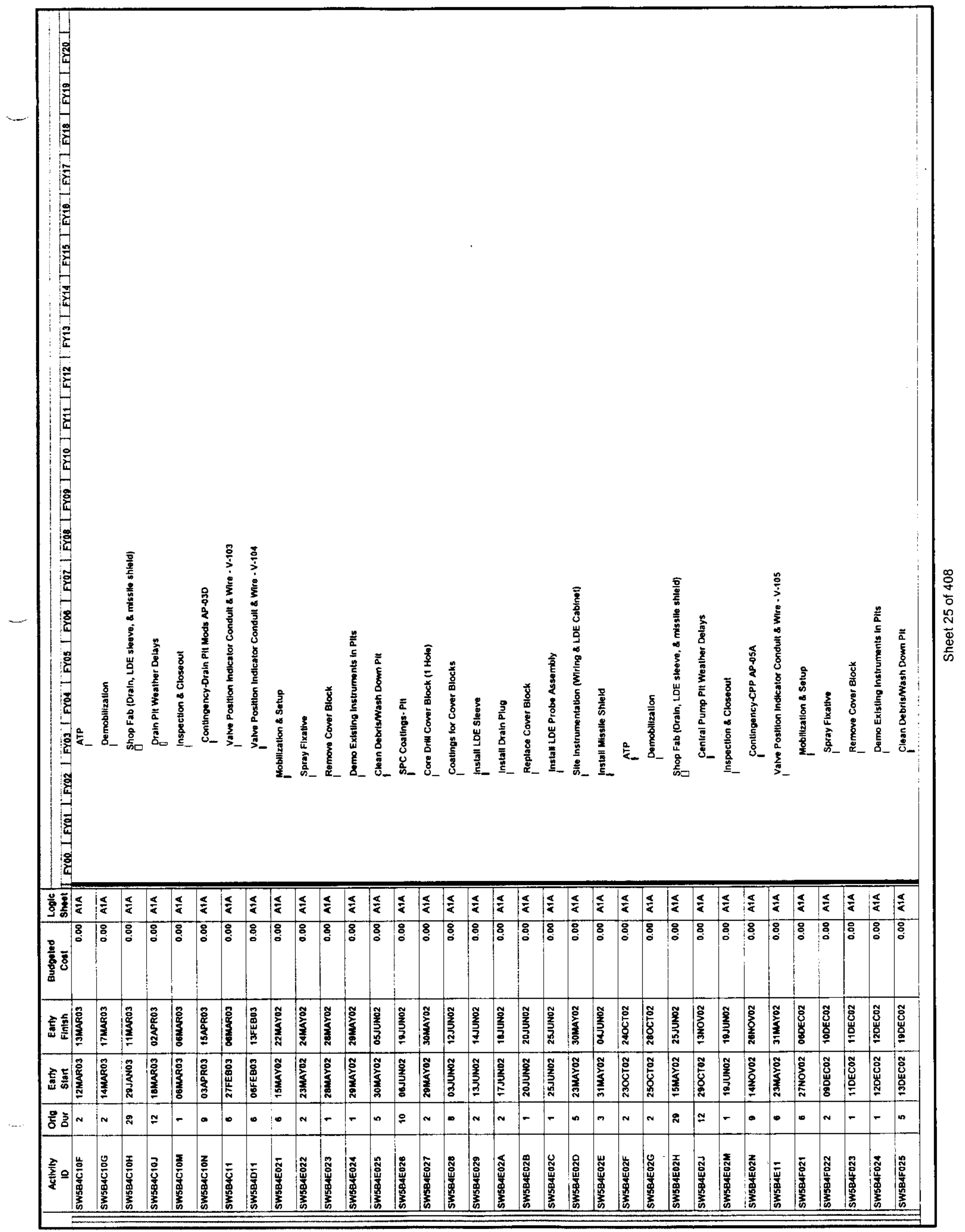




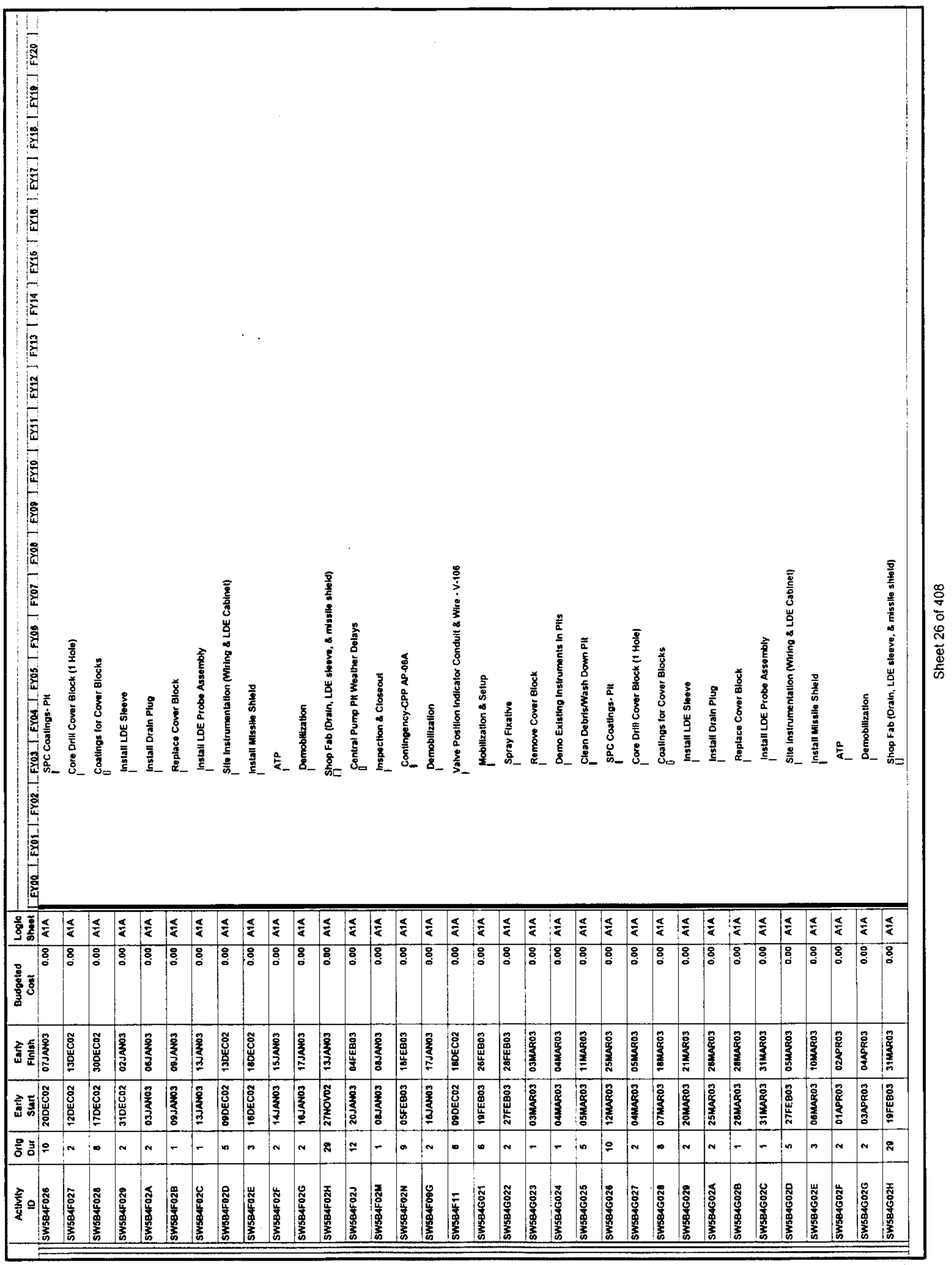




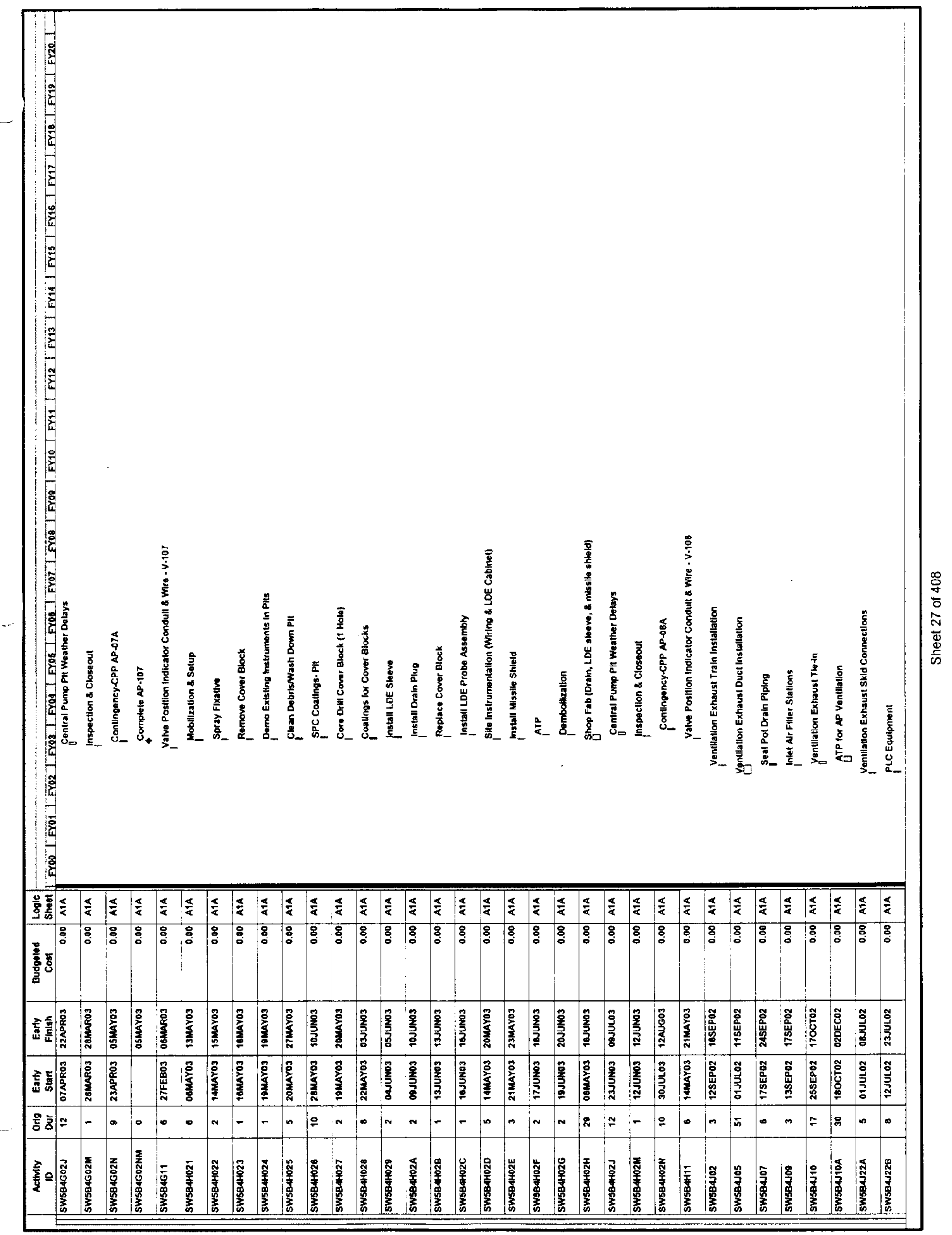




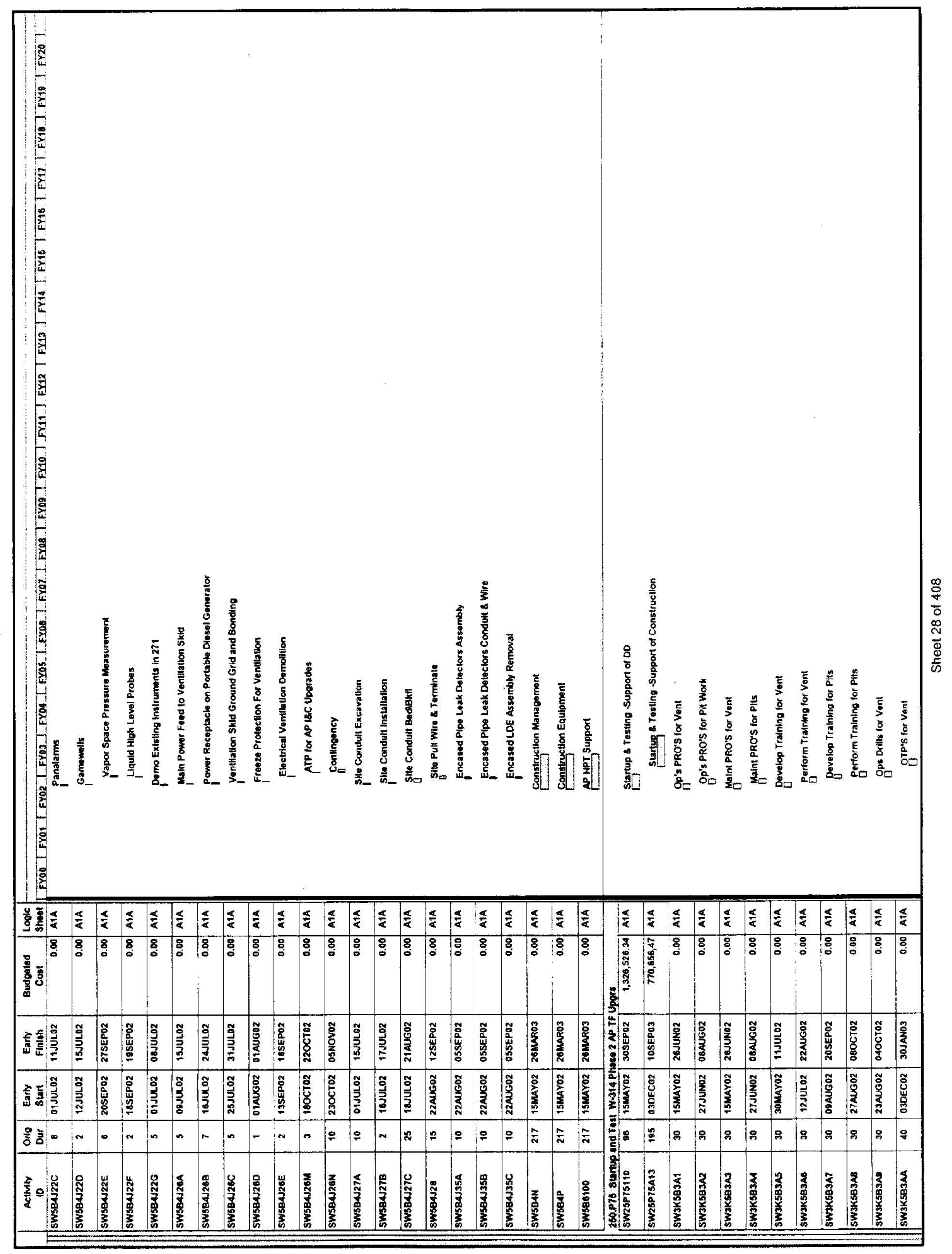




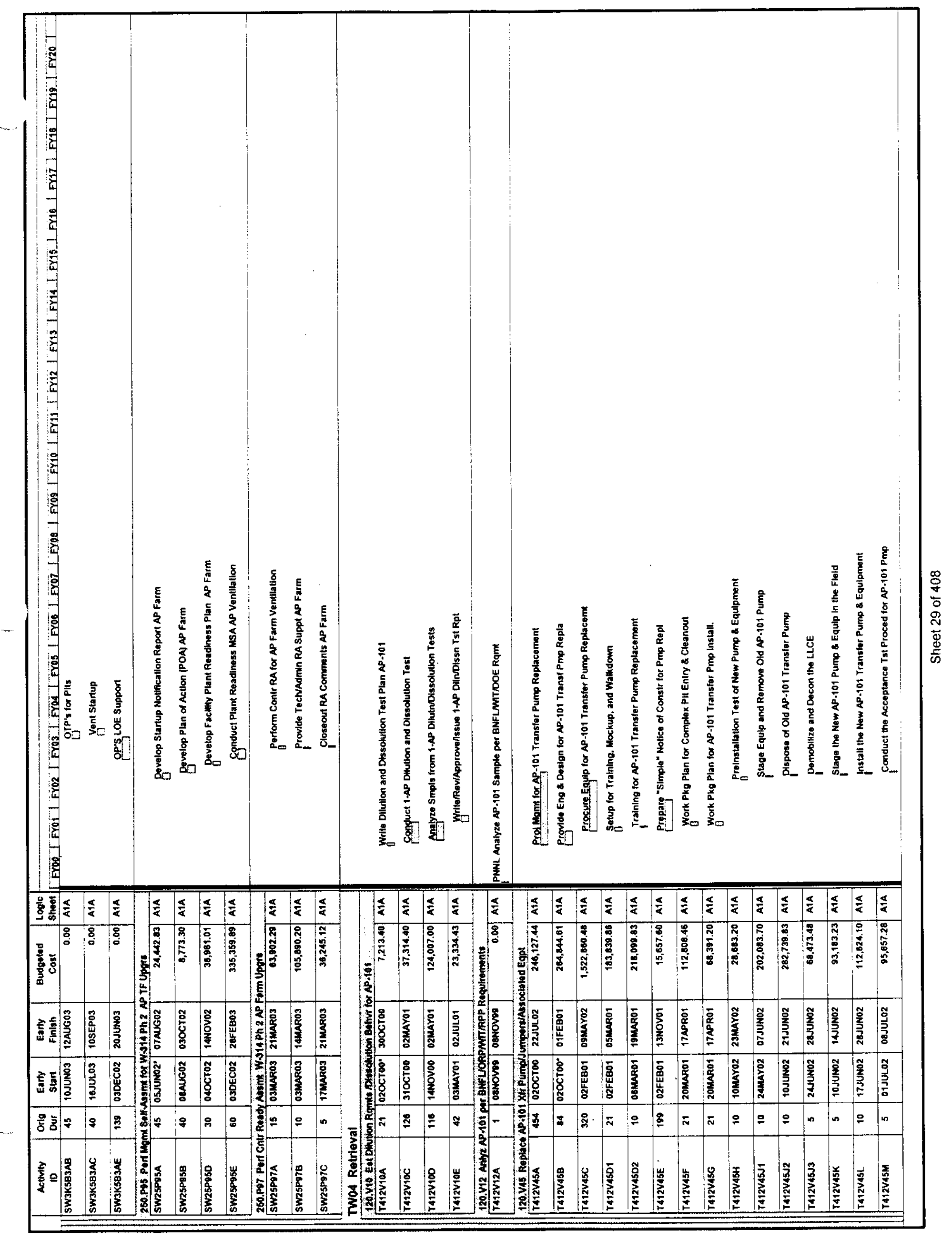




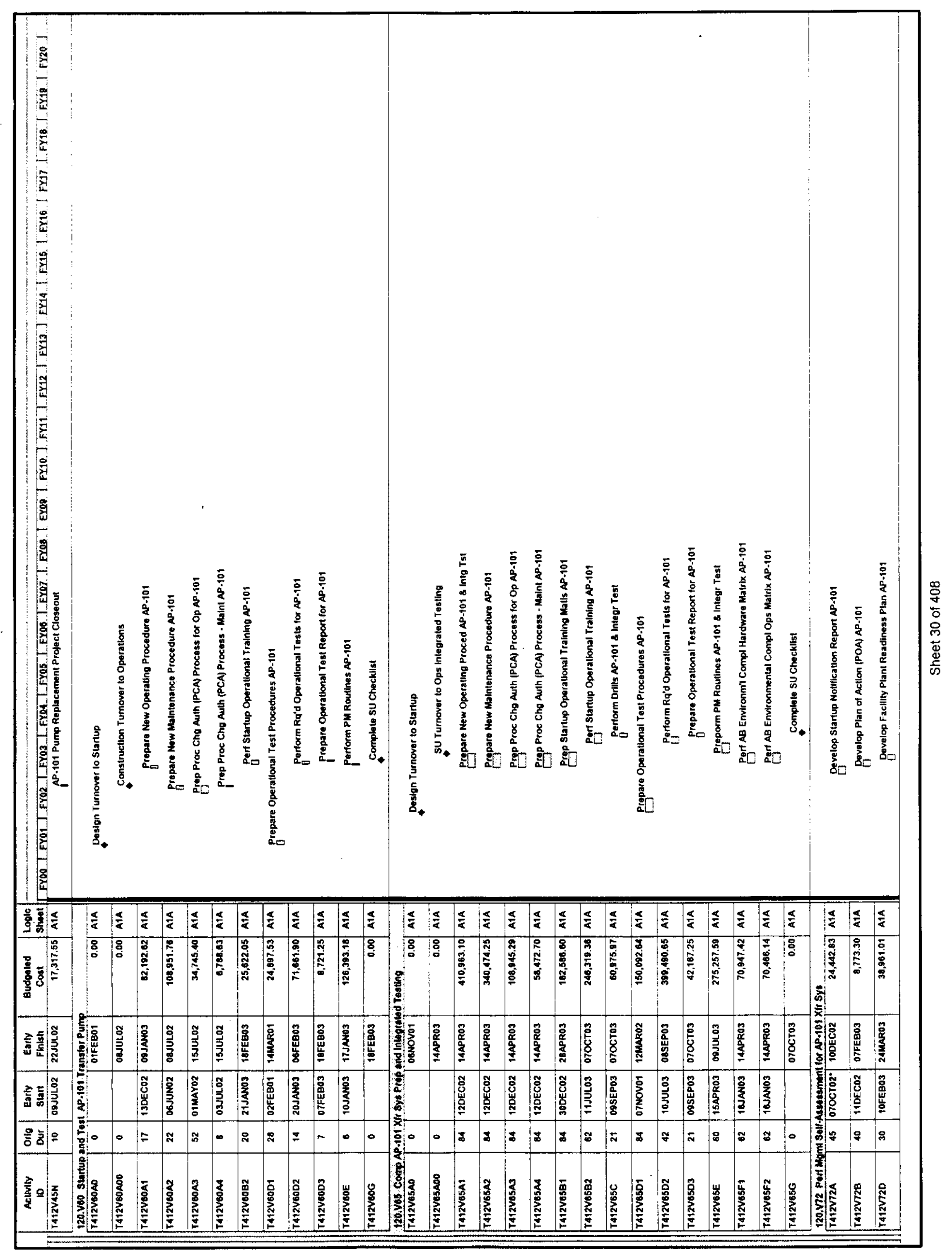




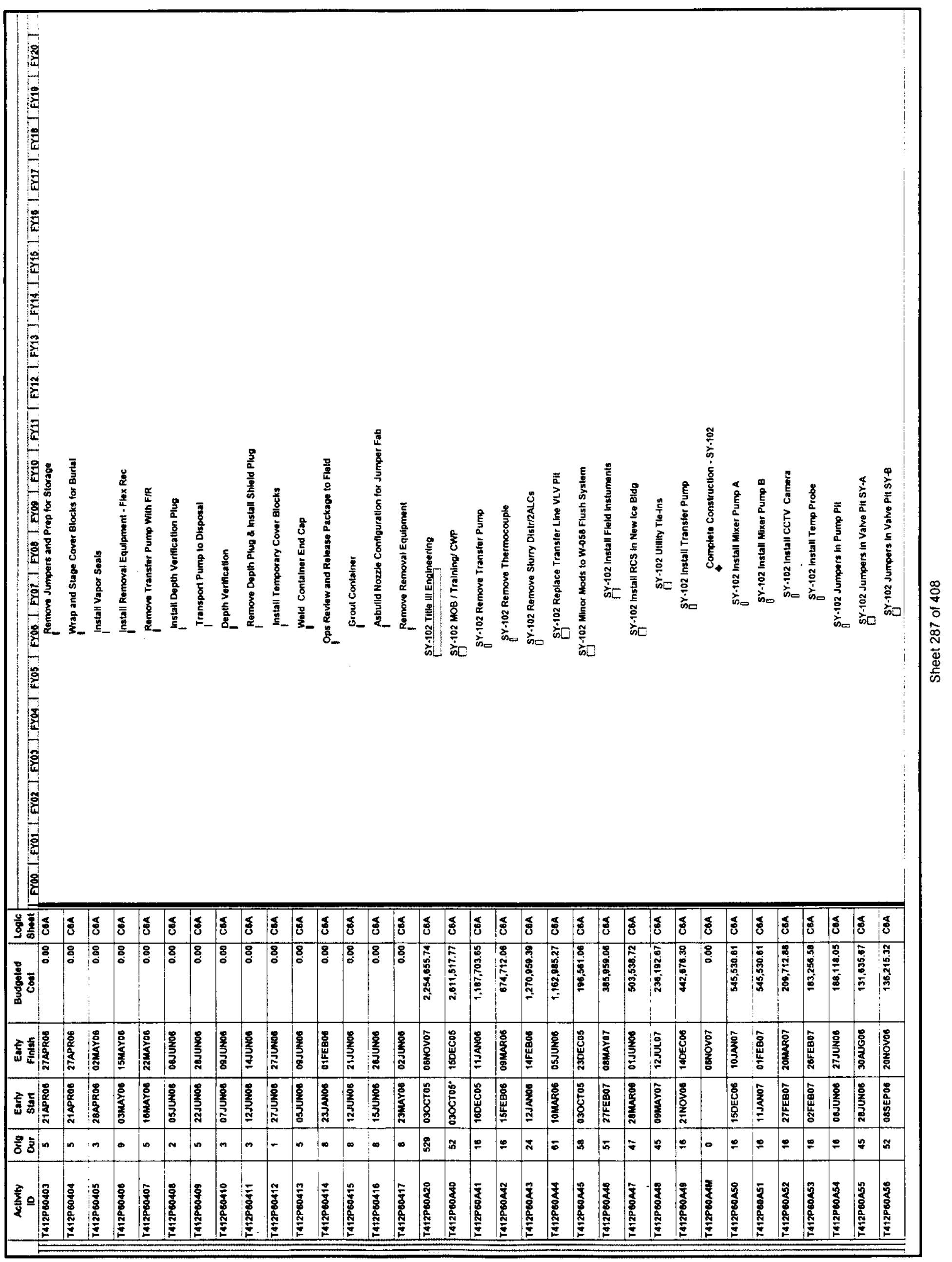




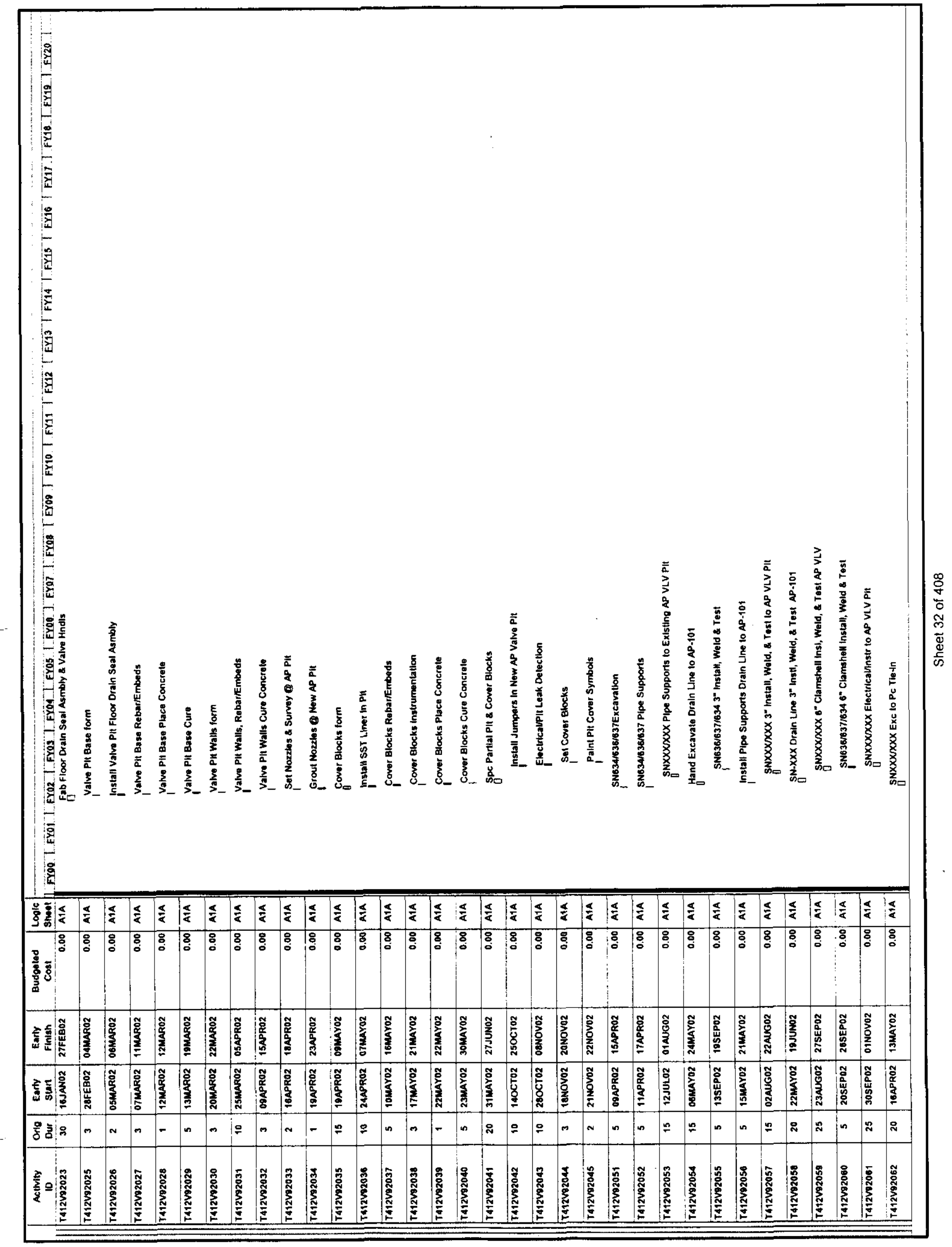




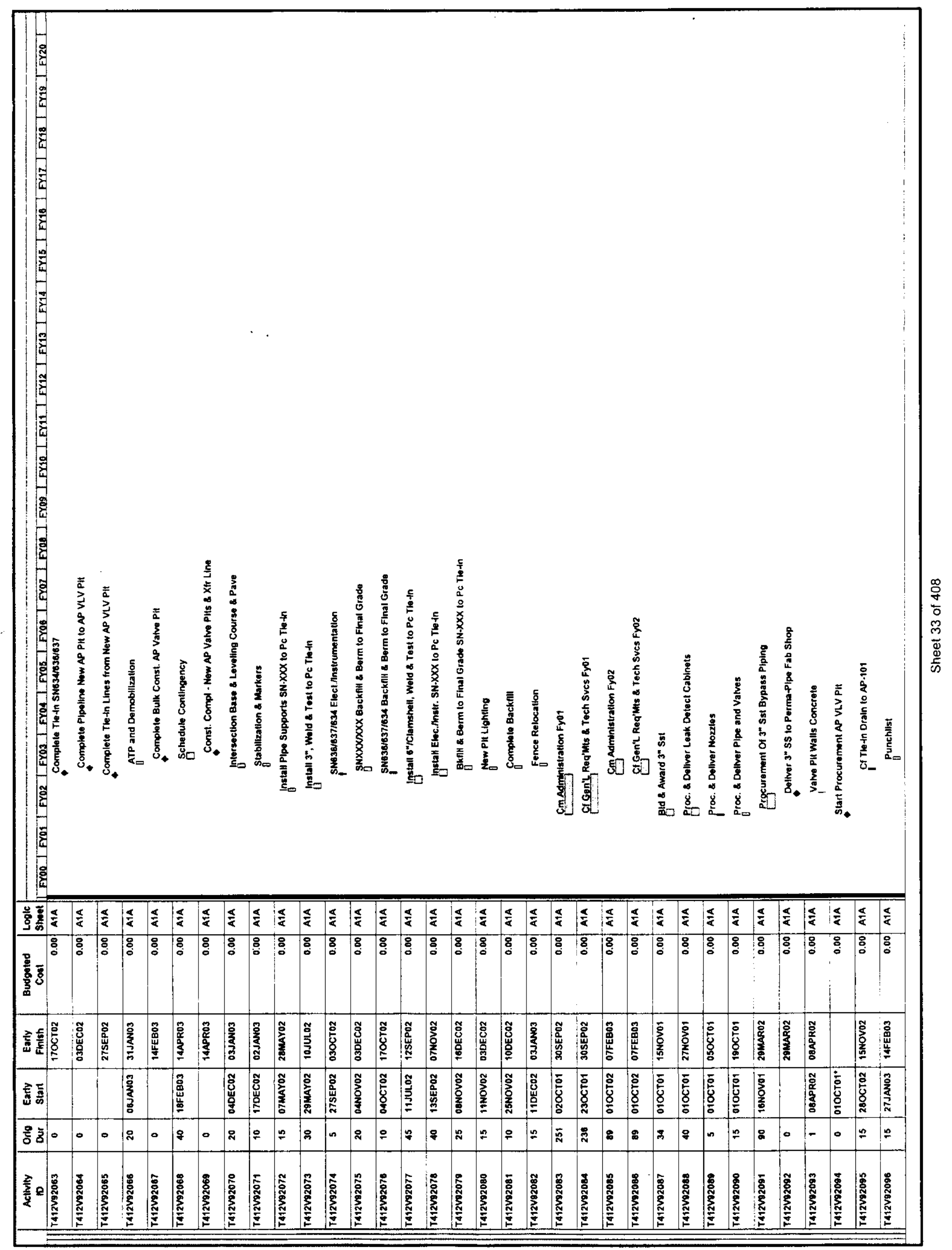




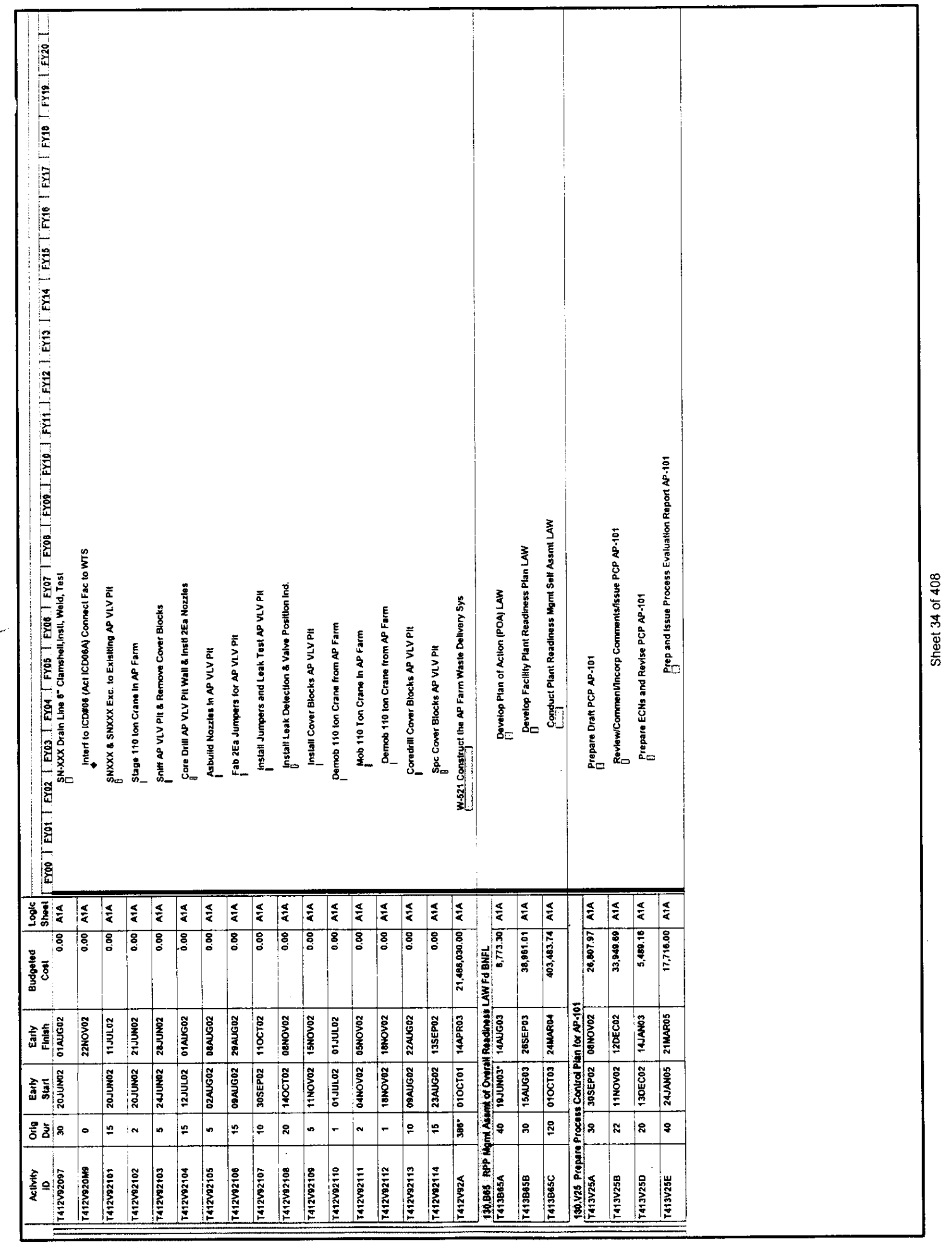




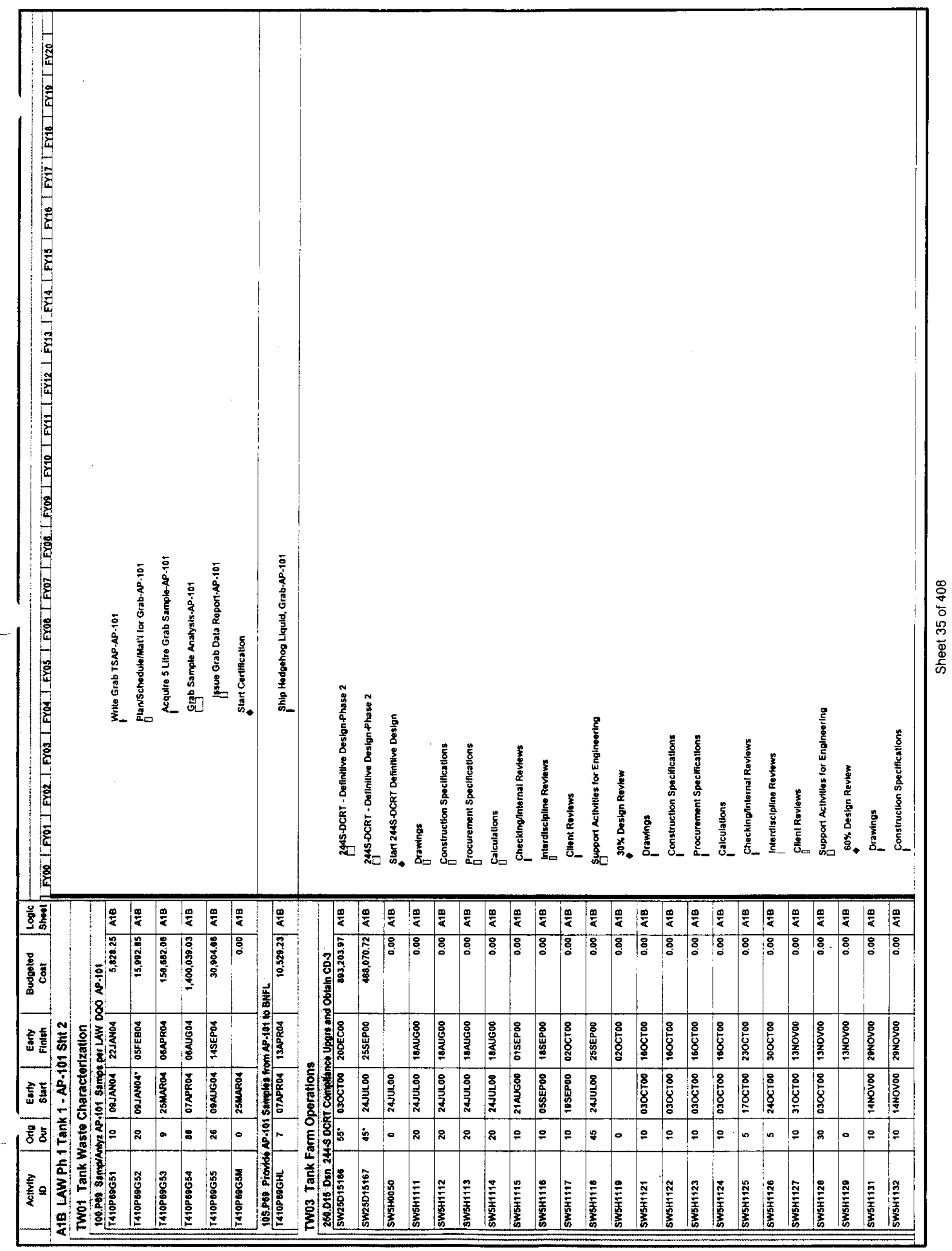




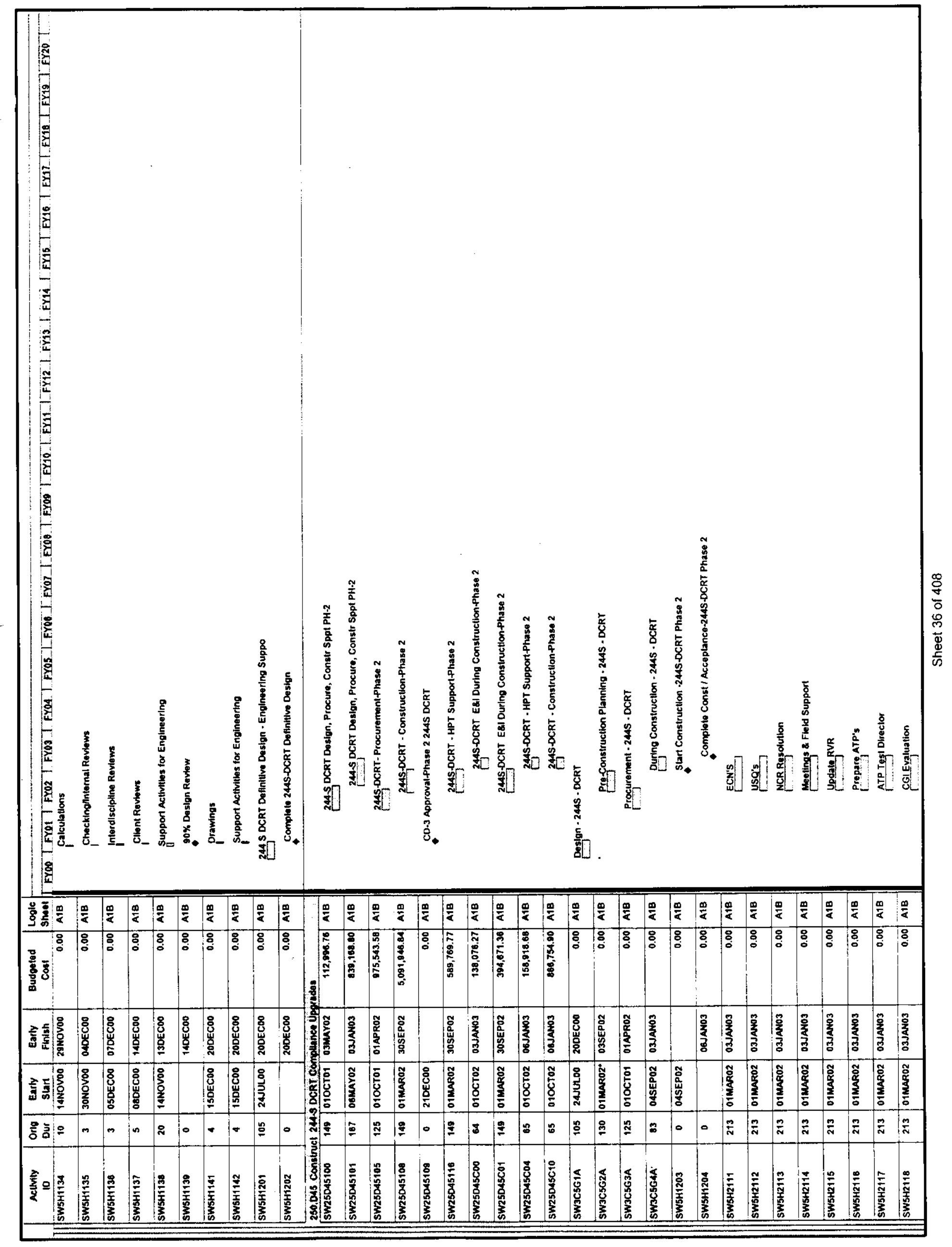




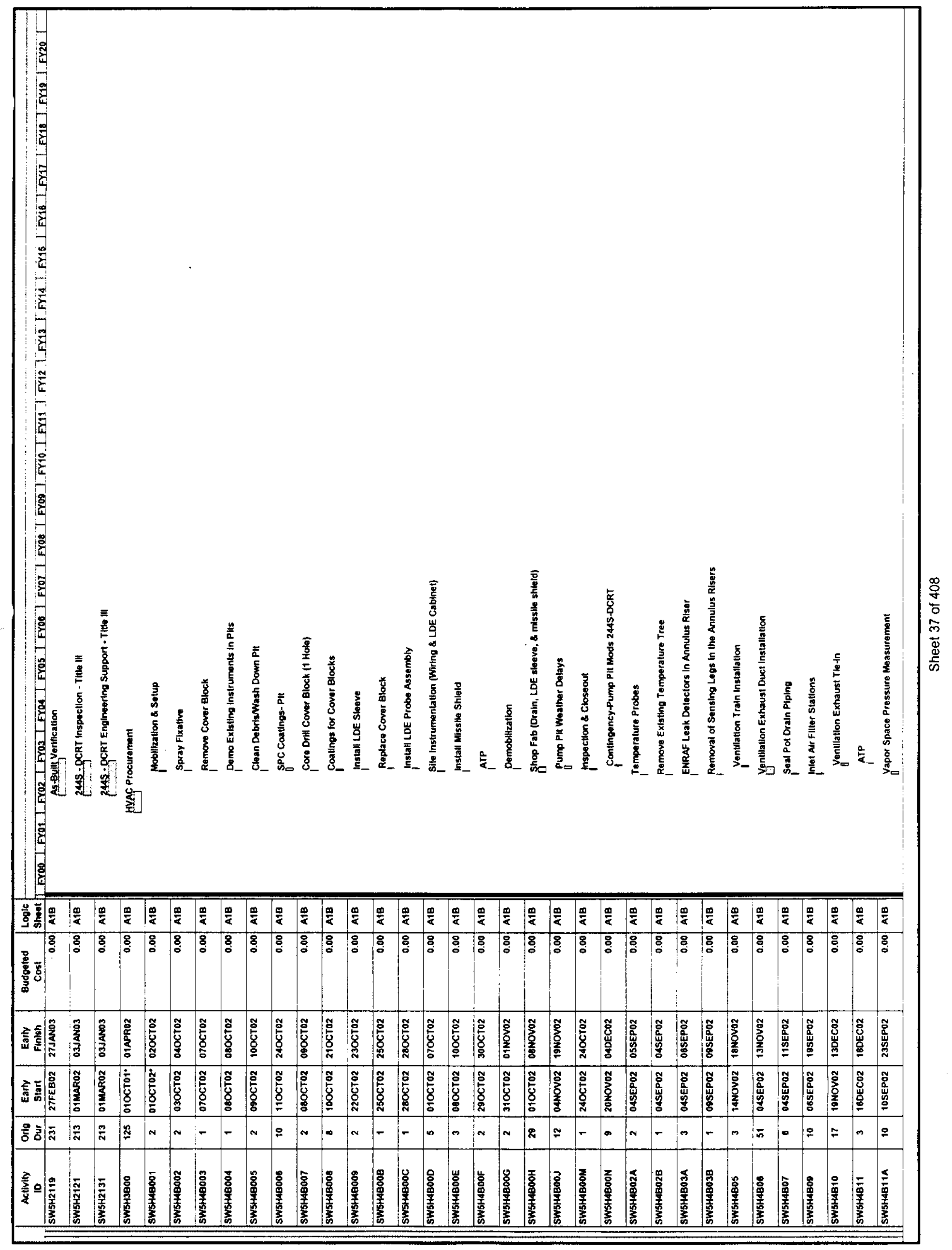




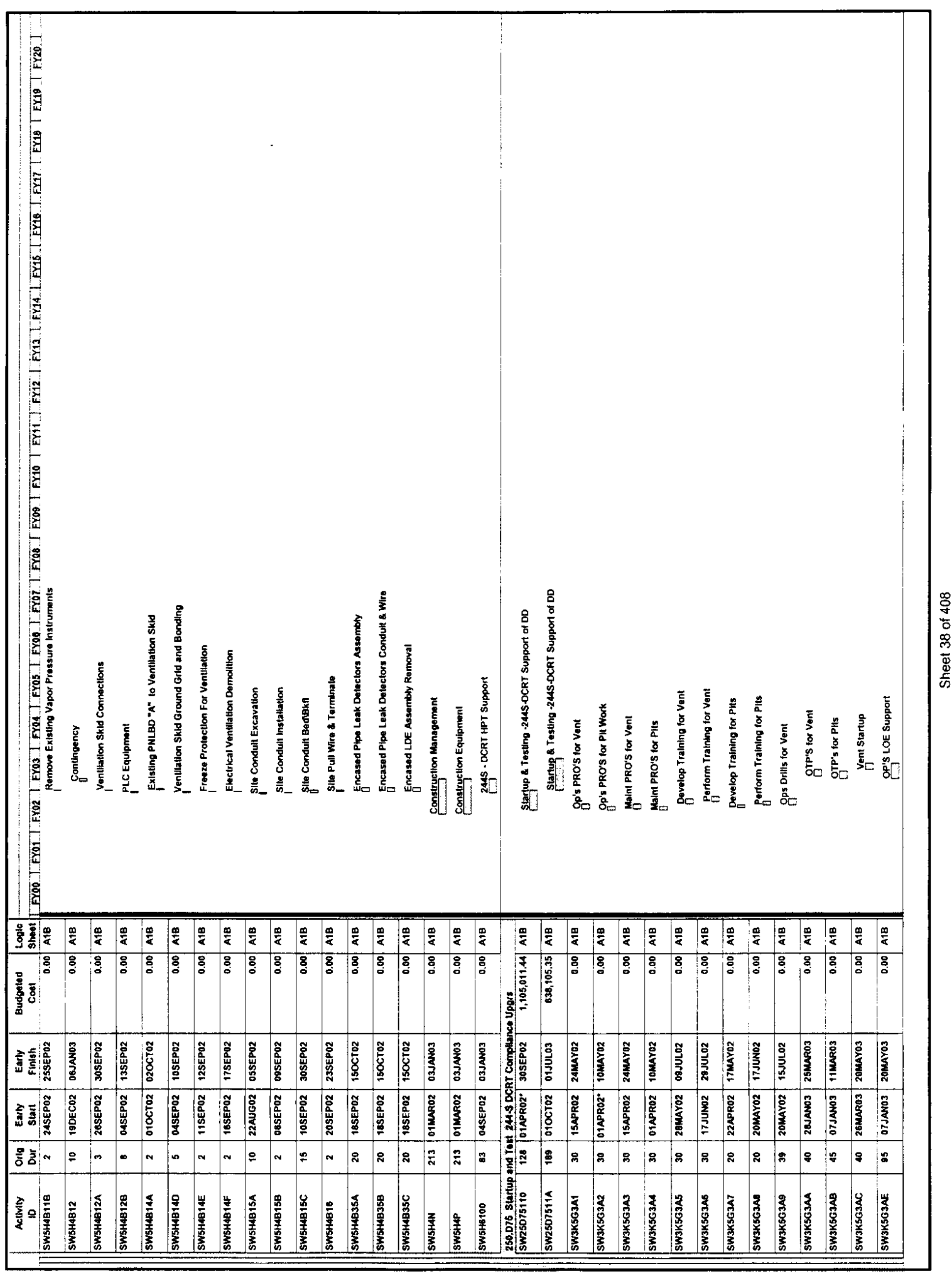




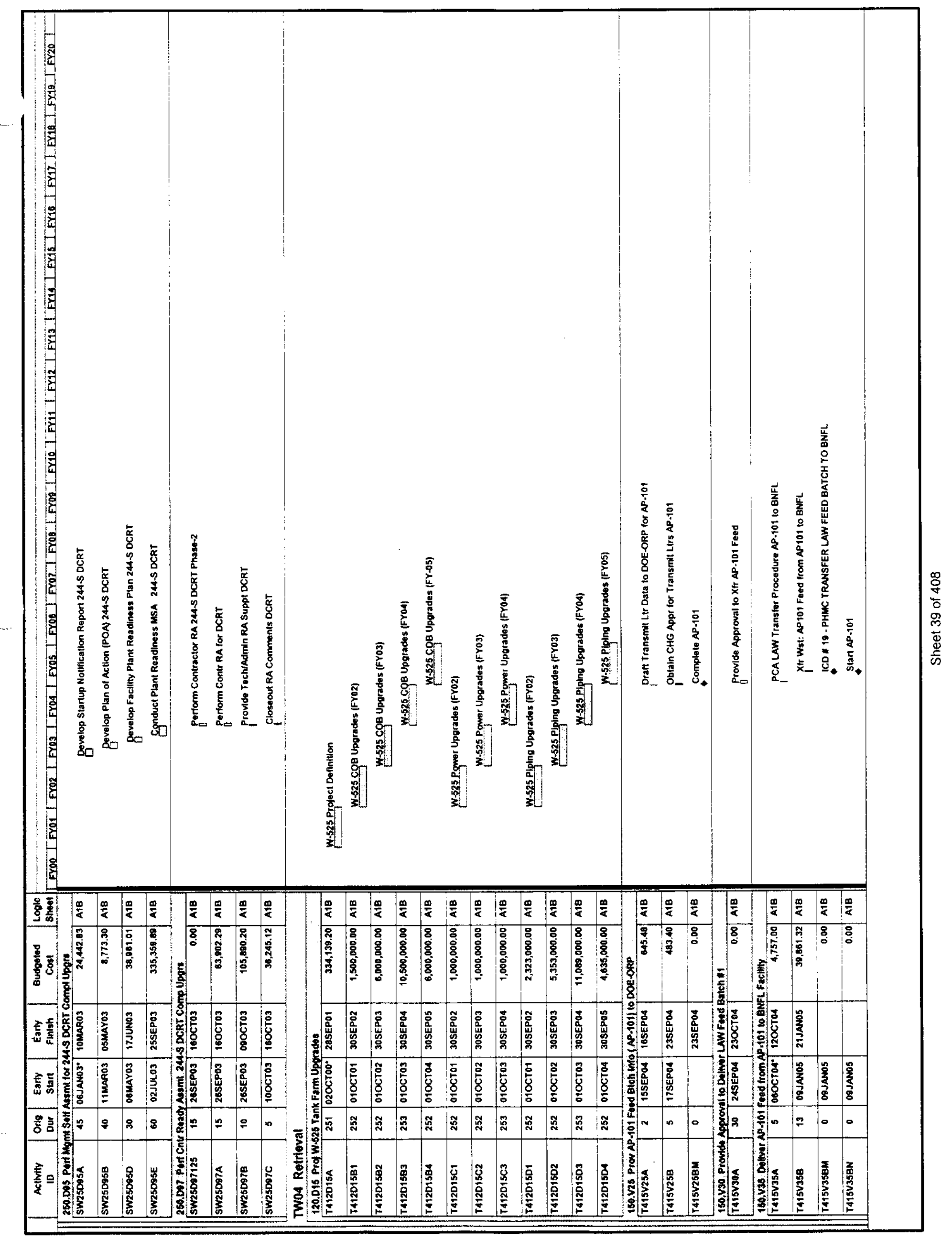




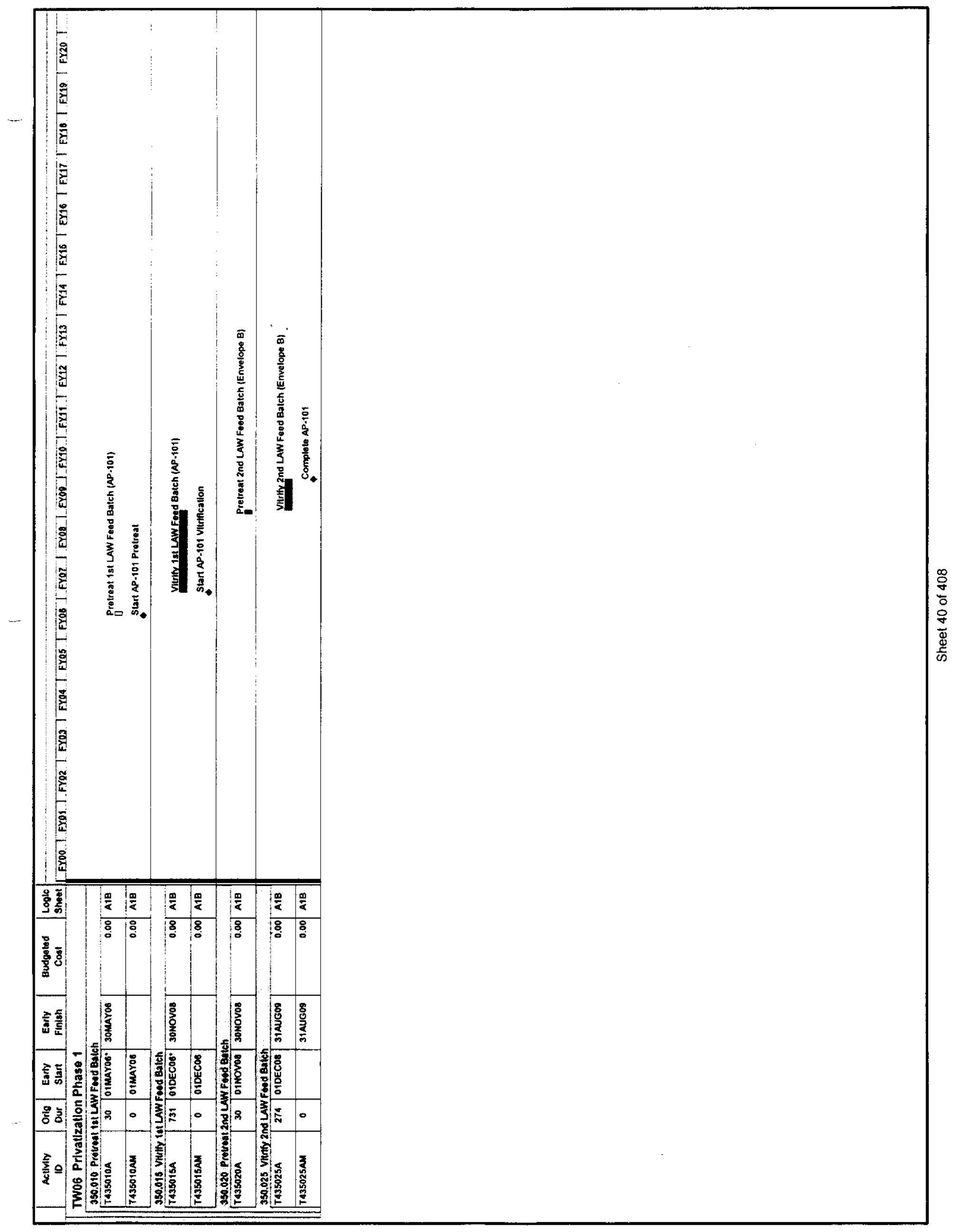




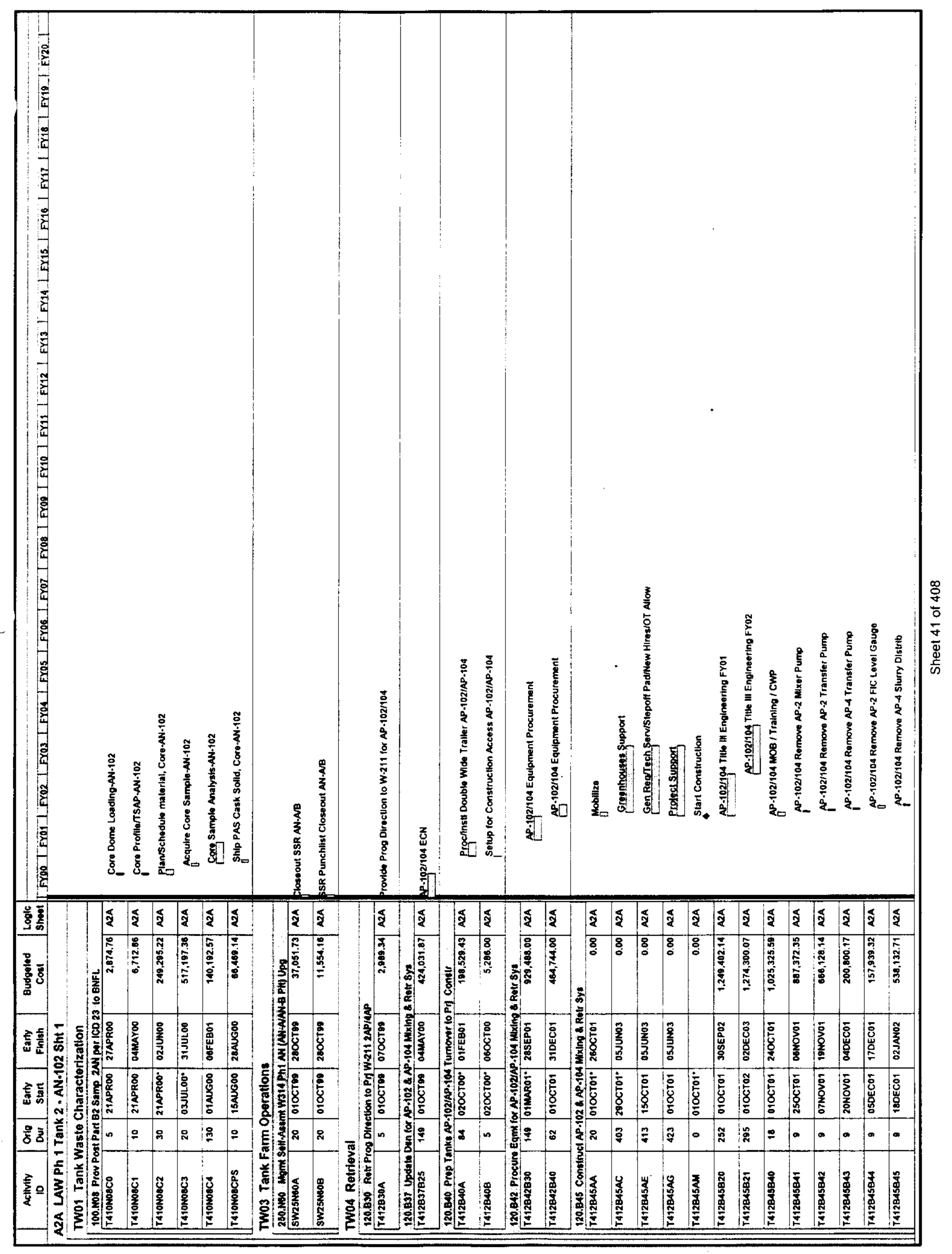




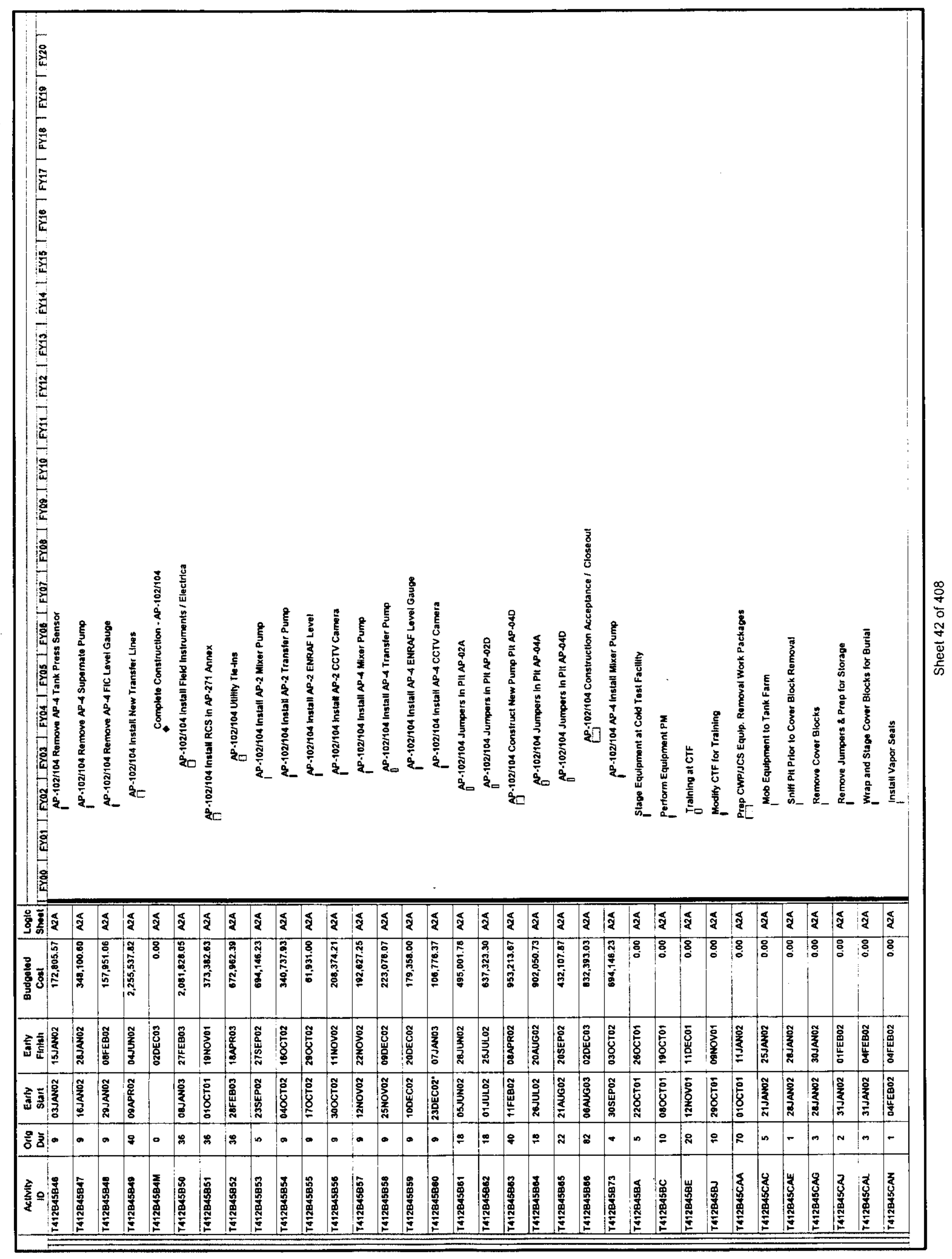




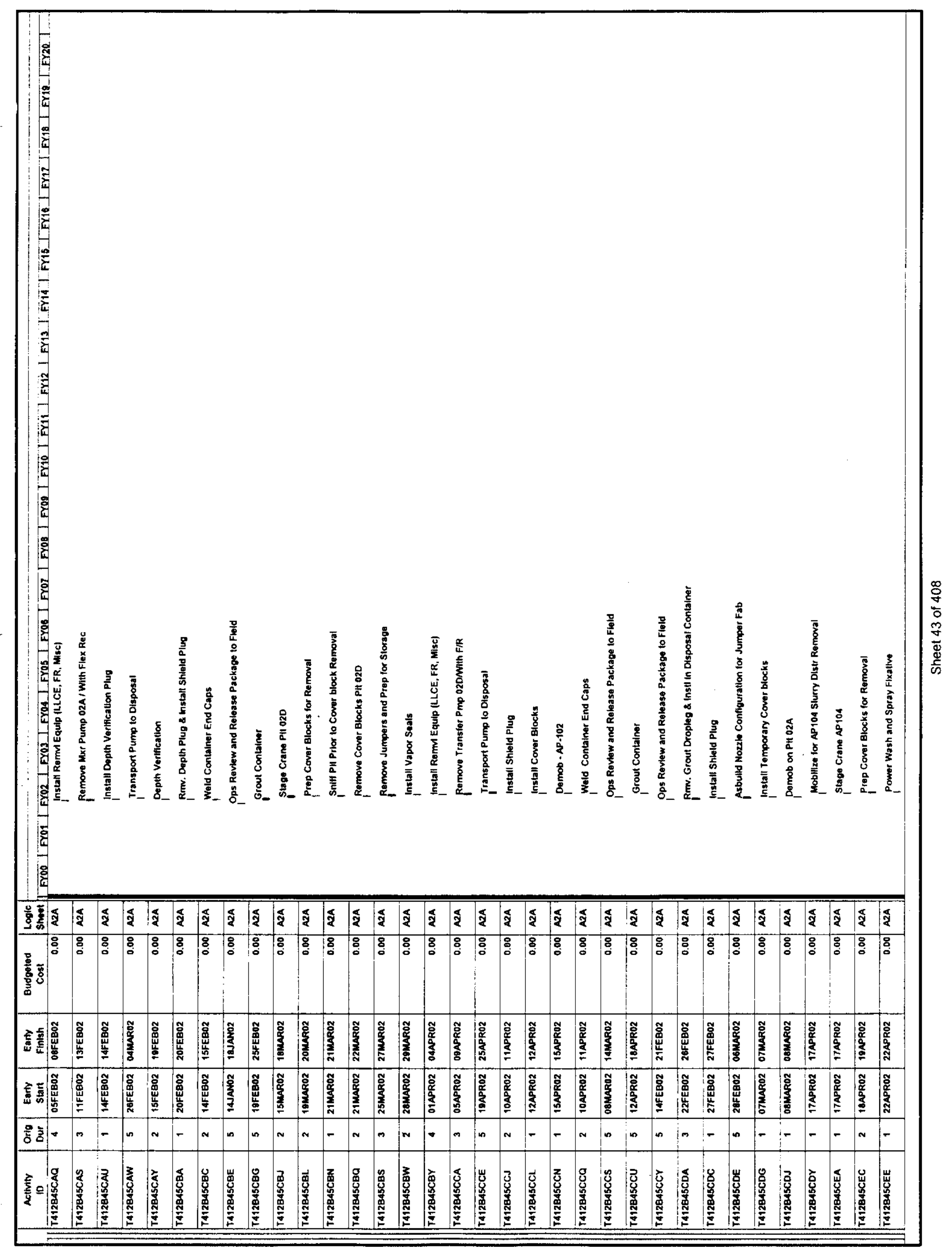




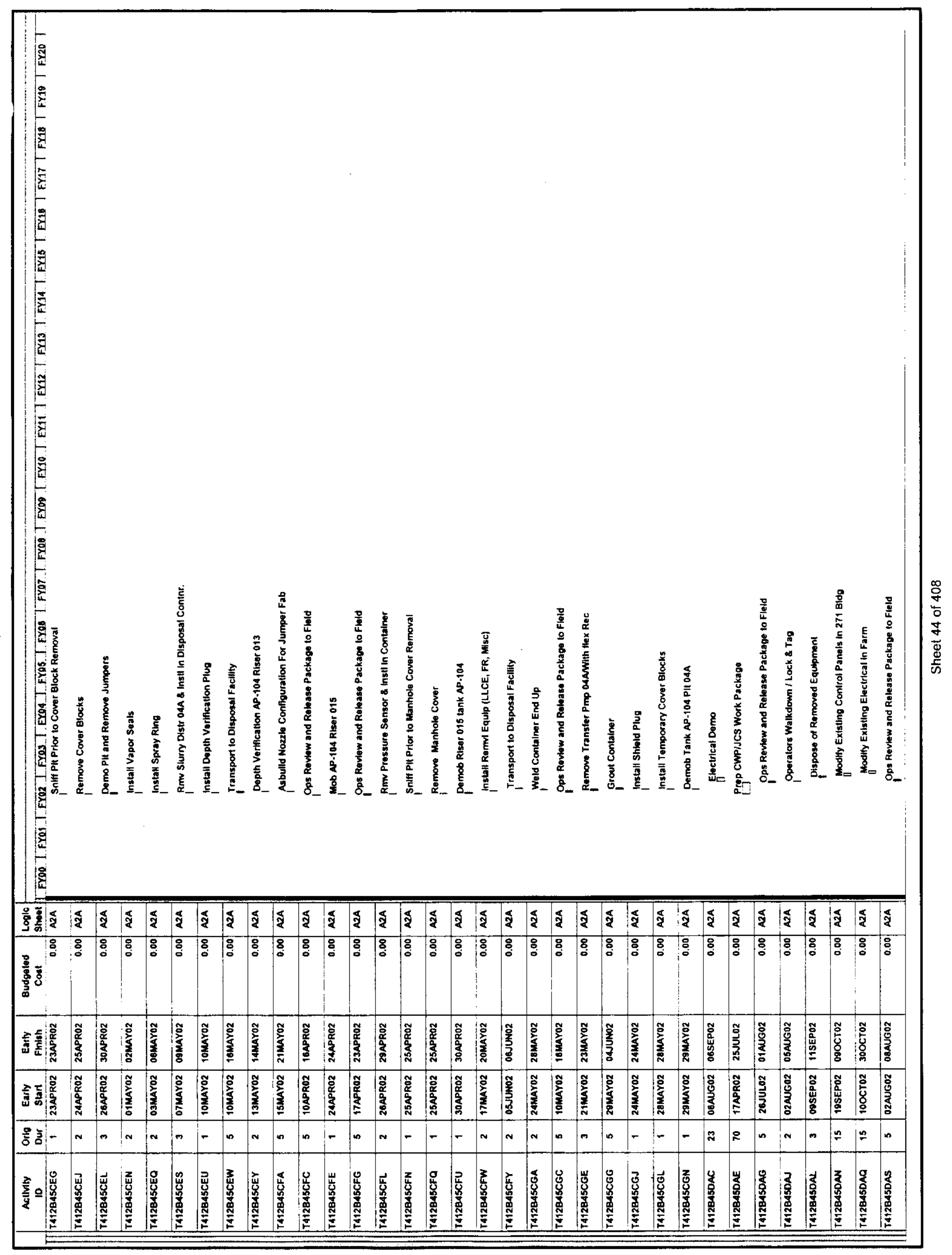




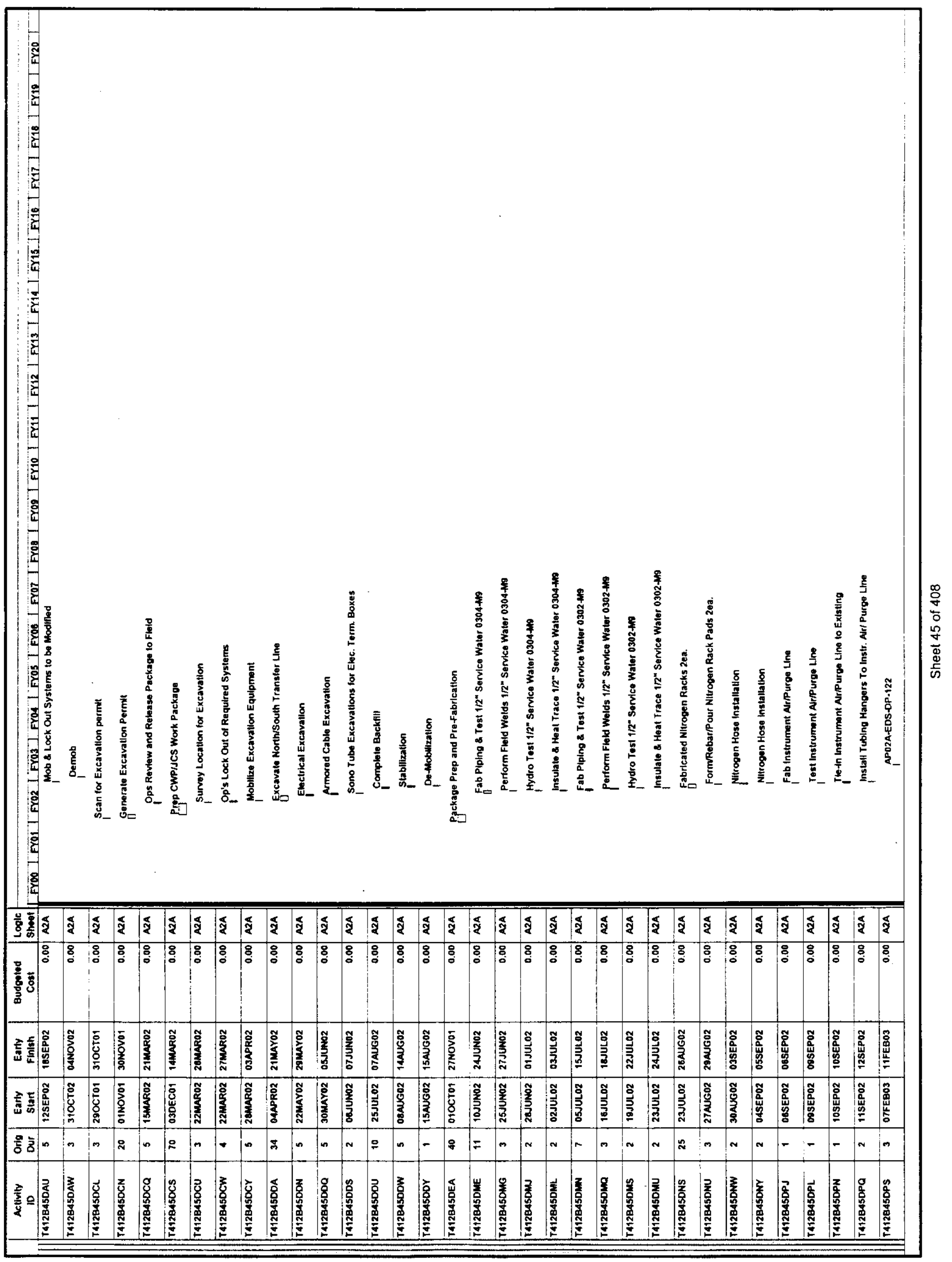




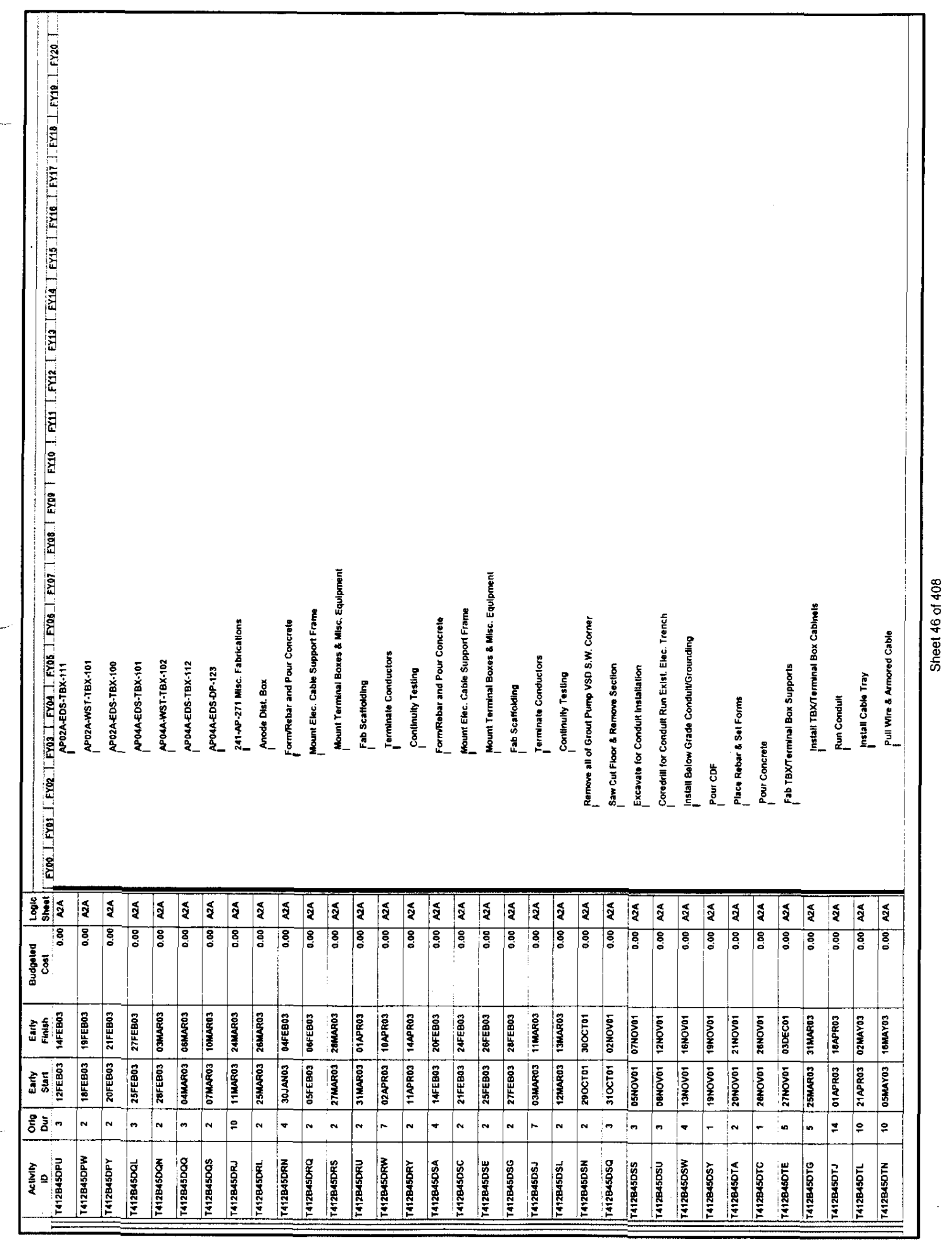




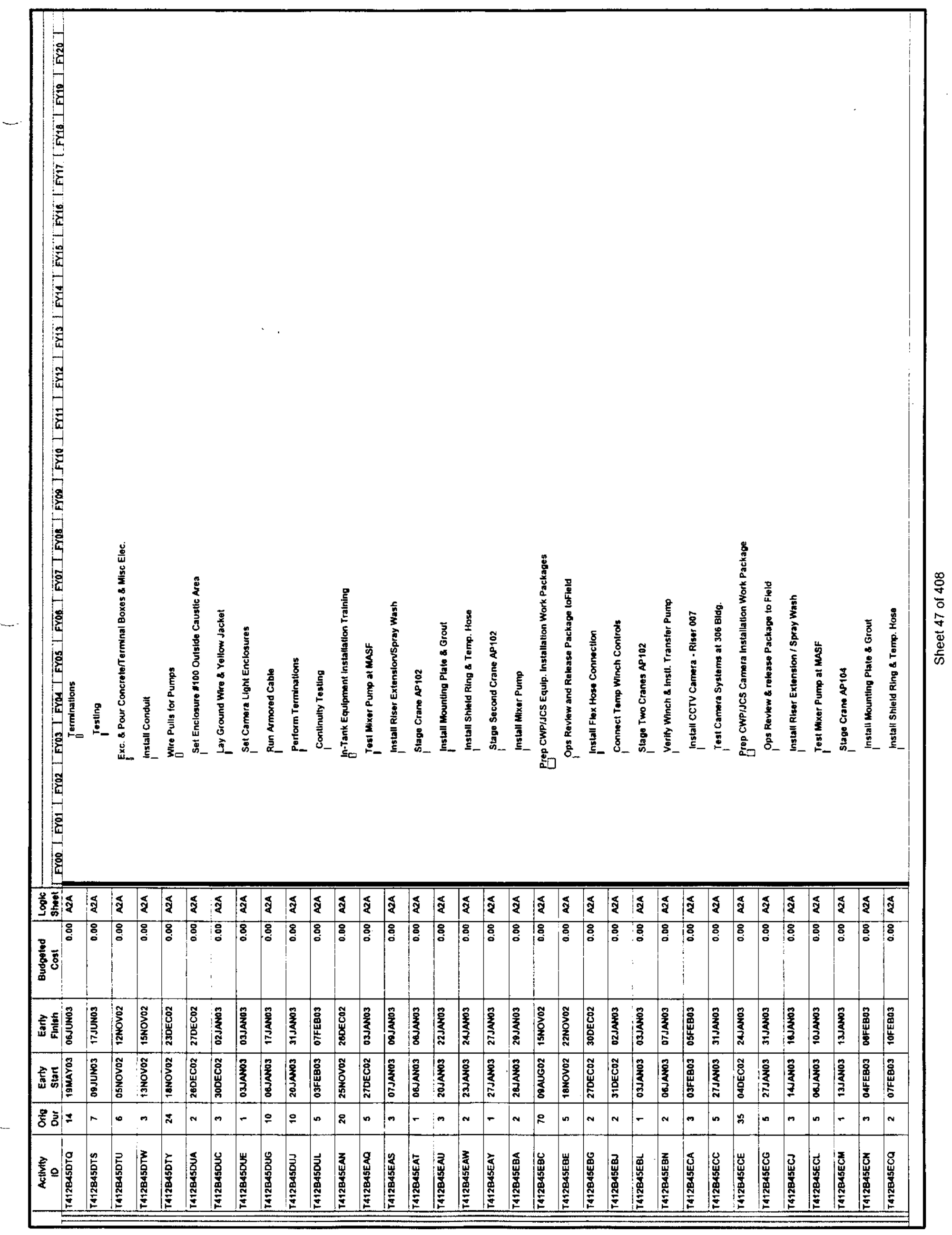




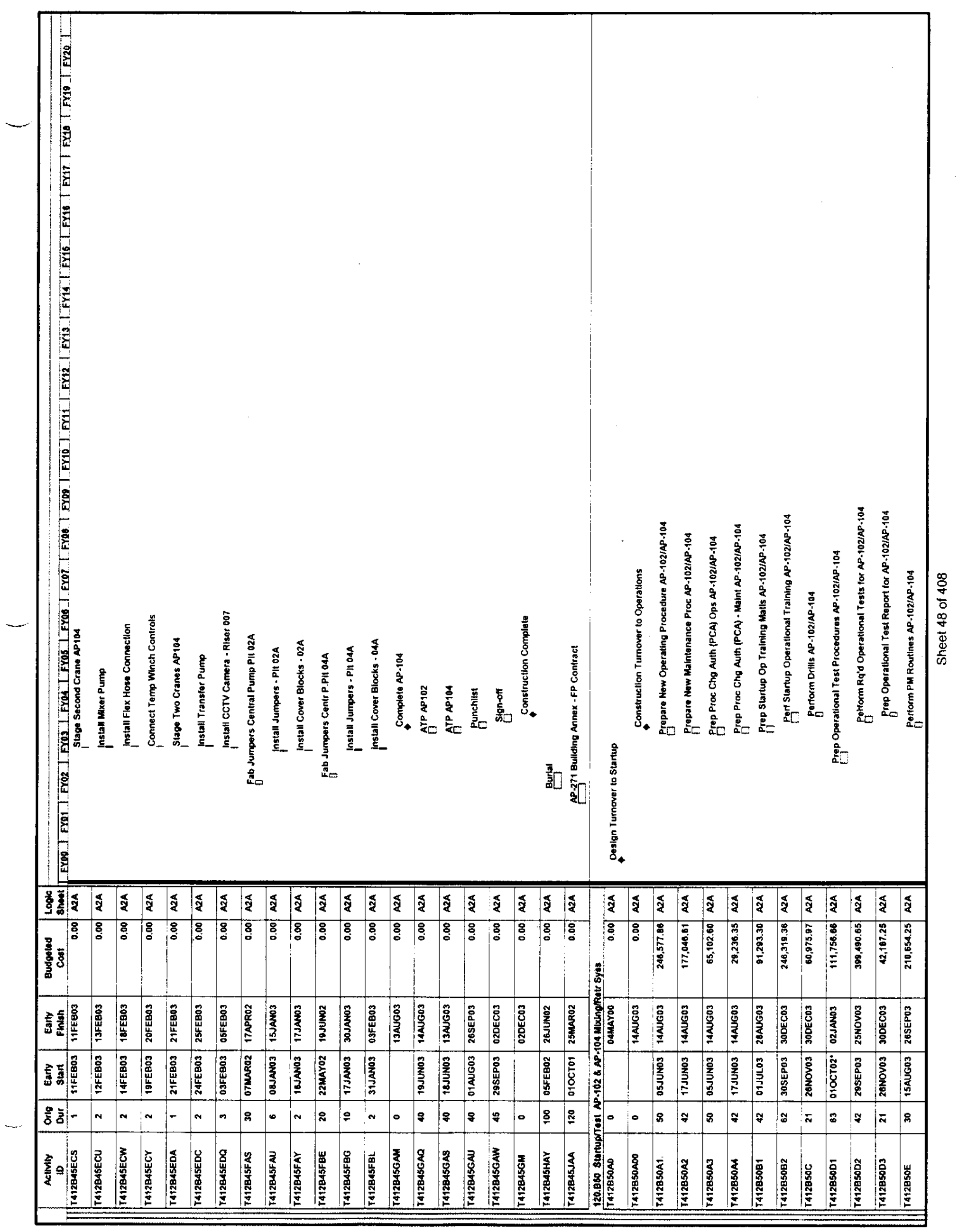




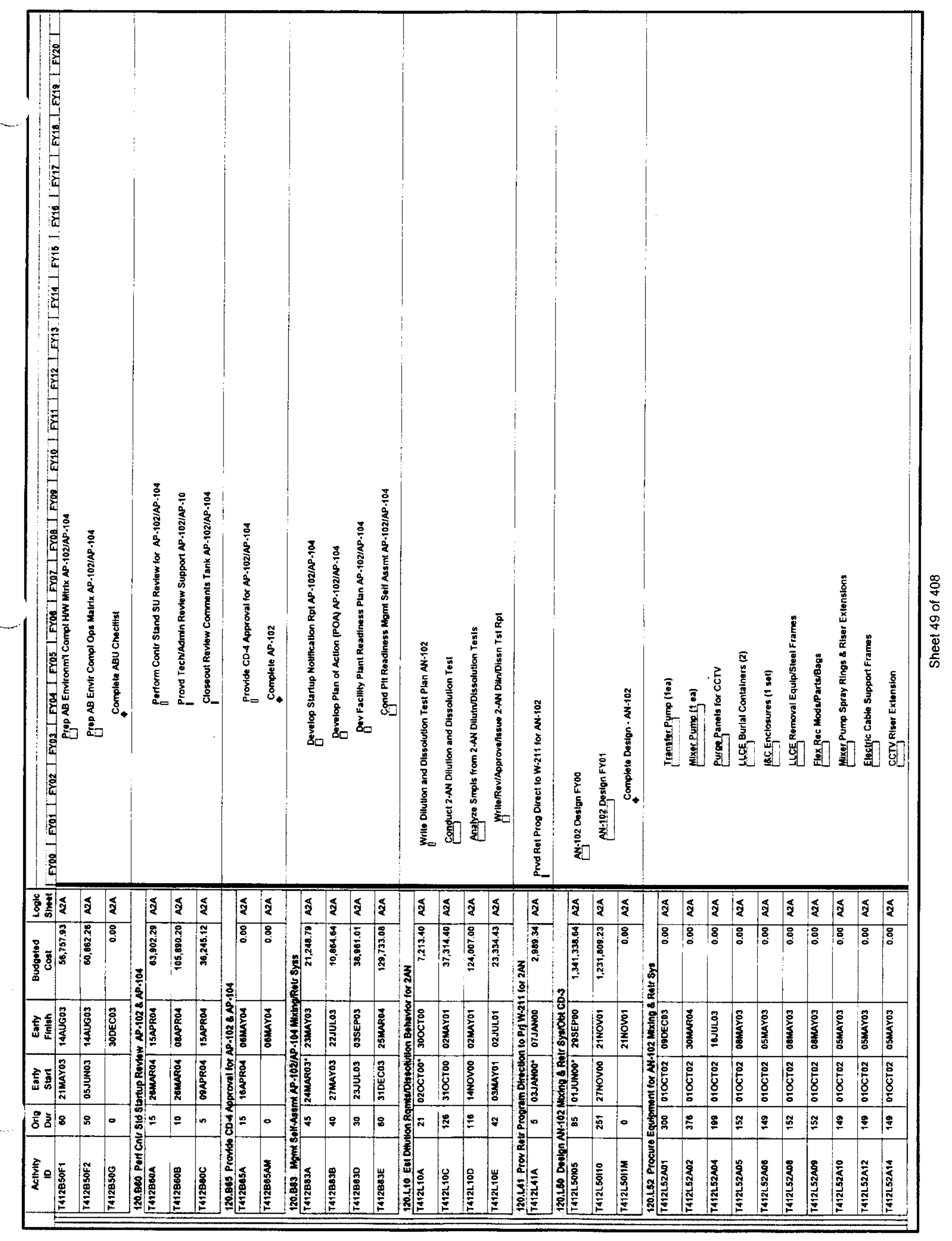




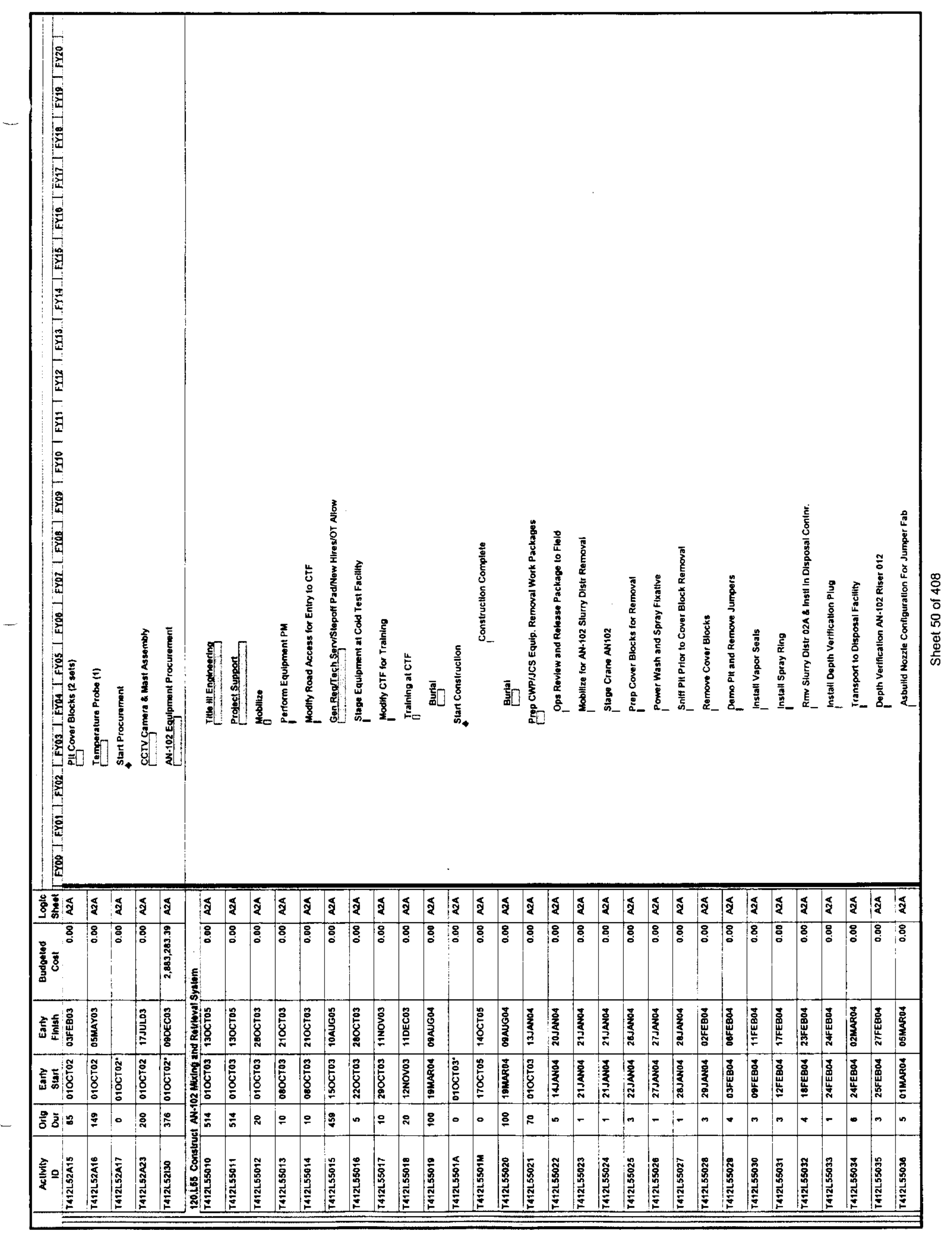




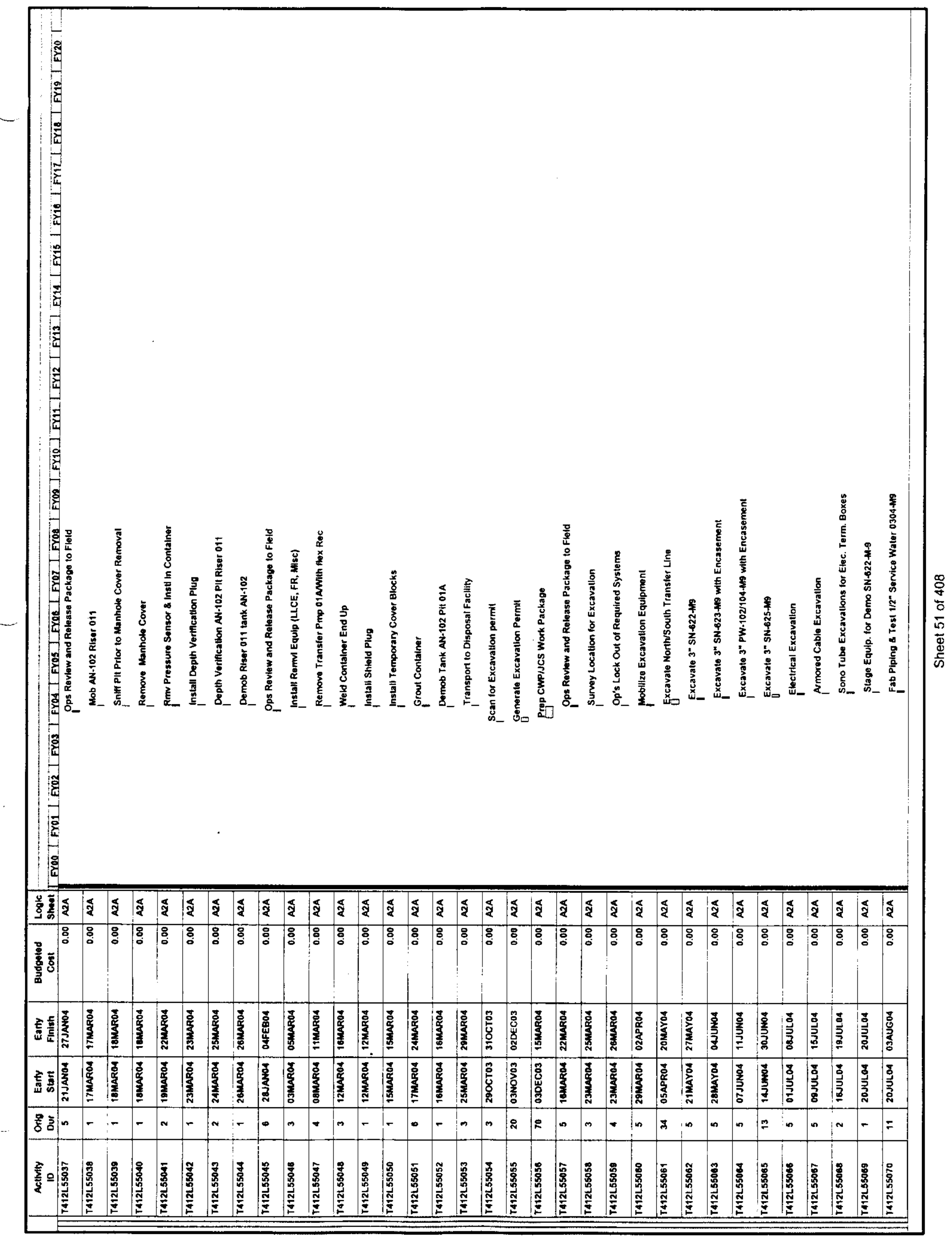




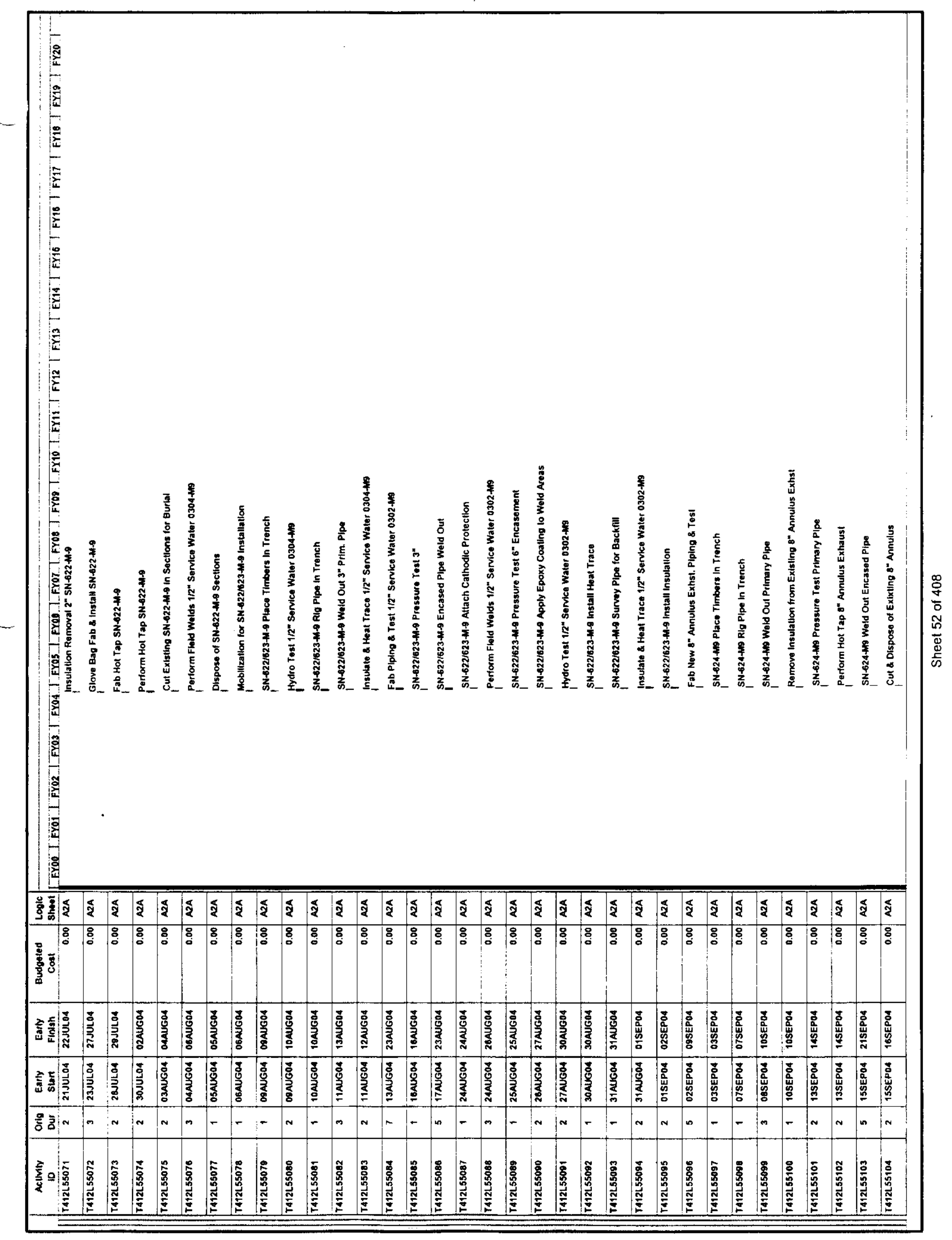




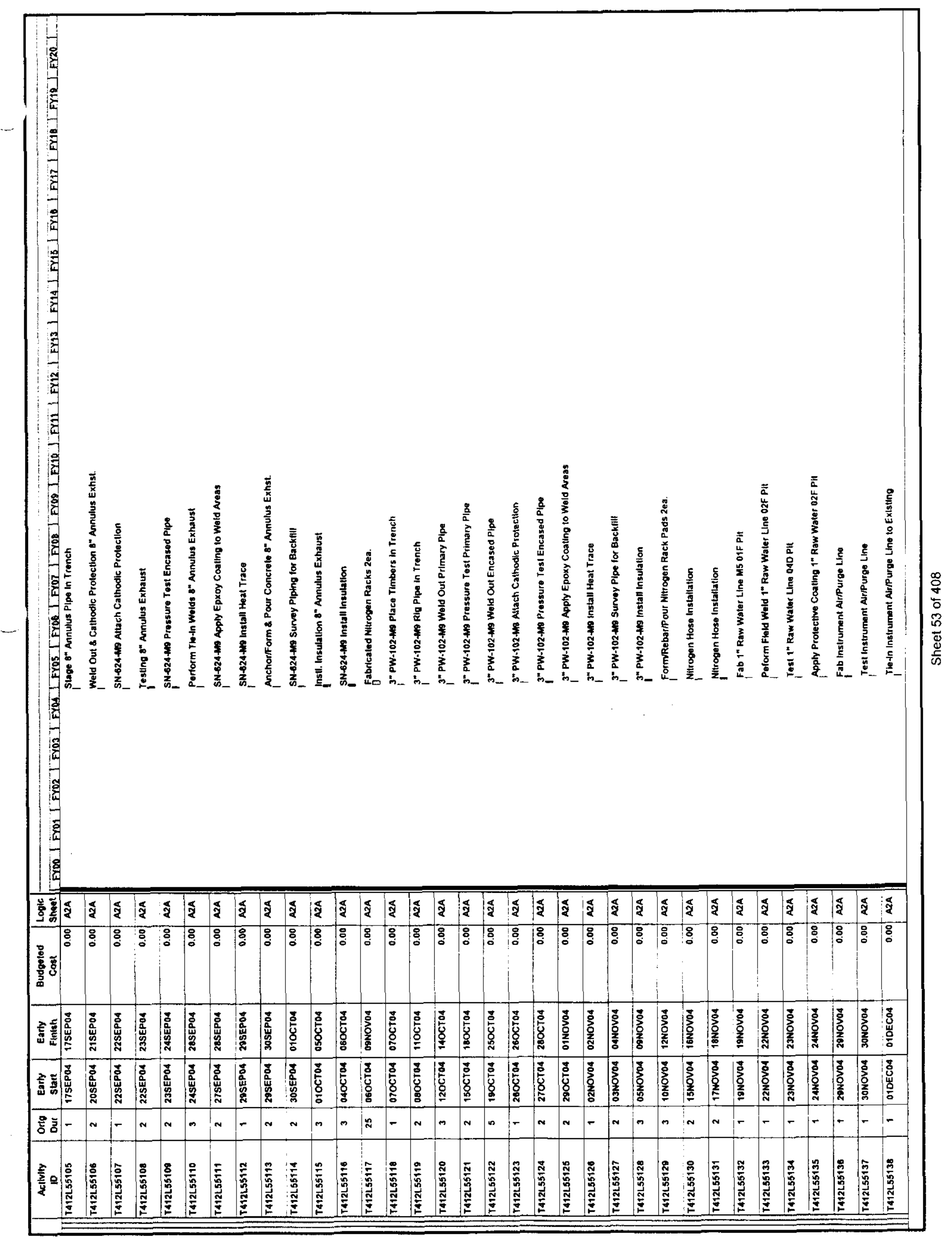




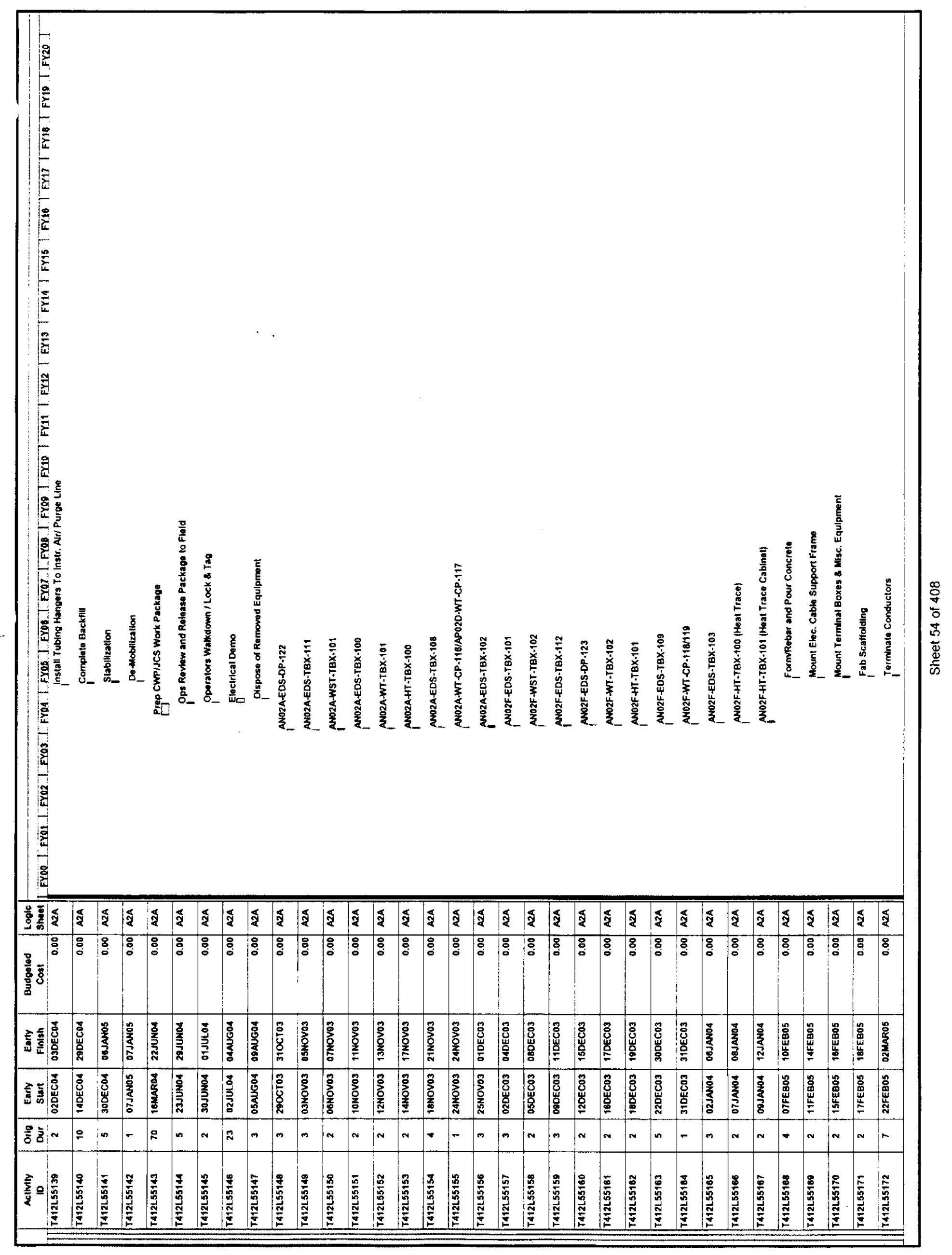




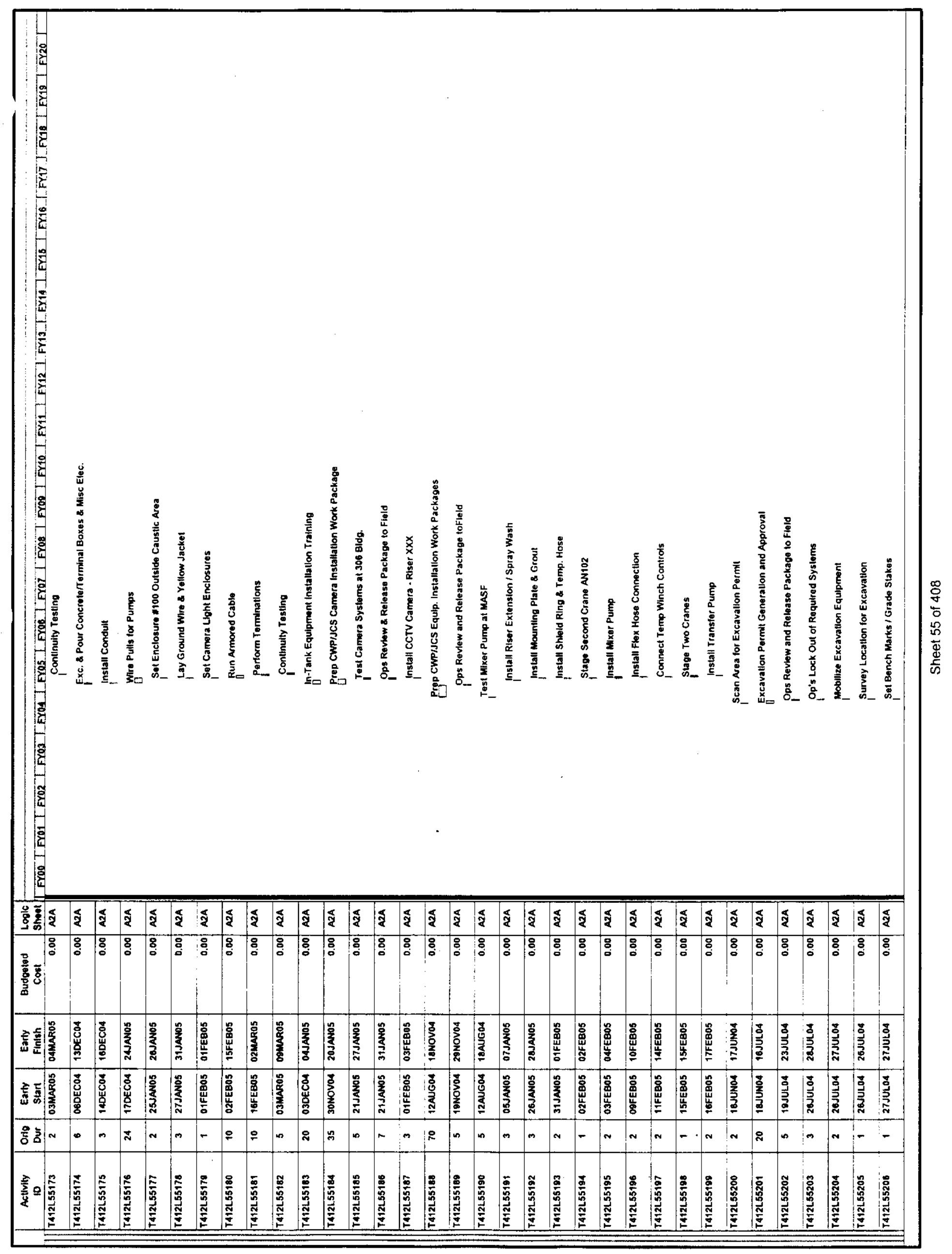




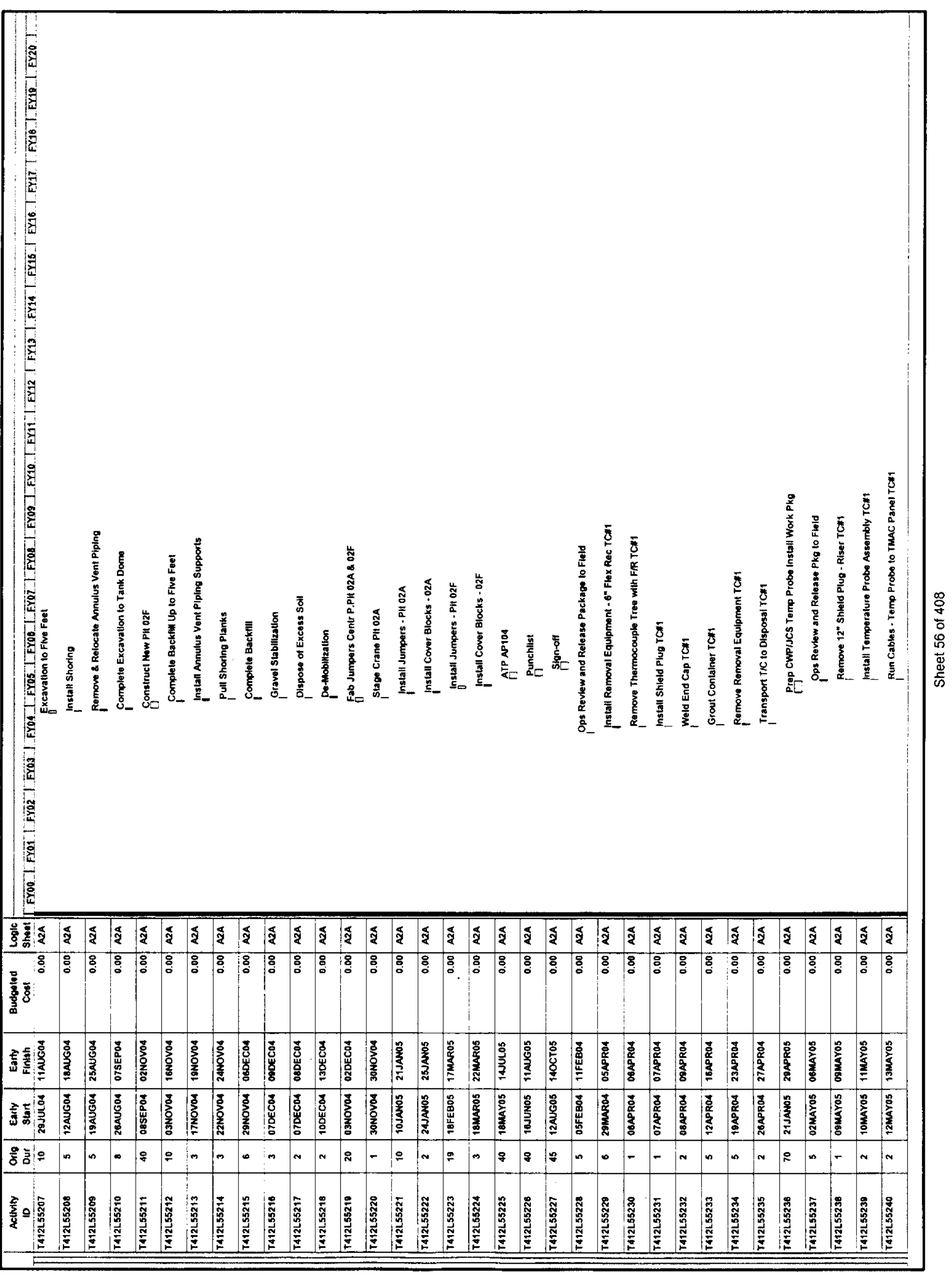




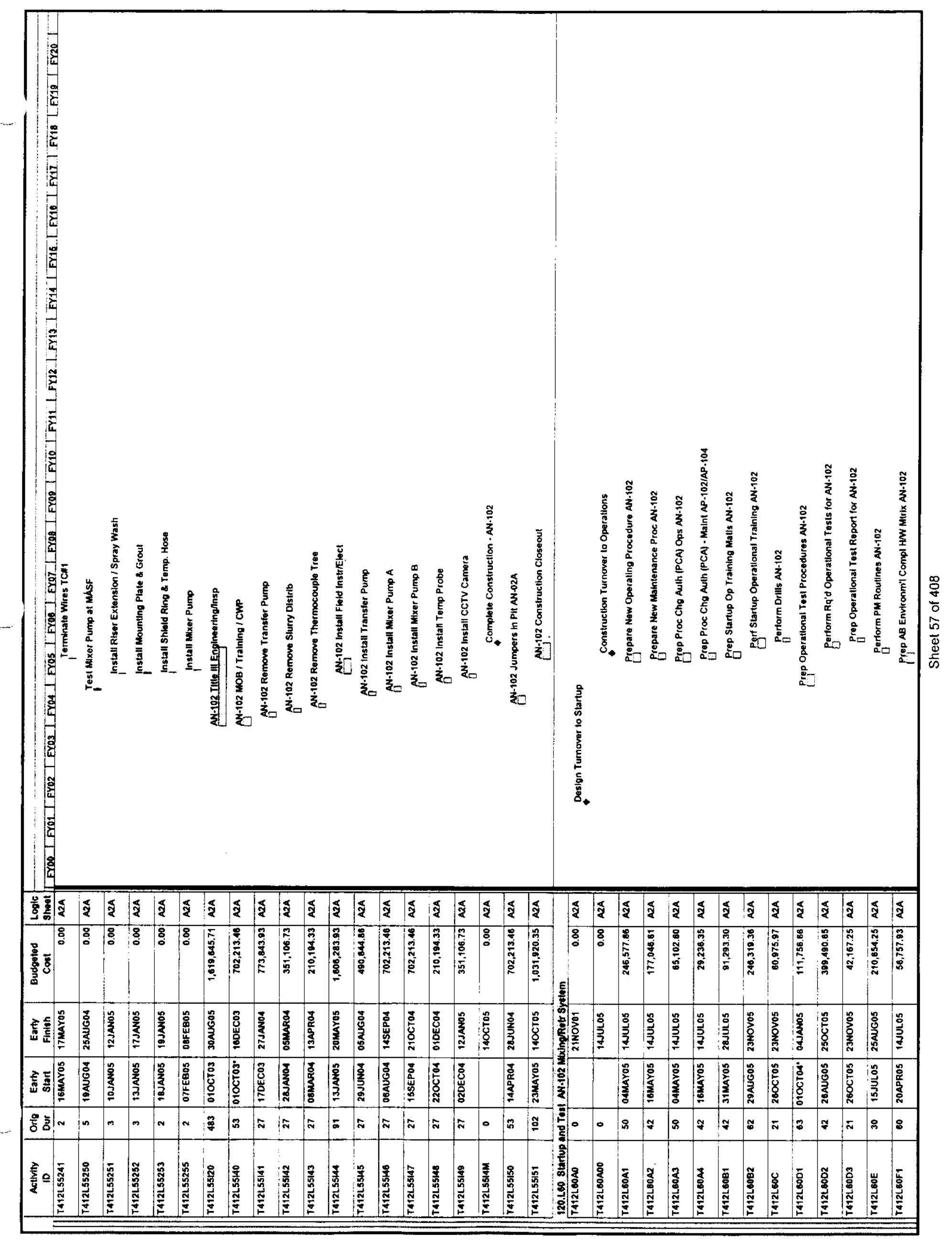




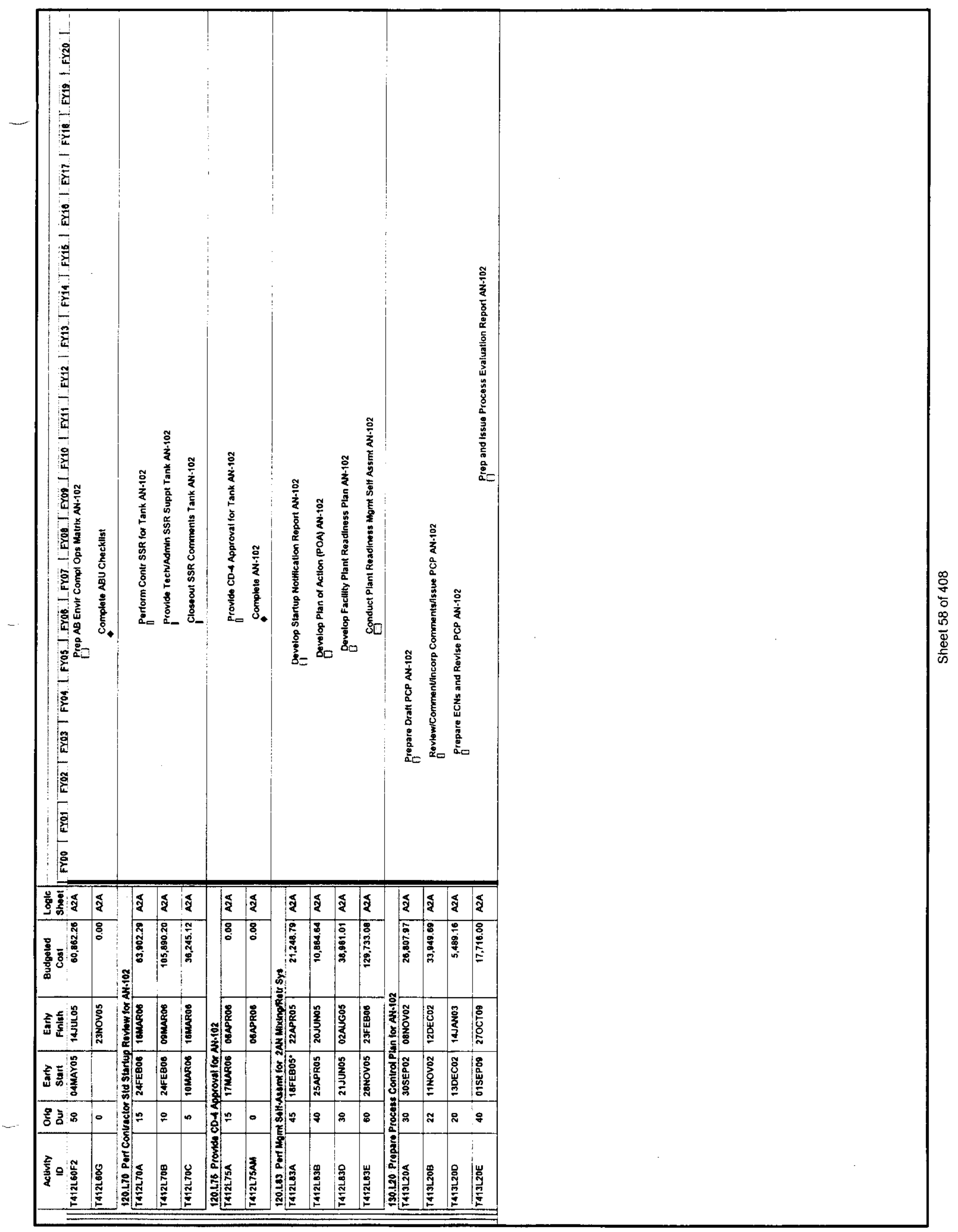




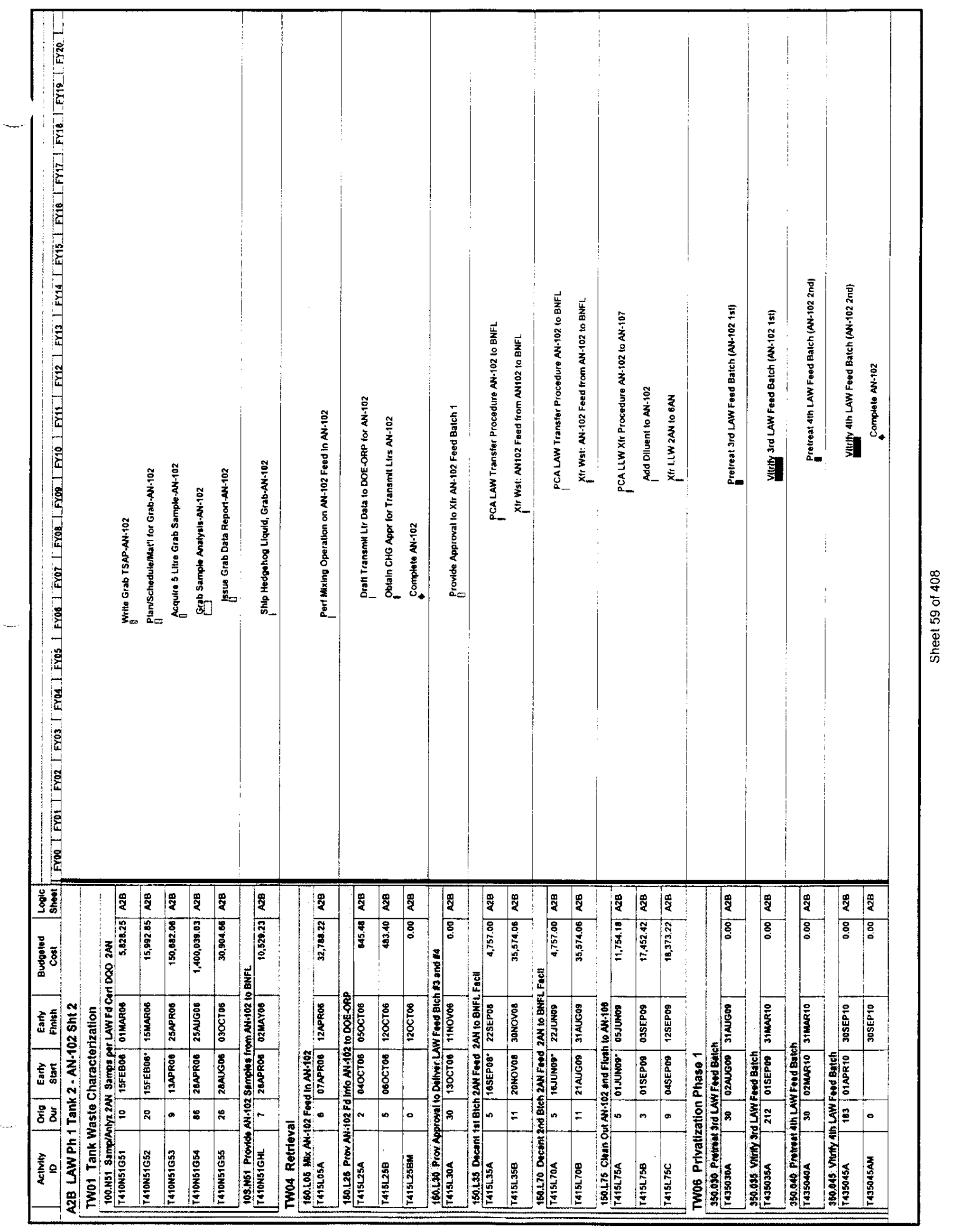




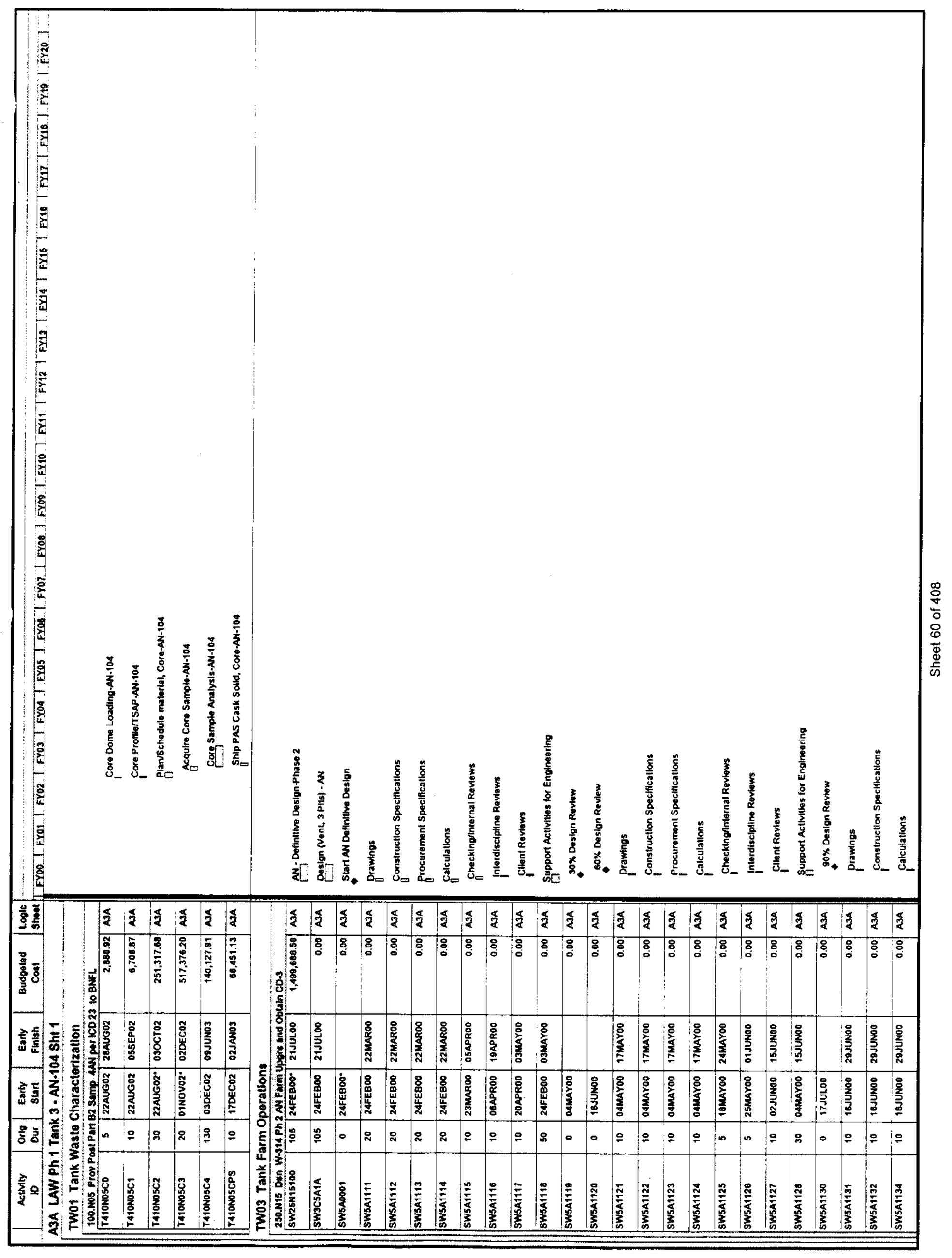




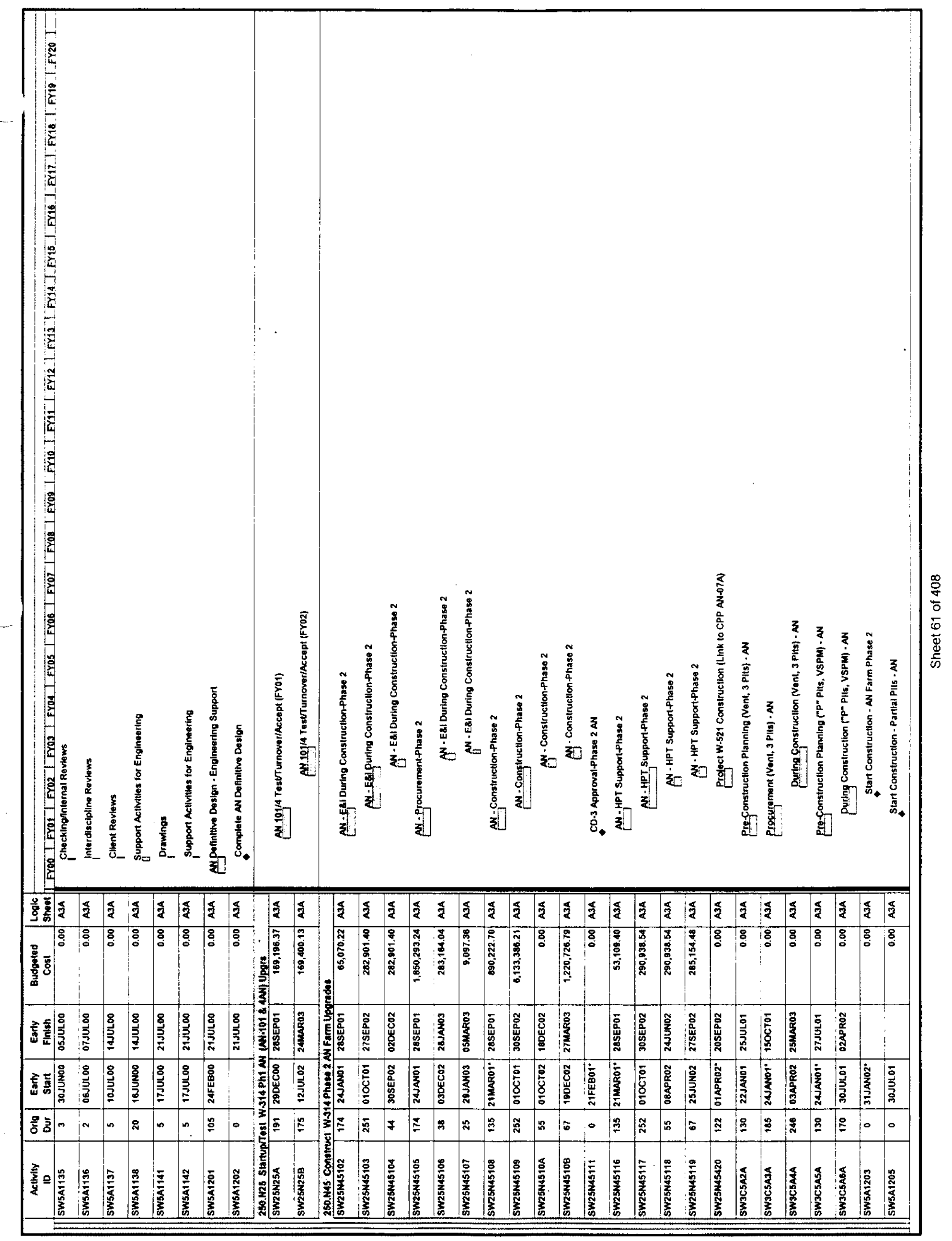




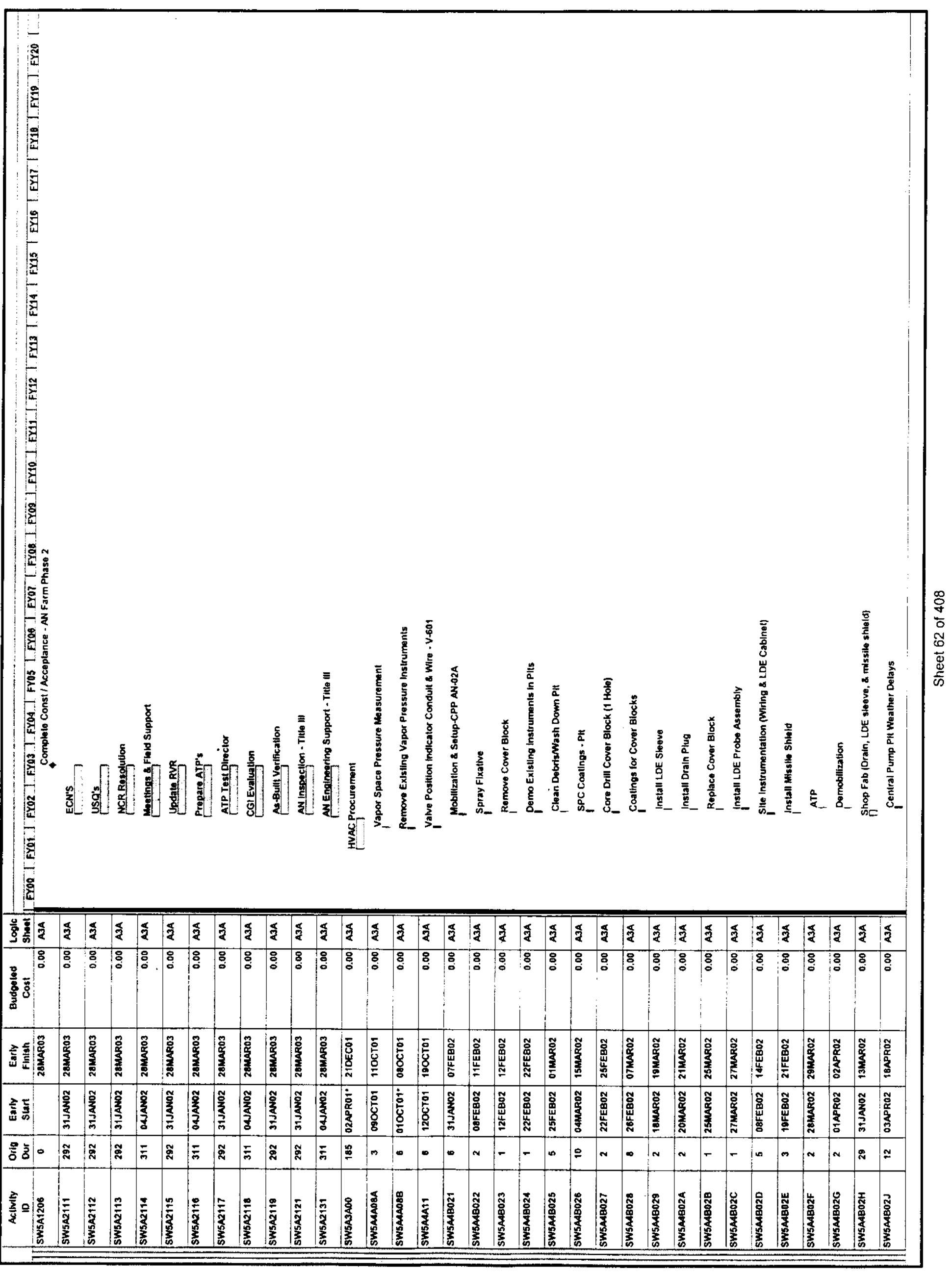




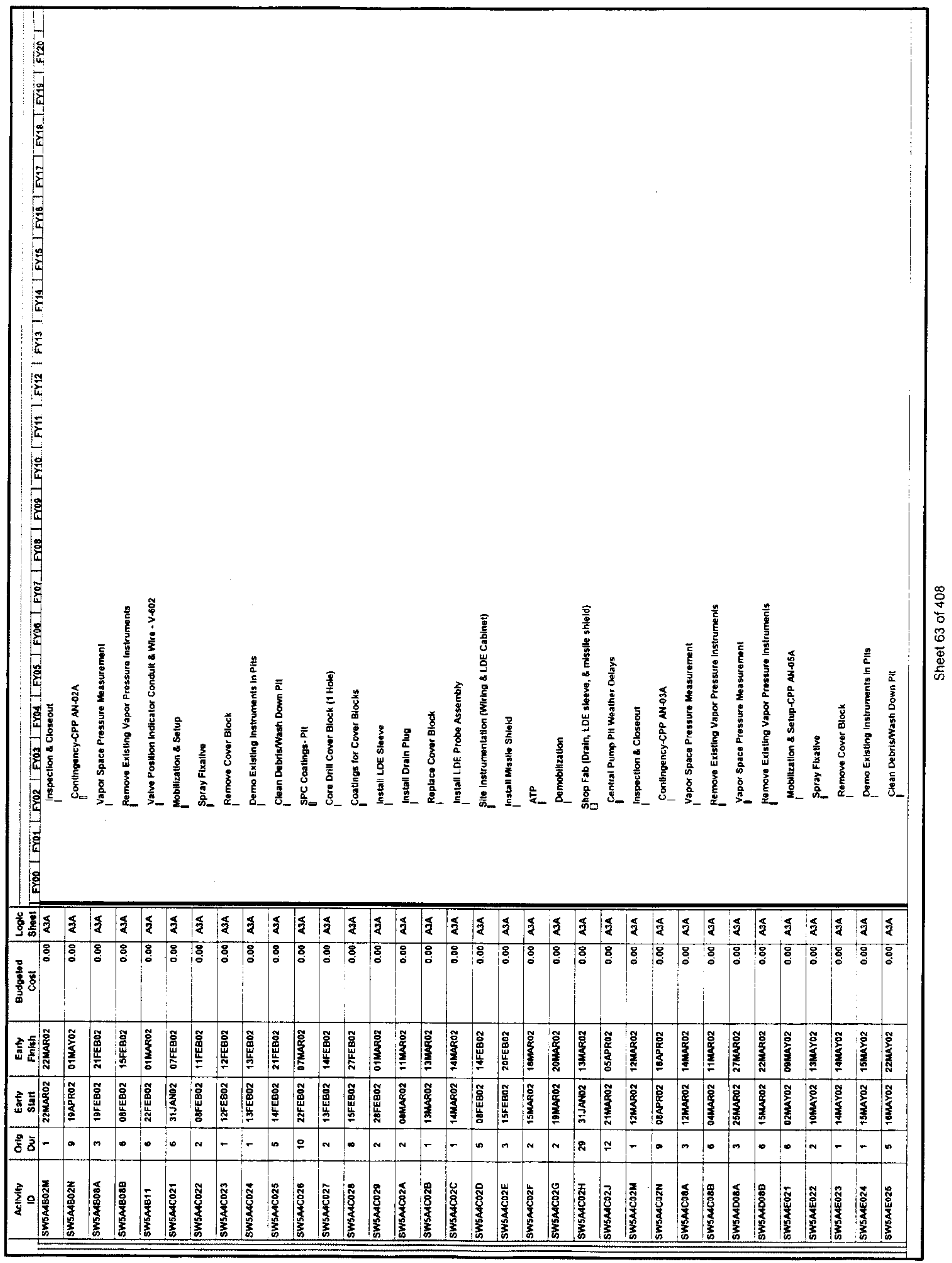




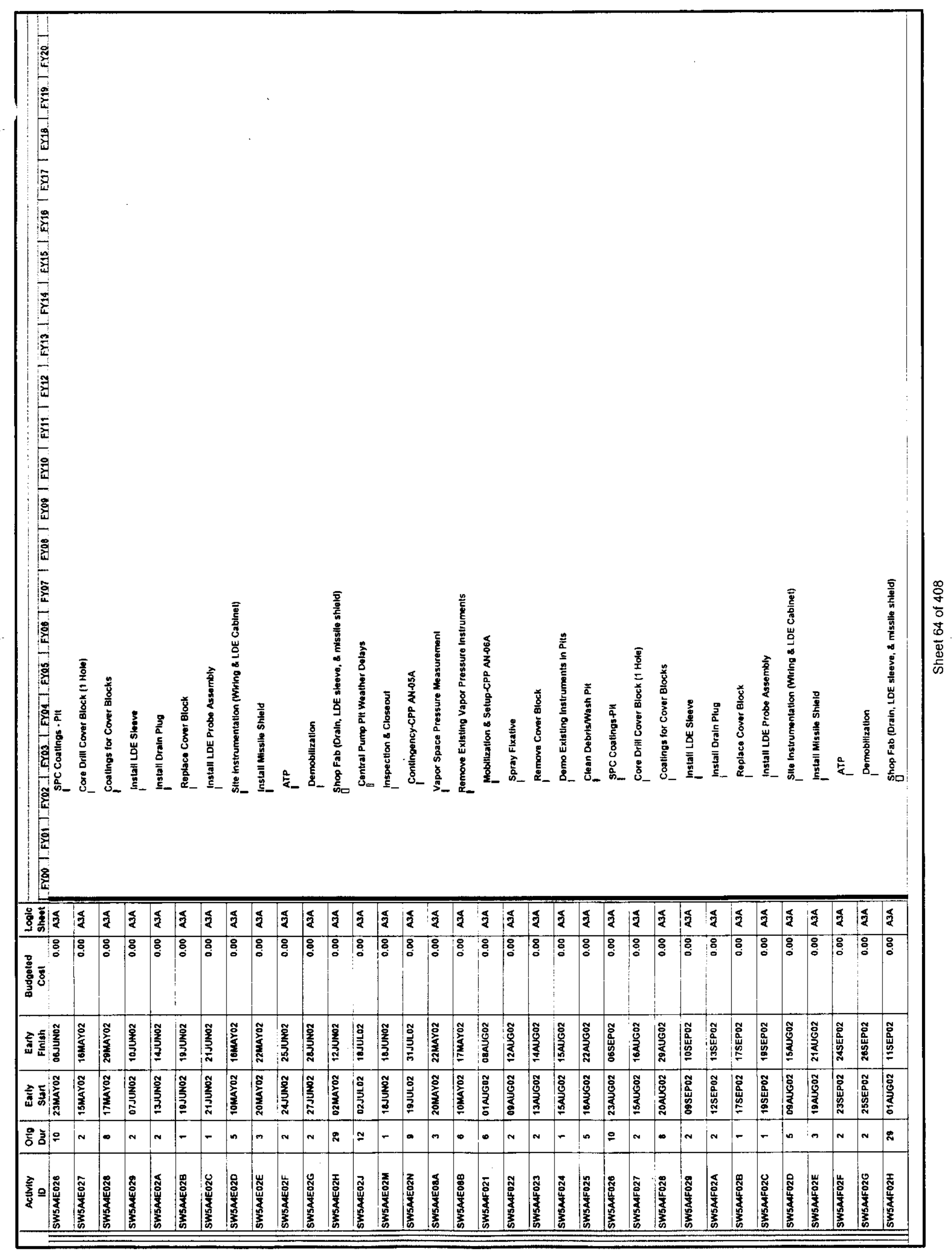




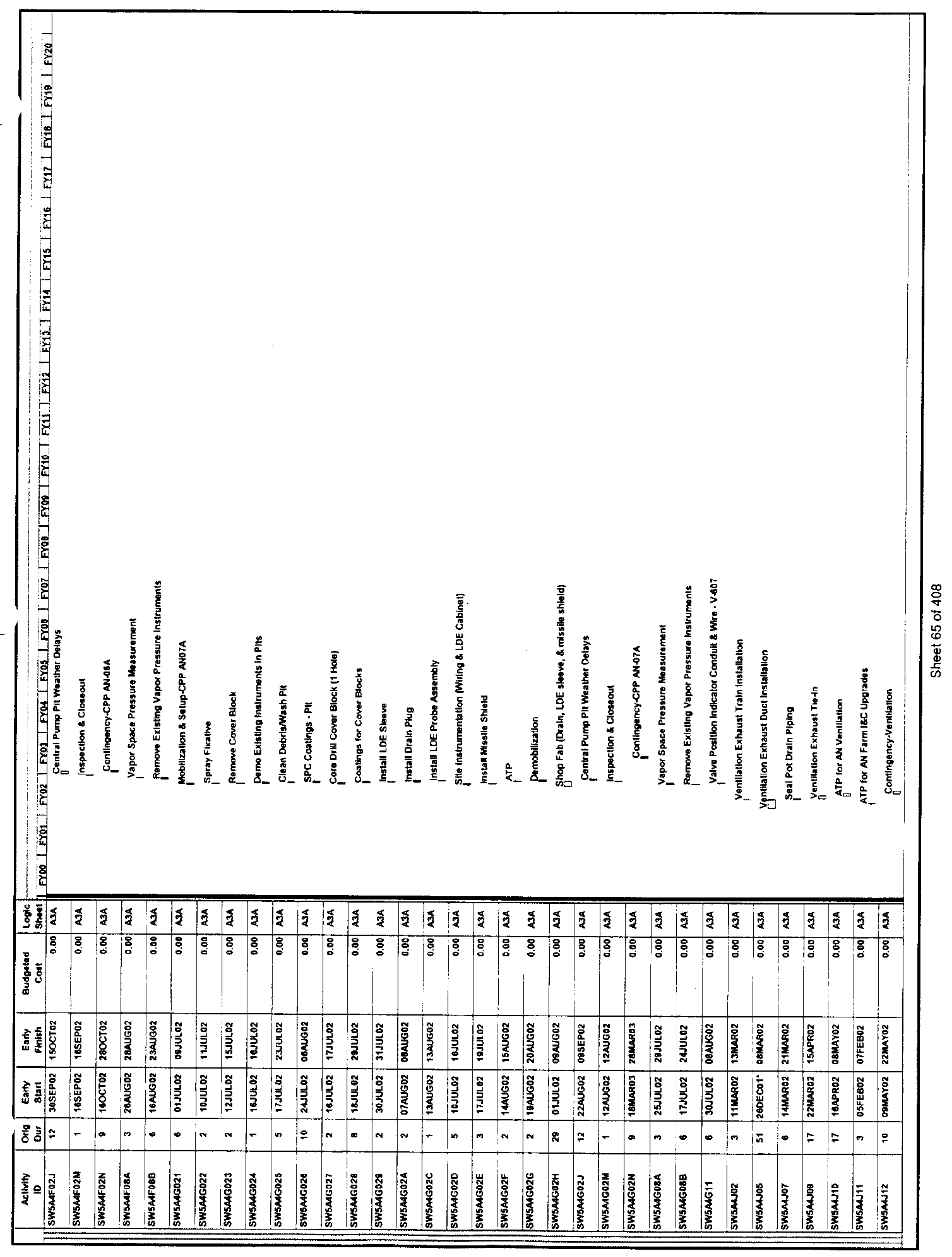




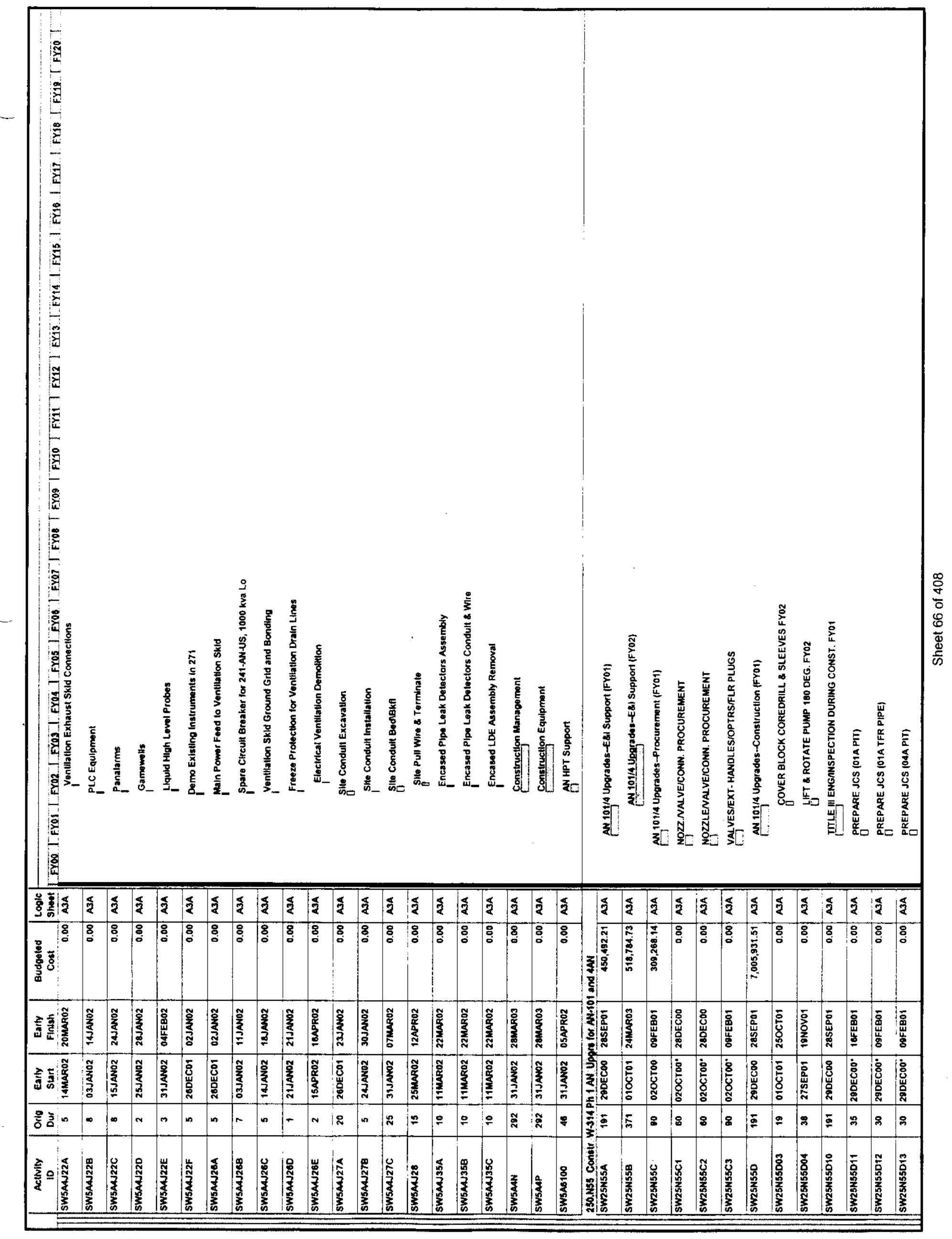




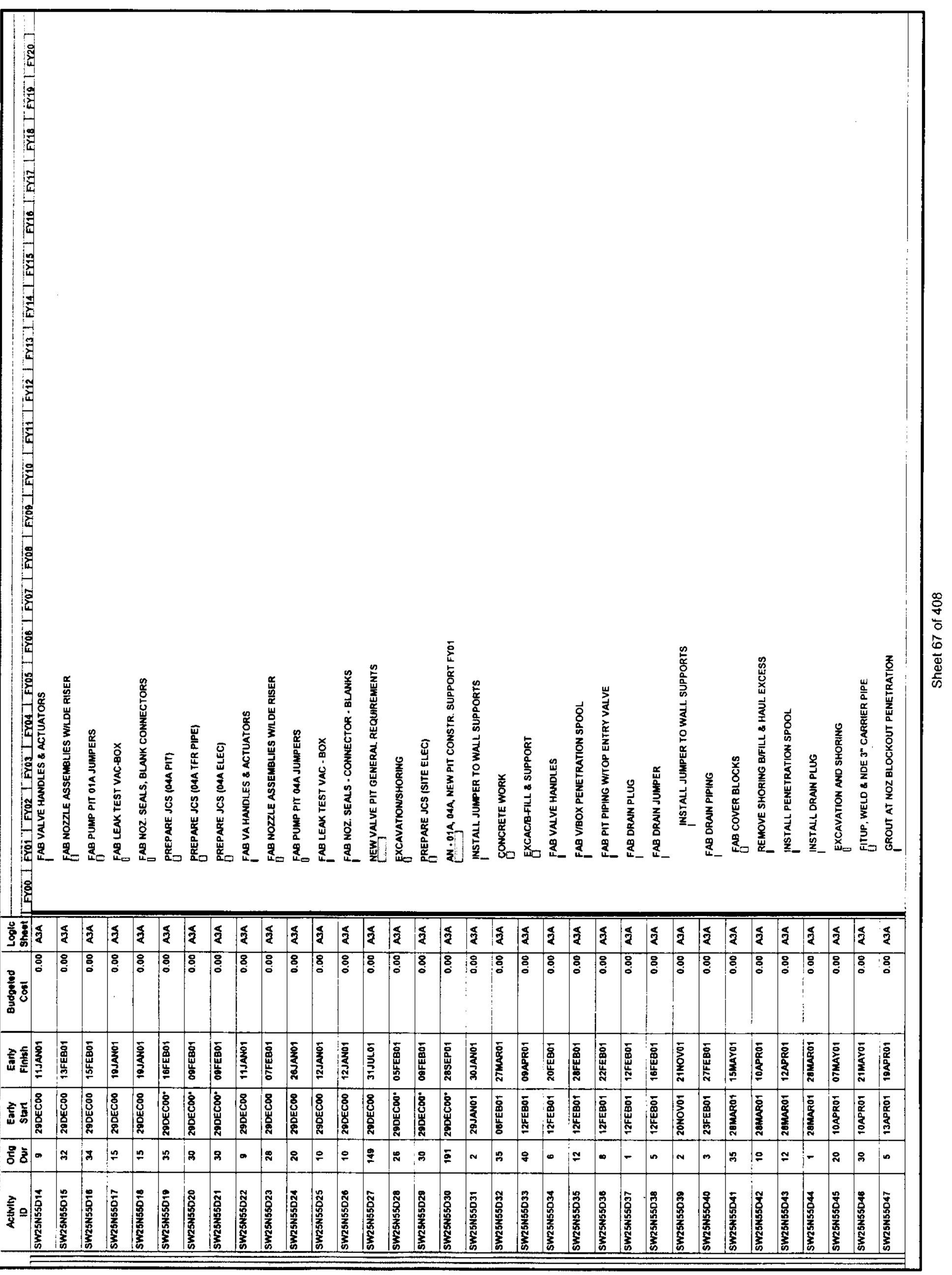




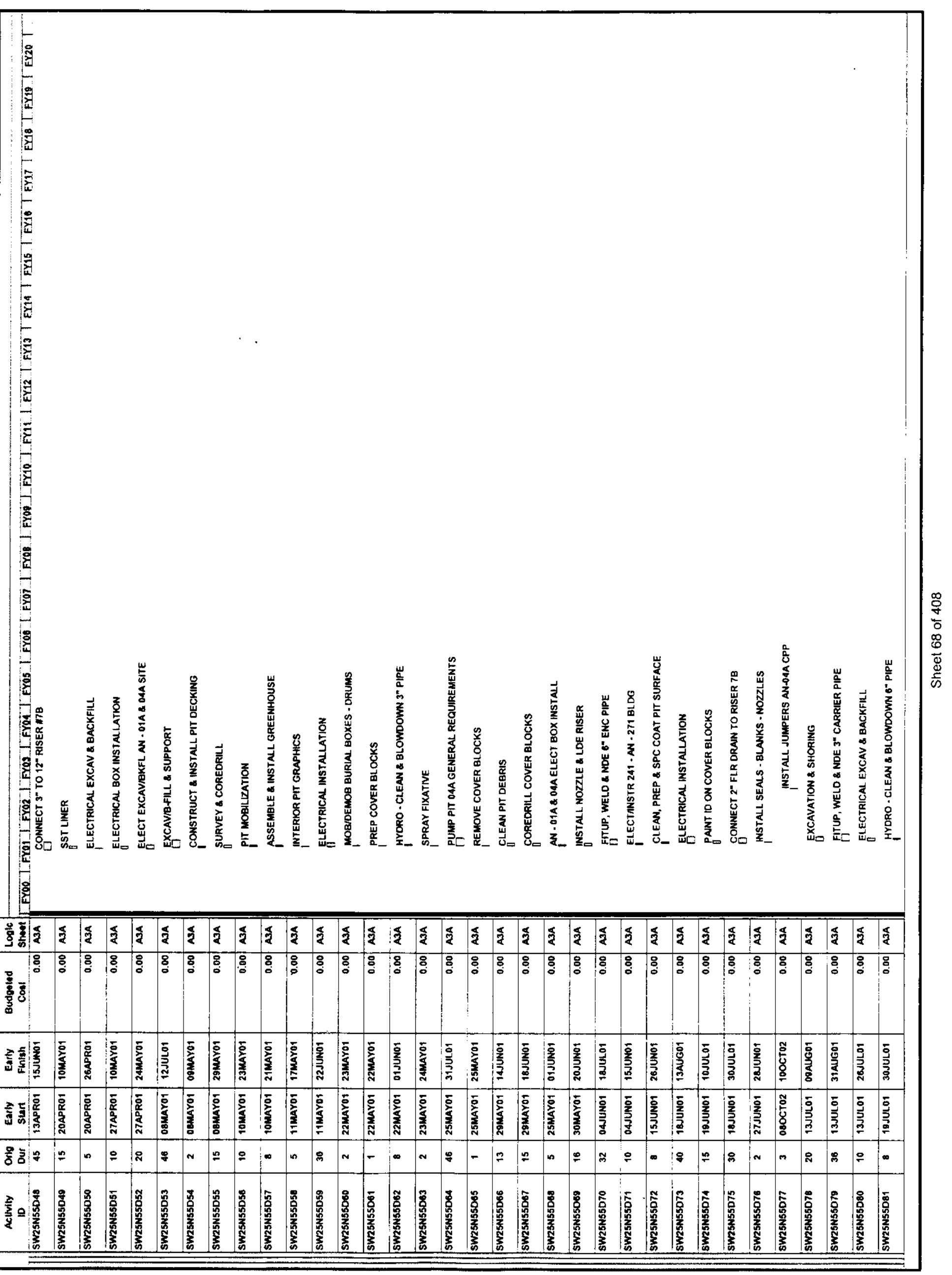




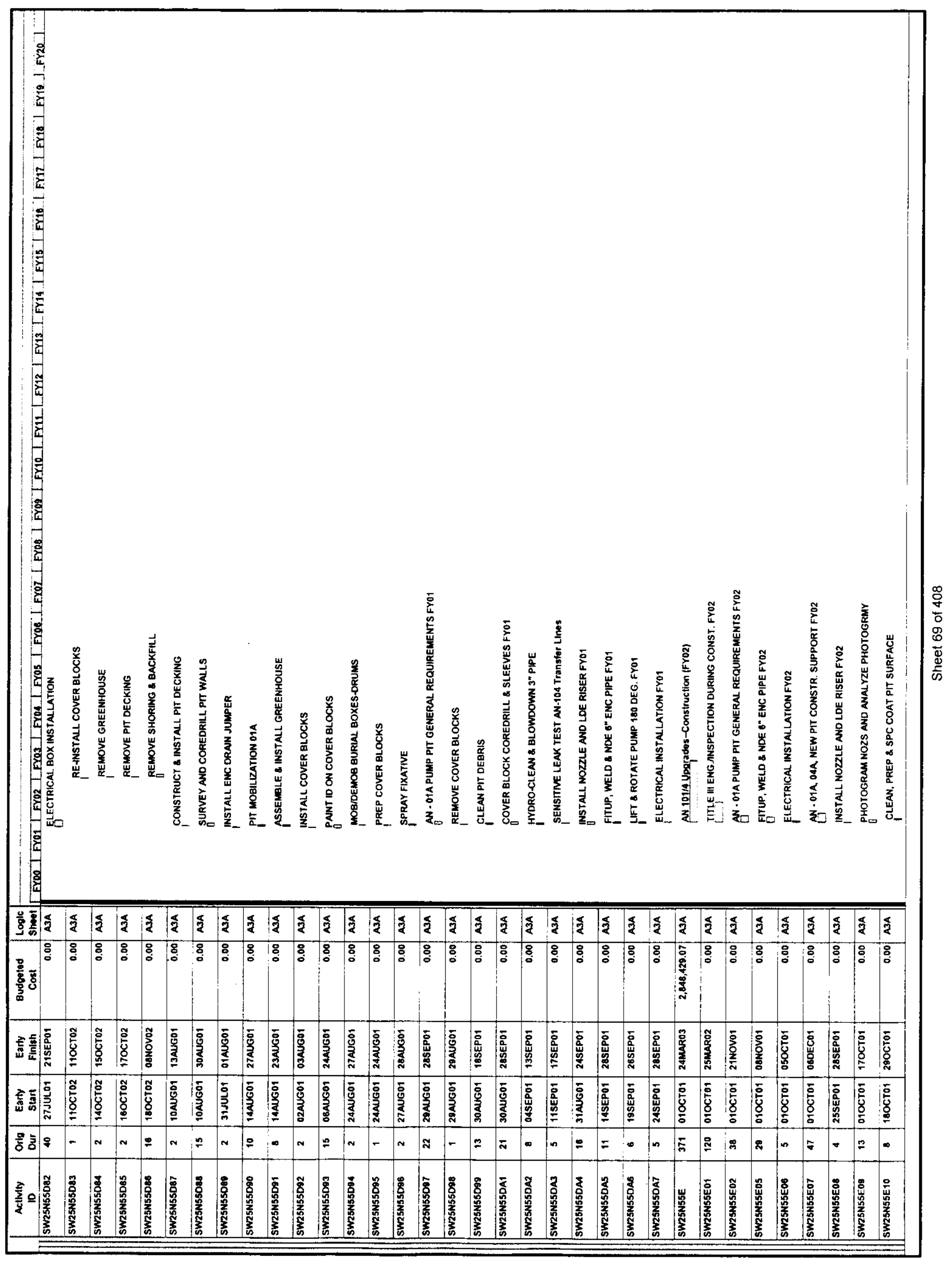




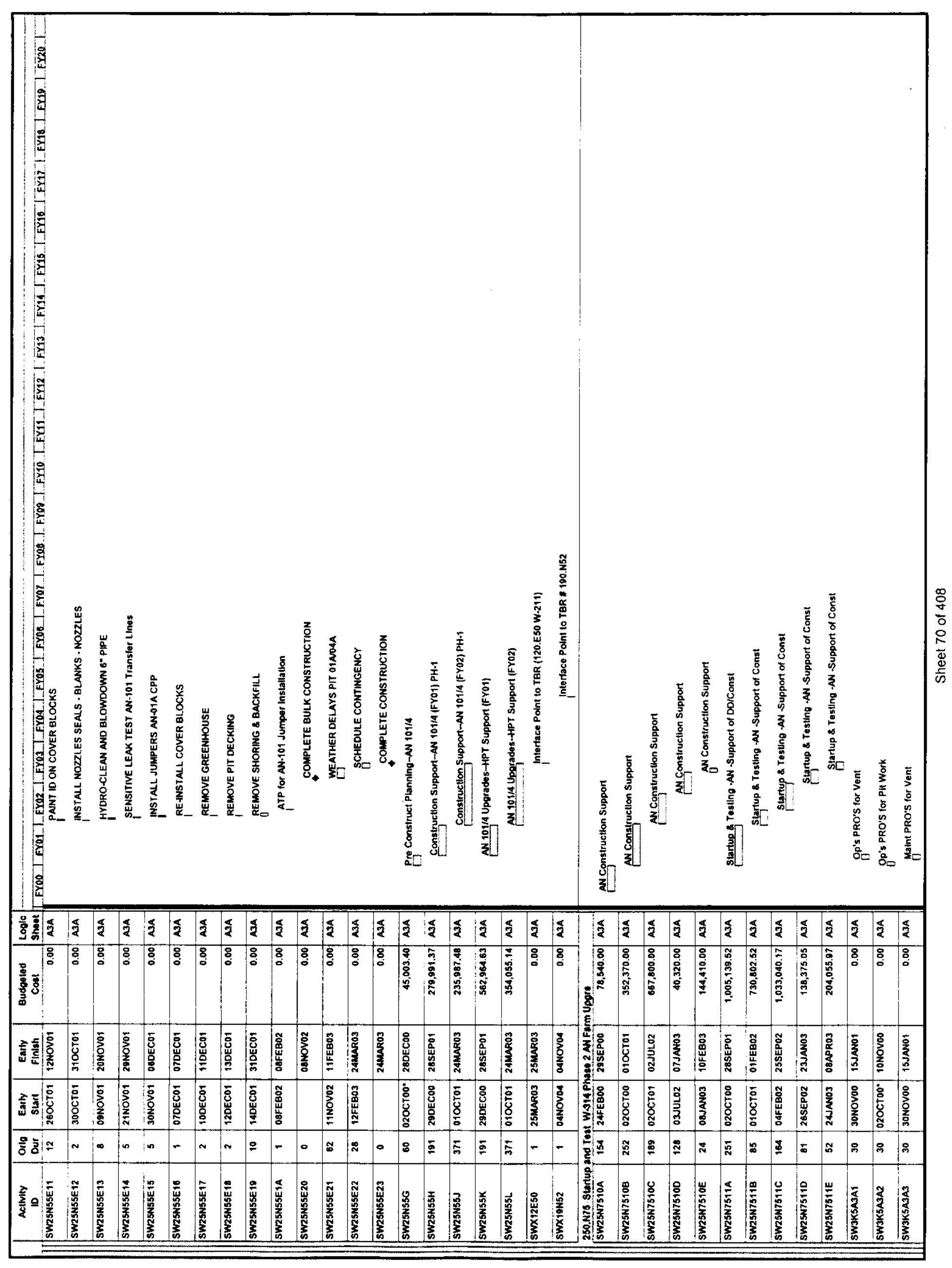




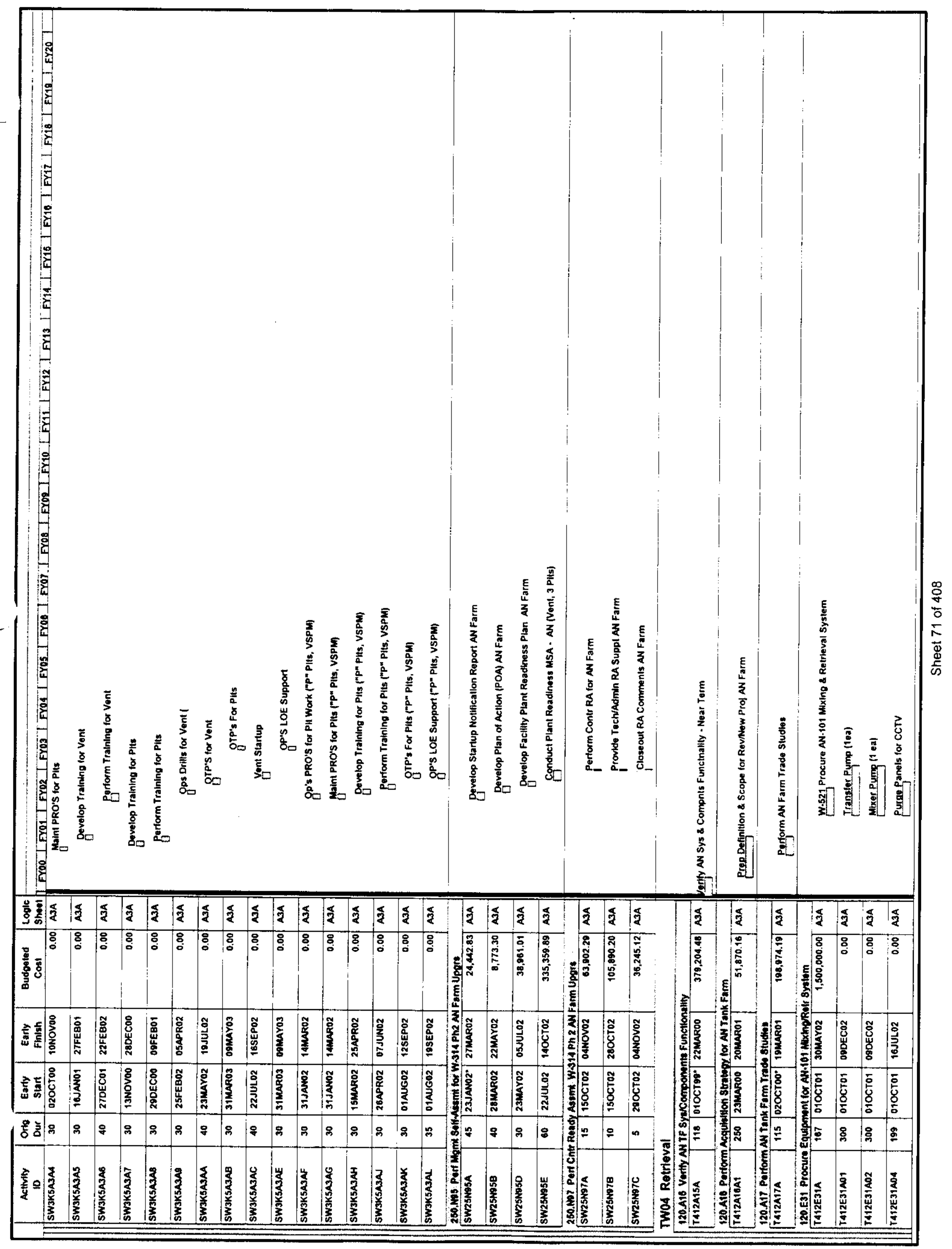




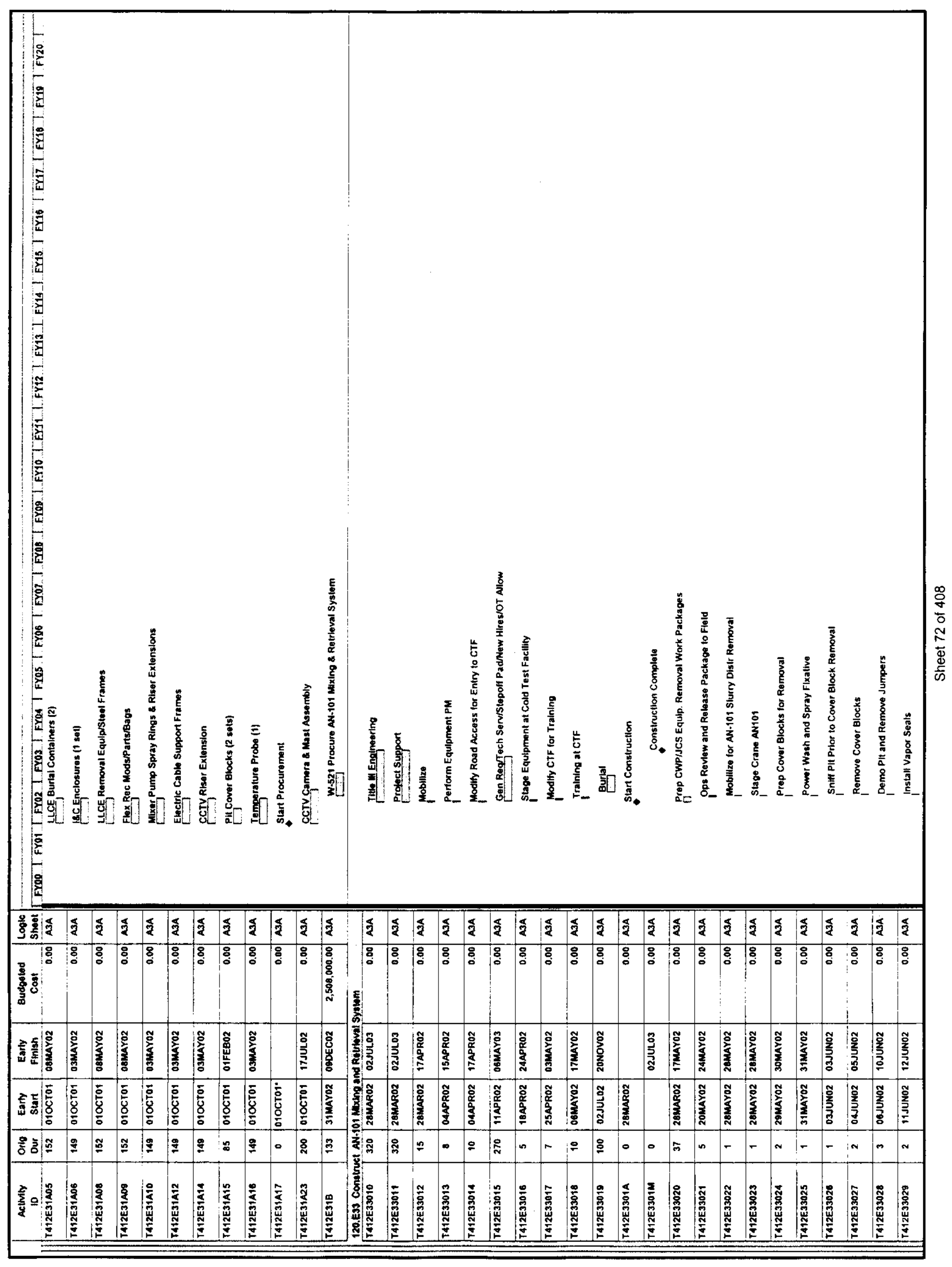




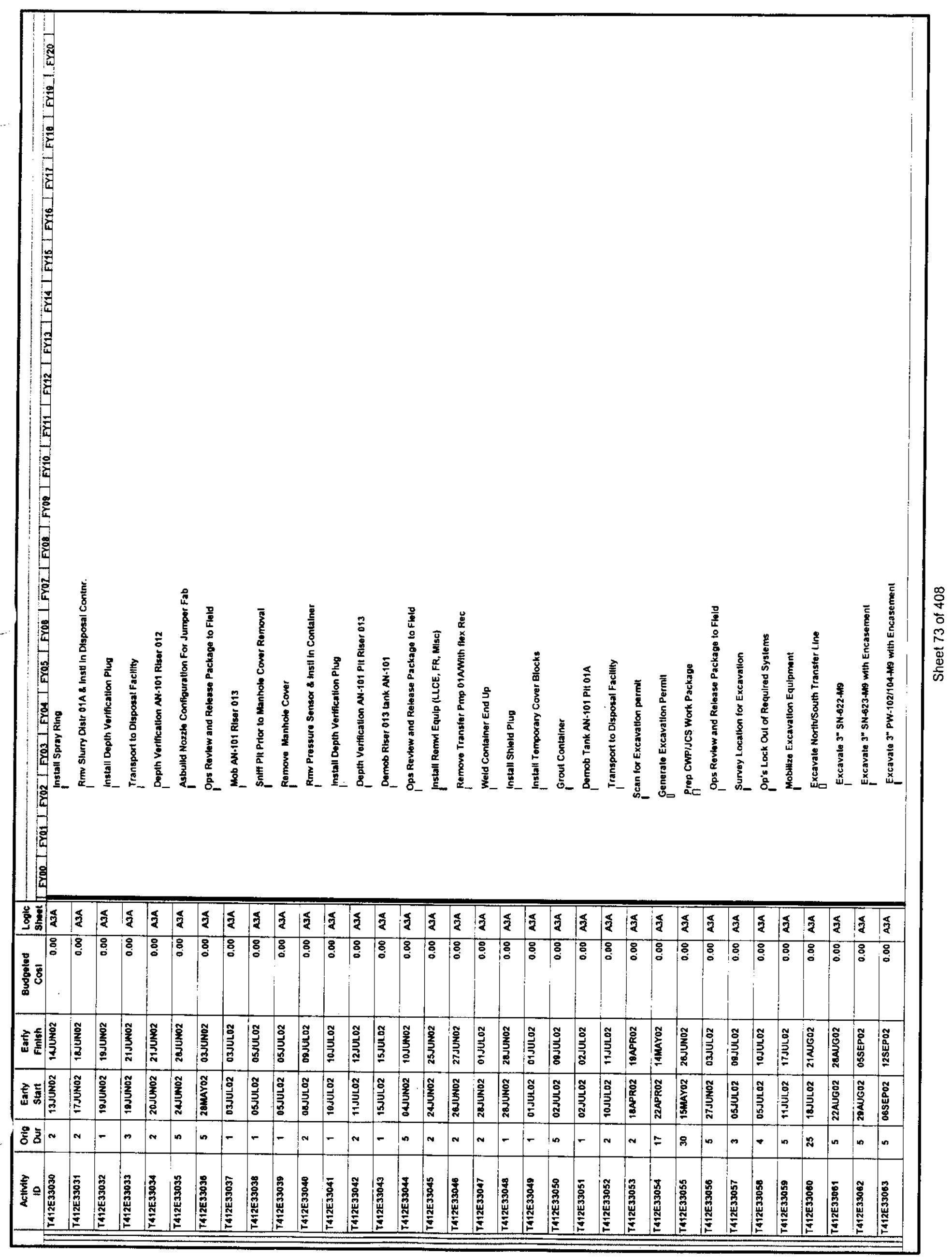




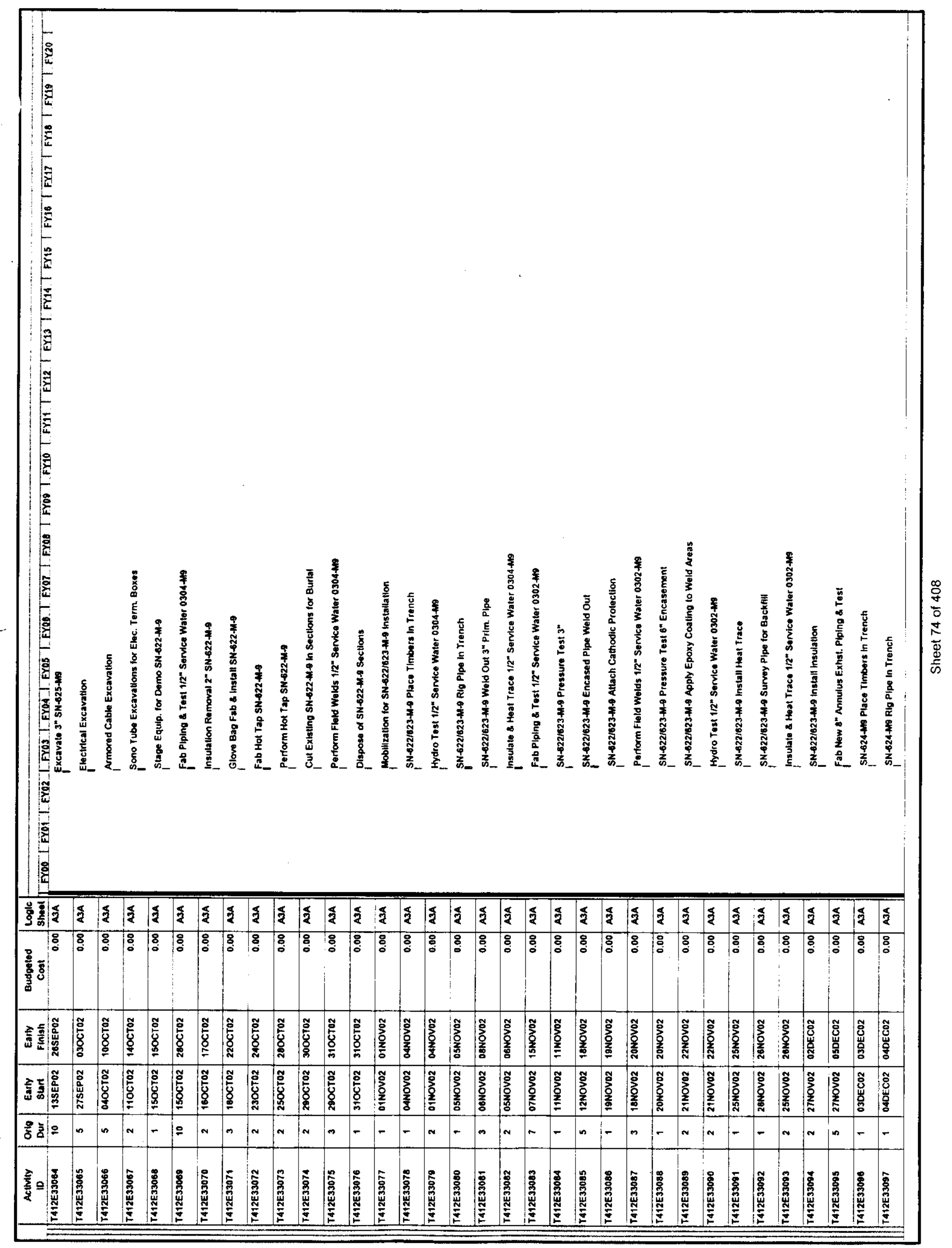




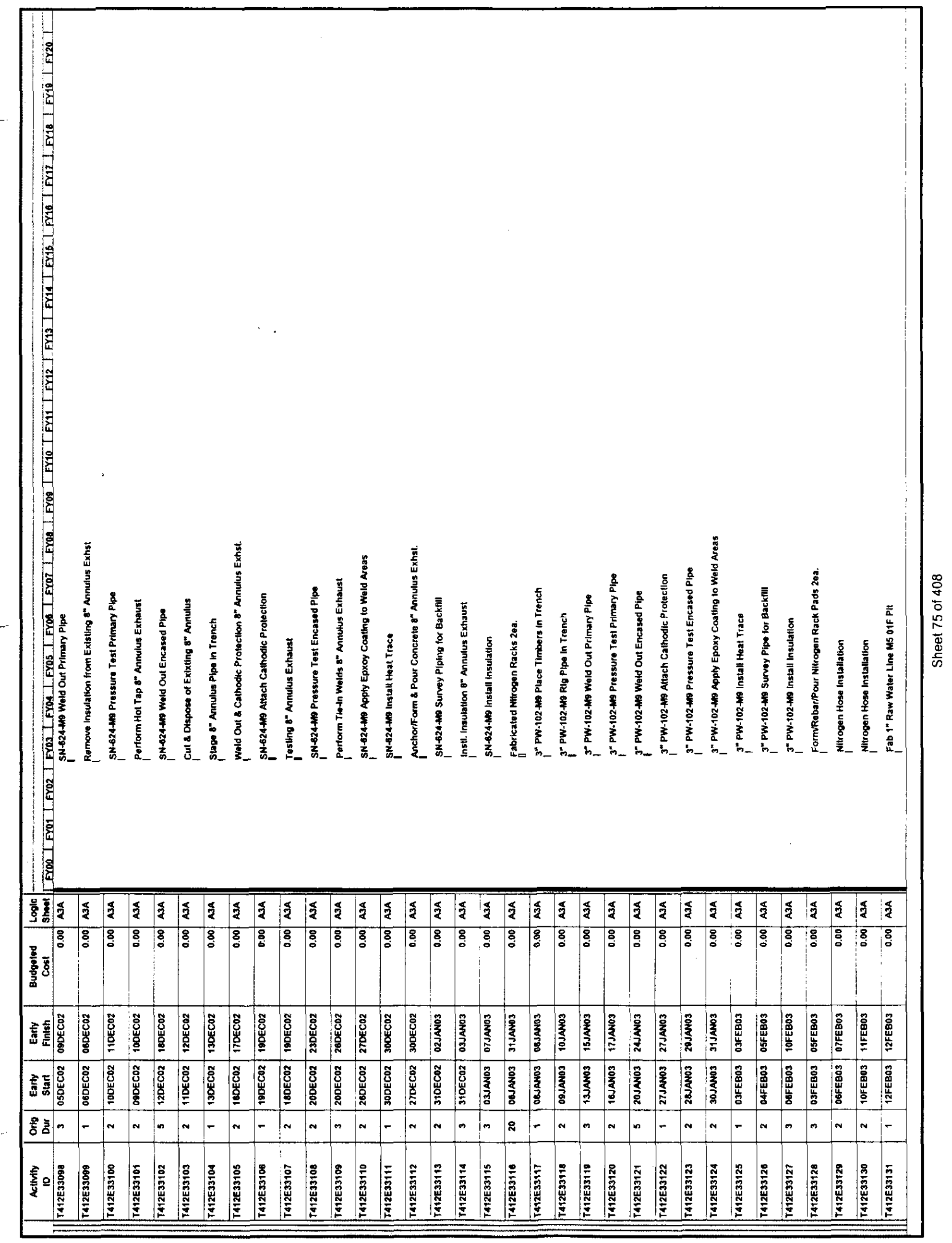




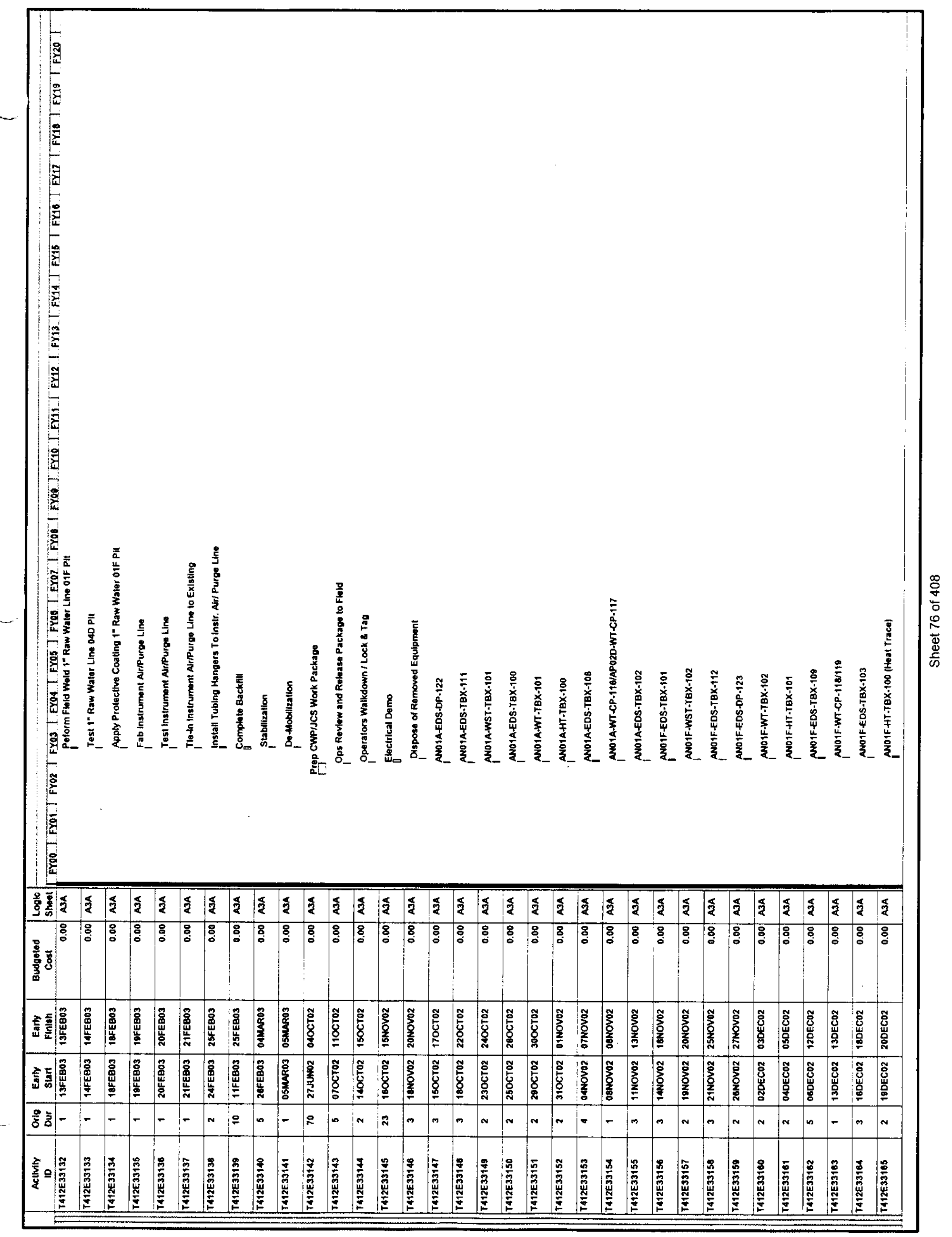




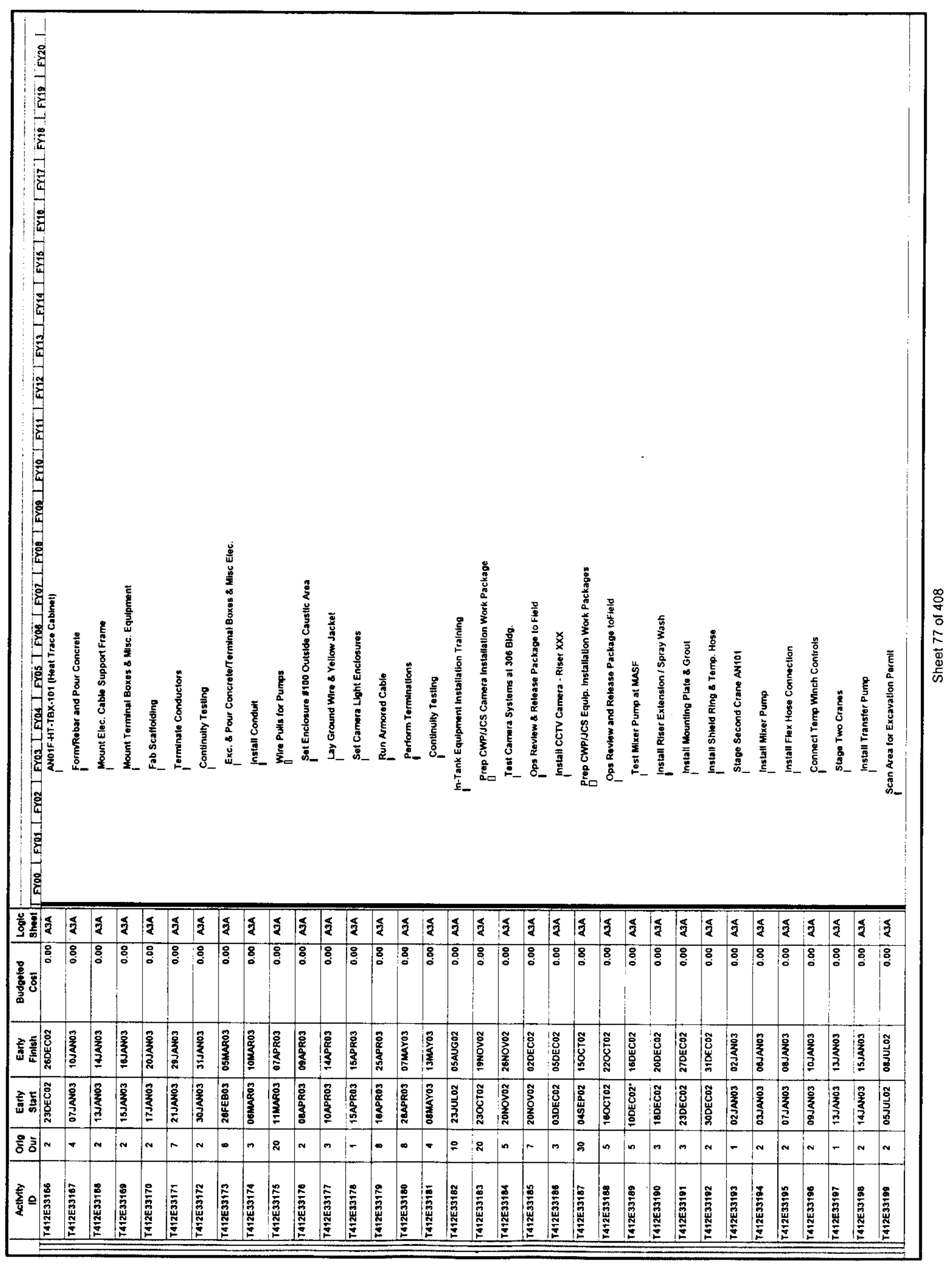




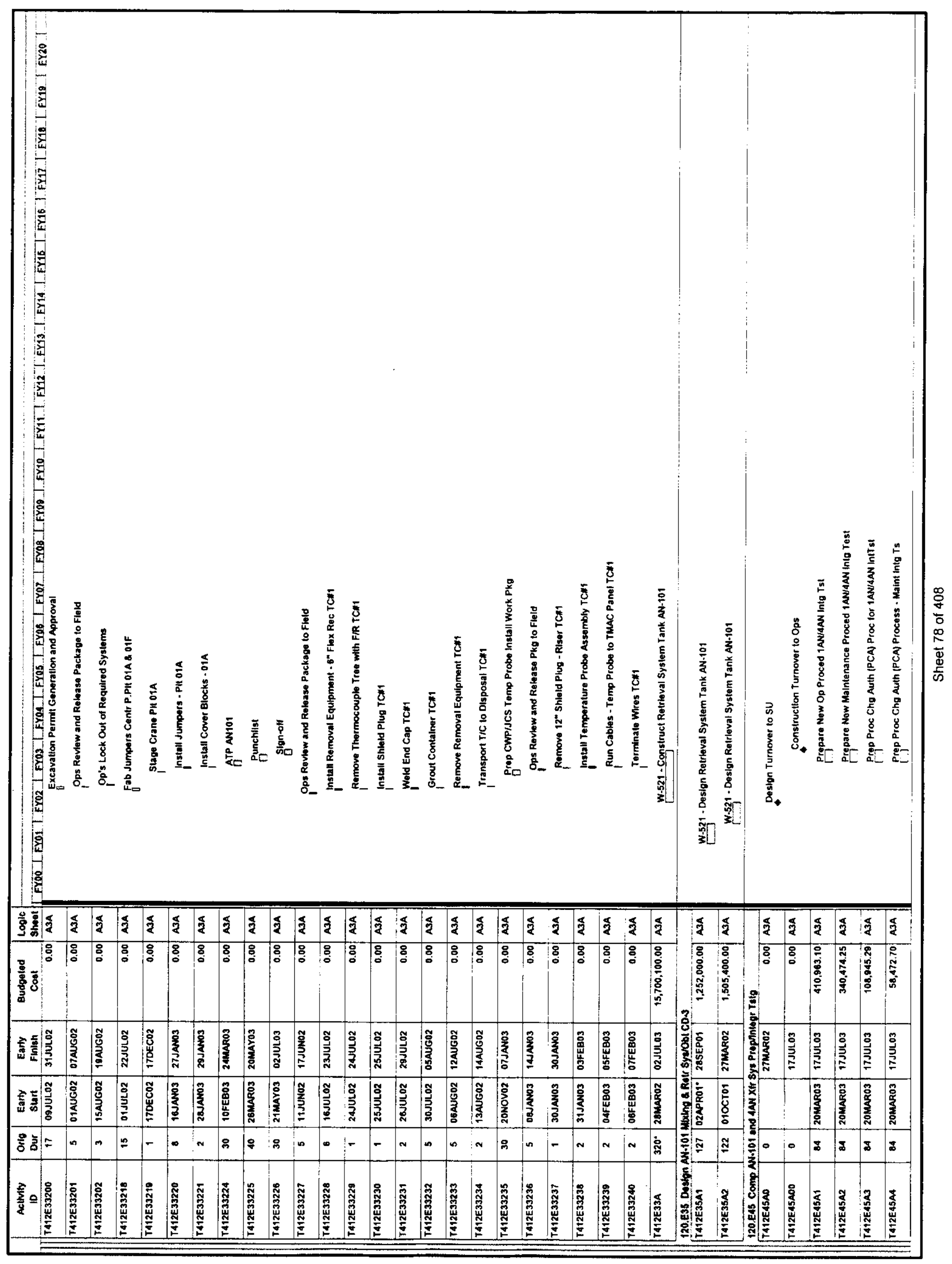




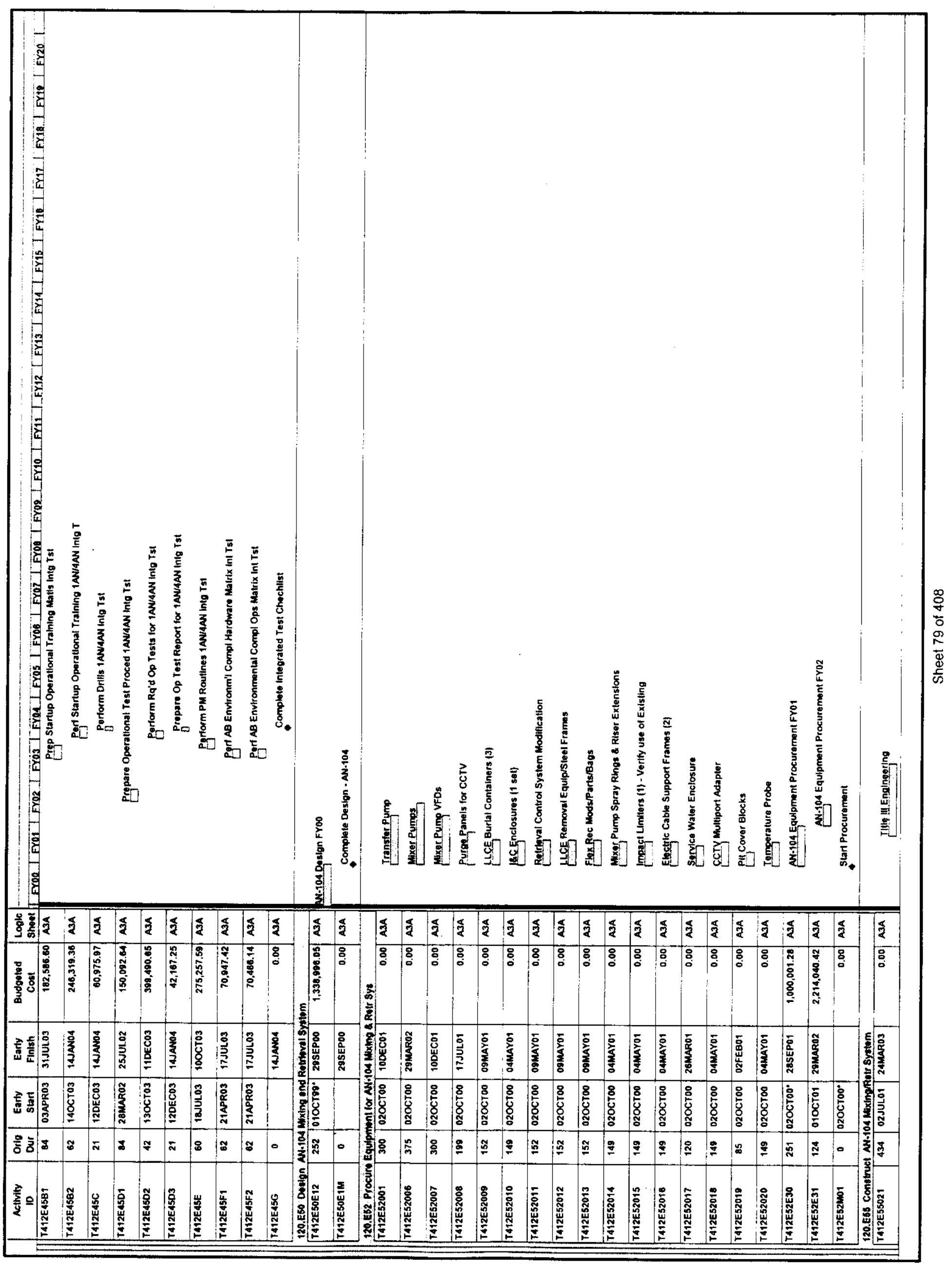




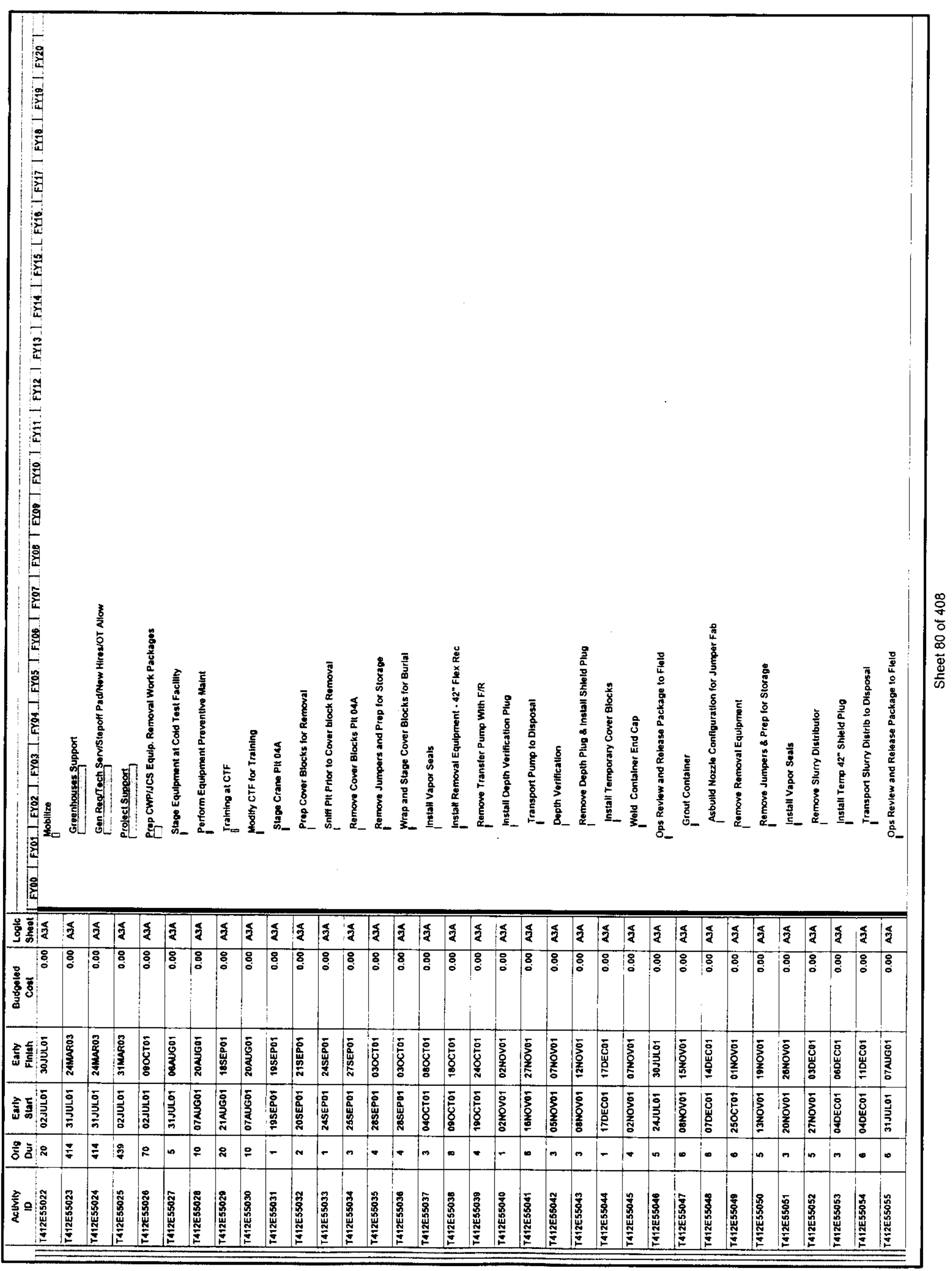




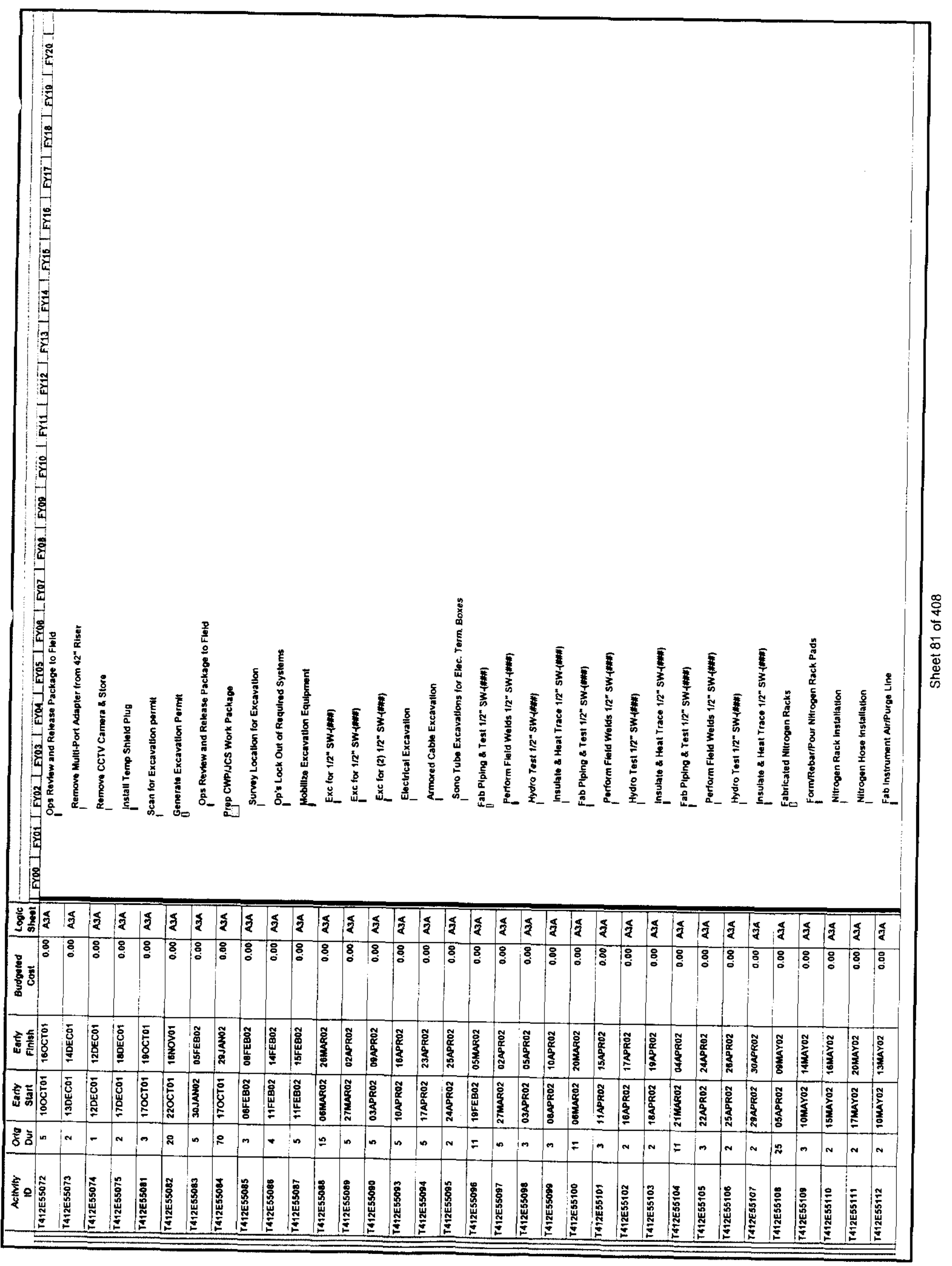




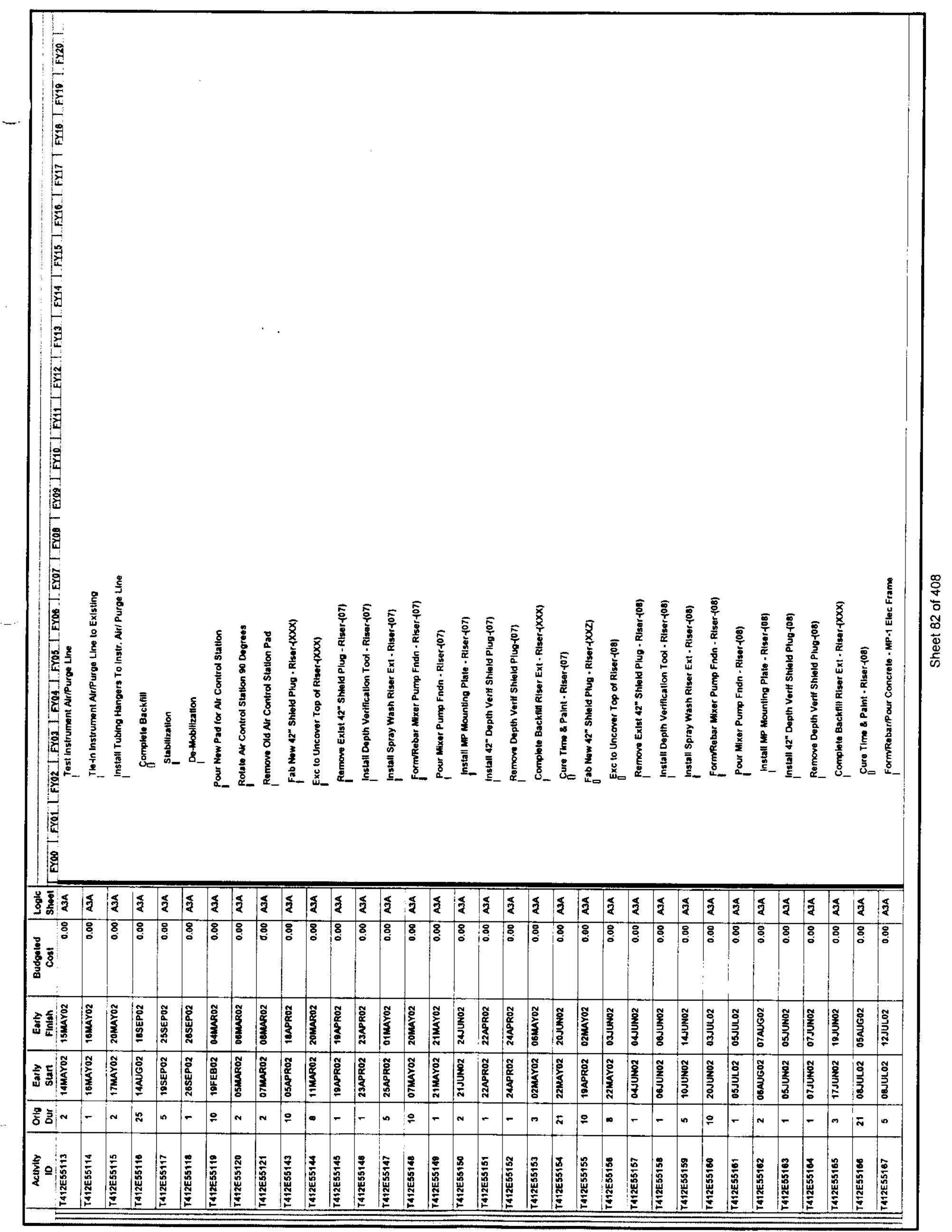




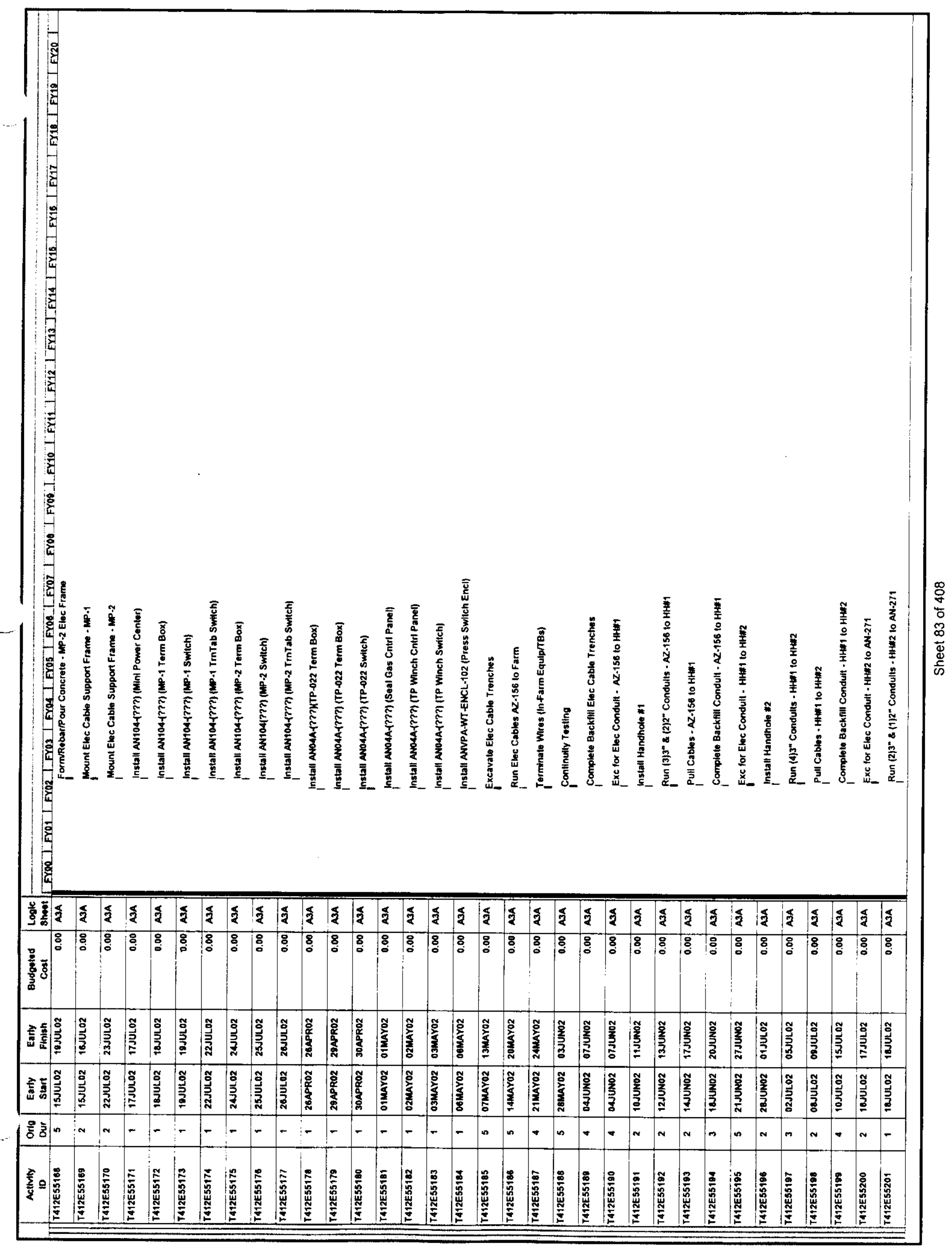




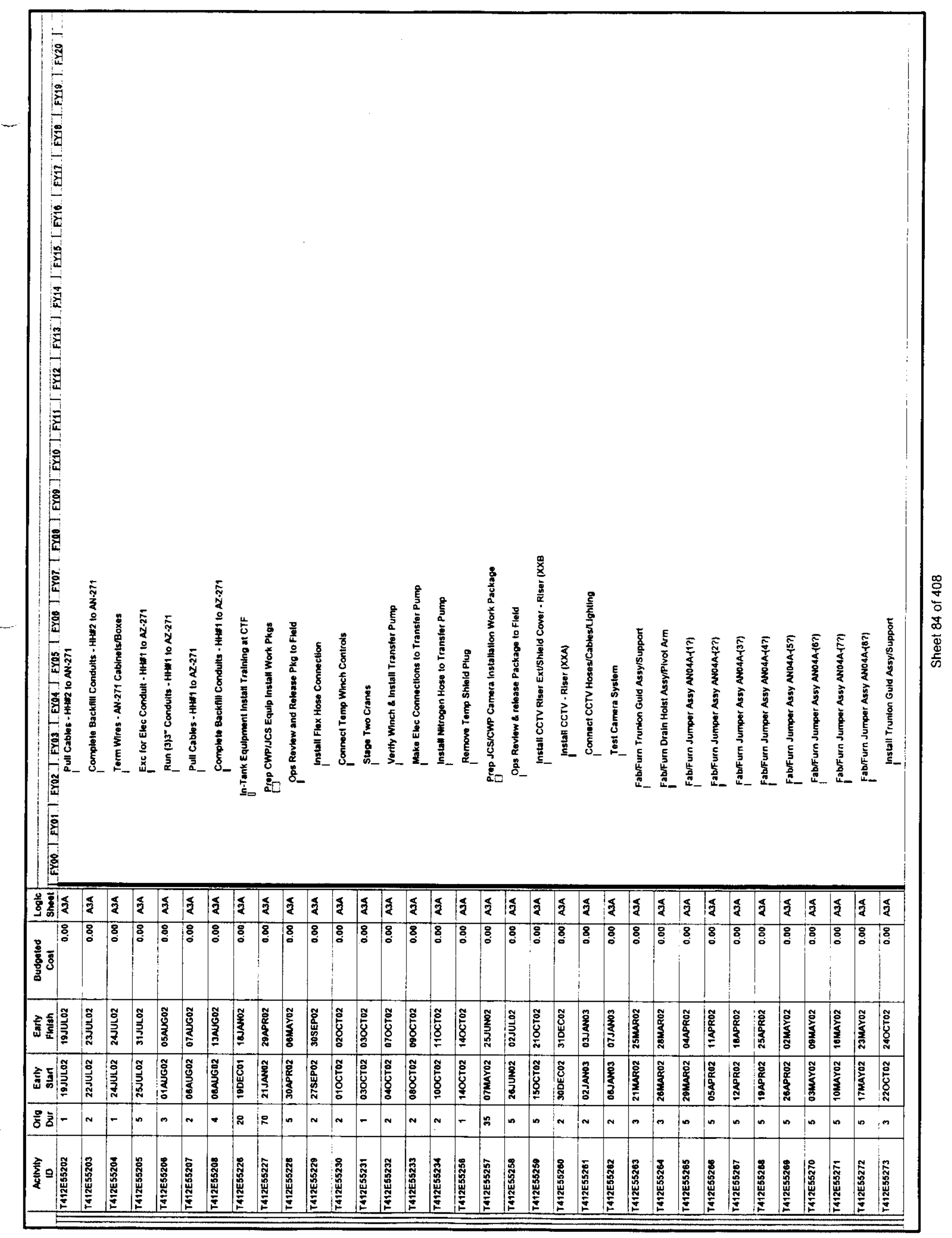




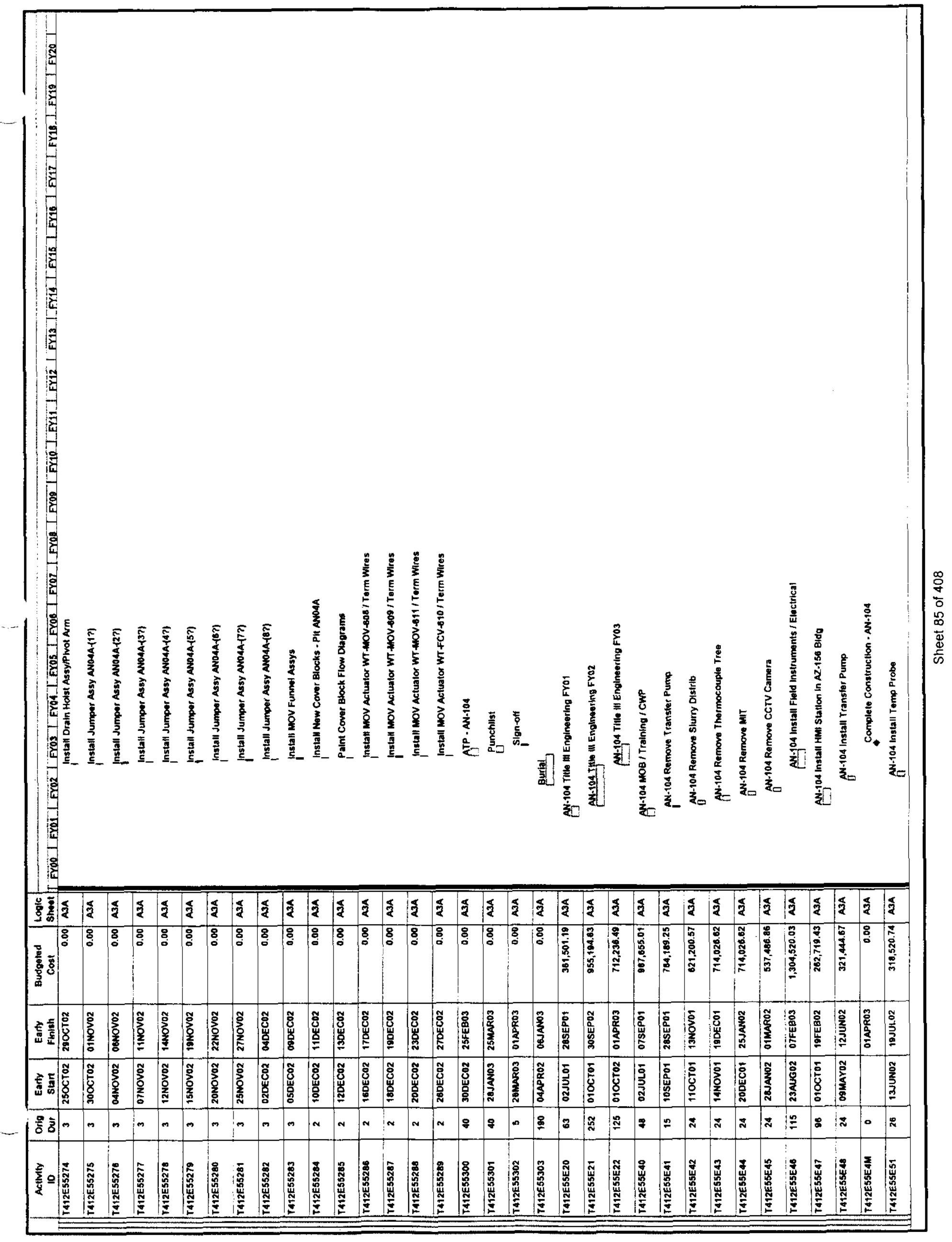




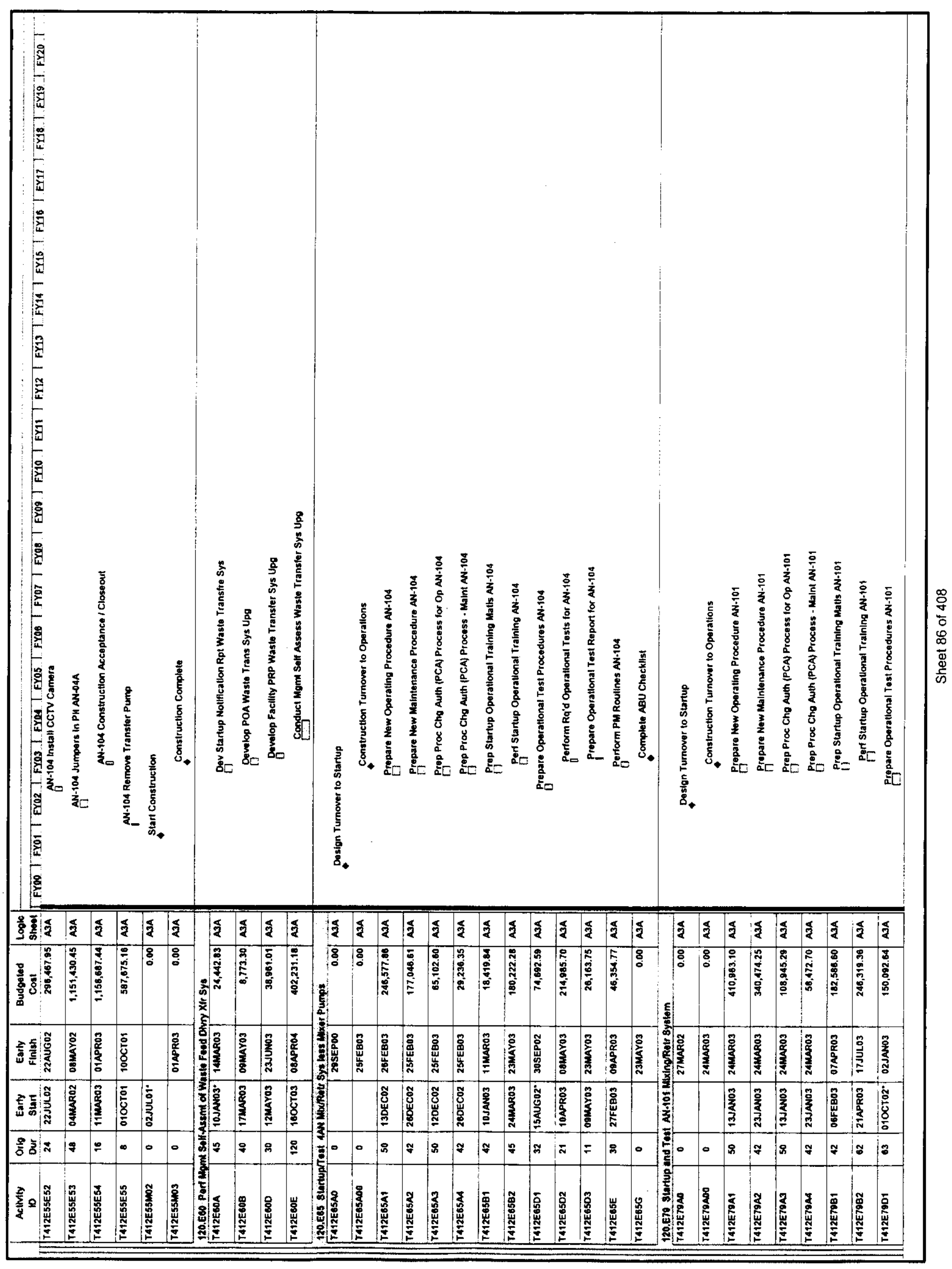




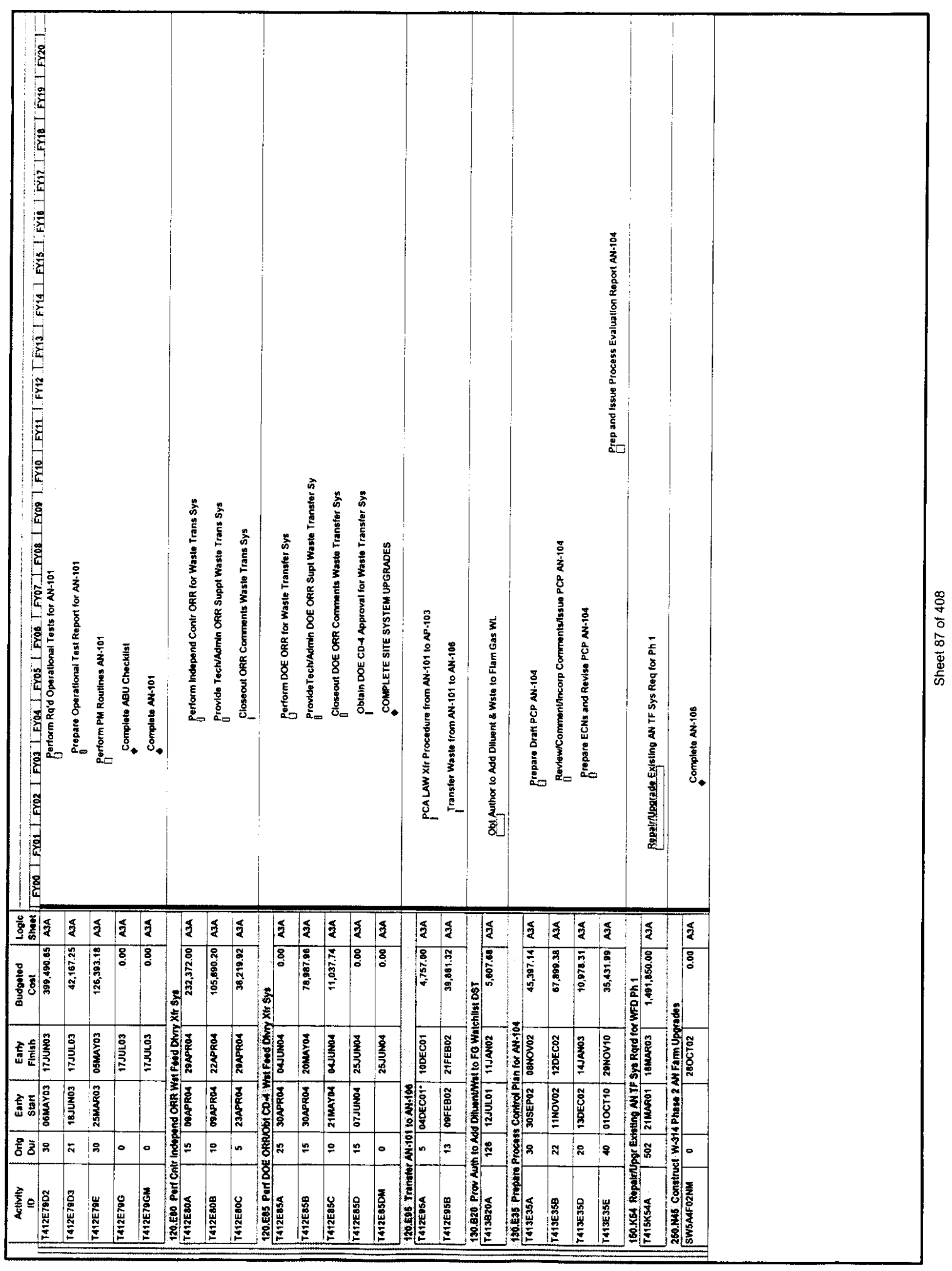




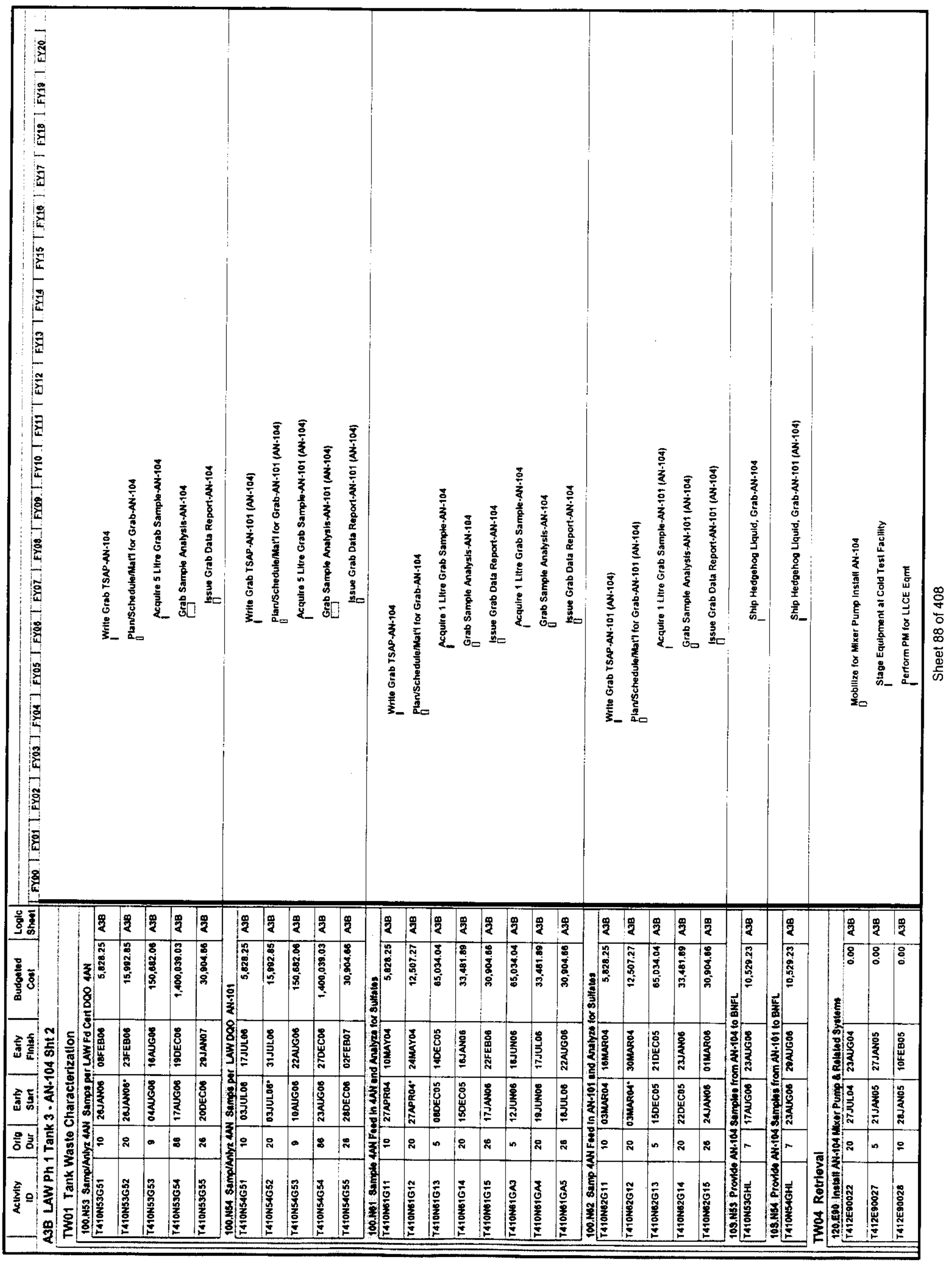




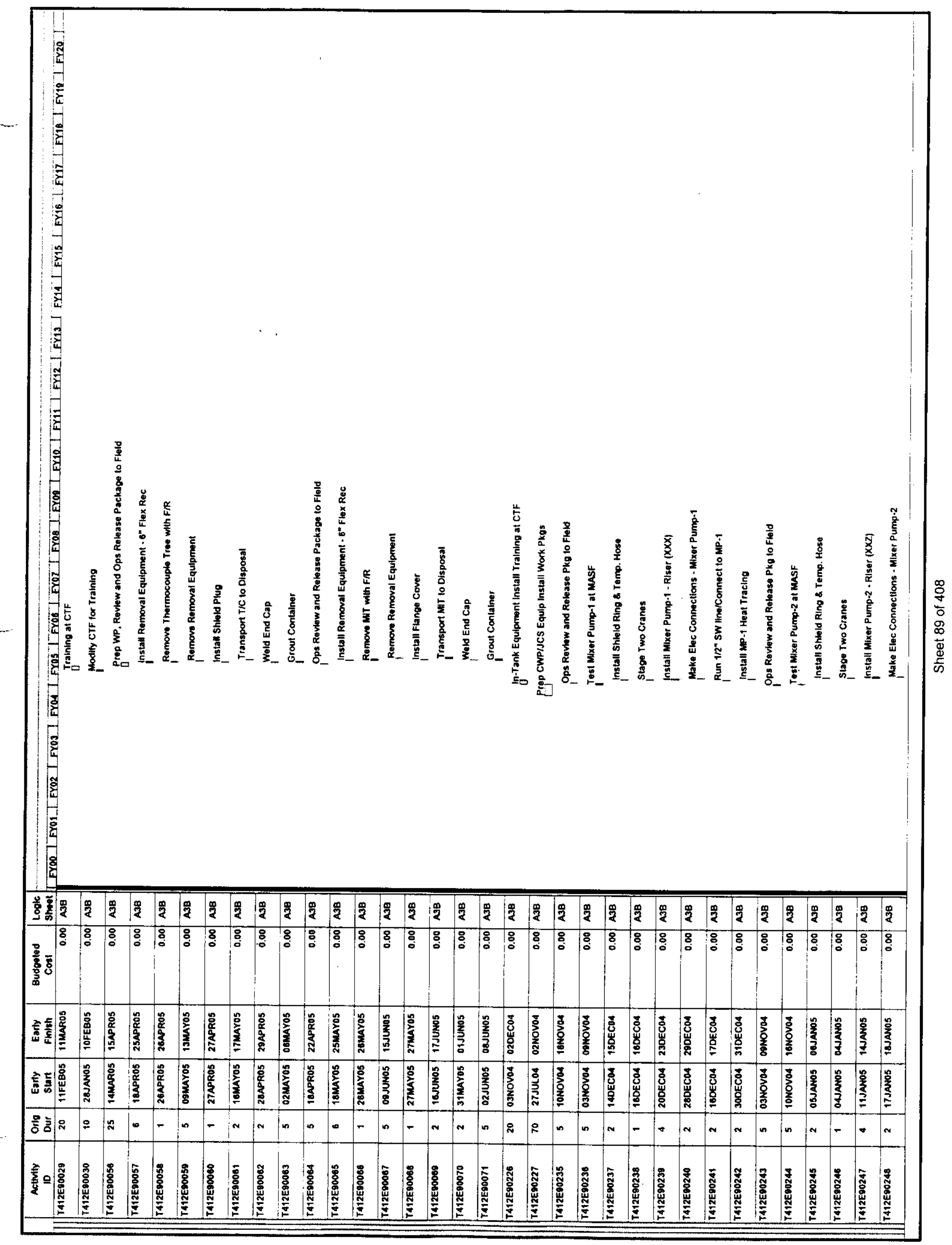




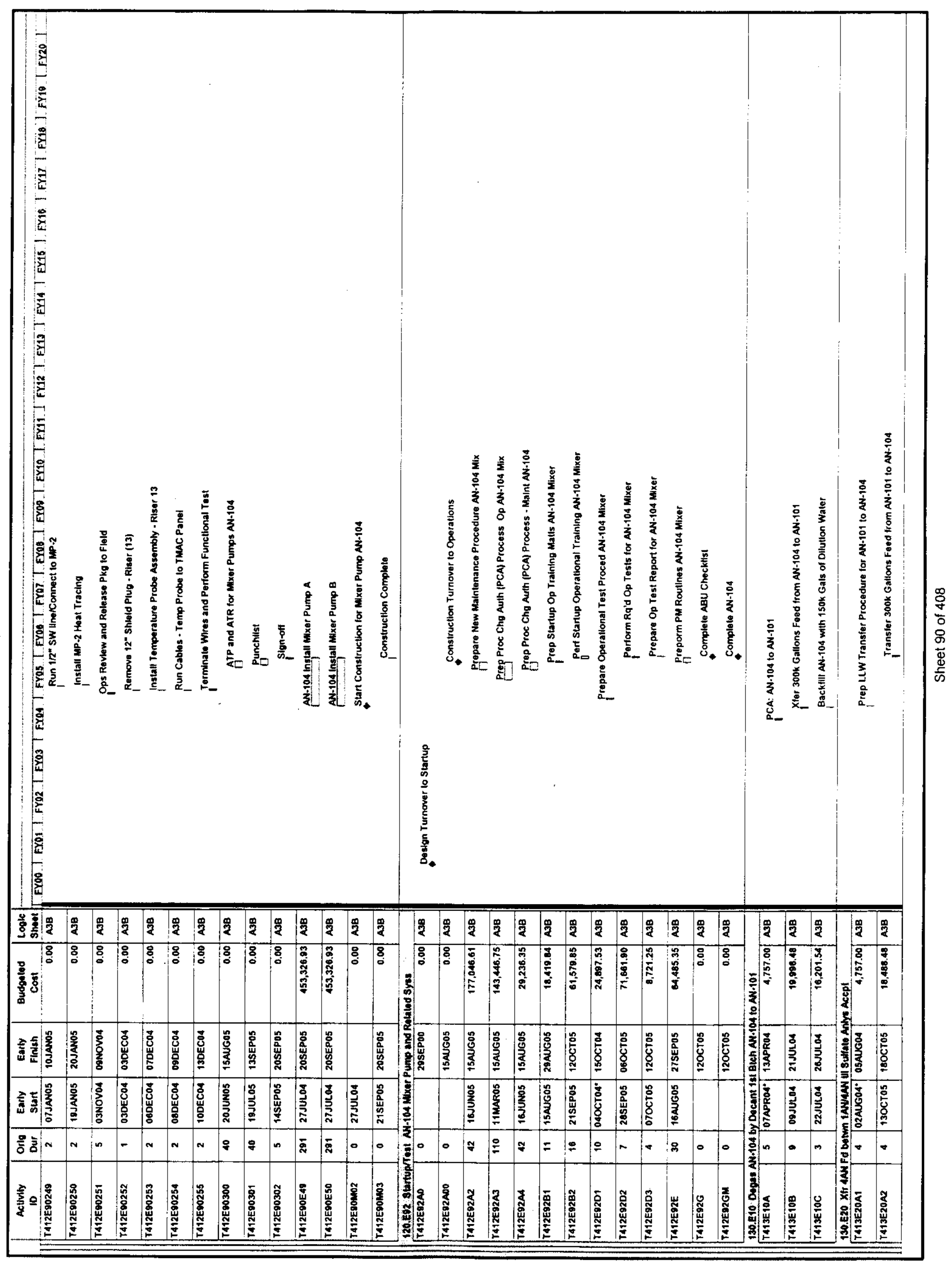




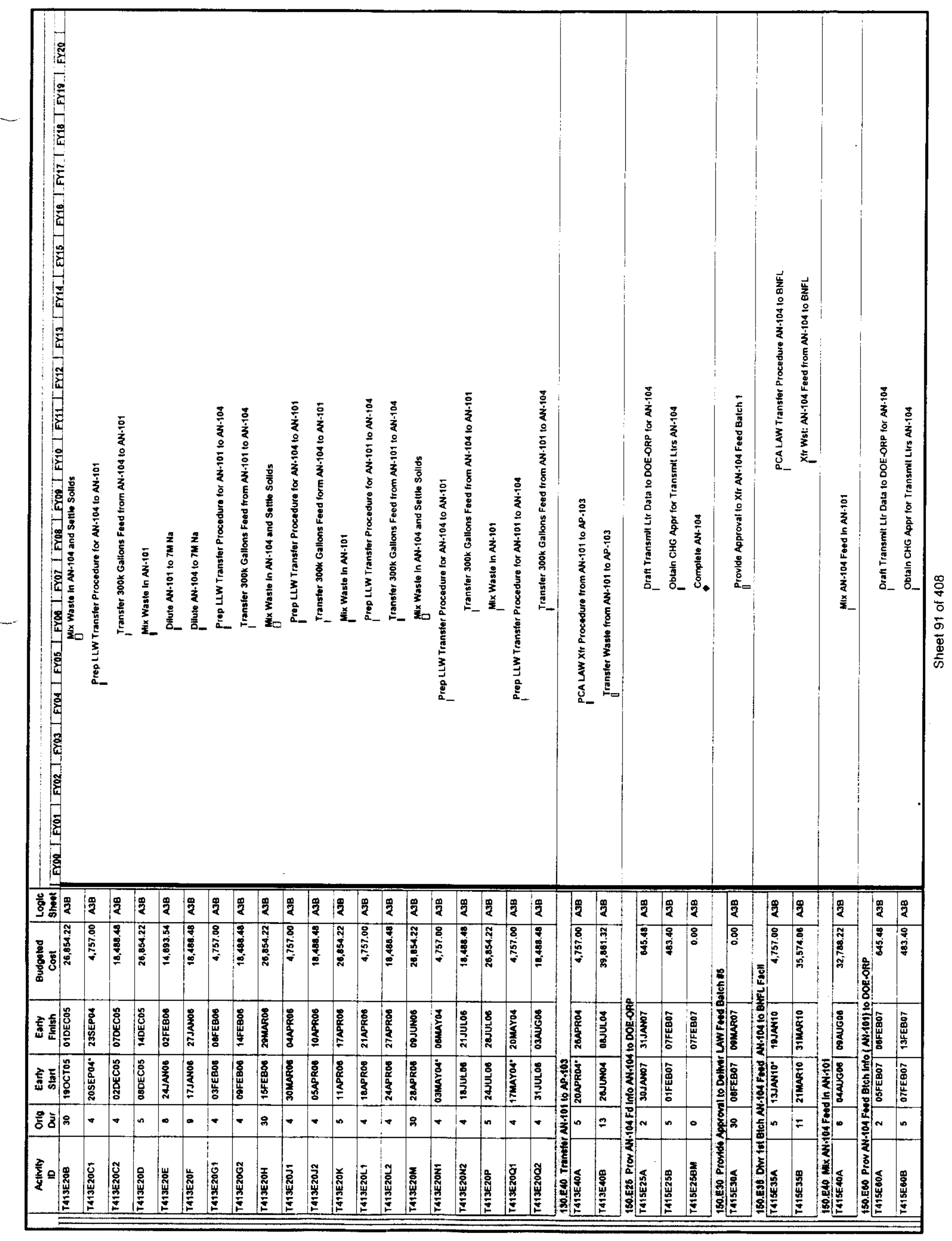




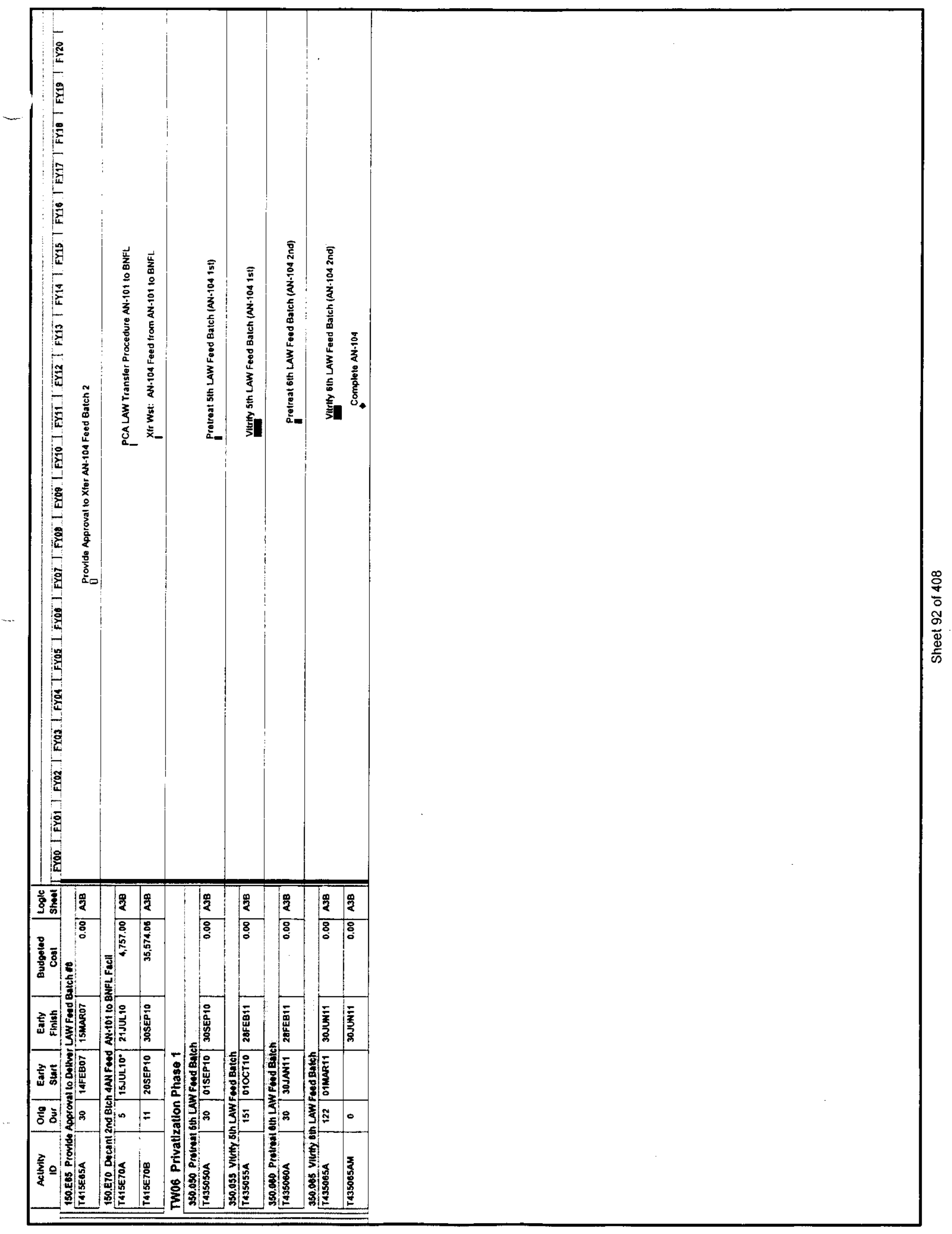




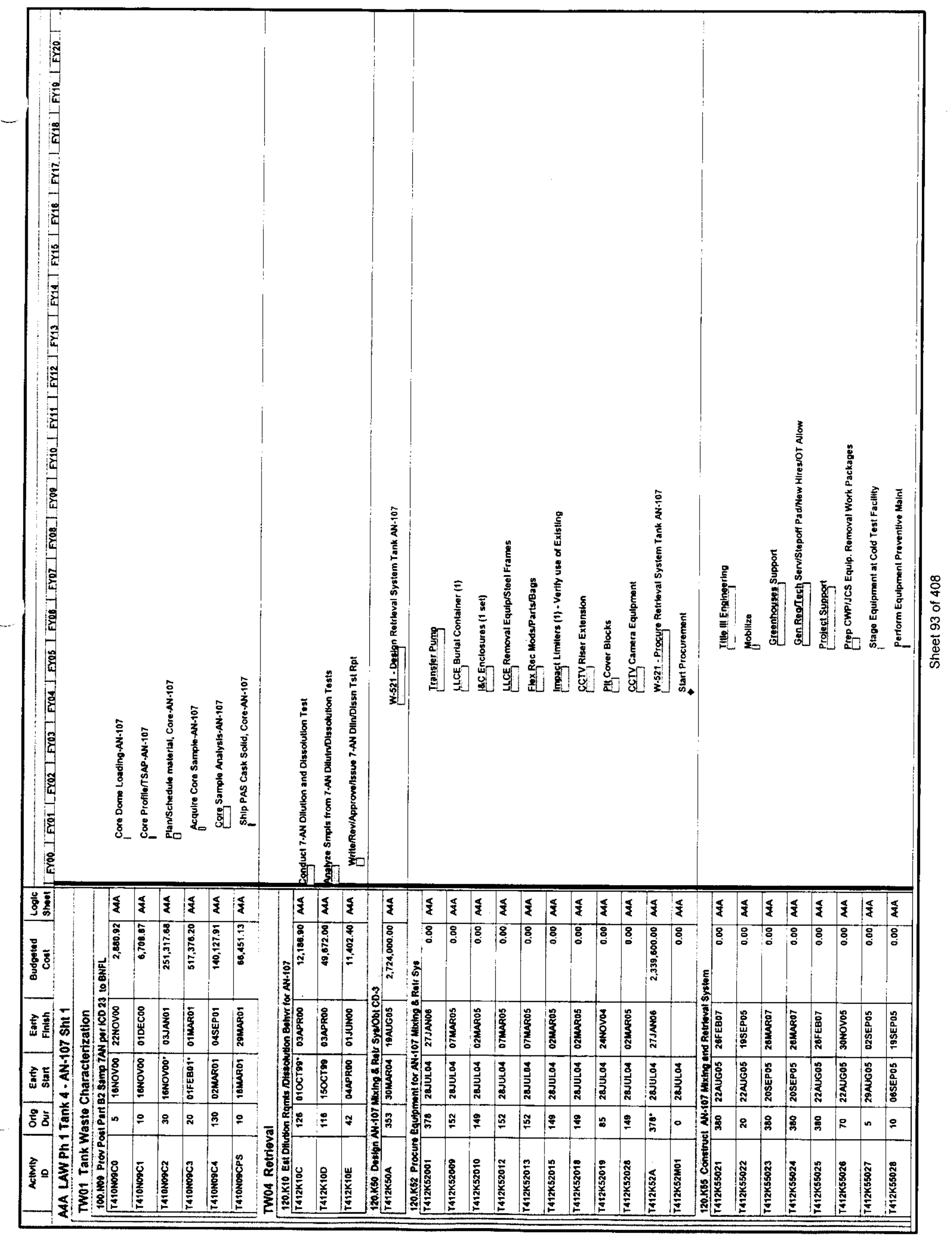




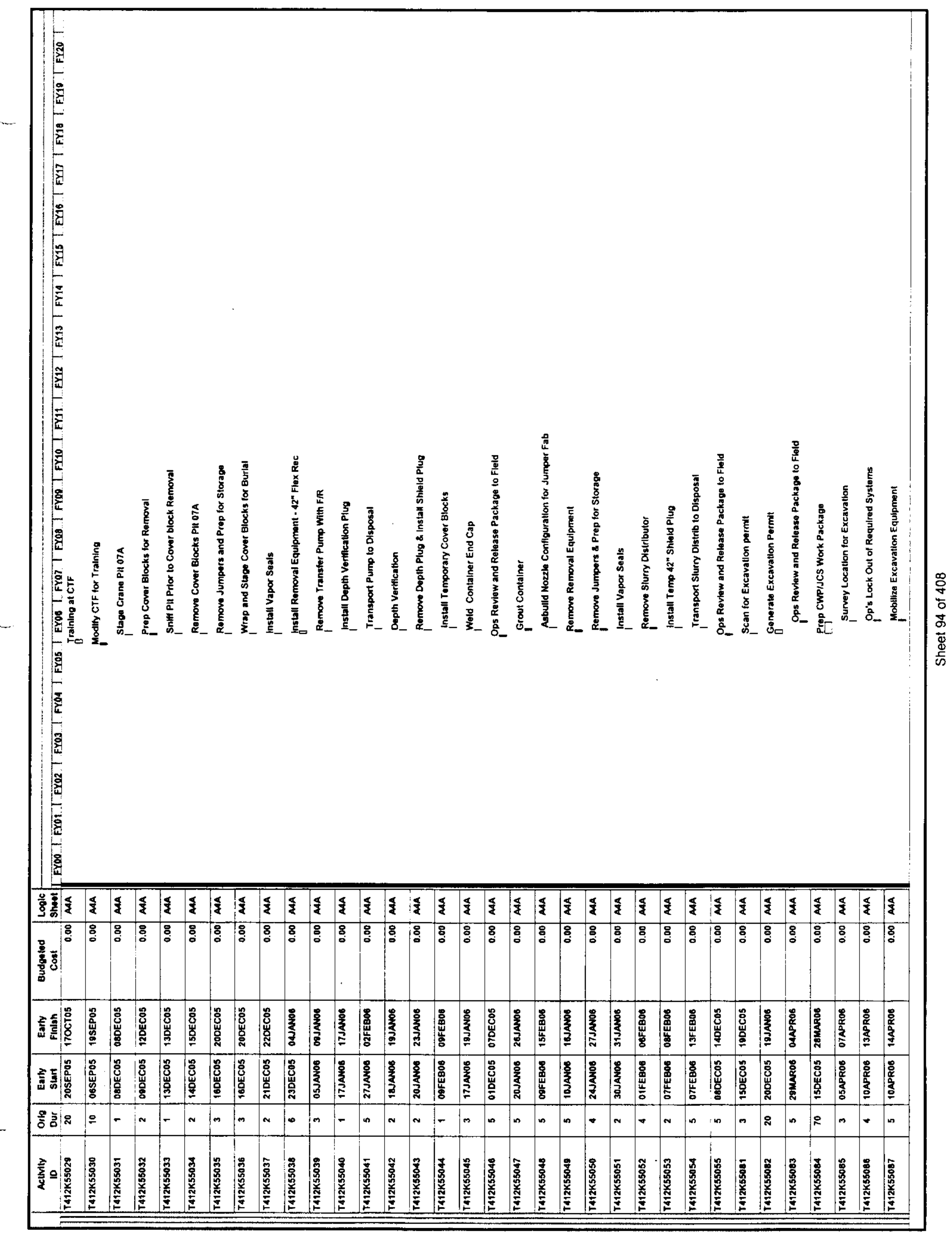




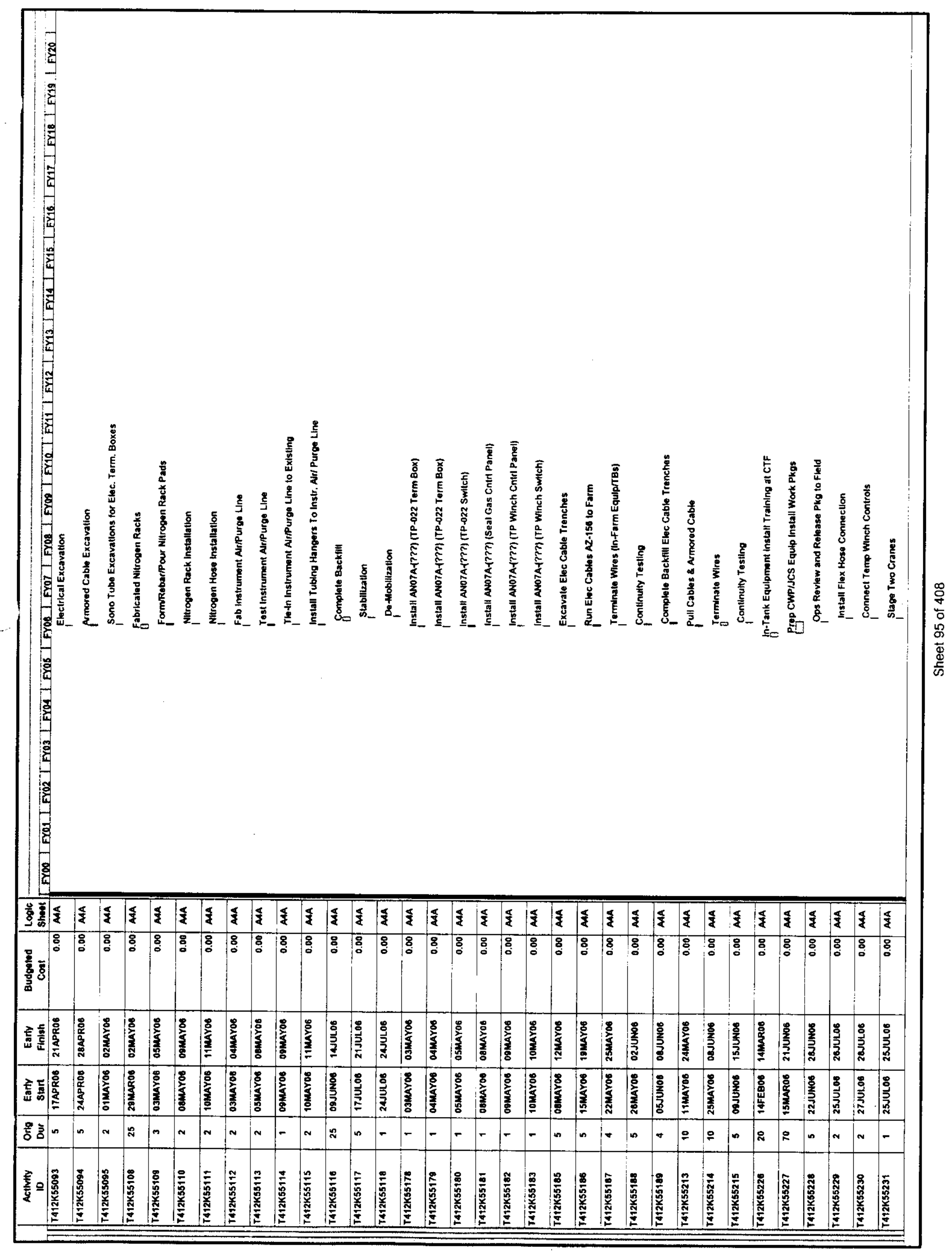




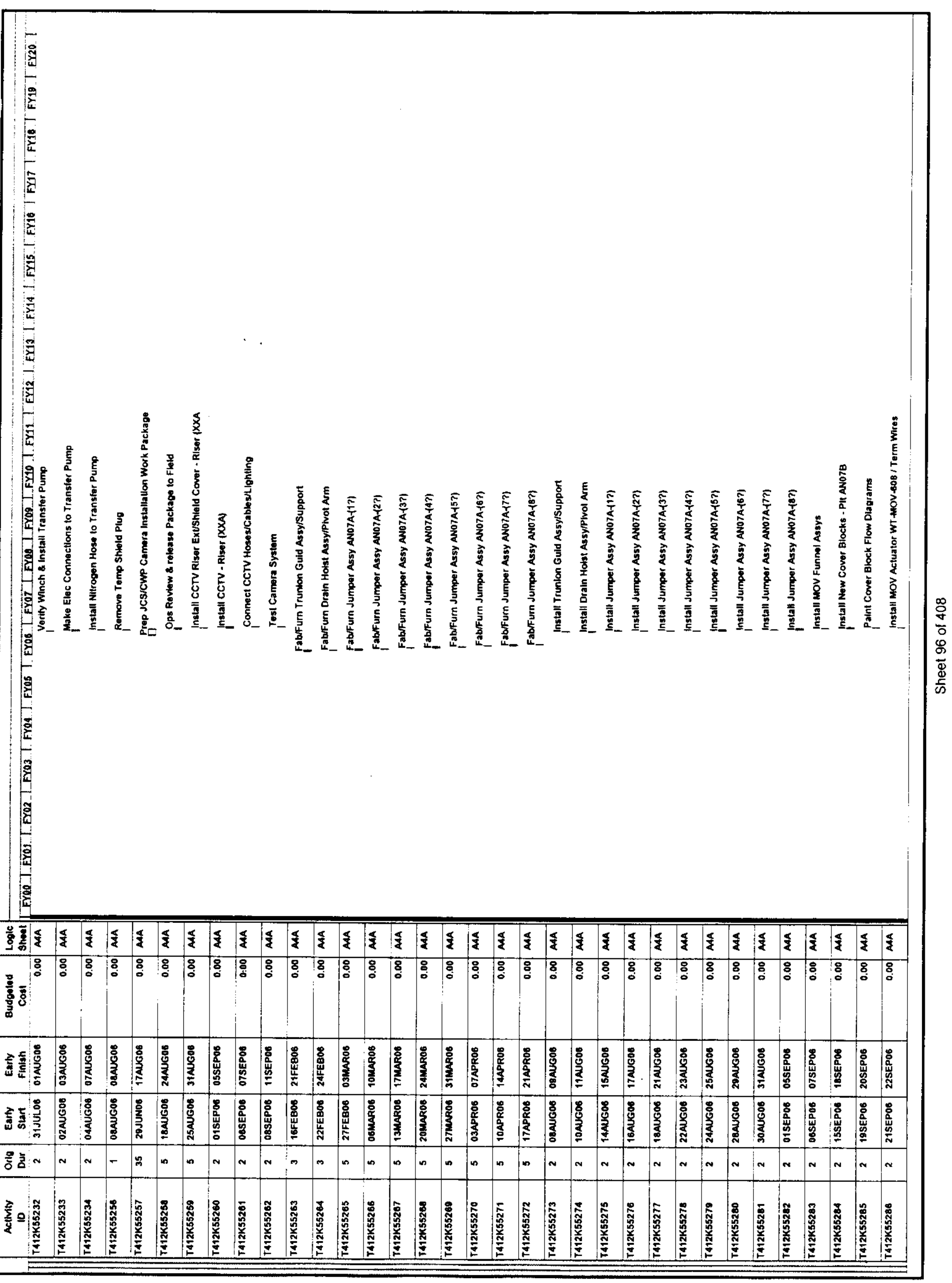




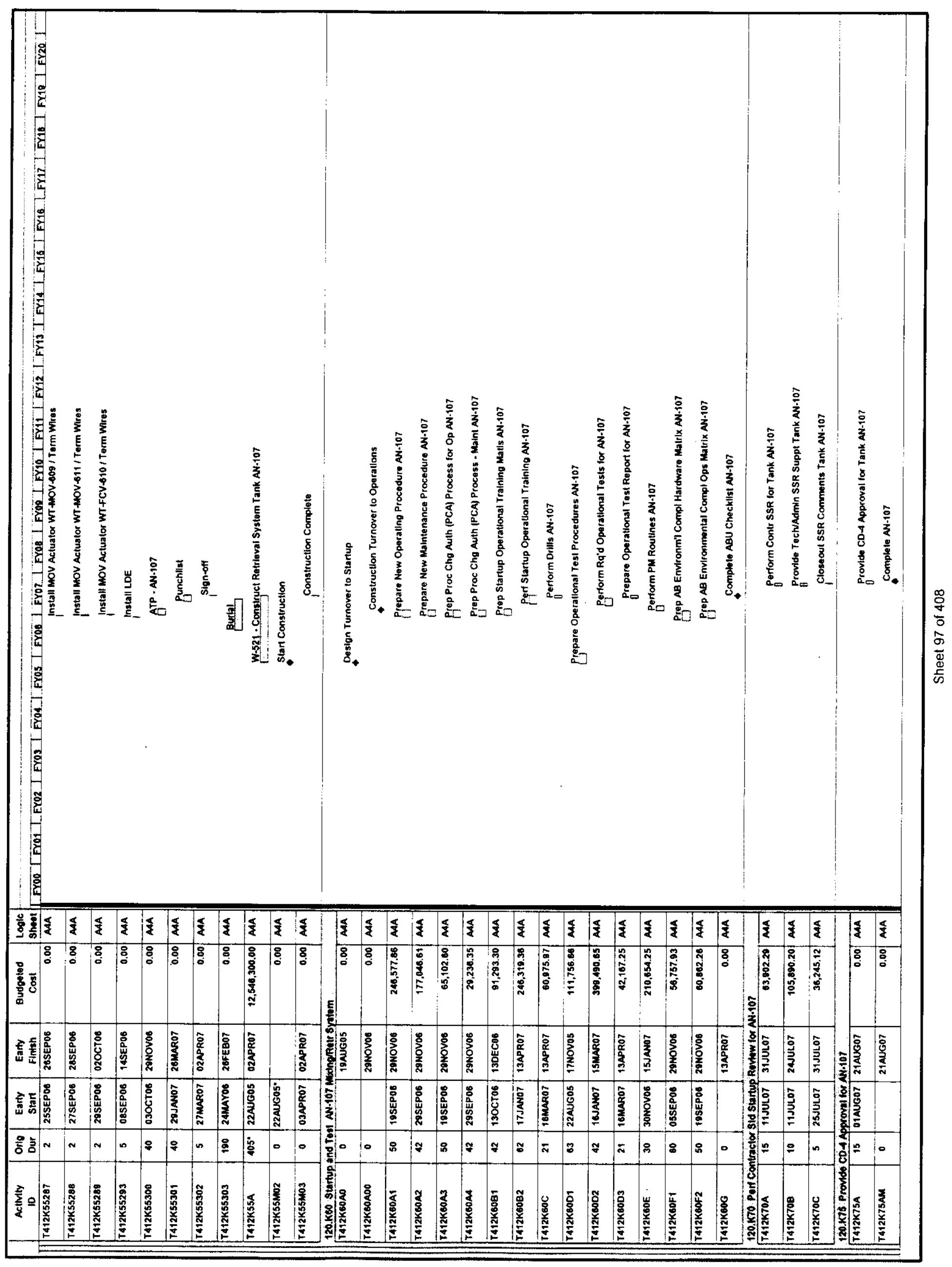




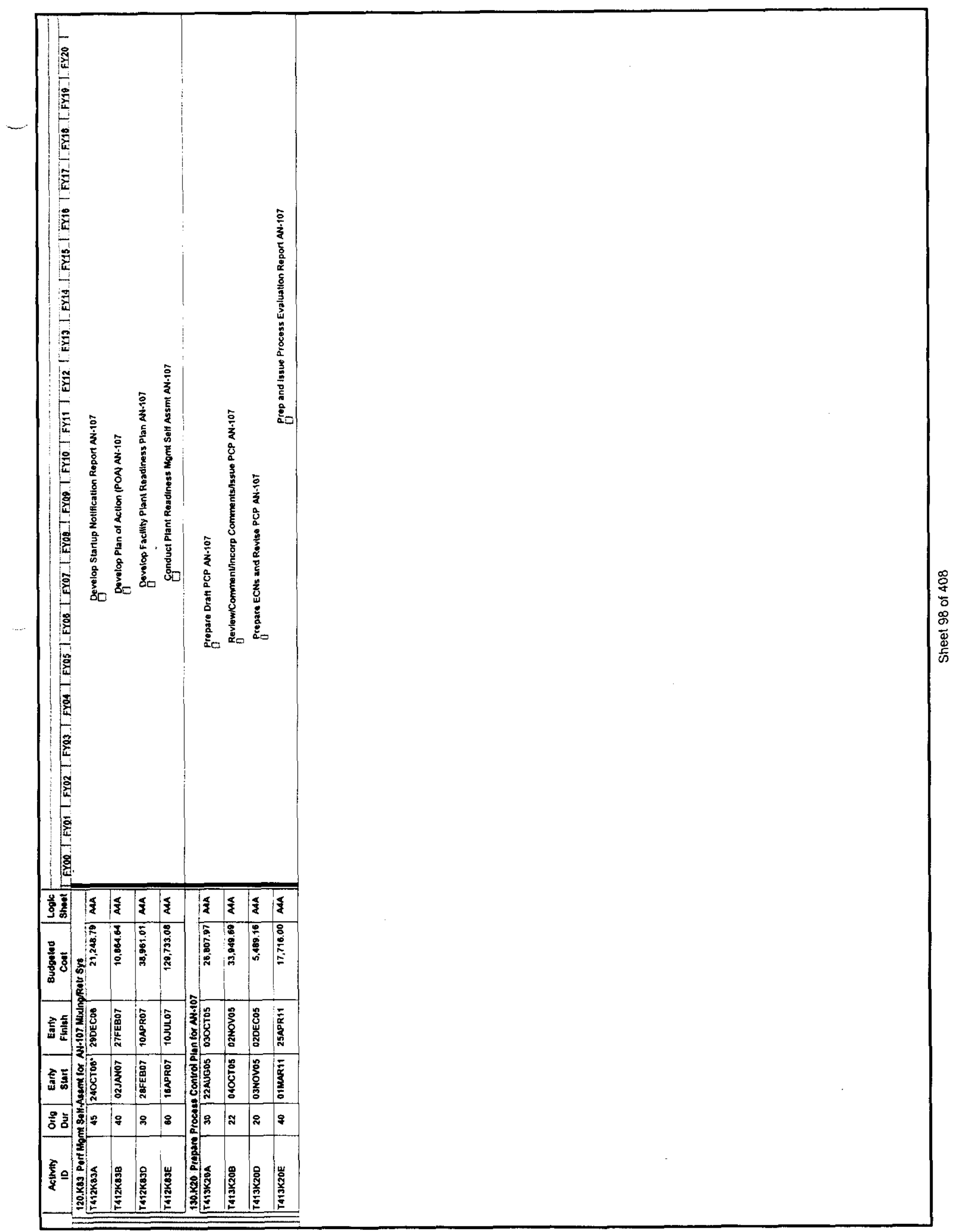




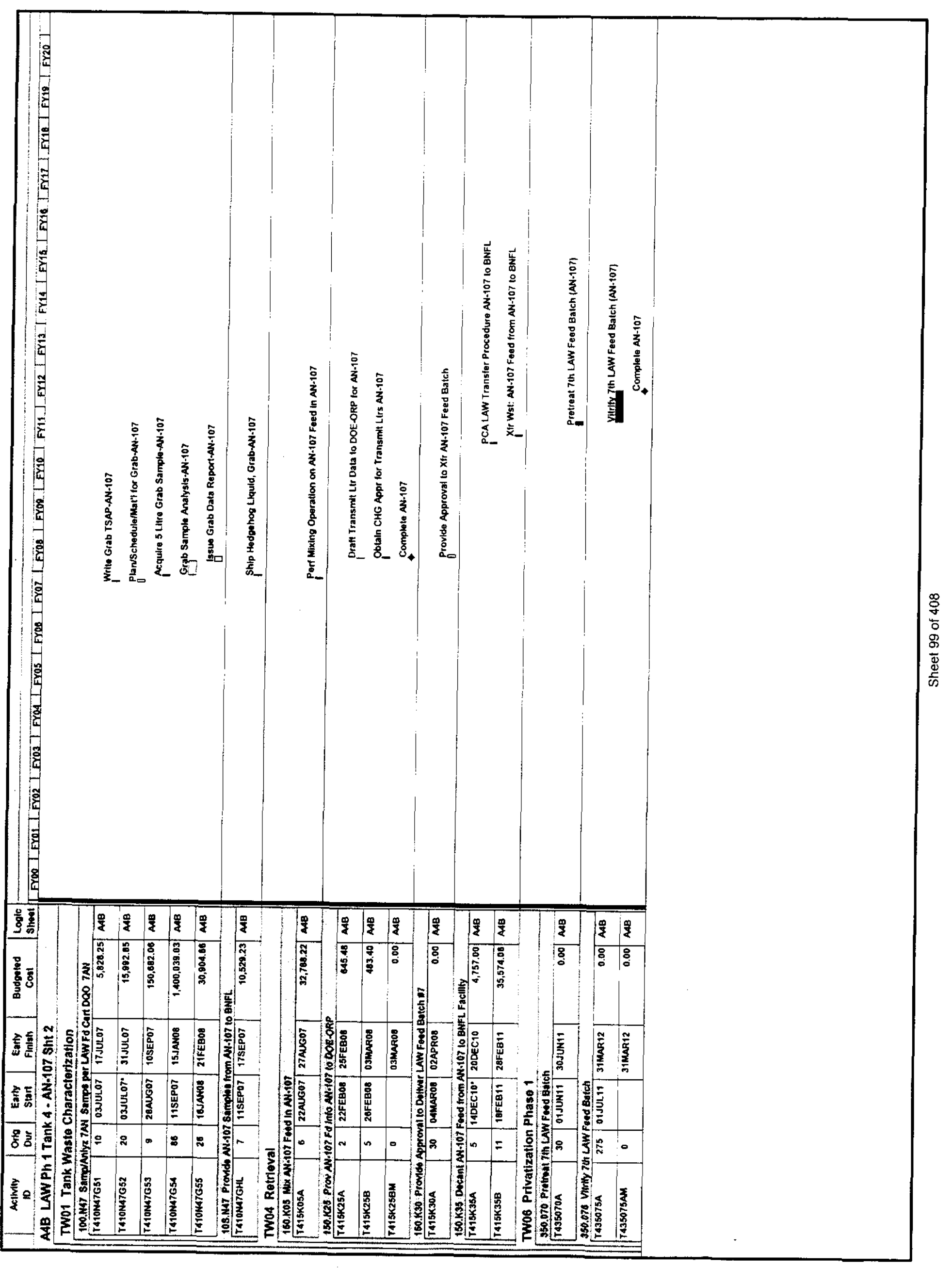




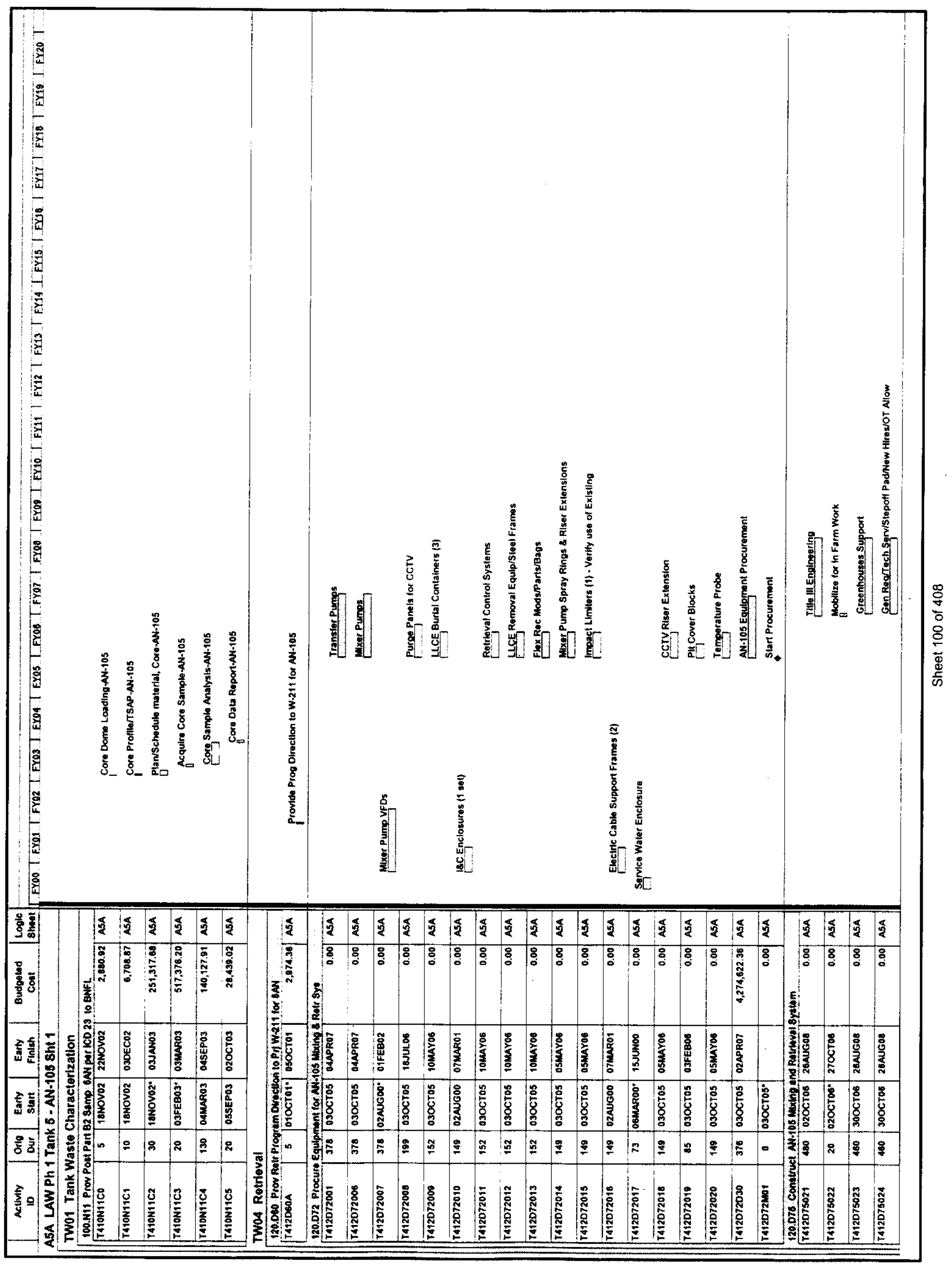




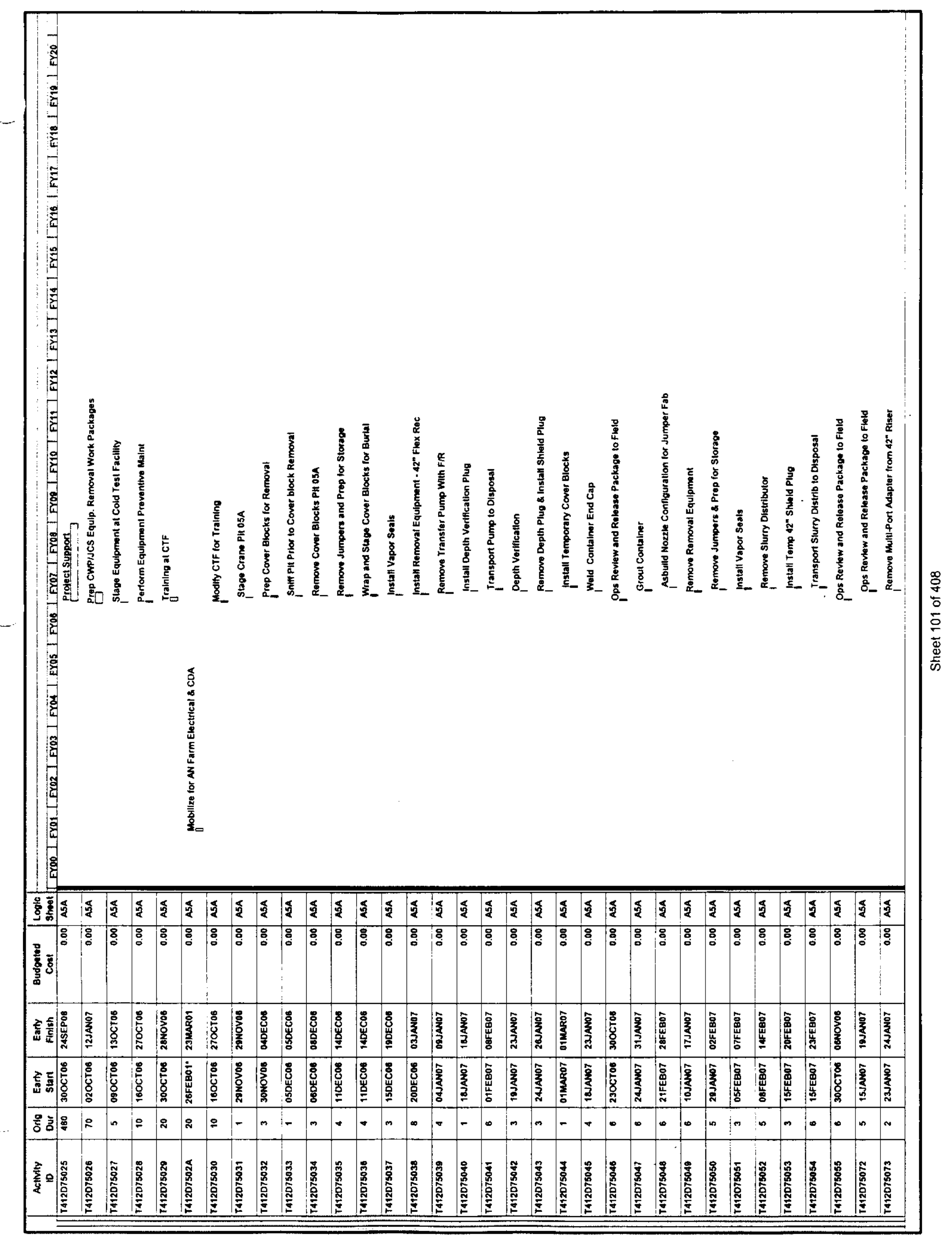




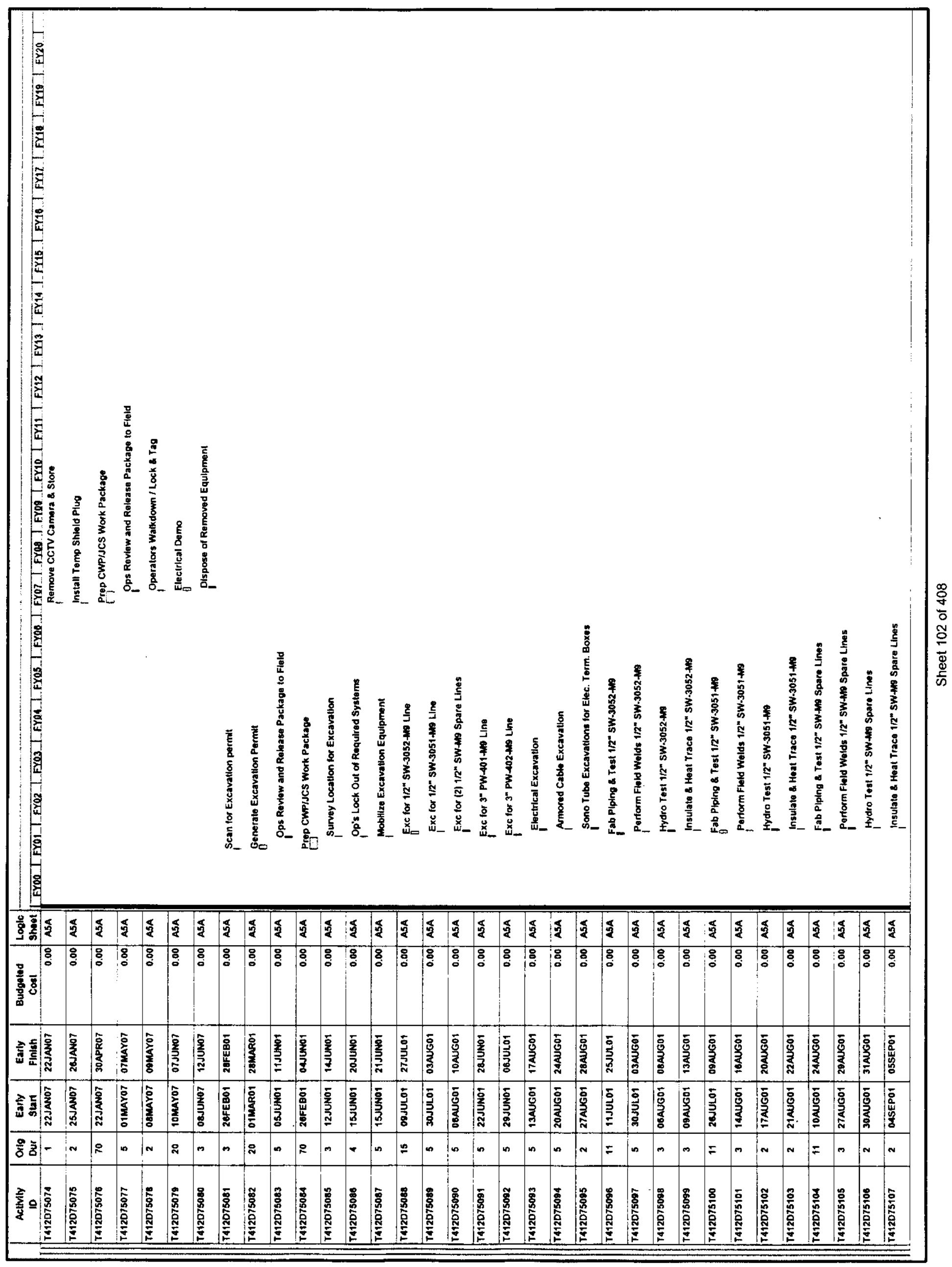




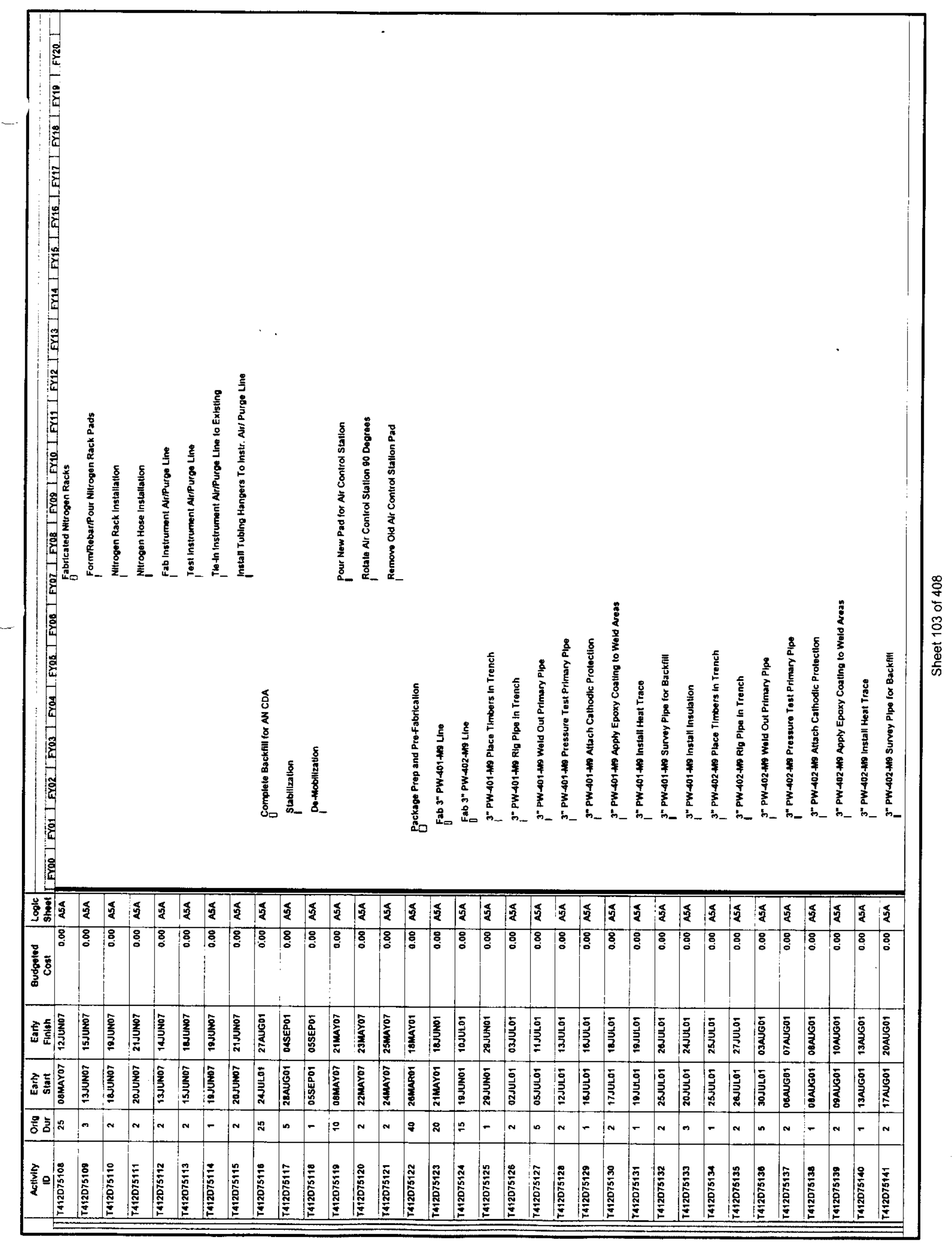




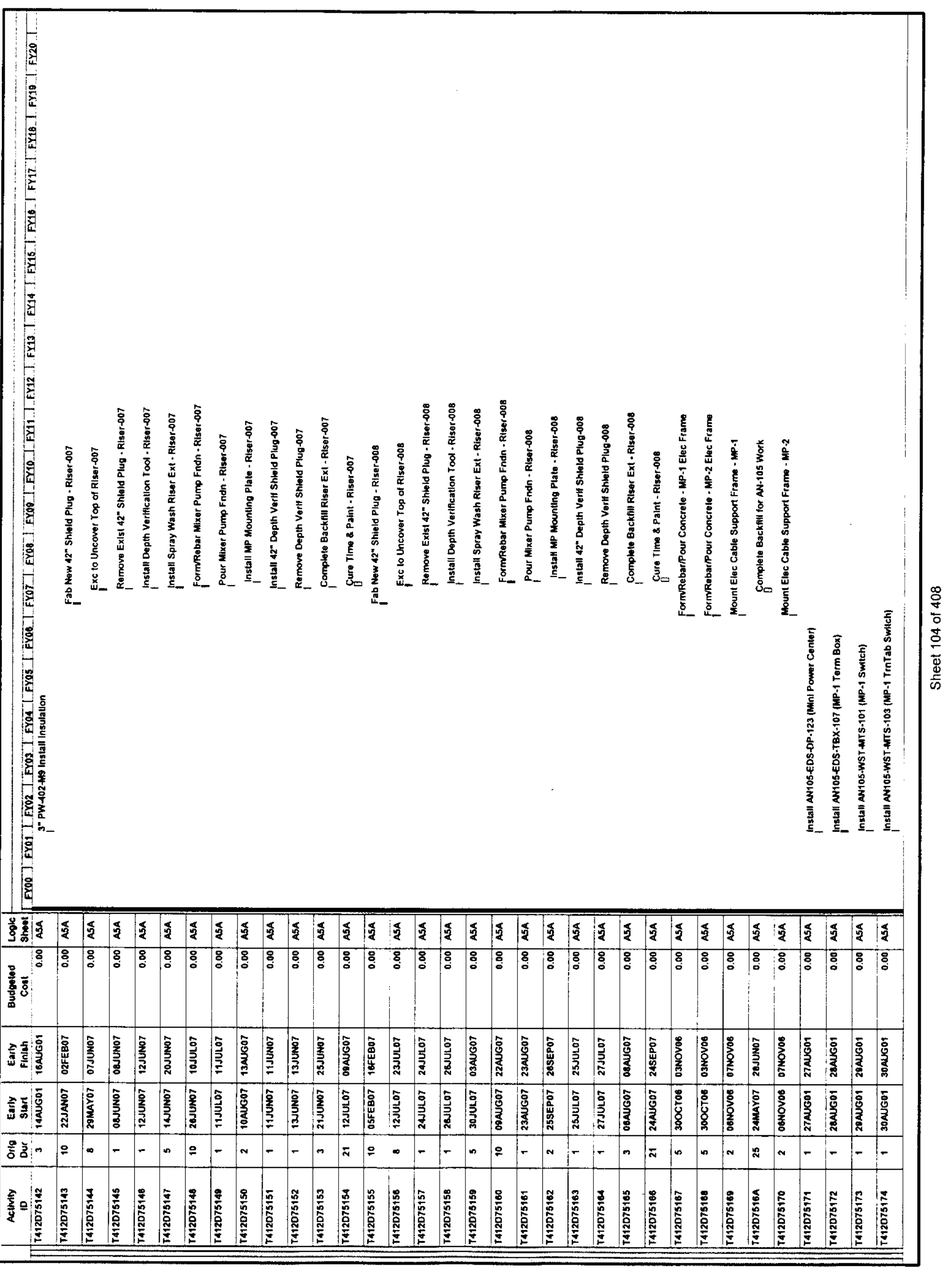




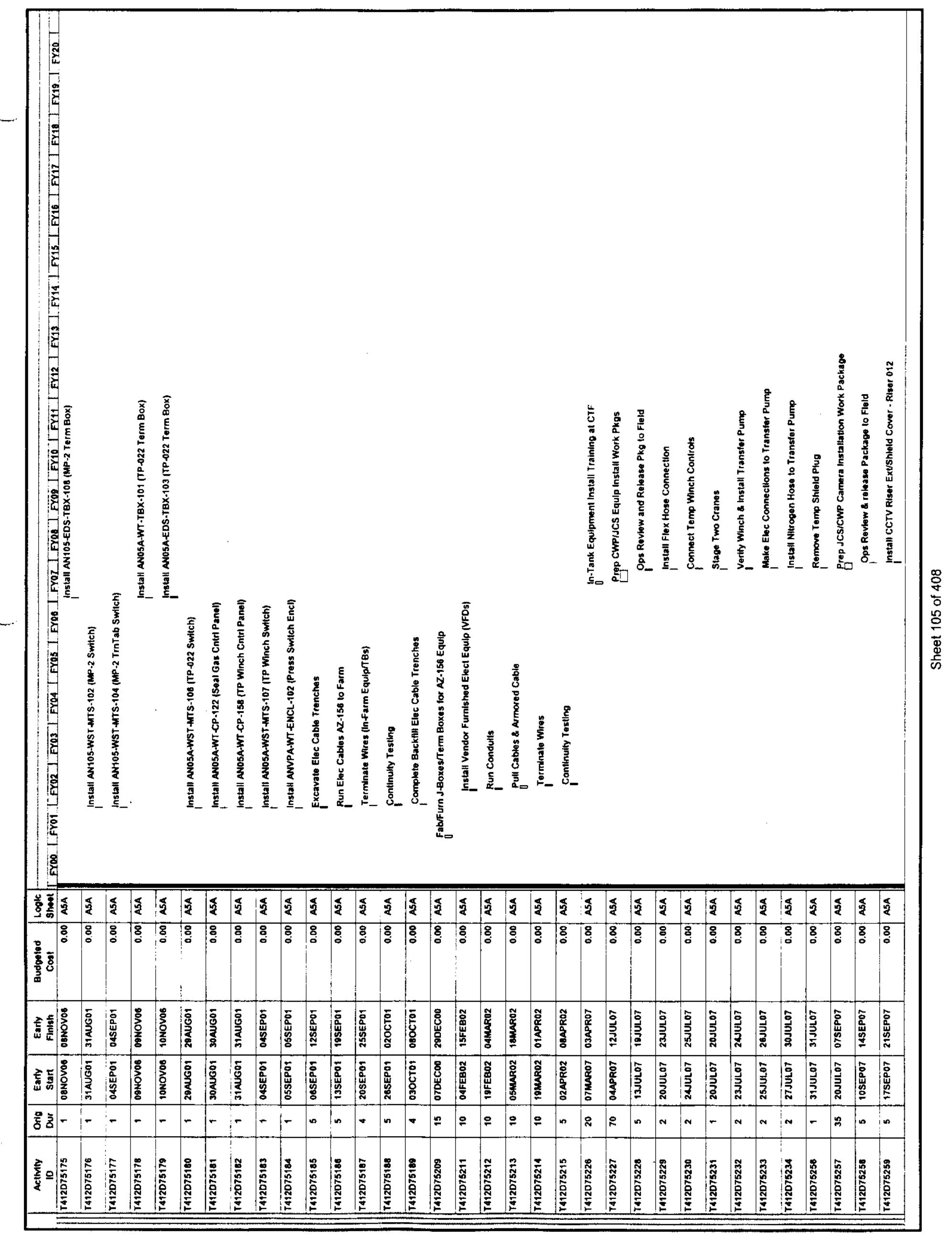




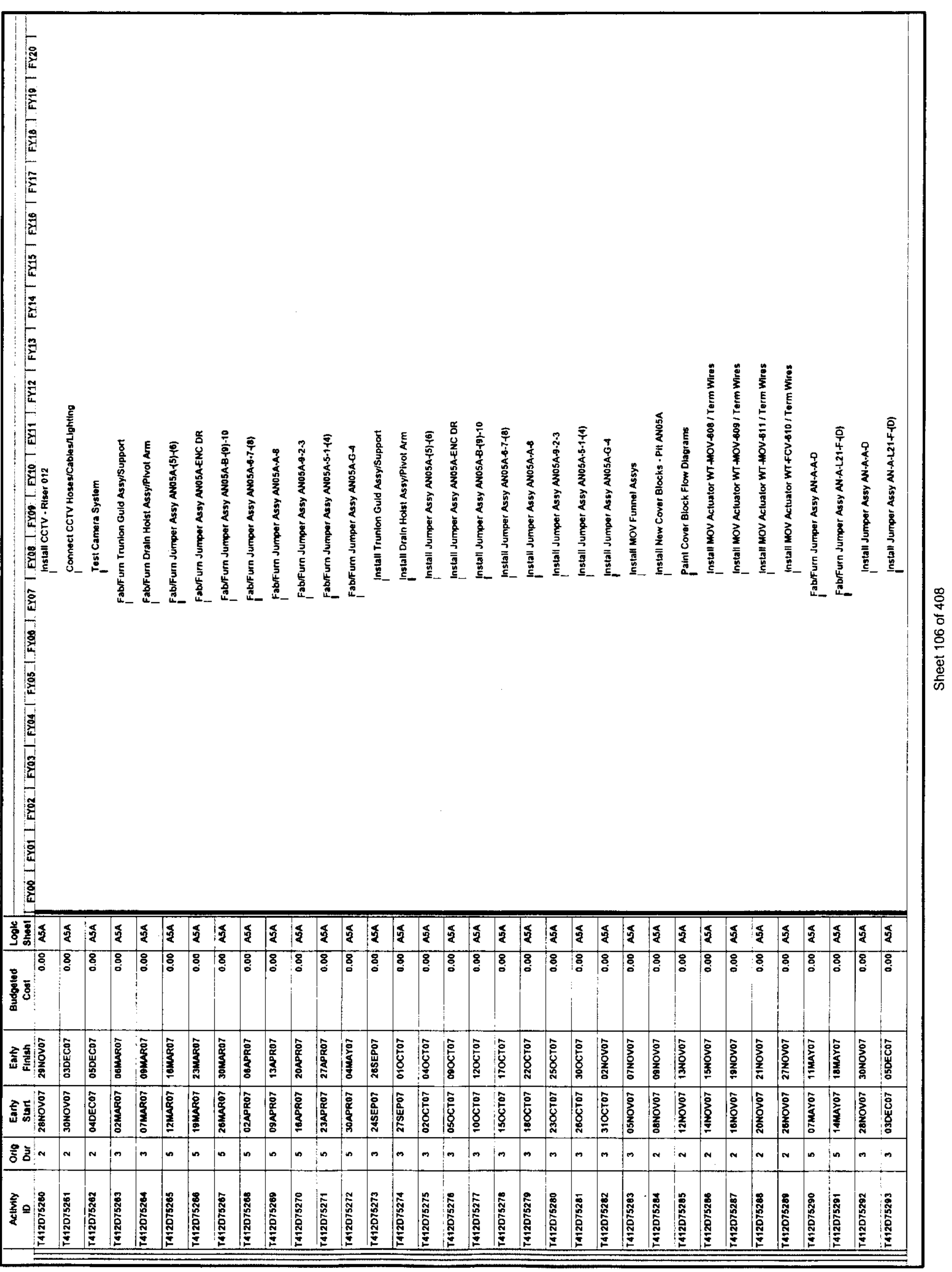




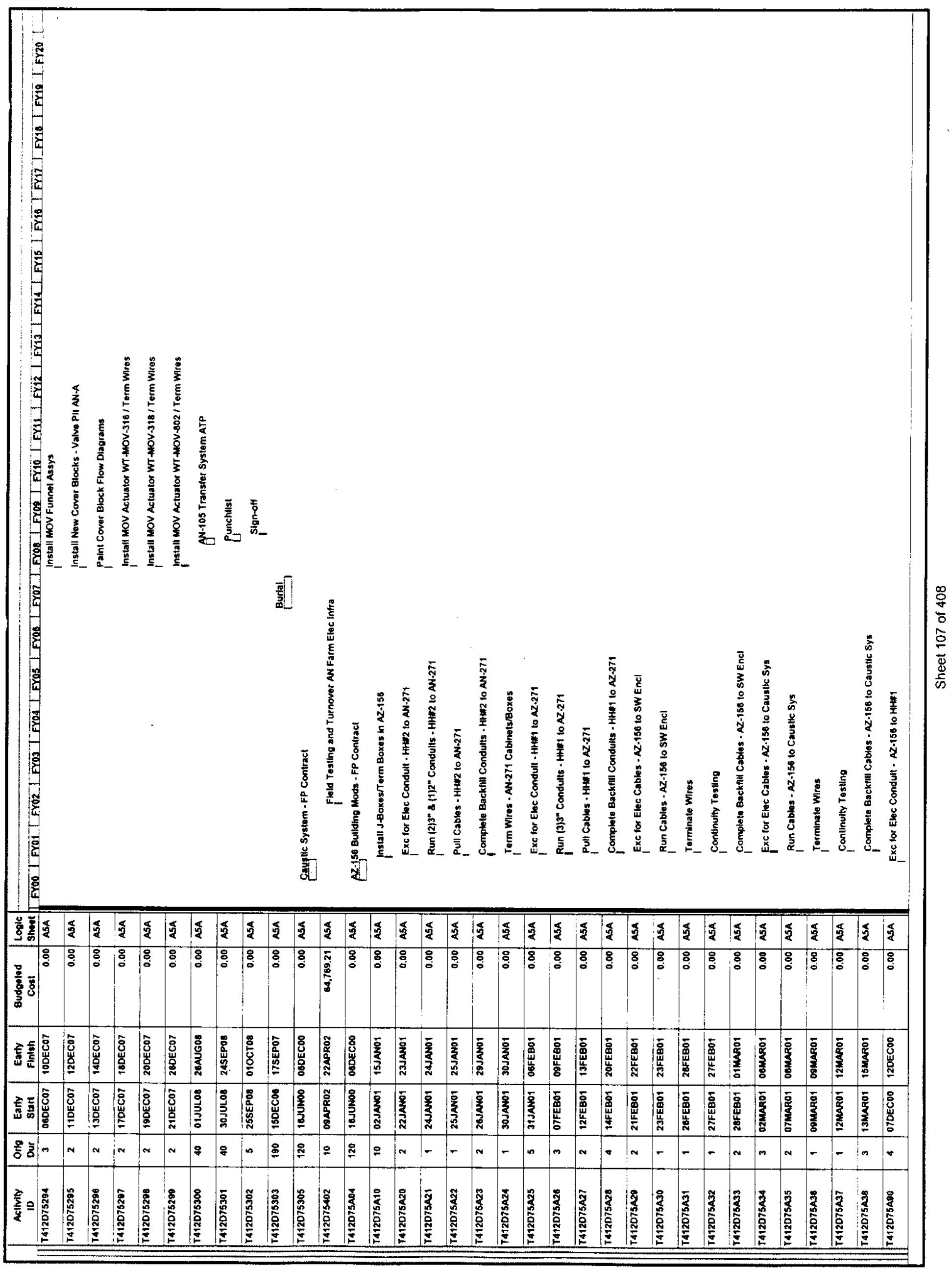



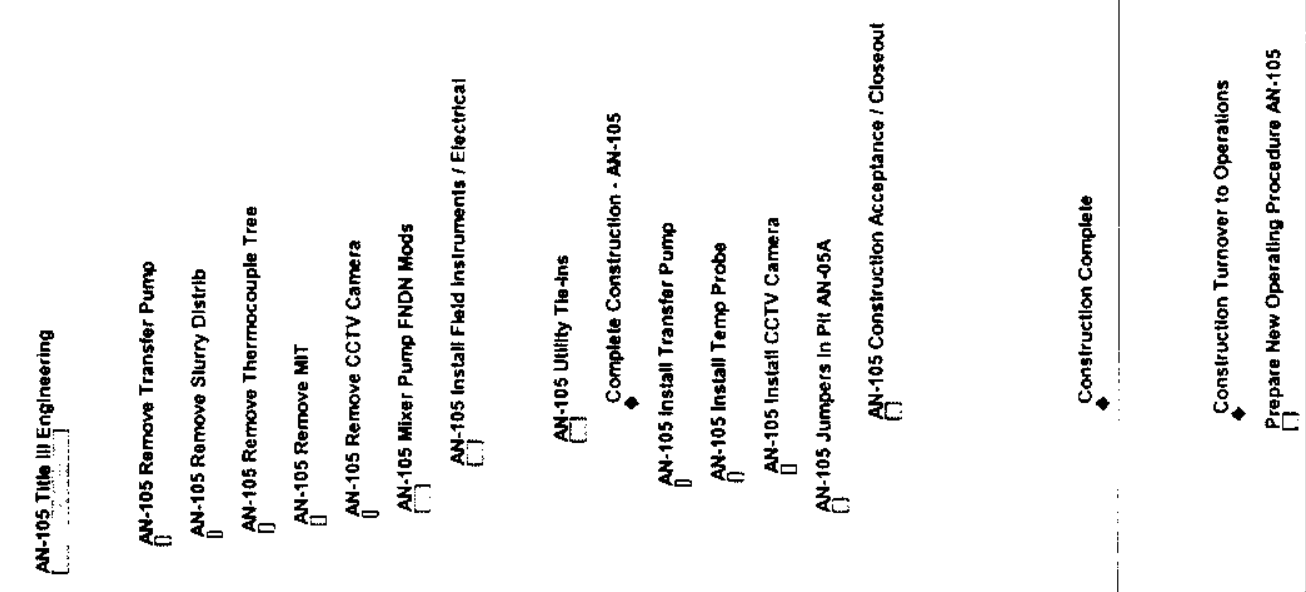

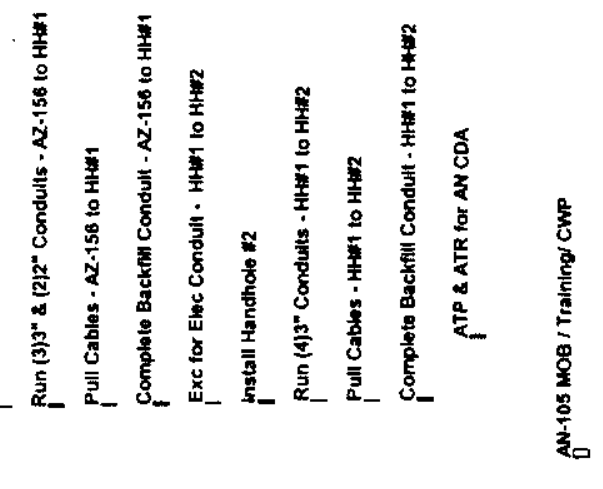
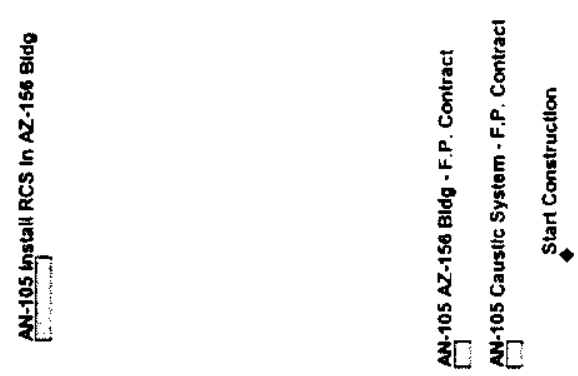

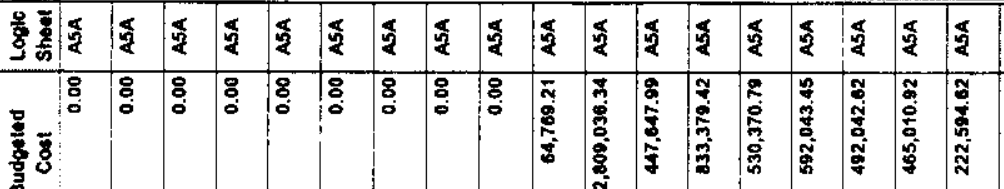

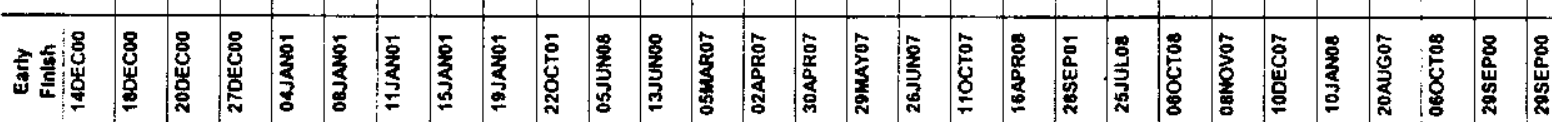

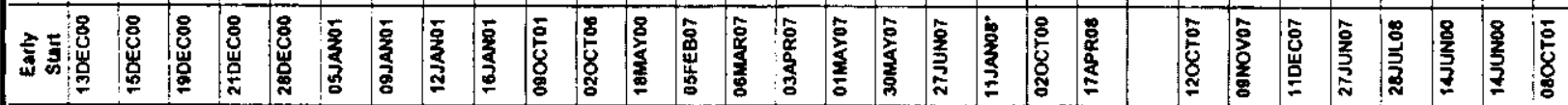

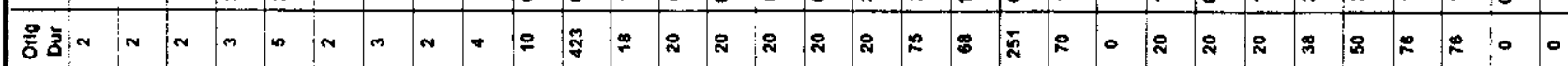




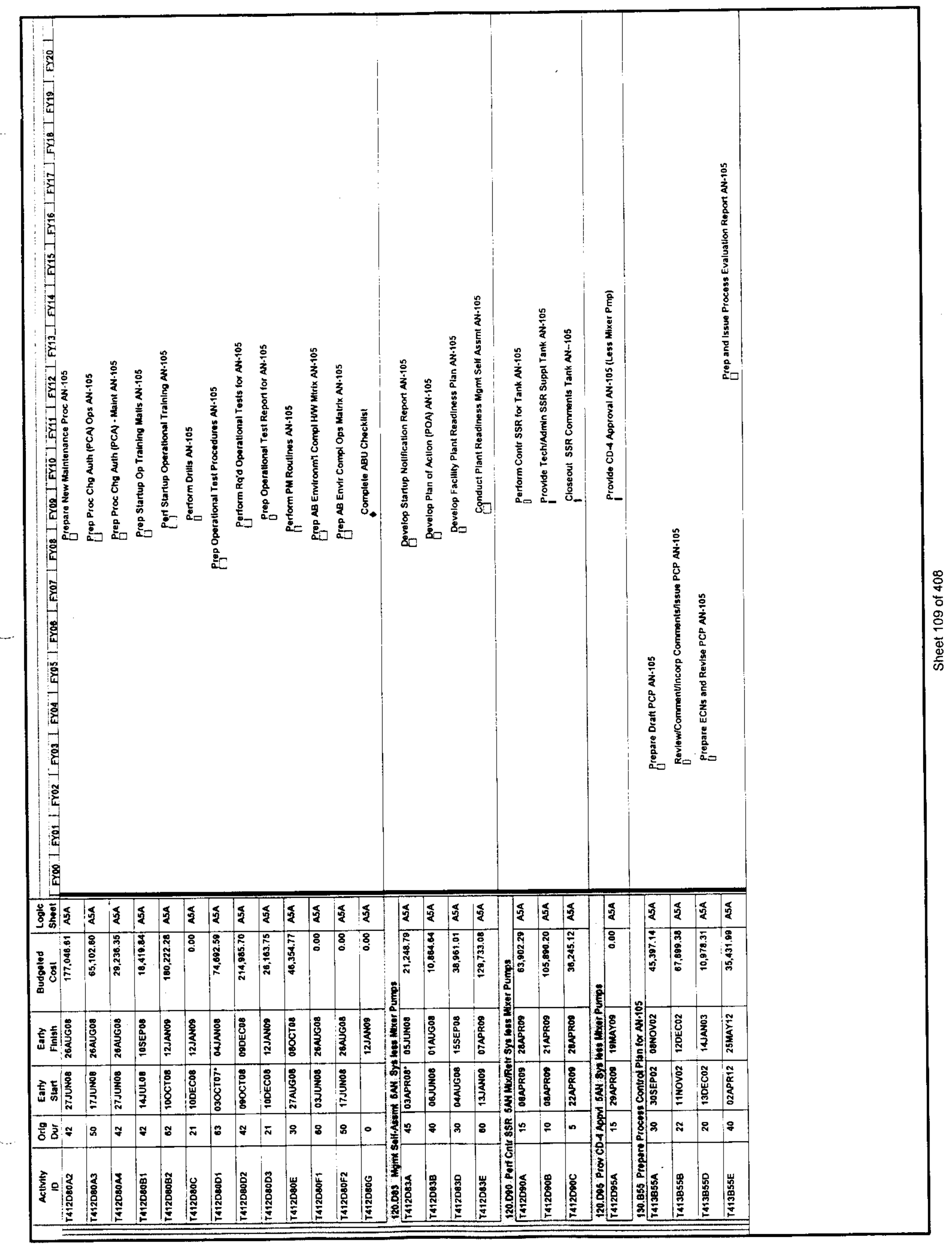




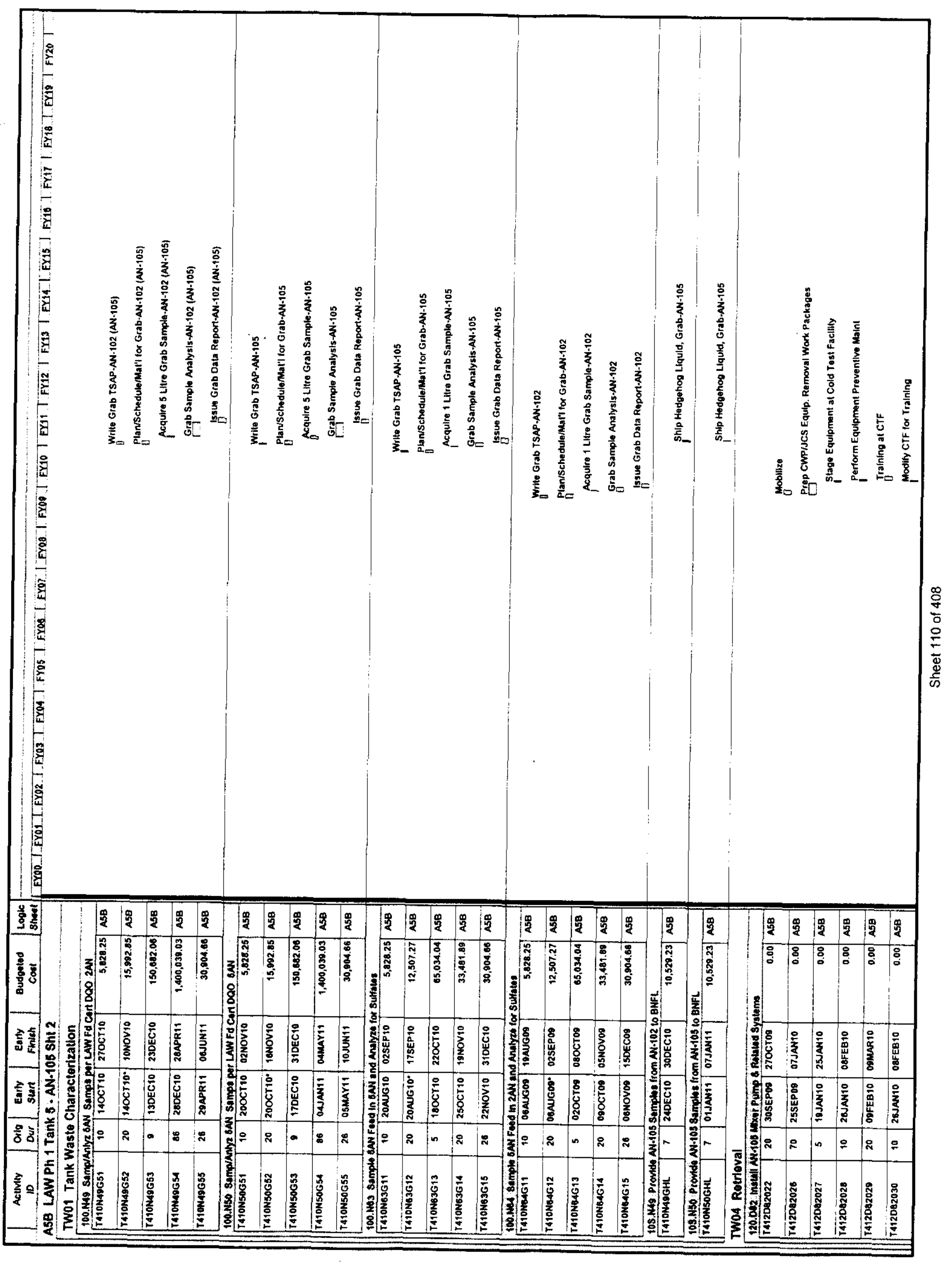




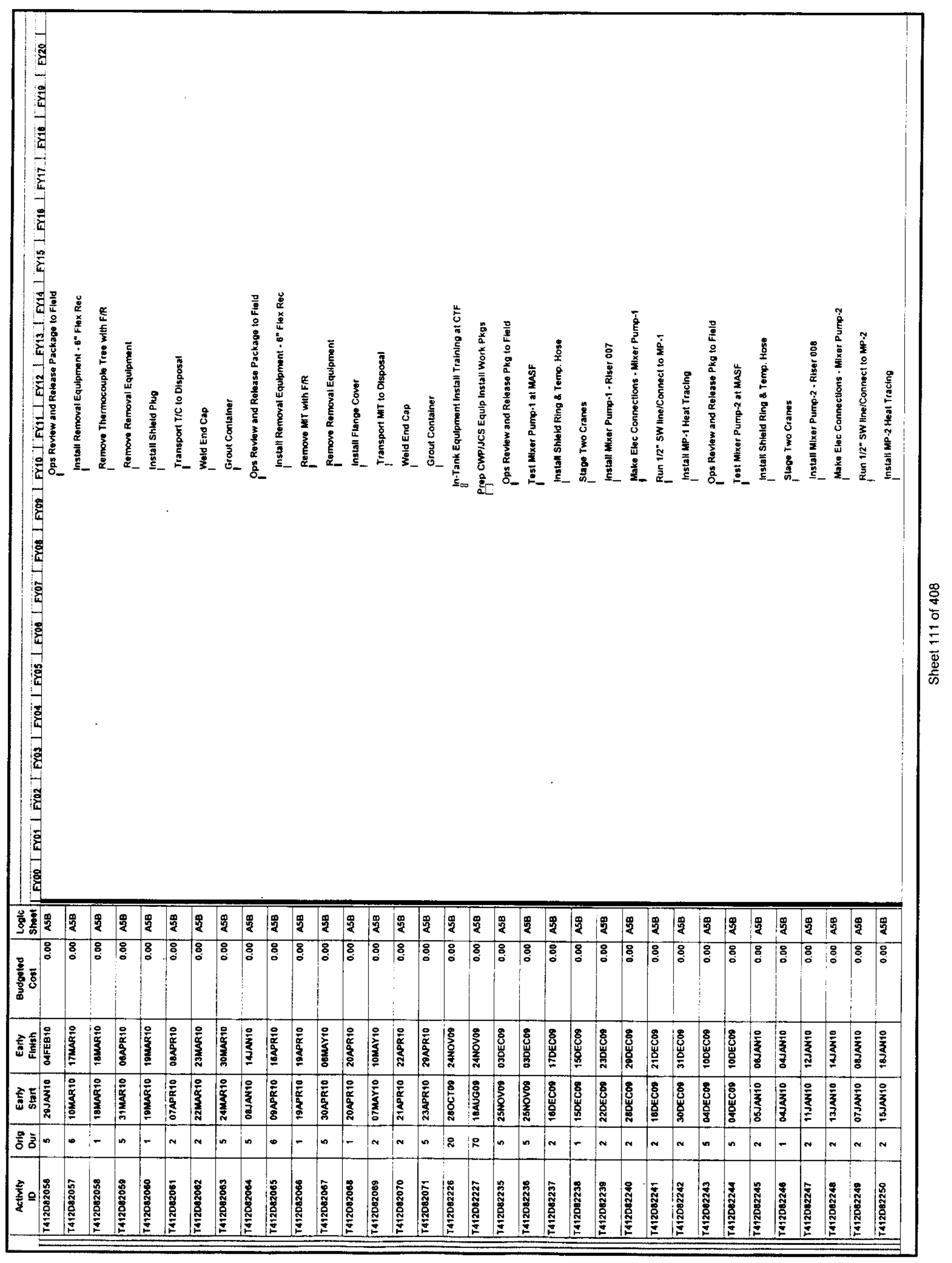




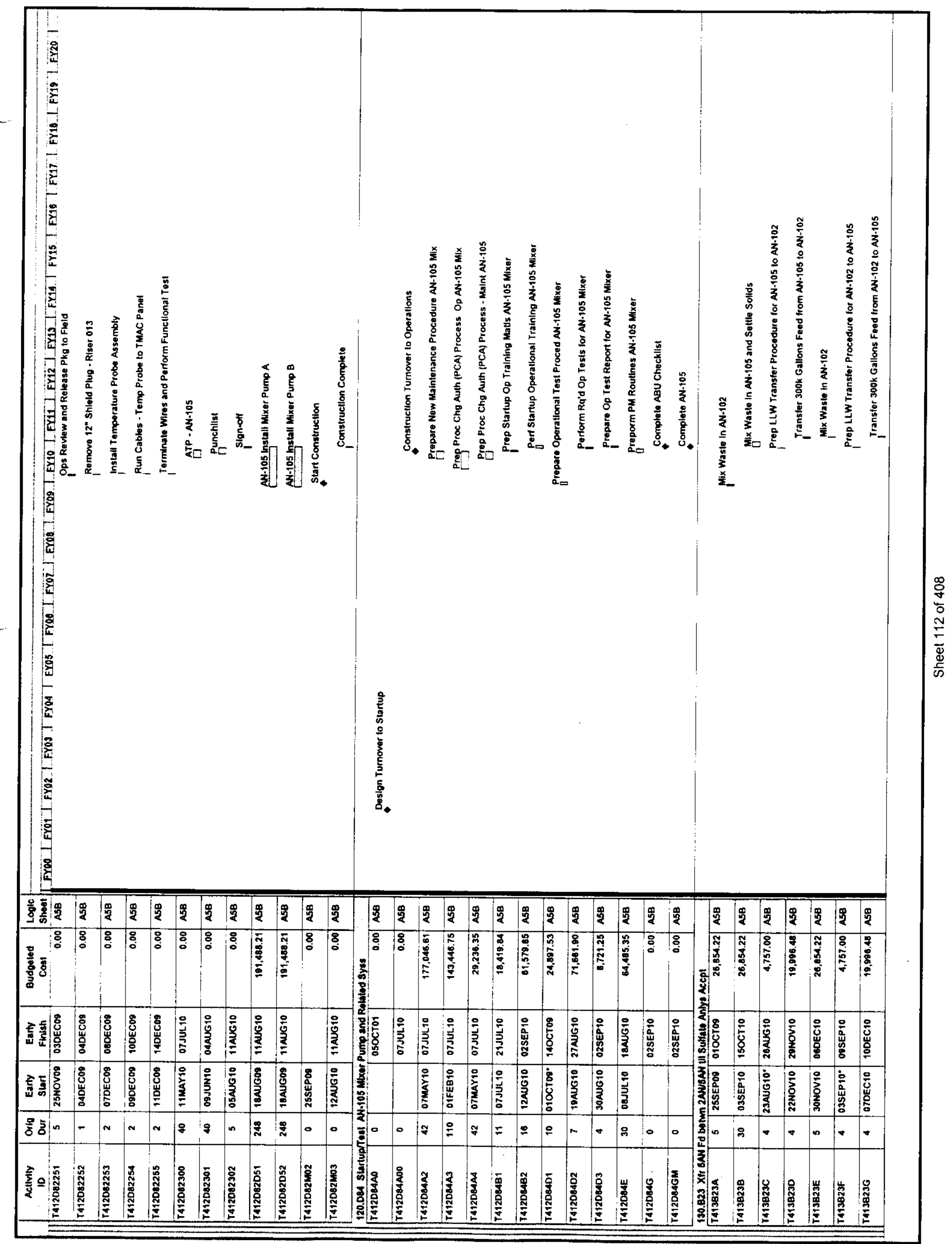




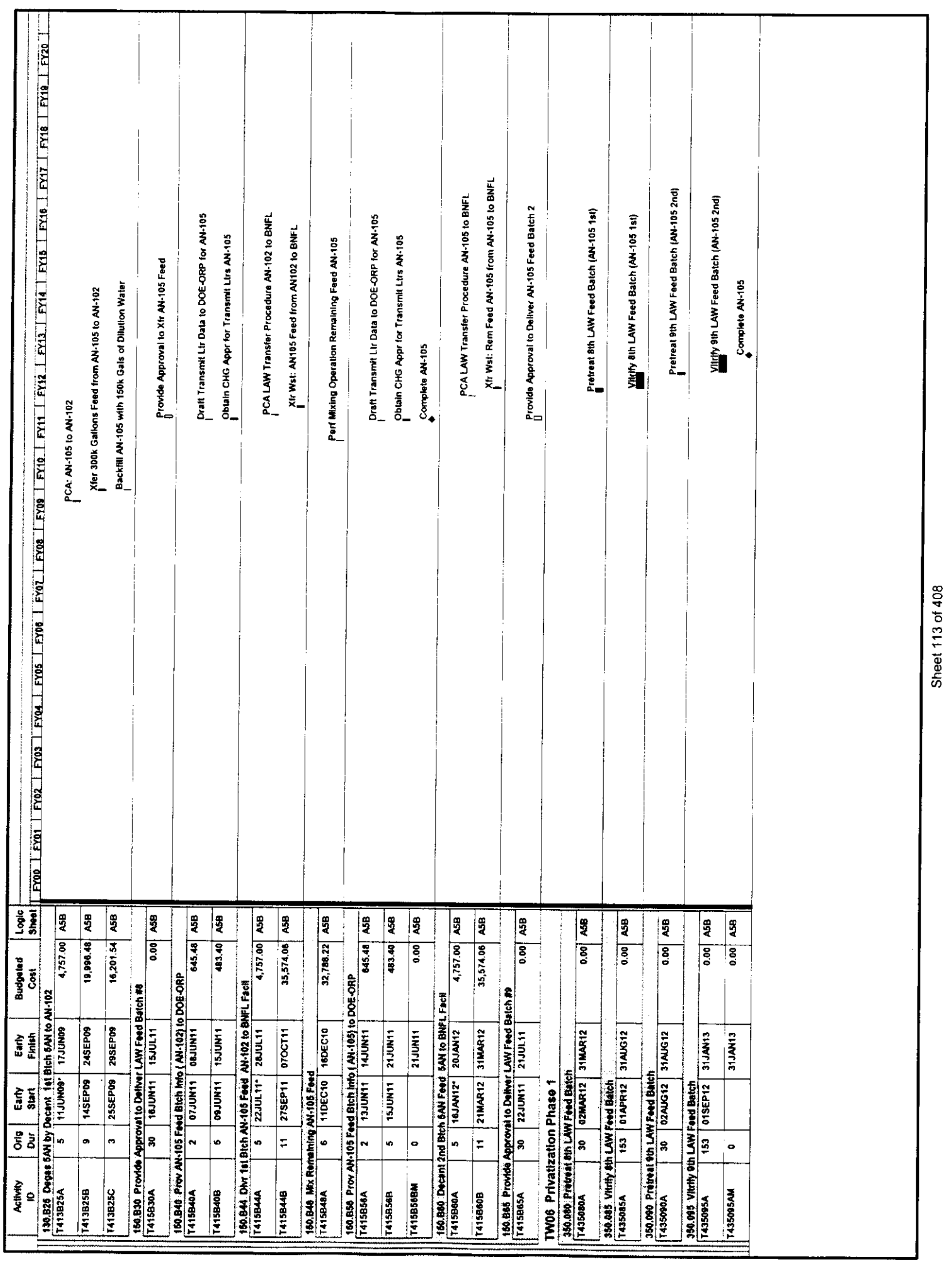




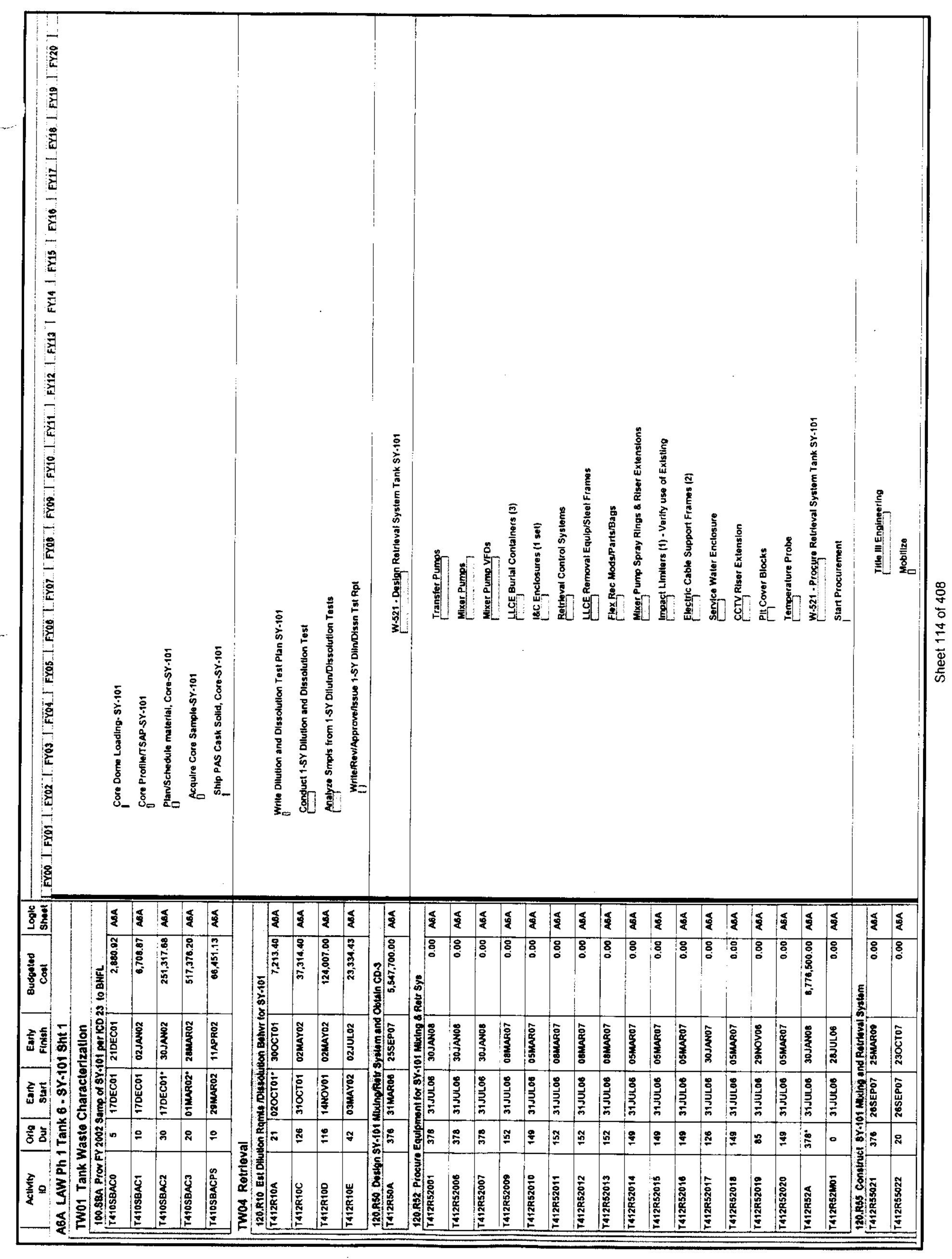




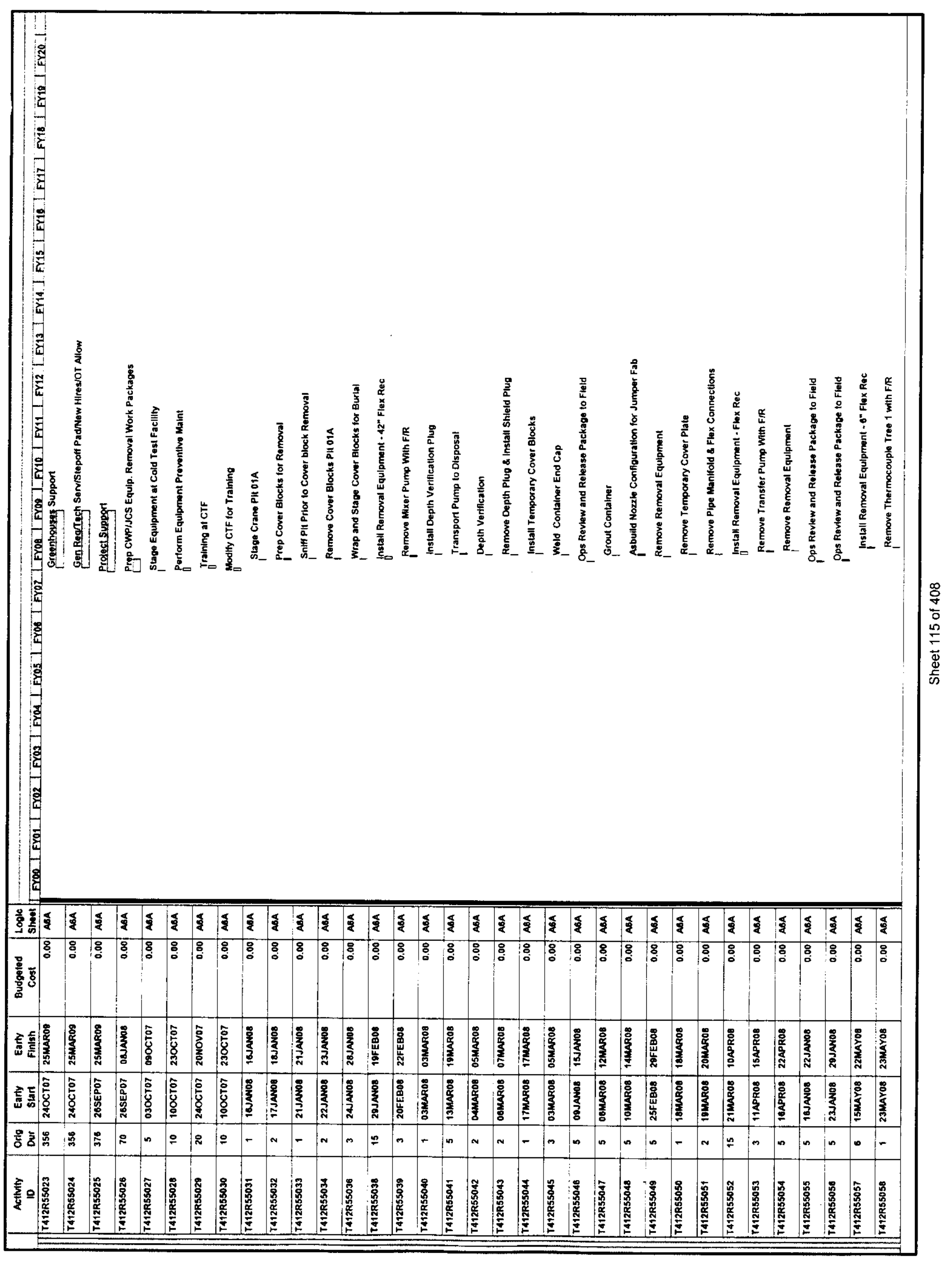




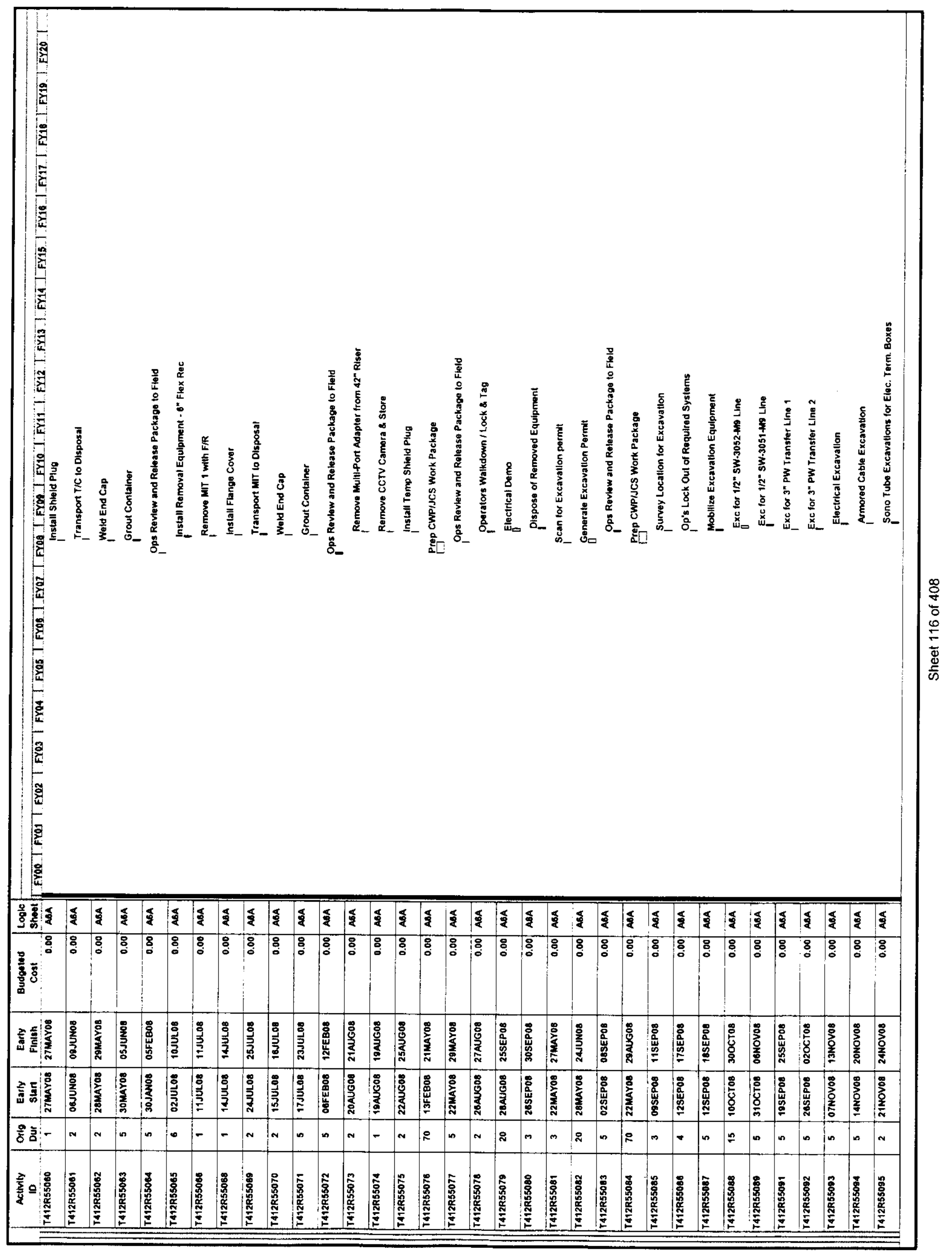




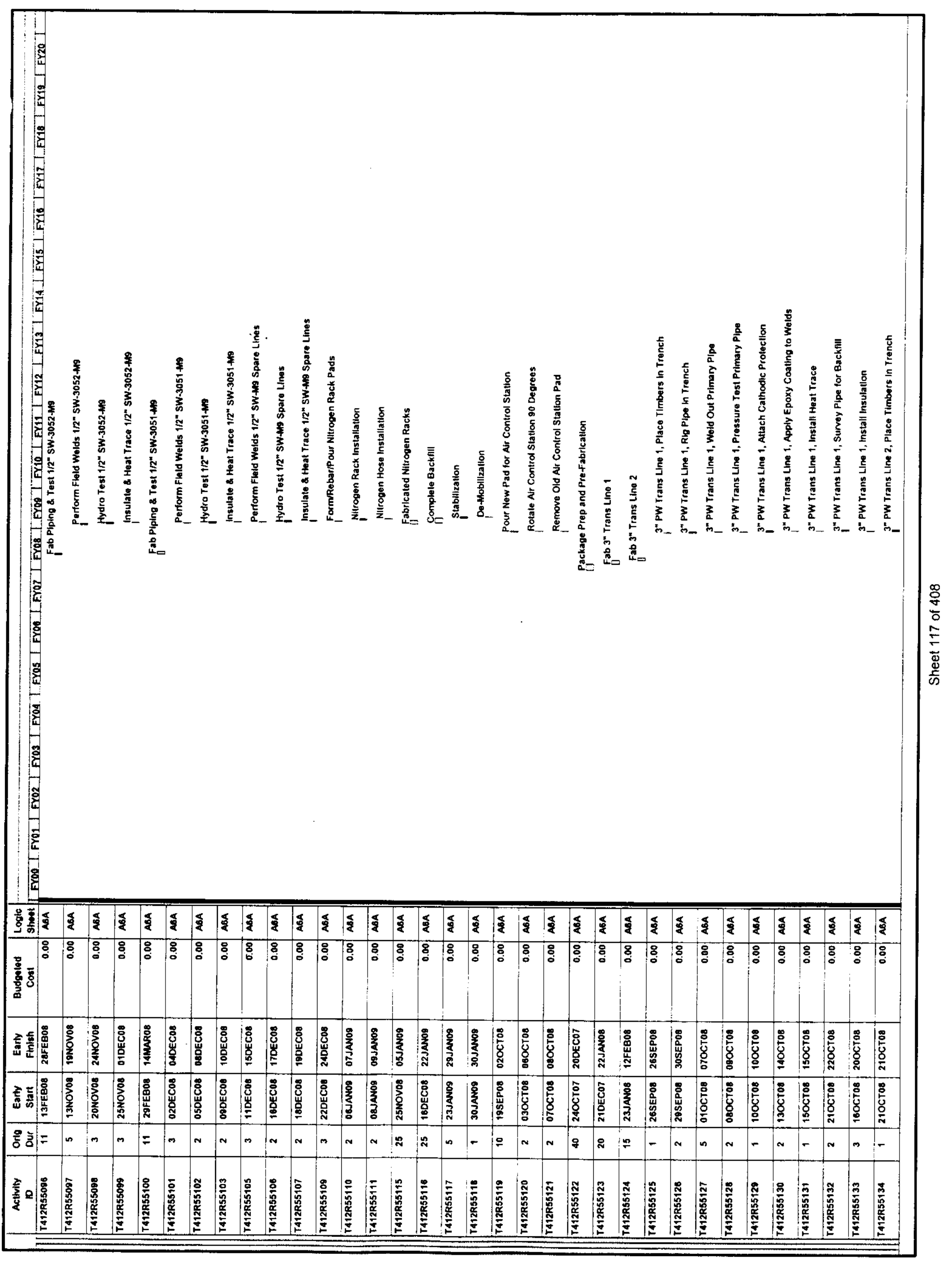




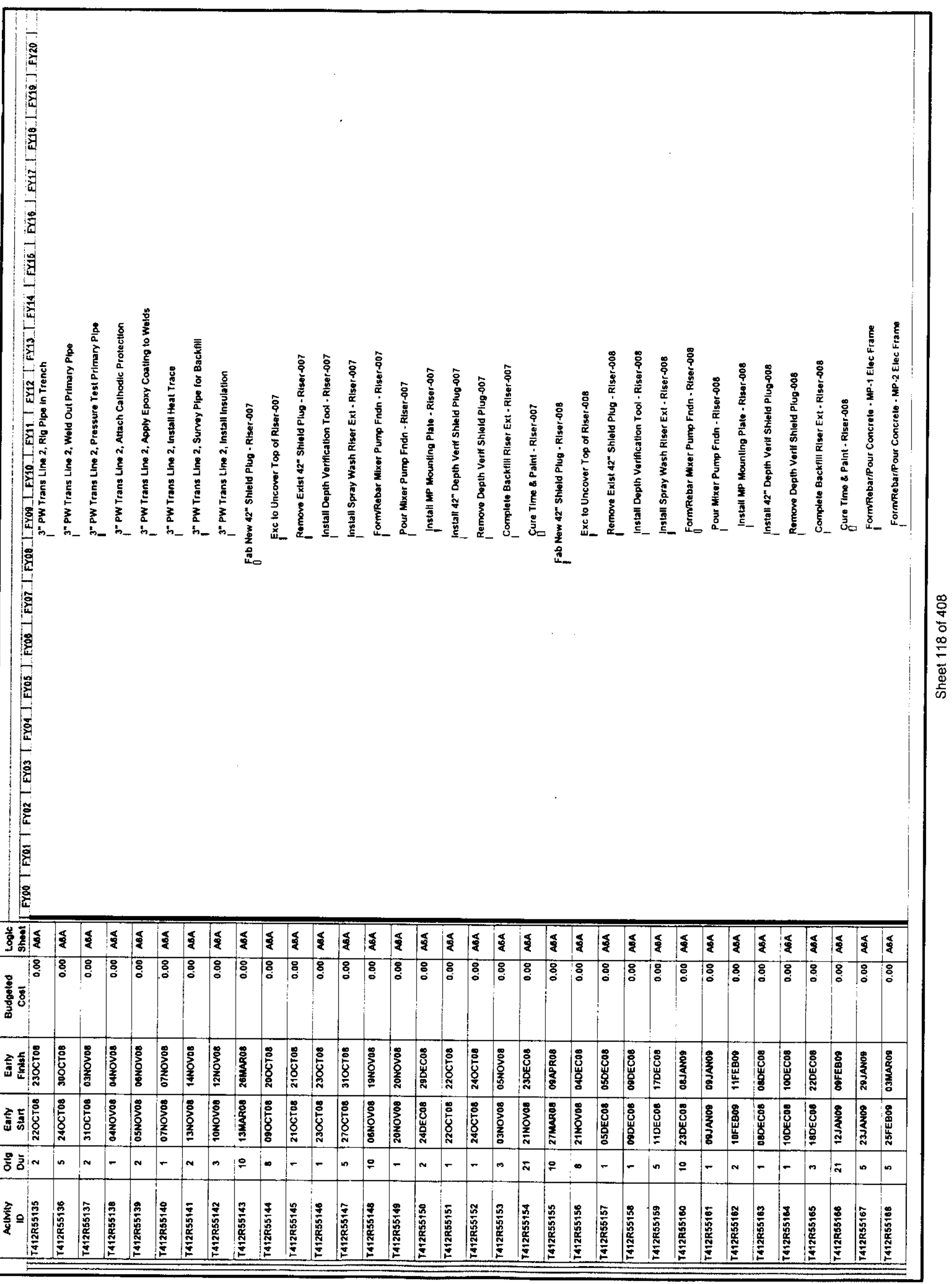




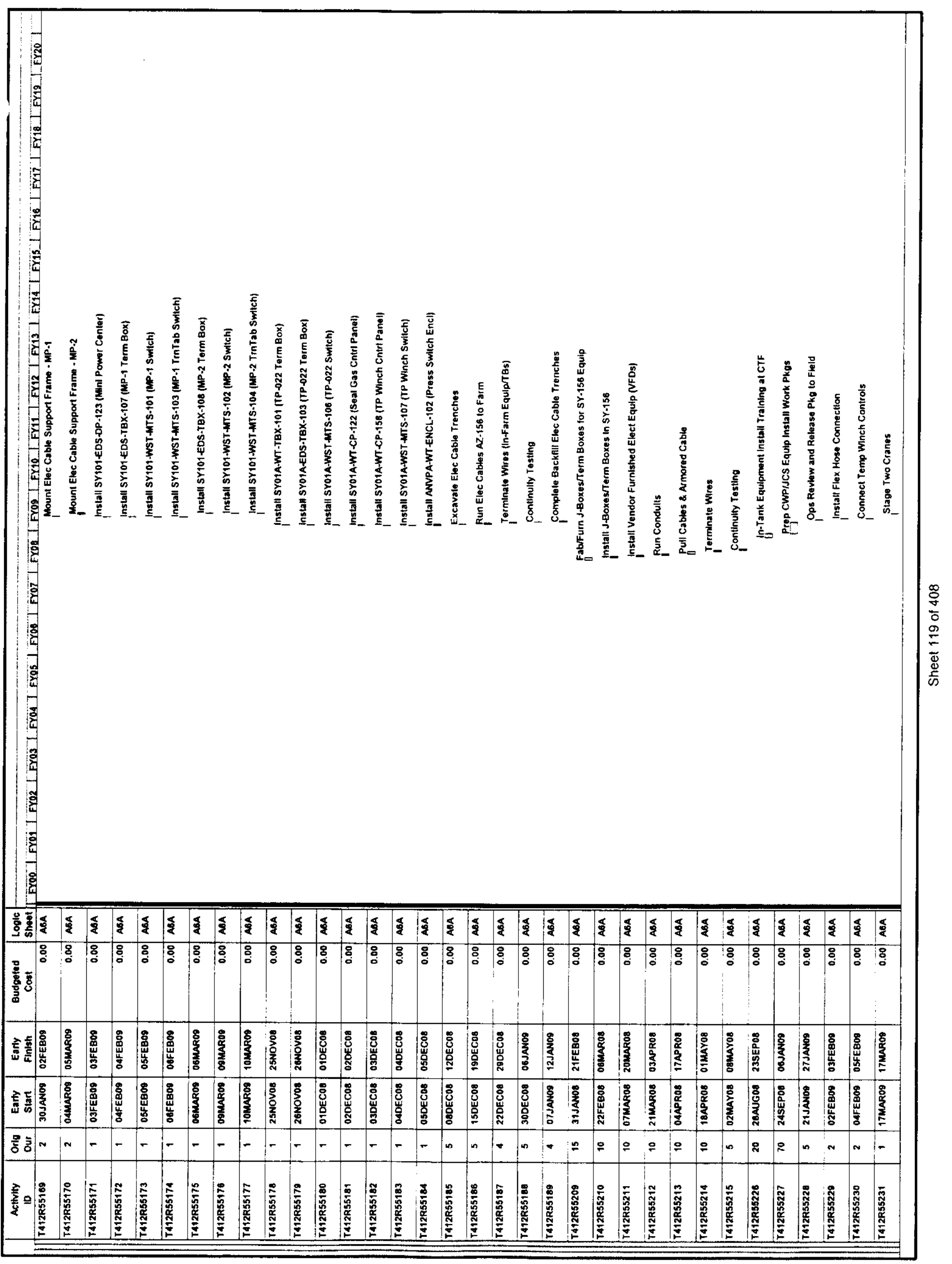




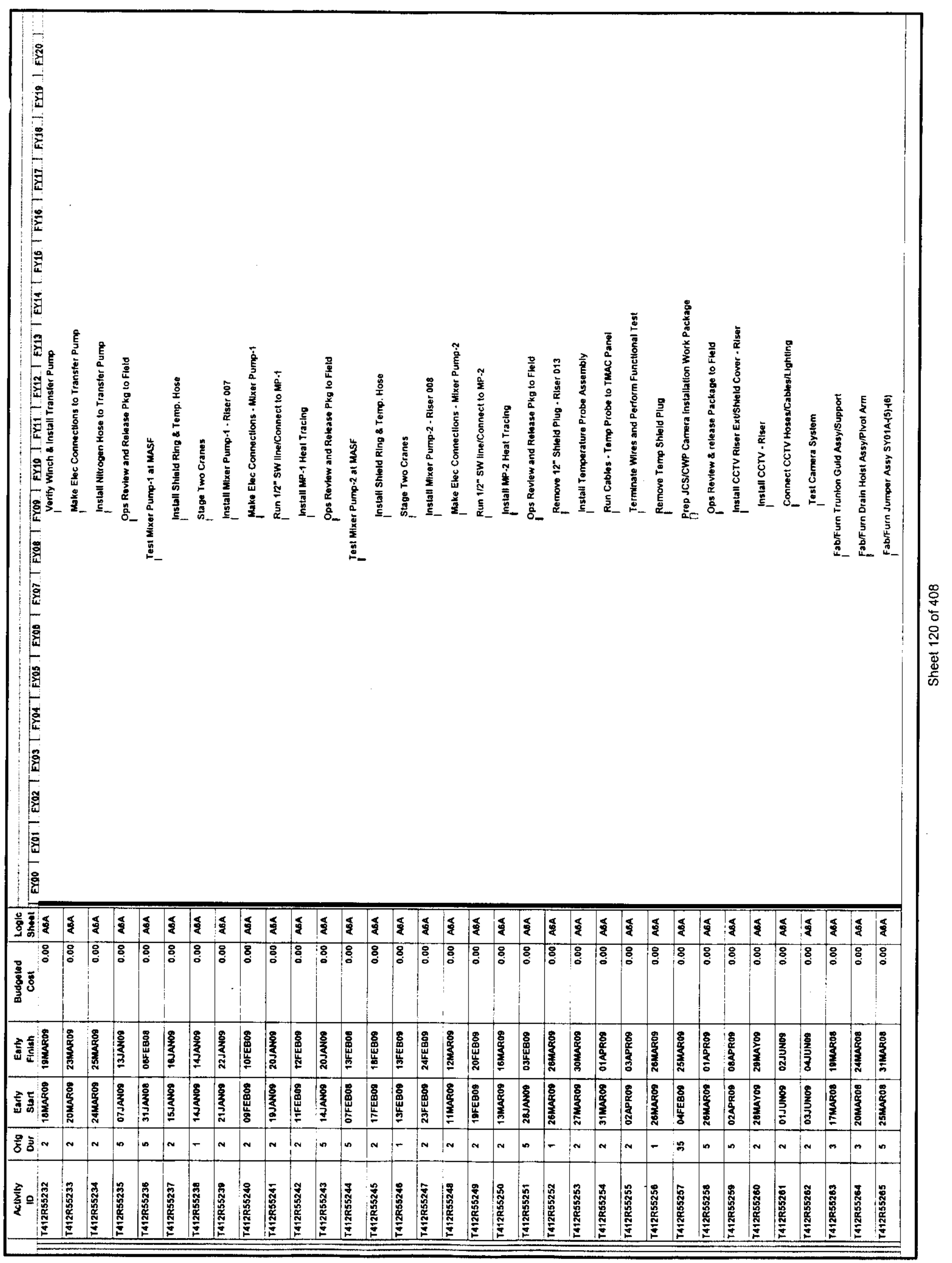




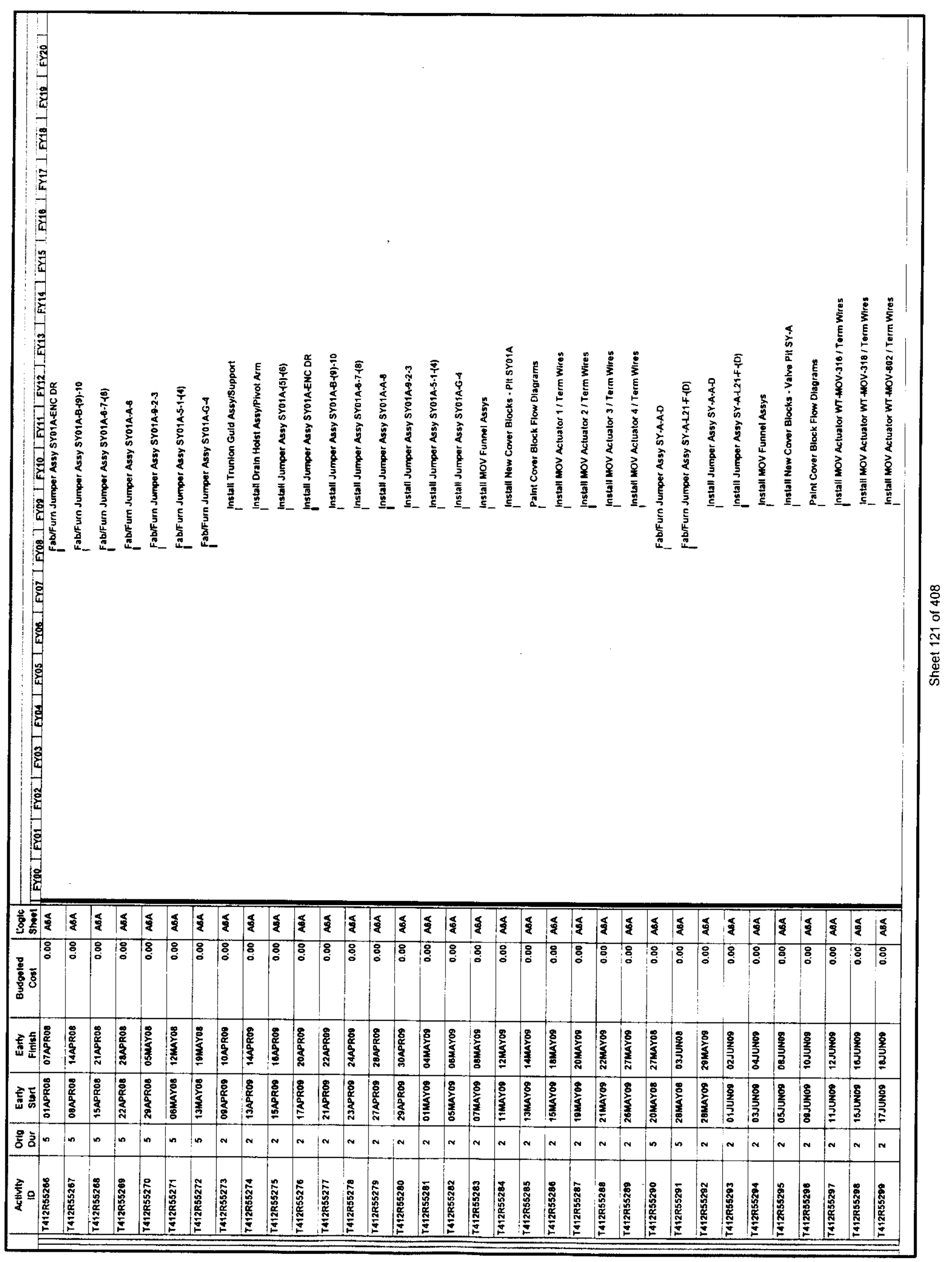




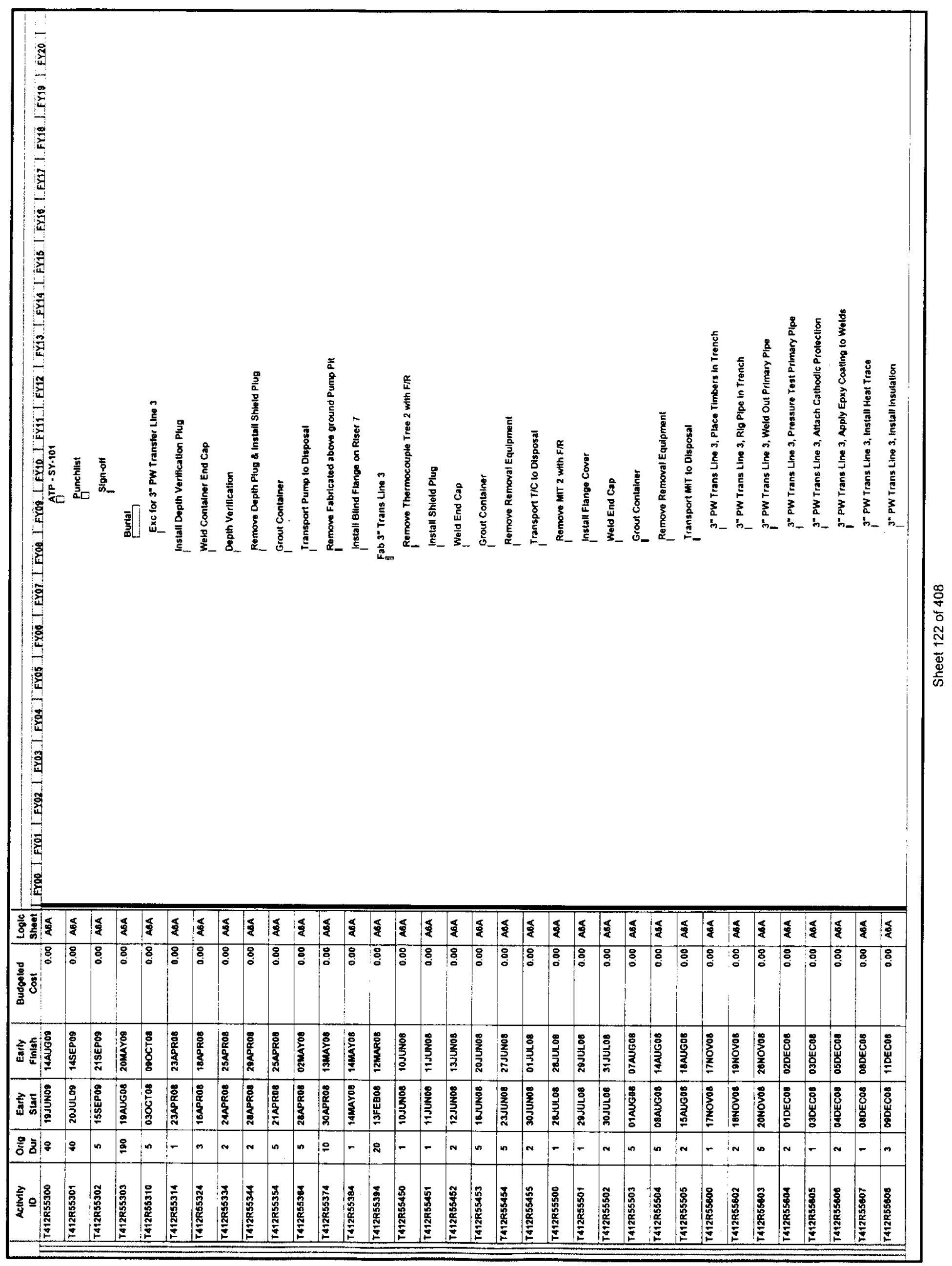




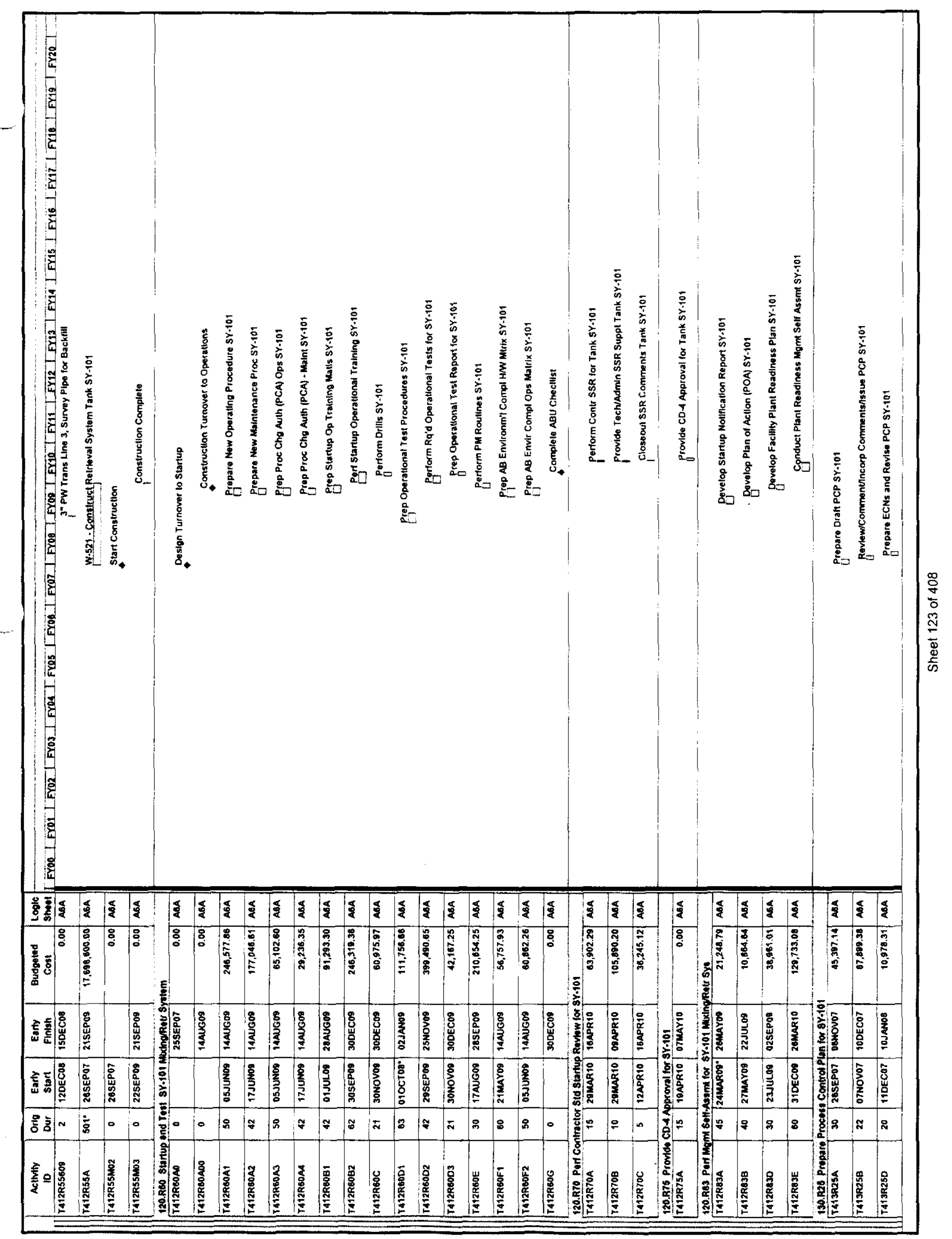




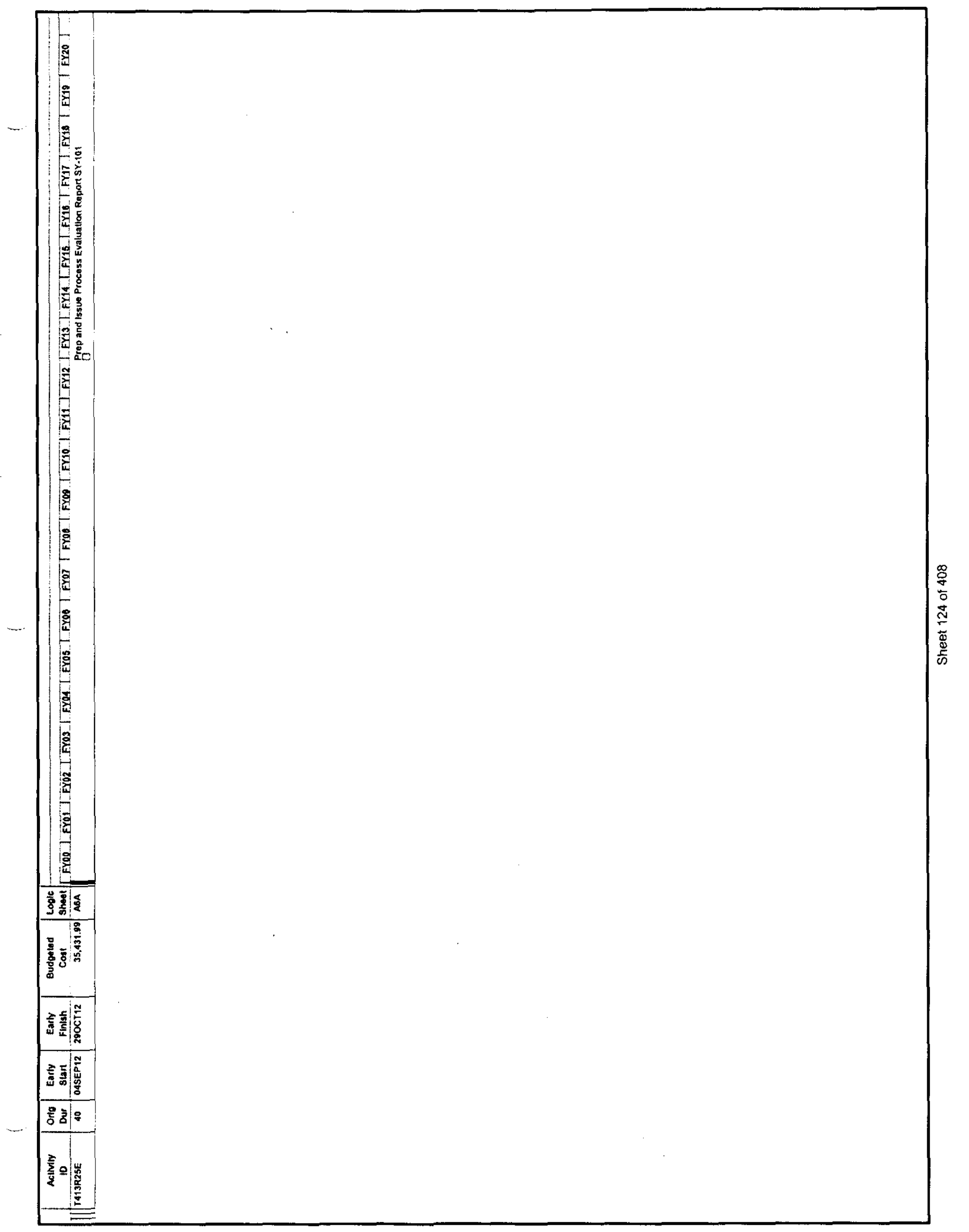




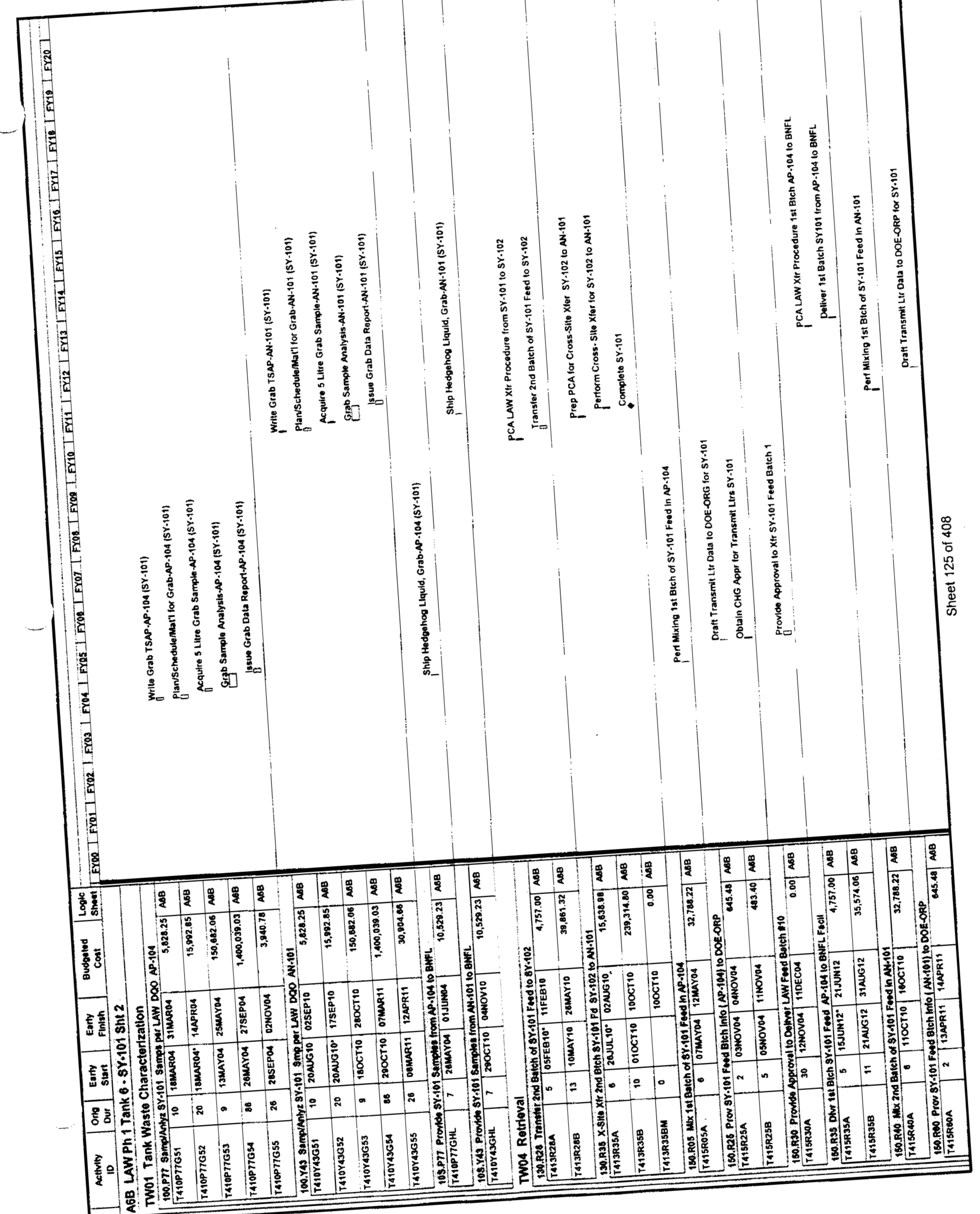




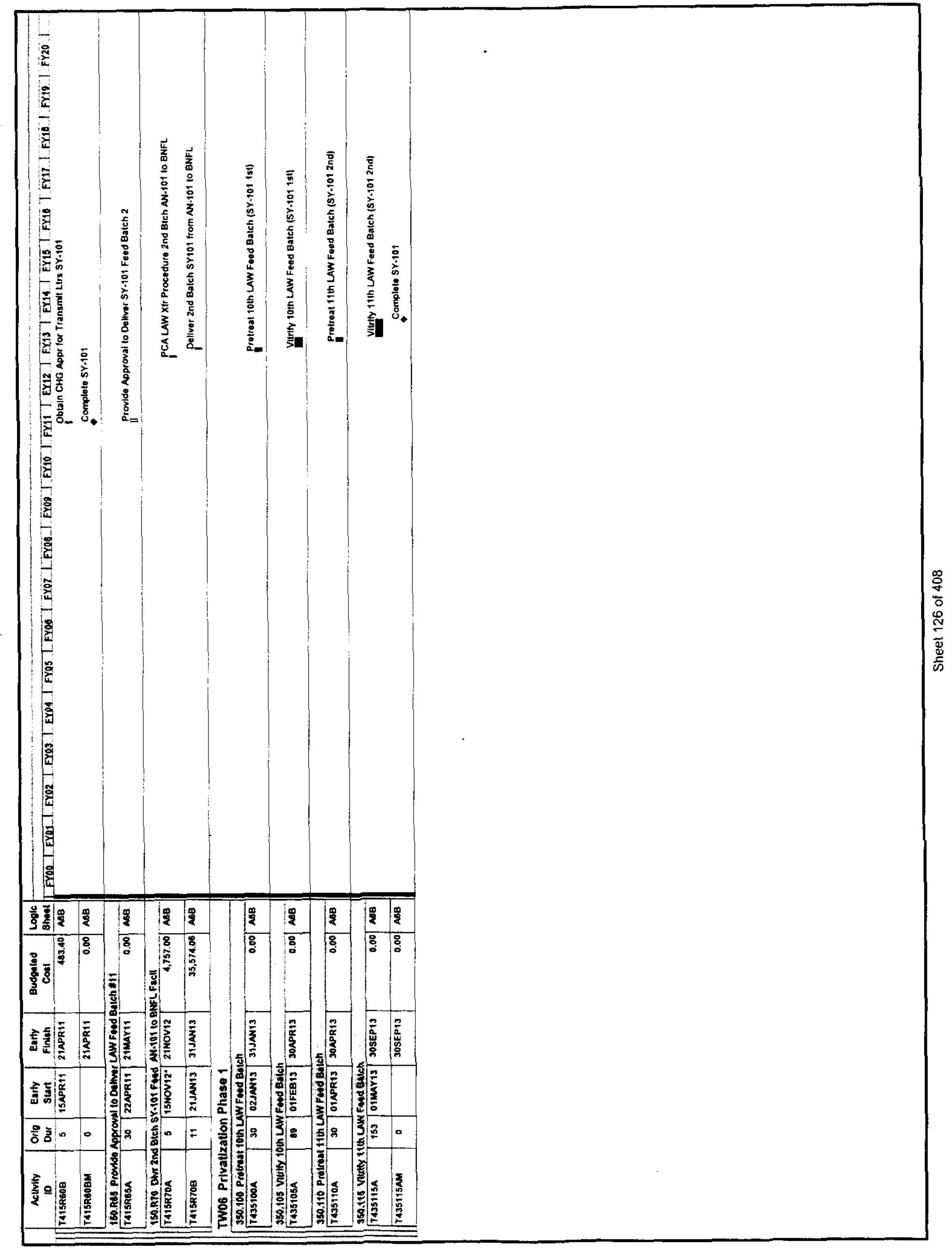




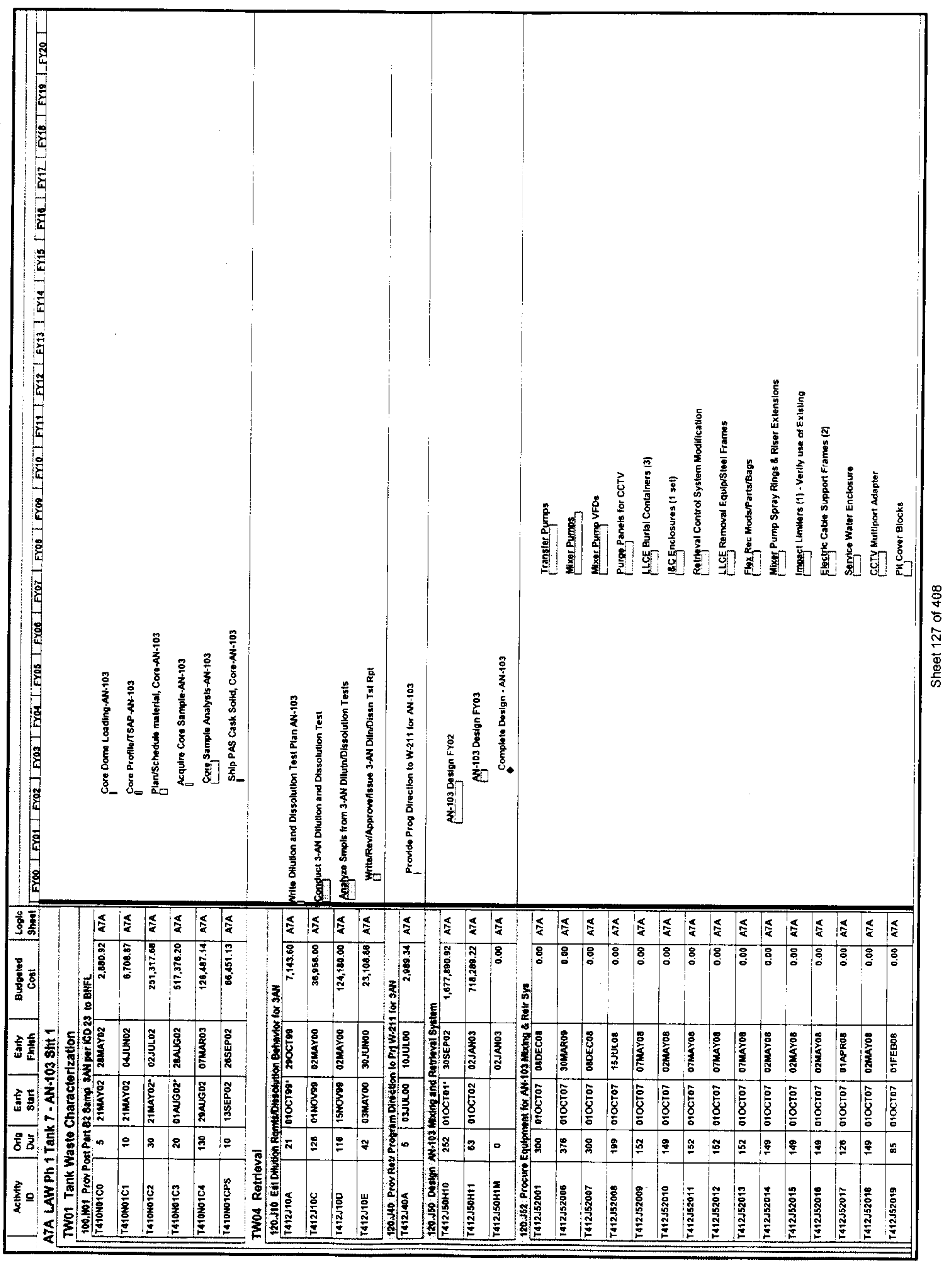




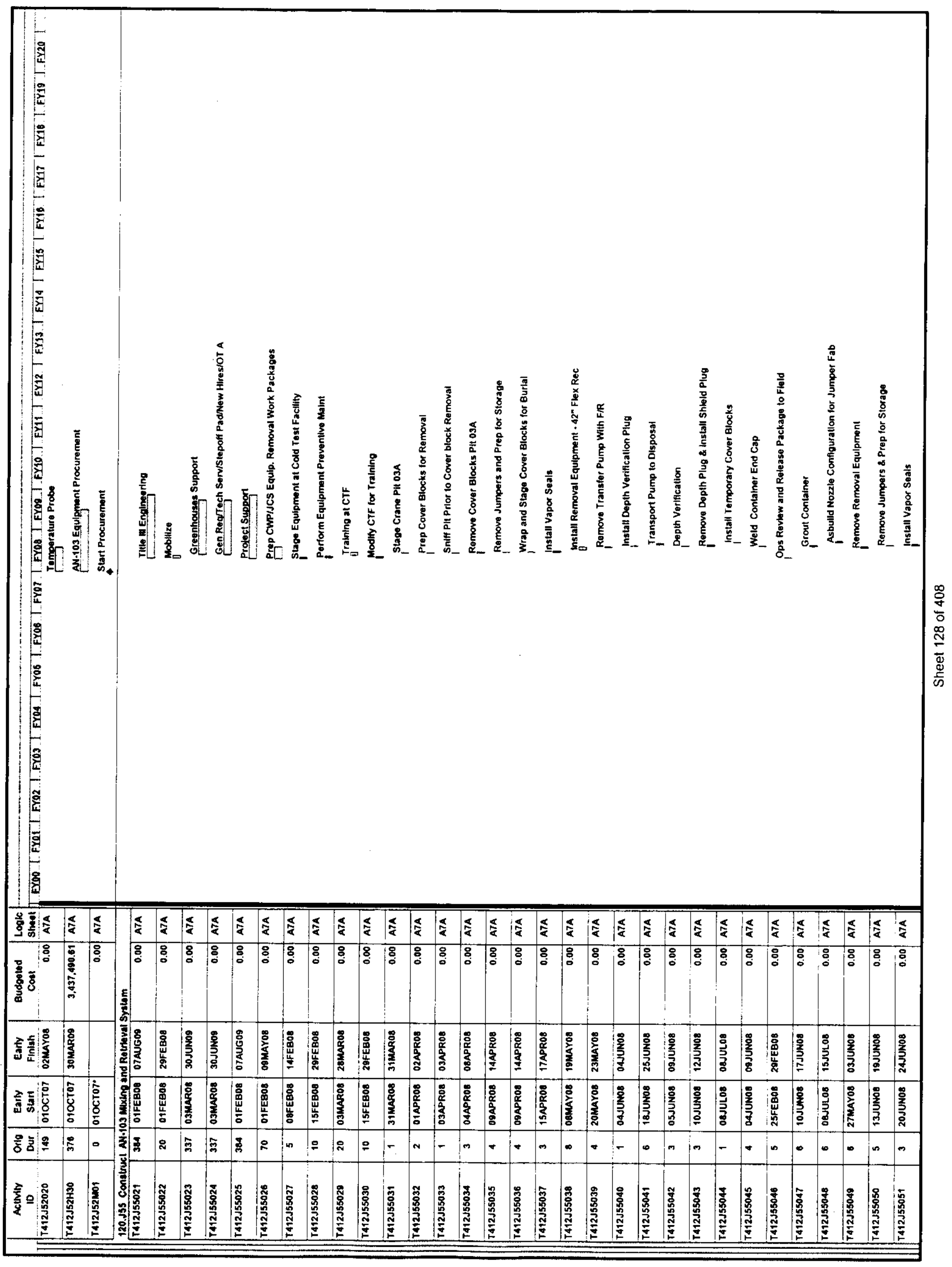




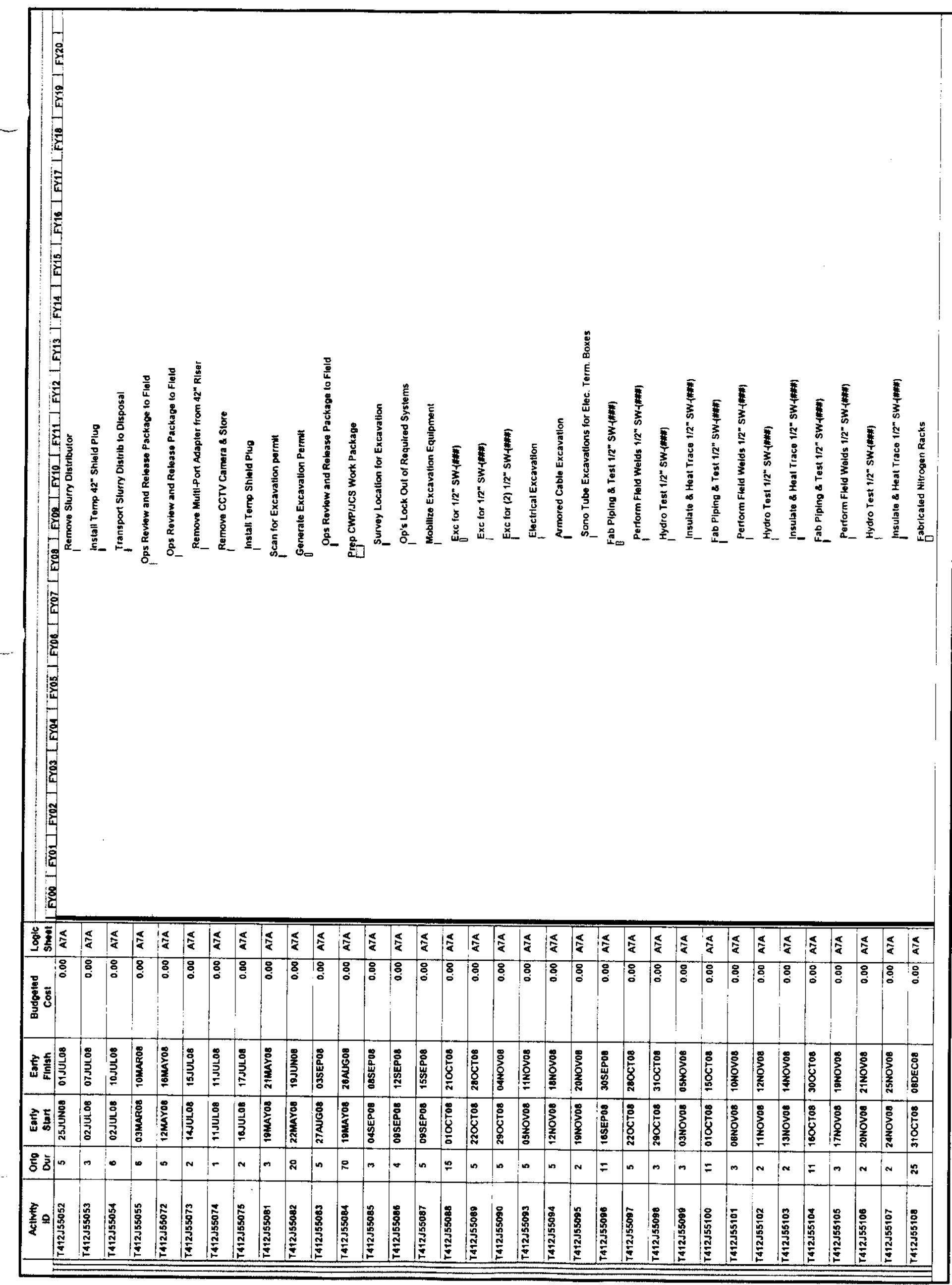




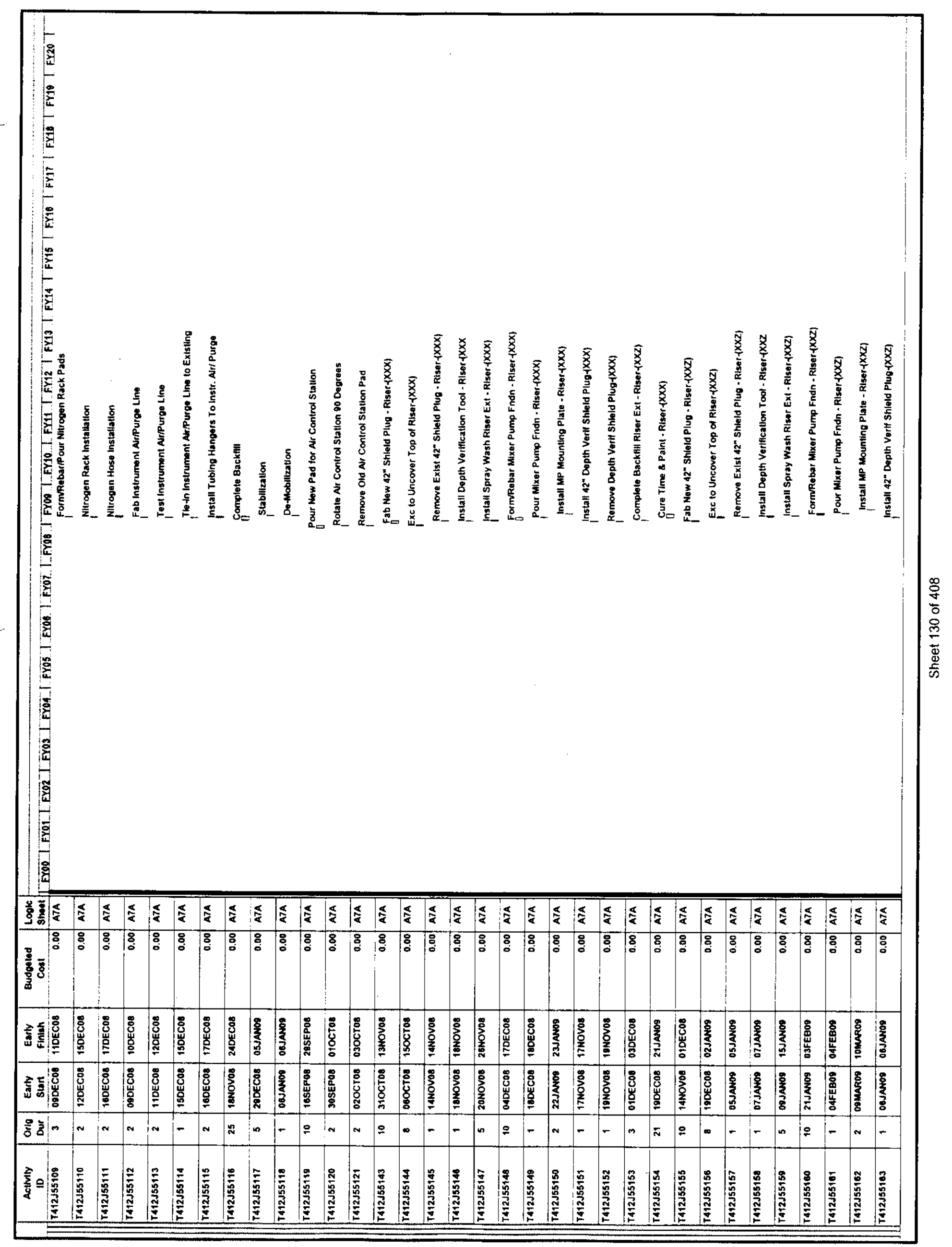




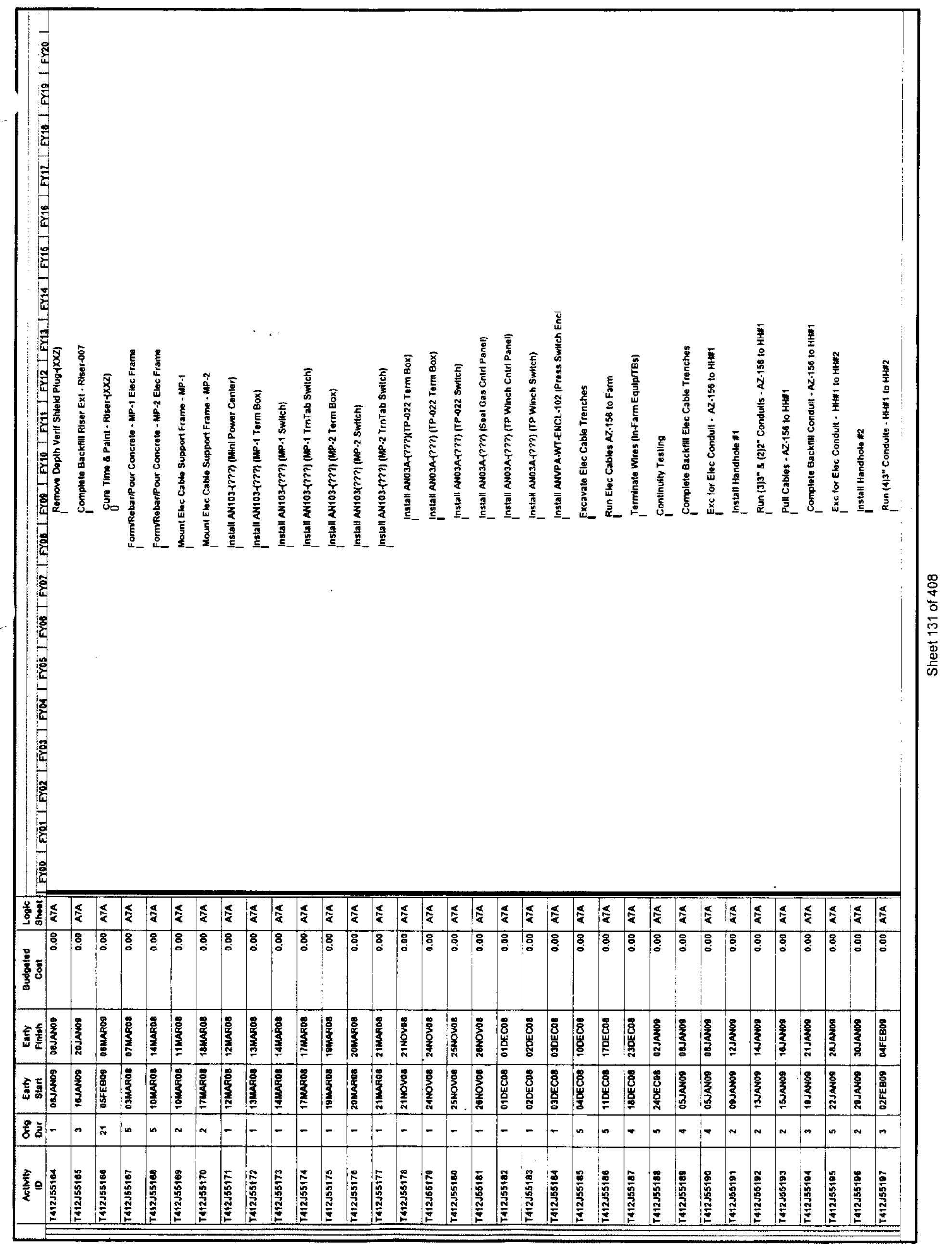




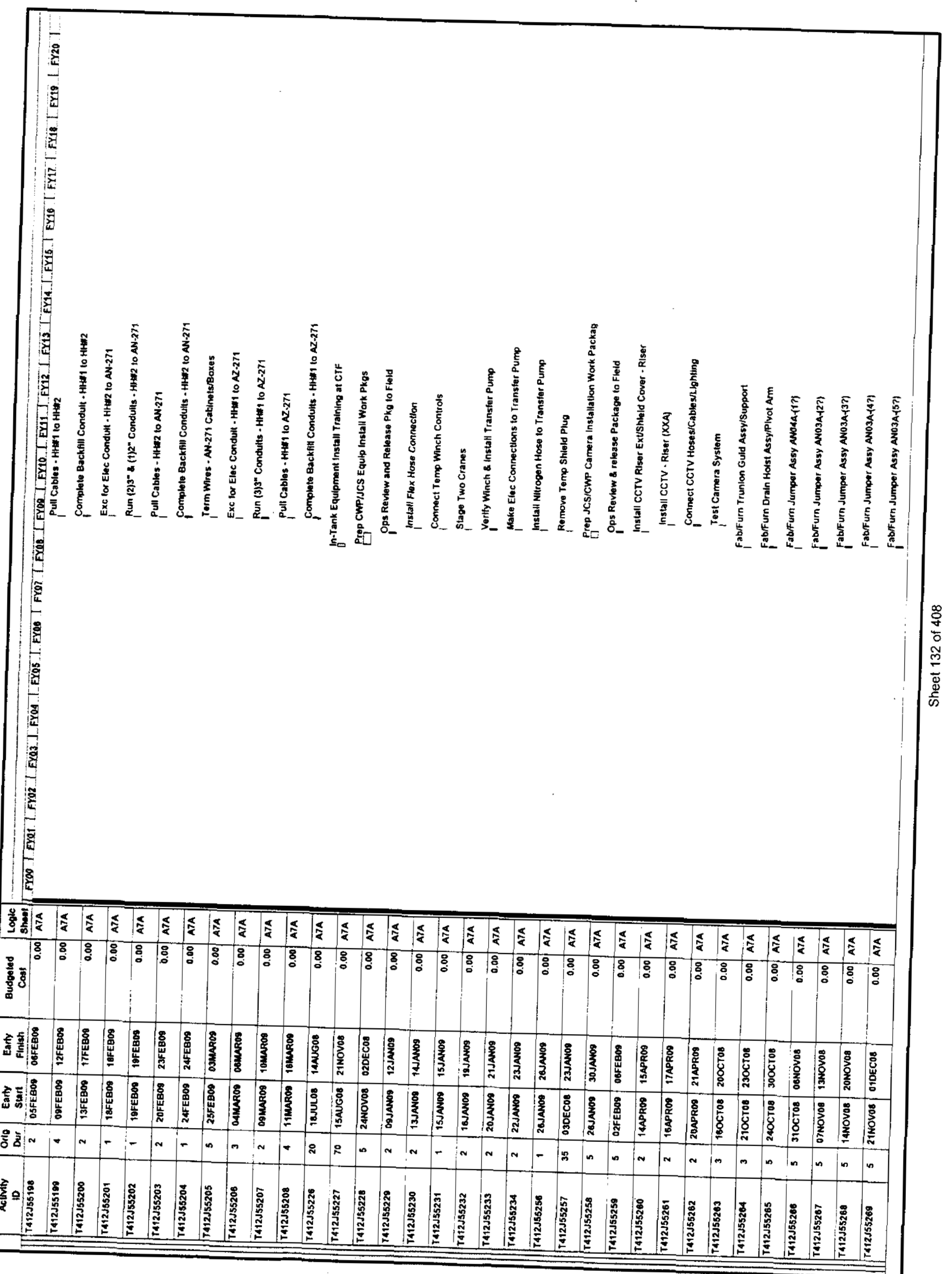




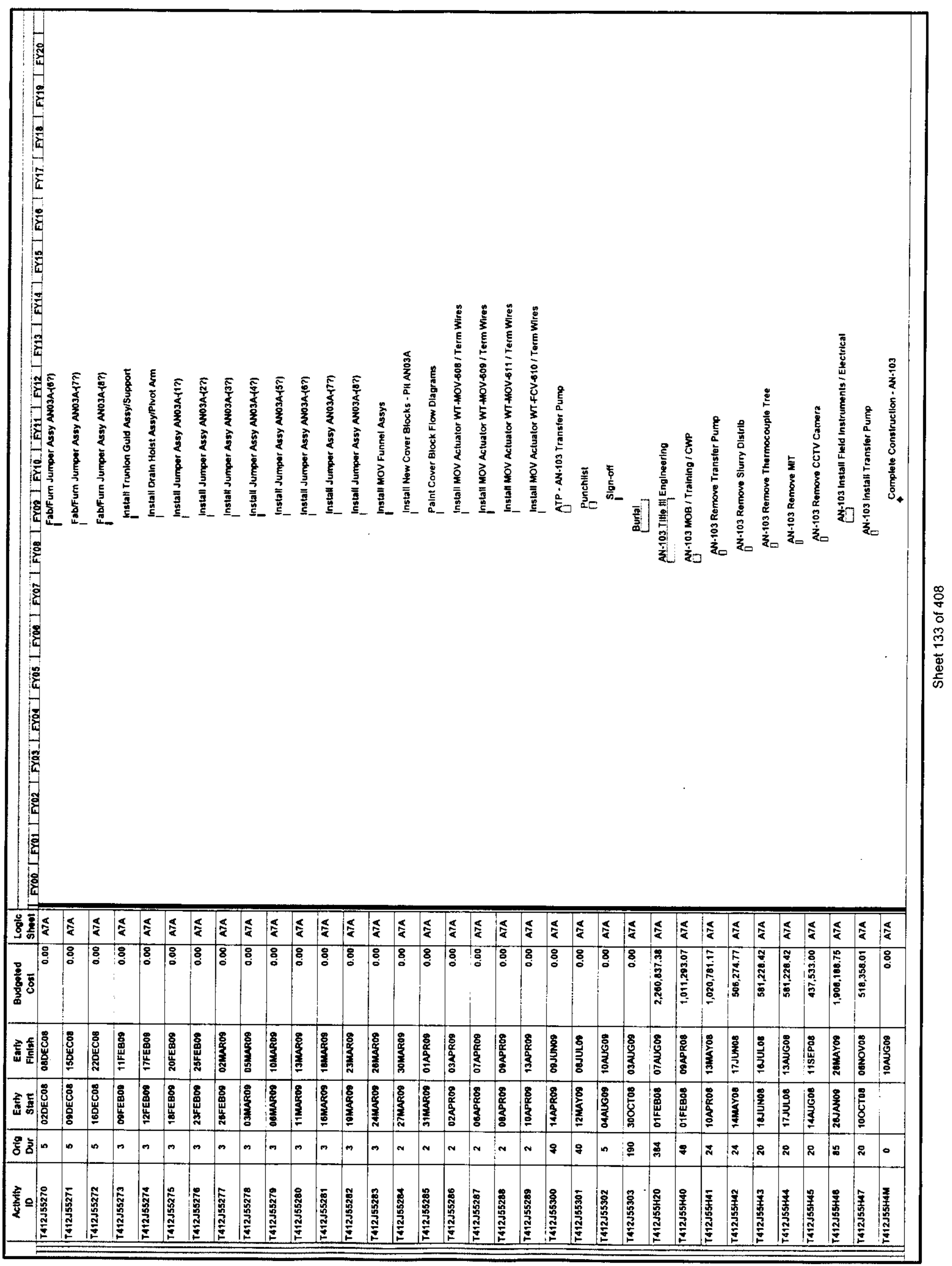




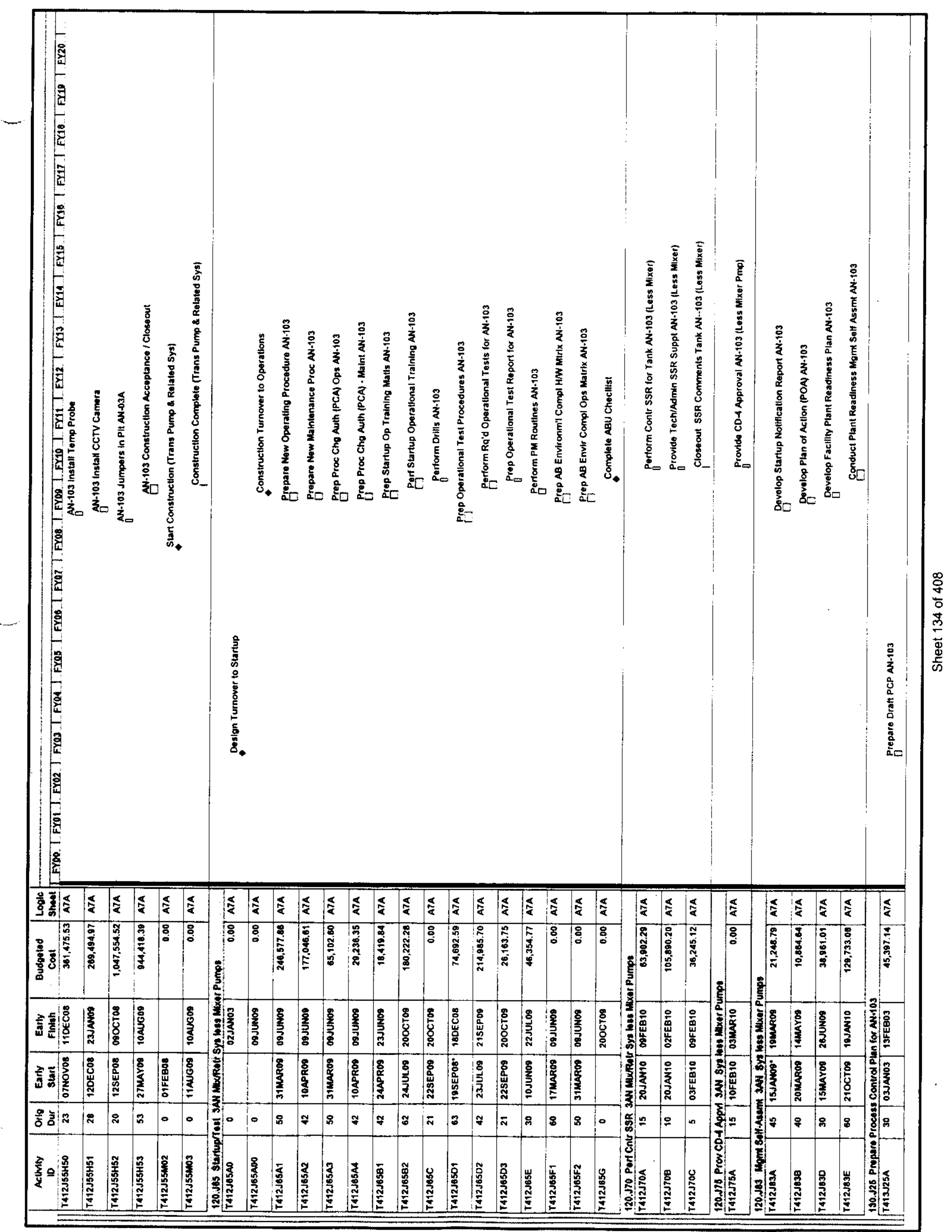




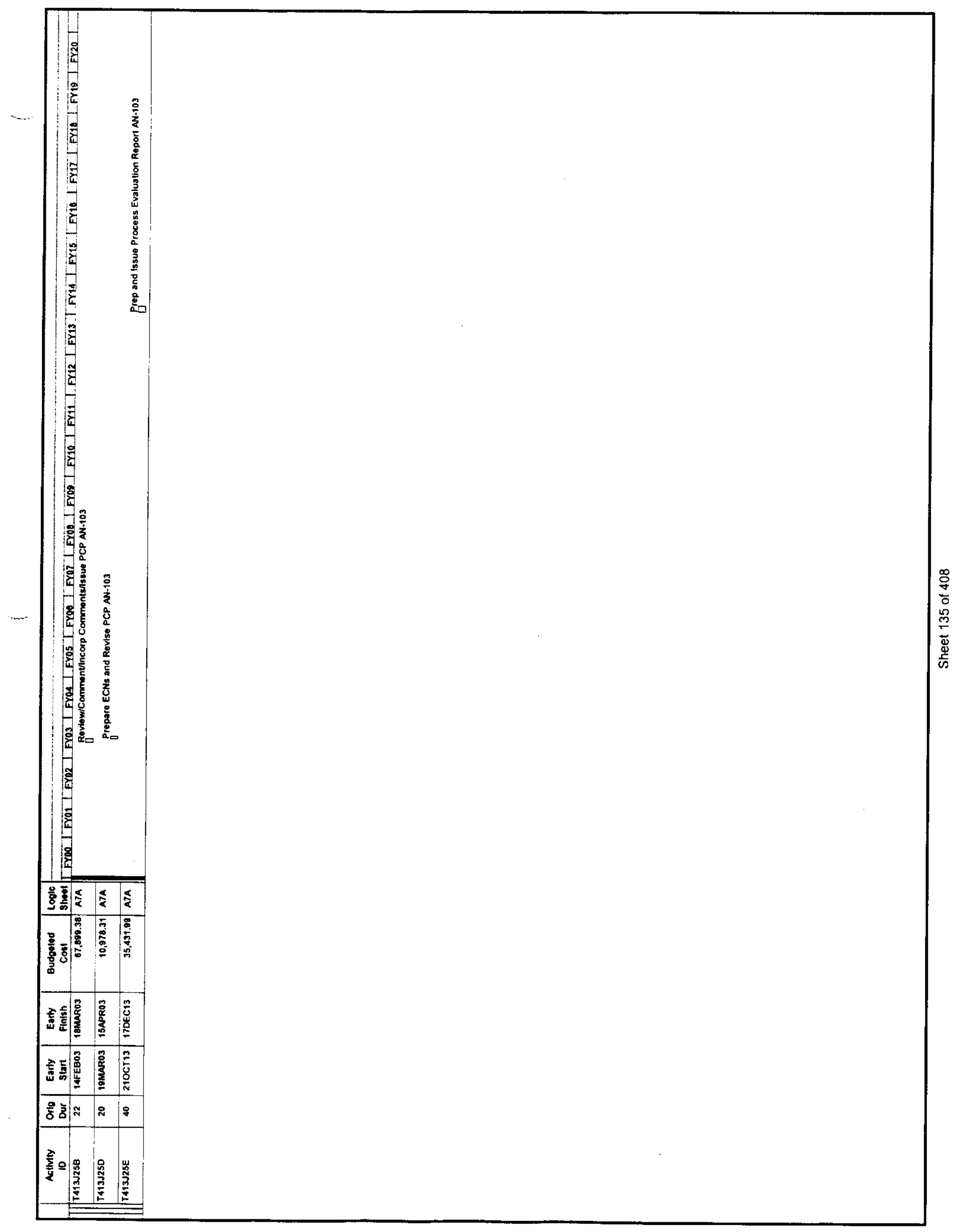




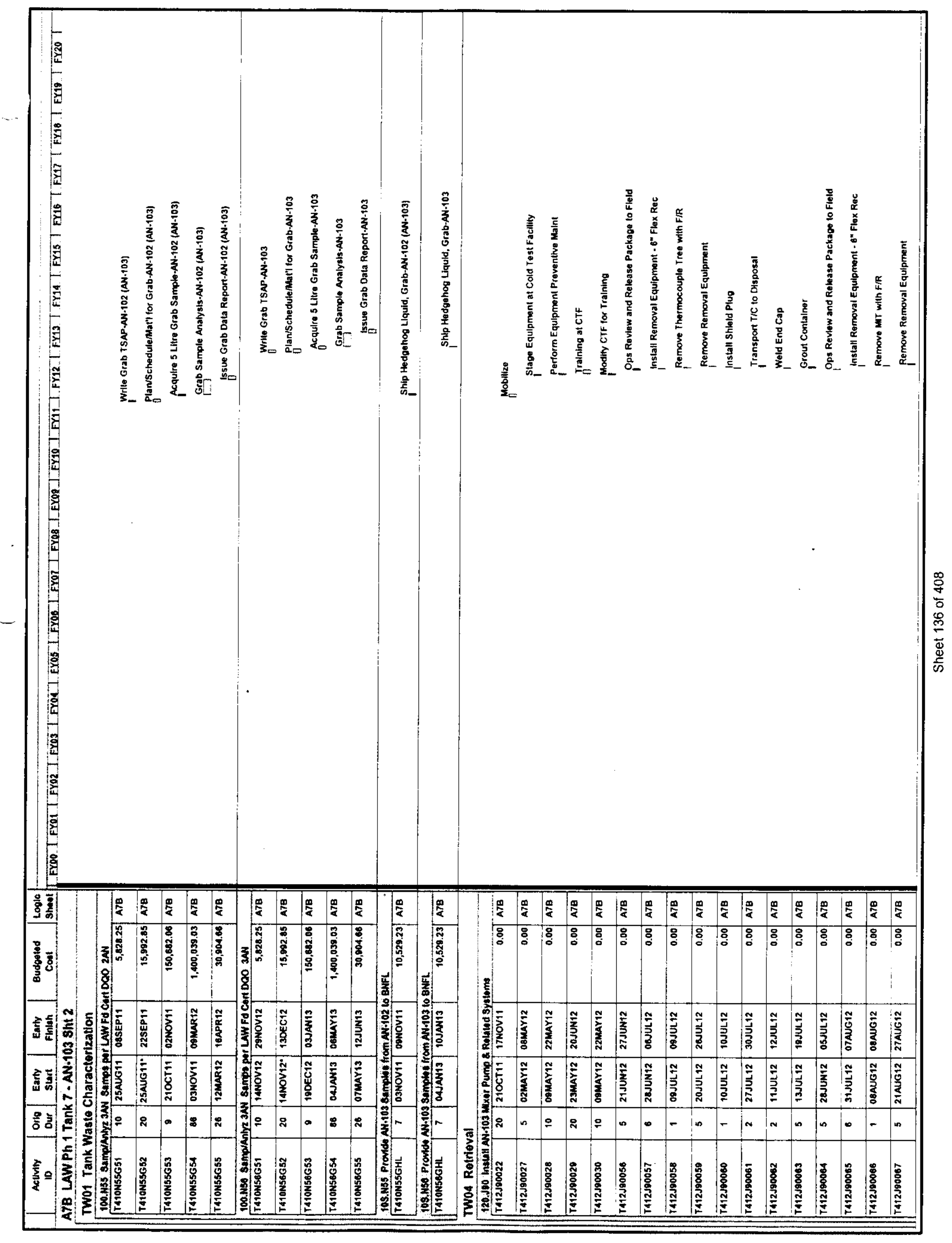




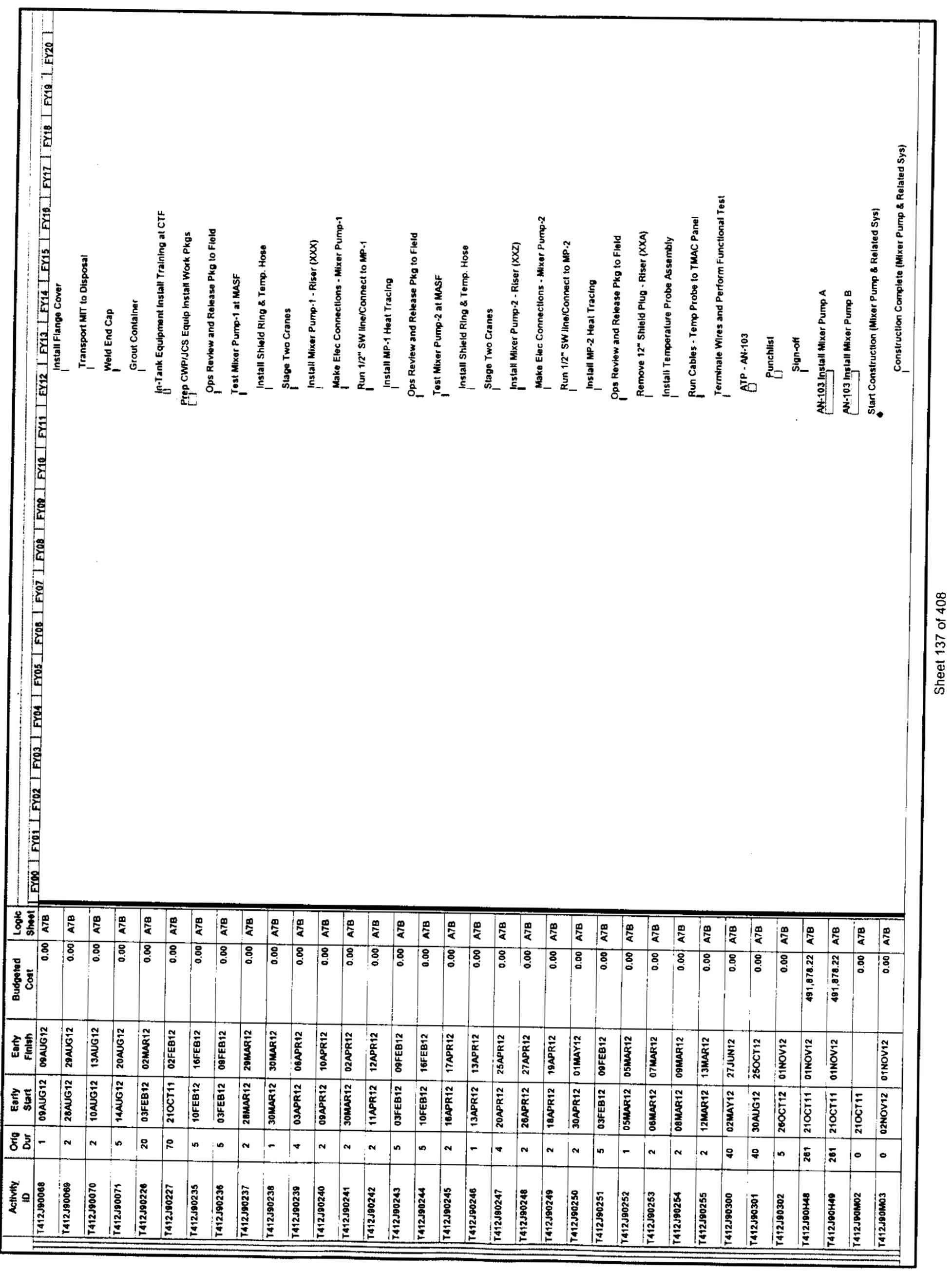




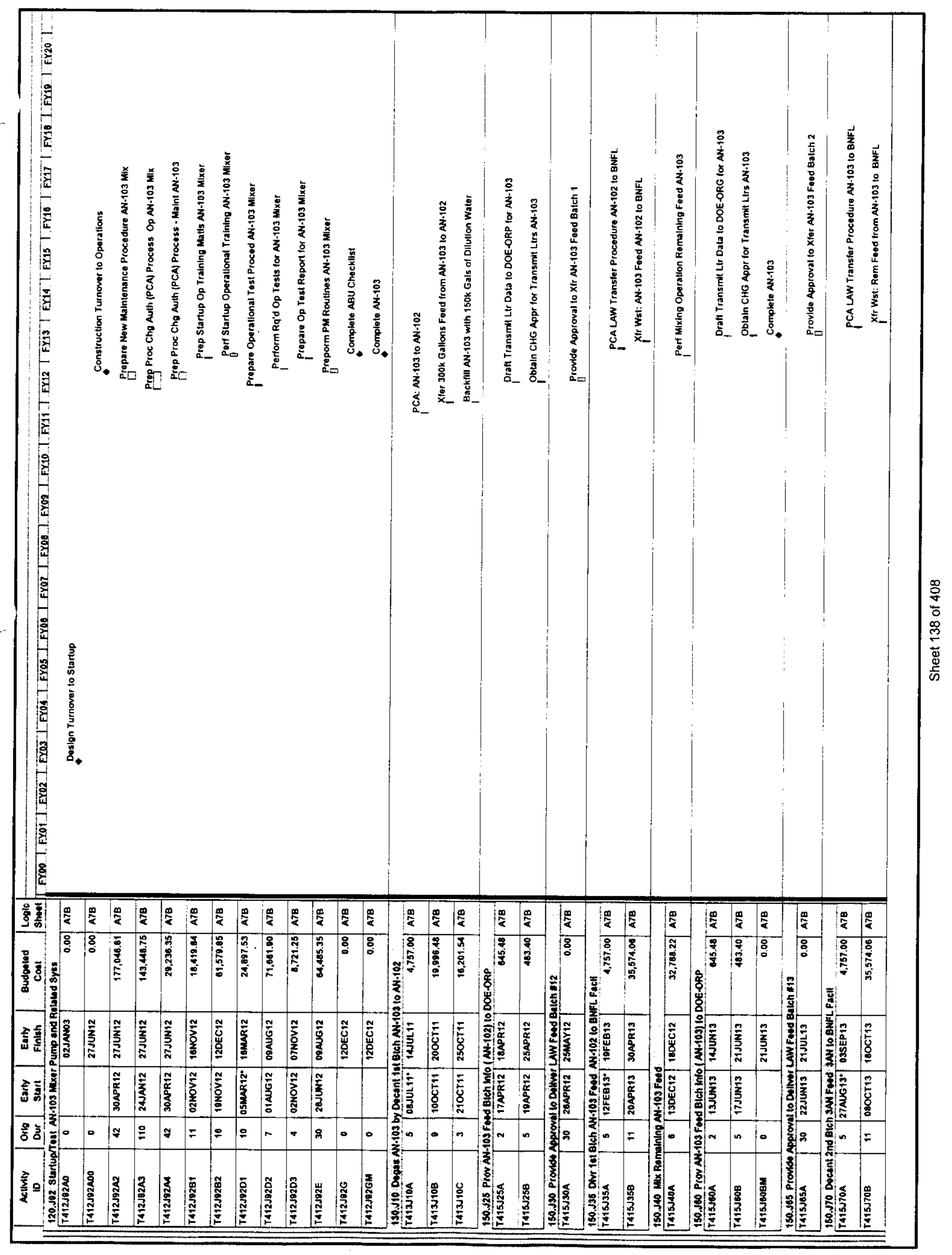




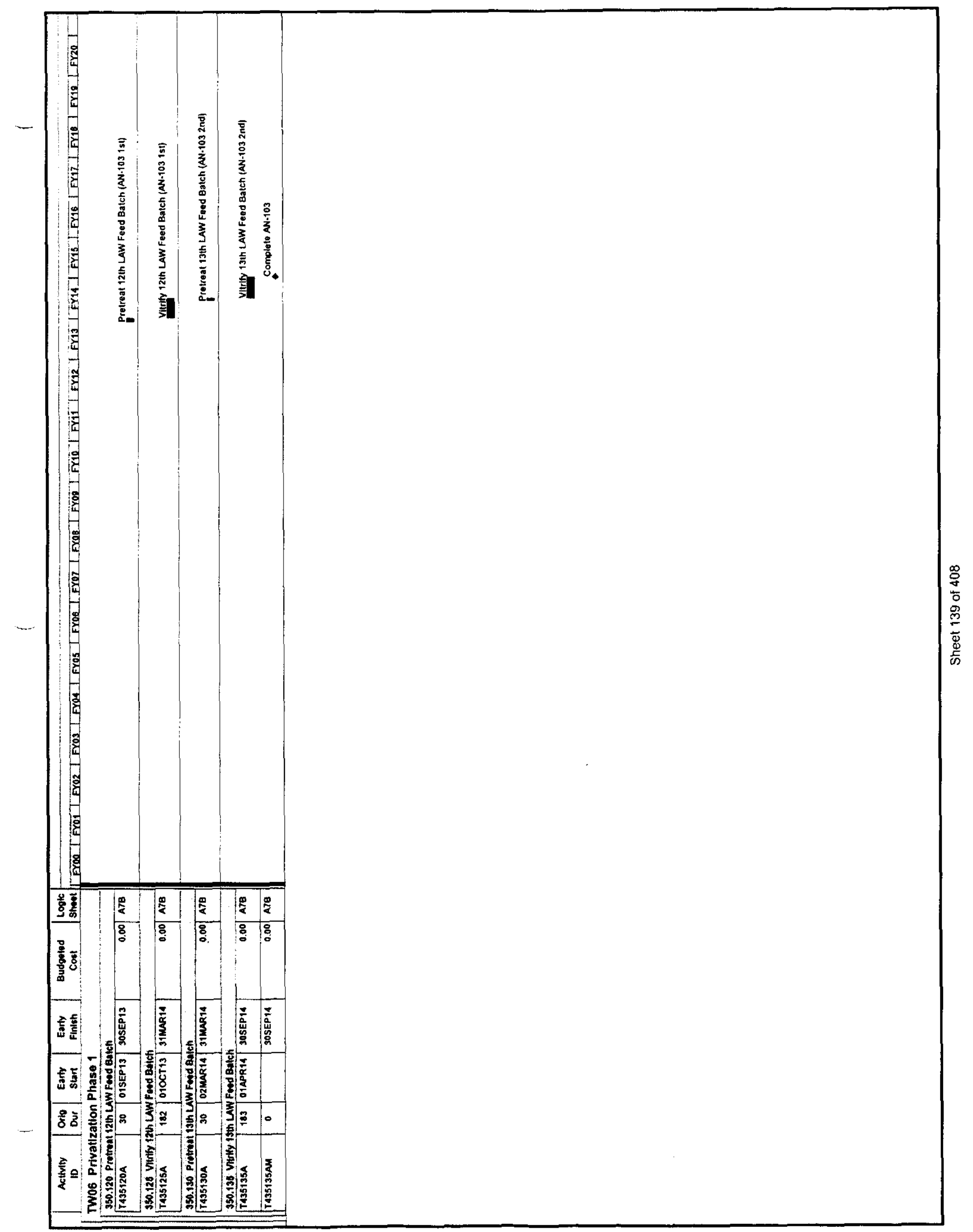




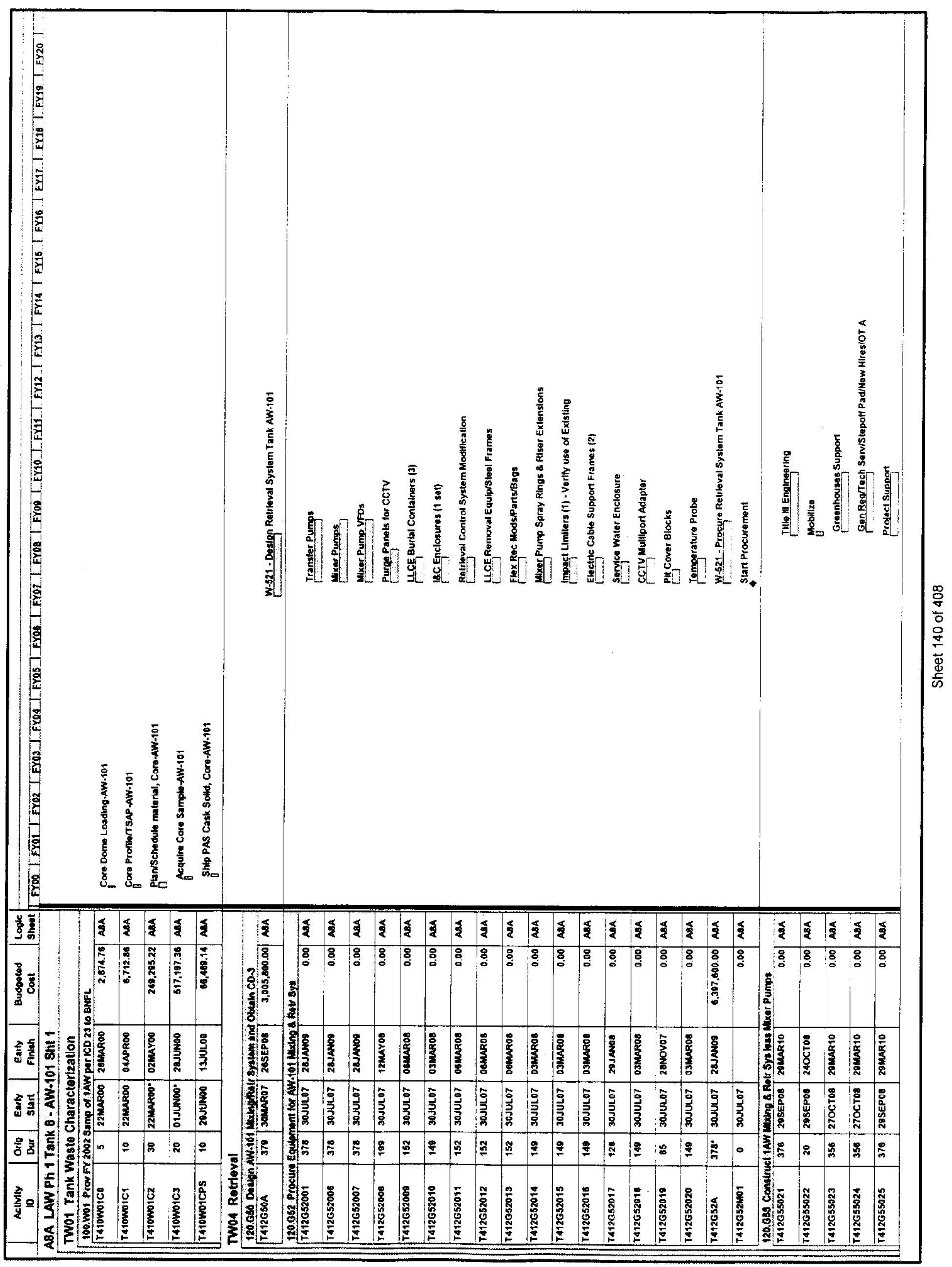




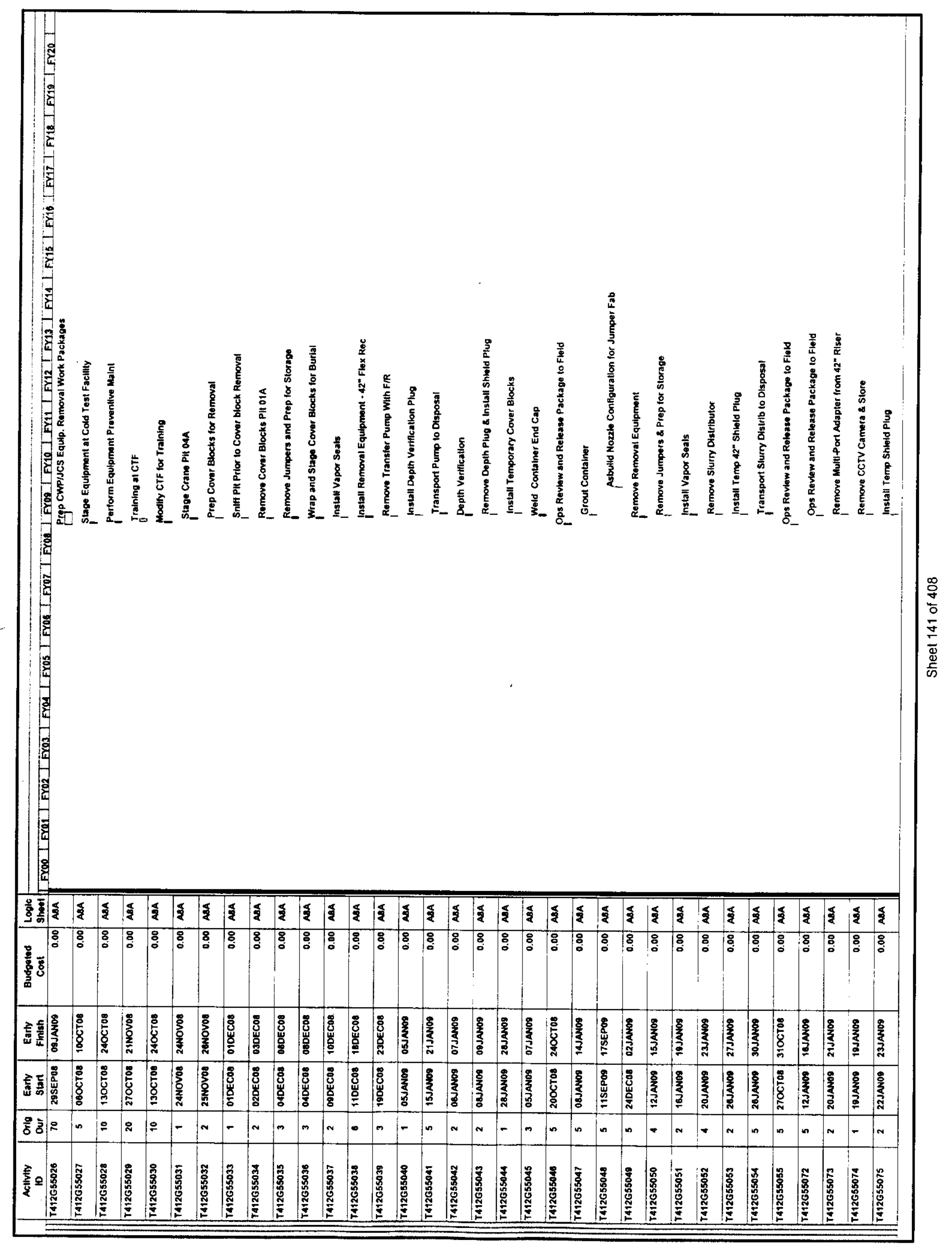




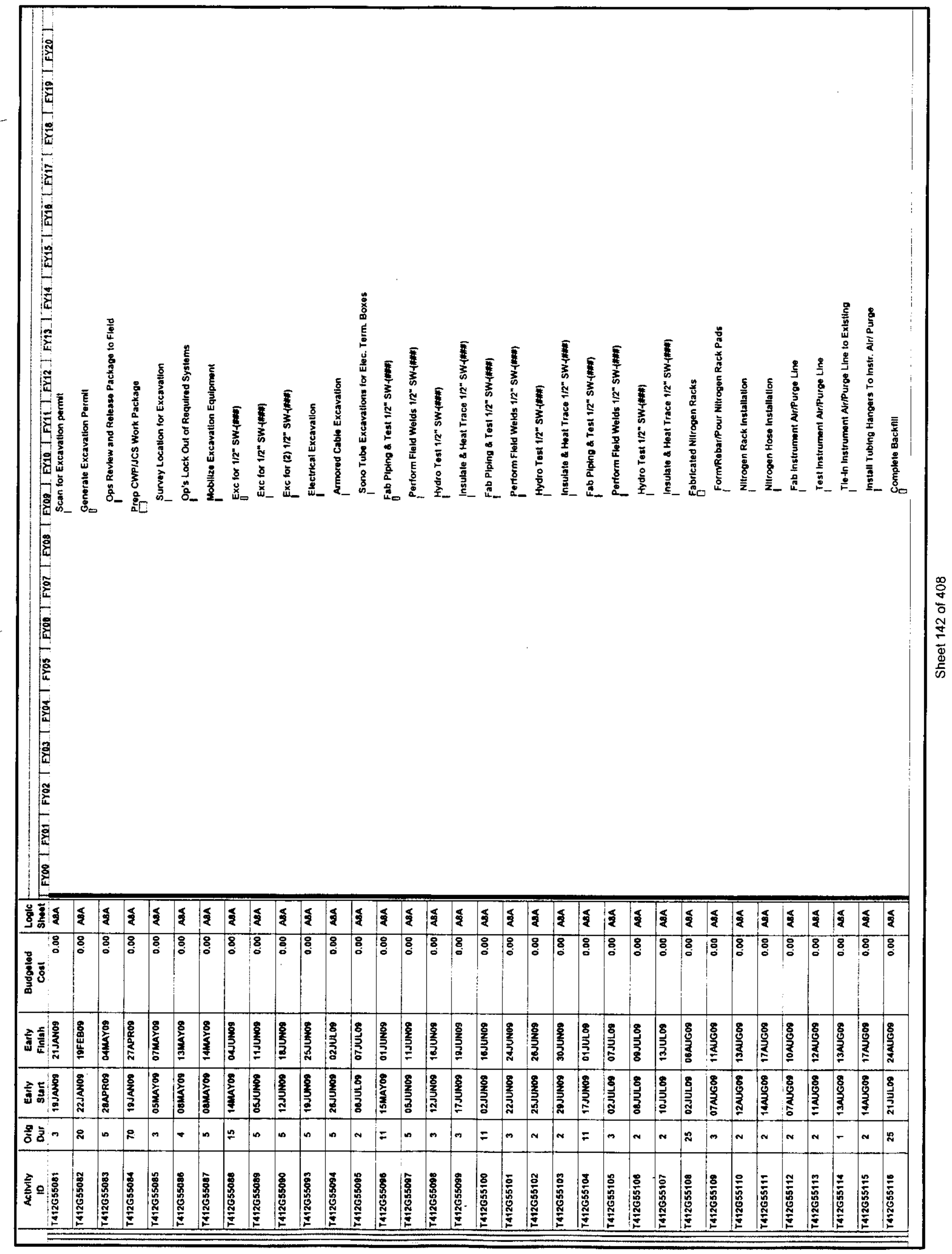




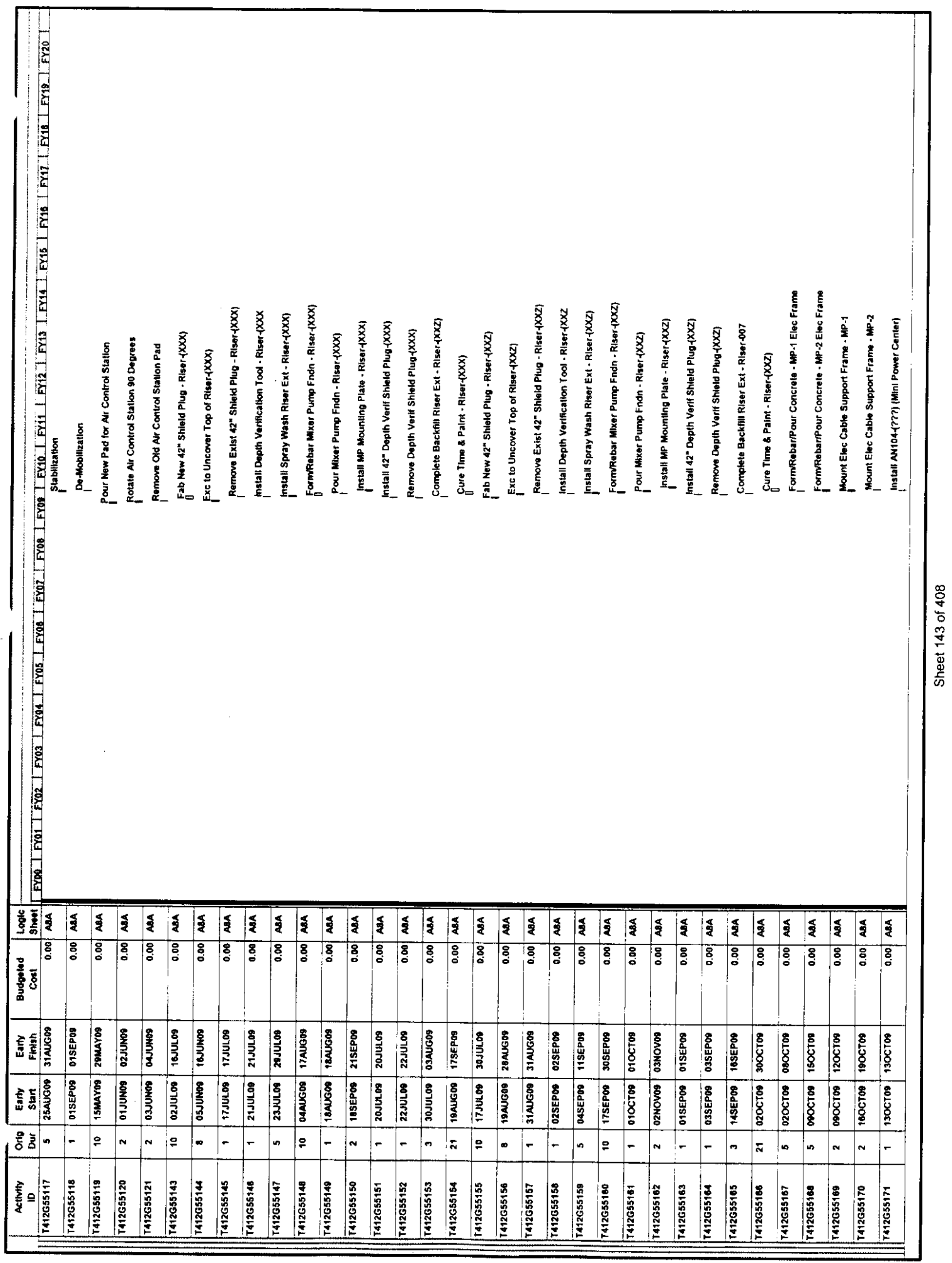




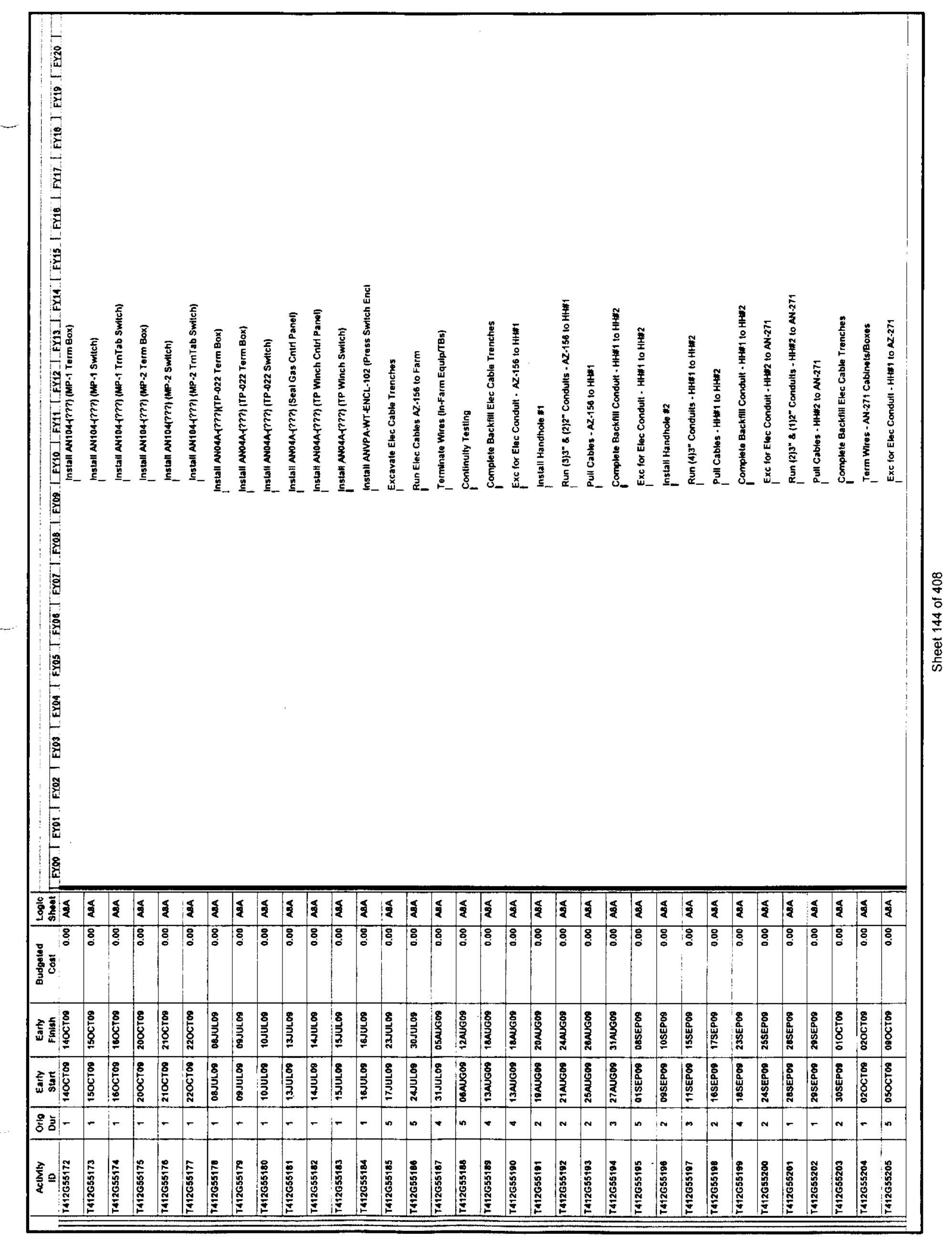




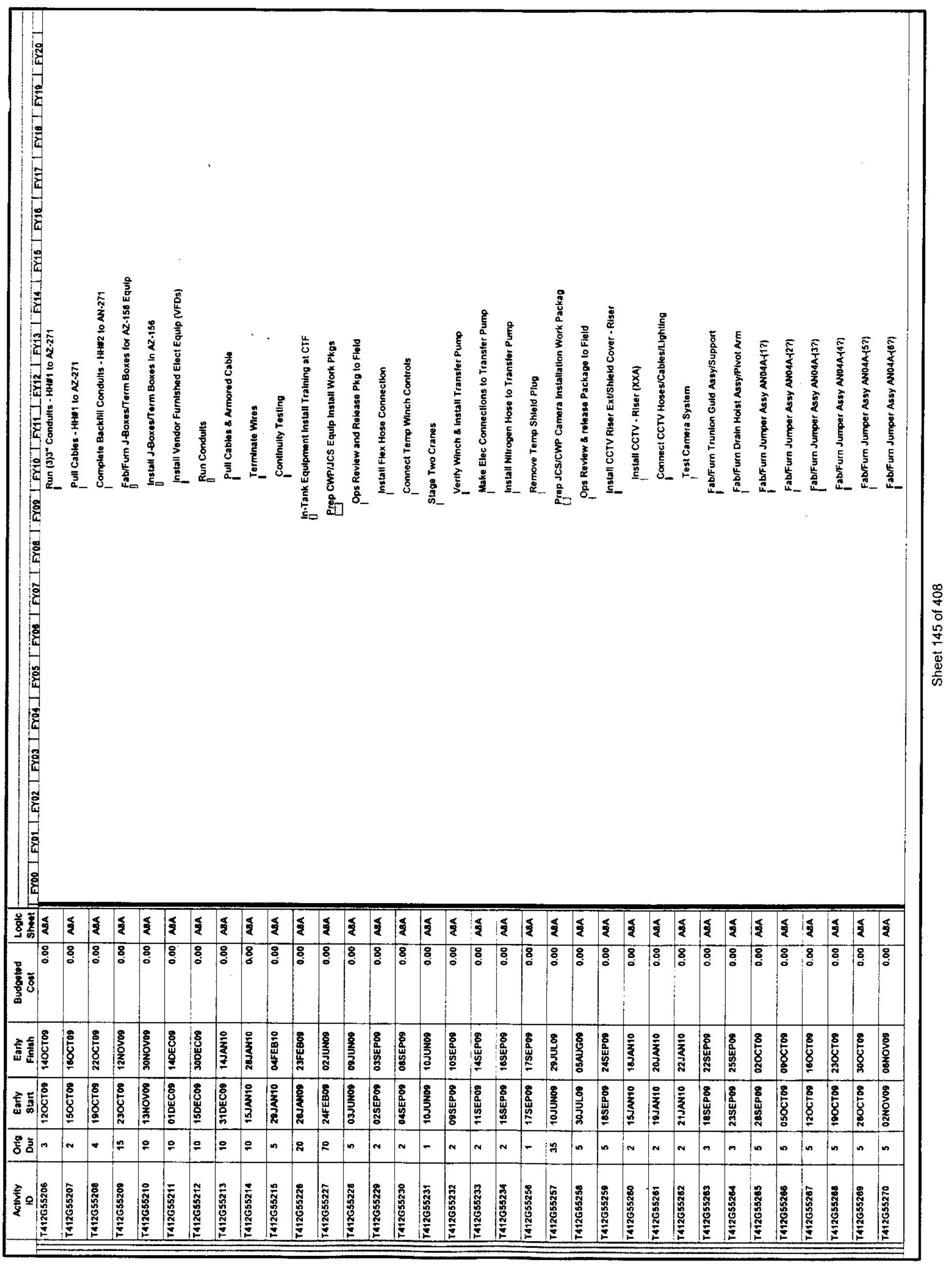




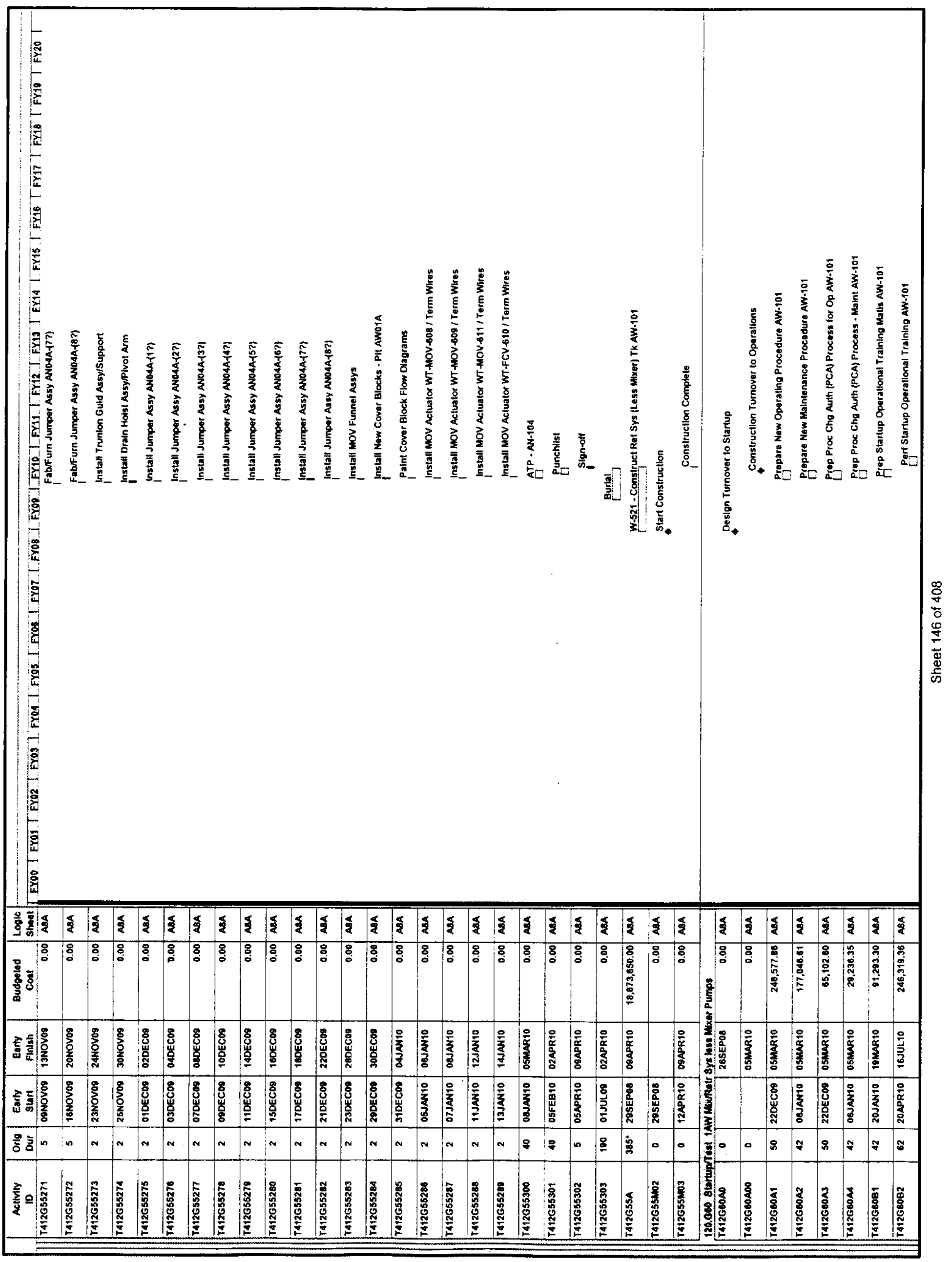




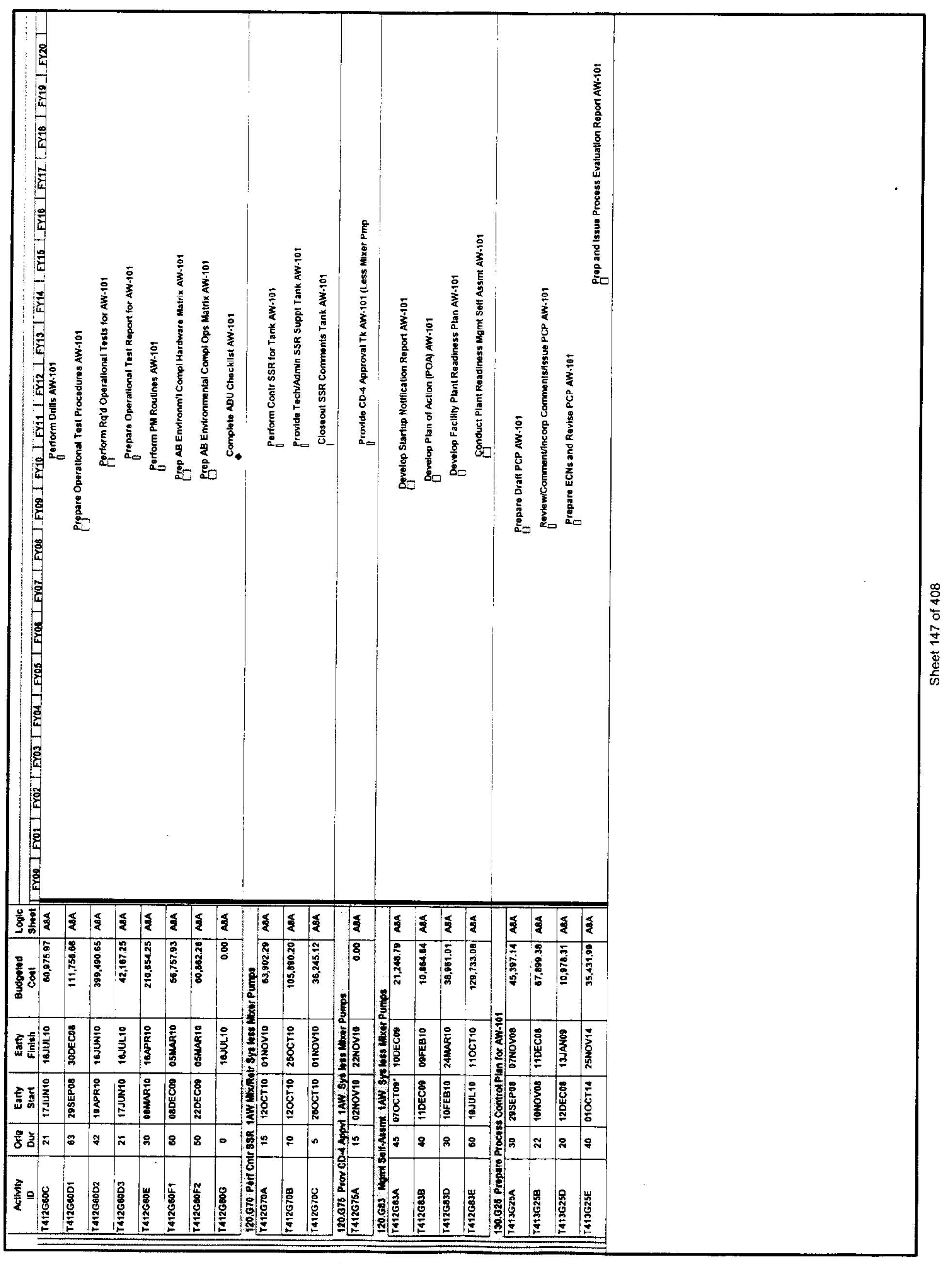




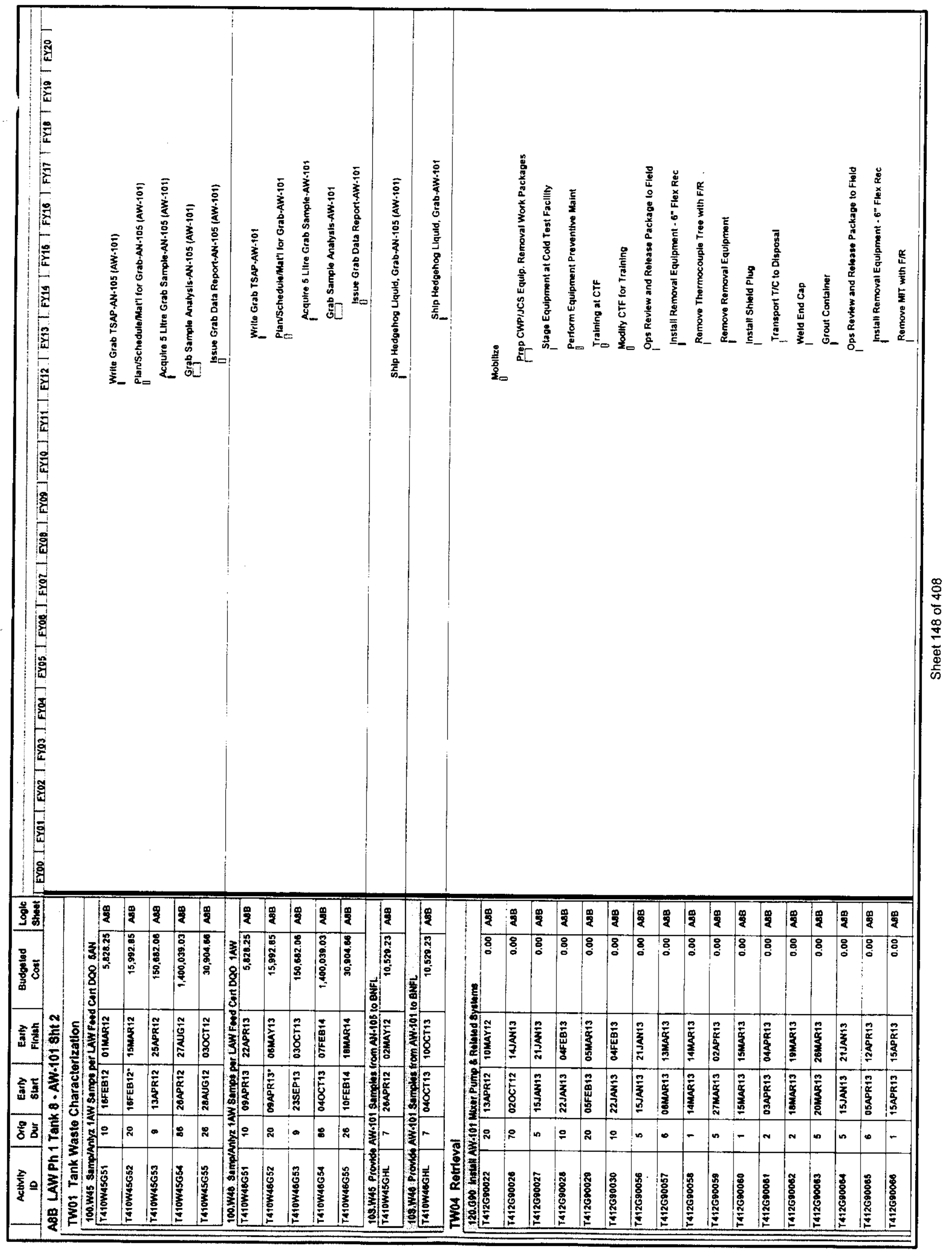




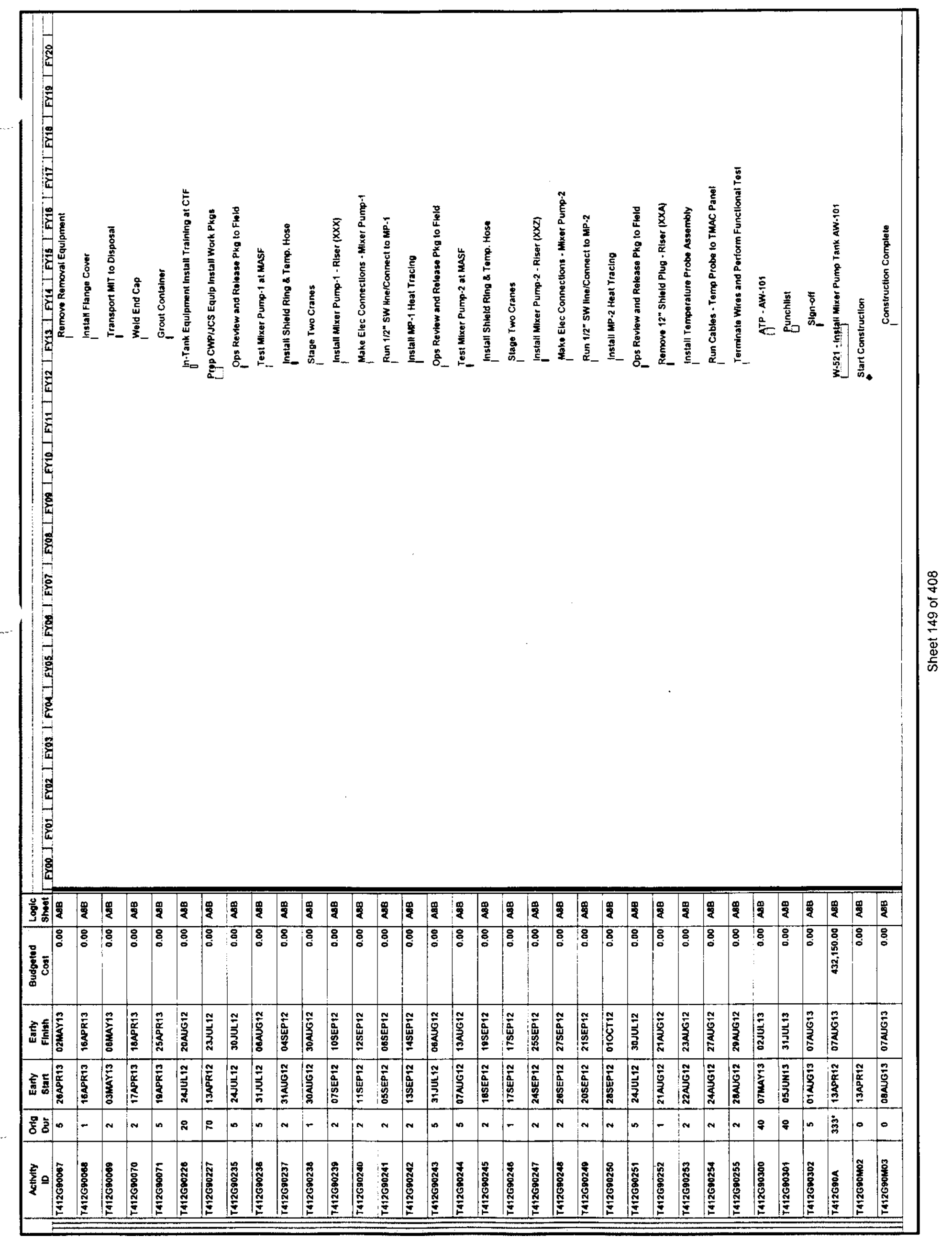




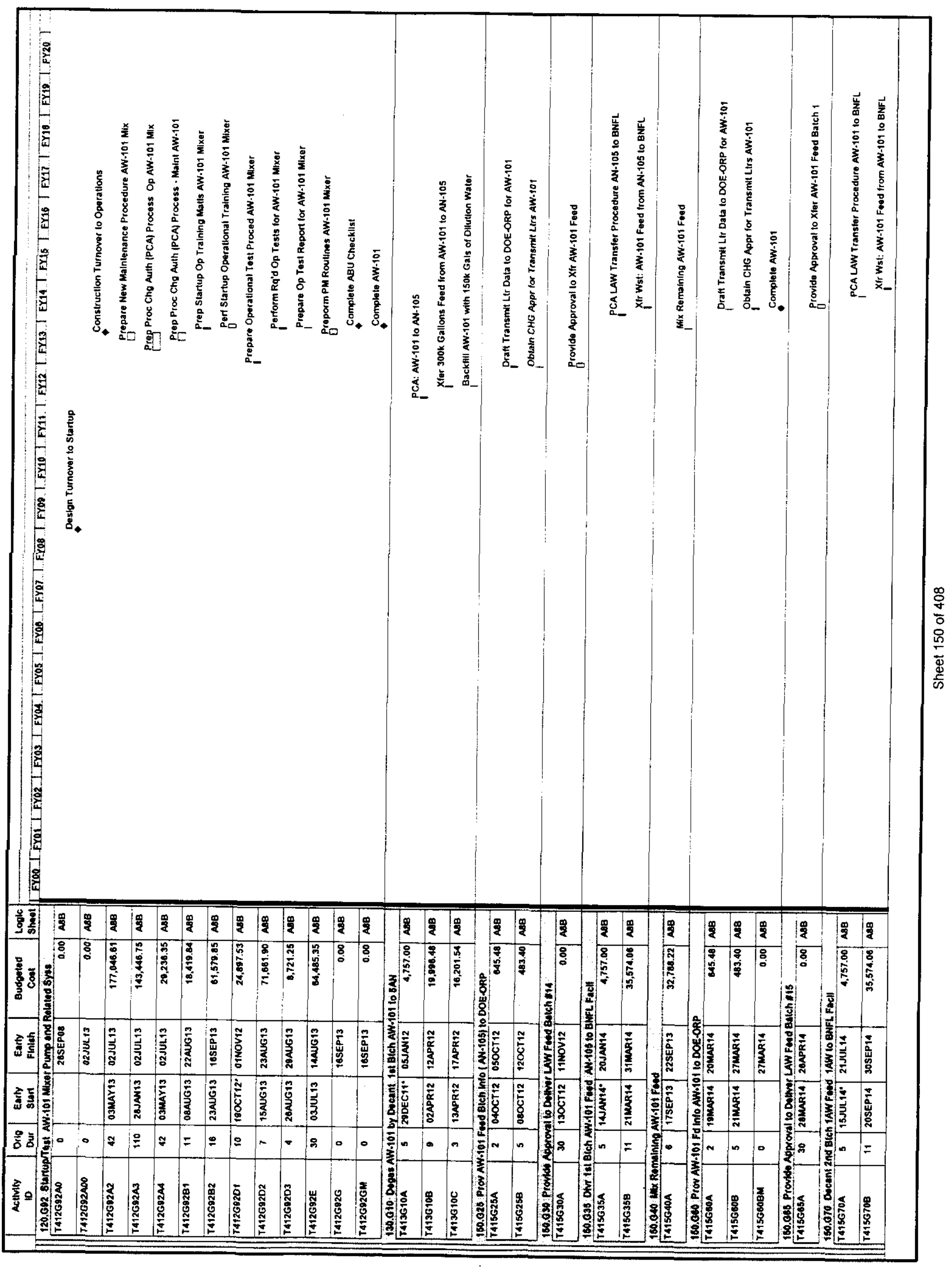




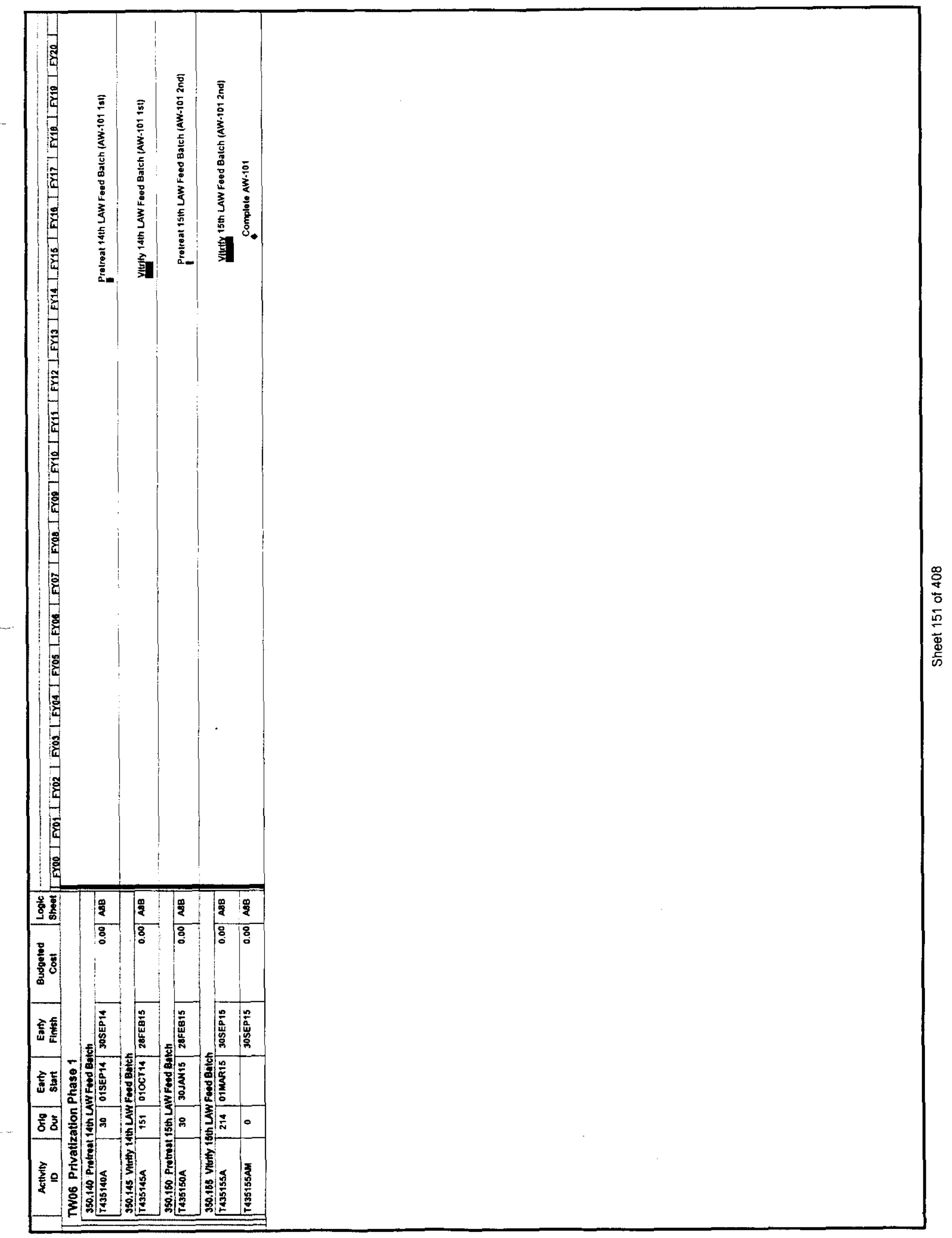




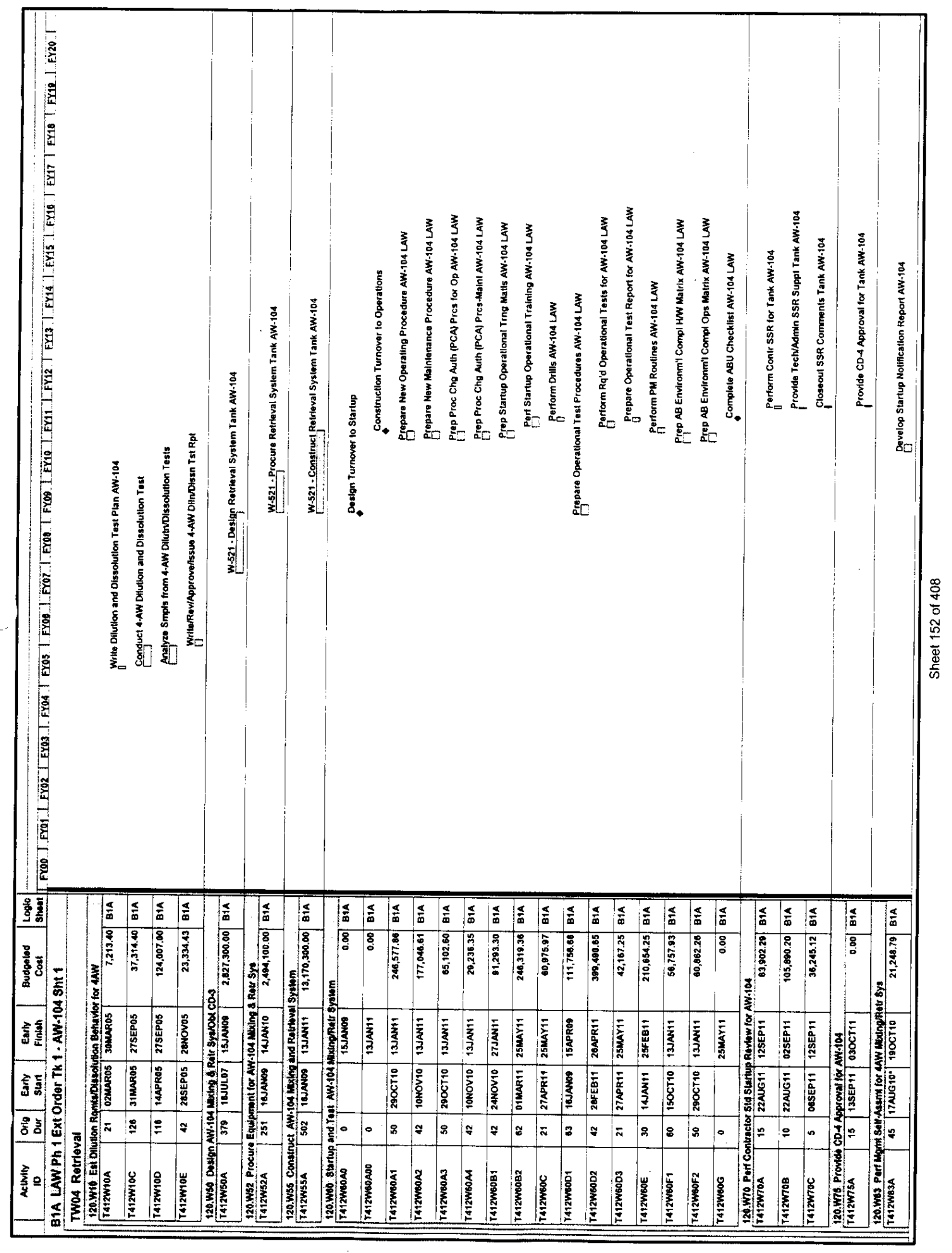




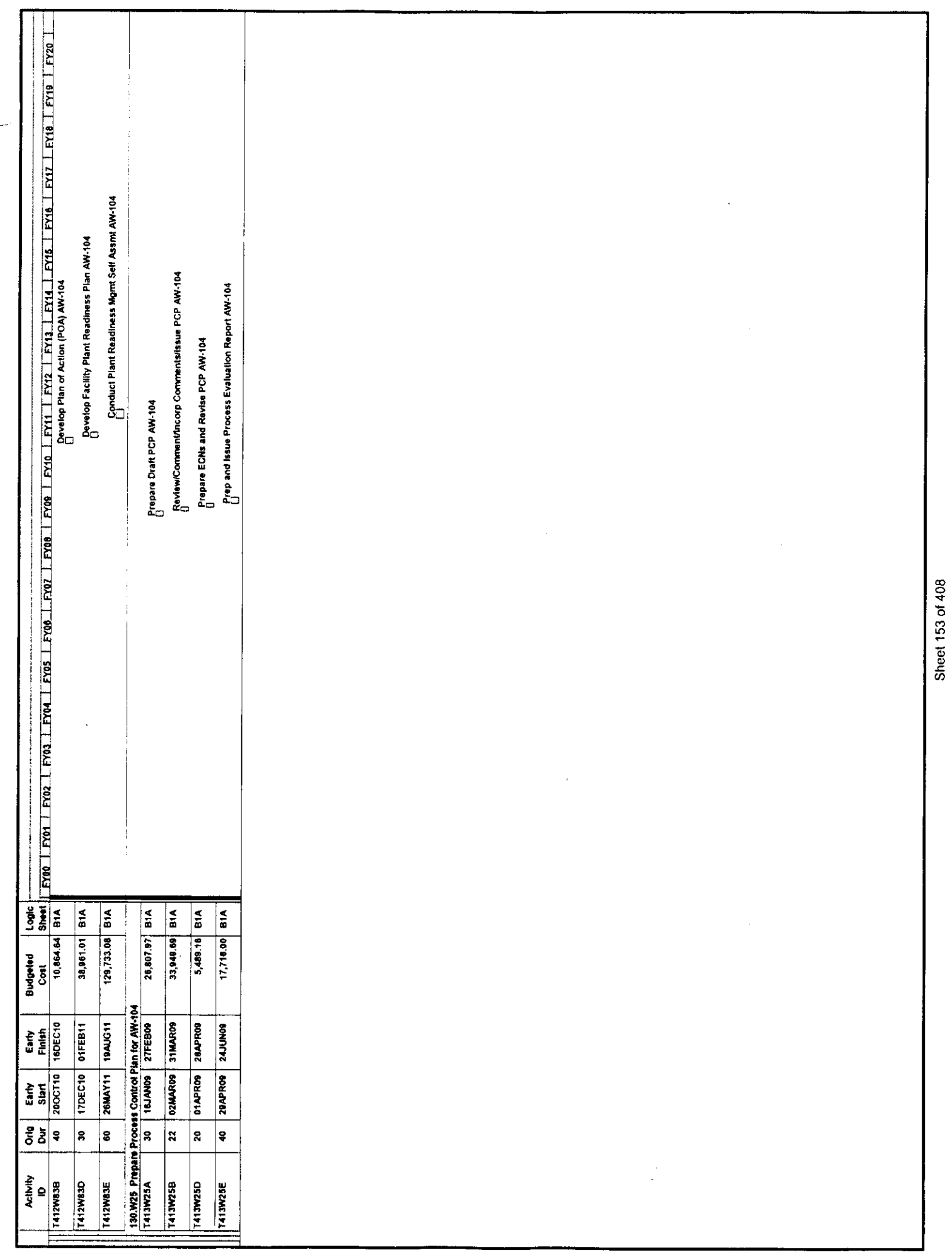




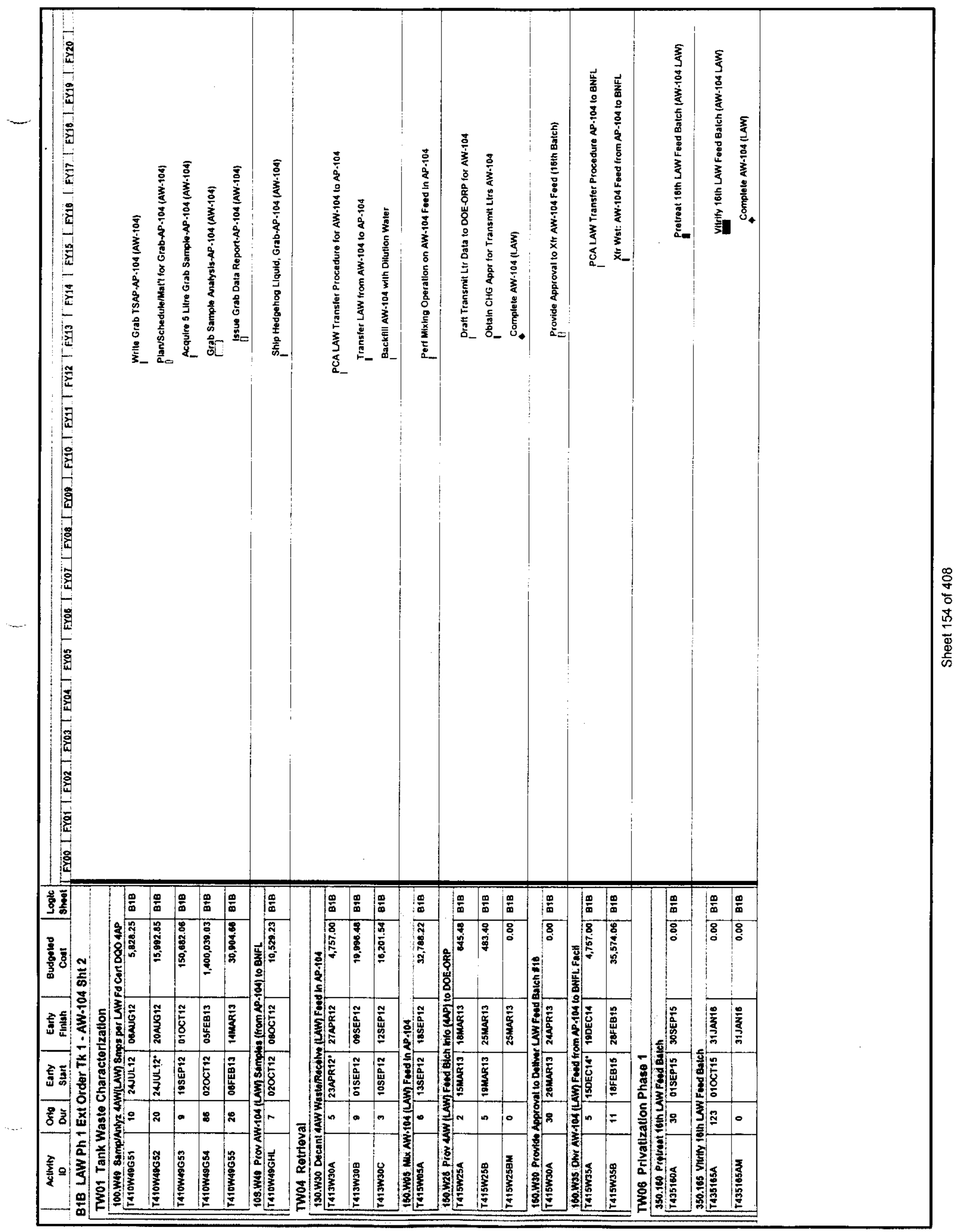




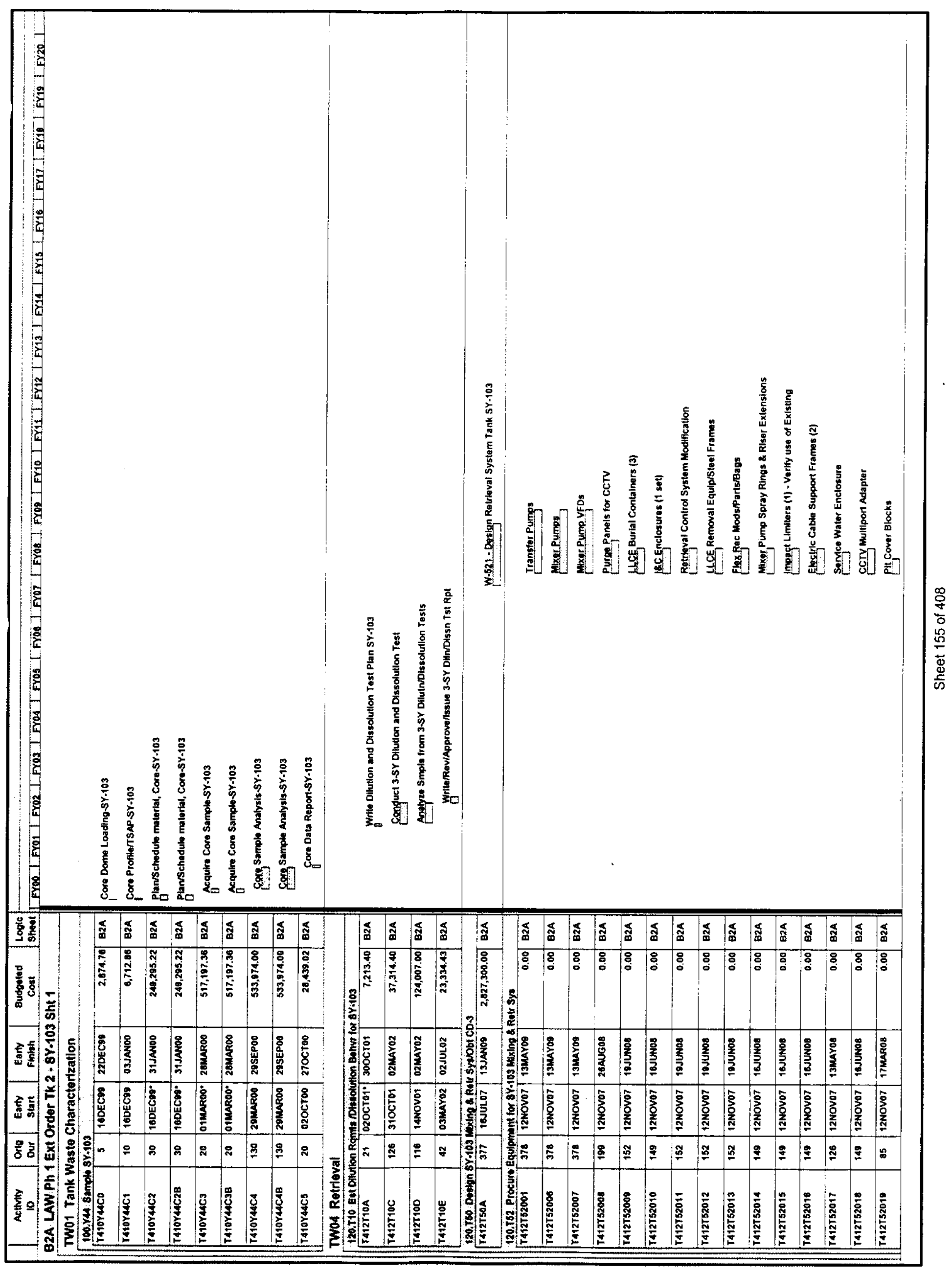




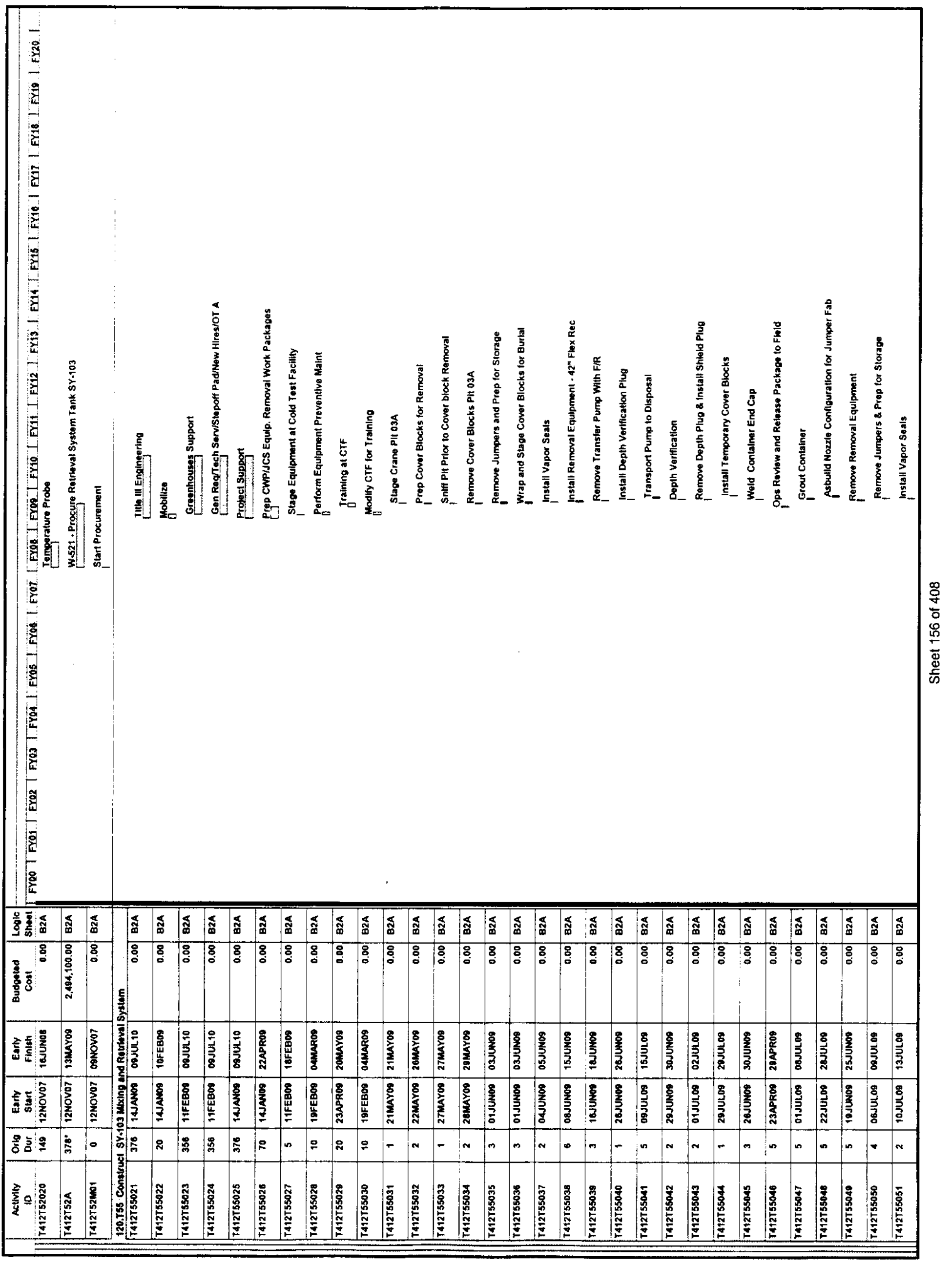




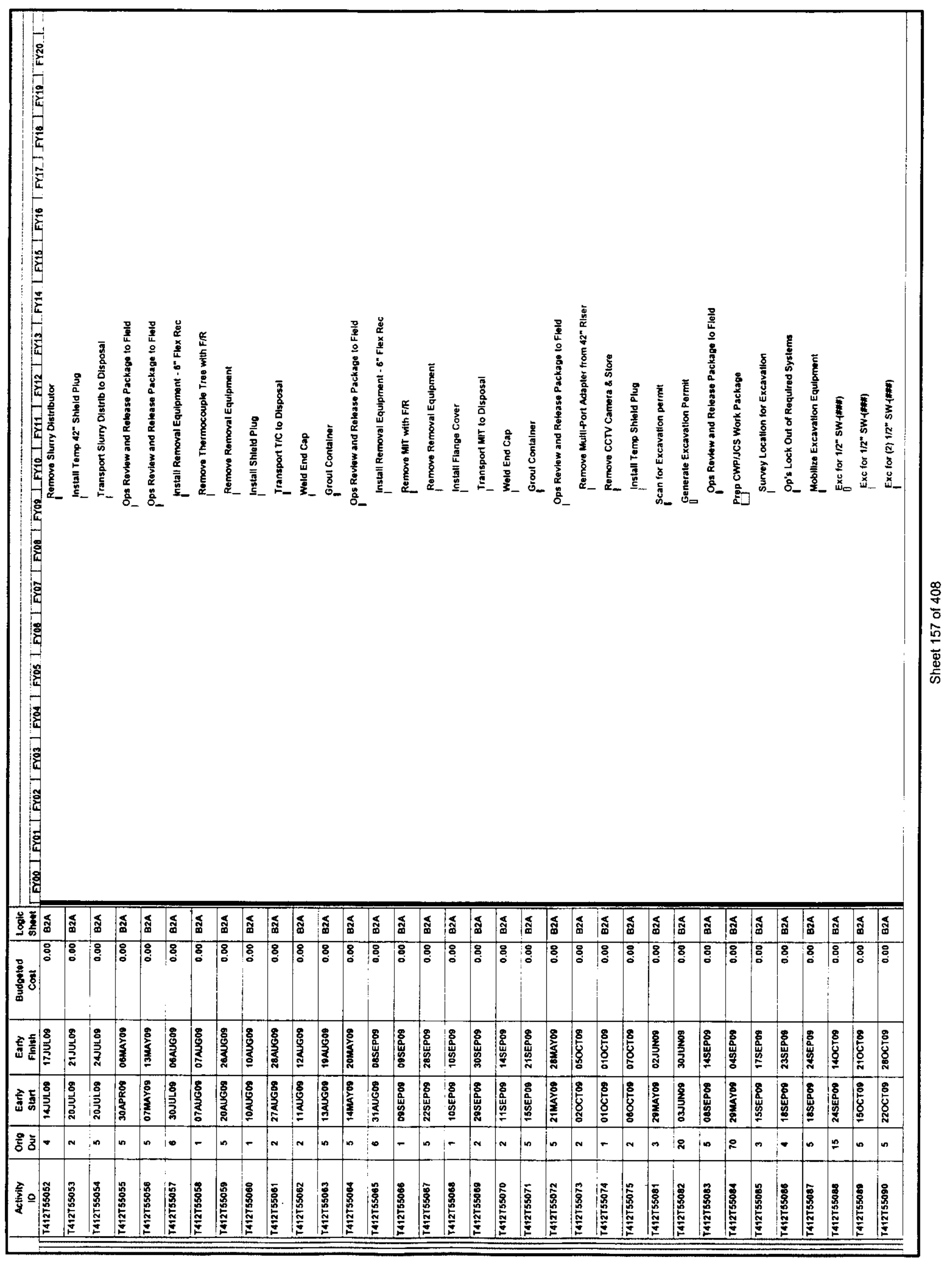




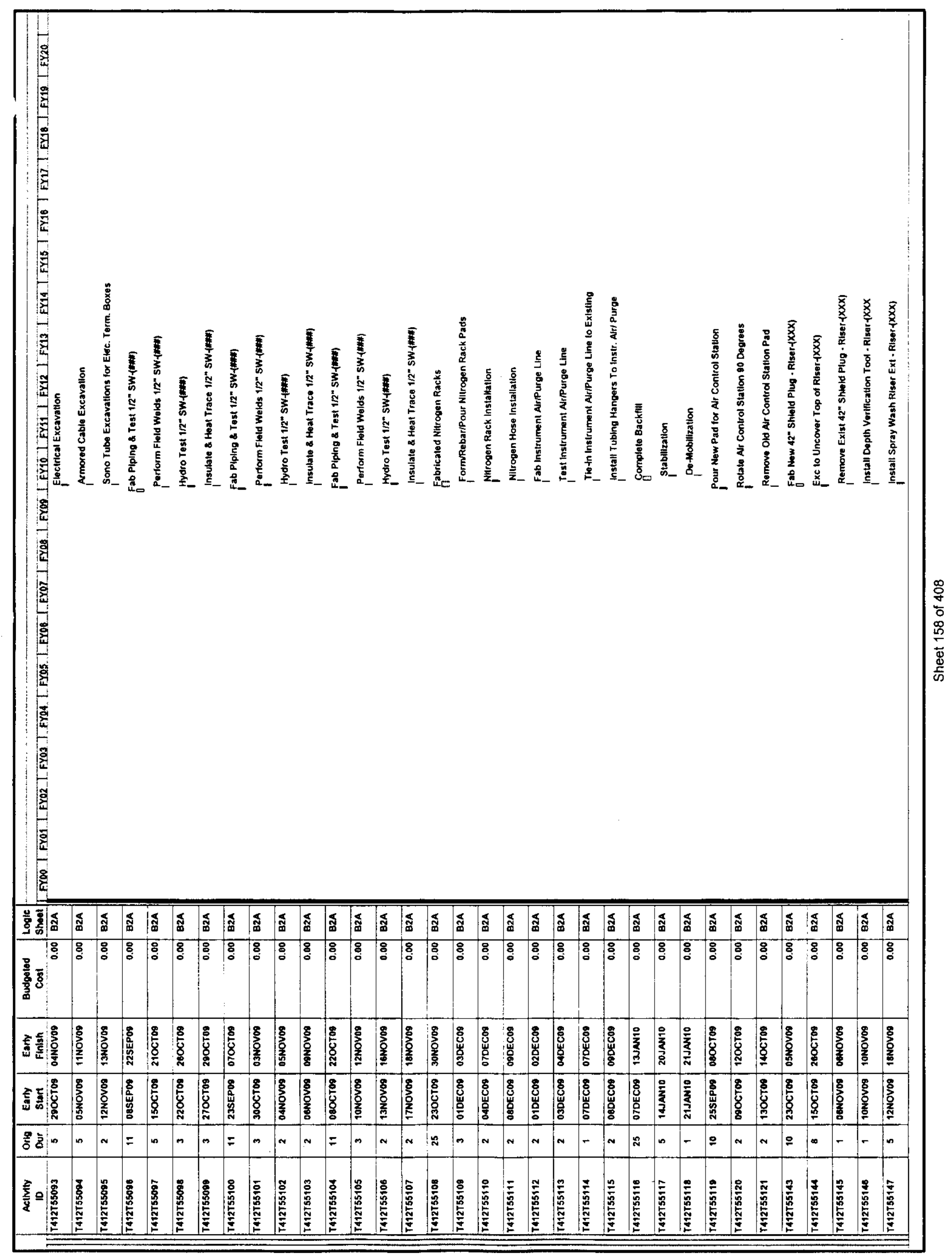




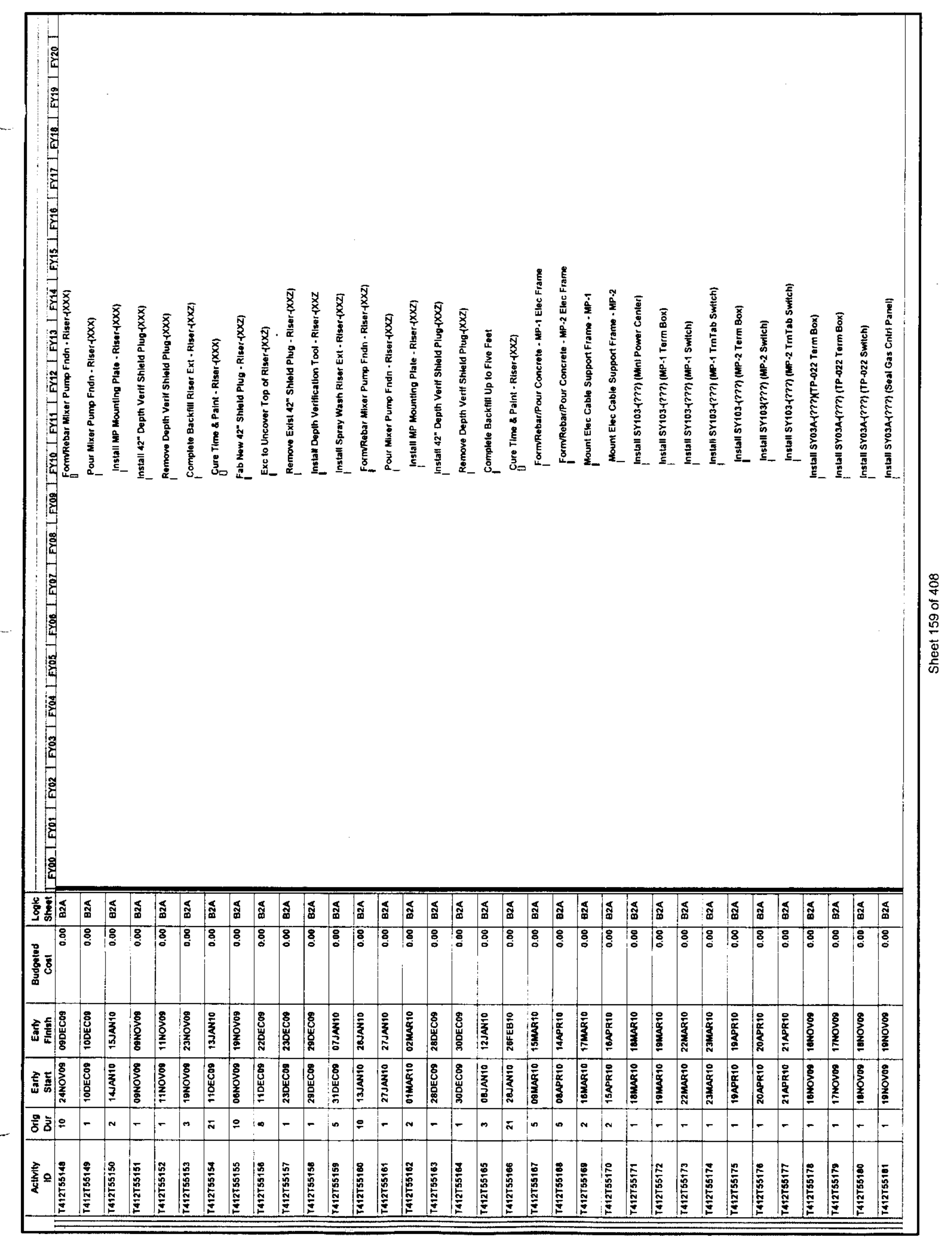




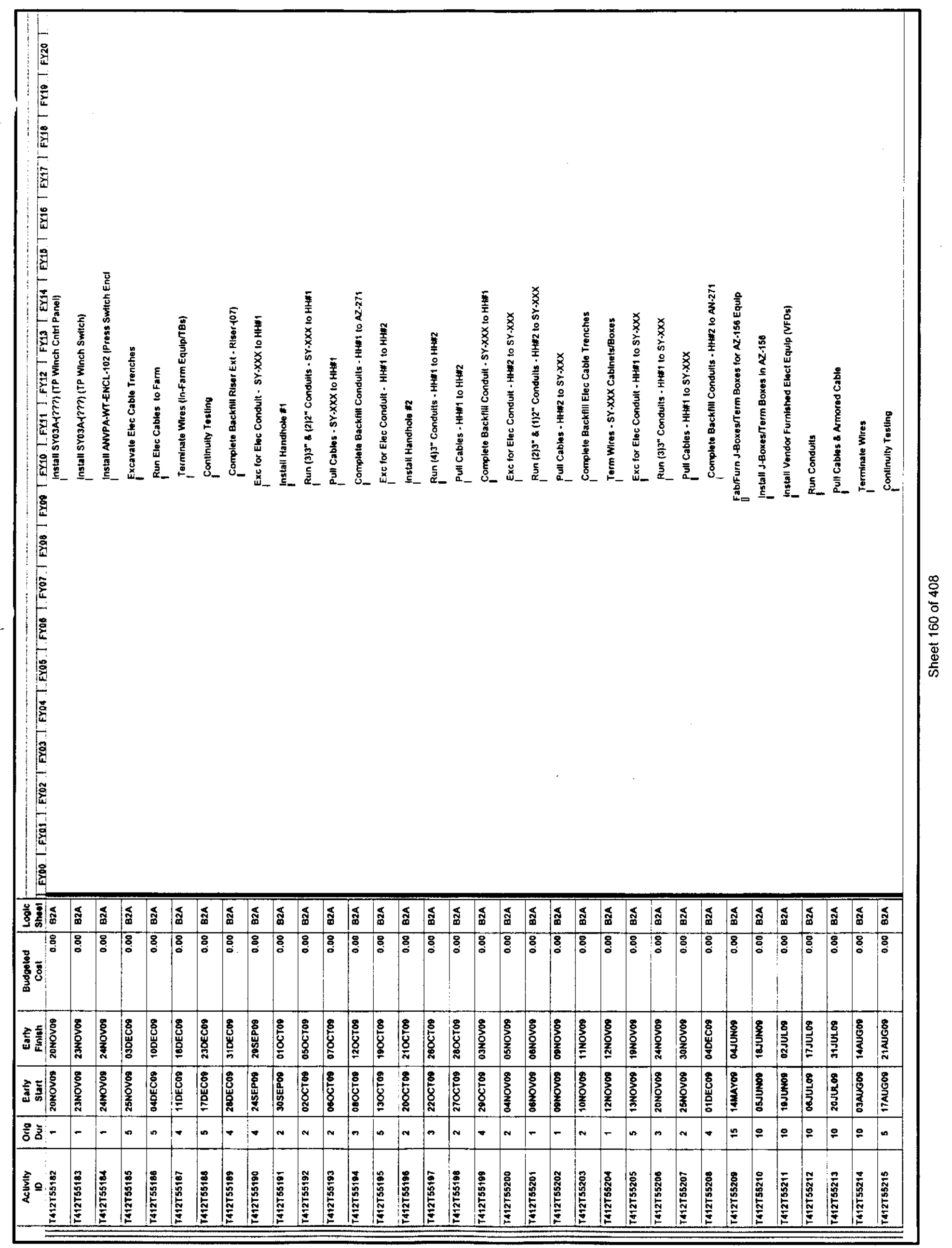




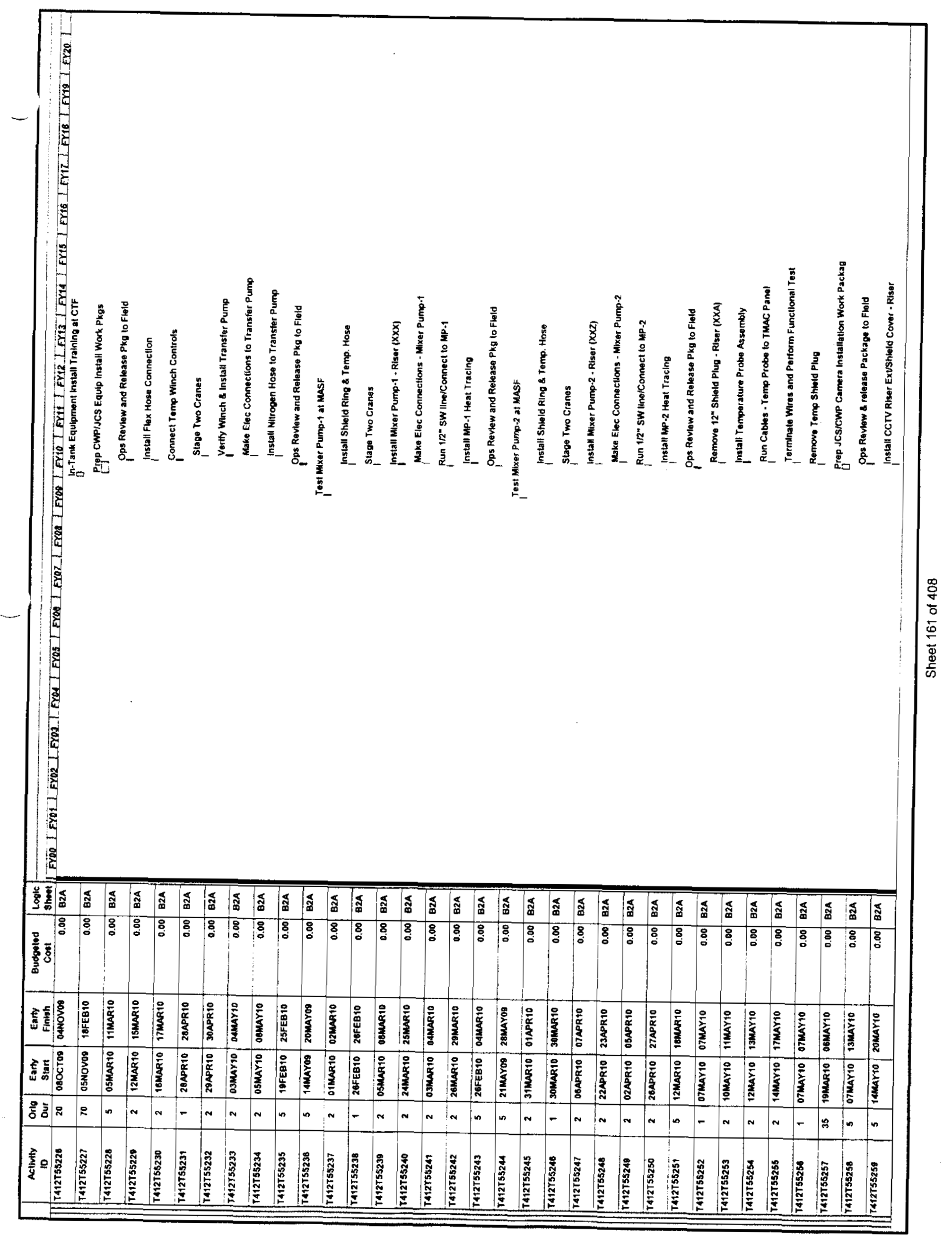




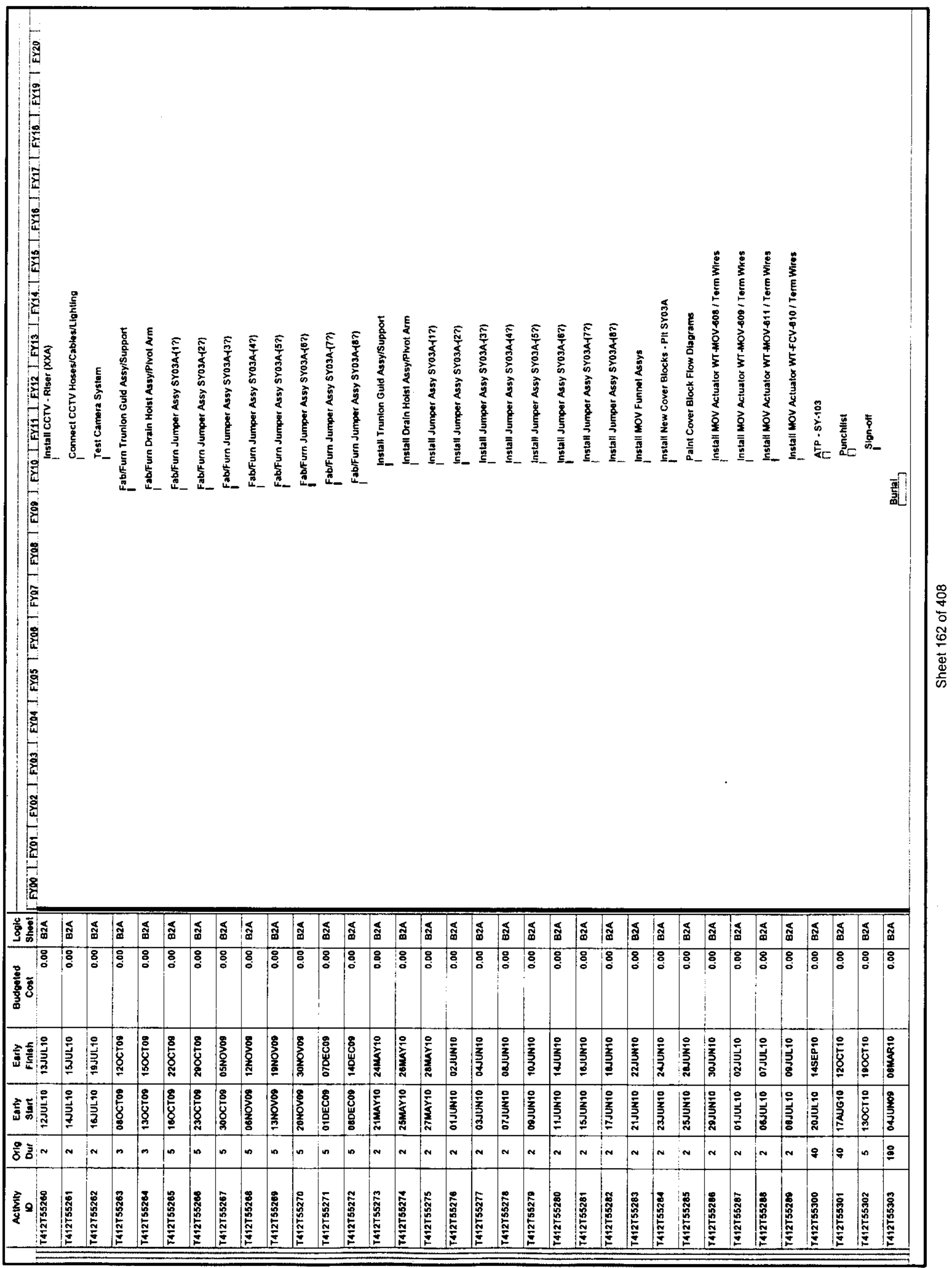




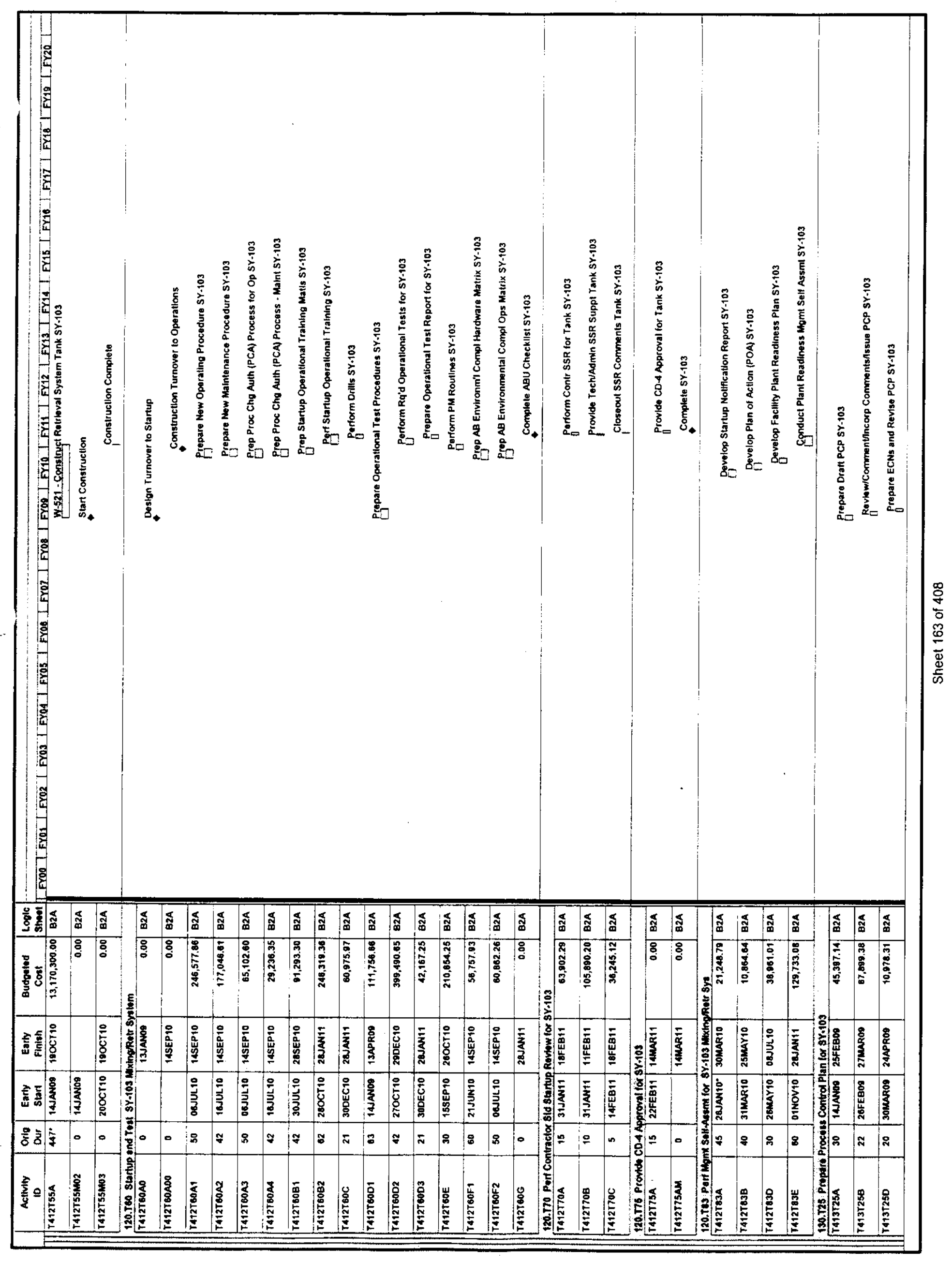




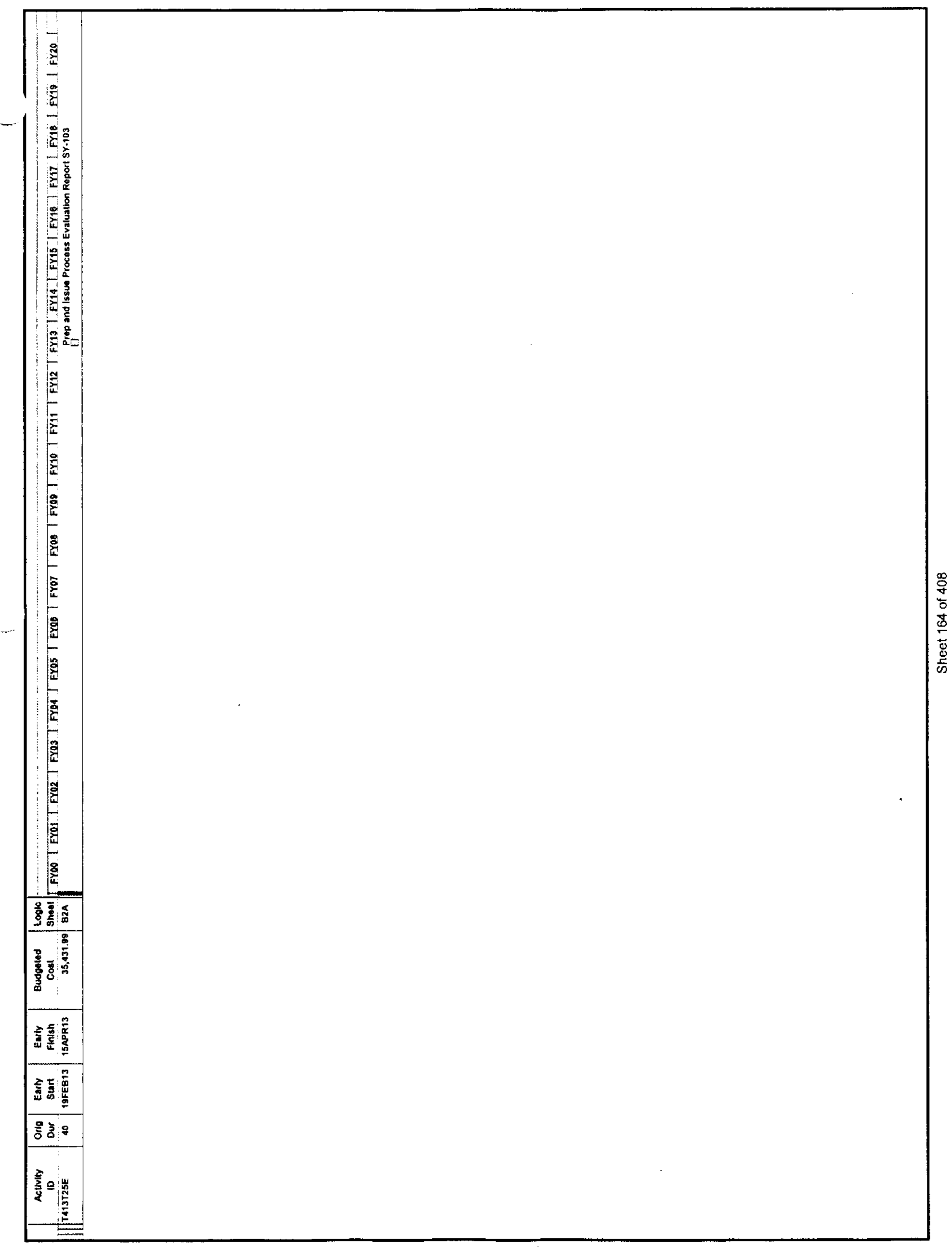




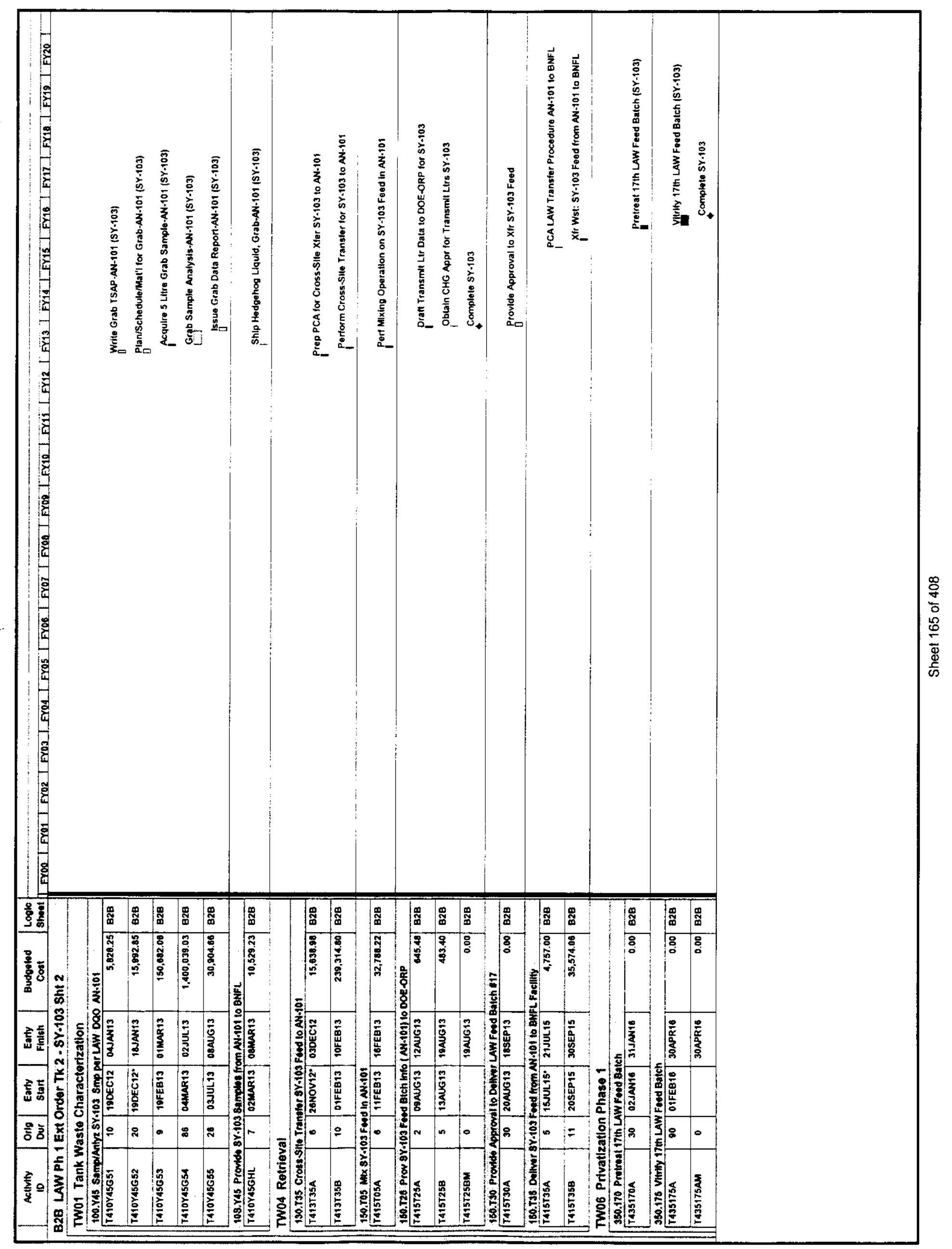




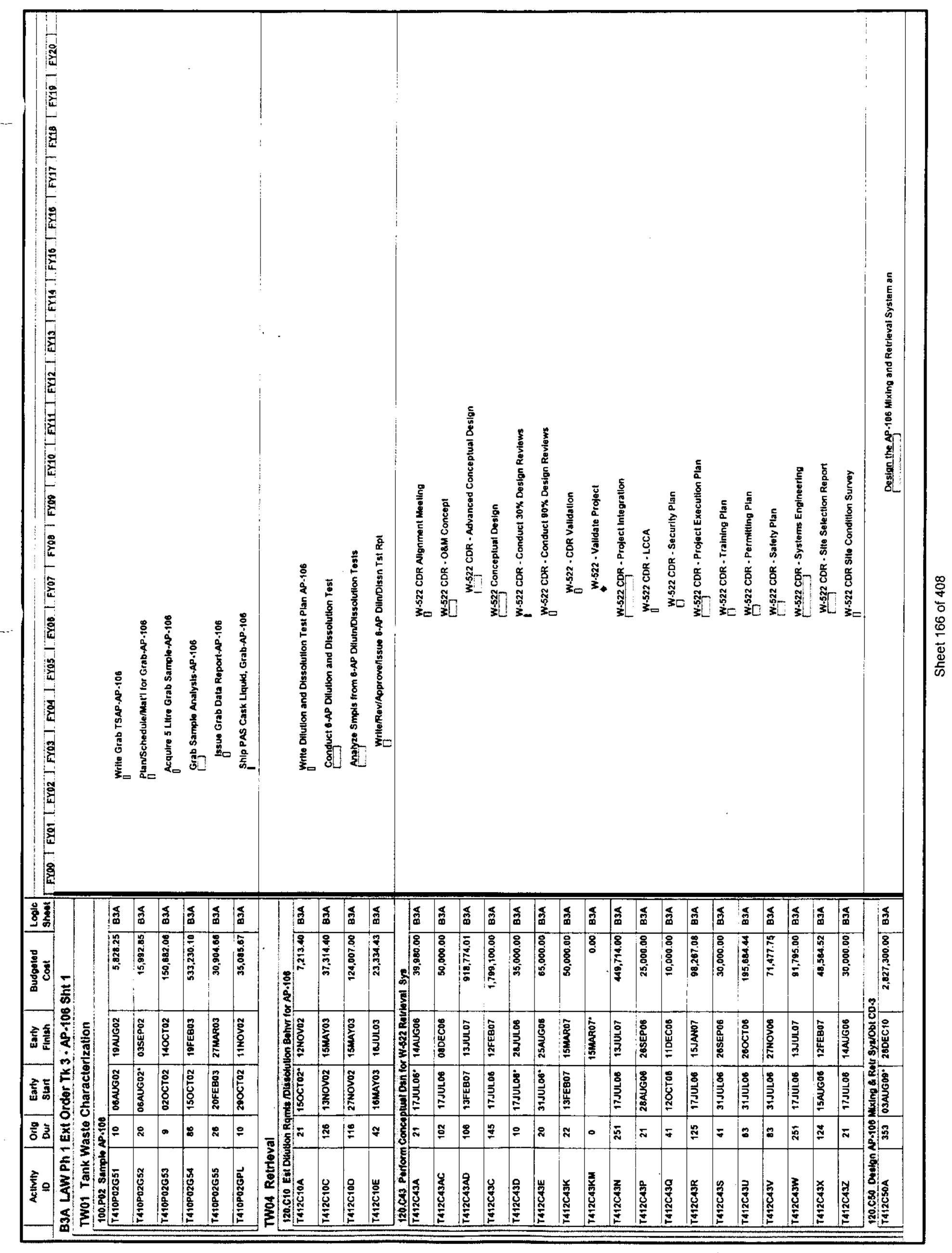




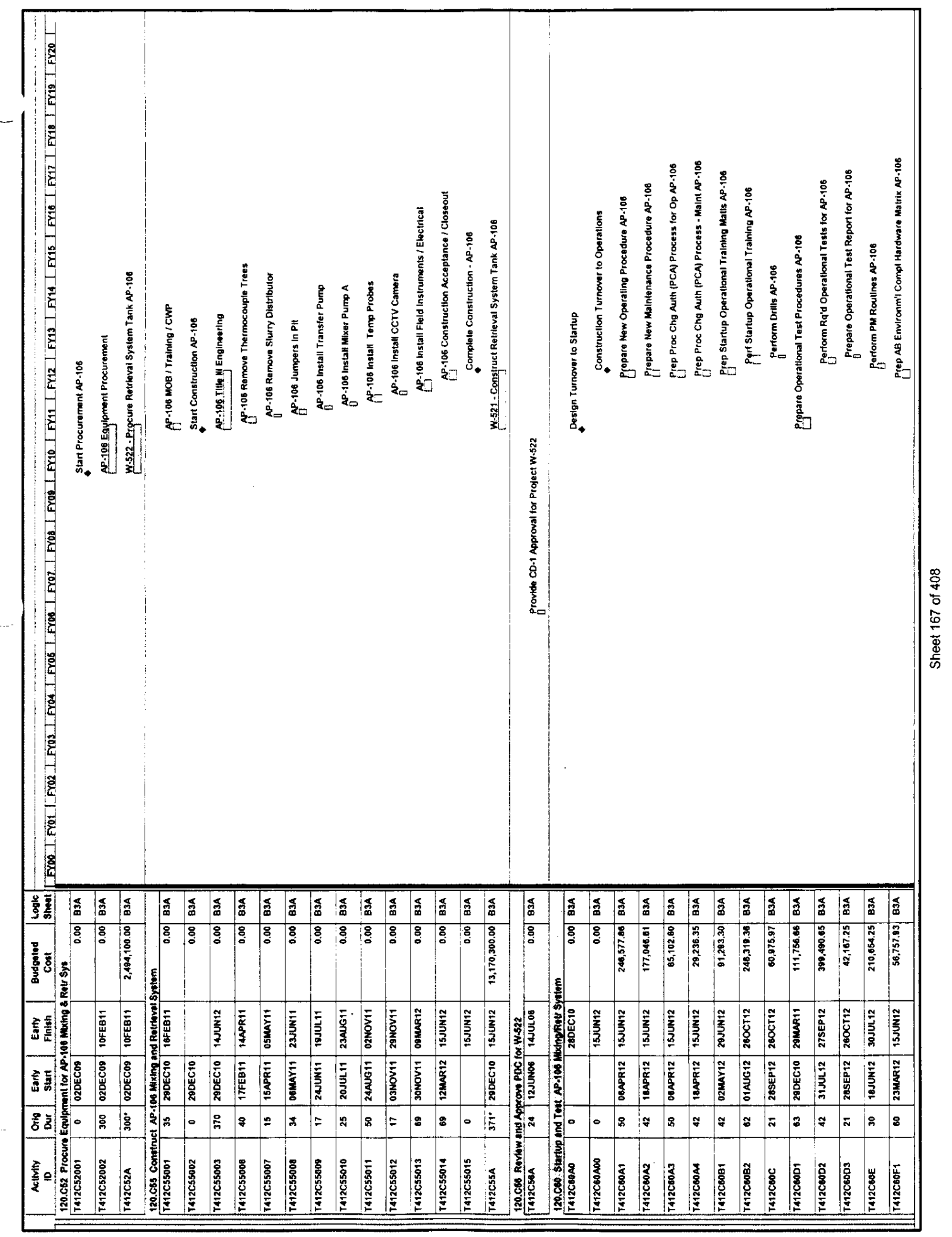




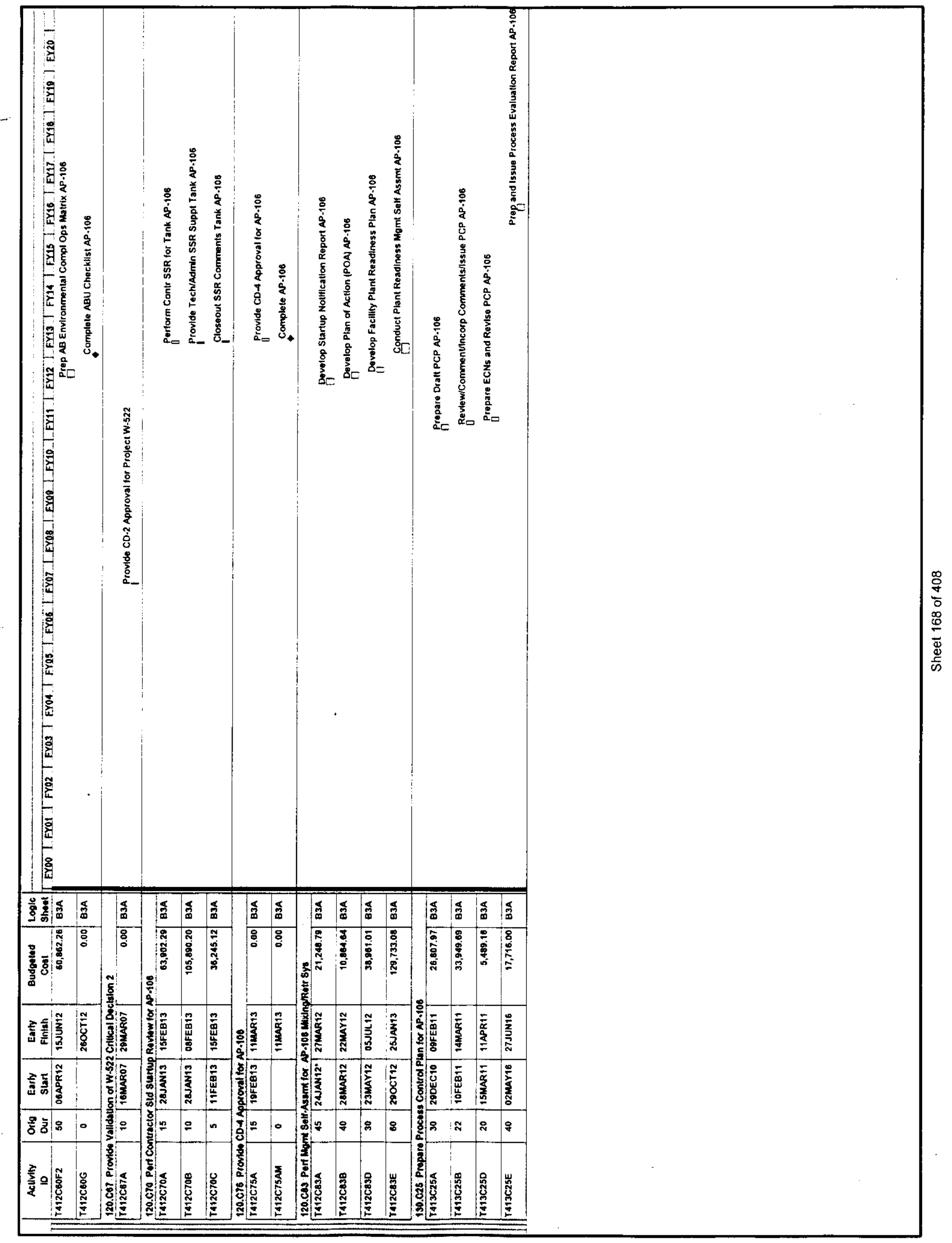




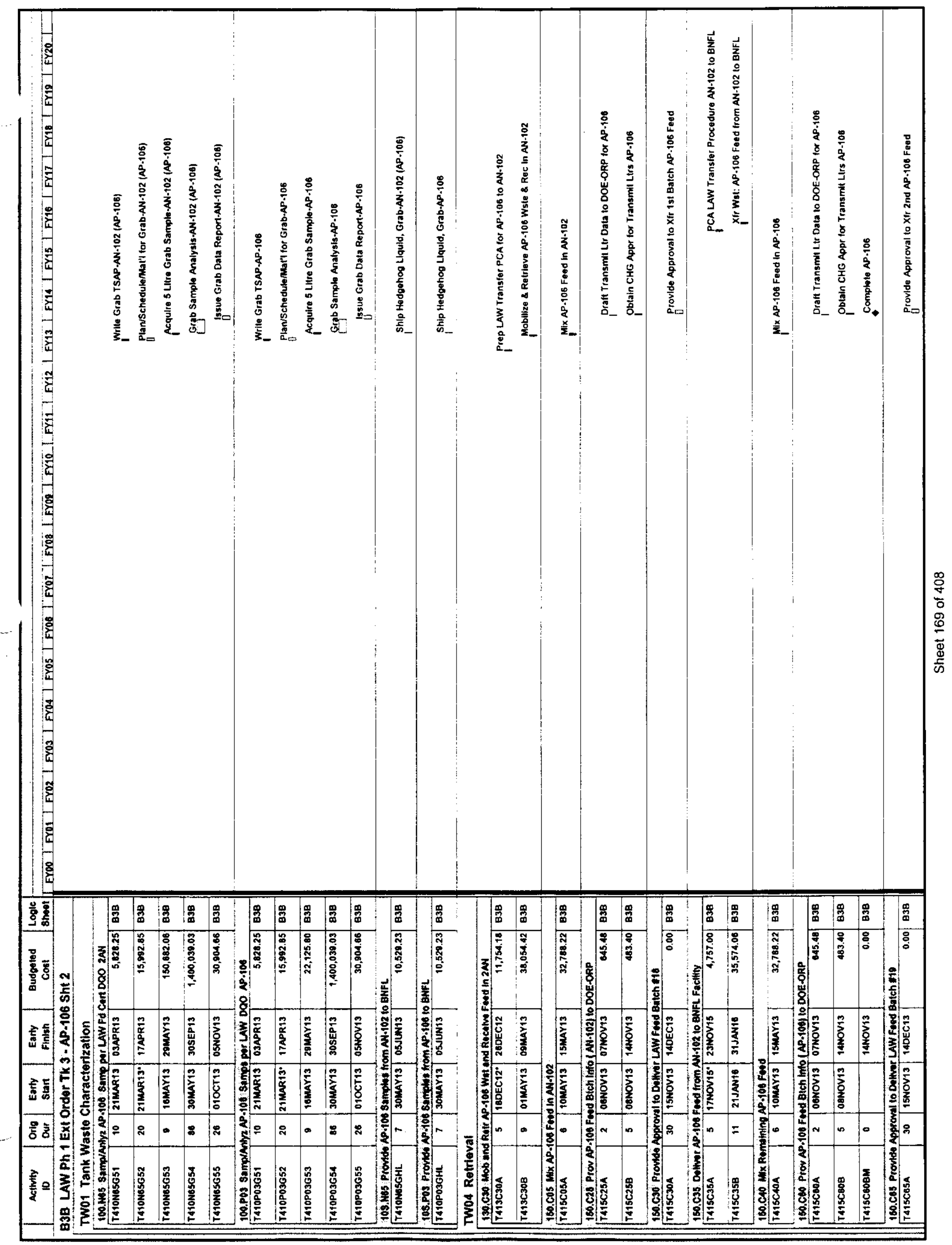




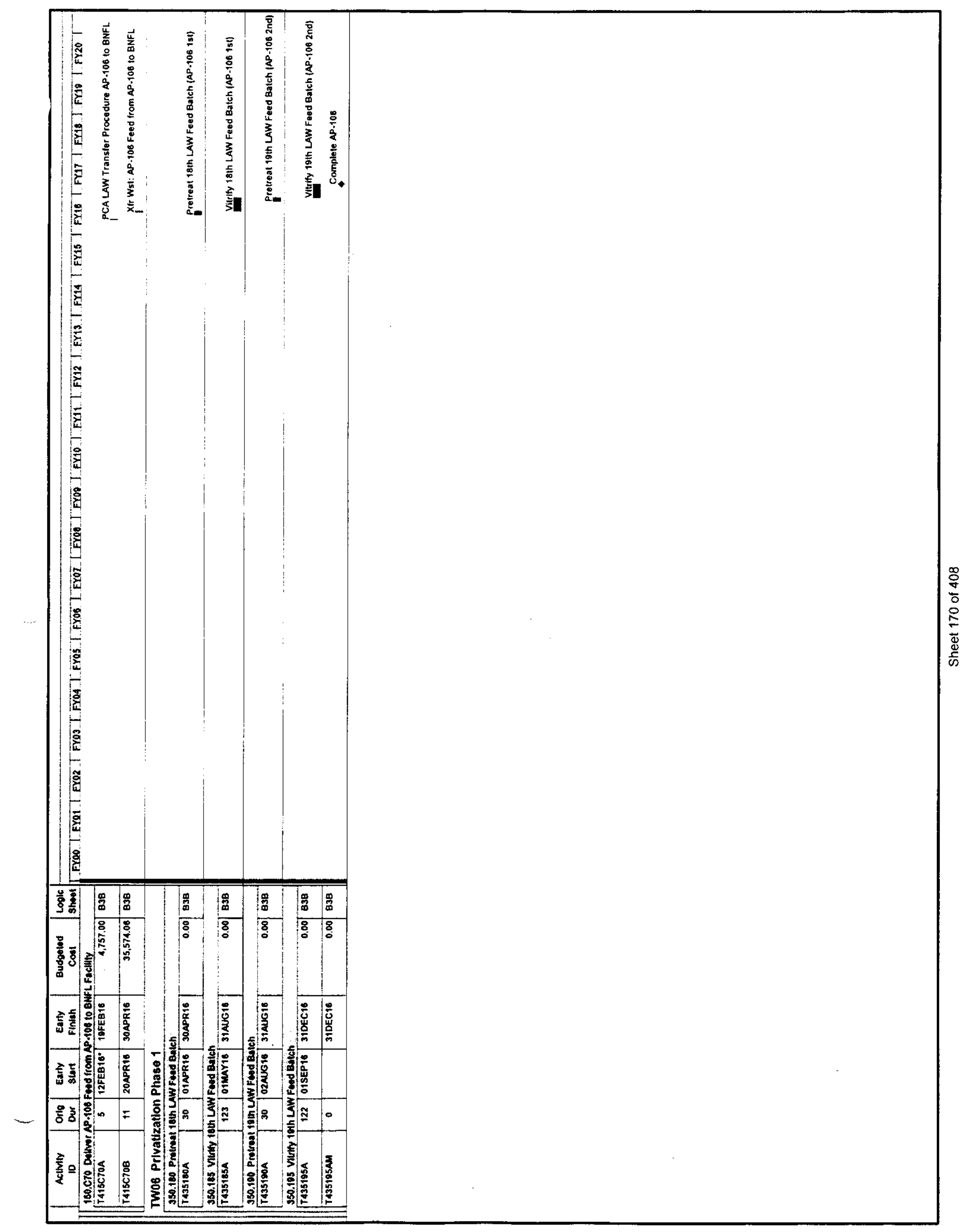




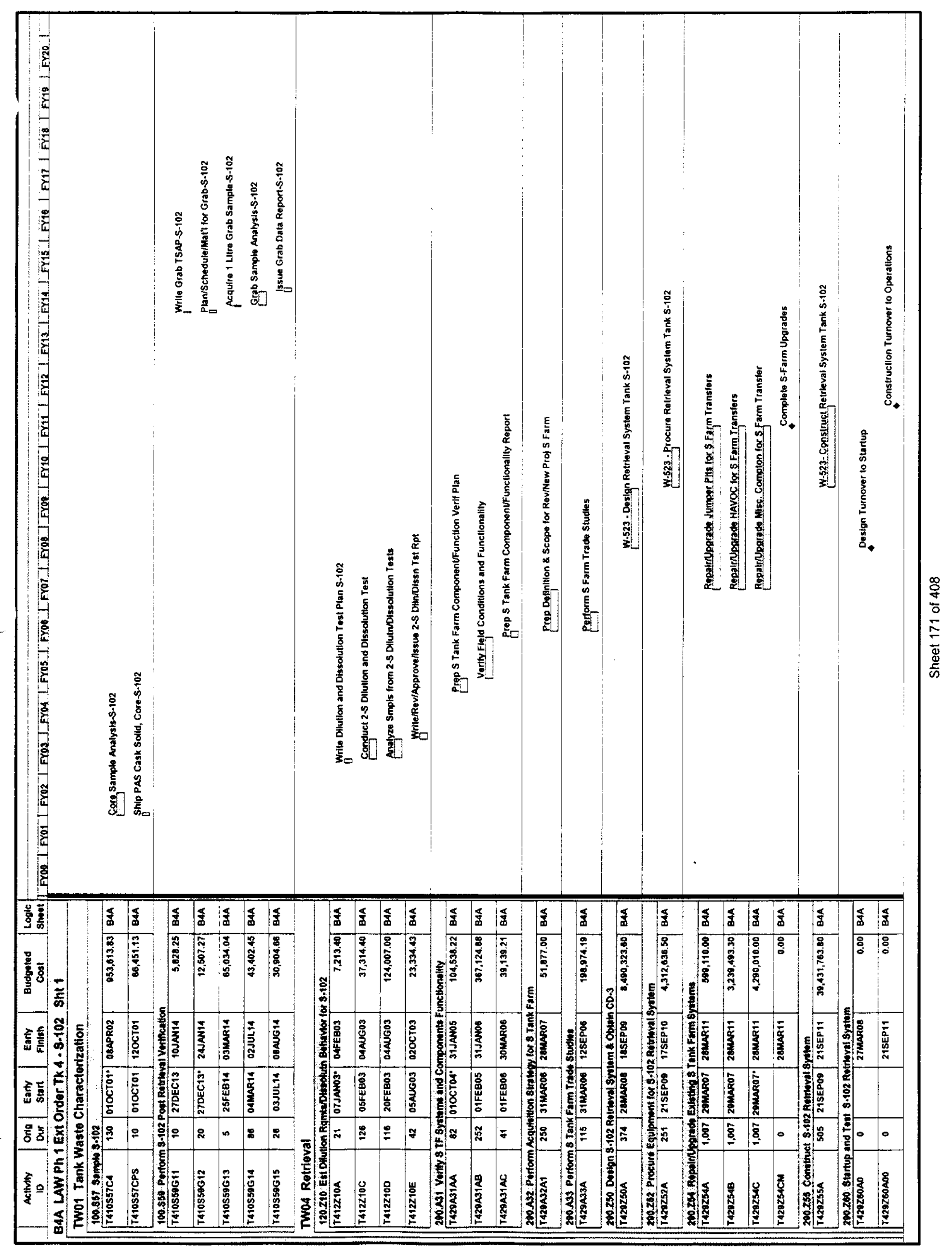




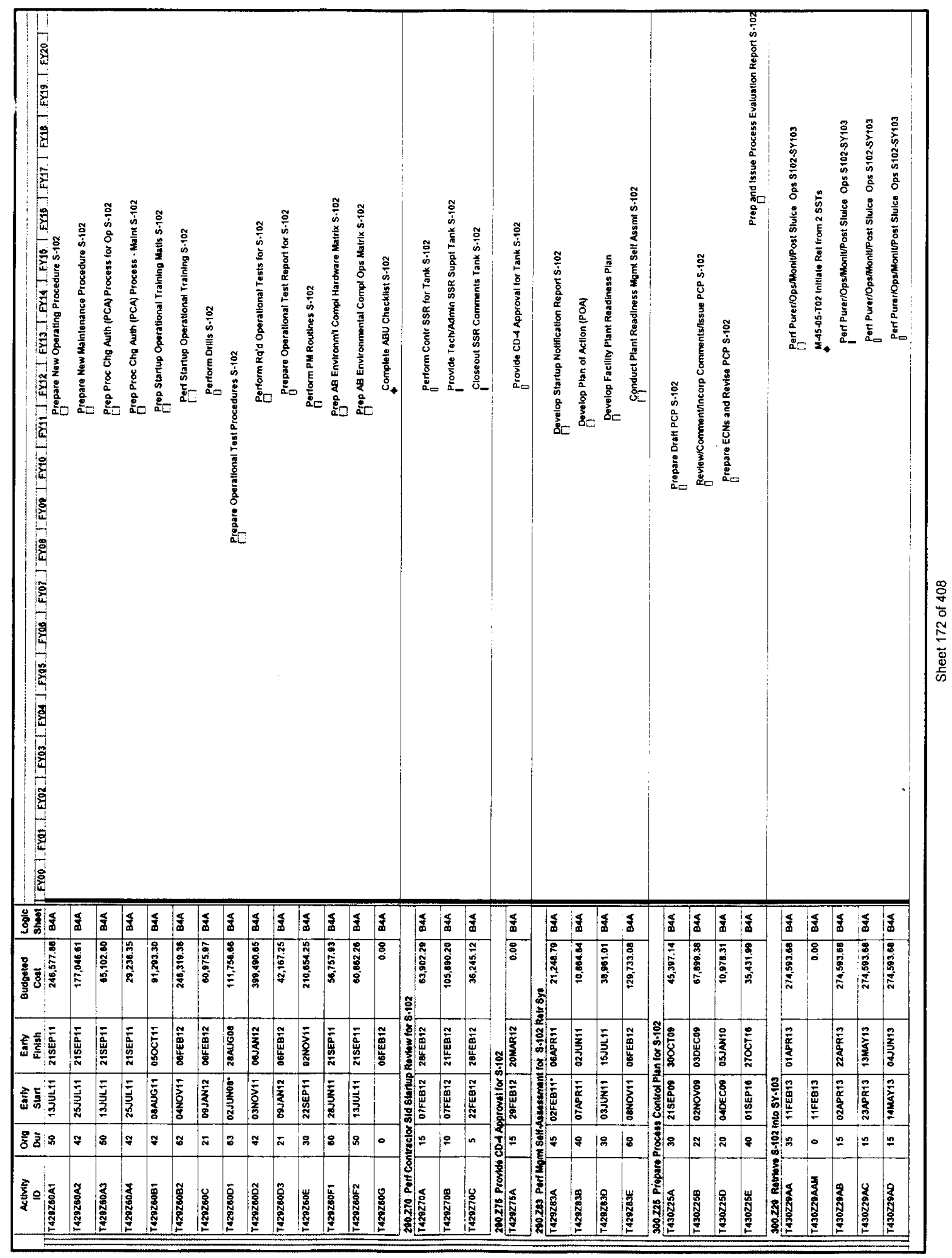




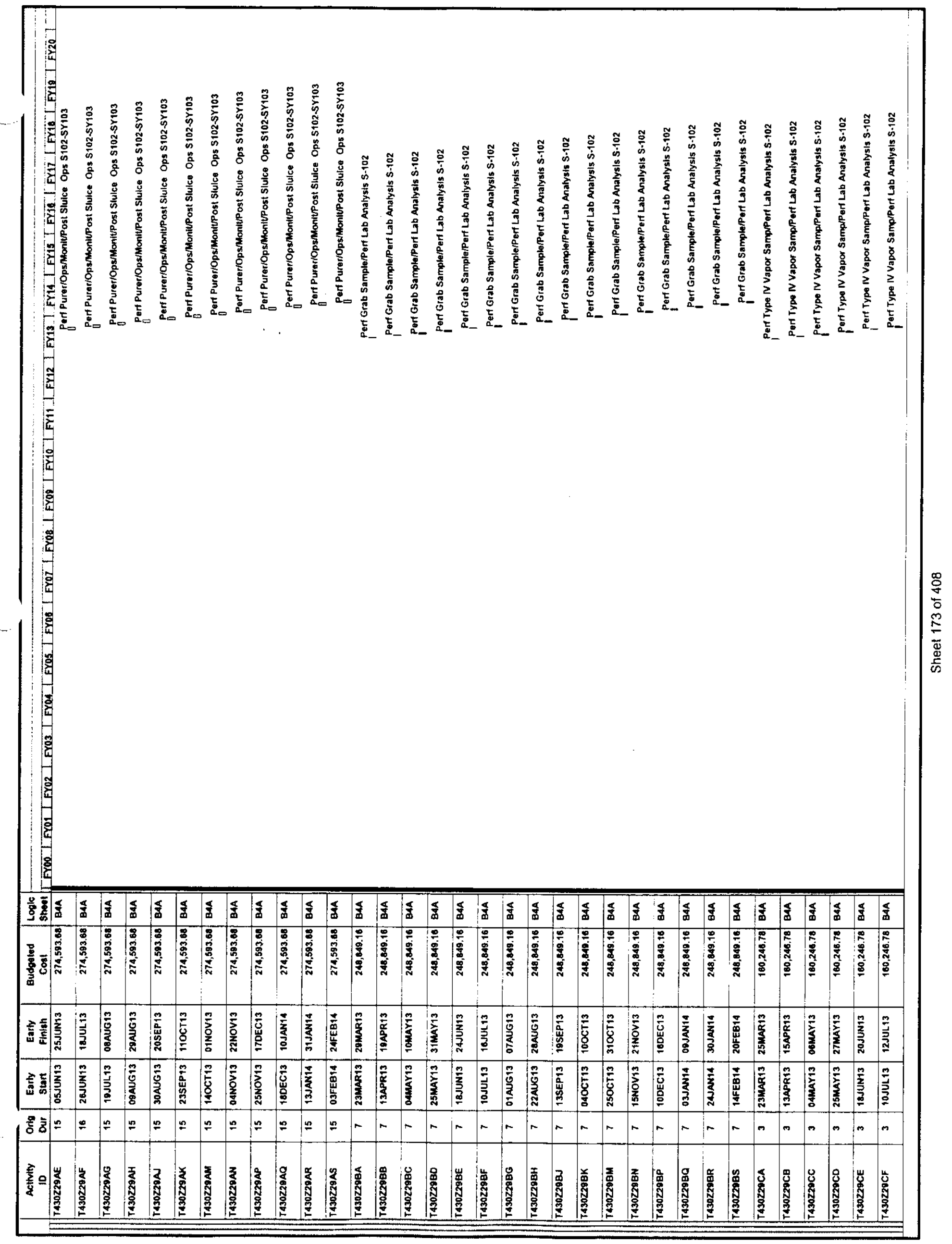




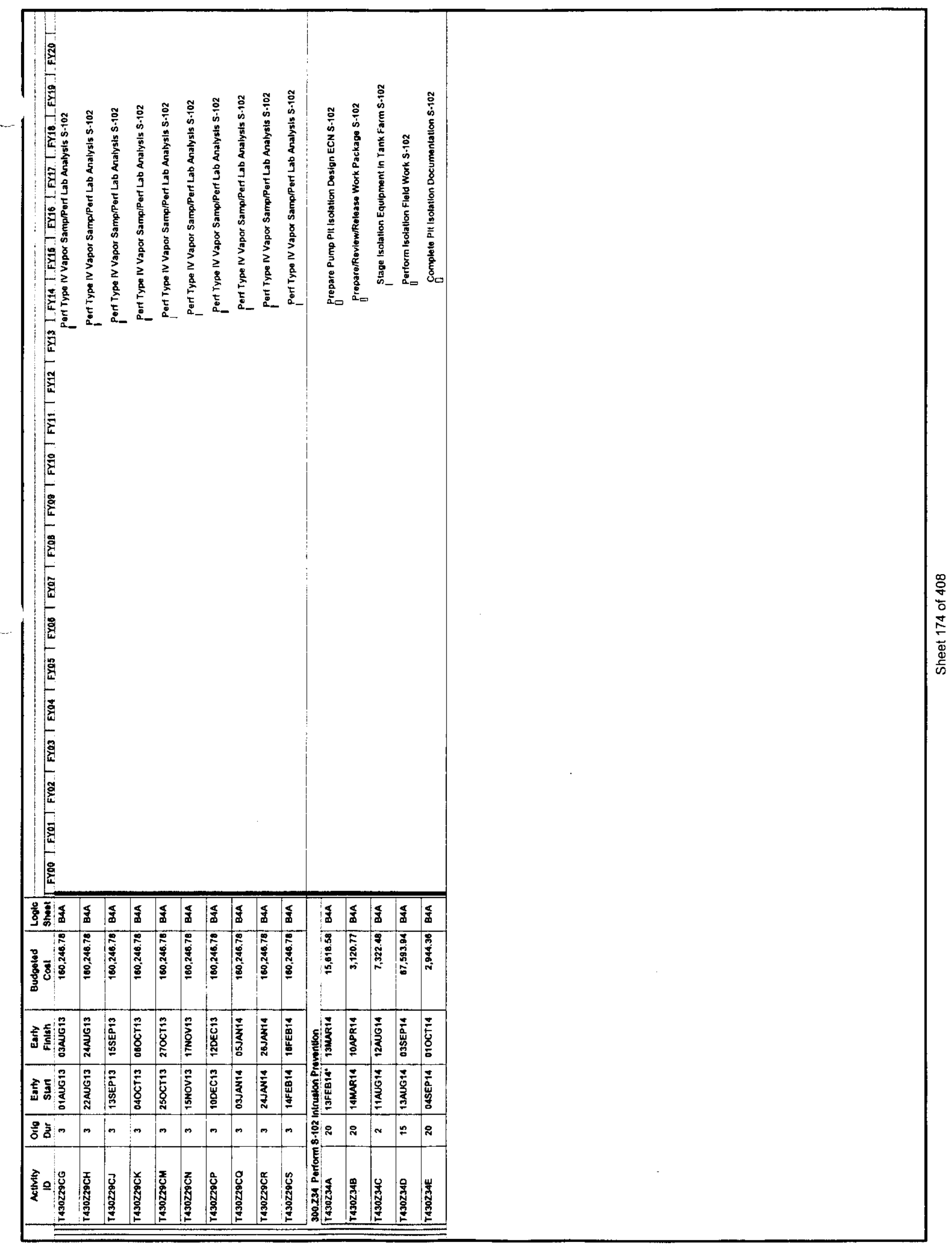




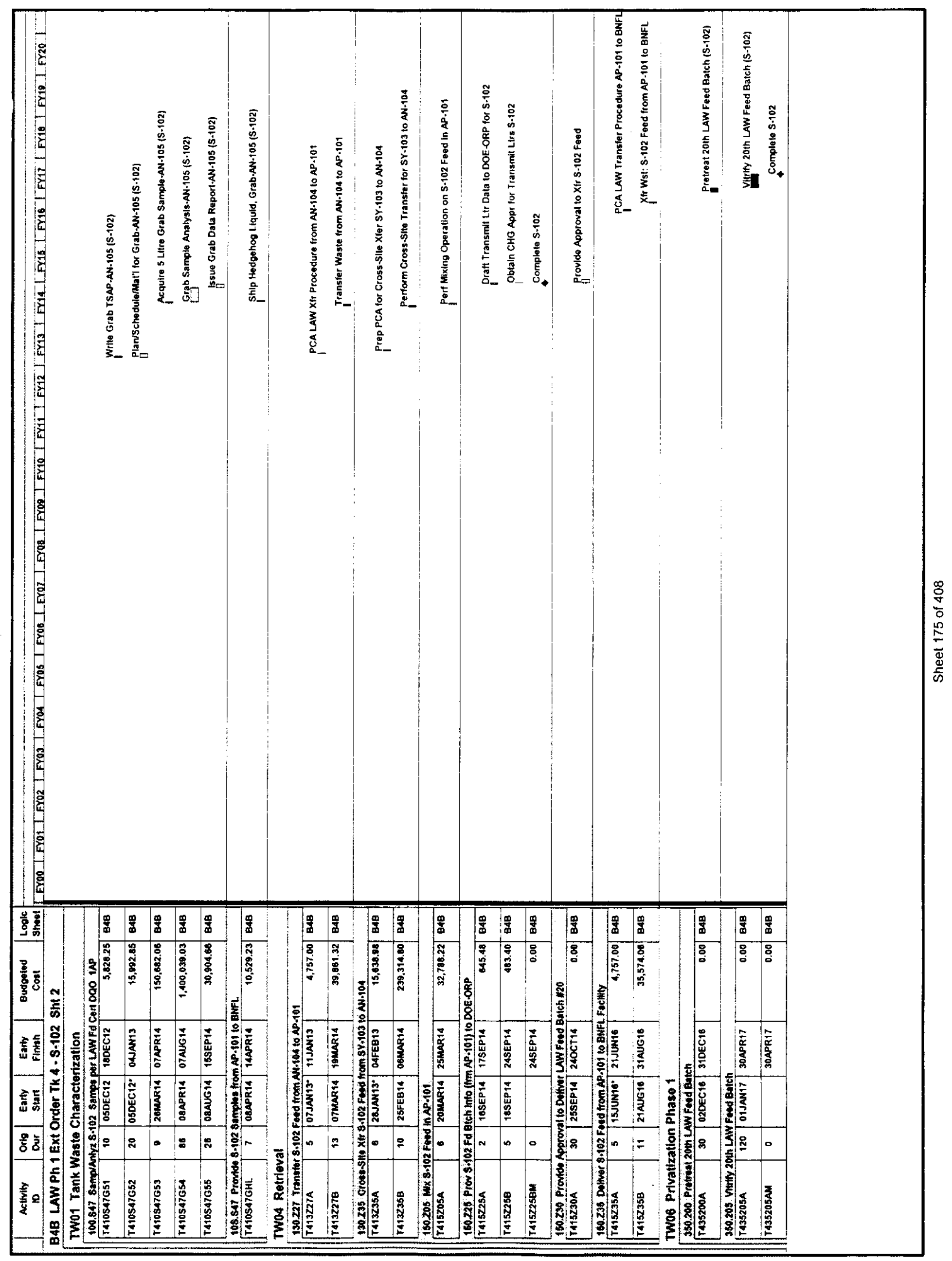




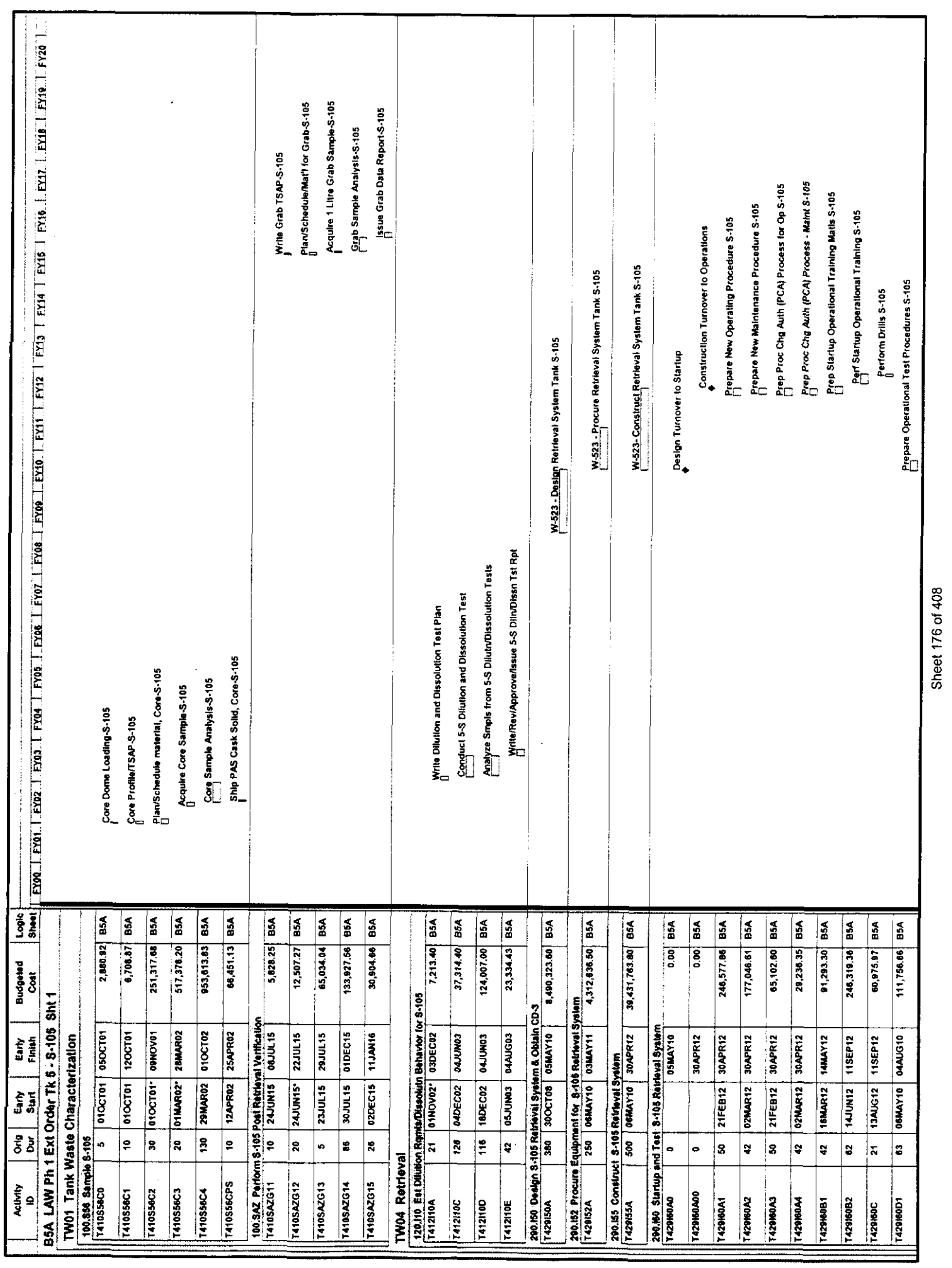




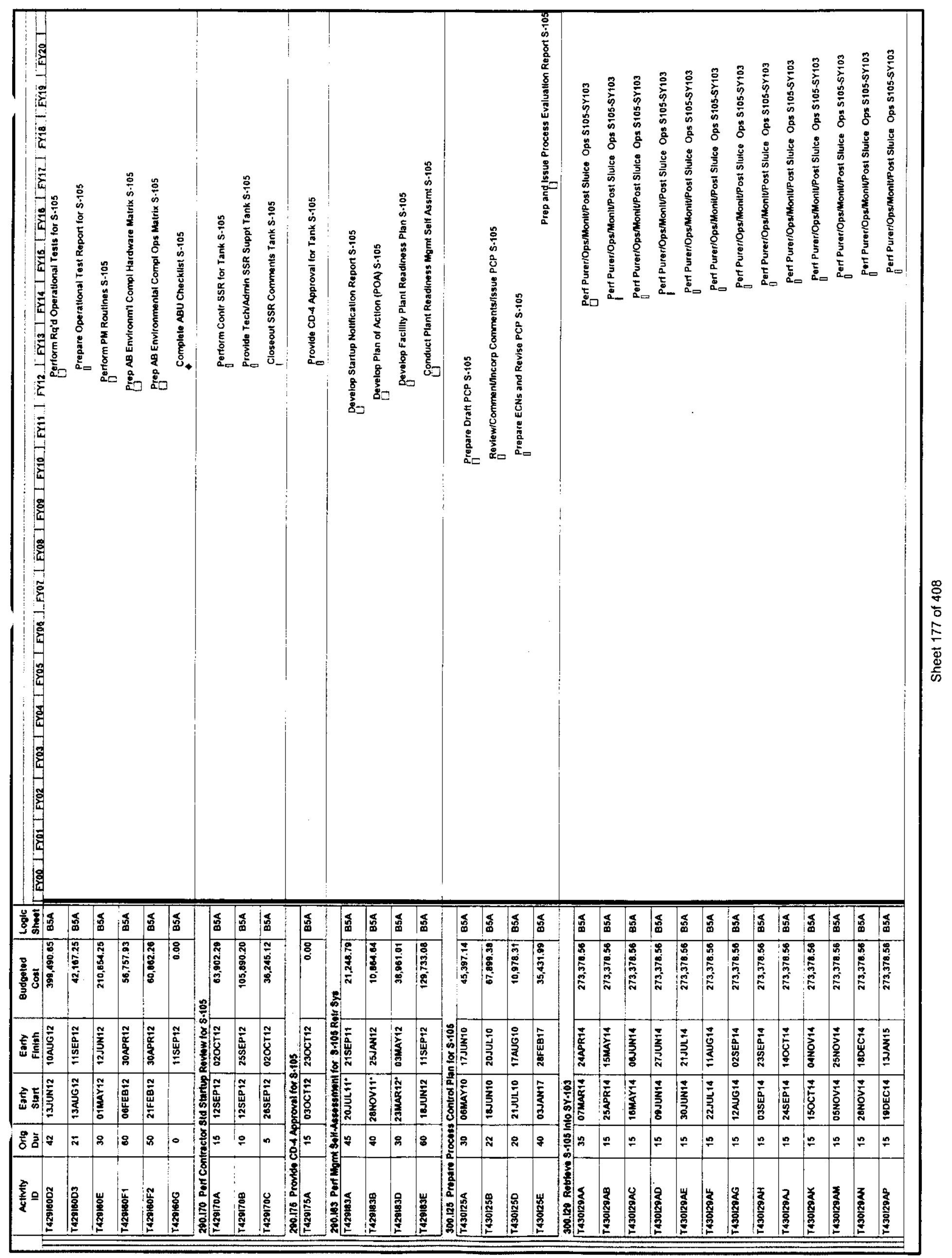




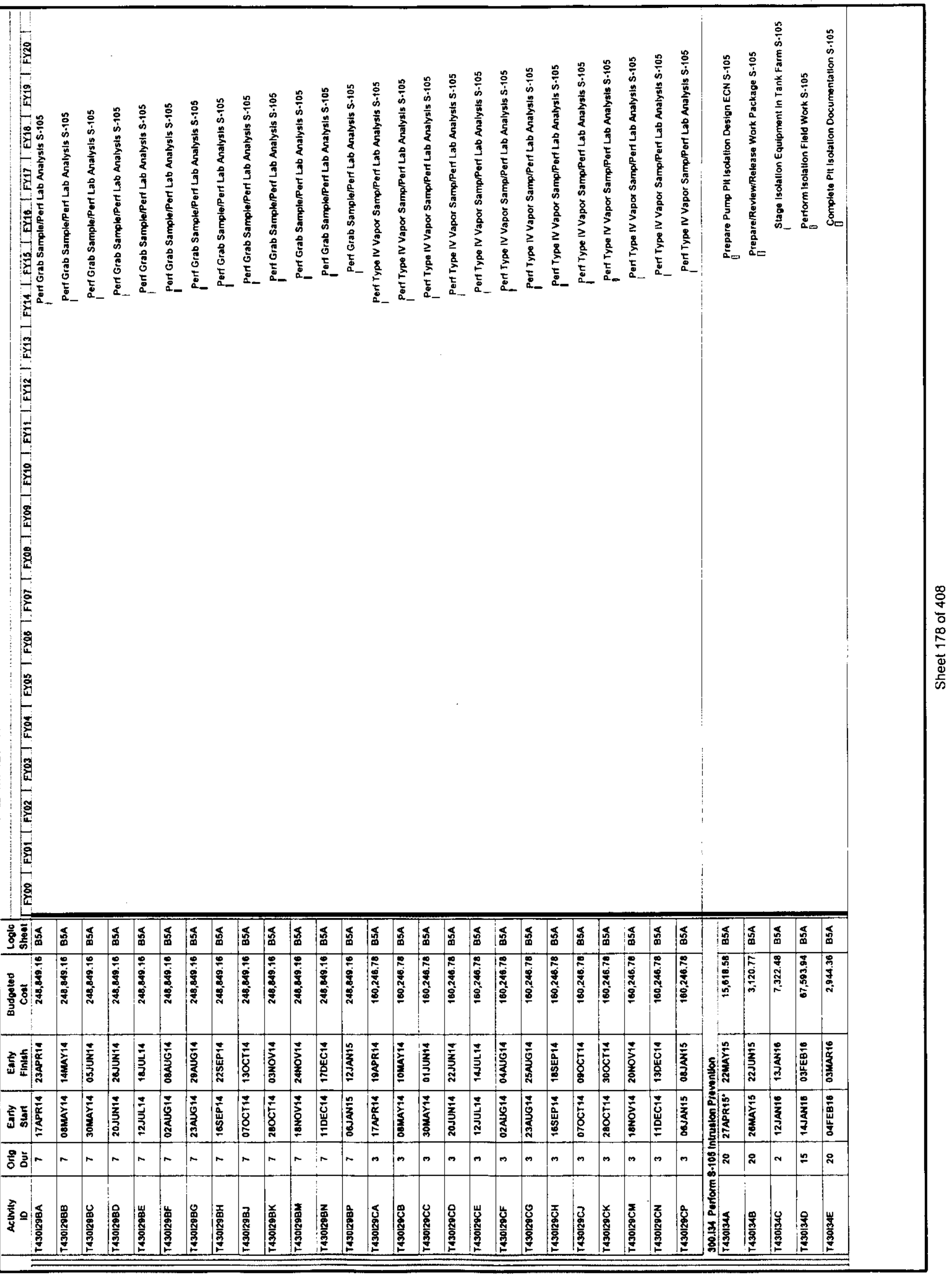




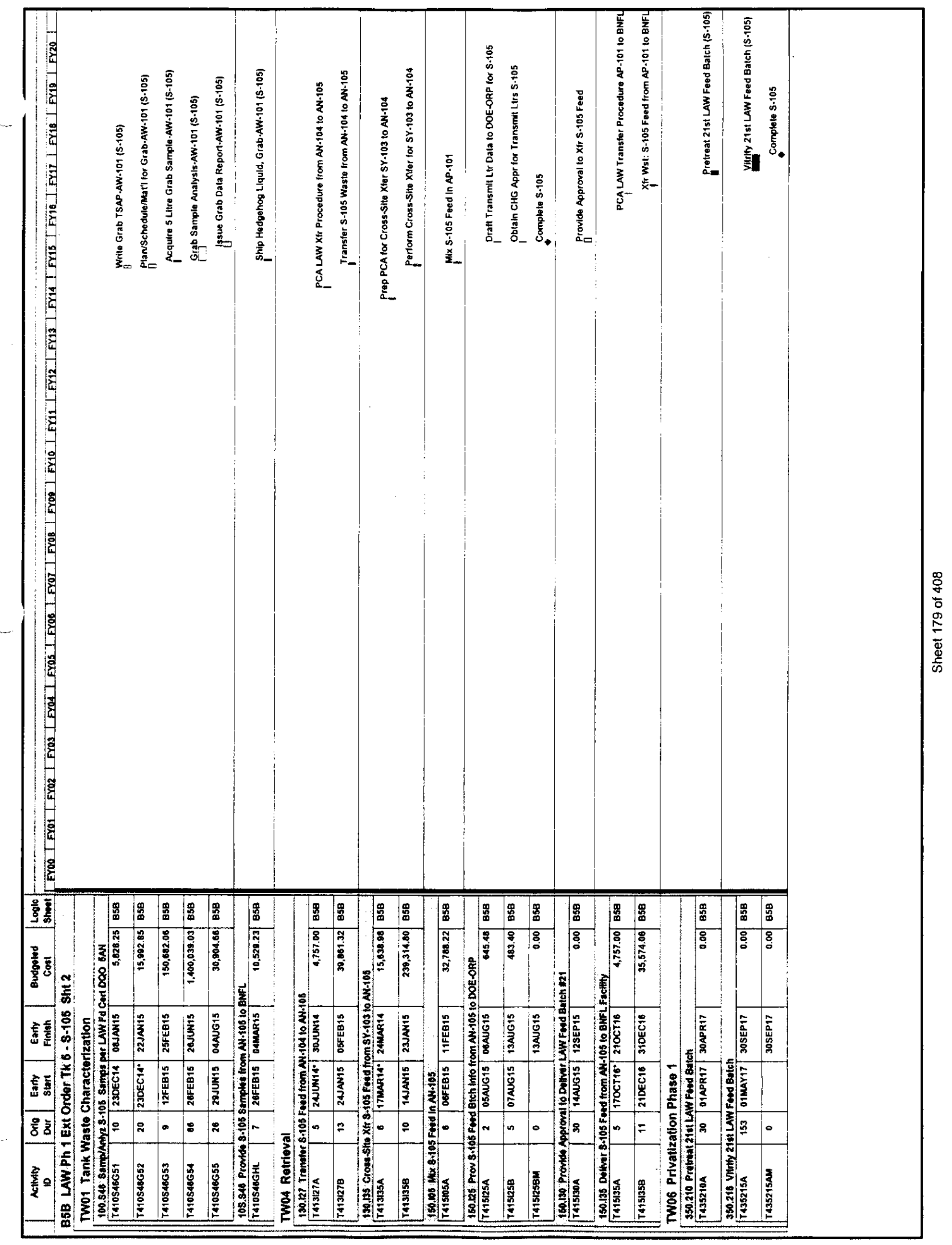




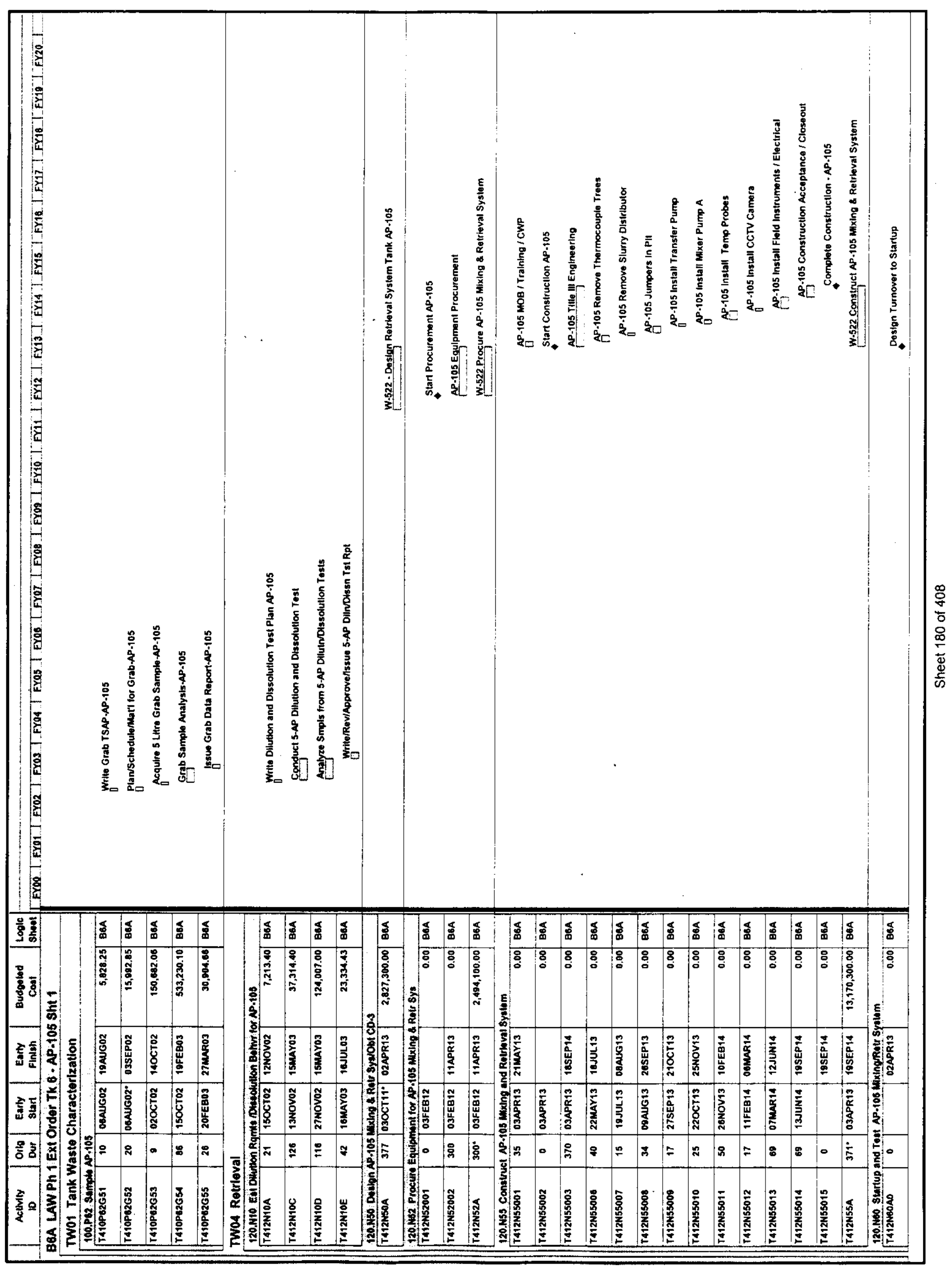




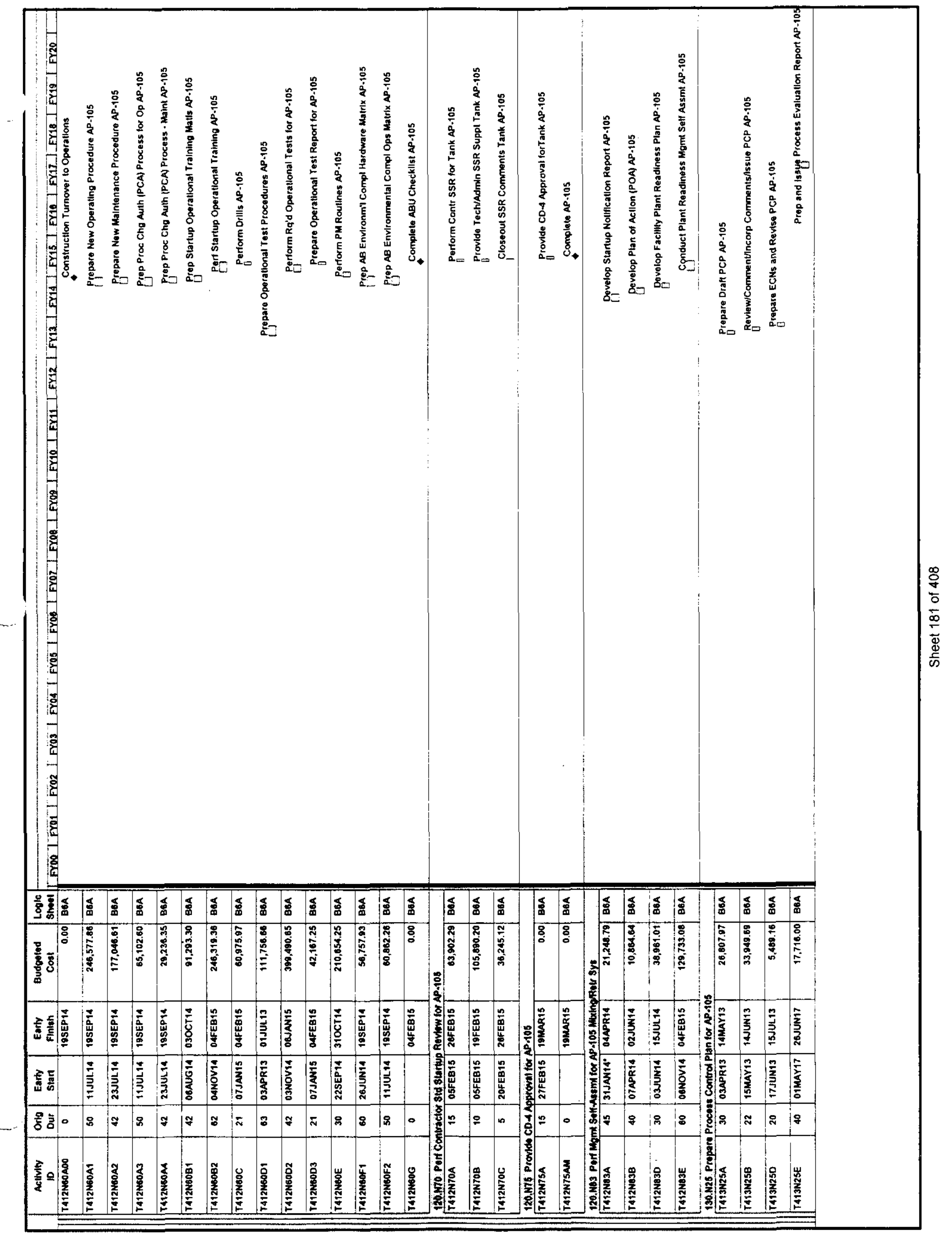




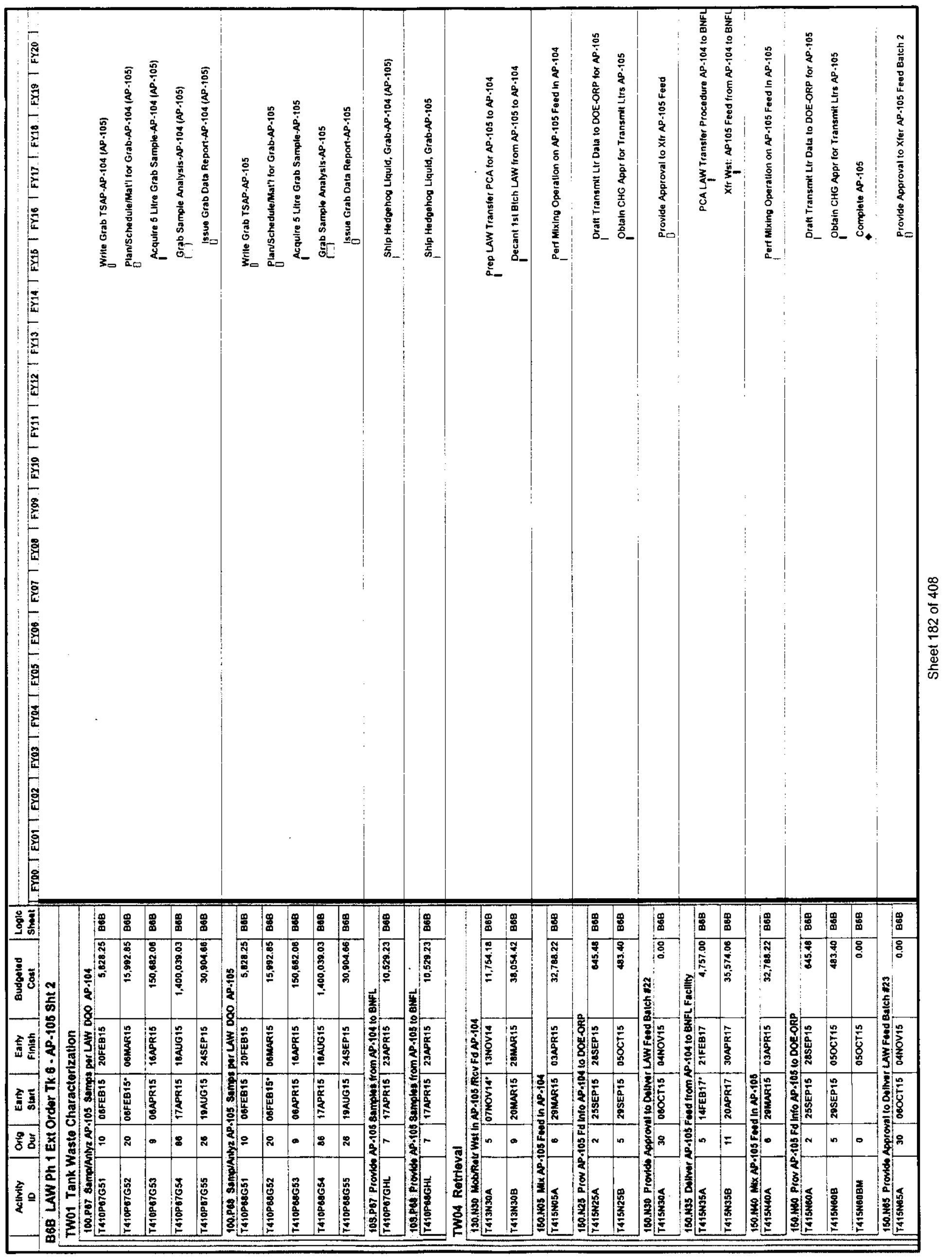




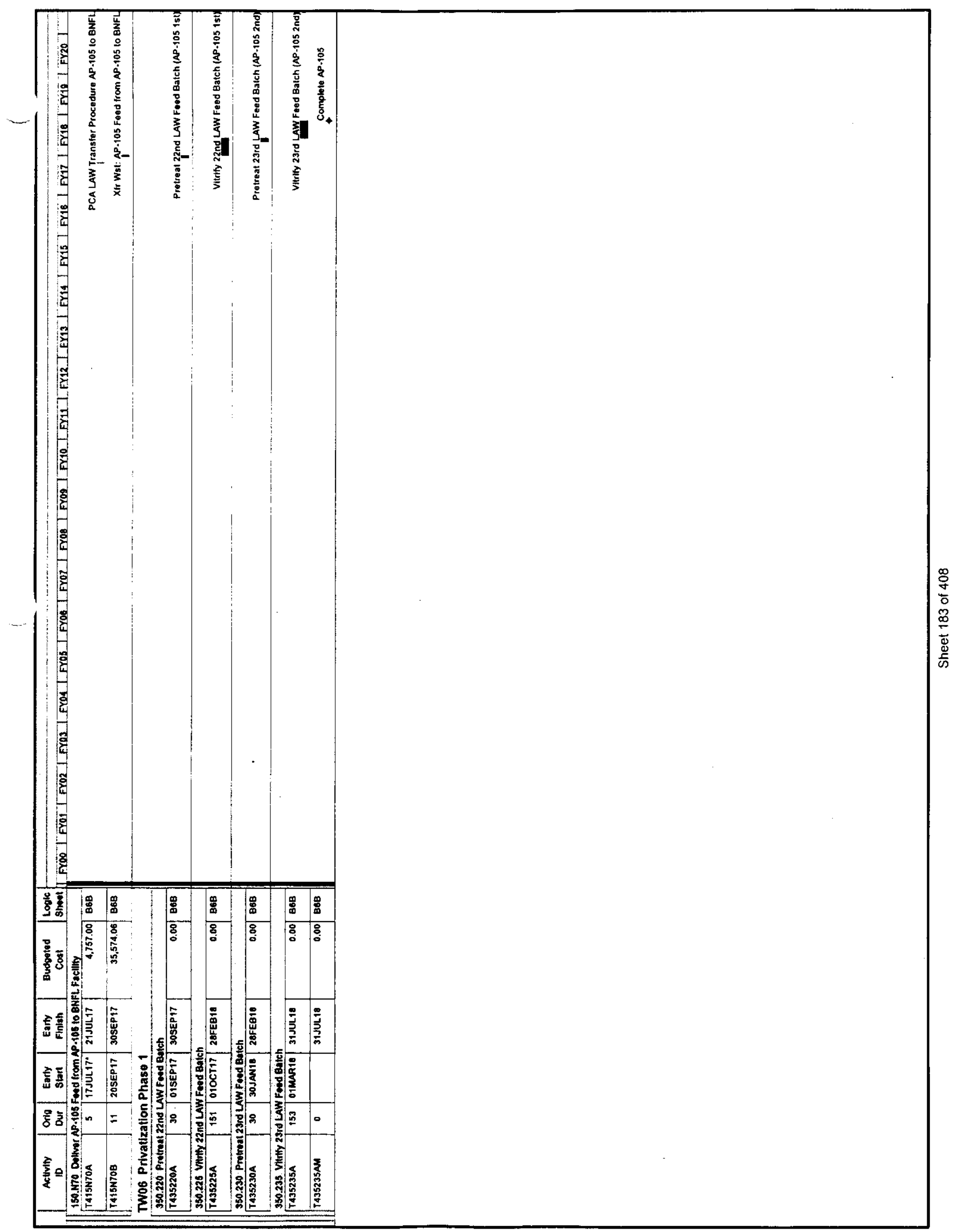




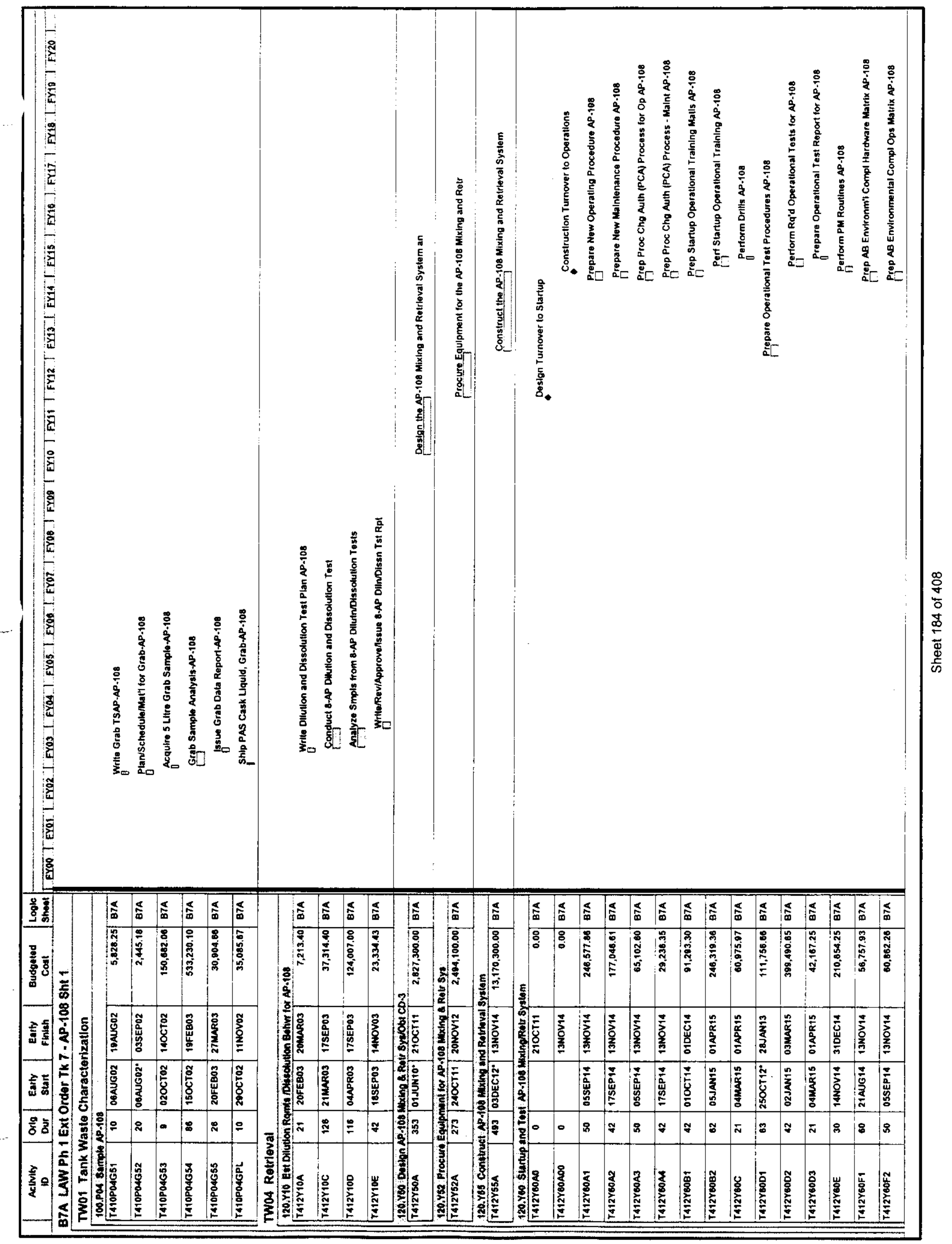




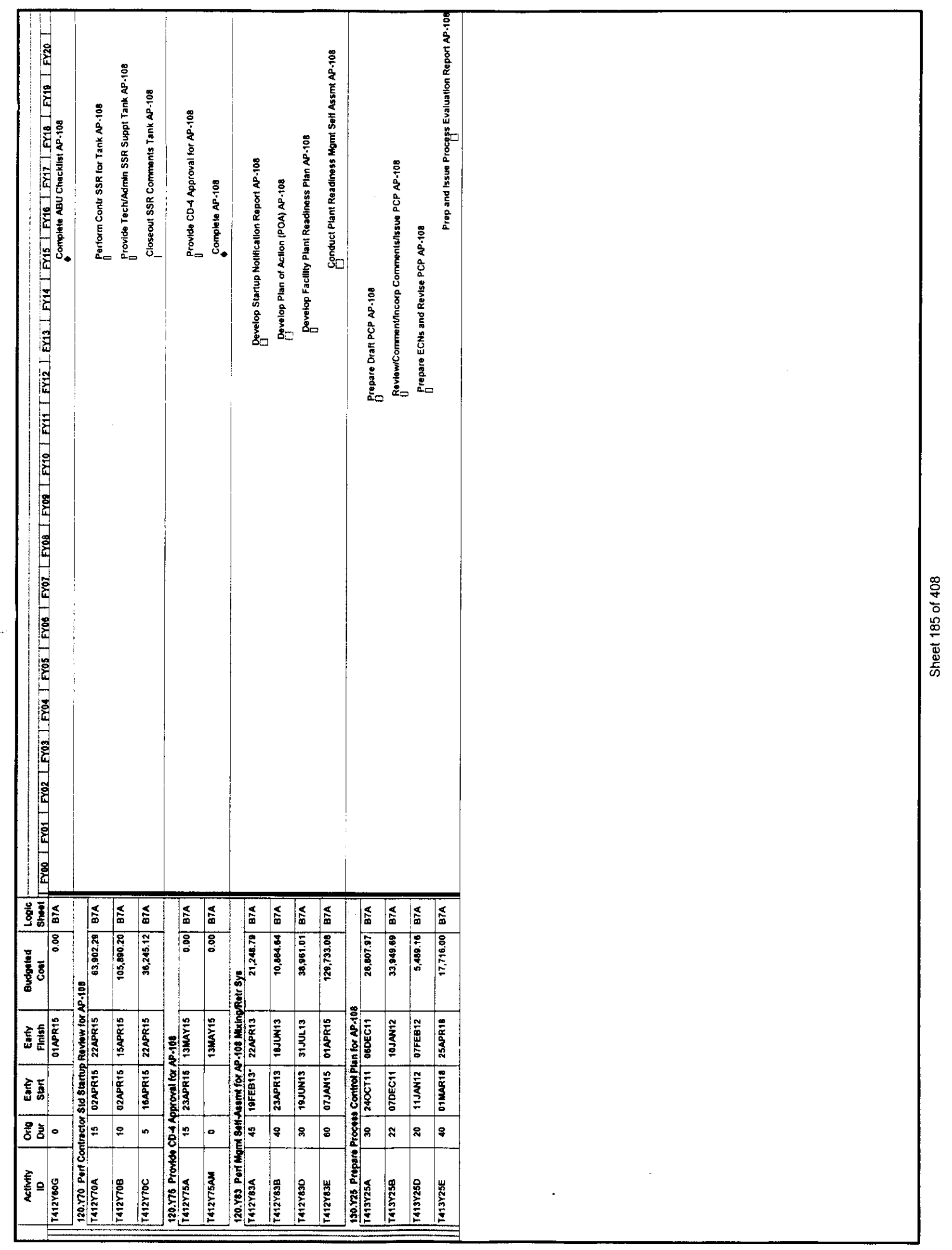




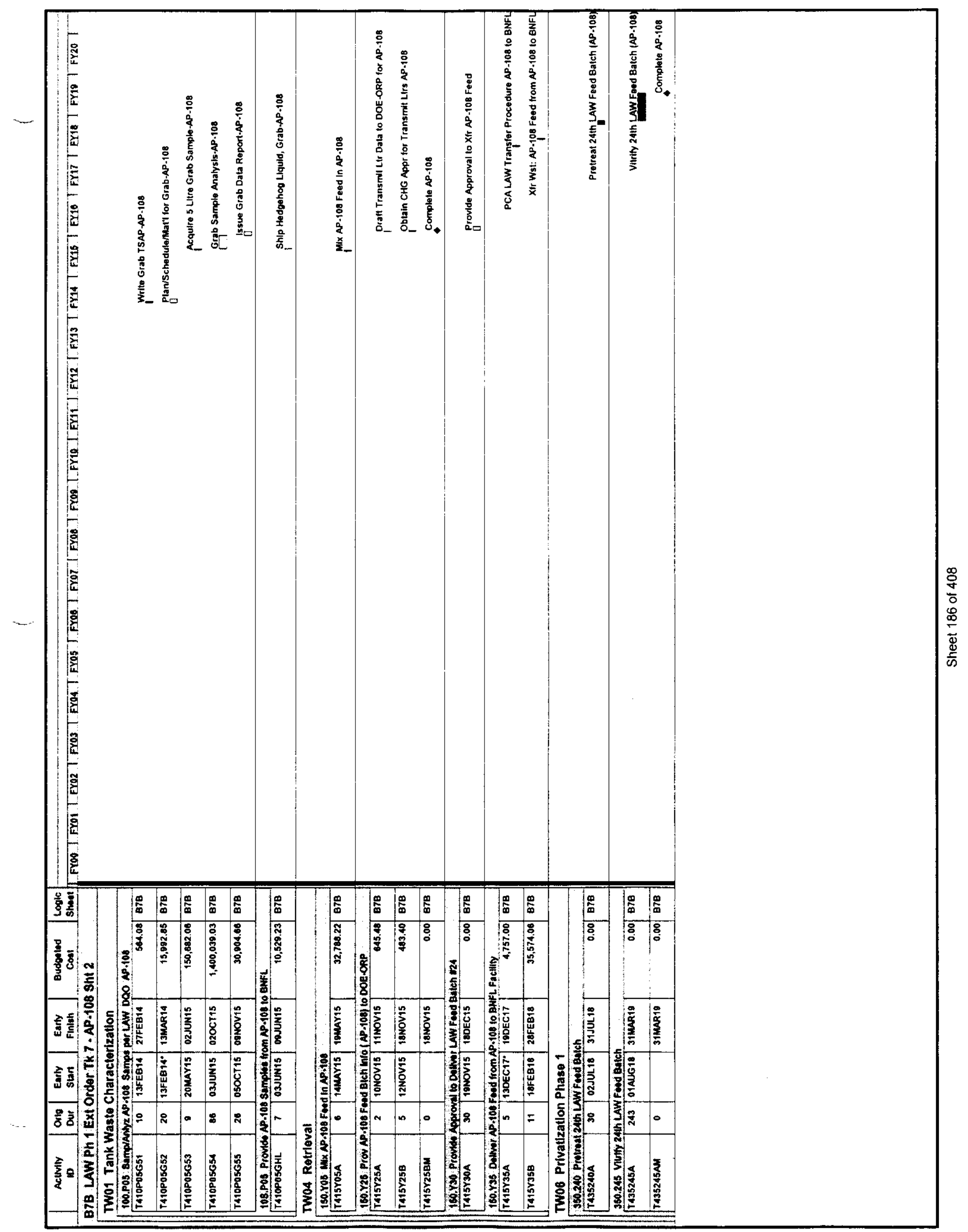




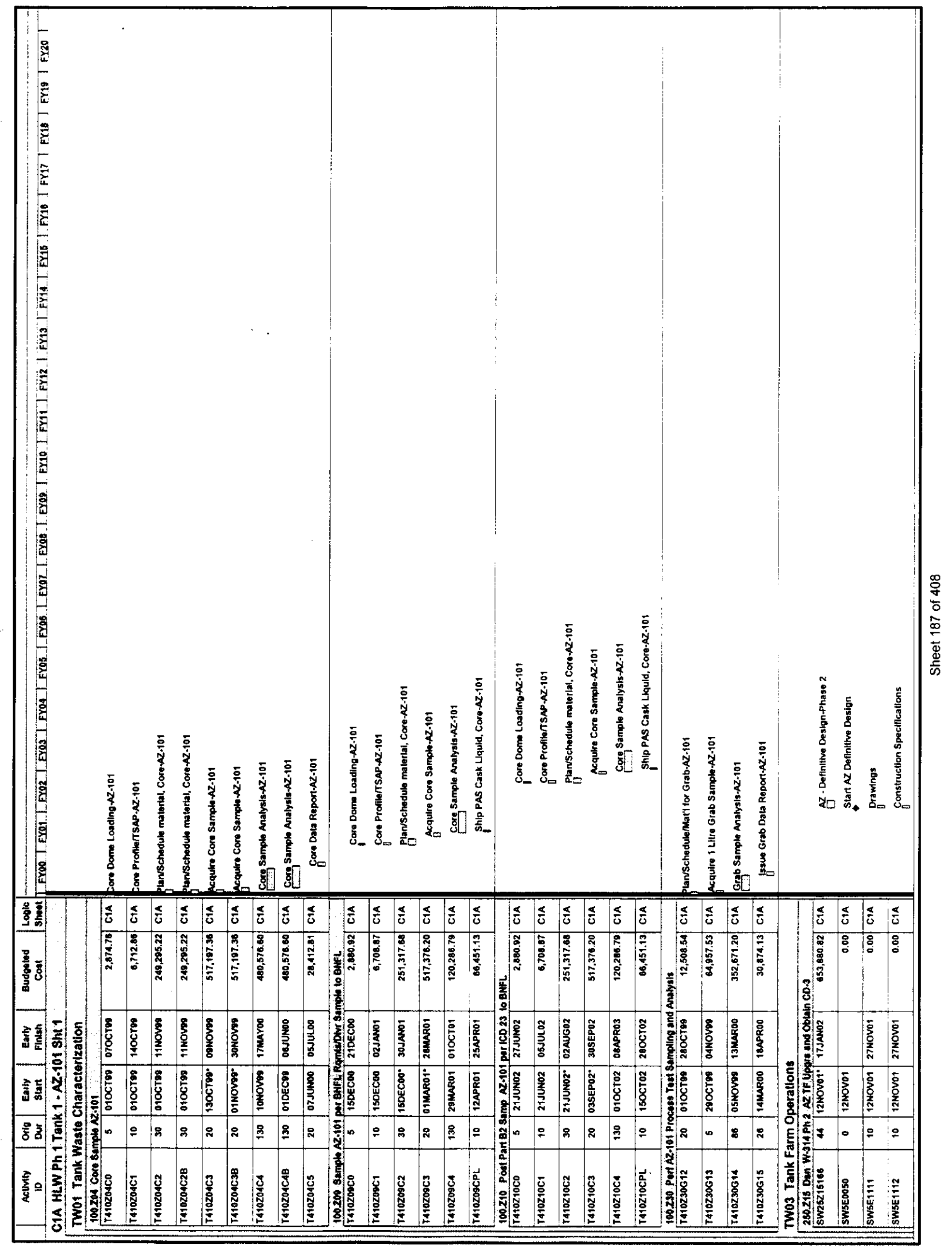




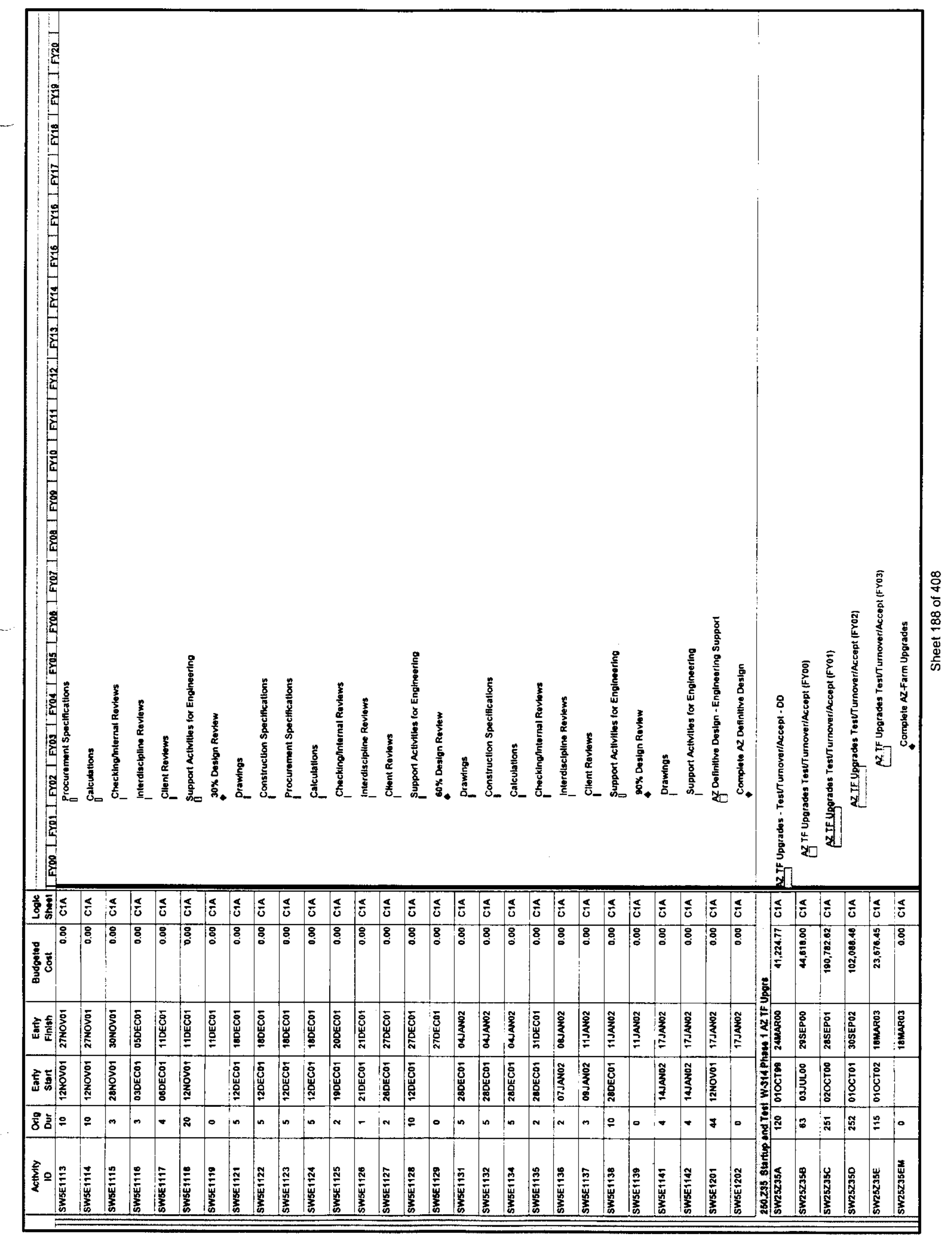




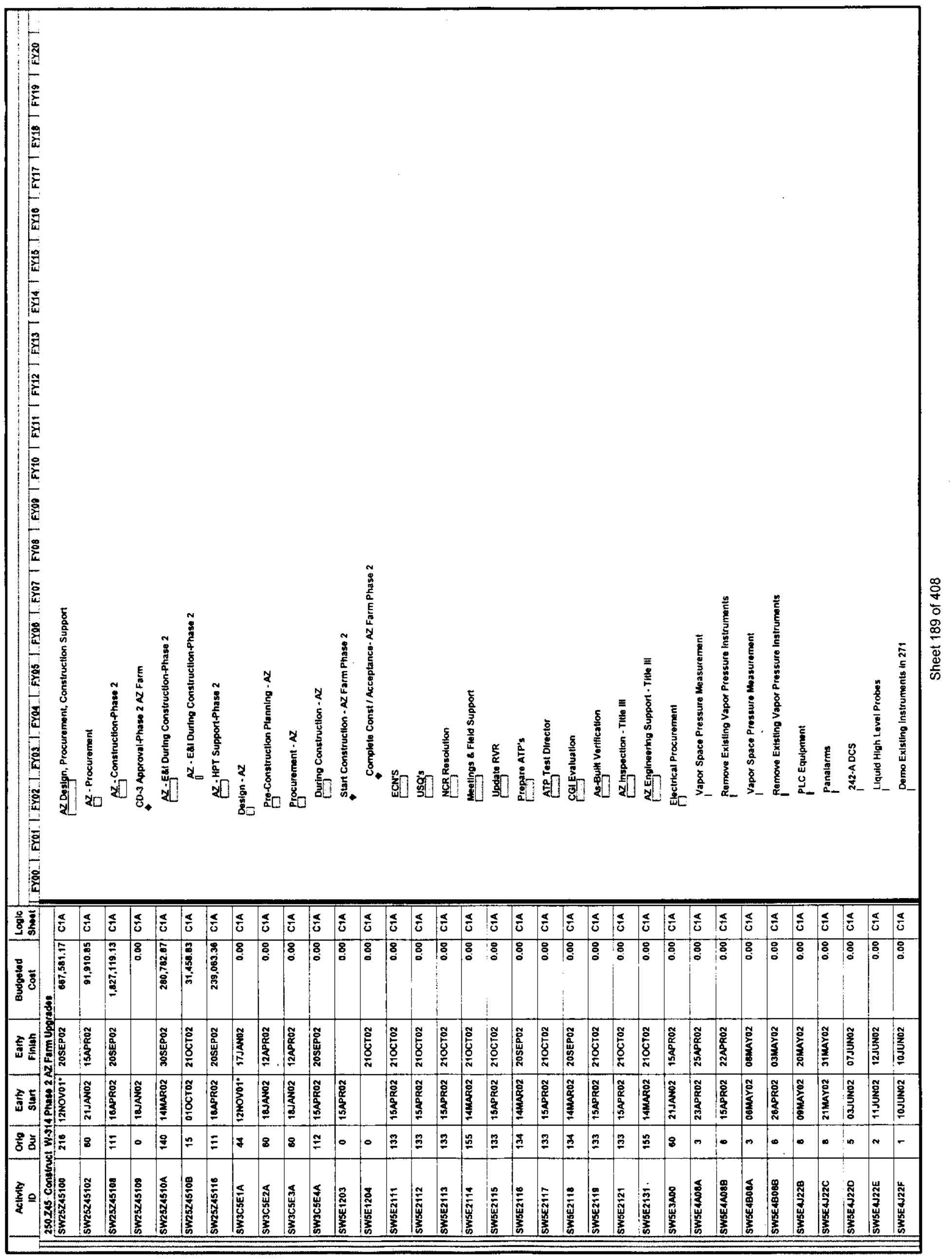




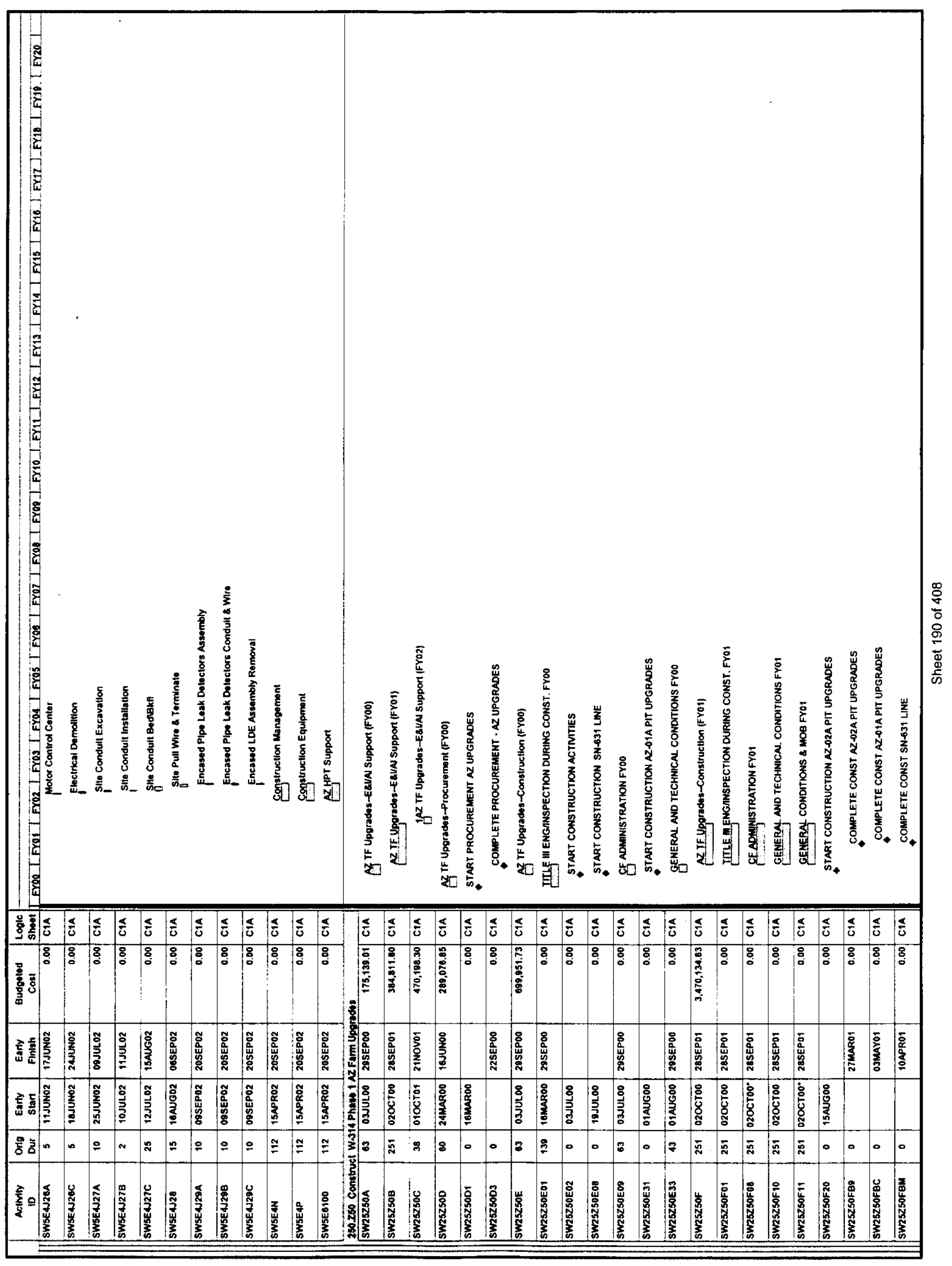




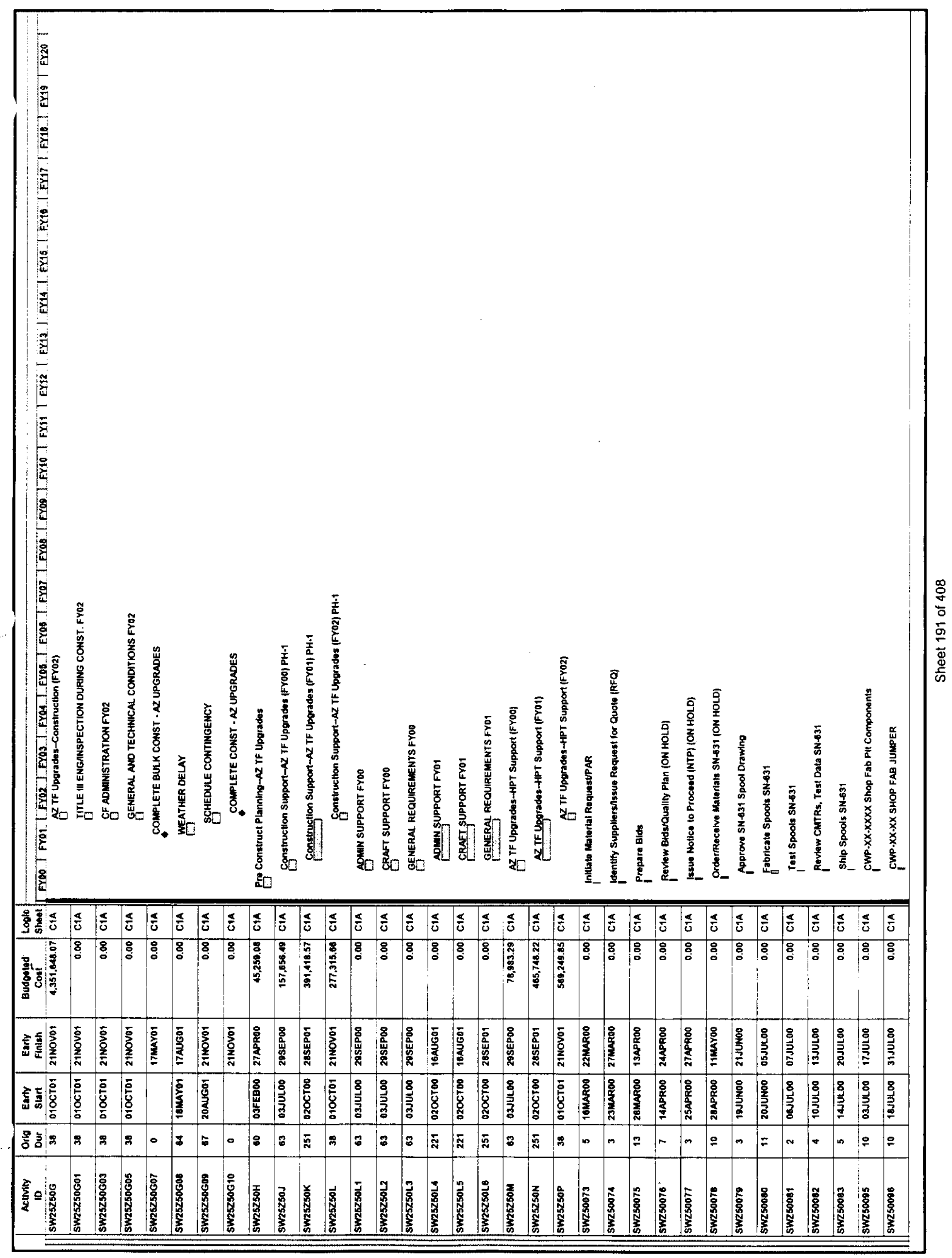




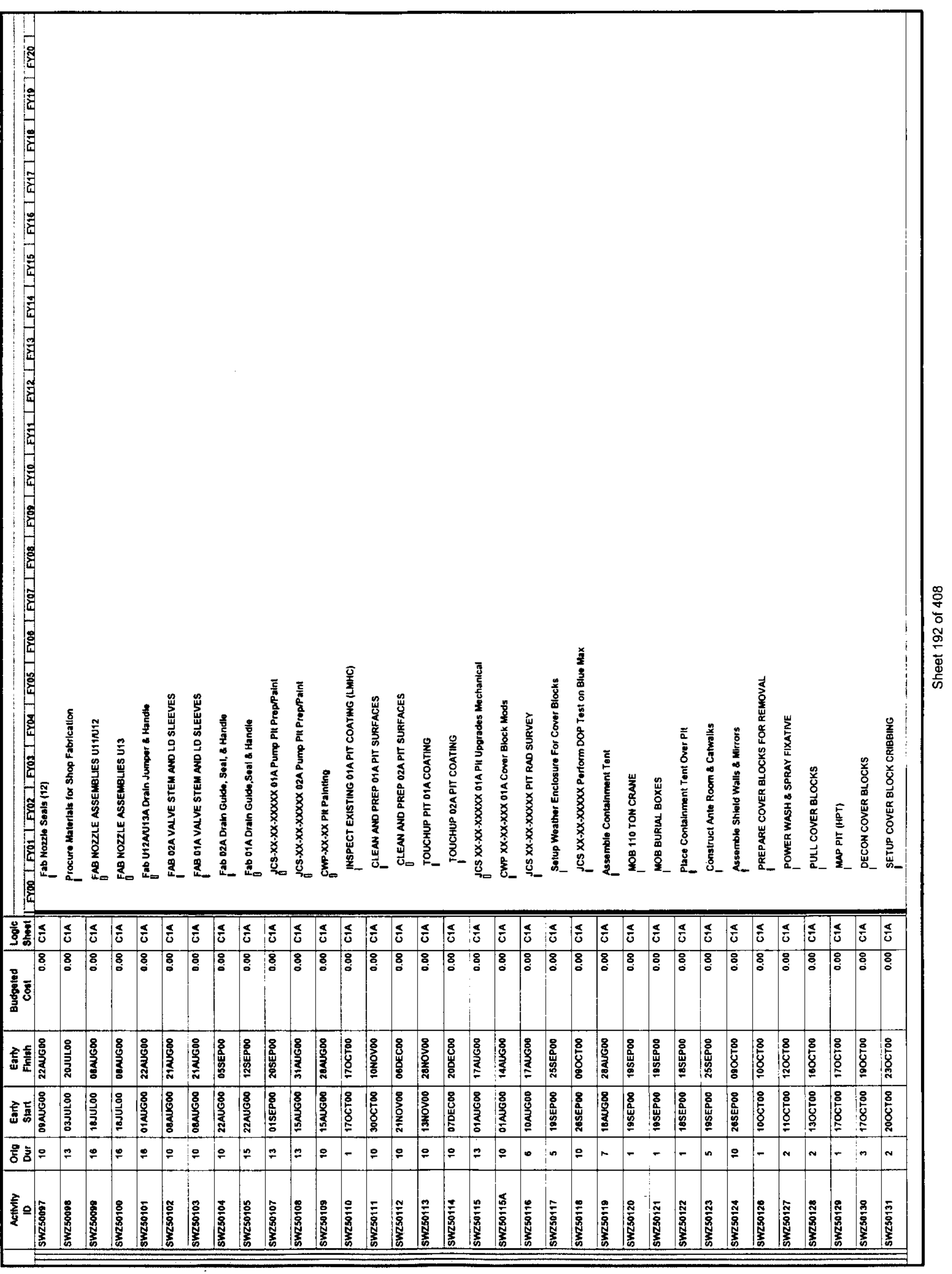




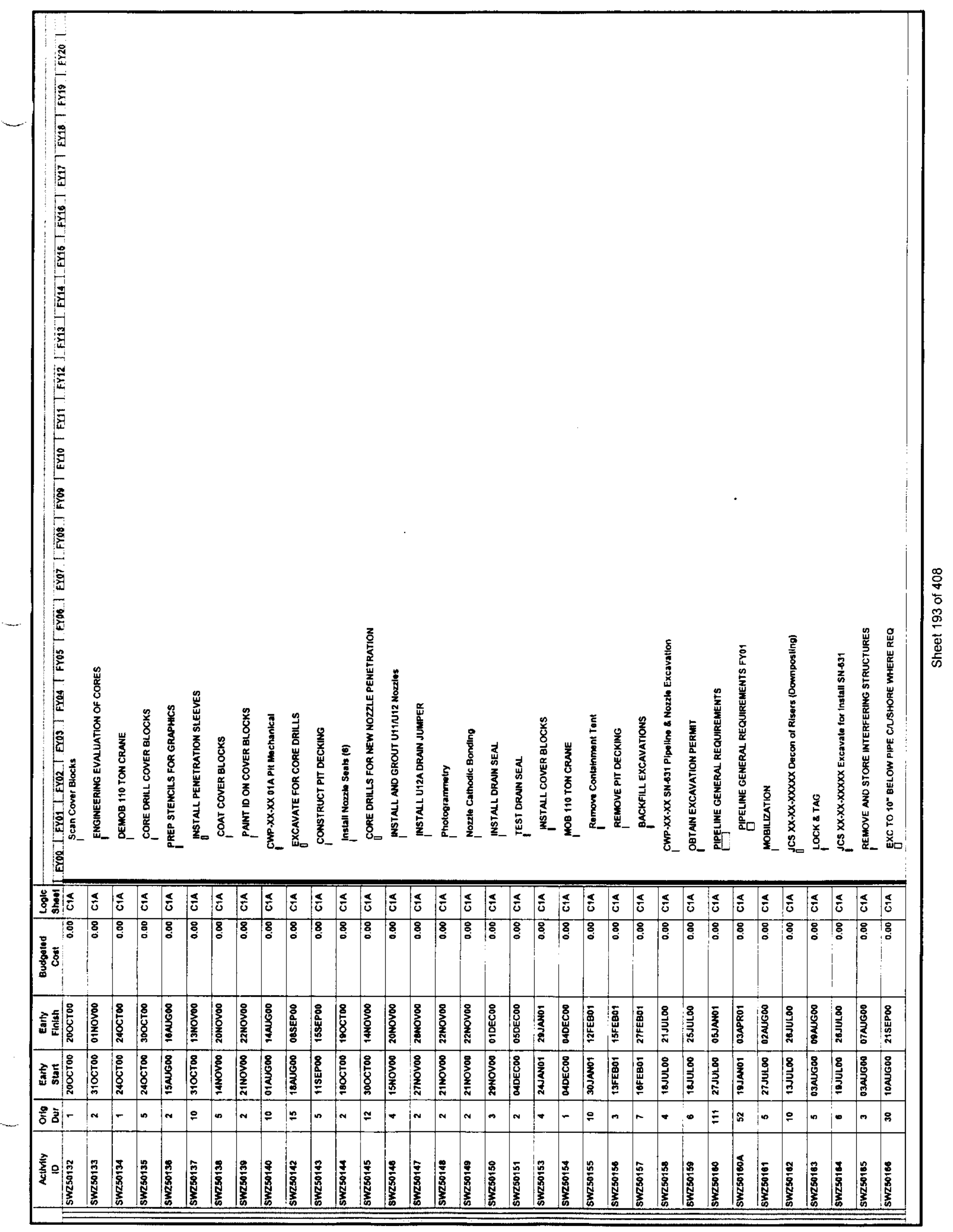




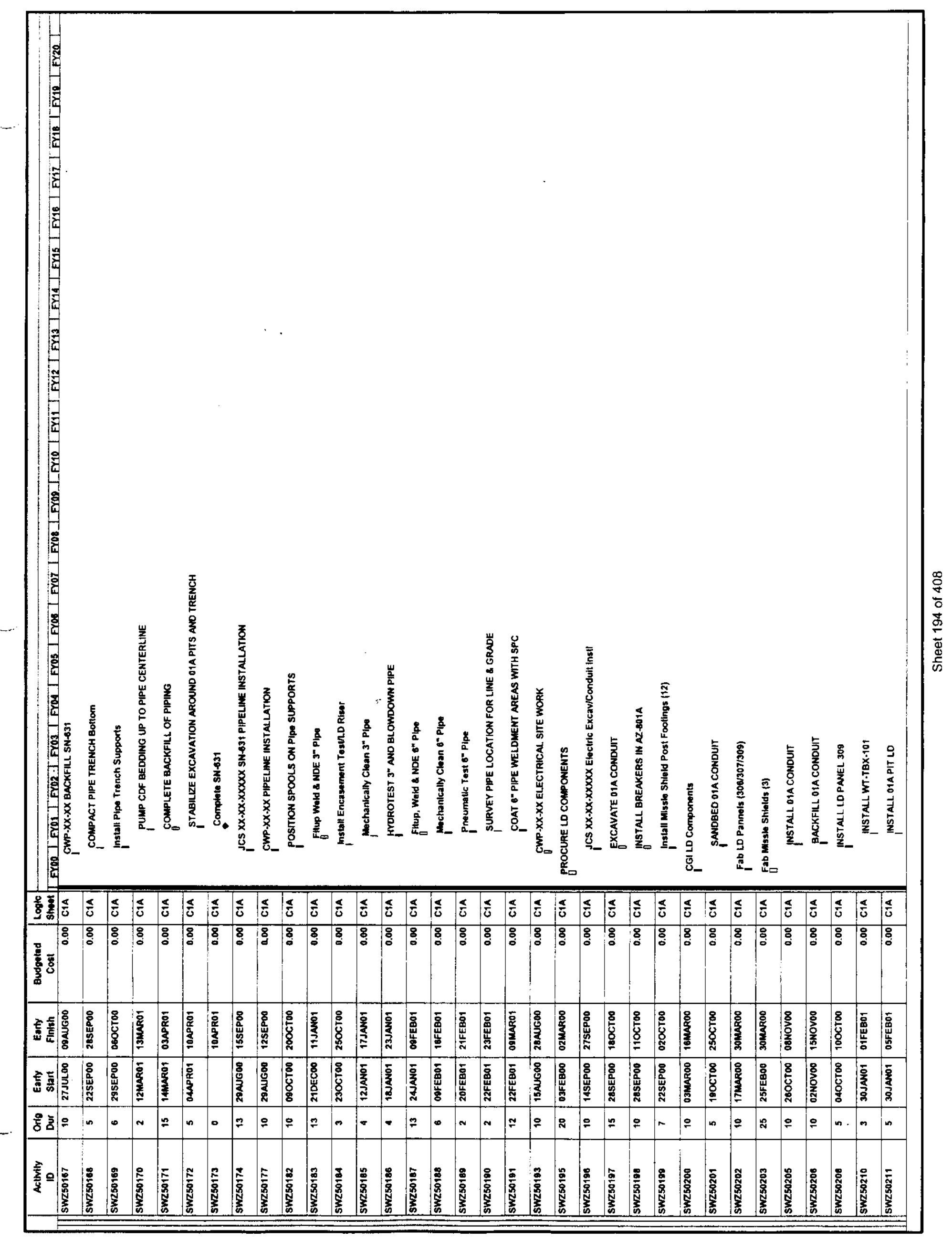




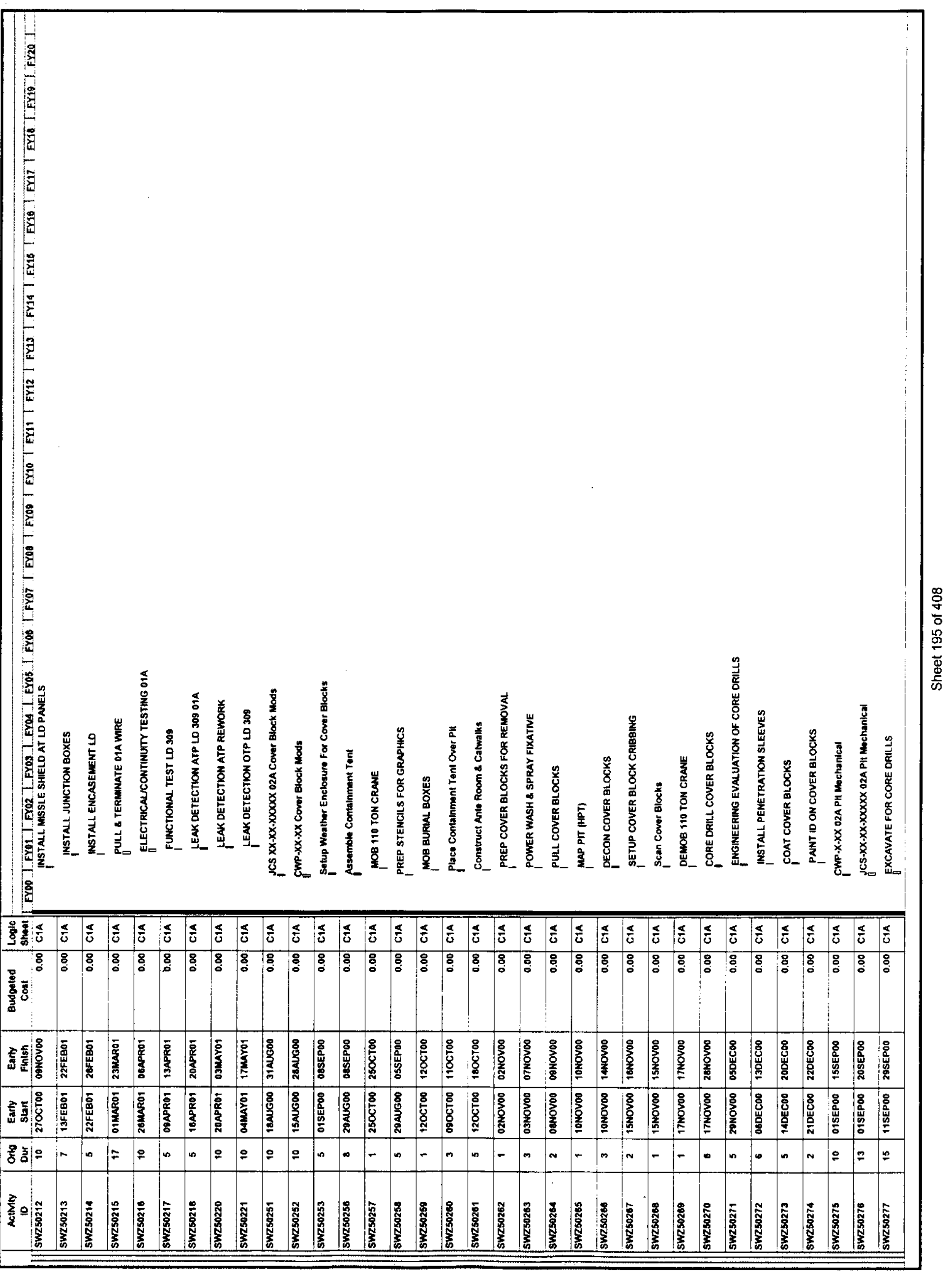




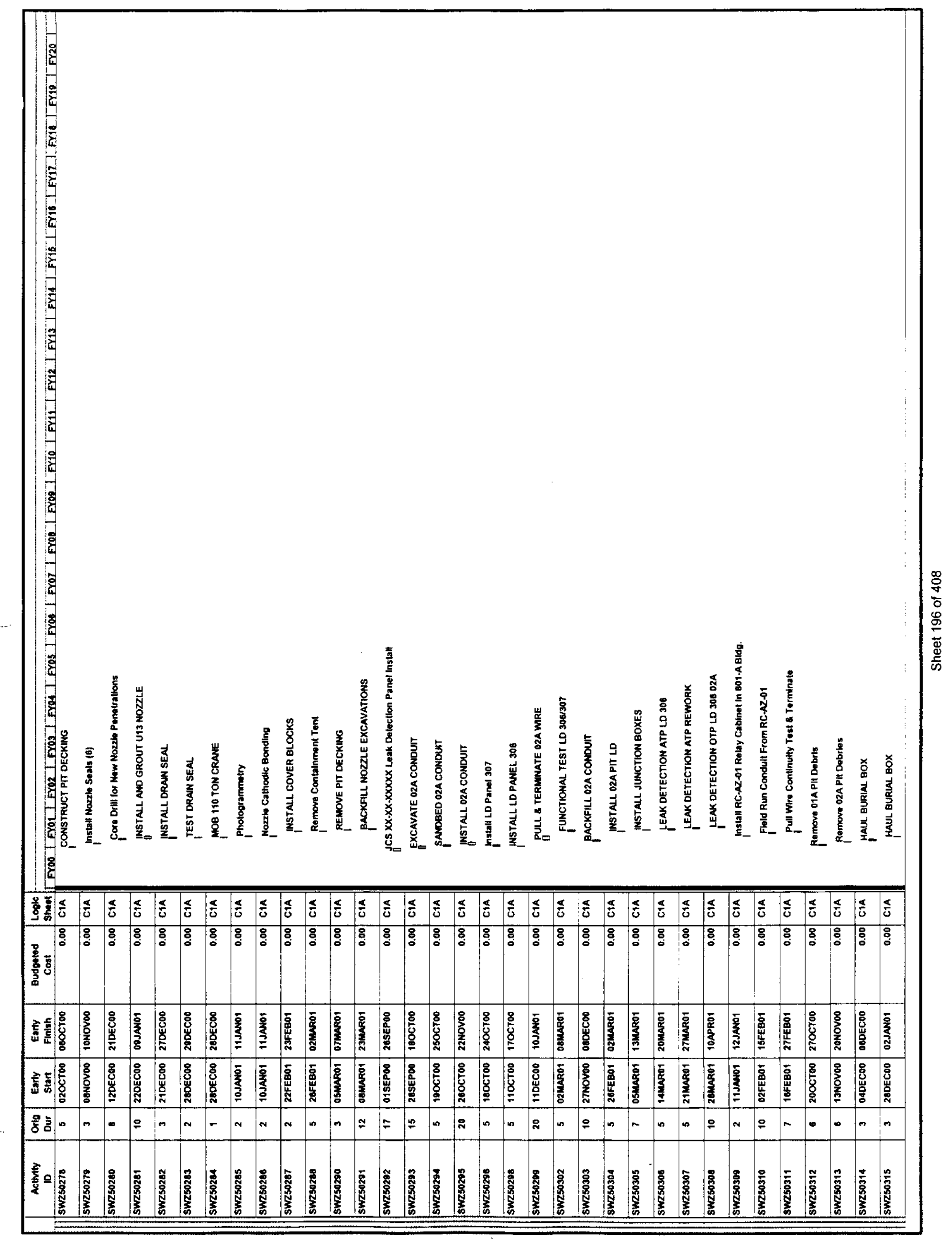




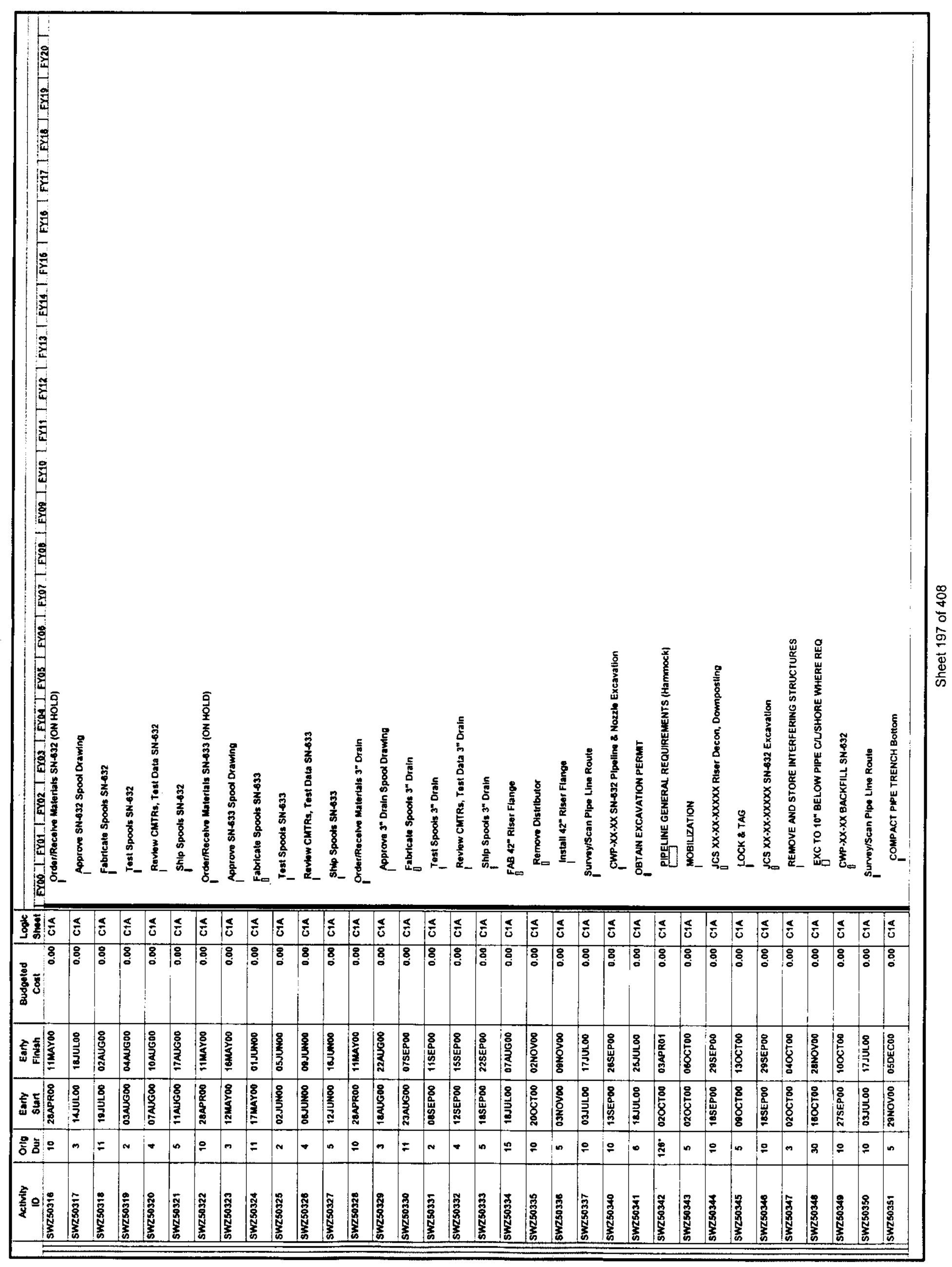




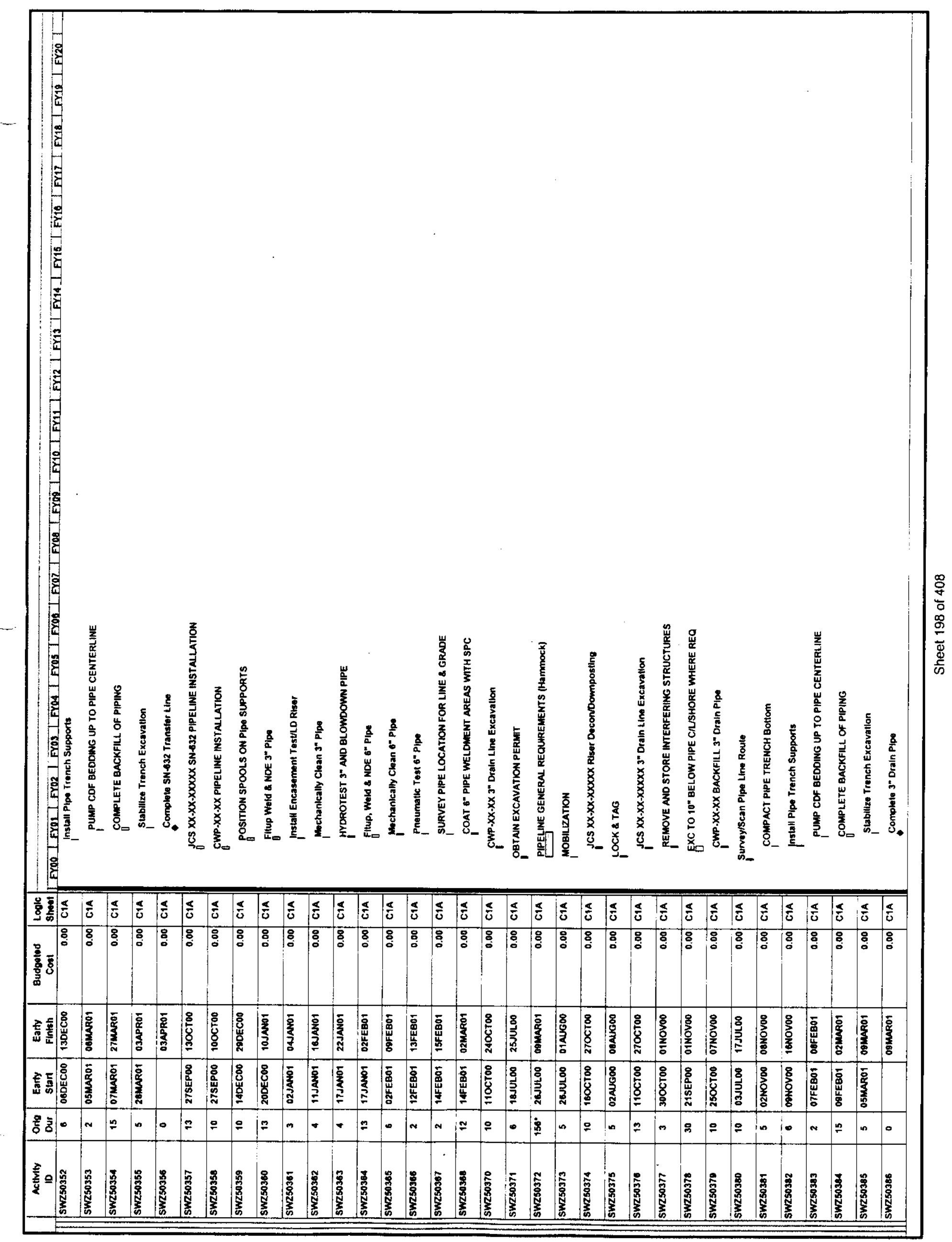




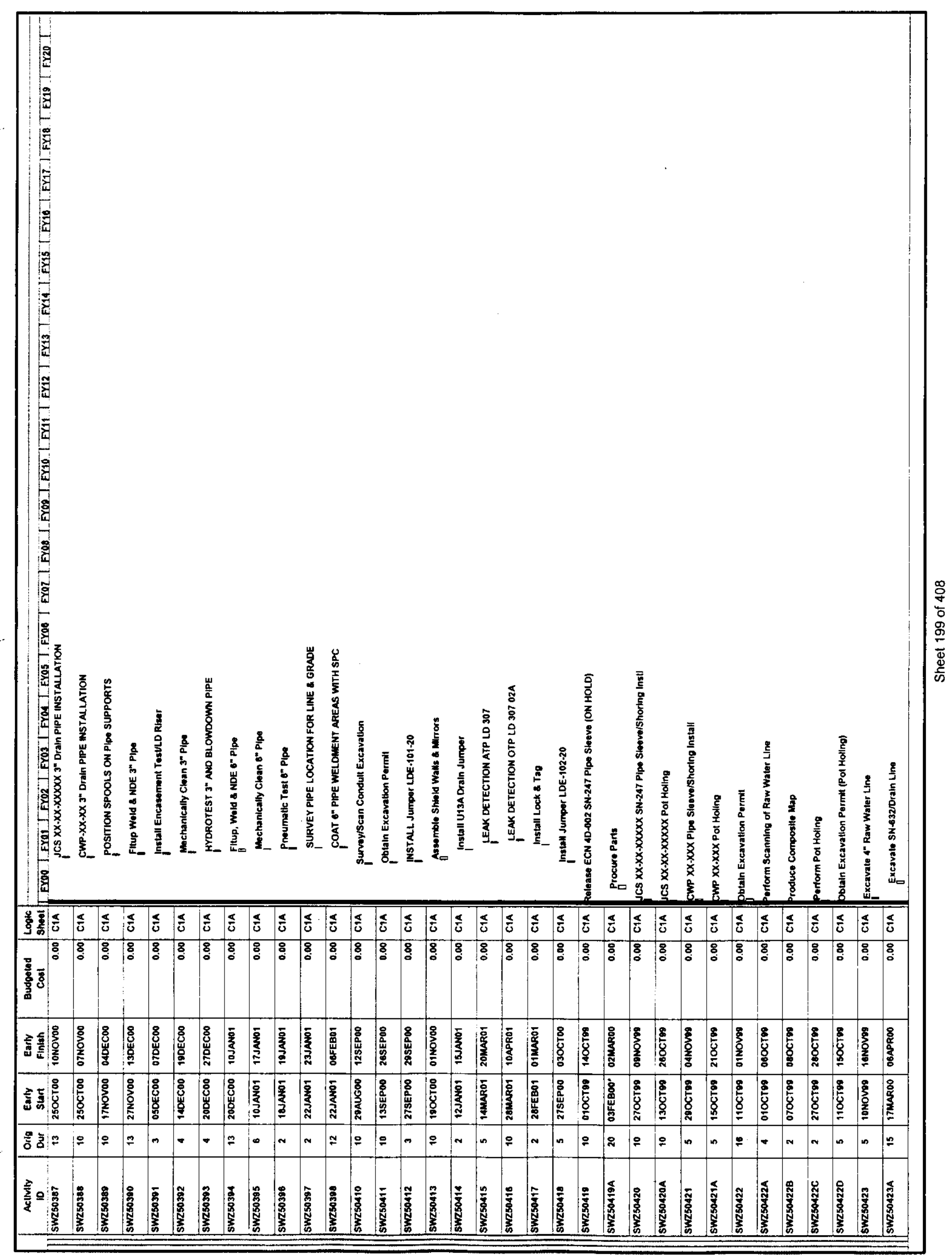




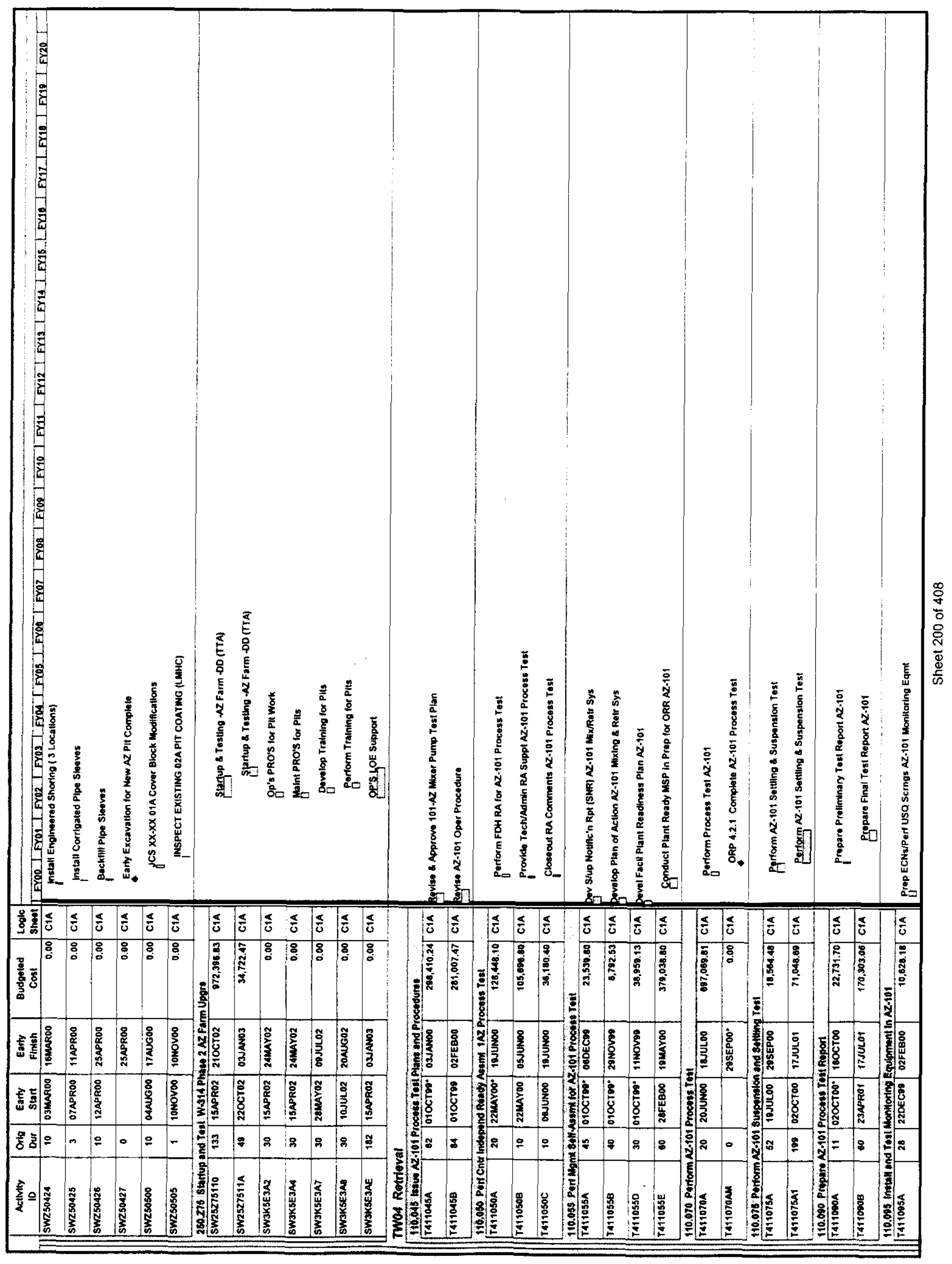




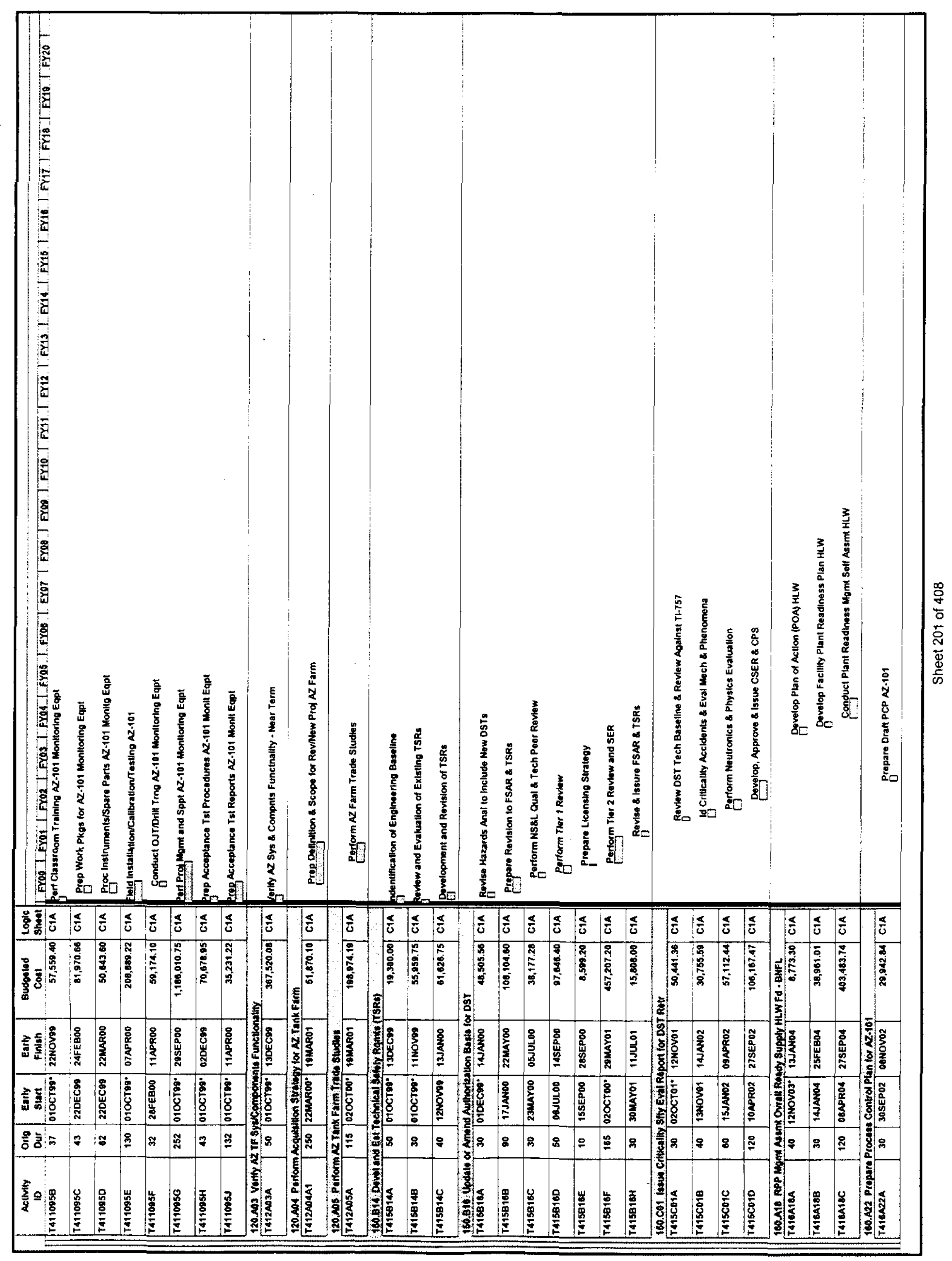




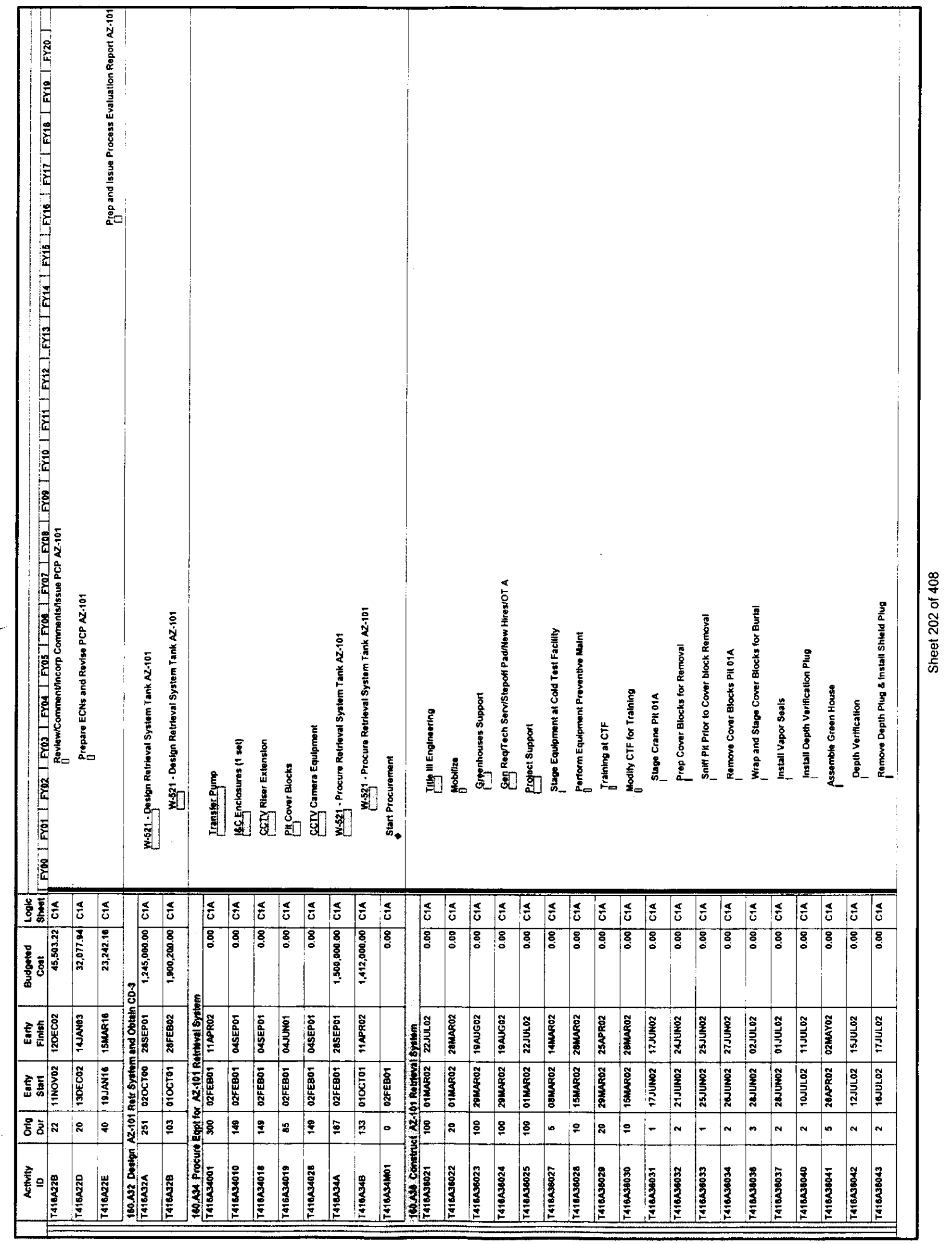




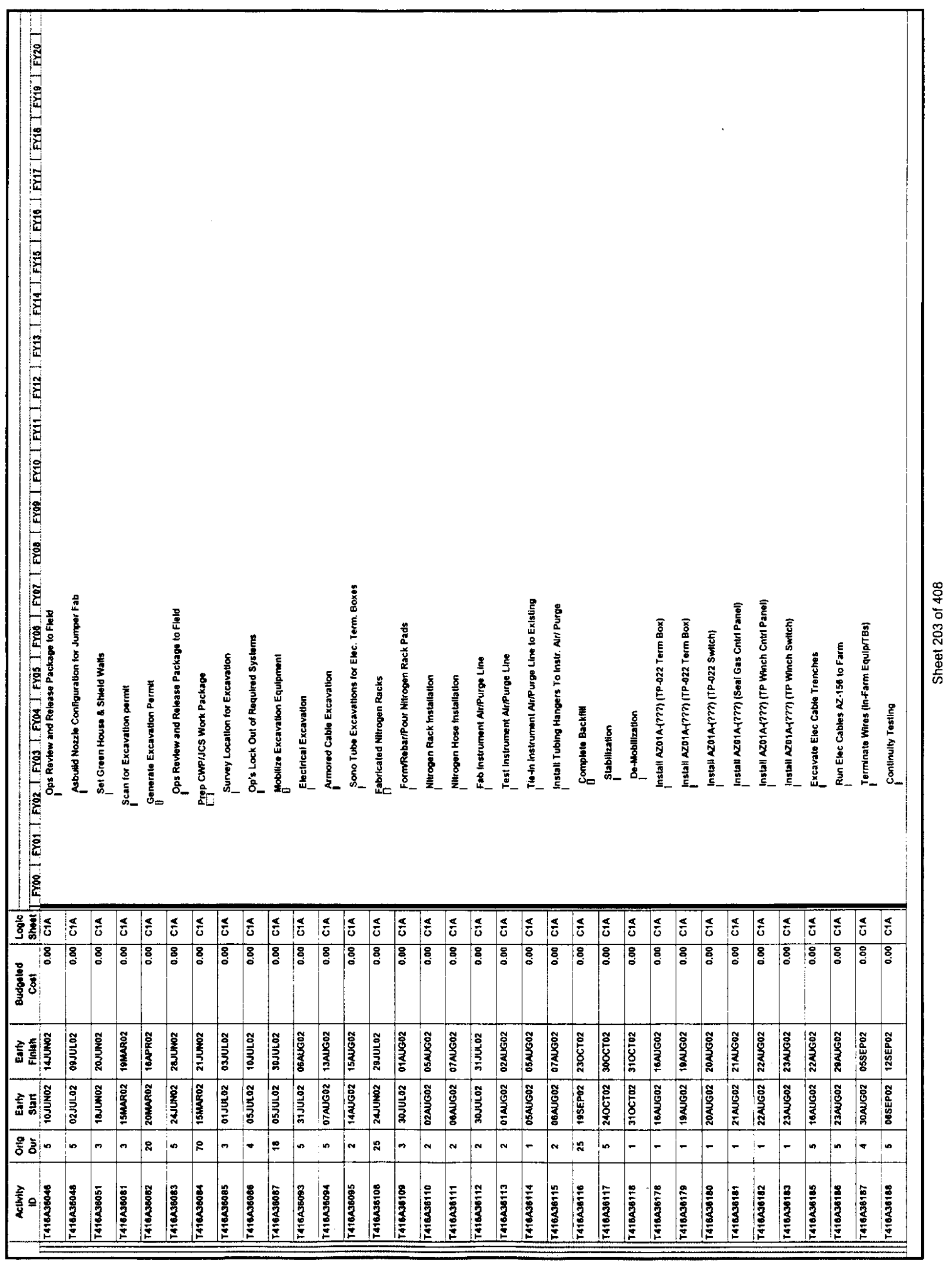




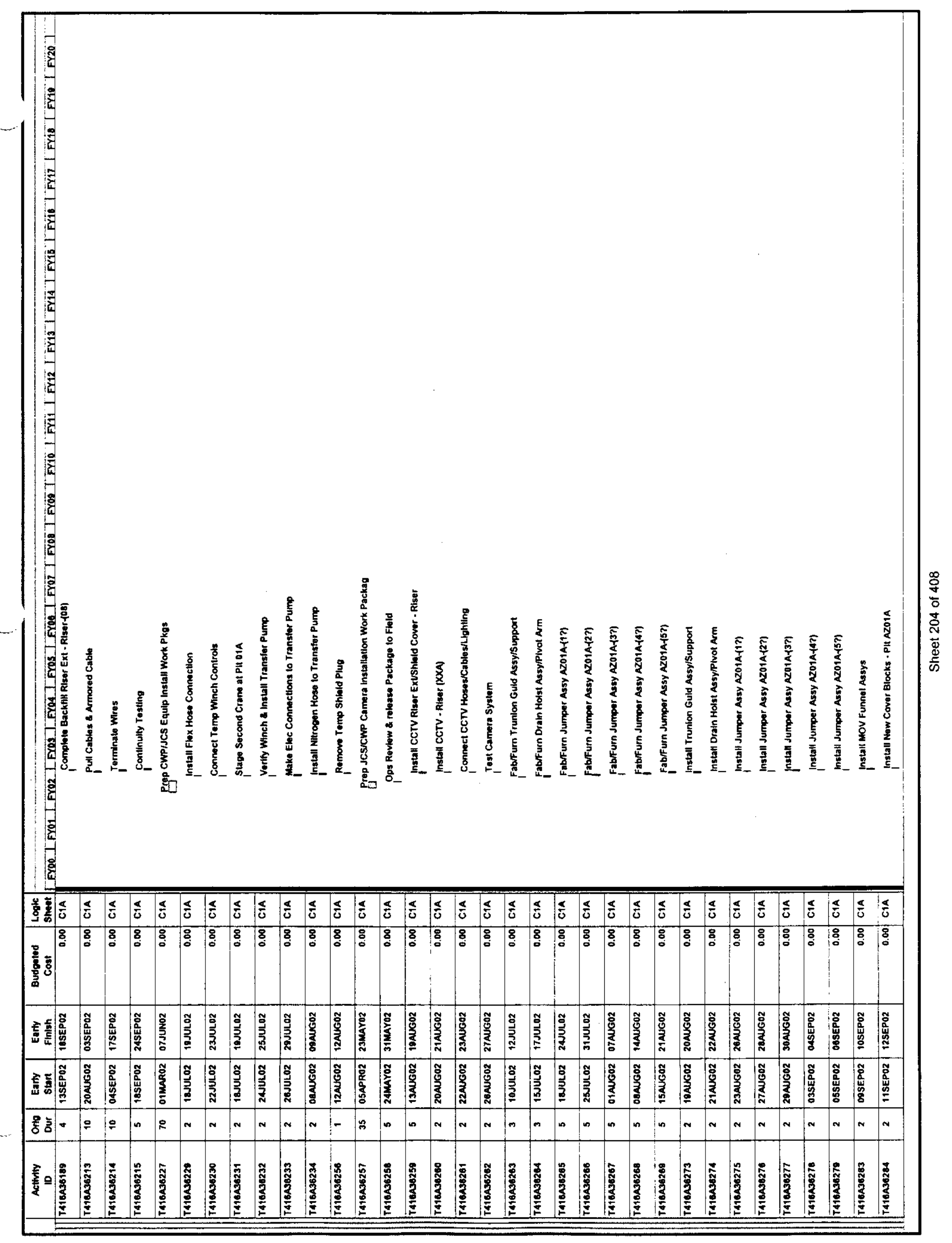




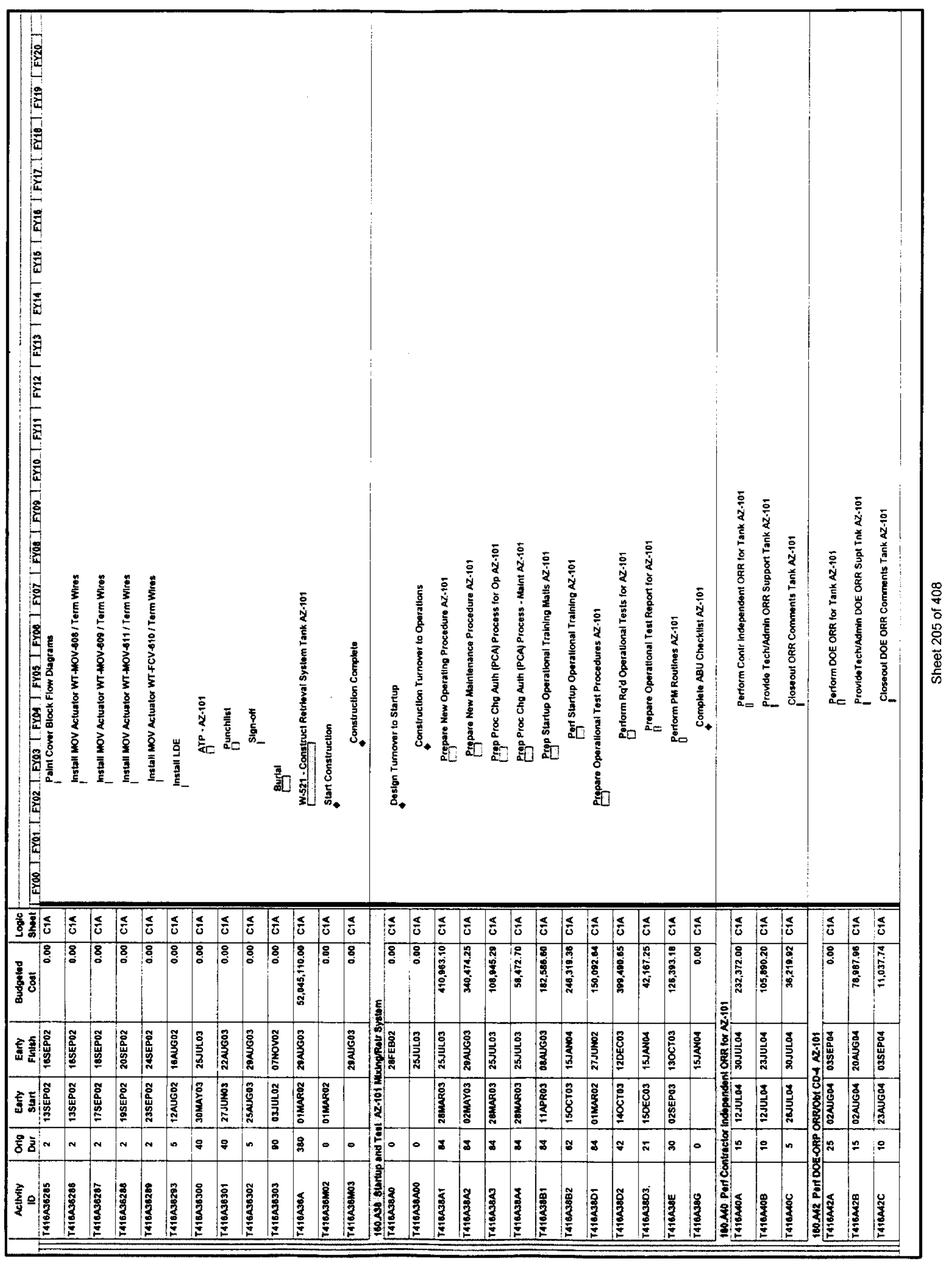




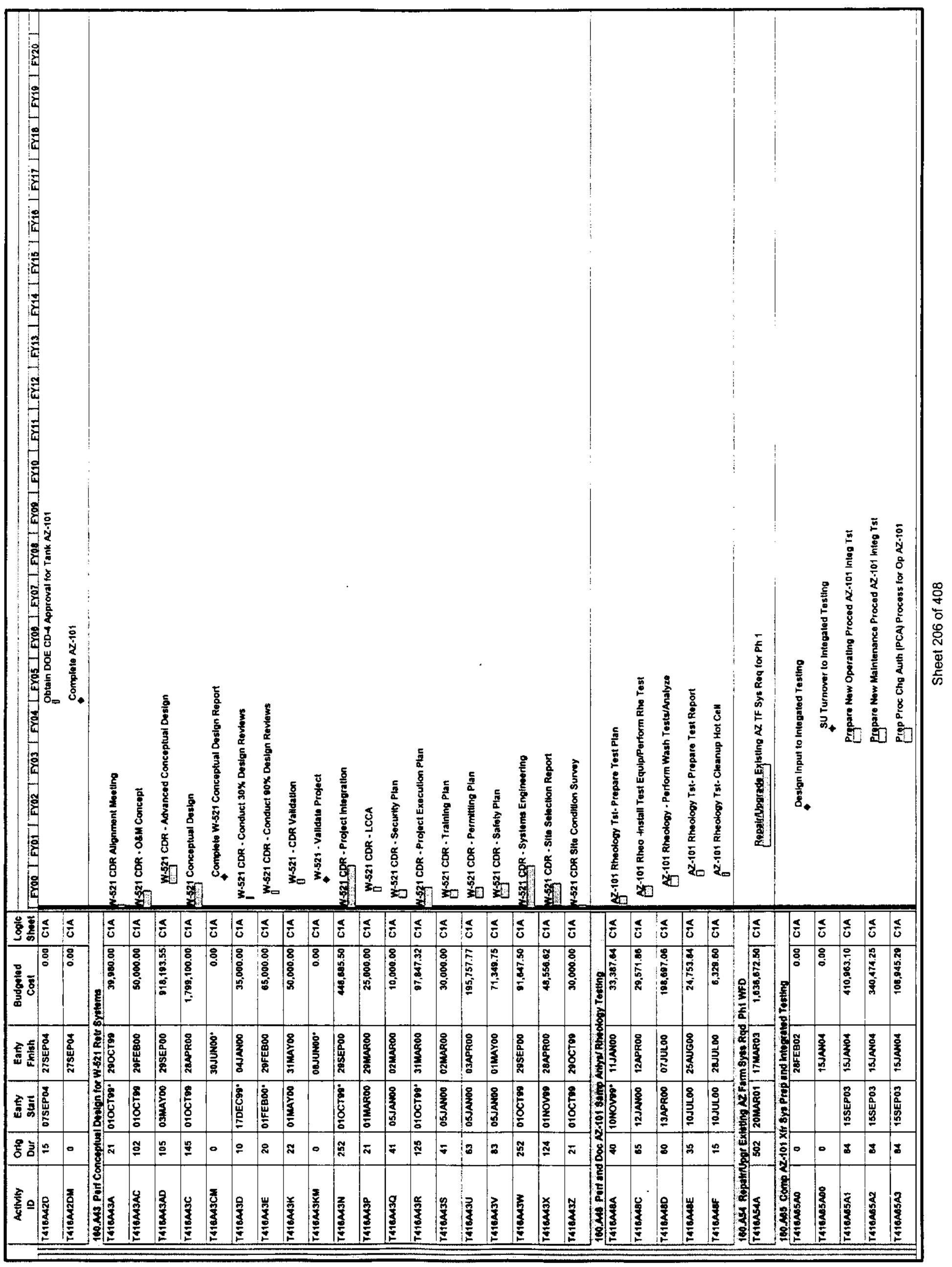




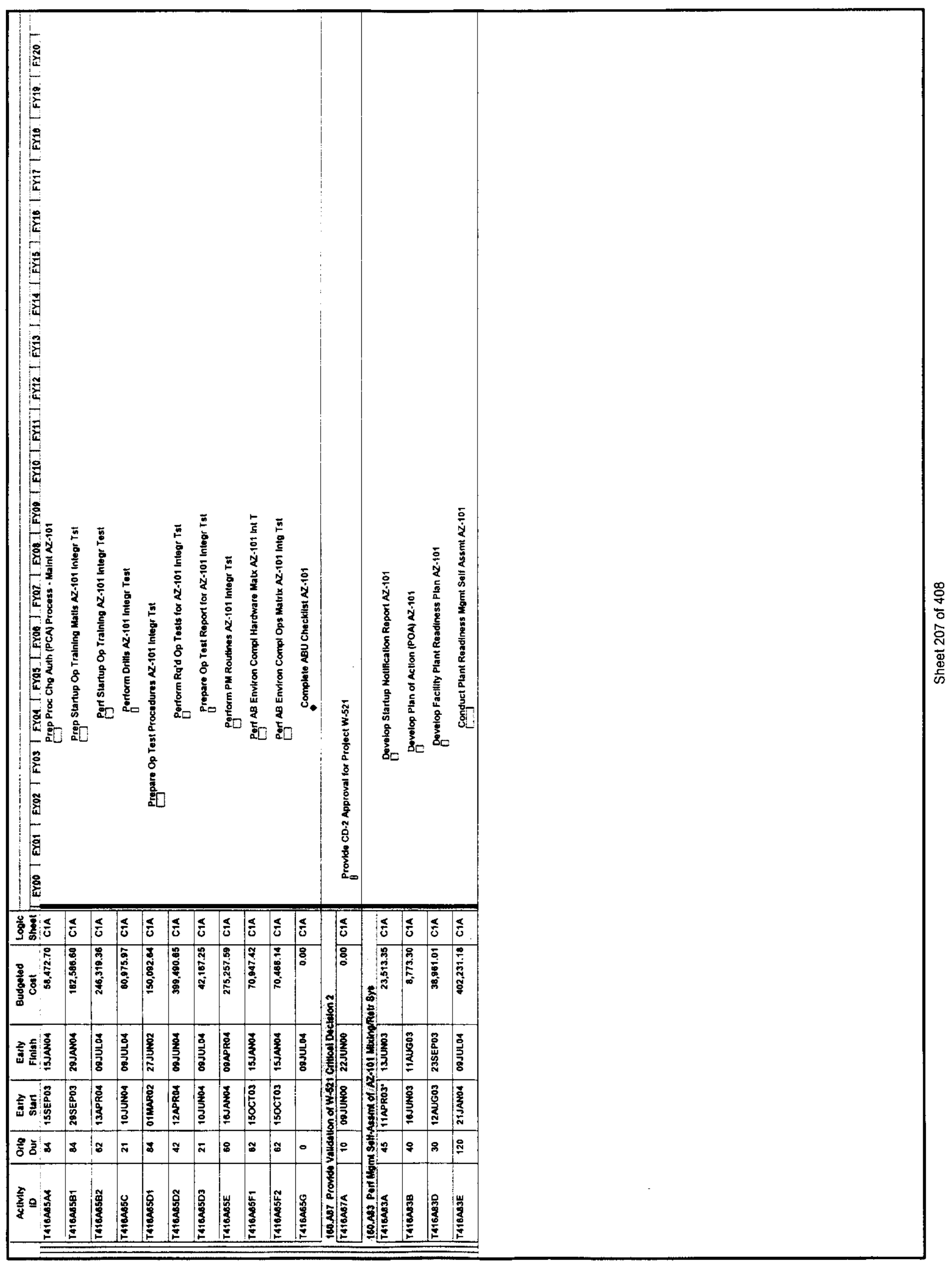




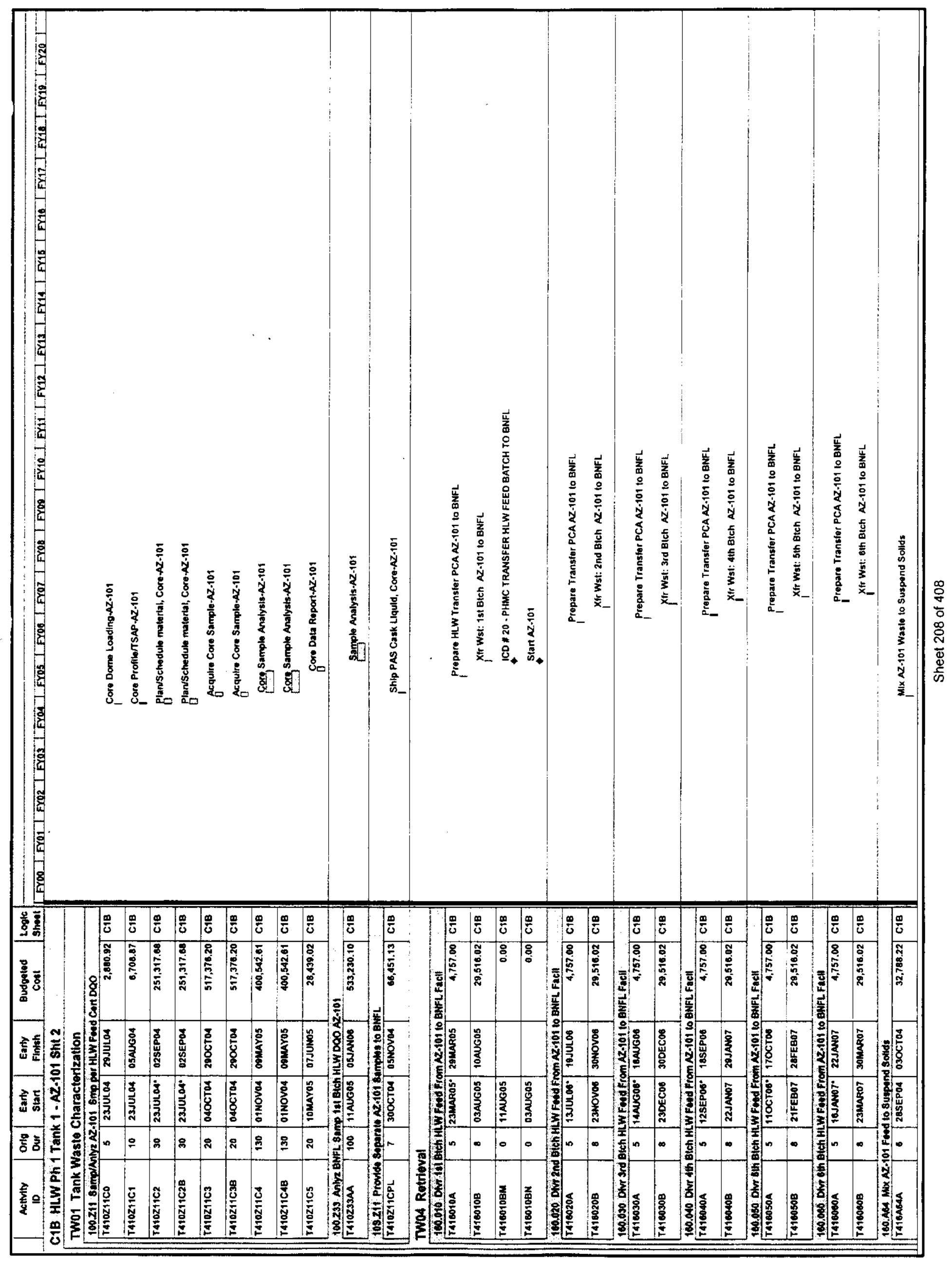




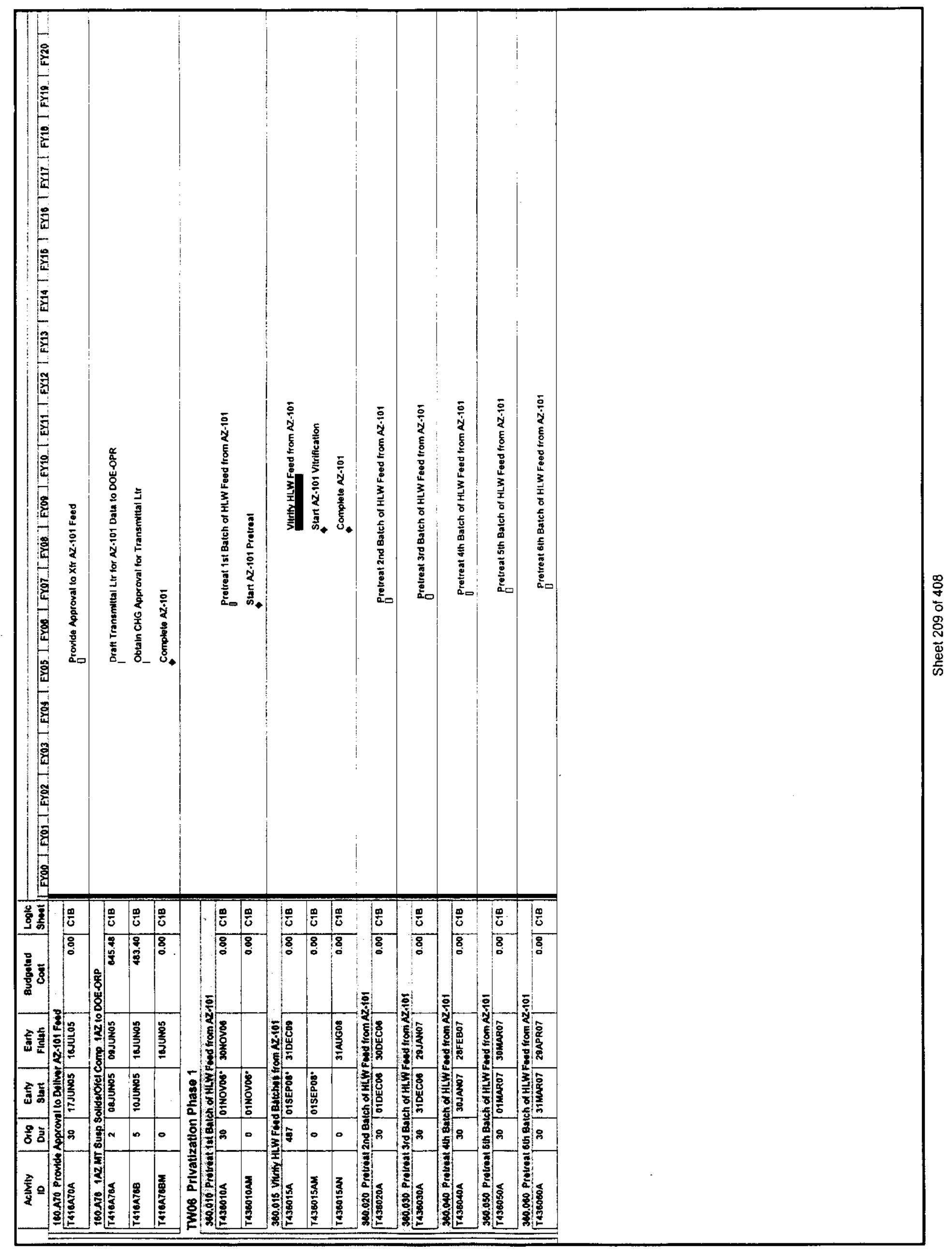




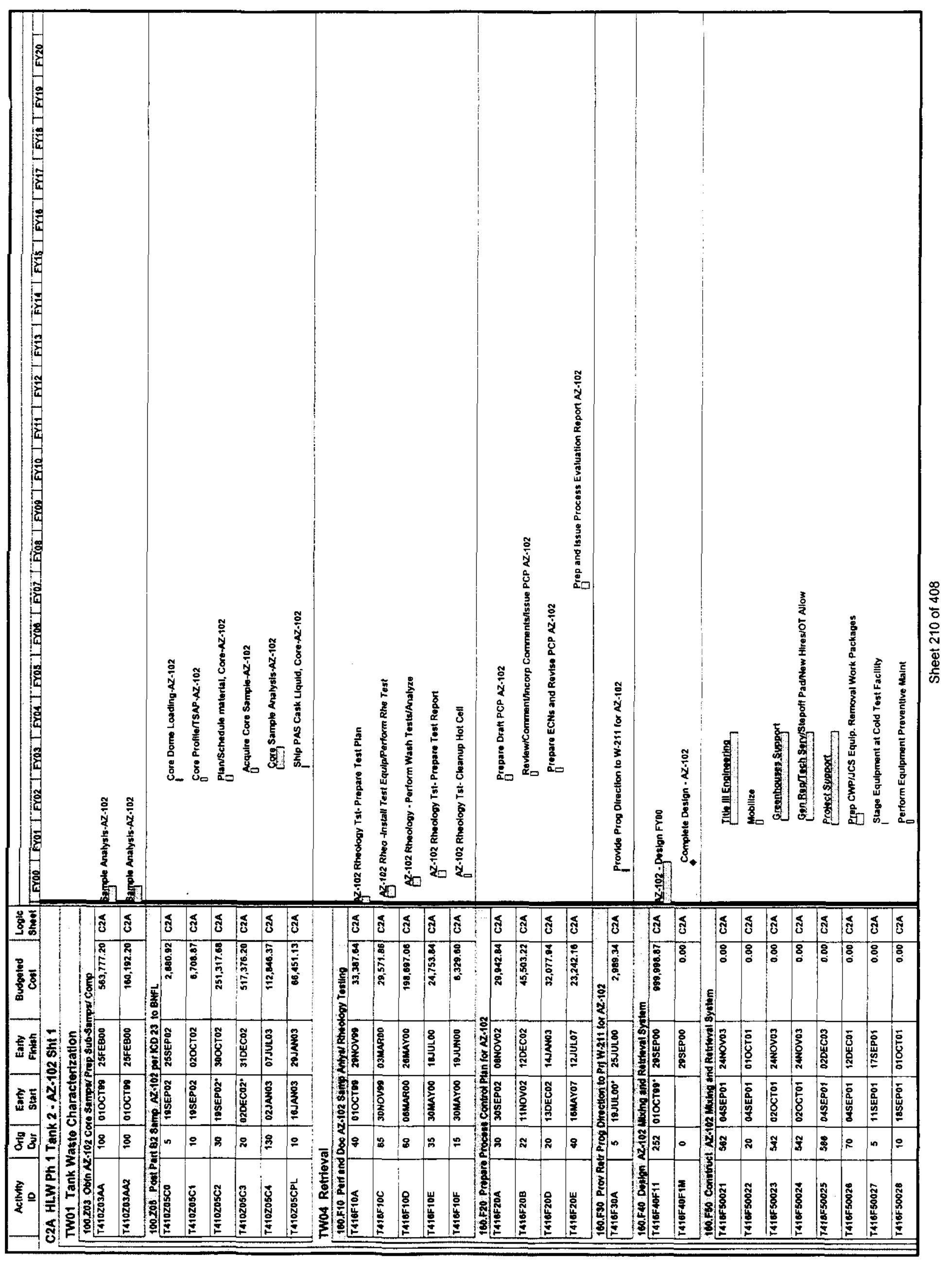




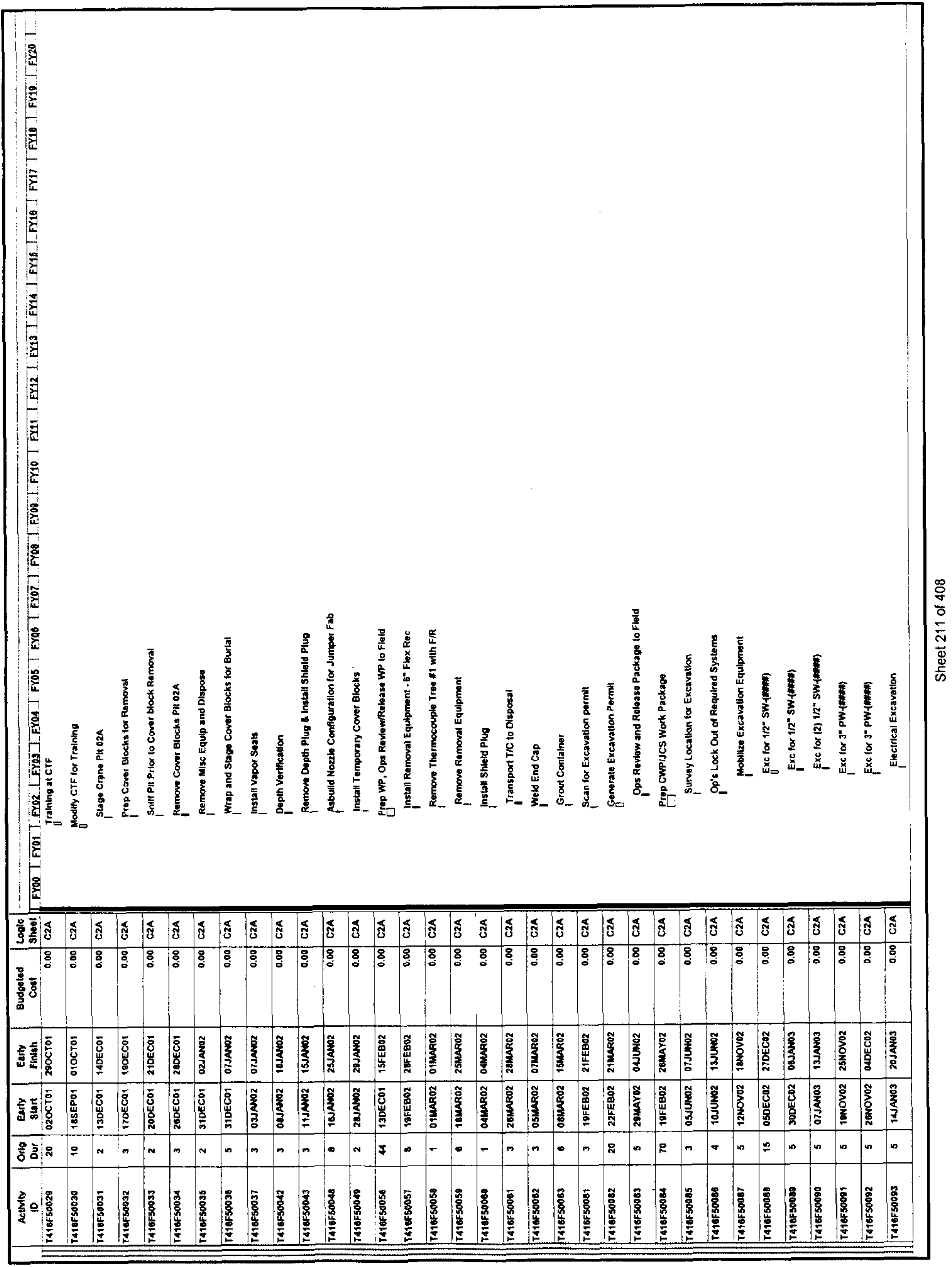




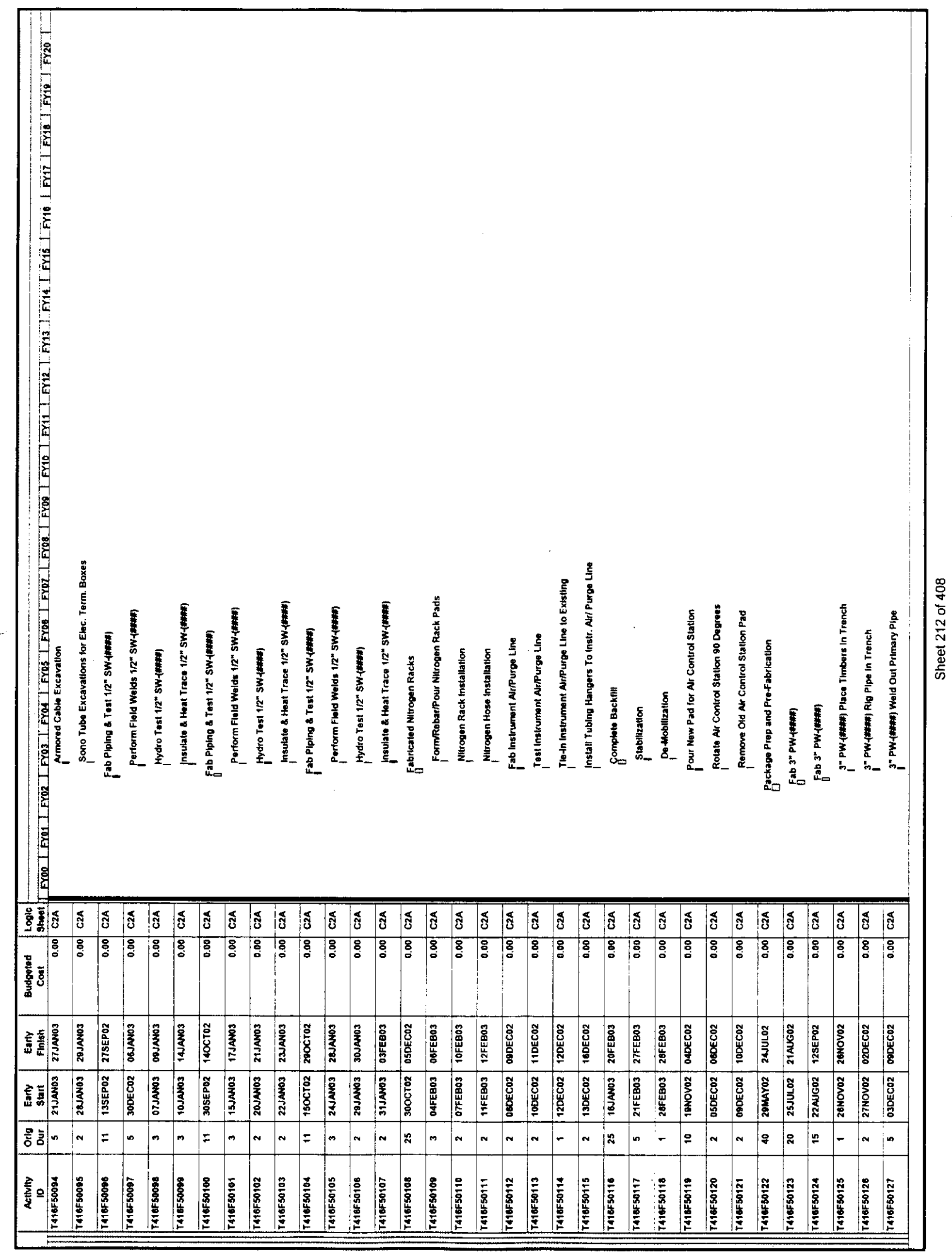




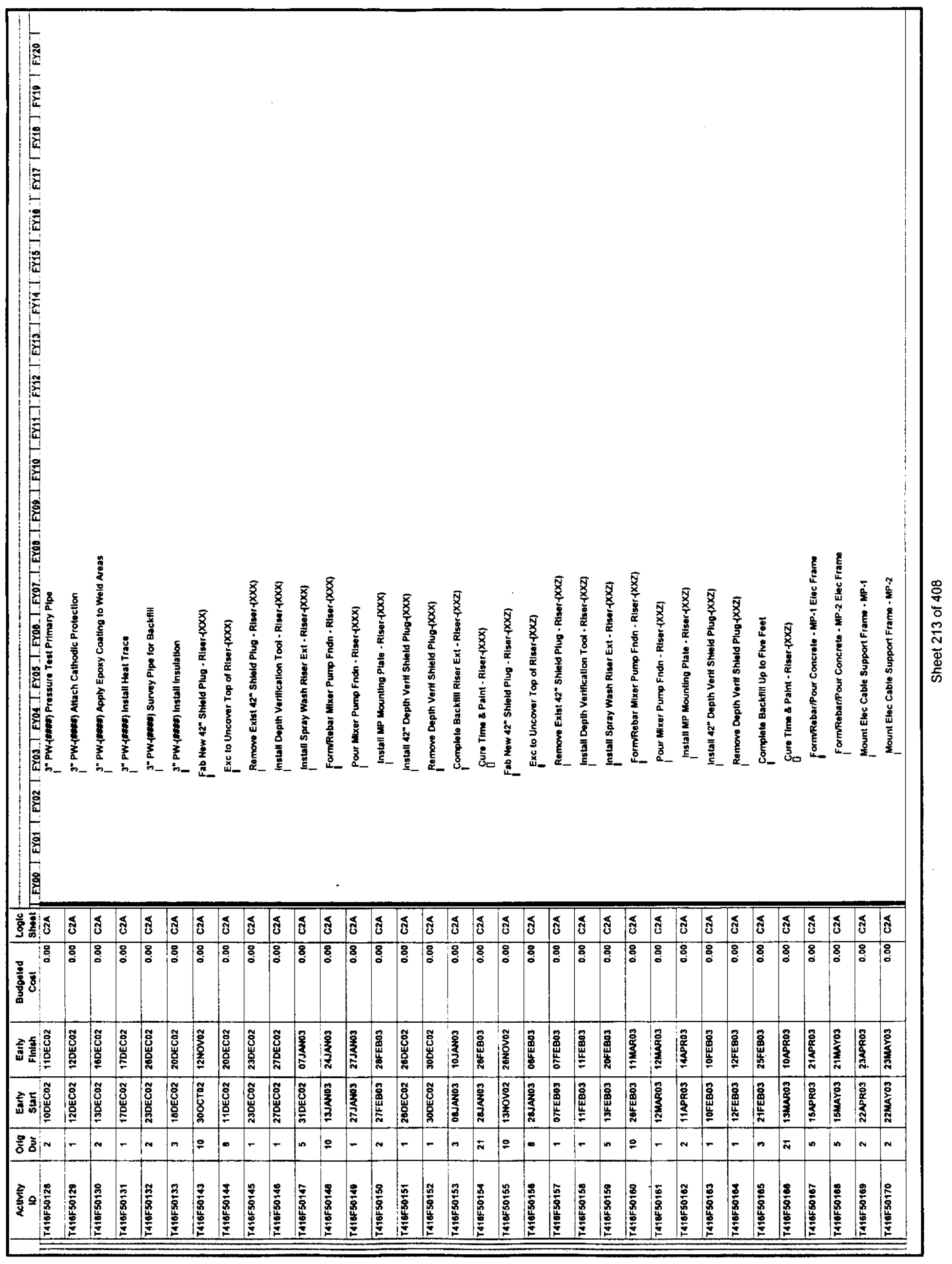




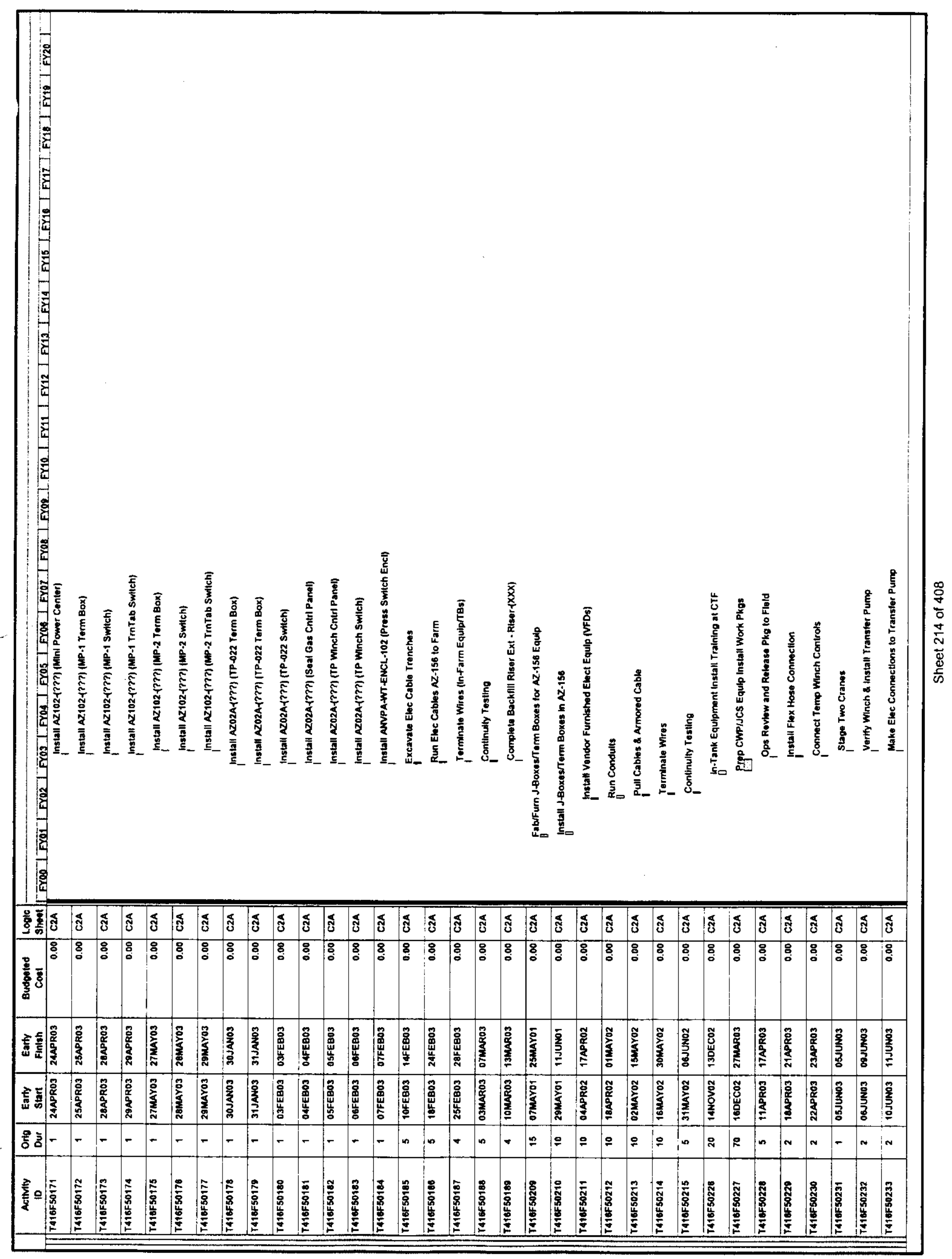




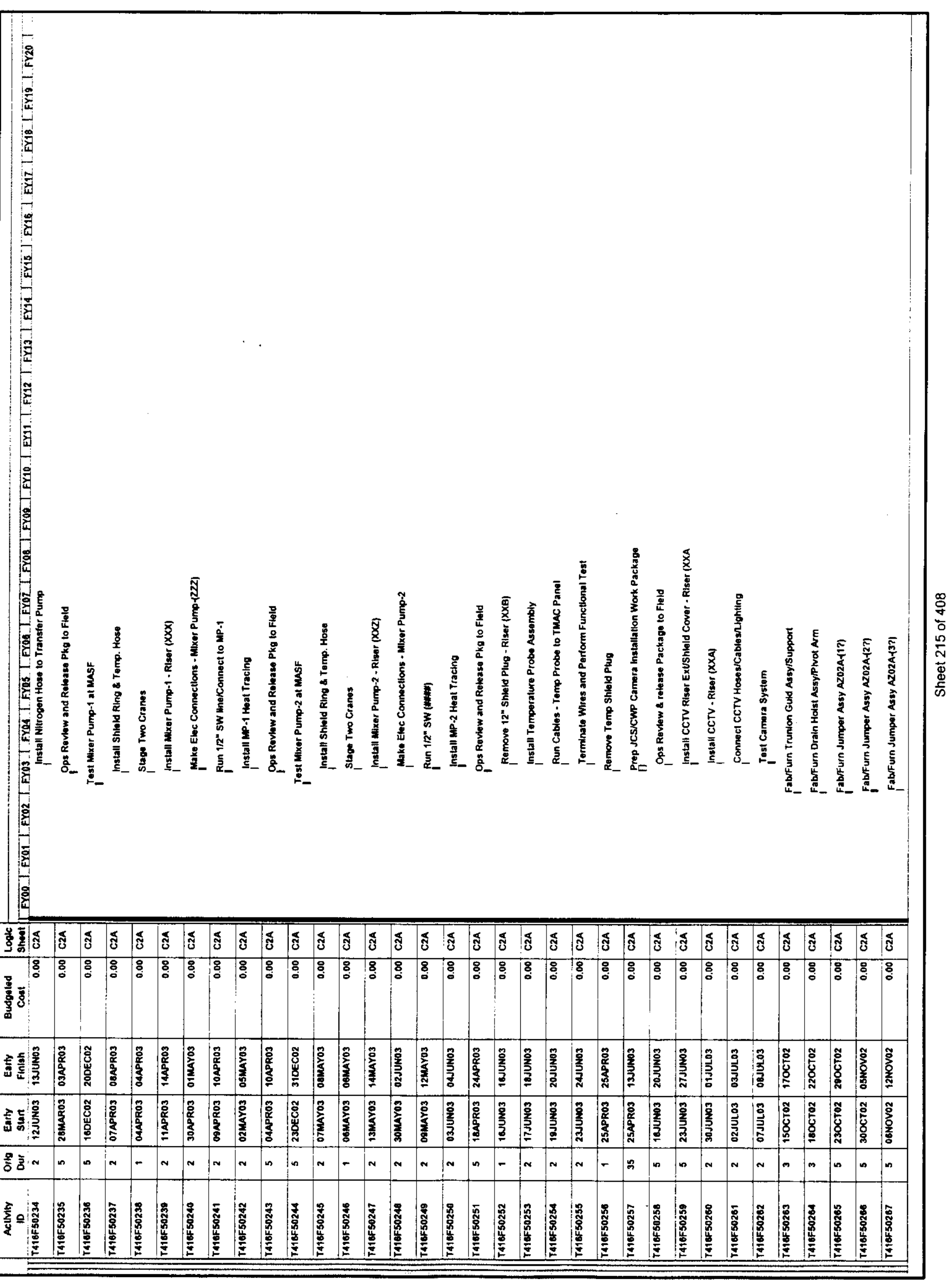




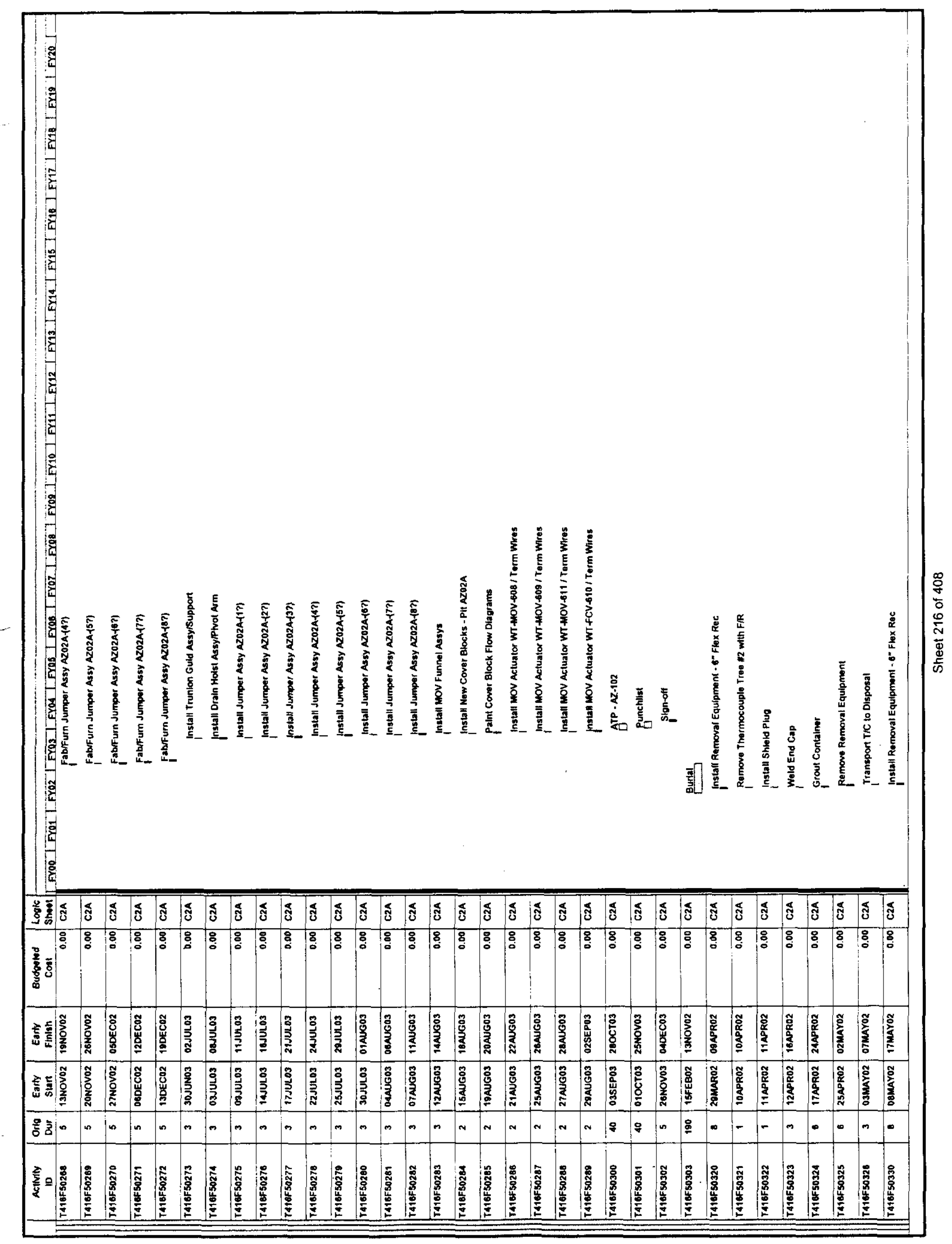




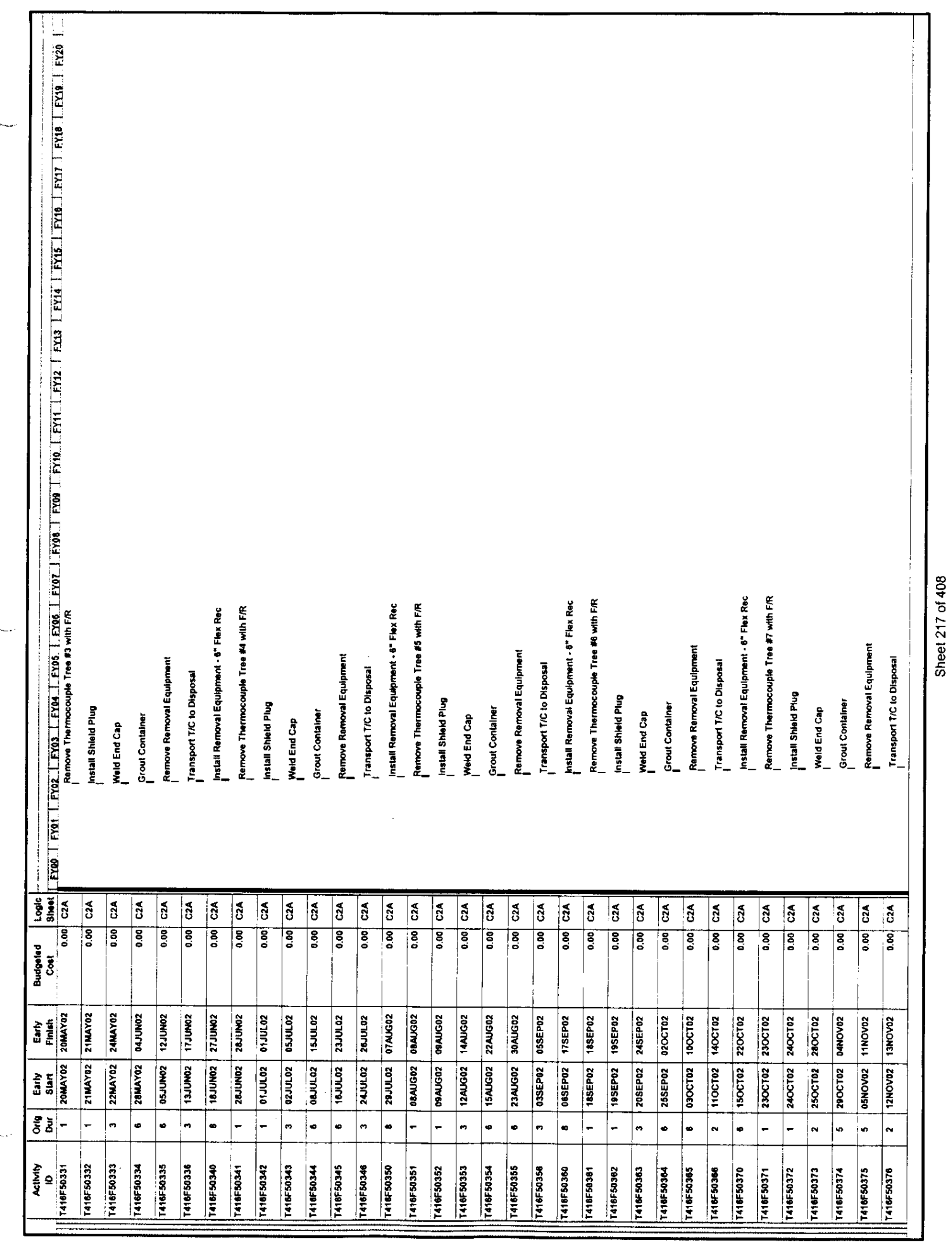




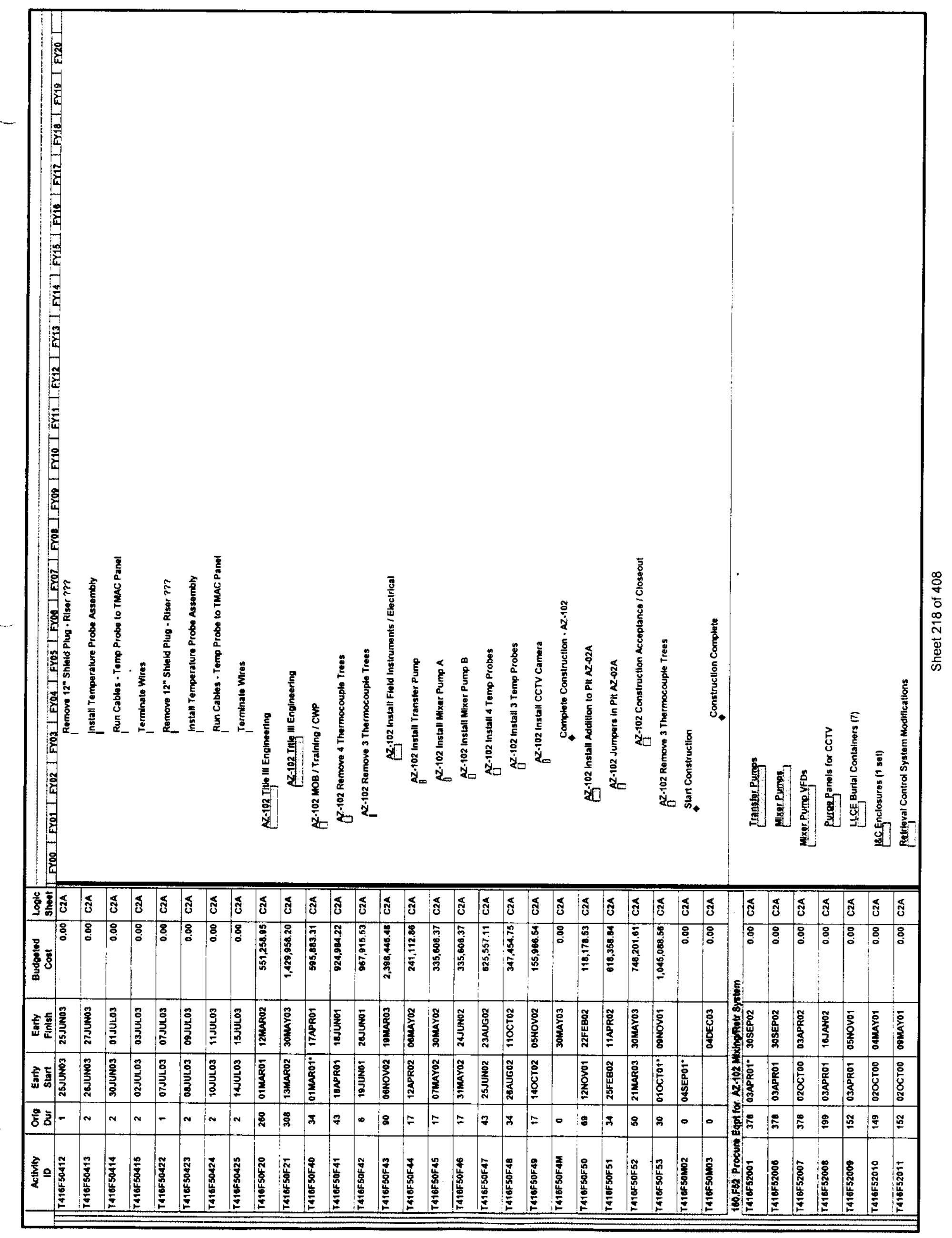




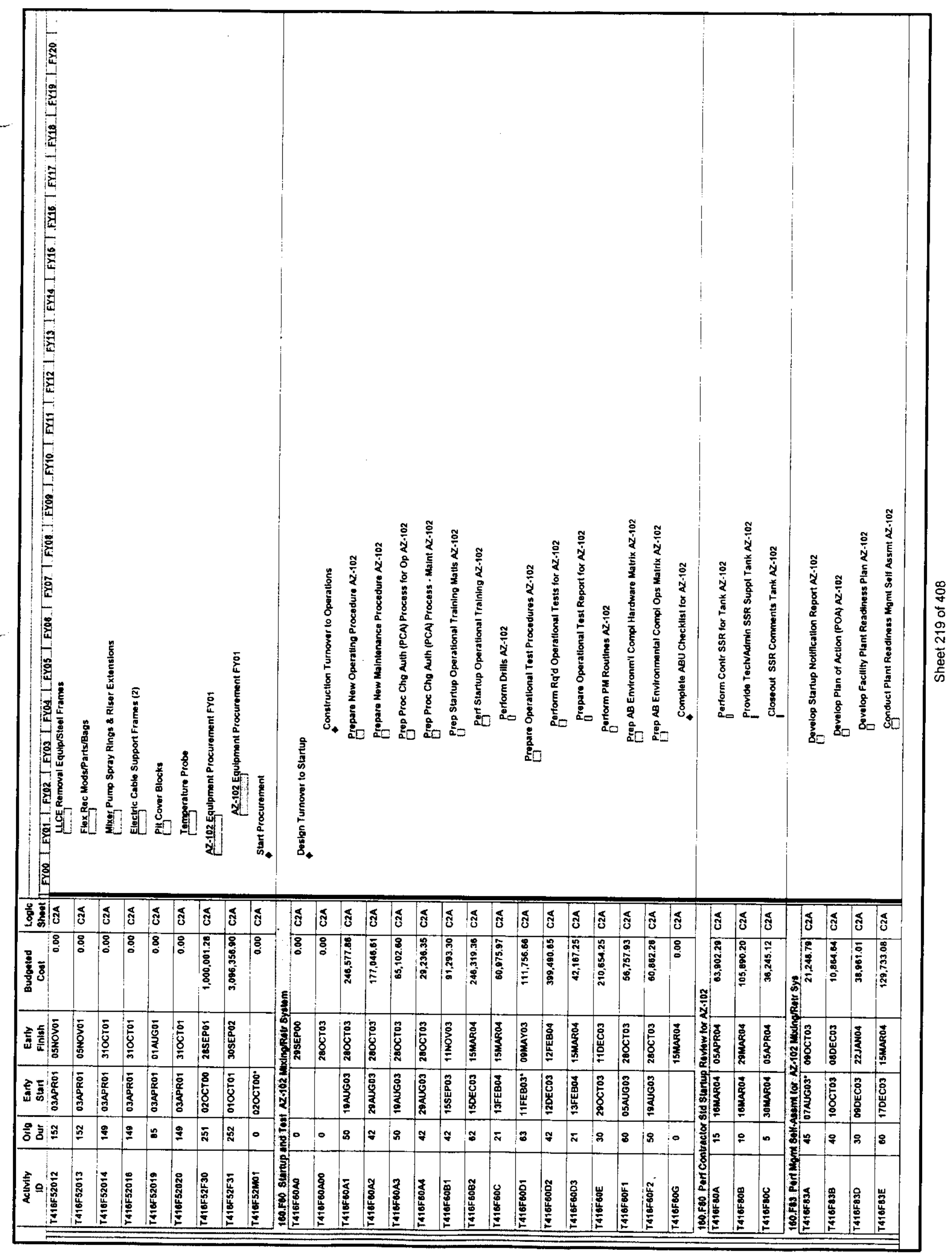




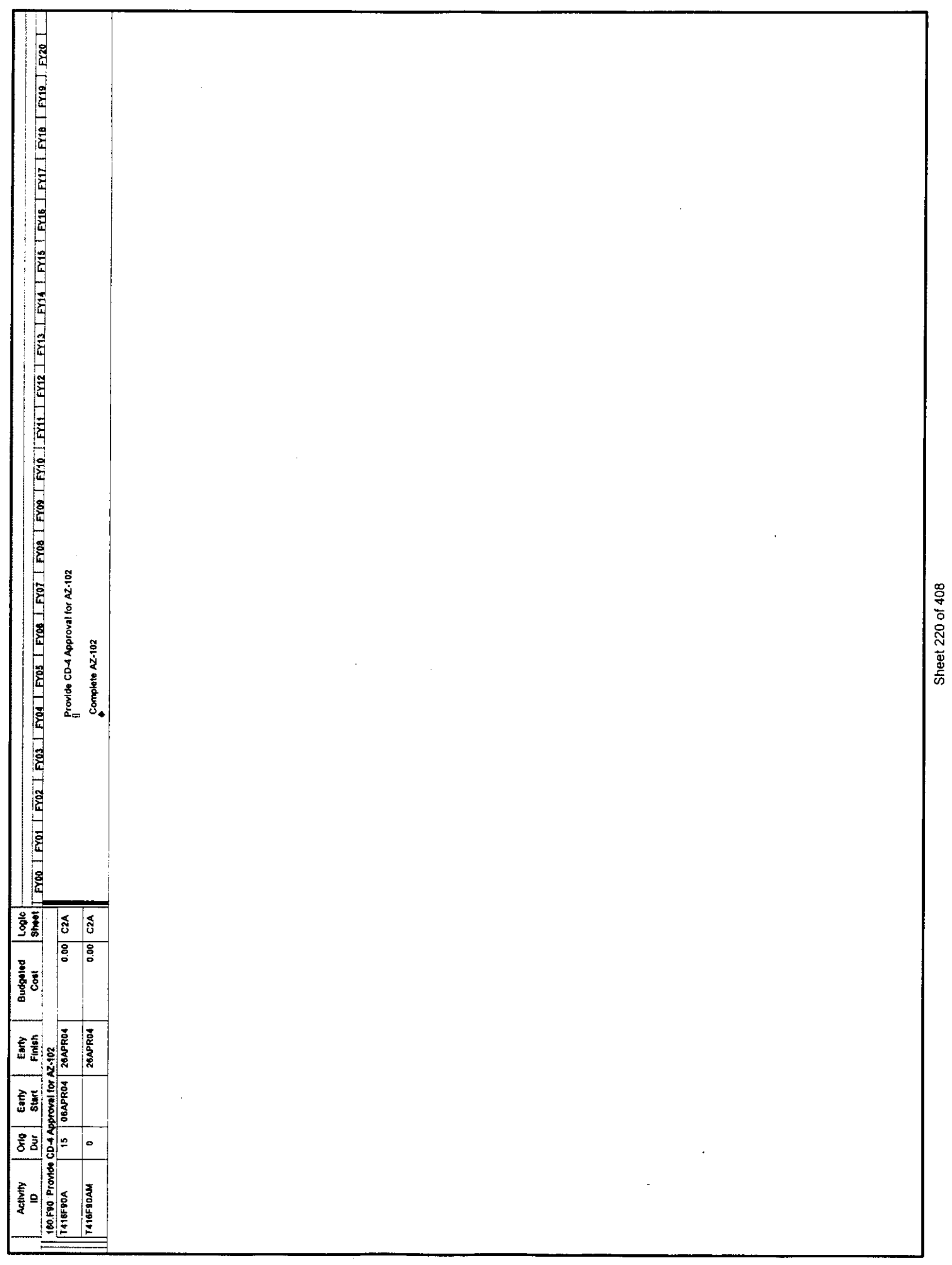




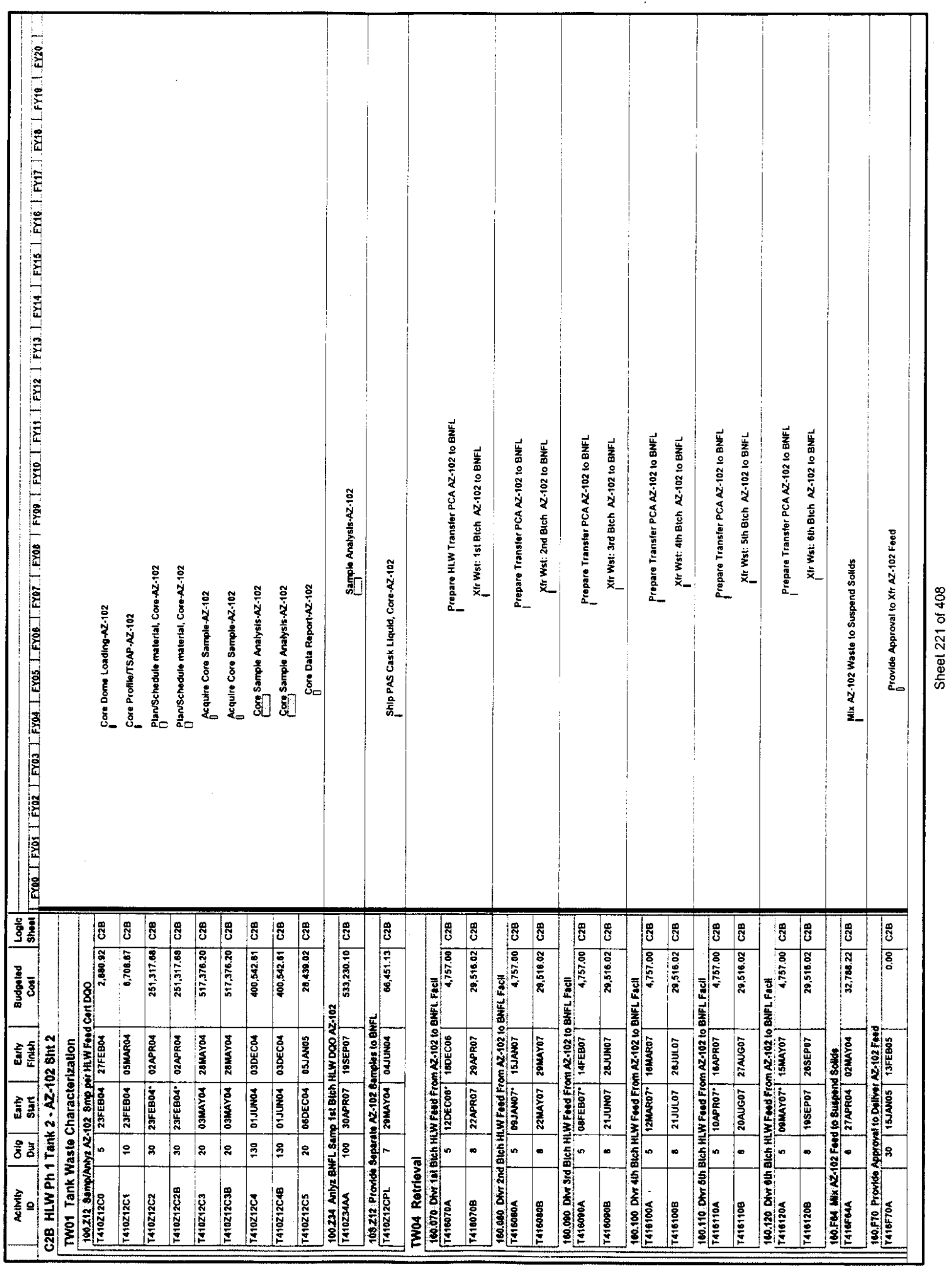




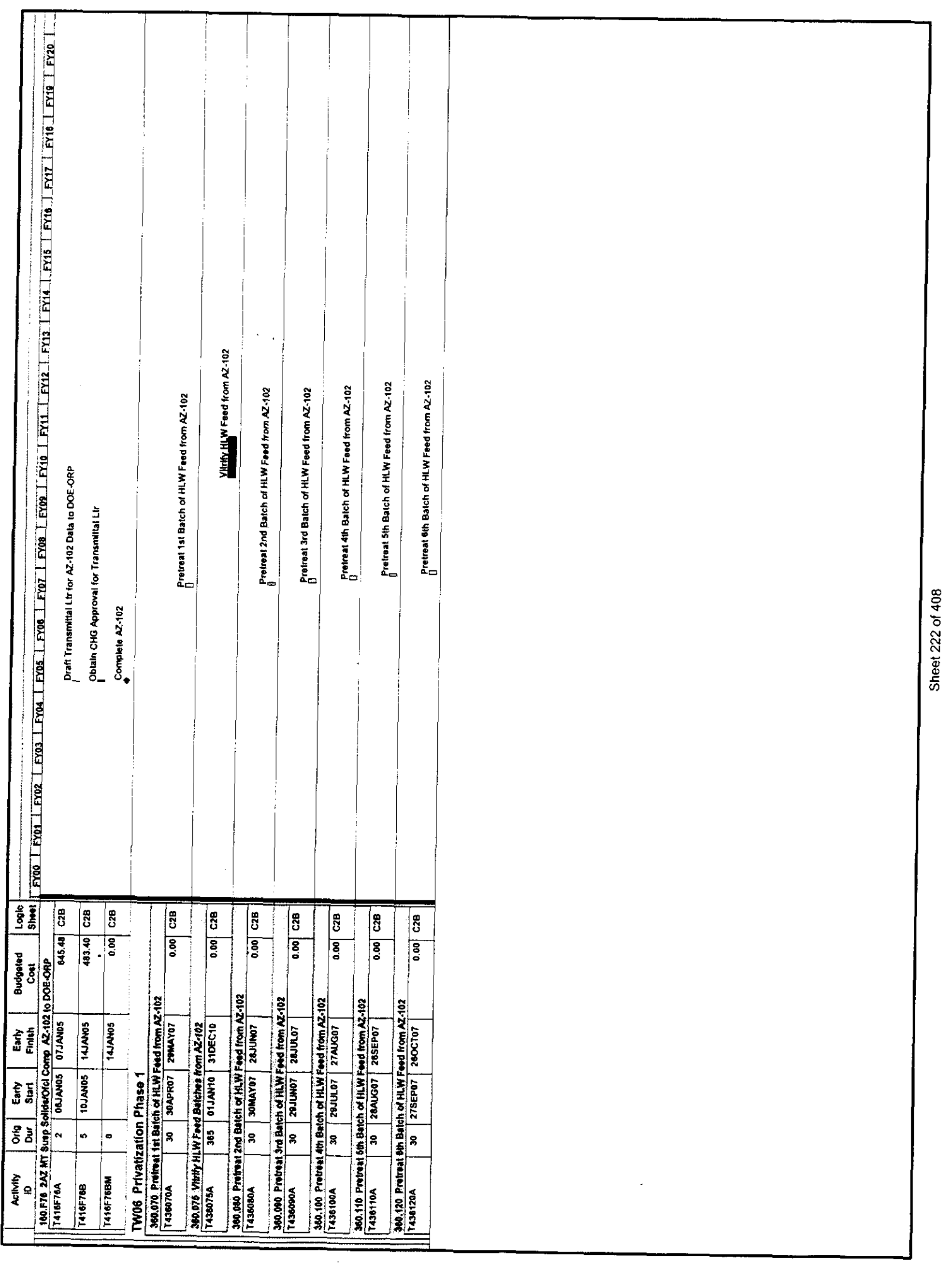




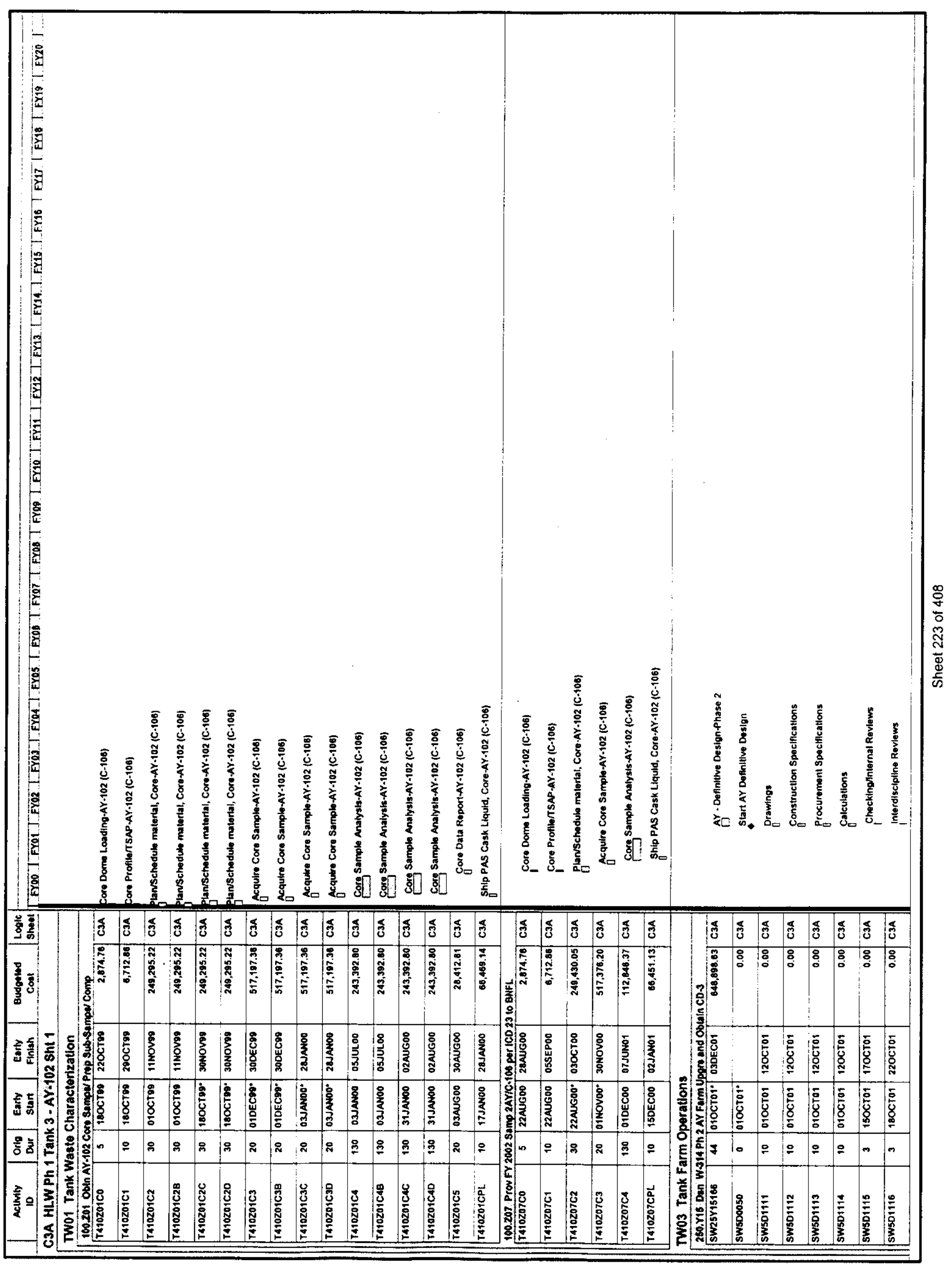




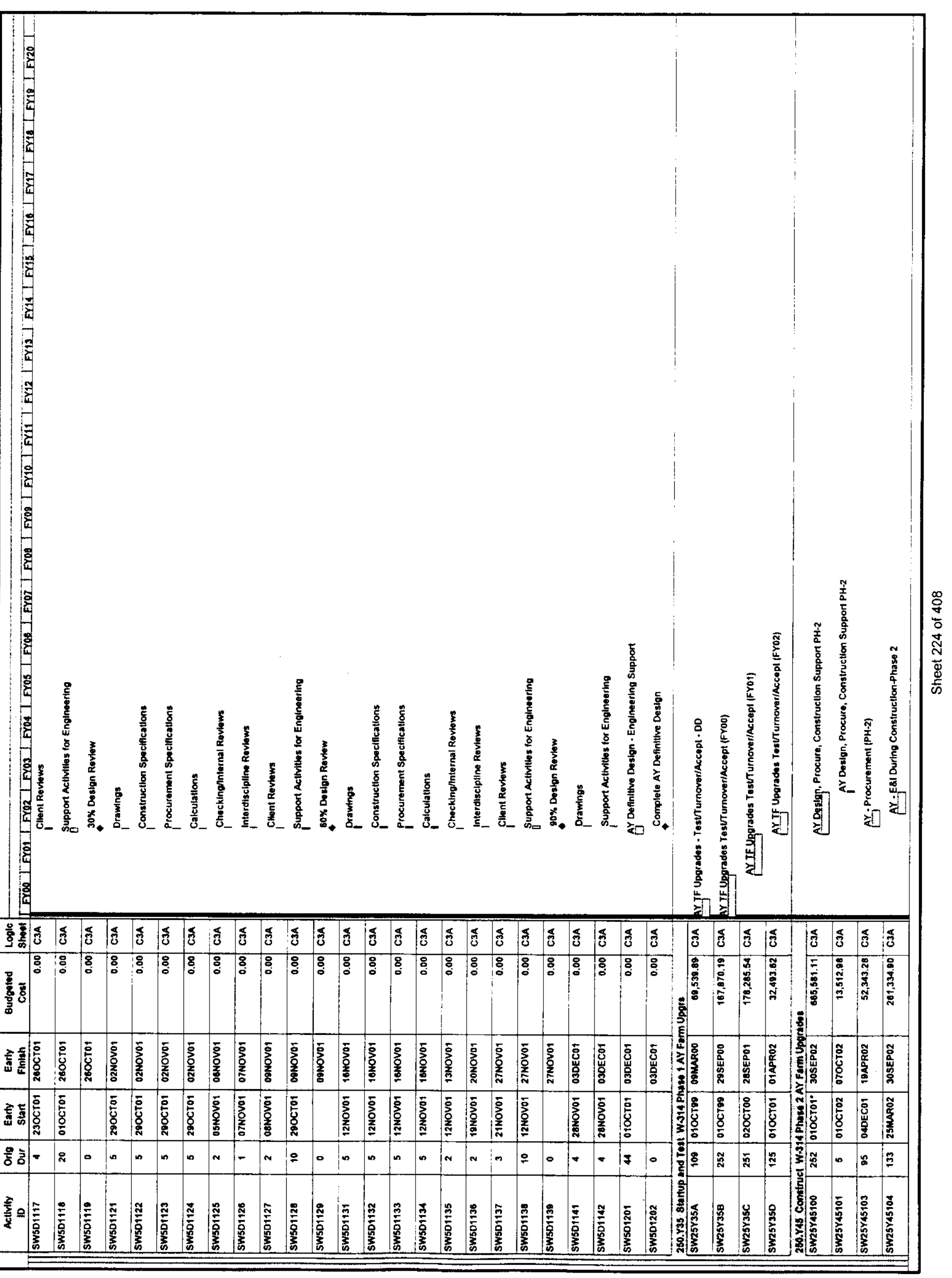




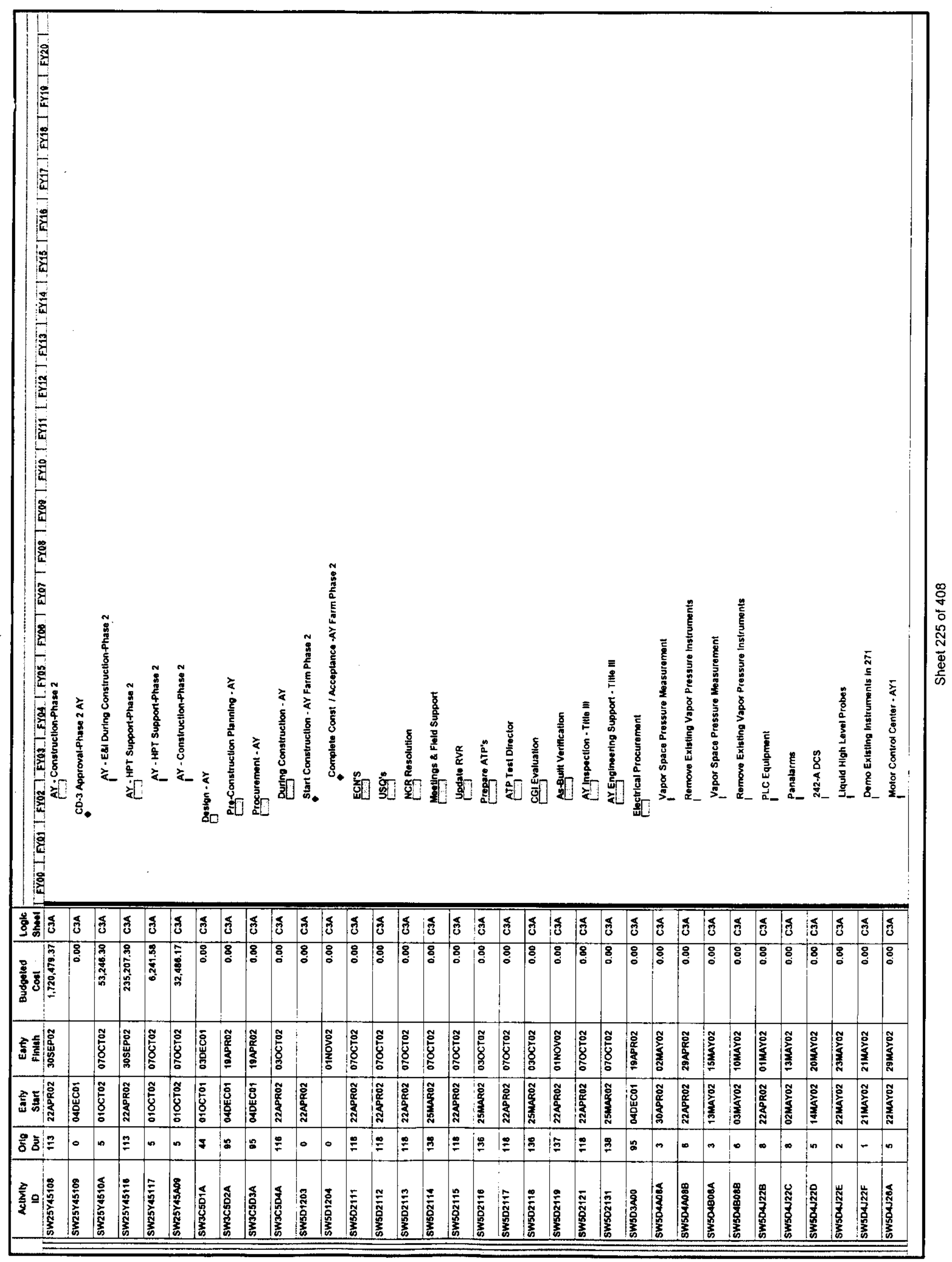




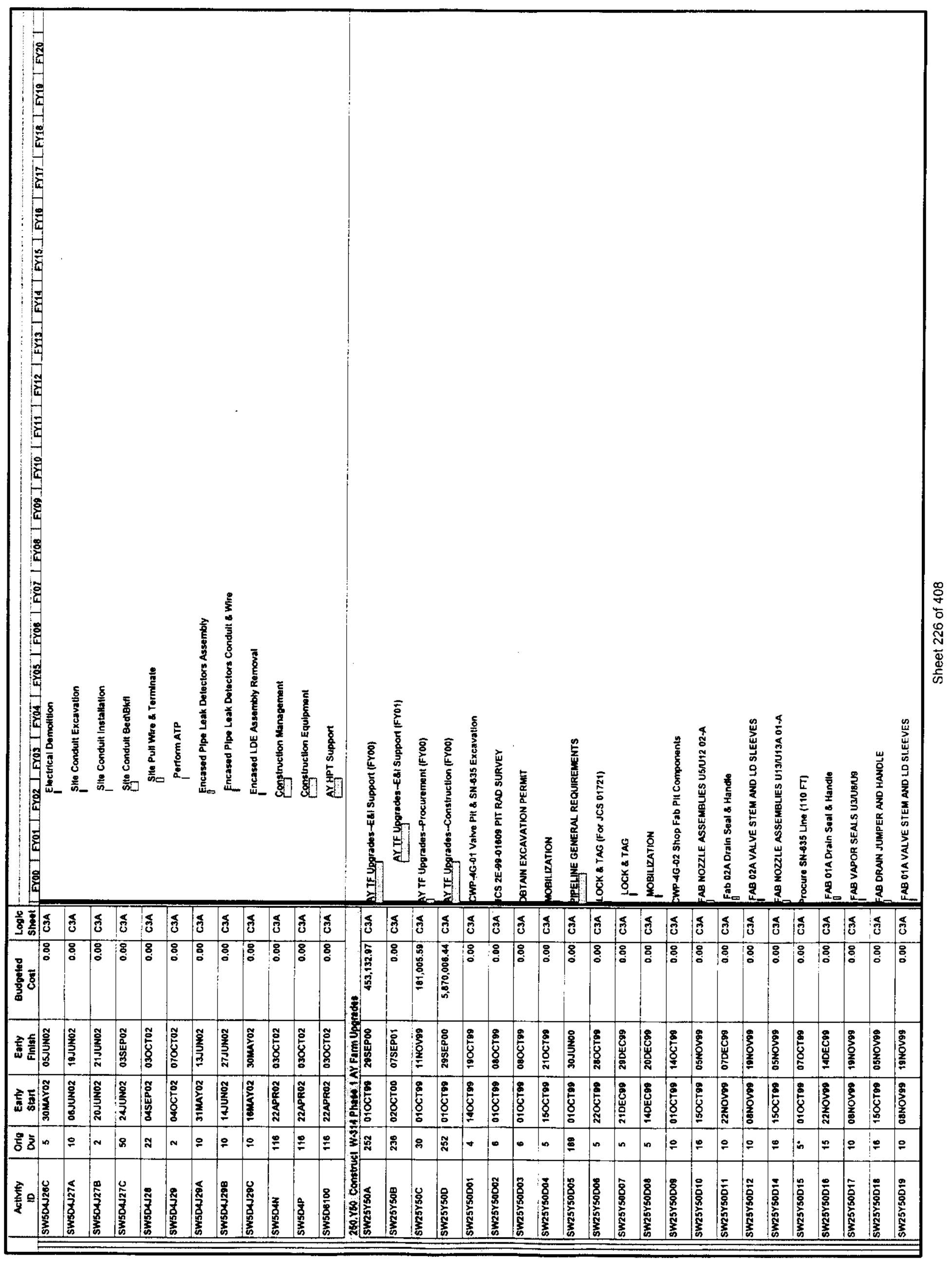




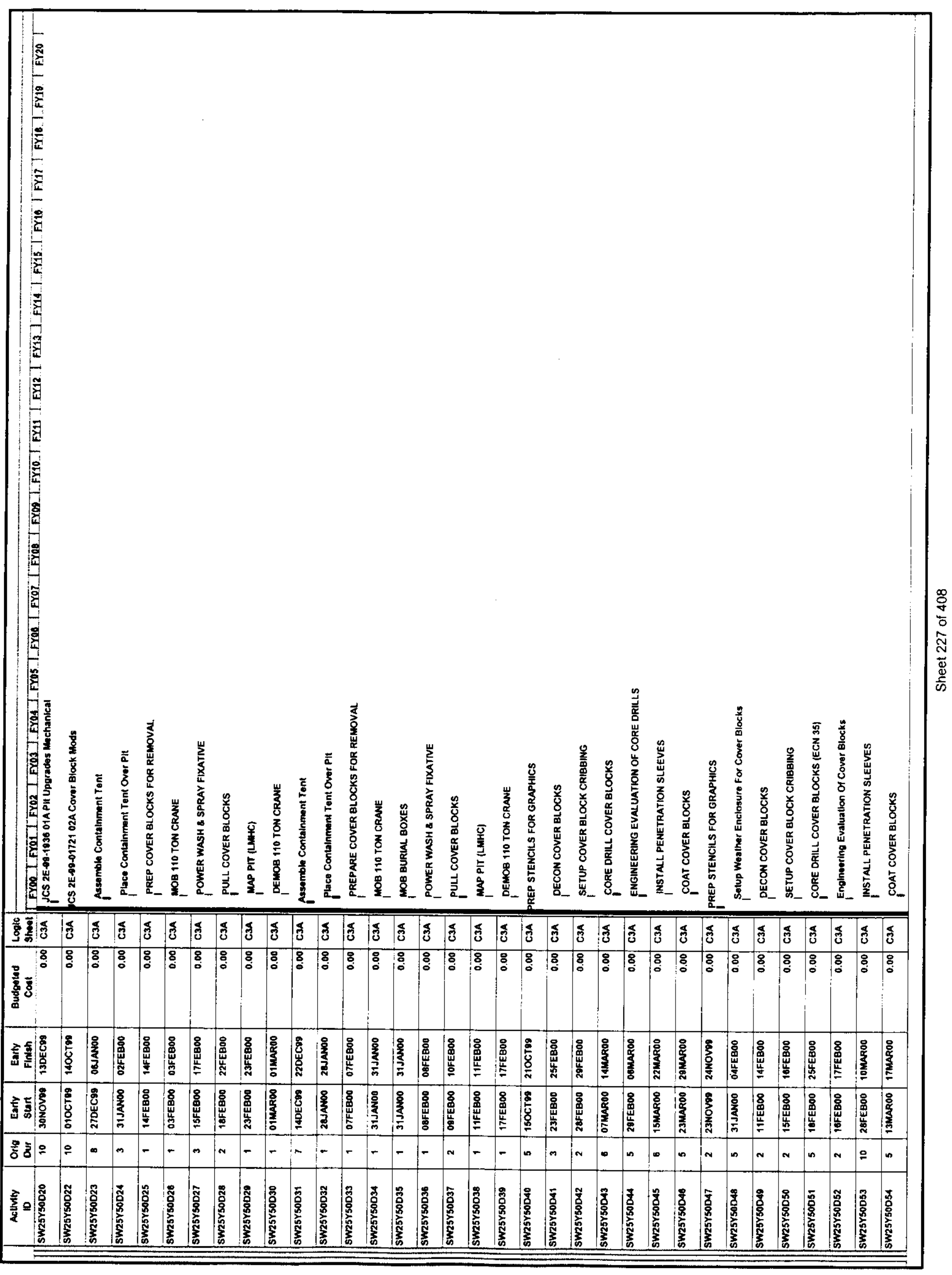




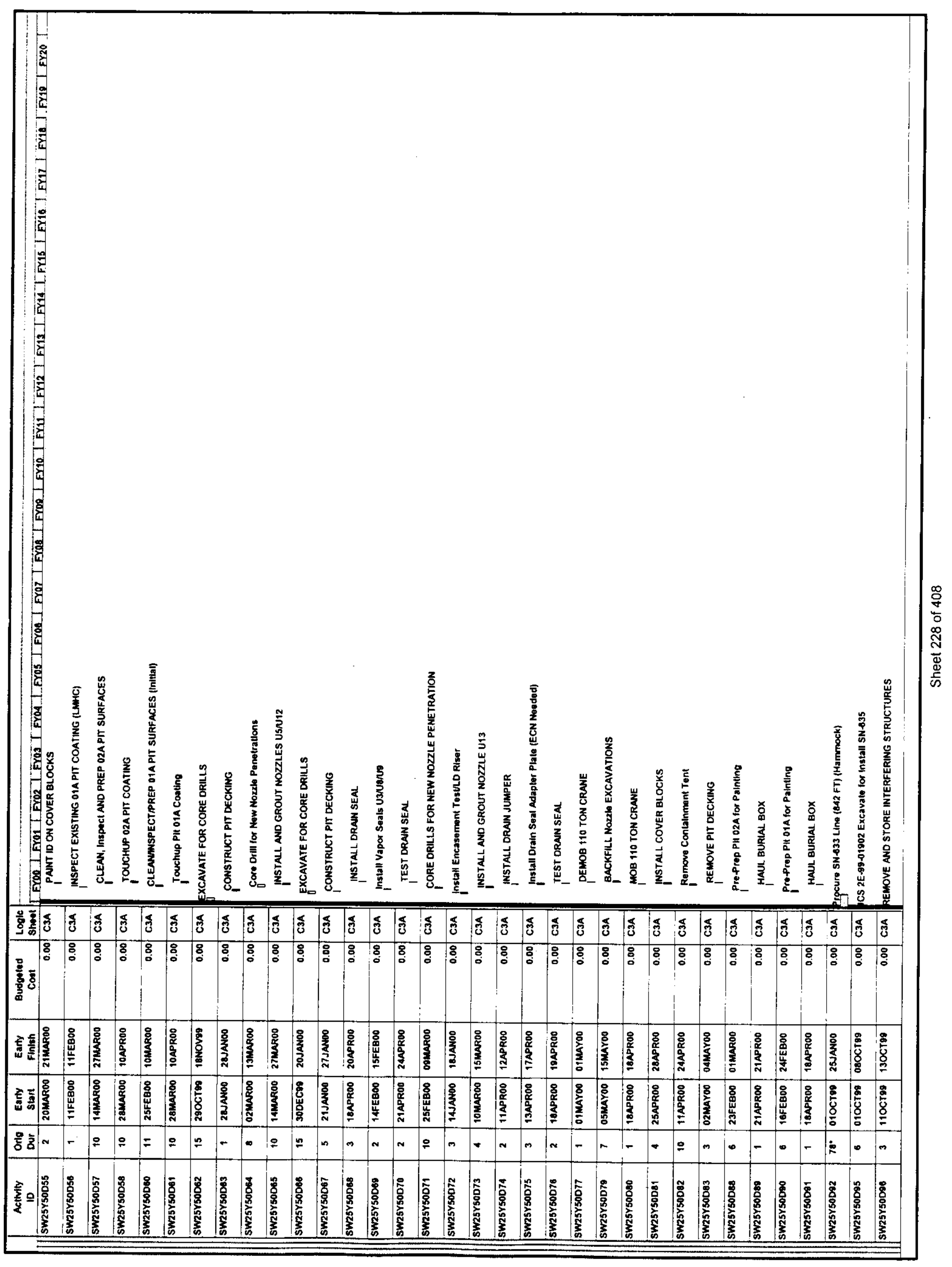




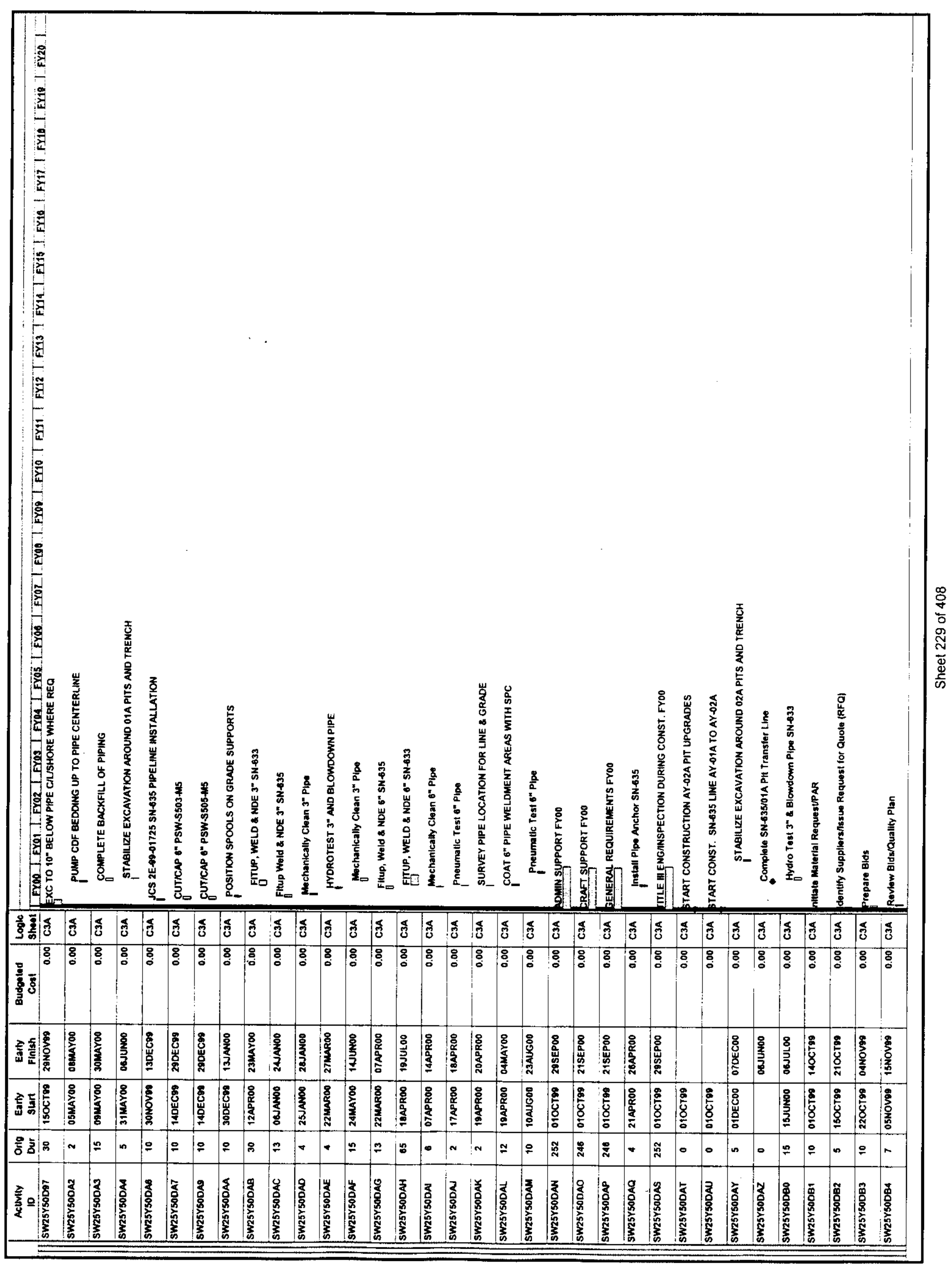




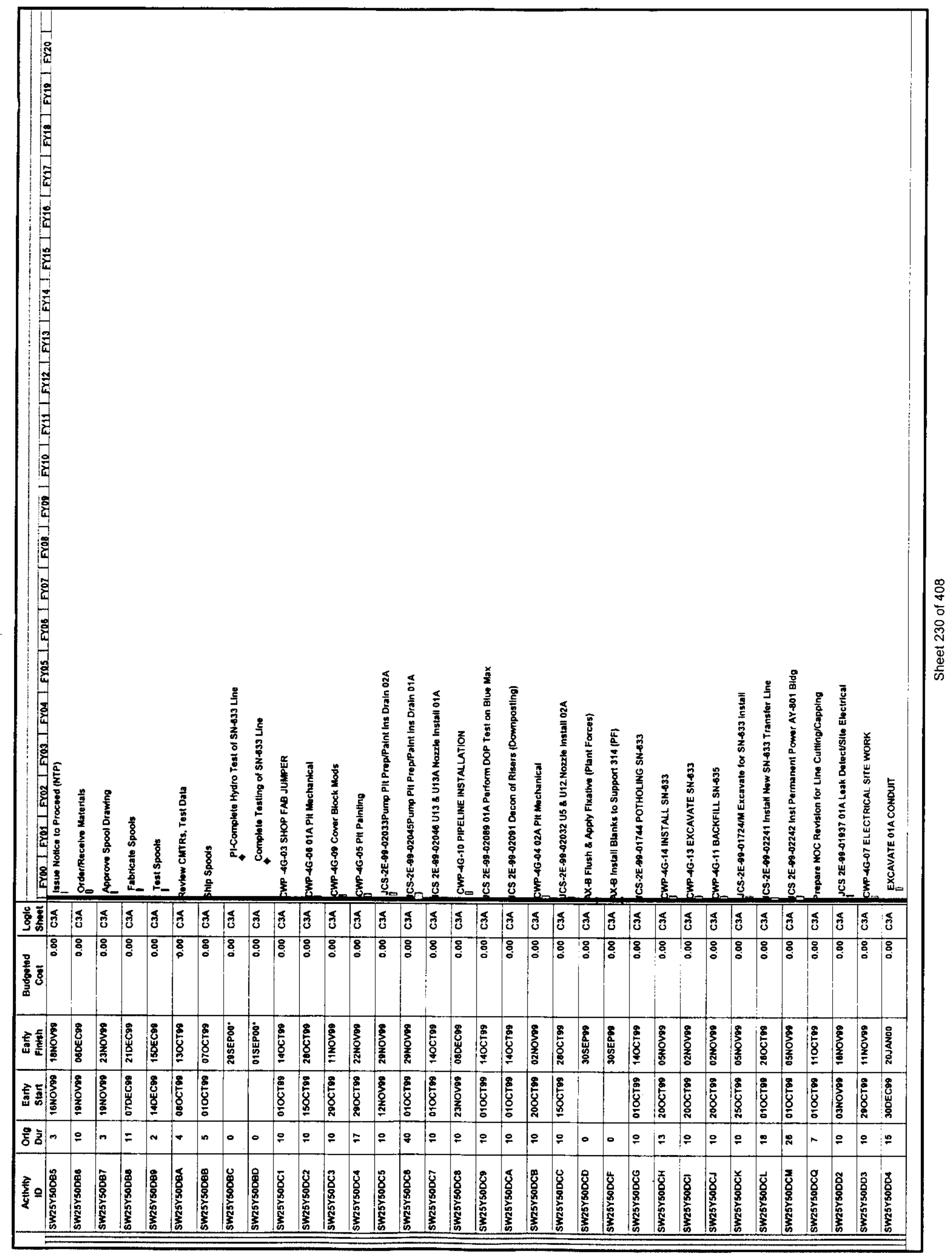




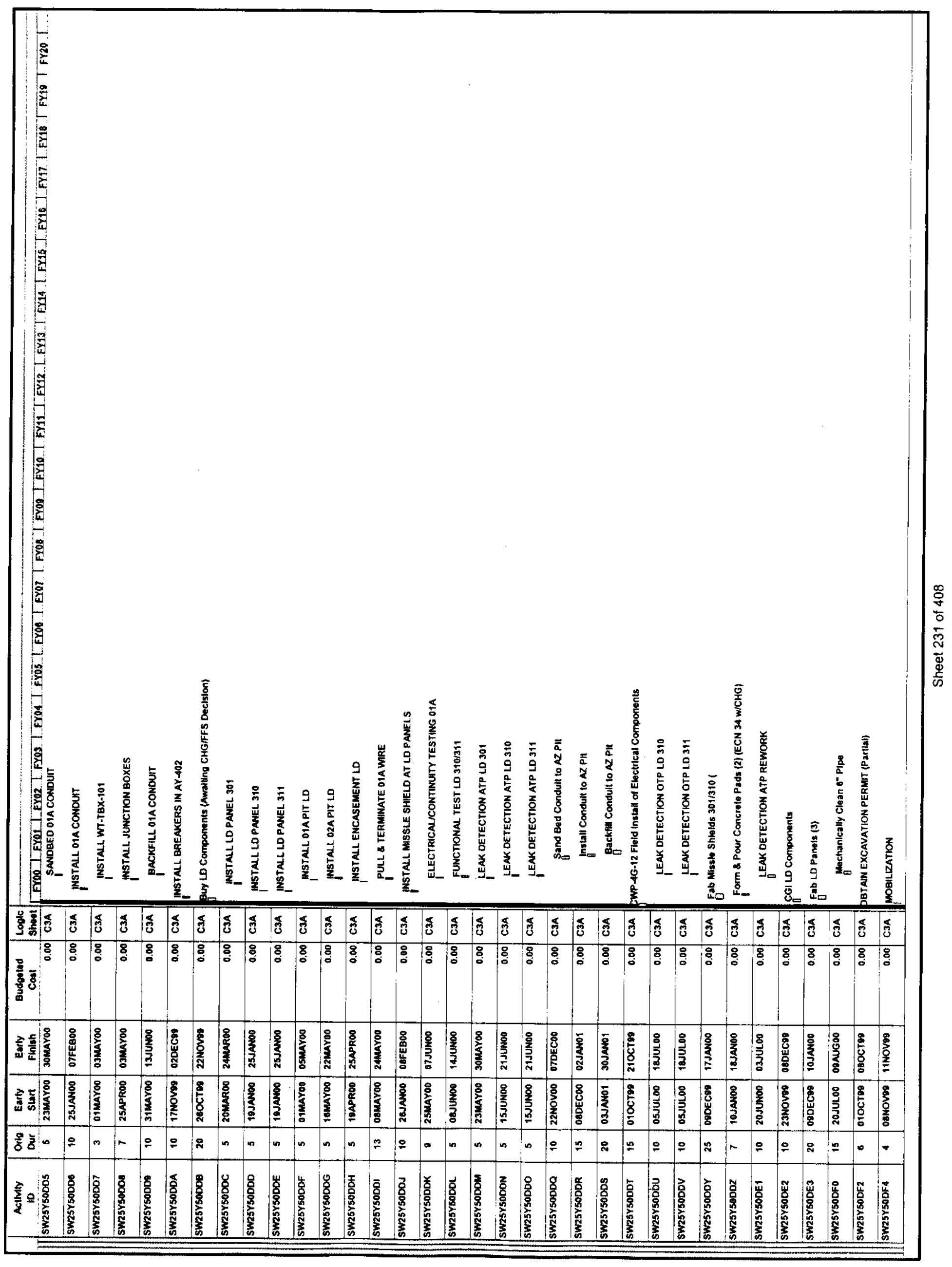




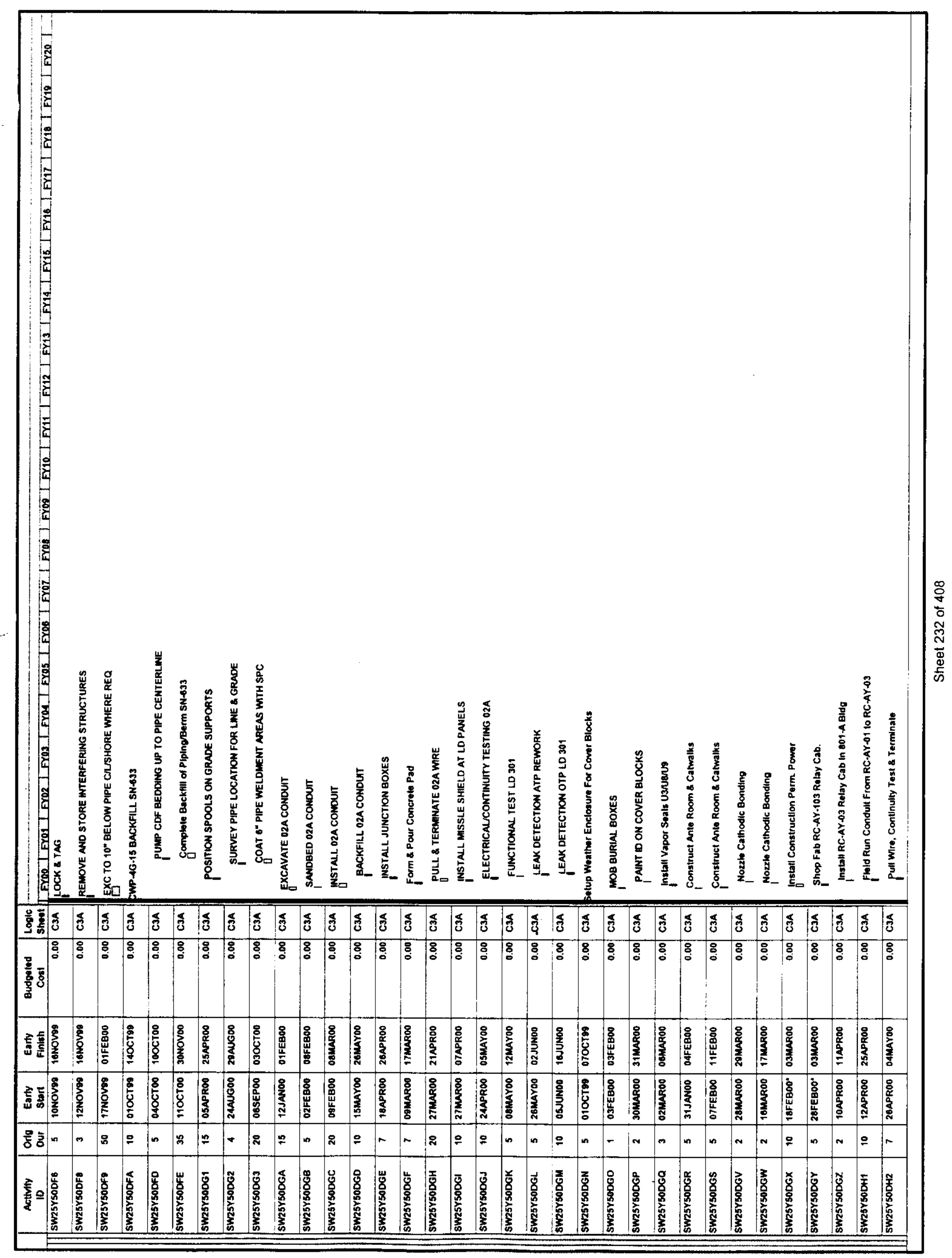




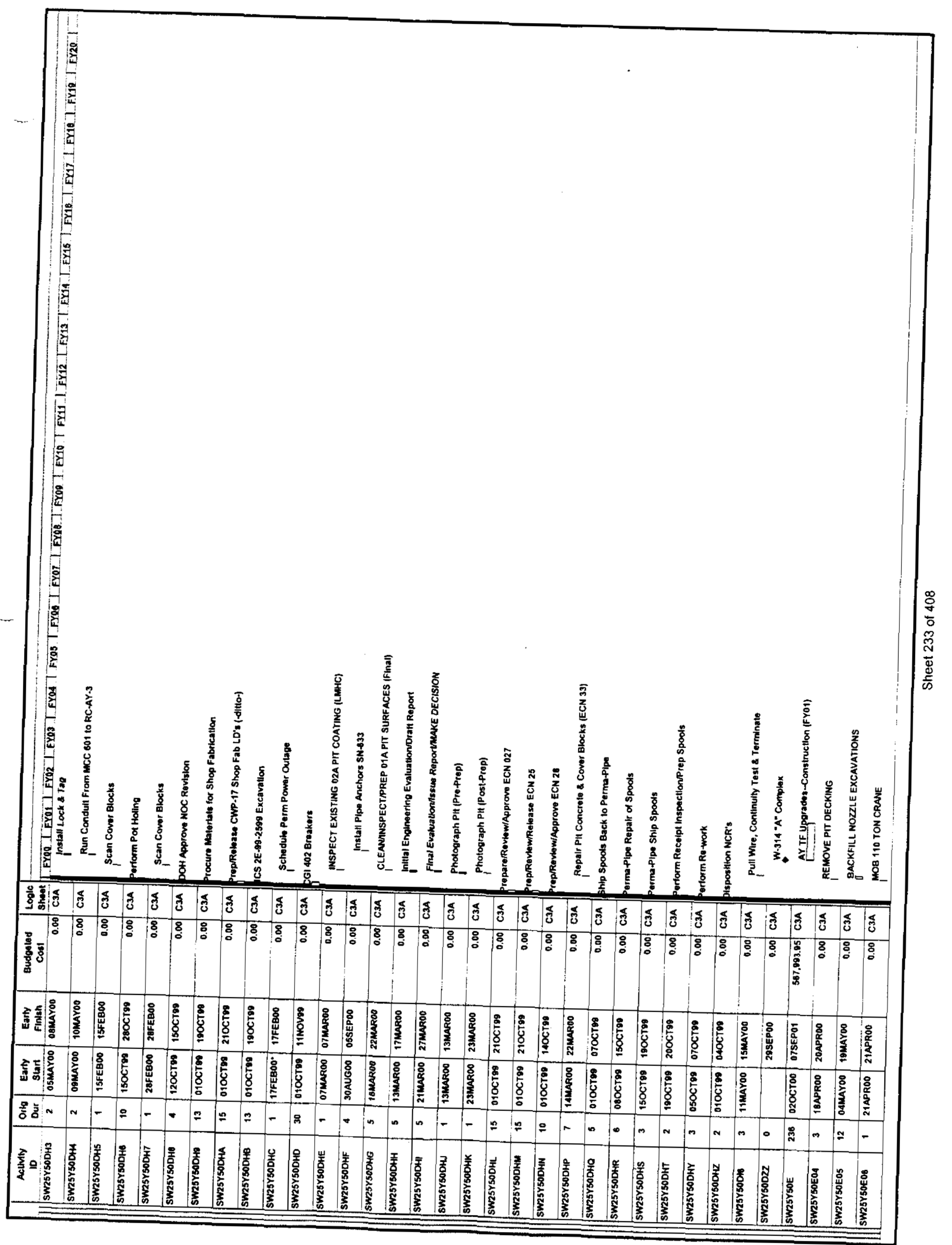




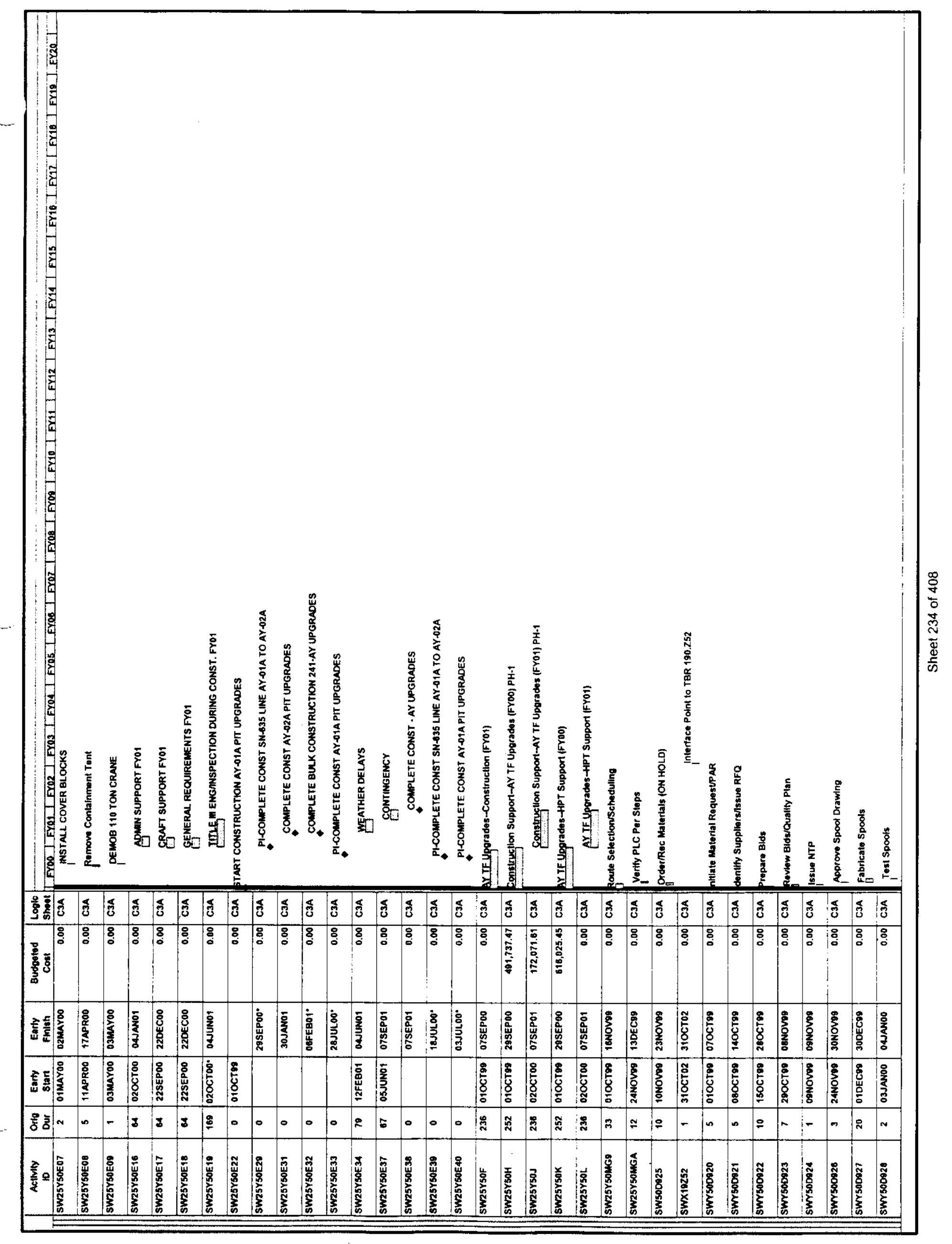




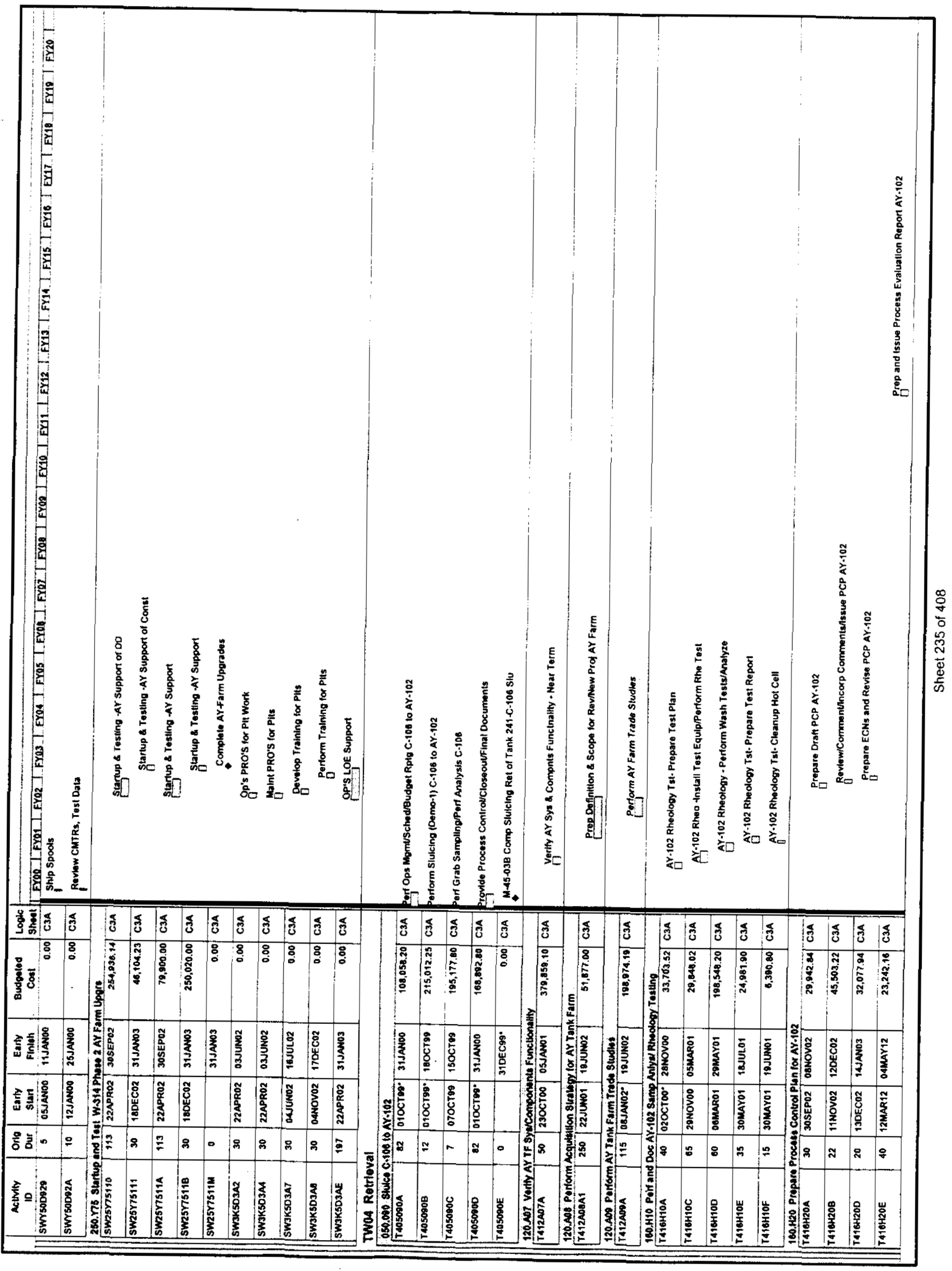




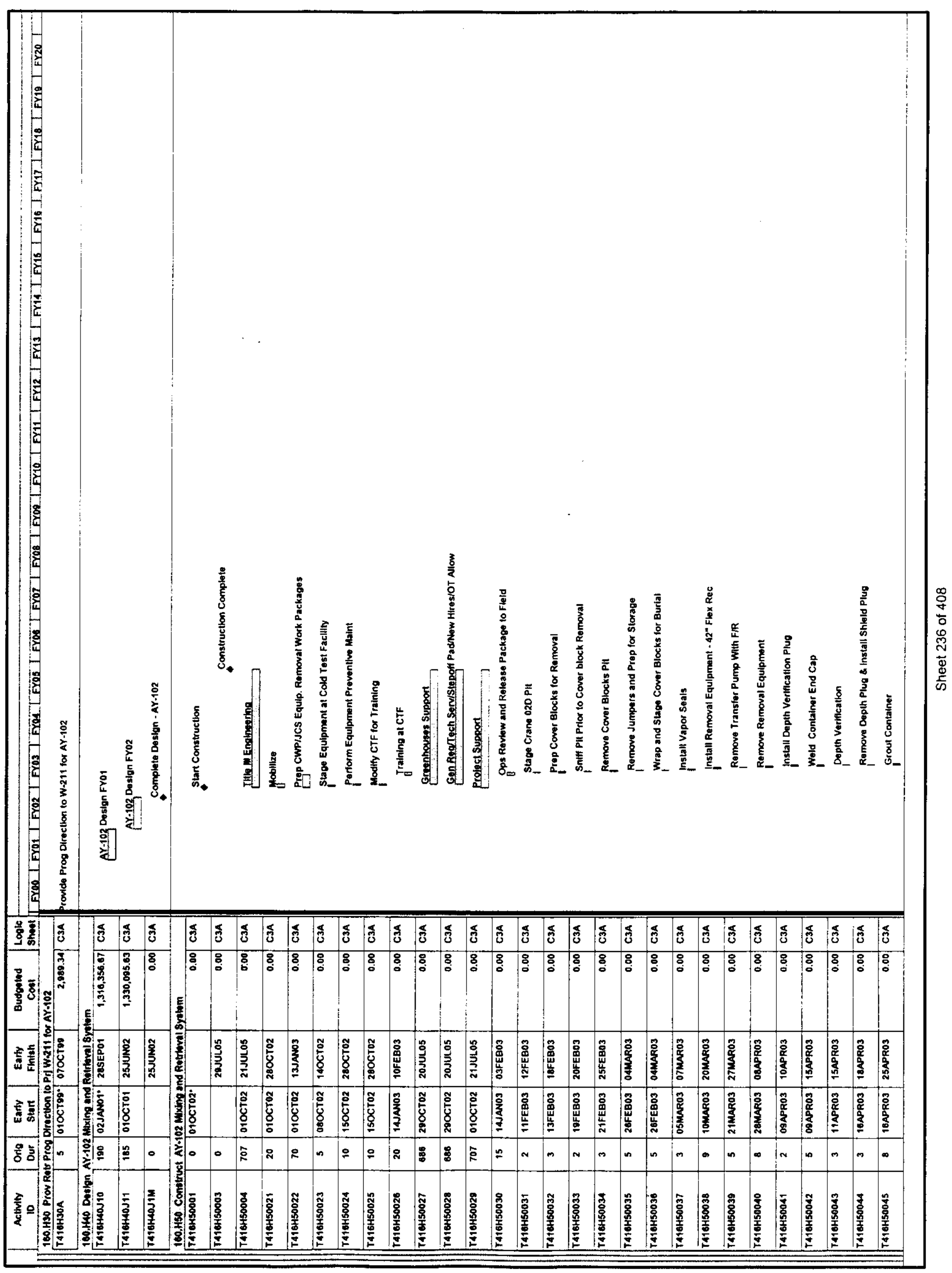




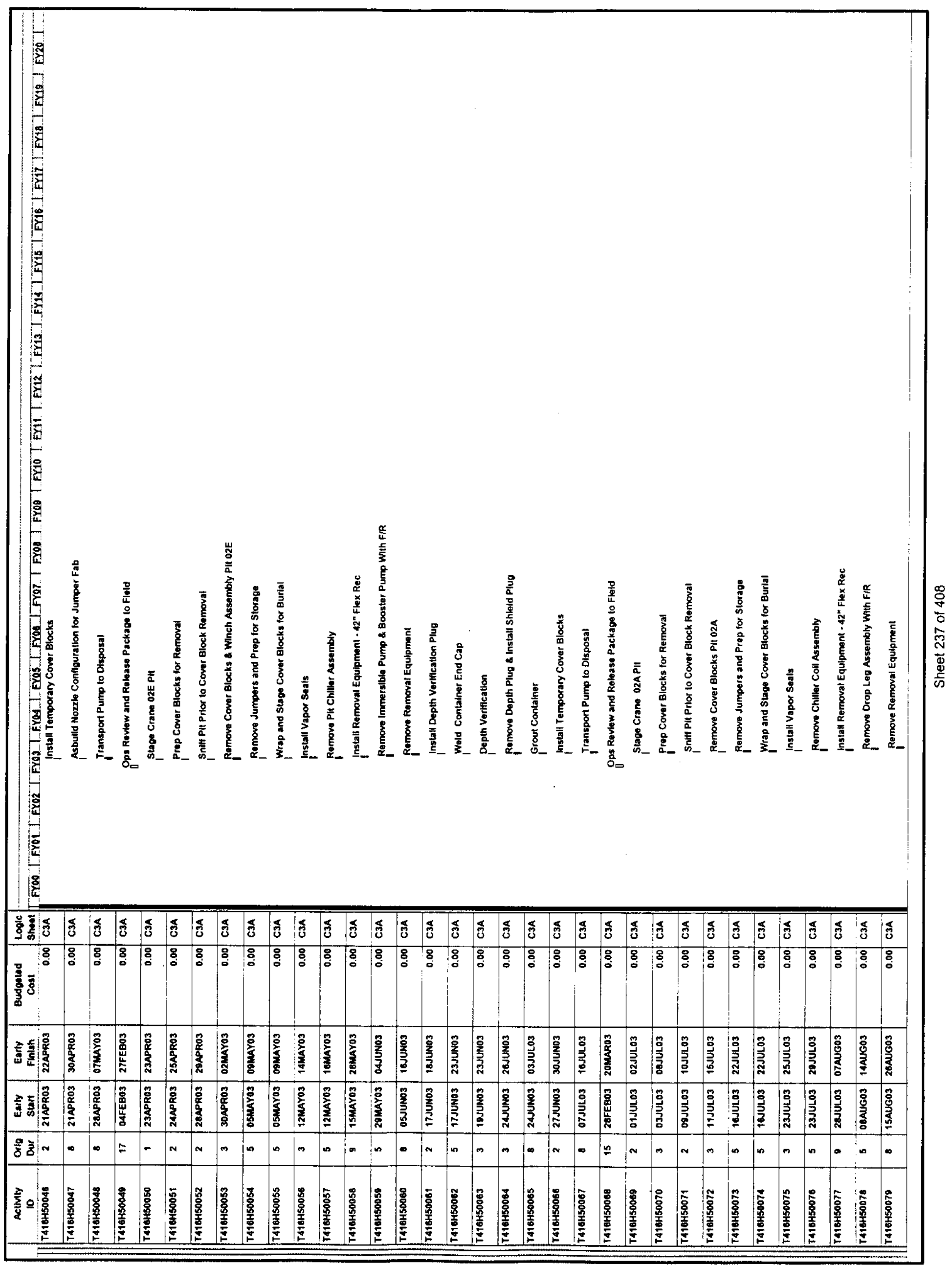




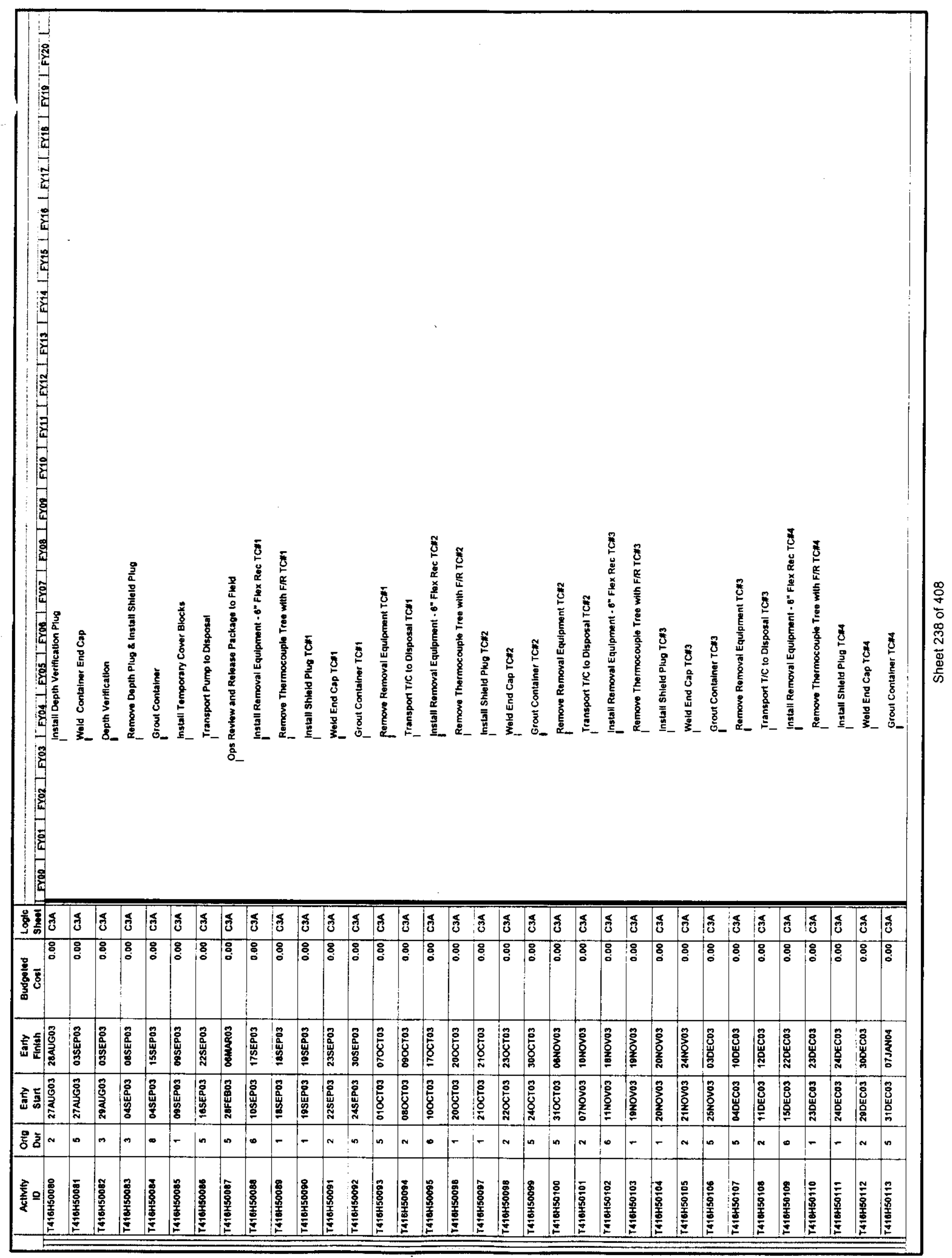




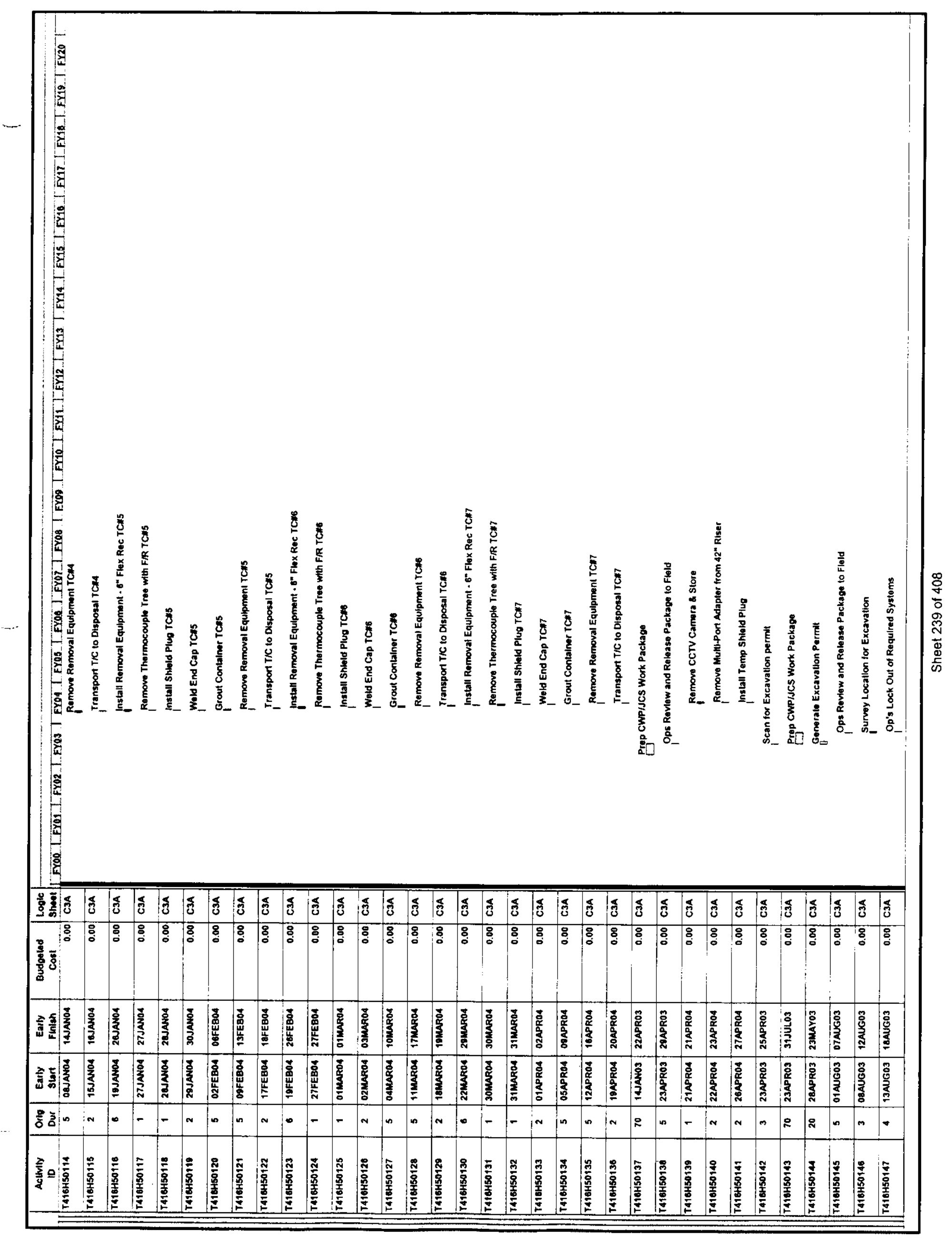




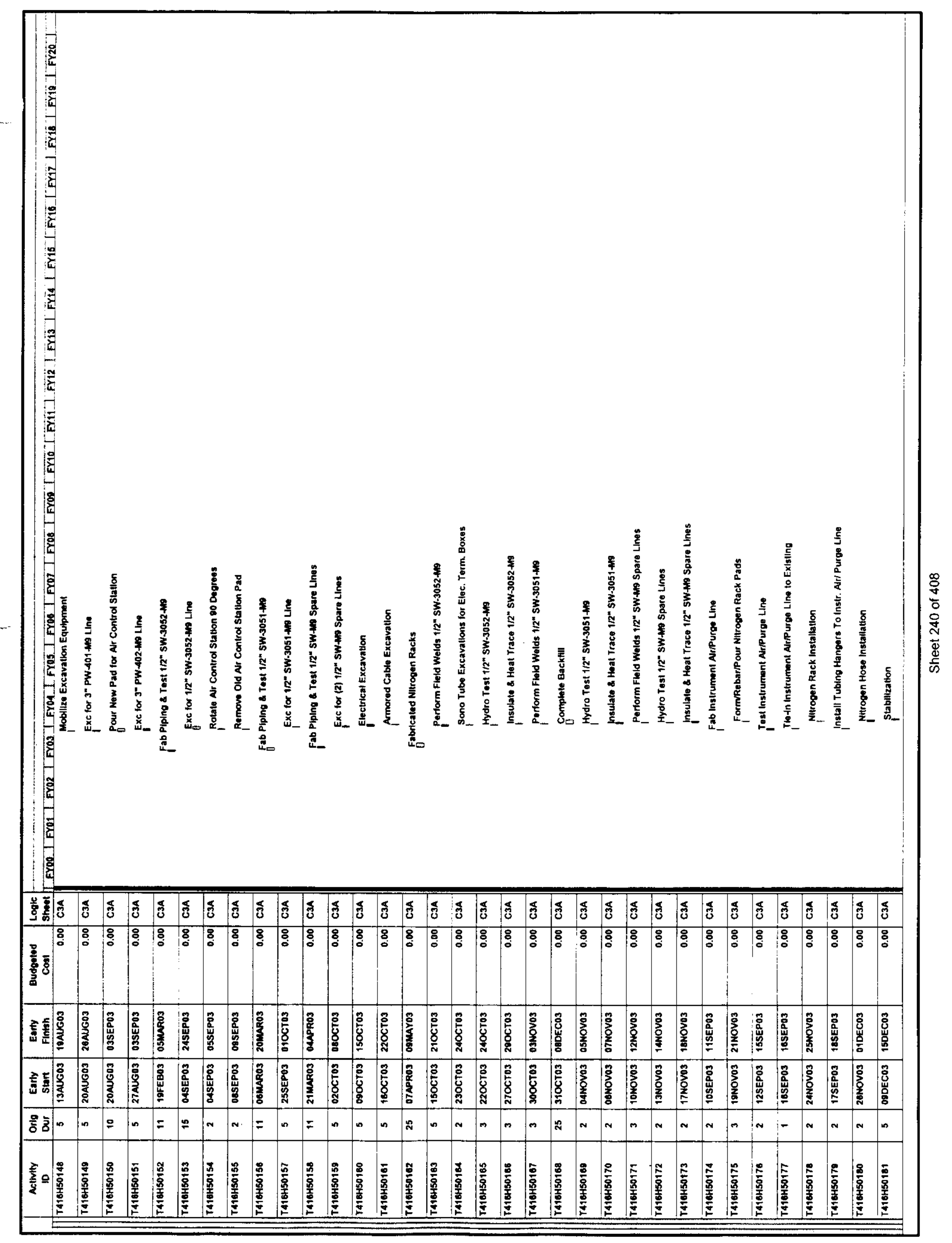




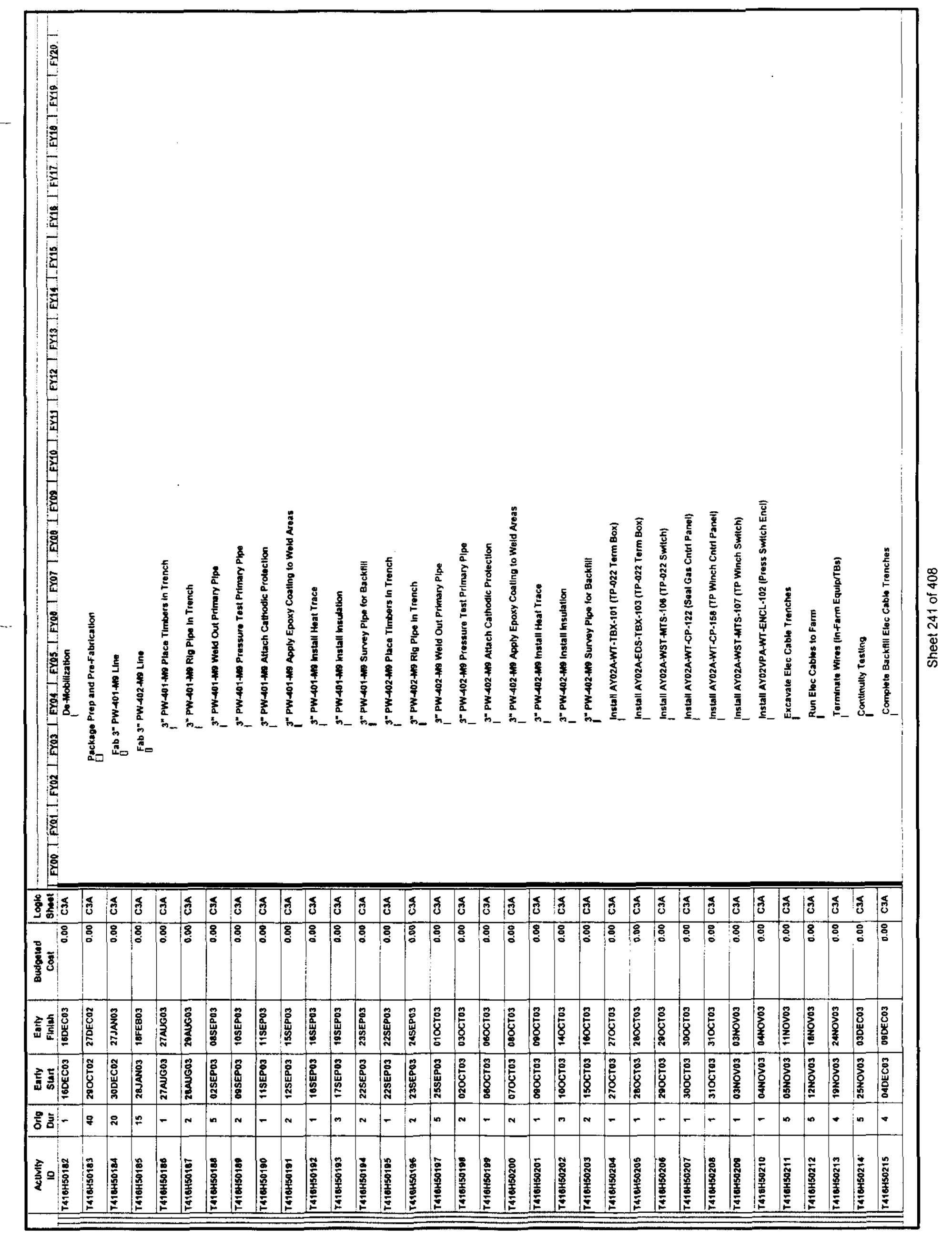




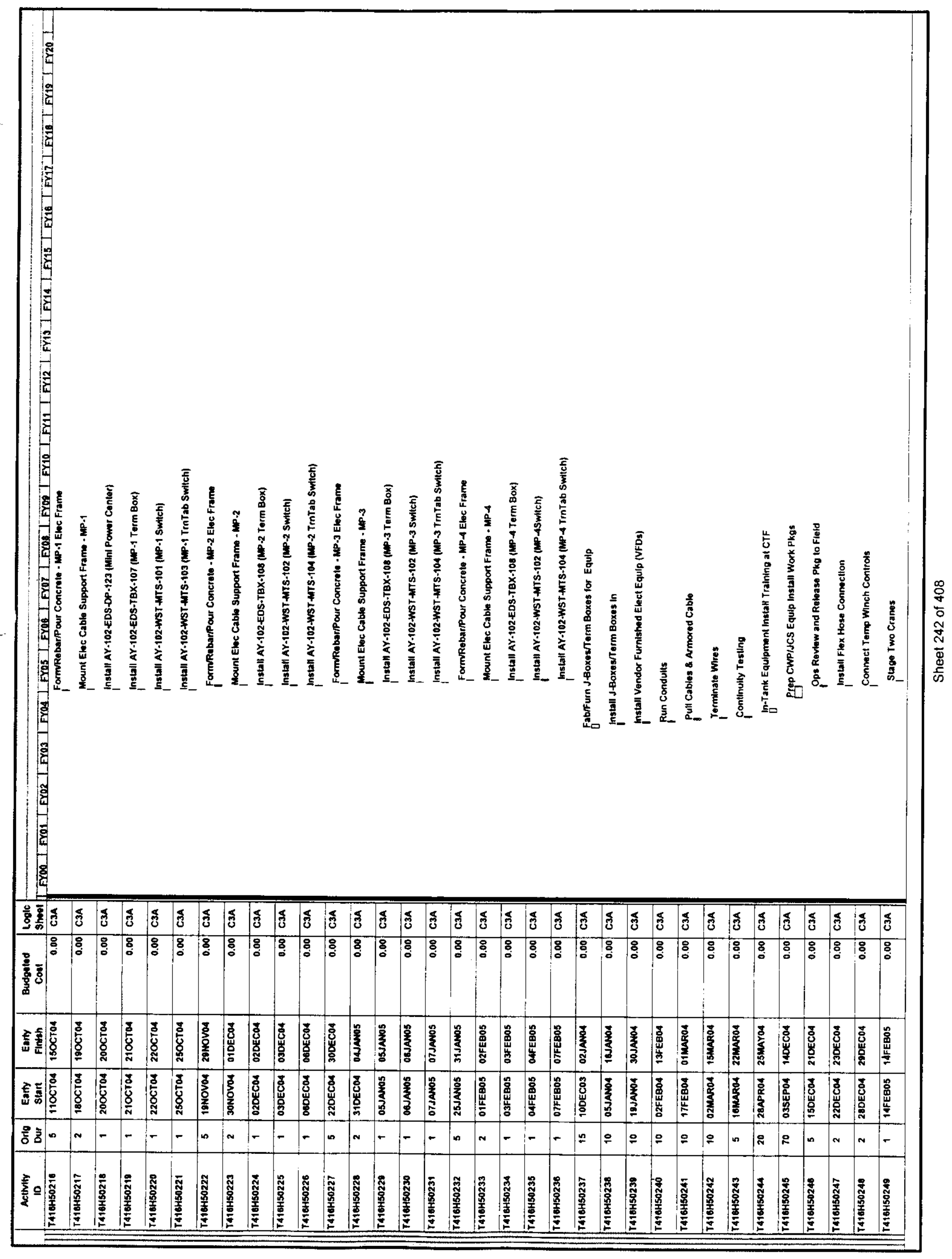




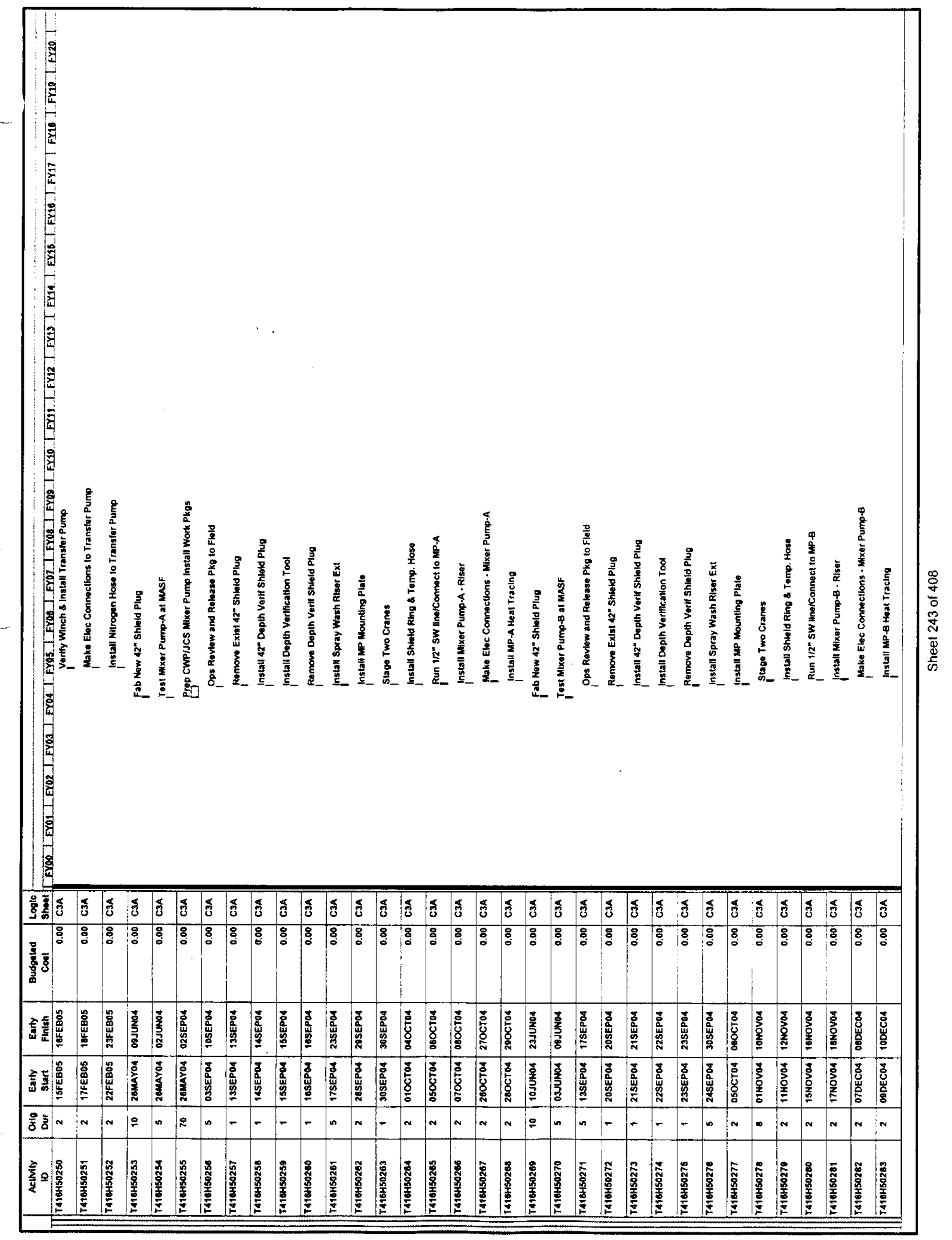




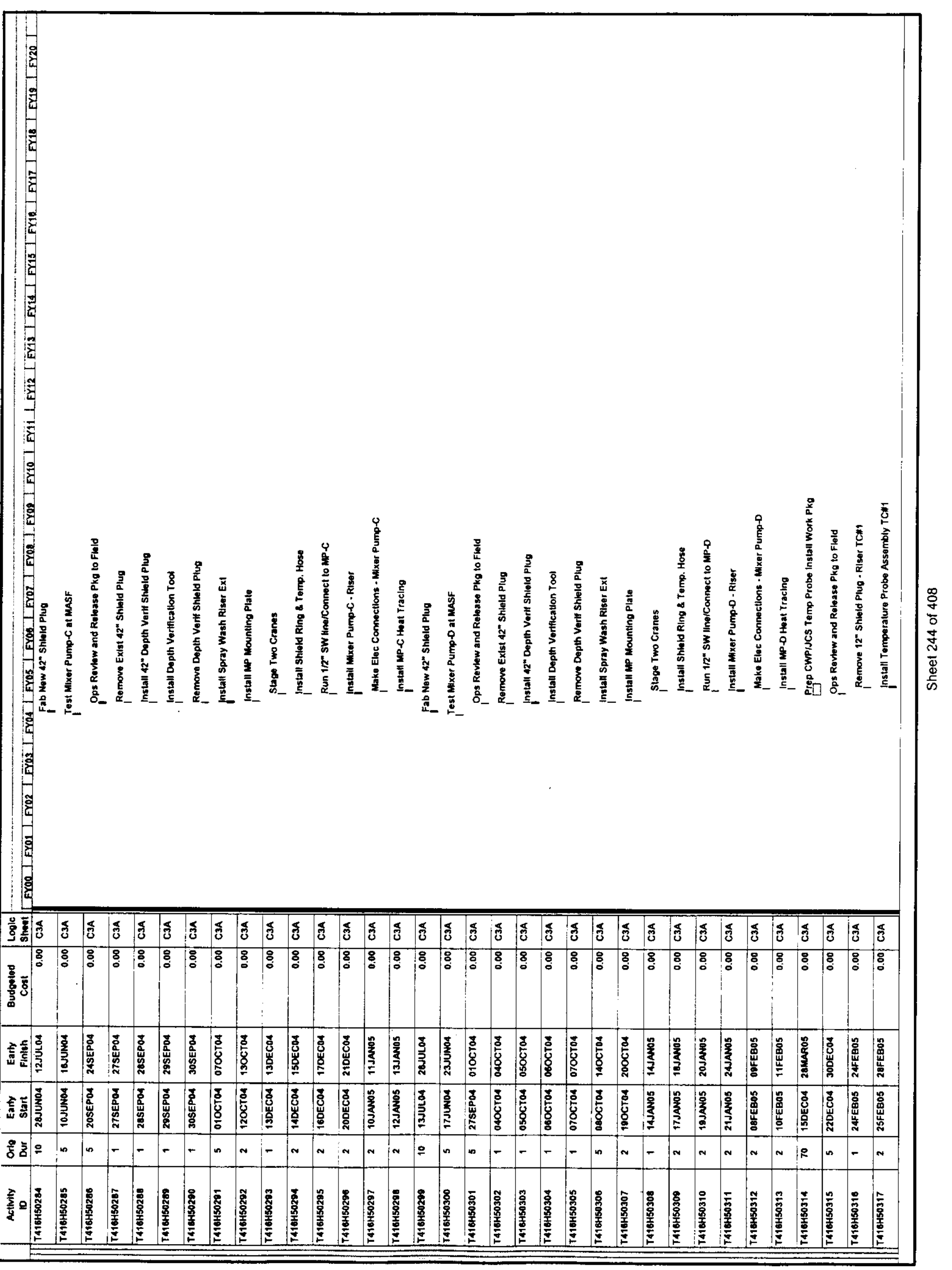




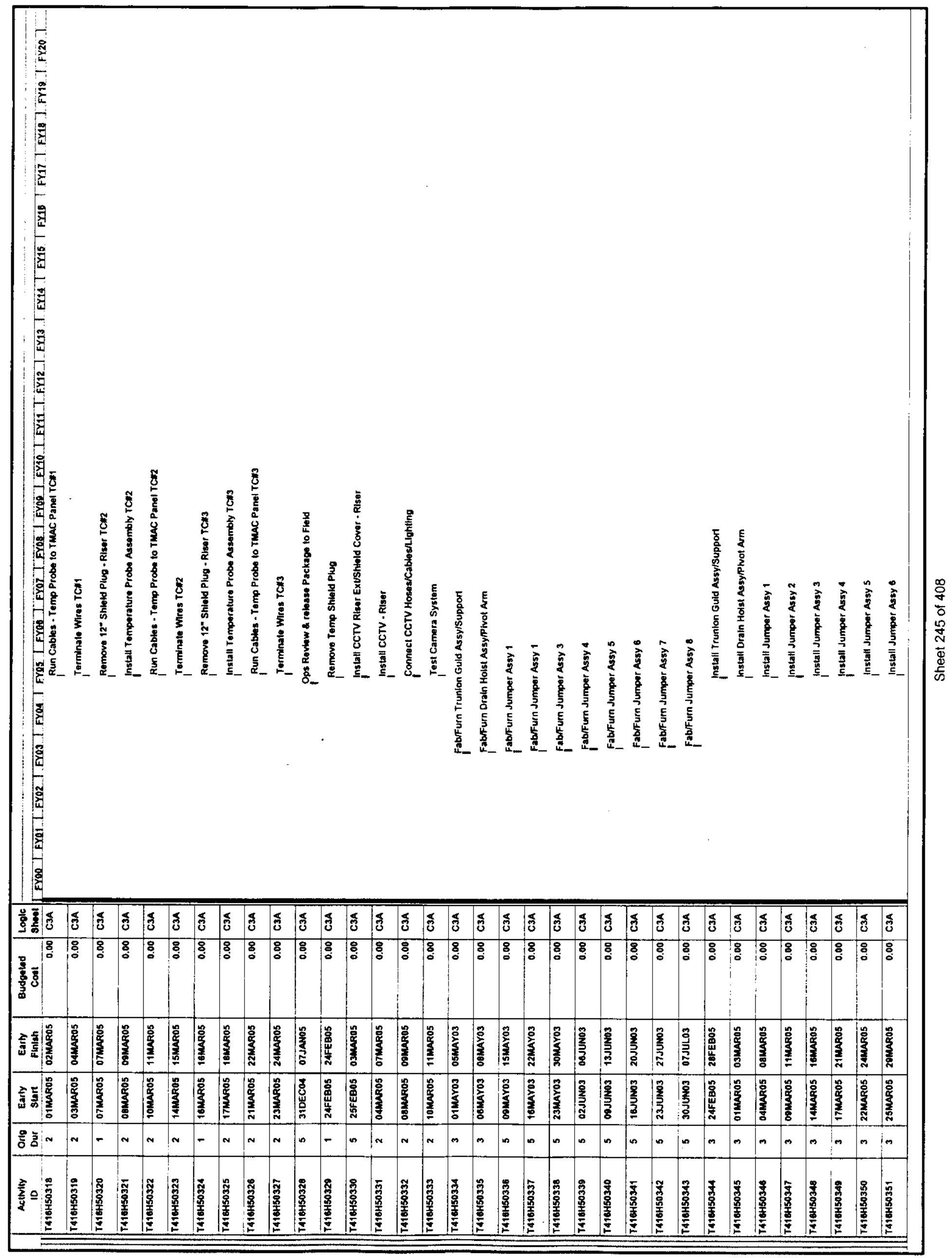




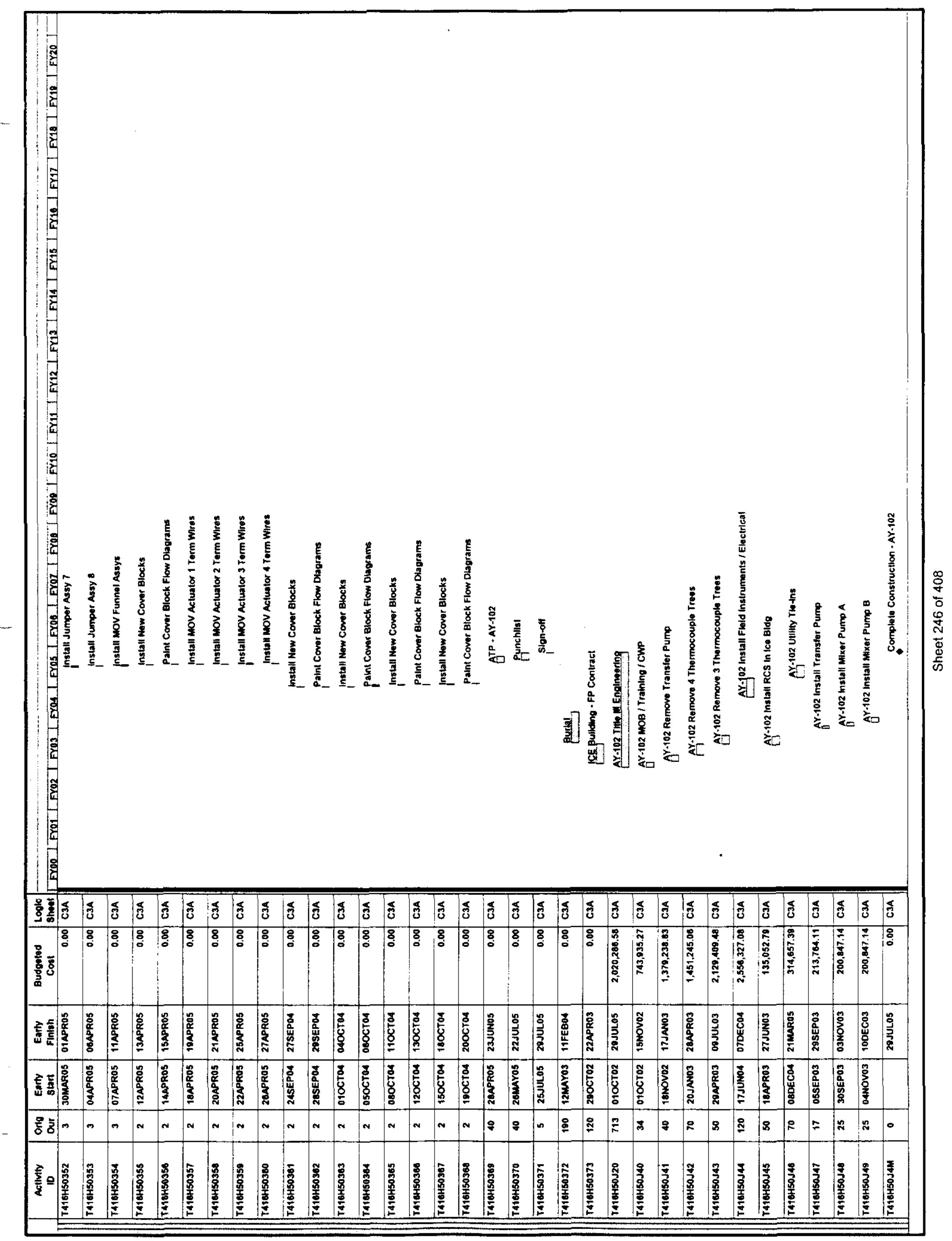




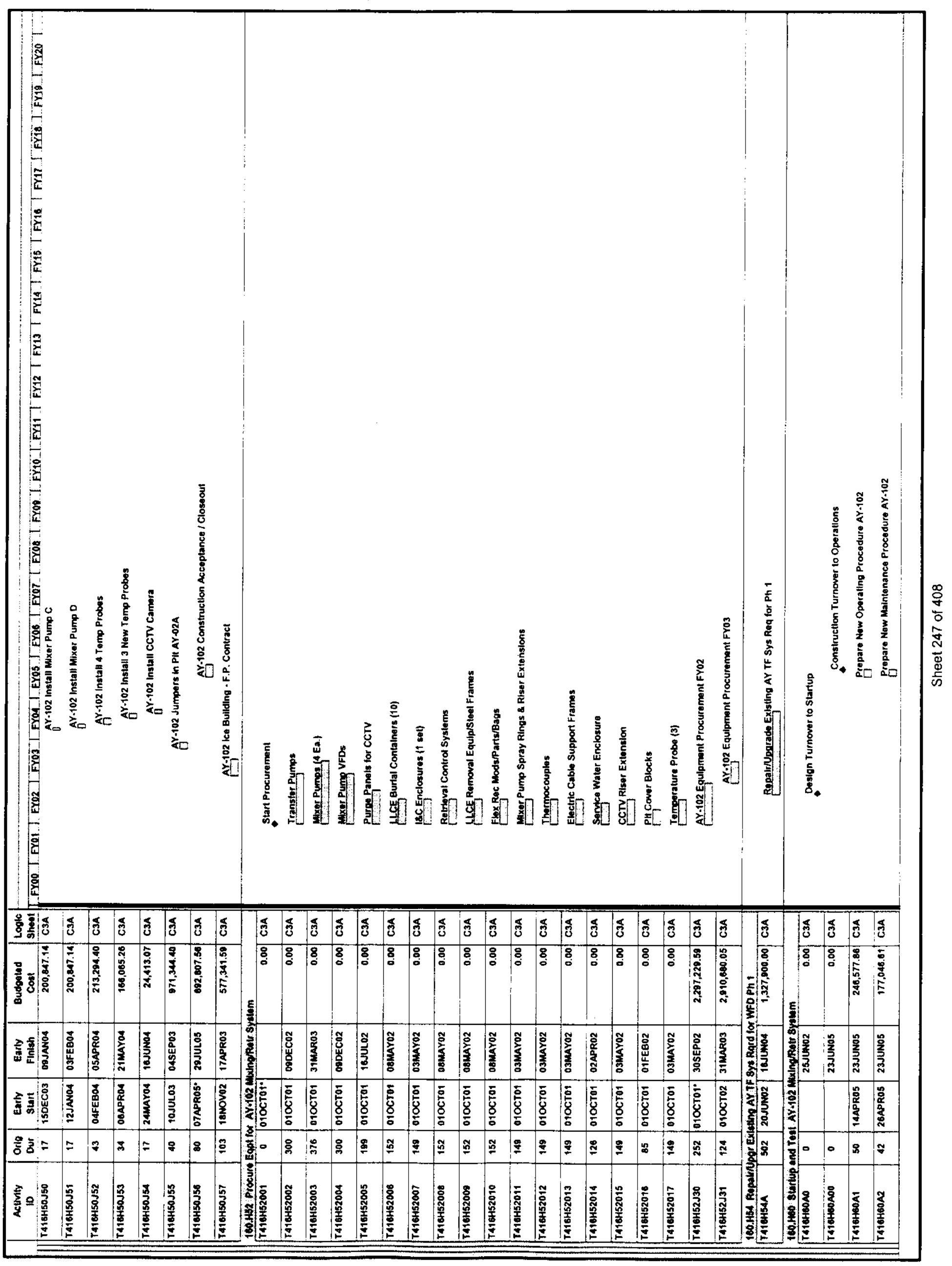




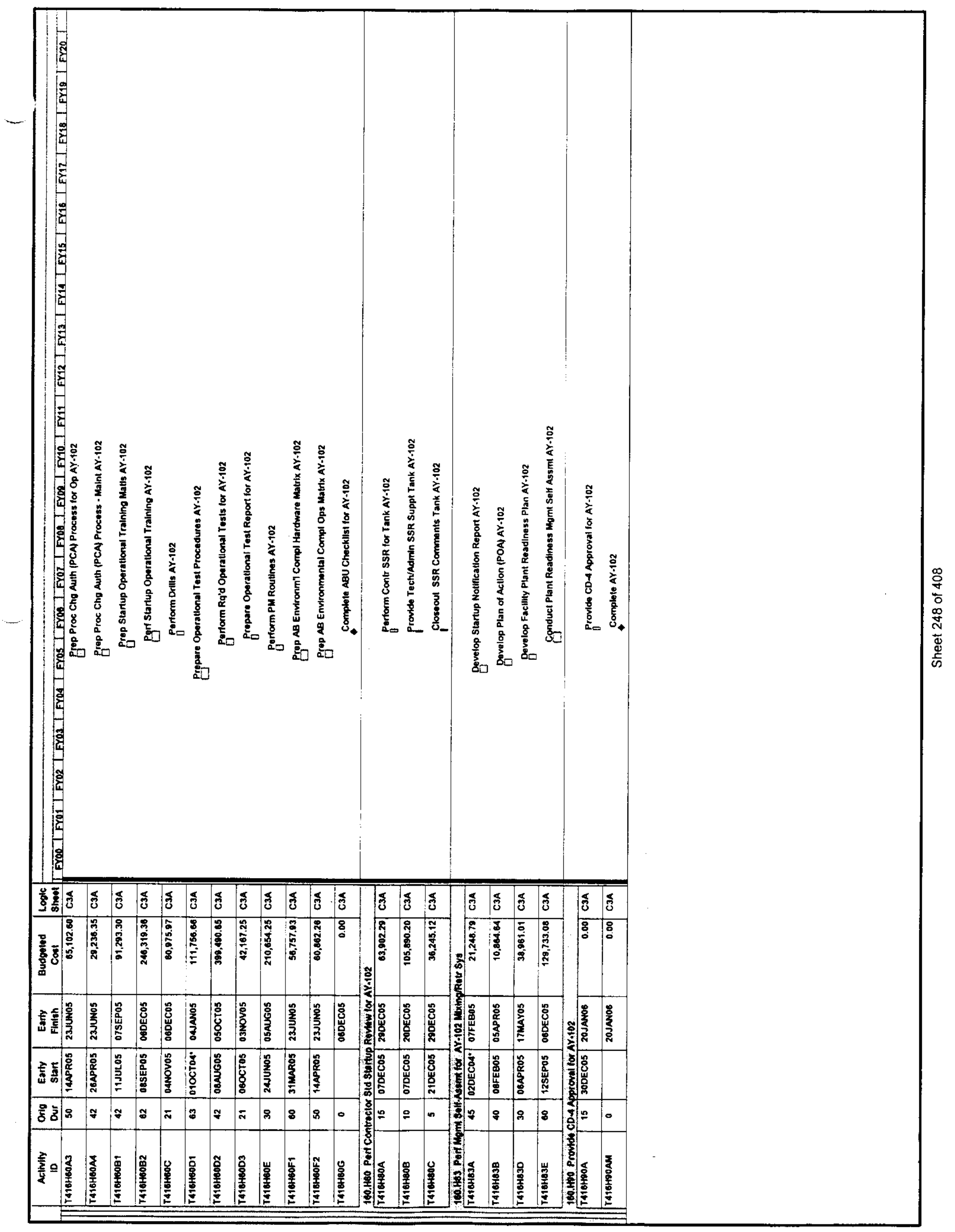




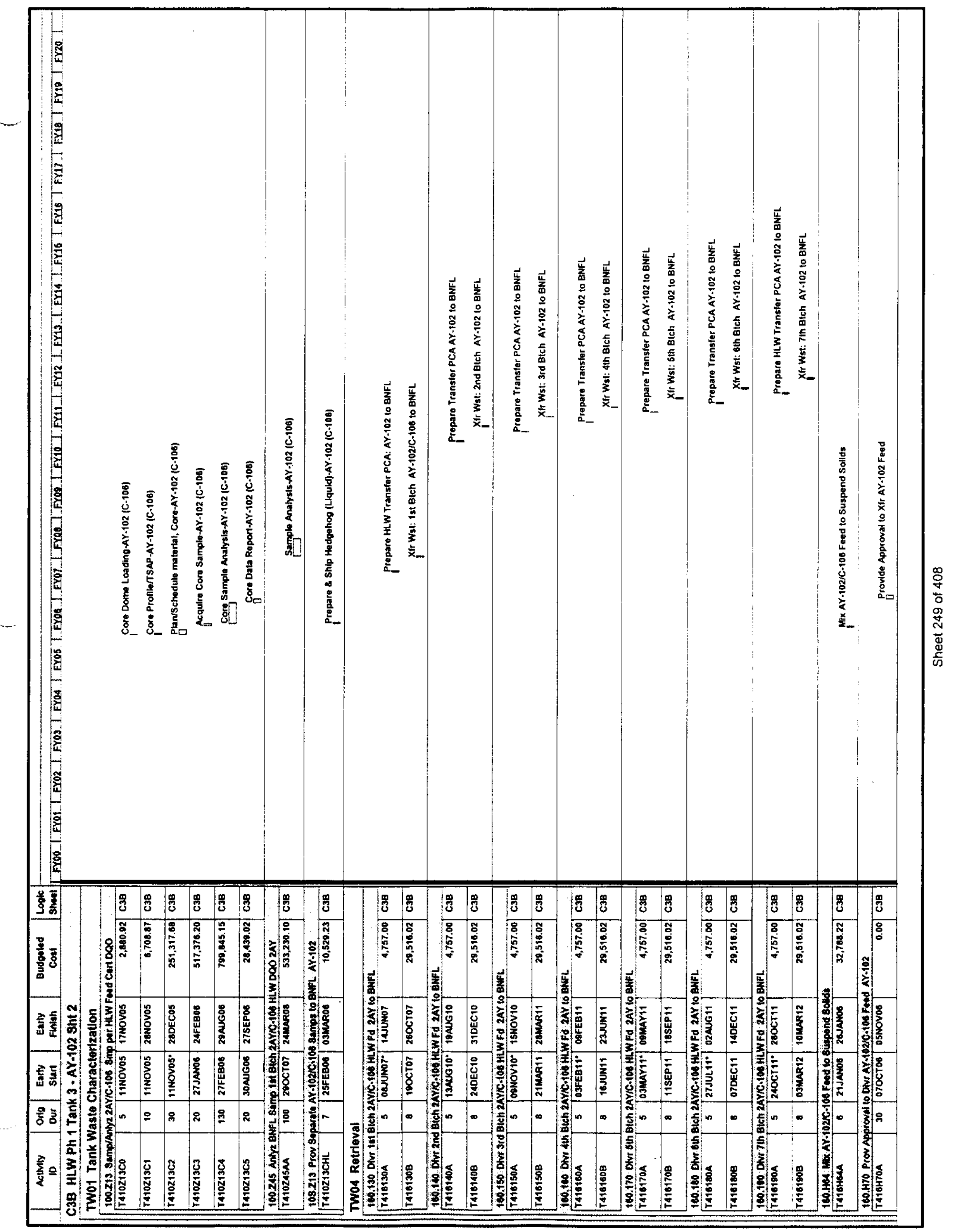




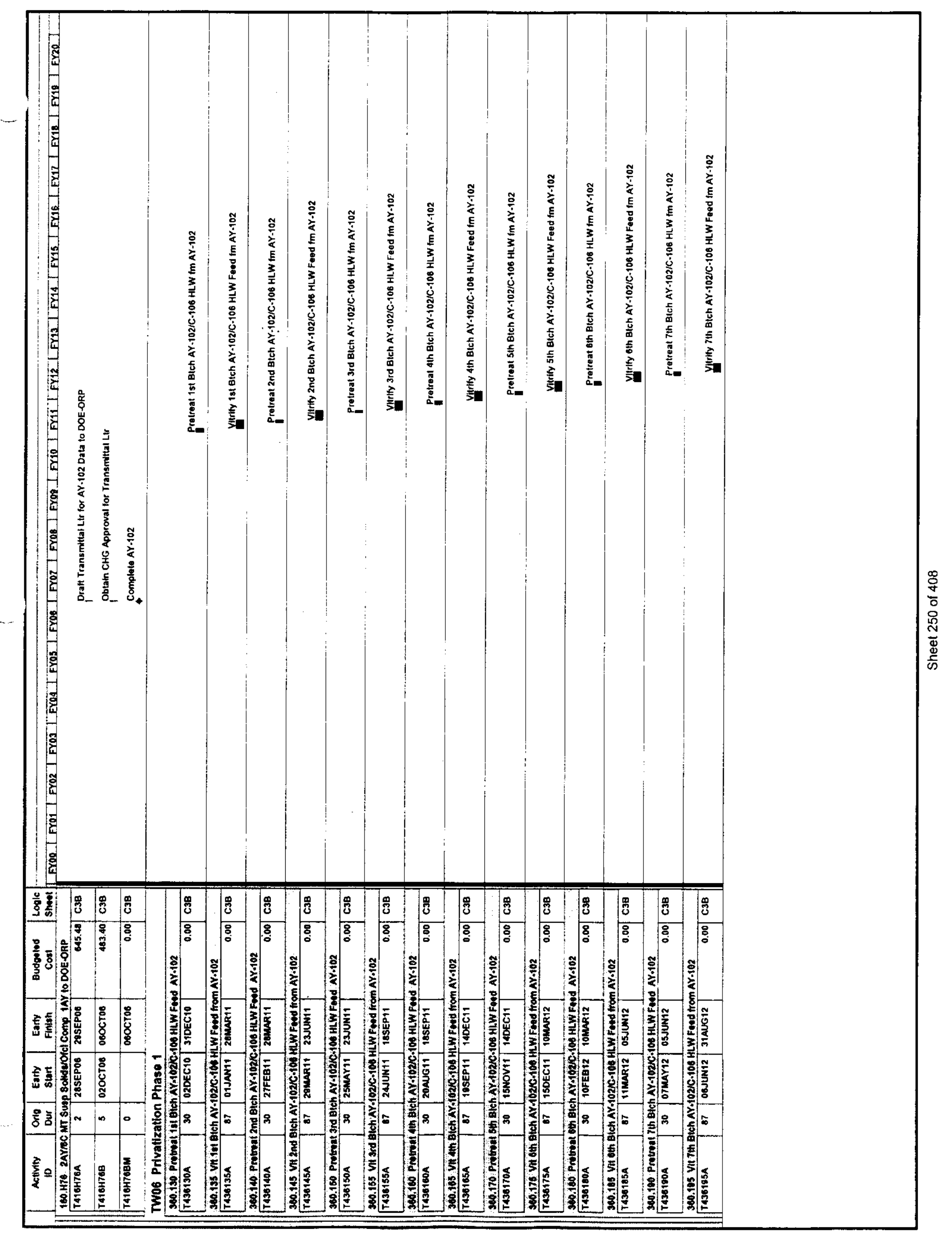




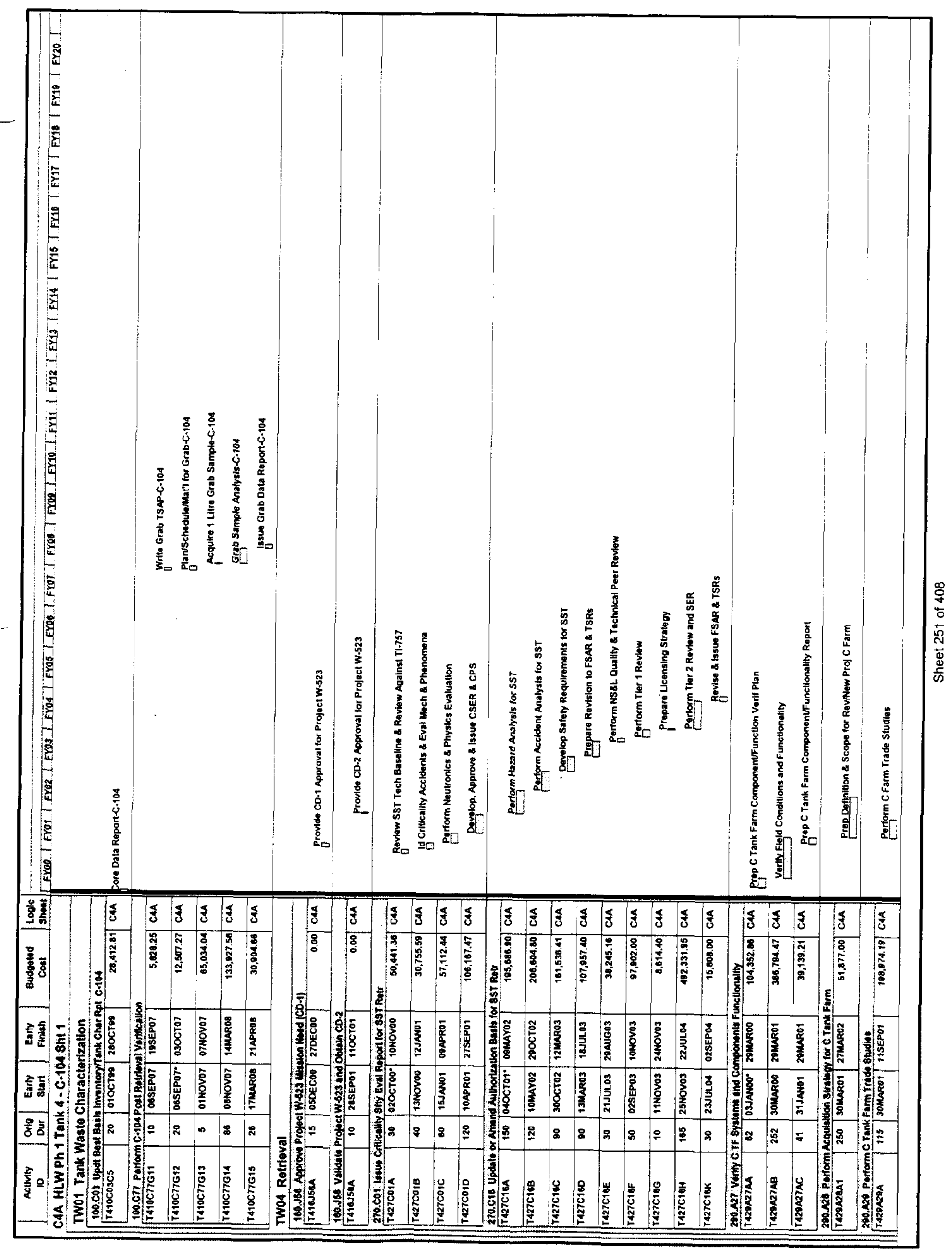




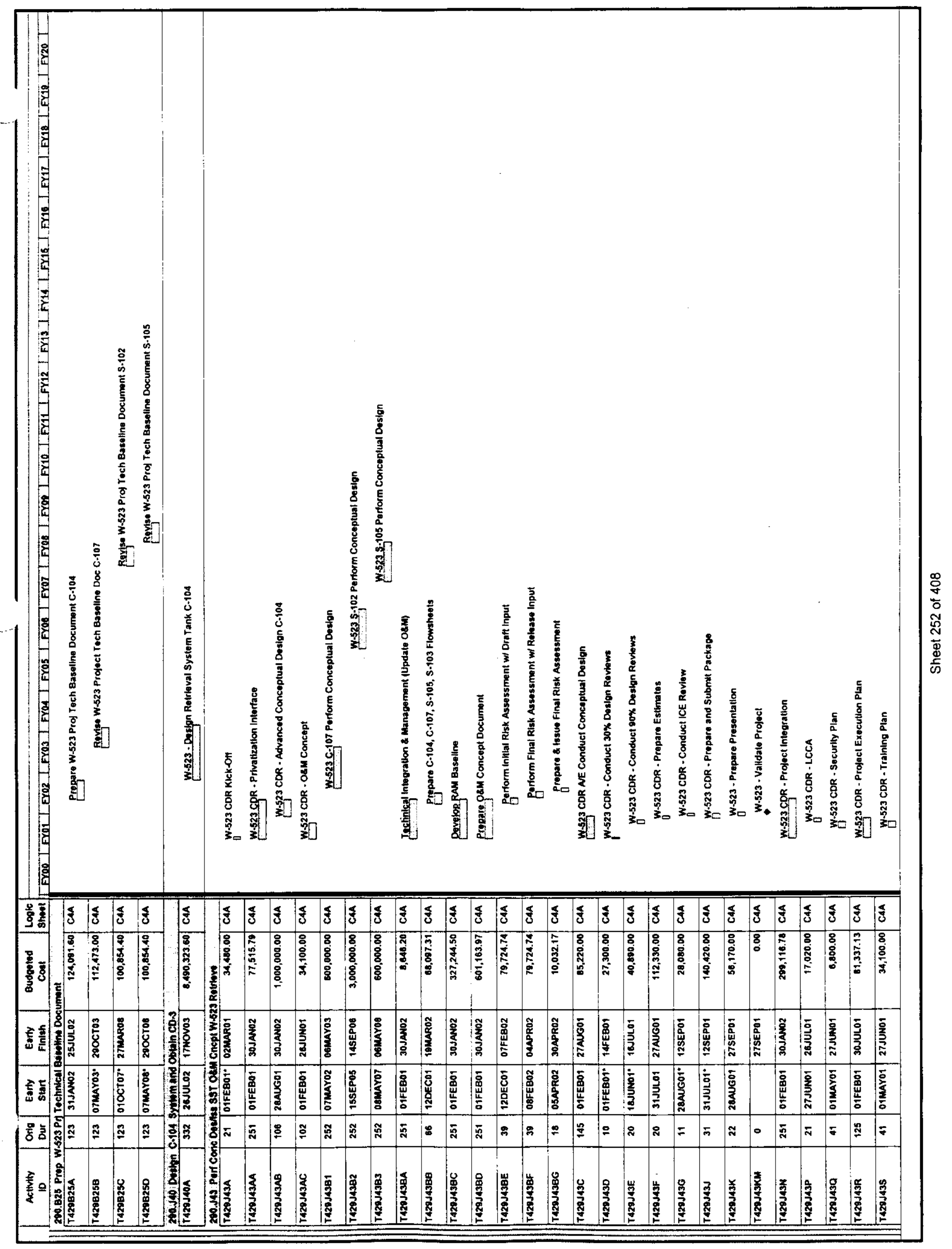




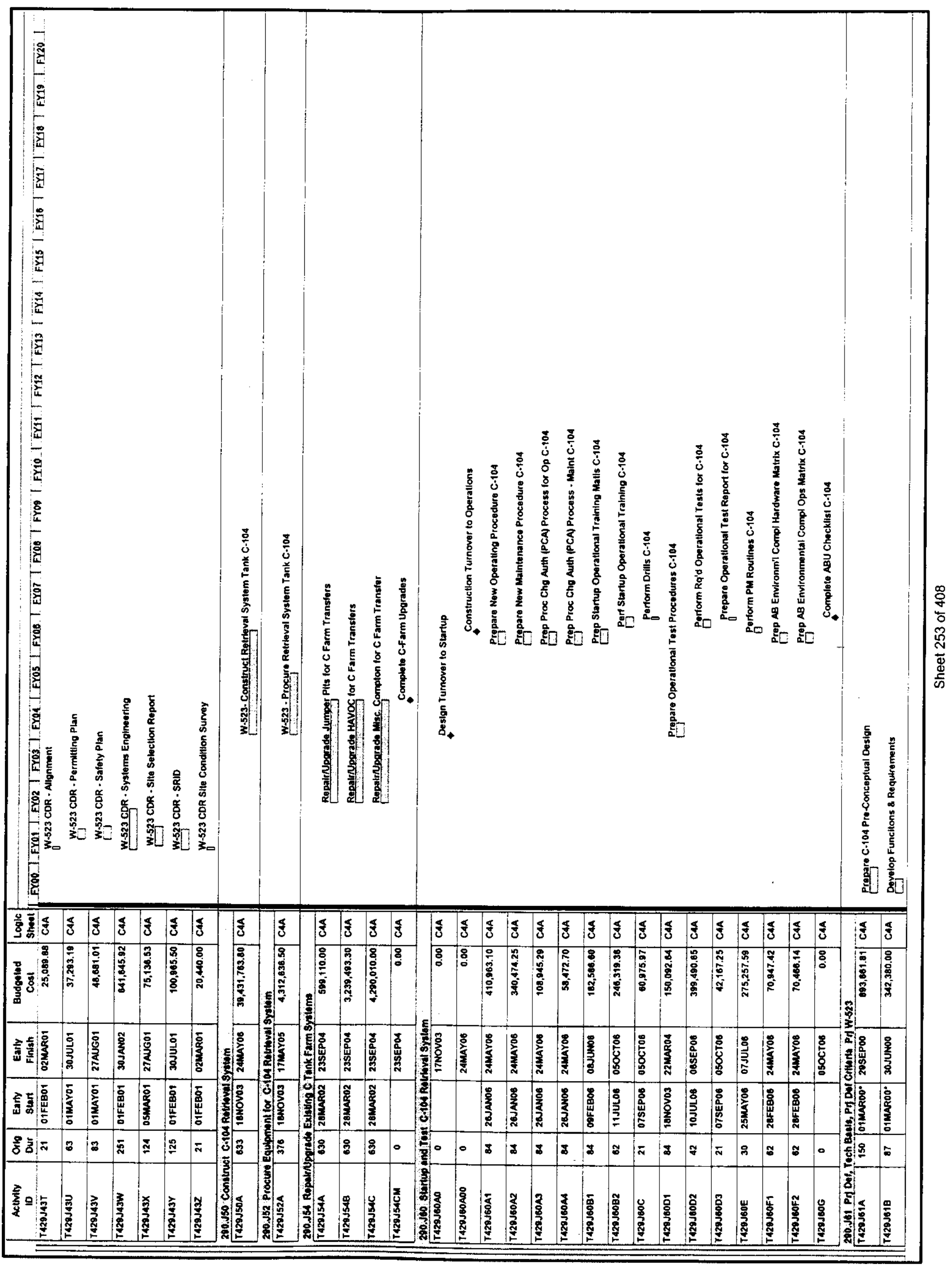




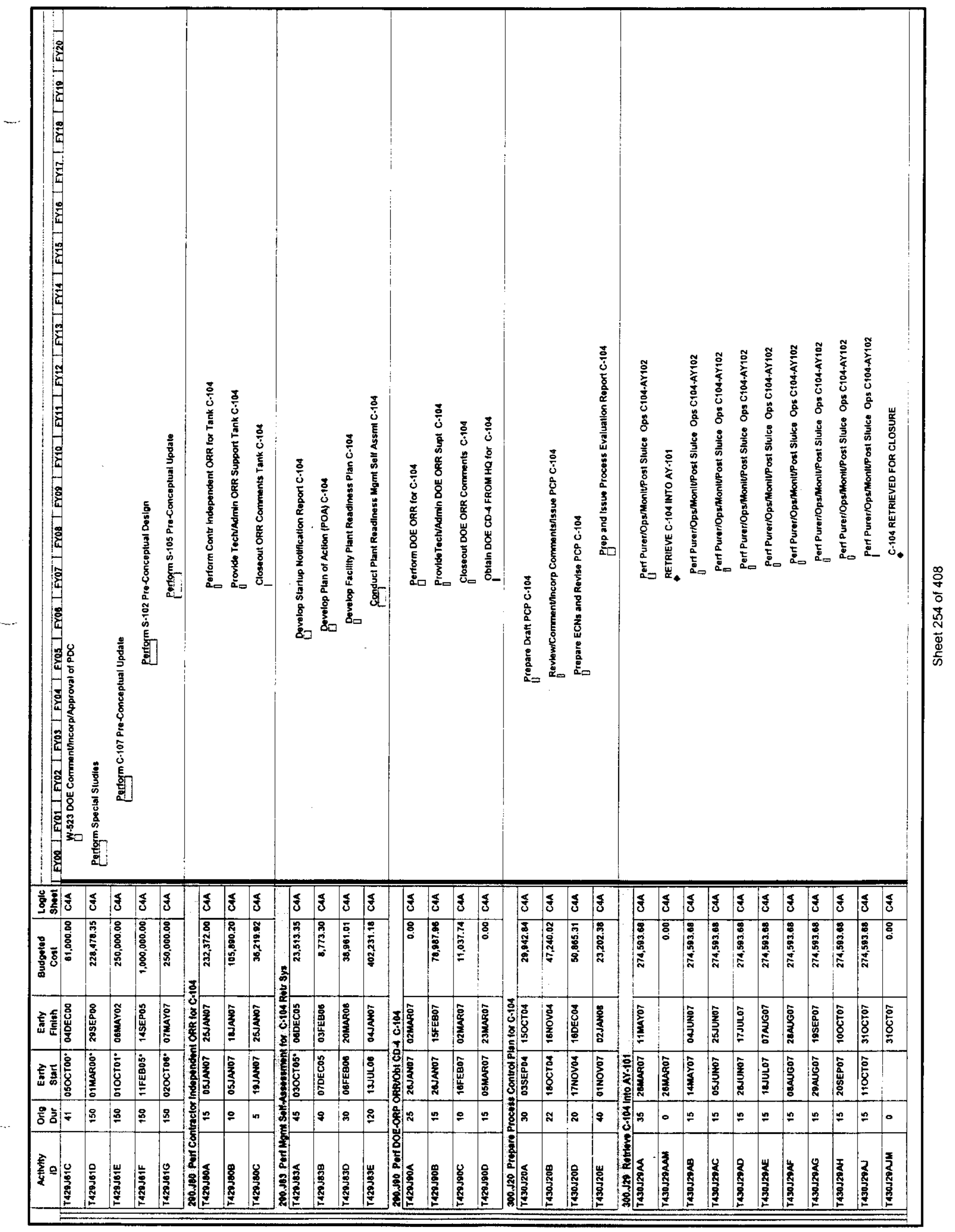




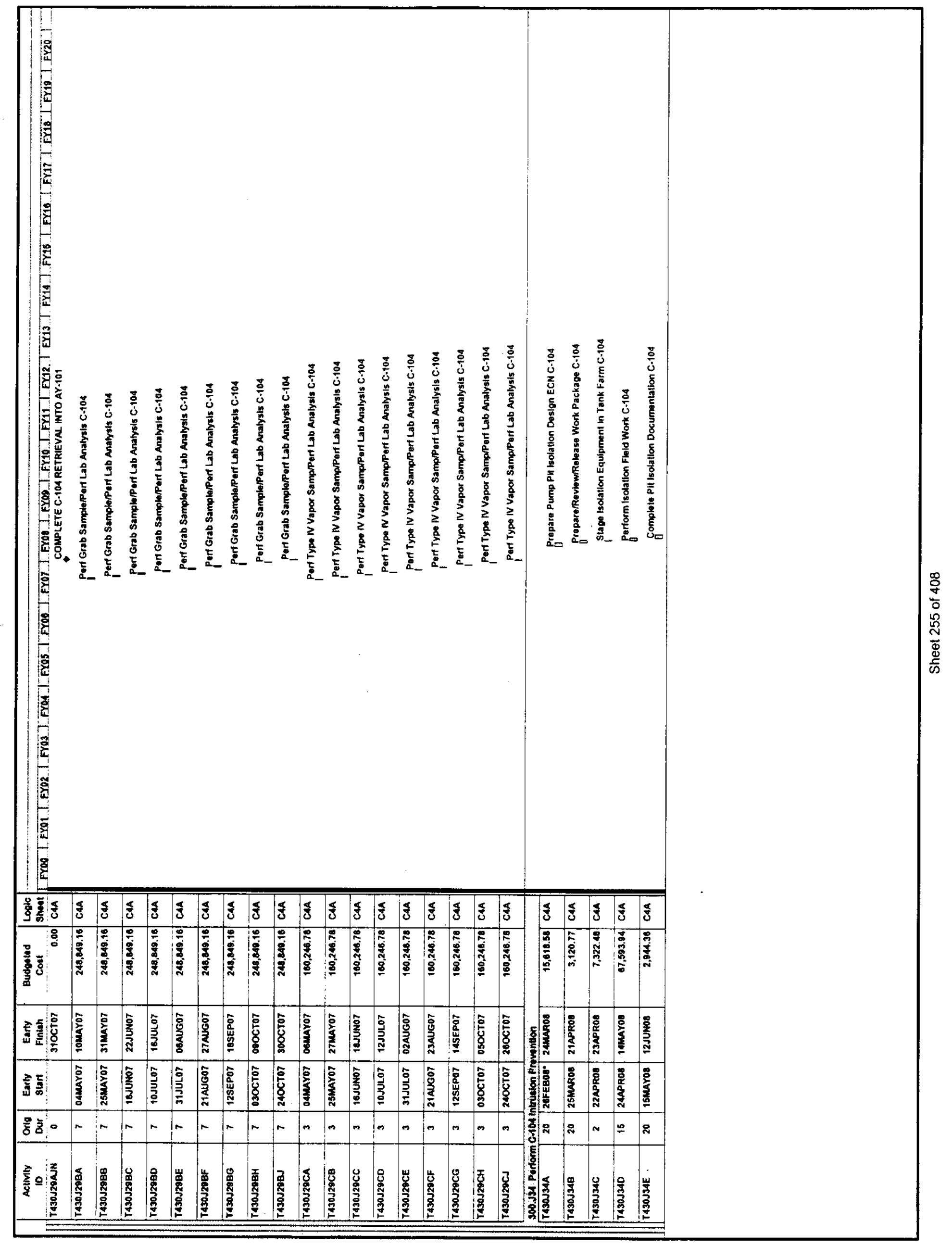




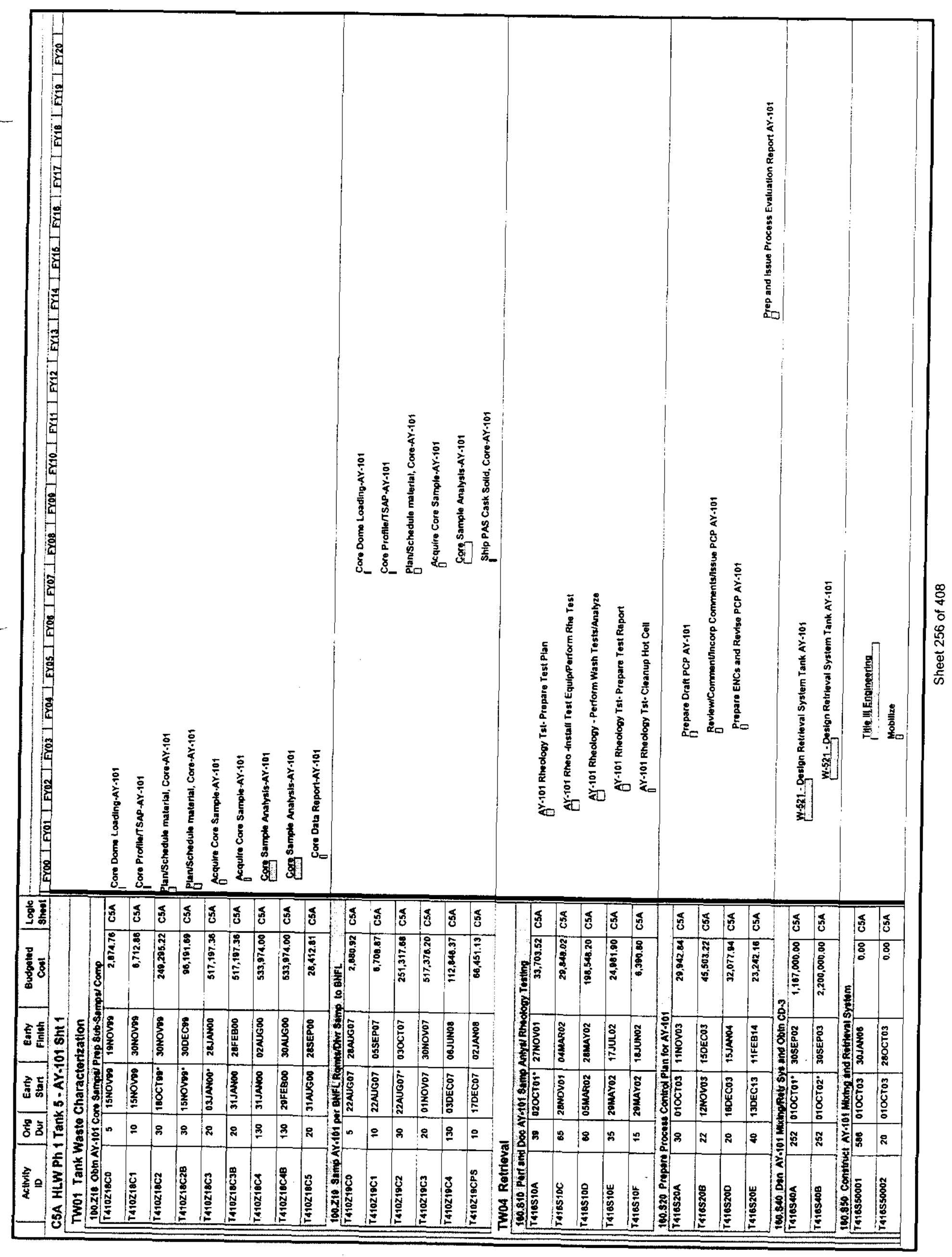




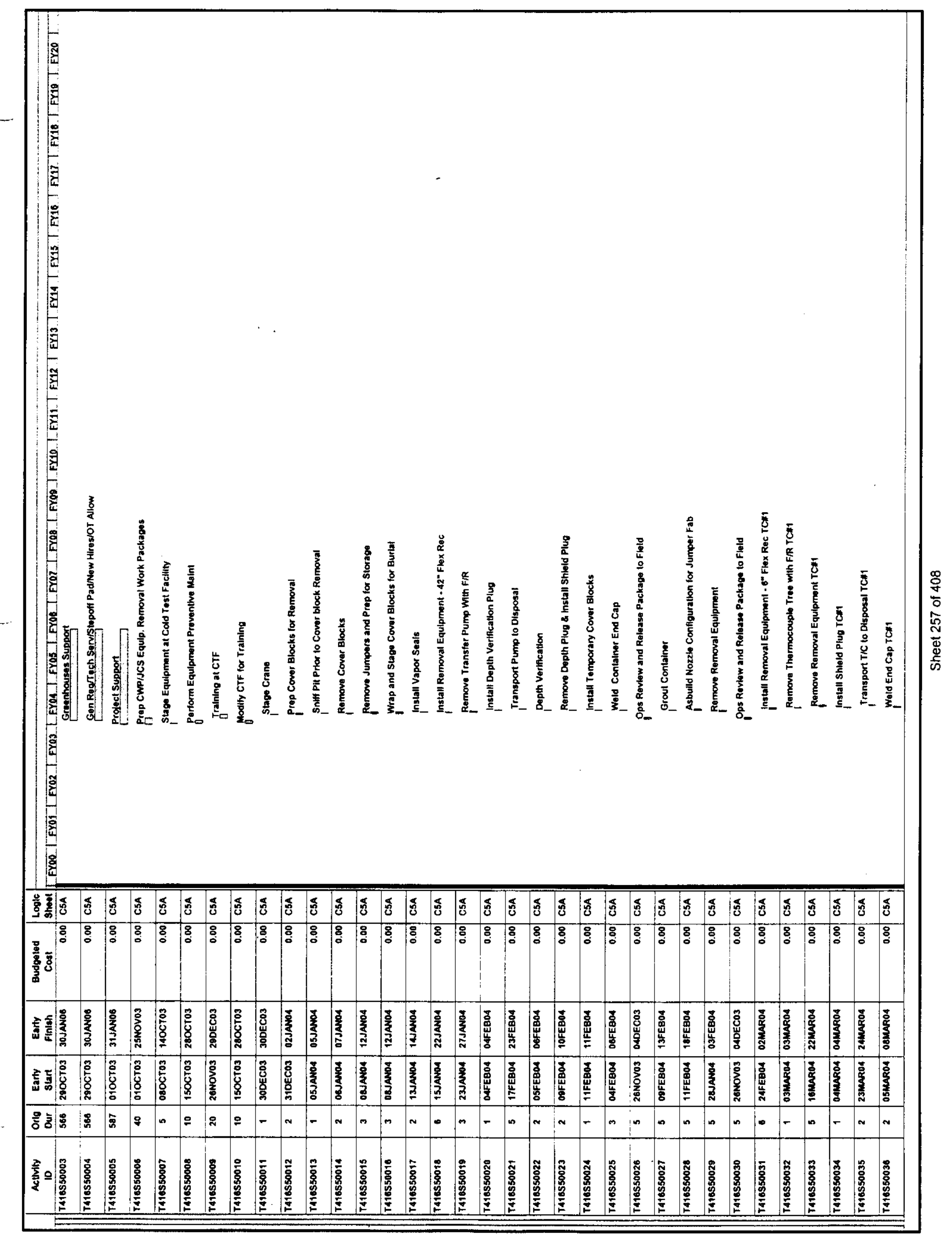




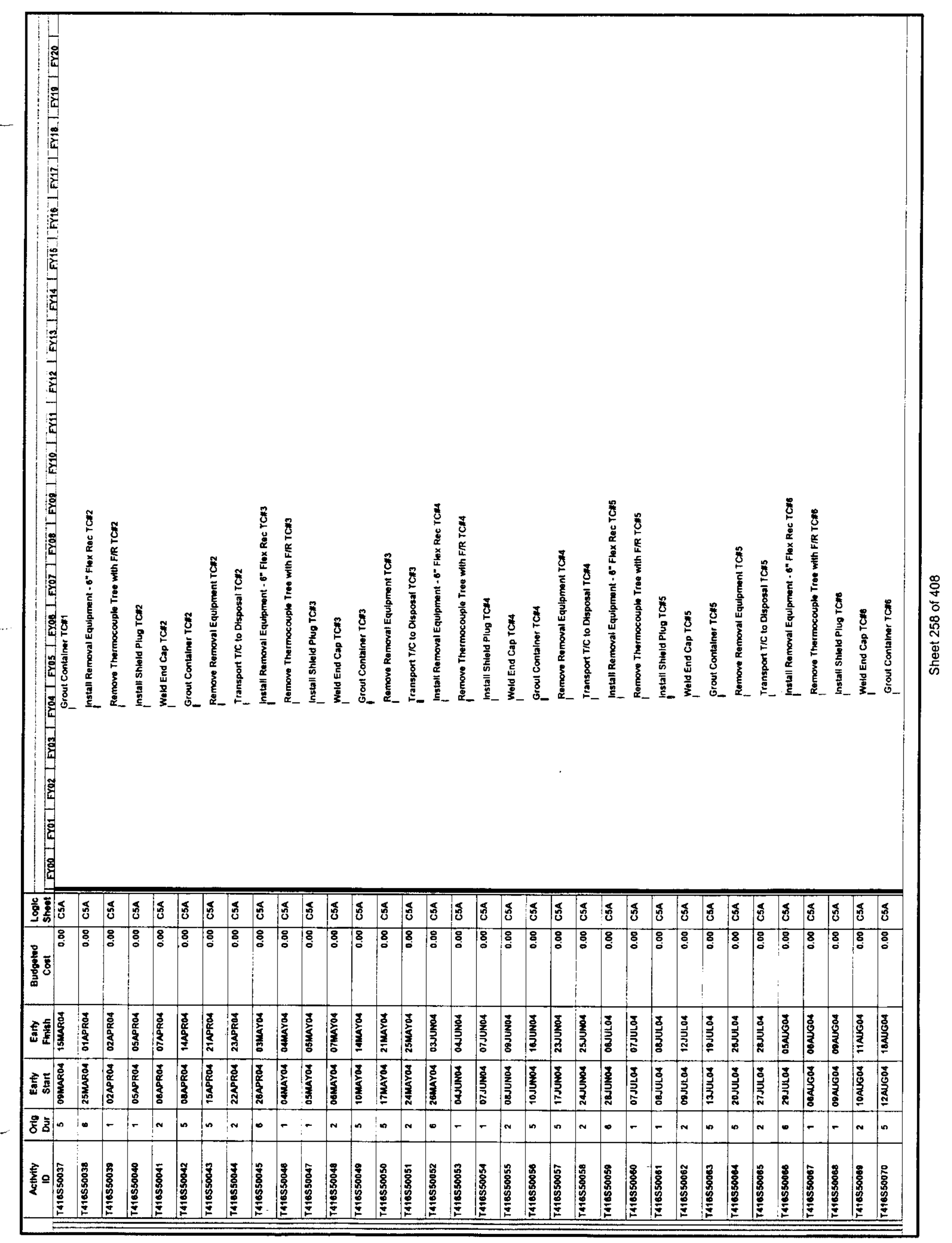




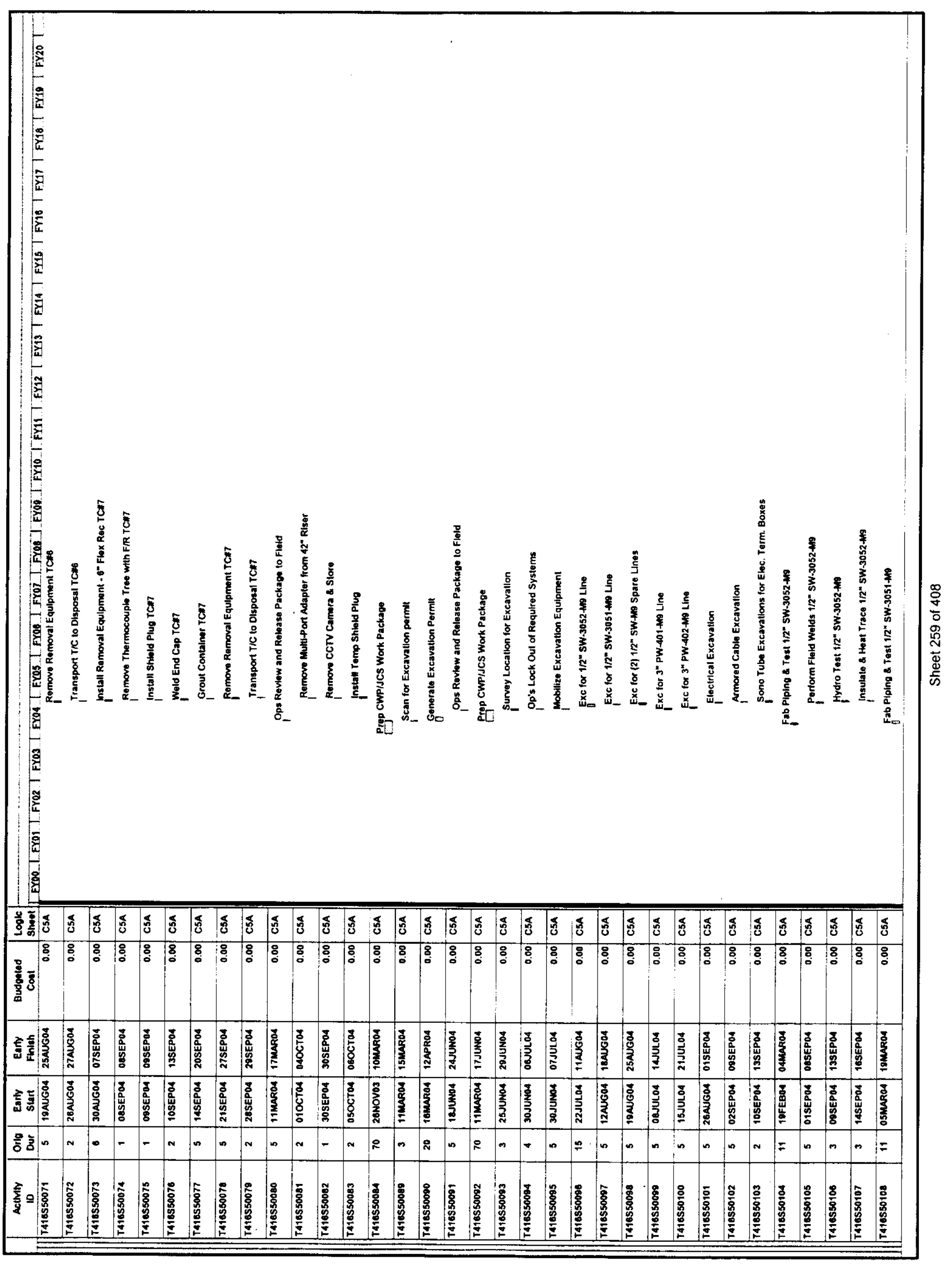




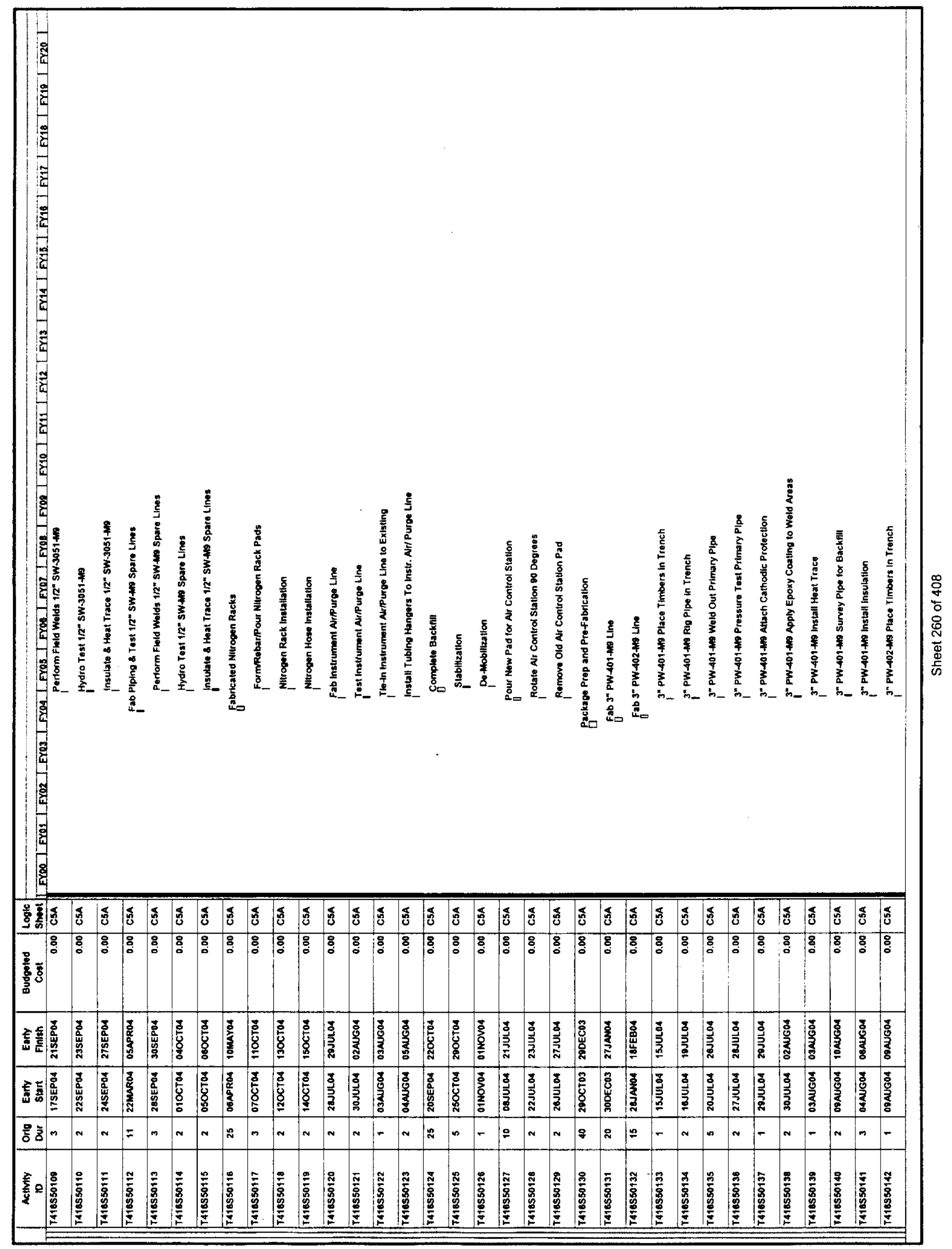




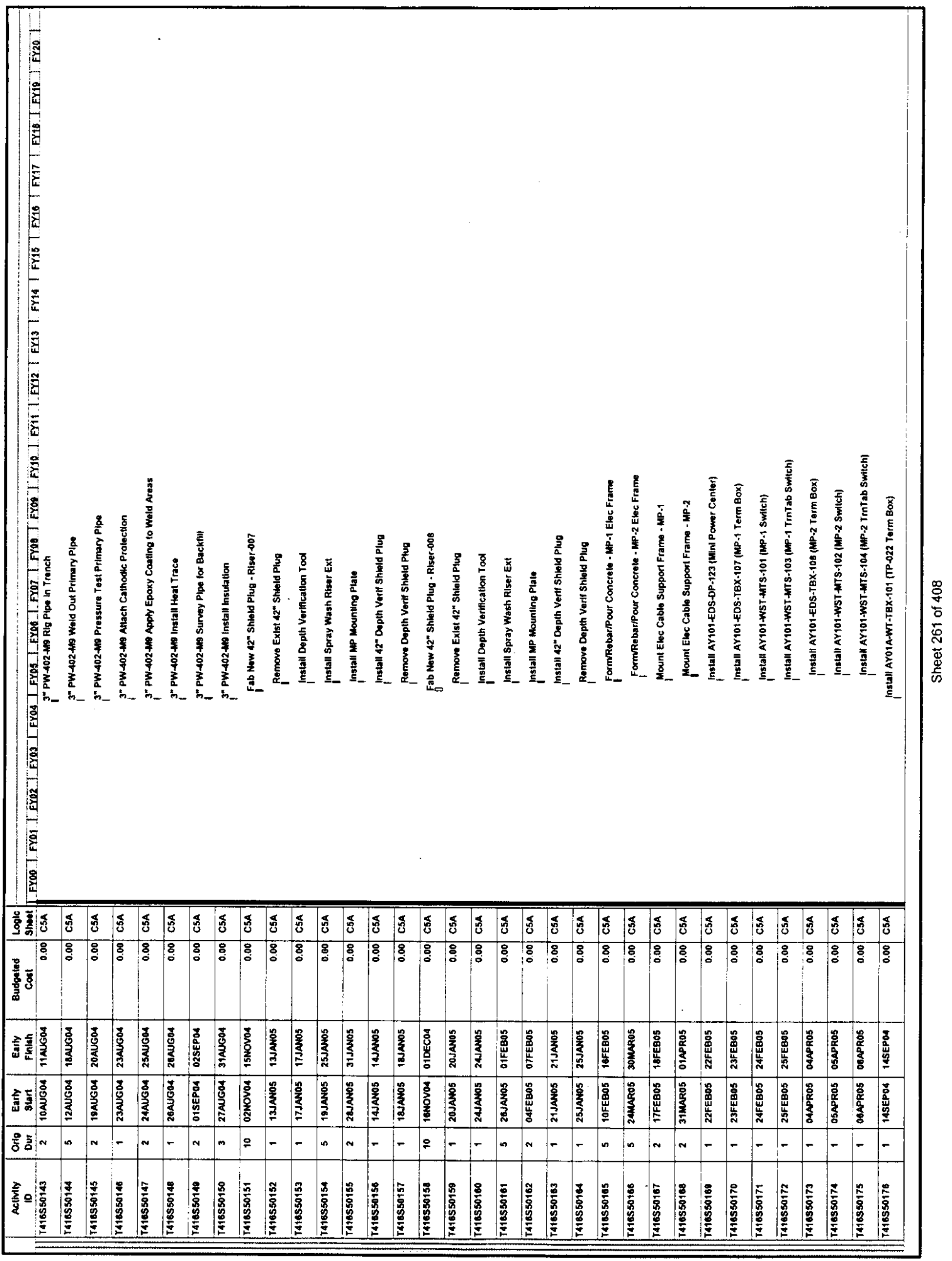




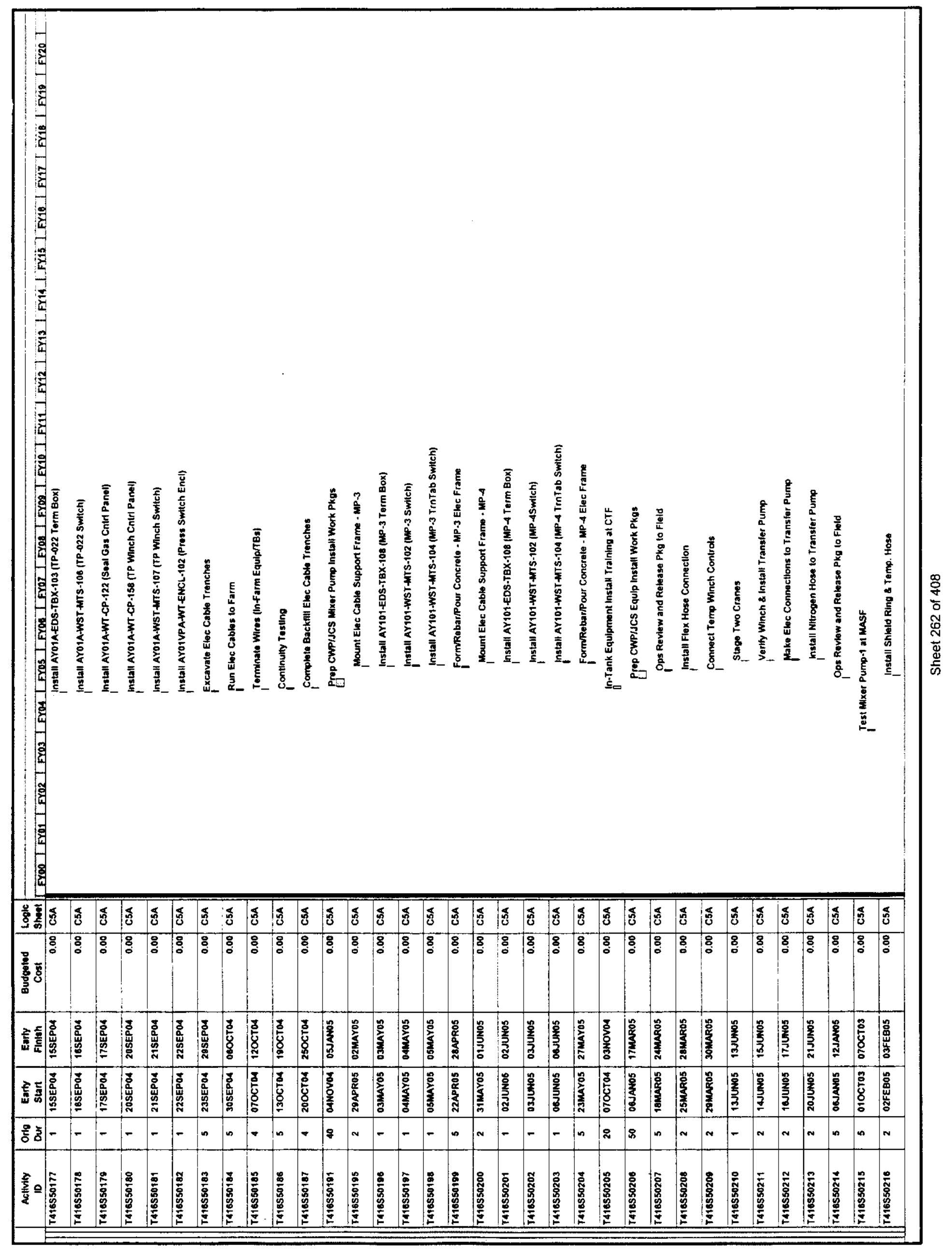




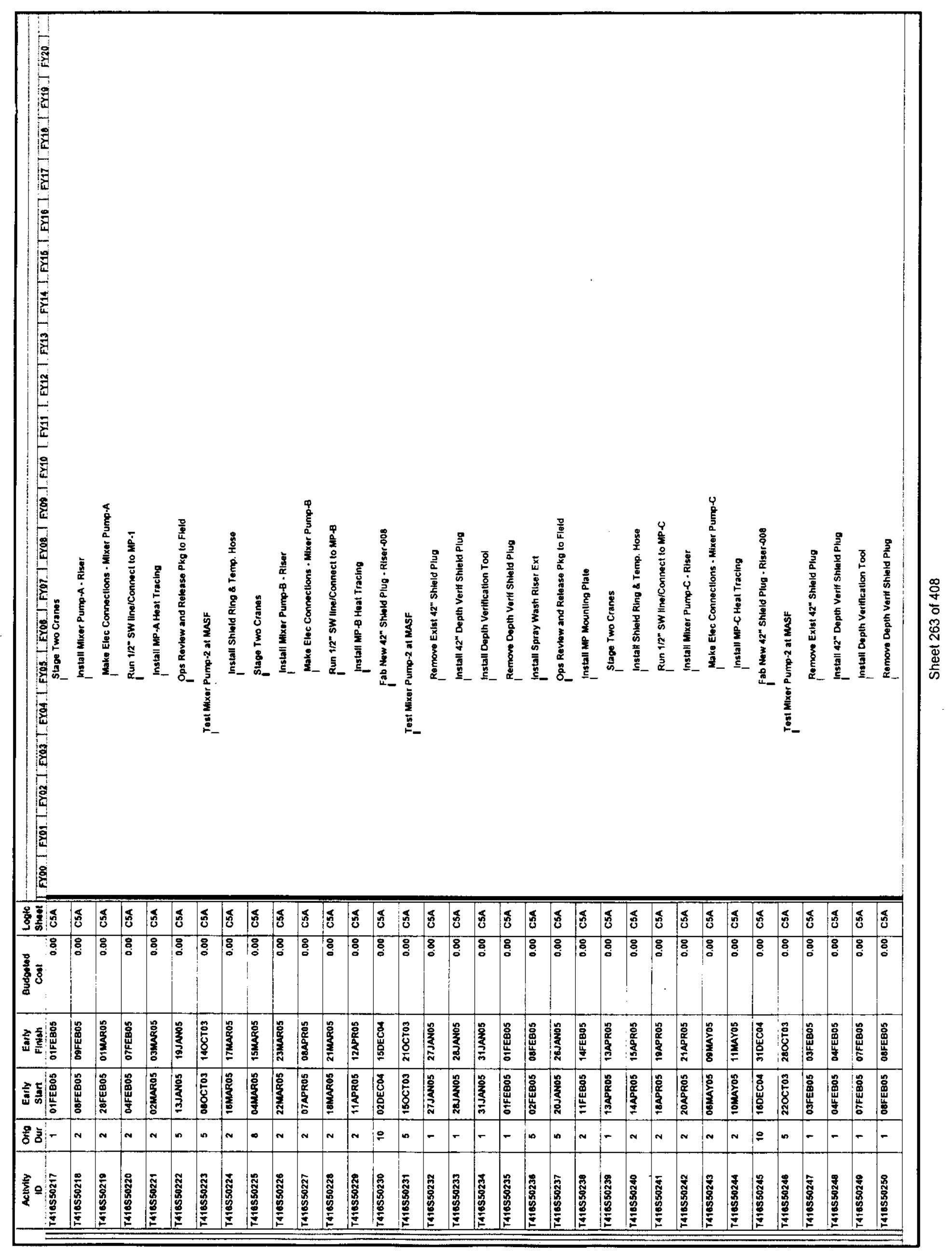




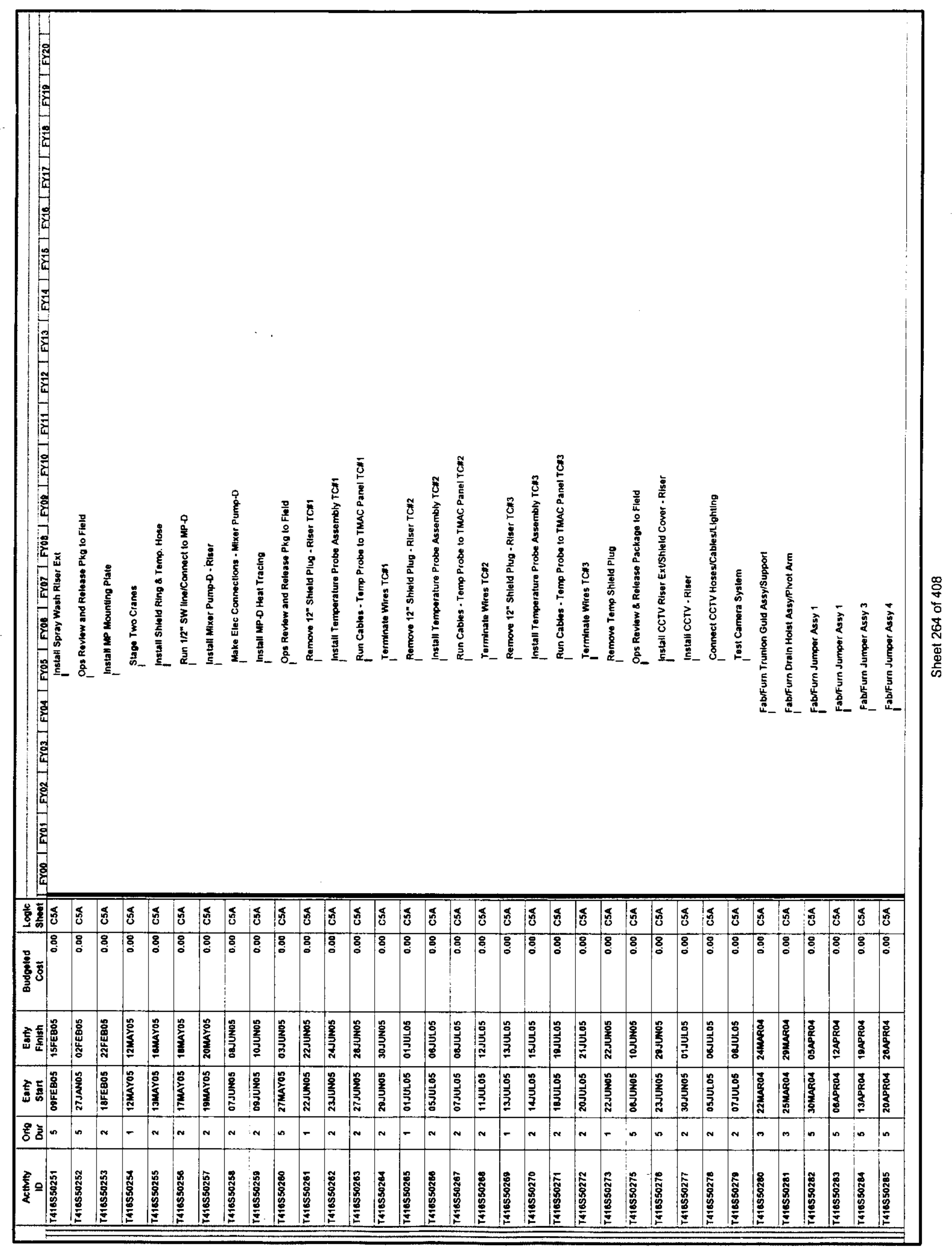




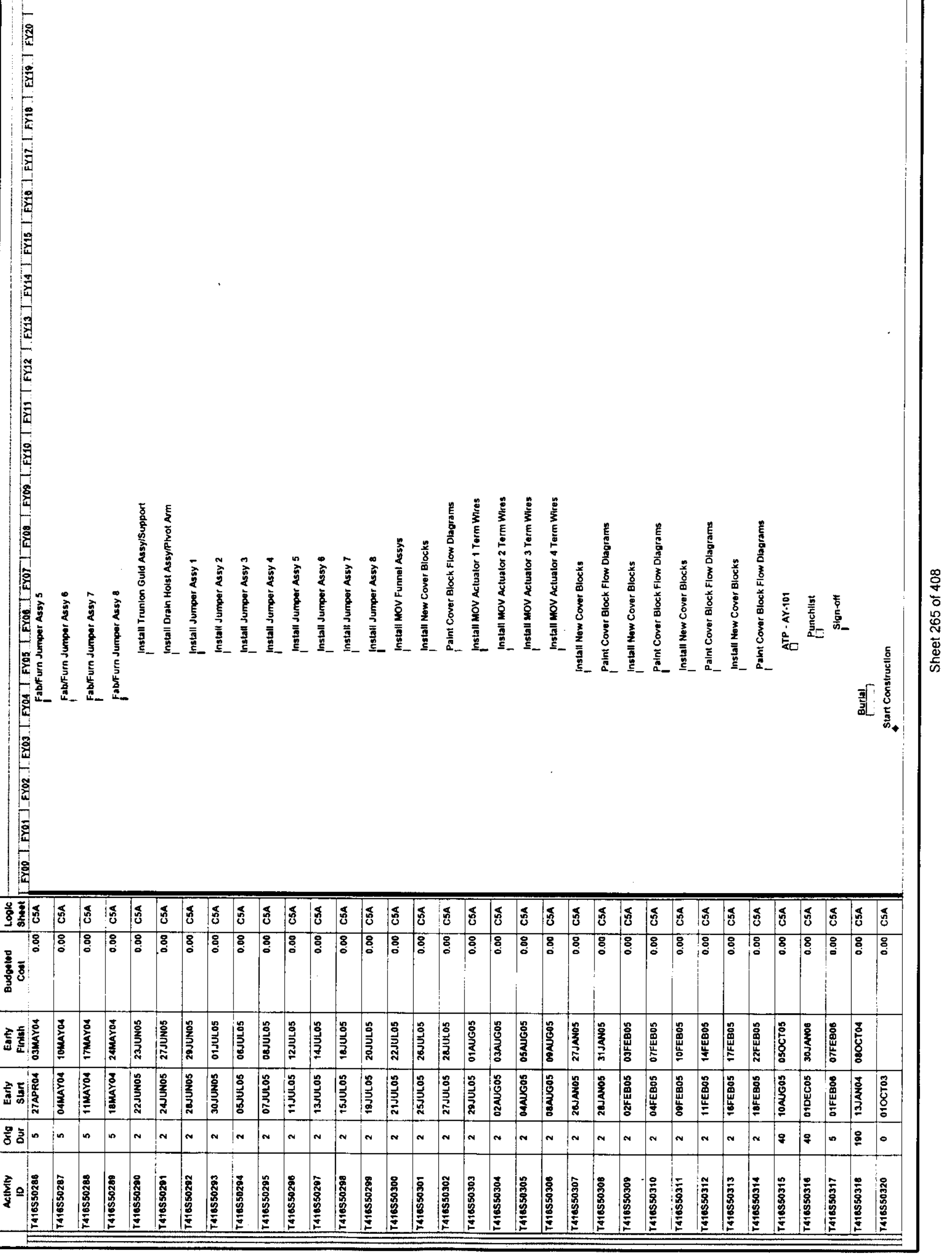




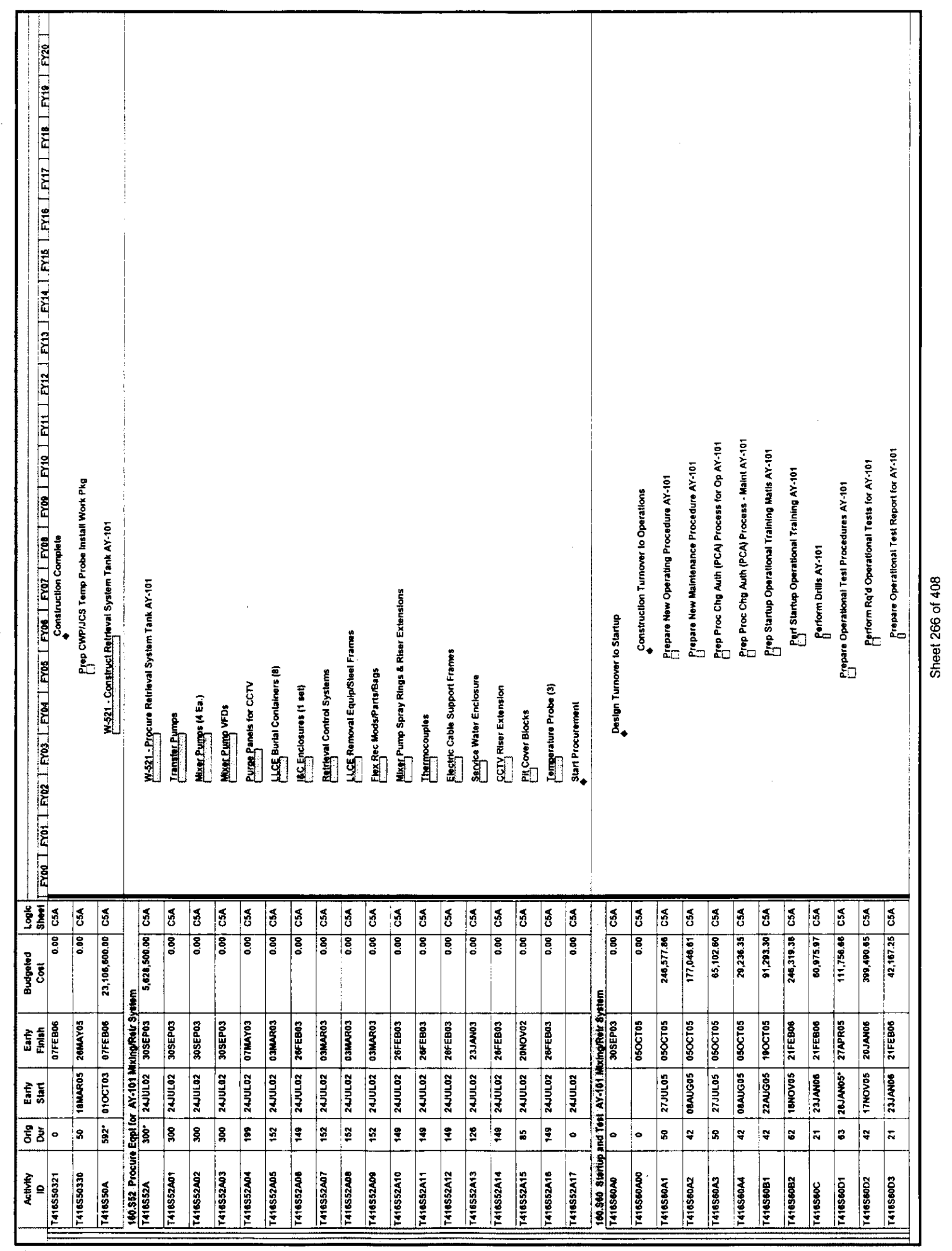




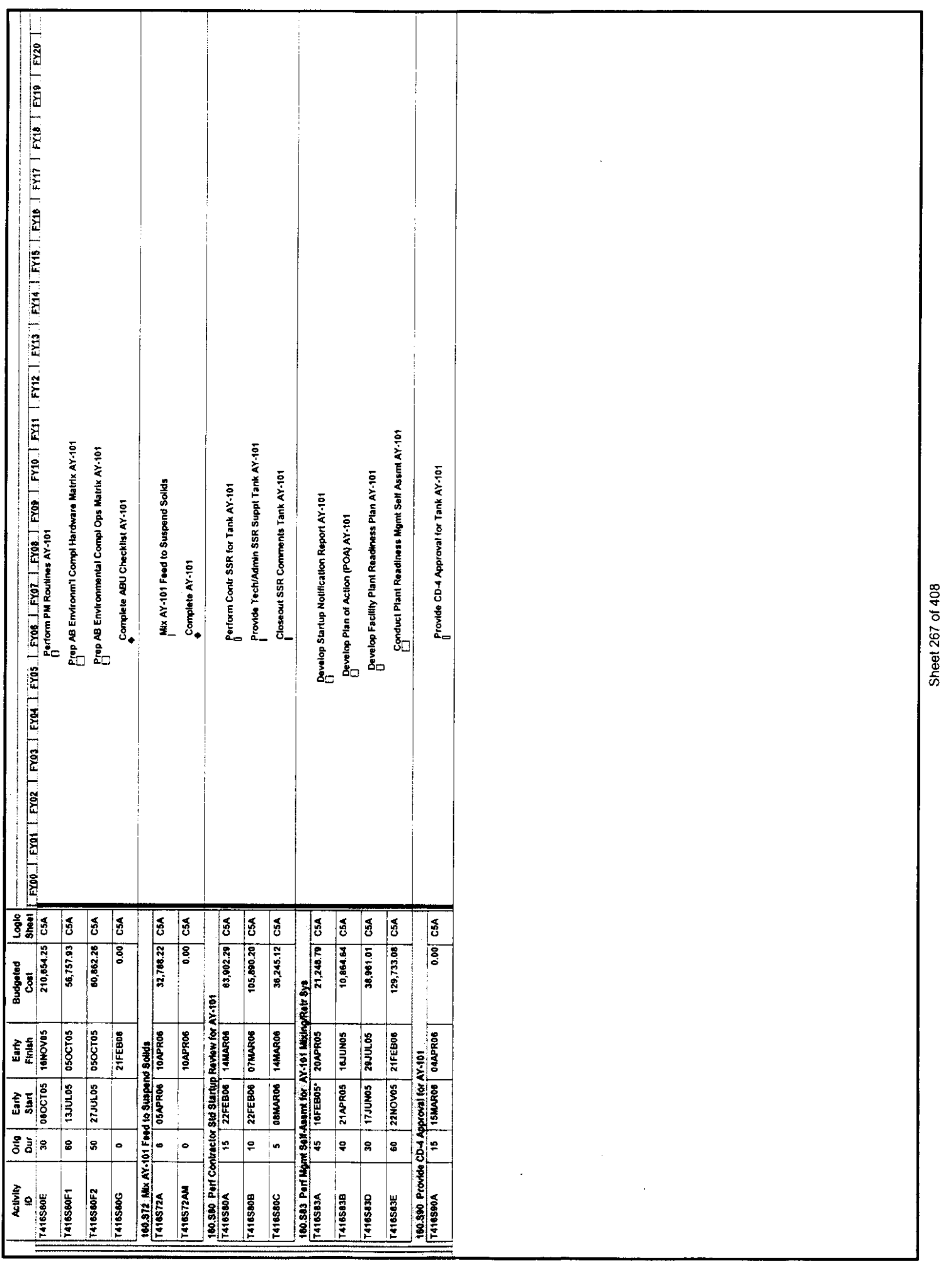




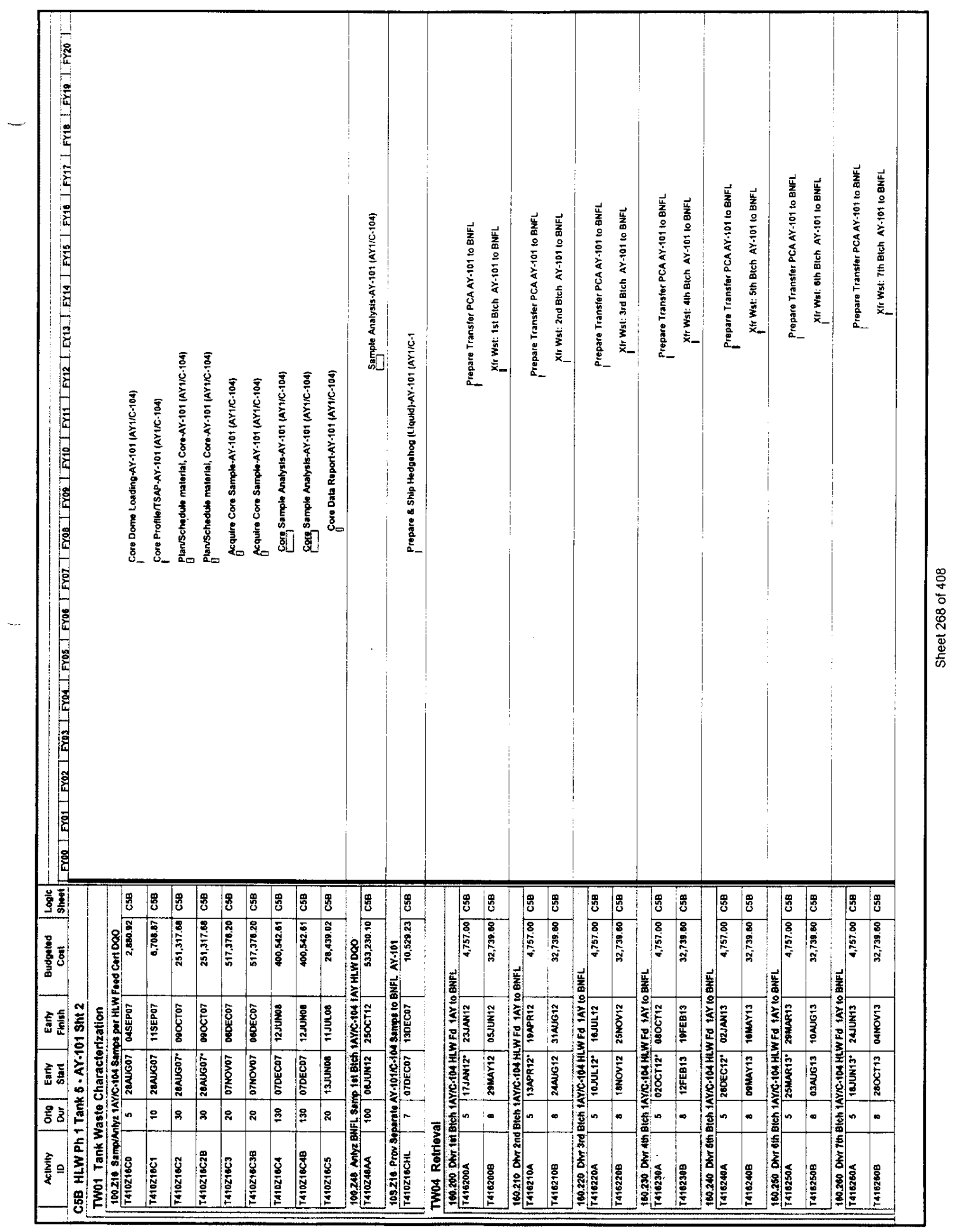




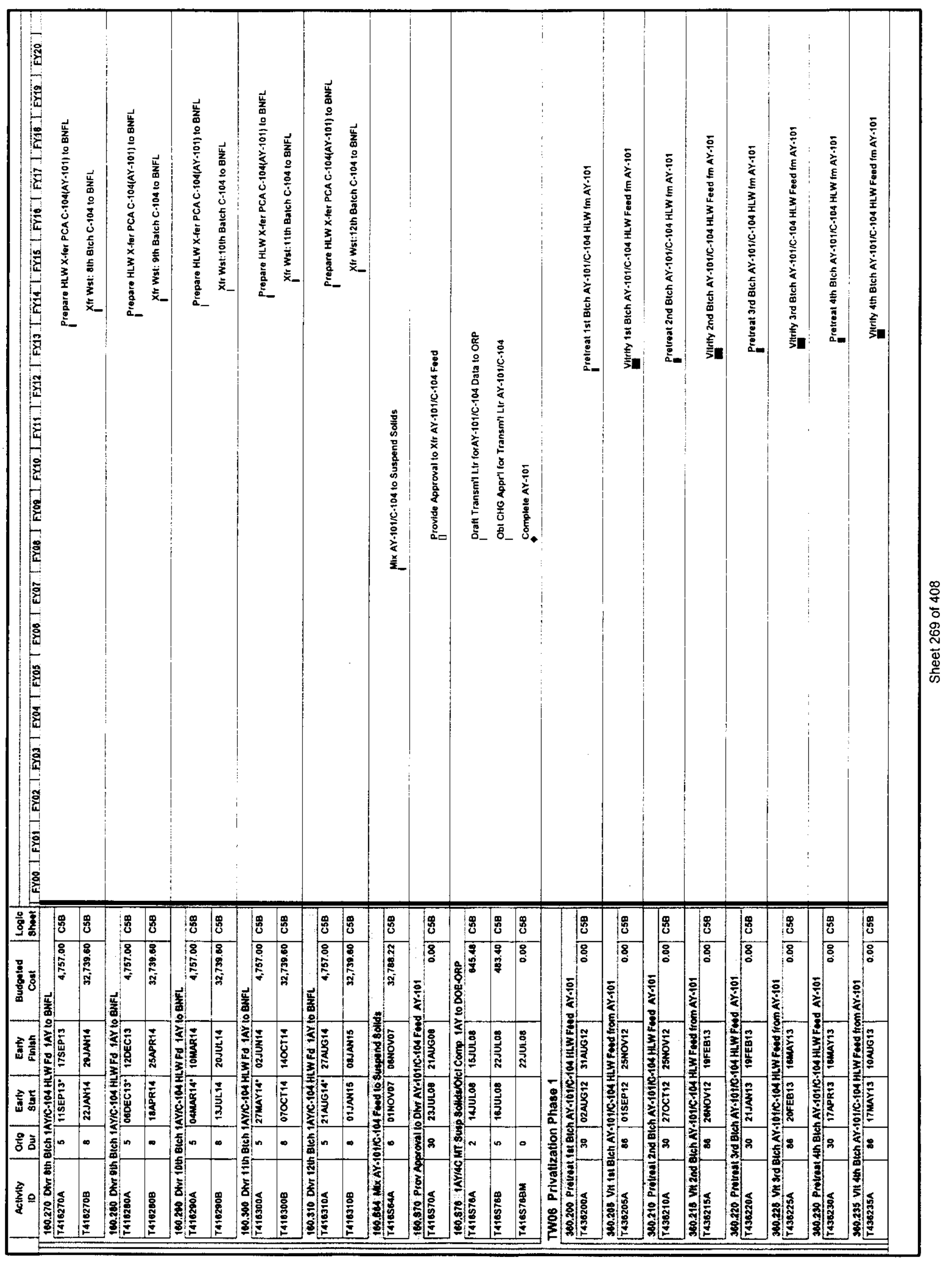




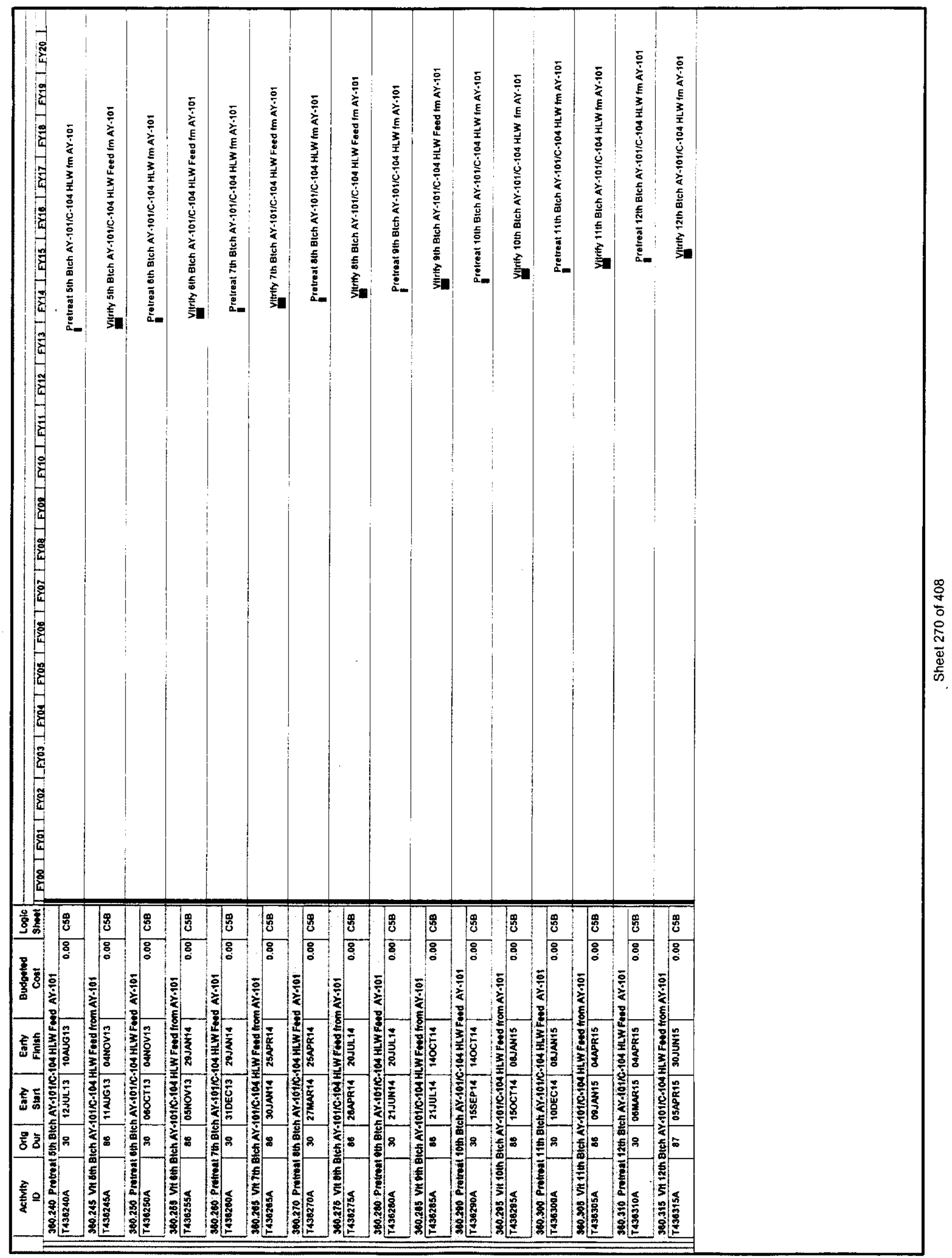




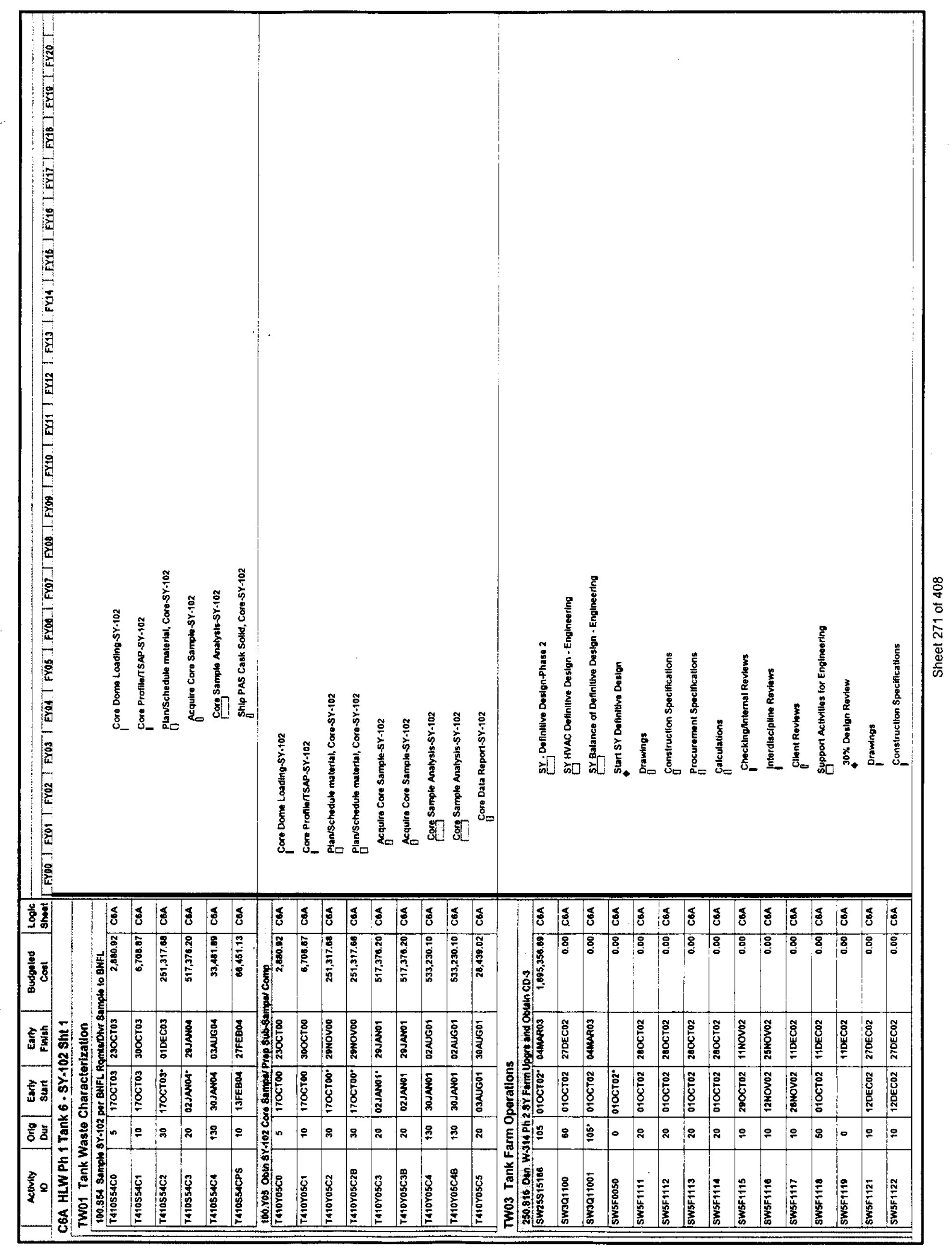




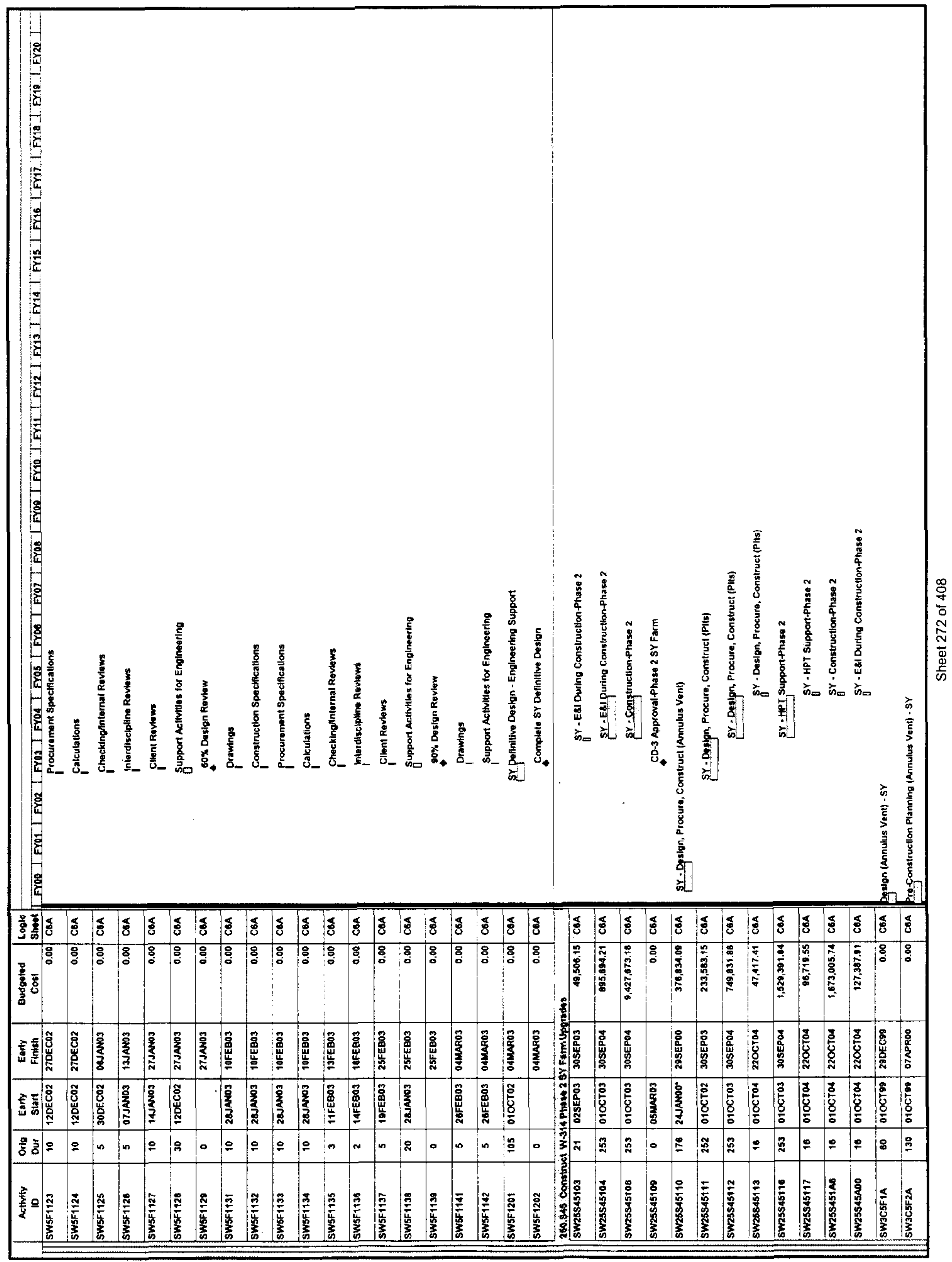




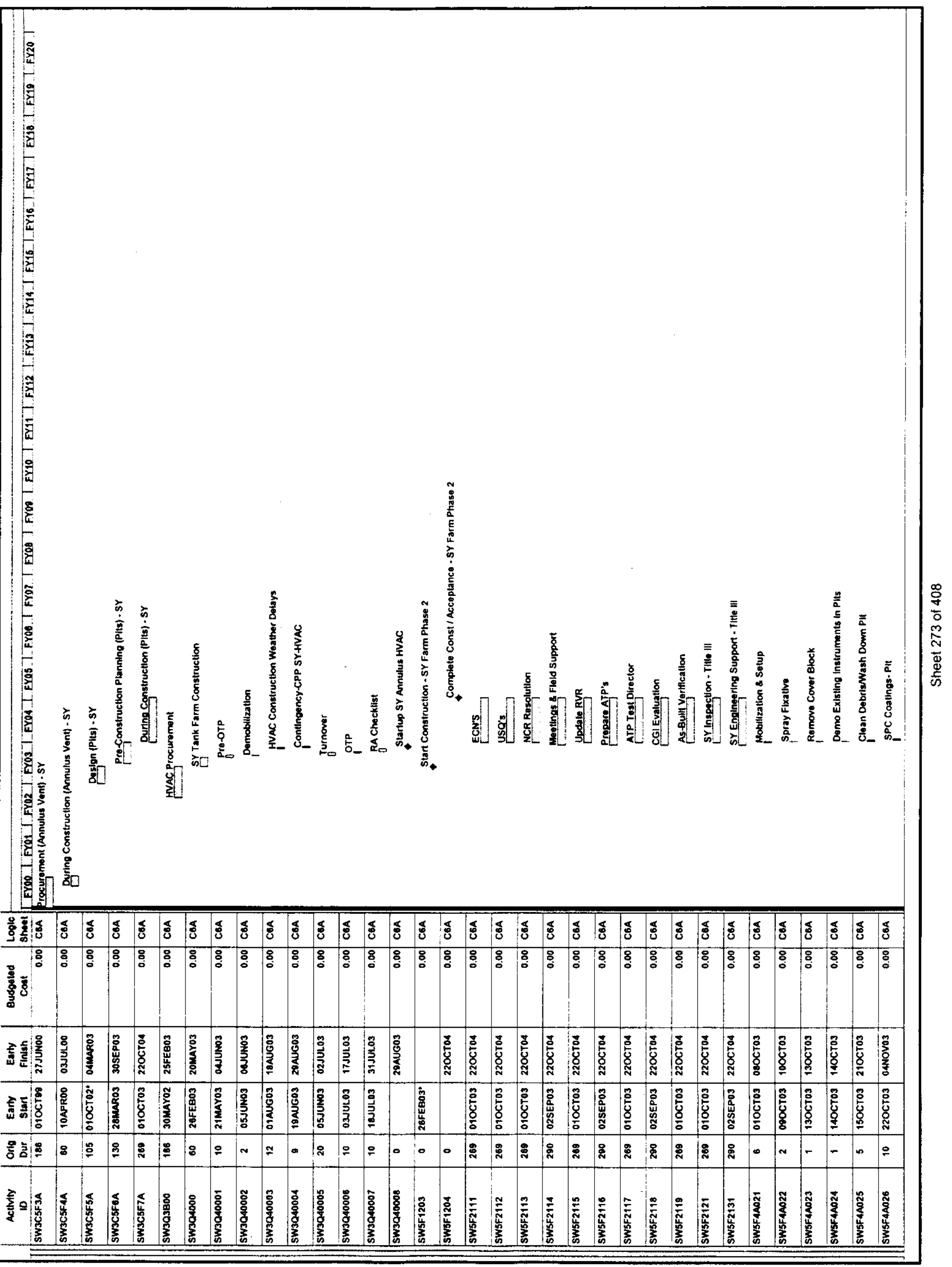




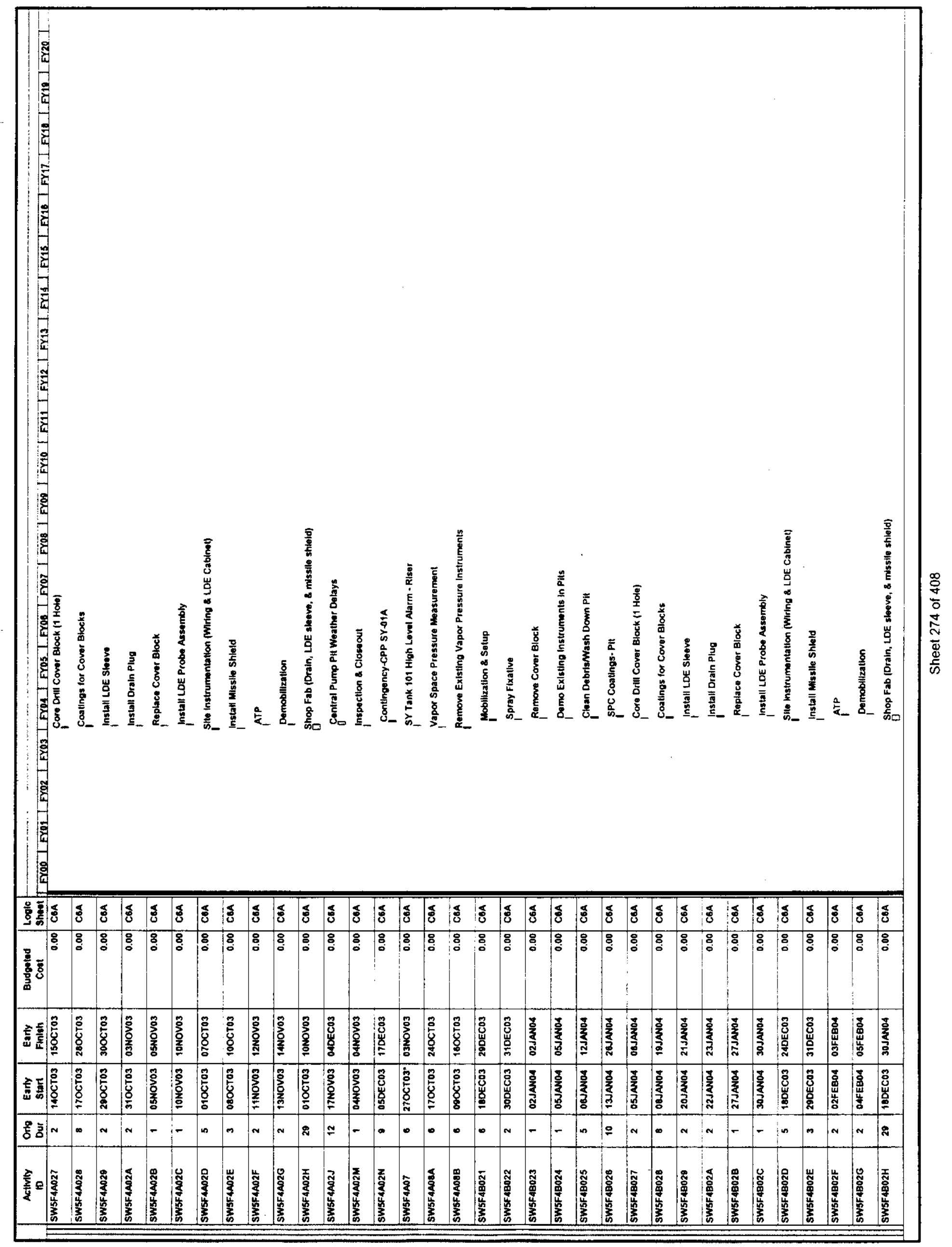




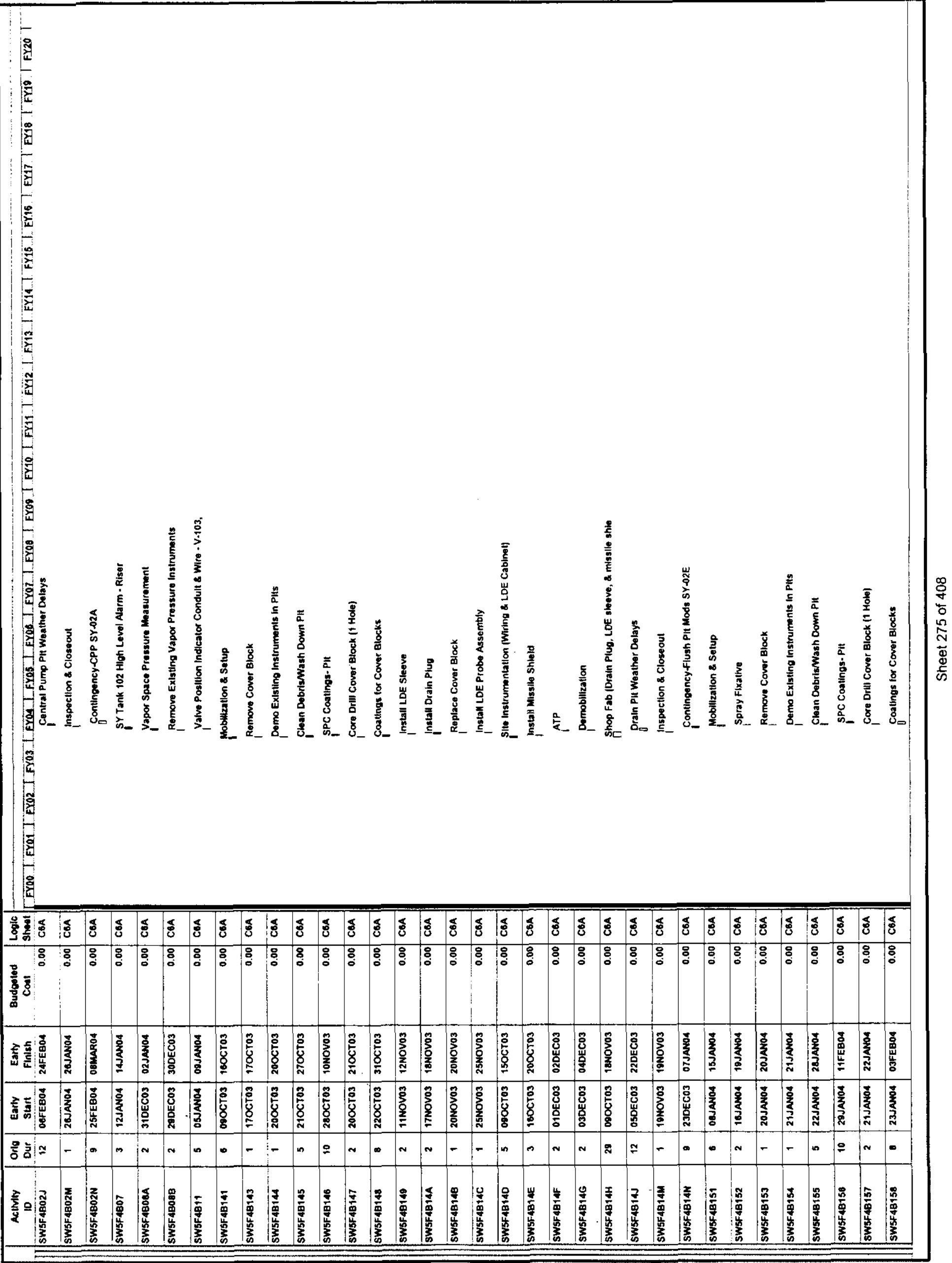




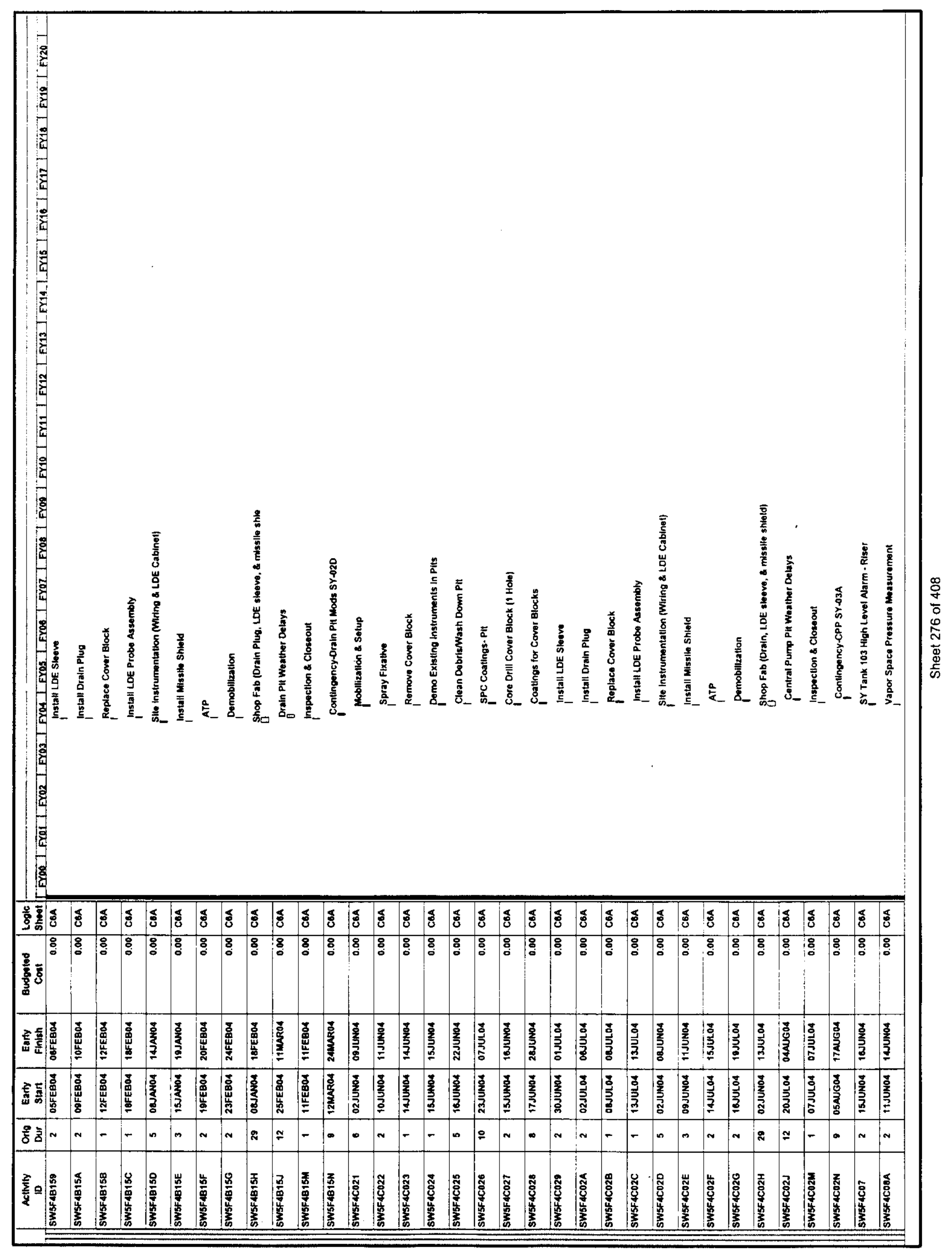




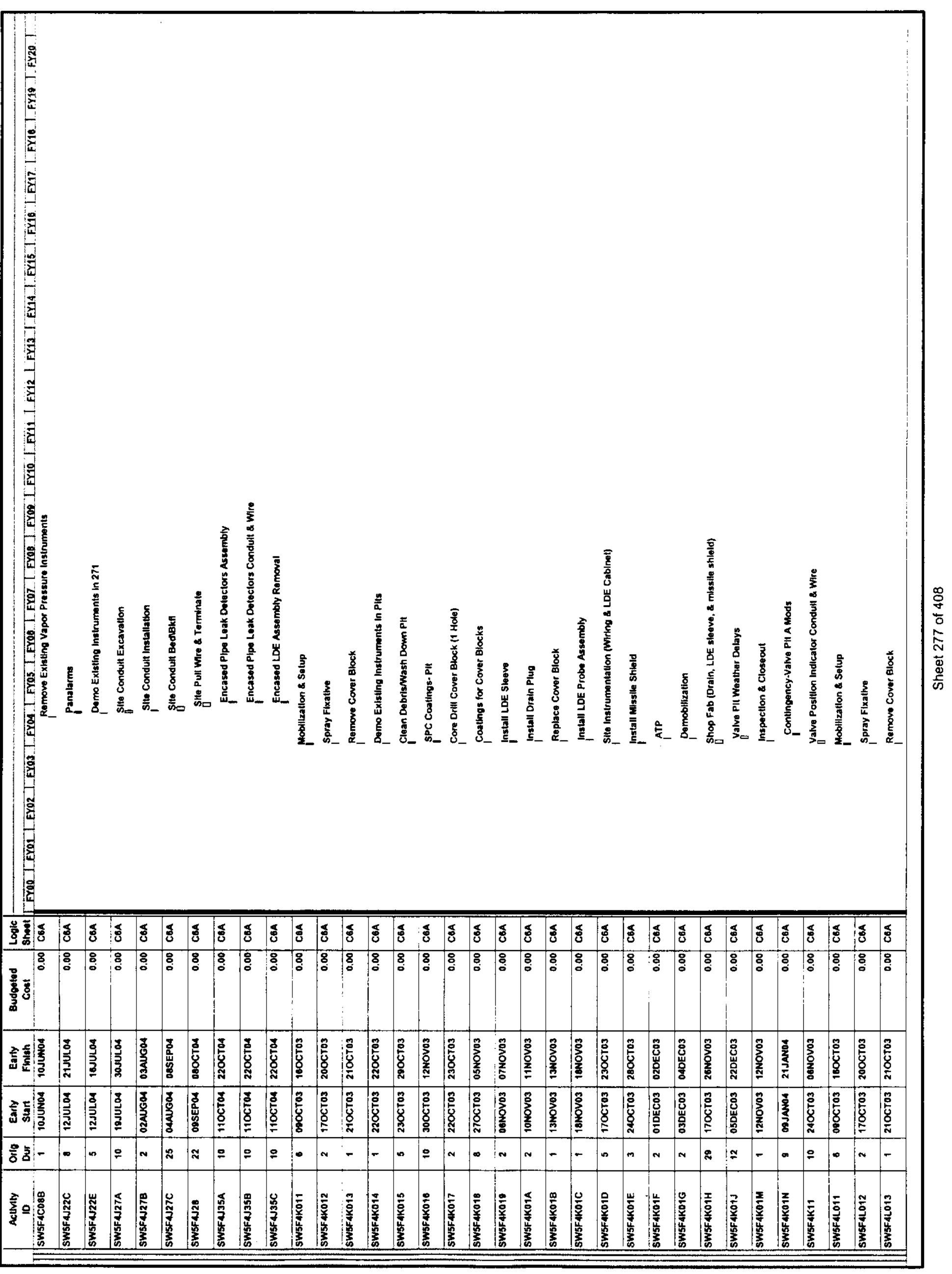




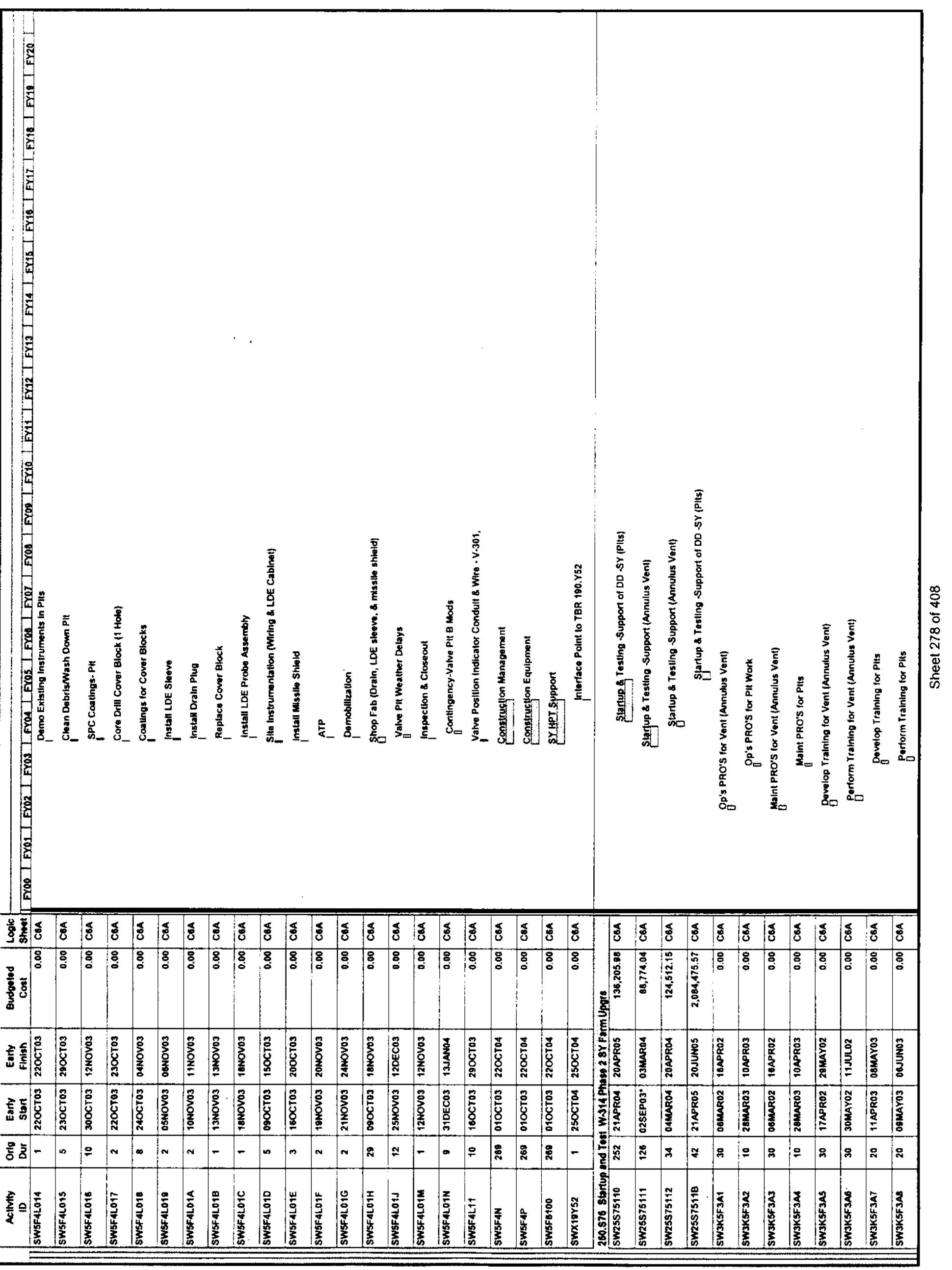




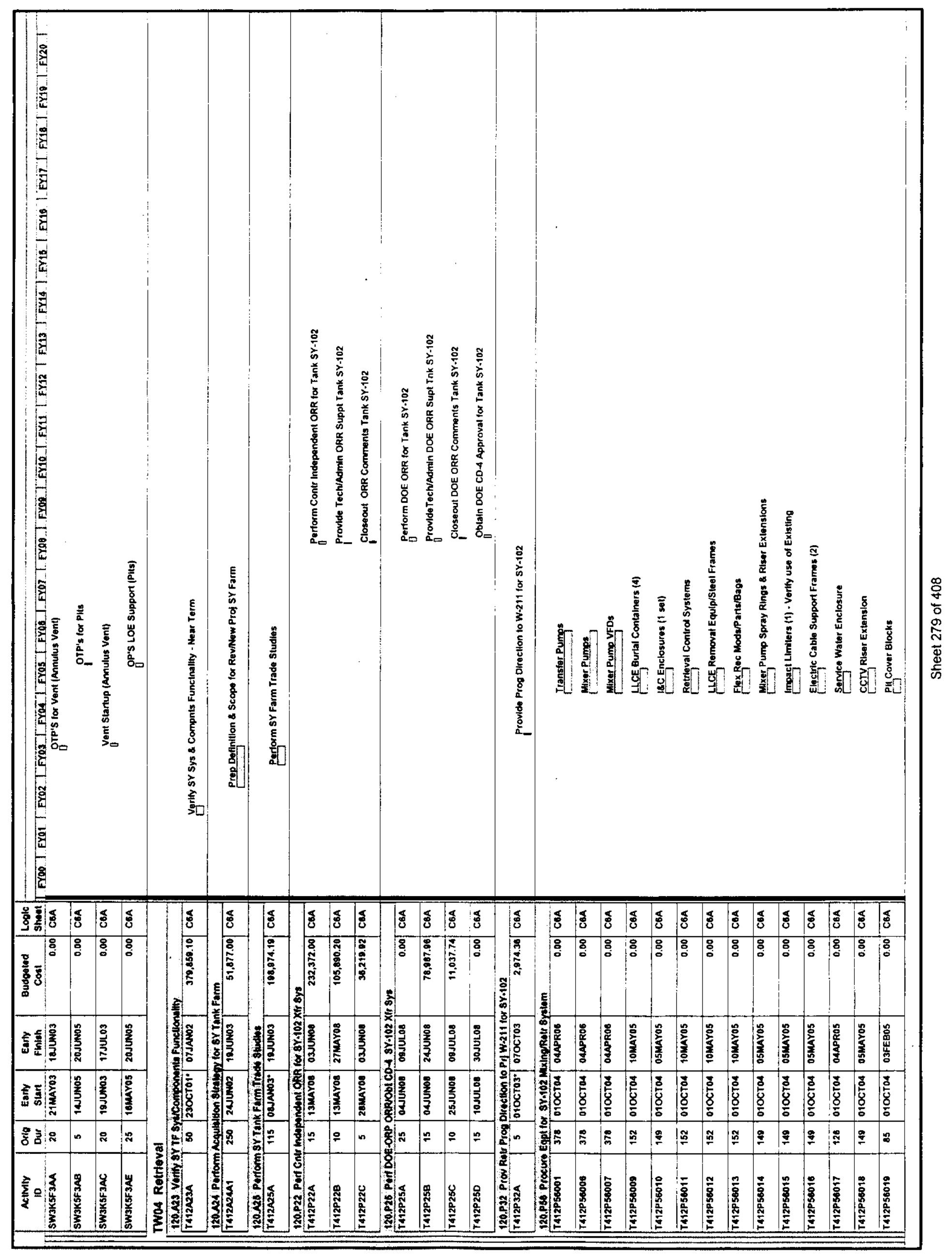




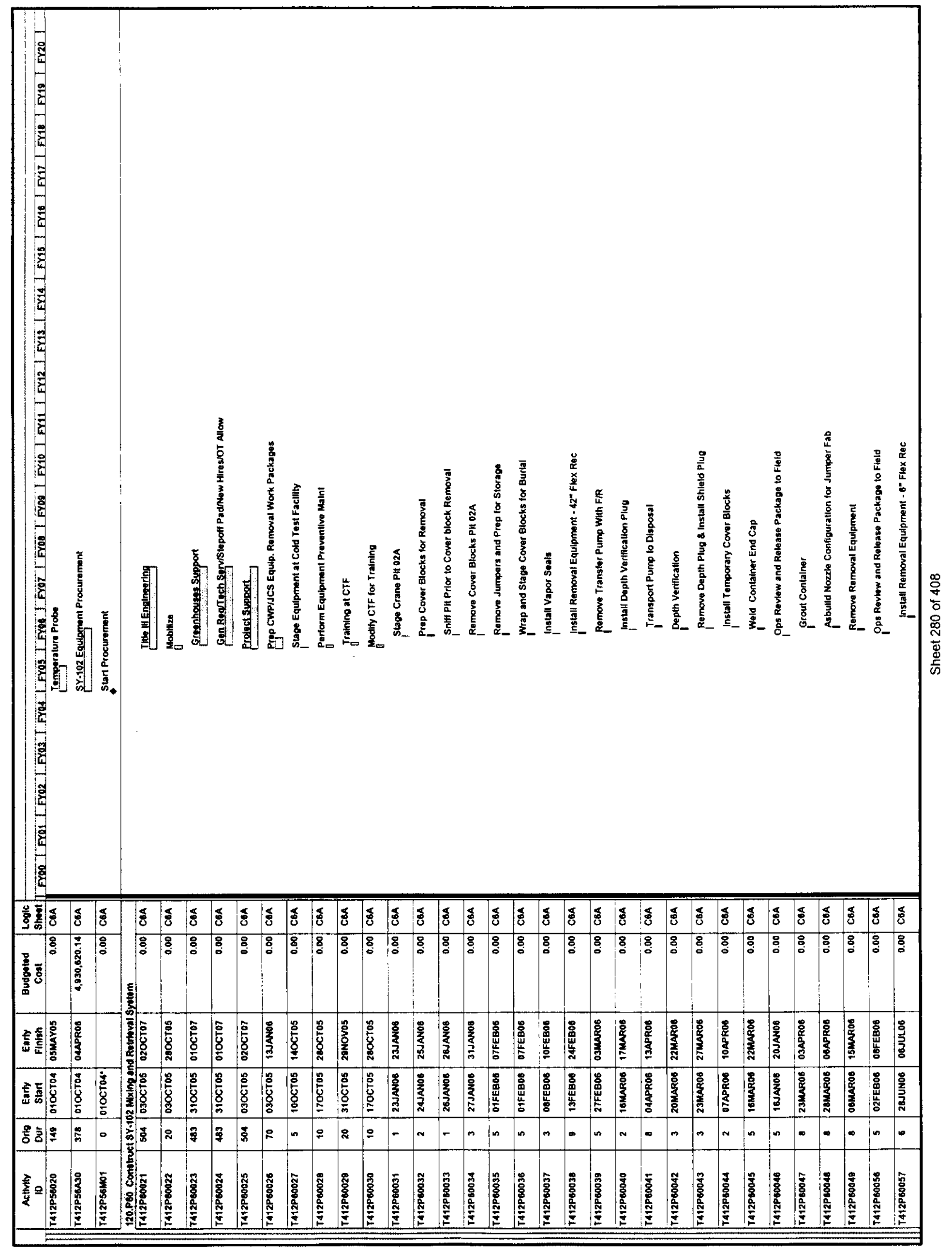




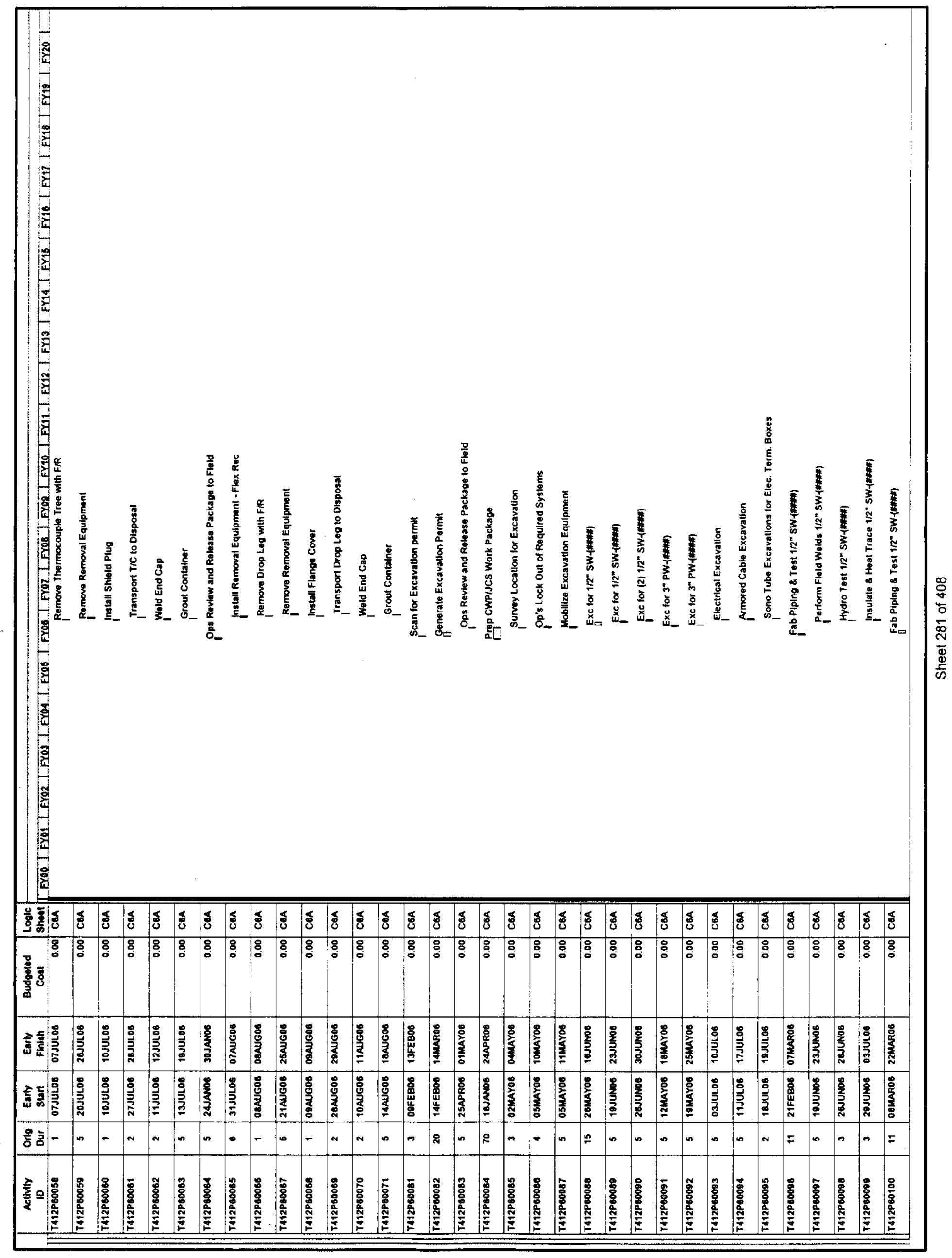




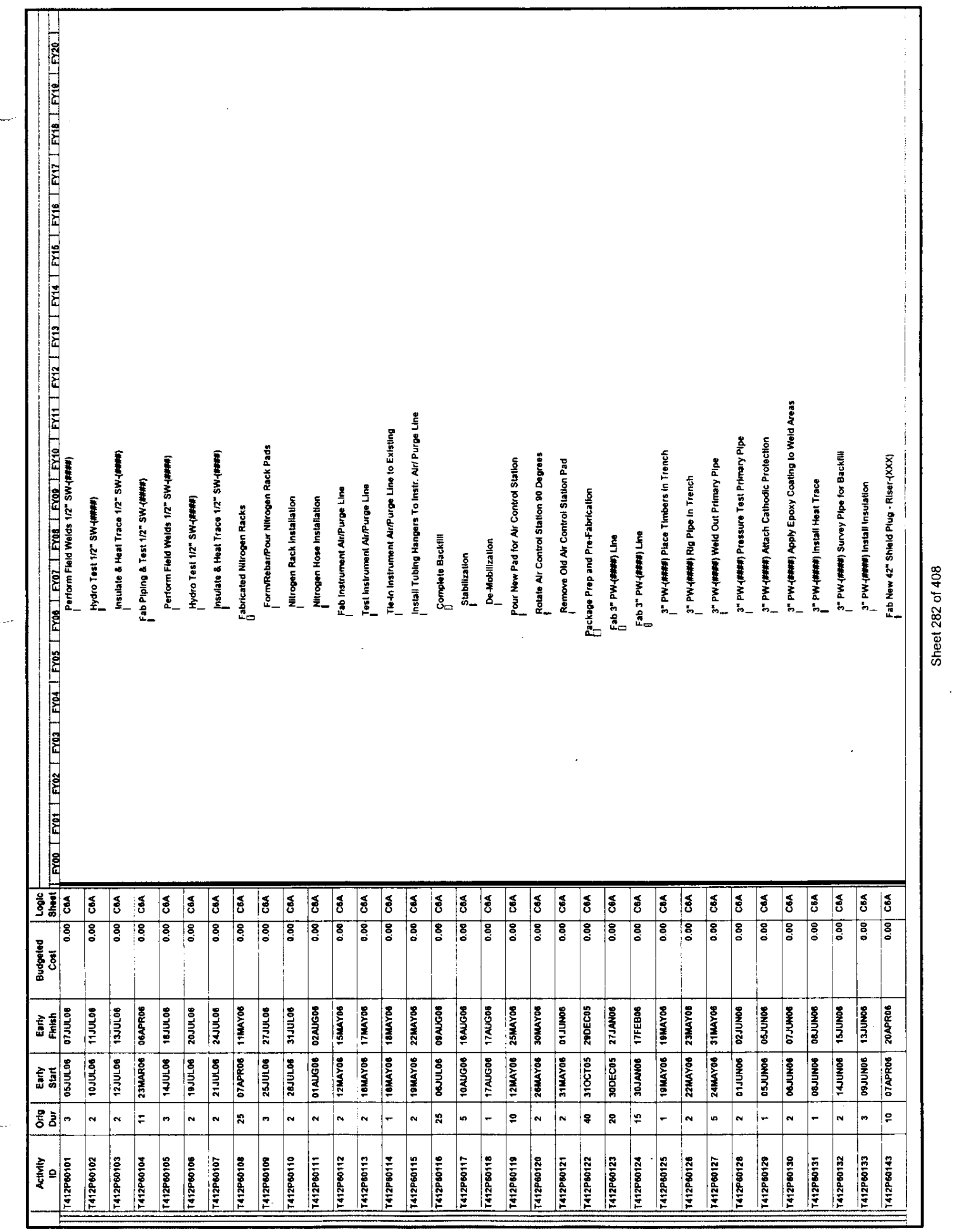




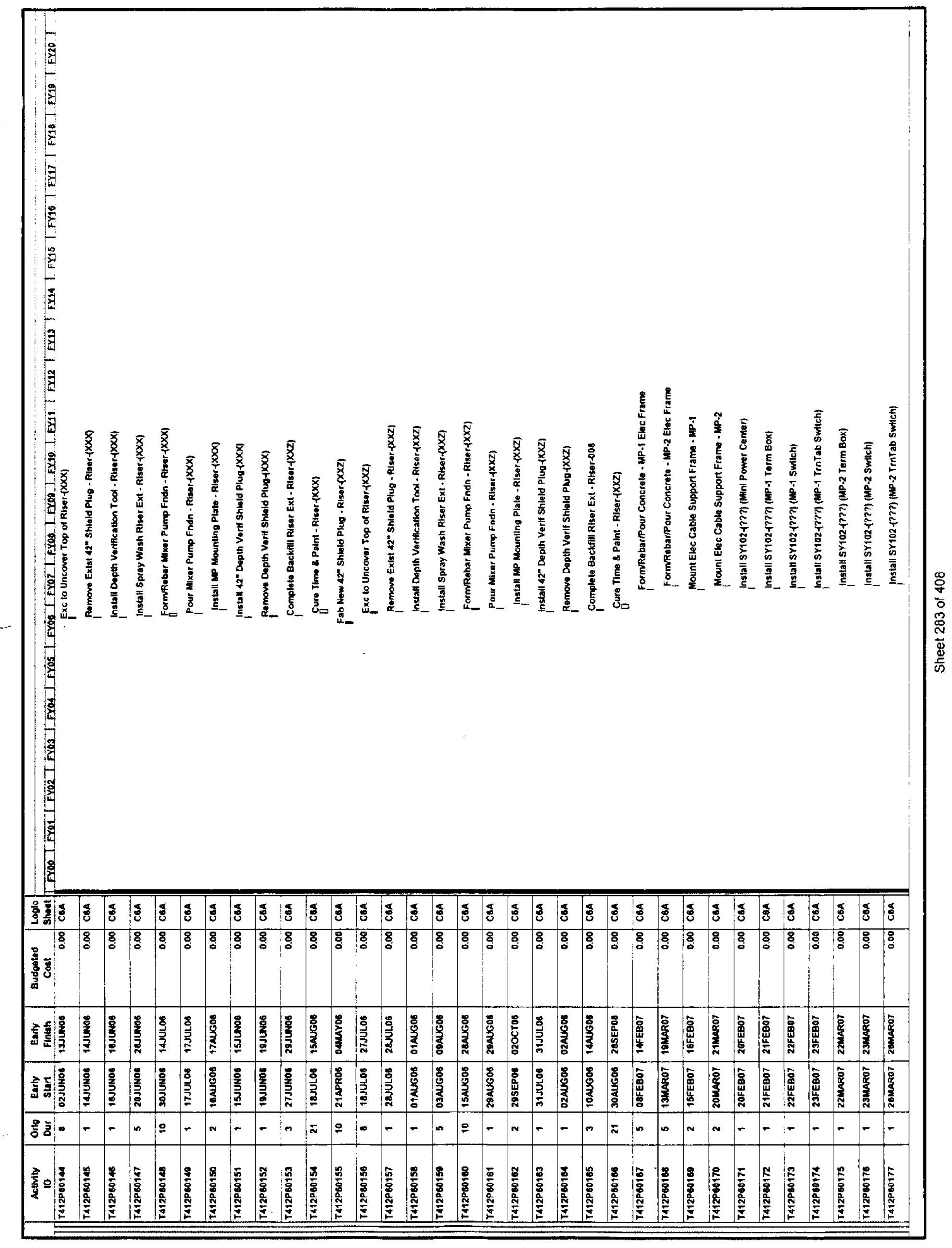




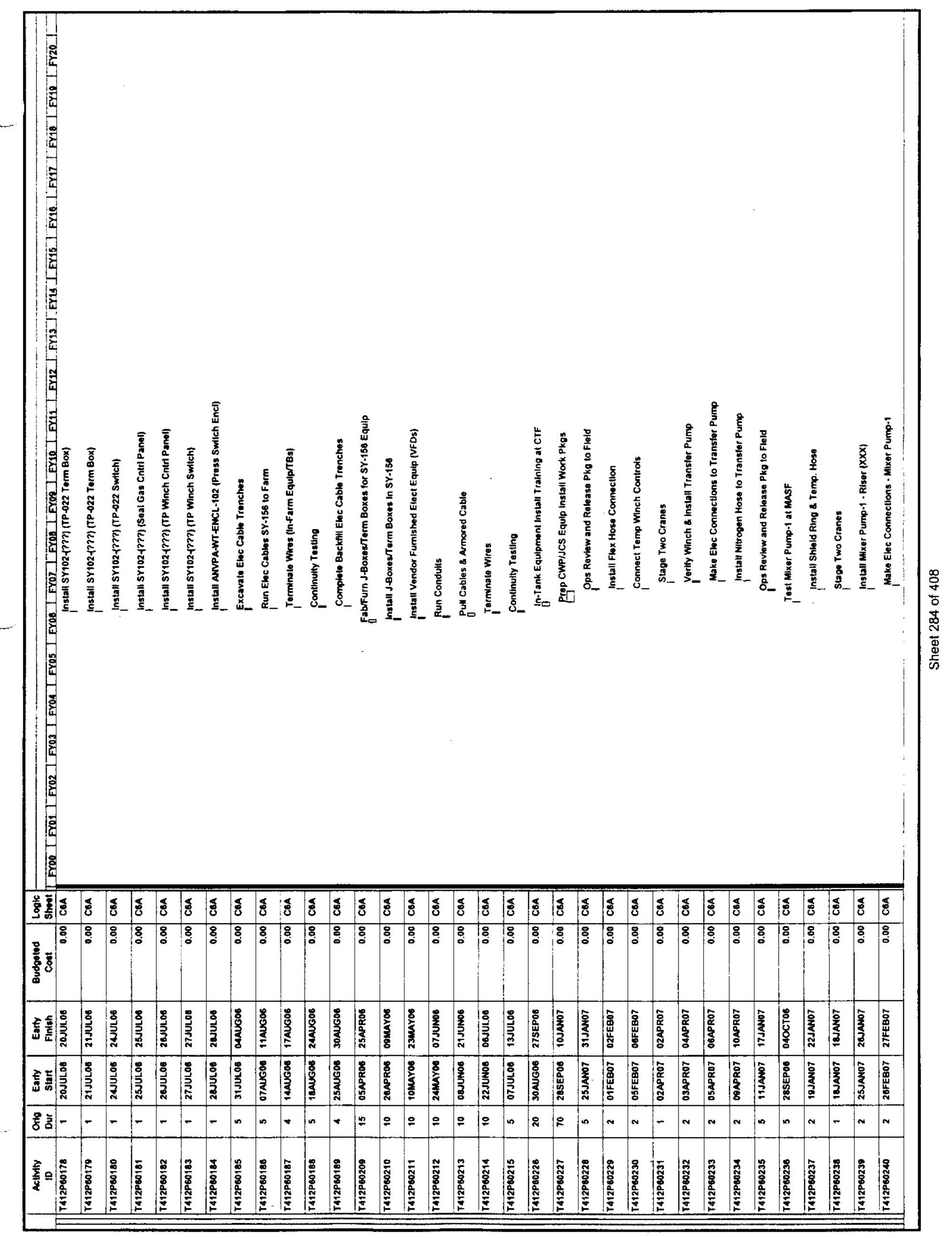




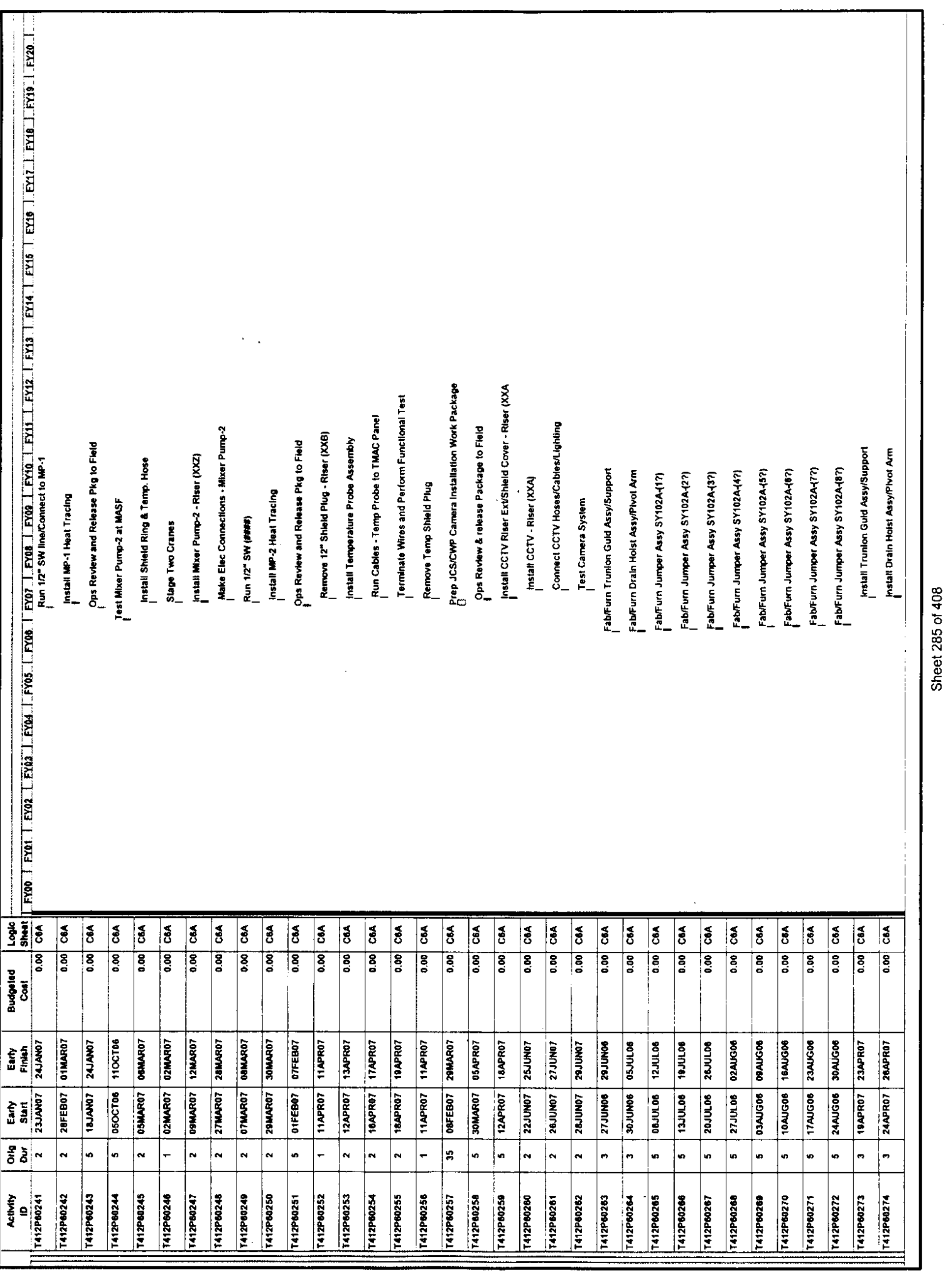




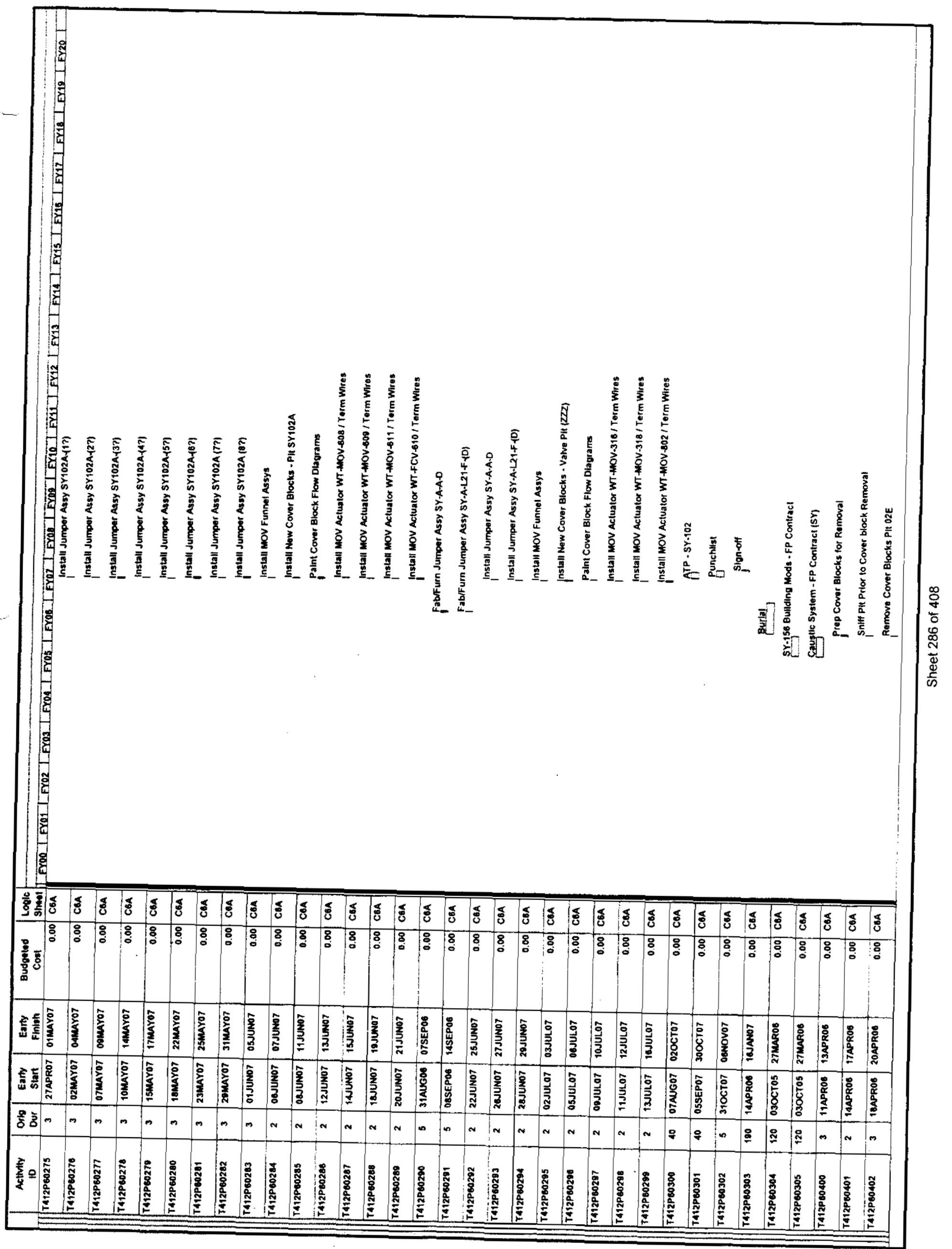




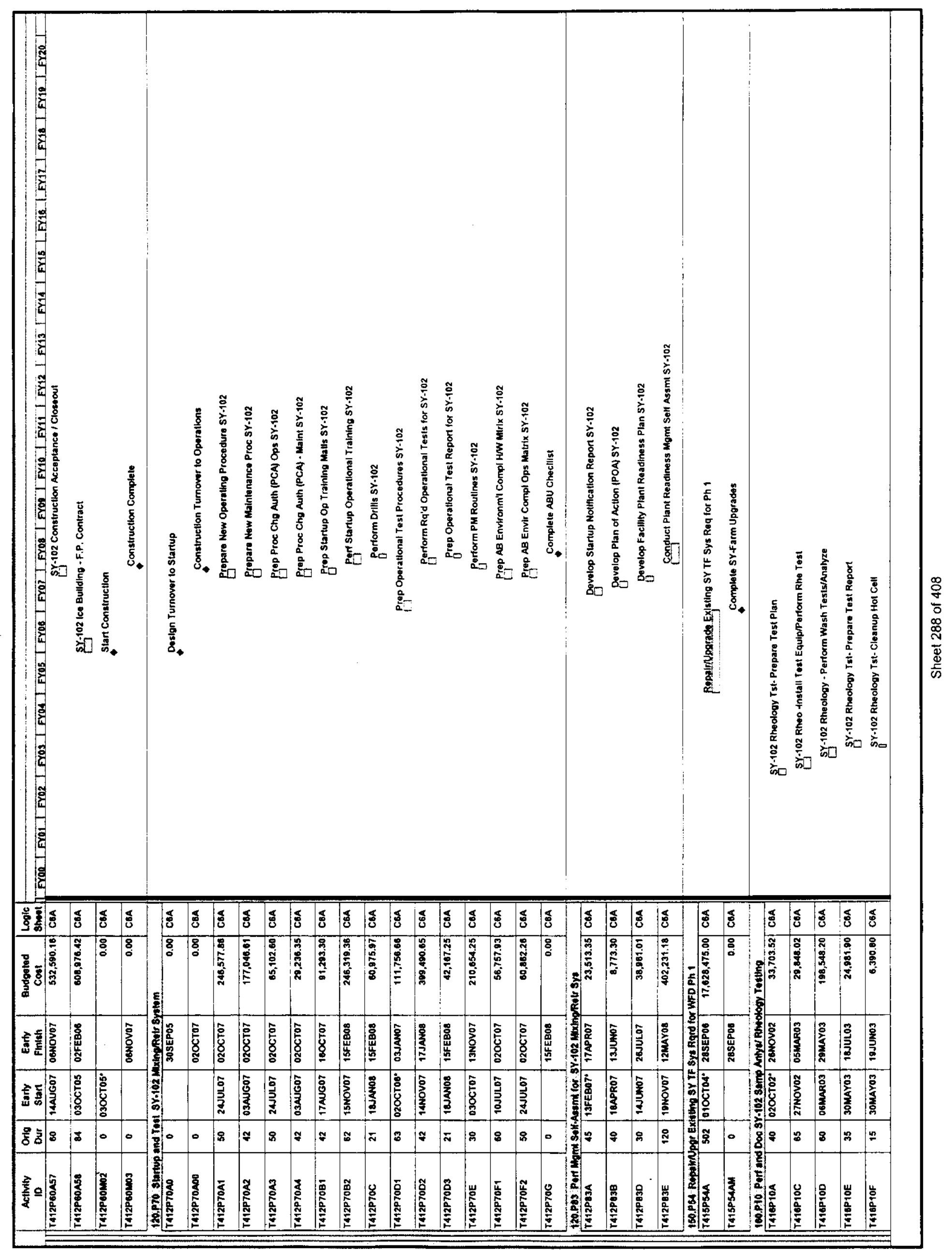




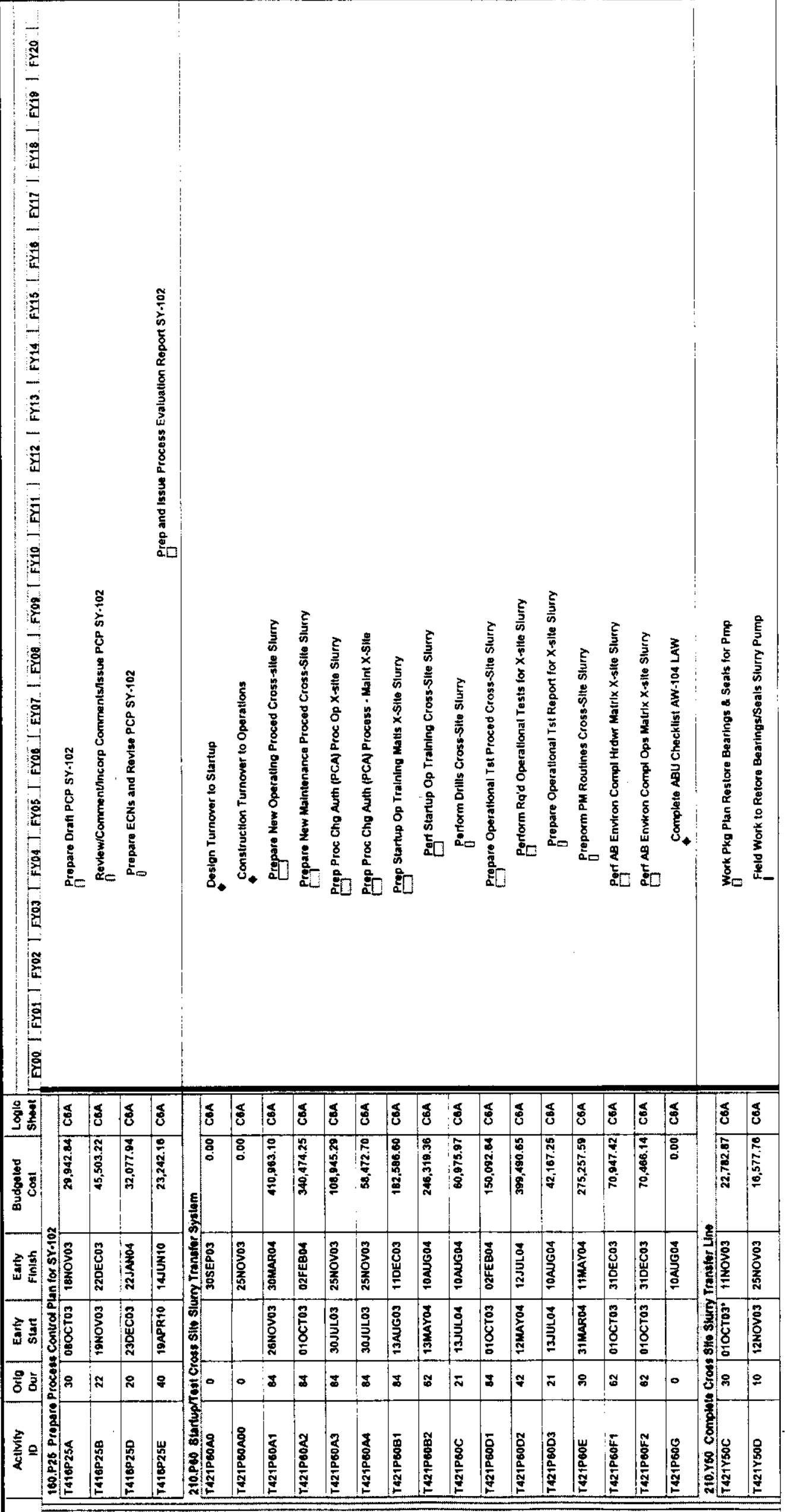




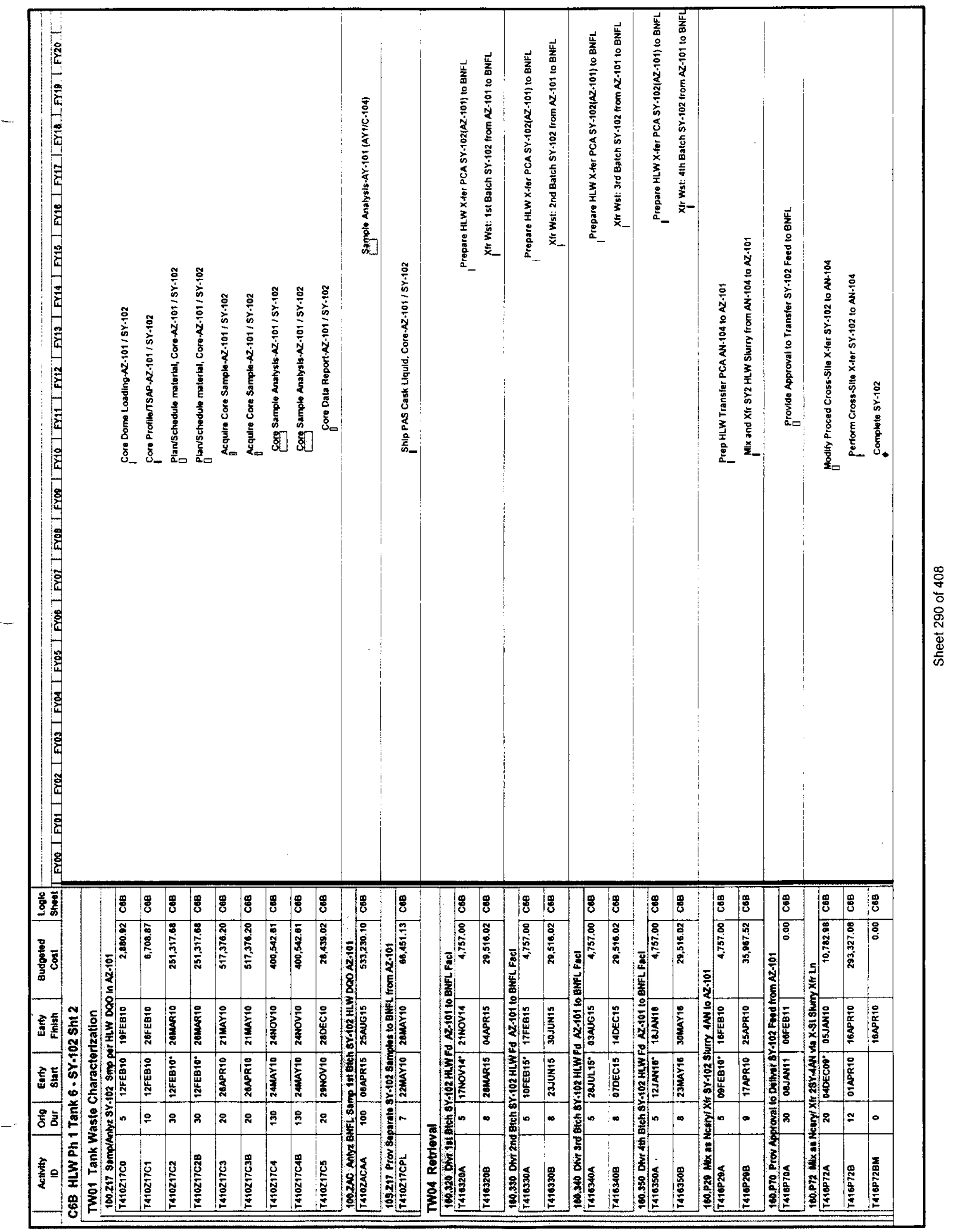




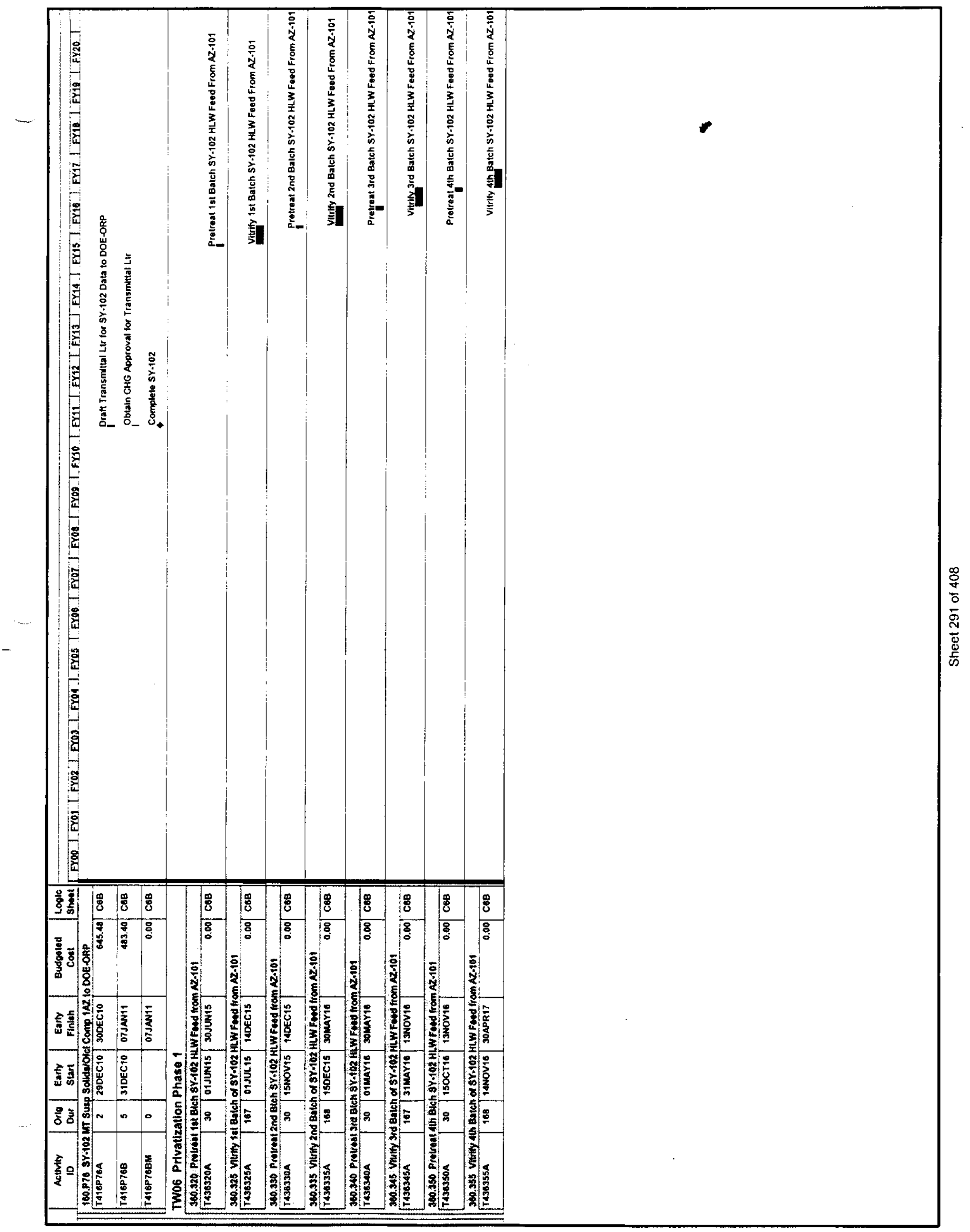




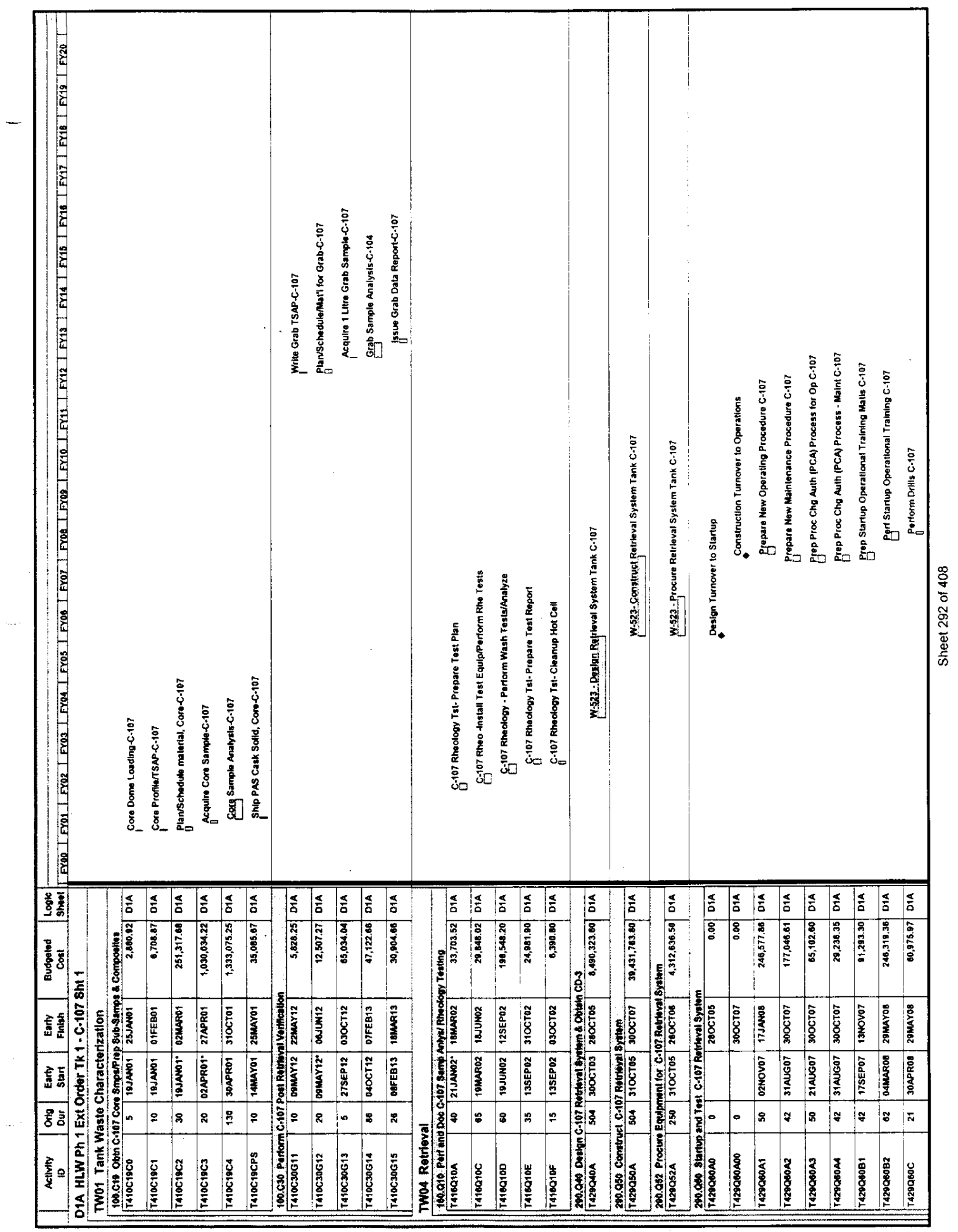




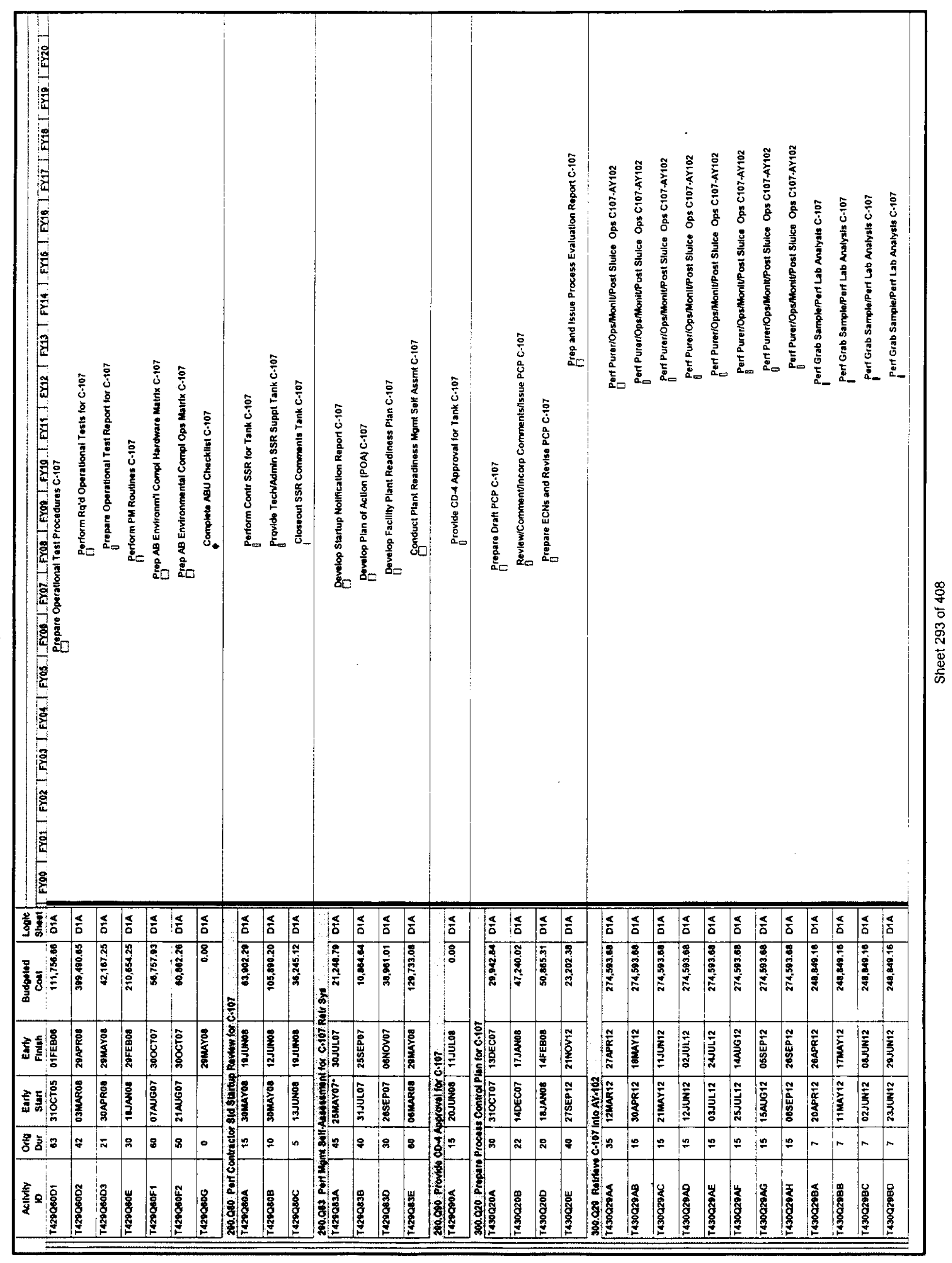




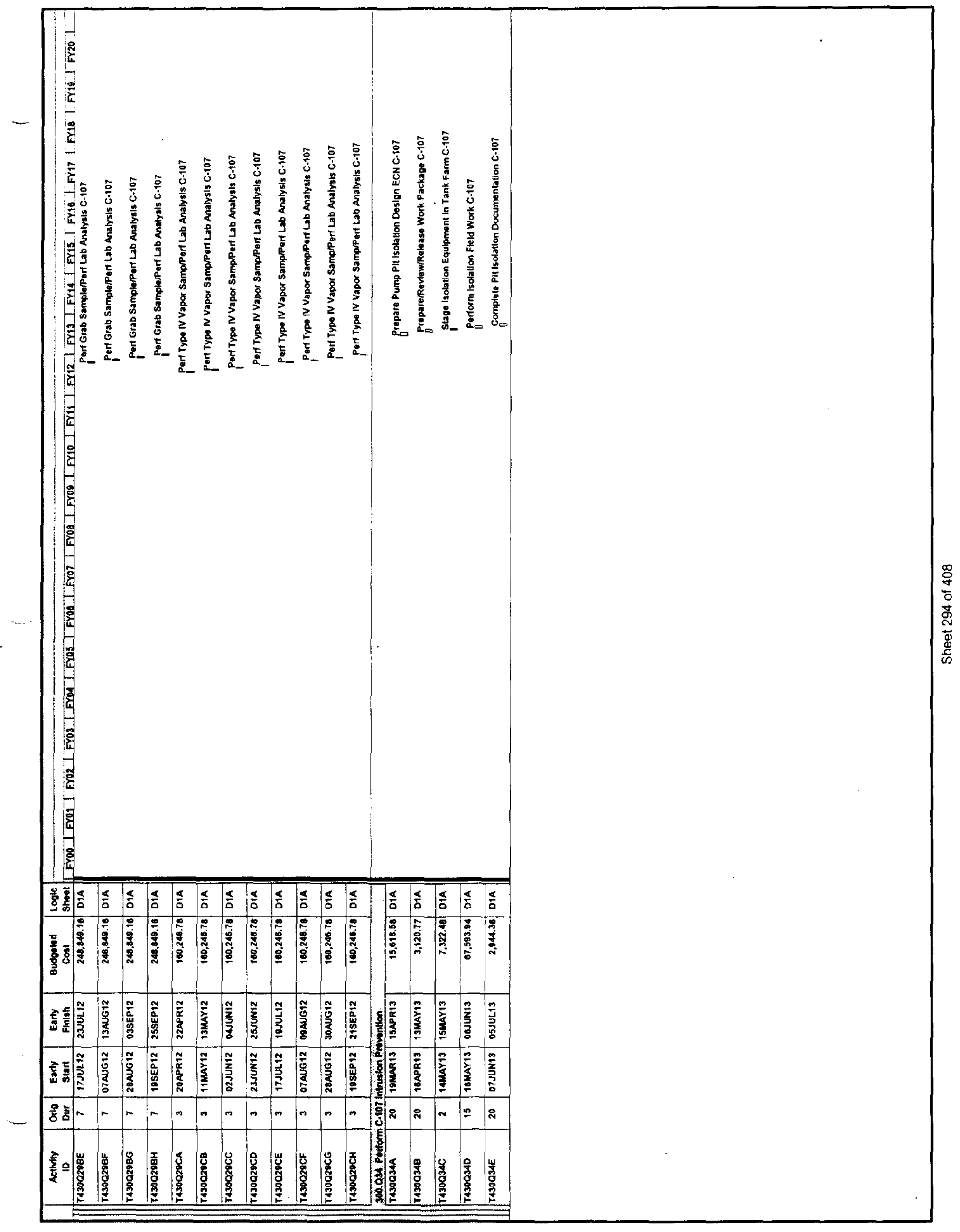




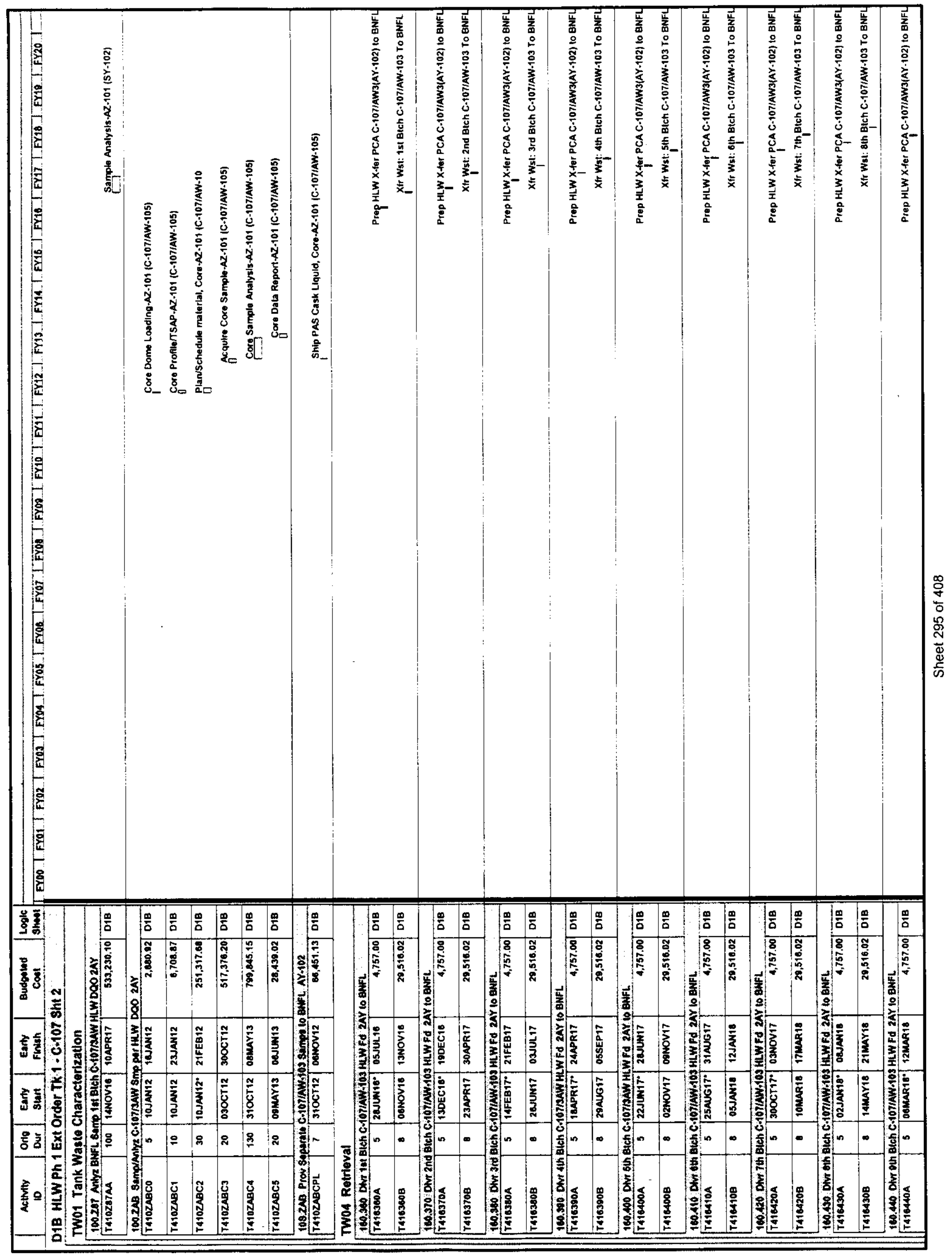




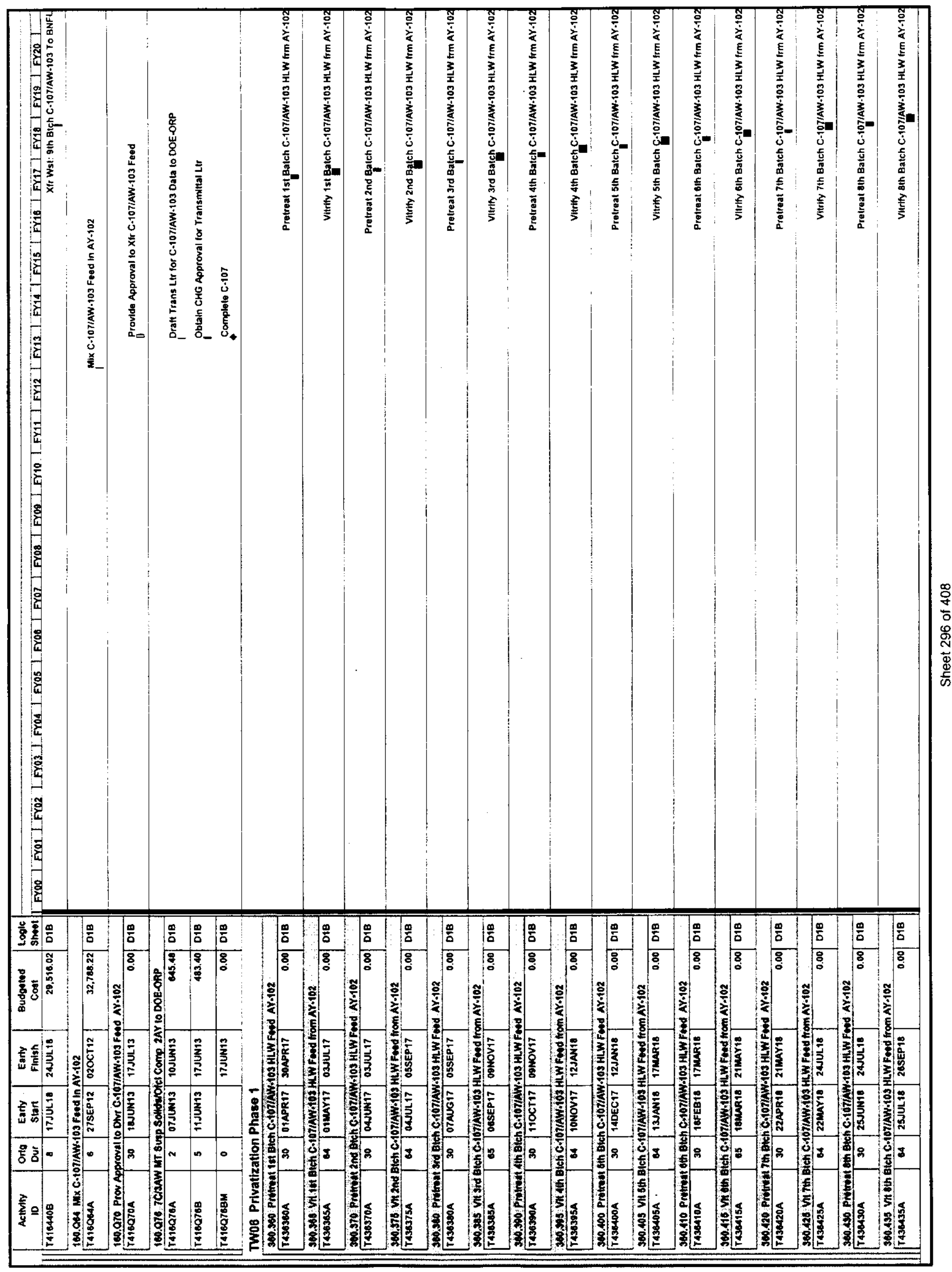




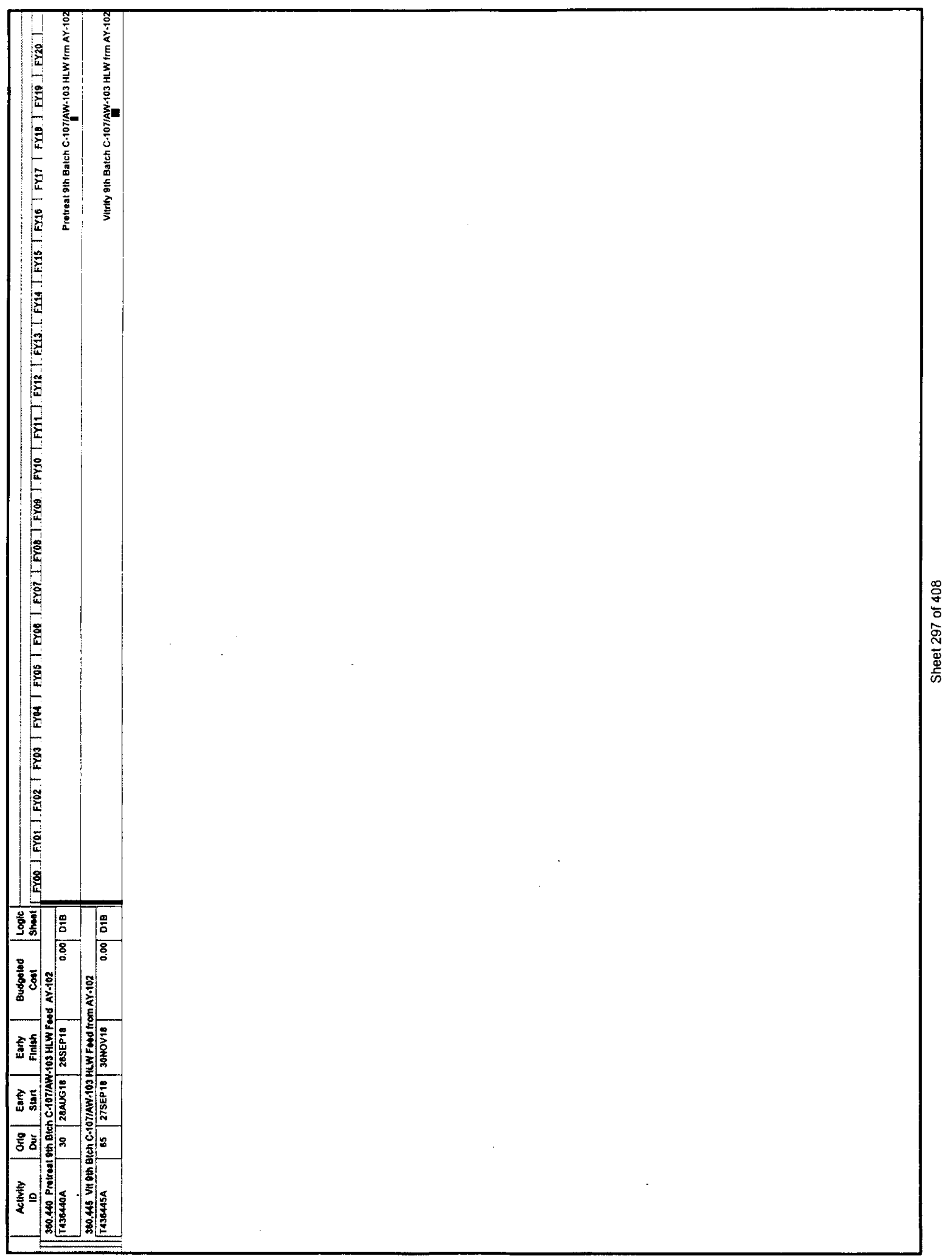




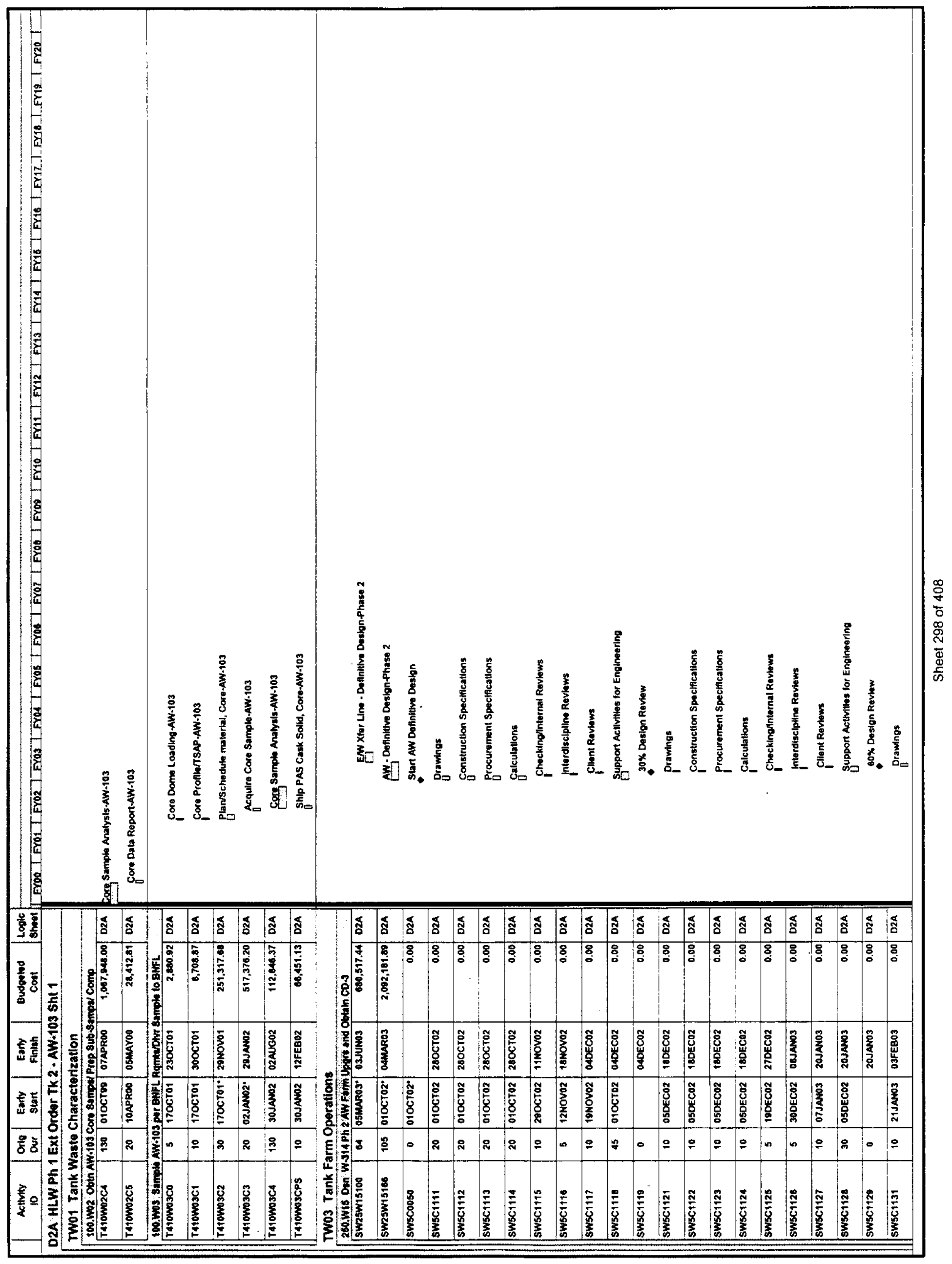




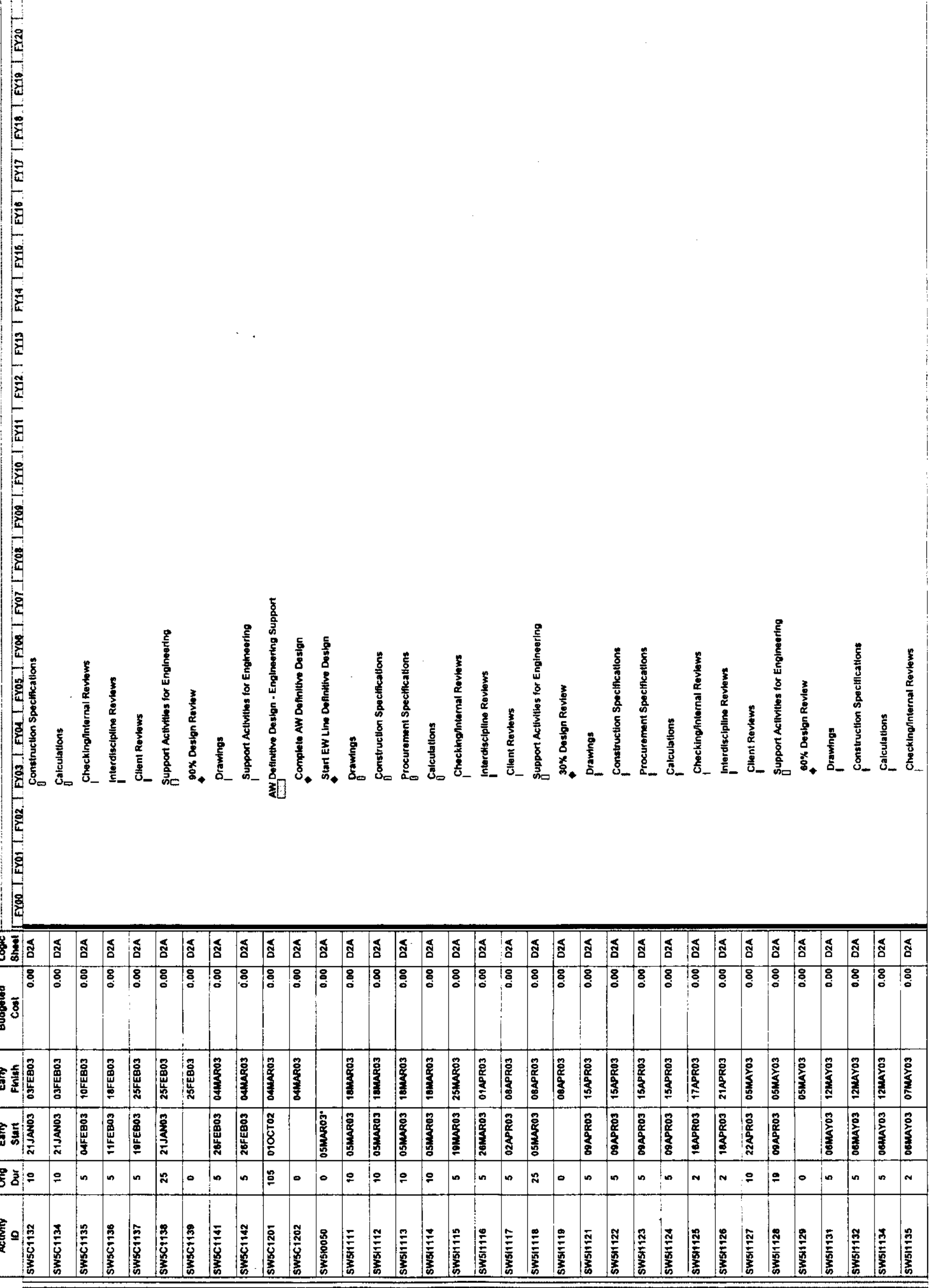




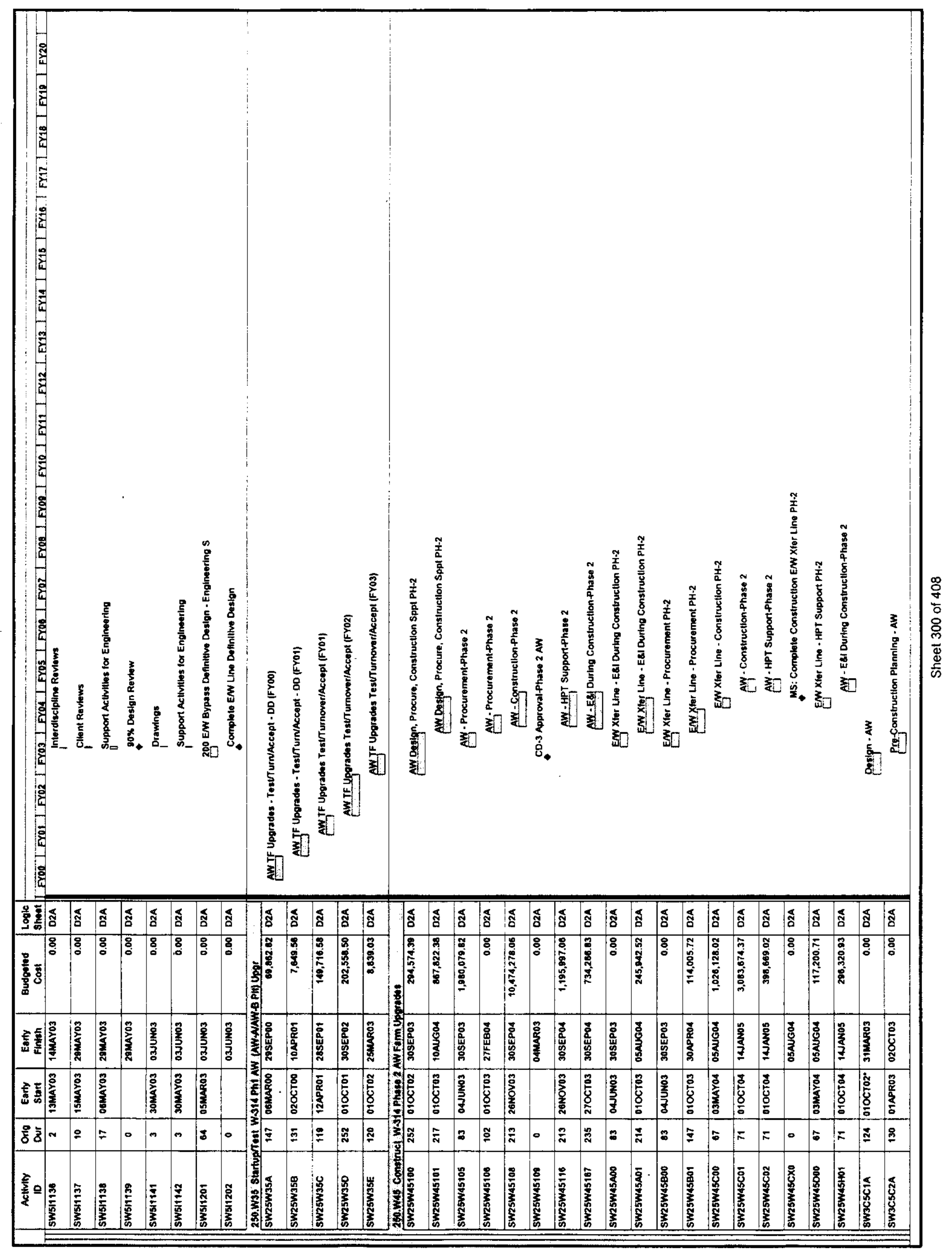




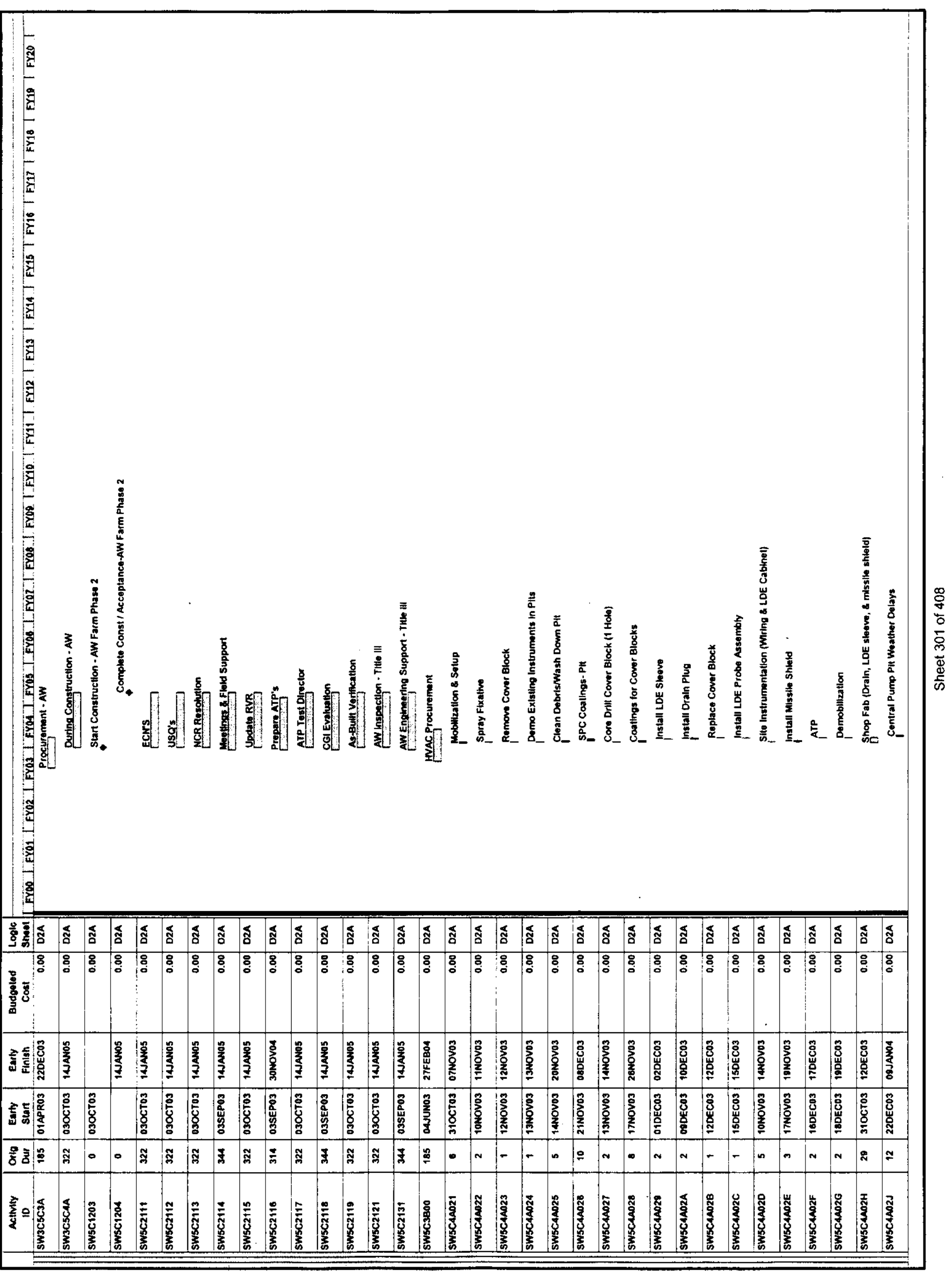




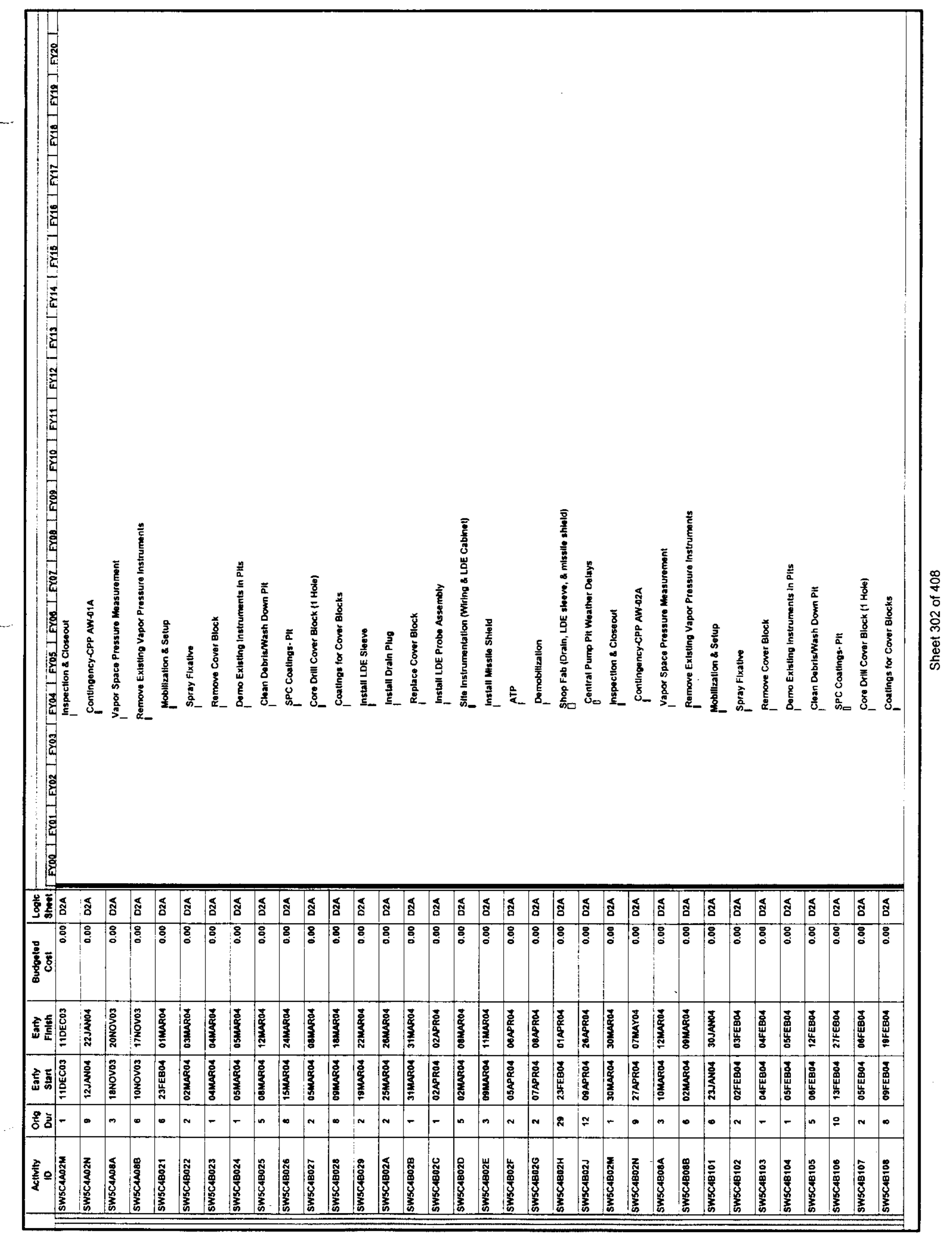




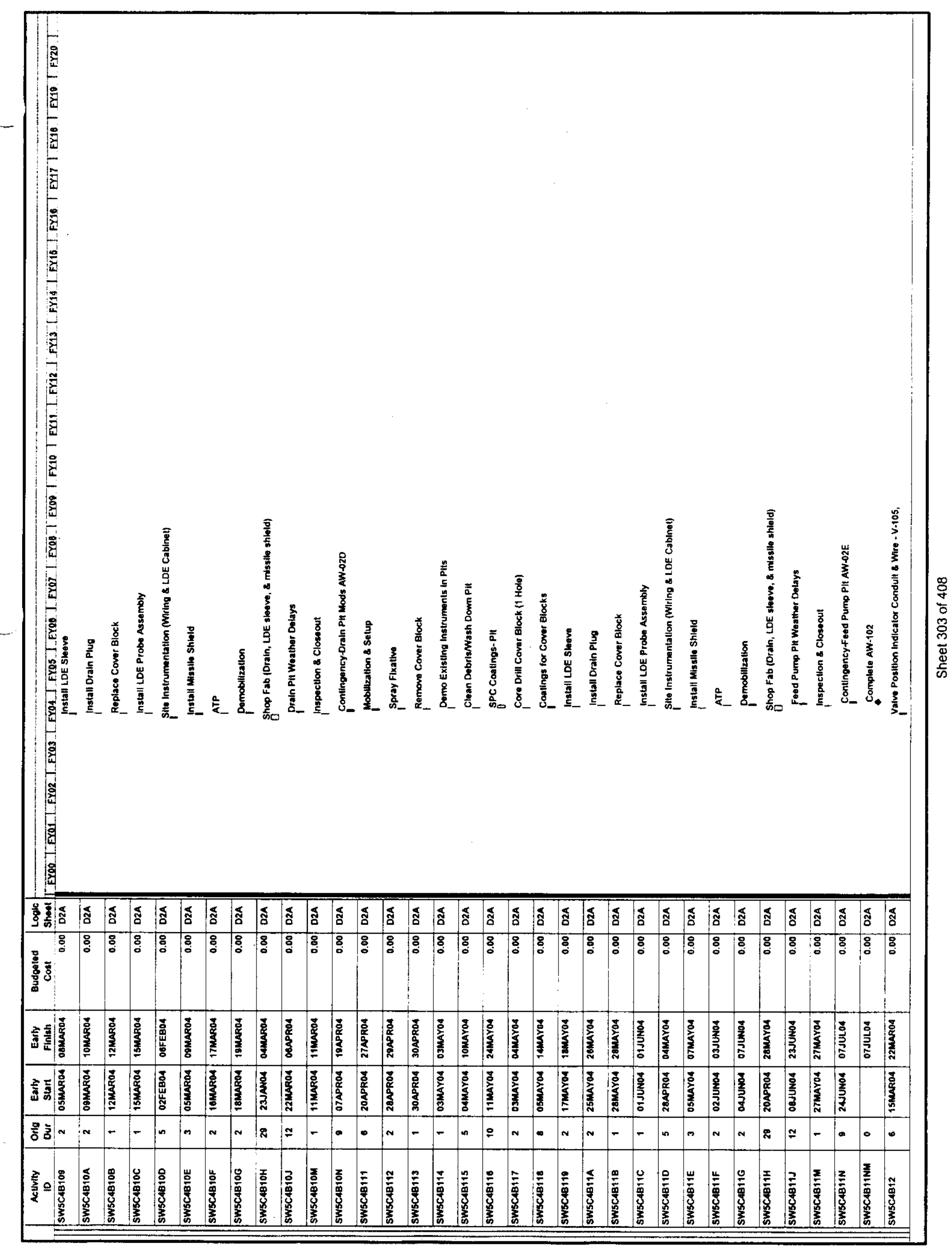




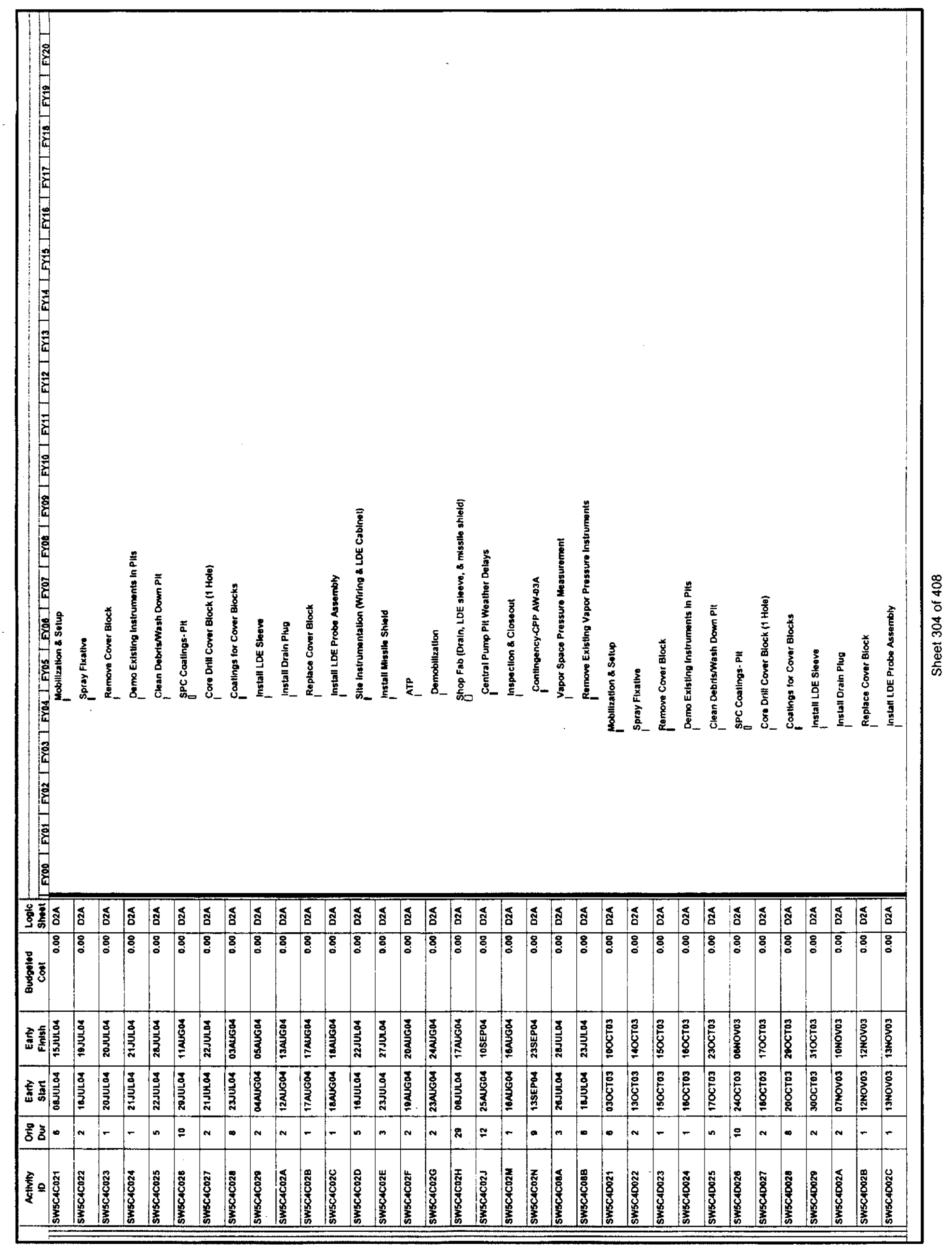




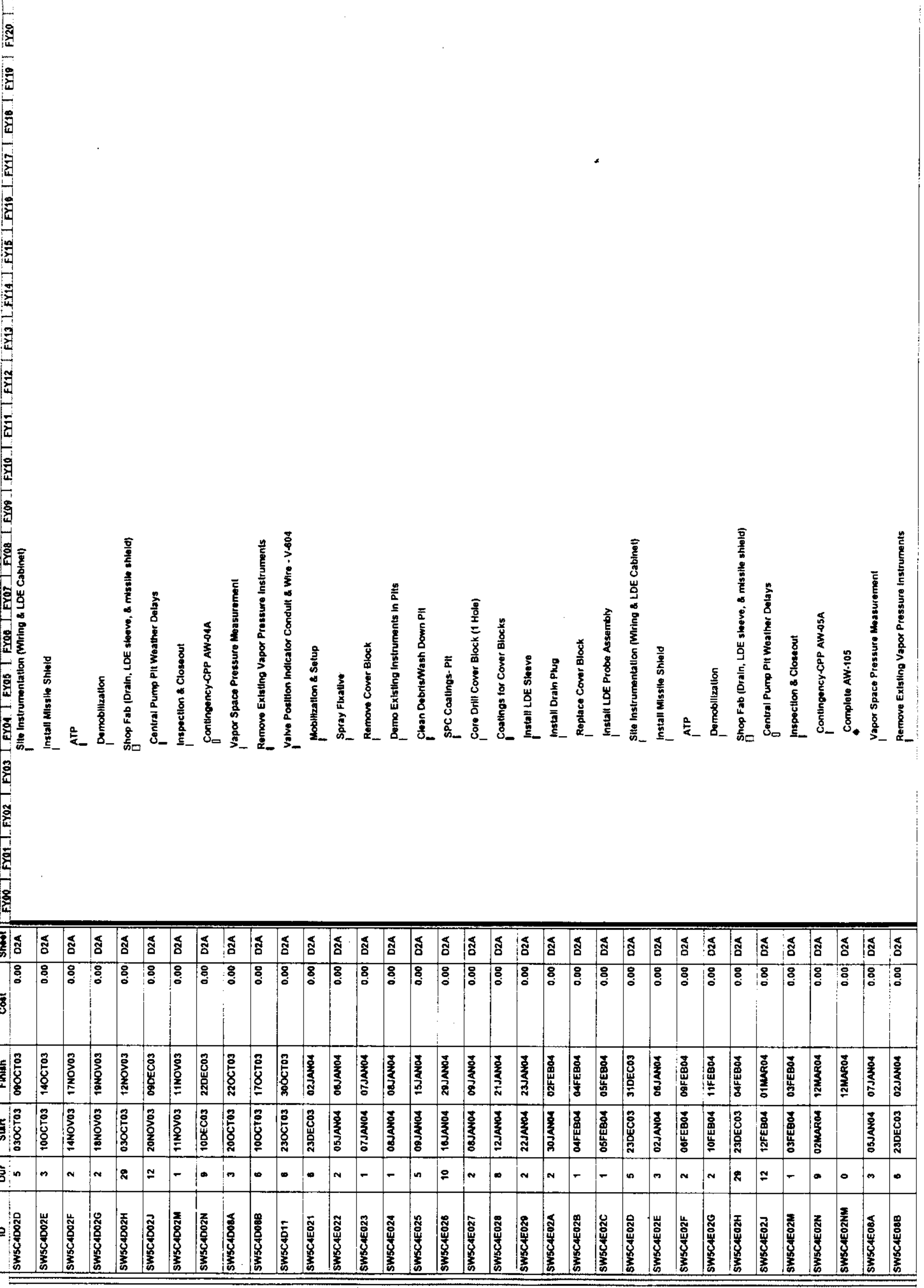




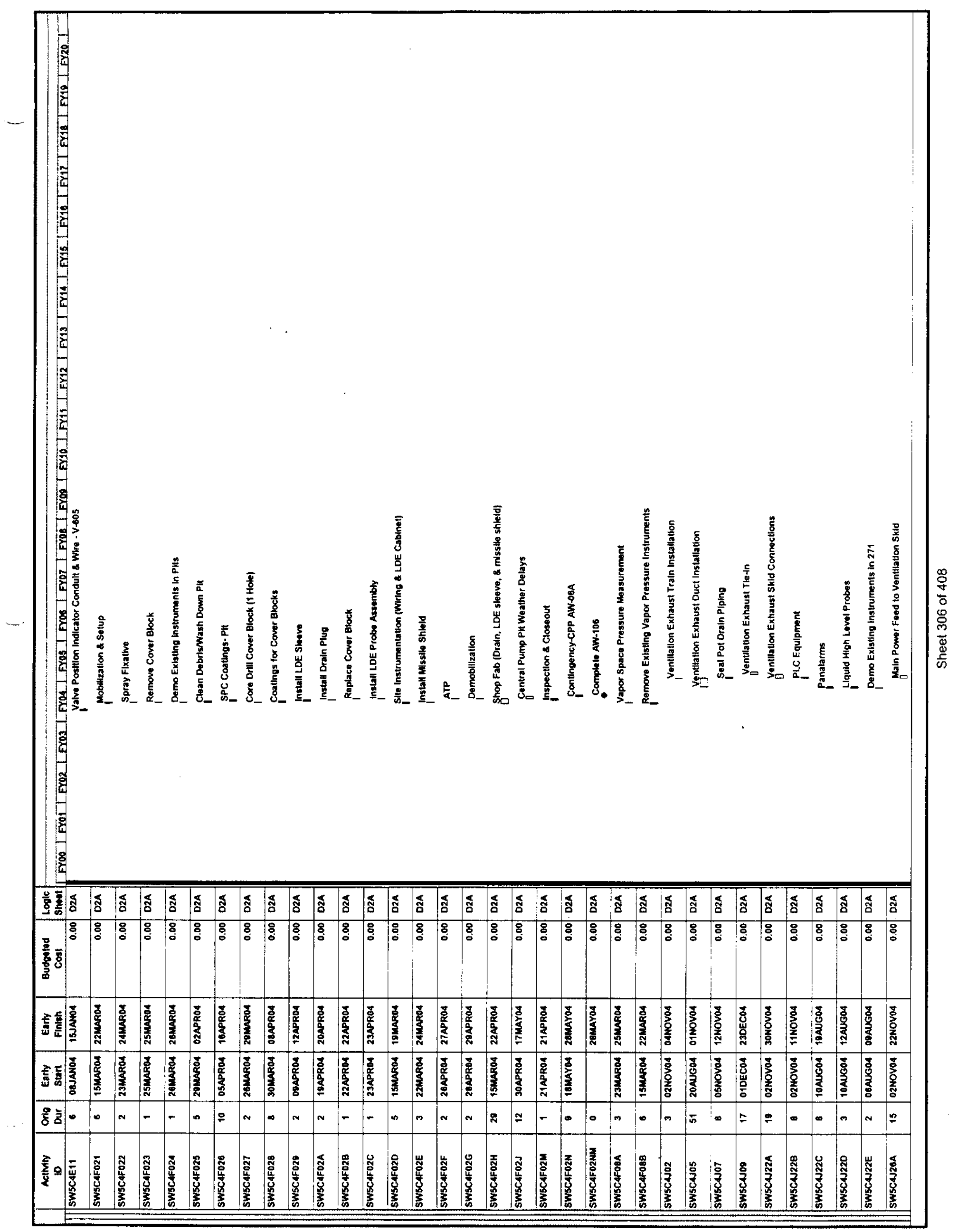




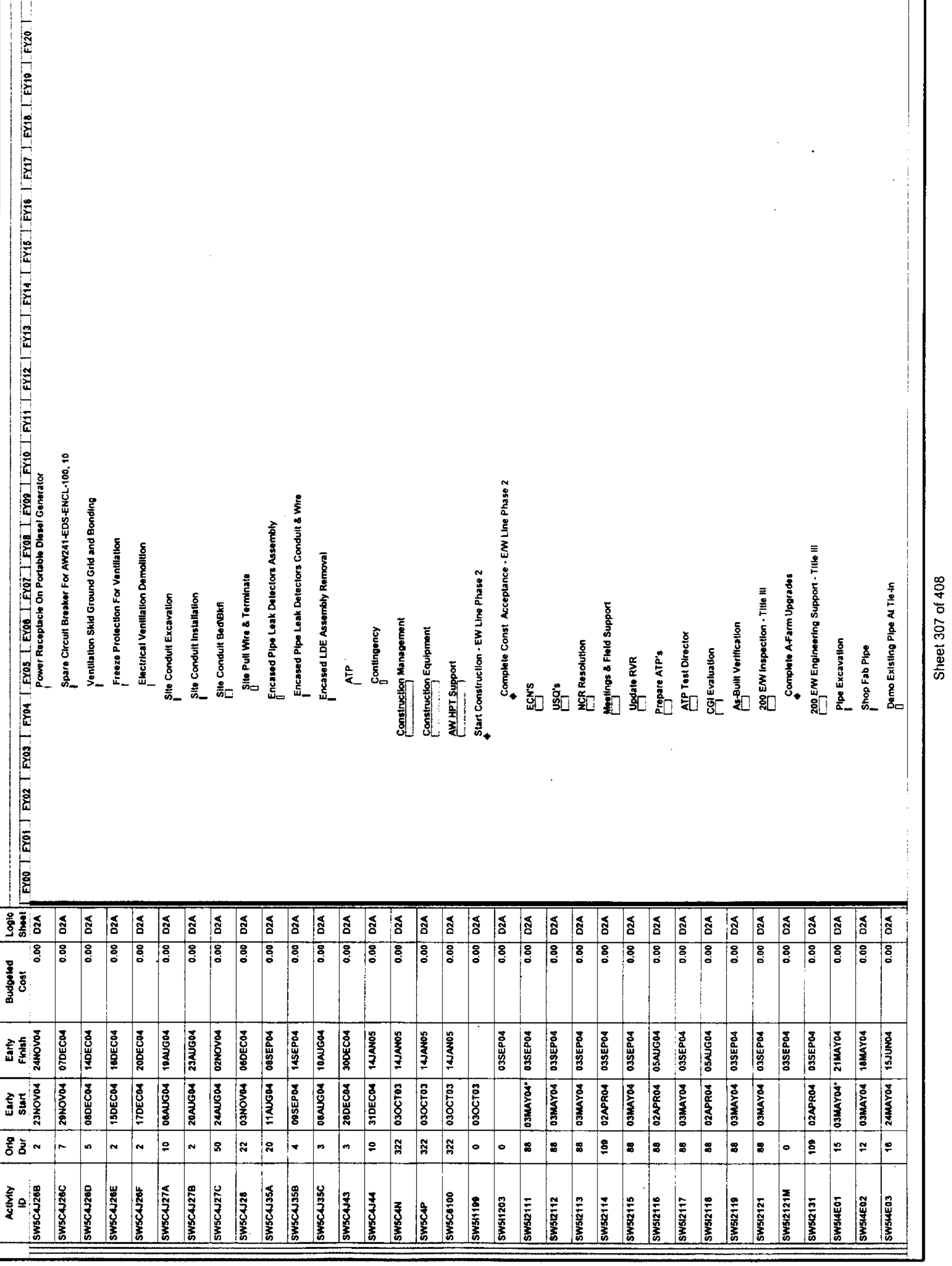




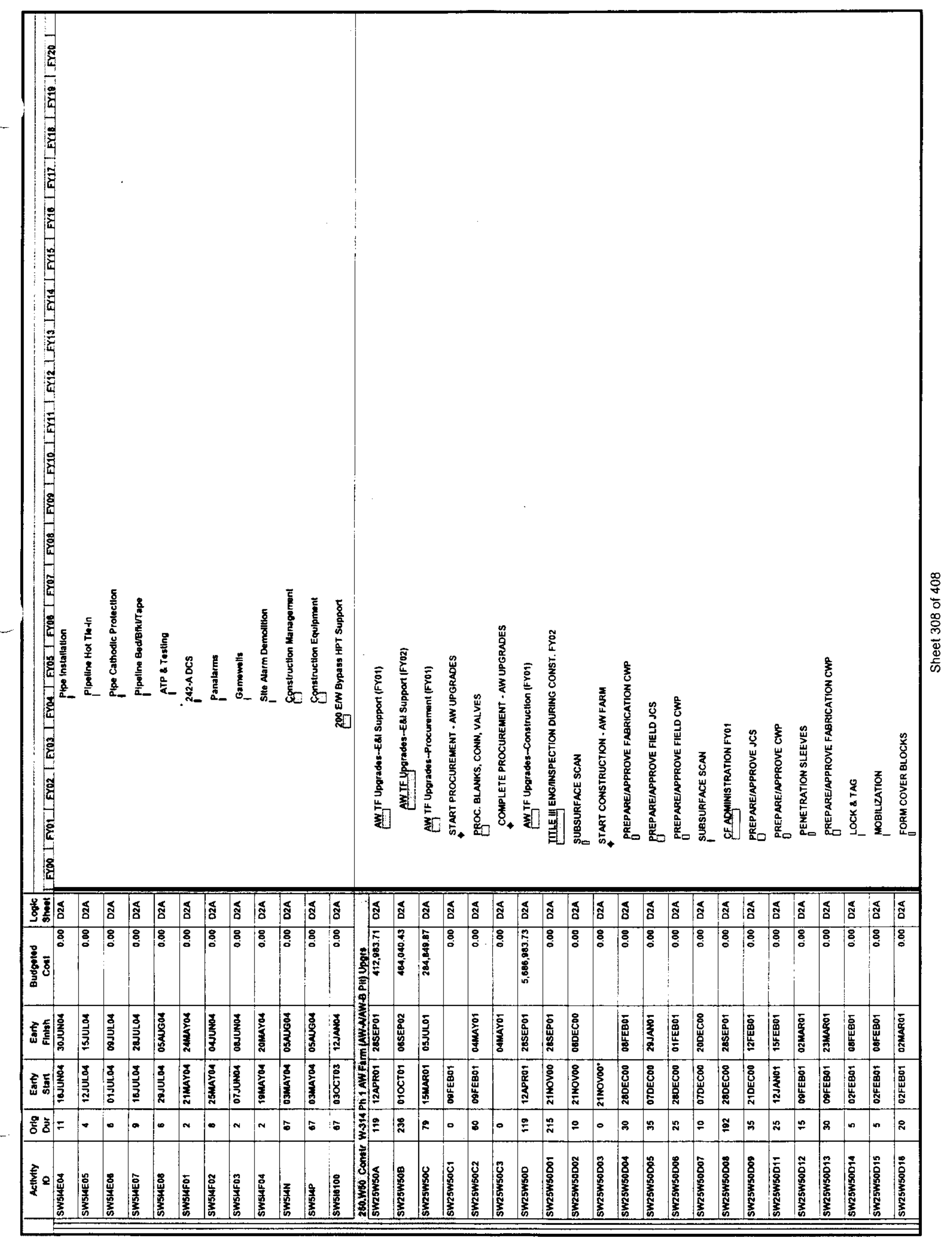




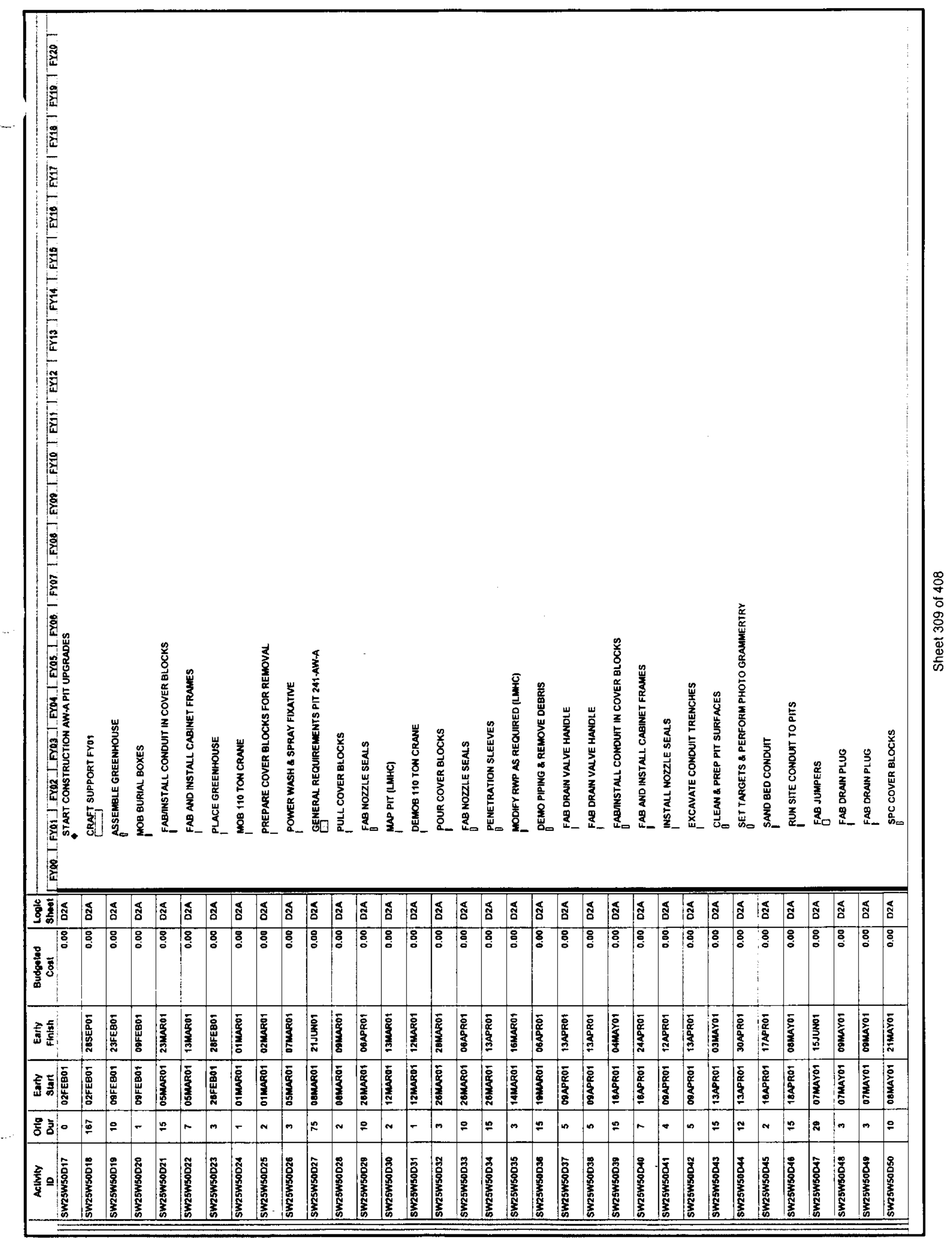




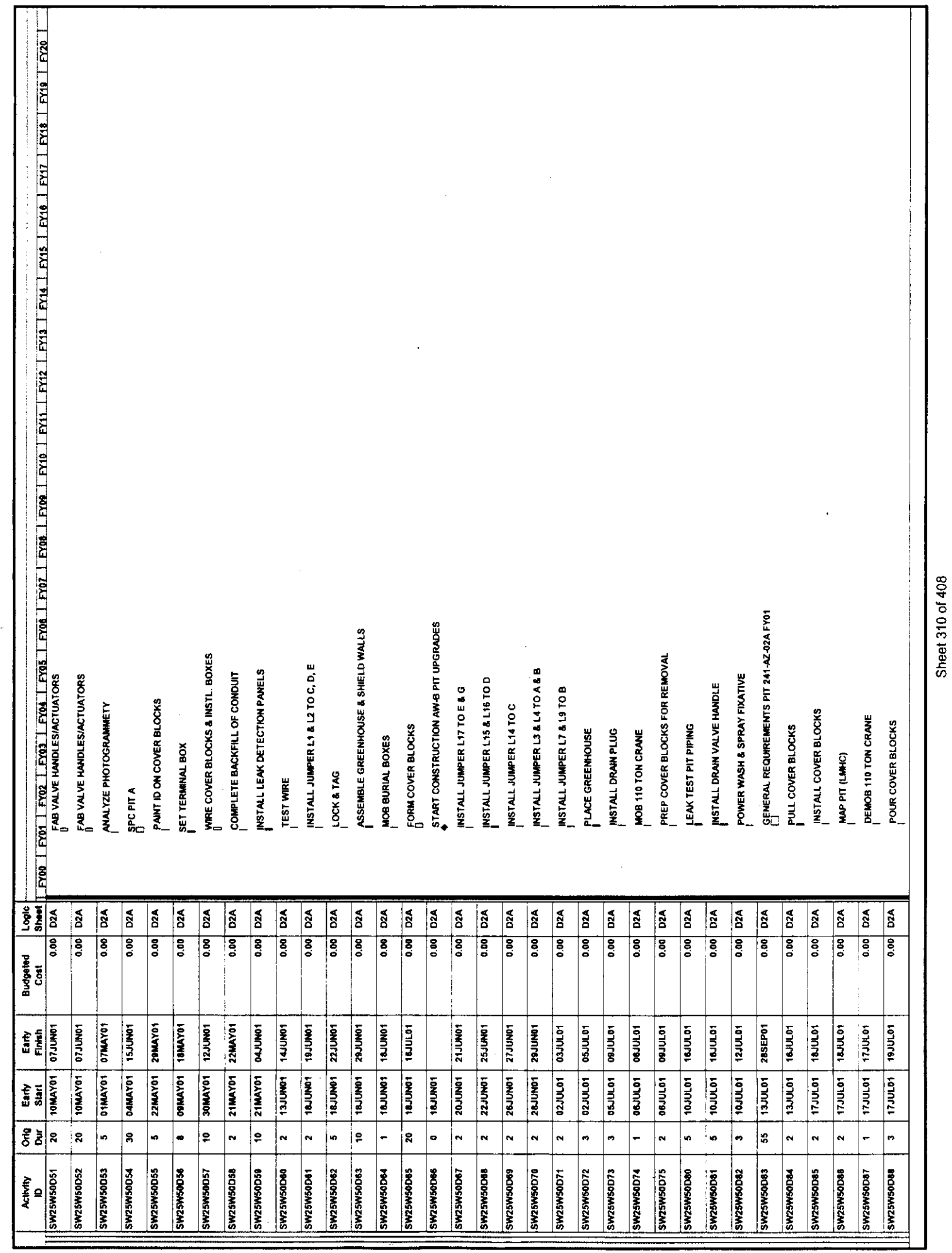




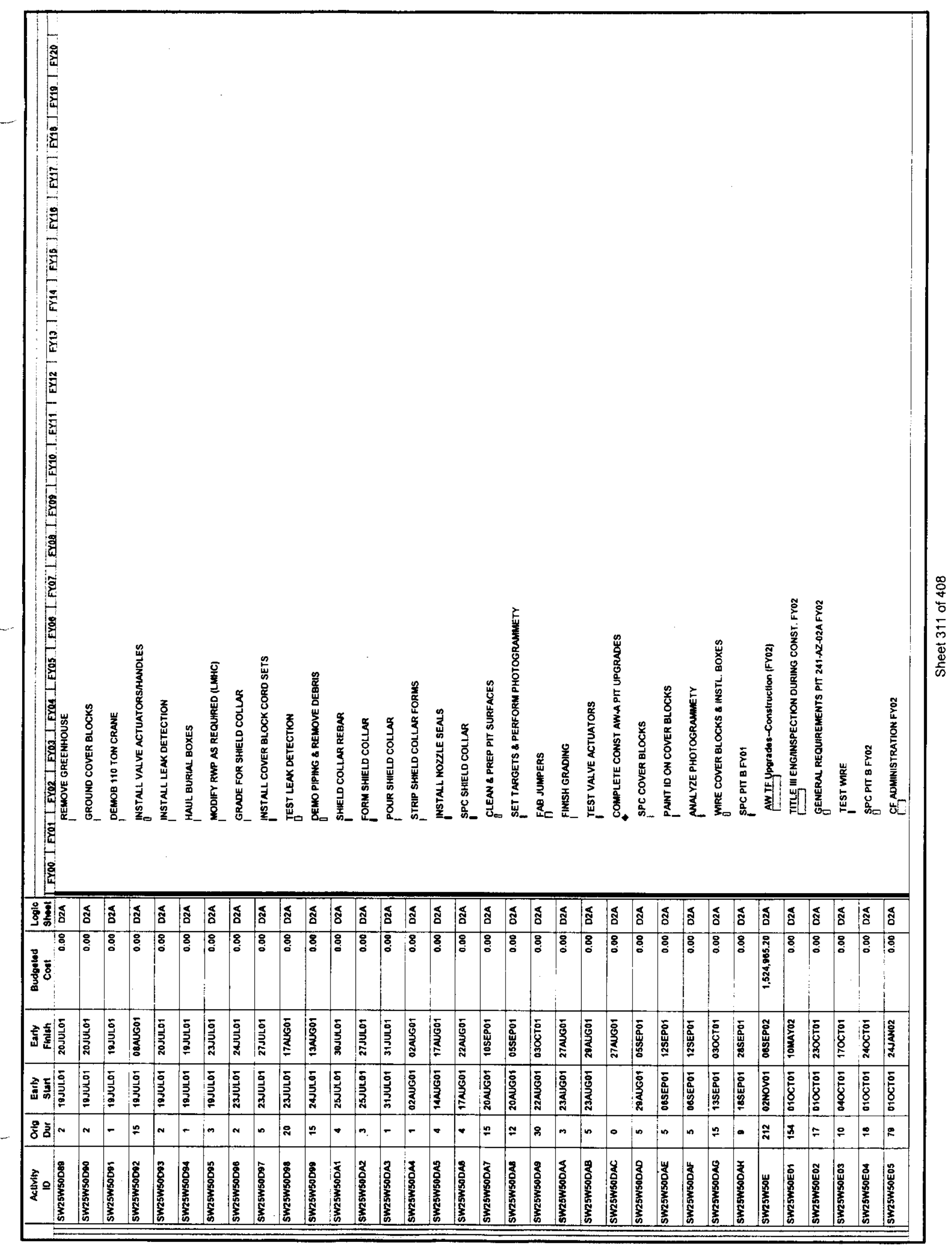




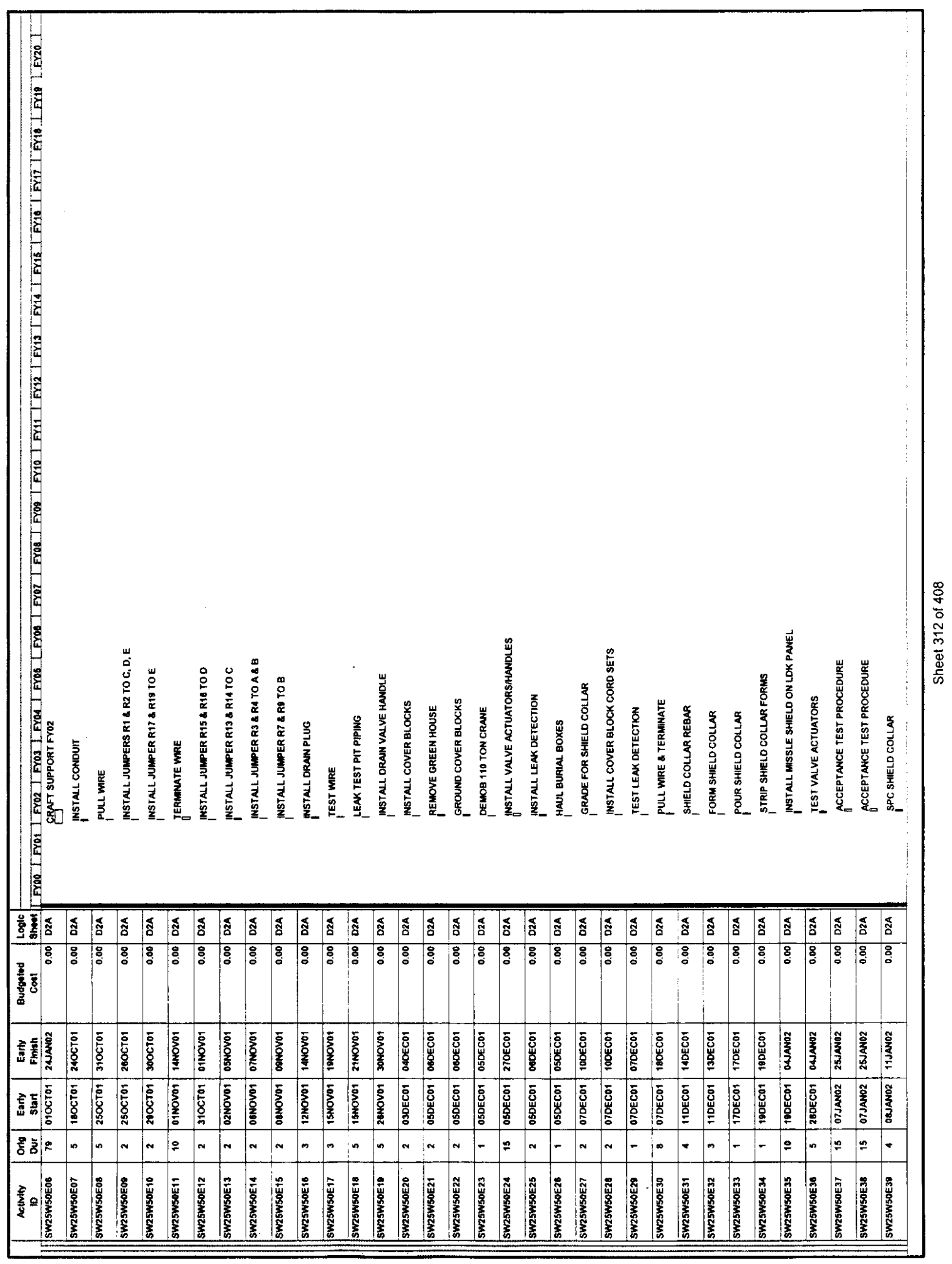




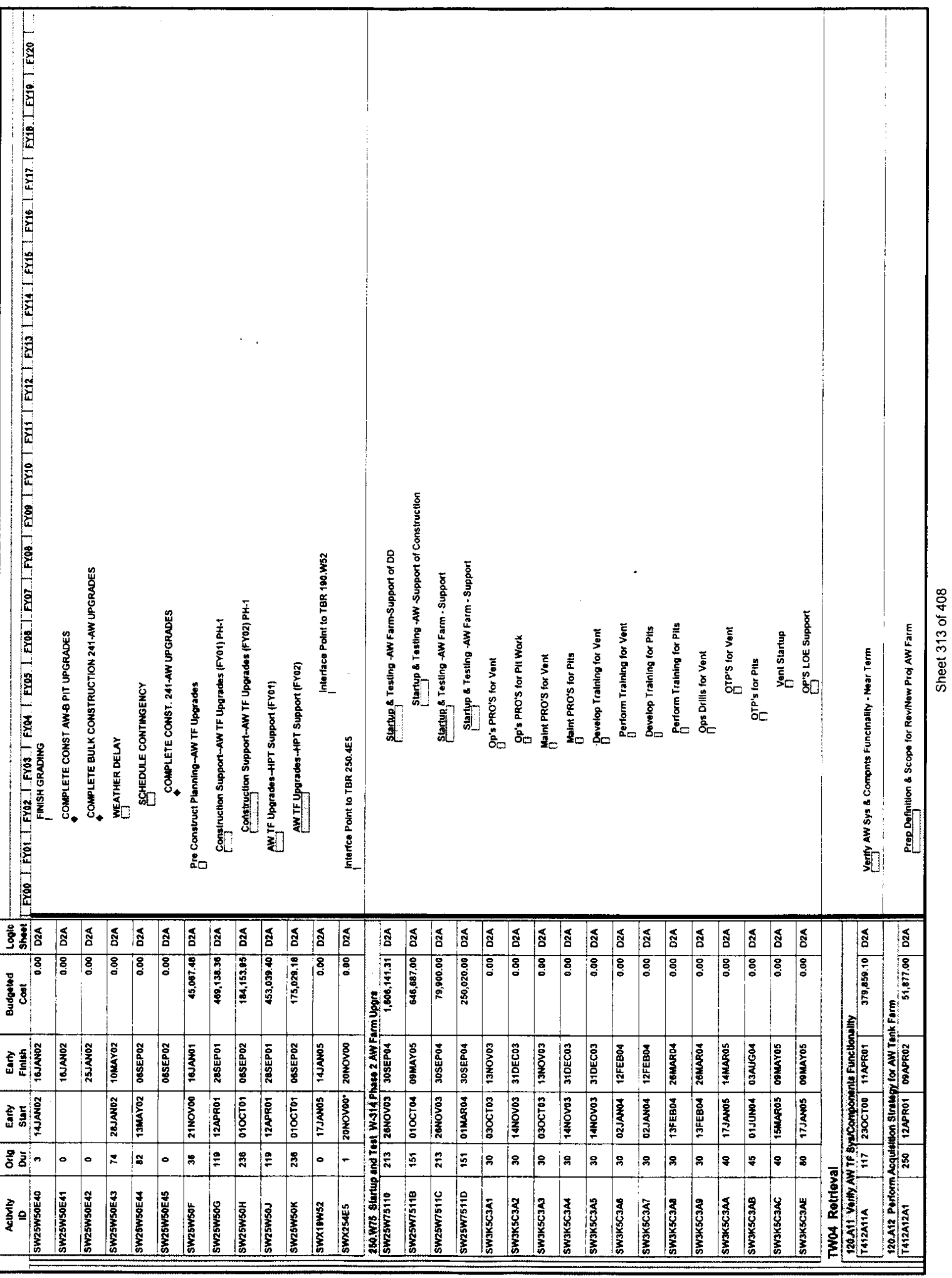




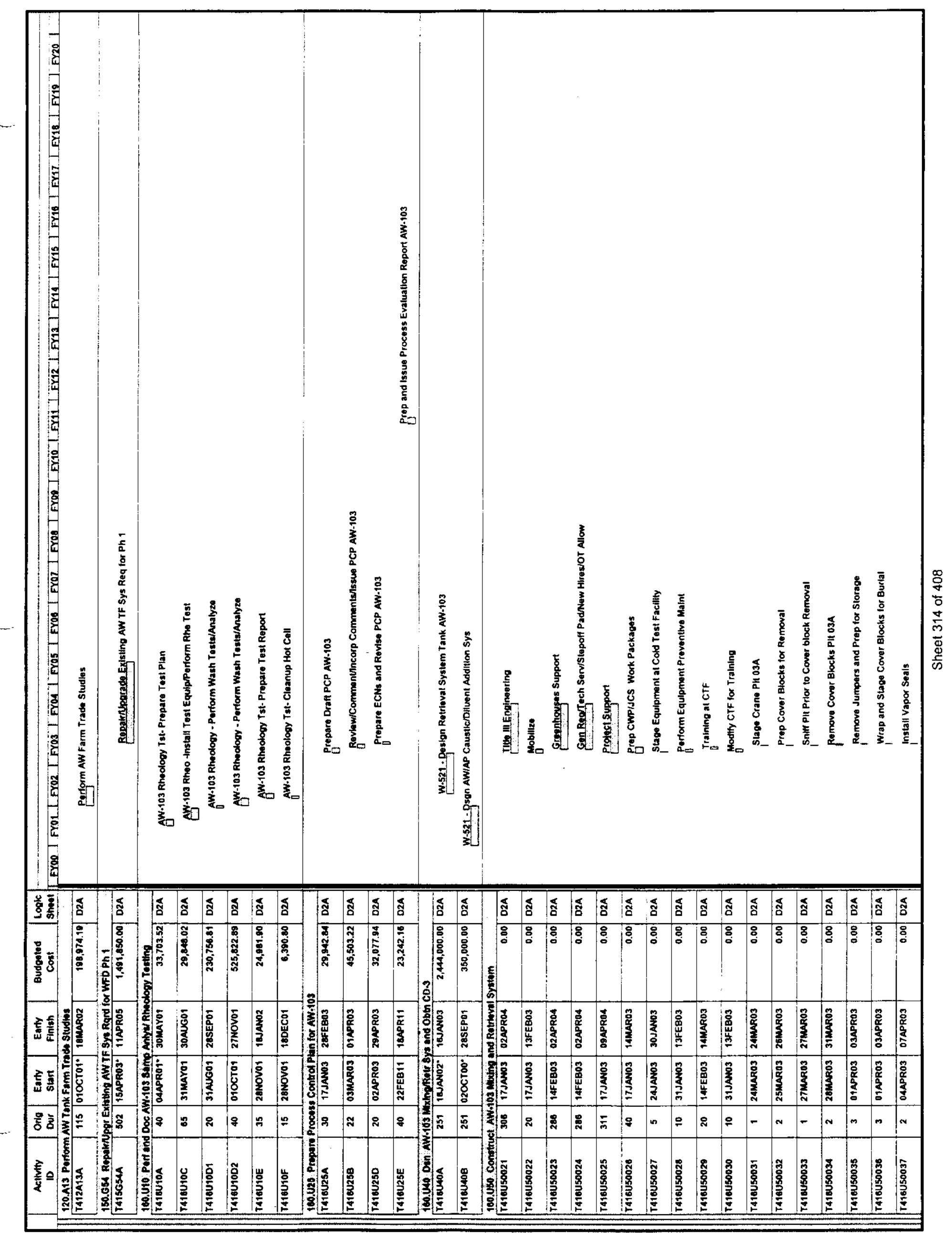




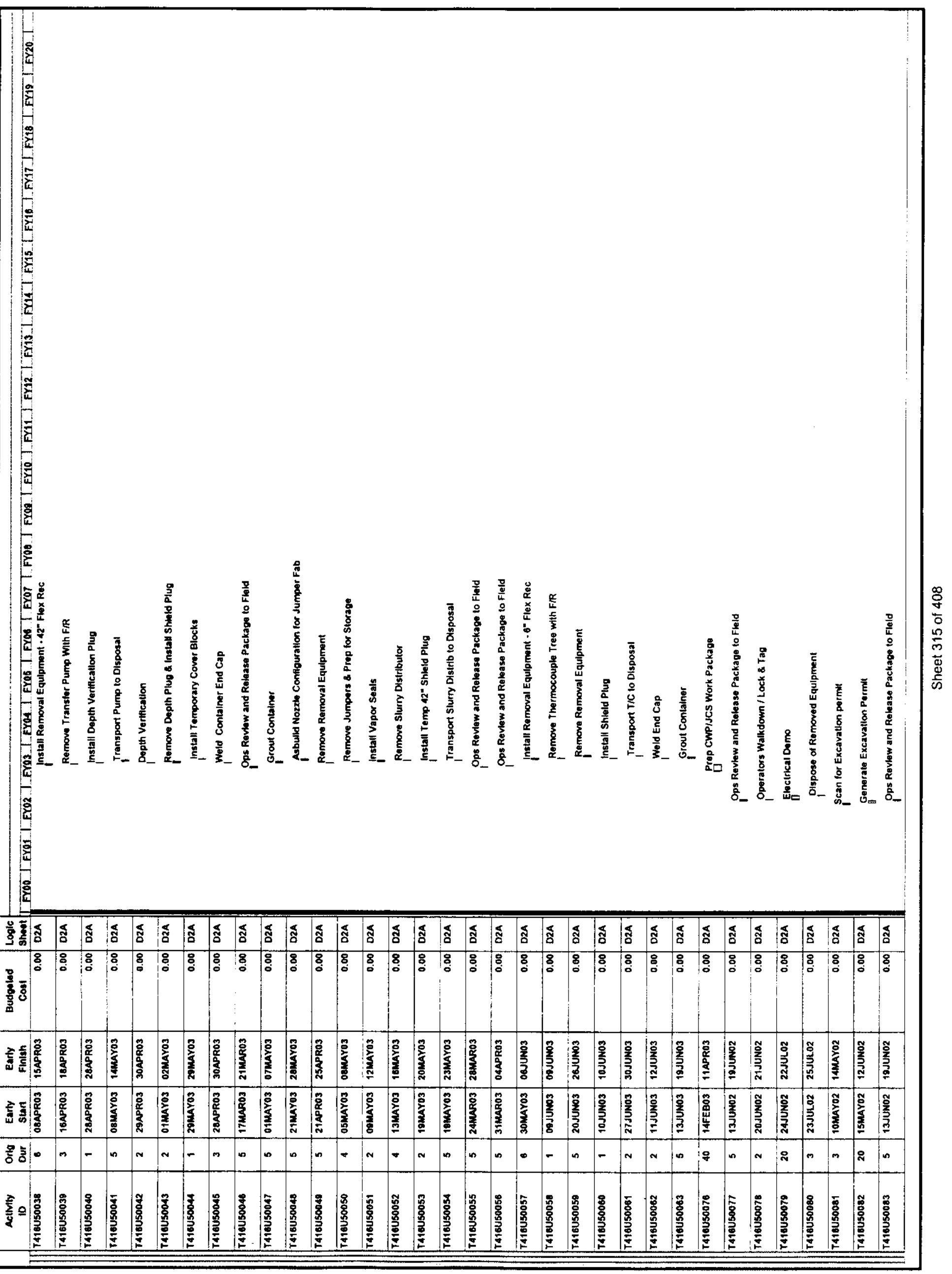




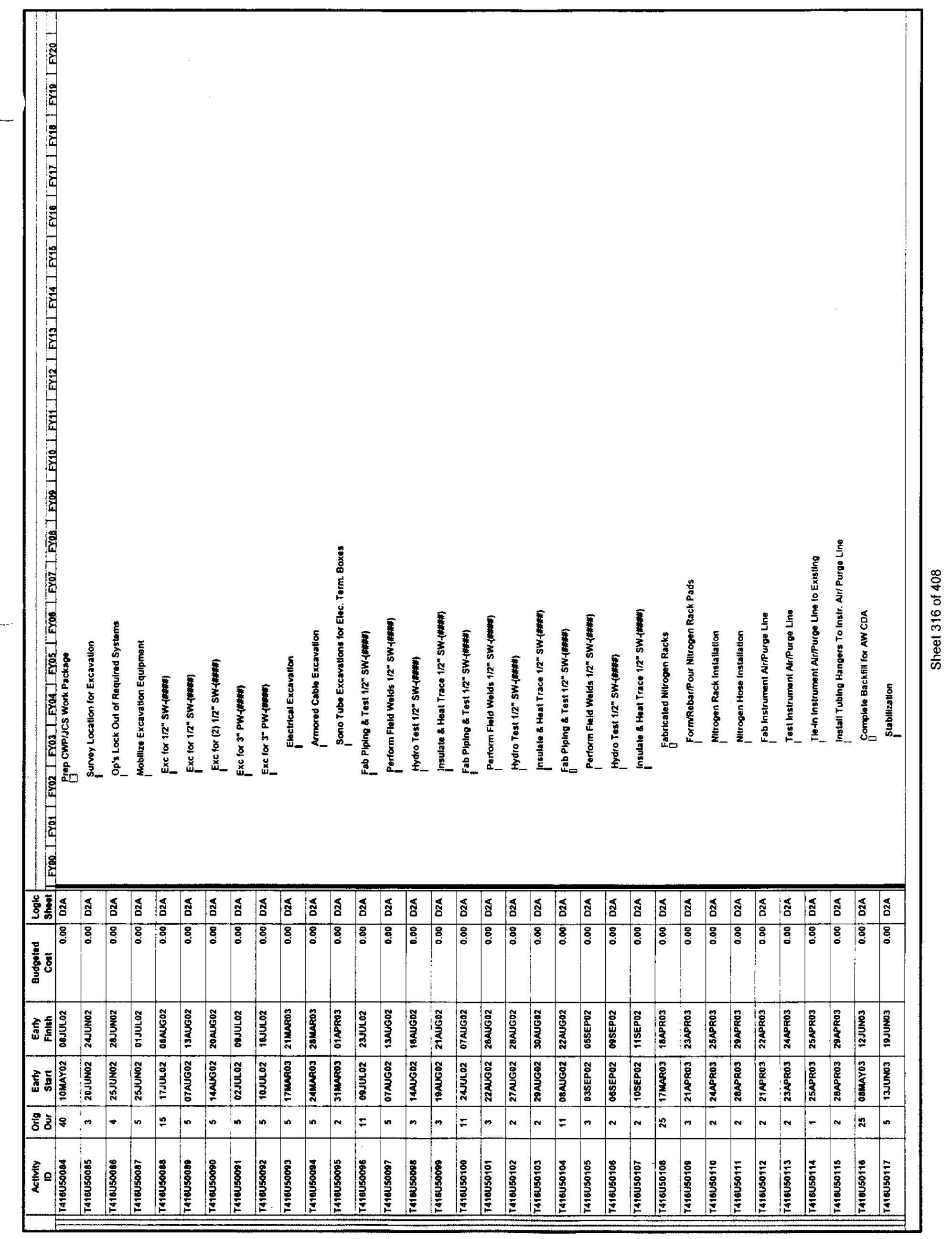




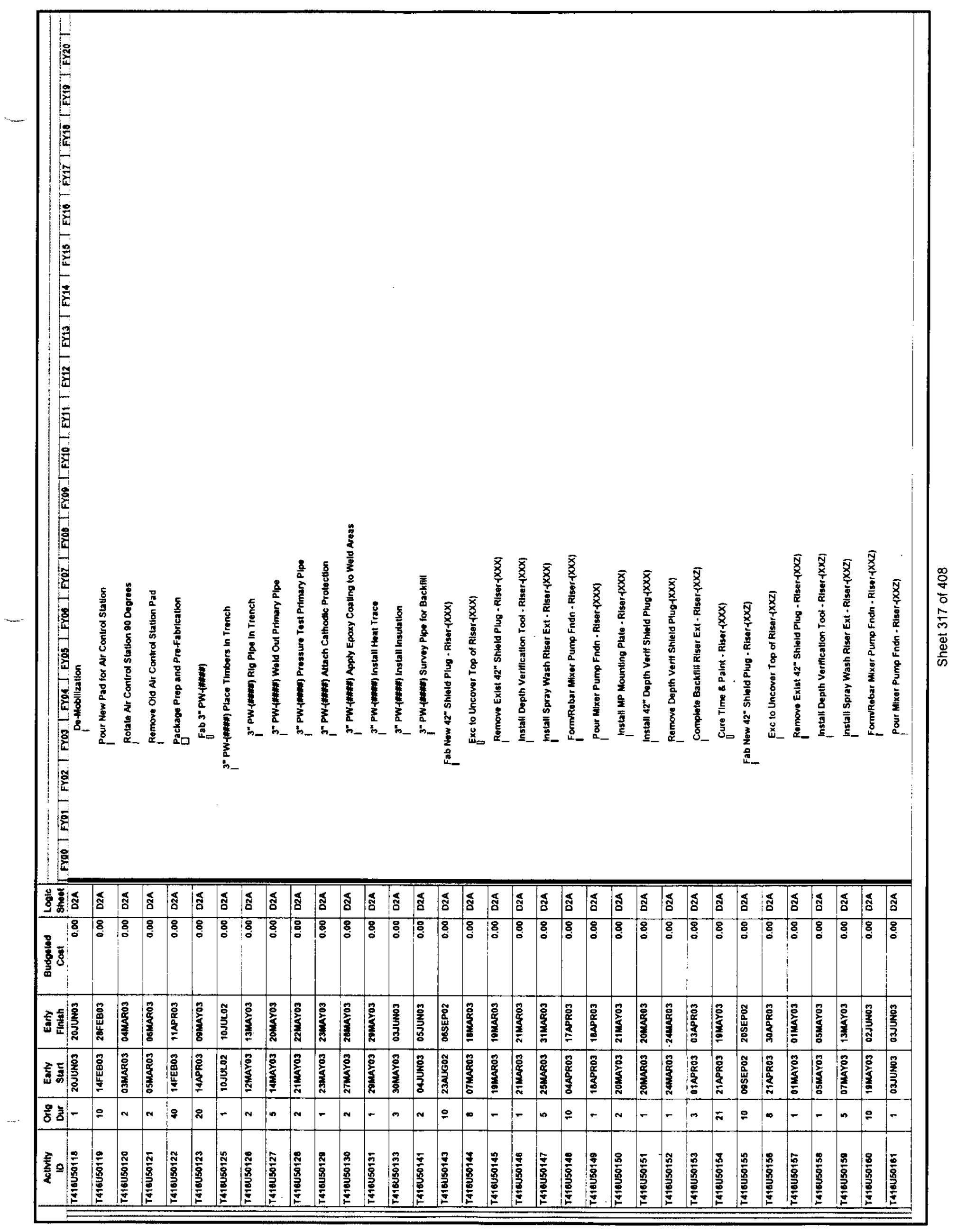




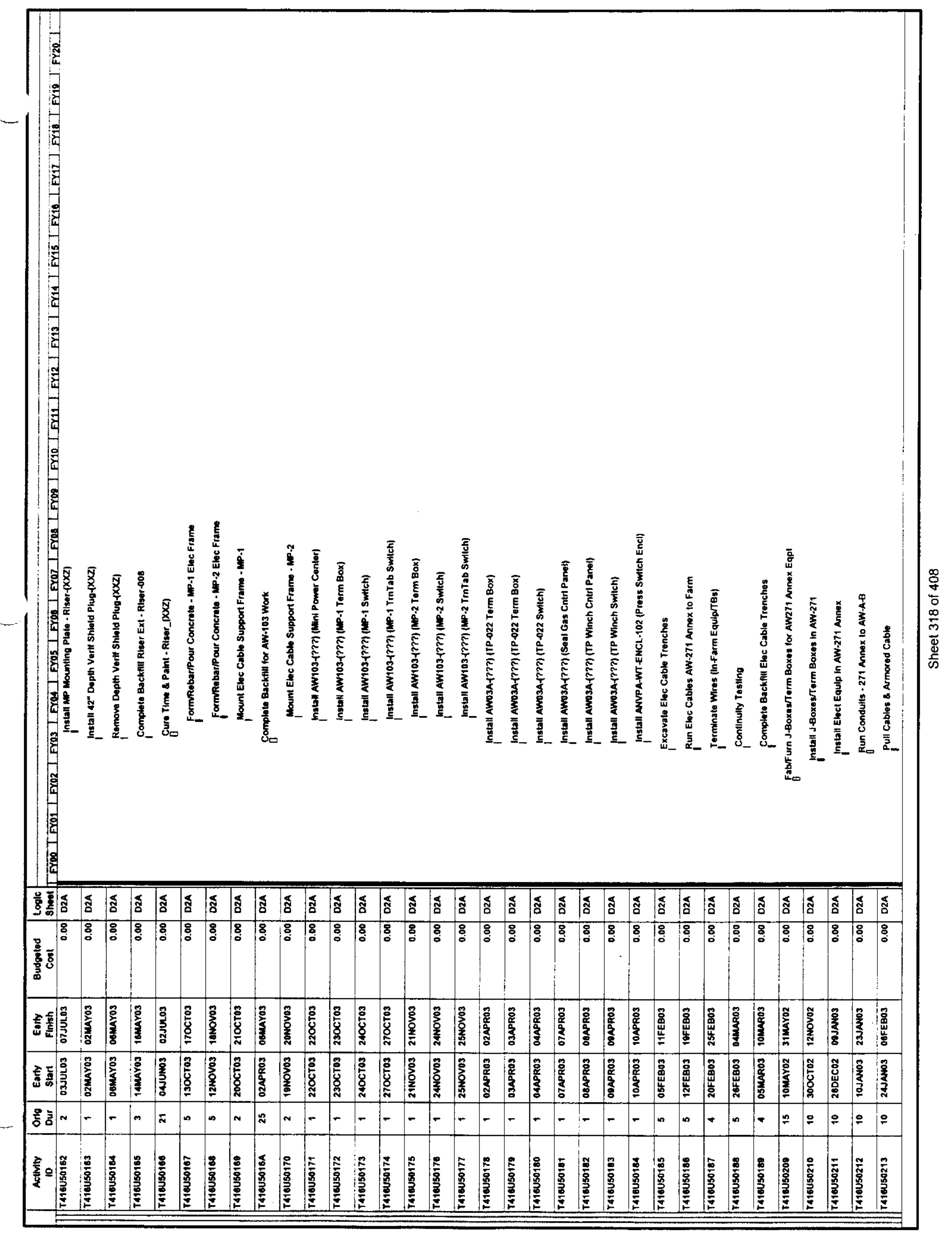




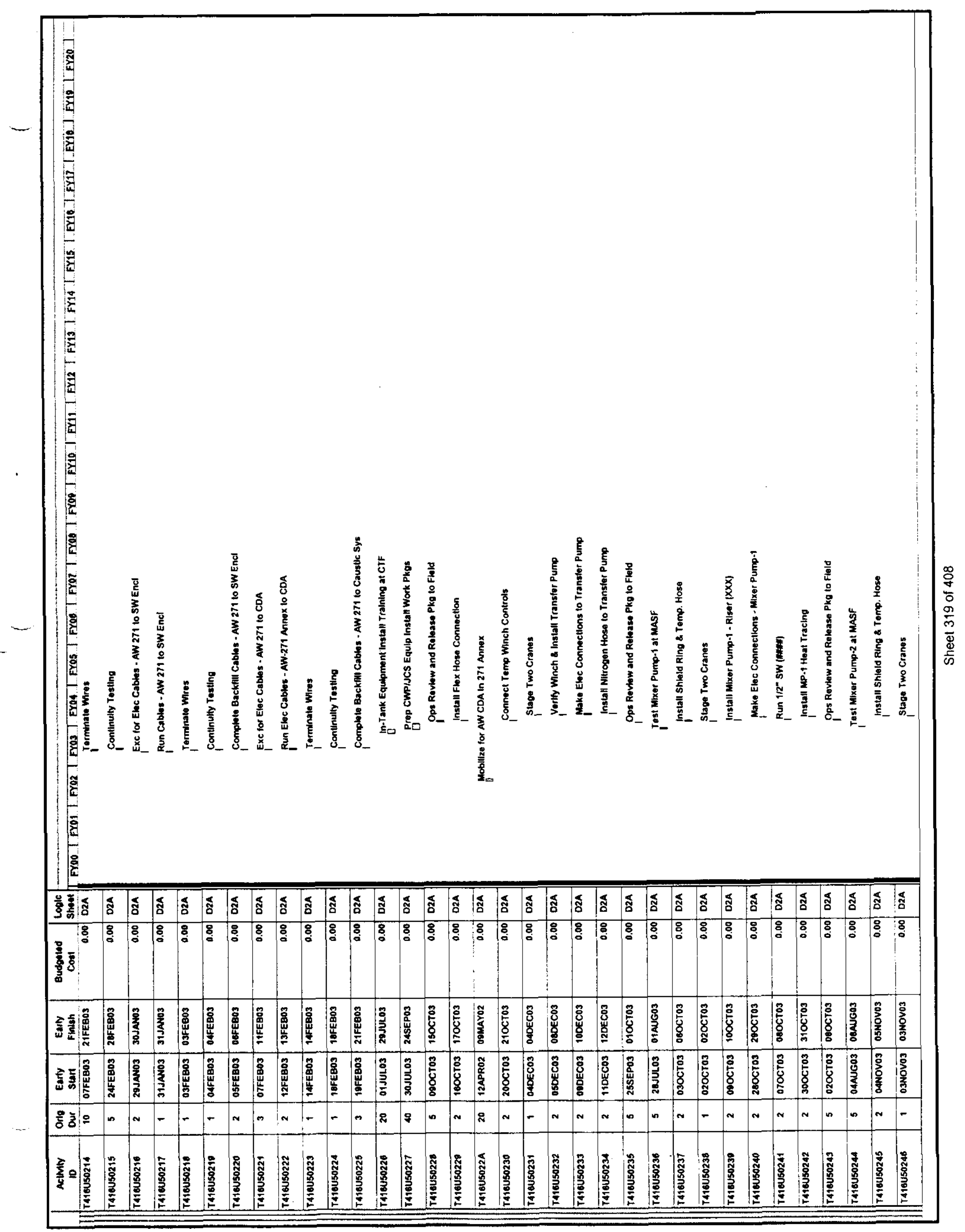




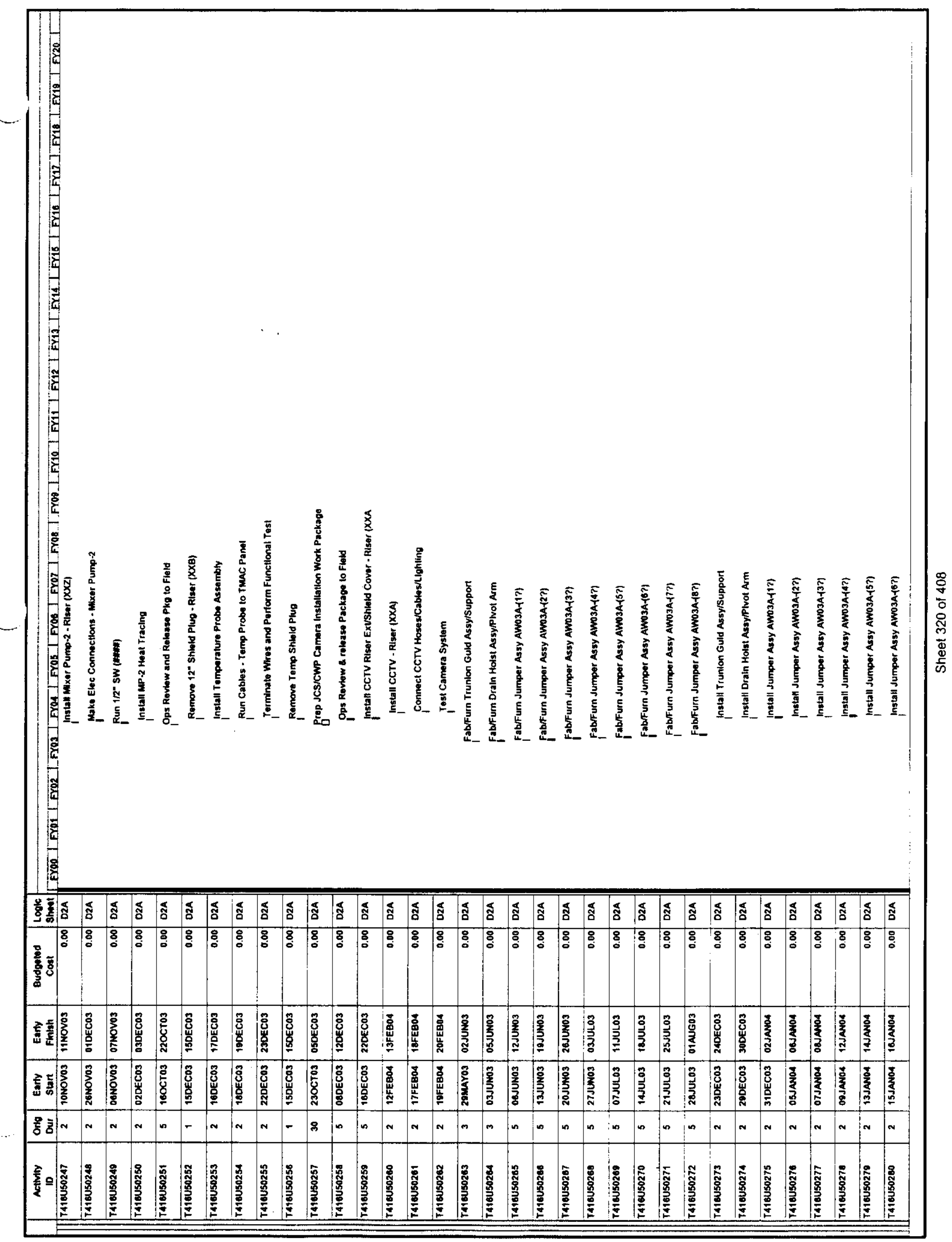




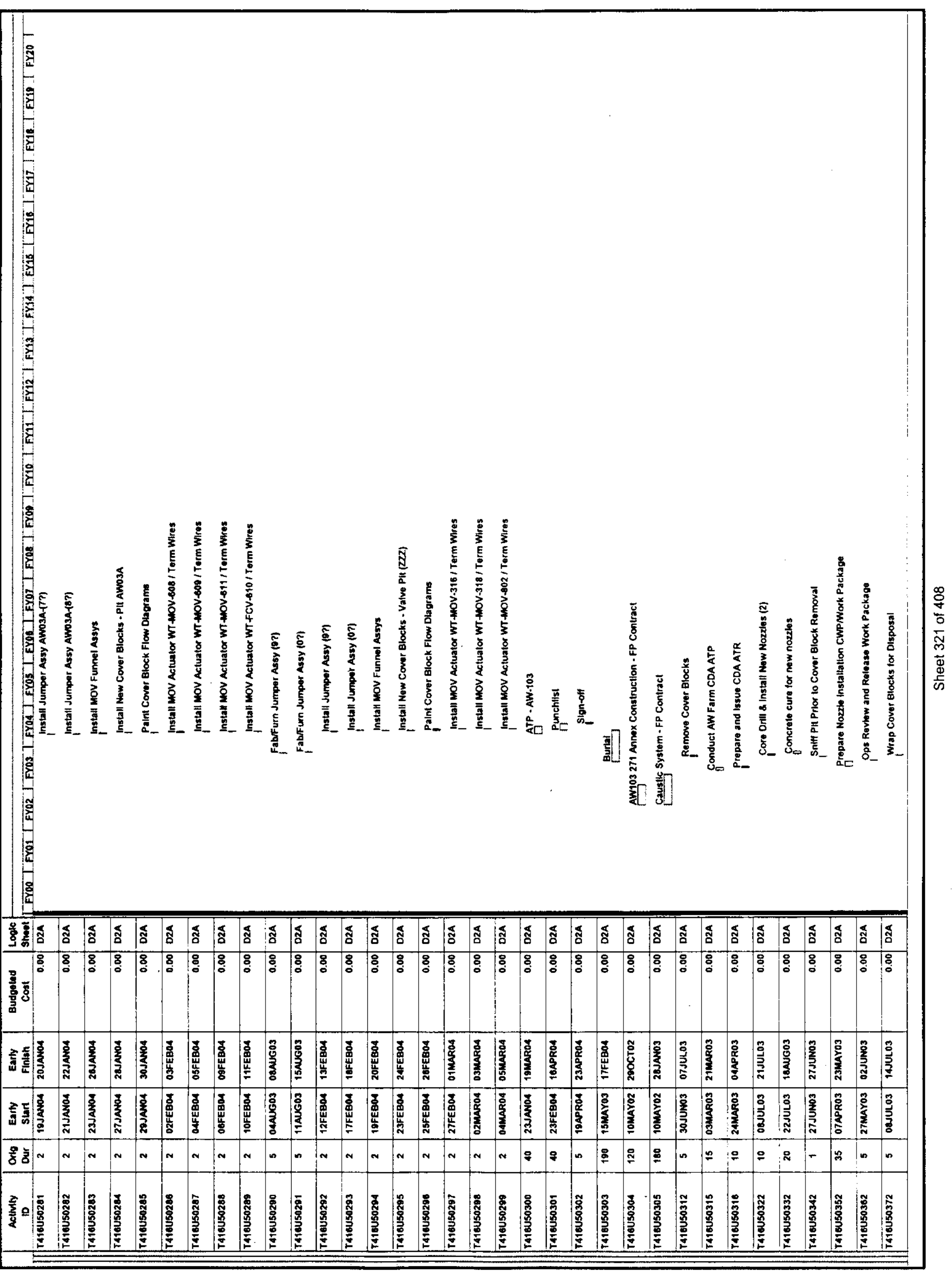




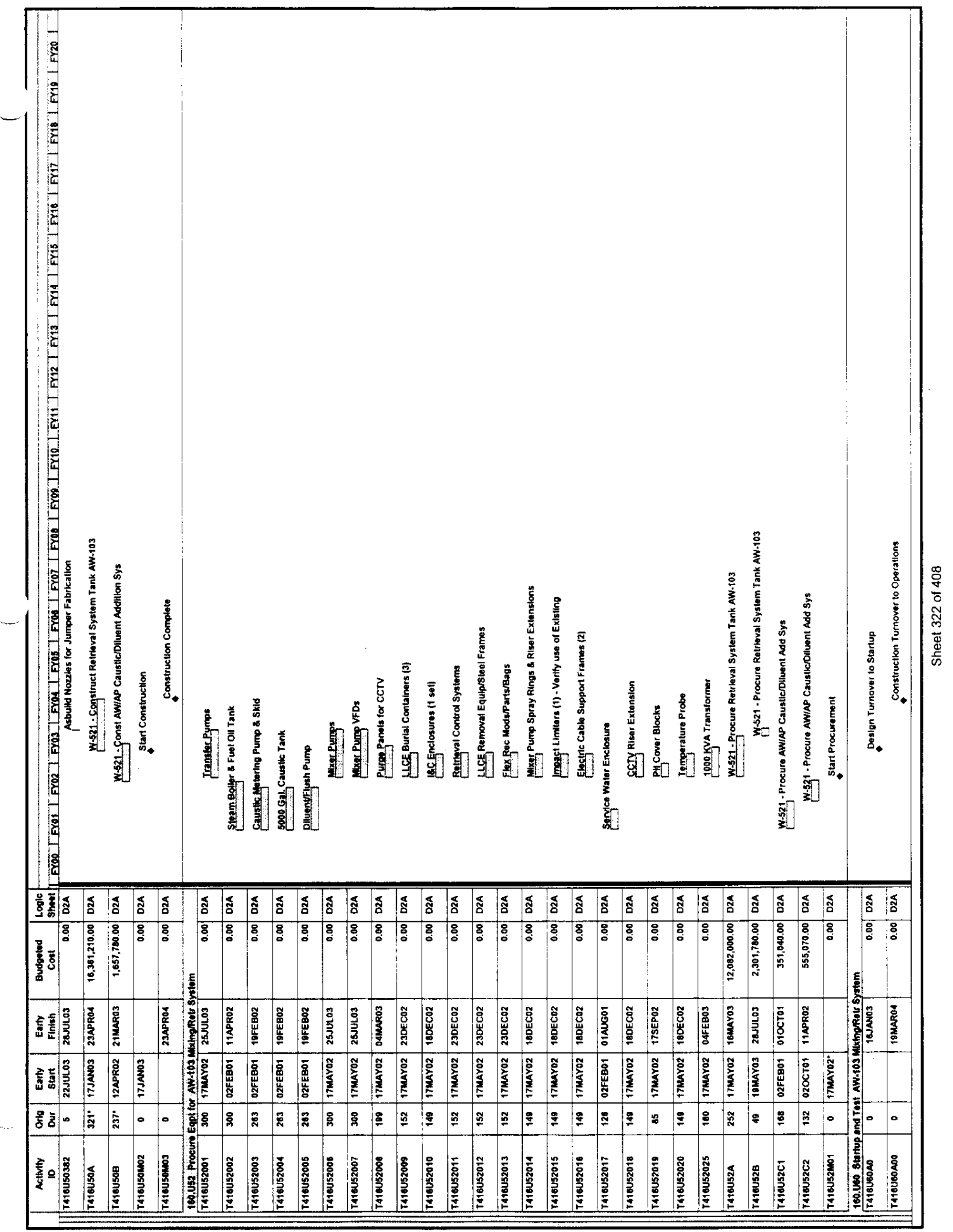




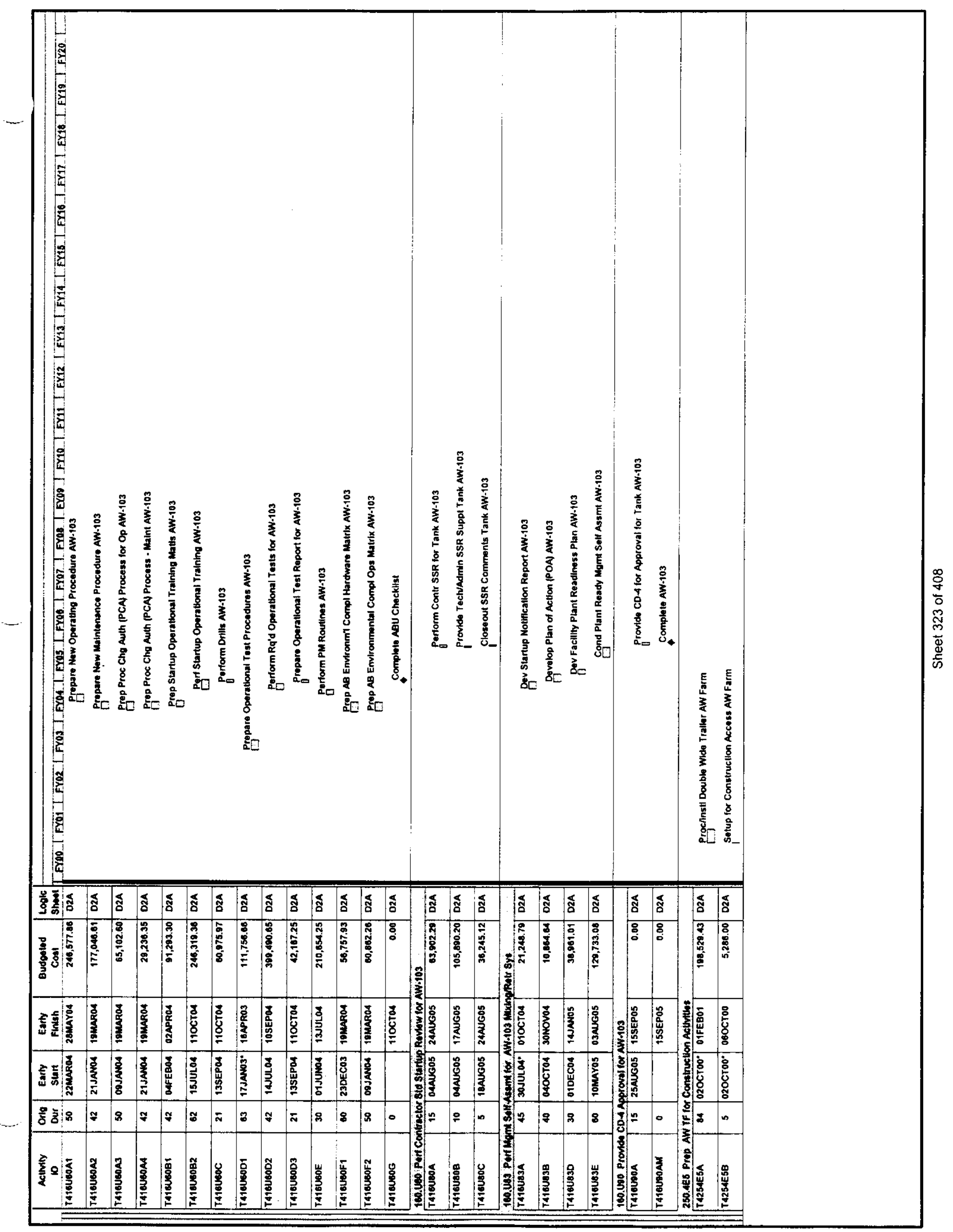




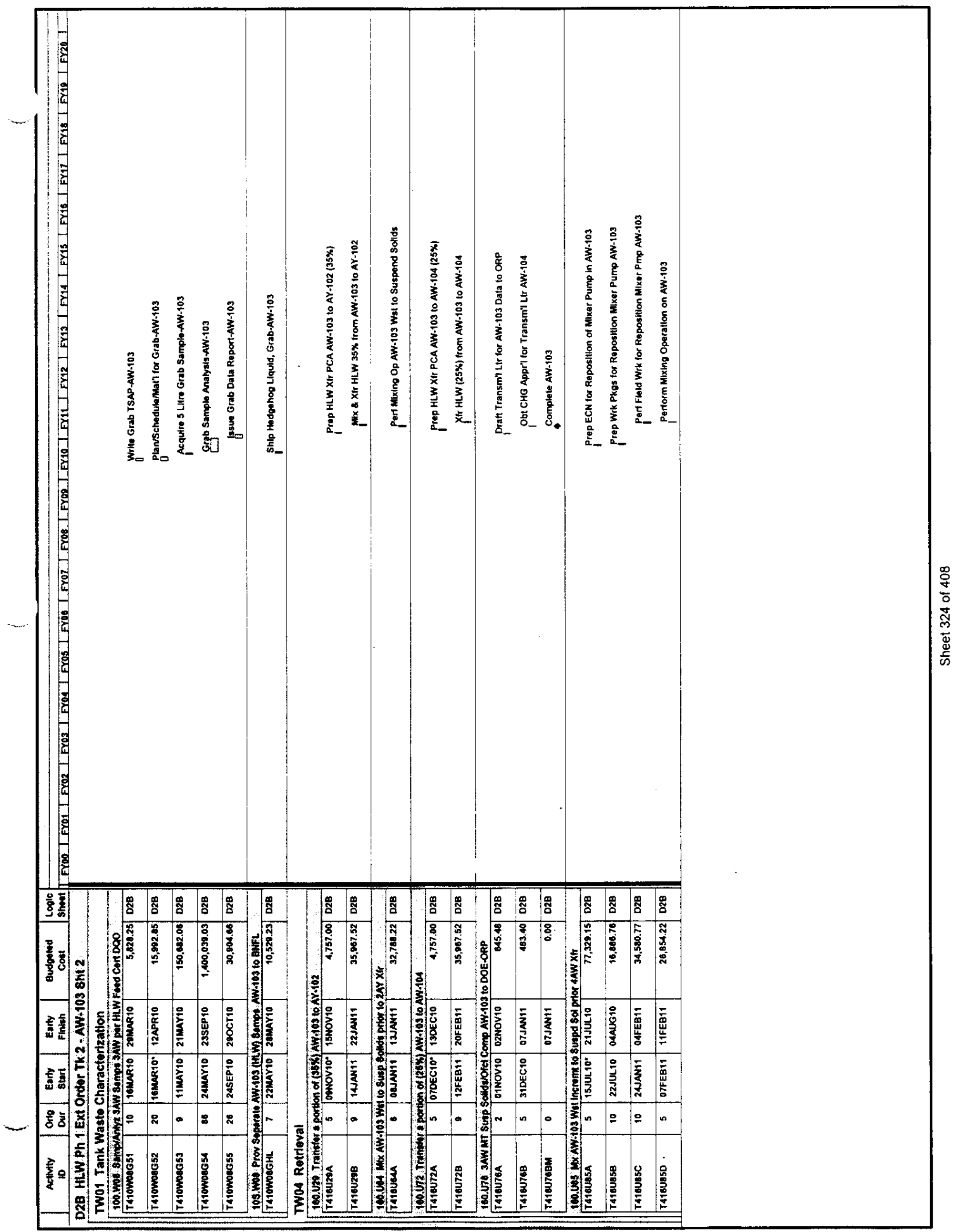




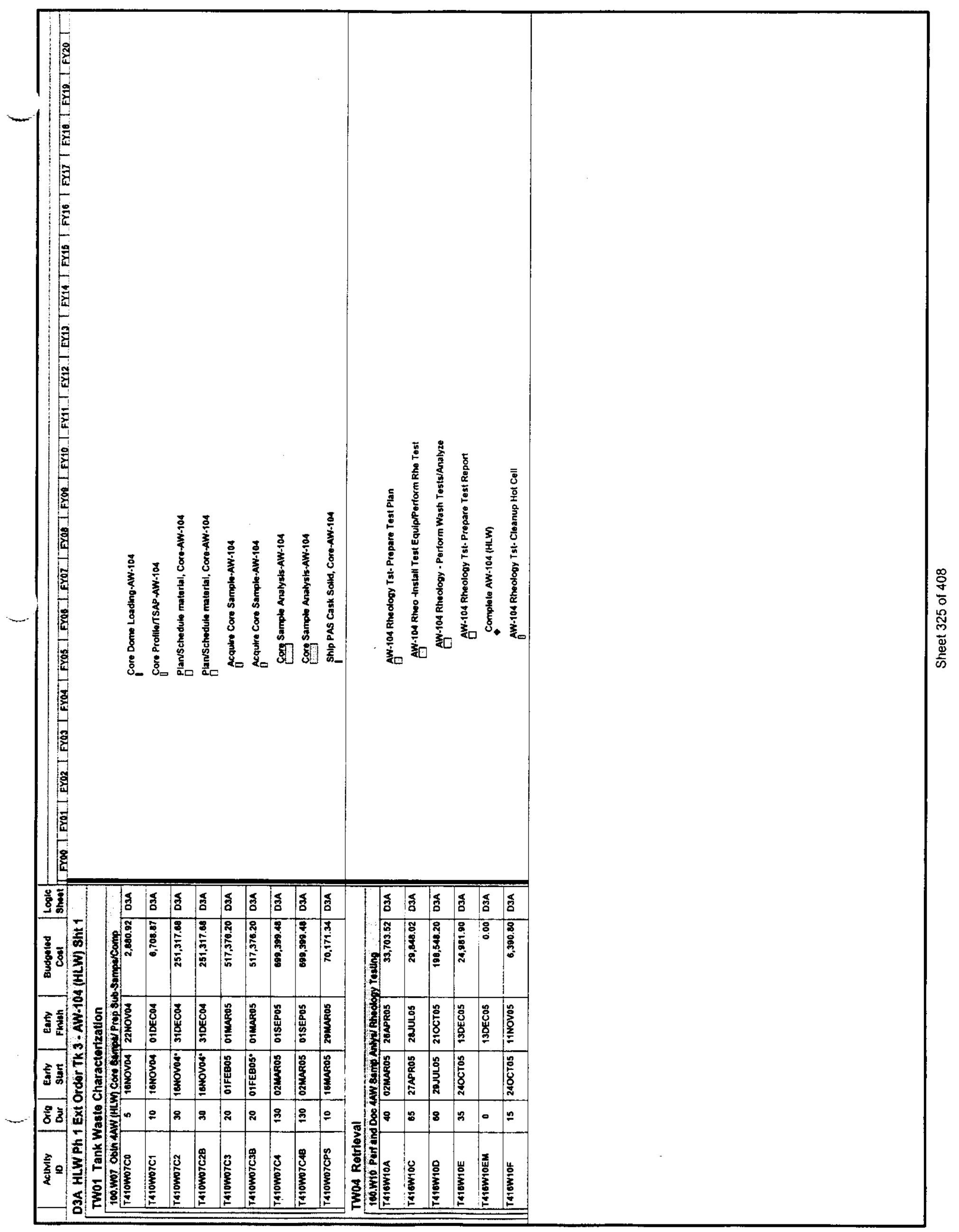




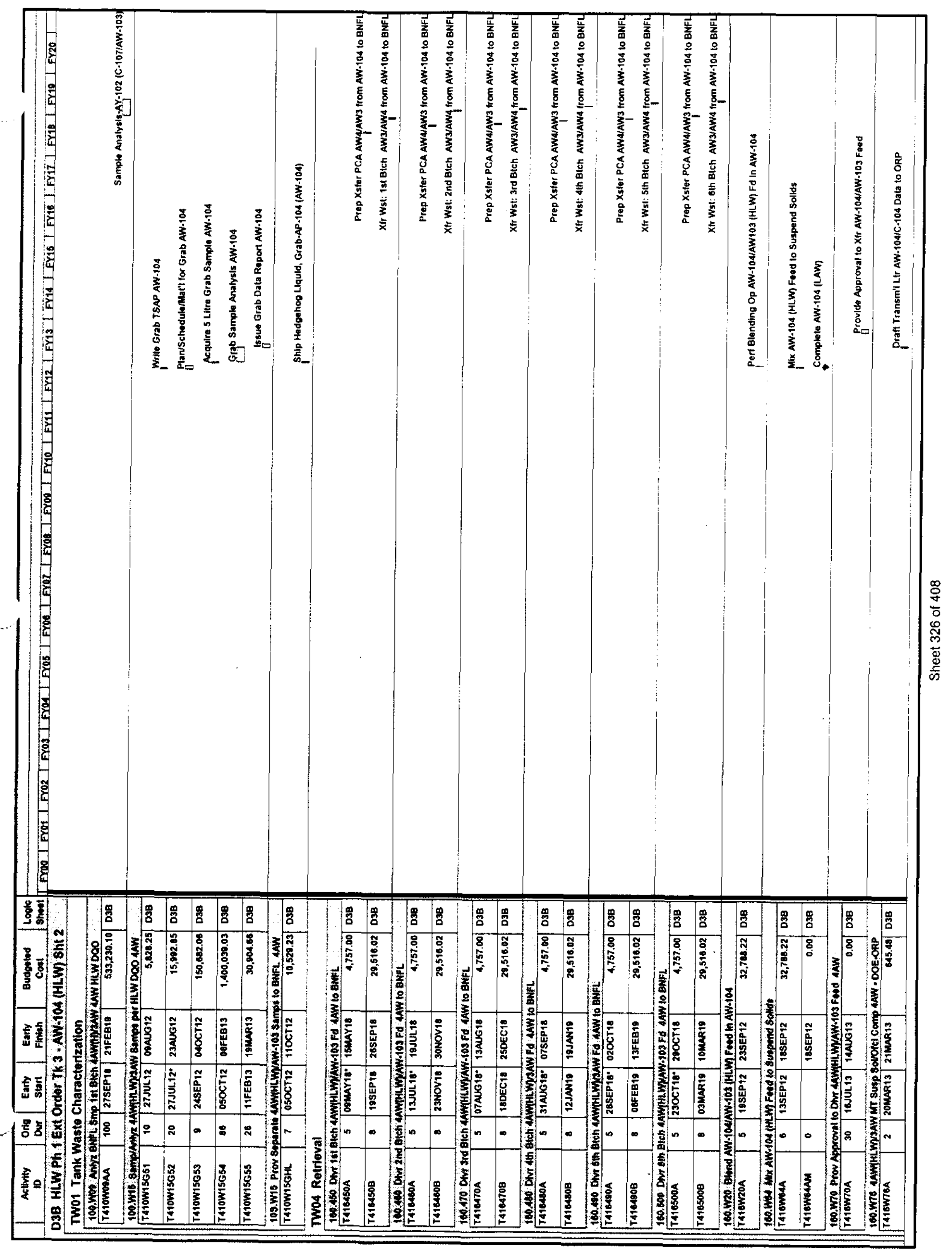




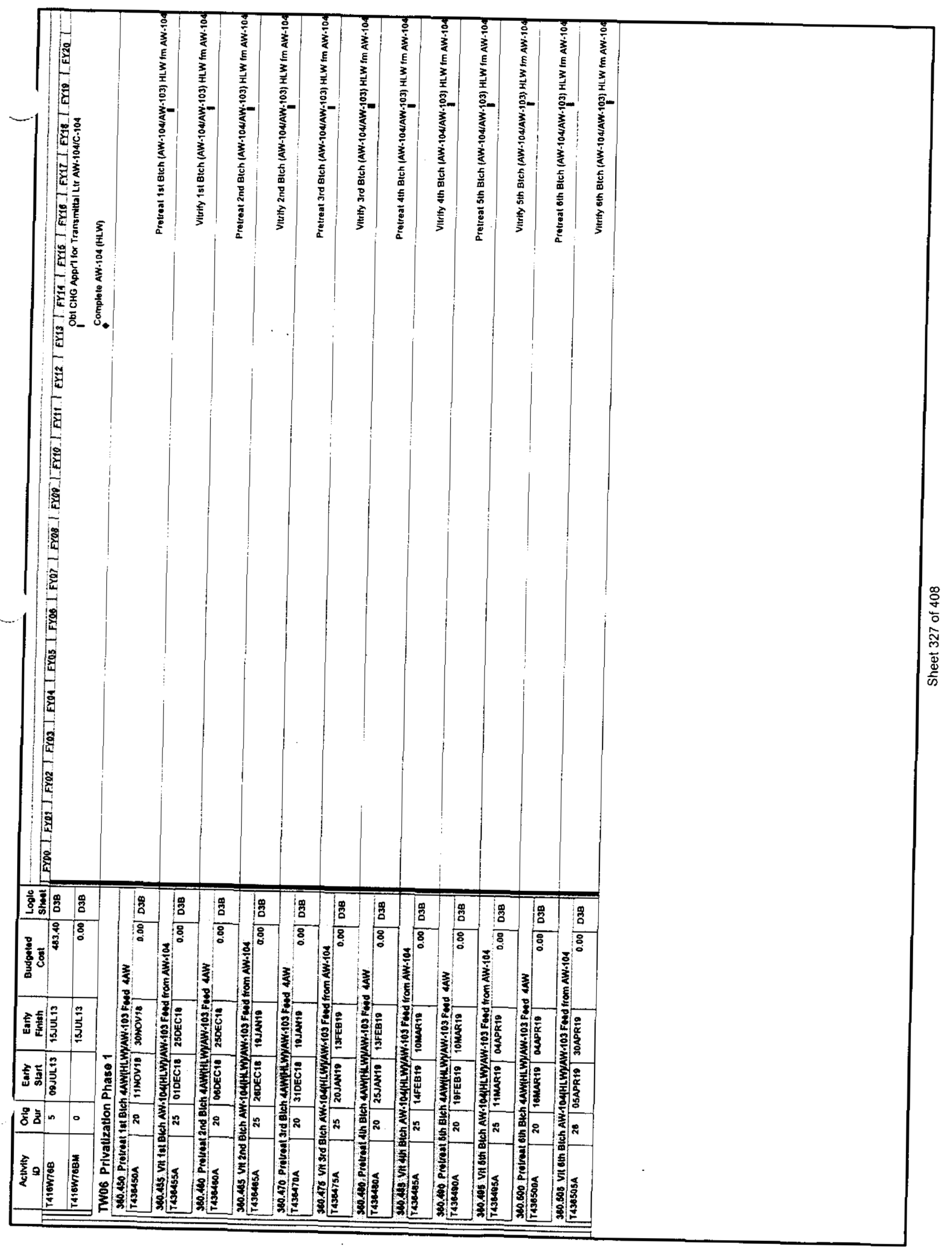




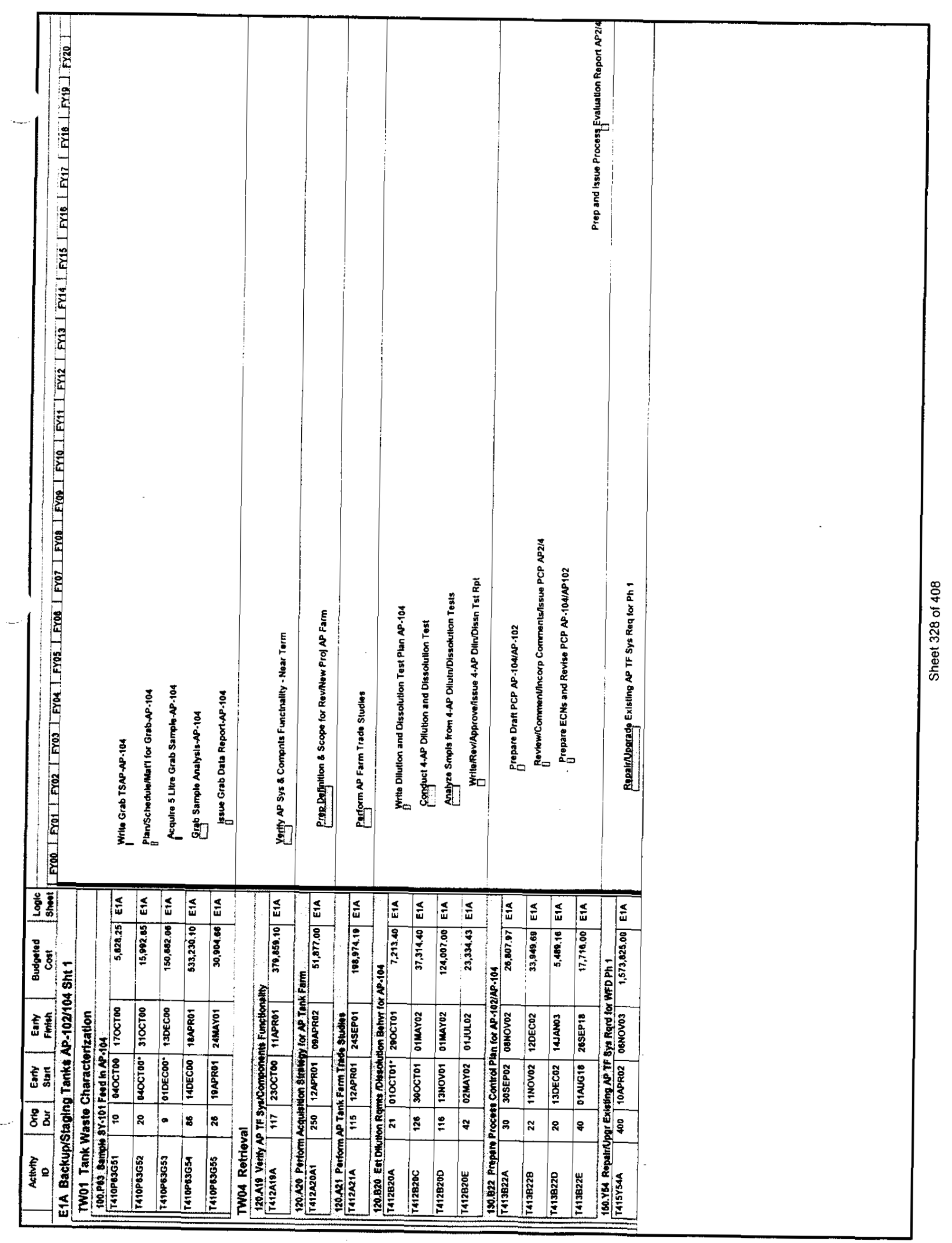




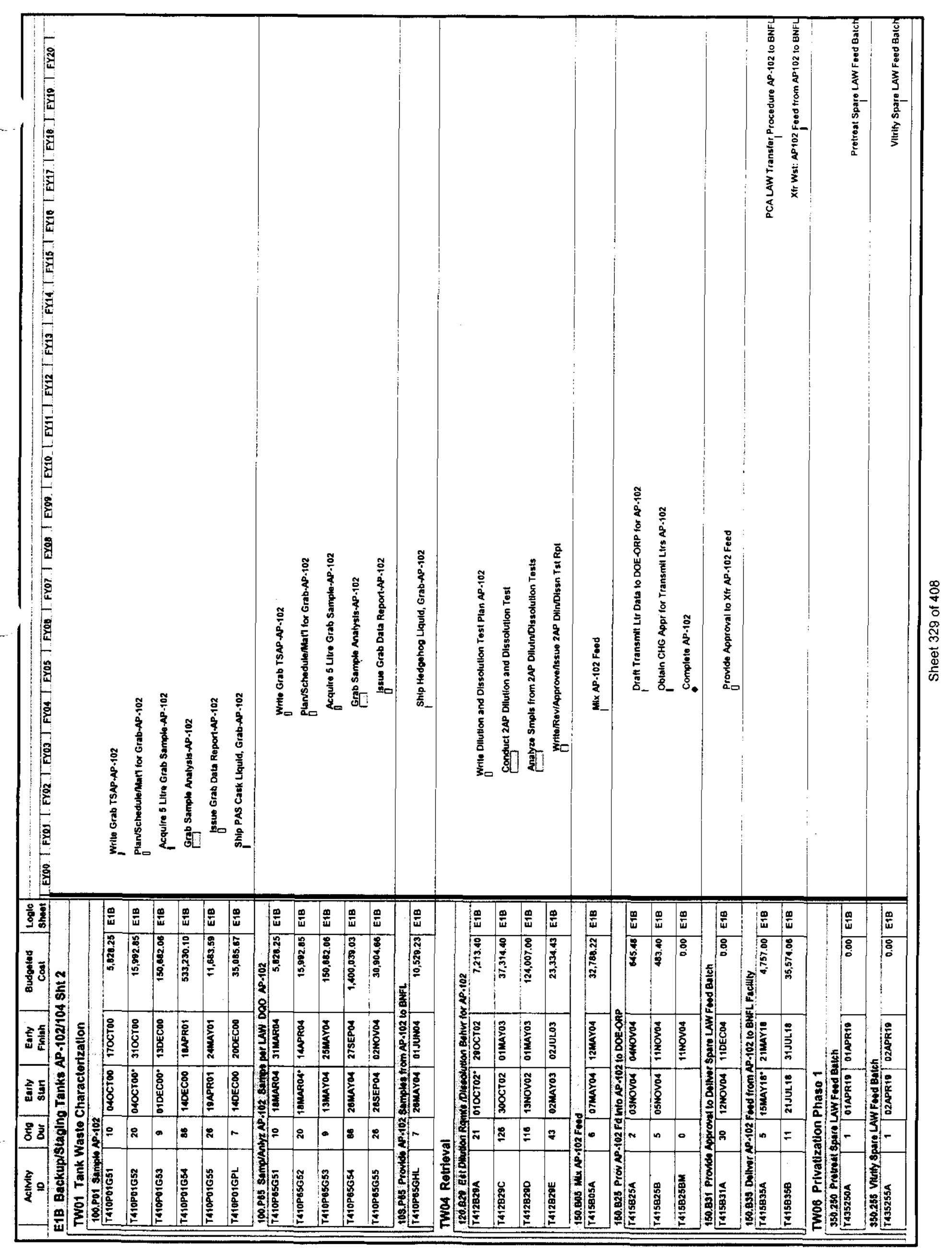




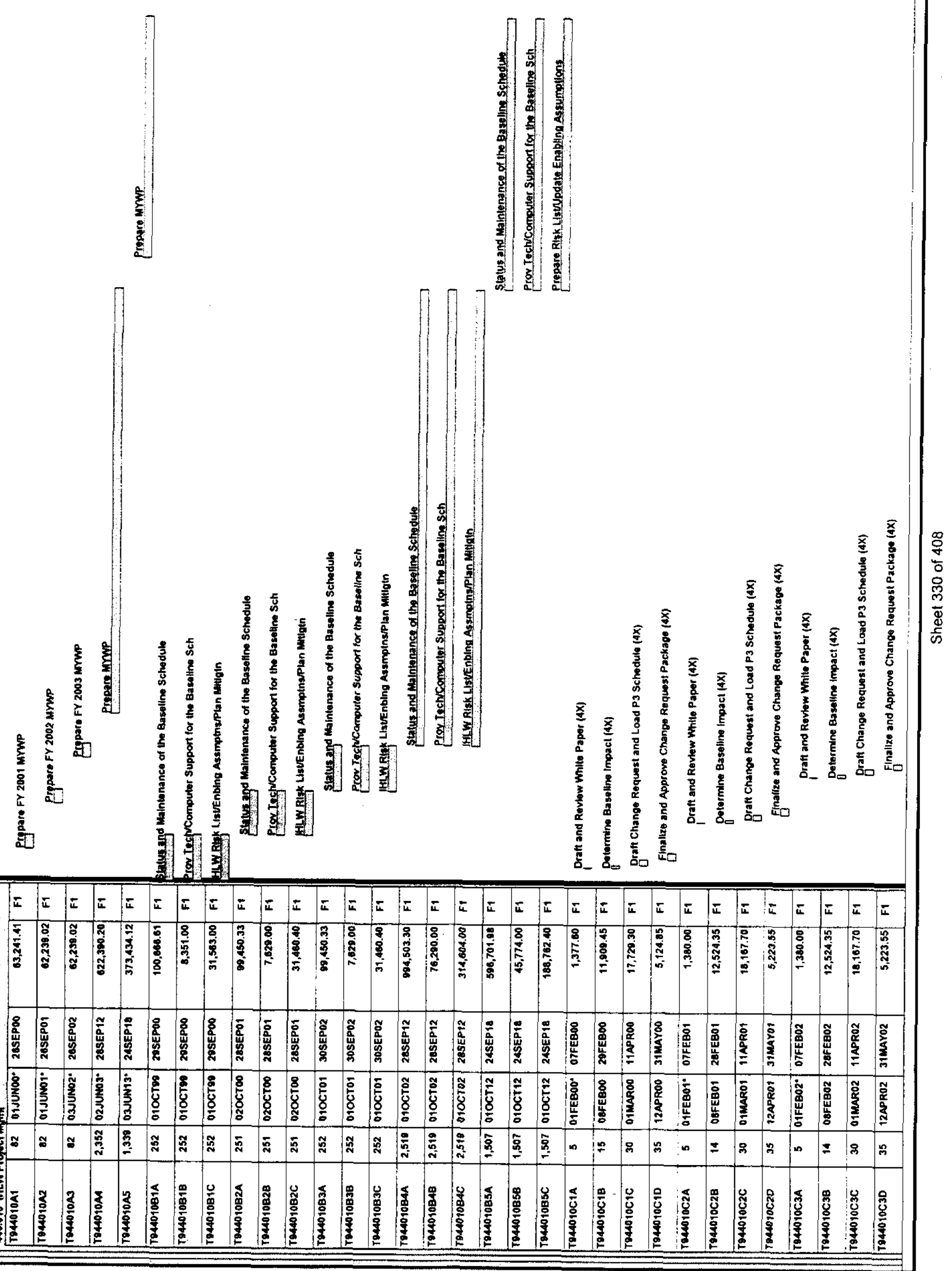




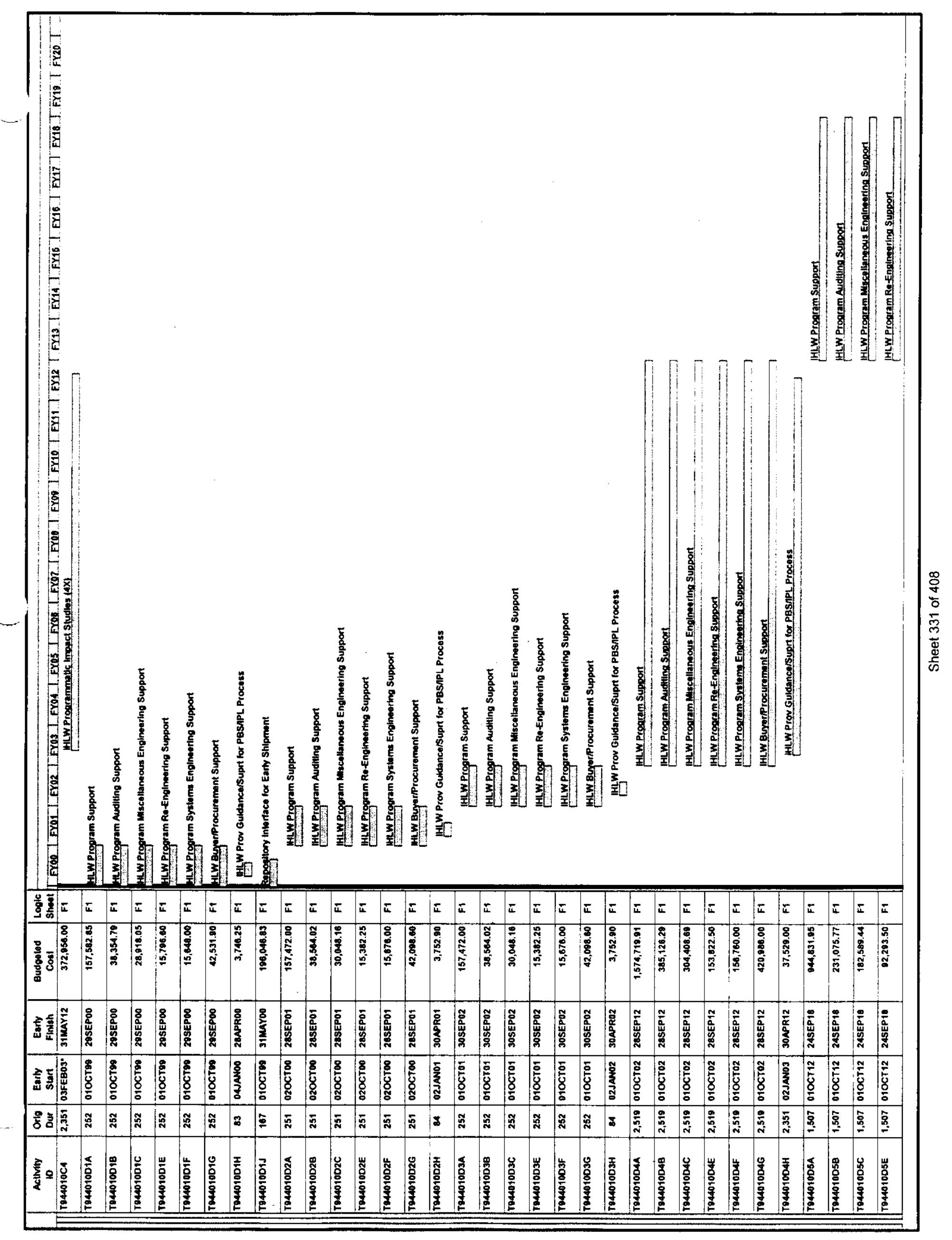




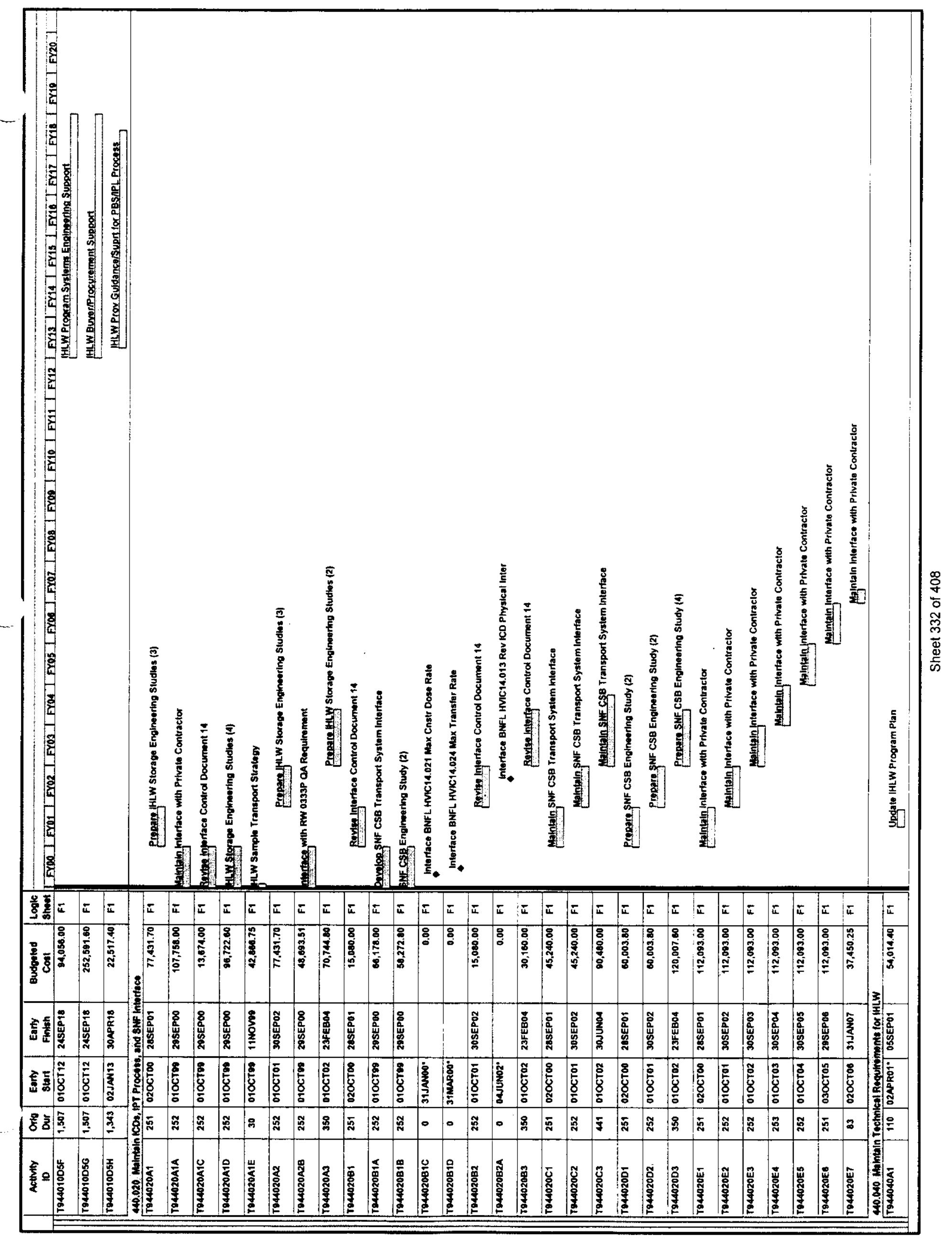




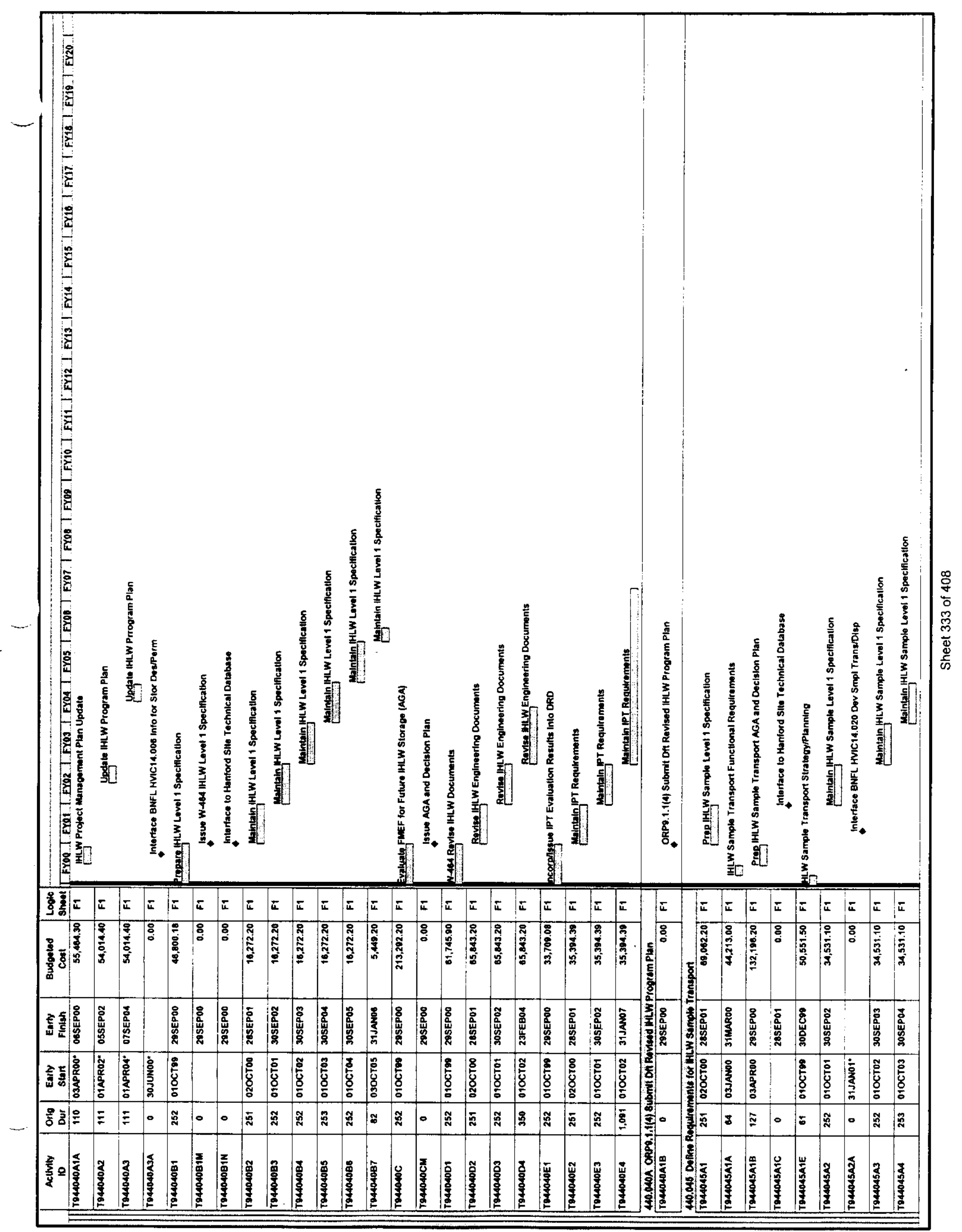




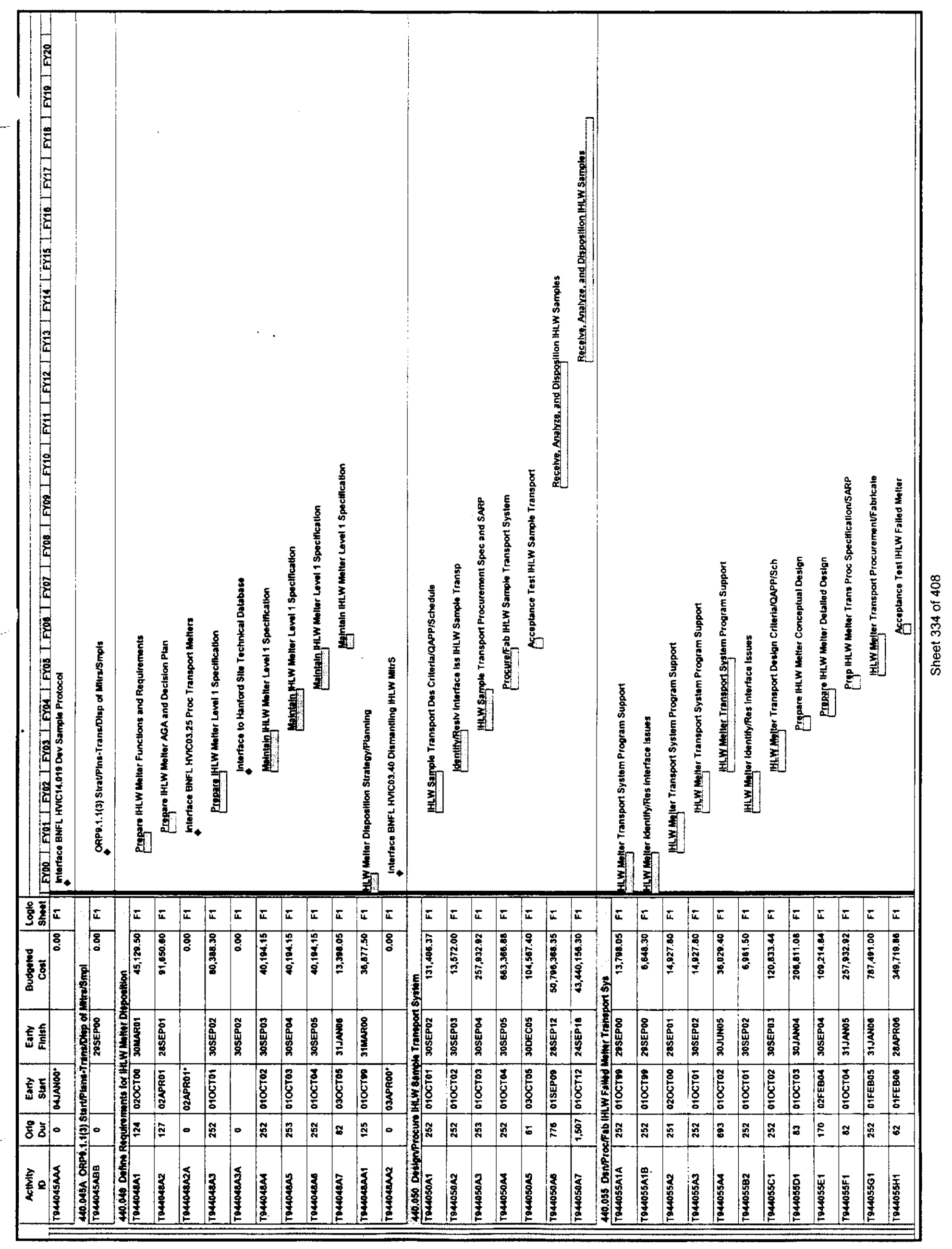




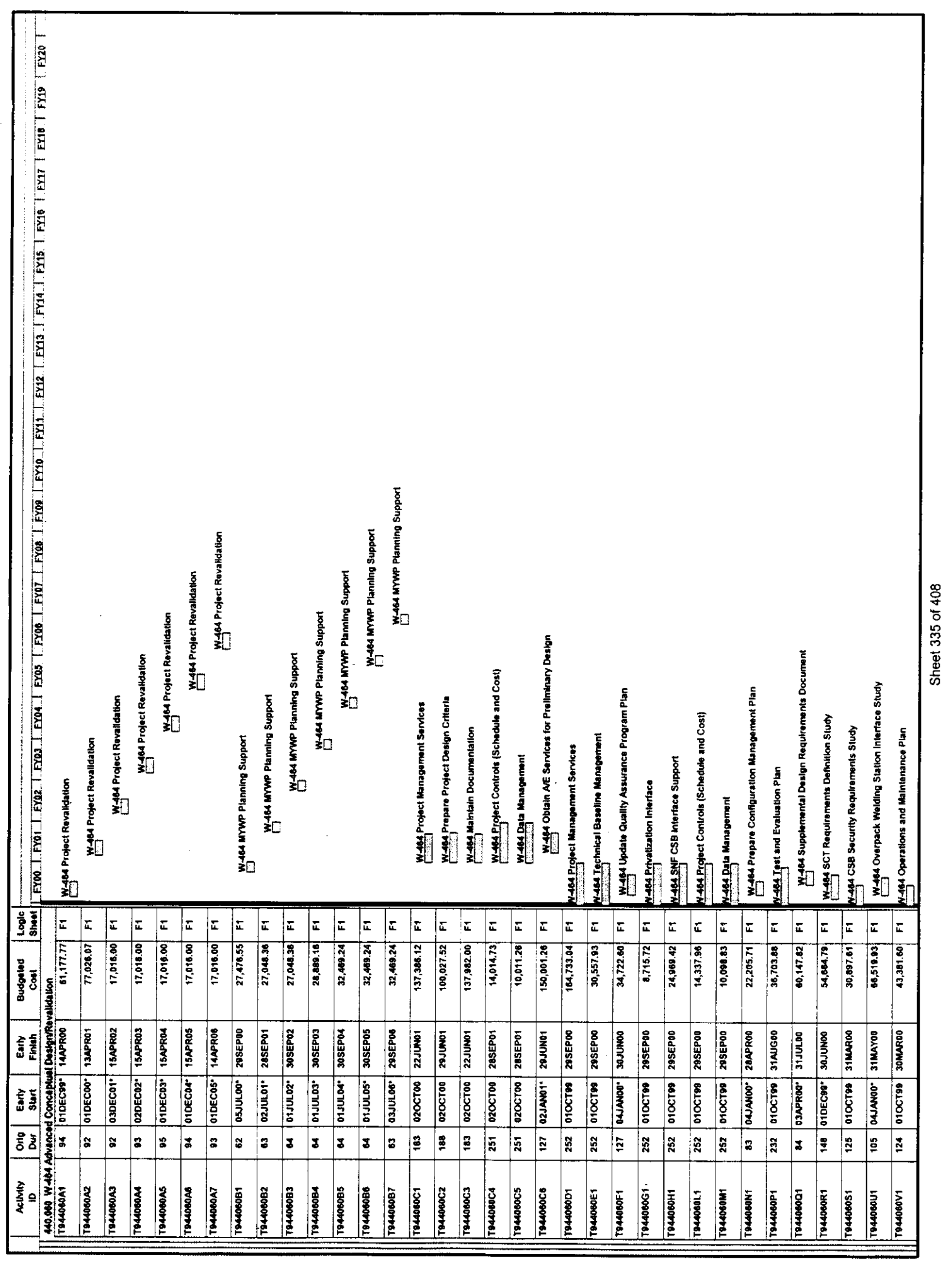




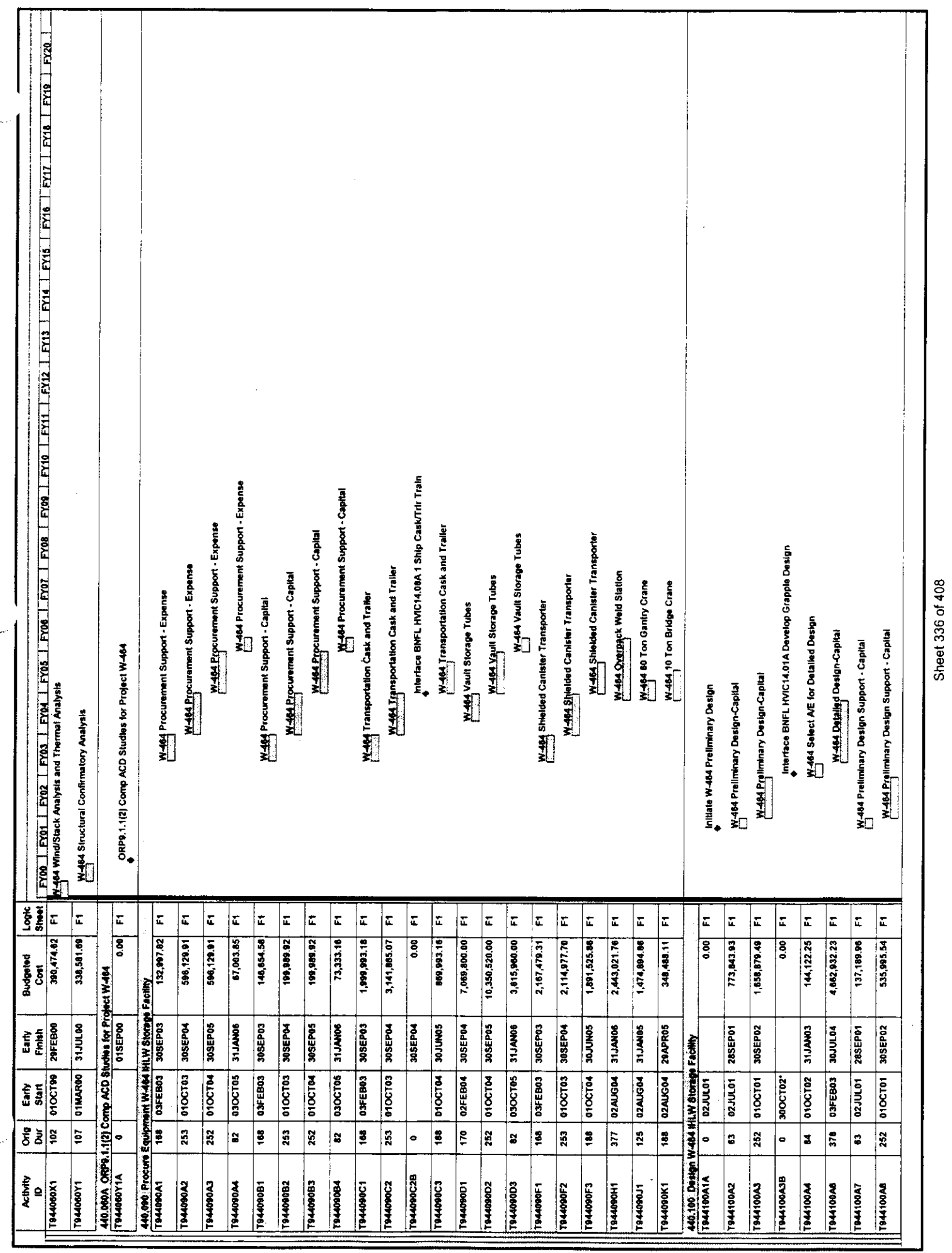




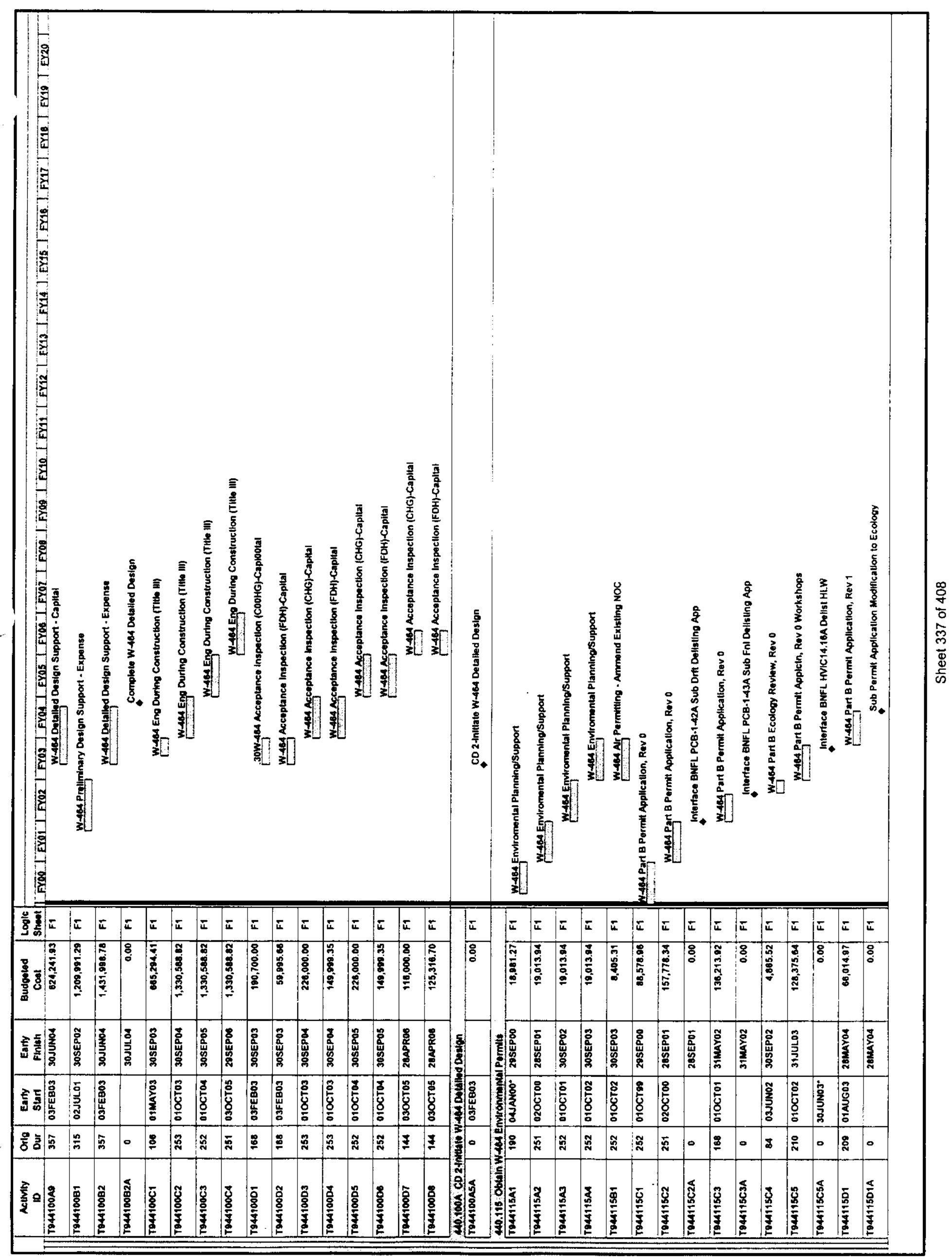




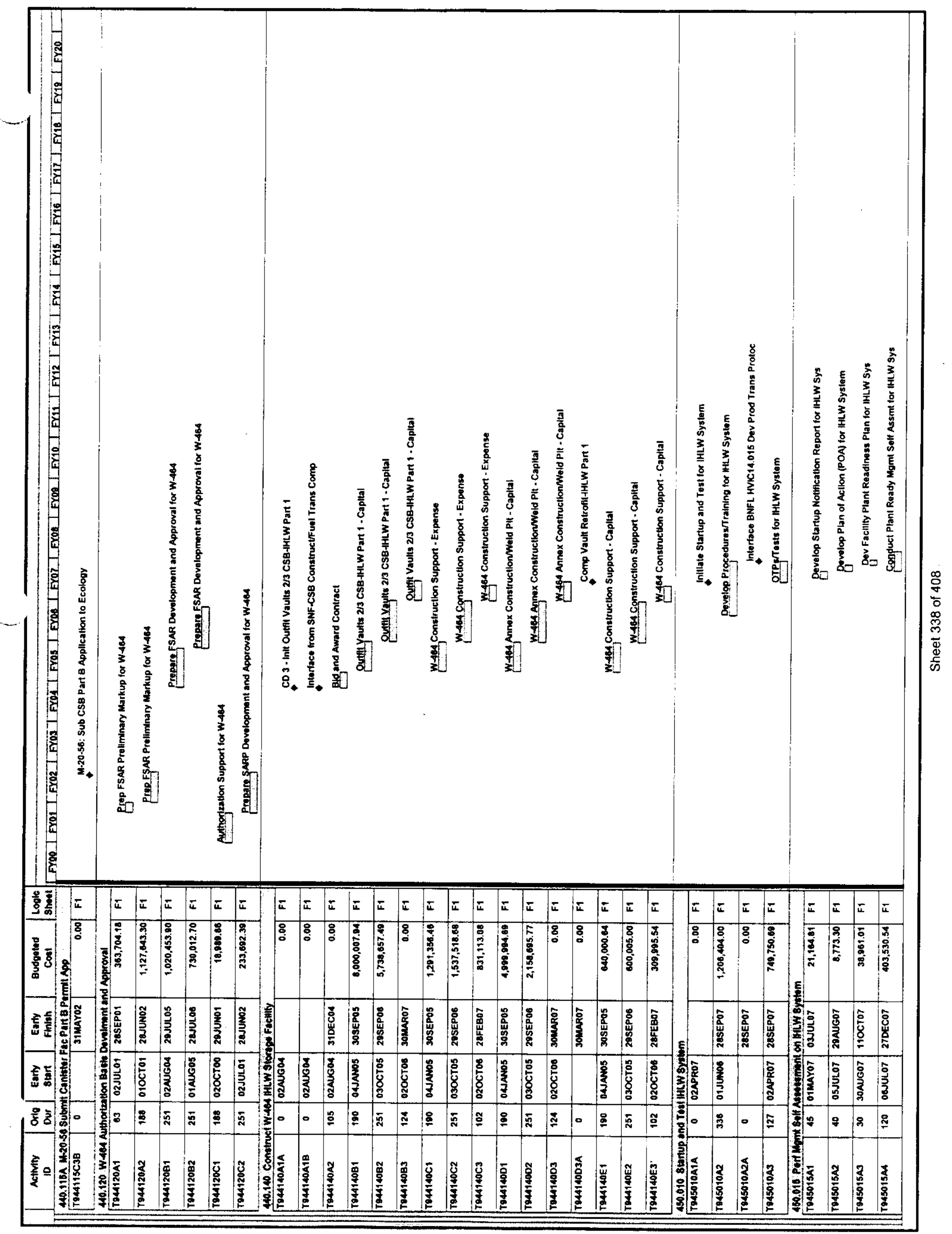




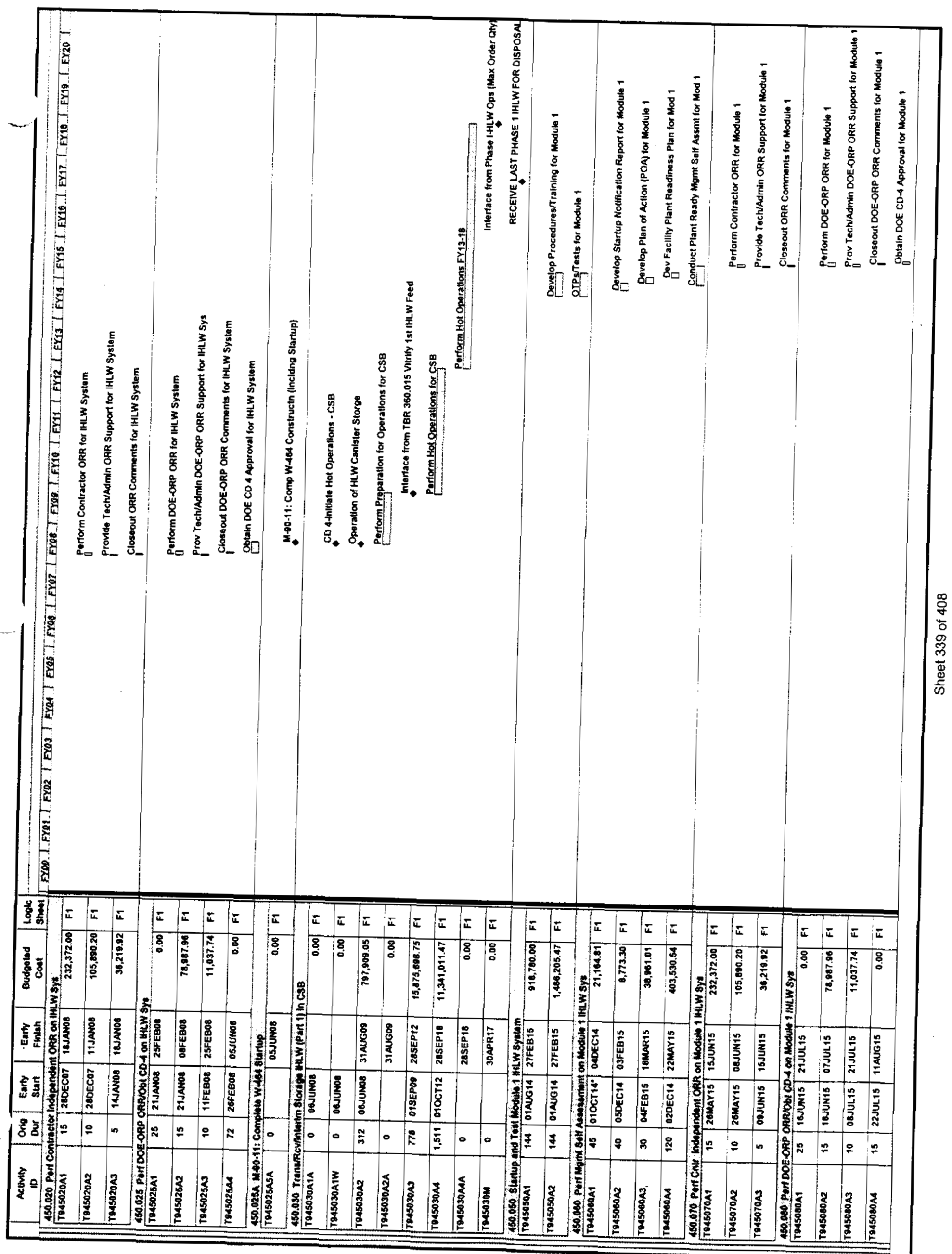




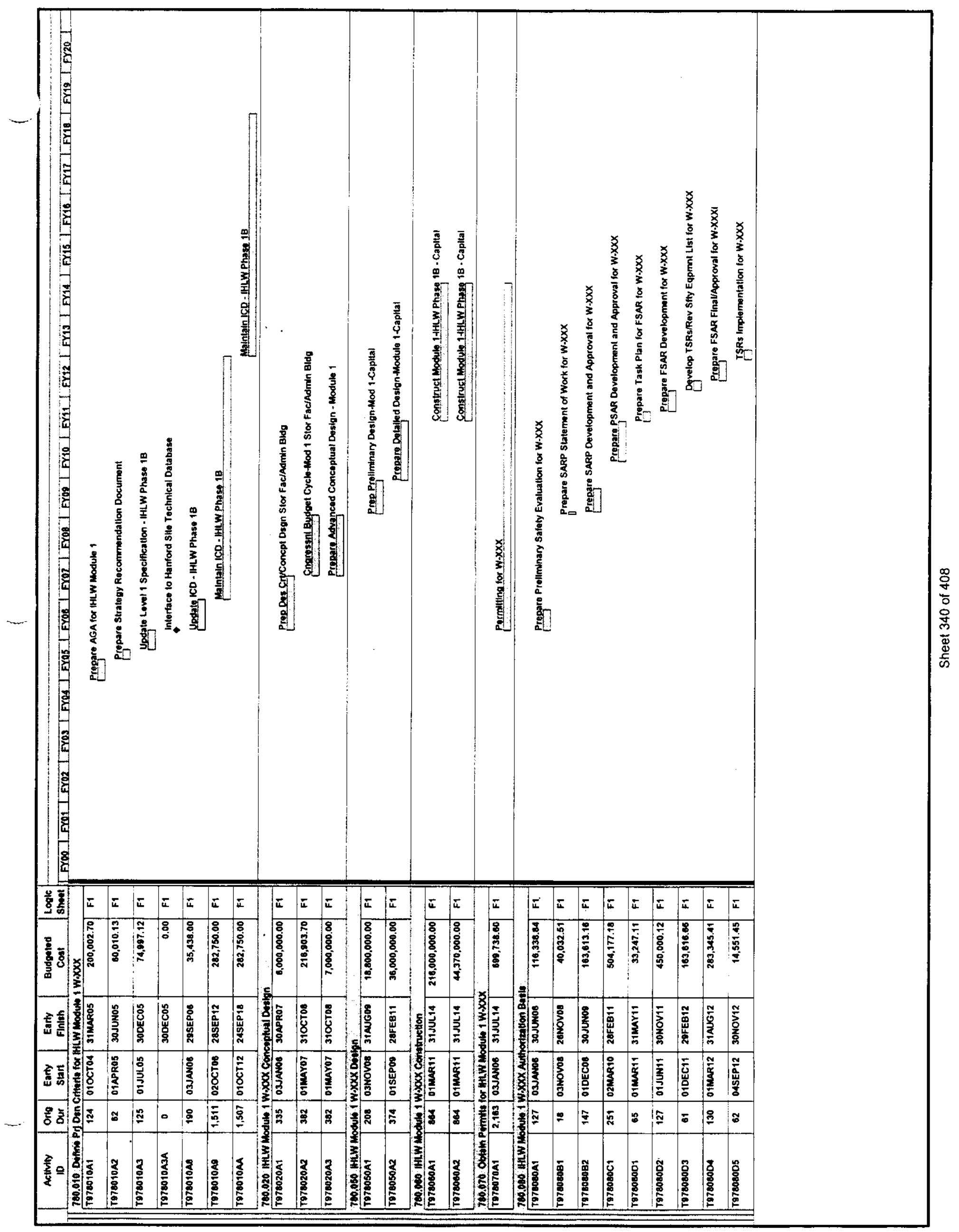




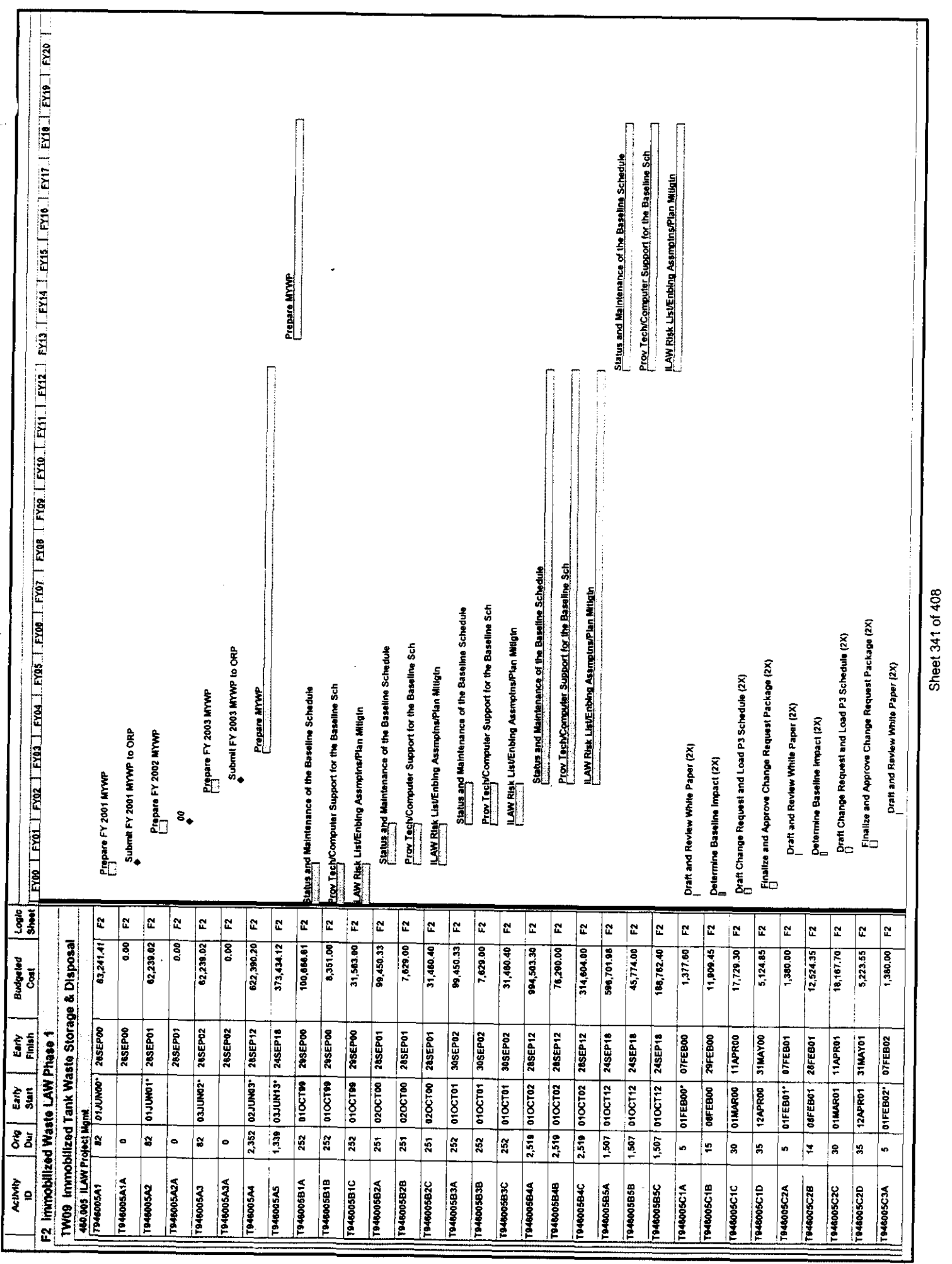




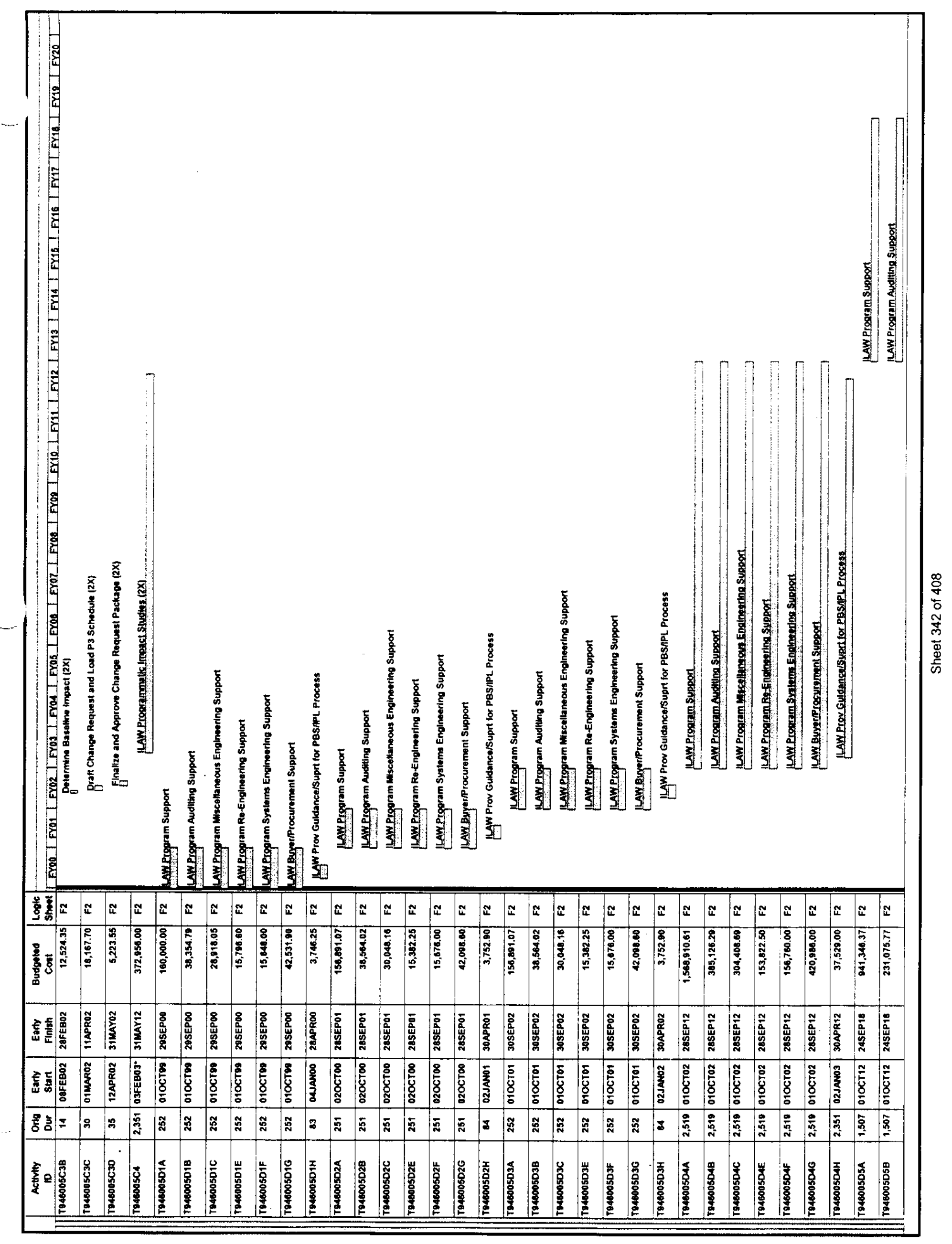




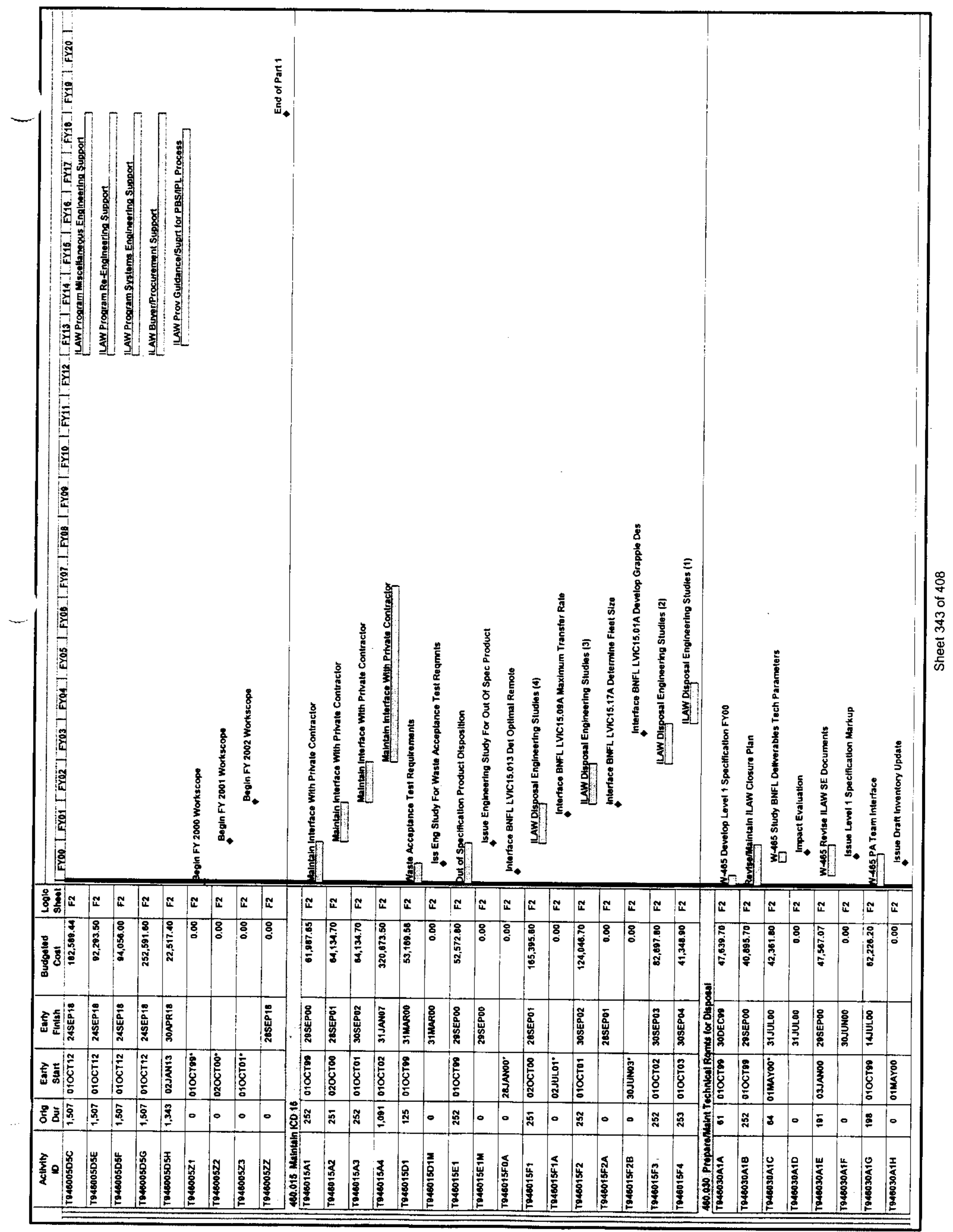




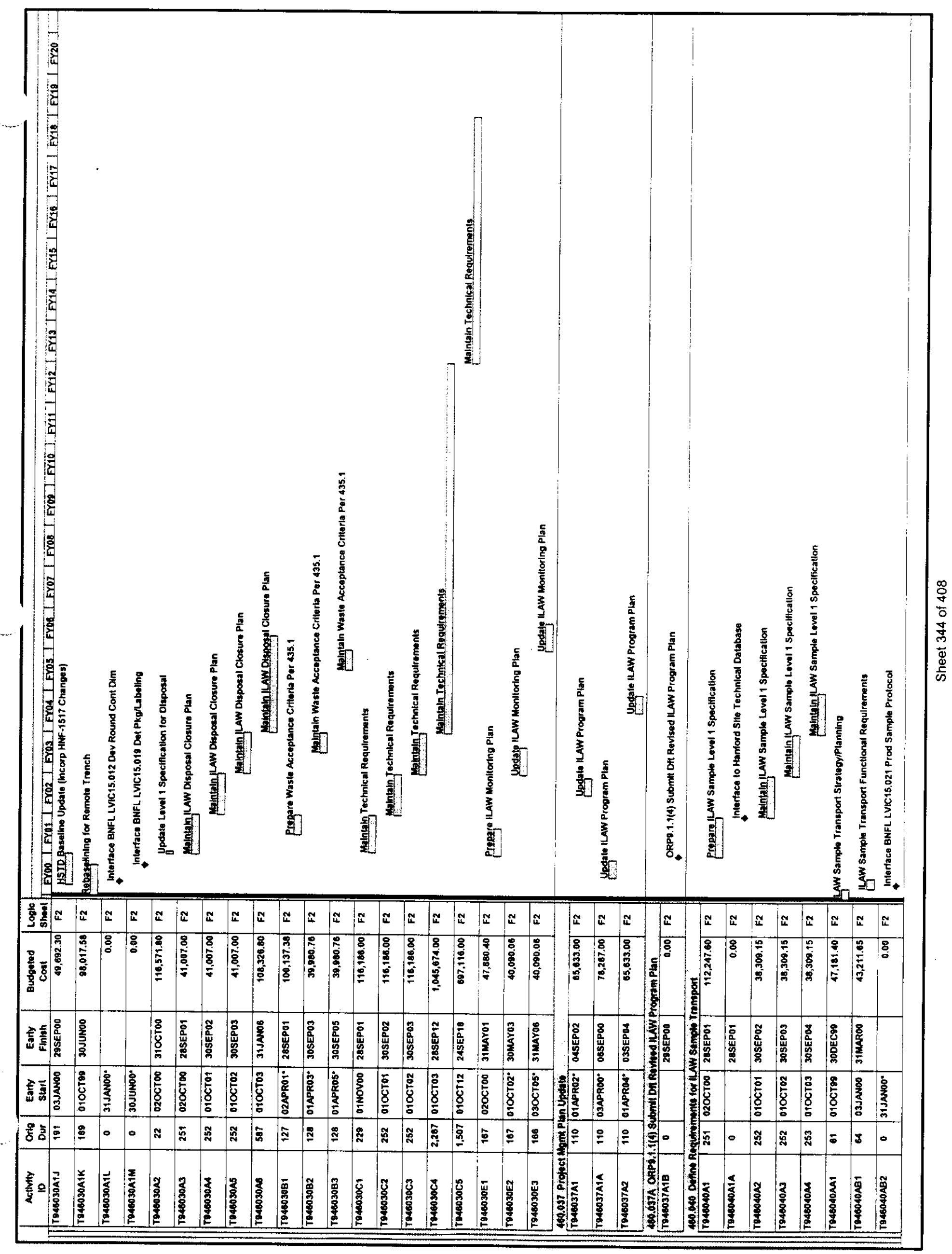




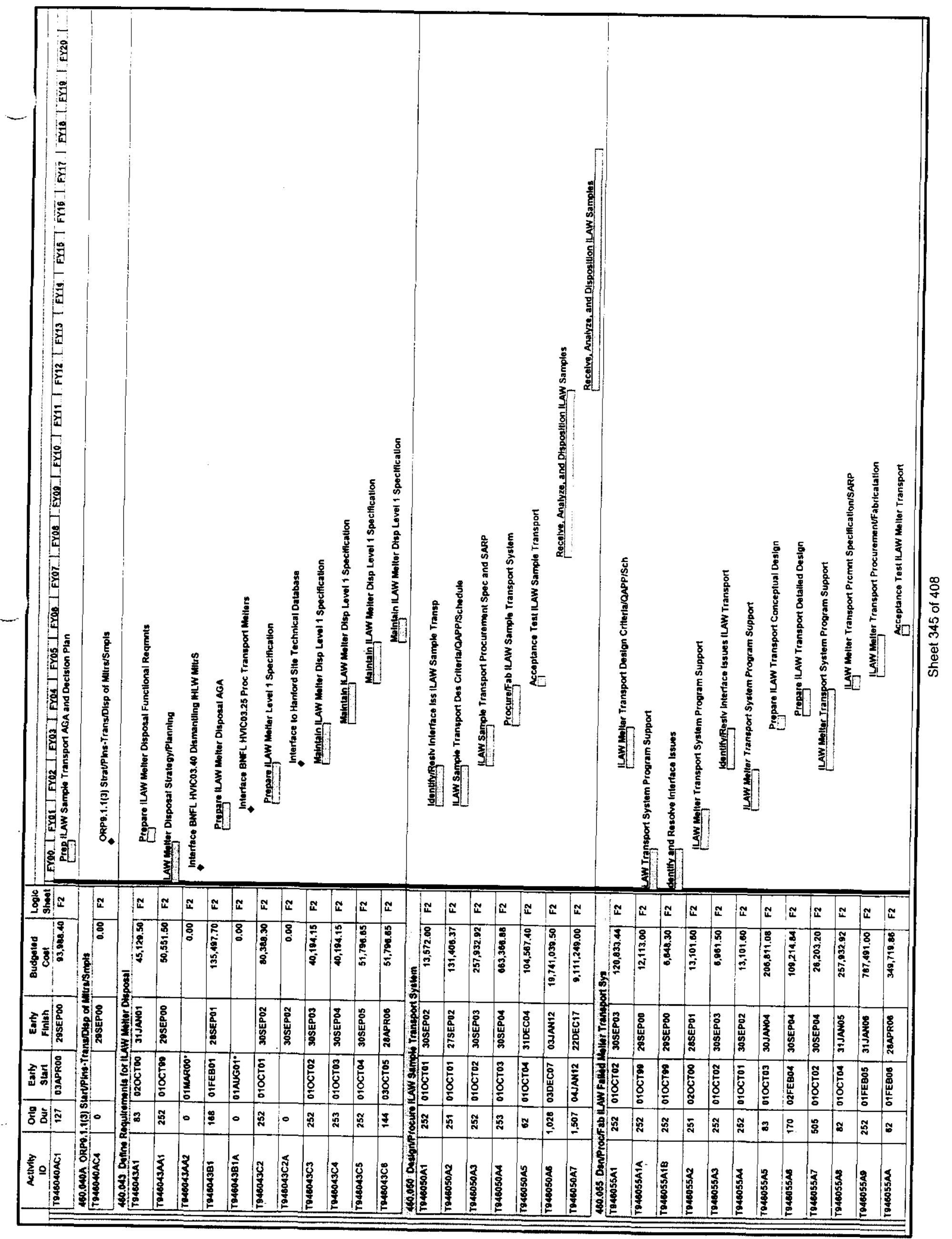




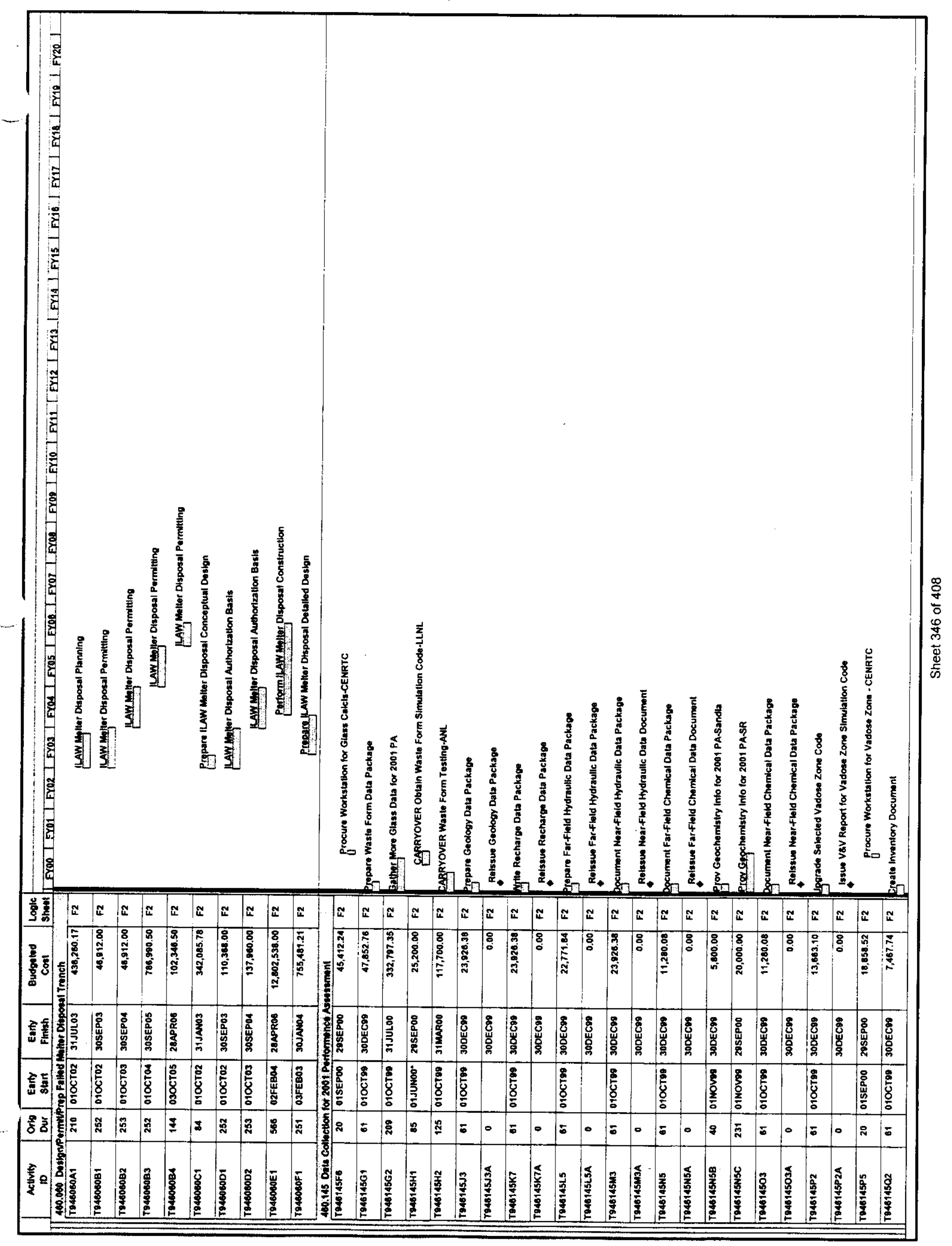




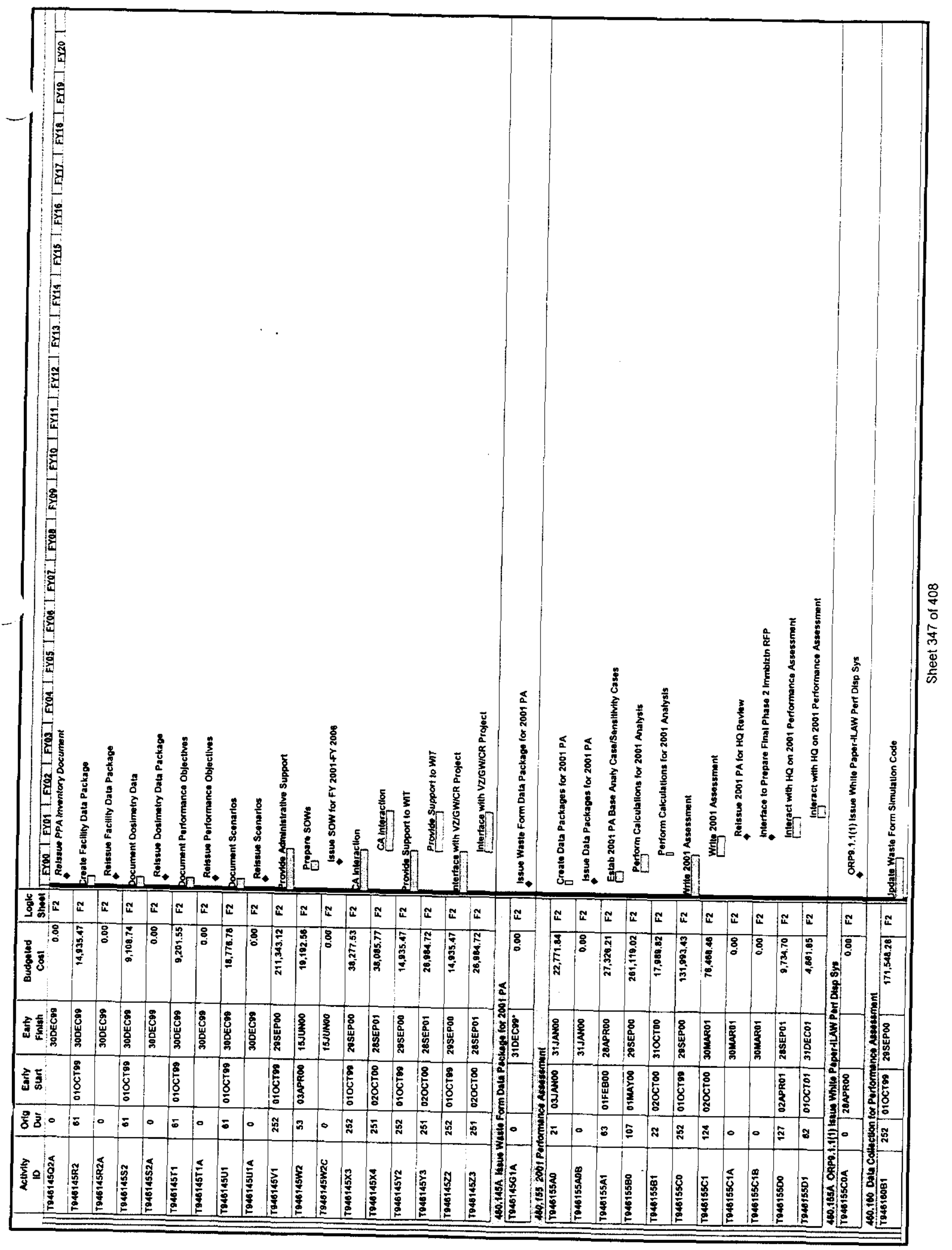




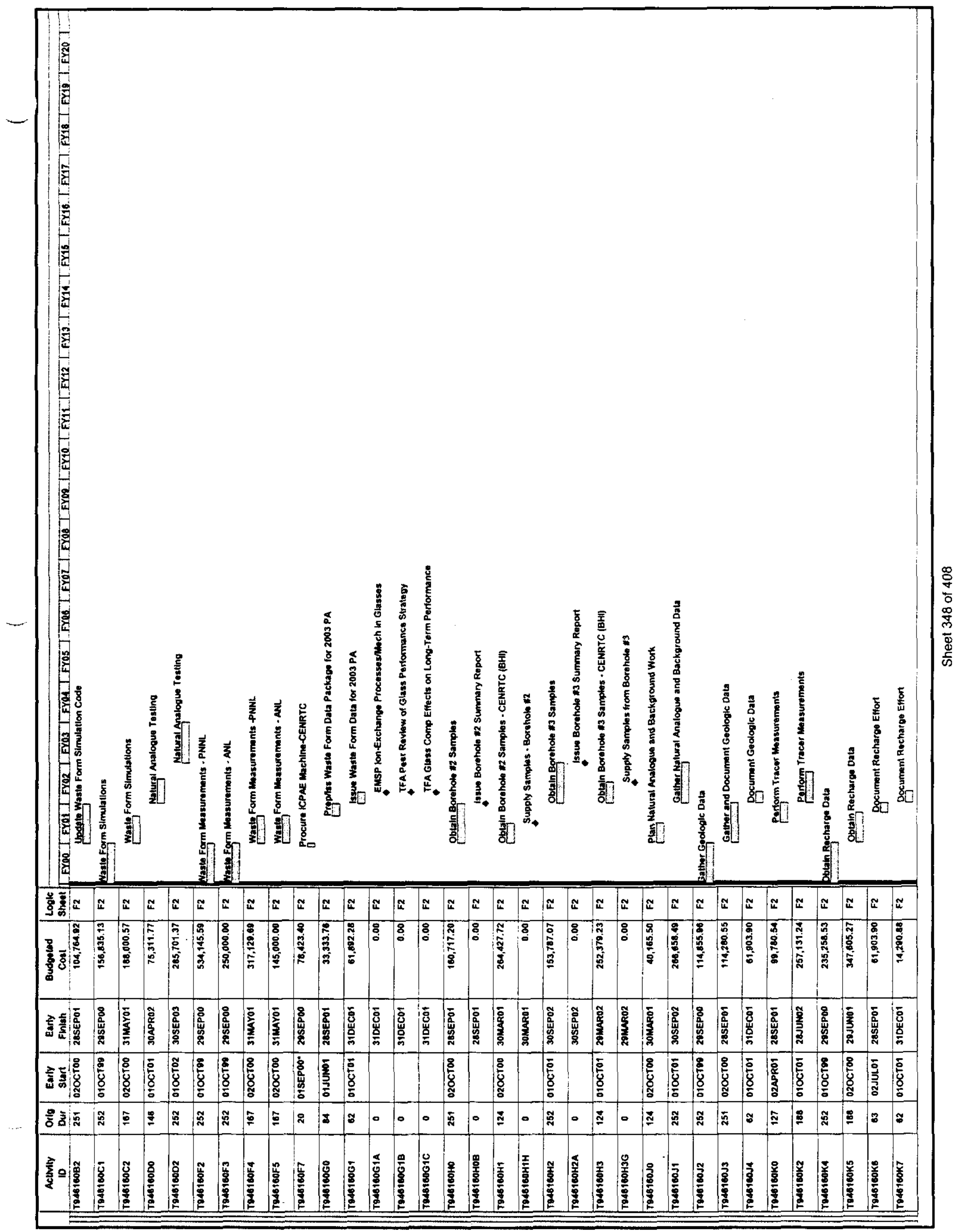




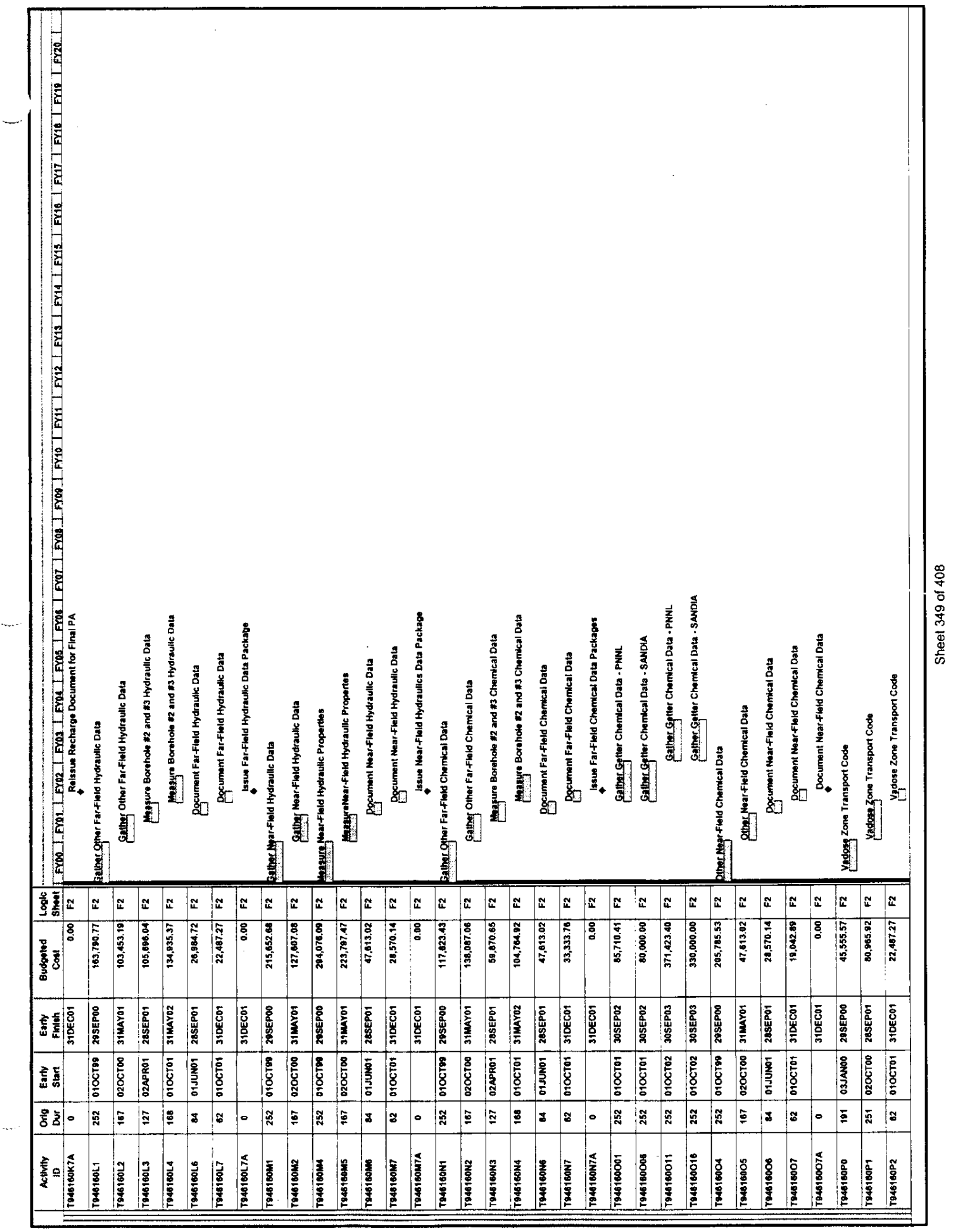




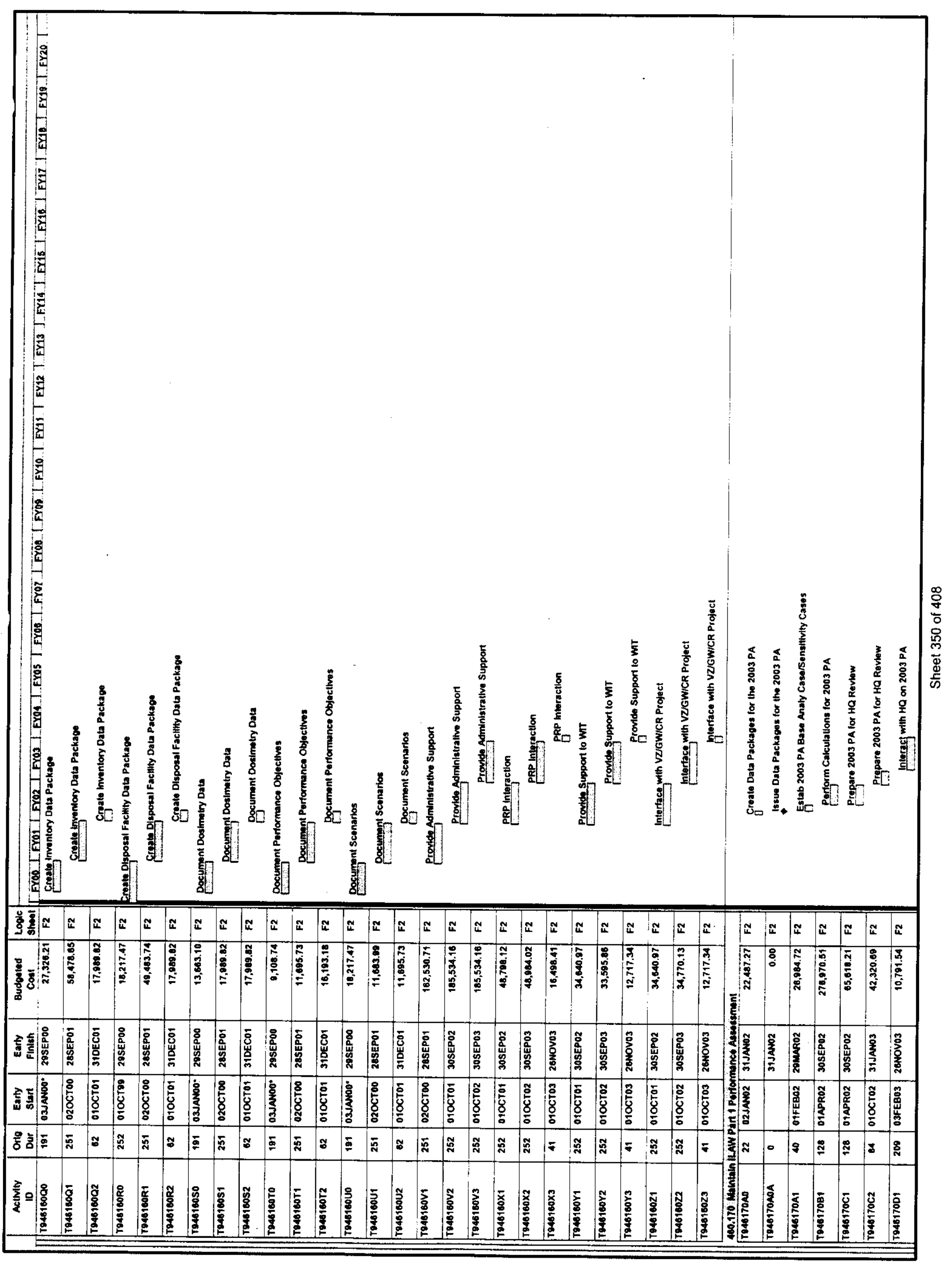




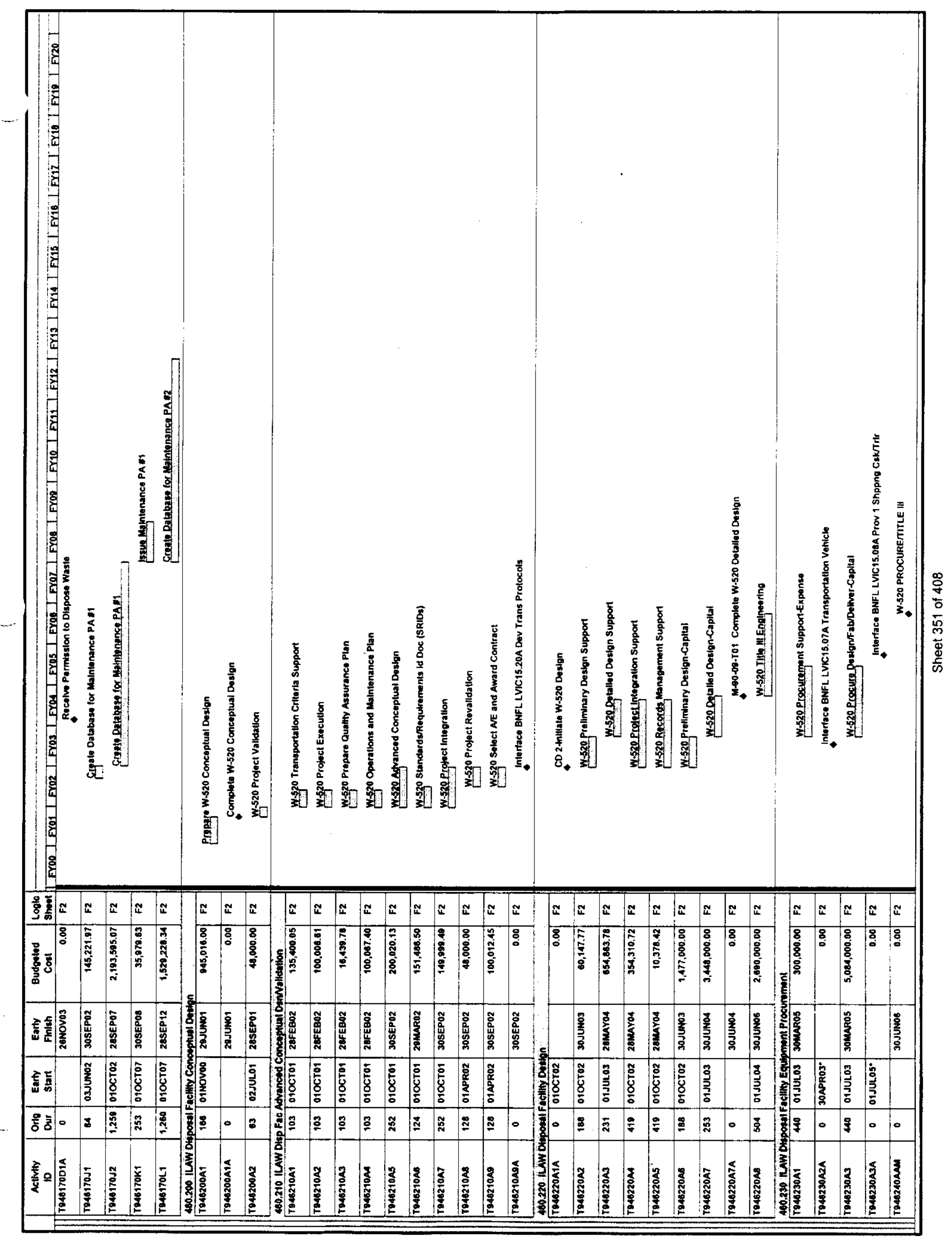




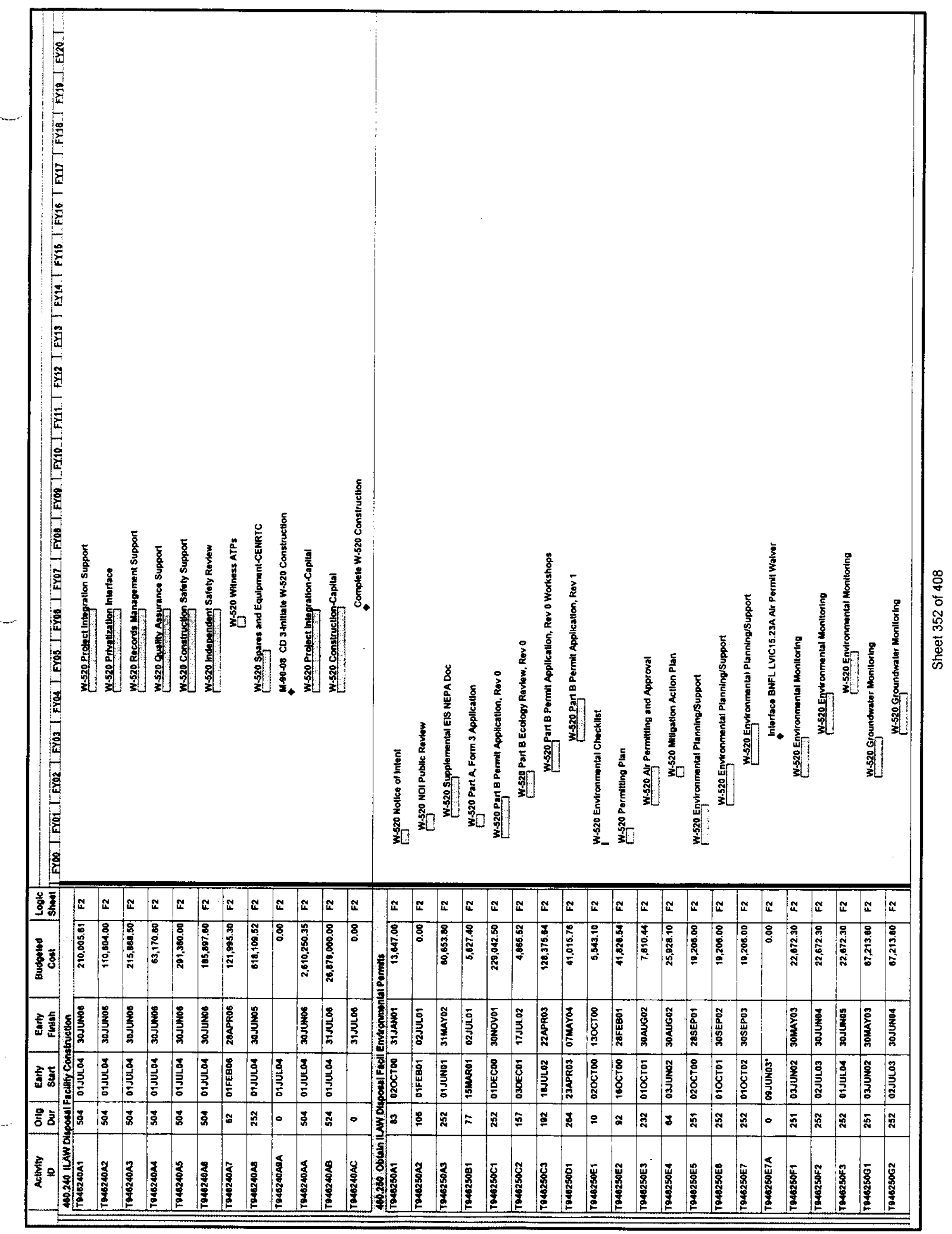




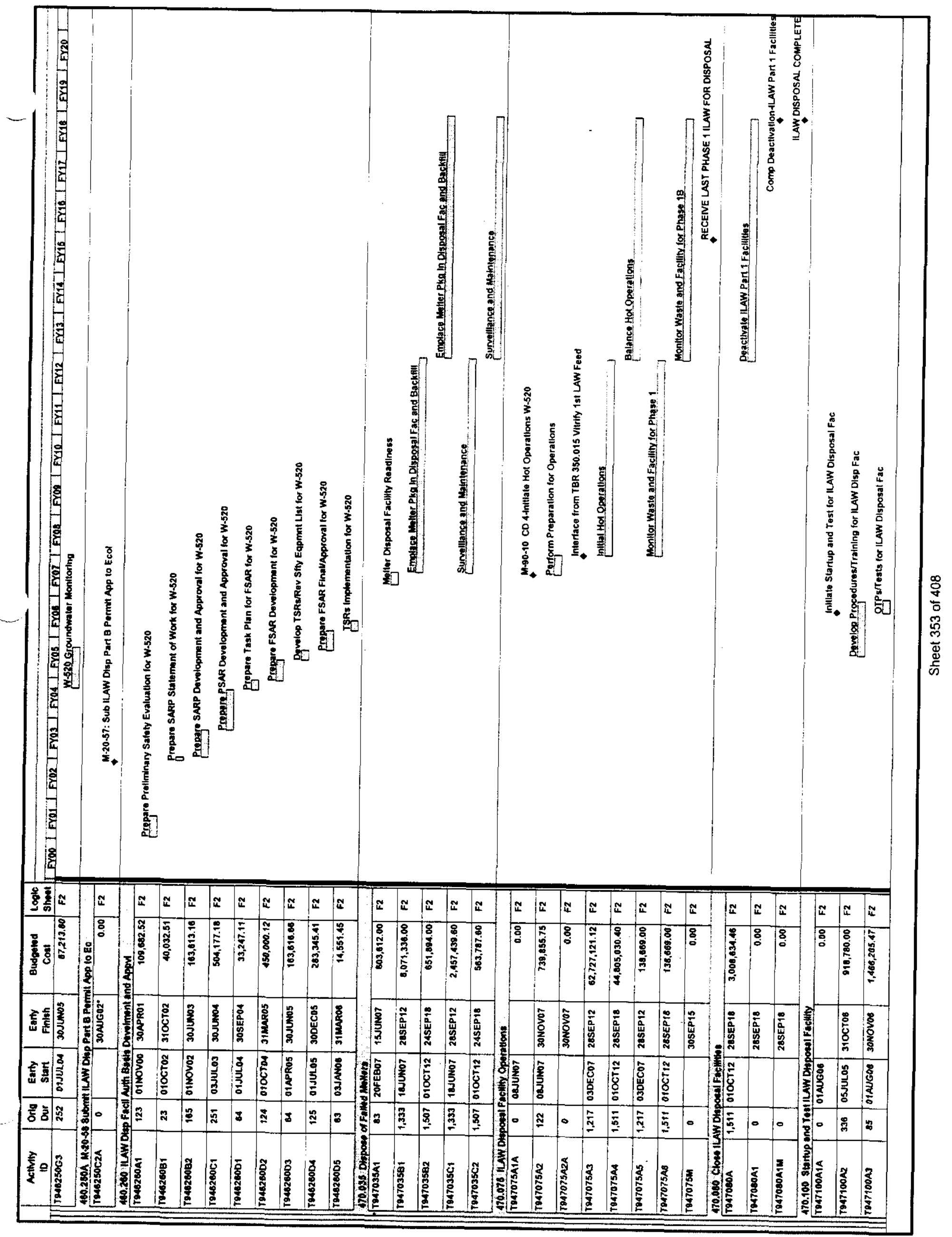




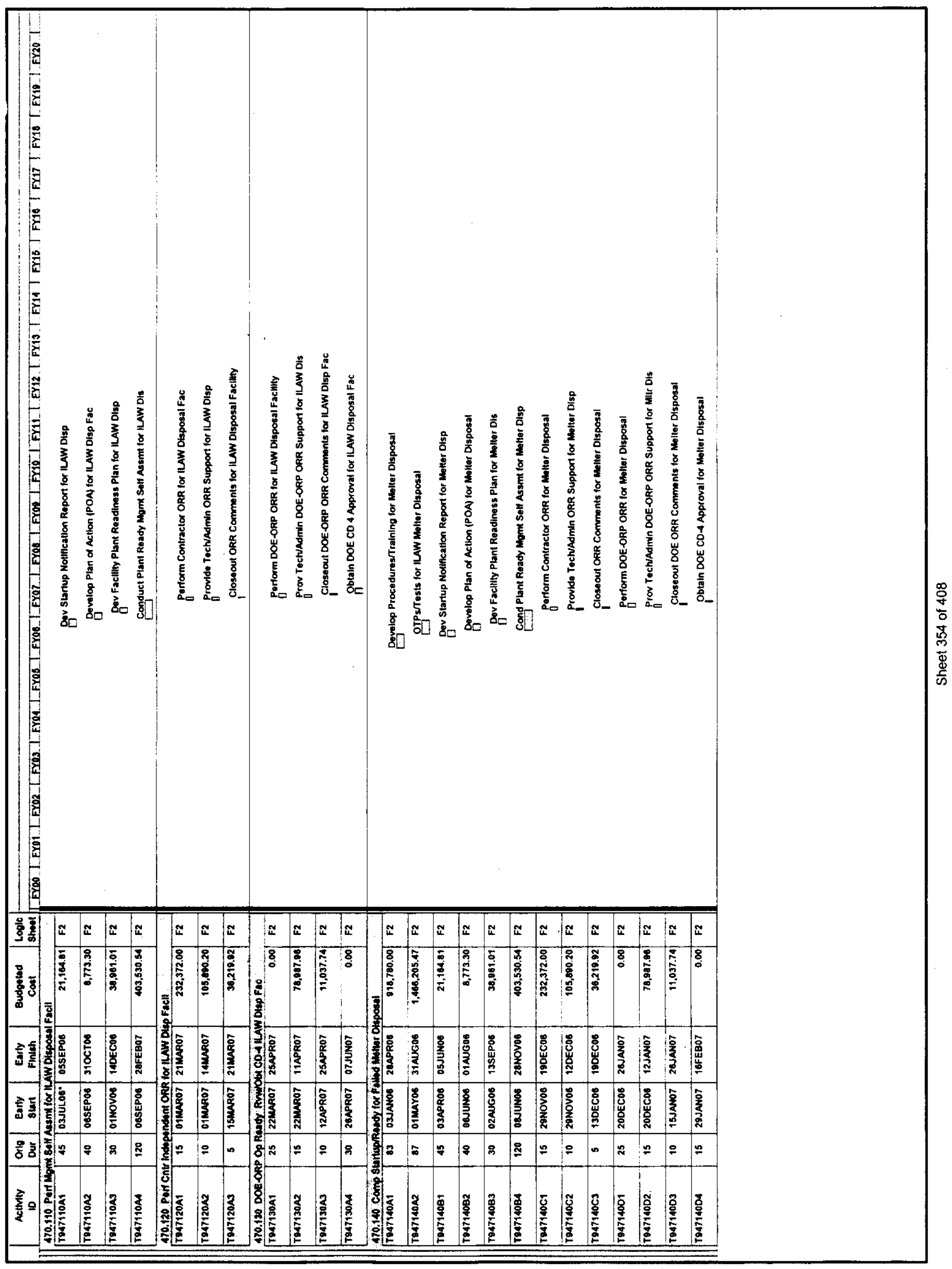




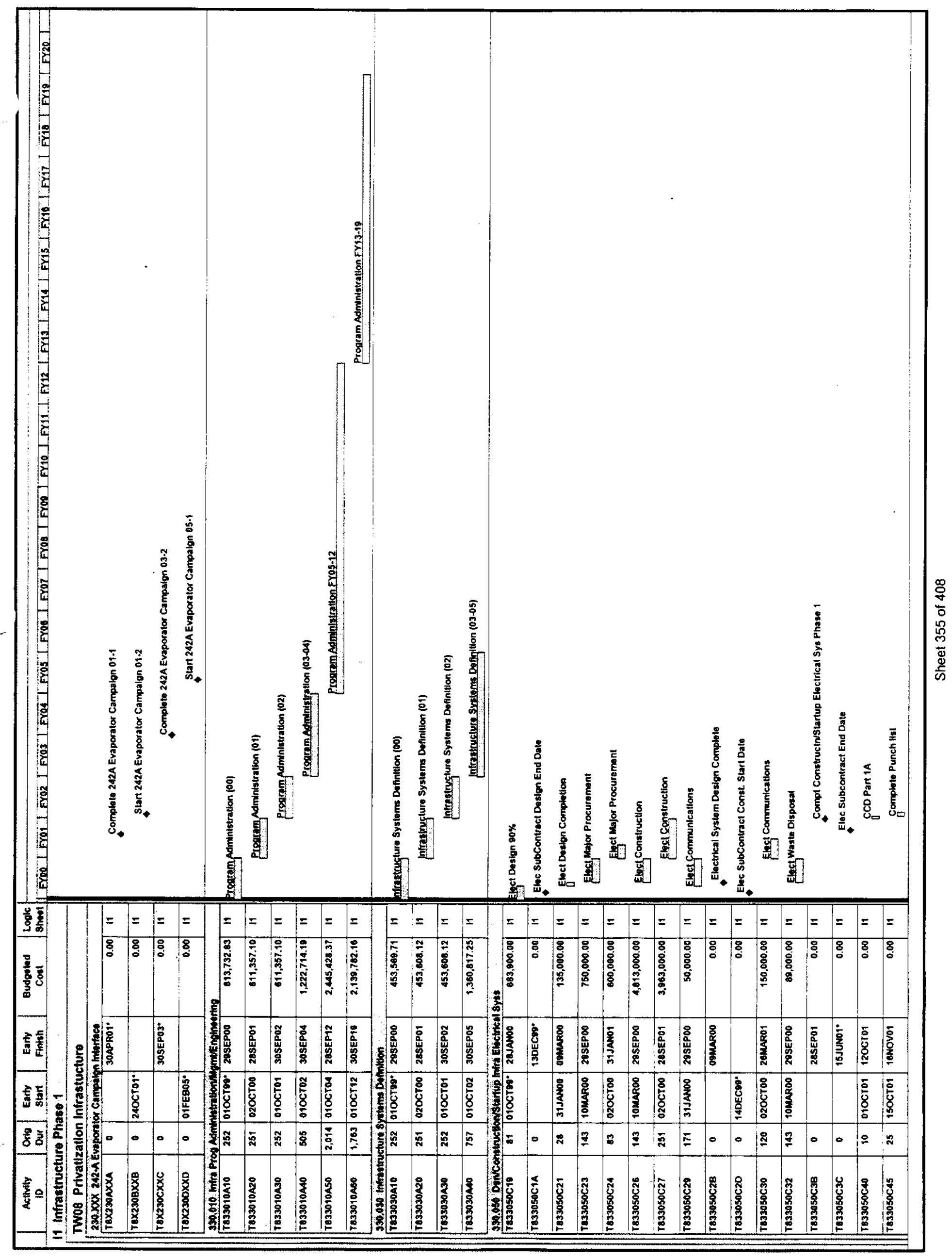




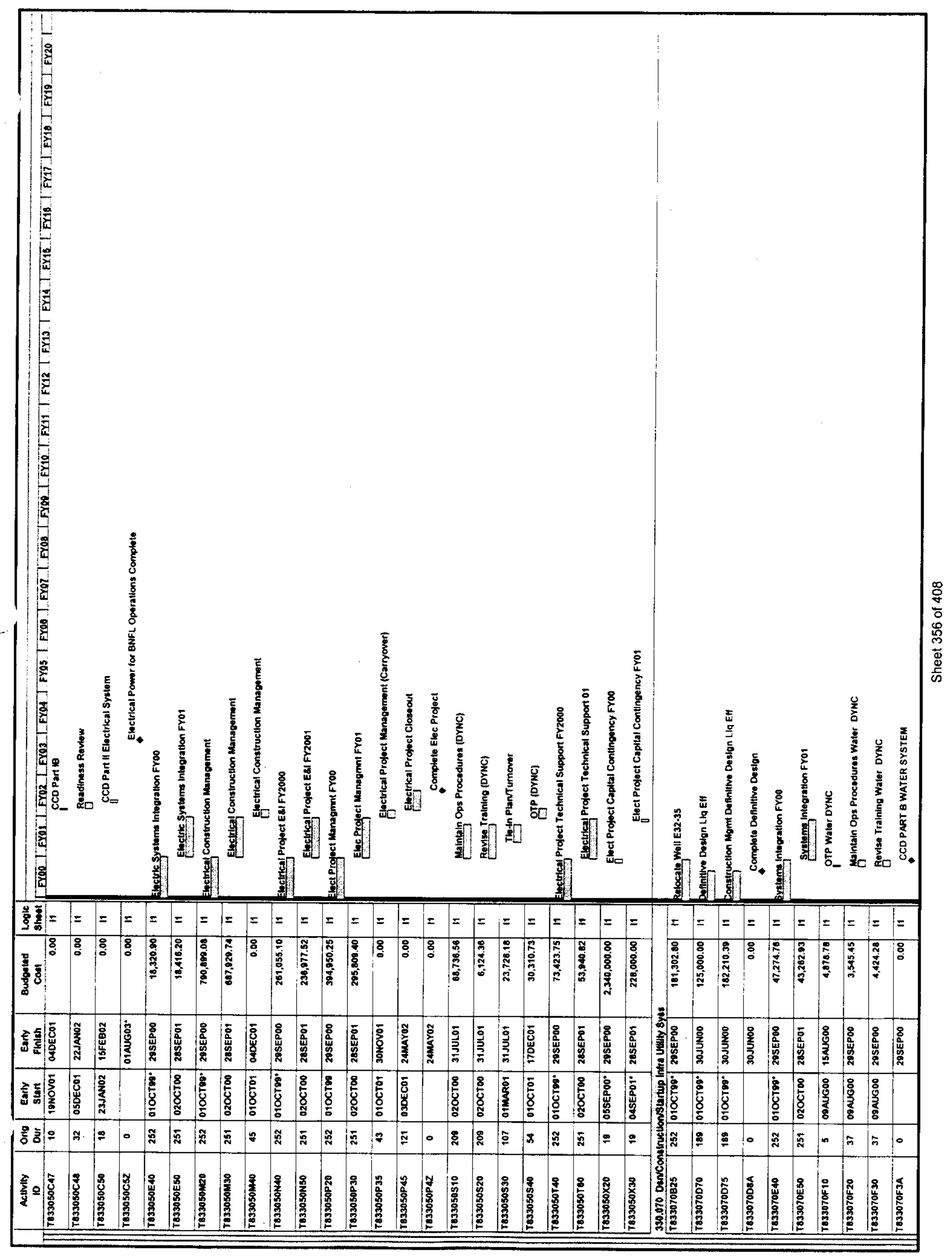




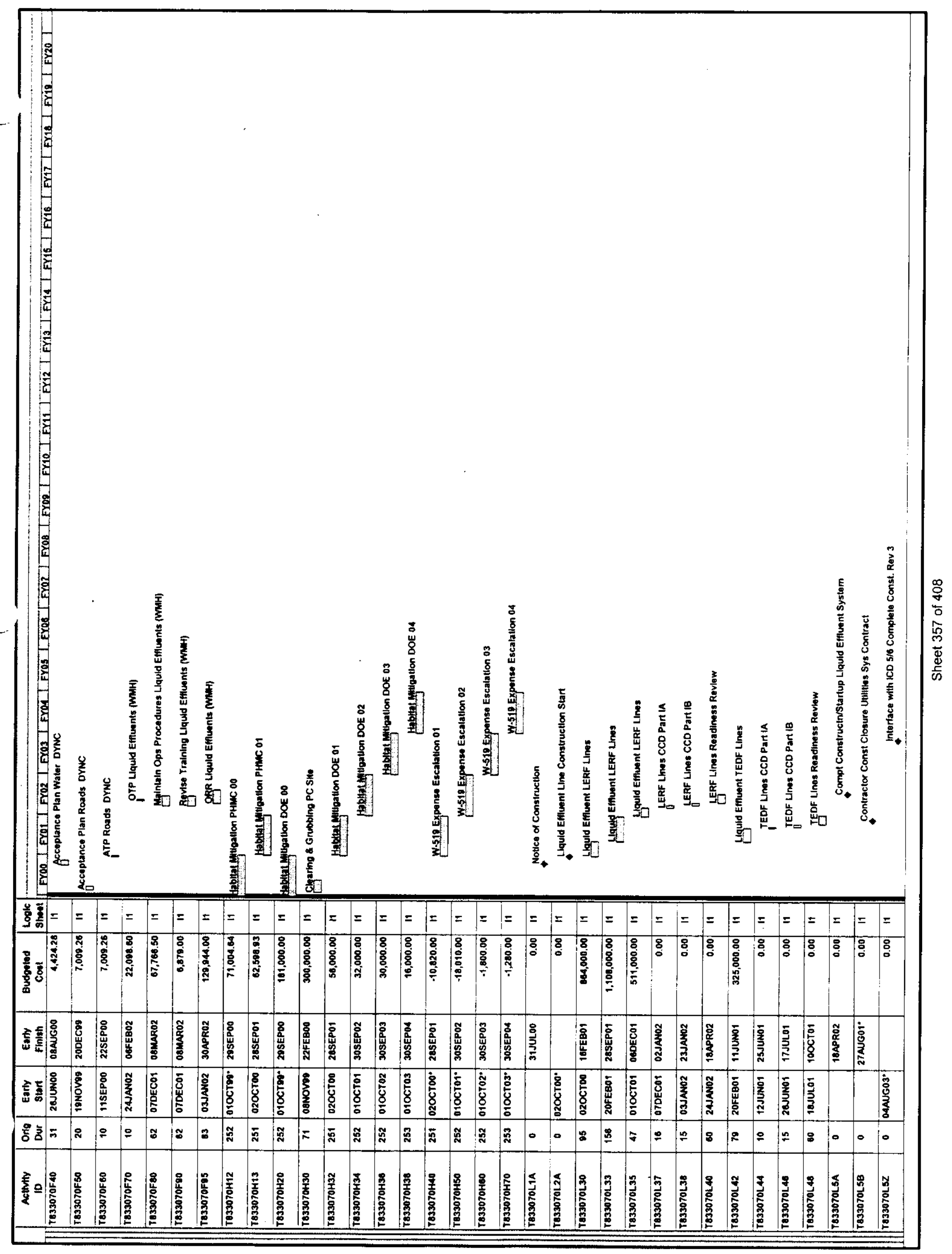




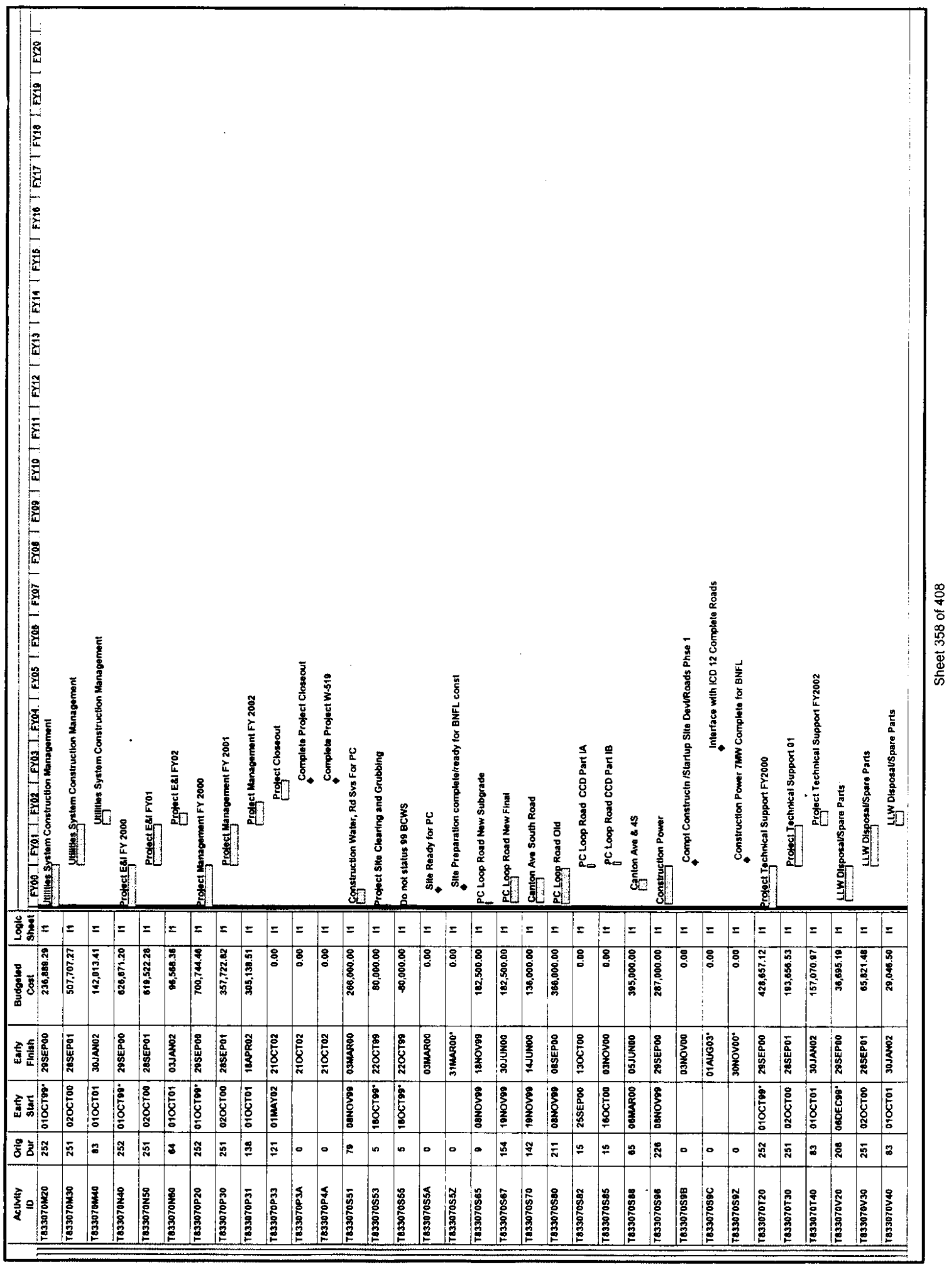




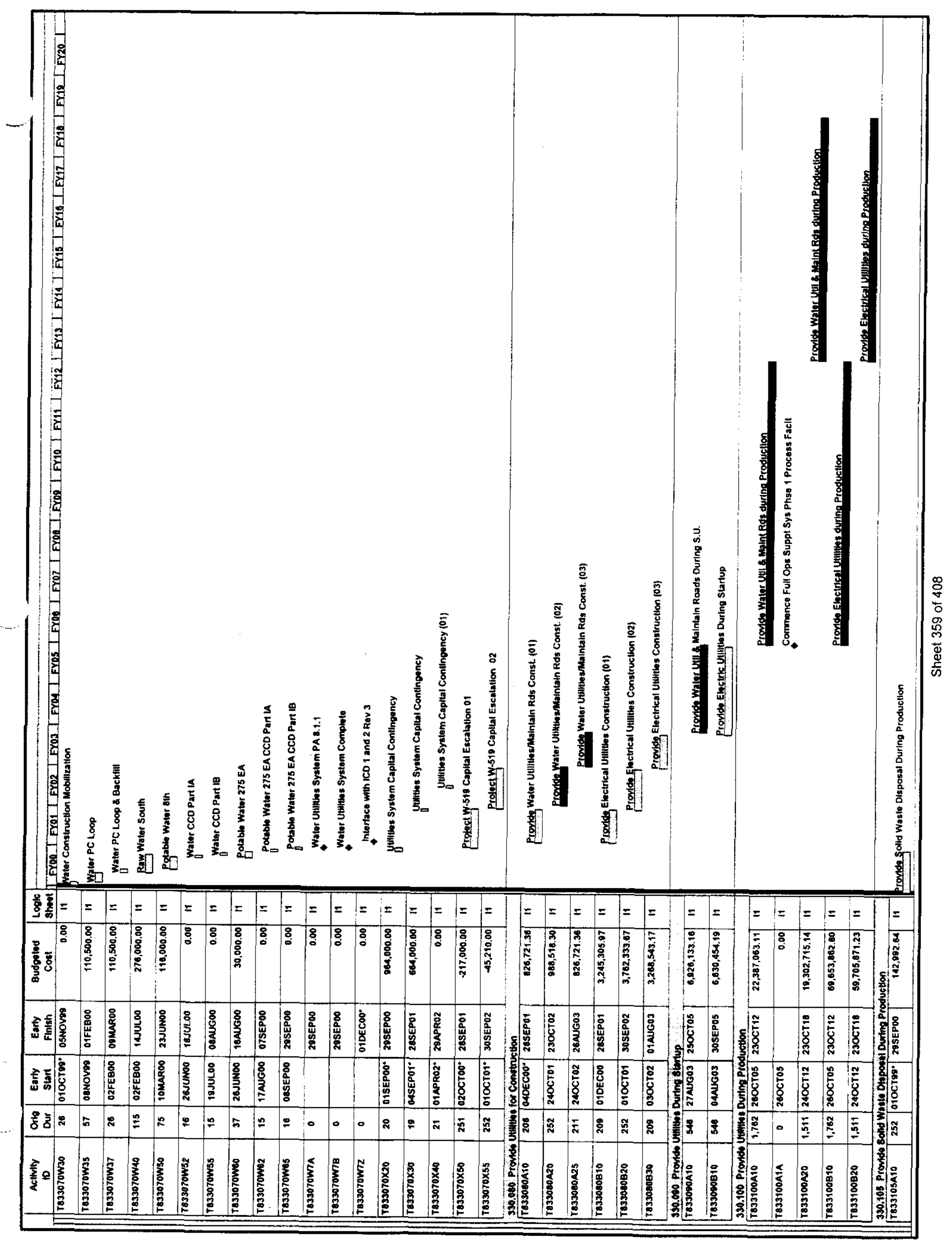




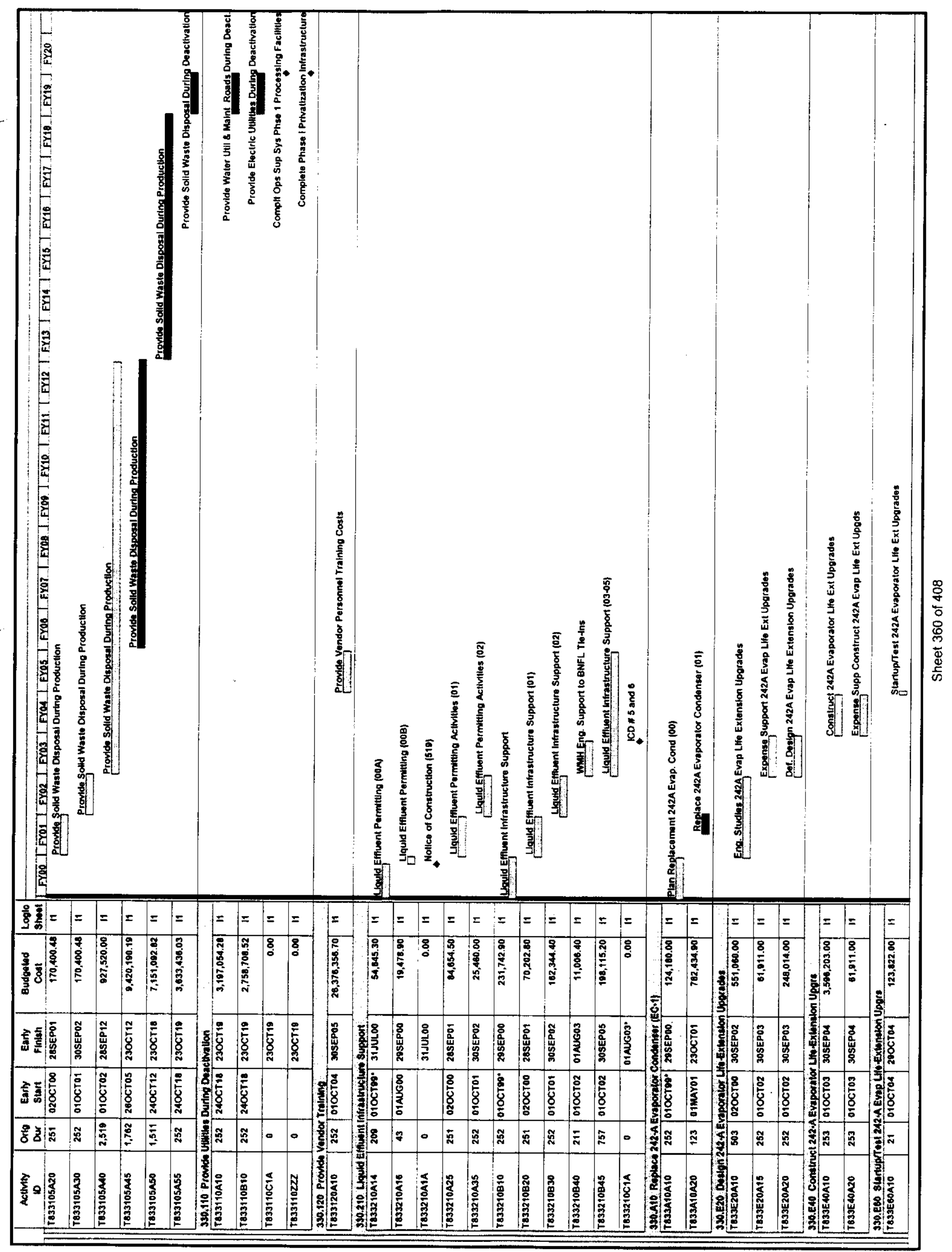




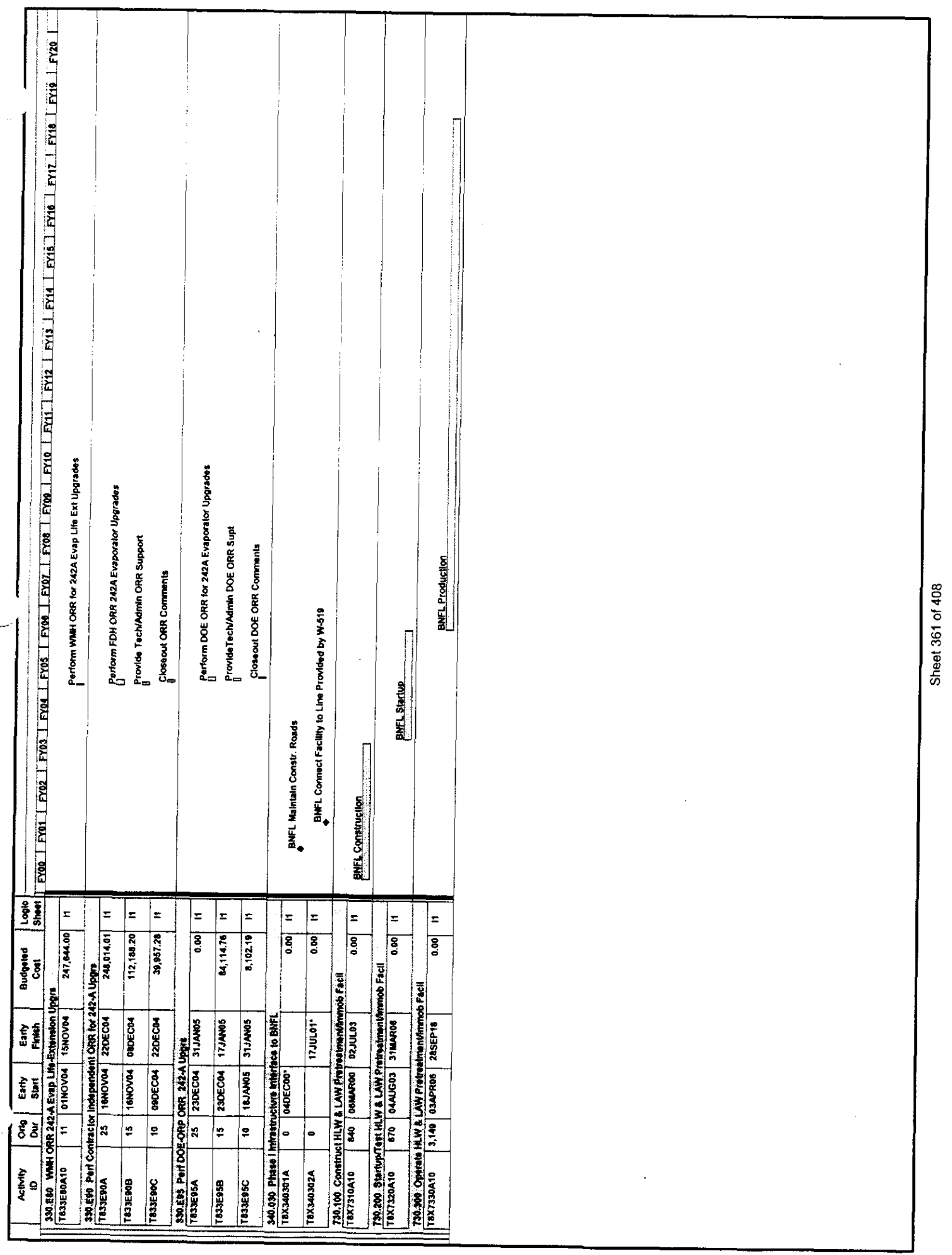




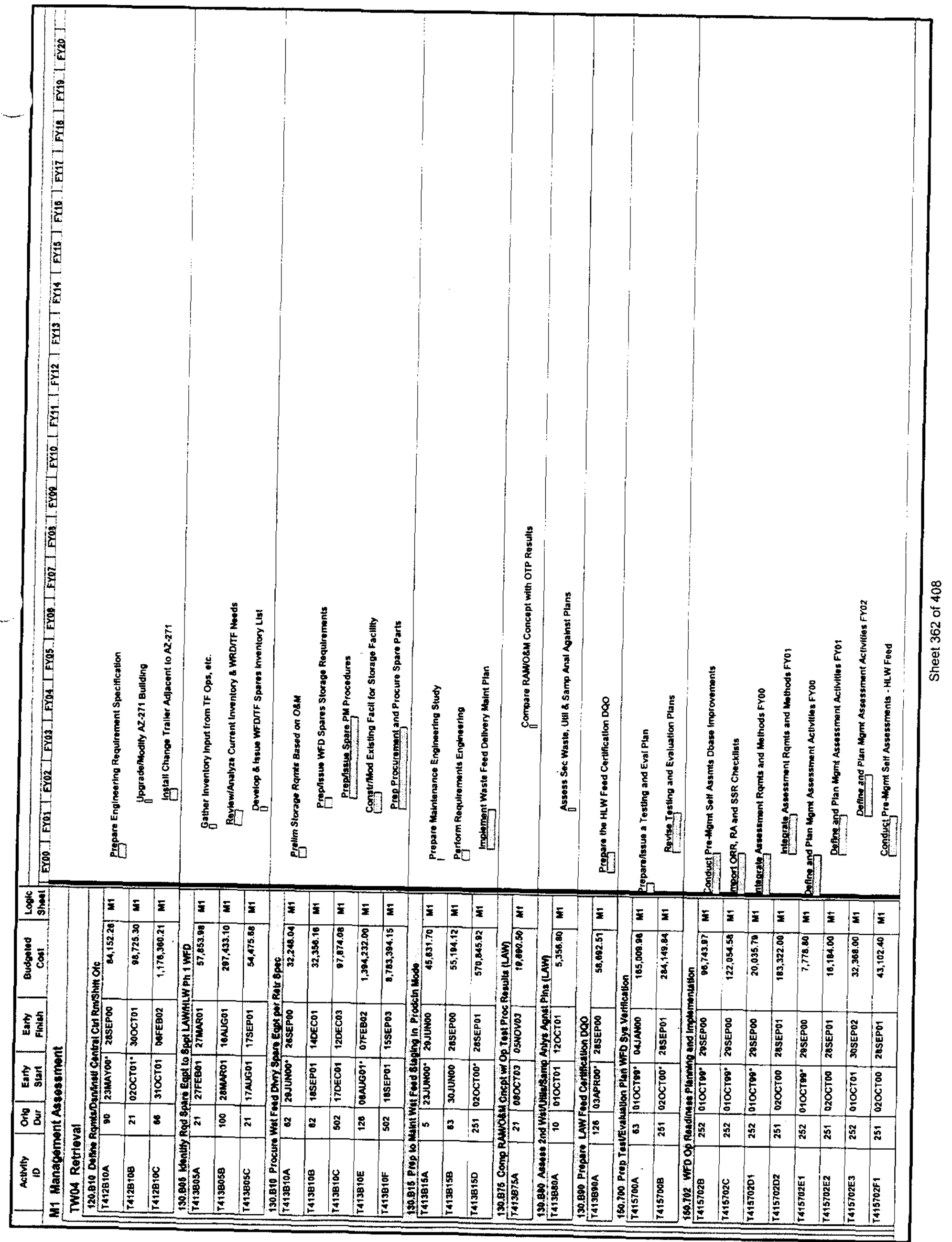




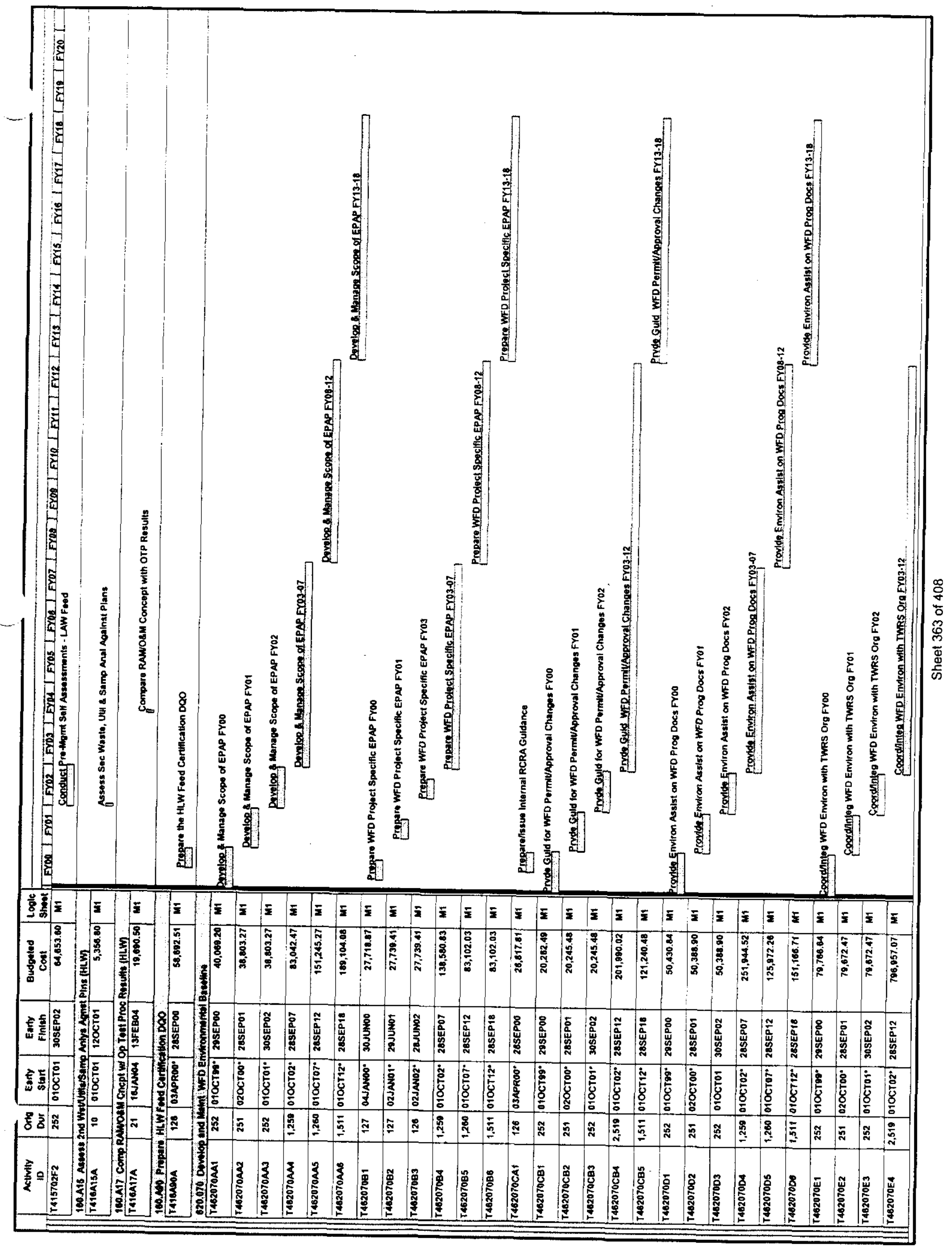




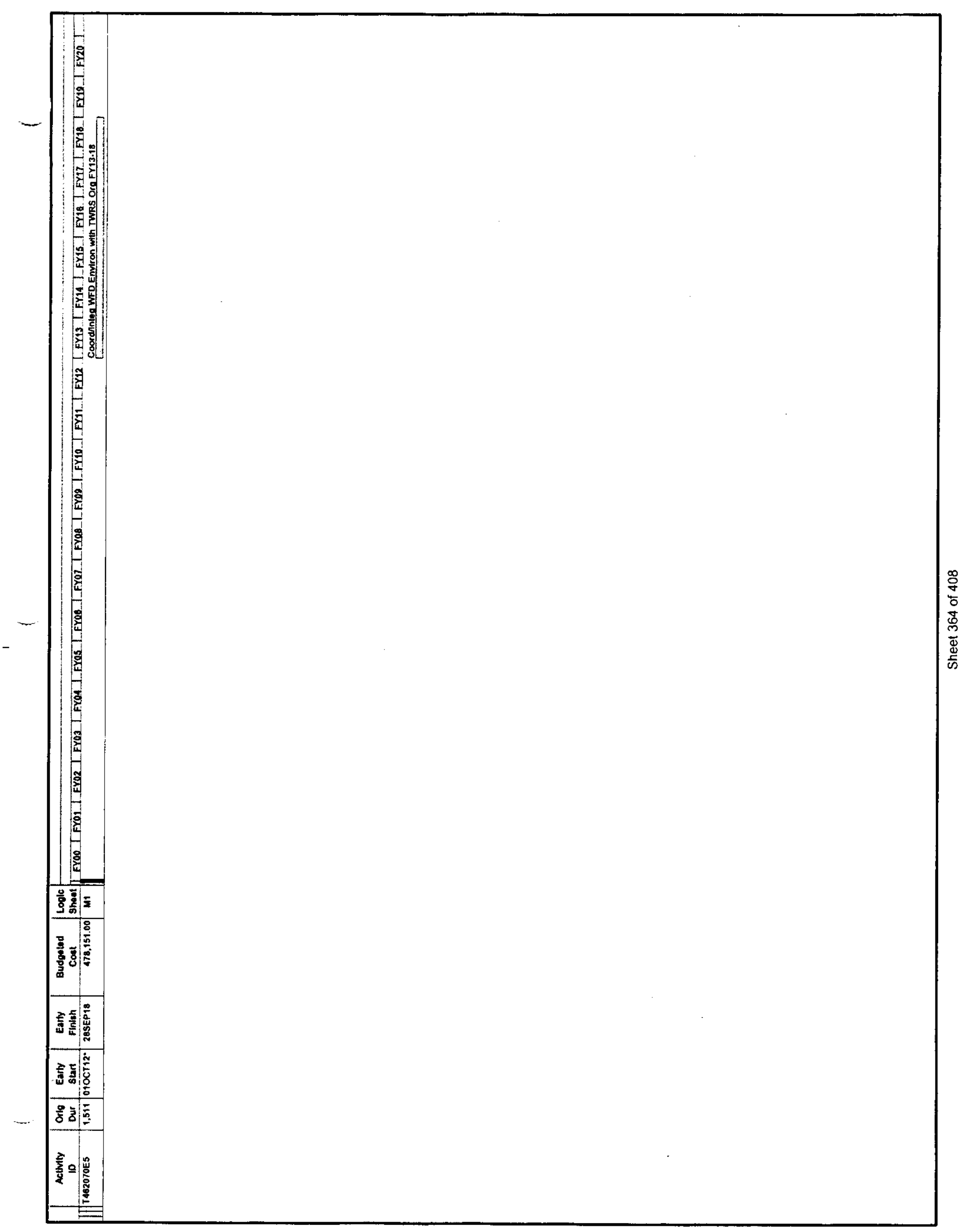




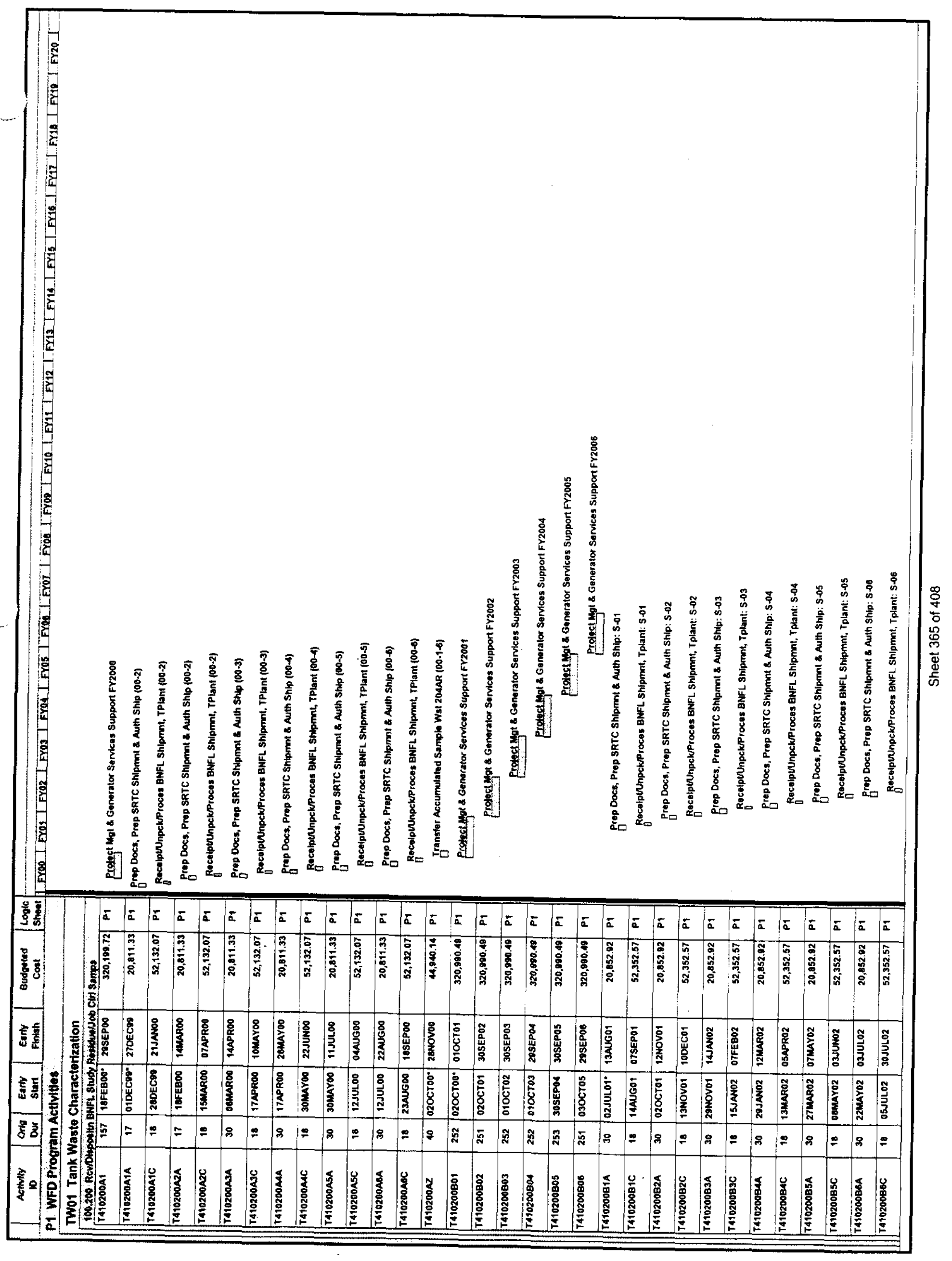




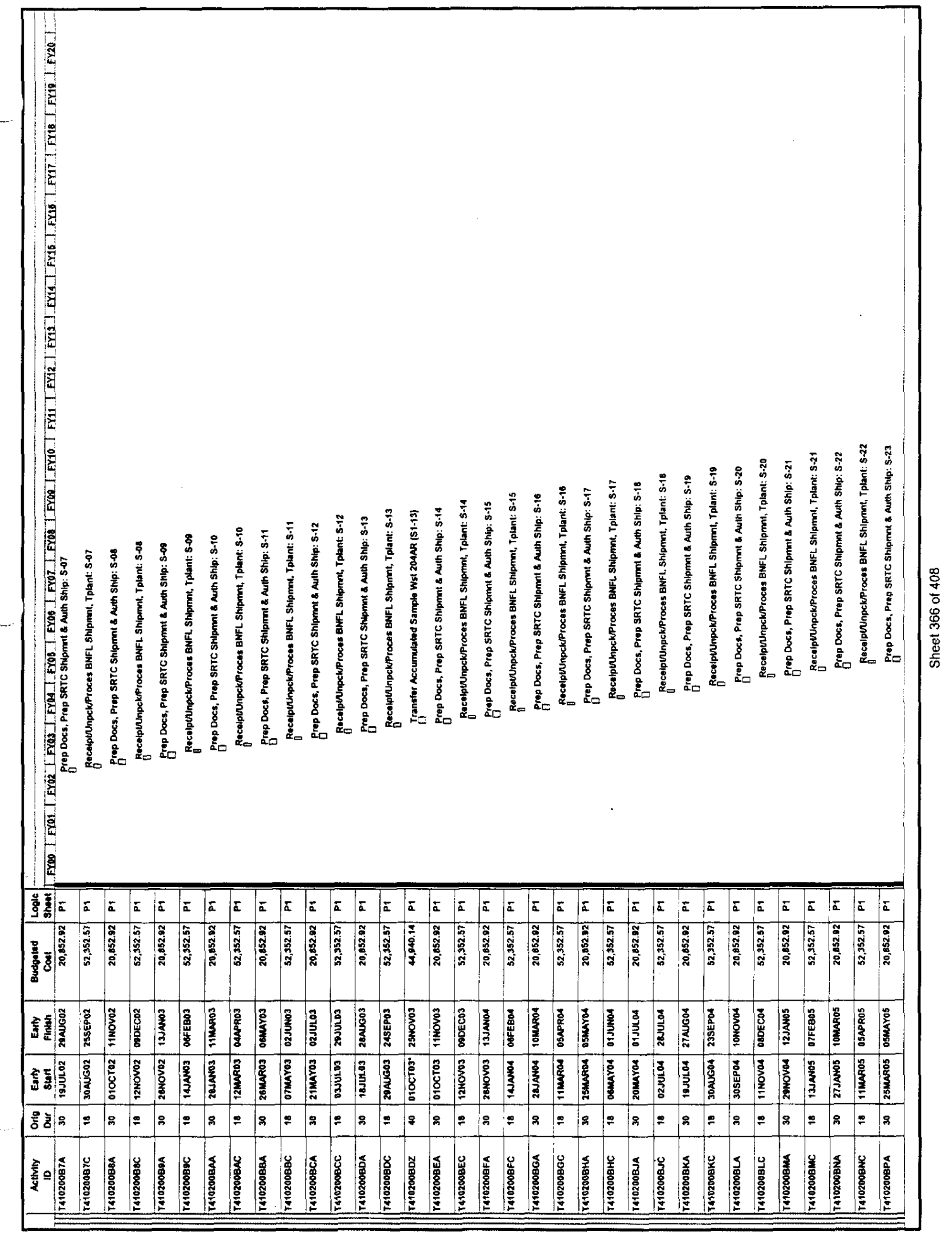




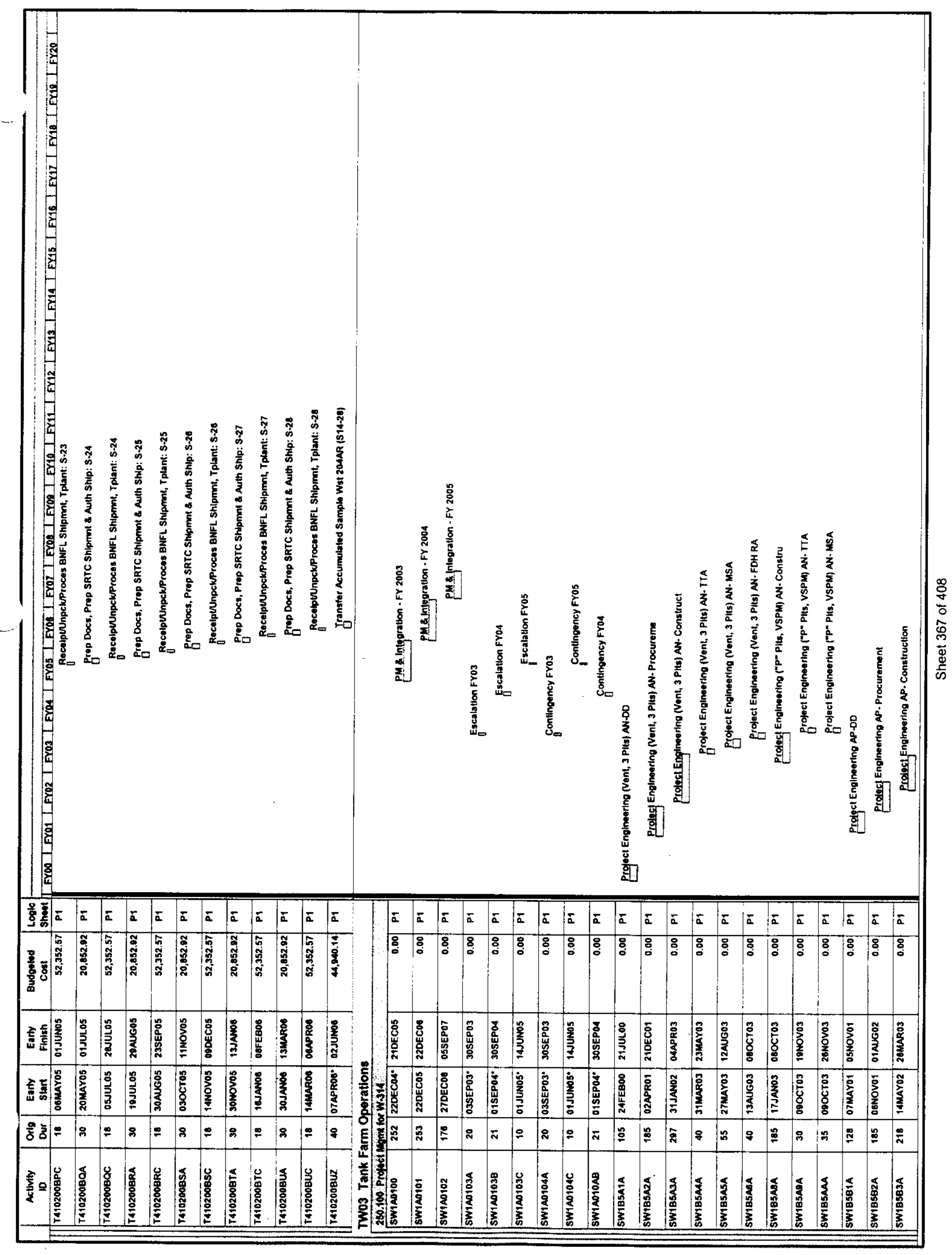




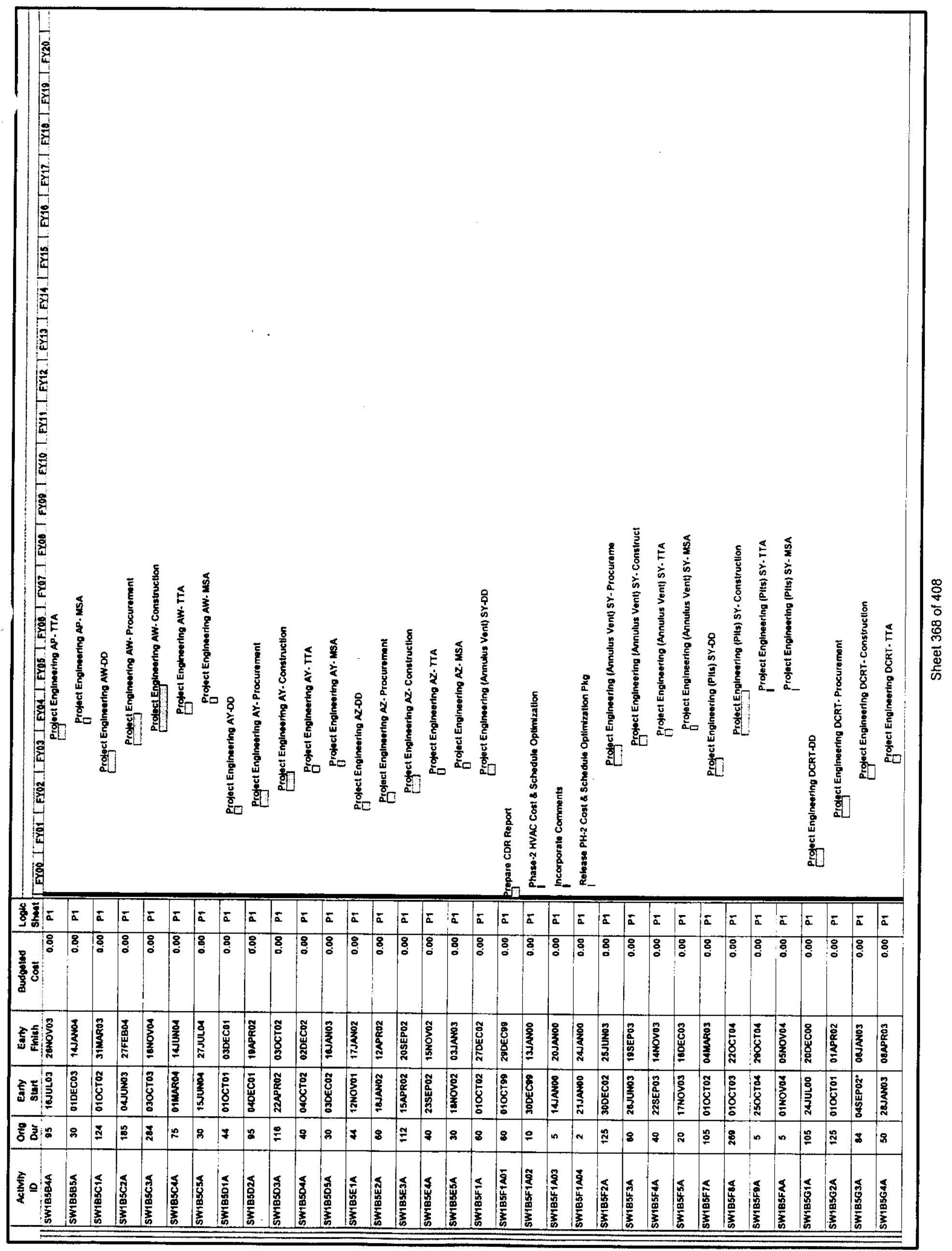




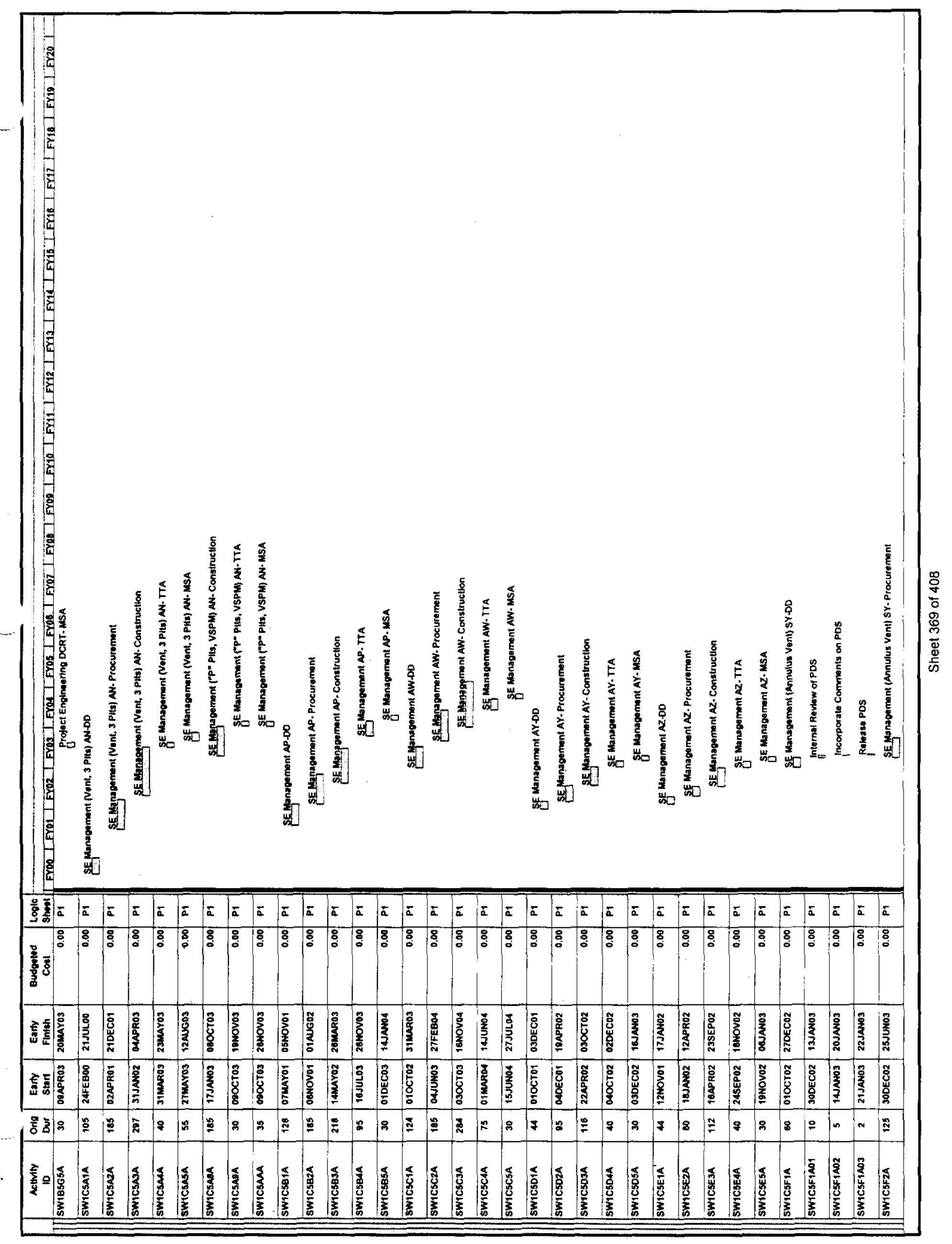




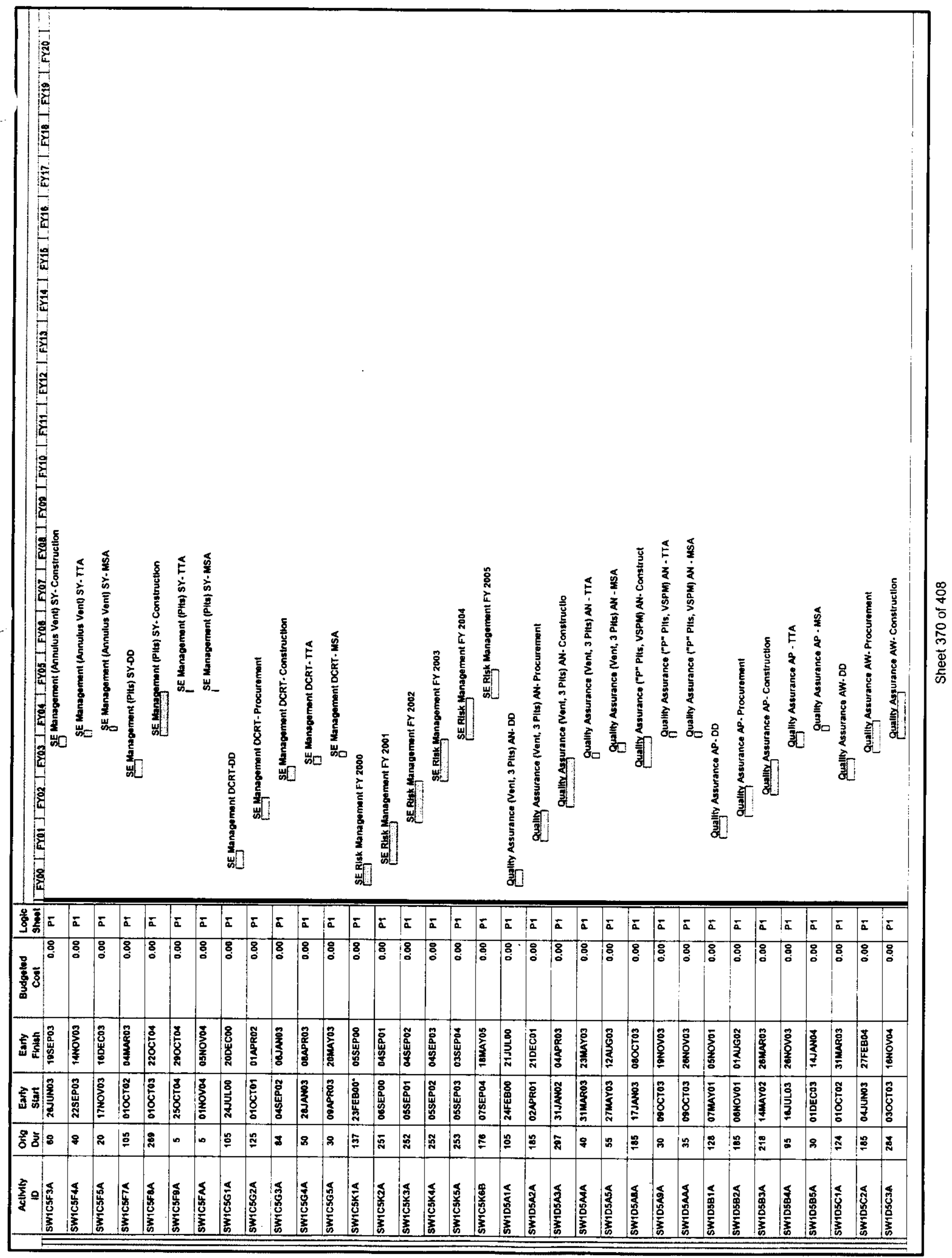




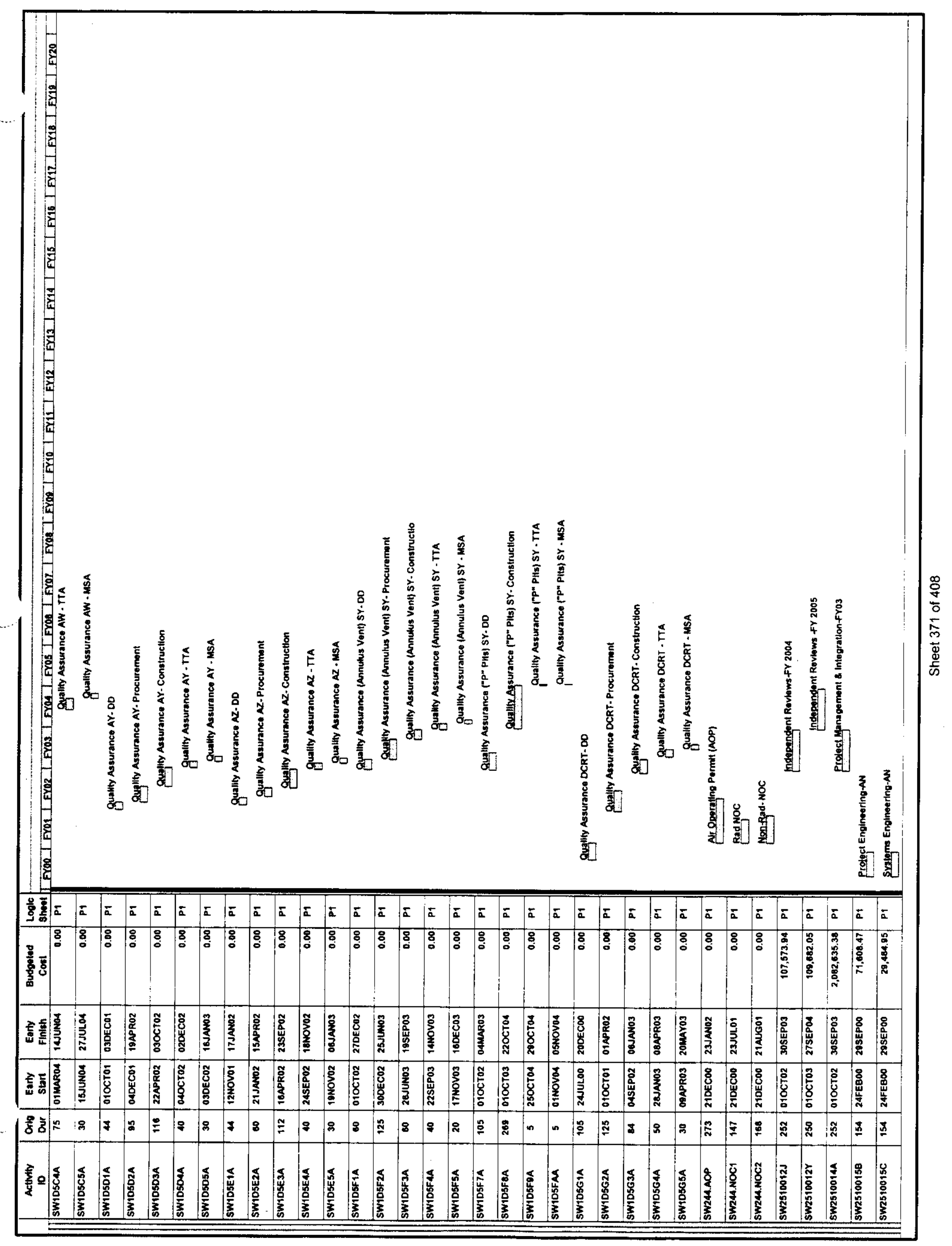




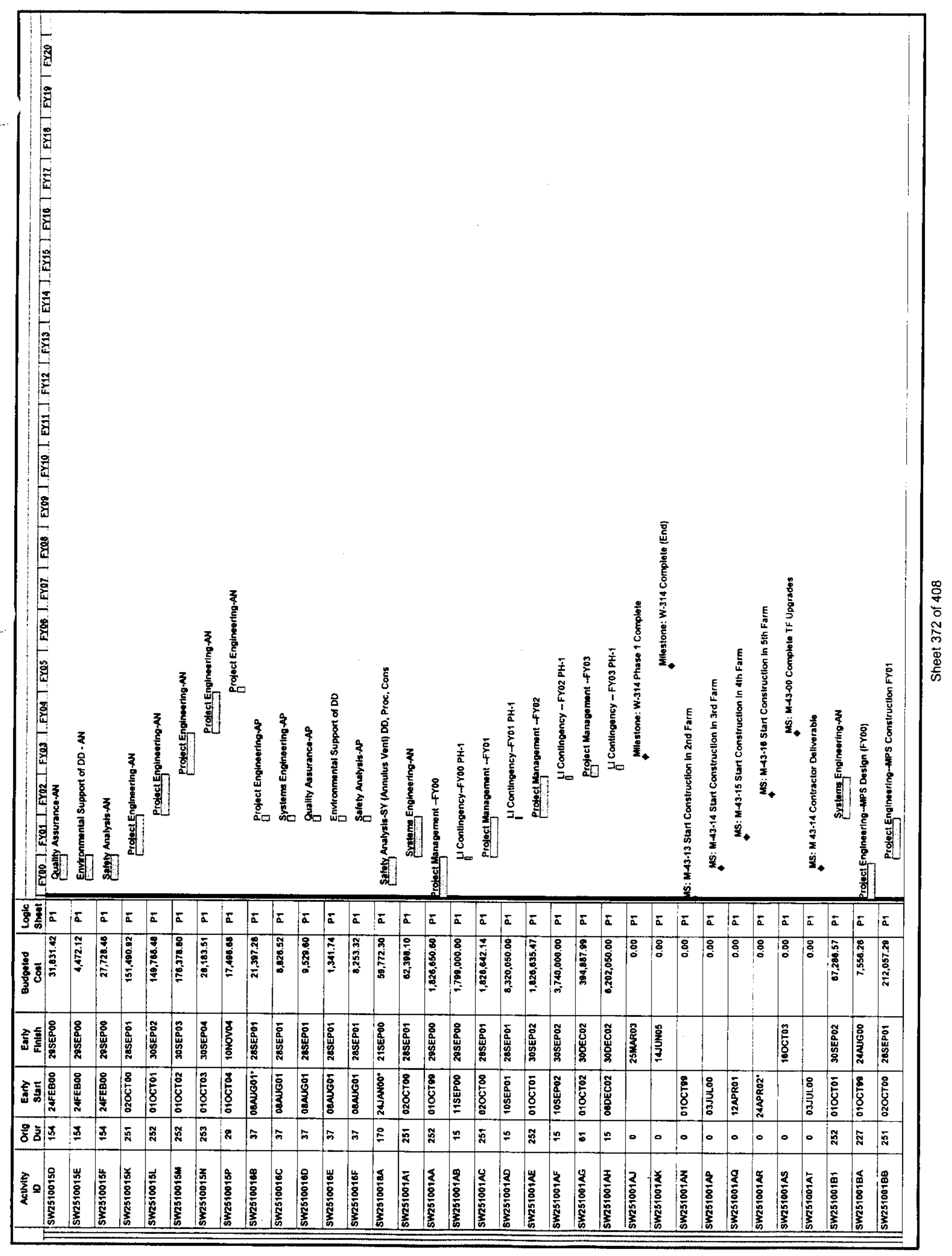




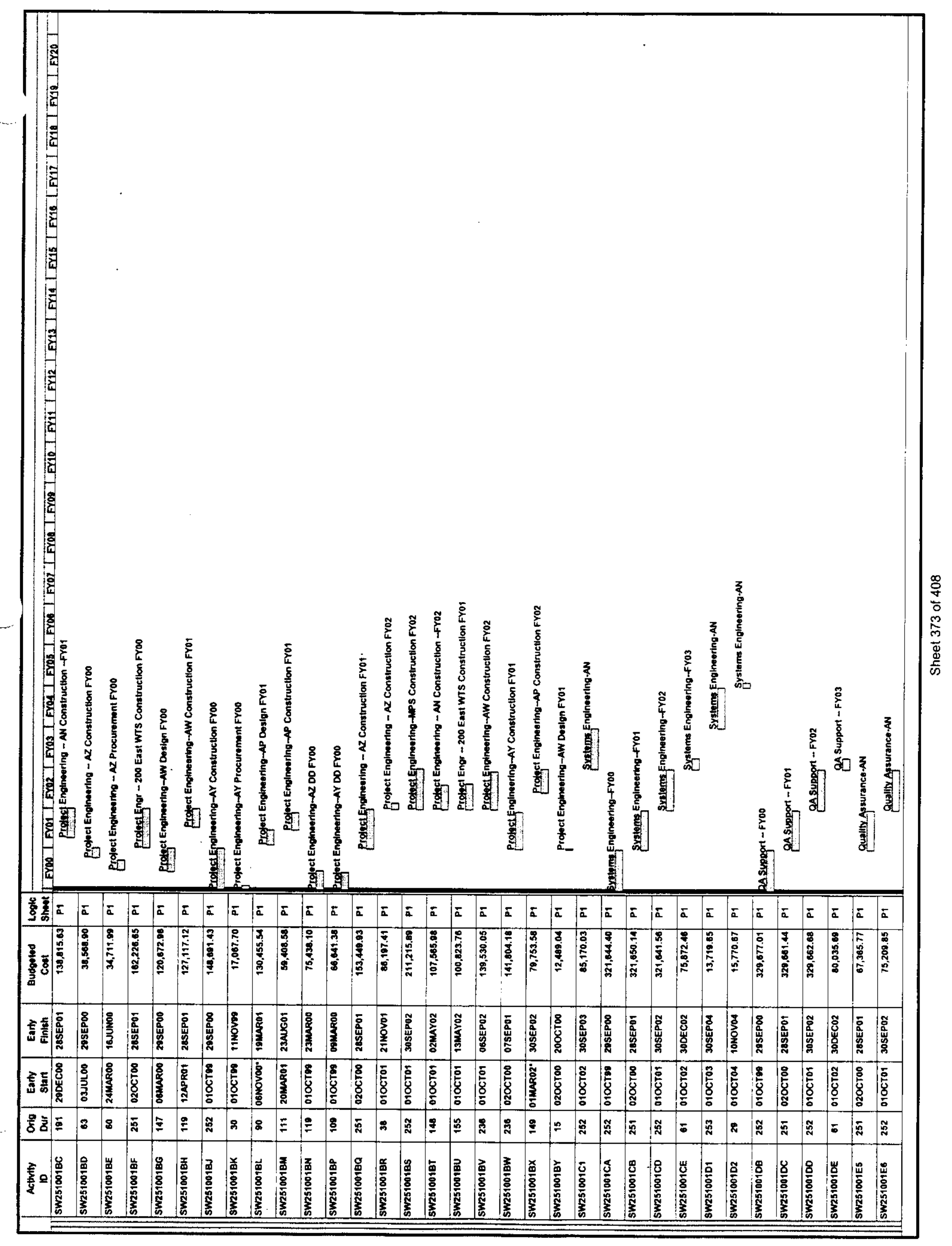




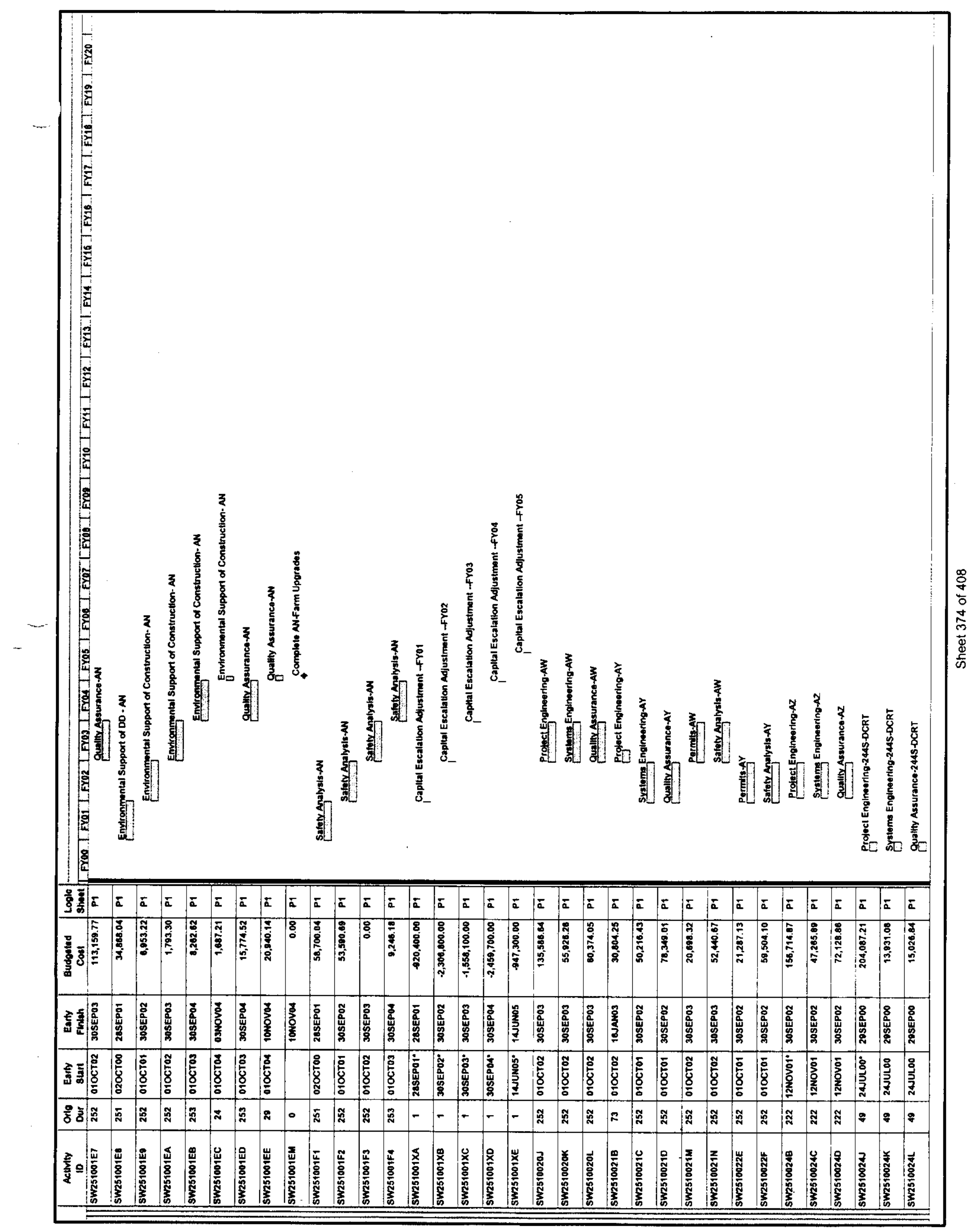




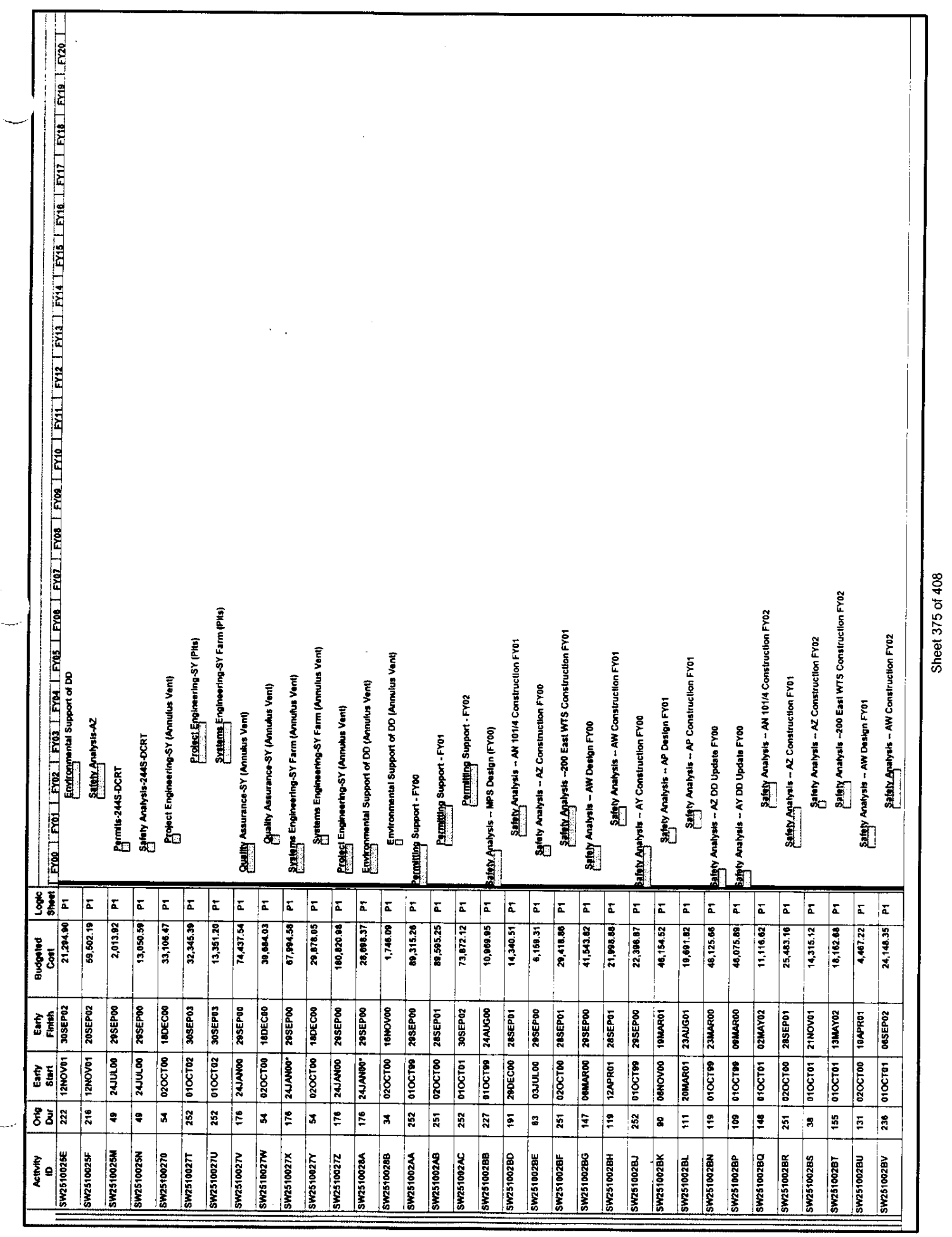




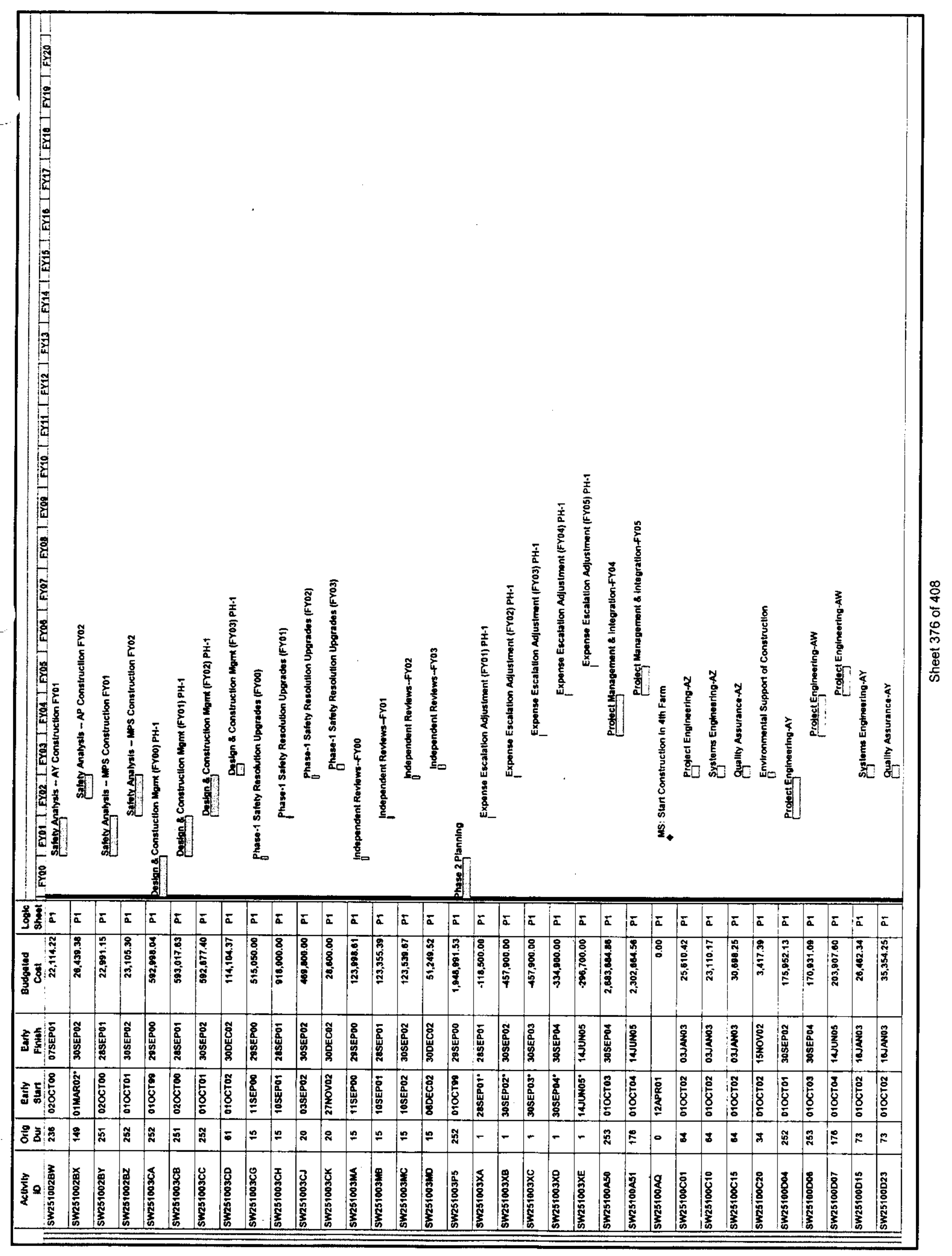




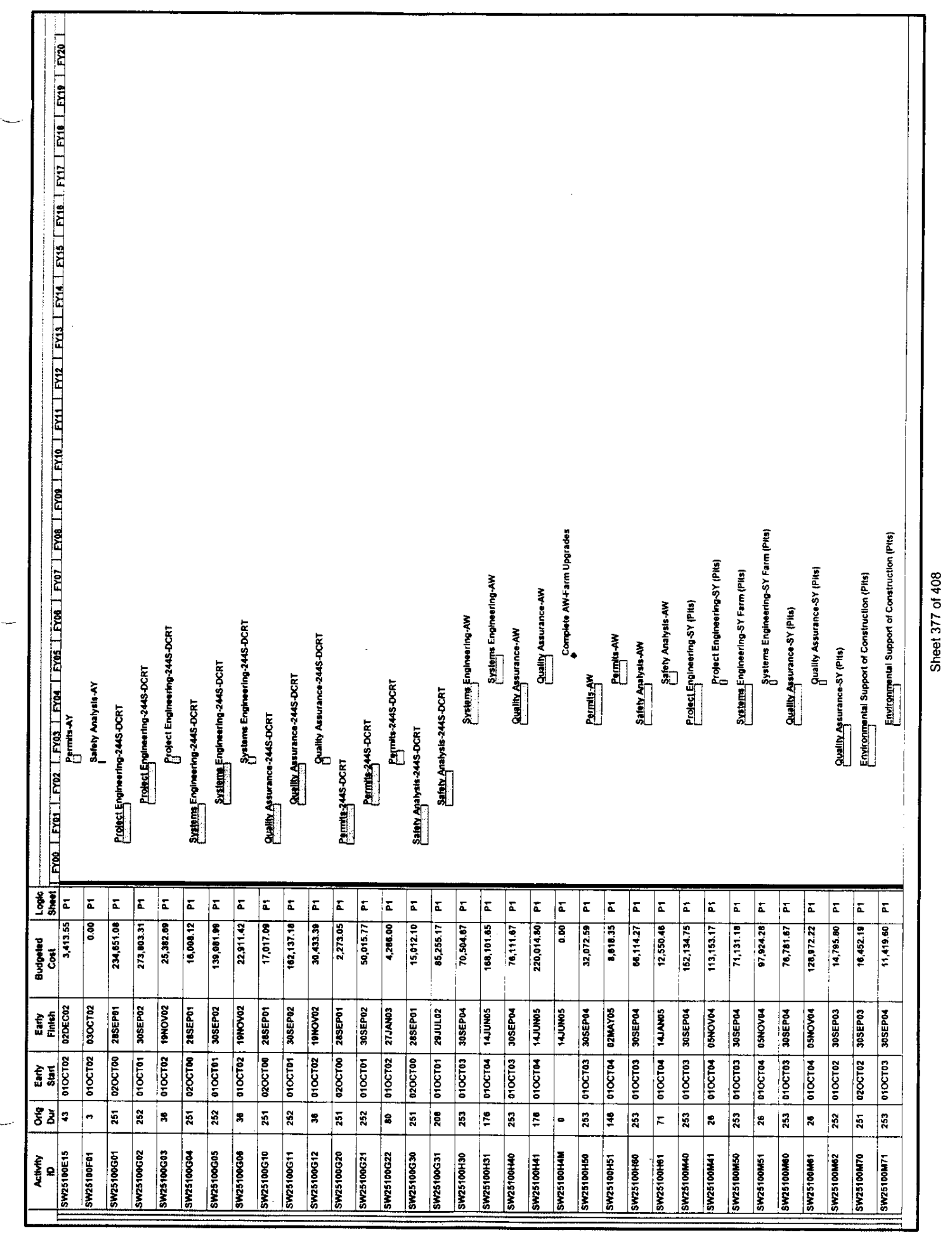




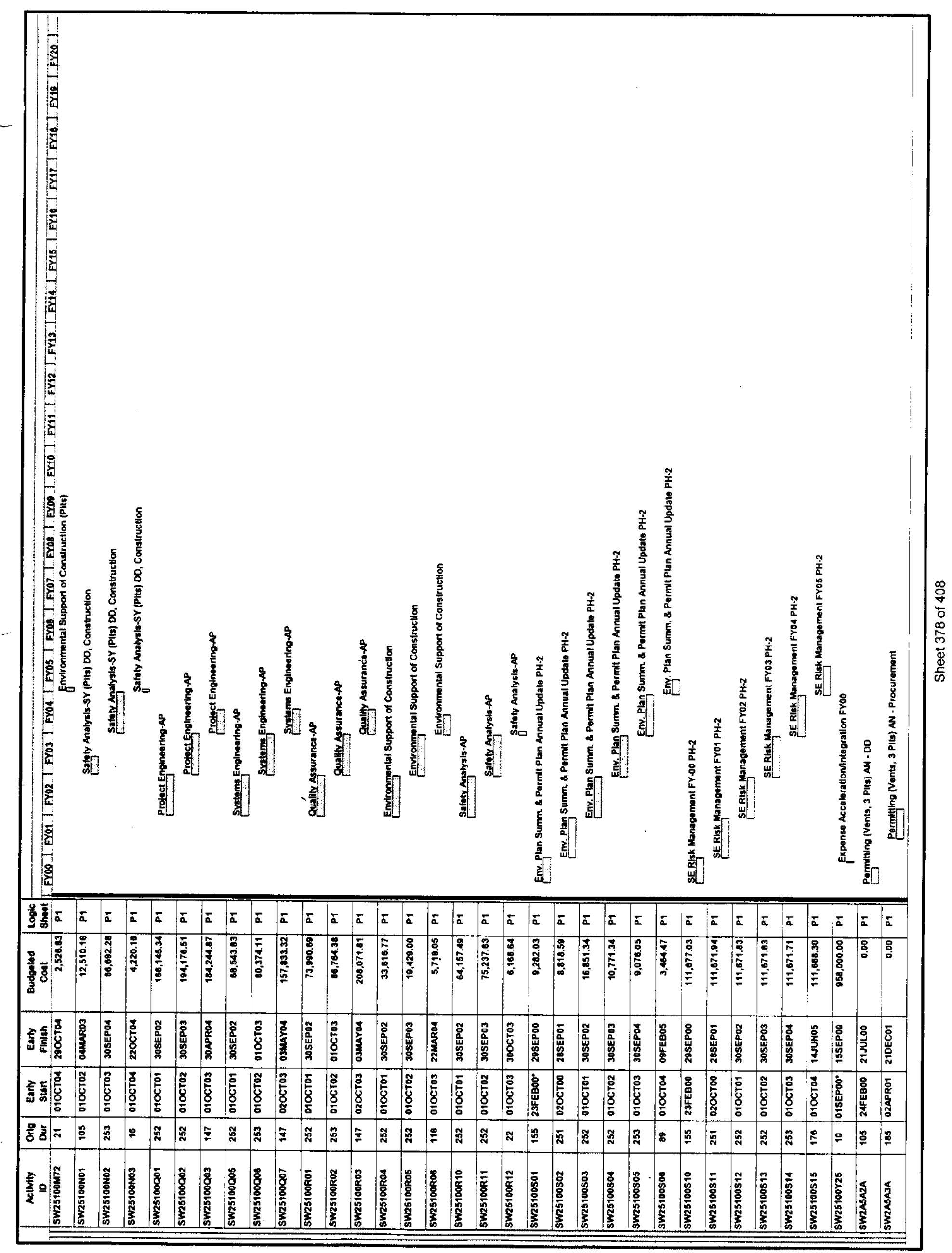




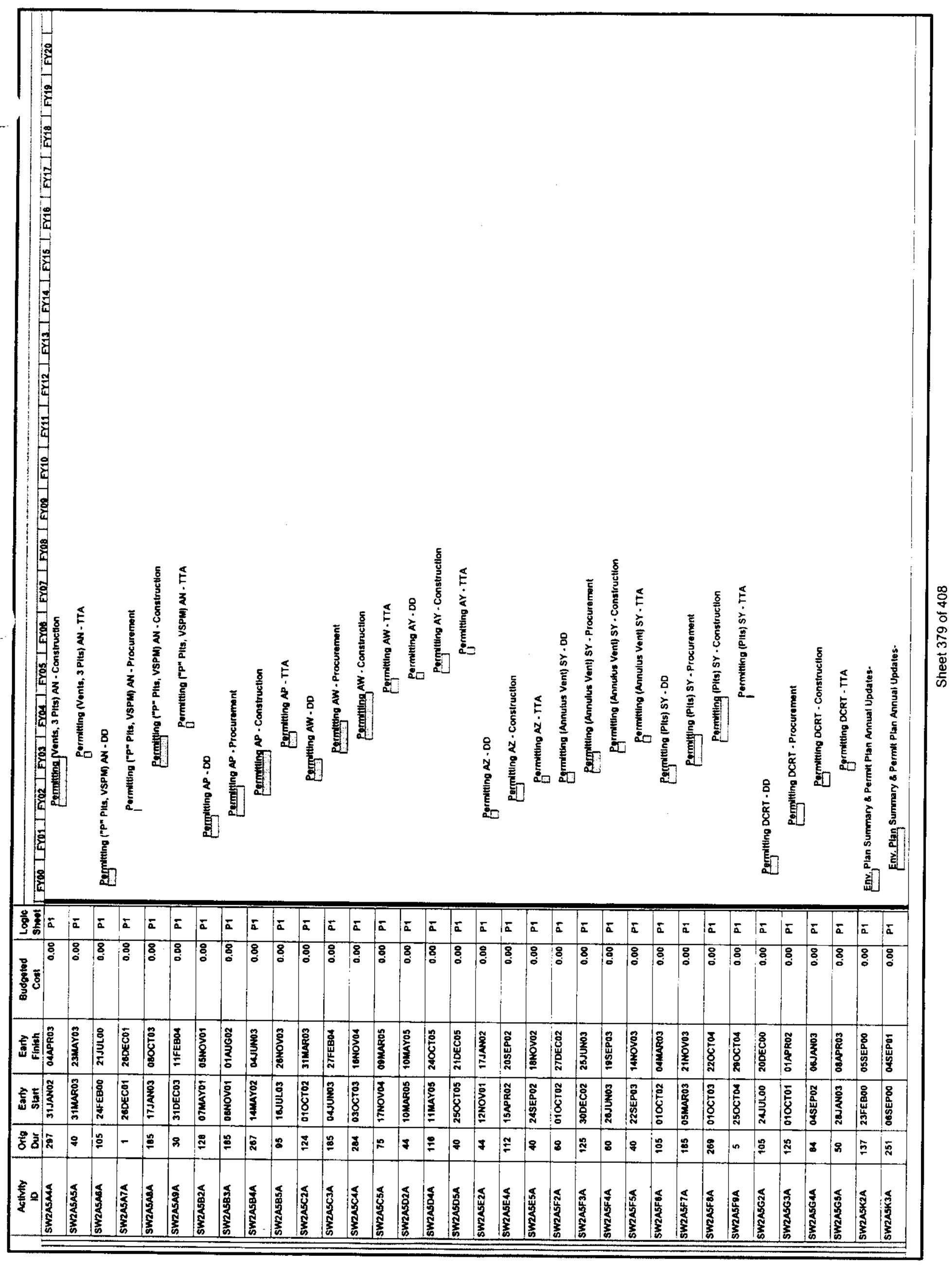




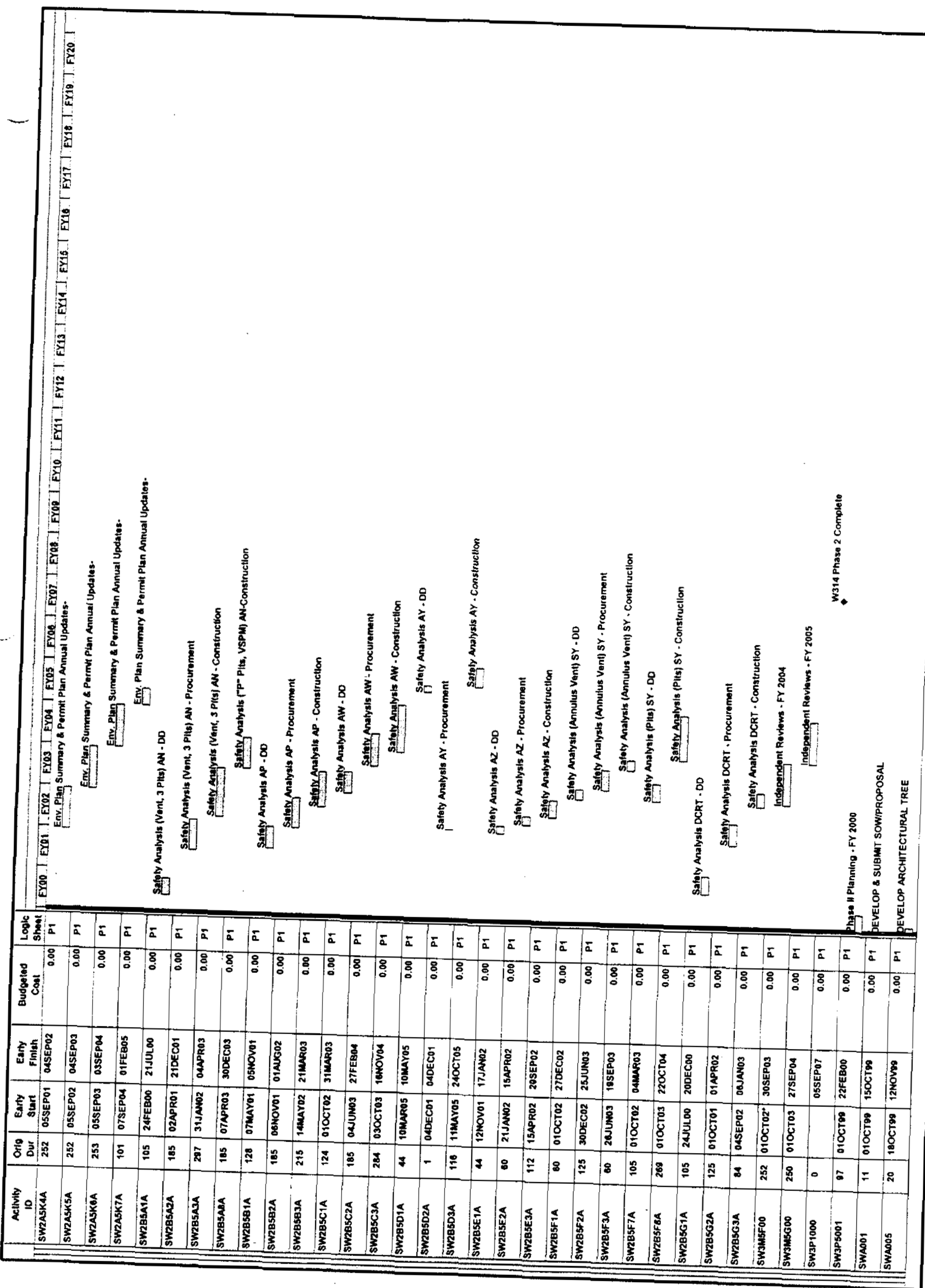




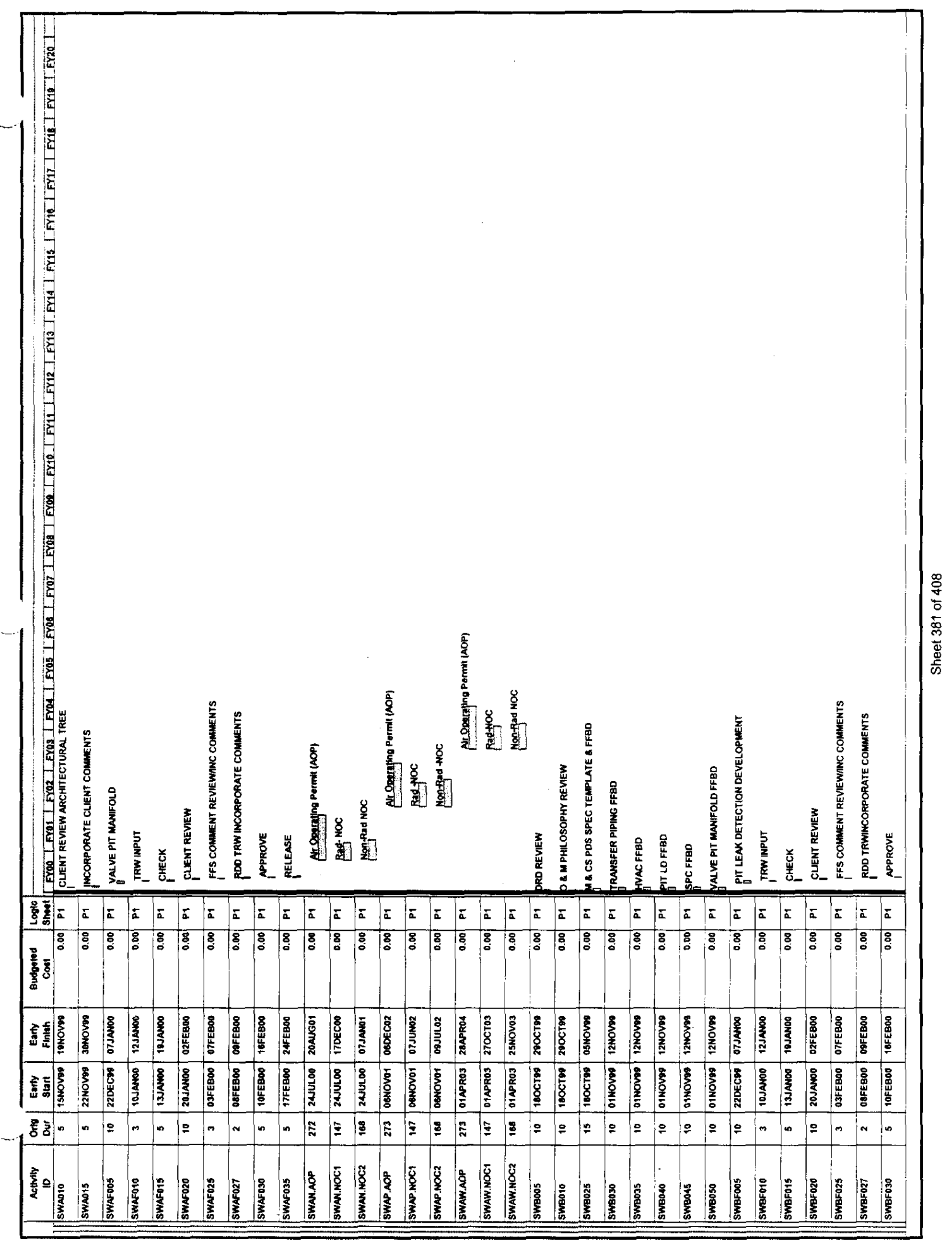




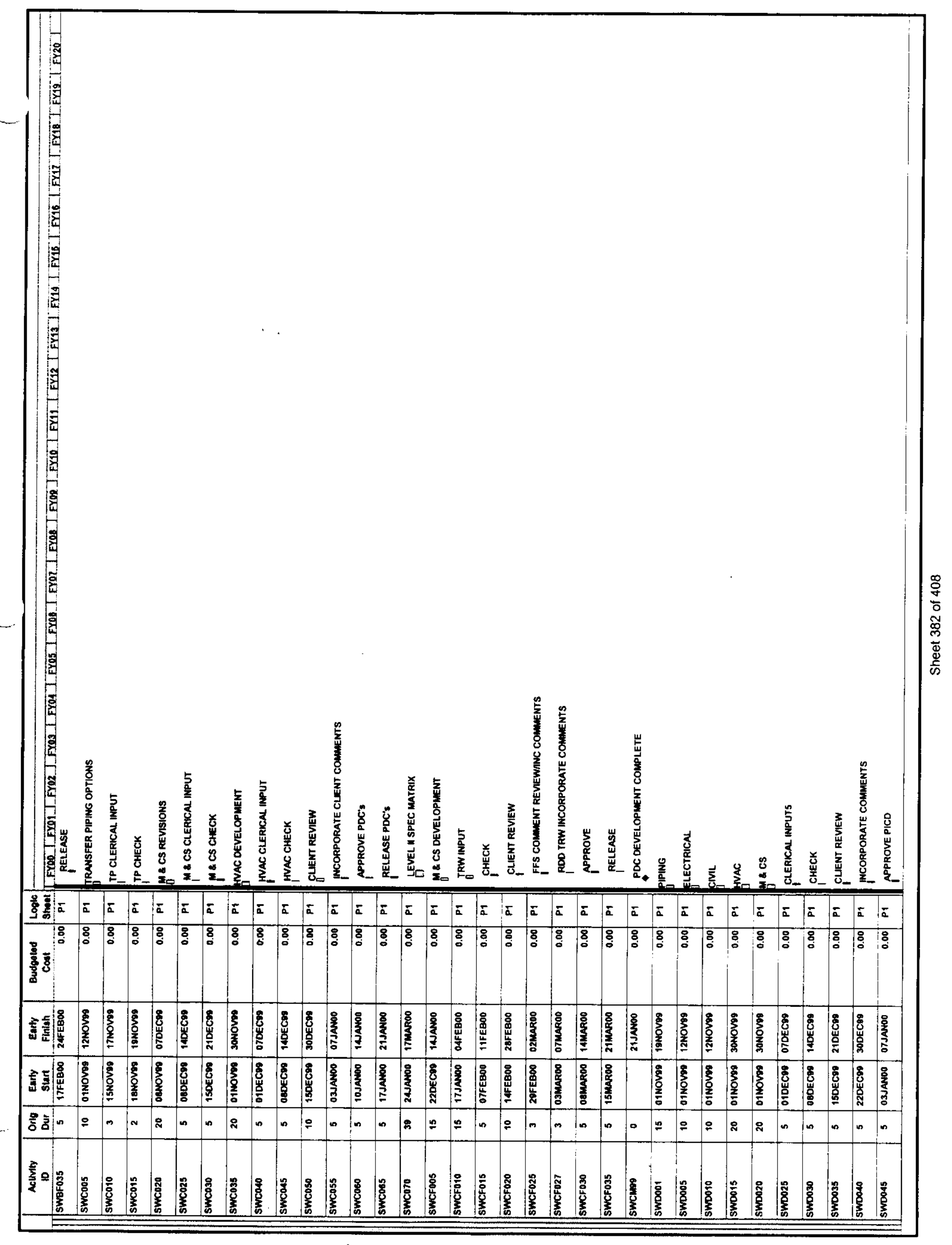




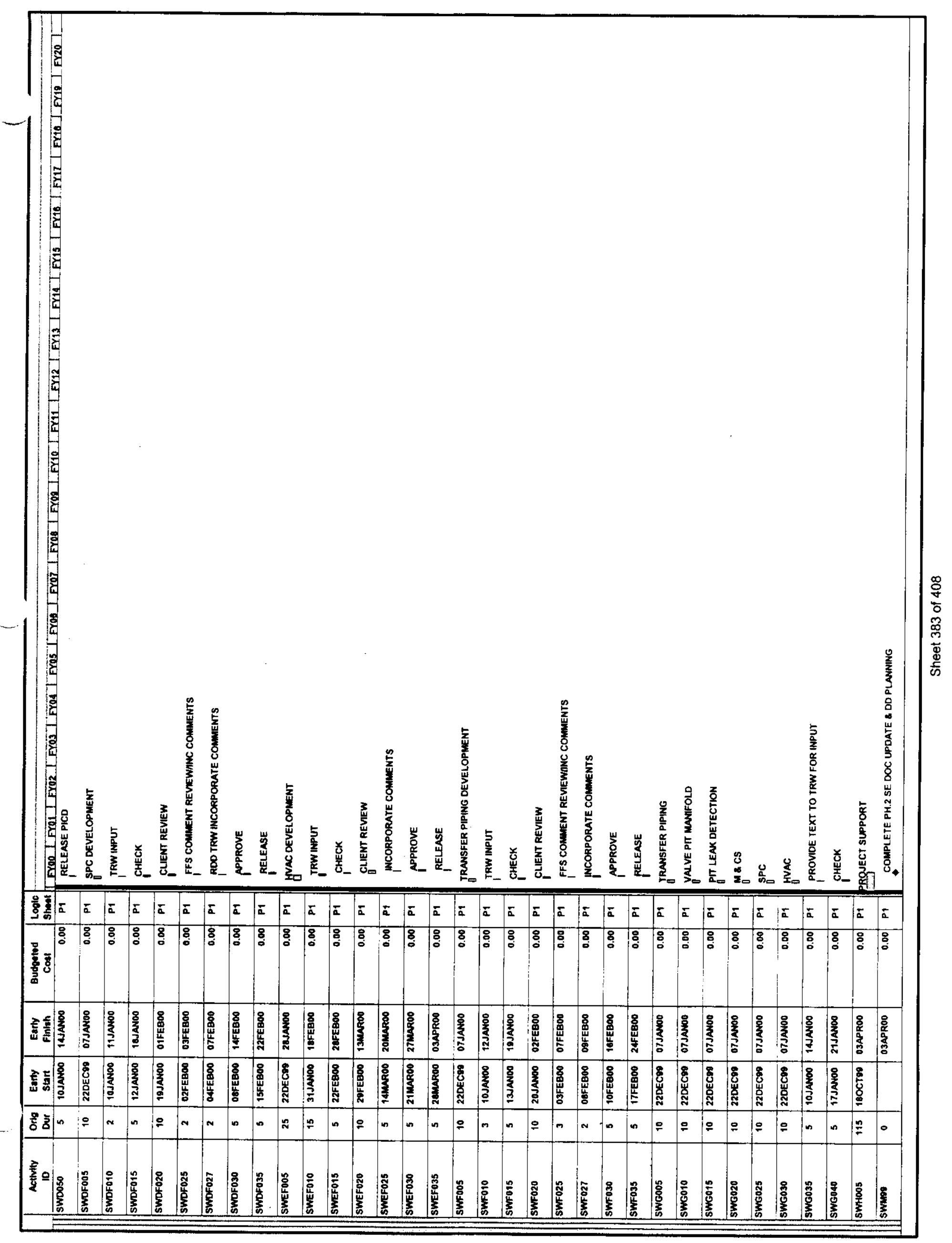




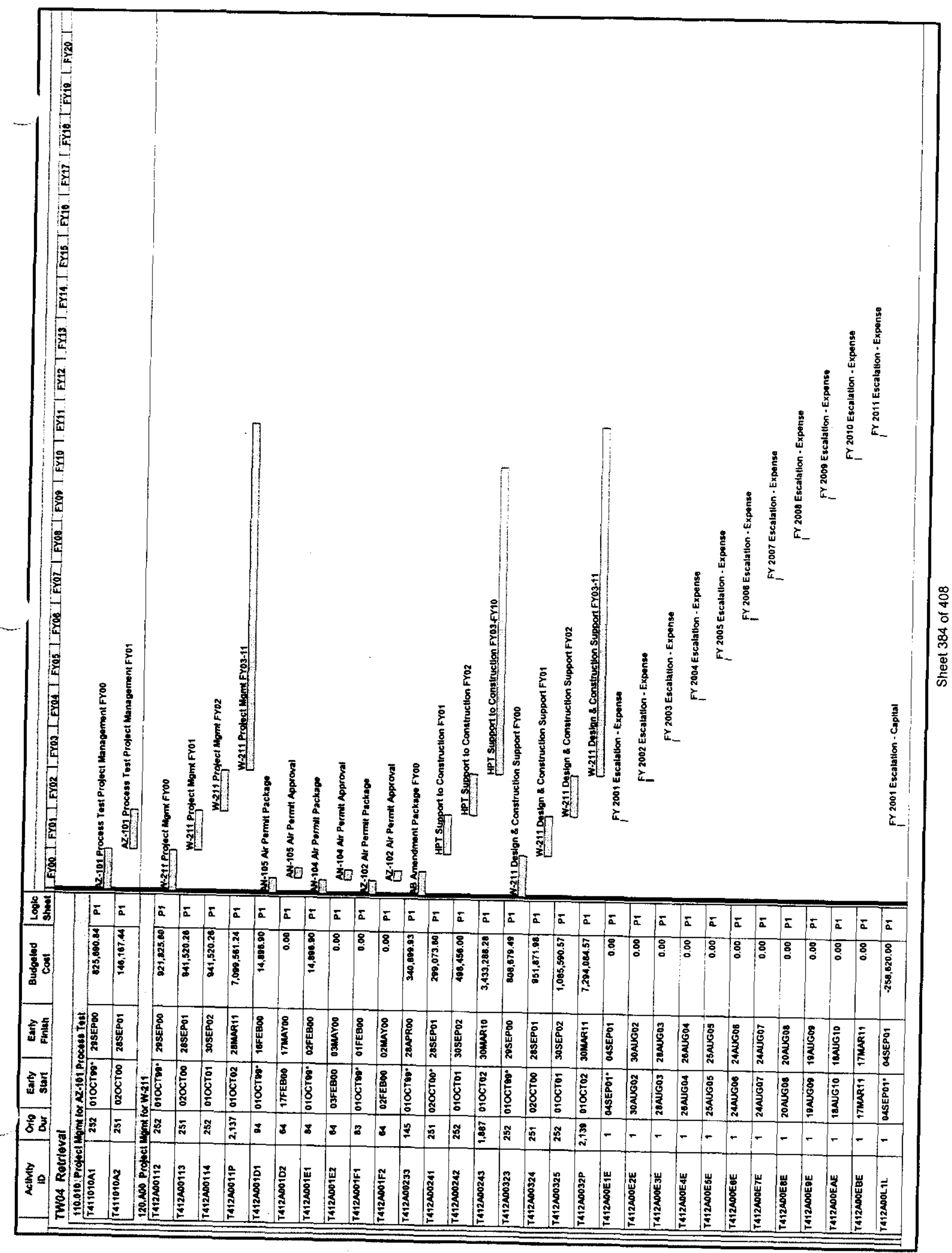




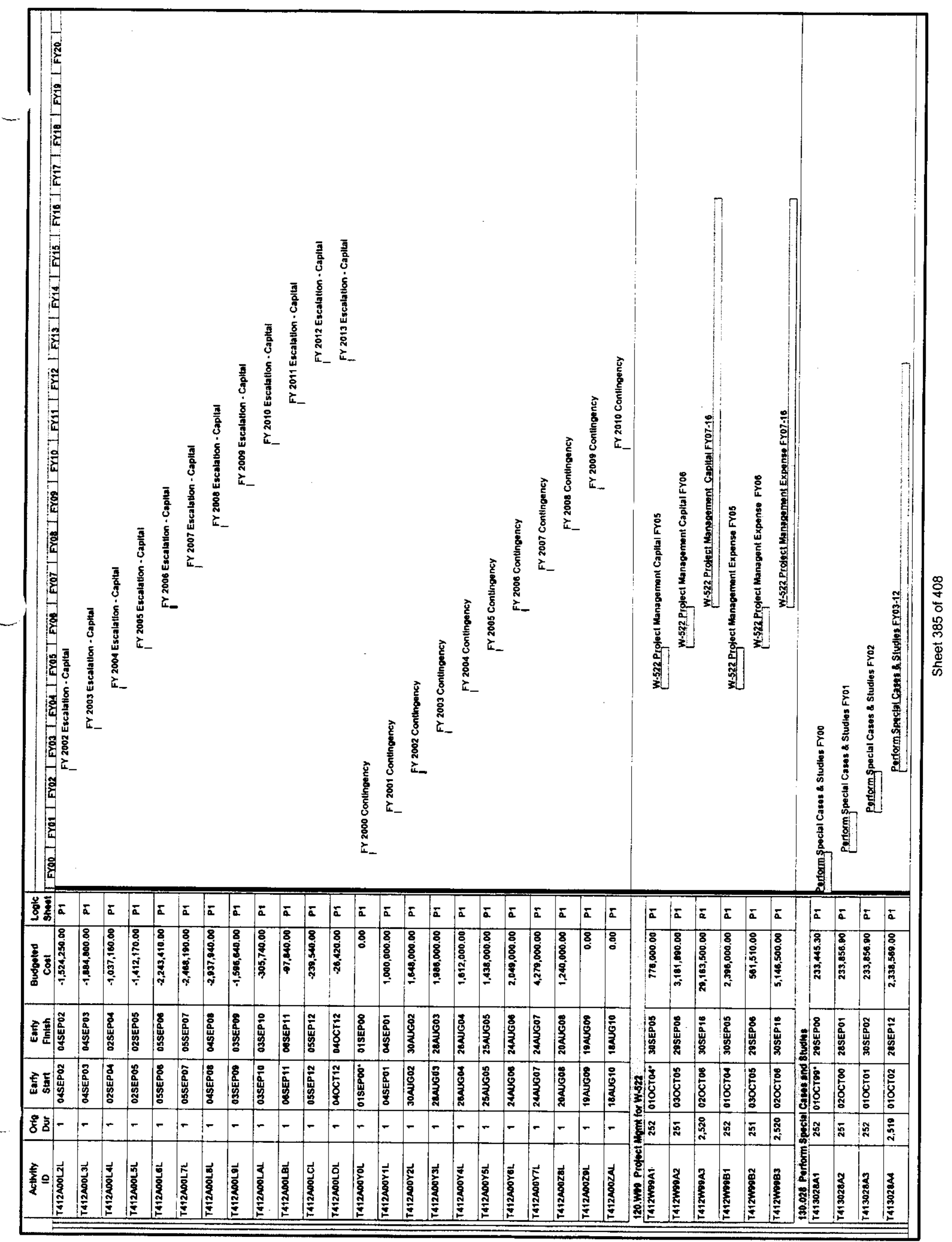




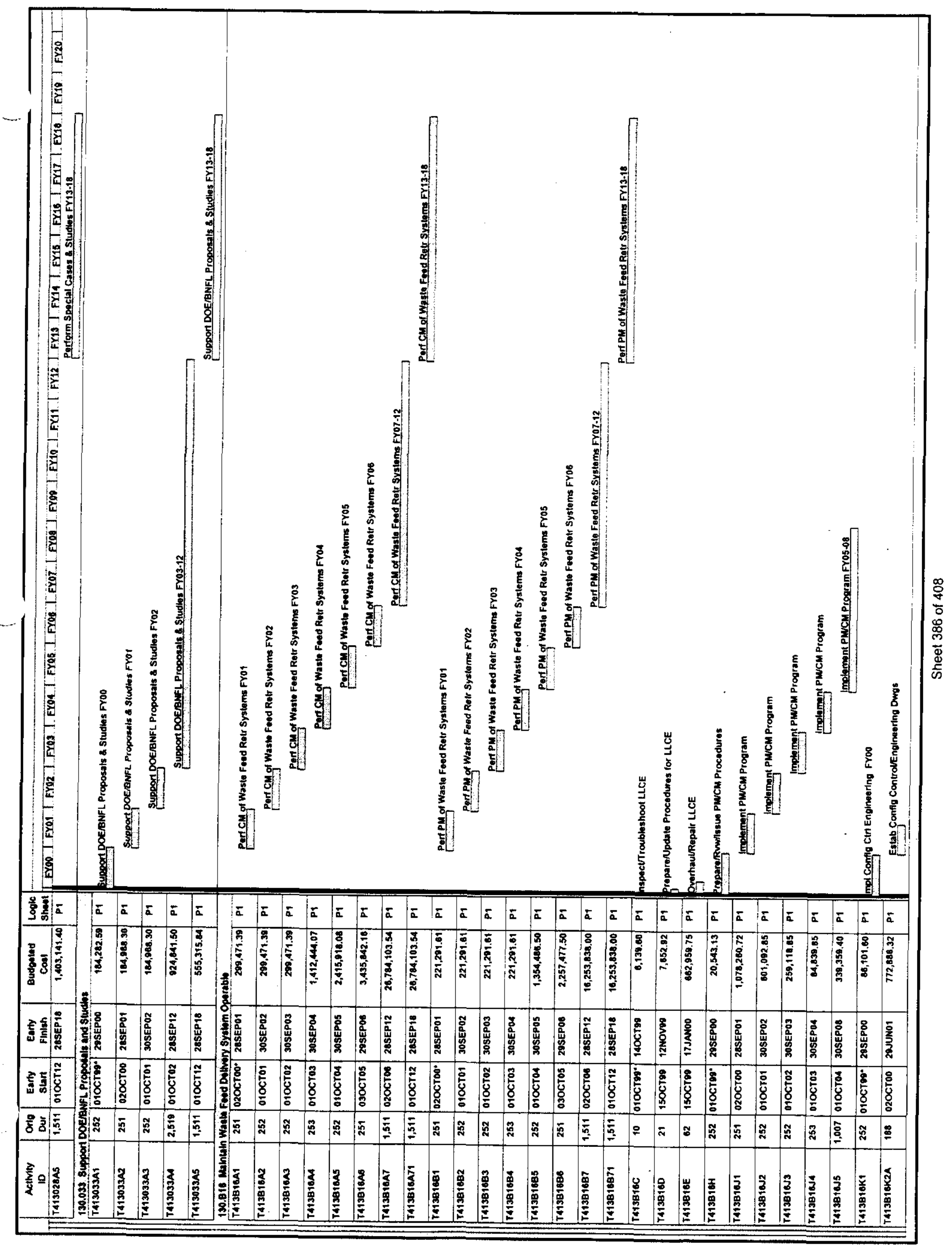




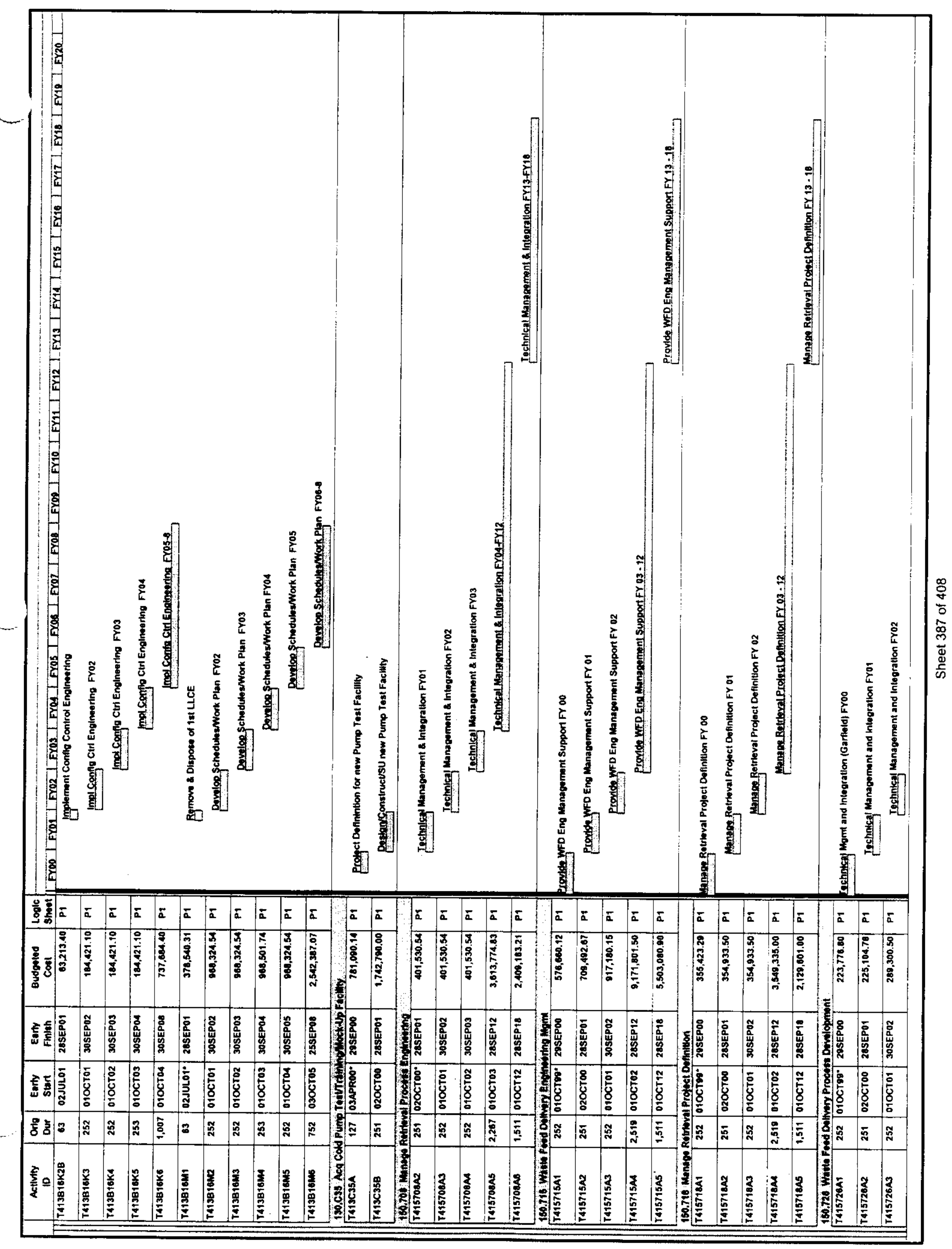




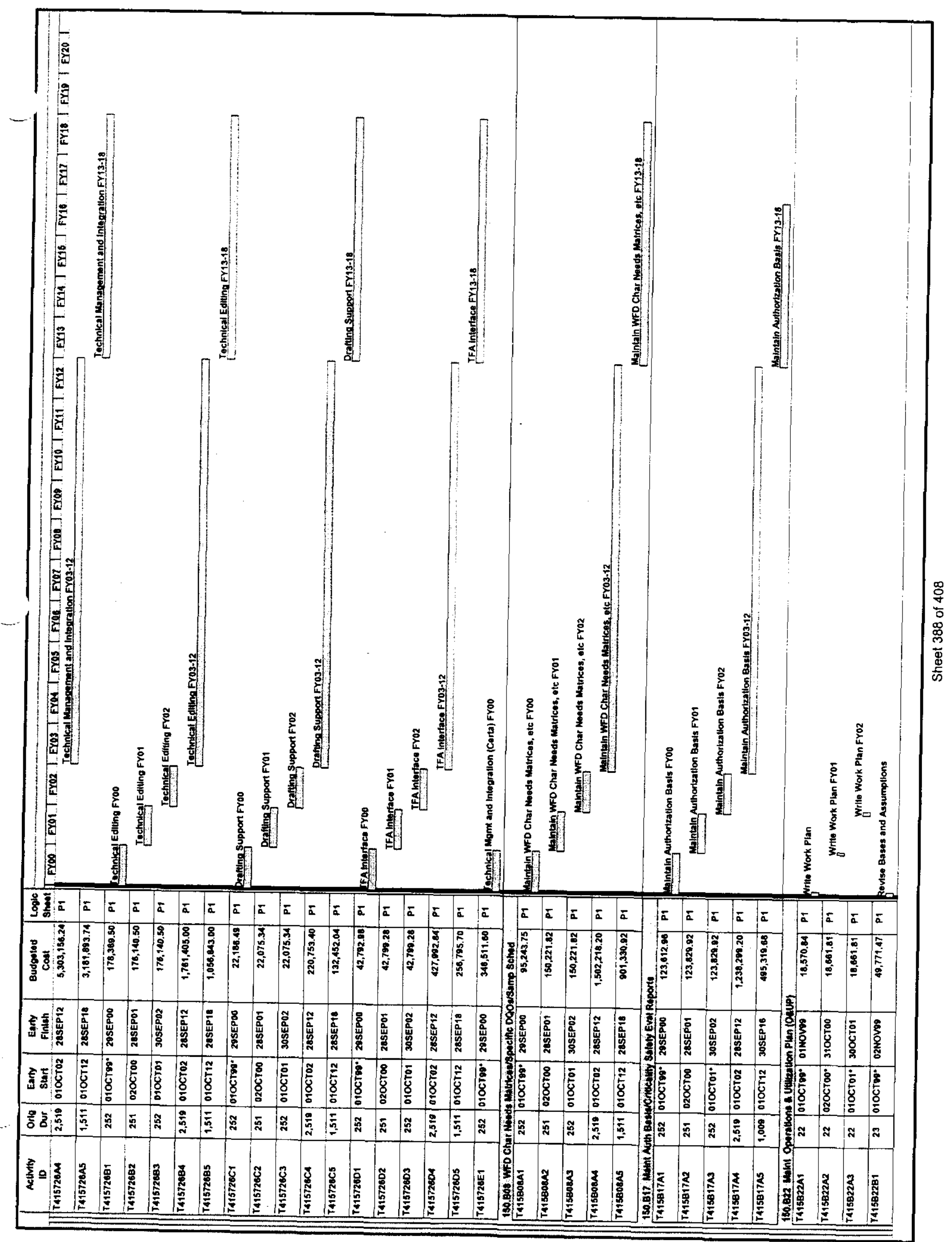




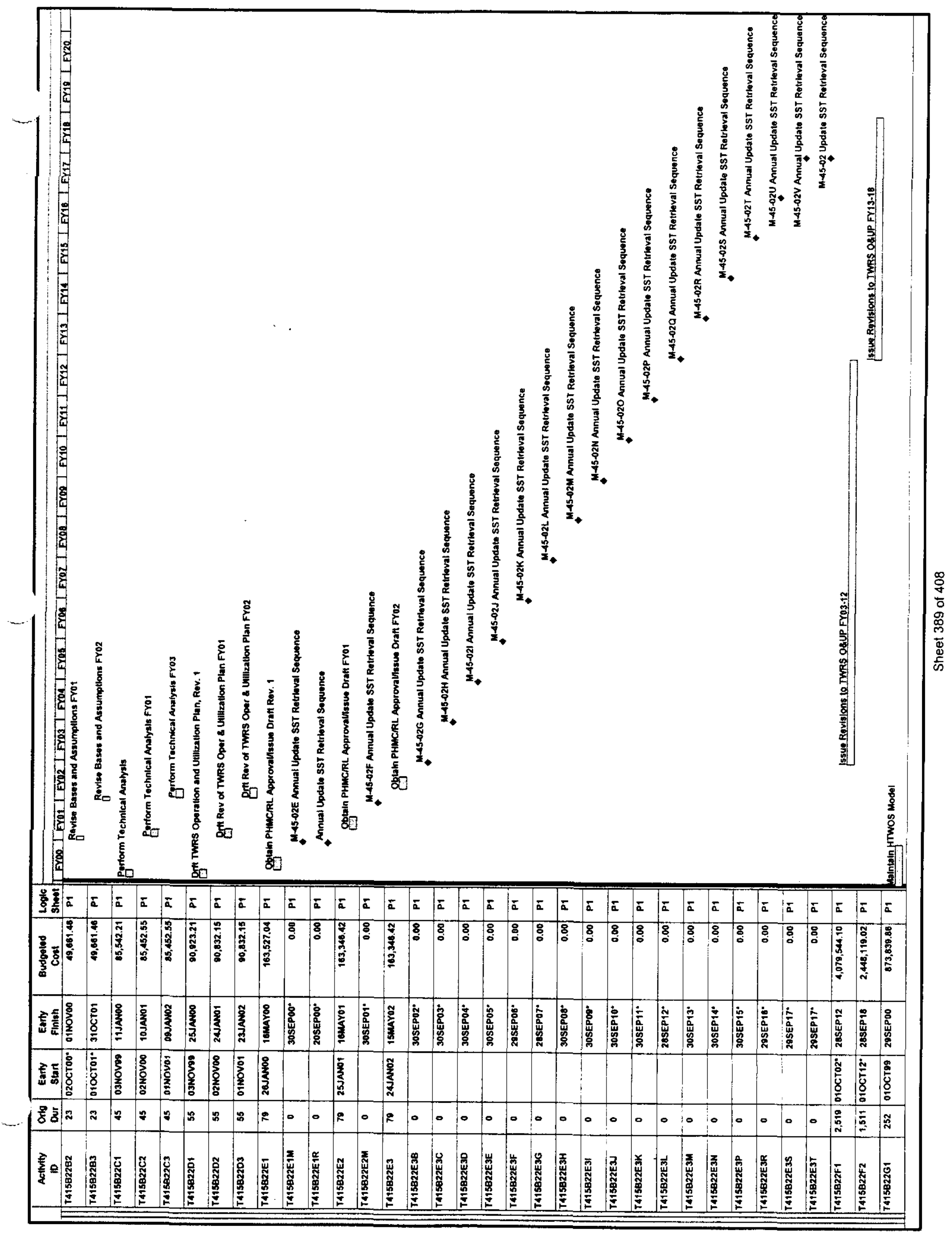




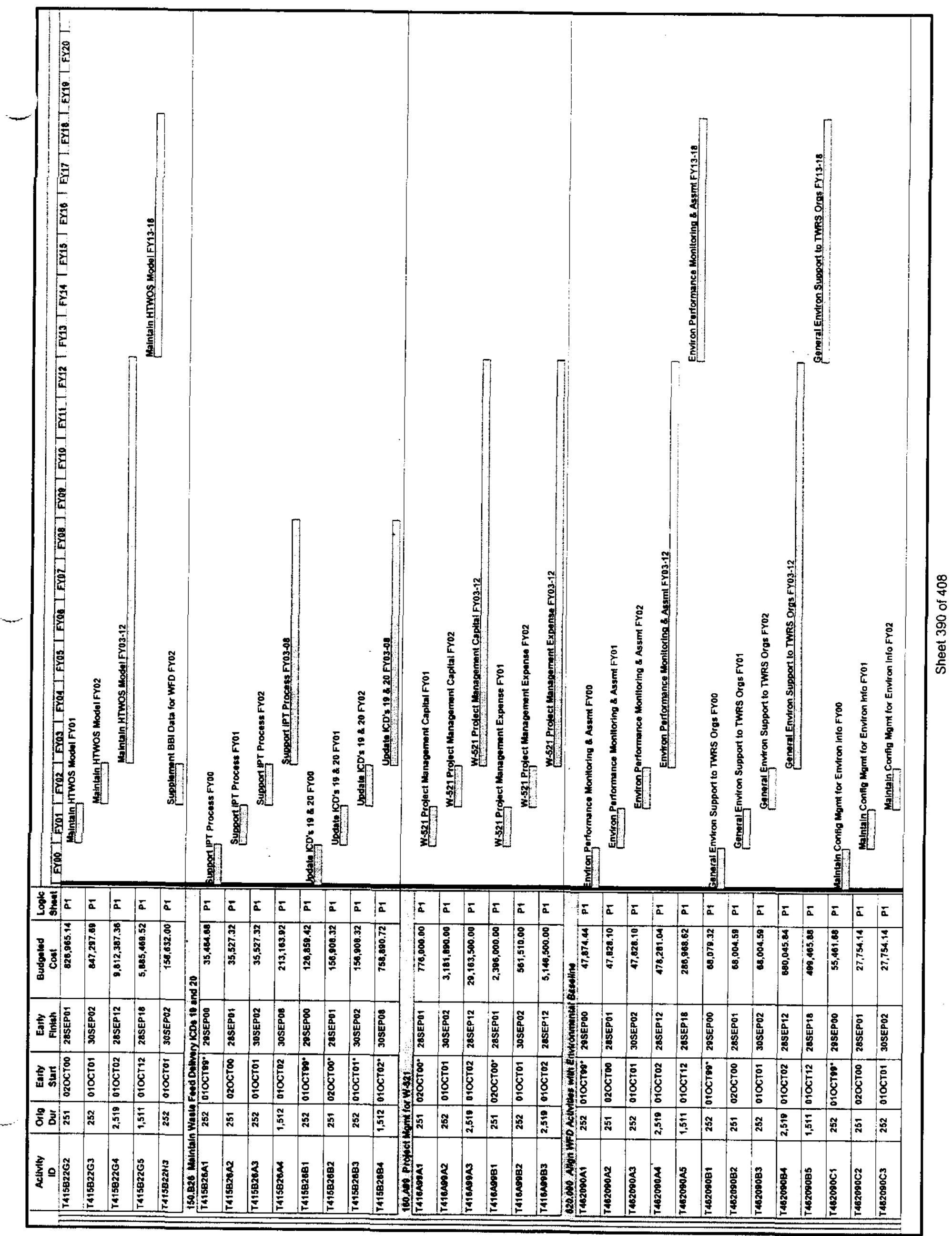




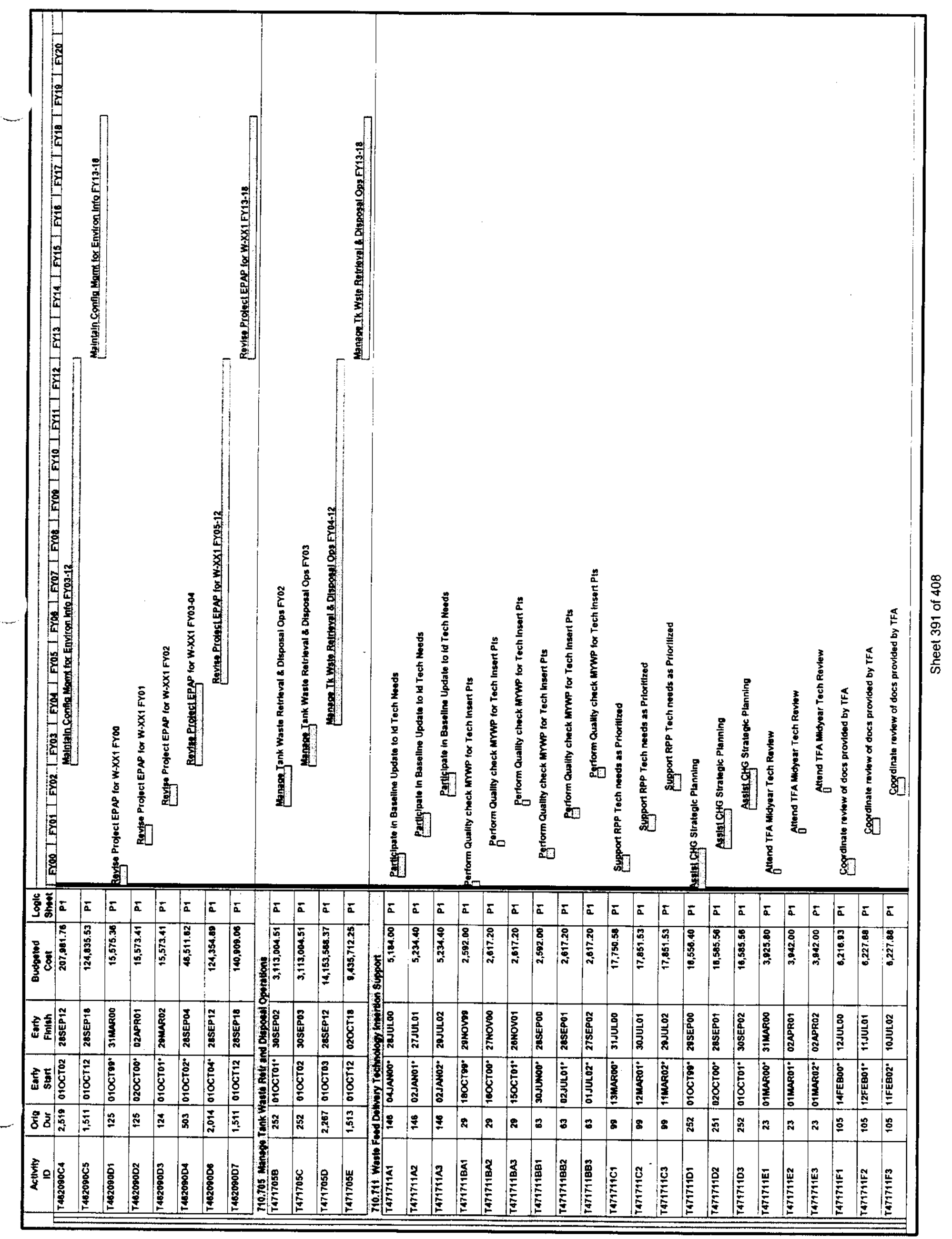




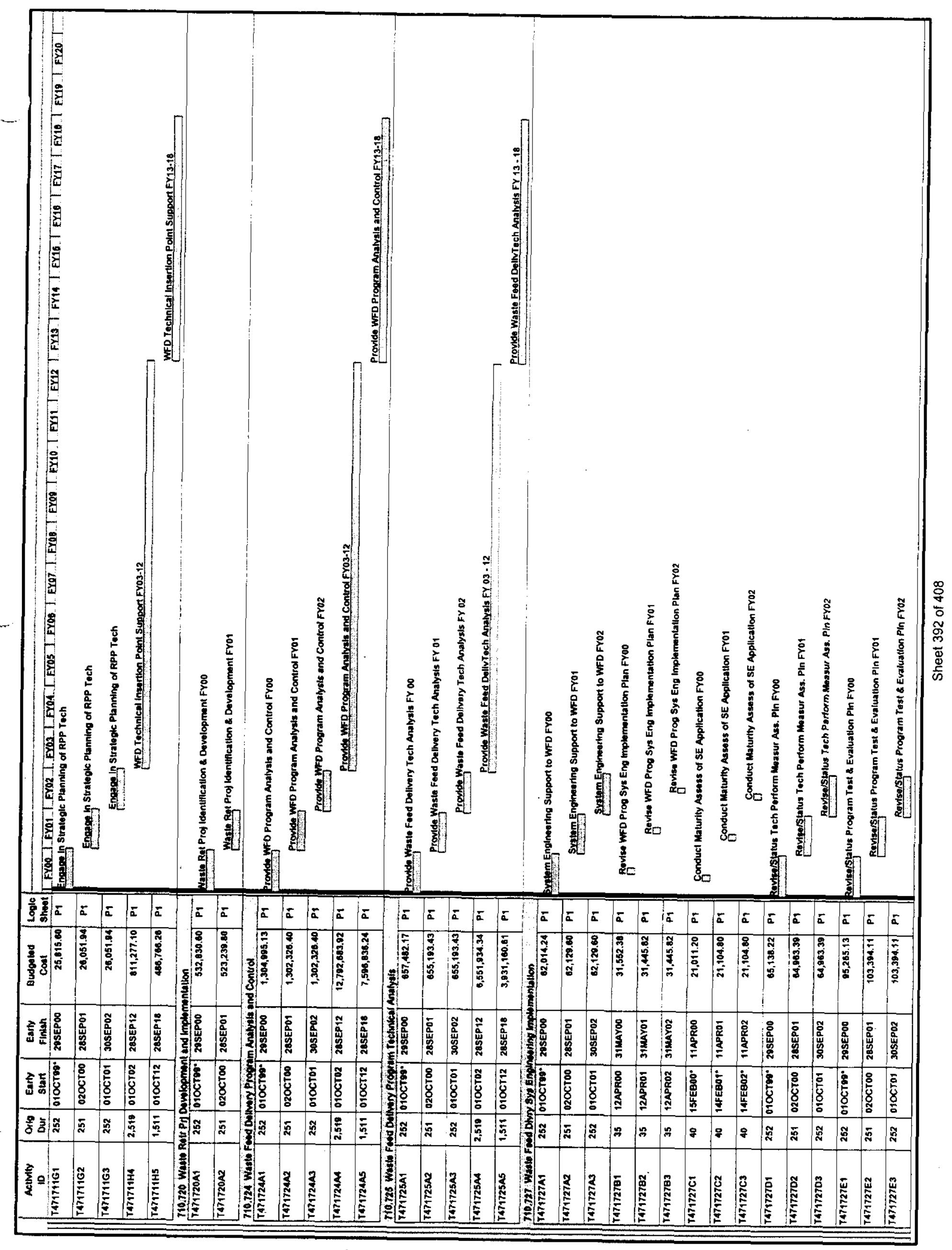




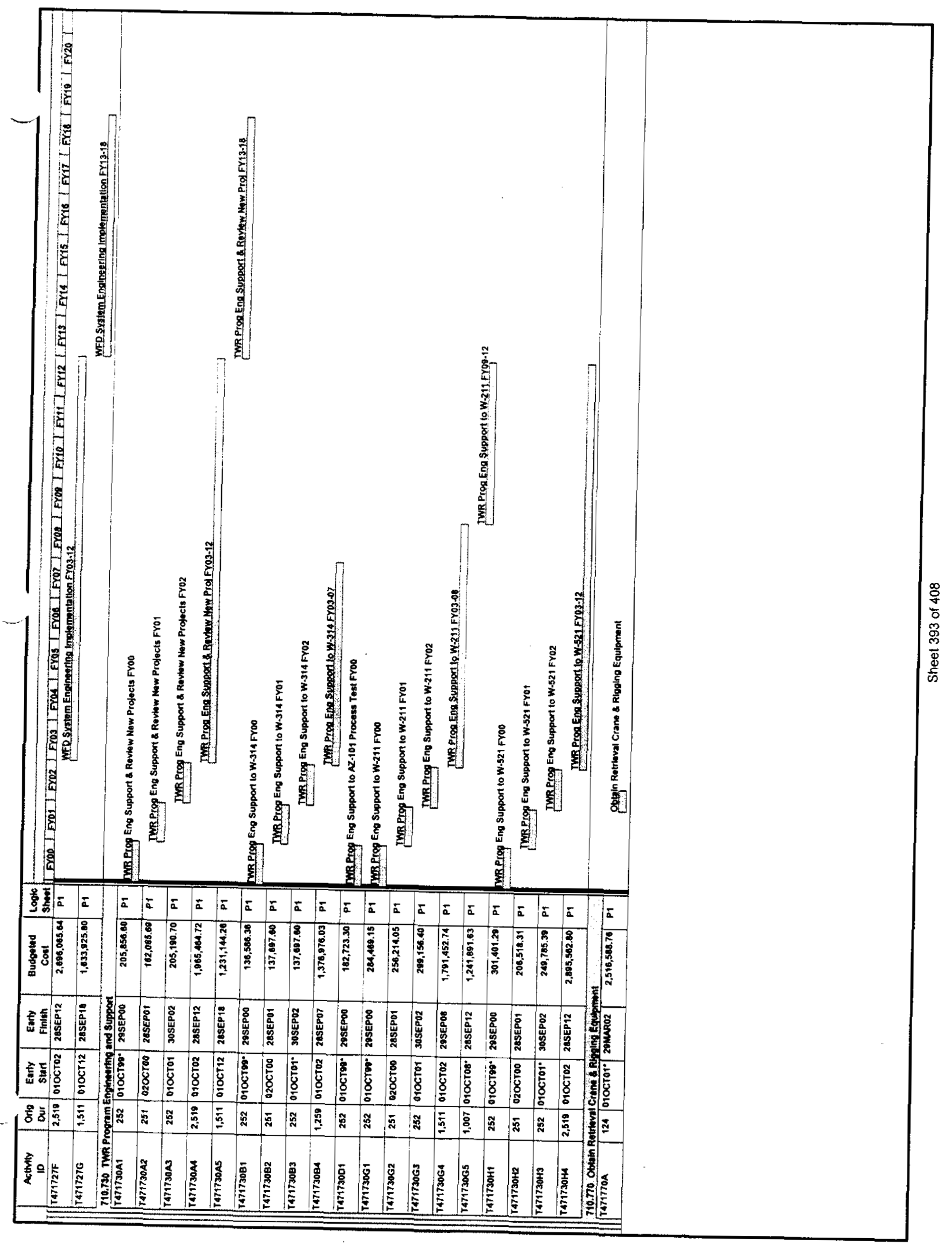




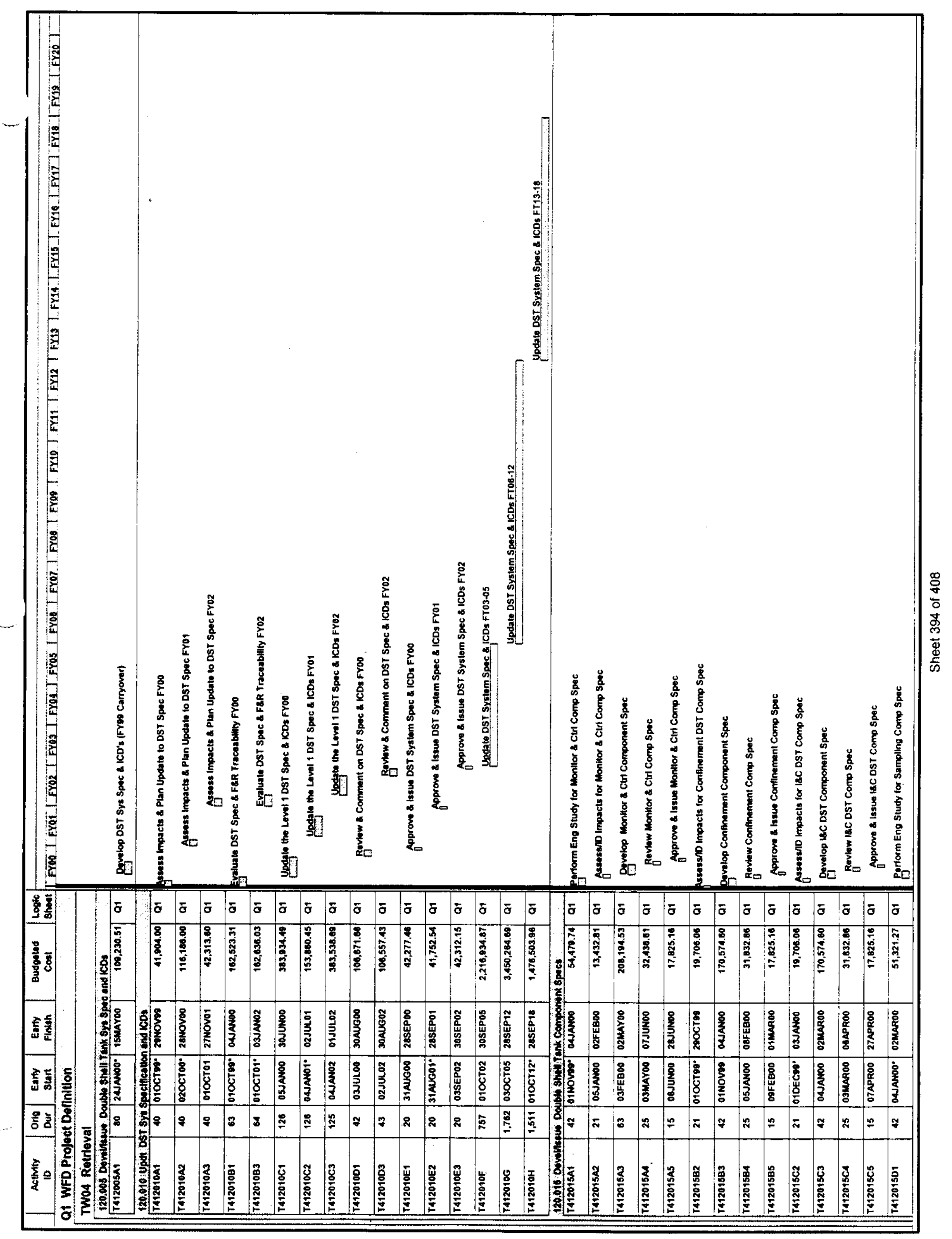




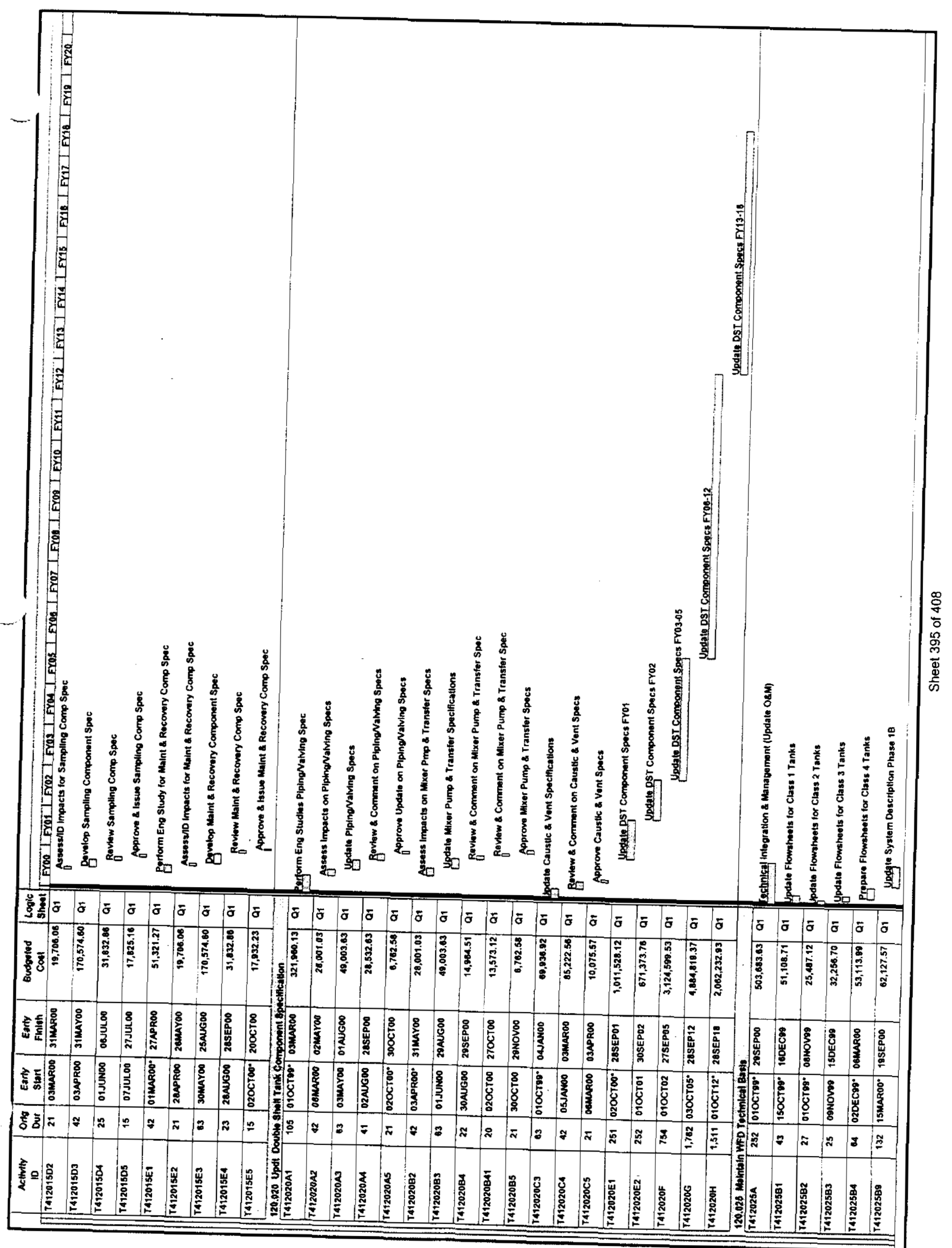




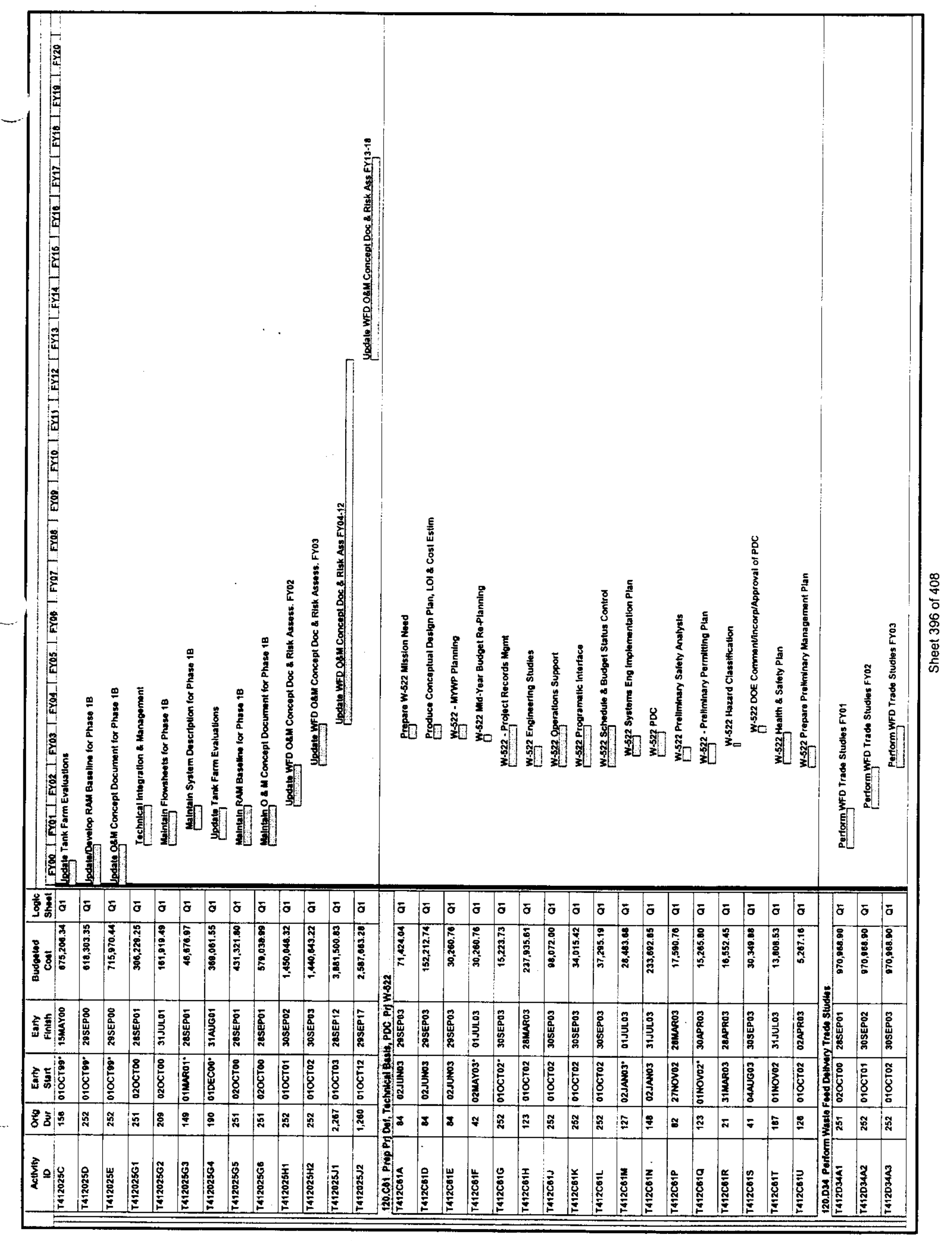




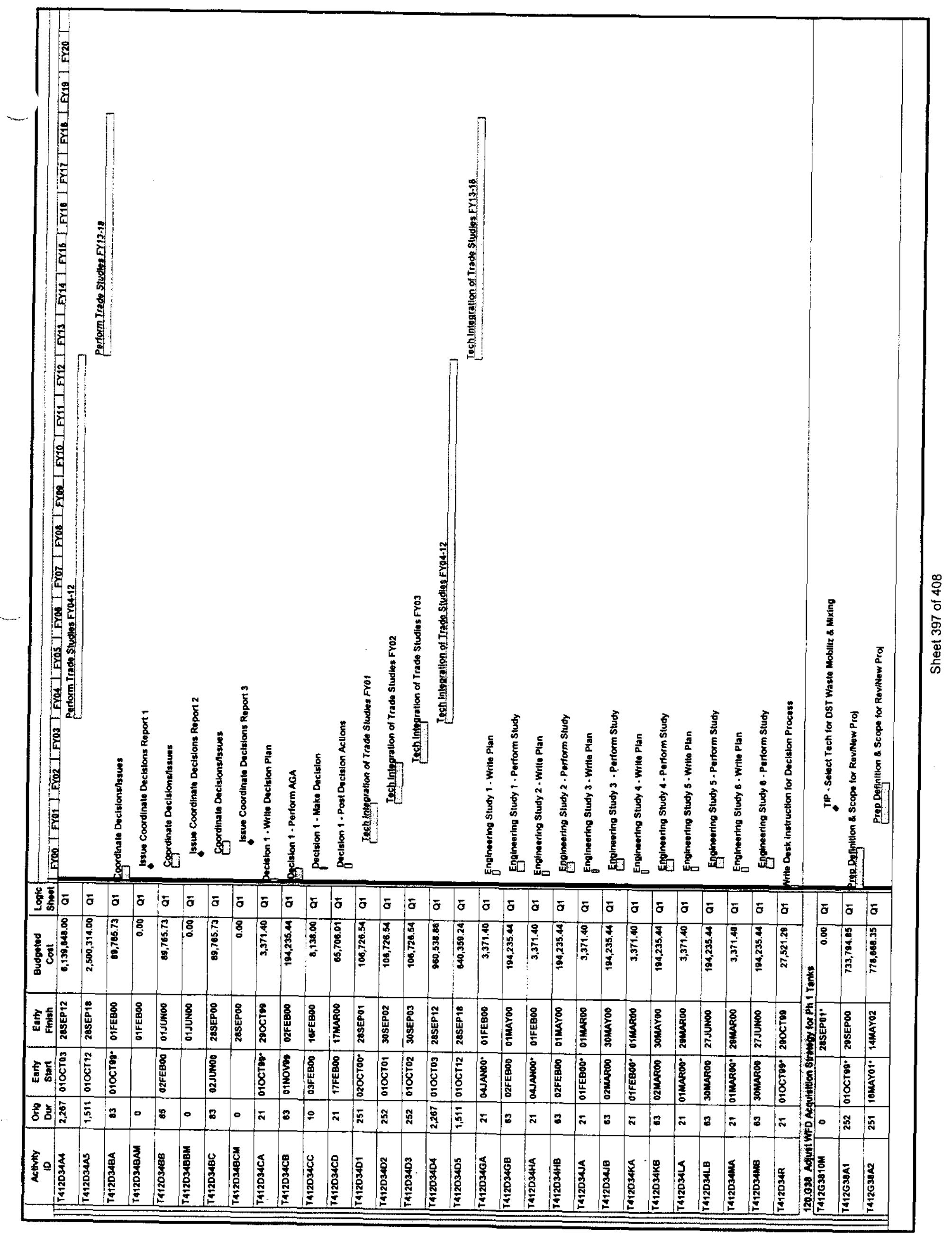




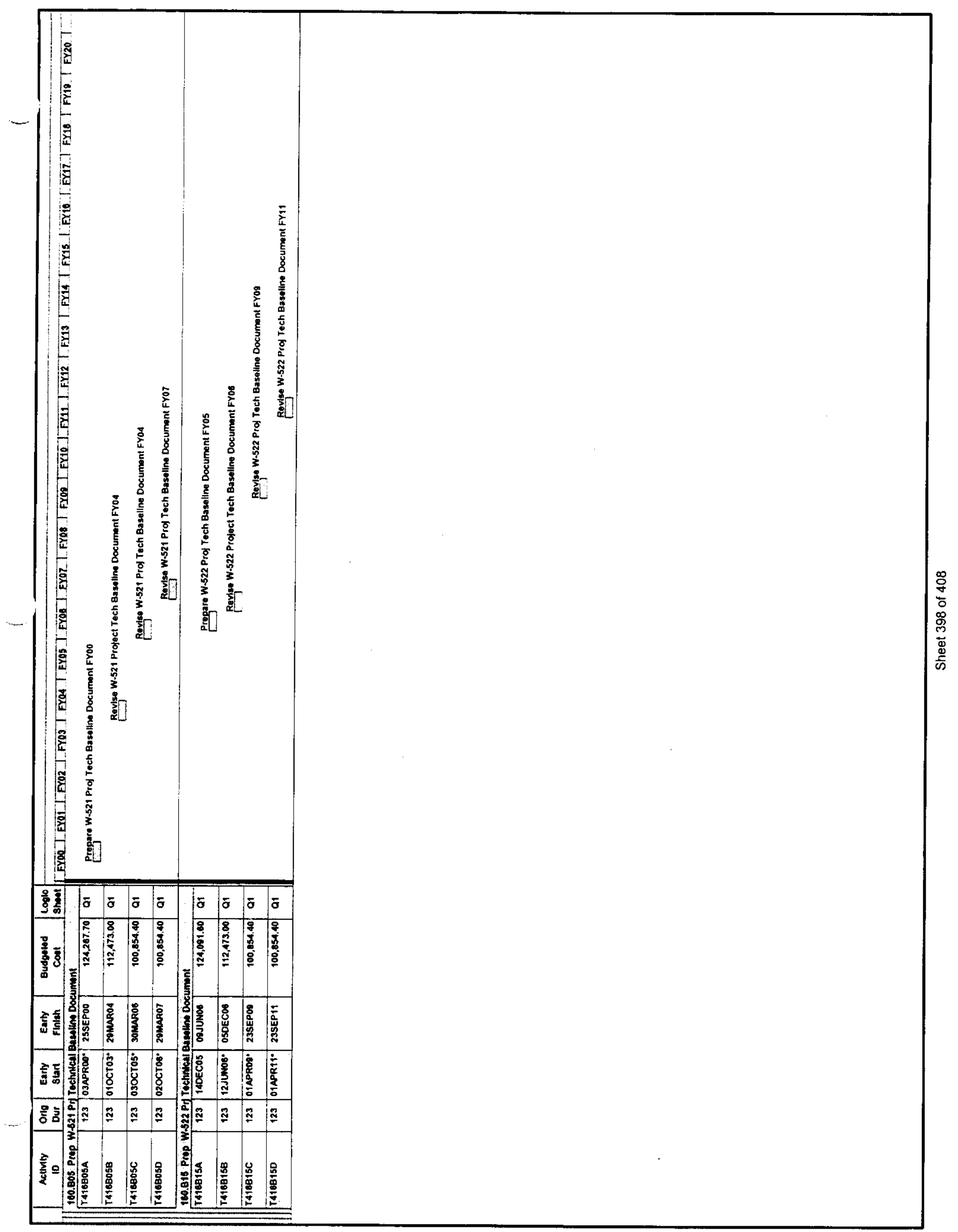




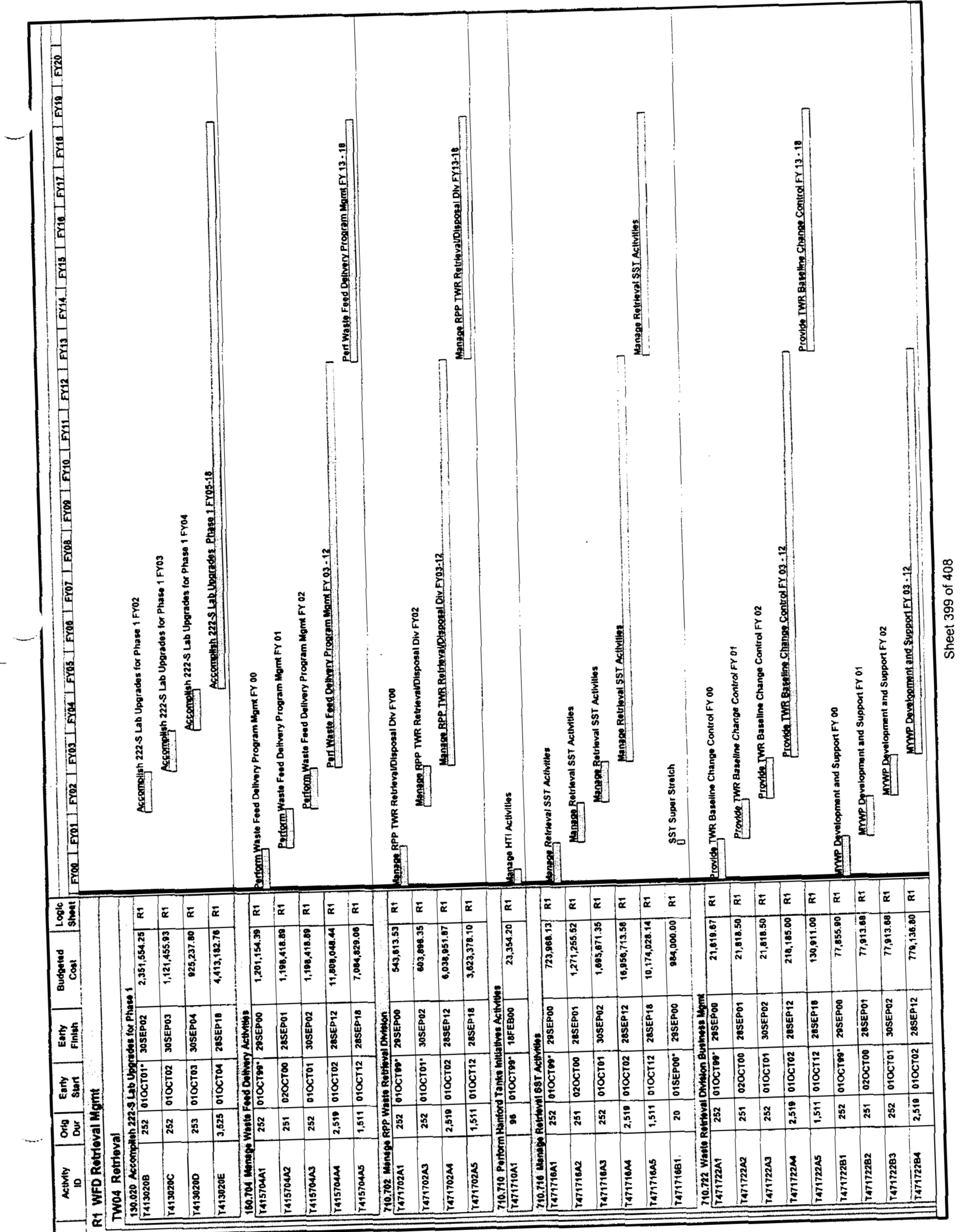




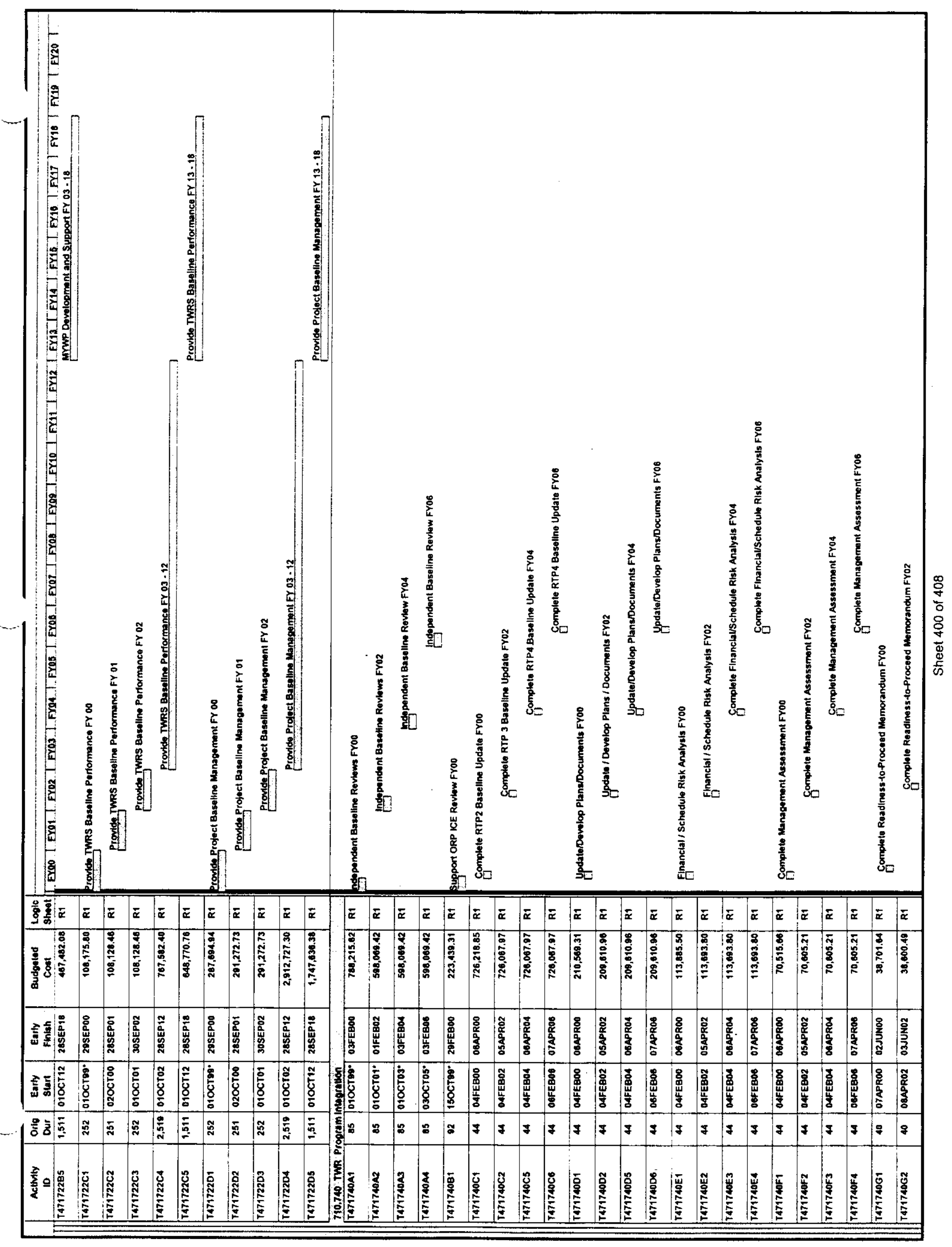




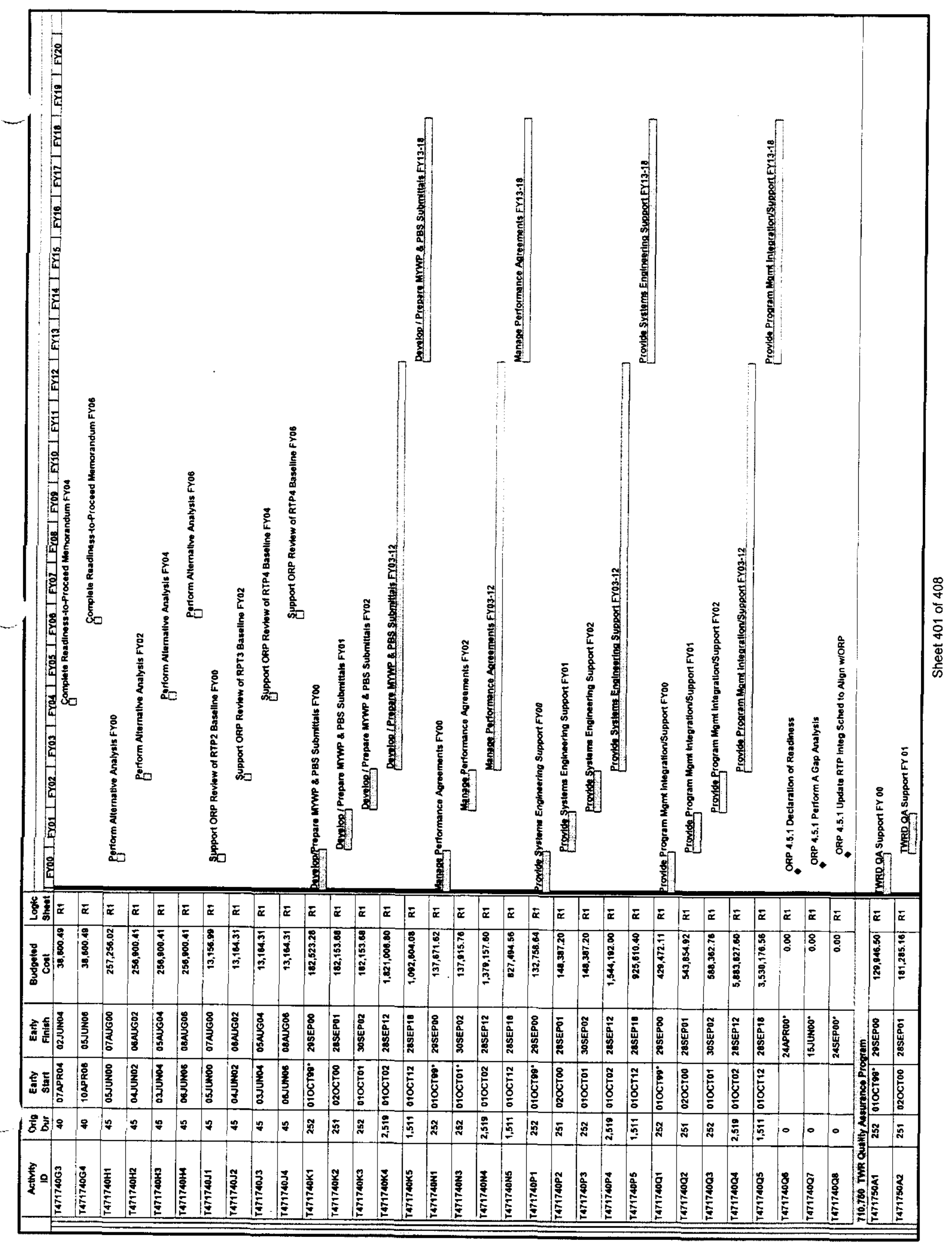




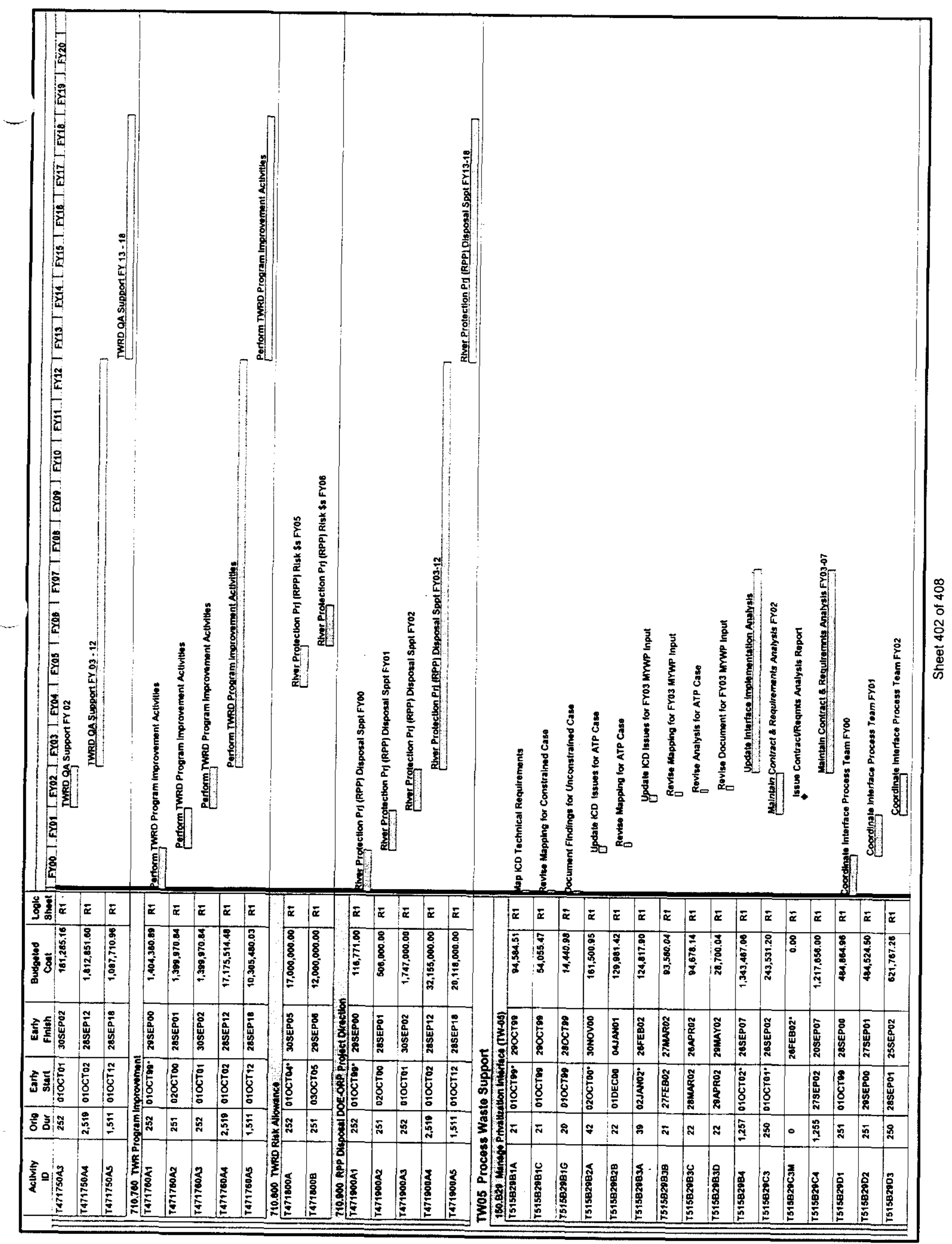




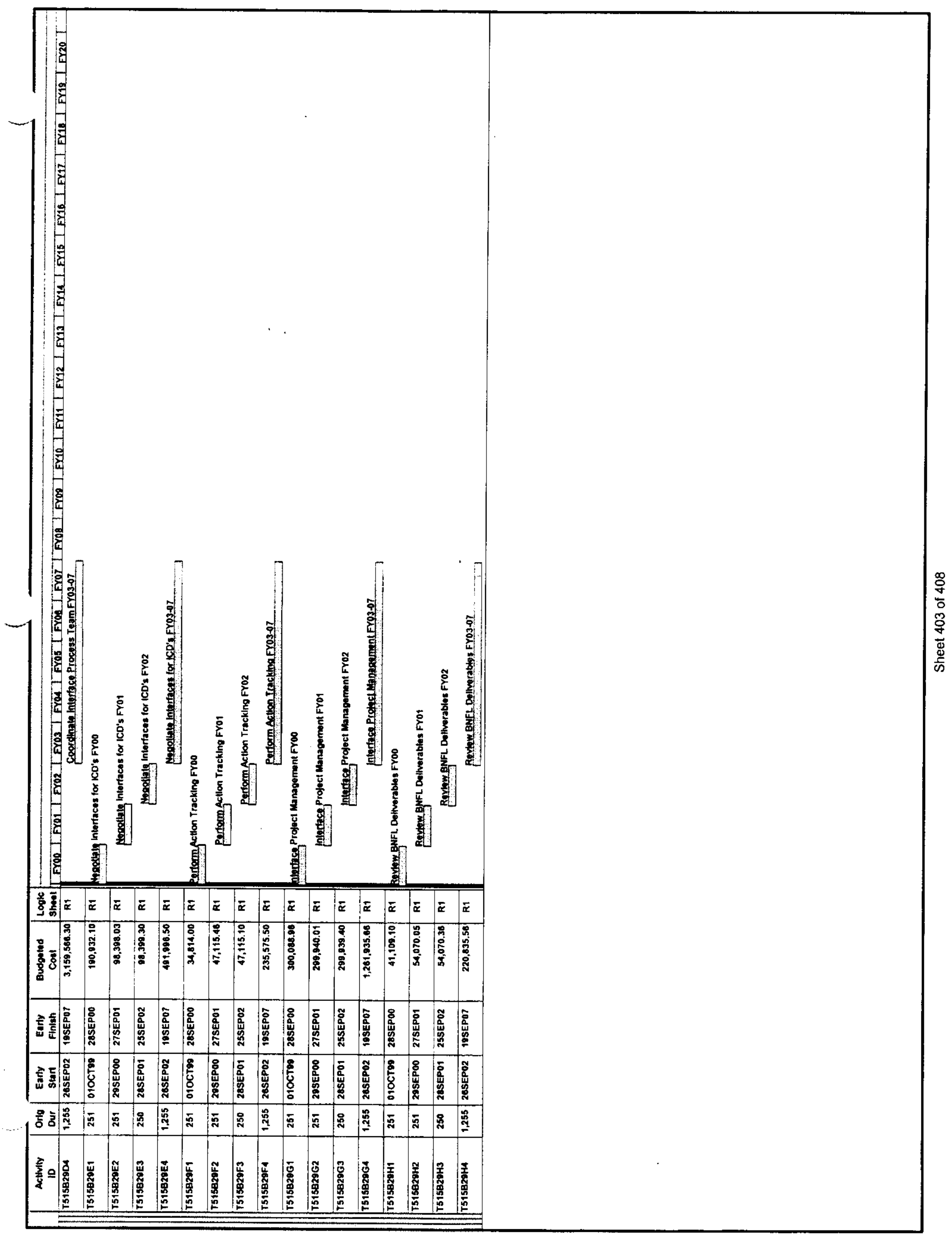




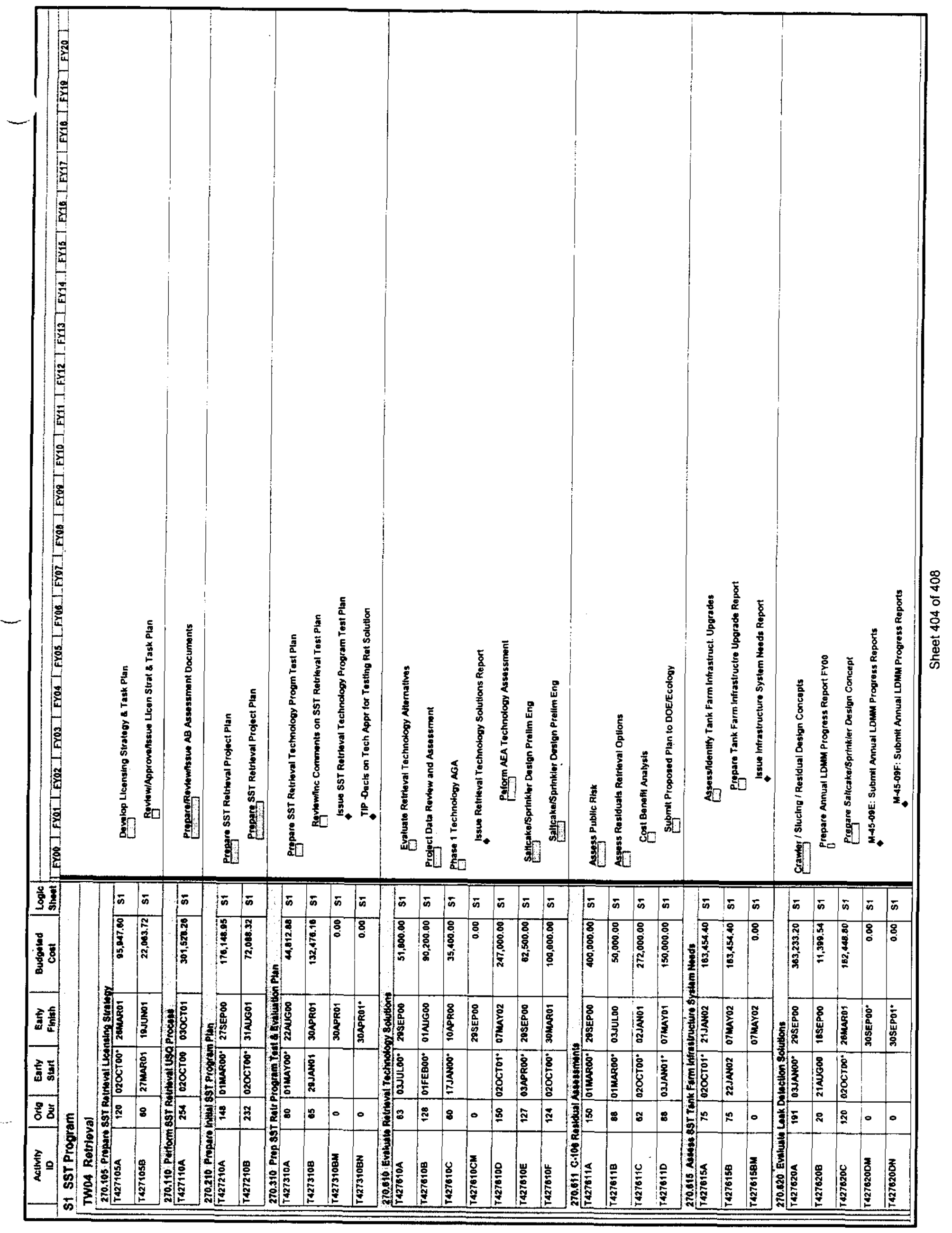




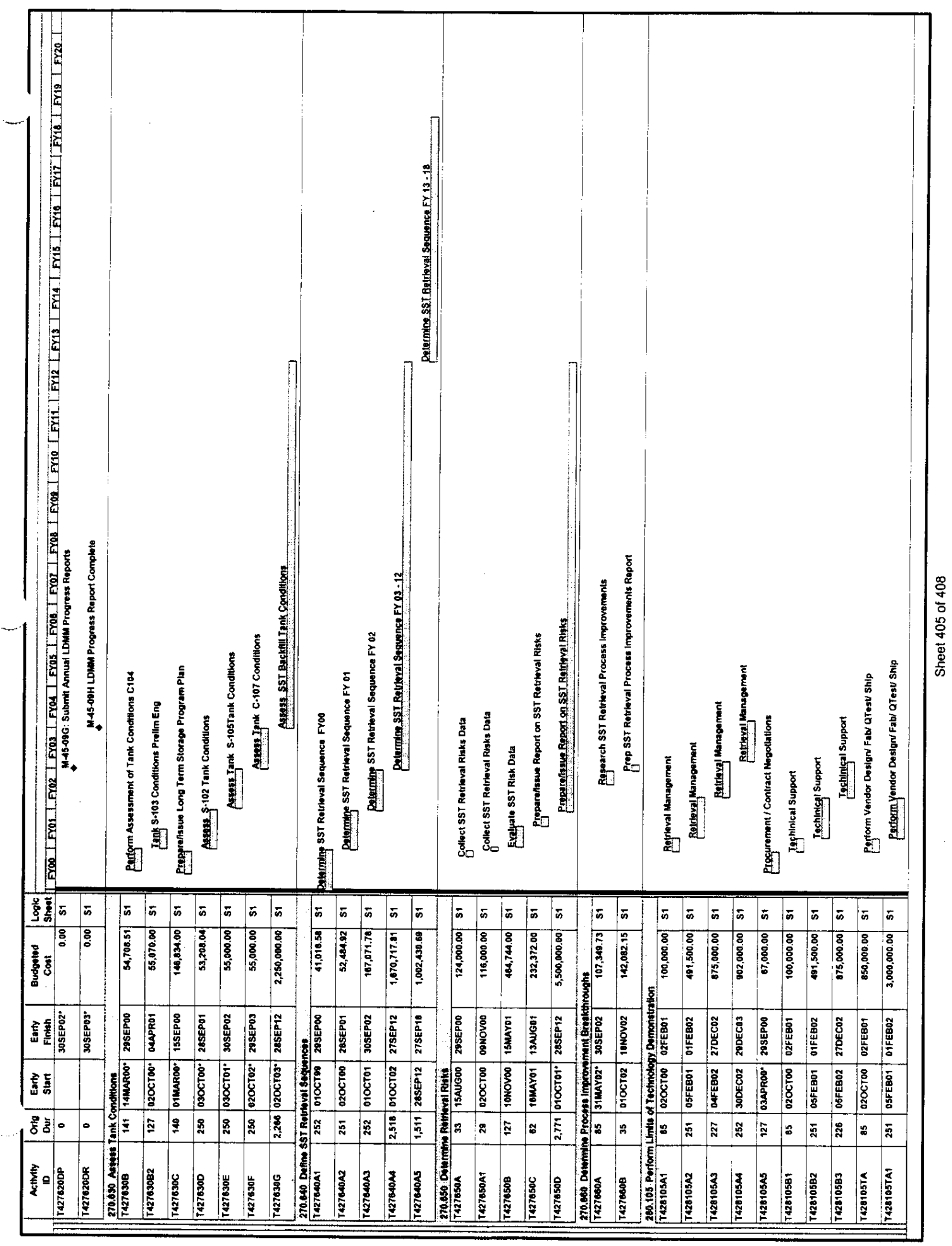




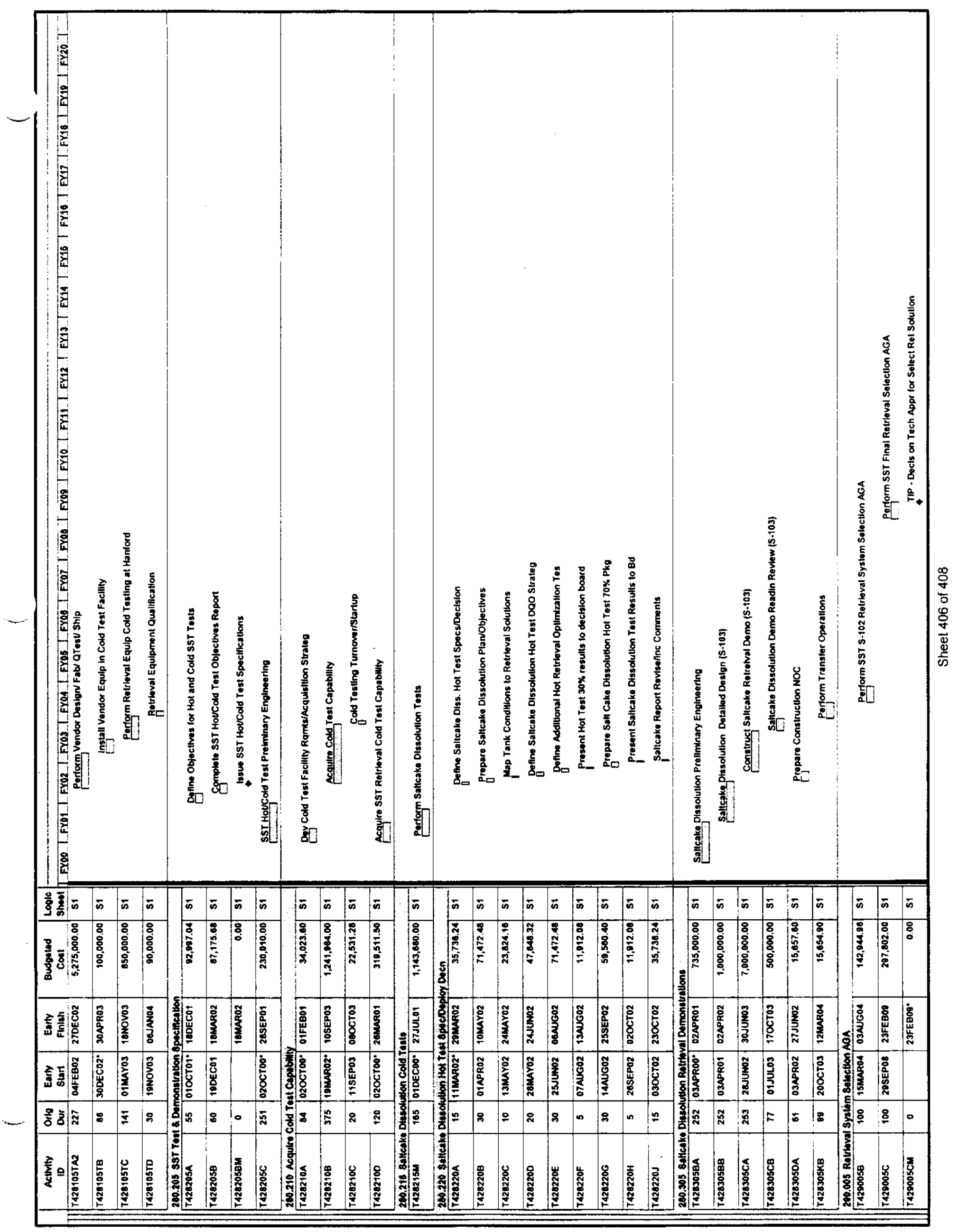




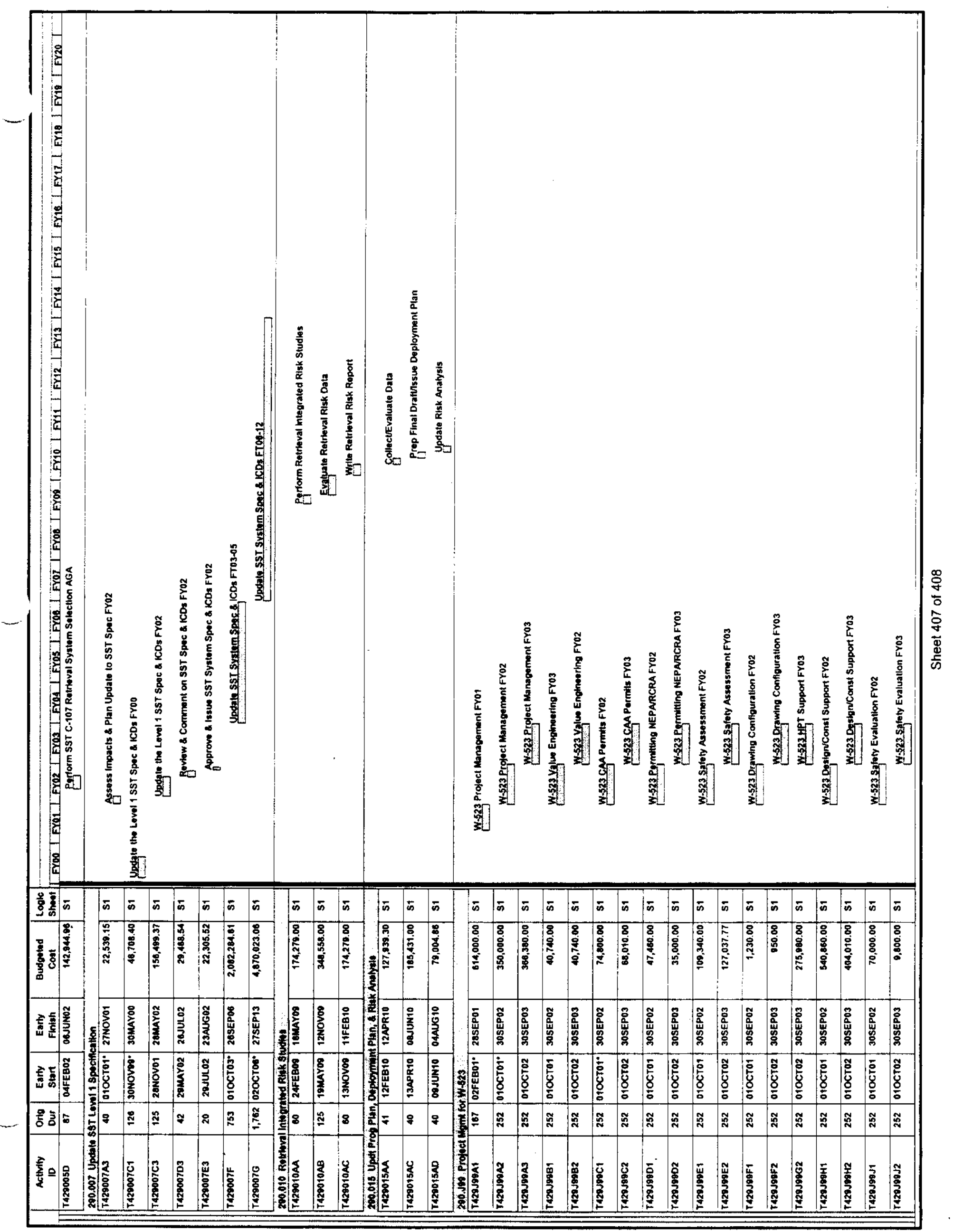




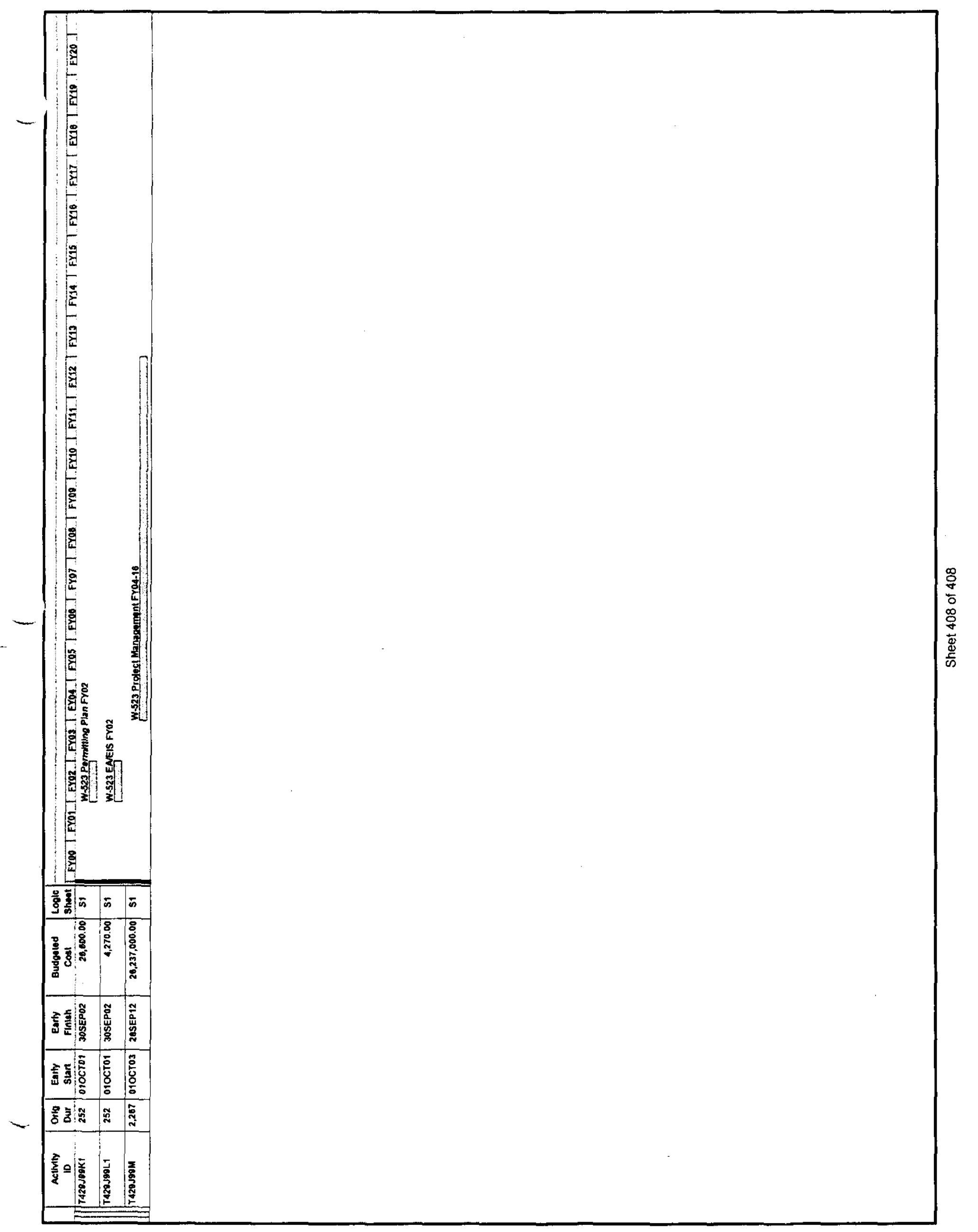

